\title{
Projeto em moda o material e o imaterial no campo acadêmico
}

Tese apresentada ao Programa de Pós-graduação da Faculdade de Arquitetura e Urbanismo da Universidade de São Paulo para a obtenção do título de Doutora em Ciências.

ÁREA DE CONCENTRAÇÃO:

Design e Arquitetura

ORIENTADOR:

Prof. Dr. Sérgio Régis Moreira Martins

São Paulo

2018 
Martins, Leilane Rigatto

Projeto em moda - o material e o imaterial no

campo acadêmico / Leilane Rigatto Martins; orientador Sérgio Régis Moreira Martins. - São Paulo, 2018.

$311 \mathrm{p}$.

Tese (Doutorado) - Faculdade de Arquitetura e Urbanismo da Universidade de São Paulo. Área de concentração: Design e Arquitetura

1. Projeto em Moda. 2. Estilismo. 3. Design de Moda. 4. Design. 5. Campo Acadêmico. 6. Moda. I.

Moreira Martins, Sérgio Régis, orient. II. Título. 


\section{TíTULO:}

Projeto em moda - o material e o imaterial no campo acadêmico

Tese apresentada ao Programa de Pós-graduação da Faculdade de Arquitetura e Urbanismo da Universidade de São Paulo para obtenção do título de Doutora em Ciências, Design e Arquitetura.

APROVADO EM:

\section{BANCA EXAMINADORA:}

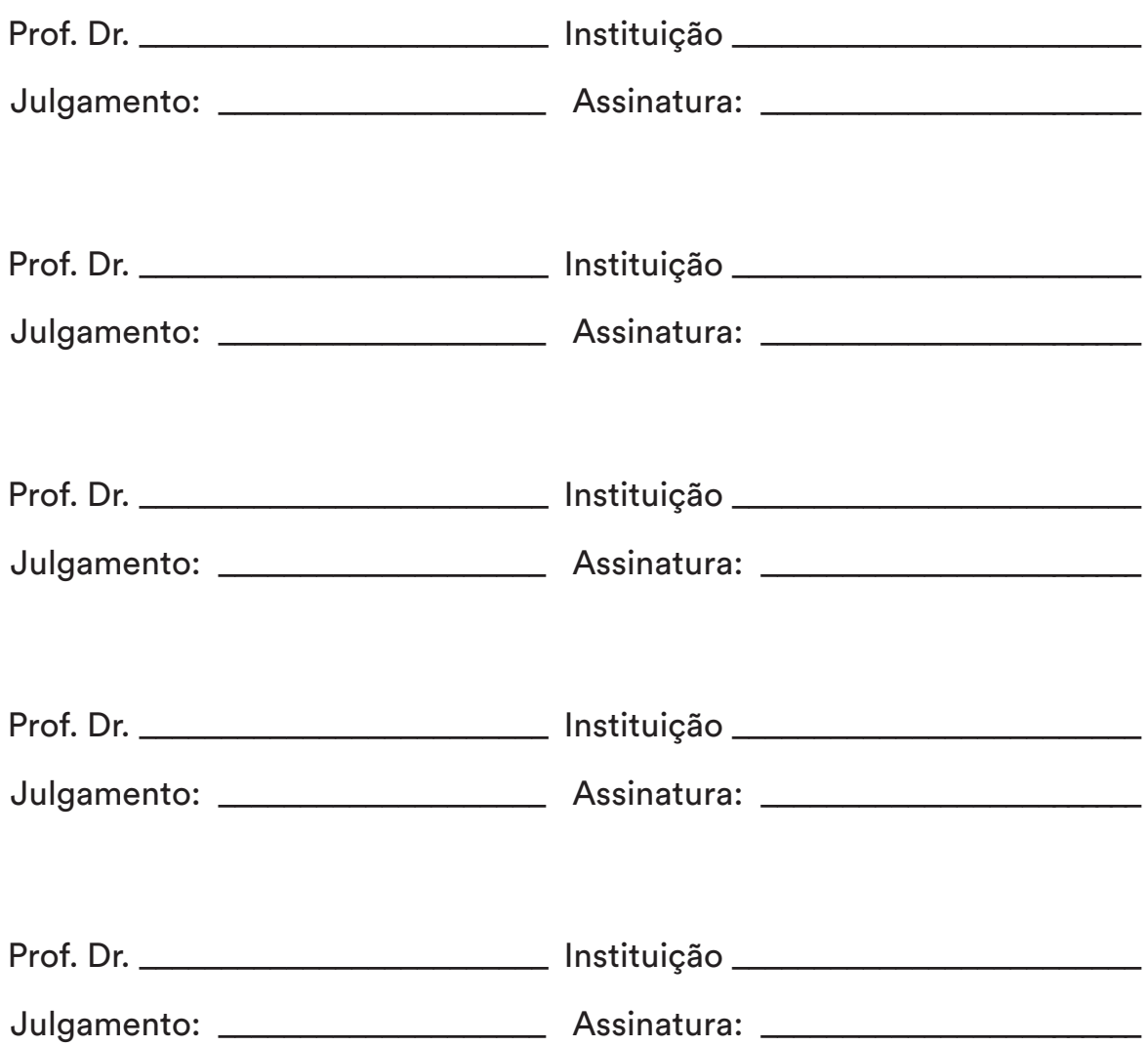


Dedico este trabalho à minha mãe, 


\section{Agradecimentos}

Agradeço com muito carinho a tantos amigos, professores e outros profissionais que contribuíram com este trabalho, direta ou indiretamente.

Deixo meu obrigada mais especial aos meus orientadores Sérgio Régis Moreira Martins e Marcos da Costa Braga. O primeiro, Sérgio Martins guiou meus passos na pesquisa acadêmica desde o primeiro momento quando entrei no Mestrado até o final do Doutorado me aconselhando e apoiando. O segundo, Marcos Braga, mesmo não sendo oficialmente meu orientador, me ensinou a pensar questões complexas com o cuidado e a lucidez devidos a respeito da minha tese e das minhas escolhas acadêmicas.

Levo para a vida recordações dessas duas pessoas que foram fundamentais no meu processo de amadurecimento acadêmico para a construção desta tese. Tive a sorte de ter ao lado acadêmicos que me ajudaram com tanta generosidade, desprendimento e de forma tão legítima como Sérgio Martins e Marcos Braga. Meu muito obrigada a vocês dois, professores.

Expresso minha gratidão à minha mãe, uma mulher inteligente, culta, $\mathrm{e}$ admirável que fez tantos esforços para me ensinar o que é ser uma pessoa idônea e o valor da cultura, além de tudo que ela colocou em segundo plano na sua vida pessoal para que eu chegasse ao doutorado.

Dois amigos que me acompanham há algumas décadas e também nesse processo de especialização acadêmica merecem meu profundo respeito e agradecimento: André Martins Bragança e João Paulo Fernandes. Essas duas pessoas estiveram presentes em momentos fundamentais sempre dividindo o que há de melhor na vida: diversão e crescimento.

Outros amigos da adolescência de Botucatu que são presentes até hoje nas minhas jornadas pessoais e acadêmicas merecem meu obrigada: Douglas da Silva Domingues e Leonardo de Fávero Sartori. 
Obrigada meus amigos da FAUUSP, pessoas admiráveis, que muitas vezes servirarm de exemplo, me ensinando, me guiando nos caminhos acadêmicos e pessoais: Cristiane Alcântara, lara Pierro Camargo, Lina Kamitsuji, Renata Figueiredo Lanz, Vanessa Espínola, João Carlos Kuhn e Victor Martins.

Participaram da minha vida de alguma outra forma os amigos que agradeço: Beatriz Ramos, Cristina Martins, Elena Fornasari, Fernando Rovéri, Max Olivetti, Rafael Charnet, Ricardo Mangabeira, Thiago Silva e Vinícius Galante. Vocês são muito especiais para mim. Muito obrigada!

Sou grata aos meus entrevistados que inspiram respeito pela sua postura e percurso e também por contribuírem para a expansão acadêmica de uma área como a moda com o seu pioneirismo, cedendo seu tempo à mim e à minha pesquisa. Seus depoimentos, elucidações, pensamentos, interesse pelo viés acadêmico da moda e todas as trocas foram fundamentais para que essa tese pudesse ser escrita. Muito obrigada a Auresnede Stephan Eddy Pires, Circe Bernardes, Elá Camarena, João Braga, Márcio Ito, Mariana Rocha, Renata Zaganin de Oliveira, Simone Mina, Vera Lígia Pieruccini Gibert, Cristiane Mesquita, Francisca Dantas Mendes, Kathia Castilho, Mário Queiróz, Rosane Preciosa, Andrea Canton, Cyntia Santos Malaguti de Sousa, Eunice Higa, Maria Cláudia Bonadio, Maria Eduarda Araújo Guimarães, Cláudia Garcia, Cibele Haddad Taralli, Feres Lourenço Khoury, Maria Celeste de Fátima Sanches, Robinson Salata, Mônica Moura, Patrícia de Mello Souza, Alberto Cipiniuk, Aline Monçores, Deborah Christo, Evelyn Grumach, Irina Aragão, Sérgio Sudslowsky, Izabel Maria de Oliveira, Troy Nachtigall, Eugenio Andrés Diaz Merino, Luiz Henrique Lopes dos Santos e Ricardo Triska.

Também sou grata aos professores do Politecnico di Milano que deram acesso às suas aulas e entrevistas: Federica Vacca, Giovanni Conti, Nanni Strada, Paola Bertola e Paolo Volonté.

Outras duas pessoas importantes na minha trajetória na Itália foram Lenise Castro e Giovanna Carnazza. $\mathrm{O}$ apoio dessas duas novas amigas foi fundamental para o sucesso dos meus estudos na Europa.

Meus agradecimentos à secretaria da FAU que torna mais leve as etapas burocráticas da pesquisa sem as quais ela não seria possível. Obrigada Cristina Maria Arguejo, Cilda Gonçalves de Oliveira, Dina Vasconcellos Leone, Elias da Silva Fontes, Heitor Silveira Abbade, Isaide Francolino dos Reis, Lucia Nepomuceno, Marcelo Dias, Maria Aparecida Alves Rodrigues, Ivani Sokoloff, Robson Alves de Amorim, Maria Lúcia Caira Gitahy, expresidente da CPG, João Sette Whitaker Ferreira, atual presidente da CPG, além da professora Clice de Toledo Sanjar Mazzilli que sempre esteve presente de alguma forma.
Por último agradeço à Fundação de Amparo à Pesquisa do Estado de São Paulo, FAPESP, que forneceu à minha pesquisa a bolsa de doutorado FAPESP/CAPES sob o número de processo $n^{\circ}$ 2014/23513-6 permitindo o desenvolvimento, nas melhores condições possíveis, desta tese. 


\section{Resumo}

MARTINS, L. R. Projeto em moda - o material e o imaterial no campo acadêmico. 2018. 311 p. Tese (Doutorado) - Faculdade de Arquitetura e Urbanismo, Universidade de São Paulo, 2018.

A presente tese, intitulada Projeto em moda - o material e o imaterial no campo acadêmico, tem por objetivo abrir o debate sobre estilismo e projeto em moda, pois de acordo com a hipótese principal, depreende-se que, em decorrência de diversos fatores, não há um consenso sobre o conceito de projeto em moda no Brasil no âmbito acadêmico, inaugurado em 1988. Para estimular esse debate, o estado da arte em estilismo e projeto em moda foi adotado como percurso metodológico, proporcionando as condições de averiguação das convergências e divergências sobre o tema entre os agentes da área. No decorrer desta investigação foram realizados: a revisão de literatura das principais obras sobre o tema, a entrevista dos pioneiros do campo, a análise dos artigos sobre 0 assunto produzidos para o Colóquio de Moda e para o Congresso Brasileiro de Pesquisa e Desenvolvimento em Design, o P\&D. Também foram coletados os depoimentos dos coordenadores de área do design das principais agências os depoimen fos corden de visão, por parte do a visáo, por parte destas agencias, en relaçáa a a area po ma. O trabaho foi

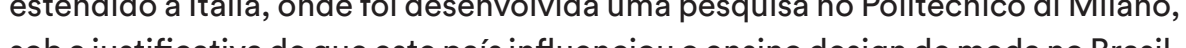
sob a justificativa de que este pais influenciou o ensino design de moda no Brasil. Por fim, foram abordadas as questões simbólicas que envolvem a projetação em moda na atividade profissional do estilista e do designer, traduzidas por meio dos conceitos de mito, aura, anonimato e indústria. Esses conceitos e noções que orientam práticas, e são nominados por certos termos, participam dos aspectos imateriais que permeiam a falta de consenso sobre uma noção de projeto em moda no Brasil, no âmbito acadêmico. Se os aspectos materiais ficam a cargo do que é objetivado fisicamente por meio de etapas de projeto que se traduzem em painel, cartela de cores, pesquisa de materiais, acabamentos, croquis, peças piloto e, por fim, o produto final; os aspectos imateriais descrevem relações subjetivas, portanto tácitas, que demandam uma discussão mais profunda, além de circunscreverem conceitos e noções que orientam práticas imateriais, tais como a "inspiração" do estilista, a escolha de um tema para uma coleção, o limite entre a influência do repertório do criador e sua interferência individual na configuração prático-estética dos produtos, a delimitação entre o individual na configuração prático-estética dos produtos, a delimitação entre o
que é produção acadêmica, de ateliê e industrial e seus possiveis cruzamentos no que se refere à etapas de projetação. Essas relações imateriais estão direta ou indiretamente vinculadas à noção de mito. A pesquisa buscou evidenciar pontos de vista convergentes e divergentes por meio do cruzamento dos dados obtidos em todas as etapas descritas anteriormente concorrendo para algum consenso acerca das noções de estilismo e projeto em moda.

\section{palavras-chave:}

Projeto em Moda. Estilismo. Design de Moda. Design. Campo acadêmico. 


\section{Abstract}

MARTINS, L. R. Fashion project - the material and the immaterial in the academic field. 2018. $311 \mathrm{p}$. Dissertation (Doctorate) - Faculdade de Arquitetura e Urbanismo, Universidade de São Paulo, 2018.

The aim of this study called Fashion project - the material and the immaterial in the academic field is to undertake a debate surrounding fashion design because according to the main hypothesis, due to a number of factors, we understand, there is no consensus with regard to the idea of fashion design within higher education institutions in Brazil, inaugurated in 1988. To stimulate the debate the state of art in fashion design was adopted in the present study as a methodological path, so as to determine the lack of concordance on the theme among the agents within the area. In the course of this investigation had been performed: a bibliographic review with the main books about the theme, interview with the pioneers from the field, a review of the articles published about the issue in the events Colóquio de Moda and Congresso Brasileiro de Pesquisa e Desenvolvimento em Design, known as P\&D. Were collected the testimonies from directors of the main Brazilian agencies of promotion, such testisa FAPES, CAPES as fashion field. The work was extended to laly, and part of the research was developed at Politecico di Milano, because this country has influenced the fashion design teaching in Brazil. Finally, were approached symbolic issues
that evolve the fashion design in the professional activity translated through concepts like myth, aura, anonymity and industry. This concepts that guide practices, and receive some names, are part of immaterial aspects which permeate the lack of consensus about a fashion design notion in Brazil, in the academic field. If the material aspects correspond to what is physical through design steps which translate themselves into boards, color story, material research, embellishment, drawings, samples and, finally, the final product; the immaterial aspects describe subjective relations, thus implied, that demand a deeper discussion, besides containing concepts and notions that guide immaterial practices, such as the designer inspiration, the choice of a theme for the collection, the boundary between the creator repertoire and your individual interference in the practical-aesthetic configuration of products, the difference between what is academic, atelier and serial production and the possible crosses regarding design steps. These immaterial relations are directly or indirectly linked to the myth notion. This research aimed to point convergent and divergent points of view crossing the obtained data in all steps described before in order to achieve some consensus on the fashion design notions. 


\section{Lista de Tabelas}

1 Profundidade do

Mix de Produtos P. 5 


\section{Lista de Figuras}

Ficha de organização
para tecidos $P .66$

2 Ficha de organização para compra de tecidos P. 6

3 Caderno de Pesquisa de Susana Choi (2010) P. 140

4 Caderno de Pesquisa de Susana Choi (2010) p.14

5 Pesquisa colada sobre figura (2009) P. 147

6 Pesquisa colada sobre figura (2009) P. 147

7 Textura e gradação Lingerie da Buttress \& Snatch, de Rachel Kenyon P. 1 re

8 A terminologia "habilitação" ainda era utilizada em curso superio de Moda em São Paulo P. 176

9 Exemplo de moodboard ou painel de inspiração (2017) P. 225

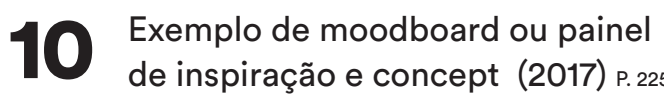

11 Moodboards com imagens de produtos de moda (2017) P. 226
12 Amostra de teste de malha da

etapa de prototipagem (2017) P. 227

13 Amostra de teste de malha da tapa de prototipagem (2017) P. 228

14 Trabalhos manuais

15 Croquis coloridos

15 em Illustrator (2017) P. 22

16 Croquis coloridos em Illustrator

17 Croquis coloridos em Illustrator

18 Trabalho que mostrou grande desenvolvimento ao longo do semestre (2017) P. 234

19 Apresentação do moodboard de Estudo de Análise de Caso em gráfico cartesiano com eixos " $X$ " e " $Y$ " da etap Cenário de Design (2017) P. 241

20 Seated Woman with Bent Knee,

21 Final Portrait, Lucien Freud,

1976-1977 Р. 271

22 Diploma de bacharelado em Desenho de Moda da FASM de 1998 P. 287 23 Diploma de bacharelado em Design de 24 Diploma de bacharelado em Desenho

25 Diploma de bacharelado Universitário das Faculdades Metropolitanas Unidas) de 2015 P. 289 


\title{
Lista de Quadros
}

\author{
1 Lista de Autores P. 53 \\ 2 Cruzamento dos autores \\ e suas etapas de estilismo, \\ projeto em moda e projeto \\ em design P.75 \\ 3 Instituições pesquisadas \\ em São Paulo e Rio de Janeiro P. 83 \\ 4 Pioneiros entrevistados dentro \\ do recorte proposto pela tese $P .84$ \\ 5 Lista de Pioneiros de São Paulo \\ e do Rio de Janeiro P. 86 \\ 6 Cruzamento das instiuições e suas \\ etapas de estilismo, projeto em moda \\ e projeto em design P. 131 \\ 7 Pesquisador no exterior P. 132 \\ 8 Nomenclaturas de painéis \\ - Listas de entrevistados \\ 9 das Agências de Fomento P. 198
}




\section{Sumário}

35 Introdução

Capítulo 1

49 Revisão de Literatura Crítica sobre Estilismo e Projeto em Moda

52 Etapas do Estilismo e do Projeto em Moda

74 Referências do Capítulo 1

Capítulo 2

79 Noções de Estilismo e Projeto em Moda no Campo Acadêmico 


\section{FASM — Faculdade Santa Marcelina}

2.2

98 UAM — Universidade Anhembi Morumbi

2.3

108 SENACSP — Serviço Nacional de Aprendizagem Comercial de São Paulo

2.4

115 Universidades Estaduais de São Paulo

2.4.1

116 EACHUSP — Escola de Artes, Ciências e Humanidades da Universidade de São Paulo

2.4 .2

120 FAUUSP —_ Faculdade de Arquitetura e Urbanismo da Universidade de São Paulo

2.4.3

122 FAACUNESP BAURU —_ Faculdade de Arquitetura, Artes e Comunicação da Universidade Estadual Paulista "Júlio de Mesquita Filho"
2.5

123 Instituições do Rio de Janeiro: PUCRJ - Pontifícia Universidade Católica do Rio de Janeiro; SENAI CETIQT — Serviço Nacional de Aprendizagem Industrial / Centro de Tecnologia da Indústria Química e Têxtil; e UVA - Universidade Veiga de Almeida

$1322^{2.6}$

132 Convergências e divergências entre as noções de estilismo e projeto na literatura e no campo acadêmico

$133^{2.6 .1}$

Convergências e Divergências

156 Referências do Capítulo 2

161

As Noções de Estilismo e Projeto em Moda no Colóquio de Moda e no Congresso Brasileiro de Pesquisa e Desenvolvimento em Design 
3.1

165 Análise dos artigos -

Convergências e divergências entre as noções de Estilismo e projeto em moda no Colóquio de Moda e no P\&D

3.2

166 Diálogo entre arte, design e moda e o nascimento dos ideais de estilismo e design no Brasil por meio das iniciativas da Rhodia e do MASP

3.3

171 Nomenclaturas do campo do design no campo da moda

3.4

172 Ensino e pesquisa no design de moda

3.5

175 Discussão sobre as diretrizes do MEC para o curso de Design de Moda

3.6

177 Observações sobre etapas de estilismo e projeto em moda publicadas nos artigos do colóquio de moda e no P\&D Design
186 Considerações sobre os artigos analisados

190 Referências do Capítulo 3

Capítulo 4

195 Nas agências de fomento como se vinculam as áreas de moda e design na FAPESP, CAPES e CNPq

4.1

200 Avaliação da submissão e distribuição de recursos por área

4.2

203 O perfil das agências de fomento e os pedidos de apoio para projetos em moda e design

4.3

208 Os autores de projeto, as especificidades do design de moda e o grupo moda como campo do saber 
4.4

212 Considerações finais sobre as agências de fomento

216 Referências do Capítulo 4

Capítulo 5

219 As noções de estilismo e projeto de moda no Politecnico di Milano, na Itália

224 A disciplina Laboratorio

Di Sintesi Finale ministrada por Giovanni Conti

235 A disciplina Metaprogetto ministrada por Paola Bertola

5.2 .1

235 Aspectos históricos e

político-pedagógicos em Metaprogetto

237 As aulas de Metaprogetto
5.3

246 A noção de projeto por Nanni Strada

$250 \stackrel{5.4}{O}$ ensino de projeto por Nanni Strada

252 Referências do Capítulo 5

Capítulo 6

255 Mito e aura versus anonimato e produção industrial nas noções de estilismo e projeto em moda

6.1

258 Fundamentação da noção de mito

261 mito na fala dos autores e pioneiros

6.3

284 A noção de mito nos artigos do colóquio de moda e no P\&D 
6.4

286 A nomenclatura dos cursos

de moda em São Paulo

291 Referências do Capítulo 6

295 Considerações Finais

302 Referências Gerais

309 Anexos

311 Anexo A

CD com as entrevistas 


\section{FAPESP}

Fundação de Amparo à

Pesquisa do Estado de São Paulo

\section{Lista de siglas e abreviaturas}

\section{FASM}

Faculdade Santa Marcelina

\section{FAUUSP}

Faculdade de Arquitetura e Urbanismo da Universidade de São Paulo

\section{MASP}

Museu de Arte de São Paulo

Assis Chateaubriand

\section{CA/DI}

Coordenação de Area de Desenho Industria

\section{MEC}

Ministério da Educação e Cultura

\section{CAPES}

Coordenação de Aperfeiçoamento

de Pessoal de Nível Superior

\section{CETIQ}

Centro de Tecnologia da

Indústria Química e Têxti

\section{$\mathrm{CNPq}$}

Conselho Nacional de

Desenvolvimento Científico e Tecnológico

\section{CPTC}

Cadeia Produtiva Têxtil e de Confecção

\section{CPTV}

Cadeia Produtiva Têxtil e de Vestuário

\section{EACHUSP}

Escola de Artes, Ciências e Humanidades da Universidade de São Paulo

\section{FAACUNESP}

Faculdade de Arquitetura, Artes e

Comunicação da Universidade Estadual

Paulista "Júlio de Mesquita Filho"

\section{P\&D}

Congresso Brasileiro de Pesquisa e Desenvolvimento em Design

\section{PUCRJ}

Pontifícia Universidade

Católica do Rio de Janeiro

\section{SENACSP}

Serviço Nacional de Aprendizagem

Comercial de São Paulo

\section{SENAI}

Serviço Nacional de Aprendizagem Industrial

TCC

Trabalho de Conclusão de Curso

TFG

Trabalho Final de Graduação

UAM

Universidade Anhembi Morumbi

UVA

Universidade Veiga de Almeida 
Introdução 
A vivência proporcionada pelo contato com o ensino das atividades de pesquisa, criação e desenvolvimento de produtos em importantes faculdades de moda da cidade de São Paulo e no Politecnico di Milano na Itália, denominadas, ora como estilismo, ora como projeto em moda, levou à percepção de que, mesmo com enormes diferenças entre a divisão por etapas e as atividades, existia uma mesma noção que permeava as duas práticas; esta percepção aumentou o interesse na investigação de algum consenso sobre elas. 
Dois fatores foram determinantes diante da dificuldade de se obter algum consenso sobre a noção de projeto em moda. Um deles diz respeito às diferentes formações dos docentes e pesquisadores que deram corpo ao campo acadêmico de moda e, consequentemente, às noções de estilismo e de projeto em moda; e o outro se refere à diversidade de posicionamentos perante as noções de estilismo e projeto em moda encontrada nas primeiras e mais tradicionais instituições (FASM, UAM e SENAC SP) a criarem os cursos superiores em moda.

O ensino e a produção de moda ${ }^{1}$ originam-se de um mundo complexo. A exemplo do design italiano, a configuração de produtos industriais no Brasil foi, durante muito tempo, realizada e ensinada por arquitetos, para só bem mais tarde se tornar uma atividade regulamentada pelo estatuto que rege a profissão de designer. Essa realidade também afetou os cursos superiores de moda.

Diante desse contexto, a hipótese central apresentada pela presente pesquisa é de que não existe consenso sobre o conceito de projeto em moda no Brasil, no âmbito acadêmico, inaugurado em 1988.

Assim, apurar as noções de estilismo e projeto em moda $^{2}$, oferecendo um mapeamento homogêneo sobre essas noções praticadas no campo a partir do diálogo entre os pioneiros, é um dos objetivos principais desta tese, direcionado por essa hipótese central. Averiguar como a noção de estilismo foi influenciada pela noção de projeto ao longo do tempo, uma vez que a noção de estilismo é anterior à de projeto em moda, representa um outro objetivo importante desta pesquisa. Em seguida, pretende-se abrir os temas do estilismo e do projeto em moda no âmbito acadêmico para o debate, tendo em vista que a hipótese reforça tal necessidade.

Enfim, detectar quais são as etapas e em que ordem elas ocorrem, conseguindo deflagrar dessa forma um processo; gerar registros escritos $\mathrm{e}$ reconhecidos como discursos oficiais sobre a noção de estilismo e projeto em moda por meio de livros e artigos; verificar como as questões da aura, do design de autor e do mito afetam as noções de estilismo e de projeto em moda e em que instituições elas se mostram mais fortes representam os objetivos secundários deste trabalho.

Esses objetivos visam propiciar alguns avanços rumo à indagação central que motivou esta tese e ajudou a formular a hipótese: seria possível diminuir as discordâncias e institucionalizar práticas projetuais voltadas à moda a partir da troca entre professores e pesquisadores do campo?

Buscou-se vincular os capítulos que serão apresentados nesta tese de modo a fornecer um panorama geral das noções de estilismo e de projeto, dentro do recorte proposto (eixo RJ-SP), visando fomentar o debate na Academia. A divisão por etapas de projeto foi a forma escolhida para contemplar o estudo das noções de estilismo ou projeto em moda, nesta tese, uma vez que tais atividades configuram processos usualmente descritos através da divisão por fases.

Essas etapas de projeto dependem de uma ordem de encadeamento característica da maioria das metodologias de projeto, sendo capaz, ao mesmo tempo, de otimizar a organização e facilitar a leitura deste texto. Além disso, a disposição em etapas ordenadas auxilia na manutenção da coerência e dá unidade ao trabalho, à medida em que as noções de projeto são discutidas. Embora essa característica seja marcante em todos os capítulos da tese, ela se mostra mais evidente nos capítulos 1 e 2 , sobretudo no tópico 2.6.

O capítulo 1, "Revisão de literatura crítica sobre Estilismo e Projeto em Moda", propõe um exame sobre os principais livros sobre estilismo, projeto em moda e projeto em design, de forma a relacioná-los a partir da ótica dos principais autores da área dentro de seu campo de atuação, promovendo um diálogo entre eles.

Optou-se por pesquisar também a noção de projeto em design, pois, além do fato de o campo do design ter absorvido o campo da moda em termo acadêmicos no que tange à noção de projeto, entende-se que há influênci sobre as noções de estilismo e projeto em moda. Isso se deu pelo fato de o campo do design da ter sido formalizado e legitimado em um momento anterior, apresentando, portanto, um corpo de maior produção acadêmica do que o campo da moda.

Os autores que se dedicam ao tema do estilismo ${ }^{3}$ e projeto em moda são Sue Jenkin Jones (2005), Simon Seivewright (2009), Elinor Renfrew e Colin Renfrew (2010) e Doris Treptow (2013). No campo do projeto de produto ${ }^{5}$ destacam-se Bernd Löbach (2007), Bruno Munari (2008) e Gustavo Amarante Bomfim (1998), e no design visual, Bruno Munari (2011). As análises e reflexões propiciadas pela leitura da tese e pelo depoimento de Cláudia Garcia Vicentini (2010), que tratam das ferramentas e da metodologia de projeto aplicadas à criação de produtos para a indústria têxtil-confecção contribuíram de forma decisiva sobretudo para o Capítulo 1 desta tese.

Entre os oito autores analisados, duas delas, Treptow e Vicentini, são brasileiras. Isso mostra que há produção na área no país e, sobretudo, que há interesse pelo assunto.

Em seguida, no Capítulo 2, a discussão é estendida aos chamado "pioneiros" da área, a fim de averiguar como a questão é refletida no campo da moda, a partir das informações coletadas por meio de entrevistas. Os dados sobre projeto foram coletados durante pesquisa de campo do ano 2014 ao ano 2018.
2 Moda - a palavra Moda com letra maiúscula é tratada por esta tese corresponde a um fenômeno cíclico que se baseia na imitação se baseia na imitação
presente em todas as sociedades desde a Antiguidade (TARDE, 1993). Ele esta relacionado a um movimento de imitação na busca de reconhecimento
social em determinado contexto histórico, ou eja, está relacionado a modos e formas de viver SAPIR (1931). Este conceito de moda se pauta por mudanças constantes $e$ de curta duração. Para Bellavitis (2007), a moda absoluta da renovação uma vez que denuncia o desconforto por meio de diferentes manifestaçōes de tribos distintas que compõem a sociedade que por sua vez, é divida em classes. A Moda em seu sentido efêmero é discutid por Christo (2006) em comparacẵo ao styling no

Estilismo - atividade de pesquisa, criação e desenvolvimento de produto composta por uma atividade pautada pela lógica do campo da arte, ou seja, mais orientada pela produção do mito (vide Capitulo 6).

4 Projeto em Moda desde 1998, passa a se pautar pela atividade de Projeto de Produto advinda do campo do design. Atualmente ainda prevalecem controvérsias
em funcăo das etapas de em funçăo das etapas de projeto do design nem as etapas necessárias ao desenvolvimento 
5 Projeto de Produto - atividade composta saber: processso, projeto e produto, pautada por um posicionamento ideológico mais orientado a racionalizar etapas de processos como sugere Bonsiepe ou Bomfim. mais rígida como atividad projetual se comparado ao estilismo. Rafael Cardoso Denis (2000) alerta que "o design no Brasi tem forte influência da tradiçăo modernista" que o vincula ao racionalismo e ao funcionalismo como
instrumentos ideológicos instrumentos ideologicos acordo com Christo (2006)

São considerados pioneiros, nesta tese, os primeiros docentes e pesquisadores que atuaram no início e no desenvolvimento do campo acadêmico de moda até o presente momento, e que colaboraram para a especialização do campo do projeto em moda por meio de suas pesquisas e ações, tais como a prática docente e a criação de cursos de stricto sensu.

Nesse capítulo, intitulado "Noções de Estilismo e Projeto em Moda no campo acadêmico", são apresentadas as noções de estilismo e projeto em moda em cada uma das instituições investigadas, isto é: FASM, UAM, SENACSP, EACHUSP, FAUUSP, FAACUNESP BAURU, no estado de São Paulo, além da PUCRJ, SENAI CETIQT e UVA na cidade do Rio de Janeiro. No mesmo capítulo, privilegia-se a divisão por etapas de projeto extraída do testemunho dos pioneiros, de forma a tornar a leitura e a busca de informações mais fluente. A escolha dessas instituições baseou-se no fato de as mesmas reunirem a maior e a melhor produção sobre projeto em moda no país.

Ao todo foram realizadas trinta e cinco entrevistas com trinta e três pioneiros, utilizadas no segundo capítulo. Além dos denominados pioneiros, foram também entrevistados seis profissionais cujo perfil não corresponde à noção do que denominados, nesta tese, um pioneiro. No total, a tese conta com trinta e nove entrevistados.

Para a coleta das fontes primárias, a obra de Verena Alberti (2013, p. 2159, passim) "Manual de História Oral", foi utilizada como principal obra de orientação do processo de construção de roteiros, métodos e técnicas de entrevista e transcrição, carta de cessão dos depoimentos, assim como em relação ao armazenamento e preservação de dados dentro de um cronograma, no sentido de alinhar o processo de entrevistas, o que foi importante principalmente para a coleta adequada de dados.

As entrevistas realizadas possuem caráter temático (ALBERTI, 2013, p. 48) e exploratório. As entrevistas de caráter exploratório permitem conhecer um fato a partir de uma visão geral, sobre a qual as pessoas envolvidas com a discussão e reflexão sobre determinado problema estimulam sua melhor compreensão, por meio de suas experiências relatadas.

No que diz respeito ao tratamento de dados qualitativos, Jean Poupar (2008, p. 215) mostrou-se um autor relevante, por abordar algumas dimensões da entrevista de tipo qualitativa que enfatizam a importância do contexto no discurso, o papel da subjetividade do pesquisador e a influência que os relatos sofrem no processo de transcrição.

A atividade do pesquisador no momento da coleta e tratamento de dados qualitativos deve ser pautada pelo senso crítico e pelo cuidado em evitar distorções de significados durante o processo de transcrição, de acordo com Gilberto Velho (1980, p. 16).
Além de Alberti, Poupart e Velho, outros autores que contribuíram para a estruturação do Capítulo 2 foram Alberto Cipiniuk (2014), que enfatizou a importância de um embasamento teórico sobre o projeto na formação do designer e, novamente, Bruno Munari (2008), Elinor Renfrew e Colin Renfrew (2010), além de Cláudia Garcia Vicentini (2010), cujas reflexões deram suporte às suas teorias e ações sobre projeto.

Por meio do cruzamento entre as etapas de estilismo e projeto apresentado nos capítulos 1 e 2, que expõem os resultados da revisão da literatura e da pesquisa de fontes primárias, por intermédio de entrevistas de caráter exploratório, buscou-se o estado da arte sobre os conceitos de estilismo projeto em moda. $O$ estado da arte em estilismo e projeto em moda foi tratado por esta pesquisa como uma etapa metodológica para a comprovação de sua hipótese central.

Ficou a cargo do tópico 2.6, "Convergências e divergências entre as noções de Estilismo e Projeto na literatura e no campo acadêmico", apontar as possíveis convergências e divergências estabelecidas acerca dessas noções, o que foi possibilitado pelo estado da arte das mesmas.

A partir da ordem em que costumam ocorrer as etapas de estilismo $e$ projeto, tal como consagrada pelo ensino e pela pesquisa, buscou-se construir analogias entre elas e suas nomenclaturas, relacionadas a seus respectivos autores ou depoentes.

O habitus ${ }^{6}$, conceito profundamente analisado por Pierre Bourdieu (1989), foi útil para evidenciar, nesta pesquisa, o porquê de várias faculdades que já adotaram a disciplina de projeto em moda continuarem operando a disciplina como se ela se tratasse do ensino sobre estilismo.

Entre os autores abordados por este tópico estão: Gustavo Amarante Bomfim (1998), Sue Jenkin Jones (2005), Bernd Löbach (2007), Bruno Munari (2008/2011), Simon Seivewright (2009), Elinor Renfrew e Colin Renfrew (2010) e Doris Treptow (2013), que contribuíram com as explicações e análises sobre as etapas de estilismo, projeto em moda projeto em design examinadas, além do já citado Pierre Bourdieu (1989).

Outro entrevistado, Troy Nachtigall, apesar de não se encaixar no perfil de pioneiro, contribuiu para complementar o tópico 2.6. Trata-se de um pesquisador e designer experiente, que já atuou em marcas como Hugo Boss, Jean Paul Gaultier Jeans, Calvin Klein e Calvin Klein Jeans possui uma visão um pouco diferente da noção brasileira, o que enriquece o debate. Ele foi entrevistado na Holanda, por ocasião de uma visita técnica em março de 2016 à TU/e, Technische Universiteit Eindhoven.

O Capítulo 3, "As noções de Estilismo e Projeto em Moda no Colóquio de Moda e no Congresso Brasileiro de Pesquisa e Desenvolvimento em Design P\&D” procurou mapear as noções sobre estilismo e projeto em
Segundo Bourdieu (1989: 61) $o$ habitus refere-se a uma disposiçăo incorporada por um agente em determinad
área, ou seja, trata-se de uma atividade natural a um campo de atuação exercid por um agente reconhecido por este campo. $O$ agente só é reconhecido pelo campo quando seus pares 0 econhecem. 
moda a partir da visão de pesquisadores que publicaram e/ou publicam análises sobre estes temas nos eventos Colóquio de Moda e P\&D.

$\mathrm{O}$ capítulo 3 é dividido em sete partes. A primeiras delas busca destacar as convergências e divergências encontradas nos artigos escritos sobre estilismo e projeto em moda para o Colóquio de Moda e para o P\&D. Alguns autores contribuem para os dois eventos e, por vezes, são encontradas contradições. Em seguida, na segunda parte, descreve-se a possível existência de um diálogo entre arte, design e moda, que pode ser evidenciado em alguns artigos que tangenciam a noção de projeto. Esse diálogo teria influenciado o ideal de estilismo $\mathrm{e}$ de projeto em moda décadas antes do surgimento dos cursos de nível superior em Moda, correspondendo às iniciativas da Rhodia e do MASP que deflagraram tanto pontos em comum quanto contradições entre as ações dos campos da moda e do design.

A questão da nomenclatura aparece na terceira parte do Capítulo 3 e permeia inúmeros artigos que se dedicam às etapas de estilismo e projeto em moda, seja no ensino, na pesquisa ou na atuação profissional. As denominações e as respectivas atividades desenvolvidas em cada etapa de estilismo ou projeto em moda variam entre os autores dos artigos. Um dos pontos que despertam a atenção diz respeito à interpretação feita pelos autores dos artigos sobre projeto, utilizados como fonte secundária de apoio à escrita dos textos publicados nos eventos. Um mesmo autor de um livro reconhecido de projeto em moda ganha diferentes interpretações e têm etapas diversas enfatizadas entre os artigos analisados, mesmo que 0 enfoque, entre estes artigos distintos, seja o mesmo.

O ensino e a pesquisa sobre estilismo e projeto em moda surgem na quarta parte do Capítulo 3, como objetos de análise recorrentes em artigos dedicados ao tema. Na quinta parte, a deliberação de diretrizes do MEC para a regulamentação dos cursos de Design de Moda é tratada como um tema indiretamente relacionado à questão do ensino e da pesquisa.

Na sexta parte foram consideradas as divergências e convergências, com foco nas etapas de estilismo e projeto em moda, procurando manter a mesma ordem dos capítulos 1 e 2 . A sétima parte apresenta uma breve reflexão acerca das questões examinadas ao longo do Capítulo 3.

O Capítulo 4, nomeado "Nas agências de fomento - como se vinculam as áreas na FAPESP, CAPES e CNPq" dedica-se a esclarecer como tais agências enxergam as áreas da Moda e do Design, a partir da questão do estilismo e do projeto em moda, e como as vinculam nesse processo, do ponto de vista dos coordenadores de área dessas agências de fomento.

Para esse Capítulo foram entrevistados Luiz Henrique Lopes dos Santos, coordenador adjunto da grande área de Ciências Humanas e Sociais da
FAPESP, que coordena, entre outras áreas, Arquitetura e Urbanismo, a qual responde por Design e Moda; Ricardo Triska, coordenador da área de Arquitetura e Urbanismo, área responsável pelo Design e pela Moda na CAPES; e Eugenio Andrés Diaz Merino, coordenador da área de Desenho Industrial do CNPq.

Dados dos relatórios anuais publicados pelas agências em seus sites também foram utilizados nesse Capítulo, para esclarecer ou reforçar a fala dos entrevistados.

Como alguns pioneiros também contribuem na avaliação de projetos, fornecendo pareceres a pedido dessas agências de fomento, alguns de seus depoimentos também são reportados nesse capítulo.

O Capítulo 4 está dividido em quatro partes. Começa por destacar alguns aspectos considerados na avaliação de projetos submetidos à análise, e na distribuição de recursos dessas agências. Na segunda parte, busca traçar um panorama das agências de fomento e do perfil dos pesquisadores e projetos do campo do Design e do Design de Moda. Na terceira parte, são discutidos os autores de projeto, as especificidades do campo do Design de Moda e o grupo Moda como campo do saber. Por último, na quarta parte, são feitas considerações gerais sobre o capítulo, com ênfase no cruzamento dos pontos de vista dos coordenadores de área entrevistados.

Até este ponto da tese são apresentados diversos quadros nesses capítulos. Sua função é descrever as atividades acadêmicas e profissionais dos entrevistados nos capítulos 1,2 , e 4, auxiliando a leitura da tese e agilizando o acesso à informações.

Em função do legado projetual que o ensino brasileiro em moda herdou da Itália, por intermédio de inúmeras iniciativas envolvendo os chamados pioneiros, o Capítulo 5, intitulado "As noções de estilismo e projeto em moda no Politecnico di Milano na Itália", lança um olhar sobre a questão do projeto em moda a partir da pesquisa em um grande centro de estudo internacional, o Politecnico di Milano, na Itália.

Essa escola possibilitou o contato da pesquisadora com importantes designers, professores e pesquisadores que atuam ou já atuaram nesta instituição, entre eles Nanni Strada, Giovanni Conti, Paola Bertola, Federica Vacca e Paolo Volonté. À exceção de Strada, que não leciona atualmente no Politecnico, foram assistidas as disciplinas dos demais professores citados no ano de 2017, principalmente quando estas se relacionavam diretamente à problemática do projeto. Além disso, foram também entrevistados Nanni Strada e Giovanni Conti.

No momento da abertura dos cursos superiores em moda no Brasil, sabe-se que especialistas brasileiros pesquisaram cursos no exterior na construção de um modelo que se adaptasse à realidade brasileira. Assim, foram tomados como modelos principalmente os cursos franceses, italianos, 
ingleses e americanos, sendo que os três primeiros países exerceram uma influência mais forte sobre o ensino de moda no Brasil.

Uma vez que a formação dos designers ingleses ocorre dentro de escolas de arte, as quais apresentam uma forte tendência ao estilismo, e pelo fato de a França não contar com cursos ou pesquisas em nível de doutorado no campo da moda, o ensino de moda italiano foi o que mais despertou o interesse desta pesquisa, já que é aquele que mais fomenta a noção de projeto em moda, privilegiada por esta tese. No mesmo capítulo há uma breve análise da condição social do designer, apoiado principalmente sobre as reflexões de Angela McRobbie (1998).

De caráter conclusivo, o Capítulo 6, "Mito e aura versus anonimato e produção industrial nas noções de estilismo e projeto em moda" se dedica a refletir acerca do conteúdo dos capítulos anteriores, com vistas a analisar o papel do mito, da aura, do anonimato e da produção industrial, elementos que podem estar presentes de diversas formas no trabalho do estilista e do designer de moda.

O interesse aqui é compreender como a noção de Mito interfere na constituição do campo do Design de Moda. O Mito tenta explicar ou justificar fatos que não podem ser compreendidos a priori, mas que aferem poder simbólico a um "escolhido". Para fundamentar a noção de Mito foi utilizada a abordagem de Pierre Bourdieu e Yvette Delsaut (1989), segundo a qual o mito reside nas relações cultivadas pelo criador, que o cercam de poder (BOURDIEU; DELSAUT, 2001, p. 26). Também foi relevante contar com a abordagem de José Carlos Durand (1988, p. 53-55, passim), o qual também sustenta que o poder que o criador possui está diretamente ligado ao reconhecimento que $\mathrm{o}$ aparelho de celebração promove em torno dele $\mathrm{e}$ ao irreconhecimento da crença.

Além dos autores acima, outros três colaboram para a conceituação de mito: Roland Barthes (2007), Cecilia Almeida Salles (2013) e Angela McRobbie (1998)

A ideia de que o mito é um "sistema de comunicação, uma mensagem" está na base do pensamento de Barthes. O mito trata de investir imagen e uso social à matéria, no caso, ao produto de moda. Ao longo do tempo ele muda e dá a sensação de desaparecer, mas na verdade outro mito o substitui e assim, ele se propaga em uma forma fugidia, vazia, parasitária e empobrecida marcado por associações frágeis e ilimitadas (BARTHES, 2007, p. 199-210, passim) à semelhança da violência simbólica imposta pelo mito, na visão de Bourdieu e Delsaut, segundo a qual, o mito só se mantém enquanto ele não pode ser apreendido em sua realidade.

A matéria só se torna acessível por meio da materialização de um significado que faz parte de um sistema de signos construídos para manter uma "nova realidade" (SALLES, 2013, p. 139), a do mito. A matéria nesse contexto seria o produto de moda.

Onde ○ Mito opera ele dispensa explicações, reflexões e debates (BOURDIEU; DELSAUT, 2001, p. 45-46), o que torna as atividades de estilismo e projeto cada vez mais distantes de serem compreendidas como assunto acadêmico e profissional em suas questões práticas e dialéticas, fundamentadas por uma crítica séria. E também pela existência de práticas dentro das instituições que perpetuam esse comportamento (McROBBIE, 1998, p. 63)

As acepções de Bourdieu, Delsaut, Durand, Barthes, Salles e McRobbie coincidem e complementam-se entre si. Mais do que isso, elas confirmam as impressões que rondam a atividade criativa do estilismo e projeto em moda. Essas impressões se traduzem pela "magia" e por "um algo mais" quase místico e esotérico, portanto difícil de ser apreendido, que parece reger $\mathrm{o}$ ato projetual quando associado ao mito.

Existe uma ideia predominante no meio acadêmico relacionada ao mito, segundo a qual ele sustenta o fazer do estilista como uma atividade mais artística, enquanto o fazer do designer estaria envolvido com o pragmatismo da indústria. Ao longo do Capítulo 6 o que se percebe é que nem sempre é isso que ocorre.

Por último, nas Considerações Finais buscou-se articular questionamentos que surgiram a partir das discussões realizadas nos capítulos anteriores, de modo a propor um balanço sobre o assunto, guiando as reflexões finais, apontando como os objetivos foram alcançados e se a hipótese foi confirmada, de forma a contribuir com a comunidade científica. 
BARTHES, Roland O Sistema da Moda São Paulo: Universidade de São Paulo, 1979.

BARTHES, Roland. Mitologias. Rio de Janeiro: DIFEL, 2007.

BELLAVITIS, A.A.. Prefazione. In: Cappellieri, A. Moda e design: il progetto dell'eccellenza. Milão: FrancoAngeli, 2007.

BOURDIEU, Pierre; DELSAUT, Yvette. O costureiro e sua grife: contribuição para

uma teoria da magia. Trad. Maria da Graça

Jacintho Setton. In: Educação em Revista, Belo Horizonte, n. 34, p. 7-66, dez. 2001. Disponível em: <http://docslide.com.br/documents/

bourdieu-o-costureiro-e-sua-grife.html>. Acesso em: 30 jul. 2016.

CHRISTO, Deborah Chagas. Designer de moda ou estilista? Pequena reflexão sobre a relação entre noções e valores do campo da arte, do design e da moda. In: COLOQUIO DE MODA, 2., 2006, Salvador. Anais... Salvador: UNIFACS, 2006.

DENIS, Rafael Cardoso. Uma introdução à história do design. São Paulo: Edgard Blücher, 2000.

DURAND, José Carlos. Moda, luxo e economia. São Paulo: Babel Cultural, 1988.

LIPOVETSKY, Gilles. 0 império do efêmero: a moda e seu destino nas sociedades modernas. São Paulo: Companhia das Letras, 1989.

SALLES, Cecilia Almeida. Gesto inacabado: processo de criação artística. São Paulo: Intermeios, 2013, p. 186.
SAPIR, Edward. Verbete "Fashion" in E R.A. Seligman (Ed.), Encyclopaedia of Social Sciences. New York, Macmillan, 1932, vol. VI, pp. 139-144.

TARDE, G. As leis da imitação. Porto: Rés Editora, 2000.

VESTUÁRIO. In: DICIONÁRIO Priberam da Língua Portuguesa. 2008-2013. Disponível em: <https://www.priberam.pt/dlpo/

vestu\%C3\%A1rio>. Acesso em: 15 jun. 2018. 
Revisão de Literatura Crítica sobre Estilismo e Projeto em Moda 
Este capítulo propõe uma breve revisão e reflexão das principais obras sobre estilismo e projeto em moda e design, através da exposição de suas etapas. $O$ fato de a bibliografia de projeto em moda ser recente serve como justificativa a esta revisão.

Foram indicados abaixo autores que publicaram livros sobre projeto em moda ou estilismo (TREPTOW, 2003/2013; JONES, 2005; SEIVEWRIGHT, 2009; RENFREW; RENFREW, 2010), e elencados também autores nos campos do projeto do design de produto (LÖBACH, 1976/2007; BOMFIM, 1998) e da comunicação visual (MUNARI, 1989/2011), considerando o reconhecimento e alcance das obras dos mesmos. 
A seleção de autores, principalmente no campo do design, se deu por meio do depoimento de um informante privilegiado, no caso o professor Marcos da Costa Braga que colaborou intensamente na co-orientação desta tese.

O método qualitativo de usar um informante privilegiado consiste na coleta de informações por meio de um depoente envolvido na discussão (POUPART, 2008, p. 223). O professor Marcos Braga é designer de formação e lecionou por doze anos a disciplina de Metodologia de Projeto em dois cursos de graduação em Design na cidade do Rio de Janeiro, além de ser pesquisador e orientador de trabalhos de pesquisa no campo do design. Sua experiência e vivência direta com o problema o qualificam como informante privilegiado e, como tal contribuiu fornecendo referências de autores mais recorrentes no campo do design de produtos e visual.

Justifica-se a inclusão da noção de projeto de produto e visual pelo fato de o campo do design ter se solidificado anteriormente à constituição do campo do estilismo e do design de moda. Daí, acredita-se que possa ser possivel a transferência de conhecimento do design de produto e visual para as áreas do estilismo e do design de moda.

Embora as etapas analisadas variem de um livro para outro, objetivou-se promover uma reflexão sobre as mesmas a partir da descrição das principais etapas do projeto em design de moda ou estilismo, a partir desses autores e de suas ênfases.

A maioria dos livros de projeto ora reportam-se ao profissional ora ao estudante. Isso nem sempre é muito claro e há afirmações que se aplicam aos dois casos. Embora respeitando a visão dos autores, este texto irá procurar assinalar quando a fala se dirigir ao estilista, ao designer já formado ou ao aluno.

Ao longo da tese ao comparar as metodologias de projeto em moda com as de projeto em design tem-se a impressão de que principalmente as metodologias do design de produto parecem menos flexíveis em relação às subjetividades do campo do design de moda. No design as metodologias tendem a se mostrar mais preocupadas em racionalizar todas as etapas de processos como se vê em autores como Bonsiepe ou Bomfim.

\section{Etapas do Estilismo 1.1 e do Projeto em Moda}

Abaixo segue a noção de projeto em moda descrita por cada autor elencado por este capítulo organizada por etapas. 


\section{Quadro 1}


Local e data de nascimento

Local e data de morte

Bernd Löbach

Nasceu em 05/11/1941 em Wuppertal (Alemanha)

\section{Bruno Munari}

Nasceu em Milão (Itália) em 24/10/1907

e faleceu em 30/09/1998 em Milão (Itália)

\section{Colin Renfrew}

Nasceu em Paisley (Escócia) 31/03/1957

\section{Doris Treptow}

Nasceu em Pelotas (Brasil) em 11/05/1970

\section{Atividades profissionais e obras publicadas}

Estudou design e sociologia. De 1968 a 1975 foi professor de design na Fachhochschule Bielefeld (Escola Técnica Superior de Bielefeld) e desde 1975 é professor na Hochshule für Bildende Künste (Escola Superior de Artes Aplicadas de Braunschweig). Entre os livros que publicou é de interesse especial desta pesquisa "Design Industrial - Bases para a configuração dos produtos industriais", lançado em 1976 pelo próprio autor e traduzido para o português pela Editora Blucher em 2001. A edição utilizada nesta pesquisa é a de 2007. Além desse livro publicou "Design e Desenvolvimento: 40 anos depois" (2016) e mais nove livros sobre Design, além de outros quarenta livros sobre temas diversos.

\section{Elinor Renfrew \\ Nasceu em 30/11/1954}

Artista e designer gráfico com produção reconhecida em sua área, publicou entre outros livros "Das coisas nascem coisas" (1981; 2008) e "Design e comunicação visual: contribuição para uma metodologia didática" (1989; 2011) objetos de estudo desta pesquisa. Seus livros se dedicam à visualidade voltada ao design, às artes e à literatura infantil. Possui cerca de quarenta livros publicados.

Graduado pela Glasgow School of Art, possui MA pela Central Saint Martins College of Art and Design, atualmente é vice-reitor da Manchester Metropolitan University no Reino Unido. Leciona há vinte e sete anos no Reino Unido, Sri Lanka, Austrália e Rússia. É professor visitante do Instituto de Tecnologia em Moda de Pequim e da Academia de Arte da China. Atualmente é coordenador da School of Design and Technology no London College of Fashion. Juntos,
Elinor Renfrew e Colin Renfrew lançaram em 2009 pela AVA Publishing o livro Basics Fashion Design: Developing a Collection que chegou ao Brasil em 2010 pela editora Bookman com o título "Desenvolvendo uma coleção".

Desde 2005 é professora do Savannah College of Art and Design nos Estados Unidos e em Hong Kong. Foi professora da Universidade Regional de Blumenau. Seu livro, lançado pela primeira vez em 2003, intitulado "Inventando moda: planejamento de coleção" ganhou nova edição ampliada em 2013. O livro nasceu em 2002 como apostila da disciplina "Desenvolvimento de coleção" no curso de bacharelado em moda da Universidade Regional de Blumenau (FURB).

\section{Gustavo Amarante Bomfim Nasceun} e faleceu no Rio de Janeiro em 30/12/2005
Atuou durante quinze anos em diversas áreas da indústria da moda, incluindo um negócio próprio. Possui MA pela Central Saint Martins College of Art and Design e leciona há quinze anos em cursos de moda em Melbourne, Edimburgo e Manchester. Atualmente ela é coordenadora do B.A. em moda na Kingston University. Juntos, Elinor Renfrew e Colin Renfrew lançaram em 2009 pela AVA Publishing o livro Basics Fashion Design: Developing a Collection que chegou ao Brasil em 2010 pela editora Bookman com o título "Desenvolvendo uma coleção".

\section{Simon Seivewright}

Nasceu no Reino Unido em 14/06/1973

e faleceu em 13/09/2013 em Hove no Reino Unido
Possui graduação em Desenho Industrial pela Escola Superior de Desenho Industrial, ESDI (1975), especialização em Teoria e Metodologia do Design pela Bergische Universitaet Wuppertal (1981), mestrado em Engenharia de Produção pela Universidade Federal do Rio de Janeiro (1978) e doutorado em Design pela Bergische Universitaet Wuppertal (1988). Foi professor Associado da Pontificia Universidade Catolica do Rio de Janeiro, da Universidade Federal do Pernambuco e Universidade Federal da Paraíba. Tem experiência na area de Desenho Industrial, com ênfase em Desenho de Produto, tendo atuado principalmente nos seguintes temas: design, estética, história. Entre seus livros pode-se citar "Ideias e Formas na História do Design", publicado em 1998 pela editora João Pessoa da UFPB que é de maior interesse desta pesquisa.

Estudou moda na Universidade de Brighton, onde se formou como "estudante de graduação do ano". Após sua graduação dedicou-se ao ensino e se tornou coordenador do Northbrook College em Worthing, West Sussex, onde lecionou para os cursos de moda e design. No Northbrook College, publicou seu livro "Academic Research and Design" que no Brasil foi traduzido em 2009 pela editora Bookman como "Fundamentos de design de moda: Pesquisa e Design".

\section{Sue Jenkin Jones}

Dedica-se ao ensino superior e à indústria como designer de moda. Desenvolveu numerosos currículos de B.A. e Mestrado e programas de formação de curta duração em inúmeras práticas de moda e assuntos culturais. Participa de equipes internacionais de pesquisa, planejamento acadêmico, validação e comitês de exame. Durante os anos 1980 atuou como CEO da moda marcas No? Yes!, BarRoque e Clones, as quais desfilavam regularmente na London Fashion Week e eram comercializadas em lojas de departamentos tais como Harrods, Harvey Nichols (Londres), Printemps e Galerias Lafayette (Paris), Barneys (New York), Fiorucci (Itália) e Isetan (Tokyo). Posteriormente, atuou na Quorum (Radley Group) e French Connection também como designer de moda. Em 2002 lançou seu livro "Fashion design" pela Central Saint Martins Book Creation, lançado no Brasil em 2005 pela editora Cosac Naify como "Fashion design - manual do estilista". 


\section{Modelos de Briefing e Projeto}

O Projeto é o momento em que informações de natureza abstrata serão transformadas em algo concreto, a forma. Há três principais tarefas nessa atividade: a organização de informações, a geração de conceitos e a apresentação de resultados (BOMFIM, 1998, p. 162).

"A organização é a tarefa de definição dos objetivos do projeto e das características do produto" (BOMFIM, 1998, p. 162). O Briefing faz parte da "organização" e também pode ser chamado de proposta, delimitação ou definição de conceito, de acordo com Renfrew e Renfrew (2010, p. 140). Para Jones (2005, p. 167-168) o briefing especifica o título, as tarefas e os objetivos relativos ao produto.

Ele representa o início de qualquer projeto criativo. Para Seivewright $(2009$, p. 12) é o projeto que fornece informações a respeito de quais tarefas ou resultados finais devem ser atingidos. $O$ projeto ajuda a identificar qualquer restrição, condição específica ou problema que demande uma solução e, dessa forma, ajuda a estabelecer que tarefas devem ser realizadas para que os objetivos sejam cumpridos.

O confronto entre os termos evidencia que uma mesma etapa, ou partes dela, é chamada de "organização" por Bomfim, briefing por Jones e de "projeto" por Seivewright.

E preciso estabelecer prazos para o cumprimento de uma sequência de atividades em cadeia para que seu objetivo seja alcançado. $O$ projeto é também um conjunto de atividades que guia o estilista e o processo, com 0 auxílio de um cronograma. A finalidade do cronograma é delinear as metas auxílio de um cronograma. A finalidade do cronograma é delinear as metas (1998, p. 162) o cronograma também pertence à fase de "organização" das informações.

O projeto abrange o problema e deve ter sua enunciação bem definida. Ele pode ser proposto pela indústria ou pelo designer. $O$ problema analisad apresenta dois componentes principais: o físico e o psicológico. O físico diz respeito à forma e o psicológico refere-se à relação entre o objeto e seu usuário (MUNARI, 2011, p. 344).

Jones $(2005$, p. 166) cita os tipos de projeto de acordo com sua experiência: há o projeto patrocinado, quando é proposto às escolas por empresas julgado por ambos. $O$ projeto para concursos, que também é proposto por empresas, tem o resultado julgado somente pela empresa. Por último, no projeto em grupo, os alunos devem interagir para criar produtos de moda. Neste último, a função de cada membro é definida em grupo e a pressão grande, simulando um ambiente de trabalho. Em geral trata-se de trabalho interdisciplinares que envolvem várias disciplinas do curso de moda.

Assim como o briefing para Jones equivale ao projeto para Seivewright, - oposto também é verdadeiro. $O$ que Jones interpreta como projeto equivale ao briefing para Seivewright (2009, p. 13), que o divide em cinco tipos: 0 acadêmico, que é solicitado pelo professor; o concurso, que tem 0 
intuito de promover uma marca ou produto; o comercial, voltado a atender às necessidades de uma empresa; para o cliente de ateliê, quando alguém contrata um estilista e dá a ele algumas regras expressas a serem seguidas; e em grupo, no qual se trabalha em equipe.

É possível comparar os tipos de briefing e de projetos propostos por Jones e Seivewright, respectivamente. Analisados em conjunto, os projetos para concurso e grupo de Jones e os briefings de concurso e grupo elencados por Seivewright são complementares.

O briefing estaria mais suscetível a mudanças que o projeto, de acordo com Jones (2005, p.168), pois o primeiro é passível de ser ajustado, podendo variar de acordo com a estação, ocasião, cliente, mercado-alvo, problema a ser resolvido, custeio etc.

No design de produto o briefing varia menos que no design de moda, pois de acordo com Löbach (2007, p. 187), "quando a direção de uma empresa realiza o briefing do produto, na maioria das vezes, não dá nenhuma indicação sobre as características a serem incluídas na aparência estética" como sugere Seivewright (2009, p. 13). São definidos somente os materiais, o processo de fabricação e as funções práticas.

No decorrer de um curso universitário o aluno toma contato com vários aspectos dos briefings de projeto que determinam os processos que devem ser seguidos, o número ou o tipo de peças a fazer, quais técnicas usar e como deve ser a forma de apresentação final do trabalho. Tais aspectos podem já ser descritos no título do projeto e têm relação com o "problema" a ser resolvido (JONES, 2005, p. 168-169).

Nas coleções de final de curso o aluno aborda os seus interesses para mostrar suas habilidades e criatividade da melhor forma possível (RENFREW; RENFREW, 2010, p. 140), em detrimento da necessidade de um possivel público-consumidor. $O$ briefing da coleção costuma ser decidido pelo próprio aluno. No design de moda uma demanda ou um briefing nem sempre configuram um problema.

\section{Pesquisa}

O designer de moda ou estilista deve ser capaz de demonstrar, entre outras qualidades, a "capacidade de absorver e sintetizar ideias e técnicas", o que se dá no processo da pesquisa, tendo como resultado a geração de novas variantes e soluções para o problema de cobrir o corpo, além de renovar a percepção deste mesmo corpo, buscando comprovar sua criatividade como profissional (JONES, 2005, p. 8-12).

A pesquisa, de acordo com Seivewright (2009, p. 7) é uma ferramenta fundamental no processo criativo e fornece inspiração, informações direcionamento para uma narrativa ou coleção. É uma atividade pessoal que fornece ao observador "um insight sobre o pensamento, as aspirações, os interesses e a visão criativa do estilista".
A etapa subsequente ao briefing é a pesquisa de tendências (TREPTOW, 2013, p. 102). Esse é o momento em que o designer coleta todo tipo de informação e materiais que servirão de suporte para o desenvolvimento da coleção. Os painéis de tendência, importantes para visualizar elementos de estilo como amostras de cores, tecidos e aviamentos, entram neste momento.

No design de produtos as etapas de pesquisa e outros aspectos do projeto estão permeados por um pensamento crítico e marcadamente ideológico. Essas aspirações são transmitidas à etapa de pesquisa, ao retratar 0 consumidor como um usuário, por exemplo.

Löbach (2007, p. 11-14) defende que o usuário, as posturas do fabricante e do designer são alguns pontos a serem trabalhados quando se trata de design. Destes elementos, o mais fácil de ser transposto para o universo do design de moda é o usuário, uma vez que a moda não é diretamente determinada por aspectos ideológicos relacionados a tópicos tais como as posturas do fabricante e do designer.

Este traço mais simbólico e menos ideológico do design de moda é traduzido nos produtos de uso individual, os quais estabelecem uma forte relação psíquica com o usuário; o caráter identitário é neles investido, de forma que "a maneira de vestir é sempre importante nas dinâmicas sociais humanas" e, portanto, o produto de moda privilegia as questões comportamentais (LÖBACH, 2001 apud MORAIS, 2006).

No produto de moda "a função estética satisfaz necessidades psiquicas no nível sensorial, atuando por meio da aparência do produto" (MORAIS, 2006).

Apesar de o design de moda não possuir o caráter funcional-racionalista mais comum ao design, o design de moda deve contemplar alguns critérios práticos. A coleção deve começar pela pesquisa e planejamento. É preciso conhecer com clareza o cliente ao qual se destina o produto, os registros de venda, o estoque, a qualidade da mercadoria e o preço (RENFREW RENFREW, 2010, p. 13). Nota-se que o design de moda não costuma utilizar o termo "usuário", preferindo cliente e/ou consumidor.

Preço, qualidade e caimento também devem ser considerados na pesquisa, de acordo com Jones (2005, p. 29). Raramente eles são avaliados na discussão sobre $\circ$ processo criativo, mas alimentam o impulso para comprar e satisfazer necessidades reais e subliminares do público.

Treptow (2013, p. 72) defende pesquisas comparativas em relação às tendências, tema de coleção, vocações regionais, mercado, comportamento e tecnologias.

Seivewright (2009, p. 65-133, passim) também chama a atenção para a pesquisa de mercado, comportamento e tecnologias. Outros dados também devem ser elencados na pesquisa, segundo o autor, como demografia estilo de vida. Uma das fontes de informação do profissional é o material produzido pelas agências de pesquisa.

As agências de pesquisa de moda são empresas que dão suporte indústria, atuando atraves da análise de tendencias de moda e manifestaçôes 
culturais atuais. Seivewright e Renfrew e Renfrew são os únicos autores aqui apresentados que se dedicam a esses tópicos em suas obras.

Muitos temas surgem como resultado de pesquisas de tendências "identificadas e compiladas para estilistas na forma de prognósticos, onde cores, tecidos, fios, silhuetas e ilustraç̃es são reunidos em livros ou apresentados on-line", em sites como o WGSN. Agências de pesquisa de tendências estabelecem direções como os bureaux Trend Union, de Li Edelkoort, que produz as revistas View on color e Bloom (RENFREW; RENFREW, 2010, p. 22).

Seja qual for a metodologia utilizada, é a partir da pesquisa que despontam os elementos do design. Eles se definem por proporção, linha, formas e estruturas, silhuetas, função, detalhes, adornos, cor, texturas, tecidos, estampas e superfícies, ornamentação, influências históricas, culturais e contemporâneas (SEIVEWRIGHT, 2009, p. 19-35). Outros autores também se dedicam a apresentar os elementos do design, mas como Seivewright se mostrou mais completo, optou-se por não repetir trechos do mesmo conteúdo, encontrados em outros autores.

A "coleta de informações" sugerida por Löbach como etapa ${ }^{7}$ metodológica do design de produtos pode ser entendida até certo ponto como a pesquisa dos elementos de design de moda, pois ambas tratam da coleta de informações, embora, no design de produtos, detalhes de aparência estética sejam secundários e no design de moda não haja foco obrigatório no problema.

A pesquisa de referências históricas na moda acontece principalmente através da análise de peças de roupas de época. Trata-se, aqui, de selecionar informações, sintetizálas em algo novo misturando-as a outras refecências de pesquisa (SEIVEWRIGHT, 2009, p. 132)

É necessário que o estilista tenha conhecimento do que está acontecendo à sua volta em termos de tendências contemporâneas, por isso Seivewright (2009, p. 133) recomenda efetuar a pesquisa de influências contemporâneas e culturais. Isso pode ajudar na escolha das cores, tecidos ou função das peças. O estilista deve conhecer também os diversos segmentos e gêneros da moda.

Por último, há dois tipos de pesquisa: a tangível, que diz respeito a tecidos e aviamentos, e o segundo tipo, que se refere à inspiração visual para a coleção, auxiliando a definir o "tema" da colccão, inspiração ou conceito, conferindo identidade ao trabalho proposto (SEIVEWRIGHT, 2009, p. 14).

Posteriormente, a pesquisa vailevar a um conceito, tema ou direcionamento para uma coleção. Prefere-se usar o termo 'direcionamento', já que 'tema' considerado problemático por ser mostrar limitador.

Esse direcionamento ou conceito pode ser dividido em três tipos. De acordo com Seivewright (2009, p. 38-39) o conceito abstrato é quando uma palavra se torna uma ideia. Conceitual é quando várias fontes visuais sem relação imediata se combinam. Por último, há o conceito narrativo, que se refere ao relato escrito sobre uma história.

\section{Registro da Pesquisa}

A criação nasce de uma inspiração para criar um clima ou visual geral para uma coleção (JONES, 2005, p. 129). Estes termos utilizados por Jones, apesar de bastante vagos, dão margem a entender que o "clima" seria formado pelas referências repertoriais recebidas pelo estilista durante o processo de pesquisa, ou pouco tempo antes, somadas ao seu repertório já constituído, enquanto o "visual geral" para a coleção seria como uma narrativa criada com estas referências do clima, as quais seriam distribuídas de forma homogênea em todos os produtos da coleção.

Em última instância o processo seguiria a seguinte ordem: inspiração, clima e visual geral para uma coleção, sendo que este último poderia aind ser entendido como a edição da coleção.

Depois de decidido qual será o clima da coleção, os próximos passos ainda de acordo com Jones (2005, p. 129) são desenhar os croquis, pesquisar tecidos, materiais e ter conhecimento de processos para então passar para a criação de protótipos. Segundo a autora essa é a ordem usual.

Essa sequência costuma ser registrada em um painel ou caderno de criação. $O$ processo de pensamento do estilista deve ser explicitado com o auxílio destes meios, através do registro das ideias de como a criação se originou.

Quanto os cadernos de croquis, Jones (2005, p. 177) afirma que eles devem ser usados para registrar a evolução dos interesses do estilista, tais como as impressões sobre artefatos, pessoas e posturas do corpo, notas sobre roupas e detalhes, cores e aspectos do meio ambiente. Eles representariam uma espécie de "diário visual" sobre uma linha de pesquisa ou tema específico.

É no caderno de croquis (ou de esboços) que se reúnem e processam todas as informações coletadas e, assim, ele se torna um espaço pessoa para trabalhar ideias, como explica Seivewright $(2009$, p. 84). Ele mostra como o estilista percebe o mundo à sua volta e expressa sua capacidade de pensar de forma criativa. Nele são exploradas e experimentadas várias maneiras de apresentar as informações produzidas.

Após os registros no caderno de croquis (ou ainda caderno de criação), pode ser começado o Painel de criação ou moodboard, que é "uma apresentação mais formal das concepções e intenções pesquisadas por meio de imagens e recortes coletados e organizados cuidadosamente" (JONES 2005, p. 177). Nele são dispostos os resultados, frutos do amadurecimento da pesquisa que foi experimentada no caderno.

O caderno de esboço não é de uso exclusivo do estilista. Ele pode ser usado como uma ferramenta ${ }^{8}$ para descrever e ilustrar uma coleção para a equipe de criação.

Visual. Esse e o nome generico para painéis que auxiliam no processo de (2010, p. 89) eles são unatos, e segundo Baxter (2001, p. 91) apud Vicentini
Ferramenta de projeto - ela permite que uma etapa seja cumprida. Dess forma, a ferramenta auxilia cumprir uma etapa de projeto. Em alguns casos, podem ser tanto uma ferramenta como uma apa. Além disso, no ponceitos tamberm nonnimos. 
informações pertinentes ao produto que está sendo elaborado, porém [...] a clareza da informação deve ser prioritária para que todos os envolvidos 2010, p. 89).

Com um bom número de imagens e ideias é possível começar a desenvolver a criação. Entre todos os autores, somente Seivewright (2009, p. 85) oferece uma metodologia para experimentar maneiras diversas de apresentar as primeiras informações produzidas. Nesse sentido, ele propõe o desenho, a colagem, a justaposição, a desconstrução e as referências cruzadas.

Das cinco metodologias propostas acima, a mais conhecida é o desenho, que é um processo fundamental de registro. A segunda é a colagem, organizada a partir de recortes de imagens que não precisam necessariamente ter relação entre si, mas que devem apresentar novas possibilidades criativas. A terceira é a justaposição, que consiste na "disposição criativa de imagens e tecidos lado a lado na página, criando contraste" (SEIVEWRIGHT, 2009, p. 86-88).

A quarta metodologia é representada pela desconstrução, baseada na análise das informações originadas de um novo ponto de vista. $\mathrm{Na}$ desconstrução, a intenção é analisar como a informação foi criada para apreender padrões e detalhes de construção que podem ser usados em novas ideias de design.

A quinta forma de organizar a informação pesquisada é a referência cruzada, que permite procurar referências visuais interrelacionadas, que guardam alguma semelhança entre si. Estas metodologias tratam de um processo de análise inicial da pesquisa (SEIVEWRIGHT, 2009, p. 89-90) e, ao serem apresentadas, auxiliam na organização do caderno de criação e na construção dos painéis.

Os métodos são instrumentos auxiliares no processo. Sua aplicação em um projeto não é garantia de bom resultado. $O$ método sempre será dependente da habilidade criativa do projetista (BOMFIM, 1998, p. 162).

maneira geral, o projeto segue um método. Este é composto por etapas e e por meio do cumprimento e superaçăo dessas etapas Um método de projeto também pode mostrar um posicionamento ideológico.

Ainda em relação aos painéis de criação, além dos moodboards, poderão er solicitados os storyboards, que consistem em várias folhas ou quadros que representam o histórico de soluções para o projeto proposto. O storyboard inclui o moodboard ou painel de criação, a arte-final das ilustrações, os tecidos e acabamentos coordenados, além de um pequeno texto explicativo sobre o tema, cores e mercado (JONES, 2005, p. 179). Os storyboards, de acordo com Jones, exibem

Assim como Sanches, Renfrew e Renfrew consideram que temas, direcionamentos e explicaçôes que norteiam a aparencia de uma nova coleção devem ser compartilhados com toda a equipe de criação ou estilo, com o intuito de facilitar a comunicação. Para isso são usados painéis de inspiração, de referência ou conceituais, que abrangem elementos tais como cor, esboços, fotografias, recortes, textos, ilustrações, amostras de tecido e até roupas (RENFREW; RENFREW, 2010, p. 18-92, passim).

A finalidade dos moodboards propostos por Jones é a mesma dos por Jos guardam relação com o painel proposto por Seivewright. Este deve incluir: cartela de cores, direcionamento ou conceito, tecido, palavras-chave e texto, pesquisa de mercado e estilo de vida. Para Seivewright, a pesquisa de mercado deve ser ilustrada por imagens, que apresentam quem é o cliente por intermédio da utilização de logos de marcas de moda. Por outro lado, o estilo de vida do público deve se basear na construção imagética da personalidade ideal para (SEIVEWRIGHT, 2009, p. 96-97)

Treptow (2013, p. 82) e Seivewright (2009, p. 94) são unânimes em validar a utilidade dos painéis para o registro dos "elementos de estilo" ou "elementos-chave" identificados pelo designer.

A pesquisa e seu registro podem revelar "elementos de estilo" de uma estação, que são os pontos que aparecem com maior frequência na pesquis de tendências (TREPTOW, 2013, p. 81). Eles também podem ser chamados de "elementos-chave" e se repetem, atribuindo coerência à coleção bem são "elementos-chave" aqueles que mas aos ol do estilista ao longo da pesquisa, tendo o papel de enfatizar determinado aspecto.

\section{Mix de Produtos}

Antes de iniciar o processo de confecção dos protótipos na moda, "ao criar uma coleção é necessário pensar no equilíbrio entre o número de itens que serão feitos, [sua função], os tecidos que serão a base e os que darão o devido destaque" (JONES, 2005, p. 131).

O mix de produtos requer a separação dos produtos por sua função como jaquetas, roupas de malhas e jérsei, vestidos, saias, calças, blusas e camisetas e roupa de uso externo, para depois focar na criação de suas variantes.

Essa divisão por peças é denominada Mix de Produtos. Em geral, o Mix de Produtos é formado por desenhos técnicos em preto e branco e é dividido em categorias: top (parte de cima), bottom (parte de baixo) e one piece

\begin{tabular}{lccccc} 
& 1 & 2 & 2 & 1 & \\
\cline { 2 - 5 } Cor & $\mathbf{P}$ & $\mathbf{M}$ & $\mathbf{G}$ & $\mathbf{G G}$ & Total \\
\hline Preto & 10 & 20 & 20 & 10 & 60 \\
\hline Branco & 10 & 20 & 20 & 10 & 60 \\
\hline Azul & 5 & 10 & 10 & 5 & 30 \\
\hline
\end{tabular}

Tabela 1- Profundidade
do Mix de Produtos Fonte: Elaborada pe autora (2016). 
(inteiro). No Mix de Produtos os artigos também são divididos por tecido, comprimento, volume etc.

Mix de Produtos também pode ser intitulado como "Quadro de coleções" (ou linha). Nele, cada peça pode ser desconstruída em função de tarefas e prazos. O número de produtos em cada linha de uma coleção é chamado de "extensão do mix de produtos". (RENFREW; RENFREW, 2010, p. 144).

A extensão do Mix é dividida pelo número de modelos de tops, bottoms e one pieces dentro da coleção. Ampliar a extensão do mix de produtos significa aumentar o número de modelos oferecidos. $O$ briefing precisa considerar qual a extensão do mix que a empresa já possui e se ele será mantido, reduzido ou ampliado (TREPTOW, 2013, p. 95).

A profundidade do mix de produtos equivale ao exercício de "fazer a grade", como se diz popularmente no mercado de moda. Em outras palavras, a "extensão do mix de produtos" é o número de produtos em cada linha e a "profundidade do mix de produtos" é o exercício de "fazer a grade", ou seja, apresentar o número de número de cores oferecidas em um artigo e em quantos tamanhos ele é ofertado (TREPTOW, 2013, p. 95). O mais comum é pedido de grade "1-2-2-1", ou seja, isso define a proporção de peças por tamanho, "1P-2M-2G-1GG", como mostra o exemplo a seguir.

$\mathrm{O}$ mix de produtos se divide em três categorias de produtos. $\mathrm{O}$ produto básico é aquele que está presente em quase todas as coleções, e em geral é caracterizado por peças funcionais. Produtos básicos devem representar pelo menos $10 \%$ da coleção. $O$ produto fashion é aquele que incorpora as tendências do momento. Costuma ser um atrativo para o consumidor e corresponde a $70 \%$ dos produtos de uma coleção de moda. Já o produto de vanguarda se refere às peças complementares, cerca de $30 \%$ dos produtos da coleção. Incorporam as tendências atuais ou futuras e, em geral, não são muito comerciais. Usualmente, são as peças mais diferentes e traduzem o "espírito" da coleção. São aquelas apresentadas em vitrines, fotos e desfiles (PIRES, 2000 apud TREPTOW, 2013, p. 96).

Aliando o desenho ao desenvolvimento de produtos, Treptow (2013, p. 136) afirma que o designer deve criar propostas para a coleção que valorizem a intercambialidade das peças, garantindo assim, que uma mesma peça possa compor vários looks ${ }^{10}$. Ademais, Treptow sugere que o designer esboce pelo menos três propostas para cada modelo definido no mix de produtos.

\section{Elementos do Design}

thestuario- conjuntó de todas as peças necessárias para uma pessoa se vesti,
trajo; roupa (Disponivel em: https://www. priberam.p esse sistema de vestuário que rege o lugar do moda. Em São Paulo, po exemplo, concentra-se nos bairros do Bom Retiro, nas grandes indústrias que do mito do estilista criador.

Os livros sobre projeto analisados no decorrer da pesquisa consideram que os elementos do design são tratados de maneira bastante específica pelo design de moda e de forma mais generalista pelo design de produtos.

$O$ fato de o design de produtos trabalhar com uma maior variedade de segmentos de produtos dificulta o estabelecimento de parâmetros de elementos tais como cor, forma, textura etc de modo mais preciso.

No design de moda é mais factível estabelecer padrões para a detecção dos elementos do design e sua aplicação, já que ele se concentra mais no vestuário"
Pelo fato de esta tese estar direcionada principalmente ao design de moda, buscou-se explicitar cada elemento do design de forma mais aprofundada, sob a ótica deste campo.

\section{Estudos de formas / Silhuetas}

Silhueta é o contorno ou forma que é delineada em volta do corpo por uma peça de vestuário [e sua] inspiração deve vir dos diferentes elementos da pesquisa, especialmente das formas e estruturas, vestimentas históricas ou ainda, de formas abstratas. A proporção de uma roupa refere-se à maneira uso de corpes é edividido por linhas horizontais, verticais ou curvas ou pe/o

Nos elementos do design de moda as linhas, mencionadas por Seivewright, constituem os recortes e limites das bainhas. A silhueta pode ser expressa por meio de letras, como, por exemplo, linha A, linha $Y$ e linha $\mathrm{H}$, por exemplo, e está relacionada ao volume da roupa. Ela pode seguir os contornos do corpo ou alterá-los (TREPTOW, 2013, p. 125-128).

A função de uma roupa refere-se ao que ela é: um vestido, blusa, saia, calça, colete etc. A função também pode estar relacionada a um objetivo específico, tal como roupas para práticas esportivas de desempenho (SEIVEWRIGHT, 2009, p. 126).

A função e a silhueta são elementos do design que se relacionam diretamente com a forma e a estrutura da roupa.

Há diversas maneiras de explorar a construção de silhuetas. A utilização de metodologias mais avançadas que a colagem, justaposição, desconstrução e as referências cruzadas exploradas em "Registro da Pesquisa" permitem a obtencão de uma maior variedade de produtos. É O caso da "análise de pesquise", que requer o de as quais não precisam de uma experims ampliação e silhueta, desenhos, detalhes de construção, texturas (testes com tecidos), padronagens e ornamentação (SEIVEWRIGHT, 2009, p. 92-93).

Além da "análise de pesquisa" há uma metodologia para refinar o material oriundo da pesquisa denominada "preenchendo lacuna", utilizada para preencher a lacuna entre o processo de pesquisa e o produto, e que pode ser abordada segundo duas formas: "pesquisa colada sobre figuras" "fotomontagem dos registros de moulage 12 ".

Em relação à "pesquisa colada sobre figuras", Seivewright (2009, p. 119) sugere que o estilista comece copiando diferentes imagens de sua pesquisa/ caderno. Em seguida, deve desenhar uma série de croquis, sem vesti-los, para então cortar e colar os diferentes aspectos da pesquisa diretamente sobre os croquis, criando propostas de silhuetas e volumes. A técnica favorece a criação de formas e silhuetas, mas também pode ser utilizada para sugerir cores, estampas e texturas. Ela favorece a reflexão sobre vários pontos de referência do corpo, tais como pescoço, ombros, busto, cintura e quadris. Braços e pernas também devem ser considerados como pontos a serem desenvolvidos, para as mangas e calças.
12 Moulage é a técnica que consiste em trabalhar
o tecido diretamente no manequim, respeitando o fio reto ou viés, sem um molde anterior. Difere da modelagem plana, a qual desenvolve a peça meio do uso de papel, réguas e esquadro, a partir da construçăo de um eixo de coordenadas $\mathrm{Xe}$ Y. 
A "fotomontagem dos registros de moulage" é efetuada a partir dos registros fotográficos do processo de moulage, sobre os quais é possivel trabalhar bidimensionalmente para explorar o detalhamento dos exercícios de moulage. Será necessário novamente fazer uma boa quantidade de croquis e sobre eles será trabalhada a colagem das fotos provenientes da moulage.

Após a colagem, Seivewright (2009, p. 121) considera que as imagens obtidas podem ser trabalhadas, com o auxílio do desenho, em busca de novos resultados. É interessante tentar mover a imagem sobre o croqui e tentar mudar a escala e o seu posicionamento.

"É mais simples [...] cortar uma forma e deslocá-la numa superfície do que desenhá-la e pintá-la”. A intenção, neste caso, é deslocar os elementos da composição sobre a superfície, e, assim que for encontrado o equilíbrio visual, fixá-los (MUNARI, 2011, p. 27)

No que diz respeito à criação de silhuetas, Seivewright e Munari incentivam a experimentação por meio da sobreposição de imagens, pois uma forma estudada livremente sobre o corpo tende a desconstruir sua escala e posicionamento habituais, podendo favorecer resultados mais criativos.

\section{Cartela de Cores}

Jones (2005, p. 112) observa que a cor deflagra a primeira reação do consumidor quando em contato com a coleção, e é ela que informa "sintonia" com a estação. As paletas de cores variam de um público consumidor para outro e há convenções sociais ligadas às cores que devem ser observadas pelo designer de moda.

A cor é especialmente indicada para atingir a psique do usuário do produto, e por isso ela influencia vários aspectos do design de produto. É preciso saber que efeitos se pretendem a partir do uso da cor (LOBACH, 2007, p. 163-166, passim)

Como ela é, em geral, o primeiro elemento a ser notado em uma peça, necessário possuir um entendimento básico da teoria das cores para saber montar uma cartela de cores, mas a maioria dos estilistas não escolherá uma cartela com base em teorias (SEIVEWRIGHT, 2009, p. 128).

Enquanto uma paleta de cores ideal tem entre quatro e dez cores, para Jones (2005, p. 119) e para Treptow (2013, p. 109) ela deve ter de seis a doze.

É preciso investir uma porcentagem da coleção na "cor da moda" de acordo com Treptow (2013, p. 121), seja em peças inteiras ou em detalhes. A "cor da moda" de Treptow equivale às cores acentuadas de Jones. "Cor da moda" é aquela que não é tradicional e não aparece em todas as coleções, ou que não costuma aparecer em um determinado tipo de artigo.

Para montar uma Cartela de Cores as amostras de cor devem ser de $2 \mathrm{~cm} \times 3$ $\mathrm{cm}$ ou de $3 \mathrm{~cm} \times 2 \mathrm{~cm}$, sempre em fundo branco, com uma distância de $1 \mathrm{~cm}$ entre uma e outra. A amostra deve ter um tom uniforme, sem texturas ou diferenças de nuances (TREPTOW, 2013, p. 109), e de preferência no mesmo tecido.

ostilista compra tecidos com base em uma cartela já estabelecida, a não ser que consuma uma metragem significativa, de modo a poder encomendar tecidos tingidos nas cores de sua paleta particular.

Até o início dos anos 2000 as tecelagens só atendiam a pedidos de tingimento em cores especificadas ou desenvolvidas por designers en grandes quantidades. Em um momento posterior, com a popularização da estamparia à laser, principalmente a partir de 2005, as tecelagens precisaram flexibilizar na quantidade para que, na última parte da CPTV ${ }^{13}$ demanda do consumidor final por variedade fosse atingida. As confecções nessa situação sofriam um lead time (tempo entre o pedido e a entrega) muito grande, pois as grandes quantidades de confecções maiores eram privilegiadas, o que não é muito diferente até hoje. Por fim, atualmente 0 que permite tingir lotes menores para atender a coleções menores foi avanço tecnológico que proporcionou um lead time menor.

\section{Cartela de Matérias}

Muitas vezes a seleção do tecido é a peça fundamental para o sucesso de uma roupa. O tecido é um elemento tanto visual quanto sensorial. Para uma coleção ser diversificada é preciso ter acesso a tecidos com diferentes qualidades, pesos e tipos, para não se ficar limitado a determinados tipos de modelos (SEIVEWRIGHT, 2009, p. 130).

A importância da comunicação visual pode estar no toque dos tecidos, o que produz um efeito tátil particular ligado à aparência, a qual, por outro lado, encontra-se intimamente ligada ao estudo das superfícies (MUNARI, 2011, p. 11-12).

Para Munari (2011, p. 69-74) tecidos podem ser amostras de texturas, pois equivalem a superfícies sensibilizadas. Os autores da área de projeto em moda chamam a atenção para a necessidade de, em primeiro lugar, pesquisar a textura para, em seguida, abordar o tecido.

Enquanto $\circ$ design visual interpreta $\circ$ tecido como uma textura, o design de moda escolhe ou cria um tecido a partir do estudo de texturas provenientes de outro universo visual.

O estilista precisa conhecer as características dos tecidos, seu toque, su qualidade e caimentos, pois eles são a sua matéria-prima. A textura revela a relação tátil da roupa e a padronagem é a alteração de cor ou textura obtidas em tecidos (TREPTOW, 2013, p. 112-127, passim).

$\mathrm{Na}$ fase da modelagem, produção de toiles ${ }^{14}$ e peças-piloto é que devem ser feitos os pedidos dos tecidos e organizados os aviamentos. Também é importante diversificar as matérias no desenvolvimento da coleção, recorrendo-se às tricoteiras a beneficiamentos tais como bordados, estamparia e tingimento.
3 CPTV-Cadeia Produtiva Têxtil e de Vestuário Cadeia Produtiva Têxtil e Confeç̧ão.
14 Toile é a representação
de uma peça de roupa em termos de forma, sem acabamentos fin tais como overloque, casa ou bolsos (RENFREW; RENFREW, 2010, p. 28), e equivale ao mock up do design na indústria do vestuário. A peça-piloto equivale ao modelo e é primeira peça criada. Come a ajustes e testes de caimento, medida etc. A primeira peça confeccionada na produção industrial pode ser comparada ao protótipo ou cabeça de série no design industrial e pode ser representada por peças distintas: distintas: calça, saia,
camisa, vestido etc. 
Ficha Técnica de Tecido

Fabricante

Representante

Figura 1-Ficha de

organizaçăo para tecidos

Fonte: Elaborada

pela autora (2016).

Amostras

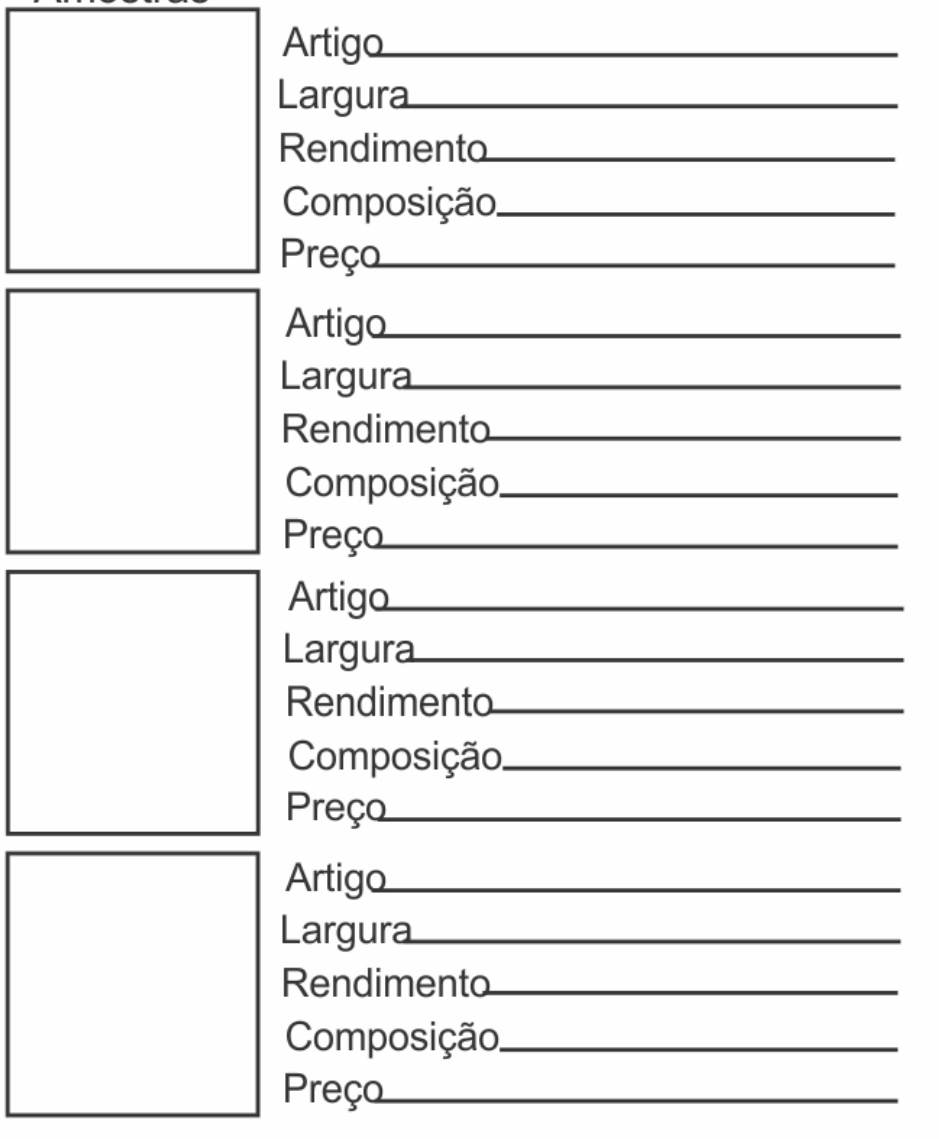

Figura 2 - Ficha de organização para
compra de tecidos Fonte: Elaborada pela autora (2016)
É importante criar um modelo de ficha de organização para os tecidos. Em um caderno devem ser colocadas as amostras com até $10 \mathrm{~cm}$ com suas informações: nome do fabricante, nome do tecido e/ou código, composição, largura, preço e rendimento, no caso de malhas. A amostra deve ser cortada com tesoura de picote para não desfiar e, no caso de estampas, embora seja difícilo representante autorizar, oidealé que se consiga cortar da bate (a amostra maior do representante) o rapport (TREPTOW, 2013, p. 117).

No mercado, poucas confecções contam com designers ou estilistas que fazem essa ficha, pois a informalidade e a desinformação ainda são recorrentes em muitos desses ambientes. Mesmo antes da orientação do livro de Treptow, dada a necessidade de reunir informações sobre tecidos e aviamentos, a autora desta tese já havia sistematizado duas fichas. Abaixo seguem modelos de ficha de organização e de compra de tecidos.

Em condições ideais, nas faculdades ou feiras, a cartela de tecidos é apresentada sob a forma de janelas ou pequenos passepartouts que permitem o toque tanto do lado direito quanto no avesso. $O$ tecido deve ser mostrado com o lado direito para cima e obedecendo ao fio reto (TREPTOW, 2013, p. 121).

No cotidiano de uma confecção o tempo é muito limitado para inúmeras tarefas que têm de ser resolvidas, então, em geral, o retalho de tecido é colado na ficha exposta acima com fita adesiva dupla face, colada só no alto, de forma a permitir o toque. Em uma confecção, o tecido é um material de apoio interno, que deve ser registrado com agilidade. Nos trabalhos acadêmicos, nas feiras e nas tecelagens há um cuidado maior com a amostra de tecido, pois seu uso é diverso. Em uma feira o tecido é o produto e, portanto, ele deve ser apresentado da melhor maneira possível. Já na faculdade, o aluno deve ser ensinado o mais corretamente possível em relação a estas técnicas.

As informações entre as cartelas de cores e de tecidos devem ser cruzadas, com o intuito de avaliar se todas as cores estão sendo utilizadas nos tecidos escolhidos (TREPTOW, 2013, p. 121) e assim completar as informações do Mix de Produtos.

No que diz respeito aos aviamentos, é o designer de moda quem busca novidades. Os aviamentos devem ser catalogados e divididos por meio de códigos em uma confecção (TREPTOW, 2013, p. 122), para facilitar sua localização. Há empresas que possuem várias amostras do catálogo de aviamentos, como forma de facilitar a comunicação entre setores distintos.

Treptow (2013, p. 124) divide os aviamentos por função e visibilidade. No primeiro caso, trata-se de qualquer aviamento sem o qual não é possível a peça existir, como por exemplo, linha, zíper etc. No segundo caso trata-se de aviamentos aparentes, aplicados após a confecção, como botões, apliques etc. representante comercial da elagem leva aos clientes de confecção como amostra para venda. Ele costuma medr

\begin{tabular}{|c|c|c|c|c|c|c|c|}
\hline \multicolumn{2}{|c|}{ ARTIGO VARIANTE } & \multirow[t]{2}{*}{ QTDADE. } & \multicolumn{2}{|c|}{ ARGURA RFND } & PREÇO & TOTAL & \multirow[t]{2}{*}{ AMOSTRA } \\
\hline Nome e & & & & & $\mathrm{R} \$$ & $\mathrm{R} \$$ & \\
\hline tecido & Cor 2 & & & M/KG & UNIT. & & \\
\hline \multirow{3}{*}{$\mid \begin{array}{l}\text { No. } \\
\text { PEDIDO }\end{array}$} & Cor 3 & & \multirow{3}{*}{\multicolumn{2}{|c|}{ COMPOSIÇÃA }} & & \multirow[b]{3}{*}{ METROS } & \\
\hline & Cor 4 & & & & & & \\
\hline & Cor 5 & & & & & & \\
\hline
\end{tabular}




\section{Beneficiamentos}

16 Lei das etiquetas $n^{\circ} 5.956$, de 03 de dezemb de 1.973, regulamentada pela resoluçăo $n^{\circ} 1 / 01$ de de 12 de abril de 2002 , e substitui a res. $04 / 92$ de 08/01/1992. A lei das etiquetas é valida para o Brasil e países membros do Mercosul. Disponivel em: <http://www.slcomex.com br/pdf/lei_etiquetas.pdls.
O designer deve conhecer bem fibras e tecidos de modo a ser capaz de saber quais beneficiamentos (tingimentos, hot fix, plissagem etc) são passíveis de serem aplicados ou não a determinado tecido. Isso diz respeito à etiquetagem. Jones (2005, p. 122) relata que, na Inglaterra, é indispensável a presença da etiqueta de composição para cada fibra que represente $7 \%$ ou mais na composição da peça. No Brasil esse percentual é de $30 \%{ }^{16}$.

A estampa, o tingimento, as lavagens e os bordados ajudam a ilustrar não somente a cartela de cores, como também os temas e influências pesquisados pelo estilista. Eles podem oferecer um efeito tridimensional e decorativo ou podem servir ainda para dar forma ou volume à peça (SEIVEWRIGHT, 2009, p. 131).

\section{Princípios do Design}

Os modos como os elementos do design de moda podem ser combinados são denominados princípios do design (JONES, 2005, p. 99). Estes princípios são regidos por: repetição, ritmo, gradação, radiação, contraste, harmonia, equilíbrio e proporção. Jones é a única autora que trabalha a questão dos princípios do design aplicados à moda de maneira completa, por isso a preferência em focar na sua contribuição.

É interessante esclarecer resumidamente os princípios do design elencados por Jones (2005, p. 103-108, passim). A repetição se dá quando o uso de elementos de estilo, detalhes ou acabamentos é visto mais de uma vez na mesma roupa. $O$ ritmo ajuda a criar efeitos a partir da repetição regular nas peças.

A gradação é a repetição predeterminada em distâncias ou tamanhos maiores ou menores de insumos e efeitos. A radiação corresponde às linhas que se abrem em forma de leque a partir de um eixo central, como no drapeado ou no plissado. $O$ contraste ressalta a diferença entre duas peças e, segundo Jones, é considerado um dos princípios mais úteis da criação.

Munari (2011, p. 339) trata do princípio do design do contraste de forma similar à sua utilização na moda. Ele chama de contraste simultâneo a proximidade de duas formas de natureza oposta que valorizam e intensificam a comunicação visual.

A harmonia, outro princípio do design, está relacionada à similaridade entre as peças que compõem um look e um visual "não agressivo".
No design de produtos, enquanto a simetria estuda a maneira de acumular formas (MUNARI, 2011, p. 170), no design de moda, a simetria é tratada por um princípio do design chamado equilíbrio.

A proporção diz respeito ao modo como são relacionadas visualmente todas as partes individuais de um todo (JONES, 2005, p. 108-109).

Outro princípio citado por Jones (2005, p. 109) é chamado de fazer o "teste de realidade" para saber como o corpo humano interage com os tecidos. Esse teste só existe no campo do design de moda. Para esse teste são necessários a observação minuciosa e o estudo de fotografias, filmes e desenhos. Estes requisitos ajudam a perceber e apreender como o corpo se movimenta e se comunica não verbalmente, e como nuances de corte, caimento e tecidos causam importantes efeitos na silhueta, nas linhas e no volume do corpo.

\section{Desenho}

Após o registro da pesquisa por meio do moodboard, o trabalho é direcionado aos croquis. Uma sugestão apresentada é desenhar todos os detalhes juntos, criando uma série de colagens visuais (RENFREW; RENFREW, 2010, p. 150) de acordo com as preferências do estilista e de suas ideias para cada look.

Os detalhes podem configurar uma categoria de organização dos desenhos. À medida que os desenhos ficam prontos, eles também podem ser agrupados conforme os tecidos e silhuetas (JONES, 2005, p. 91).

Os tipos de desenhos exigidos na faculdade são os esboços, desenvolvimento do design (detalhamento do desenho e composição) e a arte-final (croquis). Em um primeiro momento é preciso esboçar mais rapidamente certo número de ideias, mostrando o esboço e o desenvolvimento do design; em seguida, deve-se marcar os melhores rascunhos, os que possuem elementos importantes, para então desenvolver estes esboços, para mais uma seleção ser feita (JONES, 2005, p. 91-177, passim).

'O esboço não visa à verossimilhança, mas um clima ou um 'visual'. As modelos de moda são notavelmente mais altas e magras" do que a maioria da população e têm os ossos sobressalentes e "o comprimento das pernas femininas é exagerado". As proporções do corpo são distorcidas [...] com pescoço e pernas mais compridos se comparados ao desenho com um modelo vivo clássico (JONES, 2005, p. 83-90, passim).

Antes de serem acrescentados tecidos e características ao croqui, $n$ etapa de desenvolvimento do design, os esboços devem registrar silhuetas e elementos do design (JONES, 2005, p. 91). A arte-final (JONES, 2005, p. 93) deve mostrar o clima ou o "visual" da roupa.

O esboço é um estudo inicial que será aprimorado no desenvolvimento do design. Trata-se de uma etapa que preza por maior fidedignidade em 
termos de projeto, sendo destinado a vestir um corpo real, que não tem medidas distorcidas, e oferece mais informações para que o produto possa ser desenvolvido.

Esboço ou croqui são sinônimos na visão de Simon Seivewright (2009, p. 158). Esse tipo de desenho mostra silhueta, detalhes, tecidos, estampas, ornamentos e cores. Serve para descrever e mostrar o vestuário. Pode ser utilizado como ferramenta para comunicar ao modelista o modelo que ele deve fazer.

Quanto à ilustração de moda, Seivewright e Jones concordam que ela deve evocar o clima da coleção e permitir o uso criativo de diferentes técnicas e materiais. Ela não precisa mostrar o detalhamento da roupa, nem mesmo a própria roupa de maneira óbvia.

Além dos esboços, croquis e ilustração existem os desenhos técnicos. Jones (2005, p. 94) discute a diferença entre os tipos de desenho técnico. Ela menciona dois tipos de desenho: o "desenho plano animado" e o "desenho técnico" ou de "especificação". O desenho plano é um desenho mais rígido que o croqui, porém não apresenta medidas nem tantos detalhes como o desenho técnico. Ele pode demonstrar algum movimento. $O$ desenho técnico ou de especificação é um desenho que deve conter as medidas (com marcação de cotas) e detalhes colocados em proporção (com linhas de chamada).

"Desenhos de trabalho", "de especificações" ou "planificados" são sinônimos de desenho técnico. Eles mostram todos os detalhes de construção da peça, sem representação da figura humana, e não têm indicação de cor, textura ou forma (SEIVEWRIGHT, 2009, p. 150). Devem representar a frente e as costas da peça. Precisam conter as proporções corretas do corpo, uma vez que não são fluidos e criativos como um croqui de moda. Eles serão interpretados pelo modelista junto ao esboço e, portanto, devem ser proporcionais.

\section{Plano de Coleção ou Mix de Coleção}

Existe outra forma de divisão e organização, posterior ao Mix de Produtos, que dá visibilidade à coleção à medida que ela é desenhada ou quando está pronta. É o Plano de Coleção. Nele os croquis coloridos são expostos formando looks para apresentar uma ideia de cor, textura e composição entre as peças.

Plano de Coleção ou de "Plano de Linha" é a divisão da coleção agrupada por tipo de tecido, conforme define Mark Eley, citado por Renfrew e Renfrew (2010, p. 126).

Apesar de não usar denominações, quando Jones (2005, p. 131) fala de mostruário, ela define o Plano de Coleção e sua finalidade.

Desenhos ou fotogratias de tamanho reduzido dos itens finalizados, tanto individualmente quanto em conjunto, são úteis para ajuda na construção do mostruário e posteriormente na venda da coleção (JONES, 2005, p. 131).
O lookbook, produzido pelos estilistas, fabricantes e varejistas a cada temporada ou para cada tema de inspiração é também uma espécie de Plano de Coleção fotográfico (RENFREW; RENFREW, 2010, p. 158).

O Plano de Coleção é complementar ao Mix de Produtos, pois ao colocar as peças ou looks lado a lado, permite conferir se há muita repetição ou se faltam tecidos, silhuetas, cores ou peças programadas no Mix de Produtos para equilibrar a coleção.

\section{Geração de Alternativas}

É fundamental desenvolver ideias a partir de desenhos que testem diferentes opções de decotes, mangas, ajustes etc. Esses testes que Jones propõe equivalem à geração de alternativas descritas por Seivewright.

Na metodologia de Seivewright a "geração de alternativas" serve para aprimorar os croquis já obtidos, focando na elaboração de detalhes. $\mathrm{Na}$ "geração de alternativas", a criação pode ser pensada como uma árvore genealógica, na qual muitas ideias surgem de algumas "ideias matrizes", por intermédio da adição, mistura de outras referências e manipulação dos elementos do design (SEIVEWRIGHT, 2009, p. 137).

Para gerar alternativas no design de moda, é necessário separar três colagens, que podem ser retiradas do exercício "preenchendo lacunas", visto em "Estudos de formas/Silhuetas" neste mesmo capítulo. Cada uma delas produz uma nova alternativa. Podem ser incluídos cor, estampa, recorte, mudança da função da peça etc. A partir dessas três novas alternativas, a parte seguinte do exercício é a mistura destas três primeiras alternativas. Surgem assim vários looks, todos com uma relação de semelhança entre si (SEIVEWRIGHT, 2009, p. 137).

A etapa seguinte é o "desenvolvimento e refinamento de peças", quando são propostas roupas mais específicas, após a geração de alternativas. Uma coleção deve ter uma diversidade de peças em termos de estilo, determinada por recortes, volumes, comprimento e material.

Essa diversidade de peças é quantificada no Mix de Produtos. A partir dele é possível focar na criação das variantes (SEIVEWRIGHT, 2009, p. 138). Desta forma, é possível compreender o "desenvolvimento e refinamento de peças" como o aprimoramento do Mix de Produtos.

No design de produtos a etapa seguinte à "geração de alternativas" é a "avaliação de alternativas". Nela surgem questionamentos relacionados à importância do novo produto para o êxito financeiro da empresa (LÖBACH, 2007, p. 154). 
Existe uma crítica ao design de moda, relacionada à preocupação de retorno financeiro ligado aos seus produtos, e que está de certa forma vinculada à "geração de alternativas". Quando Löbach fala sobre o "êxito financeiro da empresa", percebe-se a importância do lucro também no direcionamento do projeto no design de produto.

\section{Volumetria / Moulage}

Quando a pesquisa já estiver adiantada, Seivewright (2009, p. 105) propõe partir para abordagens de pesquisa tridimensionais. Trata-se de como transformar as ideias iniciais da pesquisa em formas e estruturas sobre 0 corpo, utilizando técnicas de modelagem e moulage.

A modelagem é o processo pelo qual são criados moldes e formas de roupa a partir da planificação. É uma ótima maneira de começar a tradução inicia das ideias coletadas na pesquisa. Trata-se de uma maneira mais expressiva de desenvolver roupas que vai além de desenhar (SEIVEWRIGHT, 2009, p. 106).

O modelista é responsável por ajudar a concretizar uma ideia ou visão em três dimensões, enquanto a pilotista (ou piloteira) trabalha auxiliando o modelista em relação às costuras e acabamentos, além de costurar as primeiras "peças-piloto" (RENFREW; RENFREW, 2010, p. 28).

A moulage ajuda a compreender a relação entre o esboço de um modelo $e$ a forma tridimensional. Essa prática ajuda a entender melhor como o corpo se relaciona com o tecido. Registrar a evolução do trabalho no manequim em fotografias também é importante para captar as mudanças feitas, além de permitir que surjam novos modelos. Conhecer a qualidade, o peso e como se deve manusear determinado tecido tem um papel importante na forma como o tecido será trabalhado no manequim (SEIVEWRIGHT, 2009, p. 106).

\section{Confecção do Look}

A etapa da pilotagem é abordada de forma difusa por Renfrew e Renfrew. Quanto a Treptow, esta etapa é abordada em seu texto mais como apoio à produção ou desenho técnico. Por isso foram elencadas as visões de Jones e Seivewright sobre $o$ assunto.

A piloteira é uma costureira que entende como montar uma peça inteira, diferentemente da costureira de produção fabril, a qual, muitas vezes, monta somente parte da peça. Logo, essa profissional tem o papel de alertar sobre possíveis defeitos e problemas antes da produção.

Uma vez pilotada, a roupa precisa ser provada. Antes disso, ela é passada, principalmente em suas pences, costuras e junções. É o que se chama de "bater a costura a ferro" ou "abrir costura". Após essa etapa a roupa é provada em uma modelo de prova, de carne e osso, para ver como a roupa se porta
(JONES, 2005, p. 163) em termos de caimento e conforto. É possível que haja a necessidade de mais de uma prova de roupa, para a correção de defeitos.

Os detalhes são aviamentos e acabamentos que implicam diretamente na costura e na modelagem. Alguns detalhes que devem ser considerados são pespontos, fechos, zíperes, botões, colchetes, ilhoses, cadarços, presilhas, alças, velcros, botões de pressão, estilos de colarinho, lapelas, mangas, formas de palas, decotes, bolsos, cintos, debruns, barra francesa, pregas etc. (SEIVEWRIGHT, 2009, p. 127).

É fundamental que o estilista comunique seu processo e as especificações desejadas ao modelista, para que este, com a colaboração da piloteira, monte a primeira "peça-piloto".

$\mathrm{Na}$ ótica do design de produtos, esse processo estaria próximo à solução do problema. É neste momento que a melhor alternativa se converte en protótipo ou "cabeça de série" (LOBACH, 2007, p. 155). No design de moda, o protótipo equivale à última peça-piloto, feita na indústria, na qual se baseará a produção industrial.

\section{Apresentação}

No design de produto, a apresentação é abordada por Bomfim (1998, p. 163) com relação à tarefa do planejamento. Ela consiste na representação do que é desenvolvido no projeto, ou seja, as ideias. Somente por meio da percepção sensorial de uma imagem é possível a sua apreciação estética, por intermédio do esboço, fotografia, aquarela, rendering etc.

No design de moda, a apresentação está relacionada ao produto confeccionado, à peça de roupa. Dessa forma, no design de produto, ela estaria no final do processo e não atrelada a uma etapa de projeto, 0 planejamento.

No caso de um Trabalho Final de Graduação (TCC), a apresentação final compreende a coleção, o lookbook ${ }^{17} \mathrm{e}$ as fontes e materiais de pesquisa $\mathrm{e}$ desenvolvimento. No caso de um estudante de graduação, recomenda-se a execução de seis looks e, no de pós-graduação, de doze a quinze looks. No caso da graduação, seis looks são suficientes para que o aluno transmit o tema e o conteúdo de sua coleção (RENFREW; RENFREW, 2010, p. 156); também permite que todos os alunos apresentem seus trabalhos com um desfile, se e quando for o caso.

Atualmente há outras formas de TCC, apresentados como trabalhos de styling, design de superfície, pesquisa teórica ou coleção desenvolvida em grupo, mas é possível perceber que ainda hoje privilegia-se a apresentação individual da coleção.

A fim de sintetizar o conteúdo deste capítulo, foi preparado o quadro a seguir, que cruza os autores e suas etapas de estilismo, projeto em moda projeto em design. espécie de catálogo no qual s peças são vestidas para chiltar sua visualizaçáo no corpo. Um lookbook eum plano de coleçăo fotogrático a cada temporada ou inspiraçăo (RENFREW; RENFREW, 2010, p. 158). Ao contrário do catálogo de moda, não se privilegia a construção de uma imagem de moda impactante, e sim facilidade de leitura 


\section{REFERENCIAS
DO CAPÍTULO}

BOMFIM, G. A. Ideias e Formas na História do Design: Uma Investigação estética. 1. ed. João

JONES, Sue Jenkin. Fashion design - manual estilista: Sue Jenkyn Jones. São Paulo: Cosac Naify, 2005.

LEl_etiquetas. Disponível em: <http://www. slcomex.com.br/pdf/lei_etiquetas.pdf $>$. Acesso

LÖBACH, Bernd. Design Industrial - Bases para a configuração dos produtos industriais. São Paulo: Editora Blucher, 2007.

MORAIS, Michael Medeiros. Reflexões metodológicas sobre o design de moda. In: CONGRESSO BRASILEIRO DE PESQUISA E DESENVOLVIMENTO EM DESIGN, 7., 2006 , Curitiba. Anais... Curitiba, 2006.

MUNARI, Bruno. Design e comunicação visual: contribuição para uma metodologia didática. São Paulo: Martins Fontes, 2011.

POUPART, Jean. A pesquisa qualitativa: enfoques epistemológicos e metodológicos. Petrópolis, RJ: Vozes, 2008.

RENFREW, Elinor; RENFREW, Colin

Fundamentos de design de moda:

Desenvolvendo uma coleção. Porto Alegre: Bookman, 2010.

SEIVEWRIGHT, Simon. Fundamentos de design de moda: pesquisa e design. Porto Alegre: Bookman, 2009.
TREPTOW, Doris. Inventando moda:

planejamento de coleção. 5. ed. São Paulo: dição da Autora, 2013.

VICENTINI, Cláudia Regina Garcia.

Ferramentas e metodologia de projeto aplicados na criação de produtos para a indústria têxtil-confecção.

157 p. (Tese) - Faculdade de Engenharia

Mecânica da Universidade Estadual de

Campinas, 2010. 


\section{Quadro 2}

Cruzamento dos autores e suas etapas de estilismo, projeto em moda e projeto em design 


\begin{tabular}{|c|c|c|c|c|c|c|c|}
\hline & Treptow & Jones & Seivewright & Renfrew & Löbach & Bomfim & Munari \\
\hline Briefing & Mercado-alvo. & Patrocinado, concursos e grupo. & $\begin{array}{l}\text { Acadêmico, concurso, } \\
\text { comercial, ateliê e grupo. }\end{array}$ & Coleção de TCC. & $\begin{array}{l}\text { Materiais, processo de } \\
\text { fabricação e funções práticas. }\end{array}$ & $\begin{array}{l}\text { Organização, } \\
\text { conceito e resultado. }\end{array}$ & $\begin{array}{l}\text { Problema físico } \\
\text { e psicológico. }\end{array}$ \\
\hline Pesquisa & $\begin{array}{l}\text { Tendências, tema, vocações } \\
\text { regionais, mercado, } \\
\text { comportamento e tecnologias, } \\
\text { cores, tecidos e aviamentos. }\end{array}$ & Preço, caimento. & $\begin{array}{l}\text { Inspiração, informações e } \\
\text { direcionamento do tema/ } \\
\text { elementos do design. }\end{array}$ & $\begin{array}{l}\text { Cliente, registros de } \\
\text { venda, estoque, qualidade } \\
\text { de mercadoria e preço. }\end{array}$ & $\begin{array}{l}\text { Coleta de informações } \\
\text { para a solução } \\
\text { de um problema. }\end{array}$ & & \\
\hline $\begin{array}{l}\text { Registro } \\
\text { da Pesquisa }\end{array}$ & $\begin{array}{l}\text { Painéis para } \\
\text { "elementos-chave". }\end{array}$ & $\begin{array}{l}\text { Caderno de croquis, painel } \\
\text { de criaçãa ou moodboard, } \\
\text { storyboards. }\end{array}$ & $\begin{array}{l}\text { Caderno de croquis ou de } \\
\text { esbocosos; painéis de inspiração, } \\
\text { temáticos ou conceituais. }\end{array}$ & $\begin{array}{l}\text { Painéis de inspiração, } \\
\text { de referência ou } \\
\text { conceituais. }\end{array}$ & & & \\
\hline $\begin{array}{l}\text { Mix de } \\
\text { Produtos }\end{array}$ & $\begin{array}{l}\text { Divisão por tops, bottons } \\
\text { e one pieces/ cores, tamanhos, } \\
\text { quantidades/ básicos, fashion } \\
\text { e intermediários. }\end{array}$ & $\begin{array}{l}\text { Divisão por número de } \\
\text { itens e tipos de tecidos. }\end{array}$ & $\begin{array}{l}\text { Diversidade de } \\
\text { peças por função. }\end{array}$ & $\begin{array}{l}\text { Tarefas e prazos } \\
\text { para cada peça. }\end{array}$ & & & \\
\hline $\begin{array}{l}\text { Formas } \\
\text { Silhuetas }\end{array}$ & $\begin{array}{l}\text { Letras que representam o } \\
\text { volume da roupa "A", " "Y" ou "H". }\end{array}$ & & $\begin{array}{l}\text { Divisão do corpo por linhas } \\
\text { horizontais e verticais. }\end{array}$ & & & & Equilíbrio visual. \\
\hline Cores & $\begin{array}{l}6 \text { a } 12 \text { cores/ cor da moda/ } \\
\text { cada cor deve ter } 2 \mathrm{~cm} \times 3 \mathrm{~cm} \\
\text { ou } 3 \mathrm{~cm} \times 2 \mathrm{~cm} .\end{array}$ & $\begin{array}{l}\text { Sintonia com a estação e } \\
\text { convençố sociais, 4a a } 10 \\
\text { cores, "cor acentuada". }\end{array}$ & $\begin{array}{l}\text { Primeiro elemento a ser } \\
\text { notado/ Estilista deve } \\
\text { conhecer a Teoria das cores. }\end{array}$ & & $\begin{array}{l}\text { Quais efeitos se desejam } \\
\text { para atingir a psique do } \\
\text { usuário do produto. }\end{array}$ & & \\
\hline Matérias & $\begin{array}{l}\text { É preciso considerar as } \\
\text { caracteristicas dos tecidos, } \\
\text { seu toque, sua qualidade e } \\
\text { caimentos/Caderno de amostras } \\
\text { de tecidos e aviamentos. }\end{array}$ & $\begin{array}{l}\text { Pesquisar comportamento } \\
\text { dos tecidos/ Caderno de } \\
\text { amostras de tecido. }\end{array}$ & $\begin{array}{l}\text { É preciso utilizar diferentes } \\
\text { tipos e pesos de tecidos para } \\
\text { diversificar a coleçăo. }\end{array}$ & & & & $\begin{array}{l}\text { Para o design } \\
\text { tecidos são texturas. }\end{array}$ \\
\hline Beneficiamentos & 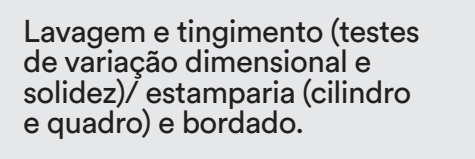 & $\begin{array}{l}\text { Sugere terceirizar } \\
\text { tingimento e estamparia. }\end{array}$ & $\begin{array}{l}\text { Estampas, tingimentos, } \\
\text { lavagens e bordados } \\
\text { ajudam a ilustrar o tema. }\end{array}$ & & & & \\
\hline Desenhos & $\begin{array}{l}\text { Esboço (peças isoladas)/ } \\
\text { Croquis (look completo) } \\
\text { com posiçōes do corpo. }\end{array}$ & 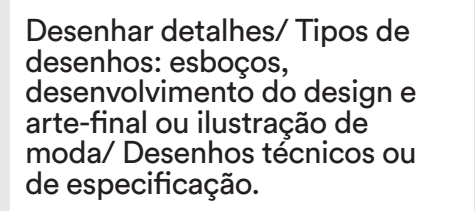 & $\begin{array}{l}\text { Esboço e croqui são sinônimos/ } \\
\text { ilustração de moda evoca o clima da } \\
\text { coleção/"Desenhos de trabalho", } \\
\text { "de especificaçôes" ou "planificados" } \\
\text { são sinônimos para desenho técnico. }\end{array}$ & $\begin{array}{l}\text { Desenhar detalhes } \\
\text { para colagens visuais. }\end{array}$ & & & \\
\hline $\begin{array}{l}\text { Plano ou } \\
\text { Mix de Coleção }\end{array}$ & & $\begin{array}{l}\text { Organiz. por desenhos, } \\
\text { fotos ou mostruário. }\end{array}$ & & $\begin{array}{l}\text { Divisão por tipos de } \\
\text { tecidos/lookbook. }\end{array}$ & & & \\
\hline $\begin{array}{l}\text { Geração de } \\
\text { Alternativas }\end{array}$ & & $\begin{array}{l}\text { Testar diferentes opções de } \\
\text { mangas, recortes e ajustes. }\end{array}$ & $\begin{array}{l}\text { Produzir } 1 \text { novo desenho a partir } \\
\text { de } 3 \text { colagens (desenhos). } \\
\text { Pode mudar cor, stampa, } \\
\text { recorte e função da peça. }\end{array}$ & & $\begin{array}{l}\text { Alternativas para a solução } \\
\text { de um problema. }\end{array}$ & & $\begin{array}{l}\text { Elementos isomorfos, } \\
\text { homeomorfos e } \\
\text { catamorfos. }\end{array}$ \\
\hline $\begin{array}{l}\text { Volumentria } \\
\text { Moulage }\end{array}$ & $\begin{array}{l}\text { Modelagem plana } \\
\text { e Moulage }\end{array}$ & $\begin{array}{l}\text { Modelagem plana } \\
\text { e Moulage. }\end{array}$ & $\begin{array}{l}\text { Modelagem plana e moulage } \\
\text { com fotografiia para } \\
\text { desenvolvimento de esboços }\end{array}$ & $\begin{array}{l}\text { Auxilio do modelista } \\
\text { e do piloteieiro para } \\
\text { constituir formas. }\end{array}$ & & & \\
\hline $\begin{array}{l}\text { Confecção } \\
\text { do Look }\end{array}$ & $\begin{array}{l}\text { Protótipo ou peça-piloto } \\
\text { confeccionada pela piloteira. }\end{array}$ & $\begin{array}{l}\text { Para avaliar a peça foco na } \\
\text { passadoria e prova de roupa. }\end{array}$ & & Depende do piloteiro. & $\begin{array}{l}\text { Solução do problema/protótipo } \\
\text { ou "cabeça de série". }\end{array}$ & & \\
\hline Apresentação & $\begin{array}{l}\text { Participação em feiras, } \\
\text { desfile e catálogo. }\end{array}$ & Desfile de TCC & & 6 looks + lookbook & & $\begin{array}{l}\text { Apresentacãão do projeto por } \\
\text { esbocoso, fotografia, aquarela, } \\
\text { rendering etc. }\end{array}$ & \\
\hline
\end{tabular}

Quadro 2 - Cruzamento dos autores e suas etapas de estilismo, projeto em moda e projeto em design Fonte: A autora (2016). 


\section{Noções de estilismo e projeto em moda no campo acadêmico}


O presente capítulo está organizado de acordo com as etapas que representam possíveis noções de projeto em moda ou estilismo.

Os aspectos das noções de projeto e estilismo que compõem este capítulo foram apurados por meio de entrevistas qualitativas com os entrevistados, apresentadas no Quadro 3, a seguir.

Um dos objetivos desta tese é, precisamente, explicitar as noções mencionadas. Por vezes, elas são apresentadas como estando relacionadas à noção de projeto do campo do design, em função da experiência dos depoentes. 
Conforme explicitado na Introdução, a escolha dessas instituições baseou-se no fato de as mesmas reunirem a maior e a melhor produção sobre projeto em moda no país.

A maior produção está no eixo RJ-SP porque estas são cidades que foram pioneiras no ensino do design de moda seja no lato sensu, seja no stricto sensu. Quando a referência são pesquisas de pós-graduação, universidades como a PUCRJ, no Rio de Janeiro, a Universidade Anhembi Morumbi, a UNESP/FAAC e a FAUUSP de São Paulo, foram as que deram os primeiros passos para apoiar pesquisas no campo do design de moda. Como fomentam o desenvolvimento de pesquisas acadêmica voltadas ao campo do design de moda há mais de vinte anos, é evidente que o acúmulo desse tipo de produção seja maior nesses estados do país.

Os professores dos cursos pioneiros dedicam-se à pesquisa no campo de moda há mais tempo nos estados de São Paulo e Rio de Janeiro se comparado a outros estados do Brasil. Portanto, de maneira geral, possuem mais experiência no campo da pesquisa em moda se comparados aos docentes de outros estados.

Um dos requisitos para a avaliação dos cursos de graduação é a qualidade do corpo docente e sua produção. Se for utilizado o RUF (Ranking Universitário da Folha de São Paulo em https://ruf.folha.uol.com.br/2017/ ranking-de-cursos/moda/) como referência, dos dez primeiros lugares, cinco são ocupados por escolas de São Paulo e Rio de Janeiro no ano de 2017, sendo que o primeiro lugar foi atribuído à Universidade Anhembi Morumbi. Vale lembrar que boa parte do corpo docente dos cursos de mestrado e doutorado destas escolas é constituído pelos mesmos professores atuantes na graduação.

A UAM possui um programa de doutorado voltado ao design e à moda pioneiro, além de ter sido pioneira no curso de moda no nível de graduação. Seus docentes são os que mais publicam em eventos de design e periódicos, além de terem fundado eventos científicos como o Colóquio de Moda.

No Quadro 3, a seguir, são apresentadas as instituições pesquisadas em São Paulo e no Rio de Janeiro:

\section{Instituições de São Paulo}

\begin{tabular}{|c|c|}
\hline Início das atividades & Início do curso de moda \\
\hline $\begin{array}{l}\text { EACHUSP - Escola de Artes, Ciências } \\
\text { e Humanidades da Universidade de } \\
\text { São Paulo, fundada em } 2005 \text {. }\end{array}$ & 2005 - Têxtil e Moda \\
\hline $\begin{array}{l}\text { FAACUNESP - Faculdade de Arquitetura, } \\
\text { Artes e Comunicação da Universidade } \\
\text { Estadual Paulista " "úlio de Mesquita Filho", } \\
\text { incorporada pela UNESP em 1988. }\end{array}$ & 1988 - Desenho Industrial \\
\hline $\begin{array}{l}\text { FASM - Faculdade Santa Marcelina, } \\
\text { fundada em 1929, oferece tradicionais } \\
\text { cursos voltados às artes. }\end{array}$ & $\begin{array}{l}1988 \text { - Desenho de Moda } \\
\text { (atualmente chama-se Moda) }\end{array}$ \\
\hline $\begin{array}{l}\text { FAUUSP - Faculdade de Arquitetura } \\
\text { e Urbanismo da Universidade de } \\
\text { São Paulo, fundada em } 1948 .\end{array}$ & 2006-Design \\
\hline $\begin{array}{l}\text { SENACSP - Serviço Nacional de } \\
\text { Aprendizagem Comercial de São Paulo, } \\
\text { fundado em } 1946 .\end{array}$ & $\begin{array}{l}1998 \text { - Design de Moda } \\
2005 \text { - Entre } 2005 \text { e } 2010 \\
\text { ofereceu o Mestrado em } \\
\text { "Moda, Cultura e Arte" }\end{array}$ \\
\hline $\begin{array}{l}\text { UAM - Universidade Anhembi } \\
\text { Morumbi, fundada em } 1970 \text {, pioneira } \\
\text { em diversos cursos no Brasil. }\end{array}$ & $\begin{array}{l}1991 \text { - Moda } \\
\text { (em } 1998 \text { torna-se Design de Moda) } \\
2006 \text { - Desde } 2006 \text { oferece } \\
\text { o Mestrado e desde } 2014 \\
\text { o Doutorado em Design, } \\
\text { Arte e Tecnologia. } \\
\text { Anteriormente, oferecia uma } \\
\text { linha de pesquisa em moda, } \\
\text { mas atualmente não possui } \\
\text { qualquer linha de pesquisa } \\
\text { na área. }\end{array}$ \\
\hline \multicolumn{2}{|l|}{ Instituições do Rio de Janeiro } \\
\hline Início das atividades & Início do curso de moda \\
\hline $\begin{array}{l}\text { PUCRJ - Pontifícia Universidade Católica } \\
\text { do Rio de Janeiro, fundada em } 1940 .\end{array}$ & $\begin{array}{l}2001-\text { o curso técnico } \\
\text { torna-se o Bacharelado } \\
\text { em Design de Moda }\end{array}$ \\
\hline $\begin{array}{l}\text { SENAI CETIQT - Serviço Nacional de } \\
\text { Aprendizagem Industrial, fundado em 1942, } \\
\text { e Centro de Tecnologia da Indústria } \\
\text { Química e Têxtil, (nome adotado a partir de } \\
\text { 1980). Desde 1980, o CETIQT corresponde } \\
\text { à antiga ETIQT (Escola Técnica da Indústria } \\
\text { Química e Têxtil), fundada em } 1949 .\end{array}$ & 2007 - Design de Moda \\
\hline $\begin{array}{l}\text { UVA - Universidade Veiga de } \\
\text { Almeida, fundada em } 1971 .\end{array}$ & 1995 - Moda \\
\hline
\end{tabular}

Quadro 3 - Instituiçōes pesquisadas em São Paulo e Rio de Janeiro
Fonte: A autora (2018) 
É fundamental explorar o tema de pesquisa em profundidade do ponto de vista dos atores (POUPART, 2008, p. 216), pois é importante percebe como os indivíduos estudados constroem e definem sua realidade, como a articulam e que peso dão aos fatos que vivenciaram (VELHO, 1980, p. 16).

A pesquisa realizou trinta e cinco entrevistas com trinta e três pioneiros. Além dos pioneiros, há quatro entrevistados que não correspondem ao perfi de pioneiro e, portanto, a tese conta com trinta e sete entrevistados no total.

São considerados pioneiros os primeiros docentes e pesquisadores que atuaram no início e no desenvolvimento do campo acadêmico de moda at o presente momento, que colaboraram para a especialização do campo do projeto em moda por meio de suas pesquisas e ações, como a pratica docente e a criação de cursos de stricto sensu.

A seguir, é apresentada relação simplificada de pioneiros entrevistados dentro do recorte proposto pela tese. Os nomes em itálico representam depoentes que cederam mais de um depoimento ou cujo depoimento foi usado para analisar mais de uma escola.

\begin{tabular}{|c|c|c|c|c|c|c|}
\hline FASM & UAM & $\begin{array}{l}\text { SENAC } \\
\text { SP }\end{array}$ & EACH & FAU & UNESP & $\begin{array}{l}\text { Rio de } \\
\text { Janeiro }\end{array}$ \\
\hline Vera Lígia & $\begin{array}{l}\text { Cristiane } \\
\text { Mesquita }\end{array}$ & $\begin{array}{c}\text { Maria } \\
\text { Claudia } \\
\text { Bondadio }\end{array}$ & $\begin{array}{l}\text { Cláudia } \\
\text { Garciciniti } \\
\text { Vicentini }\end{array}$ & $\begin{array}{l}\text { Cibele } \\
\text { tyaddadd } \\
\text { Taralli }\end{array}$ & $\begin{array}{l}\text { Mônica } \\
\text { Moura }\end{array}$ & $\begin{array}{l}\text { Deborah } \\
\text { Christo }\end{array}$ \\
\hline $\begin{array}{l}\text { Ausesnede } \\
\text { Stephan } \\
\text { Eddy Pires }\end{array}$ & $\begin{array}{l}\text { Kathia } \\
\text { Castiliho }\end{array}$ & $\begin{array}{l}\text { Maria } \\
\text { Eduarda a } \\
\text { Guimarăes }\end{array}$ & $\begin{array}{l}\text { Francisca } \\
\text { Dantos } \\
\text { Mendes }\end{array}$ & $\begin{array}{l}\text { Robinson } \\
\text { Salata }\end{array}$ & $\begin{array}{l}\text { Patríia } \\
\text { de Mello } \\
\text { Souza }\end{array}$ & $\begin{array}{l}\text { Alberto } \\
\text { Cipiniuk }\end{array}$ \\
\hline $\begin{array}{l}\text { Renata } \\
\text { Zaganin de } \\
\text { Oliveira }\end{array}$ & $\begin{array}{l}\text { Rosane } \\
\text { Preciosa }\end{array}$ & $\begin{array}{l}\text { Cynntia } \\
\text { Saltos } \\
\text { Malaguti } \\
\text { de Sousas }\end{array}$ & & $\begin{array}{l}\text { Cyntia } \\
\text { Santos } \\
\text { Malaguti } \\
\text { de Sousa }\end{array}$ & & $\begin{array}{l}\text { Aline } \\
\text { Monçores }\end{array}$ \\
\hline $\begin{array}{l}\text { Simone } \\
\text { Mina }\end{array}$ & $\begin{array}{l}\text { Mário } \\
\text { Queiróz }\end{array}$ & $\begin{array}{l}\text { Eunice } \\
\text { Higa }\end{array}$ & & $\begin{array}{l}\text { Maria } \\
\text { Celeste } \\
\text { dertitima } \\
\text { Sanches }\end{array}$ & & $\begin{array}{l}\text { Evelyn } \\
\text { Grumach }\end{array}$ \\
\hline $\begin{array}{l}\text { Mariana } \\
\text { Rocha }\end{array}$ & $\begin{array}{l}\text { Francisca } \\
\text { Dantas } \\
\text { Mendes }\end{array}$ & $\begin{array}{l}\text { Andrea } \\
\text { Canton }\end{array}$ & & $\begin{array}{l}\text { Feres } \\
\text { Lourenço } \\
\text { Khouryy }\end{array}$ & & $\begin{array}{l}\text { Sérgio } \\
\text { Sudsilowsk }\end{array}$ \\
\hline $\begin{array}{l}\text { Elá } \\
\text { Camarena }\end{array}$ & & & & & & $\begin{array}{l}\text { Irina } \\
\text { Aragão }\end{array}$ \\
\hline Márcio lto & & & & & & $\begin{array}{l}\text { label } \\
\text { Maria de } \\
\text { Oliveira }\end{array}$ \\
\hline $\begin{array}{l}\text { João } \\
\text { Braga }\end{array}$ & & & & & & \\
\hline $\begin{array}{l}\text { Circe } \\
\text { Bernardes }\end{array}$ & & & & & & \\
\hline
\end{tabular}

\section{Circe
Bernardes}

Serão denominados pioneiros, aqui, os primeiros docentes e pesquisadores que se dedicaram à formalização do campo acadêmico de moda desde seu início em 1988, e à sua manutenção até os dias atuais, por intermédio de sua atuação, que inclui a pesquisa, a prática docente e a criação de cursos de stricto sensu.

Antes de iniciar a exposição das etapas em cada instituição pesquisada, é importante esclarecer melhor a vinculação de cada pioneiro com as problematizações desta tese. A escolha de cada pioneiro foi determinada pelo potencial de seu depoimento, embasado, por sua vez, em sua experiência como pesquisador e docente. Os dados extraídos dos depoimentos, fornecidos pelos pioneiros listados a seguir (vide abaixo Quadro 5 - Lista de Pioneiros de São Paulo e do Rio de Janeiro) serão encontrados principalmente neste Capítulo.

A respeito da metodologia para a coleta de dados, o livro Manual de História Oral de Verena Alberti (2013, p. 21-59 passim) orientou tanto processo de construção de roteiros, métodos e técnicas de entrevista e transcrição, quanto a carta de cessão do depoimento e o armazenamento e a preservação de dados dentro de um cronograma, com o intuito de alinhar "procedimentos regulares que devem ser seguidos para obter maior fidedignidade e maior quantidade e qualidade de informação". É visível o efeito do levantamento de fontes primárias na pesquisa, pois ele oferece condições de avançar no que diz respeito a aspectos não teóricos da literatura. (SCHERER in MATTOS, 2015, pag. 174).

Foram realizadas entrevistas temáticas (ALBERTI, 2013, p. 48) de caráter exploratório, concentrando seu foco na obtenção de dados qualitativos, proporcionando uma visão geral de determinado fato. Esse tipo de entrevista consiste em abordar pessoas que tiveram ou têm experiências práticas com o problema pesquisado e que estimulem sua compreensão.

A pesquisa exploratória é realizada a partir de um problema ou questão de pesquisa pouco explorados. Seu objetivo se concentra em buscar padrões, ideias ou hipóteses, embora não haja interesse primordial em testar ou confirmar determinada hipótese.

Sobre o tratamento dos dados obtidos, segundo Alberti (2013, p. 160) - pesquisador deve se perguntar a respeito das razões e significados das respostas obtidas e incorporar essa reflexão à avaliação do trabalho realizado.

Algumas dimensões da entrevista de tipo qualitativa que serão consideradas nesta tese são abordadas por Jean Poupart (2008, p. 215), entre elas a determinação do contexto na produção do discurso, o papel da subjetividade do pesquisador sobre a investigação e a influência dos processos de transcrição dos relatos.

A determinação do contexto sofre influência oriunda da atitude do pesquisador. Este deve ter cuidado ao "privilegiar dados que dentro da cultura em pauta tenham outro peso e significado", alerta Gilberto Velho (1980, p. 16)
Quadro 4-Pioneiros recorte proposto pela
Fonte: A autora (2018). 


\section{Quadro 5}

Lista de Pioneiros de

São Paulo e do Rio de Janeiro 


\section{Nasc. Formação}

Auresnede Stephan Eddy Pires - um dos professores pioneiros da FASM, leciona até hoje a disciplina de Metodologia Visual para o curso de Moda.

Circe Bernardes -Lecionou no curso de Moda da FASM entre 1990 e 2000, ministrando as disciplinas de Oficina Experimental e Estilismo, e atuando em sala com Carlos Mauro Rosas.

Elá Camarena (Elaine Camarena) - egressa do curso de Moda da FASM do início da década de 1990, oi aluna de Carlos Mauro Rosas. Atualmente é professora de Expressões Gráficas da pós-graduação "Moda e Criação" da FASM.

João Braga - docente do curso da FASM desde 2000. Leciona História da Arte no curso de graduação em Moda e a disciplina de Cultura e Historia da Moda na pós-graduação Moda e Criaçăo. Como professor e colaborador esteve ou ainda está em contato com os cursos de Moda da UAM, SENACSP, UNIP e FAAP.

FASM

Faculdade

Santa

Marcelina

Márcio Ito - egresso do curso de Moda da FASM no início dos anos 2000. Foi aluno de Simone Mina, Mariana Rocha e Silvia Sato. Atualmente é professor de Planejamento e Desenvolvimento de Coleções da graduação em Moda da FASM.

Mariana Rocha - egressa do curso de Moda da FASM do fim da década de 1990, foi aluna de Carlos Mauro Rosas. Substituiu Rosas como professora de Estilismo entre 2001 e 2012. Atualmente é professor de Moda Contemporânea da graduação em Moda da FASM.

Renata Zaganin de Oliveira - egressa do curso de Moda da FASM do fim da década de 1990, foi aluna earlos Mauro Rosas. Atualmente é professora de Desenho da graduação em Moda e coordenadora da Pós-graduação "Moda e Criação".

Simone Mina - egressa do curso de Moda da FASM do fim da década de 1990, foi aluna de Carlos Mauro Rosas. Atualmente é professora de Estilismo da graduação em Moda e orientadora dos Trabalhos de

Vera Lígia Pieruccini Gibert - docente da disciplina Desenho de Estamparia da FASM, uma das

Cristiane Mesquita - professora do curso de Moda da UAM desde o fim dos anos 1990. Lecionou entre

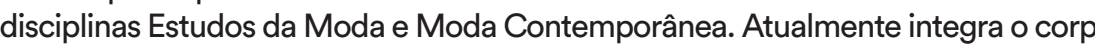
Programa de Pós-graduacão em Design da UAM onde leciona Metodologia da Pesquisa para o Doutorado. Integra o conselho científico da revista D.A.M.T.E. e do Colóquio de Moda.

Francisca Dantas Mendes - graduada em Moda pela UAM em 1994, na primeira turma do curso, onde el como docente. Atualmente e professora e vice-coordenadora do curso de Têxtil e Moda da EACHUSP.

UAM

Universidade Kathia Castilho - professora do curso de Moda da UAM desde o início dos anos 1990. Também desempenhou importante papel como docente do curso de Textil e Moda da EACHUSP. Lecionou entre outras disciplinas Moda tendo tomado posse em 16/12/2016.

Mário Queiróz - foi professor de Pesquisa, Criação e Estilo do curso de Moda da UAM desde seu início, onde também foi coordenador do curso de Moda. Leciona em importantes escolas de Moda do país. Estilista integrante da SPFW.

Rosane Preciosa - atualmente é professora no Instituto de Artes e Design da UFJF, ingressou como professora no curso de Moda da UAM em 2002
Graduação em Desenho Industrial FAAP 1967/1970: Especializacão na ESPM

1969/1970; Mestrado em Educação, Arte e História da Cultura Mackenzie

1969/1970; Mestrado em Educação, Arte e História
1997/2000; Doutorando pela FAUUSP desde 2015.

Nasceu em Graduação pela FAUUSP 1972/1978;

02/05/1951 Graduação em Artes Plásticas na FAAP 1970/1974.

Nasceu em Graduação em Desenho de Moda FASM 1988/1992;

08/03/1968 Mestrado pela UAM em “Design, Arte e Moda” 2009/2011.

Nasceu em

Licenciatura Plena em Educação Artística pela Universidade Federal de Juiz de Fora 1980/1984;

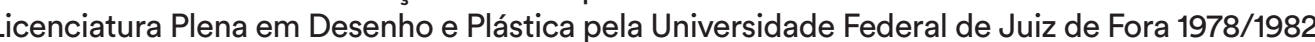

Especialização em História da Indumentária pela Fundação Escola de Sociologia e Política de São Paulo PUCSP 1999/2002.

Nasceu em Graduação em Moda pela FASM 2003/2006

27/05/1985 Especialização em Moda \& Criação FASM 2011/2012.

Nasceu em Graduação em Moda pela FASM 1996/1999;

28/12/1962 Especialização Mm Moda \& Criação FASM 2002/2004;

Mestrado em Artes Visuais pela FASM 2007-2009.

Nasceu em Graduação em Moda pela FASM 1994/1997;

24/05/1971

Mestrado em Educação, Arte e História da Cultura pela Mackenzie 2004/2005.

Nasceu em Graduação em Moda pela FASM 1996/1999;

23/05/1977 Mestranda em Educaço, Arte e História da Cultura pelo Mackenzie desde 2015.

Licenciatura em Desenho e Plástica FASM 1967/1970;

06/03/1949 Especialização em Artes FASM 1977/197/
Mestrado pela ECAUSP 1990/1993.

Cristiane Mesquita - professora do curso de Moda da UAM desde o fim dos anos 1990. Lecionou entre outras disciplinas Estudos da Moda e Moda Contemporânea. Atualmente integra o corpo docente do Doutorado. Integra o conşo em Design da UAM onde leciona Metodologia da Pesquisa para o

Nasceu em Graduação em Moda pela UAM 1990/1993; Especialização em Moda e Comunicação pela UAM 15/04/1952 2002/2003; Mestrado em Engenharia de Produçăo pela UNIP 2005/2006; Doutorado em Engenharia de Produção pela UNIP 2007/2010; Pós-doutorado pela FAUUSP 2014/2016.

Nasceu em Graduação em Ciências Sociais pela UNIBAN 1986/1990; Especialização em Design de Moda e Negócios 27/08/1961 da Moda pelo Istituto Sistema Lazio 1985/1986; Especialização em Moda, Estilo e Figurino pela Accaden Semiótica PUCSP 1995/1998; Doutorado em Comunicação e Semiótica PUCSP 1999/2003.

Nasceu em Graduação em Comunicação Social UFF 1982/1986; Especialização em Negócios da Moda UAM 1999/2000; Mestrado em Comunicacão e Semiótica PUCSP 2006/2008. Doutorado em Comunicação e Semiótica PUCSP 2013.

Nasceu em Graduação em Ciências Sociais UFRJ 1975/1979;

22/08/1960 Grastrado em Toria da Literatura UFRJ 1992/1995; 


\section{Nasc. Formação}

\begin{tabular}{|c|c|c|c|}
\hline \multirow{5}{*}{$\begin{array}{l}\text { SENACSP } \\
\text { Serviço } \\
\text { Nacional de } \\
\text { Aprendizagem } \\
\text { Comercial } \\
\text { de São Paulo }\end{array}$} & Andrea Canton - professora de Estilismo do SENACSP entre 2000 e 2015. & $\begin{array}{l}\text { Nasceu em } \\
03 / 10 / 1966\end{array}$ & $\begin{array}{l}\text { Graduação em Comunicação Social FAAP 1985/1988; Curso de Qualificação Profissional de Estilismo } \\
\text { SENAC/SMODE 1996/1998; Especialização em Moda e Comunicação UAM 2001/2003; }\end{array}$ \\
\hline & $\begin{array}{l}\text { Cyntia Santos Malaguti de Sousa - professora da FAUUSP e do SENACSP, atua na área de Design. } \\
\text { Entre } 2003 \text { e } 2005 \text { participou como membro do Conselho do curso de Moda do SENACSP na } \\
\text { reestruturação do curso, voltando-o para o campo do Design. }\end{array}$ & $\begin{array}{l}\text { Nasceu em } \\
02 / 01 / 1958\end{array}$ & $\begin{array}{l}\text { Graduação pela ESDI 1977/1980; Mestranda em Engenharia de Produção UFRJ desde } 1984 \text { - não concluído; } \\
\text { Doutorado pela FAUUSP 1991/2000. }\end{array}$ \\
\hline & Eunice Higa - professora de Estilismo do SENAC SP entre 2000 e 2015. & $\begin{array}{l}\text { Nasceu em } \\
17 / 11 / 1962\end{array}$ & $\begin{array}{l}\text { Graduação em Comunicação Social ESPM 1981/1985; Curso de Qualificação Profissional de Estilismo } \\
\text { SENAC/SMODE 1995/1997; Especialização em Psicologia Faculdade Vicentinapor, FAVI. }\end{array}$ \\
\hline & $\begin{array}{l}\text { Maria Cláudia Bonadio - atualmente é professora no Instituto de Artes e Design da UFJF, foi } \\
\text { professora de História da Moda do curso de Moda do SENACSP, entre } 2004 \text { e } 2013 \text {. }\end{array}$ & $\begin{array}{l}\text { Nasceu em } \\
09 / 07 / 1972\end{array}$ & $\begin{array}{l}\text { Graduação em História UNICAMP 1992/1996; Mestrado em História UNICAMP 1998/2000; } \\
\text { Doutorado em História UNICAMP 2001/2005; Pós-doutorado pela USP em História da Arte 2012/2014. }\end{array}$ \\
\hline & $\begin{array}{l}\text { Maria Eduarda Araújo Guimarães - professora de Cultura Brasileira, História da Moda, Antropologia e Sociologia } \\
\text { do curso de Moda do SENACSP, desde 2005. Atualmente orienta a parte teórica dos TCCs de Moda. }\end{array}$ & $\begin{array}{l}\text { Nasceu em } \\
13 / 10 / 1962\end{array}$ & $\begin{array}{l}\text { Graduação em Direito PUCSP 1981/1985; Graduação em Ciências Sociais PUCSP 1983-1987; } \\
\text { Mestrado em Ciências Sociais PUCSP 1988-1992; Doutorado em Ciências Sociais UNICAMP 1993-1998. }\end{array}$ \\
\hline $\begin{array}{l}\text { EACHUSP } \\
\text { Escola de Artes, Ciências } \\
\text { e Humanidades da } \\
\text { Universidade de São Paulo }\end{array}$ & $\begin{array}{l}\text { Cláudia Regina Garcia - professora do curso de Têxtil e Moda da EACHUSP desde 2006, } \\
\text { onde leciona a disciplina de projeto. }\end{array}$ & $\begin{array}{l}\text { Nasceu em } \\
24 / 07 / 1967\end{array}$ & $\begin{array}{l}\text { Graduação em Engenharia Têxtil FEl 1985/1990; } \\
\text { Mestrado em Comunicação e Semiótica PUCSP 2003/2005; } \\
\text { Doutorado em Engenharia Mecânica UNICAMP 2008/2010. }\end{array}$ \\
\hline \multirow{4}{*}{$\begin{array}{l}\text { FAUUSP } \\
\text { Faculdade de } \\
\text { Arquitetura e } \\
\text { Urbanismo da } \\
\text { Universidade } \\
\text { de São Paulo }\end{array}$} & $\begin{array}{l}\text { Cibele Haddad Taralli - participou da estruturação e início das atividades do curso } \\
\text { de Design da FAUUSP, no qual é docente. }\end{array}$ & $\begin{array}{l}\text { Nasceu em } \\
23 / 12 / 1951\end{array}$ & $\begin{array}{l}\text { Graduação pela FAUUSP 1970/1974; Mestrado pela FAUUSP 1978/1984; } \\
\text { Doutorado pela FAUUSP 1986/1993; }\end{array}$ \\
\hline & Feres Lourenço Khoury - professor da FAUUSP e ex-professor do curso de Moda da FASM. & $\begin{array}{l}\text { Nasceu em } \\
28 / 05 / 1951\end{array}$ & $\begin{array}{l}\text { Graduação pela FAUUSP 1972/1977; Mestrado pela ECAUSP 1986/1991; } \\
\text { Doutorado pela ECAUSP 1994/1996; Livre-docência pela FAUUSP } 2009 .\end{array}$ \\
\hline & $\begin{array}{l}\text { Maria Celeste de Fátima Sanches - foi professora de Projeto e Metodologia Visual } \\
\text { da Universidade Estadual de Londrina (UEL) entre } 2000 \text { e } 2015 \text {. }\end{array}$ & $\begin{array}{l}\text { Nasceu em } \\
11 / 05 / 1969\end{array}$ & $\begin{array}{l}\text { Graduação em Desenho Industrial UFPR 1990/1995; Especialização em Moda UEL 1998/1998; Mestrado em } \\
\text { Desenho Industrial pela UNESP 2000/2003; Doutorado pela FAUUSP 2012/2014; Doctorado en Diseño, } \\
\text { Fabricación y Gestión de Proyectos Industriales Universitat Politècnica de València, UPV, Espanha 2014/2016. }\end{array}$ \\
\hline & $\begin{array}{l}\text { Robinson Salata - coordenador e professor do curso de Design Industrial do SENACSP. } \\
\text { Participou da estruturação e início das atividades do curso de Design da FAUUSP, no qual é docente. }\end{array}$ & $\begin{array}{l}\text { Nasceu em } \\
\text { 05/10/1953 }\end{array}$ & $\begin{array}{l}\text { Graduado em Desenho Industrial pelo Mackenzie 1974/1976; Mestrado pela FAUUSP 1982/1988; } \\
\text { Doutorado pela FAUUSP 2004/2008. }\end{array}$ \\
\hline \multirow{2}{*}{$\begin{array}{l}\text { FAACUNESP } \\
\text { BAURU } \\
\text { Faculdade de Arquitetura, } \\
\text { Artes e Comunicaçăo } \\
\text { da Universiddade } \\
\text { Estadual Paulista } \\
\text { "Júlio de Mesquita Filho" }\end{array}$} & $\begin{array}{l}\text { Mônica Moura - atualmente é professora do curso de Design da FAACUNESP de Bauru. Integrou o curso } \\
\text { de Design e Moda da UAM, onde foi professora e diretora da Escola de Artes, Arquitetura, Design e Moda. }\end{array}$ & $\begin{array}{l}\text { Nasceu em } \\
07 / 05 / 1963\end{array}$ & $\begin{array}{l}\text { Graduação em Educação Artística pela FEBASP 1980/1983; Mestrado em Comunicação e Semiótica } \\
\text { PUCSP 1988/1994; Doutorado em Comunicação e Semiótica PUCSP 1998/2003. }\end{array}$ \\
\hline & Patrícia de Mello Souza - professora de Modelagem do curso de Design de Moda da UEL. & $\begin{array}{l}\text { Nasceu em } \\
20 / 08 / 1961\end{array}$ & $\begin{array}{l}\text { Graduada em Arquitetura e Urbanismo pela UPFR 1979/1983; Especialização em Moda no Centro } \\
\text { Universitário de Jaraguá do Sul, UNERJ 1997/1999; Mestrado em Desenho Industrial pela UNESP } \\
\text { 2003/2006; Doutorado em Design pela UNESP 2009/2013. }\end{array}$ \\
\hline \multirow{7}{*}{ 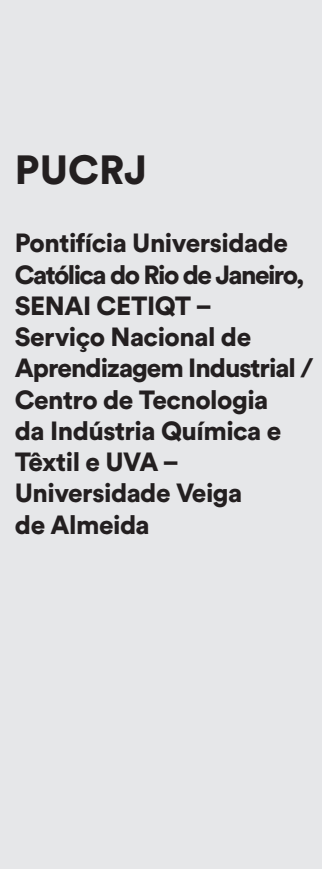 } & $\begin{array}{l}\text { Alberto Cipiniuk - professor aposentado do Departamento de Teoria e História da Arte do } \\
\text { Instituto de Artes da Universidade do Estado do Rio de Janeiro. Atualmente é professor e } \\
\text { coordenador do Departamento de Artes e Design da PUCRJ. }\end{array}$ & $\begin{array}{l}\text { Nasceu em } \\
26 / 11 / 1951\end{array}$ & $\begin{array}{l}\text { Licenciatura em História da Arte UERJ 1972/1978; Especialização em História da Arte e Arquitetura } \\
\text { 1979/1981; Mestrado em Filosofia Estética UFRJ 1982/1985; Doutorado em Filosofia e Letras pela } \\
\text { Université Libre de Bruxelles, ULB, Bélgica 1986/1990. }\end{array}$ \\
\hline & $\begin{array}{l}\text { Aline Monçores - atualmente é coordenadora do curso de Design de Moda da UVA. É } \\
\text { professora da PUCRJ e foi professora de Projeto no SENAI CETIQT entre } 2004 \text { e } 2010 .\end{array}$ & $\begin{array}{l}\text { Nasceu em } \\
27 / 08 / 1975\end{array}$ & $\begin{array}{l}\text { Graduação em Moda pela UVA 1997/1999; Especialização em Marketing de Moda pela UAM 2004/2005; } \\
\text { Mestrado em Design PUCRJ 2004/2006; Doutorado em Design PUCRJ 2008/2012. }\end{array}$ \\
\hline & $\begin{array}{l}\text { Deborah Christo - foi professora e coordenadora (entre } 2008 \text { e 2010) no SENAI CETIQT } \\
\text { e professora na UVA e na PUCRJ nos cursos de Moda até } 2015 .\end{array}$ & $\begin{array}{l}\text { Nasceu em } \\
04 / 08 / 1969\end{array}$ & $\begin{array}{l}\text { Graduação pela ESDI UERJ 1987/1990; Mestrado em Design PUCRJ 2001/2003; } \\
\text { Doutorado em Design PUCRJ 2009/2013. }\end{array}$ \\
\hline & Evelyn Grumach - professora de Projeto no curso de Design da PUCRJ. & $\begin{array}{l}\text { Nasceu em } \\
11 / 12 / 1951\end{array}$ & Graduada pela ESDI 1970/1973. \\
\hline & Irina Aragão - professora de Projeto no curso de Design da PUCRJ. & $\begin{array}{l}\text { Nasceu em } \\
23 / 01 / 1965\end{array}$ & $\begin{array}{l}\text { Graduação em Desenho Industrial pela UFRJ 1983/1988; Graduação em História UFRJ 1999/2007; } \\
\text { Mestrado em Design PUCRJ 2002/2003; Doutorado em História Comparada UFRJ 2010/2014. }\end{array}$ \\
\hline & Sérgio Sudsilowsky - coordenou o curso de Design de Moda do SENAI CETIQT entre 2009 e 2014. & $\begin{array}{l}\text { Nasceu em } \\
21 / 12 / 1975\end{array}$ & $\begin{array}{l}\text { Graduação em Desenho Industrial UNEB 1994/1998; Graduação em Administração UFRRJ 2015/Não concluído; } \\
\text { Especialização em Docência pela Cândido Mendes 2015/Não concluído; Mestrado em Design PUCRJ } \\
\text { 2001/2003; Doutorado em Design PUCRJ 2006/interrompido em 2010. }\end{array}$ \\
\hline & $\begin{array}{l}\text { Izabel Maria de Oliveira - é professora adjunta do Departamento de Artes e Design da PUC-Rio. Em } 2007 \\
\text { participou das reuniōes para a confecção da atual grade do curso de Design da PUCRJ que passou a oferecer } \\
\text { Design de Moda e que ainda hoje se encontra em vigor. Também atuou como coordenadora do curso de } \\
\text { Design de Moda da PUCRJ entre } 2013 \text { e } 2015 \text {. }\end{array}$ & $\begin{array}{l}\text { Nasceu em } \\
20 / 01 / 1949\end{array}$ & $\begin{array}{l}\text { Graduação em Desenho Industrial ESDI 1967/1980; } \\
\text { Mestrado em Design PUCRJ 1999/2001; Doutorado em Design PUCRJ 2004/2009. }\end{array}$ \\
\hline
\end{tabular}

Quadro 5 - Lista de Pioneiros de São Paulo e do Rio de Janeiro Fonte: A autora (2018). 
O desenvolvimento de produtos de moda envolve inúmeros aspectos, entre eles a pesquisa. Quando ela é voltada ao produto, é dedicada à investigação de imagens, formas, silhuetas, cores, tecidos, aviamentos, além de aspectos sociais e culturais que possam ter algum tipo de relação com o produto em questão.

Na pesquisa de mercado são levados em consideração o público, suas demandas, os relatórios de vendas, além de testes de outra natureza. E inevitável que a pesquisa voltada ao desenvolvimento de produto acabe por se cruzar com a pesquisa de mercado.

Como a pesquisa direciona o projeto em moda, ela deve ser alimentada, avaliada e revisada constantemente. Dessa forma, trata-se de um trabalho contínuo.

\section{1 $\stackrel{\text { FASM }}{\text { Faculdade Santa Marcelina }}$}

18 Faculdade
Santa Marcelina

Conhecida como Projeto em Moda por boa parte das faculdades brasileiras, a disciplina e a prática ligada à pesquisa, criação e desenvolvimento de artigos de moda na FASM ${ }^{18}$ é chamada Estilismo. Segundo Vera Lígia Pieruccini Gibert, a expressão estilismo está ligada à ideia de estilo artístico e guarda relação com o curso de Artes Visuais, também oferecido pela instituição.

A partir de 1964, a graduação em Professorado em Desenho da FASM passou a oferecer a disciplina Desenho de Modas, introduzida pela irmã Jeanne Eugènie Villien. Com seu falecimento, Gibert herdou a disciplina em 1973. O Professorado em Desenho tornou-se graduação em Desenho de Moda em 1988, a primeira a ser oferecida no Brasil.

Inicialmente, a pesquisa realizada para esta tese analisou depoimentos de professores da FASM. Entre eles figuram Elaine Camarena, professora da pós-graduação lato sensu "Moda e Criação", Mariana Rocha, professora de Moda Contemporânea e Estilismo, Márcio Ito, professor de Desenvolvimento de Coleções, Renata Zaganin, professora de Desenho, Simone Mina, professora de Estilismo, João Braga, professor de História da Arte, Auresnede Pires Stephan, professor de Metodologia Visual, Circe Bernardes, professora de Oficina Experimental e Estilismo e Vera Lígia Pieruccini Gibert, primeira coordenadora do curso, estas duas últimas hoje desligadas da escola.

Posteriormente, foram coletados os relatos de ex-alunos da graduação em Desenho de Moda da FASM que frequentaram o curso entre 1988 e 2006. Estes depoimentos ajudaram a elencar os processos que compuseram a ideia de estilismo na primeira década de curso. Foram entrevistadas as exalunas Elaine Camarena Soares, Mariana Machado Lousada Rocha, Márcio Ito, Renata Zaganin, e Simone Mina
Os idealizadores e fundadores do curso, Auresnede Pires Stephan e Vera Lígia Pieruccini Gibert, formaram uma das primeiras gerações de estilistas com ensino formal no Brasil. É fácil perceber que essa geração liderou um movimento de endogenia dentro da FASM que contratou os egressos Elaine Camarena, Mariana Rocha, Márcio Ito, Simone Mina e Renata Zaganin. $O$ bacharelado em Desenho de Moda - fundado em 1988 - teve como primeira coordenadora Gibert, que se manteve no cargo até 2000. Ela também foi responsável pela disciplina de Desenho de Estamparia.

Esse texto está organizado de acordo com as etapas de estilismo apresentadas nos depoimentos dos entrevistados. Aparentemente, até hoje essas etapas norteiam a ideia de estilismo do curso da FASM, com algumas atualizações.

\section{O Estilismo na FASM na fase de Carlos Mauro Fonseca Rosas}

As aulas de Estilismo na FASM, entre 1988 e 1997, foram quase sempre lecionadas por Carlos Mauro Fonseca Rosas. Elas aconteciam no segundo, terceiro e quarto anos de formação. Atualmente as disciplinas de Estilismo se dividem entre os professores Marcio Ito, Simone Mina e Valquíria Caversan e se tornaram semestrais.

É partindo de sua própria experiência profissional que Rosas propõe a ideia de estilismo em etapas, mas não necessariamente de forma sistematizada. A apresentação a seguir visa ordenar as etapas forma mais sistemática possível, contribuindo para o melhor entendimento das fases desse processo, no período de Rosas e no momento subsequente.

\section{Pesquisa de Referências}

Havia um exercício chamado de "Resgate do seu passado" ou “Documentação" realizado por meio de fotos, tecidos e objetos pesquisados livremente pelos alunos, inicialmente sem referências de moda. Por meio de uma dinâmica, era proposto um retorno ao passado, para que a pesquisa trouxesse uma marca pessoal, de preferência ligada à origem do aluno.

Simone Mina relata que era solicitado aos alunos que encontrassem três pontos importantes no seu passado, relevantes o suficiente e que pudessem contribuir com a moda brasileira. Segundo Mariana Rocha estes três pontos ajudariam a contar três histórias que levariam a apurar três tendências ${ }^{19}$ para a criação de três coleções desenvolvidas pelos alunos ao longo do ano letivo.
9 Estas tendências não estão relacionadas ao
uso de cores, materiais determinada estaçãa, geralmente provenientes Europa. Elas se confundiam referência. Rosas propunh que o aluno criasse suas próprias tendências, para un formador de opinião. As tendências trabalhadas nas aulas de Rosas diziam espeito a uma historíia que faria difere 
Além do "Resgate do seu passado" outra forma de pesquisa estimulada por Rosas era o Shopping. Enquanto a primeira se voltava para o mundo interior do estudante, no segundo caso, a preocupação era o ambiente externo.

No Shopping - fala-se com sotaque afrancesado com a acentuação do "i" -, a ideia era enviar o aluno às ruas, sem recorrer aos ambientes de moda. Assim como o "Resgate do seu passado", o Shopping tinha como objetivo detectar tendências.

Em sala, as tendências iam se juntando por similaridade e contiguidade. Mariana Rocha conta que, para que cada aluno extraisse três tendências, eram formadas mesas para o trabalho em grupo, como as "rodas de conversação". Estas tendências iriam surgir na coleção com maior ou menor frequência, de acordo com a sua divisão em dominantes, intermediárias e tônicas.

Tanto o "Resgate do seu passado" quanto o Shopping eram operaç̃̃es de pesquisa que geravam Ambiences.

\section{Registro da Pesquisa}

O resgate ou documentação e o shopping, representavam fases da coleta de informações, ou seja, se referiam à pesquisa e tinham como pressuposto gerar um "ambiente" que era montado coletivamente. Este era chamado pelo seu nome em francês, Ambience, ou de Ambiência, em português. Sem formato fixo, a ideia principal era produzir uma espécie de "painel" bidimensional ou tridimensional que se tornaria então a matriz temática para o desenvolvimento da coleção.

Renata Zaganin de Oliveira confirma a fala de Mariana Rocha ao contar como o professor Rosas propunha uma "roda de conversação", dispondo os alunos em círculo e sugerindo que todos se envolvessem e discutissem a dinâmica. Nas palavras de Simone Mina, era a partir dessas rodas que surgia a ambience, que deveria dar condições de o aluno extrair elementos do design para a criação da coleção.

A partir das tendências levantadas, era construída uma Ambience, que serviria de referência para toda a sala. Desse material, cada aluno criava sua própria Ambience, ou seja, extraía desse trabalho geral diretrizes para seu trabalho individual, revelando seu olhar criador a partir de suas escolhas. A ambience compreendia uma cartela de cores, bem como estampas, texturas, materiais e esboços de croquis. Ela pode ser compreendida como o suporte de documentação da pesquisa realizada para um projeto em moda. Rosas sempre preferiu o termo ambience ao vocábulo "painel".

Circe Bernardes, ex-professora da FASM, que atuava junto com Rosas, comenta que os alunos tinham dificuldade de entender o que era solicitado. Após o shopping era necessário extrair da pesquisa o "elemento mais forte" para colocar na ambience e usá-lo na coleção.

\section{Cartela de Cores}

A cartela de cores era dividida entre cores de base, intermediárias e tônicas. Em uma coleção, a cor de base é a que aparece em maior quantidade, as intermediárias compõem com as cores dominantes e tônicas e, por fim, as tônicas podem surgir em certos momentos, em pequenos detalhes.

Assim como as tendências, as cores, tal como ensiva-se nesse período na FASM, respondiam ao sistema de gradação contido na ideia de dominante, intermediária e tônica. Geralmente a cor dominante era aquela que predominava na coleção, enquanto as intermediárias e as tônicas eram representadas por várias cores que apareciam pontualmente.

A cartela de cores era pintada com tinta para caligrafia Ecoline à mão, seguindo o formato de um oito para pintar as fibras do papel de ambos o lados e, depois, eram recortados quadrados da parte pintada para montar a cartela.

Na FASM, as cores deveriam estar dispostas em fundo branco, todas cortadas do mesmo tamanho, à mesma distância e distribuídas da seguinte maneira: uma cor dominante, depois duas intermediárias ao lado da dominante que destacava a importância da cor intermediária e, por último, algumas cores tônicas. Esta era a composição da cartela de cores e era preciso tomar cuidado para que uma cor não "brigasse" com a outra, como relata Elaine Camarena.

\section{Grafismos}

Depois da Cartela de Cores, eram desenvolvidos os grafismos. O grafismo e o elemento que constitui a estampa e é estudado para o melhor encaixe do módulo no rapport ${ }^{20}$.

\section{Cartela de matérias}

A essa altura eram elencados na Ambience as texturas ${ }^{21}$, os tecidos, os aviamentos e outros insumos essenciais à criação e ao desenvolvimento de uma coleção.

\section{Maquetes de tecido ${ }^{22}$}

A maquete de tecido consistia em um exercício proposto por Rosas, no qual o aluno deveria criar bases de tecidos novas por meio de tecidos existentes e de outros materiais. Elas também podiam ser originadas a partir dos grafismos.

Elaine Camarena conta que as maquetes de tecido demonstravam a visão do estilista que não possuia ainda o conhecimento técnico. Era um exercício formal calcado apenas na criatividade.
$0 \mathrm{Na}$ área do design de superficie e estamparia, 0
ermo rapport (do francês) ét traduzido, em inglêse
portuzuês, como reeeat ou repetição. Rapport é um tipo de repetição que preza pela representaçăo form
partir de módulos.

21 Texturas são aspecto confecçãa de un têxtil. Como a referência pesquisada pode ser
distante do universo têxt I como já aconteceu com Ver Ligia Gibert (2014) no CIT, um pedaço de concreto como referência de cor - , o que não é encontrado pronto pode ser de maquetes têxteis, e depois viabilizado pela indústria.

22 Maquete de tecido ou experimental de uma representação visual de desenvolvido e produzido em série. Pode ser entendido como mock up de um tecido. criaçăo intimamente ligada textura, feita sobre base $d$ em torno de $20 \times 20 \mathrm{~cm}$, e permite ao engenheiro têx captar o aspecto final que 0 estlista desejact 


\section{Desenhos}

Após a realização da pesquisa, seja do resgate do passado (documentação) ou do shopping, e seu registro na ambience, os alunos começavam a desenhar sua coleção.

23 Look é a composiçăo
da roupa que pode cobrir corpo inteiro. Pode variar en número e funçãa de peças.
Por exemplo, um vestido é Por exemplo, um vestidoé look, uma camiseta e uma
calca também podem ser calçat tamber
umlook.

A partir das três tendências detectadas no processo de pesquisa, os alunos produziam três coleções por ano, com cerca de seis a oito looks por coleção. Na linguagem usual na área da moda, cada $l_{0} k^{23}$ equivale ao desenho de um croqui, ou seja, por ano, cada aluno apresentava, ao todo, de dezoito a vinte e quatro croquis.

\section{Estudo de Formas / Silhuetas e Modelagem / Moulage}

Eleitas as cores, as texturas e as matérias, iniciava-se um trabalho voltado à construção das silhuetas. $O$ conjunto de silhuetas diz respeito às formas predominantes nas roupas. Daí, começavam as tentativas de execução de toiles $^{24}$. De acordo com Renata Zaganin de Oliveira (2014), depois de criar as maquetes têxteis os alunos iam direto para o manequim ensaiar o que seria uma roupa.

Simone Mina lembra-se de fazer os esboços de uma coleção no manequim, que expressavam sua "vontade de forma", como aluna. Essa criação de forma era livre e se aproximava das toiles francesas, - mesmo que os alunos não tivessem consciência disso -, não possuindo acabamentos definitivos ou modelagem correta, e sendo admitida inclusive em papel.

Muitos desses mock ups de peça não possuíam cava, abertura, zíper etc; entretanto, segundo Elaine Camarena, nem sempre o estilista está pensando em uma peça passível de ser produzida. Para ela, quando alguém está criando não pondera onde vai o botão, o zíper, se entra ou se sai, qual é o forro etc.

\section{Apresentação}

Camarena relata que após a realização dos volumes, no segundo e terceiro anos, havia um desfile dessa produção. Ele poderia ocorrer em sala de aula, ou ser apresentado dias antes do desfile de $\mathrm{TCCs}^{25}$, aproveitando a estrutura disponibilizada pela escola

\section{O Estilismo na FASM a partir dos anos 2000}

Do fim da década de 1990 em diante a noção de estilismo na FASM foi se modificando, admitindo, inclusive, a noção de projeto em alguns momentos. Entre os depoimentos que se destacam na abordagem desse momento estão os relatos dos professores Renata Zaganin de Oliveira, Márcio Ito e João Braga.
$\mathrm{Na}$ visão de Oliveira, o estilismo está muito mais relacionado à parte artística do criador, do diferencial, do formador de opinião. O projeto em moda, por outro lado, está mais voltado ao desenvolvimento de produto, inclusive na utilização dos jargões, da linguagem da área, como forma de instrumentalizar o aluno quanto ao trabalho dentro de uma empresa de moda, desse "giro empresarial de moda". Ela afirma que ainda hoje o curso é mais pautado pelo estilismo.

As descrições de Márcio Ito ajudam a construir um panorama acerca das metodologias de projeto empregadas por algumas professoras que passaram pela FASM depois de 2000. Ele discorre sobre sua experiência como aluno a partir das aulas que frequentou com as professoras Mariana Rocha, Simone Mina e Sílvia Sato. Esta última se desligou da instituição há alguns anos.

É possível perceber que em 2000 já havia na FASM uma história alicerçada pelo estilismo praticado por Rosas. As entrevistas coletadas possibilitaram perceber que, a despeito das diferenças entre os períodos, os professores atuais se mantêm relativamente fiéis ao uso dos termos empregados na fase de Rosas.

\section{Pesquisa de Referências}

João Braga conta que deve muito do que aprendeu sobre projeto, $e$ sobre como fazer pesquisa de cores e de tendências a Marie Ruck Ele também recorria aos painéis ou ambiências. Braga confessa que, em termos de pesquisa, confiava muito em seu feeling, confirmando a afirmação de Oliveira sobre o l'air du temps que envolvia os criadores na década de 1980, muito mais voltado à inspiração que à formação, considerada a escassez de cursos na área de moda.

Na aula de Mariana Rocha, o aluno saia de um ponto de partida, fazia um brainstorming de ideias, pesquisava todos os elementos que envolvessem aquelas ideias e, em seguida, desenvolvia sua pesquisa por meio de imagens ou de particularidades, tais como um elemento sensitivo, olfativo, sensorial, para só então começar a desenvolver a coleção.

A professora Sílvia Sato levava muitas ideias para a sala de aula e muita informação de mercado oriunda de sua experiência. Ela ensinava a ver a roupa dentro de uma coleção e estimulava os alunos a olharem também as outras marcas, questionando quem era cada uma delas, o que elas faziam em termos de produto e qual sua linha de produtos. Sato mostrava que era possível fazer o novo a partir de produtos clássicos ou básicos, despertando o olhar dos alunos ao colocá-los em contato com produtos incomuns.

O público-alvo é um dos pontos-chave para se fazer uma boa coleção de artigos de moda, de acordo com Márcio Ito. A coleção demanda uma quantidade de peças adequada em relação ao consumo do público, deve contar com uma seleção de matérias leves, pesadas e apresentar cores equilibradas, adequadas ao gosto do consumidor. 


\section{Registro da Pesquisa - Documentação / Painel}

Na FASM os alunos registram suas pesquisas em seus cadernos, cruzam essas informações e começam a produzir esboços rápidos de ideias que surgem das percepções de seus registros.

Um pouco diferente do trabalho do estilista de vestuário é o de estilista têxtil. João Braga discorre sobre este processo criativo referindo-se ao período em que foi estilista têxtil na empresa Ragueb Chohfi. Ele conta que, como fonte de pesquisa, seguia as tendências internacionais, por meio de revistas e bureaux. No Brasil havia também o Centro de Informação de Moda (CIM), que divulgava as principais tendências. A partir daí, Braga conta que construía painéis e ambiências reunindo essas informações.

A partir do caderno ou da ambience, Oliveira solicita que seus alunos trabalhem elementos do design de moda (silhueta, proporção, linha, cor, textura, tecido, estampa, ornamentação e função) e também dos princípios do design aplicados a estes elementos, como repetição, ritmo, gradação, radiação, contraste, harmonia, equilíbrio e proporção na criação do design de moda, especificamente do vestuário. Ela enfatiza os elementos do design mais que Rosas e afirma que eles podem construir ou distorcer a imagem de um corpo.

\section{Estudo de Formas / Silhuetas}

Há um exercício proposto por Renata Zaganin de Oliveira que será explorado em maior profundidade no item "Modelagem / Moulage". Nele, a professora sugere que os alunos com dificuldade para desenhar experimentem primeiro a configuração de formas no manequim, de modo a conseguirem visualizar o look que almejam construir.

Os volumes obtidos ensejam a ideia de forma e podem servir de base para a criação e seleção de silhuetas com as quais o aluno deseja trabalhar.

Após fotografar a toile, o aluno contorna a figura da foto por meio do desenho à mão e desta maneira extrai dela uma forma que, detalhada, origina a silhueta.

Esse trabalho pode ter duas finalidades. Primeiro, é útil para a criação das formas dos looks da coleção, o estudo de formas e silhuetas, mas também pode servir como estudo inicial para a modelagem da peça que será costurada (etapa posterior).

O estudo de formas e silhuetas costuma ser representado bidimensionalmente sobre o desenho de um corpo.

\section{Cartela de Cores}

João Braga alerta para a importância das cores no processo de criação de estampas. Ele afirma que os desenhos e estudos de cor na empresa Ragueb Chohfi eram feitos no papel canson ou na cartolina, a partir de temas préselecionados.

Uma vez definidos os temas, era sugerida uma cartela de cores. Em seguida, ele escolhia a técnica de representação que julgasse mais adequada. Por exemplo, para um tema floral, ele fazia um desenho em guache que ressaltasse a leveza e o colorido do tema.

Além do floral, sempre havia os temas clássico e esportivos, e cada um contava com sua própria cartela de cores, sugerida por imagens relacionadas aos temas.

\section{Cartela de Matérias}

Segundo Oliveira, o projeto em moda começa no esboço, no detalhamento do desenho e na escolha de matérias, pois essa sequência é a que mai respeita a ordem do mercado.

$\mathrm{Na}$ aula de estilismo de Simone Mina eram trabalhados todos os itens da coleção, até a etiqueta, conta Márcio Ito. Como estilista, Ito destaca sua preocupação com os materiais. Em seu TCC ele utilizou os melhores tecidos disponíveis, tais como organza de seda, sarja de seda, musseline, e conta que suas escolhas estiveram diretamente ligadas ao resultado positivo de seu trabalho. $O$ toque da matéria após ser estampada ficou perfeito, preservando o caimento do tecido, o que é fundamental para uma roupa.

Os depoimentos de ambos os pioneiros deixam evidente que a escolha de tecidos acertada ao tipo de vestuário que se deseja produzir é fundamental para o sucesso de uma coleção, seja comercialmente ou como parte do incremento de capital simbólico para a marca.

\section{Grafismos}

Por detrás da atuação de João Braga como designer têxtil na Ragueb Chohfi, pode-se notar o tipo de planejamento que a moda demanda. Ele conta que o tamanho de cada elemento das estampas, chamado grafismo, era determinado pelo rapport. Dependendo do tipo de rapport, - grafismo era miúdo ou graúdo, nas palavras de Braga. Ele trabalhava com um rapport determinado por um acetato da Cataguazes que tinha todas as medidas padronizadas.

Era a partir das medidas contidas nesse acetato que a Ragueb Chohfi estampava os tecidos que comercializava. 


\section{Maquetes de Tecido}

A orientadora de TCC de Márcio Ito foi Simone Mina. Ele se dedicou à estamparia, daí sua maior preocupação era pensar no que poderia limitar uma estampa, aliado ao que gostaria de fazer.

Como na época, em 2006, não era financeiramente viável para um estudante fazer estamparia digital, ele buscou outra saída.

Trabalhando para Adriana Barra ele viajava com frequência para Americana, onde há inúmeras estamparias. Em uma dessas viagens ele descobriu que havia quadros para serigrafia que poderiam ser reutilizados sem a autorização prévia dos donos.

Ele escolheu desenhos prontos para sua coleção, entre eles, alguns sem uso há mais de dez anos e seu processo criativo se dava quando ele desconstruía as estampas, estampando umas sobre as outras. Ito conta que em seu processo se deparou com quadros gravados com desenhos que nunca haviam sido utilizados.

A partir de testes que geravam as maquetes têxteis, Ito escolhia o que seria estampado no tecido inteiro para os looks do TCC que teriam suas modelagens desenvolvidas.

\section{Desenhos}

Renata Zaganin de Oliveira trabalha hoje em suas disciplinas de desenho com cinco tipos de desenho voltados ao estilismo e ao projeto em moda.

Um exercício apresentado por Oliveira, o de criar esboços, consiste em pedir aos alunos que desenhem ideias rapidamente, fora do corpo, sem pensar muito. Pede a eles que trabalhem detalhes, partes de peças e, posteriormente, montem isso sobre o desenho de um corpo, repetindo elementos e montando os looks como quebra-cabeças. Essa tarefa está associada ao registro da pesquisa no caderno, mencionado anteriormente.

Na sequência, o aluno se dedica ao Desenho de moda. É quando o aluno reúne todas as informações mais o conhecimento técnico que ele tem e começa a criar em um corpo com proporção, que tem relação com a realidade. Esse corpo leva o aluno a observar os princípios do design como equilíbrio das cores, e se as formas não estão exageradas em relação à altura. O corpo com proporção também oferece informações técnicas ao aluno que permitem que, na sequência, ele construa o desenho técnico, mais rigoroso, com costuras e outros detalhamentos.

Ele deve ser exatamente proporcional e simétrico em relação à figura humana, pode ter as medidas especificadas por meio das "marcações de cota" e detalhamentos sinalizados com "linhas de chamada". Ele serve para determinar diretrizes para o trabalho do modelista e do costureiro. Pode ser desenhado à mão ou com ajuda da computação gráfica. Os programas mais utilizados para este fim são o Corel Draw ${ }^{\circledR}$ e o lllustrator ${ }^{\circ}$.
A ilustração de moda é outra forma de desenhar onde o conceito é ilustrado e a narrativa da coleção é resumida. É o momento do processo em que mais há proximidade com o desenho artístico. Esse desenho pode aparecer em revistas ajudando a divulgar o trabalho do estilista.

Por último, chega a hora "de que todo aluno gosta", o momento em que a liberdade criativa prevalece. Oliveira conta que os alunos podem alonga a perna da figura humana, colocar chifre, rabo no desenho que não tem problema, pois se trata do desenho promocional. Sua função é exercitar o lado criativo do estilista vinculando sua criação à proposta temática.

\section{Modelagem / Moulage}

Para Oliveira a construção do volume e, posteriormente, da modelagem começa pelo desenho de esboços. Para os alunos que demonstram resistência ao desenho, Oliveira sugere que comecem pela moulage.

Ela lida com essa recusa inicial do aluno em desenhar colocando-o, antes de tudo, em contato com o manequim. Oliveira estimula o aluno a trabalhar formas e silhuetas com tecido diretamente sobre o manequim para que ele tenha maior domínio do que está criando e, em seguida, parta para a etapa do desenho. Então, depois da moulage, o aluno define cada look e começa a representar essa produção graficamente, por meio do desenho.

Mariana Rocha desenvolvia um exercício de criação de formas propondo que os alunos recortassem silhuetas a partir da ideia de "sombra chinesa", para só então partirem para a moulage, conforme relato de Márcio Ito.

Ele também teve aula de moulage e estilismo com Simone Mina, que fo sua orientadora de TCC. Em sua aula, ela tratava da investigação do corpo, da questão da forma.

Com relação ao projeto da roupa, Ito trabalhava diretamente com 0 tecido sobre o manequim e depois desenhava. Ele julga interessante fazer a primeira moulage gerar outras peças. Esse exercício de geração de alternativas pode ser feito exclusivamente por meio do desenho ou contar com auxílio da fotografia.

$O$ aluno que trabalha diretamente no manequim antes de desenhar, tende a experimentar mais em termos de forma, detalhes, matéria. Oliveir afirma que o aluno que recorre à moulage sempre vai chegar a formas mais elaboradas.

Em sua opinião o aluno deve dominar os processos de desenhar e ir para o manequim e de partir do manequim para o desenho, pois o primeiro desenvolve mais a parte técnica, voltada à roupa, enquanto o segundo tem caráter mais experimenta. 


\section{Geração de Alternativas}

Professores como Renata Zaganin de Oliveira e Márcio Ito têm proposto aos seus alunos que recorram à geração de alternativas como forma de garantir variedade de produtos à coleção de moda.

A geração de alternativas era prática comum nas aulas de Sílvia Sato, embora somente recentemente, Márcio Ito tenha se dado conta de que se tratava do exercício de geração de alternativas.

A partir dos primeiros desenhos desenvolvidos pelo aluno, Sato sugeria a criação de outras peças aproveitando os mesmos elementos ${ }^{26}$, ensinando o aluno a dar unidade para a coleção, a partir da repetição e mistura de detalhes.

Às vezes para escolher cinco opções, Ito chegava a fazer cinquenta desenhos.

\subsection{Universidade}

O professor e pesquisador João Braga conta que o curso de Moda da UAM iniciou suas atividades antes do curso de Desenho de Moda da FASM, mas obteve aprovação do MEC para seu funcionamento depois da FASM. Até hoje há discussão sobre quem iniciou o curso de Moda ao nível de graduação no Brasil.

A partir dos relatos de professores e pesquisadores das áreas de pesquisa, criação e desenvolvimento de produto foram abordadas as principais noções de projeto por meio de etapas nessa escola.

Cristiane Mesquita conta que há quinze anos o tempo de desenvolvimento do projeto era outro na UAM. Hoje os currículos têm um projeto por semestre, o que exige mais agilidade, então é preciso ter mais foco em metodologias por etapas.

Somente no quarto ano o aluno tem um ano inteiro para desenvolver o projeto de TCC. Dessa forma, Mesquita alerta que é necessário que existam caminhos. Há pouco tempo para deixar o aluno divagar, requer-se focar mais em determinada parte do processo. Metodologias e consensos sobre noções de projeto em moda podem ser úteis ao otimizar tempo o produzir um trabalho com qualidade a partir de marcos processuais bem definidos.

Antes de Francisca Dantas Mendes ingressar na primeira turma do curso de Moda da UAM em 1990, ela já possuía uma vasta experiência com desenvolvimento de produto, especialmente no segmento de figurino. Pouco antes da década de 1980, Mendes possuía uma confecção no formato de ateliê chamada Fantástita e, posteriormente, outra chamada Chiquitita, de rigor infanto-juvenil.
Em sua confecção a preocupação era atender a um público com uma necessidade específica. Todas as atividades que ela desenvolvia já tratavan de projeto, mas naquele período ela não tinha consciência da noção metodológica de projeto por etapas processuais. A experiência de Mendes nas confecções irá respaldar sua visão acerca da prática de projeto neste ara a prática de ensino.

Quando Mendes começou a dar aula na UAM a partir de 2001, ela leou toda a sua experiência em confecção e consultoria em produto para dentro do curso de Moda. Seu relato será analisado a partir de etapas de projeto em moda que estejam ligadas à sua prática em confecção e sala de aula, pois sua noção sobre projeto em moda torna-se mais relevante à medida que se entende que sua experiência no ateliê foi transferida para a docência.

Também colaboraram com esta pesquisa Mário Queiróz que foi professor e coordenador do curso de Design de Moda da UAM e Rosane Preciosa, que atuou como professora da instituição.

Cabe ressaltar que a autora desta tese se graduou em Design de Moda pela UAM, entre 2000 e 2003 e realizou diversos projetos nas disciplinas dos professores entrevistados. Essa experiência discente pode contribuir com a análise da noção de projeto em moda dessa escola.

\section{Pesquisa de Referências}

Como Francisca Mendes desenvolvia figurinos sob encomenda para companhias de dança, inicialmente, ela conversava com sua cliente, a proprietária da academia sobre o tema e o que seria feito.

Os estilos de dança para os quais Mendes criava figurino eram clássico, jazz, sapateado, contemporâneo e ballet de repertório. Um único tema abrangia produtos diversos para os quais eram estipulados detalhes que compunham o figurino. Essa variedade de alunos era dividida por turmas de todas as faixas etárias.

Depois de definir o tema, a cliente começava a descrever o que ela queria para cada faixa etária a partir da sugestão de alguma professora de dança ou de Francisca Mendes. As atividades relatadas até aqui configuravam o briefing que tem a função de direcionar o projeto.

Kathia Castilho lembra que na década de 1990 a exigência feita aos alunos da UAM era a de que criassem "conceito", indo contra o sistema da cópia. Os professores sentiam necessidade de falar em um primeiro momento: "chega de cópia, pensa alguma coisa que vem da sua cabeça, do seu coração, da sua casa, da sua família, da sua cultura" (CASTILHO, 2015), senão não havia sentido para um curso de graduação em moda. Posteriormente, Castilho declara que, com o tempo, incluíram uma preocupação maior com mercado e públicos diferenciados nas pesquisas solicitadas aos alunos. 
Seguindo a linha de ensino de Castilho, Rosane Preciosa (2017) defende que a roupa pode ser um lugar de pequenos deslocamentos que dispensa a imposição da moda ditada por tendências e que muitas vezes se traduz em cópia. Para ela interessa muito mais a ideia de que 0 aluno transforme a roupa em uma experiência de algo que lhe interessa.

A pesquisa para Mendes começava no olhar da necessidade. De que as academias de ballet necessitavam? Ela alerta que o processo era muito próximo ao de desenvolvimento de uma coleção para o varejo, mas em um esquema de ateliê. Mendes confirma a previsão de Castilho de que houve momentos em que parte do corpo docente da UAM pautava sua visão de projeto pela pesquisa de mercado e de público.

Quanto à atividade docente na UAM, Mendes relata que a pesquisa começa pelas tendências, e que não são somente as de moda. É a pesquisa de tendência do mercado, do "Inventário Interno" da marca, do cenário social em que seu público está vivendo.

A pesquisa deve alimentar o estilista com ideias que permitam fazer determinado produto para atender ao desejo do cliente. A empresa precisa fornecer ao profissional o conhecimento sobre qual é o seu foco no mercado, seu paradigma produtivo e o seu "Inventário Interno".

"Inventário Interno" exibe dados voltados ao consumo. Mostra quantas peças foram comercializadas nas últimas coleções, de qual tipo de modelagem, matéria, cor, padronagem e beneficiamento. São as variações de diferenciação estratégicas para aumentar o número de produtos no mercado.

Com a pesquisa de tendências adiantada e as informações de mercado fornecidas pelo departamento de desenvolvimento de produto, o estilista faz esboços de ideias a partir de um tema e, em seguida, parte para a elaboração do painel. Mendes entende painel, grafismos, cores, formas e silhuetas como elementos inseridos na "criação do produto".

Para Mendes o tema pode até não ter relação com a pesquisa inicial, mas ele precisa fazer sentido dentro desse contexto. $O$ tema escolhido precisa se encaixar à pesquisa de tendências. $O$ tema precisa ser confirmado pela pesquisa.

Projeto para Cristiane Mesquita começa com o briefing, que propõe uma temática, um público-alvo. Em seguida, os alunos iniciam a pesquisa investigando quem é esse usuário, e fazem uma revisão de literatura do tema proposto.

Há mais de quinze anos era comum trabalhar a noção de conceito associada à criação livre. Hoje, embora o termo conceito ainda possa ser utilizado, Mesquita pontua que ele não vem de uma vontade ou paixão. Ele vem de aspectos que os alunos detectam no processo de pesquisa, como uma característica subjetiva do tema e do usuário.

Por exemplo, se o tema é inclusão social, o usuário pode ser então um deficiente que tem, portanto, necessidades específicas que devem ser contempladas do ponto de vista do design de moda.
Mário Queiróz afirma que em termos de pesquisa primeiro é preciso realizar a pesquisa de público, depois a de macrotendências e aprofundar de referências para este tema.

Os relatos mostram que, por vezes, a expressão "tema" se confunde com briefing no design de moda. Mesquita e Queiróz se referem a "tema" como algo que na verdade está mais próximo do conceito de briefing.

Para Mesquita é importante prestar atenção ao que esse grupo de futuros designers está olhando e que pode emergir como conceito. A noção de conceito aqui é tratada de forma abstrata.

A busca de "outros lugares" de pesquisa, lugares desconhecidos, incomuns à pesquisa de moda que costuma se pautar pelos segmentos é uma constante nas orientações dadas nas aulas de Rosane Preciosa (2017). A partir desse descolamento da pesquisa voltada somente ao mercado ela acredita que leva o aluno a ter contato com outro repertório visual e que desperte nele a vontade de sair do lugar comum e do universo seguro de referências que já conhece.

$\mathrm{Na}$ UAM as aulas relacionadas à criação ministradas por Castilho, Mesquita e Preciosa não se referiam à terminologia "tema".

No momento inicial do ato criativo os alunos experimentam processos mais livres como o brainstorming para que o conceito emerja A partir dessa emergência do conceito eles vão criar o "Painel Semântico", que reúne elementos do design entre outros aspectos.

\section{Registro da Pesquisa}

No caso de Mesquita, após a pesquisa e levantamento de dados a partir do briefing e o estabelecimento de um conceito, os alunos vão começar a criar a partir de referências visuais. A partir delas são criados "Painéis de Referência" e "Painel Semântico". Mesquita se refere a essas representações materiais que partem da pesquisa como elementos formais projetuais.

Até os anos 2000 o conceito da coleção dos alunos da UAM costumava se basear nesses elementos protagonistas ao invés de se fundamentar por pesquisa de público e mercado.

A medida que a pesquisa vai ganhando corpo, ela vai sendo incorporada ao "Painel de Pesquisa de Tendência", na forma de registro adotada por Mendes. Pesquisa e painel se alimentam mutuamente em um processo contínuo.

O "Painel de Pesquisa de Tendência" pode gerar uma "Ambiência" ou Ambience que conta também com peças de vestuário e costuma ocupar um espaço onde o foco é a imersão no tema. A ambience pode ser uma ferramenta interessante para apresentar ao público ou à equipe de vendas as referências que nortearam a coleção, enquanto o conteúdo da pesquisa o painel estão mais atrelados ao departamento de estilo.

Para Mário Queiróz o registro da pesquisa deve ser feito a partir da reunião de material em pastas e de arquivos no computador. 


\section{Mix de Produtos}

O "Inventário Interno" está ligado ao histórico da empresa. Ele possibilita perceber que sua consumidora gosta de determinada coleção, pela estética ou pela cor, modelagem, mas invariavelmente ela gosta e compra sempre "decote V", por exemplo. Ele mostra que todas as peças que têm "decote V" foram bem vendidas, todas que têm um mesmo tecido também foram bem vendidas e, assim por diante.

Com esse inventário a equipe de desenvolvimento de produto inicia a "Gestão de Coleção" que trata do planejamento da coleção. Mendes explica que é quando será elaborado o Mapa da Coleção, onde são organizada todas as porcentagens, números de peças por categoria de produto (básico fashion e vanguarda), número de peças em porcentagem na cartela de cor, porcentagem por tipo de tecido liso, porcentagem por tipo de tecido com estampa cor porcentagem por tipo de bordado. Essa gestão acontece em cima de uma quantidade definida de número de peças para a coleção.

Então, se a coleção contará com cento e cinquenta peças quantas serão de top, bottom e one piece? A "Gestão de Coleção" é que dá essas respostas e é planejada um pouco antes de entrar no processo de criação. Trata-se de estabelecer limites.

Depois da gestão o estilista recebe informações concretas a respeito do produtos que devem ser criados. Por exemplo, pode ser solicitado que ele crie trinta e cinco bottoms, dividido em dez básicos, vinte fashions e cinco de vanguarda dentro da coleção de tecidos e Cartela de Cores definidas.

Na realidade de uma confecção o estilista já está começando a criar no momento da gestão. Quando o estilista está criando, naturalmente é ele quem sugere o produto, o tecido, a cor e o tamanho dentro do tema.

Para o uso apropriado dos dados da "Gestão de Coleção" os estilistas e funcionários de outros departamentos têm de conferir se o que criaram atende ou não às demandas. É um trabalho em equipe de adequar as criações aos resultados obtidos na gestão.

Começa então um esforço para cortar produtos em excesso, apostar em artigos novos e conferir se não há repetições. Se, por exemplo, tem mais bottom e fashion do que a gestão orientou essas peças excedentes devem ser eliminadas. A coleção é negociada para garantir que não haja produtos em excesso. Excepcionalmente, alguma peça pode ser acrescentada após a gestão por conta de modismos repentinos.

\section{Estudo de Formas / Silhuetas}

Ao trabalhar em seu ateliê, Mendes fazia um estudo de silhuetas um pouco diferente das "sombras chinesas" de silhuetas que habitualmente se usa no design de moda. Ela desenvolvia as formas a partir de modelagens em miniatura.
A silhueta do ballet é bastante específica e, por vezes, deforma mais o corpo que uma roupa casual. Ela também conta com referências históricas que podem ou não serem reinterpretadas.

As "sombras" de silhuetas são formas que desenham um contorno sobre o corpo e como são silhuetas prescindem de detalhes do desenho, funcionando como a projeção de uma "sombra" que envolve o corpo.

O estudo de formas e volumes é solicitado por Mário Queiróz como uma etapa posterior à criação da Cartela de Matérias. Isso permite concluir que para Queiróz é preciso conhecer antes o material para, em seguida, pensar na forma, pois os pesos dos tecidos oferecem a informação necessária para montagem de estruturas vestiveis.

\section{Cartela de Cores}

Após a pesquisa que origina um conceito, os alunos vão criar o "Paine Semântico", que segundo Mesquita dá condições para que surjam estudo de formas, Cartela de Cores, técnicas etc. As experimentações vão acontecendo a partir de testes diversos.

No processo de Mendes havia um acordo entre ela e sua cliente a respeito de cores. Buscava-se um equilíbrio entre o desejo da cliente e o que o mercado disponibilizava. Tudo isso dentro do olhar do tema e do que a cliente estava querendo que fosse executado para cada turma.

Na UAM Mendes ensinava que é na Gestão da Coleção que será definida a Cartela de Cores, em função do que o mercado disponibiliza de tecido, considerando também o que dá para tingir. Atualmente ela procede da mesma maneira na EACHUSP.

Mário Queiróz defende que as cores devem ser levantadas após a pesquisa de público, macrotendências e de tema, antes da Cartela de Matérias e do Estudo de Formas e Silhuetas.

\section{Cartela de Matérias}

Em sua prática de ateliê de figurinos, imediatamente após a definição do tema, Mendes começava a pesquisar materiais como possibilidades para o produto. Na UAM ela trabalhava materiais com os alunos na pesquisa de tendências junto com as cores.

A definição da Cartela de Matérias acontece depois da Cartela de Cores na prática projetual de Mário Queiróz. No caso de Mendes sua necessidade era conhecer primeiro o material e seu preço, pois seu produto era vendido antes de ser produzido. Além disso, seu foco na construção de figurino privilegiava o material. Depois de aprovado o desenho com tecido aviamentos especificados, Mendes buscava as cores no tecido definido. 
Queiróz, por outro lado, solicita aos alunos que selecionem cores para montar uma cartela, para posteriormente, trabalhar os tecidos.

No desenvolvimento de figurinos havia uma primeira entrevista para definir o briefing e uma segunda, quando Mendes apresentava as fichas técnicas e eram definidos os tecidos. Nesse momento Mendes fazia uma cartela de materiais. Isso antecedia o desenvolvimento de modelagem que depende dos tecidos e aviamentos usados para ser executada.

A partir da segunda reunião as informações eram agrupadas e o que se tinha era um grande brainstorm. No encargo de fechar a Cartela de Matérias, Mendes sugere que o estilista pode buscar tecidos e aviamentos no mercado, convocar representantes de tecelagens e importadoras ou trazer da Première Vision.

Após a segunda reunião Mendes se dirigia à Rua Vinte e Cinco de Março onde pesquisava os preços de tecidos e se achava alguma coisa diferente. $O$ preço do tecido era um fator relevante no sentido de avaliar se ele cabia no custo da peça.

Então Mendes pesquisava matéria duas vezes. Uma vez antes de apresentar as fichas técnicas, após a primeira reunião e, outra vez, depois dos desenhos técnicos apresentados, para verificar custo e se achava mais alguma coisa em termos de matéria.

Além do negócio próprio, a partir de vivências no mercado como consultora, Mendes relata que coordenou equipes com dez a quinze estilistas que chegavam a reunir duzentas amostras de tecidos para uma coleção. Entre elas havia materiais muito parecidos, então Mendes orientava os estilistas para que se organizassem e escolhessem somente setenta tecidos para tornar viável a Cartela de Matérias e não gerar estoque desnecessário. Nas etapas de projeto de Mendes a pesquisa de tecidos antecede a "Gestão da Coleção".

\section{Beneficiamentos}

Estamparia, bordados, lavagens e outros beneficiamentos são definidos na "Gestão da Coleção", assim como as cores. Testes de outra natureza que levarão a possíveis beneficiamentos são realizados pela equipe de Estilo $e$ devem se adequar às demandas da gestão.

Beneficiamentos exigem uma ficha técnica específica. Dessa forma para cada processo, de estampa localizada, de estampa corrida, de tingimento, de bordado etc, é criada uma ficha técnica.

Depois do estudo de formas e volumes, Queiróz elenca como próxima tapa o desenvolvimento de estampas, bordados, lavagens etc. Também, nessa fase que devem ser desenvolvidos aviamentos e etiquetas.

\section{Desenhos}

Em algumas escolas de dança o briefing já era passado para Mendes com todos os desenhos. Um profissional era pago para fazê-los. Nesse caso, Mendes chegava lá e já estava tudo pronto. Seu papel era transformar tudo aquilo em "ficha técnica" e traduzir em figurino a necessidade dos dançarinos.

Quando a academia não oferecia um croqui, Mendes fazia um desenho técnico direto, sem passar pela fase do croqui. $O$ desenho técnico era feito m uma ficha técnica que ocupava meia folha sulfite. Quando ela precisava por algum motivo apresentar o croqui, ela chamava um artista plástico. Mas nesse caso ela era contratada para fazer toda a coleção.

artista fazia o croqui a lápis e Mendes mexia em todas as proporções para depois ele "arte-finalizar". Percebe-se um processo inverso no fazer projetual de Mendes em que o desenho técnico é executado antes do croqui o croqui passa a ter um papel preponderantemente estético. A referência de Mendes era sempre o desenho técnico porque ela precisava disso para modelagem, que era seu foco.

Na segunda entrevista com a proprietária da academia os desenhos écnicos eram corrigidos de acordo com o que a cliente desejava. Aumentava-se volume, diminuía-se comprimento de manga etc.

$\mathrm{Na}$ UAM e nas consultorias que Mendes realizou ela conta que eram desenhados os croquis e depois de escolhido e negociado em equipe o que era retirado e o que permanecia na "Gestão de Coleção" eram desenvolvidas as fichas técnicas de criação, onde constam a descrição do volume da peça (silhueta), sugestão de tecido, cores e tamanho. $\mathrm{Na}$ ficha técnica também devem constar medidas importantes como profundidade da prega, do decote, largura do cós, beneficiamentos etc.

A ficha técnica é onde se faz todo o detalhamento em cima de uma criação. $O$ estilista pode desenvolver um botão, um caseado novo, um costura diferente, deixar $\mathrm{o}$ avesso à mostra etc.

Definidos os desenvolvimentos e beneficiamentos Queiróz orienta seus alunos na criação dos croquis e desenhos técnicos.

\section{Modelagem / Moulage}

Entre os testes que Mesquita menciona estão os de modelagem e ergonomia, que são enfatizados no caso de públicos específicos como os deficientes físicos, por exemplo. Para eles a configuração do vestuário é um elemento formal muito importante, pois ela pode ter relação com a sua mobilidade.

Havia um problema ergonômico com relação às academias no caso de Mendes, pois em um mesmo grupo de dança havia o segmento baby voltado a crianças de três a quatro anos até as meninas maiores. 
No processo de Mendes, na segunda reunião a cliente aprovava as fichas técnicas com modelo, custo e material e a próxima etapa era a modelagem. Em seguida as peças eram cortadas e provadas. Na prova de roupa eram eliminados defeitos e então havia uma segunda prova.

$\mathrm{Na}$ UAM e em consultorias era empregada uma ficha de criação de um modelo que seria interpretado por um modelista. Depois da ficha a próxima etapa consistia na modelagem que interpreta além do desenho, o material. Nesse processo devem ser consideradas: tabela de medidas levantada no "Inventário Interno", confirmação de forma e silhueta do público-alvo, conferência do molde de base da confecção e graduação.

Mário Queiróz aponta a modelagem e a confecção do look como etapas seguintes aos desenhos.

\section{Confecção do Look}

Em suas disciplinas, a professora Kathia Castilho exigia como produto final uma pesquisa teórica aprofundada somada a uma apresentação em sala que contava com a confecção de um look que era desenvolvido nos ateliês da faculdade em horário alternativo ao da aula.

Apesar de a professora Kathia Castilho afirmar que nunca trabalhou com disciplinas de construção de objetos ou de coleção, suas disciplinas, apesar de teóricas, eram análogas às disciplinas de projeto, pois ensejavam o desenvolvimento de um look conceitual partindo de propostas criativas a partir de pesquisas de enfoque artístico, filosófico e sociológico.

O trabalho se mostrava bastante produtivo uma vez que Castilho tirava o aluno da "zona de conforto" para pensar o novo. A novidade poderia estar no processo criativo, no uso de ferramentas de desenvolvimento do produto ou na maneira de executar o produto contemplando até aspectos tecnológicos. Era fundamental que o trabalho produzido gerasse reflexão.

A etapa final de confecção do look para Mendes acontecia depois da segunda prova de figurino, quando eram corrigidos todos os defeitos e, confirmando que estava tudo certo, a próxima etapa era finalizar a peça. Como a peça era confeccionada e provada em partes, na finalização eram colocadas as mangas e saia no corpo, era feito bordado, costurada rendinha. O acabamento como bordados à mão eram os trabalhos mais intensos. Cada figurino finalizado era colocado em cabide com saco ombreiro e ficava estocado até a época da apresentação de dança no final do ano.

No ensino do design de moda da UAM é Mendes quem introduz fichas técnicas no início dos anos 2000

O papel da ficha técnica de criação é auxiliar o modelista na compreensão do modelo e o piloteiro na montagem da peça.

Depois da modelagem a peça é cortada e pilotada, ou seja, costurada para, em seguida, ser provada. Depois disso começam as correções da peça, da modelagem, e, novamente e confeccionada outra peça-piloto com $\circ$ intuito de liberar a produção em série.
A prova da peça confeccionada é um processo de criação avaliado pelo estilista, pois é ele quem vai definir se haverá correção na peça ou não. Tudo nesse momento de avaliação está nas mãos de quem criou a peça. Se ela será ajustada e quanto vai ajustar são fatores definidos pelo estilista e não pelo modelista ou piloteiro.

Finalizada a prova de roupa, para Mendes, o projeto em moda cessa por hora. O que vem adiante diz respeito à industrialização do vestuário.

\section{Apresentação}

Havia várias formas de apresentação do trabalho final do semestre relativas às disciplinas de projeto da UAM. Elas podiam ser na forma de apresentação oral, performance, instalação ou exposição organizada pela escola para que 0 aluno entrasse em contato com diferentes realidades.

Nas disciplinas "Estudos do Corpo" ou "Moda contemporânea" ministradas por Castilho, o produto final era um look confeccionado a partir de estudos teóricos que geravam uma coleção conceitual, ou seja, que não tinha compromisso de ser comercialmente viável. As relações entre os campos teórico e prático deveriam ser exploradas na apresentação do trabalho de forma a gerar reflexão.

Esse exercício, por ser conceitual, se aproximava mais do estilismo que, por sua vez, demonstra mais afinidade com o campo das artes plásticas. Esse ato "artístico" era coroado no final com uma apresentação ligada às práticas artísticas, no caso, uma exposição. Nela eram exibidos os melhores trabalhos selecionados por Castilho.

Na prática de ateliê de Mendes a apresentação estava relacionada à segunda reunião na academia de dança com a cliente onde eram mostrada as fichas técnicas.

As provas de roupa implicavam em outra parte da apresentação de resultados do trabalho de Mendes. Todas as provas eram feitas nas academias, então tudo era levado para lá. No final, depois que todas as peças eram provadas e aprovadas ainda tinham os acessórios, peças de cabeça etc para serem definidos.

Na UAM o desfile ocorria somente no último ano, voltado aos trabalhos de TCC de design de moda, que tinham como objetivo mostrar o resultado de quatro anos de curso. 


\section{SENACSP \\ 23 Serviço Nacional de Aprendizagem Comercial de São Paulo}

Maria Eduarda Araújo Guimarães participou desde o início do Mestrado em Moda, Cultura e Arte do SENAC SP, iniciado em 2005. Ele teve seu fechamento anunciado em 2010 segundo a fala institucional.

O SENAC SP tem grande importância na formação do pensamento acadêmico em moda no Brasil, pois além da graduação, possuiu o primeiro curso stritcto sensu, nível de Mestrado, em moda do país.

Apesar do fechamento do Mestrado em Moda, Cultura e Arte, Guimarães assegura que ainda há pesquisa no SENAC SP. Também foram mantidas as iniciações científicas. Além disso, o SENAC SP mantém a Revista lara, que tem nota B1 no Qualis Capes o que é uma nota bastante alta para uma revista que está fora de um Programa de Pós-graduação.

Atualmente, a lara se voltou mais para a relação da moda com o design. O Mestrado em Moda não gerou pesquisas relacionadas à noção de projeto. Aparentemente, pesquisas sobre projeto em moda eram menos recorrentes os Mestrados do SENAC SP e quando aconteciam estavam ligadas ao Mestrado em Design.

Há dois cursos de graduação em Moda no SENAC SP, Design de Moda - Estilismo, e Design de Moda - Modelagem, o vestibular dos dois independente e cada curso conta com seu próprio coordenador. Segundo Guimarães, existe uma divisão grande entre quem cria (estilista) e quem faz (modelista) a roupa

No início dos anos 2000 Cyntia Santos Malaguti de Sousa se torna responsável pela disciplina de Projeto que se dedicava ao segmento "cama, mesa e banho", de forma que não interferisse na ordem ante institucionalizada pelas disciplinas de Estilismo voltadas ao vestuário de moda.

Cada disciplina de Projeto no SENAC SP tem um foco específico. Embora tualmente as disciplinas não chamem mais Estilismo, mas Projeto, as entrevistas apontam que a prática do estilismo vigora.

Entre as inúmeras mudanças de grade do curso do SENACSP, as disciplinas que Andrea Canton conseguiu indicar como pertencentes ao campo do projeto, mesmo que algumas delas não estejam mais em vigor, são: Projeto de Dossiê; Criação de Coleção; Planejamento de Coleção; Laboratório de Criação e Estilismo. A disciplina Criação de Coleção levantava os elementos de estilo, a de Planejamento de Coleção trabalhava as etapas de projeto de forma mais concentrada. Cada professor conduzia o processo de form muito diferente e havia uma discussão sobre projeto entre os professores no sentido de entender como cada um iria se responsabilizar por projeto e por qual parte (CANTON, 2016).
No SENACSP havia os Projetos Integradores compostos por um grupo de professores com disciplinas voltadas ao projeto, entre eles Eunice Higa. Neles, as disciplinas concorriam juntas para desenvolver habilidades de projeto nos alunos a partir da análise de uma marca.

O TCC do SENACSP se divide em cinco linhas: criação, figurino, imagem de moda, pesquisa e marketing. A noção de projeto em moda é mais presente na criação, figurino e pesquisa.

\section{Pesquisa de Referências}

Maria Eduarda Guimarães revela que a noção de projeto que se tem ainda hoje nos cursos de Moda em São Paulo é pensada no sentido da disciplina de Laboratório de Criação que não usa a racionalidade e, por ser um primeiro contato do aluno com a criação, ele se desenvolve em um contexto absolutamente livre, sem relação com metodologias.

Sobre as etapas de projeto abordadas em sua disciplina, Cyntia Santos Malaguti de Sousa descreve seu trabalho como uma prática que se distanciava da criação de vestuário para evitar conflitos com as práticas legitimadas pelas disciplinas orientadas para o Estilismo no SENACSP.

Ao invés de "tema", primeiro Sousa sugeria que os alunos criassem um invés de "tema".

Na disciplina de Estilismo, lecionada por Higa, o briefing podia partir da análise de uma marca. Esse era o caso dos "Projetos Integradores" propostos de Design de Moda que envolvia diversas disciplinas além Estilismo.

Nesse caso, de acordo com Higa, o aluno precisava escolher uma marca e apresentar uma análise sobre ela, identificar seu estilo e conceito, público, segmento, concorrentes, desempenho das coleções anteriores necessidades da marca, características dos produtos, o que já foi feito, o que deu certo, o que não deu certo, materiais, cores, aviamentos para propor uma coleção de moda. Igualmente importante e ter conhecimento sobre a História da moda que, de acordo com Higa, permite que o aluno ntre em contato com diferentes tipos de produto.

Em mais de quinze anos no SENACSP, Eunice Higa trabalhou outro briefing além da análise da marca, a parte de criação ligada à questão da sensibilização dos alunos com relação a formas e volumes e, de maneira geral, ela sempre esteve mais vinculada ao Estilismo que se volta ao vestuário de moda.

No caso de Andrea Canton (2016), os alunos iniciavam o projeto a parti de um briefing direcionado a determinado segmento/público ou adovam como referência um criador conceitual. No segundo caso, o trabalho era traduzir os elementos principais de criação desse estilista pesquisado o que se repetia em termos de material, volume, silhueta de modo que 
referência trabalhada ficasse clara no trabalho do aluno. Em seguida, havia as pesquisas de tema para amarrar a relação estética, a cartela de cores, as referências da tradução imagética e de silhuetas que eram registradas em painel.

Também é importante estar "antenado", ou seja, estar inserido na sociedade, vendo o que está acontecendo culturalmente. É preciso saber e participar, pois isso se torna um alimento para pensar a criação (CANTON, 2016).

No TCC o aluno definia o que ele queria pesquisar, ou seja, o briefing. Ele determinava os assuntos para que seu olhar se traduzisse esteticamente em uma coleção.

A pesquisa é um processo contínuo de atualização, de saber o que está acontecendo nas mais diversas áreas, da cultura, tecnologia etc.

O Público e o uso do produto devem estar inseridos dentro de um contexto que compreenda os hábitos do consumidor e a identidade do lugar de uso, segundo Sousa.

Em contrapartida, Andrea Canton (2016) conta que quando o trabalho em sala de aula era voltado a desenvolver o aspecto criativo e autoral do aluno, de forma a fazê-lo perceber suas próprias referências, a etapa de escolha e pesquisa de um público/segmento era descartada. Havia um público, mas ele era construído pelo próprio aluno. Nesse cenário o fazer era menos linear que a noção de projeto de moda pautada por etapas. Na faculdade é importante que o aluno se conscientize de sua prática e essa reflexão deve proporcionar aprofundamento e transformação do olhar sobre o que é moda (CANTON, 2016)

\section{Registro da pesquisa}

Após a pesquisa do público, marcas e uso do produto, Sousa orientava a sala a extrair de toda a informação coletada, os "requisitos de projeto", do ponto de vista das necessidades do público, da identidade do local de uso, do ponto de vista do segmento em si e dentre as possibilidades dos fabricantes. Esse material era registrado no painel destinado à fase de requisitos.

Uma vez identificadas essas exigências pelo aluno, ele definia um recorte para o seu projeto. Sousa também solicitava que os alunos investigassem outras coleções, outros autores que produziram alguma coisa com relação àquela questão o que, até certo ponto, coincide com a pesquisa de "características dos produtos, do que já foi feito, do que deu certo, do que não deu certo", apontados anteriormente por Higa.

É preciso também desenvolver uma habilidade de comunicação do processo de criação que está intimamente ligada à forma como a pesquisa é registrada. Higa se refere ao desenho como manifestação de registro dessa criação. Além dela, existe o caderno de criação onde o aluno registra seus esboços que, posteriormente serão arte-finalizados.
Além do caderno, outra forma de registro e amadurecimento da pesquisa elencada por Higa eram os "Painéis de Apresentação do Projeto" onde o aluno montava as ambiências. Nesse painel eram dispostos todos os elementos de estilo, além dos esboços ou croquis, que servissem para construir a imagem que sustentasse as "referências" ou "tema". O conteúdo pesquisado era exposto em um único painel ou apresentado em vários painéis, de acordo com as necessidades do projeto, desde que eles fossem suficientes para explicitar o processo que levou o aluno aos produtos finais.

Normalmente, era exigido dos discentes que eles mostrassem conceitos. Higa comenta que era rara a utilização de um único painel, principalmente porque eles costumavam fazer apresentações em PowerPoint $\circledast$ que se dividem por slides. Havia também os textos sobre a coleção, mas estes eram entregues impressos à parte.

Na aula de Canton havia painel e ele variava de nome entre painel temático e painel semântico, que acabava sendo a mesma coisa. Mais recentemente o nome painel semântico passou a ser utilizado com mais frequência. Nele havia referências objetivas e subjetivas provenientes das pesquisas do aluno. Canton confirma a informação de Higa de que além do painel havia também o caderno de criação para registrar as referências.

Na disciplina oferecida por Sousa, os alunos tinham metade do semestre para a pesquisa e conceituação (fase de requisitos) e a outra metade para a criação e desenvolvimento do produto (fase dos requisitos já elaborados).

Como apoio ao projeto, Sousa utilizava dois tipos de painel para sua aula de projeto. Havia o "Painel Fechado", destinado somente à fase de requisitos, briefing e conceituação, onde as referências vêm de fora do campo da moda, e o "Painel Aberto", relacionado à fase dos requisitos já elaborados, com paleta cromática, volumes, formas, tecidos etc, onde as referências vêm do próprio campo da moda.

A importância do painel está em propiciar uma comunicação clara para o trabalho em equipe e para que ela tenha o mesmo direcionamento.

\section{Elementos do Design}

Higa lista cinco itens que a criação de uma roupa deve contemplar. Elas se dividem em formas, volumes e silhuetas, cores, matérias, acabamentos e detalhes das peças.

Acabamentos seriam os tipos de costuras como franzidos, pespontos, overloque aparente. Detalhes dizem respeito a partes da peça como bolsos e os tipos de bolsos, golas e o tipo de golas, martingale etc. É fundamental estabelecer a forma como esses itens serão comunicados aos envolvidos no projeto.

Nesses cinco pontos que são pesquisados e analisados no momento da criação existem subdivisões como a estamparia, tingimentos e bordados que estão atrelados ao item "matérias". 


\section{Estudo de Formas / Silhuetas}

Pensar na forma é considerar elementos muito importantes como silhueta, volume, linha, cor. Na criação de moda sempre tem de se pensar na "forma volume, silhueta".

A aula de projeto de Eunice Higa consistia basicamente em orientação. Nela eram construídas toiles de algodão em um primeiro momento e depois a peça no tecido escolhido.

Esse era o cenário ideal, mas às vezes, por falta de tempo, os alunos confeccionavam a peça direto no tecido escolhido, o que não permitia fazer uma prova de roupa da toile para corrigir os defeitos.

\section{Cartela de Cores}

O perfil do público e fabricantes fornece aos alunos elementos do design como cores e materiais para compor o painel com requisitos elaborados ou "Painel Aberto", atesta Cynthia Santos Malaguti de Sousa.

O aluno deve mostrar como a marca trabalha as cores de base ou dominantes, intermediárias ou complementares e tônicas, argumenta Higa.

No contexto do projeto, Eunice Higa alerta que é preciso compreender como o aluno interpreta a cor na vida dele. É um elemento importante ou não? Então, como o aluno se relaciona com cor? Até onde a cor é importante ou não para o estilista?

\section{Cartela de Matérias}

A questão dos materiais é muito ampla e não se resume a tecidos aviamentos. Ela demanda pesquisa e estudo desses insumos para eleger os materiais possíveis para se trabalhar o vestuário, o produto de moda. Devem-se levar em conta novos produtos e tecnologias disponíveis.

O sucesso de um artigo de moda no que diz respeito ao emprego de materiais depende de inúmeros testes e desenvolvimentos que estão ligados também à capacidade criativa do profissional. O conhecimento de matérias vinculado à tecnologia têxtil norteia as possibilidades acerca do processo de criação.

Para Higa há dois tipos de aviamentos. Os básicos que são os realmente necessários para que a roupa exista como, por exemplo, linha, zíper, elástico, botão. E os aviamentos que não são funcionais, pois estão mais no âmbito da ornamentação, como o strass, fita de cetim, apliques etc.

No processo de Canton (2016) depois do painel havia a pesquisa de material e só então o aluno passava se dedicar ao desenho.

\section{Beneficiamentos}

$\mathrm{Na}$ abordagem de Eunice Higa o desenvolvimento de design de superfície comumente chamado estamparia no design de moda, faz parte de materiais.

Algumas perguntas surgem quando o assunto é estamparia. Que materiais são esses? Que tipos de tecidos são esses? Qual a sua composição? Qual a cor do fundo? Ele aceita todas as cores? etc. É o cruzamento dessas perguntas que determina o tipo de produto a ser obtido.

Assim, o profissional recorre aos seus conhecimentos sobre tecnologia têxtil que direciona a transformação do material liso em material texturizado ou estampado. Devem ser checados todos os aspectos físicos que envolvem o material quando se desenvolve estamparia, como tipos de tecidos, fibras, que tipo de estamparia será aplicada, temperatura que o tecido suporta, teste de toque, gramatura, se haverá bordado, lavagem, ou outra intervenção antes ou depois da estamparia.

\section{Desenhos}

Como professora de graduação do curso de Moda do SENACSP, Maria Cláudia Bonadio sempre buscava contemplar a noção de projeto em suas aulas de História da Moda. Ela solicitava aos seus alunos que desenhassem três looks com base em um período histórico, depois de escolher uma temática dentro desse período e realizar uma pesquisa.

No momento de pensar o produto o aluno usa referências de tecidos, aviamentos, volumes, silhuetas que foram levantados durante a pesquisa $e$ conforme Cyntia Santos Malaguti de Sousa explica, coloca isso em prática na criação da coleção, principalmente por meio do desenho.

Após a pesquisa de público, marcas e materiais, Souza orientava os alunos no desenho da coleção, onde eles desenvolviam formas. Era preciso defini o que seria marcante na coleção, que tipo de estrutura de roupa pontuaria a coleção. Ela chama de estrutura o que é mais conhecido como silhueta no campo do design de moda.

Pesquisar materiais antes de se dedicar ao desenho de coleção é uma sequência lógica na forma como tratam as etapas de projeto Sousa e Canton (2016). Quanto ao desenho ele pode aparecer na forma de rascunho, esboço ou croqui. Com os croquis prontos o aluno desenvolve os desenhos técnicos, a modelagem e a prototipagem (CANTON, 2016).

A prática do desenho fomentada por Eunice Higa era mais voltada ao estilismo. Ela solicitava ao aluno o desenho de ilustração, com o corpo inteiro, atitude e comportamento (se a consumidora é mais jovem ou mais discreta), acessórios, tipo de poses para traduzir nessa ilustração esse público estilizado. $O$ desenho poderia ser feito à mão e no computador. Sempre existiu uma variação em termos de quantidade, mas não poderiam 
ser poucos desenhos. Era preciso um número de propostas que pudesse mostrar realmente o trabalho do aluno.

Ao longo do curso é mais comum os professores solicitarem entre vinte e trinta produtos. No TCC o aluno tem de apresentar pelo menos cinquenta produtos finais depois de uma série de desenhos. Para escolher cinquenta artigos é necessário que o aluno desenhe um número muito maior de croquis.

Na sequência do desenho de ilustração vinham os desenhos técnicos ou planificados. E existe hoje uma variação da representação dos desenhos planificados, segundo Higa, pois há a possibilidade de ser representado em três quartos, em movimento ou por programas de computador 3D.

A última etapa do projeto desenvolvido pelos alunos de Sousa se concentra nos desenhos técnicos com especificações de tecido e aviamento preparados em fichas técnicas.

O desenho técnico é executado para que o estilista possa conversar com o profissional que vai traduzir isso para uma roupa, o modelista. $O$ aluno deve pensar sobre o desenho planificado representado na ficha técnica. Ele é suficiente para que o diálogo entre estilista e modelista se sustente? Traz todas as informações? Faz uso da linguagem do estilismo? Ela funciona ou não? Como está funcionando? Atende às expectativas ou está deficitário? Precisa melhorar?

\section{Modelagem / Moulage}

Com as fichas técnicas prontas a próxima etapa é a construção desse produto

No começo do curso de Estilismo o próprio aluno pode confeccionar as criações no ateliê do SENAC SP, mas em um trabalho mais avançado, do quarto ano, por exemplo, o aluno precisava entrar em contato com profissionais que possam atender à qualidade exigida pela banca de professores que compõem a avaliação do TCC.

\section{Confecção do Look}

Conceitualmente, protótipo e peça-piloto possuem diferenças para Andrea Canton (2016). O protótipo para ela seria um estudo da forma para virar roupa, o que ainda não configura uma pilotagem. $O$ protótipo para ela antecederia a tela, ou seja, seria algo menos finalizado que a própria tela.

A ideia da prova de roupa é muito importante porque ela evidencia a qualidade da confecção do produto e é o momento de mostrar para o aluno a relação da linguagem do desenho da ilustração, do desenho técnico e da roupa confeccionada. Com o material é preciso que o aluno tenha um bom desempenho para que o projeto se efetive com sucesso.
A confecção do artigo de moda depende de uma comunhão entre dois profissionais, estilista e modelista, onde este último irá interpretar o que $\circ$ criador quis

O modelista pode fazer a roupa, mas segundo Higa, ela pode ficar sem "alma" se ele não souber interpretar. Daí a necessidade de um curso superior em Moda voltado à Modelagem.

Essa sensibilidade vai além do domínio técnico do método de modelagem. O modelista precisa entender como construir a forma, ou desenvolver metodologias para isso, para atingir um resultado condizente com o que 0 criador projetou. Nesse sentido o modelista é um criador também. Embora o desnível simbólico entre estilista e modelista seja imenso, admite Higa.

\section{Apresentação}

No decorrer do curso o formato de apresentação do projeto no SENAC SP é pautado pelo caderno de criação e pelos painéis. Em formato variável, $n$ apresentação de um projeto constam materiais, consumo, ficha técnica etc. O look confeccionado no tecido também é apresentado em sala.

Quem desfila a coleção do TCC é o curso de Design de Moda - Estilismo. TCC dos alunos de Design de Moda - Modelagem vai para exposição. Em ambos os casos só os melhores trabalhos são exibidos.

Ao final há uma exposição dos trabalhos dos dois cursos. No Estilismo é avaliada a adequação dos materiais e na Modelagem o domínio técnico.

No TCC são exigidos cinco looks para apreciação da banca mais um trabalho de imagem de moda que é formado pelo lookbook e pelo editorial.

\subsection{Universidades Estaduais
de São Paulo}

A contribuição de pesquisadores vinculados à FAUUSP e à UNESP (FAACBauru) é mais restrita em função do ensino e pesquisa do design de moda não serem o foco da produção dessas instituições.

A metodologia projetual do design de produtos nem sempre atende às demandas do design de moda. Pelo fato da FAUUSP e UNESP se dedicarem ao ensino da pesquisa em design de produto e design visual elas guardam certa dista certadistancia de loumas itens normalmente utilizados em coleções de moda careçam de informação nesses subcapítulos. 
É o caso de Estudo de Formas / Silhuetas, Cartela de Cores, Cartela de matérias, Beneficiamentos e Geração de Alternativas na FAUUSP e Formas de registro da pesquisa, Estudo de formas / Silhuetas, Cartela de Cores, Beneficiamentos, Desenhos, Apresentação / Desfile na UNESP.

Apesar de ser muito recorrente no design de produtos, a Geração de Alternativas é assunto pouco abordado nessas instituições em trabalhos dedicados ao campo da moda. Ao discutir sua aplicação ao design de moda os entrevistados admitiram não ter domínio sobre projeto em moda para isso.

\subsection{EACHUSP \\ 2.4.1 Escola de Artes, Ciências e Humanidades da Universidade de São Paulo}

Atualmente, Cláudia Regina Garcia Vicentini, professora da disciplina de projeto do curso Têxtil e Moda da EACHUSP, acredita que a solução em termos de projeto é um conjunto de diretrizes.

Em sua pesquisa de Doutorado ela analisa cinco pontos: o pensamento empresarial, a engenharia, o design, as metodologias e a relação usuárioobjeto.

No tocante à metodologia para o projeto em moda Vicentini elenca uma série de etapas oriundas do campo da engenharia e dos negócios. A linguagem da tese de Vicentini sobre projeto faz perceber sua vinculação com o campo do desenvolvimento de produto por intermédio da engenharia.

Figuram entre essas fases o Pré-Projeto que direciona o tema da coleção, o tipo de público, a estação do ano e o número de peças a serem produzidas para o faturamento pretendido. A fase seguinte, chamada de Fase 1 consiste no Estudo de Viabilidade, dividida em levantamento de informações sobre o mercado (clientes e produto) e a etapa de concepção. A fase 2 ou Projeto Preliminar é onde ocorrem testes e prototipagem. Nela também é definida uma família de produtos que caracterizará a coleção e é feito o levantamento de materiais e processos (VICENTINI, 2010, p. 73).

$\mathrm{Na}$ fase 3 ou Projeto Detalhado são desenvolvidas as fichas técnicas com desenhos técnicos e especificações sobre componentes e montagem, então a produção é liberada. A autora afirma que essas fases mantêm certa independência umas das outras.

Após essa brevíssima revisão da tese de Vicentini sobre metodologia para o desenvolvimento de produtos de moda, pretende-se, a partir de seu depoimento, verificar o que ela considera importante atualmente como metodologia e etapas dentro da noção de projeto em moda.

\section{Pesquisa de Referências}

A empresa e a figura responsável pelo desenvolvimento de produto, estilista ou designer, precisam de um conjunto de diretrizes para desenvolver produtos para a empresa que vai se basear no público-alvo e no que é o valor simbólico para esse público-alvo.

Um projeto preliminar seria então o levantamento de um conhecimento que pertence à empresa.

Quem o detém não é o profissional de desenvolvimento de produto. Ele faz uso dessa informação para entender o negócio e suas necessidades para, em seguida, atender ao mercado com um bom produto mantendo o cliente satisfeito.

A aplicação de projeto em moda, na percepção de Vicentini, tanto no ensino de graduação como em sua tese, está mais voltada ao produto comercial e tem aspecto principalmente prático. Ela sempre faz distinção entre produto comercial e conceitual em seu depoimento. A preocupação voltada ao mundo dos negócios pauta a visão de Vicentini sobre projeto em moda.

Dados apontados por Vicentini mostram que essa abordagem tem direcionado os egressos do curso de Têxtil e Moda da EACHUSP a atuarem principalmente como gerentes de produto.

Aessa altura o ponto-chave do projeto é o público-alvo, pois conhecendo-o a criação se torna mais fácil uma vez que o profissional pode ser mais assertivo ao usar seus conhecimentos e referências pessoais para criar um produto e diferenciá-lo.

\section{Registro da Pesquisa \\ e Desenvolvimento de Produto}

O uso das referências pessoais do criador serve para caracterizar um produto que tem um apelo único, ligado à produção de subjetividade do usuário.

Nesse processo é fundamental traduzir a pesquisa em um produto com apelo para o público. Esse apelo tem relação com a interferência do profissional no produto de acordo com seus gostos e repertório.

Esses gostos se expressam desde o início do registro da pesquisa que é feito em um caderno de croquis ou caderno de criação onde são registradas as informações encontradas na pesquisa como formas, silhuetas, cores, matérias, beneficiamentos e desenhos, entre outros elementos estilísticos.

Vicentini (2010, p. 79-90 passim) aponta que esses elementos fazem parte da pesquisa e costumam surgir a partir do "Painel Semântico". 
O painel deve auxiliar na definição dos elementos configurativos para que estes se adéquem ao tema proposto para a coleção. Ele pode ser construído a partir de colagens de imagens que remetam às características do material a ser utilizado entre outras qualidades do "tema" elencado que servirão de referências para a criação.

Quando é o caso são desenvolvidos estampas, bordados, lavagens, tecidos e aviamentos exclusivos entre outros beneficiamentos.

Qualquer tipo de vestuário deve contemplar as funções prática, simbólica e estética. No que diz respeito ao conforto (função prática), a função ergonômica é indispensável, mas antes dela é necessário atentar para o conforto psicológico do usuário, que passa por uma adequação daquilo que ele usa, defende Vicentini.

O bem-estar proporcionado por essa adequação vai muito além do conforto físico, por isso que o binômio "forma e função" não está em primeiro lugar na noção de projeto em moda ensejada por Vicentini. O entendimento desse tipo de suscetibilidade tem de ser claro para quem faz o produto, $\circ$ aluno e o profissional.

\section{Geração de Alternativas}

Antes de começar a desenvolver as soluções é preciso definir um critério para elas. Esse critério que tem por base os requisitos do cliente será aplicado ao "Quadro Morfológico". Ele é formado por uma coluna de "parâmetros" e outras com informações de tendências estéticas da estação. Seu uso depende de métodos como a criatividade e o brainstorming na sua aplicação (VICENTINI, 2010, p. 96).

O "Quadro Morfológico" é uma ferramenta que permite criar inúmeras combinações por meio do cruzamento entre os dados originando novos produtos que configurem uma coleção.

A tarefa "Quadro Morfológico" é uma forma de realizar a "Geração de Alternativas". O passo seguinte em seu processo é documentar as possíveis soluções encontradas por meio do registro em desenho de croqui e técnico. No caso de Vicentini esse Quadro precede os desenhos, o que não acontece na maioria das instituições pesquisadas.

\section{Desenho}

É na "arquitetura final do produto" que são representados os croquis, baseando-os na combinação de princípios de solução como o "Quadro Morfológico". Por fim, são analisadas as soluções possíveis em relação às necessidades do público em questão (VICENTINI, 2010, p. 97-98).

Tanto os croquis como os desenhos técnicos podem ser desenvolvidos à mão ou com auxílio do computador e são entendidos pela autora como ferramentas de projeto.
Os desenhos técnicos, também chamados por Vicentini (2010, p. 107) de "desenhos de montagem", são anexados a uma ficha técnica que reúne todas as informações do produto a ser desenvolvido. Nela o desenho técnico precisa ser representado frente e costas com todas as medidas necessárias à sua fabricação.

Em alguns casos também é necessário que o desenho técnico represente a vista lateral da peça a ser modelada.

\section{Modelagem / Moulage}

A modelagem éa tradução do desenho para o molde planificado que incorpora as medidas definidas. Ele será utilizado para cortar a peça em tecido.

Devem ser estabelecidos padrões pela empresa que atendam ao seu público-alvo na construção de modelagens que originarão as peças-piloto prezando por conforto e usabilidade (VICENTINI, 2010, p. 102).

\section{Confecção do Look}

O artigo de vestuário e moda tem de passar pela "análise do conforto e usabilidade". Para isso é preciso fazer o "teste de uso" final. O design de moda não costuma ensejar essa prática, mas é preciso que pelo menos os produtos clássicos, aqueles que não saem de linha, sejam testados.

Esse teste pode ser feito via consumidor e tem a intenção de testar caimento, conforto, costuras, resistência etc.

\section{Apresentação}

Ao final da disciplina de projeto, Cláudia Vicentini solicita a apresentação de um portfólio com todo o registro da pesquisa, desenhos técnicos, croquis $\mathrm{e}$ todos os detalhes da coleção que possam ser relevantes para a compreensão do processo que levou até aquele resultado de projeto. 


\subsubsection{FauUSP Faculdade de Arquitetura e Urbanismo da Universidade de São Paulo}

Sousa explica que o termo metodologia é usado no sentido de experimentação, diferente dos métodos, que são mais rígidos. Trata-se, sobretudo, de um jargão.

Para Cibele Haddad Taralli um caminho interessante ao desenvolve projetos voltados à área de moda é usar a metodologia proposta por Munari, justamente por se mostrar mais aberta à experimentação.

\section{Pesquisa de Referências}

Na moda, a forma de pensar a criação, segundo Sousa (2015a), completamente diferente do design. $O$ ponto de partida criativo no design de moda trata, muitas vezes, de considerar "marca concorrente, extensão de marca, à maneira de". Essas frases costumam aparecer com mais frequência quando relacionadas a projeto no design de moda.

No campo do design, a maneira de trabalhar o projeto, segundo Sousa, por palavra-chave ou verbo. E pensado o contexto, uma necessidade humana, uma demanda, que, no produto de vestuário seria portar, experimentar, caso a moda fosse vista efetivamente pela ótica do design.

Mudanças sociais, para Sousa, levaram a moda a trabalhar um pouco melhor a questão da forma e função. Em um momento anterior a moda privilegiou a forma e a função simbólica. Em sua opinião o design de moda deve atender à demanda da forma e função, mas também a outras necessidades das pessoas.

Para Maria Celeste de Fátima Sanches estudar determinado contexto suas restrições, ou seja, delimitar o alcance daquilo que vai ser projetado, que vai ser criado é fundamental em termos de projeto em moda.

Na prática do projeto, é comum em faculdades de moda que, antes de tudo, seja eleito um "tema" que direcione a pesquisa e o desenvolvimento de uma coleção. Sanches é crítica em relação ao termo "tema" quando fala em inicia uma pesquisa, e prefere as expressões "conceito" ou "referência" para orientar o levantamento de informações com foco no desenvolvimento de uma coleção.

\section{Registro da Pesquisa}

É comum o aluno pesquisar e registrar o resultado de sua pesquisa de form intuitiva. Muitas vezes, a maneira como é realizada a pesquisa e a forma como ela é registrada variam muito entre diferentes alunos e instituições.
Isso ocorre porque dentro das escolas, muitas vezes, é fomentado um ambiente que impossibilita perceber a diferença entre criatividade liberdade na tomada de decisões para um aluno que ainda está em formação.

$\mathrm{Na}$ maioria dos casos, os alunos desenvolvem processos criativos, mas sem ter contato com metodologias de projeto em moda. Coleções de vestuário e de estamparia desenvolvidas em TFGs ${ }^{27}$ de alunos da arquitetura da FAUUSP até 2013 mostram que não há um consenso na adoção de uma visão sobre projeto em moda.

Os dados coletados não precisam necessariamente ser tratados da mesm forma por cada aluno, mas o que se percebeu em alguns trabalhos voltados oo design de moda nessa faculdade é que etapas não foram consideradas e isso pode ter prejudicado o desenvolvimento do produto.

Para Feres Lourenço Khoury (2015), projeto em moda é o trabalho do profissional dentro de princípios, de ideias que o indivíduo desenvolve durante a sua formação e a partir daí cria as relações de conhecimento das quais o projeto precisa. Essas relações dependem de um mínimo de sistematização da informação coletada.

A afirmação de Khoury leva a crer que o projeto em moda deve obedecer a certos preceitos que atendam às necessidades desse projeto, de forma que o aluno possa utilizar sua criatividade e repertório pessoal no modo de relacionar essas informações.

\section{Desenhos}

O produto de moda, diferentemente do design industrial, é vislumbrado dentro de uma coleção, não como peça única, de acordo com Cyntia Santos Malaguti de Sousa.

Souza fala do desenho no design de moda como uma forma de amarração da coleção, o que é específico dos produtos de moda. $O$ artigo de moda desenhado pelo aluno é projetado dentro de um contexto de coleção, e não como peça única, como é mais comum no design de produtos.

\section{Modelagem / Moulage}

No projeto em moda, o aluno origina, pensa, materializa e constrói uma ideia, afirma Khoury.

Essa afirmação permite estabelecer uma relação com a materialização de uma ideia em produto de design de moda - vestuário ou acessório - por meio de sua construção, que pode acontecer por meio da modelagem plan ou moulage.
27 TFG-Sigla para e Urbanismo da FAUUSP, equivale ao TCC. 


\section{Confecção do Look}

Nos casos de TFGs voltados ao vestuário de moda na FAUUSP aos quais esta pesquisadora teve acesso, o que se observa é que o aluno confecciona suas peças, mesmo a faculdade não disponibilizando estrutura voltada à produção desse tipo de artigo.

Nos trabalhos com os quais foi possível ter maior proximidade, percebese que é o próprio aluno quem desenvolve a modelagem e costura suas peças, com ou sem ajuda de profissional especializado.

\section{Apresentação}

Os TFGs da FAUUSP voltados a projeto em moda com os quais se teve contato entre 2011 e 2013, foram apresentados em sala de aula e não houve desfile, prática mais comum em cursos de graduação em moda.

\section{FAACUNESP BAURU \\ 213 Faculdade de Arquitetura \\ Artes e Comunicação da \\ Universidade Estadual Paulista "Júlio de Mesquita Filho"}

\section{Pesquisa de Referências}

Mônica Moura considera algumas questões, quando se refere à pesquisa para a criação de uma coleção de design de moda. Entre elas estão a fase de levantamento de informações, seleção dessas informações que vão gerar o produto, quais os processos técnicos e tecnológicos disponíveis. Percebese que sua visão é pautada pelo design de produtos.

\section{Cartela de Matérias}

Como designer de moda, Mônica Moura (2015) relata que acompanhava a compra do material na confecção infantil em que ela trabalhava na década de 1980. Ela conduzia a escolha e aquisição dos tecidos. Moura encomendava tecidos exclusivos em algumas fábricas, às quais comparecia pessoalmente para acompanhar o desenvolvimento, além de receber os representantes das tecelagens na confecção onde trabalhava.
Eram comuns visitas à Rua Vinte e Cinco de Março para pesquisar aviamentos e tipos de linha, tudo dentro do processo projetual.

\section{Modelagem / Moulage}

Para Mônica Moura, parte do processo projetual está focada em saber lidar com o modelista e isso requer conhecer o próprio segmento, a estrutura de uma roupa, conhecer a base de uma modelagem, saber discutir com esse modelista para que ele acerte a modelagem.

Antes de ser designer de moda, Moura já havia atuado como designer de móveis. Ela conta que conseguia aplicar o processo do projeto do mobiliário ao vestuário, mas em dimensão, público e escala do design de moda.

Para Patrícia de Mello Souza (2015), a dicotomia entre as disciplinas de criação e desenvolvimento de produto pode comprometer a visão do profissional em formação. Para ela não existe essa separação. Não tem como pensar uma criação sem pensar em modelagem.

\section{Confecção do Look}

No desenvolvimento da peça-piloto Moura acompanhava de perto quais eram os problemas na confecção em que atuava. Ela aponta que durant a prova de roupa vários problemas relativos ao caimento desta, entre outros aspectos, podem ser detectados. Isso torna mais clara a noção de "problema" do design quando aplicado à moda. No Rio de Janeiro e mais com ũ mo proneiro atuar em diversas faculdades pesquisadas, geralmente, isso não acontece ao mesmo tempo. Nesse sentido, a separação por escolas não necessariamente ajudaria a esclarecer cada período da atividade de projeto em moda no Rio de Janeiro, por isso ela se mostra dispensável.

O ensino de projeto no Rio de Janeiro acontece às vezes pelas mãos de um mesmo profissional ao mesmo tempo em escolas que têm diferenças 
entre si. Essa situação leva os depoentes a comparar a noção de projeto em moda entre as faculdades.

Na opinião de Aline Monçores (2015), coordenadora do curso de Design de Moda da UVA, o designer de moda deve deixar de privilegiar objetos com valor simbólico e valorizar objetos que transmitam sentido dentro de algum contexto.

As etapas de projeto encontradas no Rio de Janeiro se definem por etapas para chegar a um determinado fim, pondera Deborah Christo (2015).

Há duas visões acerca de projeto em moda na PUCRJ de acordo com Izabel Maria de Oliveira. Uma prioriza o modelo de projeto de coleção voltado ao sistema de produção e à cadeia têxtil, delimitando mais a metodologia com um processo e ferramentas mais claros já legitimados pelo campo conforme comenta Christo acima. Outra argumenta que trabalhar somente pautado pela metodologia não atende satisfatoriamente à questão de projetar moda nos dias atuais. Essa vertente pode conduzir à ruptura da ideia do sistema de coleção (OLIVEIRA, 2016).

Esse último argumento se baseia na ideia de que o sistema de coleção voltado somente à metodologia limita o processo criativo, a pesquisa de materiais, a experimentação de linguagens que não são tão tradicionais, além de outros aspectos que estão surgindo (OLIVEIRA, 2016).

Para Christo, no design de produto, variando um pouco entre os vários autores, há a detecção de um problema, o processo de pesquisa ou coleta de dados, desenho, geração de alternativas e no final isso é preparado para ser executado na prototipagem. Segundo a pesquisadora, é possível inverter algumas etapas e desenhar primeiro e escolher materiais depois, mas em suma, as etapas são essas e elas podem ser aplicadas ao design de moda.

Evelyn Grumach (2015) aborda a metodologia de projeto em design para trabalhar um problema na moda, embora não considere as etapas de projeto claras. Ela as aborda metodologicamente no sentido de construir analogias entre a metodologia de design e de moda, de forma a gerar troca entre os alunos de design de produto e design de moda.

Essa metodologia que atravessa o design e a moda é mais independente, tem caráter mais amplo e considera que existem especificidades no campo do design de moda que levam em conta como pensar um produto de moda. É preciso prestar atenção a essas especificidades do design de moda, pois elas vão mudando com o tempo (OLIVEIRA, 2016).

Até certo ponto, Izabel Maria de Oliveira define o que o estilismo já fazia quando a moda era compreendida como campo autônomo, ou seja, trabalhar com menos restrições o processo criativo. Seria de certa forma um retorno ao estilismo. A sugestão de metodologias pautadas por etapas mais rígidas veio do campo do design.

Por que a moda se encontra sob o guarda-chuva do design, se há interesse em um resgate da prática que já era realizada antes de o campo da moda ser encampado pelo design?

\section{Pesquisa de Referências}

Para Alberto Cipiniuk, a leitura de bibliografia em design, especificamente em projeto, é fundamental. Essa leitura integra a pesquisa no que diz respeito a formas de fazer projeto. Cipiniuk ressalta que isso é só parte da formação do designer. Há uma parcela de profissionais que acreditam que "tem uma parte que é meio mágica na criação" e isso gera um distanciamento intelectual da pesquisa, afirma Cipiniuk (2014, p. 31).

O conteúdo oriundo da pesquisa assume duas formas, pondera Evelyn Grumach. Uma é o conteúdo de projeto em design e de projeto em moda que embasa a atividade do designer e, outro é do tema pesquisado. É preciso conhecê-los para poder fazer essa trama. Esse contato do design com a moda permite criar um objeto como agente transformador. O conhecimento de projeto em design é fundamental para transferir o conteúdo da pesquisa para o produto.

Em relação às etapas, Aline Monçores desenvolveu um método próprio de ensinar projeto em moda. Ela entende como etapas de projeto em moda identificar uma função para o produto, estabelecimento de prazos para as tarefas determinadas, avaliação do projeto, qual é a questão do projeto, se o projeto tem problema, se tem etapas a serem resolvidas, baseando-se até certo ponto em Bruno Munari (2008), "Das coisas nascem coisas".

Questionada sobre como a noção de "problema" do design pode ser aplicada à moda, Monçores afirma que prefere a nomenclatura "demanda". Ela pede ao aluno para redigir quais são as possíveis demandas do projeto. Essas demandas são o ponto de partida da pesquisa. Irina Aragão, professor da PUC RJ, prefere o termo "oportunidades de projeto" encontradas na pesquisa, no mercado e em lugares frequentados pelo público-alvo.

Essas oportunidades de projeto serão encontradas pelos alunos de Aragão a partir de um briefing proposto por ela em sala de aula. Ele está relacionado ao tipo de produto que os alunos são orientados a fazer.

Ao propor uma discussão sobre etapas de projeto em sala, Aragão percebe que os alunos acreditam que o processo começa pela pesquisa. Ela alerta que antes da pesquisa tem outra etapa, a proposta, baseada no briefing. "Alguém que te chama, te convida e vai te dizer uma questão, um problema para uma oportunidade de projeto" (ARAGÃO, 2015).

$O$ projeto deve estar sempre pautado por uma situação, seja uniforme, pijama etc. Aragão nunca aceita um projeto que preze a estética pela estética, como um fim em si mesmo. Ele não pode ser engessado pela estetização que a moda propõe. No design de moda o que Aragão chama de "situação" aparece como segmento.

O primeiro problema que o designer de moda pode resolver, na opinião de Aragão, é o vestuário para pessoas reais e com questões reais. Há problemas sérios até hoje negligenciados.

Seguindo esse raciocínio, Aragão propõe alguns briefings aos alunos. Recentemente, ela ofereceu aos alunos duas opções: uniforme para comissário de bordo aéreo ou uniforme para quem pratica limpeza profissional. Percebe-se na prática de Aragão uma abordagem de caráter funcional-racionalista. 
Alguns clientes entendem o que é um briefing, outros não. Então, em sua aula, Aragão começa esclarecendo o que é um briefing, que ele sofre ajustes que são importantes, quais as responsabilidades de quem contrata e fornece exemplos, onde maus entendimentos podem afetar o briefing, e seus conteúdos.

Há um briefing genérico, mas de acordo com a especificidade do projeto, é necessário abrir um briefing novo. Aragão defende que o briefing não é engessado, não é "receita de bolo".

Assim como Irina Aragão, o corpo docente coordenado por Sérgio Sudsilowsky no SENAI CETIQT preferia o termo "oportunidade de projeto" aos termos "problema" ou "detecção de problema". Essa opção mostra que a moda realmente demanda a partir de suas especificidades, pois nem sempre a moda traz um problema enquanto projeto, mas uma oportunidade ou demanda.

\section{Registro da Pesquisa}

A abordagem de projeto de Monçores requer primeiro que os alunos redijam as possíveis demandas do projeto. Na sequência, os alunos vão a campo para escolher uma marca já existente no sentido de oferecer um produto novo.

Em seguida, os alunos devem identificar detalhadamente uma linha de produtos. E, a partir da identificação dessa linha, o que seria uma demanda para a marca escolhida que permita identificar novas possibilidades de trabalho.

$\mathrm{Na}$ aula de Irina Aragão, após o briefing, parte-se então para o levantamento de dados que se destaca pelas partes que o compõem. Entre elas figuram a ambientação (ou painel), a posição do produto no mercado, a segmentação demográfica e outros itens abordados por Mike Baxter, autor de referência para Aragão. Ela ressalta a importância da leitura de Baxter. O levantamento de dados é composto por vários itens que têm de ser articulados e registrados, e o excesso de trabalho inicialmente surpreende os alunos.

Em alguns momentos as fases de pesquisa e registro ocorrem concomitantemente. A ambientação (ou painel), que para Aragão compreende a fase de levantamentos de dados registrados, para esta tese compõe o processo de registro da pesquisa.

A próxima etapa para Aragão é a fase de embasamento. Trata da pesquisa, levantamento de dados, similares, análise de similares, análise de correlatos. Além de Aragão e Grumach, nenhum outro entrevistado utilizou os termos "similares, análise de similares, análise de correlatos" do design de produtos quando o assunto era design de moda.

O processo criativo é contemplado após a pesquisa e análise dos dados coletados. $O$ aluno precisa chegar a um conceito na opinião de Aragão, que é o resultado da pesquisa. Então, o briefing tem o papel de fornecer informação que direciona o designer para alguns caminhos no sentido de resolver a oportunidade de projeto. As fases citadas por Aragão até aqui se referem ao desenvolvimento da primeira fase do projeto em sua disciplina.
No que diz respeito às etapas de projeto, Sudsilowsky propõe que primeiro seja feita a problematização, ou seja, a divisão dos problemas em partes menores. Para essa etapa ele sugere como bibliografia de apoio Bruno Munari, pois foi a forma mais fácil de o "aluno de moda" entender e fazer as comparações para o desenvolvimento de uma coleção, principalmente no que toca à documentação da coleção, à solução, ao teste de possibilidades, à prototipagem e à documentação dos produtos desenvolvidos.

\section{Estudo de Formas / Silhuetas}

Nas escolas do Rio de Janeiro, o assunto não foi explorado pelos depoentes, quando questionados sobre as etapas de projeto. Aparentemente a visão funcionalracionalista é marcante no ensino e pesquisa do design de moda naquela cidade.

Dessa forma, atividades projetuais mais subjetivas como estudo de formas e silhuetas, que antecedem o desenvolvimento de produto efetivo, recebem menos atenção. A preocupação com a forma é expressa na etapa da modelagem.

\section{Cartela de Matérias}

Instituir a ideia de "problema" no design de moda é a maior dificuldade ao falar sobre projeto para alunos, alerta Deborah Christo. Na prática do design de moda, a noção de "problema" não é clara e sequer configura uma etapa de projeto.

Ao mesmo tempo, a detecção de um problema no campo do design também não é algo fácil, e desenvolvimentos como Cartela de Cores podem ser vistos como partes de um problema.

A pesquisa proporciona uma imersão para entender um problema de que configuram possíveis problemas para o design de moda, a questão de vestir o corpo humano que envolve escolher materiais como tecidos e aviamentos e se comunicar bem por desenhos voltados à produção industrial.

\section{Beneficiamentos}

Um aspecto que chamou a atenção foi que entre os depoentes cariocas nenhum mencionou o design de superfície. Interessante notar que isso pode apontar certa desvinculação entre as instituições de ensino de moda e mercado uma vez que a tra dição de estamparia de moda do Rio de Janeio

\section{Desenho}

Alberto Cipiniuk é crítico em relação à etapa do desenho, dada sua importância. $O$ desenho deve auxiliar no desenvolvimento de produto, comunicando formas, medidas, tecidos e acabamentos.

O trabalhador desse métier no Rio de Janeiro está, majoritariamente, na favela, a exemplo das costureiras de Rio das Pedras. São elas as responsáveis por fazer o produto a partir de um desenho que, segundo Cipiniuk (2015), muitas 
vezes "não tem nada a ver" com um produto real, porque o estilista que desenhou não sabe modelagem. Ele critica que chega até as costureiras um "croquizinho", se referindo a desenhos mal executados que nada esclarecem, e ressalta a necessidade de uma boa formação do designer de moda para evitar gargalos.

Aparentemente, os alunos de Aragão desenham croquis e, em seguida, entram na análise dos fatos limitadores do projeto. Na sequência, eles passam para a finalização do projeto, que inclui o desenvolvimento de fichas técnicas com desenhos técnicos e o desenvolvimento de mock ups. A análise dos fatos limitadores do projeto não costuma acontecer no design de moda.

De maneira geral, nos relatos sobre a prática de projeto no Rio de Janeiro, percebeu-se que é dada menor importância à questão do desenho artístico.

\section{Geração de alternativas}

A geração de alternativas é posterior à análise de similares. Quando houver a análise de similares, Grumach atenta para não a confundir com cópia. A cópia é "um cardápio a escolher" entre soluções já prontas e não uma análise crítica de soluções que podem ser empregadas ou combinadas para a solução adequada de um problema. A análise de similares propõe analisar produtos já existentes para entender o processo do criador para, então, partir para a geração de alternativas.

Com os dados coletados e analisados, o aluno de Irina Aragão desenvolve um conceito e entra na fase do processo criativo. Então, ele pode começar a criar "coisas", considerando os elementos levantados. É quando são desenhados os croquis.

As fases anteriores citadas por Aragão, que incluem o briefing, levantamento e análise de dados e conceito resumem o desenvolvimento da primeira fase do projeto em sua disciplina.

O projeto entra na segunda fase, para Aragão, quando começam a ser analisados os fatos limitadores do projeto. Aí os alunos começam a cortar o excesso de informação do que já estava sendo criado. A ideia aqui é trabalhar como um funil, que abre a pesquisa e depois a fecha, segundo critérios limitantes.

\section{Modelagem / Moulage}

Após identificarem uma demanda, os alunos de Monçores são orientados a pesquisarem qual é o maquinário que aquela empresa disponibiliza antes de desenvolverem o produto em si, evitando perda de tempo e gastos desnecessários.

A escolha de diferentes maquinários é um assunto bastante complexo e diversificado, em se tratando de design de moda. Uma das questões relativas ao maquinário é que ele irá determinar os tipos de acabamento da peça de vestuário e influenciará sua modelagem, pois, uma vez escolhida a costura necessária, a modelagem exigirá margens de costura diferenciadas.

Se a proposta é partir de uma demanda que considere o maquinário disponibilizado pela empresa, então o que se tem é um projeto direcionado pelo produto, focado em questões práticas e que pode negligenciar o usuário.
A essa altura do processo se inicia a fase de maior interesse de Aragão, que é o desenvolvimento dos modelos volumétricos. Com as fichas técnicas em mãos os alunos de Irina Aragão passam a se dedicar ao mock up, que é a fase de seleção do material e quando será construída a primeira versão do modelo a partir do desenho. Ele deve ser executado com agilidade para colocar a ideia em prática.

É possível estabelecer relação entre os conceitos de modelagem e mock up. Este equivale no design de moda à toile, uma tela feita no manequim (com papel, algodão cru, morin ou riolen ${ }^{28}$ ), como um primeiro exercício de formas, sem medidas.

Sobre forma, assunto central na modelagem, Monçores analisa brevemente a questão sob o ponto de vista do docente. Para ela o professor deve colocar em evidência uma funcionalidade para determinado uso, em determinado objeto, além de a forma ser coerente àquela função. Essa postura tem por consequência gerar uma estética agradável em uma forma que execute a função. O professor deve habilitar o aluno a tudo isso na opinião de Monçores.

\section{Confecção do Look}

De acordo com Aragão, depois de desenvolvido o mock up, ainda seguindo as fichas técnicas, os alunos partem para a confecção do modelo e do protótipo. Quem não vai se dedicar a nenhum deles vai trabalhar em escala.

A ordem mock up, modelo e protótipo, adotada por Irina Aragão no desenvolvimento de produto permite comparação com termos do design de moda.

No design de moda, a peça-piloto equivale ao modelo no design de produtos. Ela é costurada no tecido selecionado e segue o desenho definido no projeto com os acabamentos corretos pensados a partir do mock up.

A partir do modelo são feitas as principais correções segundo Aragão. $O$ passo seguinte é a confecçáo do prototipo que e o primeiro da série, ou seja, a primeira peça confeccionada industrialmente para medição de tempo, teste de escoamento da produção a partir do desenho da célula de produção, de viabilidade técnica e análise da produção industrial do artigo em questão. A produção inteira será baseada no protótipo.

Protótipo é a peça acabada, mas que ainda pode sofrer ajustes. Ela é quase o início de uma produção em série, e é a peça final em termos de teste. A produção deve atentar à dimensão, detalhes e material para que tudo seja feito idêntico ao protótipo, afirma Aragão.

Sudsilowsky se recorda que no SENAI CETIQT os professores de projeto utilizavam o termo "peça-piloto" e não modelo ou protótipo. Preferiam a nomenclatura de moda porque entendiam que os egressos iriam atuar em um mercado de confecção, embora sempre comparassem as nomenclatura do design com as da moda.

A prática da docência permitiu a Aragão perceber que o aluno que tem contato com o design por meio das próprias relações profissionais tem um desenvolvimento melhor em sala. Ela relata que alunos que já têm alguma intimidade com o produto que estão desenvolvendo possuem rendimento maior.

$\mathrm{O}$ quadro a seguir visa resumir as etapas de estilismo ou projeto em cada instituição. 


\section{Quadro 6}

Cruzamento das instituições e suas etapas de estilismo, projeto em moda e projeto em design 


\begin{tabular}{|c|c|c|c|c|c|c|c|c|c|}
\hline Pesquisa & $\begin{array}{l}\text { Resgate, Documentação, } \\
\text { Shopping/Após anos 2000/ } \\
\text { Tendencias, brainstorming, } \\
\text { público-alvo. }\end{array}$ & $\begin{array}{l}\text { Conceito criado pelo aluno, } \\
\text { Brainstorming, briefing do } \\
\text { cliente, público e } \\
\text { macrotendências. }\end{array}$ & $\begin{array}{l}\text { Referências/Cenário/ } \\
\text { análise de uma } \\
\text { marca, público-alvo. }\end{array}$ & $\begin{array}{l}\text { Diretrizes para } \\
\text { desenvolver } \\
\text { produtos para } \\
\text { uma empresa. }\end{array}$ & $\begin{array}{l}\text { Marca/ } \\
\text { palavra-chave } \\
\text { ou verbo. }\end{array}$ & $\begin{array}{l}\text { Fase de levantamento de } \\
\text { informaçoes, seleção, } \\
\text { processos sténicos e } \\
\text { tecnológicos disponiveis. }\end{array}$ & $\begin{array}{l}\text { Bibliografia em projeto, } \\
\text { tema, briefing,levanta- } \\
\text { mento dedados, demandas, } \\
\text { oportunidades de projeto. }\end{array}$ & $\begin{array}{l}\text { Oportunidade } \\
\text { de projeto. }\end{array}$ & Demanda. \\
\hline $\begin{array}{l}\text { Registro da } \\
\text { Pesquisa }\end{array}$ & Ambience/ Cadernos. & $\begin{array}{l}\text { Painel de referência, painel } \\
\text { semântico, painel de } \\
\text { pesquisa de tendência, } \\
\text { arquivo digital. }\end{array}$ & $\begin{array}{l}\text { Cadernos/Painel } \\
\text { de apresentação } \\
\text { do projeto/Painel } \\
\text { Fechado e Aberto. }\end{array}$ & $\begin{array}{l}\text { Painel } \\
\text { semântico. }\end{array}$ & & & Painel. & & $\begin{array}{l}\text { Redigir } \\
\text { demandas. }\end{array}$ \\
\hline $\begin{array}{l}\text { Mix de } \\
\text { Produtos }\end{array}$ & & $\begin{array}{l}\text { Inventário interno determina } \\
\text { número de modelos, categoria } \\
\text { de produto (básico, fashion e } \\
\text { vanguarda), tops, bottons e one } \\
\text { pieces, cores e tecidos. }\end{array}$ & & & & & & & $\begin{array}{l}\text { Prazos para } \\
\text { as tarefas } \\
\text { demandadas. }\end{array}$ \\
\hline $\begin{array}{l}\text { Formas } \\
\text { Silhuetas }\end{array}$ & $\begin{array}{l}\text { Vontades de forma, } \\
\text { toiles/ Estudos de } \\
\text { formas no manequim. }\end{array}$ & $\begin{array}{l}\text { Modelagens } \\
\text { miniatura/sombras }\end{array}$ & $\begin{array}{l}\text { Volumes no } \\
\text { manequim com } \\
\text { algodâo cru. }\end{array}$ & & & & & & \\
\hline Cores & $\begin{array}{l}\text { Base, intermediárias } \\
\text { e tonicas/Cartela } \\
\text { feita no papel. }\end{array}$ & $\begin{array}{l}\text { Deve-se buscar o equilibrio } \\
\text { entre a oferta do mercado e } \\
\text { o desejo do cliente/ } \\
\text { nascem das tendências. }\end{array}$ & $\begin{array}{l}\text { Cores de base, } \\
\text { intermediárias } \\
\text { e tônicas. }\end{array}$ & & & & & & \\
\hline Matérias & $\begin{array}{l}\text { Tecidos, aviamentos } \\
\text { e desenvolvimento } \\
\text { de texturas. }\end{array}$ & $\begin{array}{l}\text { Pesquisar tecidos e aviamentos em } \\
\text { tecelagens, importadoras, mercado } \\
\text { ou premiere vision/ Ponderar preço, } \\
\text { disponbilidade do artigo e número } \\
\text { de tecidos em uma coleção. }\end{array}$ & $\begin{array}{l}\text { Estudo de } \\
\text { tecidos, } \\
\text { aviamentos e } \\
\text { insumos. }\end{array}$ & $\begin{array}{l}\text { Associadas } \\
\text { ao tema. }\end{array}$ & & $\begin{array}{l}\text { Tecelagens e } \\
\text { Rua } 25 \text { de março. }\end{array}$ & & & \\
\hline Beneficiamentos & $\begin{array}{l}\text { Grafismos/ Maquetes } \\
\text { de tecidos. }\end{array}$ & $\begin{array}{l}\text { Estampas, bordados, } \\
\text { lavagens e tingimentos } \\
\text { necessitam de ficha } \\
\text { técnica específica. }\end{array}$ & $\begin{array}{l}\text { Design de superfície } \\
\text { é consideradoo } \\
\text { como matéria para o } \\
\text { SENACSP. }\end{array}$ & $\begin{array}{l}\text { Desenvolvimentos } \\
\text { exclusivos de } \\
\text { estampas, bordados, } \\
\text { lavagens, tecidos } \\
\text { e aviamentos. }\end{array}$ & & & & & \\
\hline Desenhos & $\begin{array}{l}\text { Depois da ambience, } 6 \text { a } 8 \text { looks } \\
\text { por coleçãa, } 3 \text { coleçónes por ano/ } \\
\text { Esboço, desenho de moda, } \\
\text { desenho técnico, ilustracãa de } \\
\text { moda, desenho promocional. }\end{array}$ & $\begin{array}{l}\text { Croquis e desenhos } \\
\text { técnicos. }\end{array}$ & $\begin{array}{l}\text { Desenho de ilustração à } \\
\text { mão ou no computador/ } \\
\text { cerca de } 20 \text { c croquiis/ } \\
\text { desenhos técnicos. }\end{array}$ & $\begin{array}{l}\text { Croquis e } \\
\text { desenhos } \\
\text { ténicos à mão } \\
\text { ou computador. }\end{array}$ & $\begin{array}{l}\text { Desenhono no design } \\
\text { de moda se refereà } \\
\text { coleçâd desenho } \\
\text { de prodututo pode } \\
\text { ser único. }\end{array}$ & & & & \\
\hline \multicolumn{10}{|l|}{$\begin{array}{l}\text { Plano ou } \\
\text { Mix de Coleção }\end{array}$} \\
\hline $\begin{array}{l}\text { Geração de } \\
\text { Alternativas }\end{array}$ & $\begin{array}{l}\text { Primeiros desenhos geram } \\
\text { novos desenhos a partir da } \\
\text { repetição e mistura de detalhes } \\
\text { dando unidade à coleção. }\end{array}$ & & & $\begin{array}{l}\text { Quadro } \\
\text { Morfológico. }\end{array}$ & & & $\begin{array}{l}\text { Análise de similares } \\
\text { e análise de fatos } \\
\text { limitadores do projeto. }\end{array}$ & & \\
\hline $\begin{array}{l}\text { Volumetria } \\
\text { Moulage }\end{array}$ & Moulage. & $\begin{array}{l}\text { Testes de ergonomia/ficha } \\
\text { técnica, tabelas de medidas, } \\
\text { materiais e silhuetas } \\
\text { intepretadas pelo modelista. }\end{array}$ & $\begin{array}{l}\text { A partir das } \\
\text { informaçoeses da } \\
\text { ficha técnica. }\end{array}$ & $\begin{array}{l}\text { Modelagem } \\
\text { plana trata da } \\
\text { traduçãa do } \\
\text { desenho para } \\
\text { o produto. } \\
\end{array}$ & $\begin{array}{l}\text { Materialização } \\
\text { e construção } \\
\text { de uma ideia. }\end{array}$ & $\begin{array}{l}\text { Requer boa } \\
\text { comunicação do } \\
\text { designer com o } \\
\text { modelista. }\end{array}$ & & & \\
\hline $\begin{array}{l}\text { Confecção } \\
\text { do Look }\end{array}$ & & $\begin{array}{l}\text { Produzidos fora do horário de } \\
\text { aula/peça deve ser avaliada } \\
\text { pelo estilista. }\end{array}$ & $\begin{array}{l}\text { Prova de roupa é } \\
\text { elo entre desenho } \\
\text { e produto. }\end{array}$ & $\begin{array}{l}\text { Teste de } \\
\text { uso final. }\end{array}$ & & $\begin{array}{l}\text { Prova de roupa deve } \\
\text { ser acompanhada } \\
\text { pelo designer para } \\
\text { detectar defeitos. }\end{array}$ & & Prototipagem. & \\
\hline Apresentação & Desfile. & $\begin{array}{l}\text { Performance, instalação, } \\
\text { exposição / Desfile }\end{array}$ & $\begin{array}{l}\text { Apresentação } \\
\text { em sala/ Desfile. }\end{array}$ & Portfólio. & Sala de aula. & & $\begin{array}{l}\text { Mock up, Modelo } \\
\text { e Protótipo. }\end{array}$ & $\begin{array}{l}\text { Documentação } \\
\text { dos produtos } \\
\text { desenvolvidos. }\end{array}$ & \\
\hline
\end{tabular}

Quadro 6 - Cruzamento das instituições e suas etapas de estilismo, projeto em moda e projeto em design Fonte: A autora (2016). 


\subsection{Convergências e divergências entre literatura e no campo acadêmico}

Além dos nomes citados, em março de 2016 foi realizada uma pesquisa de campo no exterior, que resultou em uma entrevista com Troy Nachtigall, doutorando em Design pela Technische Universiteit Eindhoven (TU/e) da Holanda. Seu depoimento é relevante, dada sua atuação no campo do projeto em importantes marcas conforme mostra o quadro a seguir.

\section{Troy Nachtigall}

Quadro 7-Pesquisador no
exterior.

É um pesquisador americano que desenvolve sua pesquisa sobre projetação em moda na Holanda onde na época cursava doutorado na
Technische Universiteit Eindhoven (TU/e). Além disso, é um designer
experiente que que já atuou em marcas como Hugo Boss, Jean Paul experiente que que já atuou em marcas como Hugo Boss, Jean Paul Gaultier Jeans, Calvin Klein e Calvin Klein Jeans.

Neste Subcapítulo o interesse é estabelecer, por meio de comparações e analogias, relações entre etapas, terminologias e seus estudiosos, cruzando dados produzidos pelos autores e pioneiros investigados.

Procurou-se manter a ordem por etapas de projeto na medida do possível, uma vez que a intenção não é mais descrevê-las, e sim confrontá-las.

A intenção é produzir uma análise crítica que possa cooperar com a noção de projeto em moda e estilismo por meio do exame de suas etapas expostas, baseando-se no tratamento de dados qualitativos.

Segundo Bomfim (1998, p. 7), a relação entre a teoria do design e sua prática tornou-se tão contraditória que o elo de ligação entre elas se rompeu. A construção da teoria no projeto em moda deve buscar fortalecer o vínculo entre teoria e prática, gerando benefícios para a indústria por meio da reflexão da forma de projetar e, para a Academia, fazendo uso da experiência da indústria no campo da pesquisa.

No que diz respeito principalmente aos pioneiros, reitera-se a importância de focar na descrição do ponto de vista dos autores diante do tema explorado (POUPART, 2008, p. 217).

Além dos pioneiros, contribuiu na descrição de etapas Troy Nachtigall. A seguir ele lança um breve olhar sobre as etapas de projeto. Os dados provenientes de seu relato estão neste Subcapítulo de forma a separar sua contribuição do Capítulo 1, uma vez que não é considerado um pioneiro do campo, e também para facilitar a comparação com outros depoimentos dentro desse mesmo capítulo.

A primeira etapa do desenvolvimento de uma coleção de moda, segundo Troy Nachtigall (2016), é a pesquisa de tendência. Além disso, ele defende que também é importante pesquisar o que vem sendo feito pelos concorrentes para então ilustrar a pesquisa por meio do moodboard ${ }^{29}$ e assim tornar as informações acessíveis a toda a equipe envolvida no desenvolvimento da coleção. Depois do moodboard, são escolhidos os tecidos, feitos os fim de cortar gastos de tempo e dinheiro. Além dessas etapas, Nachtigal não associa a atividade do designer de moda ao acompanhamento das fases de modelagem, pilotagem e costura.

Na medida do possível, pode ser útil entender por que um depoente atribui determinado significado ao projeto em moda e suas etapas no ensino ou na pesquisa de acordo com sua trajetória e posição no campo. Nesse sentido, é preciso considerar o pioneiro por meio de suas opiniões, história tem a possibilidade subjetiva de interferir no processo de transformação da sociedade.

\subsubsection{Convergências}

O termo estilismo está ligado à ideia de estilo artístico, de acordo com Vera Lígia Pieruccini Gibert, logo privilegia a escolha estética do usuário. Dessa maneira, o estilista definirá como determinado objeto será criado $e$ desenvolvido pautado pelo seu valor simbólico.

O rigor racional-funcionalista do projeto evidenciado por Irina Aragão vai de encontro à visão de Gibert. Há uma reserva por parte de Aragão relativa ao valor simbólico atribuído aos objetos de moda. Esse posicionamento fica claro nos projetos que seus alunos desenvolvem, pois estes não podem ser caracterizados pela configuração simbólico-funcional.

Deborah Christo caminha entre as duas noções esclarecendo que a construção do design, de certa forma, nega o consumo e tem dificuldade de trabalhar com esse dado, mas muitas vezes produz artigos onde a função estética que tem apelo comercial é preponderante.

Como exemplo, Christo questiona se a cadeira Bertoia atende efetivamente às demandas do usuário, ou melhor, se alguém demandou aquele objeto. Nesse ponto, design de produto e de moda se parecem, contrariando em partes o posicionamento de Aragão. $O$ que faz diferença para o consumidor não é o processo ou o projeto, mas a escolha estética.

A abordagem dos livros de projeto em moda e estilismo tem teor menos ideológico e mais prático, voltado às etapas. No prefácio do livro de Doris Treptow afirma-se de que a obra em questão é uma contribuição inédita. $E$ de fato é. Seu livro é o primeiro que se dedica ao ato de projetar moda no que diz respeito a desenvolver uma coleção. 
Logo na introdução a autora coloca conceitos importantes, como o de desenvolvimento de produto que engloba a definição, criação, estudo de viabilidades e métodos para a produção de um artigo de moda (TREPTOW, 2013).

A obra de Seivewright é mais voltada à etapa da pesquisa em design de moda, então prescinde das outras etapas do desenvolvimento de produto. O livro, chamado "Pesquisa e Design" leva a crer que ele trata da etapa da pesquisa no projeto do design de produtos. Quando se percebe que 0 assunto é design de moda, a expectativa em função do título do livro é de mostra que a linguagem predominante é a do estilismo.

Há vários exemplos no emprego de palavras e expressões como "inspiração", "diário pessoal da vida criativa do estilista", "acontecimento que inspirou e impactou a vida do estilista", além de afirmações de que a pesquisa é uma prática solitária que acabam por distanciar a noção de projeto do campo do design e a aproximam da noção de estilismo, mesmo que esta também seja idealizada.

O entendimento da pesquisa como prática solitária tende a empobrecer a prática do projeto do ponto de vista do design vinculado à indústria, porque, nesse caso, trata-se de uma prática coletiva onde uma equipe deve se comunicada o tempo todo sobre seu direcionamento. Logo, não é possíve enxergar a prática da pesquisa centrada na figura de um único criador no contexto industrial.

Essa prática solitária ou que envolve menos profissionais é mais recorrente no estilismo e tem suas atividades centralizadas na figura do estilista proprietário de ateliê que toma todas as decisões sozinho. A visão idealizada de estilismo faz supor que os esforços desse profissional devem ser canalizados exclusivamente para a criação, distanciando-o dos encargo administrativos e fabris. $O$ que se vê é que também recaem sobre ele as responsabilidades financeira e de gerenciamento do seu negócio que priori seriam vistas pela tradição do estilismo como um ônus, assim como o mérito da criação de sucesso seria percebido como um bônus.

Basicamente a ordem de projeto em moda para Renata Zaganin de Oliveira consiste em esboço, detalhamento do desenho e escolha de matérias, pois para ela essa é a sequência que mais respeita a ordem do mercado. Embora Oliveira se refira ao mercado, o que se percebe na verdade é certo descolamento dele, pois antes de tudo sua noção de projeto aponta esboços, mas paira a dúvida sobre quem é o cliente que demanda esse produto.

Outra possibilidade, mostrada por Eunice Higa, é o aluno iniciar o projeto escolhendo uma marca para apresentar uma análise sobre ela, identificar seu estilo e conceito, público, segmento, concorrentes, desempenho das coleç̃̃es anteriores e necessidades da marca, características dos produtos, o que já foi feito e funcionou ou não, materiais, cores, aviamentos para propor uma coleção de moda. Para Mendes esses aspectos são analisados e decididos na "Gestão da Coleção" com base no "Inventário Interno".
Segundo ela, o projeto se inicia pela pesquisa de tendências, em seguida parte para a análise do "Inventário Interno", passa pela "Gestão de Coleção" que fecha com a Cartela de Matérias, de Cores e o número de desenhos que precisam ser aprovados. Só depois dessas etapas é que se parte para desenho. $O$ "Inventário Interno", que analisa as necessidades do cliente e a "Gestão de Coleção", são os pontos que merecem mais atenção, para Mendes. $\mathrm{O}$ usuário também é o protagonista na noção de projeto adotada por Cristiane Mesquita. Os alunos devem investigar quem é esse usuário, levantado na pesquisa de público-alvo, e fazer uma revisão de literatura do tema proposto.

Além de Mesquita, a pesquisa de outras coleções que visa conhecer o que outros autores produziram também é solicitada por Cyntia Santos Malaguti de Sousa, Robinson Salata e Eunice Higa. Robinson Salata e Eunice Higa se complementam. Higa concorda que é preciso estudar as "características dos produtos, do que já foi feito, do que deu certo e do que não deu certo", enquanto Salata afirma que é necessária a troca de informações sobre projeto entre moda e design para diminuir o "fazer repetitivo sem questionar".

É preciso analisar criticamente o que já foi produzido para que não se repitam processos inadequados e, dessa forma 0 ato projetivo seja otimizado. No contexto atual, faz sentido o design de moda absorver do design de produtos a prática defendida por Bernd Löbach (2007, p. 144) de fazer a "análise do desenvolvimento histórico" de um produto quando $s$ tratar de um novo desenvolvimento para extrair dados de antigos produtos.

As etapas listadas por Christo têm sua origem no design de produto e podem ser aplicadas ao design de moda, de acordo com a autora. Variando um pouco entre os vários autores, há a deteç̧ão de um problema, o processo de pesquisa ou coleta de dados, desenho, geração de alternativas e no final isso é preparado para ser executado na prototipagem. Há uma diferença marcante entre o projeto de produto e o projeto em moda e estilismo na maioria dos termos e etapas utilizados por Christo para resumir a noção de projeto.

Outro ponto onde design de moda e o de produto diferem é que quase sempre o projeto em moda visa produzir uma coleção de produtos, e não um único produto. Coleção é um "conjunto de produtos, com harmonia do ponto de vista estético ou comercial, cuja fabricação e entrega são previstas para determinadas épocas do ano" (RECH, 2002, p. 68 apud TREPTOW, 2013, p. 37).

O tempo é outra particularidade que distingue o projeto de produto do projeto em moda. Cyntia Santos Malaguti de Sousa afirma que, no primeiro o designer se dedica um semestre inteiro para desenvolver uma geladeira, por exemplo. No segundo, o estilista ou designer de moda precisa cria constantemente coleções de produtos para cada estação do ano ou em prazos ainda menores.

Mesmo com as diferenças, para Christo é possível inverter algumas etapas do projeto de produto quando aplicado ao design de moda e, por exemplo, desenhar primeiro e escolher materiais depois, concordando nesse caso com Oliveira, mas em suma, essas são as etapas apontadas por Christo. 
A possibilidade de inversão de etapas levantada por Christo denota certa flexibilização das etapas de projeto do design de produtos em relação ao projeto em moda, uma vez que, por exigência do MEC, o design encampou o design de moda. Para dar conta dessa demanda, ao perceber que as teorias de design não iam ao encontro das propostas de estilismo ou mesmo de projeto em moda, etapas do projeto de produto precisaram ser adaptadas no ensino.

Na primeira faculdade investigada, a FASM, a pesquisa aponta que, embora as etapas de estilismo sejam predominantes, houve mudanças no modo de pesquisar, criar e desenvolver produtos ao longo das últimas três décadas. Percebe-se uma boa vontade por parte de Renata Zaganin de Oliveira e Márcio Ito em se relacionar com o mercado no contexto da produção industrial, o que leva à assimilação de noç̃es de projeto marcadas por aspectos práticos.

Isso se deu em função de novos professores que ocuparam o lugar de Rosas a partir dos anos 2000. Eles possuem diferentes repertórios, vivências e experiências de mercado como estilistas, diferenciando-se de Rosas que não atuou no mercado projetando. Isso leva esse corpo docente renovado a buscar proximidade com as necessidades reais do público e da indústria mesmo que ainda hoje esteja vinculado à tradição do estilismo.

A leitura atenta dos livros e dos depoimentos abre muitas possibilidades de relação quanto ao processo de aplicação das etapas de projeto em moda. O conteúdo ministrado pelos professores da FASM nos últimos anos guarda semelhanças com os conceitos abordados pelos livros, variando as terminologias. E interessante observar também como alguns exercícios coincidem, mesmo que intuitivamente.

Essa intuição é percebida na medida em que, ao entrevistar os pioneiros, eles demonstraram desconhecer em termos metodológicos algumas etapas que aplicam em sala de aula, como etapas legitimadas por autores de projeto em moda. Muitos desses pioneiros não reconhecem a nomenclatura de design de produto e às vezes nem de design de moda das etapas que adotam e que foram formalizadas por autores de projeto em moda. É possível perceber que a transmissão de conhecimento se baseia na prática, e acontece com mais frequência pela forma oral do que pelos livros, e as tarefas que se repetem fazem parte de um acordo tácito entre teóricos, professores e profissionais.

No projeto, há uma ordem relativa de projeto que pode ser subvertida de acordo com o processo do estilista ou pelo briefing. Treptow (2013, p. 100) define briefing como a "forma de transmitir instruções finais ou informação essencial". Na edição mais recente de seu livro, do ano de 2013, Treptow utiliza Jones (2005) para definir briefing acadêmico e Seivewright (2009) para definir briefing comercial, o que denota alinhamento com estes autores de projeto em moda.

A prática estabelecida por Aragão de iniciar o projeto oferecendo ao aluno um briefing, remete ao briefing acadêmico descrito por Seivewright (2009, p. 13) e ao briefing em grupo elencado por Jones (2005, p. 166), no qual a turma trabalha a partir do que o professor solicita, e os critérios de avaliação são claramente expostos.
A ordem das etapas de projeto sugeridas por esta tese se baseia em autores reconhecidos pelos campos do design e da moda. A etapa subsequente ao briefing é a pesquisa. Ela se caracteriza, no campo do design de produtos, pelas tarefas de levantamento de dados, levantamento de similares, análise de similares e analise de correlatos trabahados por Irina Araga do design de moda.

Embora haja certa insistência dos entes do campo do design em adaptar a moda às teorias do design de produtos, termos como "análise do problema", elencado por Löbach (2007, p. 143) e por vários pioneiros vinculados design de produtos, não são comuns à noção de projeto de moda e menos ainda à de estilismo.

O projeto em moda poucas vezes é desencadeado por um problema efetivo e, este é um fator que desvaloriza o campo acadêmico da moda no tocante a projeto perante 0 design em termos simbólico 30

No design de moda, passa-se da etapa do briefing diretamente pesquisa histórica ou de referências, público, mercado, formas, volumes, painel, cores, texturas etc que na demanda por uma possível equivalência encontram seus referentes no design de produtos na etapa de "coleta de " apontada por Löbach (2007, p. 143) " de Aragão e "fase de requisitos" de Sousa, respectivamente.

A pesquisa de público-alvo é um ponto relevante da pesquisa. Embora no Capítulo 1 Renfrew e Renfrew atentem para a importância de conhecer com clareza o cliente ao qual se destina o produto, ao descreverem consumidor, Renfrew e Renfrew (2010, p. 16) caem na fórmula da "musa" que seria a cliente "ideal" ou "inspiradora" que serve como modelo para quem deseja consumir aquele produto.

A despeito de ser um modelo a ser seguido, a "musa inpiradora" estaria antes de tudo subordinada à lógica da alta-costura, onde é o estilista quem impõe o que o cliente vai usar.

No interior das faculdades, principalmente os trabalhos finais não costumam ser voltados ao público de massa ou inovações em design, por isso a persistência da criação de uma consumidora almejada, quase irreal, a "musa" (RENFREW; RENFREW, 2010, p. 142). A cultura de imaginar um cliente idealizado ainda vigora na escola de moda, pois o estudante que nela ingressa está lá para mostrar sua potência como criador e tem na "musa" um suporte de divulgação de sua "obra" como estilista.

O estudante pode definir seu cliente ideal "imaginando-o" ou criando sua própria "musa" e para isso é suficiente pesquisar onde ela vive, onde compra e como usa a moda para definir a si própria (RENFREW; RENFREW, 2010, p. 142). A ideia de criar ou se inspirar em uma musa sem se basear em pesquisas de mercado mais profundas, além de incompleta, hoje soa ingênua.

Os apontamentos de Jones (2005, p. 166) quanto à pesquisa de mercado coincidem com os de Seivewright (2009, p. 13) que defende que um briefing baseado no cliente irá impor metas e objetivos muito específicos que devem se pautar pelo mercado, estação, gêneros, custo e ocasião. As pioneiras Mendes e Vicentini também se voltam às necessidades do mercado e do público pautadas por pesquisas mais assertivas.
30 Na acepção de cimbólicu" de poder invisivel que só pode ser exercido com a
cumplicidade daqueles que não querem saber
que estão sujeitos a ele ou mesmo que o exercem. 
Tanto Seivewright (2009, p. 96-97) quanto Higa defendem que o aluno deve ilustrar nos painéis ou desenhos o ambiente e comportamento do público para o qual a coleção é pensada. É importante representar para a equipe de criação e produto a paisagem onde esse cliente se insere e sua atitude.

Se por um lado Jones considera relevante a pesquisa de mercado, por outro ela considera válido que o estilista siga um briefing voltado para o cliente pautando-se pela ideia de "musa". Portanto, Jones se situa no meio termo entre as noções de "musa" e consumidor/usuário que Renfrew e Renfrew e Seivewright descrevem respectivamente.

A "musa", metade imaginária, metade real serve para referências estéticas e de inspiração, mas para cotejar público-consumidor é muito distante da realidade, alerta Christo (2013, p. 57-58).

Uma visão mais pragmática do cliente no processo leva Aragão a criticar a abordagem da "musa", comum no design de moda, destacando que $\circ$ primeiro problema que o designer de moda pode resolver são questões de vestuário que persistem até hoje para a média da população, pois não é dada a devida atenção a elas.

O design industrial seria um processo de adaptação dos produtos de uso, fabricados industrialmente, as necessidades físicas e psiquicas dos usuários ou grupos de usuários (LÖBACH, 2007, p. 21).

O design de moda flexibiliza essas necessidades dos usuários, principalmente no que tange ao aspecto físico e ergonômico.

O resultado de desenvolver um produto baseado em uma "musa" pode levar a problemas como desconforto, mas se mesmo assim esses artigos são endossados por um grande número de usuários, é preciso compreende que isso ocorre, já que o design de moda foge à lógica racionalista que embasa parte da produção do design industrial. Nesse contexto, a noção de "necessidade" no design de moda é mais abrangente que a do design de produtos.

Há um caráter intangível que diz respeito às necessidades do cliente, com o qual Bomfim (1998, p. 153) colabora ao defender que a formação estética do designer deve proporcionar uma práxis que possa contribuir para a satisfação das necessidades materiais e espirituais dos usuários. Para Simone Mina, o estilista deve pensar que tipo de mal-estar da civilização o mobilizou para criar determinado produto, e o usuário, para adquirilo. O estilista deve se preocupar com "o porquê" de o usuário desejar ter determinado objeto ao seu lado.

A formação do designer deve permitir que ele entre em contato por meio de seus gostos com o l'air du temps vigente e transforme o impulso criativo resultante dessa relação em um produto dotado de sentido que alcance $\circ$ usuário, no que diz respeito à sua produção de subjetividade.

Parte dos integrantes do campo do design de produtos tem dificuldade em perceber que no design não há um equivalente ao fenômeno da moda a não ser o próprio fenômeno da moda. E ele que motiva a mudança de gostos, que têm uma duração temporária.
A exemplo da alta-costura, ainda hoje em muitos casos a moda $^{31}$ vai propor ao usuário o que ele deve usar e muitos deles acatam a moda. Isso ocorre graças à força que o fenômeno moda possui enquanto agente que pulveriza tendências de comportamento que podem atender às necessidades psíquicas dos usuários, em detrimento de necessidades físicas, sem que isso seja tão relevante para o público consumidor de produtos de moda.

Mudanças sociais levaram o design de moda a incluir segmentos diferentes à sua agenda de projeto e isso o levou a trabalhar um pouco melhor a questão da forma e função, na opinião de Sousa. Para ela, o design de moda deve atender à demanda da forma e função, mas também às demais necessidades das pessoa.

$\mathrm{Na}$ última década houve uma emergência, no sentido de abordar segmentos por um viés aparentemente mais funcionalista no campo do design de moda, mas o que se vê é que ele continua priorizando questões subjetivas.

O conforto psicológico, primordial para o artigo de moda, explorado por Vicentini no Capítulo 2, é um exemplo disso. Ele passa a ser visto com mais frequência em alguns segmentos antes negligenciados pelo design de moda, como o activewear que está relacionado ao desempenho e à funcionalidade, - homewear que tem como pressuposto básico o conforto e bem-estar outros segmentos relacionados à inclusão social como os deficientes físicos.

preciso esclarecer que $\circ$ design de moda também preza pela funcionalidade, mas vai além do binômio forma e função. $O$ termo função (SEIVEWRIGHT, 2009, p. 126) está atrelado à forma que a peça tem, como por exemplo, saia, calça, colete etc, ou seja, ela cumpre a função de cobrir 0 corpo, mas essa função está associada ao conforto psicológico e simbólico de maneira inexorável no caso do design de moda.

descarte de produtos de moda por causa da obsolescência perceptiva ${ }^{32}$ denota o quanto aspectos subjetivos são referenciais de uso do produto, mesmo que o consumidor não tenha consciência deles ou que a academia insista em refutá-los.

O mercado demanda produtos que sejam fáceis de produzir e tenham apelo de venda para seu público para garantir o giro do capital, declara Aline Monçores e, nesse sentido, as escolas mais voltadas ao design, pelo seu teor ideológico, por vezes se distanciam das necessidades subjetivas do consumidor.

Ao mesmo tempo em que a pesquisa é realizada, ela é registrada. $\mathrm{Na}$ etapa de registro da pesquisa, é importante explicitar como a pesquisa embasou o processo de reflexão. As metodologias visam o desenvolvimento do aluno/estilista em relação ao seu processo, e, esse progresso é mais visível à medida que o indivíduo passa a ter clareza do seu processo criativo (SEIVEWRIGHT, 2009, p. 92) disposto de forma física em cadernos, painéis ou ambiências. 
Enquanto deve apreender seu próprio processo criativo durante a graduação, o aluno entra em contato com etapas de projeto que internaliza. Elas devem ser revistas criticamente sob a lente da experimentação. Higa explica que nesse período é fundamental que o aluno passe por várias experimentações e que ele possa se perceber nisso, pois executar um produto de qualidade do início ao fim do seu desenvolvimento é uma tarefa difícil para $o$ aluno. Devem ser proporcionadas oportunidades nas quais esse indivíduo possa perceber com o que ele se identifica mais, se é cor, materiais, formas, volumes. A escola deve propor essas vivências, por meio das quais o aluno irá descobrir por onde começa o seu processo.

O processo de pensamento do estilista durante o projeto é explicitado por meio de "pistas" de como as ideias de criação se originaram, afirma Jones (2005, p. 16). Essas pistas parecem corresponder ao que Bomfim se permanecem como objeto de pesquisa de disciplinas que não o design.
Figura 3-Caderno de Pesquisa de Susana Choi (2010) Fonte: Arquivo pessoal de Renata Zaganin de Oliveira
(2014)
No decorrer do ato criativo encontram-se tanto fases que podem ser descritas e fundamentadas de modo sistemático, como outras que não são precisas, cuja natureza e motivação permanecem como objeto de pesquisa de disciplinas, tais como a psicologia (BOMFIM, 1998, p. 163).

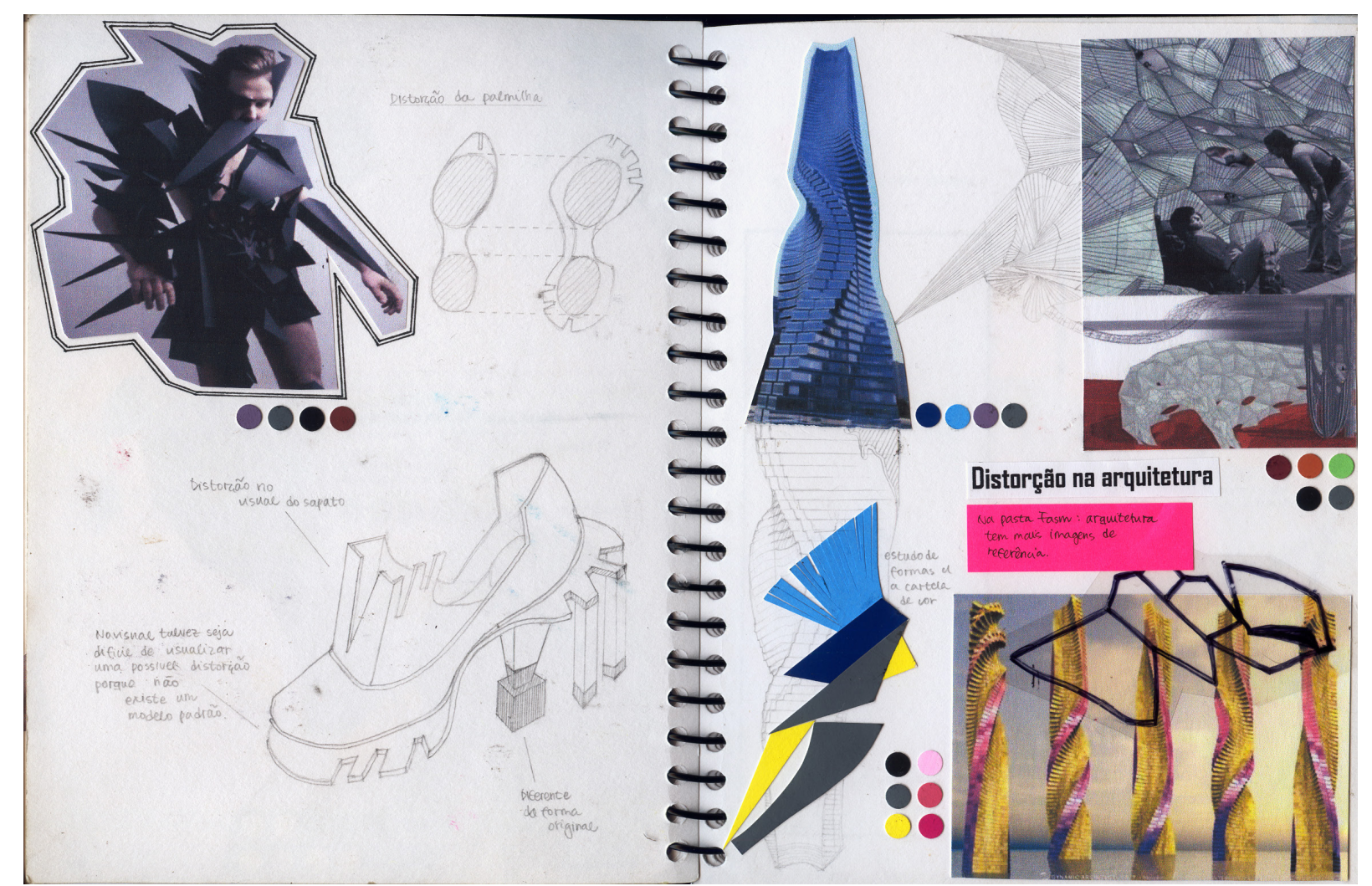

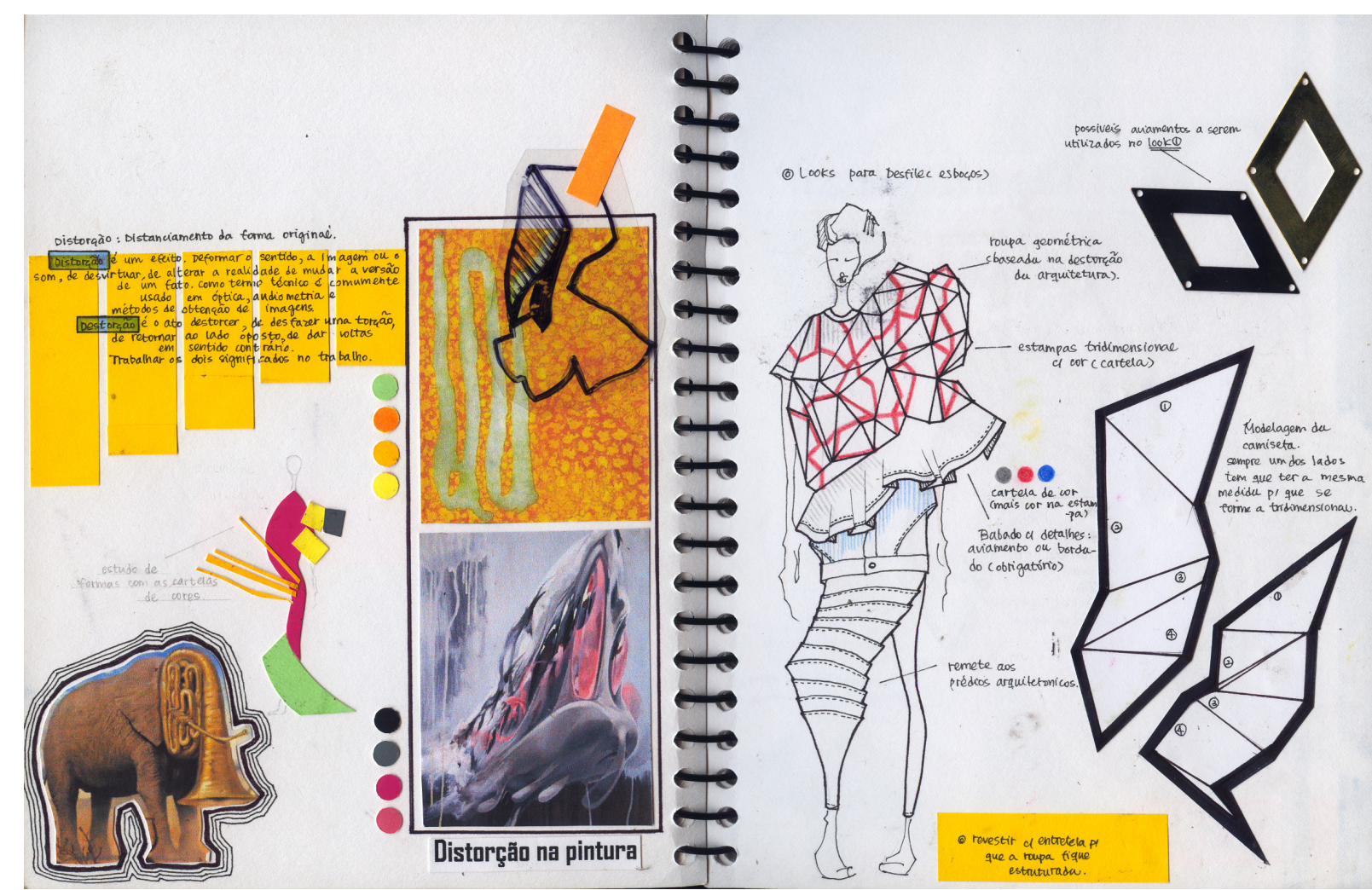

Outras formas de dispor as informações da pesquisa são os painéis ou mbiências. Neles as informações já devem estar mais amadurecidas, portanto a mensagem torna-se mais clara. Treptow toma como modelo de painel as ambiências geradas pela equipe de estilo de Angelo Uslenghi para a feira Moda In que acontece em Milão.
Figura 4- Caderno de Pesquisa de Susana Cho (2010) Fonte: Arquivo pessoal de Renata Zaganin de Oliveir
140 cartela de cores referente ao tema, imagens e objetos de inspiração ras de tecido são colocadas à (TREPTOW, 2013, p. 79).

É possível perceber que as ambiências de Uslenghi e a Ambience de Rosas guardam semelhanças. Ambas tratam de um suporte para registro de pesquisa e do processo criativo, mas no caso de Rosas se refere a um estágio anterior de pesquisa, menos acabado, enquanto que a de Uslenghi já mostraria a pesquisa finalizada.

Essa diferença se justifica se for pensado que Rosas se dedicava ao ensino, que focava na construção do processo, enquanto Uslenghi preparava uma compilação da pesquisa voltada ao público profissionalizado, portanto se apresentava mais bem-acabada.

Enquanto Rosas e Gibert da FASM, Uslenghi (citado por Treptow) e Vicentini da EACHUSP se referem à ambiência como uma espécie de montagem de um ambiente, quase um cenário, Higa se refere aos "Painéis de Apresentação do Projeto" como lugar para montar ambiências. 
O conceito de ambiência para Higa está vinculado ao painel, portanto ele está distante da ideia de criar um ambiente, contrariando assim a definição de ambiência adotada pelos teóricos citados anteriormente. É possível tomar ambiência por painel, como faz Treptow, pois o sentido de painel passa a ser amplificado, mas não é possível chamar um painel de ambiência, pois dessa forma o sentido de ambiência se tornaria restrito.

Assim como Higa, o que Seivewright e Renfrew e Renfrew definem como painéis de uma maneira geral, Jones chama de moodboard e storyboard. Nos casos de Seivewright e Renfrew e Renfrew, quase todos os itens que compõem seus painéis são os mesmos e se mostram os mais completos entre os autores. Entre eles estão cor, tecidos, texto e imagens, mas Renfrew e Renfrew falam em compor o painel com esboços e roupas, o que volta a aproximar sua noção de painel da de ambiência, pois a roupa remete a um espaço, ambiente.

O Moodboard ou Painel de Criação de Jones reúne imagens de inspiração para que surjam ideias para o início de uma coleção. Ele também pode ser comparado ao "Painel Fechado" de Cyntia Santos Malaguti de Sousa, que busca referências imagéticas fora do campo da moda.

Os painéis evidenciam a variação de nomenclatura que as etapas de projeto podem ter. Seus nomes mudam bastante de uma escola para outra e de um profissional para outro. Foram identificados treze nomes diferentes associados ao painel no projeto em moda. A seguir apresenta-se uma lista com a nomenclatura adotada por cada pioneiro ou autor, o nome deste e a instituição quando for o caso.

As finalidades dos painéis variam muito pouco entre si, e como é difícil captar essas nuances e esse não é o tema central desta tese, a explicação sobre cada tipo de painel será deixada para outro momento.

Cláudia Vicentini critica a falta de rigor em relação à nomenclatura das etapas, no campo do projeto em moda. Para ela a situação tende a gera confusão, pois a cada hora uma mesma tarefa ganha um nome diferente.

Somente Mendes sugere um painel baseado exclusivamente na pesquisa de tendências de moda, o painel de pesquisa de tendências, mesmo que ele não se restrinja às tendências de moda.

Sobre tendências Troy Nachtigall (2016) divide a projetação de coleções de moda em três: os trendy moments que são os momentos em que os estilistas procuram fazer a mesma coisa que vêm outros profissionais fazendo; os contrary moments quando eles estão fazendo exatamente 0 oposto à tendência; e os empty trend moments, quando todos os estilistas, além de não se pautarem pelas tendências, estão desenhando coisas muito diversas. Como exemplo, ele cita a marca Gucci que às vezes cria moda a partir dos trendy moments e às vezes não tem sucesso comercial em um movimento empty trend moments (NACHTIGALL, 2016).

Cruzando os depoimentos de Nachtigall (2016) e Preciosa (2017), é possível assinalar uma divergência. Enquanto Nachtigall expõe que a finalidade da moda é ganhar dinheiro, Preciosa é bastante crítica quanto ao dogmatismo

\begin{tabular}{lll} 
Nomenclatura & $\begin{array}{l}\text { Pioneiro ou Autor } \\
\text { de Projeto em Moda }\end{array}$ & Instituição \\
\hline Painel Semântico & $\begin{array}{l}\text { Cristiane Mesquita/ } \\
\text { Cláudia Vicentini/ } \\
\text { Andrea Canton }\end{array}$ & $\begin{array}{l}\text { UAM } / \\
\text { EACHUSP/ } \\
\text { SENACSP }\end{array}$ \\
\hline Sintese Visual & Cláudia Vicentini & EACHUSP \\
\hline Painel de Criação & Sue Jenkin Jones & \\
\hline Storyboard & Sue Jenkin Jones & \\
\hline Moodboard & Sue Jenkin Jones & SENACSP \\
\hline Painel Temático & $\begin{array}{l}\text { Julien Macdonald (apud } \\
\text { Andrea Canton }\end{array}$ & FASM \\
\hline Painel de Inspiração & $\begin{array}{l}\text { Elá Camarena/ } \\
\text { Renfrew e Renfrew (2010) }\end{array}$ & \\
\hline Painel Conceitual & Renfrew e Renfrew (2010) & FASM \\
\hline Painel de Pesquisa & Francisca Dantas Mendes & EACHUSP \\
\hline de Tendências & Francisca Dantas Mendes & EACHUSP \\
\hline Dossiês & Reo6, p. 45) & SENAC SP/FAU \\
\hline Ambiência Zaganin de Oliveira/ & FASM \\
\hline Ambience & Carlos Mauro Rosas & \\
\hline Painel Aberto & Cyntia Santos Malaguti de Sousa & Cyntia Santos Malaguti de Sousa \\
\hline
\end{tabular}

das tendências no campo da projetação em moda. Para ela tendência, de certa forma, é dizer como e o que tem que ser feito, o que é diferente de se alimentar de referências culturais como cinema, artes visuais, poesia $e$ outras referências "além-moda" para depois iniciar um processo criativo mais autêntico no campo do vestuário.

Após o painel de pesquisa de tendências, a próxima etapa para Mendes é o mix de produtos. Mendes prefere a nomenclatura "mapa de coleção"3 ao invés de "mix de produtos". Ele visa o equilíbrio da coleção por meio da divisão bem distribuída de seus produtos por critérios explorados no capítulos 1 e 2, e de acordo com o que o público de uma marca se identifica.
Quadro 8-Nomenclaturas Fonte: Elaborada pela a

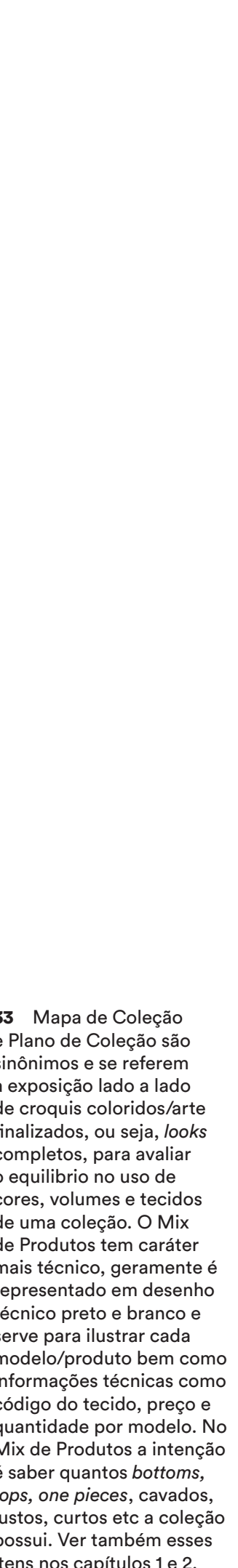


Mendes possui a visão mais abrangente sobre mix de produtos, que engloba todas as explicações do pioneiro Ito e das autoras de livros de projeto em moda Jones, Treptow e Renfrew e Renfrew que tratam do tema.

Jones fala da divisão de artigos de moda na coleção por tecidos, Pires (apud Treptow) aponta a divisão por cores, tops, bottoms e one pieces e básico, fashion e vanguarda e Renfrew e Renfrew alertam que o mix de produtos serve para determinar tarefas e estabelecer prazos. Renfrew e Renfrew se referem a essa etapa como "quadro de coleções".

Dentro do mix de produtos, o que Pires (2000 apud Treptow, 2013) identifica como três categorias de produto em uma coleção, básicos, fashion e vanguarda, Vera Lígia Gibert (1993, p. 202) define e divide em três segmentos, continuidade, evolução e novidade. Produtos básicos equiva à continuidade, fashion à evolução e vanguarda à novidade.

A comparação entre os depoimentos dos pioneiros Mendes, Ito e das autoras Jones, Treptow e Renfrew e Renfrew permitiu identificar três nomes para a mesma atividade, a saber: mix de produtos, mapa da coleção e quadro de coleções. Outros autores e pioneiros não foram elencados, pois não abordaram o tema.

De qualquer forma, a maioria dos elementos do design ou elementos configurativos como forma, material, superfície, cor são expressos no cadernos, painéis ou ambiências. Eles aparecem na literatura de projeto em moda aplicados ao vestuário de moda e, portanto, se diferenciam da visão generalista do design industrial exposta por Löbach.

No design de produtos, a figura só se origina pela reunião dos elementos do design que se dividem em macro e microelementos ( $L O ̈ B A C H, 2007$, p. 161). É possível construir uma ponte entre essa teoria do design para o design de moda. Os macroelementos se referem à forma, material, superficie, co etc e no design de moda equivalem ao tecido, estampa, bordado, tingimento etc. Os microelementos são os que não aparecem de forma imediata como parafusos, rebites etc e no design de moda podem ser comparados aos aviamentos, detalhes e acabamentos.

A expressão elementos do design é pouco utilizada no design de moda, enquanto a expressão elementos configurativos não aparece. No design de moda, os elementos do design dão origem ao que Rosas chama de "elemento mais forte", Mesquita de "elementos centrais" que, por sua vez, coincidem com os "elementos-chave" abordados por Seivewright (2009, p. 94) e os "elementos de estilo" de Treptow (2013, p. 82). Os quatro termos se referem a uma cor ou textura ou silhueta, ou seja, um elemento do design que sera enfatizado na coleção para criar unidade entre os produtos.

Para o design de moda é menos relevante como os elementos do design são divididos, se em macro ou microelementos, mas quais elementos centrais eles apontam.

Outro termo incomum ao projeto em moda, mas que pode ser aplicado ao produto de moda é o "princípio de configuração adequado" (LOBACH, 2007 p.159) que consiste em organizar "os elementos configuracionais segundo um princípio de configuração adequado para alcançar o efeito desejado" É preciso considerar que o design de moda é regido segundo critérios estéticos próprios e que mudam de tempos em tempos e não de acordo com o formalismo do design.

Também o "efeito desejado" tem sentidos diferentes para a moda e para o design. Para o design ele é mais voltado a uma solução funcional, enquanto na moda ele é mais voltado ao universo simbólico.

A visão geral sobre matérias-primas e processos de fabricação apresentada por Löbach em seu livro se aplica a produtos de diversas categorias do design. $O$ design de moda tem necessidades específicas e, dessa forma a abordagem ampla do design parece não atender às especificidades do projeto em moda.

Produtos para uso individual, ou seja, aqueles que possuem vida útil maior e geram identificação com o usuário são produtos que foram convertidos em elementos de moda, segundo Löbach (2007, p. 49), portanto, o designer só se preocuparia com a "cosmética dos produtos" nesse caso e não com su configuração efetiva já que eles não se modificam em seu funcionamento.

Há um equívoco fundamentado em um preconceito na fala do autor. Sua afirmação acaba por diminuir a função simbólica dos objetos estéticos presentes não só na moda, mas no próprio design que é afetado pela moda como um conjunto de características que possui apelo para um determinado público em um espaço de tempo (LIPOVETSKY, 1989, p. 29).

É um engano circunscrever os artigos de moda a produtos que têm unicamente função estética, assim como também é uma interpretação incorreta do design de moda acreditar que ele não se volta à funcionalidade dos objetos.

Roupas de performance e uniformes não podem ser configurados somente por princípios estéticos ou simbólicos. E quando determinado artigo de moda for pensado do ponto de vista estético ou simbólico, a atividade projetual que o envolveu não pode ser neutralizada como mera "cosmética do produto", por questões ideológicas advindas do campo do design de produtos. Estética ou funcional, a concepção de um produto no campo do design de moda envolve todas as etapas de projeto, portanto não deve ser diminuída.

Nenhum autor de projeto em moda ou pioneiro cita o termo "cosmética do produto".

Sobre os princípios do design, que até certo ponto podem ser equiparados ao "principio de configuração adequado" de Löbach (2007, p. 159), Jones (2005, p. 99) comenta que:

alguns cursos de moda ensinam os elementos e princípios [do design] em aulas convencionais: outros durante o desenvolvimento de projetos ou deixando o aluno descobri-los por conta própria. 
Se por um lado, a experimentação deve ser ensejada por meio de processos individuais, por outro é ingênuo esperar que o aluno descubra sozinho conteúdos como elementos e princípios do design. Nos cursos investigados, os "princípios do design" costumam ser ensinados na prática de projeto, mas sem essa terminologia. Os elementos do design têm seu uso determinado pelos princípios do design.

A seguir, uma divisão proposta por Bruno Munari pode se mostrar útil para o exercício de "desenvolvimento e refinamento de peças" sugerido por Seivewright. Munari $(2008$, p. 134) propõe uma separação dos elementos do design em três categorias: isomorfos, homeomorfos e catamorfos. Os elementos isomorfos possuem módulos ou partes de forma e dimensão idênticas. Os homeomorfos se constituem por módulos ou partes de forma igual, mas com dimensões diferentes. E os elementos catamorfos se caracterizam por módulos ou partes com relação interfigural, ou seja, partes de formas e dimensões diferentes, mas que permitem colocá-las em um mesmo conjunto.

Uma coleção de moda deve considerar a divisão desses elementos, pois o resultado obtido a partir dela expressa a coerência formal das partes e do todo. Em outras palavras, as categorias de Munari ajudam a dar forma a "famílias" de produtos que são pequenas coleções dentro da coleção e configuram uma prática bastante comum no projeto em moda e no estilismo.

Os princípios do design, bem como a divisão de seus elementos por Munari, concorrem para a configuração do produto. Ela consiste no processo onde os elementos se submetem a uma forma, sendo que a forma é o conceito central da estética do objeto (LÖBACH, 2007, p. 161). Embora seja possível falar em "configuração", no projeto em moda esse conceito não aparece com esse nome, nem tendo a forma como ideia que norteia o processo. A noção de forma, para a moda tem sentido específico ligado à silhueta.

A silhueta é um elemento do design que configura uma etapa projetual. Ela é proposta a partir da ideia de sombras por Mariana Rocha e tem a mesma finalidade da "pesquisa colada sobre figuras" apontada por Simon Seivewright (2009, p. 119). Nela a forma deve ser obtida ao colocar imagens da pesquisa sobre o desenho do corpo e então vão sendo desenvolvidos detalhamentos dessa forma. As figuras 5 e 6 , abaixo, mostram exemplos de como uma forma é extraída a partir de referências visuais e são transmitidas para o desenho. A repetição dessas formas pontua as principais silhuetas de uma coleção.

Essas silhuetas são mais ou menos evidenciadas pelo uso da cor, que é a etapa seguinte do processo. As cores se dividem em três grupos, segundo a frequência com que são utilizadas e o fator novidade. Outra questão relativa à nomenclatura aparece relacionada às cores.

Elaine Camarena chama de cores de base o que Jones chama de cores dominantes. Elas são as cores mais presentes na coleção. Camarena intitula cores tônicas o que Jones chama de acentuadas e Treptow de "cor da moda". Por serem novidade ou extravagantes, elas são as cores menos presentes na

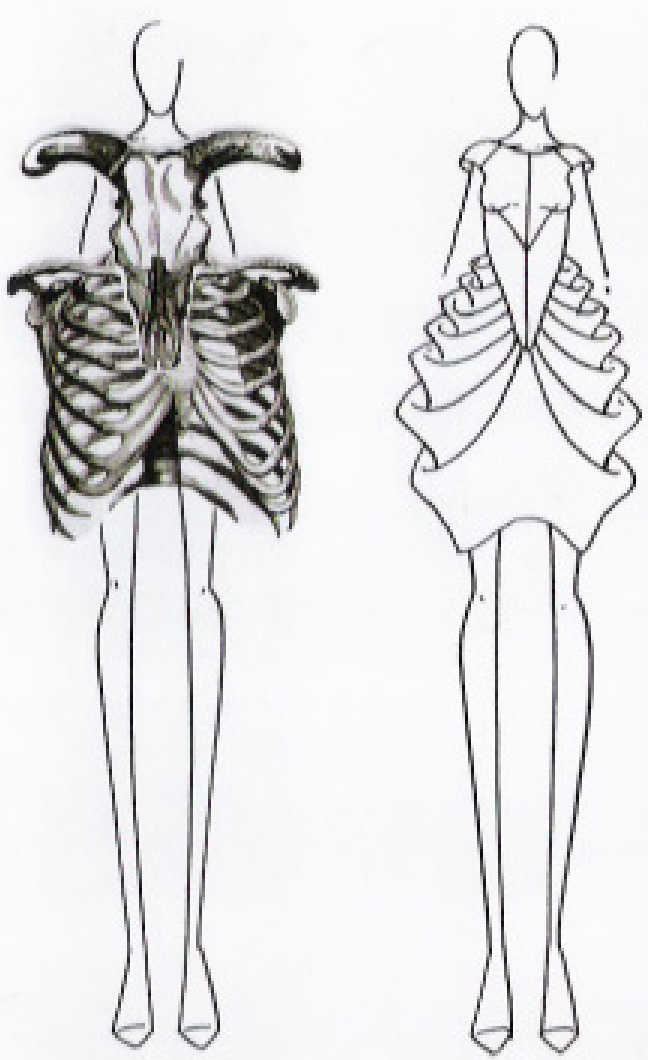

Figura 5 - Pesquisa colada sobre figura (2009) Fonte: Fundamentos de design de moda: pesquisa e Desig de Simon Seivewrigh (2009), p. 119.
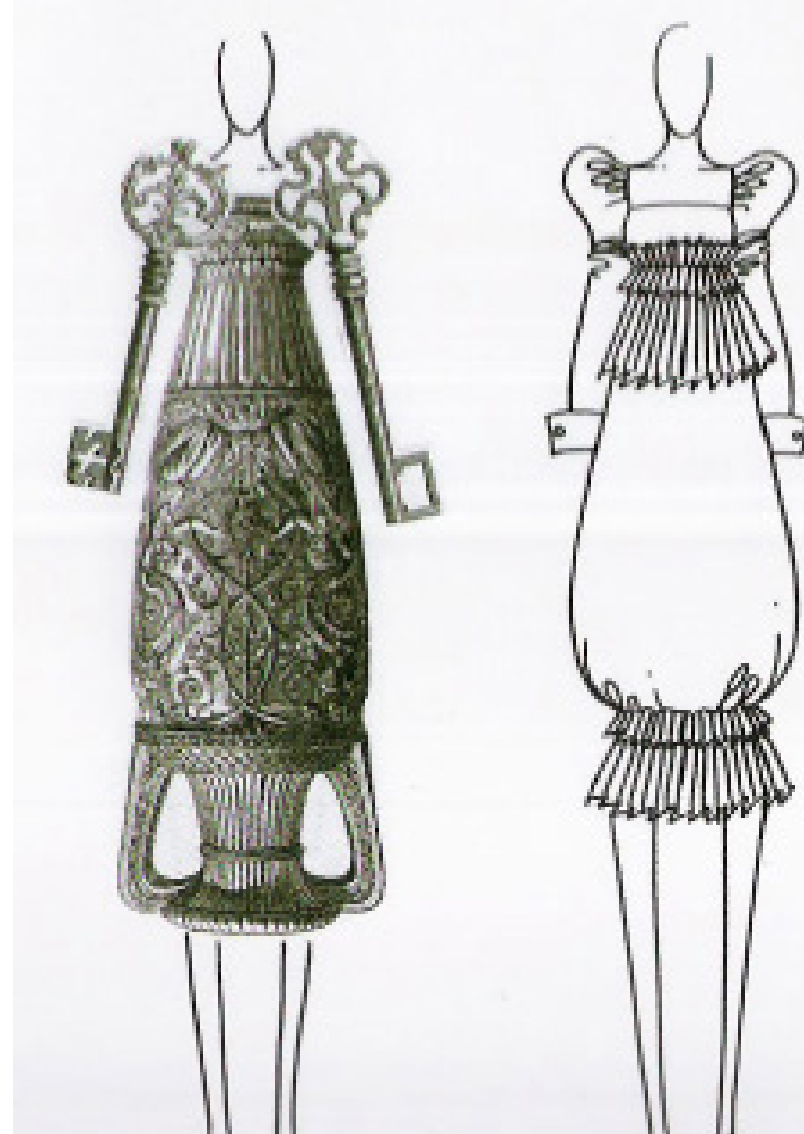

Figura 6- Pesquisa colada sobre figura (2009) Fonte. Fundamentos de design de moda: pessut
146 coleção. As cores intermediárias de Camarena são chamadas de complementares por Jones, e são aquelas que fazem a ponte entre as cores de base ou dominantes e as tônicas, acentuadas ou a "cor da moda".

A pesquisa de materiais, basicamente tecidos e aviamentos no design de moda, é a etapa seguinte à criação da Cartela de Cores para a maior parte dos autores e entrevistados.

O material ajuda a determinar a forma. A superfície produz associação de ideias como limpeza, calor, frio, frescor etc por meio de materiais brilhantes, foscos, polidos, rugosos etc. A superfície perfeita (automóvel, sapato de vinil) sugere perfeição das suas características de uso, mas o cuidado exagerado por parte do usuário pode levar ao que se denomina fetichismo das superfícies (LÖBACH, 2007, p. 163).

$\mathrm{O}$ apelo da superfície é recorrente tanto no design de produtos como no de moda, mas é mais fetichizada no produto de moda que preza pela configuração estética simbólico-funcional. A relação do corpo com a roupa também torna o toque, logo a superfície, uma questão premente para o design de moda. 
O conhecimento sobre materiais abre possibilidades de beneficiamentos. Neles, além da cor, a textura é um dos pontos principais. Um "bom toque" do tecido no design de moda refere-se a manter uma textura agradável de um tecido tingido, por exemplo. A textura também pode ser utilizada para modificar o "toque do tecido", além do aspecto visual, como é o caso dos emborrachados.

As texturas são superfícies uniformes consideradas "não anônimas", pois sempre trazem consigo alguma informação visual ou tátil. Com uma caracterização material podem ser animadas adensando-se ou rarefazendose as até gerar figuras reconhecíveis (MUNARI, 2011, p. 13-14).

Esse procedimento de criar texturas é caro à moda. Há exemplos na estamparia, tinturaria, bordado, aplicação de hot fix (termocolantes) recortes etc.

Além disso, é interessante observar que o conceito de texturizar uma matéria, exposto por Munari, vai ao encontro da ideia do princípio do design chamado de gradação, discutido por Jones (2005, p. 108) e Treptow (2013, p. 129).

Munari (2011, p. 41) defende que se deve colocar um pouco de ordem no caos, de forma a tornar uma ordem evidente no projeto. A ordem é determinada por um pequeno número de elementos configurativos e por uma pequena quantidade de características de ordenação. Ela pode ser determinada pelos elementos do design e pelos princípios que o regem como a gradação, vista no exemplo acima.

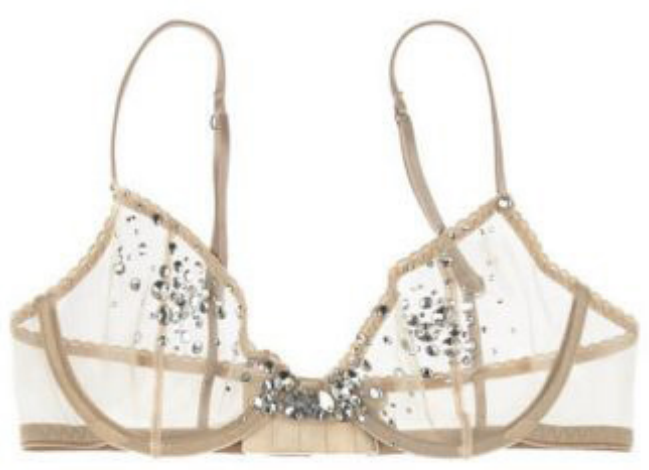

Figura 7- Textura e gradacăo - Lingerie da Ructress \& Snatch, $\mathrm{de}$ Fonte: <http://ww helingerieaddict. com/2013/03/spotlight-onbuttress-and-snatch-lingerie. html $>$. Acesso em: 2016
Quando se tem uma ordem elevada, isto significa que o conteúdo de informação é baixo. Ordem transmite a sensação de segurança (LÖBACH, 2007, p. 166-167). Löbach e Munari (2011, p. 58) consideram a ordem um importante elemento do design onde "deve-se trabalhar mais para tirar que para acrescentar" informação.

Esse axioma moderno costuma estar distante da realidade da moda, no âmbito do projeto. Para o design de moda, muitas vezes a quantidade de informação é mais relevante que a ordem.

O projeto em moda segue e subverte alternadamente, sem linearidade a "ordem", ferramenta projetual comum ao design de produtos e gráfico. A transposição do conceito de ordem para o design de moda pelo viés da gradação mostra que é possível aplicar muitos conceitos do campo do design de produtos ao design de moda, mas isso exige esforço, pois como se vê esta não é uma prática habitual.

Definidos os materiais, o estilista precisa ter ciência do que os fornecedores podem thes oferecer. "Nada mais frustrante para um estilista do que descobrir tarde demais que um bom desenho não pode ser reproduzido na qualidade e no preço requeridos" (JONES, 2005, p. 59). Infelizmente essa falta de cuidado com aspectos práticos da pesquisa como qualidade, custo e prazos ainda hoje é observada e para evitar esse problema é preciso aproximar o projeto em moda praticado na Academia da Indústria.

Retomando a divisão dos aviamentos proposta por Higa, tem-se os básicos. que são os aviamentos realmente necessários para que a roupa exista, tais como linha, zíper, elástico, botão. E existem outros aviamentos que não são funcionais, estão muito mais no âmbito da "adornagem" como fita de cetim, termocolantes, apliques etc. Treptow (2013, p. 124) divide os aviamentos entre função e visibilidade, em uma espécie de equivalência à definição de Higa.

Ambas ignoram a divisão dos aviamentos em quatro categorias propostas por Francisca Dantas Mendes, que consiste em: aviamentos de fechamento, estrutura, embelezamento e legislação e se mostram mais completas e atuais. Os aviamentos podem possuir mais de uma função ao mesmo tempo. Essas categorias são ensinadas na UAM desde o ano 2000.

Aviamentos, acabamentos e detalhes serão representados por meio do desenho. Os termos e práticas do desenho de moda apresentados nos Capítulos $1 \mathrm{e} 2$ evidenciam diferenças de um autor para outro. Comparando o conteúdo dos depoimentos de Renata Zaganin de Oliveira, Eunice Higa e Francisca Dantas Mendes com o dos livros sobre projeto de Sue Jenkin Jones e Simon Seivewright que focam na etapa do desenho, percebe-se que não há tanta assertividade sobre termos relativos às categorias de desenho de moda, que é uma atividade basilar para a comunicação na atividade projetual. Isso mostra que ainda há muito que se avançar na discussão sobre nomenclaturas e suas conceituações no design de moda.

Para detalhar os croquis a fim de facilitar a comunicação com modelist e piloteiro, Renfrew e Renfrew (2010, p. 150) sugerem desenhar todos os detalhes juntos criando uma série de colagens visuais com as preferências 
do estilista e ideias para cada look. De forma análoga, Oliveira explora um método para criar e desenhar que ela chama de montar as peças "por edição". O exercício exige desenhar mangas, punhos, volumes, golas soltas e depois montar o look a partir de formas que, inicialmente, podem até ser forma mais experimental.

Além de proporcionar o entendimento para o modelista e piloteiro por meio dos detalhes da coleção, esse método oferece ao estilista a chance de entrar em contato com seu próprio processo criativo podendo iniciá-lo por meio do desenho de detalhes.

Detalhes são partes de peça como bolsos e golas para Higa, enquanto para Seivewright (2009, p. 127) eles somam acabamentos de modelagem e costura. Higa separa detalhes de acabamentos dos de costura.

A especificação de medidas que ocorre por meio do desenho técnico, depois do esboço e dos croquis, é um aspecto levantado por Mendes e Vicentini. Para Mendes a ficha técnica precisa conter medidas como larguras, alturas e profundidades. A ficha técnica, para Vicentini, (2010, p. pida por "desenhos de montagem" que reúnam todas as informações do produto a ser desenvolvido.

Com os desenhos prontos busca-se criar mais looks para a coleção, a fim de obter maior variação de produtos e poder escolher o que realmente será produzido.

Para obter a diversificação de produtos dentro de uma coleção recorrese à "geração de alternativas" e a outras metodologias análogas. A tese de Cláudia Vicentini traz ferramentas menos conhecidas no campo do design de moda para definir atividades que se aproximam do brainstorming e da geração de ideias. Por estarem distantes do campo do design de moda e não serem utilizadas nem pela própria Vicentini atualmente, elas não serão abordadas neste texto, mas a eles método 6.3.5, método DELPHI, diagrama de Mudge e Cinéctica que merecem ser revistos em outro momento.

A "geração de alternativa" é o método mais comum para criar variantes de produtos de moda. Os autores Simon Seivewright (2009, p. 106-121 passim) e Bernd Löbach (2007, p. 141) propõem a "geração de alternativas" como saída para a resolução de um problema e diversificação do produto, consagrando no design de moda uma das práticas mais tradicionais originadas pelo design de produtos.

"Existe um problema que deve ser bem definido; reúnem-se informações a seu respeito; criam-se alternativas e desenvolve-se a mais adequada", afirma Löbach (2007, p. 141) definindo "geração de alternativas" de forma um tanto generalista.

No campo do design de moda a "geração de alternativas" proposta por Seivewright (2009, p. 137) é bastante objetiva quanto às tarefas que devem ser realizadas pelo estilista e quais resultados esperados, como visto no Capítulo 1. No caso do design de produtos, Löbach (2007, p. 150-153) dá pistas, como a fase da "incubação" ou faz críticas, como a "tentativa e erro" e a "aguardar a inspiração", mas não fornece etapas claras a serem experimentadas.
Renfrew e Renfrew (2010, p. 24) sugerem que o estilista mantenha um banco de referências onde são armazenados ideias ou protótipos descartados para, posteriormente, serem revistos e reavaliados. Essa prática de projeto em moda pode servir de base para a "geração de alternativas" e pode ser equiparada à proposta de Löbach (2007, p. 139) de observar fatos conhecidos sob novos pontos de vista para que se possa exercer uma postura crítica.

Um assunto pouco abordado pelos pesquisadores da FAUUSP e FAACUNESP foi a "geração de alternativas". Apesar de ser muito recorrente no design de produto, ao discutir etapas relativas ao projeto em moda os entrevistados não mencionaram a etapa, evidenciando lacunas na aplicação das etapas de projeto do design ao design de moda. Isso mostra que os conceitos de projeto de produto atendem até certo ponto às demandas do projeto em moda.

O exercício "geração de alternativas" aparece na fala de Márcio Ito e Simon Seivewright. Ito conta que o aprendeu, de maneira subentendida na aula de Sílvia Sato, como uma etapa de estilismo. Ele admite a similaridade entre a prática proposta por Sato e o exercício de "geração de alternativas" elencado por Seivewright (2009, p. 139), que consiste em gerar novas propostas de looks a partir da cópia de desenhos iniciais para posterior detalhamento. $O$ exercício é usado até hoje na FASM.

Vicentini utiliza o "Quadro Morfológico" ou "Matriz Morfológica" para trabalhar a "geração de alternativas" de forma um pouco diferente de Seivewright e lto. O mesmo funciona pelo cruzamento de informações, que posteriormente darão forma a um produto. Eunice Higa alude ao "Quadro Morfológico" por meio das perguntas que precisam ser feitas quando o assunto é estamparia.

As indagações de Higa sobre estamparia são sobre o tipo de materiais que serão estampados, sua composição, cor do fundo, se ele aceita todas as cores de acordo com a técnica a ser aplicada etc. É o cruzamento das respostas diante de limitações técnicas que indicará como o produto deve ser desenvolvido e seu aspecto final. O cruzamento proporcionado pelo "Quadro Morfológico" também se assemelha à "Geração de Alternativas" não no sentido de gerar um novo desenho, mas de proporcionar maneiras de desenvolver um produto que interferem nesse desenho.

Somente Irina Aragão declarou utilizar uma etapa que se concentra em cortar o excesso de informação do que já estava sendo criado, depois da "geração de alternativas". Essa etapa funciona como um funil que abre a pesquisa e depois fecha segundo critérios limitantes e corresponde à segunda fase do projeto para Irina Aragão.

O ajuste das ideias, da segunda fase da prática de projeto de Aragão pode ser compreendido como a "avaliação das alternativas" em Löbach (2007, p. 154), pois ambas as tarefas visam cortar os excessos por meio de critérios limitantes estabelecidos e revistos pelo briefing.

Com as alternativas avaliadas, o passo seguinte é a modelagem ou moulage, com vistas à pilotagem da peça de vestuário de moda ou prototipagem. Com a peça-piloto pronta, ela é provada em um manequim humano. 
No campo do design de moda, os testes com produtos ocorrem, de maneira geral, na prova de roupa, e ela é avaliada por critérios como caimento, corte, harmonia, se está adequado ao gosto do público e conforto. O conforto nem sempre é privilegiado no design de moda, sendo esse um dos problemas apontados por Aragão.

A moulage pode ser comparada até certo ponto à prova da peça-piloto, pois ambas auxiliam na compreensão da relação entre o esboço e a forma tridimensional. Para Higa, a prova de roupa evidencia a qualidade do produto, e é o momento em que o criador conecta croqui, desenho técnico e roupa confeccionada. Esse momento desperta a percepção do estudante ou do estilista para seu processo.

Mendes demonstra uma certa reserva com o termo pilotagem, pois para ela parece que a peça é feita e avaliada pelo piloteiro. Na verdade, 0 piloteiro é influenciado pelo processo de criação do estilista, que é traduzido até certo ponto na ficha técnica. Acabamentos de costura e modelagem são pensados pelo estilista para o piloteiro executar. Ao final, na prova de roupas, é o estilista quem avalia o produto.

Tanto Renata Zaganin de Oliveira quanto Márcio Ito, mesmo sem utilizar o livro de Simon Seivewright (2009, p. 106-121 passim), descrevem da mesma forma etapa projetual proposta pelo autor, denominada "fotomontagem dos registros de moulage", que consiste em fotografar uma peça executada por moulage e, a partir da foto, criar novas peças com auxilo do desenho. Esse método transita entre as etapas de desenho, geração de alternativas e modelagem.

Sobre as considerações de aspecto prático na modelagem, a ergonomia é um ponto pacífico, para Vicentini e Mendes. Vicentini (2010, p. 102) defende que a empresa adote padrões que atendam ao seu público, principalmente na construção de modelagens que garantam conforto e usabilidade. Mendes concorda com Vicentini ao defender que devem ser estabelecidas tabelas específicas para determinado público, bem como a confirmação da silhueta que agrada a esse consumidor, a conferência do molde base e suas medidas e qual graduação será adotada para prezar pelo conforto e caimento de un artigo de moda.

Para além do confrontamento entre as terminologias e visões acerca das etapas de projeto em design, em moda e estilismo, algumas questões dos depoimentos e dos livros revisados merecem ser exploradas, entre elas, alguns termos que não encontram equivalente nas etapas apresentadas no design de moda. São questões relativas à nomenclatura de cursos de moda e a preferência por autores de design de produtos.

Embora Christo argumente que as etapas de projeto do design de produtos podem ser aplicadas ao design de moda, ela reconhece que é impossível adaptar completamente o pensamento de projeto do design para a moda. A autora estrutura seu raciocínio, baseando-se na discrepância de termos entre os campos do design e da moda, e toma como exemplo alguns conceitos, como "parâmetros projetuais", "mandatórios restritivos" "mandatórios desejáveis", que pertencem ao campo do projeto do design não são sequer apresentados em cursos superiores de Moda.
Outras terminologias pouco usuais aparecem na acepção de projeto em moda, adotada por Cyntia Santos Malaguti de Sousa no SENAC SP. Na disciplina de Projeto em Moda, ela trabalhava conceitos de design como anteprojeto, mock up e protótipo. Até hoje, o curso está sob o "guardachuva" do design, daí que, para Sousa, o "aluno tem que saber" esses termos, referindo-se ao conhecimento que instrumentaliza o aluno de design. Por fim, ela admite que na construção da coleção de moda, os alunos utilizam os conceitos do design, mas não tão afins.

Em contato mais próximo com a primeira visão de projeto apresentada por Oliveira, o aluno desenvolve seu trabalho passo a passo, com briefing número de peças, temática etc. Em outro momento, pautado pela segunda visão, na disciplina de Projeto Final, por exemplo, o aluno é estimulado a desenvolver sua própria metodologia. Ele não tem uma metodologia prédeterminada. Elo vai construir o seu processo a partir de questões que ele traz para o campo da moda, desde uma temática, segmentação, materiais até outras questões que possam surgir para o vestuário (OLIVEIRA, 2016).

Tanto Christo quanto Sousa evidenciam as fragilidades de pautar o ato projetivo do design de moda pelas teorias de projeto do design de produtos. Partindo da segunda acepção de projeto em moda de Oliveira, a apropriação da metodologia de design que Christo defende no sentido de subverter etapas faz sentido, pois, quando o designer se serve de várias metodologias e, caso seja preciso, as subverta para moldá-las ao que o projeto demanda, ele milita em prol da construção de um processo próprio de projetar, e assim organiza de maneira independente sua própria metodologia de forma contemplar questões reais e atuais no campo do design de moda.

Para Preciosa (2017), talvez seja relevante, dentro da Universidade, compreender como são acessados os talentos do discente, para ele se desenvolver profissionalmente, de uma forma gratificante, repertorial, nem sempre imediata. $O$ campo projetual é abalado por vários fatores que não se limitam ao estilismo. Será que os nomes das coisas são importantes ou será que o importante é como as coisas se realizam?

Ainda em relação à visão de design, Andrea Canton (2016) diferencia conceitualmente protótipo e peça-piloto da seguinte maneira: o protótipo, nessa visão de design de moda, seria a peça menos acabada, ou seja, equivaleria ao mock up, enquanto, sob esta mesma visão, a peça-piloto seria o protótipo ou cabeça da série, quando na verdade, a peça-piloto equivale ao modelo do design de produtos.

Como visto, os termos mock up, modelo e protótipo encontram equivalentes no design de moda em tela, peça-piloto e primeira peça, montada na célula de produção industrial para teste. Percebe-se assim que há um equívoco na adoção dos termos por Canton, pois o protótipo é peça na qual a produção inteira se baseará. Ela não foi a única entrevistada a cometer esse engano.

Embora Andrea Canton se refira a etapas de projeto e reconheça importância do livro "Fundamentos de design de moda: pesquisa e Design" de Simon Seivewright, o processo desenvolvido em suas aulas se assemelha 
muito mais ao que a Academia intitula como estilismo. A expressão "na moda a gente não costuma sistematizar" traduz o pensamento e o modus operandi de parte dos docentes do campo do design de moda, que relegam a metodologia ao segundo plano.

Sem dúvida, como alerta Preciosa, as práticas são mais importantes do que os nomes, mas é preciso prestar atenção a quais práticas estão sendo ensinadas e difundidas nos cursos superiores e na pesquisa de moda, pois a importância em dominar as terminologias reside em conhecer o que se pratica, e não em limitar à prática.

Os cursos de moda do SENAC SP têm nomes que merecem atenção, "Design de Moda - Estilismo" e "Design de Moda - Modelagem". O primeiro nome é Design de Moda, mas se verificam duas ênfases, uma no Estilismo e outra na Modelagem. Os cursos são independentes, e cada um possui seu próprio coordenador e vestibular.

A nomenclatura que se mostra mais problemática é Estilismo. É interessante refletir como um curso pode ser Design e Estilismo ao mesmo tempo, e se ele fornece as habilidades necessárias para a formação de um designer de moda ou de um estilista, ou ainda, de ambos.

É preciso alertar que, assim como a maioria dos cursos de Moda analisados, o curso do SENACSP possui quatro anos de duração, o que leva a crer que não há tempo suficiente para formar um "designer-estilista" nesse período. Eunice Higa e Maria Eduarda Guimarães consideram que, apesar de o nome da disciplina ser "Projeto em moda", nesse curso, a prática vigente é de Estilismo. Esse habitus ${ }^{34}$ tem relação com os primeiros cursos fundados no Brasil, na FASM e na UAM, que por muito tempo ensinaram estilismo e que serviram de modelo para os cursos que surgiram em um momento posterior.

$\mathrm{Na}$ UAM, até meados dos anos 2000, o egresso do curso de Design de Moda recebia uma formação de "designer-estilista" e não "designer de moda industrial", e isso permitia que o profissional tivesse uma formação mais completa, tal como a pretendida pelo SENAC SP. A carga horária na época era de cerca de quatro mil horas, ou seja, havia mais possibilidade de êxito dessa "dupla formação" ser proporcionada do que no caso do SENACSP hoje.

Existe o designer conceitual e o designer técnico para Troy Nachtigall (2016). O primeiro caça tendências e faz muitos moodboards, o segundo trabalha mais com questões voltadas à parte técnica. Percebe-se que cursos com esse perfil de formação de designer conceitual e designer técnico são comuns nas faculdades europeias. Além da Technische Universiteit Eindhoven (TU/e) na Holanda, o curso de Design de Moda do Politecnico di Milano, na Itália, também oferece essas duas possibilidades de profissionalização: a Laurea Triennale, que é um curso de três anos e forma o designer técnico; e a Laurea Magistrale, que oferece mais dois anos complementares e form um designer com mais possibilidades no campo de atuação conceitual.

Assumir o nome Estilismo parece mais adequado, para Mendes, do que Design de Moda, pois esse último tende a sujeitar a concepção do produto de moda às metodologias de projeto de produto, o que gera lacunas para o Estilismo ou o que se pretende como Design de Moda. Nem o projeto em moda nem o estilismo abarcam efetivamente um "problema", portanto, nem uma "solução" efetiva sob a ótica do design conforme discutem Christo Sousa.

Nos cursos que tendem a uma visão mais voltada ao design de produtos, como os da FAUUSP, FAACUNESP e os cursos do Rio de Janeiro, observouse uma preferência pelos autores Bruno Munari, Bernd Löbach e Gustavo Amarante Bomfim quando o assunto é projeto em moda.

Cibele Taralli valoriza a metodologia de Munari, para quem vai fazer um projeto mais experimental, pois ela possibilita essa experimentação. É uma metodologia, portanto não possui a rigidez de um método. Taralli conta que os livros de metodologia de Munari sempre respaldaram atuações em moda na FAUUSP, como o TFG, por exemplo. Como na FAUUSP o trabalho com moda não é habitual, normalmente o caminho costuma ser apontado pela bibliografia de Munari.

Os livros de Munari também foram adotados por Sérgio Sudsilowsky no curso de Design de Moda do SENAI CETIQT. Utilizar Bruno Munari n bibliografia foi a forma encontrada por Sudsilowsky para o "aluno de moda" entender e fazer as comparações entre projeto em design e projeto em moda voltados para o desenvolvimento de uma coleção, principalmente no que toca a documentação da coleção, a solução, o teste de possibilidades, a prototipagem e a documentação dos produtos desenvolvidos.

$\mathrm{Na}$ abordagem de projeto em moda de Sudsilowsky aparecem termos relacionados somente à noção de projeto, o que denota um esforço para que $\mathrm{o}$ aluno de moda se encaixe às metodologias de projeto de produto para conceber produtos de moda.

Outra pioneira do Rio de Janeiro, Aline Monçores declara que se baseia até certo ponto em Bruno Munari (2008), no livro "Das coisas nascem coisas".

O que se percebe nesses casos é um predomínio dos conceitos do campo do design, e não uma ponte entre os conceitos de projeto em design e moda, como alude Sérgio Sudsilowsky, pois, aparentemente não há aderência por parte dos designers de produto à bibliografia sobre projeto em moda.

Por fim, Preciosa (2017) e Christo (2015) propõem como alternativa compreender o modo como cada processo opera para mesclar esses modos, a fim de descobrir outros modos. 


\section{REFERENCIAS}

ALBERTI, Verena. Manual de história oral. Rio de Janeiro: Editora FGV, 2013.

BOMFIM, G. A. Idéias e Formas na História do Design: Uma Investigação estética. 1. ed. João Pessoa: Editora Universitária da UFPB, 1998. v. 1

BOURDIEU, Pierre. 0 poder simbólico. Rio de Janeiro: Bertrand, 1989.

CHRISTO, Deborah Chagas. Estrutura e funcionamento do campo de produção de objetos do vestuário no Brasil. 146 f. (Tese de Doutorado) - Departamento de Artes e Design da Pontifícia Universidade Católica do Rio de Janeiro, Rio de Janeiro, 2013.

CIPINIUK, Alberto. Design: o livro dos porquês: o campo do Design compreendido como produção social. Rio de Janeiro: Ed. PUC-RIO; São Paulo: Ed. Reflexão, 2014.

GIBERT, Vera Lígia P. O entorno acadêmico e industrial têxtil no vestir e morar brasileiros. 317 p. (Dissertação) - Escola de Comunicação e Artes da Universidade de São Paulo, São Paulo, 1993.

JONES, Sue Jenkin. Fashion design - manual do estilista: São Paulo: Cosac Naify, 2005. p. 240

LIPOVETSKY, Gilles. 0 império do efêmero: a moda e seu destino nas sociedades modernas. São Paulo: Companhia das Letras, 1989.

LÖBACH, Bernd. Design Industrial - Bases para a configuração dos produtos industriais. São Paulo: Editora Blucher, 2007.
MARTINS, Suzana B. O paradoxo sustentáve na moda: diretrizes para sustentabilidade en produtos de moda e vestuário. In: CARLI, Ana Mary Sehbe de; MANFREDINI, Mercedes Lusa. Moda em sintonia. Caxias do Sul: Educs, 2010, p. $80-89$.

MATTOS, Maria de Fátima da Silva Costa de Mattos (org.). Pesquisa e formação em moda.

MENDES, Francisca Dantas. Cadeia Têxtil e as estratégias de manufatura na indústria do vestuário de moda. 209 p. (Dissertação) Programa de Pós-graduação em Engenharia de Produção da Universidade Paulista, São Paulo, 2006

MUNARI, Bruno. Das coisas nascem coisas. São Paulo: Martins Fontes, 2008.

MUNARI, Bruno. Design e comunicação visual: contribuição para uma metodologia didática. São Paulo: Martins Fontes, 2011.

POUPART, Jean. A pesquisa qualitativa: enfoques epistemológicos e metodológicos. Petrópolis, RJ: Vozes, 2008.

RENFREW, Elinor; RENFREW, Colin Fundamentos de design de moda: desenvolvendo uma coleção. Porto Alegre: Bookman, 2010. p. 176

RANKING UNIVERSITÁRIO FOLHA 2017. São Paulo: RUF, [2017]. Disponível em: <https:// ruf.folha.uol.com.br/2017/ranking-de-cursos/ moda/>. Acesso em: 15 jun. 2018.

SEIVEWRIGHT, Simon. Fundamentos de design de moda: pesquisa e design. Porto Alegre: Bookman, 2009.
SPOTLIGHT on Buttress and Snatch Lingerie. 5 mar. 2013. Disponível em: <http://www. thelingerieaddict.com/2013/03/spotlight-onbuttress-and-snatch-lingerie.html>. Acesso em: 23 jul. 2016.

TREPTOW, Doris. Inventando moda: planejamento de coleção. 5. ed. São Paulo: Edição da Autora, 2013.

ELLHO, Gilberto. O desafio da Cidade: novas perspectivas da antropologia brasileira. Rio de Janeiro: Campus, 1980.

VICENTINI, Cláudia Regina Garcia. erramentas e metodologia de projeto aplicados na criação de produtos para a indústria têxtil-confecção. 157 p. (Tese) Faculdade de Engenharia Mecânica da Universidade Estadual de Campinas, 2010.

\section{FONTES DAS ENTREVISTAS}

ARAGÃO, Irina. Entrevista realizada com Irin Aragão, em 21 de outubro de 2015, na cidade do Rio de Janeiro, com 1 hora e 15 minutos de duração.

BERNARDES, Circe. Entrevista realizada com Circe Bernardes, em 22 de janeiro de 2015, na cidade de São Paulo, com 2 horas e 42 minuto de duração.

BONADIO, Maria Cláudia. Entrevista realizada com Maria Cláudia Bonadio, em 17 de novemb de 2015, na cidade de São Paulo, com 1 hora e 21 minutos de duração.

BRAGA, João. Entrevista realizada com João Braga, em 8 de dezembro de 2014, na cidad de São Paulo, com 2 horas e 36 minutos de duração.
CAMARENA, Elaine Soares. Entrevista realizada com Elaine Soares Camarena, em 5 de dezembro de 2014, na cidade de São Paulo, com 52 minutos de duração.

CANTON, Andrea. Entrevista realizada com Andrea Canton, em 12 de outubro de 2016, na cidade de São Paulo, com 1 hora e 33 minutos de duração.

CASTILHO, Kathia. Entrevista realizada com Kathia Castilho, em 15 de dezembro de 2015, na cidade de São Paulo, com 1 hora e 33 minutos de duração.

CHRISTO, Deborah. Entrevista realizada com Deborah Christo, em 21 de outubro de 2015 na cidade do Rio de Janeiro, com 1 hora e 46 minutos de duração.

CIPINIUK, Alberto. Entrevista realizada com Alberto Cipiniuk, em 19 de outubro de 2015, na cidade do Rio de Janeiro, com 1 hora e 43 minutos de duração.

GIBERT, Vera Ligia P. Entrevista realizada com Vera Lígia Pieruccini Gibert, em 25 de ovembro de 2014, na cidade de São Paulo, com 2 horas e 27 minutos de duração.

GRUMACH, Evelyn. Entrevista realizada com Evelyn Grumach, em 14 de outubro de 2015, na cidade do Rio de Janeiro, com 1 hora e 35 minutos de duração.

GUIMARÃES, Maria Eduarda Araújo. Entrevista ealizada com Maria Eduarda Araújo Guimarães, em 9 de outubro de 2015, na cidade de São Paulo, com 1 hora e 50 minutos de duração.

HIGA, Eunice. Entrevista realizada com Eunice Higa, em 5 de julho de 2016, na cidade de São Paulo, com 1 hora e 34 minutos de duração.

TO, Márcio. Entrevista realizada com Márcio to, em 16 de dezembro de 2014, na cidade de São Paulo, com 1 hora e 42 minutos de duração. 
KHOURY, Feres. Entrevista realizada com Feres Khoury, em 9 de dezembro de 2015, na cidade de São Paulo, com 27 minutos de duração.

MENDES, Francisca Dantas. Entrevista

realizada com Francisca Dantas Mendes, em 29 de junho de 2016, na cidade de São Paulo, com hora e 47 minutos de duração.

MESQUITA, Cristiane. Entrevista realizada com Cristiane Mesquita, em 23 de novembro de 2015, na cidade de São Paulo, com 58 minutos de duração.

MINA, Simone. Entrevista realizada com Simone Mina, em 19 de dezembro de 2014, na cidade de São Paulo, com 2 horas e 9 minutos de duração.

MONÇORES, Aline. Entrevista realizada com Aline Monçores, em 15 de outubro de 2015, na cidade do Rio de Janeiro, com 1 hora e 47 minutos de duração.

MOURA, Mônica. Entrevista realizada com Mônica Moura, em 26 de maio de 2015, na cidade de São Paulo, com 1 hora e 42 minutos de duração.

NACHTIGALL, Troy. Entrevista realizada com Troy Nachtigall, em 7 de março de 2016, na cidade de Eindhoven (Holanda), com 50 minutos de duração.

OLIVEIRA, Izabel Maria de. Entrevista realizada com Izabel Maria de Oliveira, em 25 de outubro de 2016, na cidade do Rio de Janeiro, com 55 minutos de duração.

OLIVEIRA, Renata Zaganin de. Entrevista realizada com Renata Zaganin de Oliveira, em 28 de novembro de 2014a, na cidade de São Paulo, com 2 horas e 9 minutos de duração.

OLIVEIRA, Renata Zaganin de. Entrevista realizada com Renata Zaganin de Oliveira, em de dezembro de 2014b, na cidade de São Paulo, com 53 minutos de duração.
PRECIOSA, Rosane. Entrevista realizada com Rosane Preciosa, em 10 de março de 2017, nas cidades de São Paulo e Juiz de Fora (via Skype), com 1 hora e 31 minutos de duração.

QUEIROZ, Mario. Entrevista realizada com Mario Queiroz, em 15 de julho de 2016, na cidade de São Paulo, por e-mail.

ROCHA, Mariana M. L. Entrevista realizada com Mariana Machado Lousada Rocha, em com 9 com 1 hora 50 minutos de duraço.

SALATA, Robinson. Entrevista realizada com Robinson Salata, em 30 de setembro de 2015, na cidade de São Paulo, com 1 hora e 6 minutos de duração.

ANCHES, Maria Celeste de Fátima. Entrevist realizada com Maria Celeste de Fátima

Sanches, em 7 de setembro de 2015, na cidade

de Londrina, com 1 hora e 13 minutos de duração.

SOUSA, Cyntia Santos Malaguti de. Entrevista realizada com Cyntia Santos Malaguti de 2015a, na cidade de São Paulo, com 51 minutos de duração.

SOUSA, Cyntia Santos Malaguti de. Entrevista realizada com Cyntia Santos Malaguti de

Sousa, em 25 de novembro de 2015b, na cidad de São Paulo, com 57 minutos de duração.

SOUZA, Patrícia de Mello. Entrevista realizada com Patricia de Mello Souza, em 8 de setembro de 2015, na cidade de Londrina, com 29 minutos de duração.

STEPHAN, Auresnede P. Entrevista realizada com Auresnede Pires Stephan, em 19 de novembro de 2014, na cidade de São Paulo, com 2 horas e 32 minutos de duração.
SUDSILOWSKY, Sérgio. Entrevista realizada com Sérgio Sudsilowsky, em 20 de outubro de 2015, na cidade do Rio de Janeiro, com 44 minutos de duração.

TARALLI, Cibele H. Entrevista realizada com Cibele Haddad Taralli, em 2 de dezembro de 2015, na cidade de São Paulo, com 55 minutos de duração.

VICENTINI, Cláudia Regina Garcia. Entrevista realizada com Cláudia Regina Garcia Vicentini, m 31 de março de 2016, na cidade de São Paulo, com 1 hora e 2 minutos de duração. 


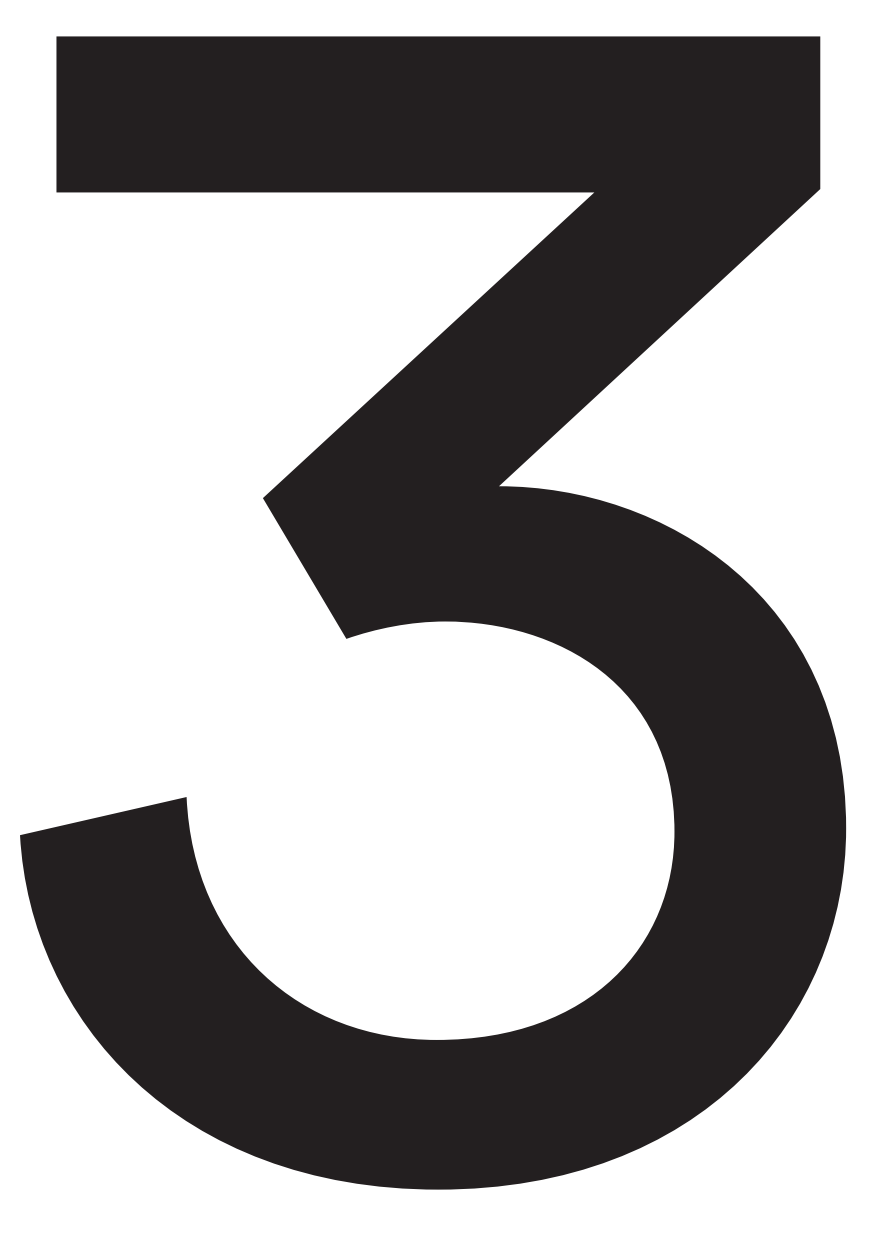

As noções de estilismo $\Theta$ projeto em moda no colóquio de moda e no congresso brasileiro de pesquisa e desenvolvimento em design 
Este Capítulo se dedica a revisar artigos sobre os temas "estilismo" e "projeto em moda". Foram analisados textos apresentados em dois eventos: Colóquio de Moda e Congresso Brasileiro de Pesquisa e Desenvolvimento em Design (P\&D). Para isso, foram consideradas as divergências e convergências percebidas sobre ambas as noções.

Tanto o Colóquio de Moda quanto o P\&D encontram-se na 13a edição. O Colóquio de Moda nasceu em 2005 e acontece anualmente como um evento internacional. O P\&D surgiu no ano de 1994, é bianual e também se caracteriza por ser um evento internacional. 
Sobre o P\&D há certa intermitência no oferecimento de sessões específicas dedicadas aos assuntos sobre o campo têxtil, vestuário e moda, que vale a pena observar.

A primeira, terceira, quarta, oitava, nona e décima primeira edições do Congresso P\&D Design, ocorridas respectivamente em 1994, 1998, 2000, 2008, 2010 e 2014, não contaram com nenhuma sessão de comunicação oral voltada especificamente aos temas Moda, Vestuário ou Têxtil. Chama a atenção não haver sessão dedicada ao tema no $8^{\circ}$ P\&D Design, em 2008, uma vez que o evento foi sediado na Universidade Anhembi Morumbi em São Paulo, berço de um dos primeiros e hoje considerado o melhor curso de moda do país ${ }^{35}$. 35 http://ruff.folha.uol.
com.br/2017/ranking-de-

O segundo e o quinto P\&D Design, dos anos de 1996 e 2004, foram os primeiros a dar alguma visibilidade ao tema, criando a sessão de apresentação de artigos intitulada "Design Têxtil".

No sexto P\&D, em 2004, e no décimo P\&D, em 2012, a sessão assume um nome mais abrangente se refere-se não só à superfície têxtil, mas também

A sessão "Design de Moda" só aparece em duas edições do evento, na sétima, no ano de 2006, e na décima segunda, de 2016 como "Design da Moda", além da sessão "Sociabilidade e Moda". A sessão mostra maior receptividade do P\&D para receber a publicação de trabalhos relacionados ao tema "design de moda", que abrange as esferas do têxtil, do vestuário e da moda, mas contando com nome mais atualizado.

É interessante notar que mesmo quando surge pela primeira vez a sessão "Design de Moda" em 2006, ela é interrompida por dez anos, voltando a acontecer somente na décima segunda edição do P\&D Design. Durante esse intervalo, que durou uma década, em várias edições, o evento sequer fez alguma menção ao tema, no que diz respeito a dedicar uma sessão específica a ele. Não cabe nesse momento, nem é objeto desta tese explorar tal variação, mas ela dá indícios da transição enfrentada até hoje rumo ao reconhecimento do campo de projetação em moda por parte do campo do design.

$\mathrm{Na}$ edição de 2016 do P\&D, a décima segunda do evento, não foram encontradas publicações que interessassem diretamente a esta tese. O artigo "O projeto em moda no Rio de Janeiro - PUC, SENAI, UVA, ESDI e UFRJ", de autoria desta pesquisadora é de interesse deste trabalho, mas o assunto já foi esgotado no Capítulo 1 desta tese.

A trajetória da sessão sobre design de moda no P\&D não é linear, mas mesmo quando não houve sessão dedicada ao tema, poucos, mas bons artigos sobre projeto em moda foram encontrados em outras sessões e analisados.

Entende-se que é importante expor o conteúdo dos textos sobre estilismo e projeto em moda produzidos para os dois eventos, resultantes de pesquisas dos pioneiros entrevistados para o segundo Capítulo desta tese, de forma que se torne possível traçar um caminho a respeito do direcionamento de suas pesquisas sobre o tema, quais foram os rumos estas tomaram e como sua visão se modificou ou não ao longo da última década.
Certamente, nem todos os pesquisadores entrevistados para esta tese contribuíram para esses eventos. Também foram elencados artigos de outros autores, que não foram entrevistados, quando se notou que a contribuição de suas abordagens sobre algum tema, seria pertinente.

Dentro do possível, foi mantida a ordem cronológica de publicação dos artigos nos eventos, privilegiando, porém, a otimização das informações e, quando necessário, autores, eventos e datas foram reunidos em uma mesma parte do texto para suscitar o diálogo. Tomando sempre por base os artigos publicados nos dois eventos, este capítulo se organiza em seis partes: 1) Divergências e convergências sobre as noções de estilismo e projeto em moda; 2) Divisão entre arte, design e moda e seus valores considerando também as iniciativas do MASP e da Rhodia; 3) Nomenclaturas vinculadas às práticas; 4) Ensino e pesquisa em design de moda; 5) Discussão sobre diretrizes do MEC para os cursos de Moda; e, por último, 6) Etapas de estilismo e projeto em moda.

\section{Análise dos artigos - convergências e divergencias entre as noçoes de estilismo e projeto em moda no colóquio de moda e no P\&D}

Ao iniciar a análise dos artigos, é possível já encontrar um conflito entre ideal racional funcionalista, a moda e o consumo. Michael Morais (2006) faz críticas ao consumismo, enquanto Deborah Chagas Christo, autora que articula a partir de diversas colaborações no Colóquio de Moda e no P\&D, o faz tecendo críticas ao design racional funcionalista em oposição ao funcionamento do campo da moda.

Para Morais (2006), um traço marcante da moda que interfere diretamente na projetação é o estímulo ao consumo. $O$ consumismo está muito mais atrelado ao desejo do que à satisfação, pois "a qualidade de vida passou a ser medida pelo acúmulo de bens".

As soluções precisam visar também às necessidades subjetivas, ou seja, aos desejos, anseios e expectativas. Os significados não são estanques, eles podem ser alterados à medida que o contexto se modifica (CHRISTO, 2008).

Pensando a partir das colocações dos dois autores, se um produto cumpre uma função simbólica, além da prática, ou seja, supre desejos, anseios e expectativas, simplesmente condená-lo sob o olhar ideológico do design de produto talvez desvie a atenção do assunto.

A tradicional ideologia racional-funcionalista afastou o design de conceitos relacionados à arte e à moda. Trabalhos mais voltados à forma, mas não exclusivamente, sofrem constantemente juízo de valor por meio do nome que recebem, como é caso do styling. Se, por um lado, o styling tornou-se um termo pejorativo quanto ao exercício do design, por outro, é preciso reconhecer que o incentivo ao consumo de produtos 
que ele estimula, por meio da renovação de forma e estilo, foi um dos responsáveis pela estabilização da economia estadunidense na década de 1930. Essa característica de renovação estética aproxima o design da moda (CHRISTO, 2006).

A questão demanda uma postura crítica diante do consumo excessivo, com vistas ao bem-estar geral, diante das questões de esgotamento de recursos e da novidade efêmera, superficial, destinada a manter vivo um ciclo de formas sem significados reais para um desenvolvimento de melhorias da qualidade da cultura material.

A inovação é relevante quando melhora produtos via criatividade, desde que estes façam sentido para a cultura ou para o cotidiano das pessoas. A inovação efetiva objetiva a melhoria da qualidade real dos produtos e da vida dos envolvidos, e ela deve se pautar por mudanças que acompanhem e dialoguem com o desenvolvimento da cultura, rumo a caminhos mais duradouros e imbricados com expressões mais legítimas ou espontâneas do público, do qual essa cultura material emerge ou será inserida.

É preciso lidar com as ênfases no consumo efêmero, naturalizadas pelo campo da projetação em moda. no sentido de repensá-las e não apenas se restringir a censurá-las.

A dicotomia entre os papéis do designer e do designer de moda leva a pensar se atualmente "o estilista é somente aquele que trabalha com a criação de moda?". Ao tratar o designer de moda como um projetista, Navalon (2007) levanta o debate sobre o que "vem a ser a atividade de projetar uma coleção", pois ela questiona se um designer de automóveis ou de mobiliário não seria um estilista, assim como o designer a que Christo se refere, e questiona: qual seria a diferença entre ambos?

\subsection{Diálogo entre arte, design e moda e o nascimento dos ideais de estilismo e design no brasil por meio das}

Para o design, o conteúdo simbólico teria menor importância do que para a moda, assim como as questões de mercado não seriam uma questão central para o estilista de criaç̃oes conceituais ou "criador". O estilismo estaria limitado ao campo da arte, enquanto o projeto seria influenciado pelos campos da arte e do "mercado" (CHRISTO, 2006).

A origem do design estar associada ao campo das artes tem relação direta com a valorização do desenho como projeto desde a Idade Média (CHRISTO, 2006). Ethel Leon reforça uma vinculação do design com a arte por meio da noção de "design de autor". Nessa atividade, o designer produz objetos assinados, os quais, legitimados pelos pares, passam a ser comercializados como "design de autor" em lojas de museu (LEON, 2012, p. 165).
Sabe-se que na produção de artigos de moda, seja pelo processo de projeto de design ou de estilismo, sempre existe uma função comercial, mesmo que esta seja velada. Sobre o estilismo, a "limitação ao campo da arte" apontada por Christo não exclui suas intenções comerciais. Nesse sentido, o design mostra-se um bom investimento em termos de custo retorno que proporciona.

Estudos feitos pela Xerox, Motorola e Honda apontam que, em média, o design custa $6 \%$ do custo total de desenvolvimento e representa $70 \%$ do resultado final. Em 1988, a Confederação Nacional do Indústria - Programa Brasibiro de Design informou que cada dólar investido em design, na comercialização, traz cinco dól res de retorno, e, na produção, $15 \%$ do custo final de um produto é referente desenvolvimento do projeto de design. Os demais $85 \%$ são gastos com produção propriamente dita (PIRES, 2004).

A necessidade de diferenciação entre os campos do design e da moda recai também sobre a necessidade de legitimação daquilo que o design difunde como arte, mercado e projeto, associados ao seu campo. Para a moda ser reconhecida pelo campo do design, desde 1998 ela passou a fomentar bem mais a prática de design de moda e bem menos a de estilismo.

A aderência dos indivíduos do campo da moda à noção de projeto, pede certa coerência que, nesse contexto, também se traduz como uma dependência da moda em relação à legitimação por parte do campo do design, e para isso a moda se vê muitas vezes sujeitada aos conceitos desse campo.

A ideia de uma "marca Brasil" no campo da moda foi engendrada pela empresa Rhodia, que promovia desfiles e anúncios de produtos de vestuário associados à noção de uma "moda brasileira". Naquela época, a atividade praticada se aproximava mais da noção de estilismo, se afastando da noção de projeto, que surgia no início dos anos 1960 como campo acadêmico no país.

Durante as décadas de 1960 e 1970, a empresa Rhodia fez história, investindo no conceito de "marca Brasil" no campo da moda, por meio do estilismo. Os desfiles da Rhodia na Feira Nacional da Indústria Têxtil (Fenit), em São Paulo, organizados por Livio Rangan, importante figura no cenário de difusão de uma moda brasileira, eram "shows megalomaníacos" com influência da cultura brasileira. "A ideia era popularizar os fios sintéticos que a empresa produzia. As roupas eram feitas pelos costureiros da época, como o próprio Dener" (BONADIO apud GILBERTO JÚNIOR, 2015).

Anúncios da Rhodia circulavam em revistas brasileiras como $\mathrm{O}$ Cruzeiro, Manchete, Claudia e Joia. Além disso, eram promovidos desfiles e viagen patrocinados pela empresa, para a difusão de seus produtos associados a uma "marca Brasil". Os "indicativos de uma autoafirmação de identidade nacional" aparecem associados à "qualidade internacional da moda produzida no país" que buscava naquele momento se impor como tendência, o que possibilitaria o entendimento de que "o Brasil está na moda" (BONADIO, 2006). 
A iniciativa da Rhodia deu início ao que seria o ideal de criação de "uma moda brasileira" associada à indústria, sem abrir mão de sua valorização simbólica, uma vez que os produtos eram criados por expoentes da pintura brasileira daquela época e, conforme Bonadio (2006), tinham a aprovação dos "papas da elegância feminina em Paris".

Entre os artistas que criaram moda a pedido da Rhodia desde os anos 1960 estão Idemir Martins, Alfredo Volpi, Antonio Bandeira, Antonio Maluf, Carlos Vergara, Carmélio Cruz, Carybé, Danilo Di Prete, Fernando Lemos, Fernando Martins, Francisco Brennand, Genaro de Carvalho, Gilvan Samico, Glauco Rodrigues, Hércules Barsotti, Hermelindo Fiaminghi, Isabel Pons, Ivan Serpa, João Suzuki, José Carlos Marques, Kenishi Kaneko, Licínio de Almeida, Lívio Abramo, Luigi Zanotto, Lula Cardoso Ayres, Manabu Mabe, Manezinho Araújo, Moacyr Rocha, Nelson Leirner, Tikashi Fukushima, Tomoshigue Kusuno, Waldemar Cordeiro e Willys de Castro.

36 IAC - Instituto de Arte Contemporânea, funciono
nas dependências do MASP, Museu de Arte de São Paulo por iniciativa da arquiteta Lina Bo Bard
Pietro Maria Bardi.

37 ESDI - Escola Superior
de Desenho Industrial, de iníio ao primeiro curso de nivel superior em Desenho
Industrial no Brasil em 10 de julho de 1963. Em 1975 a Escola foi incorporada pela UERJ, Universidade
Estadual do Rio de Janeiro.

O fenômeno de moda Rhodia aconteceu entre as décadas de 1960 e 1970 entre outros eventos importantes. Entre eles estão o nascimento do primeiro curso de desenho industrial ou "arte industrial" do Brasil no IAC ${ }^{36}$ em São Paulo, que funcionou de 1951 a 1953; a criação do primeiro curso superior de Desenho Industrial no Rio de Janeiro em 1963, a ESDI ${ }^{37}$; o Festival de Moda - I Exposição Retrospectiva da Moda Brasileira, de 1971 e, mais adiante, o surgimento dos primeiros cursos superiores em Moda, na FASM em 1988 e na UAM em 1991.

Esse cenário conta uma história complexa, pois se, a princípio, o processo de desenvolvimento do produto de moda aparece associado ao estilismo nas ações da Rhodia, e é reforçado como "arte" pela exposição de seu produtos no MASP em 1971, por outro contradiz os ideais do curso do IAC que se desenvolveu no MASP e se baseava no gosto e na racionalidade das formas associadas ao progresso, logo, ao que se desenvolveria como noção de projeto em design.

Naquele período, a delimitação entre os campos da arte, arte industrial e desenho industrial não eram tão evidentes nas atividades do MASP, como dão a entender essas iniciativas, mas elas já apontam divergências.

Aparentemente, antes do surgimento dos cursos de Desenho Industrial já existia uma atividade projetual da Moda paralela à do Design. Em termos práticos, o estilismo já existia antes do campo do design reconhecê-lo e is deve ser considerado quando se trata de resgatar as origens do ato projetua em moda e suas especificidades.

Segundo precursores do design brasileiro, entre eles Ernesto Hauner, Fernando Lemos, Pietro Bardi, Francesc Petit, Mona Gorovitz e Alceu Penn "com exceção da Rhodia e outras poucas indústrias são raros os que aceitam o trabalho do designer brasileiro." (Revista de domingo, Jornal do Brasil, 05/07/1970).

Essa fala permite relacionar a importante empresa produtora de moda da época, a Rhodia à atividade do design, o que permite estabelecer uma relação entre moda e design e, portanto, de design de moda. Mas o que se observa é que o entendimento e a aceitação de tal atividade naquele momento eram restritos a poucas empresas. Sem dúvida, isso não impedia que as atividades de criação e confecção de vestuário existissem e se proliferassem no Brasil, a exemplo dos trabalhos de Madame Rosita e Zuzu Angel, mas estas se posicionavam de acordo com a lógica do ateliê e do fazer manual, de maneira diametralmente oposta aos ideais do design. Para além de exemplos de estilistas reconhecidas, entende-se que grande parte da atividade de criação e confecção do país se avizinhava mais ao estilismo que ao design.

Mesmo diante deste cenário, os designers brasileiros supracitado defendiam que o desenho de moda era uma atividade de design de moda. Alceu Penna é apontado por uma matéria como com profissional que "há mais de trinta anos vem se dedicando ao trabalho de designer de moda." (Revista de domingo, Jornal do Brasil, 05/07/1970). Se for levado em consideração que essa afirmação é de 1970, é possível afirmar que atividade de designer de moda data pelo menos desde de 1940, se for tomada como referência a prática de Alceu Penna.

Havia certo otimismo relacionado ao trabalho de designer e à moda nos posicionamentos de Mona Gorovitz, pintora, editora e desenhista de moda, e também por parte de Pietro Bardi, um dos fundadores do MASP. Para Bardi, a atividade de Desenho Industrial da década de 1970 já incluia a moda. Mona Gorovitz articula: "o caminho mais árduo já foi percorrido por nós designers mais antigos.” (Revista de domingo, Jornal do Brasil, 05/07/1970).

Os valores que delineiam essas divergências persistem até os dias atuais, no ensino, na pesquisa e na prática de projeto em moda. Essas primeiras noções do que viria a ser o estilismo, o design de moda e o design no MASP e no IAC também são constituídas por valores. $O$ conhecimento, gerado pelo estudo e pela experimentação é afetado por esses "valores, crenças hábitos" que são transmitidos ao longo do tempo (NAVALON, 2007).

Esses valores podem se transfigurar em "incoerências" no ato de projetar e no produto final. Os objetos do nosso meio são a materialização dos ideais e das incoerências, de acordo com Bomfim (1999 apud NAVALON, 2007). Concordam com essa citação Christo e Cipiniuk (2010). Esse sentido, embora um pouco poético e, por isso, tendendo ao mito, somado aos valores, crenças e hábitos de que fala Navalon, soam bastante familiares às práticas do estilismo e do projeto em moda.

As questões e fases que envolvem o estilismo e o projeto em moda tendem a se diferenciar ainda mais, porque, de acordo com Christo (2008), parece não existir um consenso na aplicação do termo design, dentro do campo da moda.

Ao mesmo tempo em que há uma busca pela especialização de cada campo, a discussão sobre estilismo e projeto em moda só tem a ganhar, quando conceitos tidos como fixos a um determinado campo se movem em direção a outro campo. Um exemplo é a citação acima de Gustavo Amarante Bomfim, de que os objetos do nosso meio são a materialização dos ideais e das incoerências. Essa afirmação soa muito mais natural se associada ao design de moda, pois tende ao aspecto simbólico, que não costuma ser privilegiado pelo design. 
A atividade projetual tem papel importante, sobretudo por seu rigor ideológico, baseado no anonimato e na ética. $O$ caráter ideológico vinculado à ética atualmente é pautado por princípios que definem o tripé da sustentabilidade (social, econômica e ambiental). Ao mesmo tempo, a experiência acumulada pela maneira como o campo de moda se formalizou academicamente e as de moda relacionadas ao estilismo, não podem ser deixadas de lado.

É necessário conhecer os valores culturais e estéticos que a roupa estabelece, além do conhecimento anatômico do corpo, que é fundamental para a projetação em moda (NAVALON, 2007). Tais valores propiciam o enaltecimento de aspectos simbólicos por meio do trânsito desses valores no meio social, e são mais frequentes em produtos de moda.

O valor simbólico pode ser atribuído ao produto pelo criador. O Mito impõe que o poder simbólico é dado a um "escolhido" pelas relações sociais que ele cultiva e, assim ele pode aferir valor aos produtos que cria (BOURDIEU; DELSAUT, 2008, p. 37-48 passim). O poder do criador depende do reconhecimento que $\mathrm{o}$ aparelho de celebração promove em torno dele $\mathrm{e}$ do irreconhecimento da crença (DURAND, 1988, p. 53-55).

A inovação, além de gerar a melhoria da qualidade de vida dos usuários em vários pontos do ciclo de vida do produto, também pode ser vista como um valor simbólico vigente. Mas é preciso cuidado. Cristófoli e Mayer (2008) afirmam que "a inovação pode fazer um designer profissional reconhecido". O equívoco aqui se estabelece com base na manutenção do mito, pois as autoras enfatizam o reconhecimento do autor sobre o trabalho.

O designer pode ter "seu nome" associado a grandes descobertas (CRISTÓFOLI; MAYER, 2008). Novamente, a noção de mito aparece na necessidade de impor o reconhecimento do autor, onde o valor da obra é secundário ou serve como escalada para o reconhecimento profissional do designer. É válido reforçar que as autoras utilizam o termo "designer". Na maior parte do tempo, o estilismo é apontado como a prática que sustenta o mito, mas aqui o mito é empregado claramente pelo design.

Defensores de termos como "boa forma" com "aura superior" buscavam se distanciar da "degenerescência cultural" do produto que fosse dispendioso em material e trabalho e que, em última instância, afetaria $\mathrm{o}$ usuário e toda a sociedade (CHRISTO; CIPINIUK, 2010). O que se entende por estilismo, desvinculado dogmaticamente da noção de projeto racional, pode ser entendido nesse contexto como "mau design", pois tem fases distintas e não necessariamente formalizadas em seu processo, que se caracteriza por ser mais aberto.

Grupos de design tais como Memphis, Radical Design e Grupo Independente abalaram o conceito de "boa forma" (CHRISTO; CIPINIUK, 2010). Nesse argumento pode ser encontrado um dos fatores que teriam influenciado o despertar do interesse do design pela moda no Brasil, e que culminaria no encampamento da moda pelo campo do design em 1998.

Além disso, corroborando a ideia de mito de Bourdieu e Delsaut e de Durand, o objeto é imbuído de ideias dos produtores, que determinam as decisões tomadas sobre a sua forma, mas quando ele circula, ele adquire outros sentidos dados pelo usuário, por vezes, diversos dos atribuídos pelos designers e produtores (CHRISTO; CIPINIUK, 2010). É também ness ressemantização que reside o valor simbólico do produto de moda. No ato projetual, até onde é possível programar racionalmente o uso simbólico que será feito de um produto?

Analisar modelos de produção do conhecimento no design "pode contribuir para o entendimento dos modelos e pressupostos que também aparecem no design de moda, absorvidos por completo, em parte ou mesmo rejeitados, ou modificados [...]" (CHRISTO; CIPINIUK, 2010). O mesmo pode se estender à análise de metodologias de projeto em moda e processos do estilismo.

O discurso de tendências da moda que visa antecipar o futuro aproximou-a do design na esteira do interesse pelo mercado "[...] aproximando assim, o campo de produção de objetos de moda do campo de produção de objetos tradicionalmente entendidos como de design" (CHRISTO; CIPINIUK, 2010).

Percebe-se nas colocações de Christo e Cipiniuk que a moda se aproxim do design, denotando dependência do primeiro campo em relação ao segundo. Ao que se sabe, a demanda por encampar a moda veio do design e não o contrário.

Se criar e produzir moda por meio do design é criar e produzir um universo material e imaterial (MOURA, 2008), não fica clara qual a contribuição efetiva em substituir o estilismo pelo projeto em moda, se o campo da moda já realizava essas atividades antes de se tornar design.

\section{3 Nomenclaturas do campo
do design no campo da moda}

Sabe-se que as metodologias de design e suas nomenclaturas não atendem plenamente ao design de moda. Nos artigos analisados surgem expressões que, embora úteis, até hoje suscitam dúvidas sobre quais os limites entre a projetação no campo do design e no campo do design de moda. Entre elas estão "projetar", "configurar" e "solução de problemas" (MOURA, 2008).

Outros termos aplicados na configuração do desenvolvimento de produto de design encontrados durante a pesquisa foram os requisitos apontados como "parâmetros de análise" por Braga (1994). Entre eles figuram: ambiente, subsistemas, interação com o meio e funções. Não há registros no Colóquio de Moda ou no P\&D do uso de tais termos no campo do design de moda.

Novas denominações surgidas no design são difíceis de entender mesmo no campo do design, e mais ainda de traduzir para o campo da moda. Alguns exemplos seriam os termos "parâmetros projetuais", "mandatórios restritivos", "mandatórios desejáveis", criticados por Christo (2015) em seus artigos, pois na tentativa de aplicá-los ao campo do design de moda, estes se esvaziam de sentido. 
É preciso pensar além das limitações de determinados campos e nomenclaturas, pois o mais importante é observar que a produção de objetos no campo da moda necessita de metodologias mais alinhadas às especificidades de sua prática. Elas devem ser um guia para o projeto, organizando etapas, mas evitando o dogmatismo. $O$ profissional bem formado deve ter domínio sobre ambas as noções, estilismo e projeto em moda. Quando necessário, acessa parte de uma, de outra ou de ambas para resolver determinado problema ou demanda, conforme estes se apresentam.

Expressões características do campo do design que nem sempre são comuns ao campo do design de moda evidenciam a importância de se pensar em adaptações às especificidades do campo da moda no ato projetual, mais voltadas às práticas que aos nomes em si.

\subsection{Ensino e pesquisa}

Chama a atenção uma afirmação sobre a profissão do estilista em artigo de Wolff, Kunzler, Prati e Nascimento (2012). "A formação superior em Design de Moda não é uma exigência das empresas e estas não possuem profissionais formados em nível superior, mas sim, estilistas". Aparentemente, para as autoras o estilista é aquele que não possui nível superior.

Opõem-se a essa afirmação Ruthschilling e Anicet por meio de artigo publicado no $11^{\circ}$ P\&D. Para elas, estilistas, assim como designers, são profissionais que passam pela formação de nível superior. $O$ posicionamento das autoras fica patente em trecho de seu artigo a seguir. "Observa-se [..] que o Brasil já possui mais do que quatrocentos cursos de moda que formam estilistas ou designers de moda" (RUTHSCHILLING; ANICET, 2014).

Um problema apontado por Ruthschilling e Anicet (2014) é que "normalmente os designers de moda trabalham de forma instintiva e não tomam total consciência sobre os critérios que vão conduzi-los no caminho seguro de refinamento de cada projeto individual de roupa, no conjunto da coleção".

Dizer que "os designers de moda trabalham de forma instintiva" denota certa contradição, se a ideologia do campo do design for considerada. $\mathrm{Na}$ área do desenvolvimento de produtos de moda, sabe-se que o racionalismo não está na base de seus processos. Como uma das causas, pode ser apontada a dimensão da CTV (Cadeia Têxtil e de Vestuário).

É difícil pensar que um profissional possa vislumbrar como um todo a CTV, pois cada fase da cadeia é muito específica e tem tempo próprio. Talvez essa seja uma questão da confecção de produtos de moda, no que diz respeito a apreender processos por vezes dogmatizadores, em um setor com tamanha variação.
No ensino-aprendizagem, as parcerias entre escolas e empresas deven ser estimuladas por meio da exposição de propostas desenvolvidas pelas faculdades ao empresariado. "Geralmente, as parcerias estabelecem-se ao nível de fornecimento de materiais, mas também ao nível do desenvolvimento de tecidos e malhas especificamente para o projeto e até de confecção de peças de vestuário e acessórios." (CUNHA in MATTOS, 2015, pág. 195).

As disciplinas de projeto devem instigar "os alunos a resolver e propor soluções para problemas de maneira criativa, reflexiva e inovadora, através do domínio de linguagem própria da Moda" (MOREIRA; CAMARGO; SOARES; GIONGO, 2014), pois é preciso aproximar os estudantes das empresas para aplicarem a teoria no mercado (MOREIRA; CAMARGO; SOARES; GIONGO, 2014). O Politecnico di Milano é uma escola que que serve de exemplo nesse quesito, pois tem mostrado bons resultados ao unir a teoria da Academia à produção industrial na Itália em seus projetos.

A experiência da Universidade do Minho de Portugal é relatada no artigo intitulado "O ensino por problemas em design de moda: experiência no curso de Design e Marketing de Moda da Universidade do Minho (Portugal)". Joana Cunha (in MOTTA, 2015, pág. 195-196), divide em três as etapas de projeto em moda e não se refere objetivamente ao que seria uma noção de problema em moda. Na primeira etapa, Cunha sugere o desenvolvimento do briefing, que estabelece público-alvo, conceito da marca e da coleção, seleção de tendências, além da producão dos painéis semânticos. A segunda etapa se dedica à discussão do problema com os alunos de forma a levá-los "a refletir sobre o seu percurso e adequação e exequibilidade das suas propostas".

A exequibilidade da proposta diz respeito ao problema, uma vez que, para dar vazão à seriação do produto e disponibilizar em maior escala a soluçăo para o problema detectado, o produto e os processos que o envolvem devem ser factíveis. Mas a reflexão sobre o percurso do próprio aluno dentro do processo tem relação com um balanço do que foi aprendido, mais do que com o conceito de problema. Portanto, embora Cunha contribua ao discutir a ideia de problema no campo do design de moda, sua noção permanece vaga.

A terceira e última etapa de projeto em moda proposta por Cunha (in MATTOS, 2015, pág. 196) está relacionada aos ajustes da coleção e à finalização de seu desenvolvimento, protótipos e materiais de divulgação.

Há autores que apontam que o que se observa de fato no ensino e na atuação profissional, é que "as coleções de moda costumam ser desenvolvidas sob metodologias próprias, de estrutura diametralmente estranhas às estrutura utilizadas no projeto de produtos de outros segmentos que não o têxtil (HORN; MEYER, 2012).

O método projetual não pode ser muito rígido, pois para cada etapa vão existir diferentes métodos. Portanto, o método é um apoio, um checklist (MACIEL, 2011)

Por vezes, projeto em moda e projeto de produto são tratados de forma indistinta. Muitos autores de design se ocupam em comentar a produção de vestuário de moda sob o viés das metodologias de projeto de produto. Embora a contribuição possa ser válida, por vezes percebe-se um movimento para forçar o desenvolvimento de produtos de moda nas metodologias do design. 
Um exemplo é visto no artigo sobre ensino e criatividade das professoras Ana Broega e Karla Mazzotti (2015). A partir do relato das tarefas atribuídas na disciplina de Design de Vestuário do curso de licenciatura em Design e Marketing de Moda, da Universidade do Minho, em Guimarães, as professoras solicitam aos alunos a "criação de um coordenado de vestuário conceitual" a partir do tema sugerido que é "superstição" Tal atividade apresentada como problema.

Criar coleções a partir de um tema sempre foi uma premissa do estilismo, mas no texto de Broega e Mazzotti, e exposto como um problema de design: tratar como problema do ponto de vista projetual a criação de uma coleção dita "conceitual", de "criador" mais livre e criativa, voltada à autoria como exercício de crioção proposto a execicio decriaca das metodologias do design

Se o campo da moda já possuía metodologias próprias antes de ser encampado pelo design, mesmo que não estivessem formalizadas, é preciso considerá-las ao somar as metodologias de ambos os campos.

As diferenças entre moda e design devem ser respeitadas, e isso não implica em distanciamento entre as áreas. Horn e Meyer (2012) afirmam em seu artigo que adaptam a metodologia de Bonsiepe (1984) focando no produto de moda.

A crítica ao estilismo é que a discussão sempre ocorre em torno da expressão individual e autoral do estilista, em oposição à defesa pela estrutura do projeto em design. Esses embates fomentam diferentes entendimento e valores sobre os conceitos de moda, design, estilo, mercado e projeto. As discussões se estabelecem em torno de posições antagônicas (CHRISTO; SABRÁ, 2016), mas não há essa necessidade.

A atividade do estilista passou a ser nomeada e qualificada como designer de moda (CHRISTO; SABRA, 2016), mas o mercado de forma geral não aderiu a essa nomenclatura profissional.

A diferenciação entre designer de moda e estilista é ambígua. Ambas as práticas, tanto a que se volta mais à indústria quanto a que se volta mais à expressão individual, ja coexistiam antes de 1998. Atribuir nomes como estilismo ou design não impede uma prática de ser fronteiriça à outra.

Durante a formação, é importante que o aluno desenvolva seu domínio sobre o conteúdo, para transferir a aprendizagem para outras situaçõe (SIMÕES; WAETCHER, 2010).

No entanto, o método não é fixo, e pode ser adaptado e reinventado de acordo com as necessidades do profissional, moldando-se para o melhor aproveitamento das etapas, por isso a importância de se abordar o conteúdo em sala de maneira direta, para que fique claro aos alunos no momento em que esses necessitarem do método para desenvolverem seus projetos (WOLFF et al., 2012)

Também são importantes abordagens no sentido de o docente percebe o que foi fixado pelos alunos. Além do desenvolvimento de objetos vestíveis, os alunos de Joana Cunha (in MATTOS, 2015, pag. 192) realizam uma reflexão final do que foi aprendido com o problema e acerca dos conceitos e princípios apreendidos.
Existe relação entre as áreas em que um designer pode atuar, mas evidentemente há especificidades para cada uma delas. Assim, um metodo projetual pode ser ajustado conforme o projeto, porem, aqueles utilizados para o design grafico e de produto acabam tornando-se rigidos quando a licutos a ma

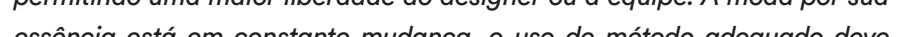
permitir os ajustes necessários a cada caso (WOLFF et al., 2012).

O importante no uso das técnicas é a aplicação em si, pois a prática permite ao aluno "identificar o momento projetual com suas necessidades específicas e avaliar a técnica enquanto ferramenta auxiliar de projeto, bem como adquirir noções básicas para escolha de métodos em situações futuras" (BRAGA, 1994).

Para o design de moda, é difícil se afiliar completamente às metodologias e ao uso propostos pelo grupo de design de produtos quando se fala em redução de riscos e "bom desempenho", por exemplo. Arriscado é acreditar que o projeto consiga prever o uso para a maioria dos produtos de moda, uma vez que seu conteúdo simbólico varia muito (MORAIS, 2006).

Como exemplo, pode ser tomado o New Look, apropriado pela classe das trabalhadoras inglesas no pós-guerra que, ao adequarem-no à sua maneira de forma pessoal, acabaram por sabotar a "aura" nele depositada. O New Look produzido em massa teve a intervenção dessas jovens que portavam um casaco mais solto e tecido mais molengo com decote mais fechado, posicionando-se contra toda a opressão que o New Look representava. Nesse caso, as consumidoras se tornaram experimentadoras (BARNARD, 2003 apud PRECIOSA; HAGEDORN, 2006).

Projetar consiste em considerar a diversidade dos grupos, e isso inclu riscos. Estes riscos também podem se apresentar como demandas ou problemas, desde que sejam pertinentes ao campo do design de moda.

\subsection{Discussão sobre as diretrizes do MEC para o curso de design de moda}

A partir dos artigos reunidos, buscou-se estabelecer um diálogo entre as falas das autoras que tratam da legitimação dos cursos de Moda e Design de Moda perante o Ministério da Educação, MEC e assuntos análogos. Intercalando excertos de texto dessas autoras, pretende-se evidenciar pontos de vistas diversos sobre o assunto.

Aparentemente, em alguns aspectos, o curso de moda ainda se encontra em um momento de transição desde sua inserção no "guarda-chuva" do design Apesar do nome do curso ter mudado para "Design de Moda" há quase vinte anos, a carga horária da disciplina de Metodologia do Projeto é insuficiente. 
E sobre a articulação entre as disciplinas de projeto do curso pairam dúvidas sobre "quais seriam os pontos de convergência e divergência entre as premissas básicas do design, e o desenvolvimento de um produto de moda? (SOUZA; HARDAGH, 2008). Essa é uma das questões centrais desta tese.

Desde 2004 o MEC orienta "todos os cursos, novos ou antigos, de formação de profissionais responsáveis pela criação e desenvolvimento de objetos de vestuário" a adequarem seus projetos pedagógicos às Diretrizes Curriculares Nacionais do Curso de Graduação em Design. Isso gerou conflitos, polarizações, embates e cisões (CHRISTO; SABRÁ, 2016).

Há autores que falam em uma ressignificação do curso de Moda e da construção de uma nova identidade fundamentada no design, quando ele se orienta por esse campo, passando a se chamar Design de Moda (SOUZA; HARDAGH, 2008). Mas essa mudança tem se realizado efetivamente?

Em 2002 a moda passou a ser considerada pelo MEC como um conteúdo curricular específico do design. As Diretrizes Curriculares Nacionais do Curso de Graduação em Design, consolidadas em 2004 passaram a nortear os cursos superiores em moda (SOUZA; NEIRA; BASTIAN, 2010).

Esse documento levou a ajustes dos cursos criados anteriormente, "de modo a manterem o direito de funcionar e conquistarem reconhecimento social" (SOUZA; NEIRA; BASTIAN, 2010). Outra pergunta é se o curso de moda precisa se tornar design para obter reconhecimento social.

Os ajustes trouxeram benefícios para a área de moda, "sobretudo pelo espaço criado para uma articulação mais abrangente, diversa e sistêmica do campo do design como um todo" (SOUZA; NEIRA; BASTIAN, 2010). Essa afirmação não é precisa quanto aos benefícios que o campo de moda logrou, e coloca de lado problemas que essa decisão do MEC gerou, além de assegurar o protagonismo do campo do design.

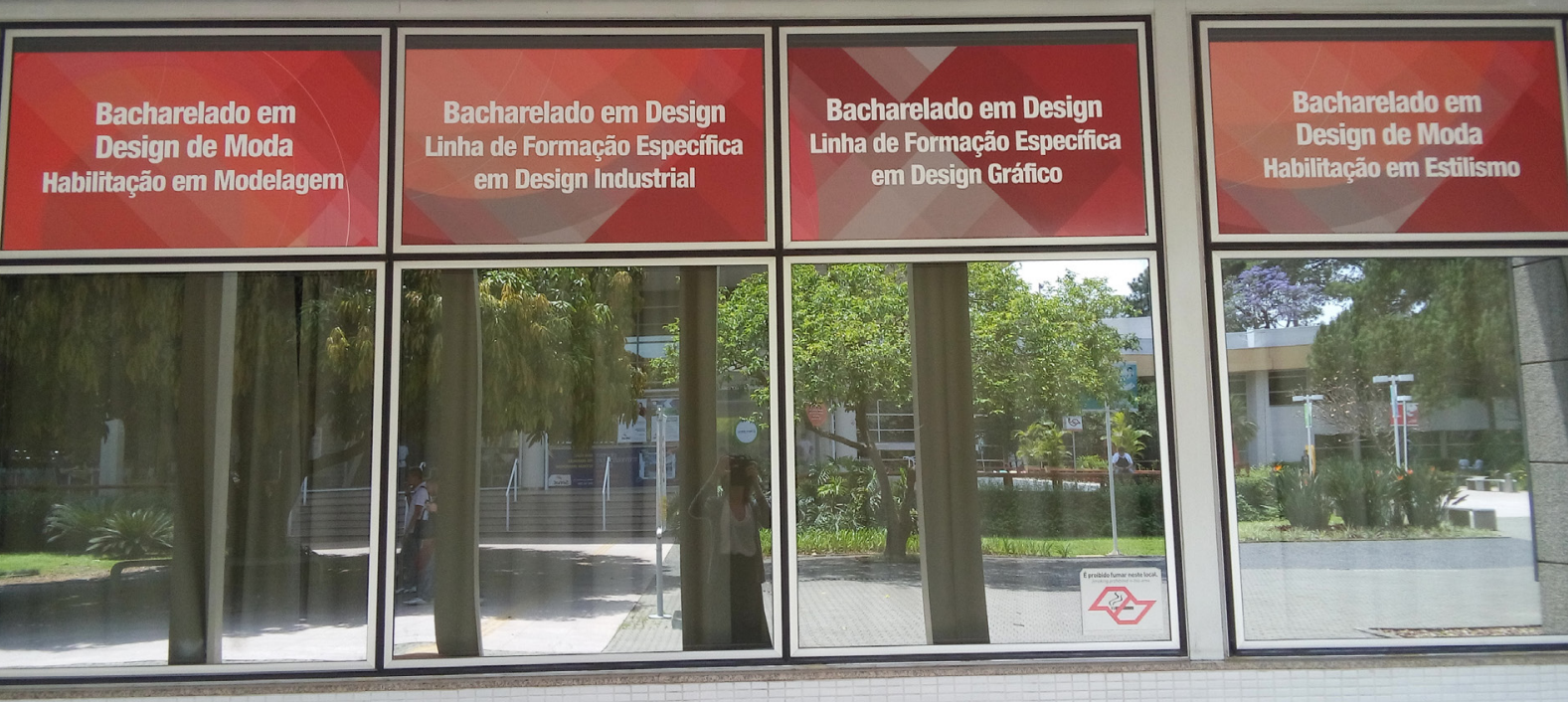

Diante da sugestão de transformar os cursos superiores de moda em cursos de "Tecnologia em Design de Moda", o design recuou em relação a encampar a moda e assim, passaria a oferecer somente o que MEC chama de "linhas de formação", não constando mais em suas nomenclaturas oficiais a "habilitação específica" (SOUZA; NEIRA; BASTIAN, 2010). O que se observa na prática é que as "habilitações específicas" ainda eram oferecidas recentemente. A seguir, a foto de publicidade de uma instituição utiliza o termo "habilitação" em 2015.

Passando a existir somente cursos de "Tecnologia em Design de Moda", esses cursos perderiam tempo de horas/aulas se comparados aos cursos de quatro anos. Haveria menos aulas de projeto em moda, como já acontece em instituições paulistanas. Esse é um problema que diz respeito ao reconhecimento das noções de estilismo e projeto em moda, que estão diretamente ligadas ao reconhecimento dos formatos dos cursos.

Enquanto a situação no exterior é de maior flexibilidade curricular, o que permite a expansão e o encadeamento do ensino no setor, no Brasil, pelo contrário, o que se observa são bacharelados generalistas e a acentuação da redução de carga horária (SOUZA; NEIRA; BASTIAN, 2010).

A adaptação dos cursos de Design de Moda às diretrizes do Design levou à diminuição da carga horária de disciplinas específicas em moda, poi para contemplar conteúdos de design há cursos que eliminaram horas de mão de conteúdos de moda para contemplar os do design.

\subsection{Observações sobre etapas de estilismo e projeto em moda publicadas nos artigos do colóquio de moda e no P\&D design}

A essa altura, interessa avaliar o emprego das etapas de projeto em moda a partir do olhar dos autores, que publicaram artigos acadêmicos no Colóquio de Moda e no P\&D. A apropriação das teorias de projeto é guiada pelas suas experiências em sala de aula ou pesquisa. Buscou-se, dentro do possível, manter a ordem em que as etapas acontecem, conforme apresentadas na revisão de literatura feita no Capítulo 1 desta tese, pois os artigos analisados baseiam-se nos autores estudados.

Por vezes o presente texto não se refere somente a artigos pertencentes ao seu recorte geográfico, o eixo Rio-São Paulo, em função da boa qualidade de trabalhos publicados por outros polos que merecem ser estudados a fim de contribuir com a pesquisa. Além disso, foram incluídos excertos do livro "Pesquisa e formação em moda", organizado por Maria de Fátima de Mattos (2015), pois ele conta com capítulos escritos por autores que publicam no Colóquio de Moda e P\&D. 
Entre eles está Joana Cunha (in MATTOS, 2015, pag. 186), que comenta sua prática de projeto em sala de aula: "os projetos são desenhados em torno de um problema que articule conceitos tratados nas várias unidades curriculares que compõem o semestre, onde 0 aluno aprende experimentando." Para Cunha, uma estrutura de projeto pouco definida favorece a exploração de múltiplas soluções, e levam o aluno a assumir responsabilidades que o tornam mais autônomo.

Nesse processo de ensino de projeto ensejado por Cunha (in MATTOS, 2015, pag. 186; 195), o modelo é ativo e participativo, de forma que os alunos pesquisam e levam para a sala o resultado da coleta realizada, partilhando as informações entre a equipe, como acontece nas empresas, pois uma coleção é um trabalho de autoria coletiva e não de membros individuais.

Esse ambiente proporcionado por Joana Cunha, no qual o aluno pesquisa e leva para a sala de aula o material encontrado e o compartilha com os colegas, se assemelha ao mercado de trabalho que encontrará assim que se graduar.

Treze etapas de desenvolvimento delineiam a metodologia utilizada na disciplina de Planejamento de Coleção do Centro Universitário do IPA, da Universidade Metodista de Porto Alegre, Rio Grande do Sul. Entre elas estão: escolha de marca no mercado; estudo do público; estação do ano; tema de inspiração e tendências; cronograma e mix de produtos; criação; aprovação dos modelos; modelagem; ficha técnica e de pilotagem; pilotagem; aprovação da peça-piloto; fichas técnicas; produção das peças (PICOLI, 2011).

Nessa metodologia a ideia de um problema aparece dividida em componentes, tomando como referência Bruno Munari (2008). Após detectar o problema é realizada a coleta de dados, em que são levantados os elementos do design de seis marcas concorrentes, os quais serão posteriormente analisados: cores, formas, texturas, repetições, matériaprima [observados sob os] princípios de design (PICOLI, 2011).

Após tratar os dados sobre as marcas escolhidas, os alunos fazem um painel de público-alvo e montam um banco de dados com imagens tendo por base os princípios do design. Depois buscam materiais e montam outro painel com os tecidos e aviamentos no sketchbook, contemplando todos os elementos do design. Sketchbook é o caderno onde as informações coletadas são registradas, preferencialmente, por meio de trabalho manual (PICOLI, 2011).

A disciplina Pesquisa e Criação do Senac de Pernambuco também utiliza um caderno para registro de pesquisa. E a partir da projeção de páginas de seus cadernos de pesquisas individuais que os alunos apresentam seu processo criativo à sala (VASCONCELOS; BORGIANI, 2016).

O conceito do tema é trabalhado após a pesquisa de tema e tendências e é apresentado por meio de um vídeo no IPA de Porto Alegre. Após o conceito do tema, os alunos desenvolvem um painel de conexões cruzando os dados coletados até o momento. Esse painel é como um mapa mental do conceito. A partir desse mapa são criados outros três painéis de inspiração para o apoio ao processo criativo (PICOLI, 2011).
A capacidade de interpretação de tendências e adaptação de um conceito de moda que dêem a um produto significado, são algumas das questões típicas da prática profissional de projeto em moda (CUNHA in MATTOS, 2015, pág. 195)

"O designer de moda não deve encarar a pesquisa como um processo temporário" (TREPTOW, 2003 apud CRISTÓFOLI; MAYER, 2008), ou seja, a pesquisa é um processo contínuo, assim como a revisão do briefing. A metodologia de Picoli tende a estimular a revisão das informações coletadas por meio da construção de vários painéis.

O termo moodboard aparece para indicar painel de tendências no texto de Horn e Meyer (2012) a partir de Treptow (2007), mas a autora, Doris Treptow, não utiliza o termo moodboard em seu livro. $O$ painel serve para documentação e visualização de elementos da pesquisa durante 0 desenvolvimento da coleção.

Os suportes usados por Picoli (2011) para documentação da pesquisa e do processo criativo são o vídeo e o sketchbook, além dos painéis.

A disciplina de Design do Vestuário do curso de Design e Marketing de Moda da Universidade do Minho, de Guimarães, Portugal, propõe exercícios de painel e moulage. Estas são consideradas "técnicas já existentes e utilizadas na prática do design [adaptados] para o universo do fashion designer", segundo Broega e Mazzotti (2015), mas se sabe que essas práticas são trabalhadas, pelo menos nos cursos de Moda no Brasil desde sua fundação sem ter, necessariamente, a interferência do design.

A síntese dos processos desenvolvidos por Patrícia de Mello Souza (in MATTOS, 2015, pág. 216), voltam-se principalmente à moulage e dizem respeito à silhueta, aos recursos ou técnicas aplicados nas silhuetas, à experimentação com materiais distintos a fim de se estruturar ou desestruturar a silhueta de acordo com o caimento percebido.

Mais comum ao campo do design, a Técnica 635 é citada em artigo de Marcos Braga (1994) como parte da sequência técnica de desenvolvimento de projeto no design de produtos.

dealizado por Warfield, a Técnica 635 consiste em seis pessoas que se reúnem em torno de uma mesa para gerar ideias sobre uma questão anteriormente levantada. É dado a cada uma delas uma folha em branco. Cada participante escreve de forma concisa três ideias dentro de cinco minutos. $\mathrm{Na}$ sequência, deve passar sua folha para outro participante e receber outra folha que já vem com ideias anteriores (TÉCNICA MÉTODO 635),

As ideias recebidas devem ser lidas para servir de fonte de inspiração para três novas ideias. Ao completar seis rodadas de cinco minutos em que todas as folhas tenham circulado ordenadamente, e somente uma vez para cada um dos participantes, haverá dezoito ideias em cada folha e cento e oito ideias no total. E normal que hajam ideias repetidas, especialmente no início de cada folha (TÉCNICA METODO 635). 
Uma variante da Técnica 635 é a Brainwriting desenvolvida pelo Instituto Battelle, que permite $o$ anonimato de quem escreve, não limita o número de participantes nem de ideias ou tempo de cada rodada e o resultado é parecido. A Técnica 635 parece mais simples e mais fácil de controlar do que o Brainwriting, sendo igualmente eficaz (TÉCNICA MÉTODO 635).

A técnica do Brainwriting 635 é aplicada já na primeira aula da disciplina Pesquisa e Criação do Senac de Pernambuco. Ela é utilizada como uma "ferramenta criativa baseada no brainstorming" na busca de soluções "para problemas de projeto por meio de uma equipe multidisciplinar contando com o apoio de um formulário" (PAZMINO, 2015, p. 216 apud VASCONCELOS; BORGIANE, 2016).

Sobre a cartela de cores aparecem duas formas de organização das cores nos artigos estudados. Uma que divide as cores em básicas e experimentais de acordo com Sorger e Udale (2009 apud HORN; MEYER, 2012) e outra que a separa em cores essenciais, centrais e fashion. Esta última coincide com a organização das cores na cartela apresentada no Capítulo 2 desta tese por Camarena e Higa, da FASM e Senac, respectivamente, a qual se divide em cores dominantes ou básicas, intermediárias ou complementares e fashion.

No desenvolvimento de coleção de Picoli (2011), os alunos escolhem alguns elementos do tema e dois ou três princípios do design. Em seguida, eles montam a cartela de cores a partir das tendências e painéis de inspiração, também chamados de painéis temáticos ou conceituais, segundo Sorger e Udale (2009 apud PICOLI, 2011). A cartela de cores é feita no sketchbook e pode haver também bordados e estampas.

A cartela de cores no processo de Simões e Waechter (2010) surge do painel e do conceito, mas para Treptow (2005) e Jones (2005), autoras utilizadas por Simões e Waechter, a cartela de cores surge junto com a pesquisa de materiais.

Há um exemplo de compra de tecidos em que Horn e Meyer (2012) citam a compra de treze cores diferentes para a produção de uma coleção de vestuário. Dependendo do porte da empresa, no caso de pequenas e médias confecções, é difícil consumir os rolos de tecido adquiridos, se forem compradas mais do que cinco variantes de cores. Isso pode gerar prejuízo por ter tecido pago que está parado na confecção e por gerar estoque.

Além das cores, é preciso considerar caimento, peso e textura dos materiais (ANDRADE; PEREIRA; LANDIM, 2014), pois "noventa por cento da superfície do corpo humano encontra-se, frequentemente, coberta por produtos do vestuário" (GASI, 2010 apud ANDRADE; PEREIRA; LANDIM, 2014).

A questão material envolve o toque, que é um dos primeiros contatos humano com o mundo exterior. $O$ vestuário é um produto que tem muita demanda e precisa ser bem projetado para adequar-se às necessidades humanas. Esses fatores reforçam a importância de discutir as fases de projeto em moda.

O texto trabalha a seleção dos tecidos durante a geração de alternativas (ANDRADE et al., 2014). Geralmente o campo da moda trabalha essa etapa ocorre antes, durante a pesquisa de materiais. Claro que materiais são revistos a todo o momento, devido à escassez, aos lançamentos e às Modas passageiras, mas o mais comum é que a pesquisa de tecidos e aviamentos seja realizada antes da criação dos desenhos, que equivale à geração de alternativas até certo ponto.

Ainda é possível relacionar a abordagem da escolha de materiais à fase de produção de ideias de Löbach (2001), quando se busca a maior quantidade possível de opções para a solução de um problema onde o tecido é parte da solução. A fase de produção de ideias também pode ser entendida como o momento em que se desenha a coleção.

Após pensar no problema e elencar ideias, a segunda etapa para Broega e Mazzotti (2015) é explorar materiais por meio da moulage e gerar "múltiplas alternativas" com ajuda de registro fotográfico e montagem e desmontagem da peça para o estudo de novas formas para atingir o resultado almejado (BROEGA; MAZZOTTI, 2015). Esse exercício se aproxima da "fotomontagem dos registros de moulage" proposto por Seivewright (2009, p. 121) que foi explorado no Capítulo 1 desta tese.

O importante do artigo de Andrade, Pereira e Landim (2014) é que ele avalia três metodologias de projeto em moda na etapa "seleção de matériaprima". Dentre as três autoras que tiveram suas metodologias analisadas, duas delas foram entrevistadas para esta tese, Maria Celeste de Fátima Sanches, também citada como Montemezzo (2003) e Cláudia Garcia Vicentini (2010), além de Suzana Barreto Martins.

Uma brevíssima revisão das três autoras elencadas por Andrade et al. (2014) permite compreender que Montemezzo (2003) é mais voltada ao desenvolvimento de produtos de moda no âmbito acadêmico e defende a selecão de materiais têxteis na delimitação conceitual. Vicentini (2010 apud ANDRADE et al., 2014) é mais voltada à indústria e Martins (2008 apud ANDRADE et al., 2014) volta-se para a ergonomia, por meio da metodologia Oikos.

O planejamento, o delineamento do problema e a delimitação conceitual do produto consideram a seleção de materiais têxteis. No refinamento, após a geração e seleção de alternativas, é feita a substituição de tecidos quando necessária, para, posteriormente atingir a etapa da realização, quanto são feitas as últimas correções nos produtos (MONTEMEZZO, 2003 apud ANDRADE et al., 2014).

Para Vicentini (2010 apud ANDRADE et al.,2014), o projeto se inicia pelo estudo de viabilidades pesquisando entre outros aspectos os materiais nos concorrentes. Nessa fase "a seleção eficaz de um tecido pode ser parte da solução do problema, quando não o principal fator". Novamente, assim como aparece no livro de Löbach (2001), aparece a ideia de que o tecido seria um dos pontos para a solução do problema.

As abordagens de Montemezzo e Vicentini coincidem até certo ponto.

As peças pilotadas têm seu desempenho testado para possíveis ajustes e revisão de componentes, matérias-primas e processos de fabricação. $O$ conforto e usabilidade são testados entre as análises. Eles têm relação direta com a matéria-prima (VICENTINI, 2010 apud ANDRADE et al, 2014). 
Na metodologia Oikos a ênfase está em detectar problemas na concepção do produto para atender às demandas dos usuários por meio da transferência de tecnologia. Entre as demandas estão acondicionamento, mobilidade, manutenção e segurança. É, sobretudo, uma metodologia de avaliação de peças de vestuário (MARTINS, 2008 apud ANDRADE et al., 2014).

$\mathrm{O}$ exame da metodologia de projeto em moda do ponto de vista das autoras Montemezzo (2003), Jones (2005) e Treptow (2005) mostra que é preciso mais maleabilidade das metodologias de criação (SIMÕES; WAETCHER, 2010)

As três metodologias são avaliadas a partir do seguinte ponto de vista: Montemezzo (2003) dirige-se mais ao ambiente acadêmico, Jones (2005) ao estilista e designer que produz uma coleção e vende e Treptow (2005) apresenta uma visão do profissional de moda que é funcionário em uma empresa (SIMÕES; WAECHTER, 2010).

A visão de Simões e Waechter (2010) sobre a metodologia de Montemezzo coincide com a de Andrade et al. (2014). Segundo esses autores Montemezzo dirige sua fala ao ambiente acadêmico.

Outro artigo, publicado por Troncoso e Teixeira (2012) sobre o estado da arte em desenvolvimento de produtos para moda, faz um levantamento da bibliografia atual que teoriza sobre o desenvolvimento de produtos, design, processos, métodos ou projetos. Para isso consideram-se as obras de VincentRicard (1989), Jones (2005), Treptow (2005) e Sorger e Udale (2009).

Tanto a pesquisa de Simões e Waetcher (2010) quanto as de Troncoso Teixeira (2012) e Wolff et al. (2012) elencaram as noções de projeto de Jone (2005) e Treptow (2005; 2007). Dois artigos com resultados de pesquis sobre projeto em moda, de Andrade, Pereira e Landim (2014) e Simões e Waetcher (2012) também elencaram uma autora em comum, Montemezzo (2003). Não se trata de mera coincidência, mas de aderência dos trabalhos científicos citados.

O cruzamento de diferentes publicações esclareceu que quando Treptow (2005; 2007) propõe o Cronograma e o briefing, Montemezzo (2003) suger a confecção do painel de imagens de Jones (2005) e o painel de públicoalvo (SIMÕES; WAECHTER, 2010).

No Mix de Produtos, Montemezzo (2003) sugere calcular a quantidade de peças, e identificar a variedade de estilos de cada peça de vestuário que irá compor a coleção entre: básicos, fashion e vanguarda. Essa etapa equivale ao Mix de Produtos de Treptow (2005). Simões e Waechter (2010) apresentam uma tabela que mescla a variedade de produtos (função, comprimento, volume etc) e o Mix de Moda (variedade de estilos).

O painel imagético estaria entre as últimas atividades para Treptow (2005) e entre as primeiras para Montemezzo (2003) de acordo com artigo de Simões e Waechter (2010). Por constituírem momentos tão distintos do projeto em moda, resta saber se esses painéis se equivalem.
Para Simões e Waechter (2010) o conceito estaria relacionado ao públicoalvo, o que para Jones (2005) é tratado como uma fonte de pesquisa. Treptow (2005) sugere para o conceito a confecção de um painel.

A metodologia de Treptow (2007) é dividida em sete fases, segundo Wolff et al. (2012). São elas: planejamento, cronograma, mix de produtos (ou parâmetro da coleção ${ }^{38}$ ), dimensão da coleção, pesquisa, desenvolvimento (desenhos técnicos e modelagens) e realização (das peças-pilotos).

Também é composta por sete etapas a metodologia de Andrea Barcaro (2008): portfólio das coleções (análise de marcas), sistematização das coleções (mix de produtos), cronograma operacional, desenvolvimento de coleção (lado criativo), revisão das redes de distribuição e mostra das coleções, campanha de vendas e produção e compra (com recebimento e teste do produto final) e entrega da coleção pronta (WOLFF et al., 2012)

Nove etapas ilustram a metodologia proposta por Joana Cunha (in MATTOS, 2015, pag. 194): segmentação de mercado, escolha do públicoalvo, seleção da tendência de moda que guiará a coleção, conceito de coleção, planejamento e desenvolvimento de coleção, prototipagem, planejamento e gestão de produção, desenvolvimento dos materiais técnicos e de imagem da coleção e suportes para sua divulgação.

Percebe-se no resumo das etapas de projeto em moda propostas por Cunha forte ênfase no conceito de coleção.

As etapas descritas por cada autor evidenciam que atividades similares nem sempre estão situadas no mesmo momento do projeto (WOLFF et al., 2012). Apesar de as metodologias de Treptow (2007) e Barcaro (2008) apresentarem o mesmo número de fases, elas não têm necessariamente uma equivalência, seja como tarefa especificamente, seja na ordem em que elas ocorrem.

Sorger e Udale (2009) possuem metodologia mais simplificada, dividida em três partes. $O$ processo inclui: a pesquisa de tendências; desenvolvimento que é composto pelos desenhos e esboços, pesquisa de tecidos e aviamentos, modelagens e confecção das peças-pilotos; 0 lançamento que conta com a demonstração e venda da coleção (WOLFF et al., 2012).

De acordo com Wolff et al. (2012), os autores mais citados pelas professoras da UNIRITTER e Centro Universitário IPA ao Sul do país são Baxter (2000), Treptow (2007), Jones (2005), Sorger e Udale (2009), Romero Filho (2009) e Munari (2008).

Na fase inicial dos cursos de moda no Brasil, os livros sobre projeto eram escassos. Uma obra que foi muito utilizada na década de 1990 foi a de Vincent-Ricard (1989), que consistia em trazer racionalização à indústria encontrar conceitos capazes de integrar criação e método. As diretrizes de Vincent-Ricard (1989) concentram-se nas cores, tecidos, formas e mercado o tempo de cada uma dessas etapas dentro do desenvolvimento da cadeia têxtil (TRONCOSO; TEIXEIRA, 2012).
38 Parâmetro de coleção é momento em que é
feito Mix de Produtos. O Mix de Produtos define a variedade de produtos
oferecidos e pode ser oferecidos e pode ser
distribuído de acordo com o uso: moda casual, trajes para surf ou por linhas de produto que
é a divisão entre tops, bottons e acessórios
(TREPTOW, 2013, p. 95) 
O ciclo de Jones (2005) é divido em duas partes por Troncoso e Teixeira (2012), e consiste no desenvolvimento de tecidos e criação de moda com foco no consumidor e na inovação. As fases propostas por Jones (2005) são: definir temporada, desenhar, planejar as linhas, confeccionar as peçaspiloto e vender. $O$ processo criativo se configura à medida que as pesquisa de tendências, cores e tecidos são desenvolvidas. Na sequência, são criados os protótipos que dependem doscroquis, tecidos, mateinis econhecimento dos processos (TRONCOSO; TEIXEIRA, 2012).

No mesmo artigo de Troncoso e Teixeira (2012) aparece outra subdivisão possivel da metodologia de Jones resumida em sete etapas, a saber: briefing, painel de criação, croquis e storyboard, peça-piloto, produção, distibu e avaliação crítica (TRONCOSO; TEIXEIRA, 2012).

A metodologia de projeto de Jones (2005) é descrita por Wolff et al. (2012) em apenas cinco etapas: briefing, desenvolvimento, custeio, gerenciamento de tempo e apresentação.

Apesar das diferenças sobre o método de Jones (2005) encontradas entre as abordagens de Troncoso e Teixeira (2012) e Wolff et al. (2012), ambos dão alguma ênfase ao briefing. Wolff et al. (2012) destacam o briefing como uma atividade que se justifica por si mesma, enquanto Troncoso e Teixeira (2012) definem que ele estabelece as condições e parâmetros que se deve seguir "[...] o título, as tarefas, as metas, os objetivos do projeto e a estação ou evento".

As etapas apontadas na metodologia de Treptow (2005) por Troncoso e Teixeira (2012) são: a reunião de planejamento, cronograma da coleção, parâmetros de coleção, dimensão de coleção, pesquisa de tendências, painel de criação, em que podem ser visualizados: o conceito, desenhos, modelagem, pilotagem, alterações, fichas técnicas, mostruário, lançamento da coleção, vendas e feedback (TRONCOSO; TEIXEIRA, 2012).

As análises feitas sobre a metodologia de Treptow por Troncoso e Teixeira (2012) e Wolff et al. (2012) guardam bastante semelhança entre si, em detrimento daquela realizada por Simões e Waetcher (2010).

Sorger e Udale (2009) definem primeiro público, gênero e o tipo de vestuário a ser criado. As tarefas são pesquisa, desenhos técnicos detalhando (TRONCOSO; TEIXEIRA, 2012)

Pesquisa e planejamento também marcam a metodologia de Elinor e Colin Renfrew (2010). Após o briefing, é realizada a pesquisa de tema consumidor, são criados painéis de inspiração e conceituais com amostras de tecidos, desenhos, peças-chaves da coleção, modelagem, peças-piloto e mostruário. As cores são apresentadas aos compradores de empresas antes de as peças serem pilotadas. Esses compradores geralmente compram look e não a peça avulsa. Assim, na edição, trabalha-se refinando os looks. O estilista nessa metodologia é responsável pela direção e gestão de todo o processo. Após a distribuição, peças bem-sucedidas em termos comerciais são repetidas novamente (TRONCOSO; TEIXEIRA, 2012).

No caso descrito acima, a geração de alternativas se estende ao Plano de Coleção ou Mapa de Coleção, por meio da escolha e desenvolvimento de peças que irão compor os looks, não se restringindo ao design de peças.
É preciso fazer sistematicamente a avaliação das coleções anteriores (PIRES, 2004). Nesse sentido, a proposta de avaliação comercial de peça que Renfrew e Renfrew (2010) propõem coincide até certo ponto com a indicação de Pires, pois, para esta autora, a Academia tem o papel de "formar indivíduos capazes de conciliar a cultura do produto com a orientação do mercado", saber gerenciar a criatividade em diferentes níveis de produtos $e$ contextos (PIRES, 2004). Mendes (2016) também indica a realização de um "inventário interno" no Capítulo 2 que tem função análoga.

Por último, balizando-se por diretrizes sustentáveis, Ruthschilling e Anicet (2014) propõem um modelo de metodologia composto pelas seguintes etapas: seleção de materiais, interação com artesãos, produção, informação interagindo com o consumidor, ferramentas online de participação do cliente, cuidados pós-venda e descarte do vestuário.

Outra fase abordada pelas metodologias é a criação. Apesar de mais voltado à subjetividade, o processo criativo exige disciplina e um convergência com os métodos que têm a responsabilidade de explicitar, demonstrar, organizar, unir os dados e definir o conceito. A criatividade depende da manipulação entre conhecimento e experiência (MACIEL, 2011).

A ideia tende a surgir em um momento em que o projetista não está conscientemente ocupado com o problema (TSCHIMMEL, 2011 apud BROEGA; MAZZOTTI, 2015). Essa atividade de pesquisa, seguida de descanso mental, pode deflagrar a solução ao separar a fase analítica da criativa, conforme enuncia Löbach (2007, p. 153).

A criação está intimamente ligada à geração de alternativas para Montemezzo (2003) e segundo Treptow (2005) e Jones (2005), está associada à inspiração (SIMÕES; WAECHTER, 2010).

$\mathrm{Na}$ fase da criação, muitos croquis são desenhados e é feita a seleção de alternativas que, no caso de uma coleção pequena, é composta por cerca de vinte looks (PICOLI, 2011). A autora sugere ainda que, em seguida, os alunos costurem dois looks.

Outra forma de pensar a criação seria considerar formas, volumes, texturas, portadoras de paradigmas ético-estéticos. É fundamental pensar em soluções formais que atendam às demandas de uma existência cada vez mais complexa e paradoxal (PRECIOSA; HAGEDORN, 2006).

Para o professor é interessante observar o caminho percorrido por cada aluno, e como decorreu o processo criativo de cada um (BROEGA; MAZZOTTI, 2015), pois o modo de criar, desenvolver e produzir roupas dentro do sistema da moda pressupõe uma construção, uma trajetória para se elaborar um método (MERLO; NAVALON, 2010).

Muitas vezes, é mais proveitoso observar o processo de projetação, pois ele oferece mais informação a respeito do método do que o produto ja configurado.

O caminho ou trajetória implicam em uma escolha de quem projeta, influenciado pelas necessidades de um projeto e como esse indivíduo as enxerga. A partir da mistura de fases de metodologias distintas, ou pela 
troca de sequências entre elas, despontam novas formas de ver e utilizar as metodologias que deflagram um processo. Tão importante quanto conhecer as etapas que compõem um método é saber interpretá-lo de acordo com o problema ou contexto dado.

A aplicação do conteúdo de metodologia possibilita uma maio organização e um melhor aproveitamento durante o trabalho. Há uma deficiência quanto às metodologias específicas para a área de moda que atenda aos alunos, aos professores e ao mercado ao mesmo tempo. Portanto, percebe-se a necessidade de uma revisão de determinados procedimentos sobre a abordagem nas disciplinas de projeto, em nível teórico e prático. "A busca por um método mais ajustado em relação aos passos que se vai cumprir [...] deve ser alvo de pesquisas mais aprofundadas [...]" (WOLFF et al., 2012).

As balizas metodológicas do campo do design de moda ainda parecem pouco fundamentadas. "Cabe à academia o desenvolvimento de pesquisas a fim de fundamentar a metodologia e a prática profissional do designer de moda" (MORAIS, 2006).

A despeito de como Treptow (2005; 2007), Jones (2005), Barcaro (2008), Sorger e Udale (2009), Montemezzo (2003) etc tratem as partes que compõem suas próprias metodologias, há certa apropriação de outras pesquisas por parte dos pesquisadores que aplicam e pesquisam tais metodologias no Brasil. Eles tendem a buscar como resultado de suas pesquisas tornar as metodologias mais claras, a partir de suas experiências no ensino e na pesquisa. Esse é um traço marcante dos artigos analisados neste Capítulo.

Deve-se pensar em formas de projetar dentro das que já se encontram em uso, de forma a preservar a produção de subjetividade, que é um traço marcante da produção de artigos de moda, e não domesticá-las sob o espectro de metodologias dogmatizantes, que estão mais ocupadas em prever o uso dos objetos.

\subsection{Considerações sobre}

Não se aprende efetivamente metodologia de design em faculdades de moda e, quando isso acontece, ela não atende às especificidades da moda. O assunto é tabu, e em muitas faculdades não é conversado abertamente. O exame dos artigos tornou clara uma suspeita que há tempos ronda esta tese. Há uma cisão clara entre professores de estilismo ou projeto em moda em

Os docentes que abordam em seus artigos o tema "projeto de produto", seja na teoria ou na prática, mostram, em geral, que tal metodologia não acompanha as necessidades da área da moda. Os jargões não são mesmos e, por vezes, percebe-se que há uma tentativa de tentar forçar o objeto moda nas teorias e práticas do design. Essa "abrangência" do campo do design por vezes anula as especificidades do campo do design de moda e a contribuição se perde.

As malfadadas experiências do ENADE em 2006 e 2009 em oferecer uma prova de aptidão aos cursos superiores em moda são conhecidas. Na segunda vez em que $\mathrm{o}$ exame foi oferecido, pensou-se em transformar os cursos superiores em moda no Brasil, que já tinham cerca de vinte anos, em cursos tecnológicos, aparentemente sem qualquer fundamento mais profundo, além da justificativa de haver muitos perfis de cursos de moda no país, o que tornaria difícil a implantação de uma política de desenvolvimento industrial.

O distanciamento do campo do design das questões simbólicas e a aproximação com a funcionalidade racional rendeu à área um status de seriedade. $O$ design ostenta uma imagem de campo mais coesa que a moda, pois, de fato se formalizou há mais tempo, mas ele conquistou tal implantação de uma política de desenvolvimento industrial? Ao que se sabe não.

E parece coerente pensar que a estratégia do design ao encampar outras "linhas de formação" como moda, interiores, games, embalagens e outras supostas habilitações do design, a despeito das especificidades desses campos, fortaleceria o design como um campo perante o MEC na busca por políticas de reconhecimento, mesmo que isso arriscasse a identidade dessas outras ditas "linhas de formação".

A indicação da mudança para cursos tecnológicos foi sugerida por especialistas, em sua maioria designers, mas segundo documento do MEC, cabe a cada curso com base em suas características "adotar a denominação que julgar mais pertinente, dentre as opções disponiveis [... e] adaptar a matriz curricular" (SOUZA; NEIRA; BASTIAN, 2010).

Como uma instituição pode adotar a denominação que julgar mais pertinente para $o$ seu curso se a mudança sugerida baseava-se em transformar todos os cursos em "Tecnologia em Design de Moda"? Se a escolha fosse livre, não haveria problemas quanto à diversidade de nomes. Ao adaptarem sua matriz curricular ao design, os cursos de moda seriam rebaixados, pois precisariam se tornar tecnológicos. Se a possibilidade de escolher o nome para o curso é real, é interessante manter, assim como foram mantidos, os cursos superiores em moda que já contam com décadas de ensino e pesquisa.

Talvez a fiscalização flexível e a falta de clareza nos posicionamentos do MEC sejam alguns dos aspectos que ainda fazem com que não haja uma imposição efetiva para que os cursos de moda se convertam em cursos tecnológicos nem tenham que trocar seus nomes.

Os textos de pesquisadores brasileiros que se dedicam ao tema do projeto em moda usam mais comumente a divisão em sete fases. É o que foi observado nos artigos de Wolff et al. (2012), Troncoso e Teixeira (2012) e Ruthschilling e Anicet (2014) que abordam as metodologias de Treptow, Barcaro e Jones. 
O distanciamento da moda em relação ao campo do design pode ser amenizado com o "conhecimento de métodos específicos para a área de moda" (WOLFF et al., 2012). O receio do distanciamento da moda em relação ao design parece ser o que norteia a busca por um método que respeite as especificidades do desenvolvimento do produto de moda. $\mathrm{O}$ design, pelo contrário, deve entrar em cena a fim de oferecer métodos que reforcem a identidade do design de moda, colaborando para o aperfeiçoamento de ambos os campos e não para manter a área da moda mais próxima ao design.

Quando Wolff et al. (2012) afirmam que há "métodos específicos para a área de moda", fica subentendido que a metodologia do campo do design gráfico e de produtos não atende plenamente à configuração dos produtos de moda.

Por outro lado, seria difícil universalizar acepções relativas à projetação, previsão do uso do produto e delimitações mais rigorosas dos papéis dos cursos de moda e design, se for tomado por base o conceito de cultura multilinear que designa que não existe somente uma cultura, mas sim linhas diferentes de desenvolvimento cultural (BARNARD, 2003 apud NAVALON, 2007).

O conceito de cultura multilinear pode ser usado para pensar as diferentes origens dos cursos de design de moda no Brasil, respeitando as diferentes bases ideológicas que os engendraram, seus desenvolvimentos e consequências. Passaria a importar menos se a discussão é sobre estilismo

Em uma leitura atenta dos artigos do Colóquio de Moda e do P\&D é flagrante a falta de aprofundamento e entendimento sobre a área de produção do vestuário em moda por parte do campo do design.

Há certa pressão social para a unanimidade (WOLFF et al., 2012) em discussões em grupo. Seria o caso de acreditar que, invariavelmente, as metodologias de design bastam para atender ao campo da criação e desenvolvimento de produtos de moda.

Essa pressão é sentida no pensamento de Fornasier, Martins e Demarchi (2008 apud WOLFF et al. 2012) que afirmam que no design, o método norteia a solução a ser encontrada e, as áreas de design gráfico e de produto seriam as que mais se aproximam do campo da moda em termos de método.

A não utilização de metodologias de projeto banalizaria a área de moda, "afastando estes profissionais da origem do design" (WOLFF et al., 2012). A moda não teve sua origem no design, e afirmar que ela precisa se filiar ao método do design para não ser banalizada não parece fazer sentido. $A$ atividade de pesquisa, criação e desenvolvimento de produto em vestuário já se encontrava reconhecida como área acadêmica muito antes do design encampá-la, e não há evidências de que se tornou melhor depois disso. 


\section{REFERÊNCIAS
DOCAPITULO}

ANDRADE, Raquel R.; PEREIRA, Livia M.; LANDIM, Paula da Cruz. Processo de seleção de materiais e o desenvolvimento projetual do vestuário. In: COLÓQUIO DE MODA, 10. 2014, Caxias do Sul. Anais... Caxias do Sul: Universidade de Caxias do Sul, 2014.

BENDER, Ana. Design de moda: intersecções no processo de projeto. In: COLÓQUIO DE MODA, 6., 2010, São Paulo. Anais... São Paulo: Universidade Anhembi Morumbi, 2010.

BONADIO, Maria Claudia. A Rhodia têxtil e a "criação da moda nacional". In: COLÓQUIO DE MODA, 2., 2006, Salvador. Anais... Salvador: UNIFACS, 2006.

BOURDIEU, Pierre; DELSAUT, Yvette. 0 costureiro e sua grife: contribuição para uma teoria da magia. Trad. Maria da Graça Jacintho Setton. In: Educação em Revista, Belo Horizonte, n. 34, p. 7-66, dez. 2001. Disponível em: <http://docslide.com.br/documents/ bourdieu-o-costureiro-e-sua-grife.html>. Acesso em: 30 jul. 2016.

BRAGA, Marcos da Costa. Projeto cabide. In: CONGRESSO BRASILEIRO DE PESQUISA E DESENVOLVIMENTO EM DESIGN, P\&D DESIGN, 1.,1994, São Paulo. Anais... São Paulo: UNIP/AEnD BR, 1994.

BROEGA, Ana C.; MAZZOTTI, Karla.

Metodologias facilitadoras da criatividade em design de moda: uma experiência acadêmica. In: COLOQUIO DE MODA, 11.,2015, Curitiba. Anais... Curitiba: Universidade Positivo, 2015.

CAMARGO, Cariane W.; MEDEIROS, Lígia. Disciplinas de projeto: o desafio de ensinar a desenvolver produtos de moda. In: COLÓQUIO DE MODA, 8., 2012, Rio de Janeiro. Anais... Rio de Janeiro: SENAI/CETIQT, 2012
CHRISTO, Deborah Chagas. Designer de moda ou estilista? Pequena reflexão sobre a relação entre noções e valores do campo da arte, do design e da moda. In: COLÓQUIO DE MODA, 2., 2006, Salvador. Anais... Salvador: UNIFACS, 2006.

. Designer de moda: construtor de significados. In: CONGRESSO BRASILEIRO DE PESQUISA E DESENVOLVIMENTO EM DESIGN, P\&D DESIGN, 8, 2008, São Paulo. Anais São Paulo: Centro Universita Anais... São Paulo: Centro Universi

CHRISTO, Deborah Chagas; CIPINIUK, Alberto. Reflexões sobre epistemologia do design enfocando o design de moda. In: COLÓQUIO DE MODA, 6., 2010, São Paulo. Anais... São Paulo: Universidade Anhembi Morumbi, 2010.

CHRISTO, Deborah Chagas; SABRÁ, Flávio G. Caminada. Moda e design ou design é moda: análise da relação entre design, moda e metodologia de projeto. In: COLÓQUIO DE MODA, 12., 2016, João Pessoa. Anais... João Pesso: Campus do Centro Universitário de João Pessoa (Unipê), 2016.

CRISTOFÓLI, Amanda C.; MAYER, Bruna. A importância da pesquisa como primeira etapa para um projeto de desenvolvimento de design e moda. In: COLÓQUIO DE MODA, 4., 2008, Novo Hamburgo. Anais... Novo Hamburgo: Feevale, 2008

\section{DURAND, José Carlos. Moda, luxo e}

economia. São Paulo: Babel Cultural, 1988.

GILBERTO JÚNIOR. Livro revive as

apresentações grandiosas da Rhodia na Fenit, nos anos 60. O Globo, 21 mar. 2015. Disponíve em: <http://oglobo.globo.com/ela/moda/livrorevive-as-apresentacoes-grandiosas-da-rhodia na-fenit-nos-anos-60-16948509>. Acesso em: 2016.
HORN, Bibiana S.; MEYER, Guilherme C. O uso de metodologia de projeto no desenvolvimento de coleção de moda. In: COLÓQUIO DE MODA, 8., 2012, Rio de Janeiro. Anais... Rio de Janeiro: SENAI/CETIQT, 2012.

LEON, Ethel. Design em exposição: o design no Museu de Arte Moderna no Rio de Janeiro (1968-1978), na Federação das Indústrias de São Paulo (1978-1984) e no Museu da Casa Brasileira (1986-2002) 195 p. (Tese) - Faculdade de Arquitetura São Paulo, São Paulo, 2012.

LÖBACH, Bernd. Design Industrial - Bases para a configuração dos produtos industriais. São Paulo: Editora Blucher, 2007.

MACIEL, Dulce M. H. Métodos e criatividade. A influência do uso de métodos no processo de criação. In: COLÓQUIO DE MODA, 7.,2011, Maringá. Anais...Maringá: Universidade CESUMAR, 2011.

MERLO, Márcia; NAVALON, Eloize. Processos projetuais para a criação em design de moda: pesquisas teóricas e referenciais In: CONGRESSO BRASILEIRO DE PESQUISA EDESENVOLVIMEN E DESENV Paulo: Universidade Anhembi Morumbi, 2010.

MONTEMEZZO, Maria Celeste de Fátima Sanches. Diretrizes metodológicas para projeto de produtos de moda no âmbito acadêmico. 97 f. (Dissertação de Mestrado) - Universidade Estadual Paulista, Faculdade de Arquitetura, Artes e Comunicação, 2003. Disponível em: <http://hdl.handle. net/11449/97020>.

MORAIS, Michael Medeiros. Reflexões metodológicas sobre o design de moda. In: CONGRESSO BRASILEIRO DE PESQUISA EDESENVOLVIMENTO EM DESIGN P\&D DESIGN, 7., 2006, Curitiba. Anais... Curitiba: UnicenP, 2006.
MOREIRA Bruna R - CAMARGO, Cariane W.; SOARES, Luciana B.; GIONGO, Marina A. A relevância da multidimensionalidade das disciplinas de projeto na graduação em moda. In: COLÓQUIO DE MODA, 10., 2014, Caxias do Sul. Anais... Caxias do Sul: Universidade de Caxias do Sul, 2014.

MOURA, Mônica. A moda entre a arte e o design. In: PIRES, D.B. Design de moda: olhares diversos. Barueri, SP: Estação das Letras e Cores, 2008. p. 37-73.

NAVALON, Eloize. Corpo, cultura e percepções reflexões para um método de design de mod In: COLÓQUIO DE MODA, 3.,2007, Belo Horizonte. Anais... Belo Horizonte: Faculdade CIMO, 2007.

PICOLI, Julia. Metodologia projetual no ensino do desenvolvimento de coleções. In: COLÓQUIO DE MODA, 7.,2011, Maringá. Anais. Maringá: Universidade CESUMAR, 2011.

PIRES, Dorotéia Baduy O desenvolvimento de produtos de moda: uma atividade multidisciplinar. In: CONGRESSO BRASILEIRO DE PESQUISA E DESENVOLVIMENTO EM DESIGN, P\&D DESIGN, 6.,2004, São Paulo. Anais... São Paulo: FAAP; AEnD/BR, 2004.

PRECIOSA, Rosane S.; HAGEDORN, Adriane. Notas sobre o design de moda e suas práticas experimentais In: CONGRESSO BRASILEIRO DE PESQUISA E DESENVOLVIMENTO EM DESIGN,P\&D DESIGN, 7., 2006, Curitiba. Anais... Curitiba: UnicenP, 2006.

RUTHSCHILLING, Evelise A.; ANICET, Anne. Estudo para construção de metodologia de design de moda sustentável. In: CONGRESSO BRASILEIRO DE PESQUISA CONGRESO BRASURO DE PESQUISA DESIGN, 11., 2014, Gramado. Anais... Gramado: UFRGS; UNISINOS; UNIRITTER, 2014.

SEIVEWRIGHT, Simon. Fundamentos de design de moda: Pesquisa e Design. Porto Alegre: Bookman, 2009. 
SIMÕES, Danielle S.; WAECHTER, Hans da Nóbrega. Procedimentos metodológicos para criação de coleções para o polo de confecções do Agreste do Pernambuco. In: CONGRESSO BRASILEIRO DE PESQUISA E DESENVOLVIMENTO EM DESIGN, P\&D DESIGN, 9., 2010, São Paulo. Anais... São Paulo: Universidade Anhembi Morumbi, 2010 SOUZA, Cyntia S. Malaguti de; HARDAGH, Cláudia Coelho. Problematizando o design de moda - o papel da disciplina metodologi de projeto. In: CONGRESSO BRASILEIRO DE PESQUISA E DESENVOLVIMENTO EM DESIGN, P\&D DESIGN, 8., 2008, São Paulo. Anais... São Paulo: Centro Universitário Senac (campus Santo Amaro), 2008.

SOUZA, Cyntia S. Malaguti de; NEIRA, Luz Garcia; BASTIAN, Winnie. Regulação do ensino do design de moda - para quem? In: CONGRESSO BRASILEIRO DE PESQUISA E DESENVOLVIMENTO EM DESIGN, P\&D DESIGN, 9., 2010, São Paulo. Anais... São Paulo: Universidade Anhembi Morumbi, 2010.

TÉCNICA MÉTODO 635. Disponível em: <http://www.innovaforum.com/tecnica/ meto635_e.htm>.Acesso em: 29 mar. 2017.

TREPTOW, Doris. Inventando moda:

planejamento de coleção. 5. ed. São Paulo: Edição da Autora, 2013.

TRONCOSO, Samira M.; TEIXEIRA, Fábio G. Estado da arte: desenvolvimento de produto para a moda. In: CONGRESSO BRASILEIRO DE PESQUISA E DESENVOLVIMENTO EM DESIGN, P\&D DESIGN, 10., 2012, São Luís do Maranhão. Anais... São Luís do Maranhão: Universidade Federal do Maranhão, 2012.

VASCONCELOS, Camila B.; BORGIANI, Danielle S. S. Ensino de pesquisa e criação em moda: uma abordagem aplicada. In: COLÓQUIO DE MODA, 12., 2016, João Pessoa. Anais... João Pessoa: Campus do Centro Universitário de João Pessoa (Unipê), 2016.
WOLFF, Fabiane; KUNZLER, Lizandra; PRATI, Marina; NASCIMENTO, Júlia. Metodologia de projeto em design de moda: perspectivas teóricas e práticas. In: CONGRESSO BRASILEIRO DE PESQUISA E DESENVOLVIMENTO EM DESIGN, P\&D DESIGN, 10., 2012, São Luís do Maranhão. Anais... São Luís do Maranhão: Universidade Federal do Maranhão, 2012.

\section{FONTES DAS ENTREVISTAS}

CHRISTO, Deborah. Entrevista realizada com Deborah Christo, em 21 de outubro de 2015, na cidade do Rio de Janeiro, com 1 hora e 46 minutos de duração.

MENDES, Francisca Dantas. Entrevista realizada com Francisca Dantas Mendes, em 29 de junho de 2016, na cidade de São Paulo, com hora 47 minutos de duração. 


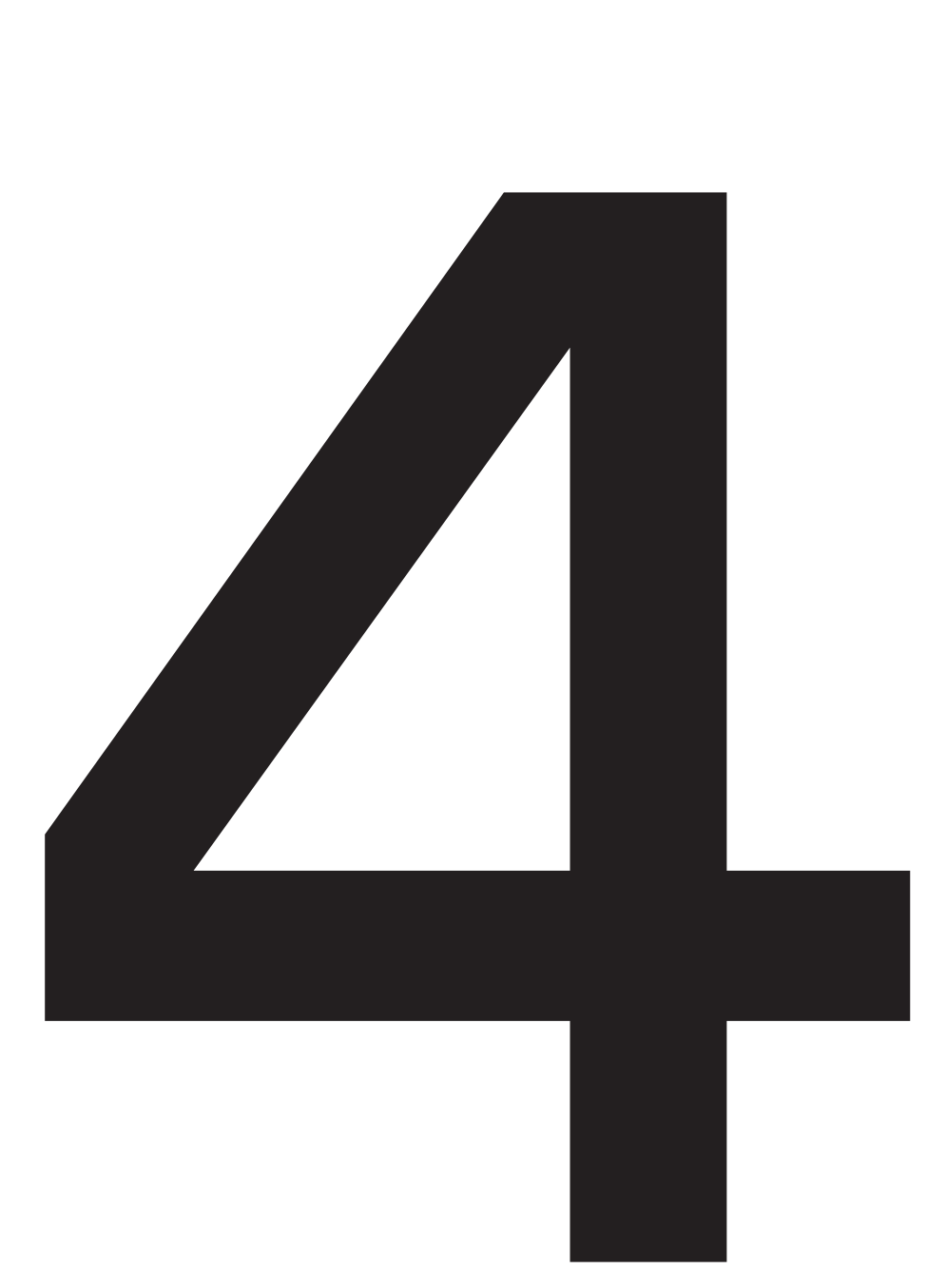

Nas agências de fomento como se vinculam as áreas de moda e design na FAPESP, CAPES e CNPq 
A partir da coleta de depoimentos de coordenadores de área que respondem pelo campo do Design, buscou-se compreender como a área de Moda está inserida dentro das agências de fomento FAPESP (Fundação de Amparo à Pesquisa do Estado de São Paulo), CAPES (Coordenação de Aperfeiçoamento de Pessoal de Nível Superior)

e CNPq (Conselho Nacional de Desenvolvimento Científico e Tecnológico) e como elas funcionam. Para essas agências, o campo da Moda faz parte da área do Design que, em linhas gerais, tem a possibilidade de pertencer às grandes áreas de Ciências Sociais Aplicadas, que se desdobra em Arquitetura e Urbanismo, Engenharia ou Inovação quando o assunto é projetação em moda. 
Neste Capítulo, foram entrevistados Luiz Henrique Lopes dos Santos, coordenador adjunto da grande área de Ciências Humanas e Sociais da FAPESP, à qual está subordinada a área de Arquitetura e Urbanismo que responde por Design e Moda; Ricardo Triska, coordenador da área de Arquitetura e Urbanismo da CAPES; e Eugenio Andrés Diaz Merino, coordenador da área de Des relaciona os entrevistados.

\begin{tabular}{ll}
$\begin{array}{l}\text { Eugenio Andrés } \\
\text { Diaz Merino }\end{array}$ & $\begin{array}{l}\text { Membro da Coordenação do Programa de } \\
\text { Capacitação Tecnológica e Competitividade } \\
\text { (COCTC) da área de Desenho Industrial do CNPq. }\end{array}$ \\
\hline Luiz Henrique & $\begin{array}{l}\text { Coordenador adjunto da grande área de Ciências } \\
\text { Humanas e Sociais, do Programa de Mídia }\end{array}$ \\
$\begin{array}{l}\text { Ciência (Jornalismo Científico) e coordenador } \\
\text { ceentífico da revista Pesquisa FAPESP. Tem } \\
\text { trabalhos nas áreas de lógica, filosofia da lógica, } \\
\text { filosofia da linguagem e história da filosofia. }\end{array}$ \\
\hline Ricardo Triska & $\begin{array}{l}\text { Coordenador de área Arquitetura e Urbanismo } \\
\text { da CAPES. Essa área engloba a área de design } \\
\text { de moda nessa agência de fomento. }\end{array}$ \\
\hline
\end{tabular}

Como inúmeros pioneiros entrevistados no Capítulo 2 também contribuem na avaliação de projetos fornecendo pareceres a pedido dessas agências de fomento, em alguns momentos seus pontos de vista foram cruzados com os dos coordenadores de área das agências.

Quando o coordenador de área recebe um processo, ele o lê e indica um assessor externo para fazer a análise. É a natureza do projeto que determina em que área este será classificado, já que sua localização não é rígida. $O$ coordenador de área tem autonomia para indicar que o projeto seja avaliado por outra área, caso entenda que não diz respeito à sua (SANTOS, 2016).

A FAPESP segue a classificação geral do CNPq, mas não de forma rígida. Luiz Henrique Lopes dos Santos afirma que, em princípio, Desenho Industrial está na área de Coordenação de Arquitetura e Urbanismo.

Na FAPESP, pelo fato de a área de Arquitetura e Urbanismo não tem um volume muito grande de pedidos, costuma-se contar com dois coordenadore de área. O critério de seleção de escolha de um parecerista ad hoc é baseado na grade do CNPq inicialmente. Então, para Desenho Industrial, com ênfase ou linha de formação em Desenho de Produto, o código de área seria 6.12.02.00-2 (TABELA..., 2017) tomando por base a tabela do CNPq. Existe uma área intitulada "Outros", com código 9.00.00.00-5, onde está alocada a área de Desenho de Moda sob o código 9.10.00.00-9, e assim por diante.
$\mathrm{Na}$ CAPES a área de Moda está vinculada à área do Design que, por sua vez, está associado à Arquitetura e ao Urbanismo, assim como na FAPESP. Ricardo Triska (2016) comenta que não há um documento que esclareça o porquê da inclusão dos campos da Moda e do Design dentro da área de Arquitetura e Urbanismo. Quando o Design foi incorporado pelo Sistema Nacional de Pós-Graduação, foi vinculado à Arquitetura e Urbanismo, e "enfim, funciona assim há 20 anos", afirma Triska (2016).

Mônica Moura e Lílian Lago (in MATTOS, 2015, pag. 60) reforçam que os cursos e programas de Pós-graduação em Design no Brasil, que respondem pela Pós-graduação em Moda, pertencem à grande área de conhecimento intitulada Ciências Sociais Aplicadas, e à área de avaliação de Arquitetura e Urbanismo.

Os cursos de Pós-graduação têm por objetivo formar recursos humanos de alto nível para o avanço da produção de conhecimento. O funcionamento desses cursos é regulamentado e fiscalizado pela CAPES (MOURA e LAGO in: MATTOS, 2015, pag. 60)

Até 2017 o Brasil conta com um único curso de mestrado voltado ao campo da moda chamado Têxtil e Moda, sediado na EACHUSP em São Paulo. Existiu um outro "curso de mestrado na cidade de São Paulo, que foi descontinuado por motivos políticos da instituição que o sediava" (MOURA e LAGO in MATTOS, 2015, pag. 60). Esse outro curso a que as autoras se referem era o mestrado em "Moda, Cultura e Arte" do SENACSP, que funcionou entre 2005 e 2010

No campo do Design, os pioneiros foram os mestrados acadêmicos da PUCRJ de 1994 e da UNESP no campus de Bauru, São Paulo, entre os anos de 1995 e 1999. Essas também foram as instituições que obtiveram o credenciamento para a implantação dos dois primeiros cursos de Doutorado em Design, formando assim os primeiros Programas e Pós-graduação em Design. Atualmente existem vinte e oito cursos de Pós-graduação em Design, sendo quinze mestrados acadêmicos, nove doutorados e quatro mestrados profissionais. É importante destacar que "em todos os cursos e programas de pós-graduação em design existe o desenvolvimento de pesquisas na área de moda a partir de diversas vertentes" e que, atualmente, existem seis grupos de pesquisa em design de moda credenciados no CNPq (MOURA e LAGO in MATTOS, 2015, pag. 60).

A CAPES possui na verdade duas subáreas, Arquitetura e Urbanismo e Design. $O$ design hoje representa $34,6 \%$ do total de programas de stricto sensu nas áreas de arquitetura, urbanismo e design, o que é muito impactante segundo Triska (2016).

O CNPq funciona de forma diferente. $O$ Design hoje está alocado em uma área denominada atualmente como "Tecnológica". A associação com tecnologia acontece, pois, historicamente, a nomenclatura Desenho Industrial está conectada com tecnologia, processo, método, materiais e questões quantitativas (MERINO, 2016). 
O Design saiu do colegiado de Engenharia, o que para o Design é uma maravilha, porque os designers ficavam disputando as mesmas bolsas das cotas das engenharias, com "Crithos de ferroho [...] entáo eu imagino que daqui a uns dois anos a gente possa começar
com outros ares dentro do design no CNPq" (TRISKA, 2016).

O Desenho Industrial no CNPq responde por todas as áreas do Design, das mais tradicionais como Produto e Gráfico às mais novas ou contemporâneas que "o design vem desenvolvendo" como a Moda (MERINO, 2016).

Algumas manifestações de fundo um pouco mais artístico vinculadas à Moda acabam transitando por outras áreas como as Artes. Áreas que se relacionam mais com a parte visual acabam se vinculando a área de Artes Visuais. O que não está circunscrito por aspectos ligados à tecnologia acaba por gerar um espaço de identificação maior com a área das Artes Visuais, entre outras (MERINO, 2016).

Quando um projeto enviado ao CNPq escapa à logica da tecnologia e de processo associada ao campo do Desenho Industrial, ele automaticamente é enviado a outro campo que não o Design. Um projeto de Design de Moda pode não ser alocado dentro da área de Desenho Industrial caso não se restrinja aos aspectos do Desenho Industrial dentro da área "Tecnológica" do CNPq.

\subsection{Avaliação da submissão e distribuição de recursos por área}

O pedido submetido à FAPESP chega para a coordenação de área, que é um conjunto de pessoas que têm diferentes especialidades. Com base na especialidade, elas recebem os processos e indicam um assessor externo para fazer a análise. A FAPESP não avalia nada internamente. Toda avaliação . (SANTOS, 2016).

A coordenação de área indica a pessoa mais capaz de analisar aquele projeto, que por sua vez emite um parecer. Internamente, a FAPESP faz o controle de qualidade para avaliar se o parecer faz jus ao projeto. Às vezes um projeto é avaliado como muito ruim porque não tem metodologia e quando é conferido percebe-se que ele tem metodologia apropriada. Então, se o parecer está contraditório, outro assessor é designado (SANTOS, 2016).

Quem confere a coerência do parecer com o projeto é a coordenação de área, em primeira instância, e se houver discrepância há uma reconsideração. A reconsideração é conceder ou negar o que foi pedido. Além da coordenação de área, existe um segundo controle de qualidade feito pelos coordenadores adjuntos (SANTOS, 2016).
Os adjuntos controlam a qualidade das duas instâncias, coordenação de área e assessoria externa e, em seguida, fazem uma recomendação. Por último, o próprio diretor científico olha os projetos e se alguma coisa parece estranha ele devolve para a coordenação adjunta. Na FAPESP são quatro instâncias avaliando as submissões: assessor externo, coordenação de área, coordenação adjunta e o diretor científico (SANTOS, 2016).

No CNPq, antes de o projeto chegar até a Coordenação de Área de Desenho Industrial, chamada de $\mathrm{CA} / \mathrm{DI}$, a qual designará os pareceristas por meio de um sistema, o processo de pedido de fomento passa por uma equipe técnica interna que revisa todo o processo para conferir se constam todas as informações necessárias para sua avaliação e se o projeto, a proposta, atende aos requisitos do edital. Todos os processos que chegam por meio dos editais são analisados pela CA/DI do CNPq (MERINO, 2016).

O parecer feito pela equipe técnica designa se o projeto está "enquadrado" ou "não enquadrado". Mesmo com o parecer anterior da equipe técnica, a CA/DI avalia todos os processos porque pode existir algum erro. Então, quando aparece um "não enquadrado", o técnico sinaliza anteriormente o item no qual ele não se enquadra, por exemplo, "ele não se enquadra no item 3.5", para facilitar o trabalho da CA/DI (MERINO, 2016).

No caso da CAPES os pareceristas ou consultores escolhidos para avaliar os projetos submetidos, têm de ser de um estado diferente do qual o projeto foi enviado. Triska (2016) justifica essa opção pelo fato de instituições sediadas em um mesmo estado possuírem laços muito estreitos, o que pode gerar conflito de interesses entre o projeto submetido e os avaliadores.

A maneira ideal de análise de projetos começa com o coordenador de área. Na CAPES, quando a escolha dos pareceristas externos que irão avaliar determinado projeto submetido é responsabilidade do coordenador de área, este envia o projeto a ser analisado a consultores que tenham aderência à área na qual o projeto foi submetido. Havia um aplicativo na CAPES que possuía um elenco de consultores e, a partir daí, eram selecionados quatro consultores para avaliar cada projeto de acordo com a identidade temática de cada parecerista. (TRISKA, 2016)

Essa forma de avaliação de bolsas deu lugar, na gestão anterior da Coordenação de Area, a uma seleção de pareceristas pelo CNPq e não trouxe bons resultados (TRISKA, 2016). Atualmente, a área do Design está pleiteando que a responsabilidade de atribuição de pareceres volte para o coordenador de área na CAPES (TRISKA, 2017).

No momento em que um projeto chega ao $\mathrm{CNPq}$, um sistema muito robusto que tem um banco de consultores é acessado. O CNPq é rigoroso na indicação de pareceristas. Eles são contatados por meio de um sistema inteligente que dispara mensagens para um, dois ou três avaliadores para cada projeto dependendo da demanda. Em geral, um projeto é avaliado por, no mínimo, dois pareceristas. Quando o avaliador recebe um projeto, inicia-se um processo de análise em que ele é orientado a verificar se esse projeto se enquadra na sua área, se o pesquisador avaliado tem experiência no assunto etc (MERINO, 2016). 
Se, por ventura, acontecer algum imprevisto, uma equipe no CNPq que cuida das áreas de Engenharia faz a interface com os membros das áreas especiais que foram designados em um primeiro momento para analisar os processos. Além deles, outros professores podem ser contatados para ajudar (MERINO, 2016).

Em caso de necessidade, Triska recorre a um terceiro, quarto ou quinto parecerista. Na CAPES, um projeto vai para, pelo menos, três pareceristas. Só que, em geral, só um responde, esse é que é o problema. "Nossos colegas não respondem. Acabo tendo resposta de vinte professores dentre todos os professores de design" (TRISKA, 2016).

Na FAPESP, Luiz Henrique Santos faz a análise de projeto em sua área de especialidade. Mesmo assim,

Eu posso achar o projeto um lixo. Se o assessor diz que é bom, não importa a minha opinião pessoal. É delicado, certo? Então nem na minha área, nem na área da minha especialidade eu dou opiniâo (SANTOS, 2016).

Questionar pareceres com os quais não se concorda parece ser mais natural para Ricardo Triska (2016), da CAPES. Ele afirma que se um parecer de um projeto que ele julga péssimo vier positivo, ele questiona. A justificativa para tal interferência é que, no final da análise dos processos, ele será responsabilizado de qualquer maneira. Então, se o projeto é fraco e o parecer é bom, ele vai querer saber qual é a relação do proponente com o tema etc (TRISKA, 2016).

Havendo discrepância na avaliação, Merino (2016) explica que aí entra o papel da Coordenação de Área (CA) constituída pelas pessoas responsáveis por analisar os pareceres. Nesse caso, é o CA/DI, ou seja, Coordenação de Área/Desenho Industrial.

No entendimento do CNPq, se houver diferenças entre os pareceres é feita uma revisão cautelosa e cabe a possibilidade de solicitar mais um parecerista, mas quem emite o parecer final é a CA/DI (MERINO, 2016).

Como apoio para gerar pareceres, o $\mathrm{CNPq}$ tem acesso a inúmeras informações. Entre elas, planilhas com dados sobre a produção científica do proponente, o histórico de petição, o projeto, entre outros documentos (MERINO, 2016).

Algumas áreas do conhecimento tradicionalmente recebem mais recursos que outras. É o caso de Saúde, que ficou com $27,9 \%$ de todo desembolso da FAPESP no ano de 2015, Biologia, com 14,9\%, Ciênncias respectivamente, com 8,6\% e 7,8\% (RELATÓRIO..., 2016).

No ano de 2015, 0,6\% do orçamento da FAPESP foi destinado à grande área de Arquitetura e Urbanismo, na qual a Moda, e por consequência, $O$ Projeto em Moda se inserem.
A FAPESP não tem controle sobre quanto desses $0,6 \%$ seriam destinados a pesquisas voltadas ao campo da Moda e ao tema Projeto em Moda. A classificação de cada projeto por área seria muito difícil em alguns casos, pois há projetos que transitam entre sociologia da moda, história da moda, entre outros campos, e possuem caráter interdisciplinar. Um mapeamento nesse nível de detalhe não é possível de acordo com Santos (2016).

A porcentagem de recursos da CAPES destinada à área de Arquitetura e Urbanismo não é do conhecimento de Ricardo Triska (2016).

\section{2 perfil das agências de fomento 4.2 os pedidos de apoio para projetos em moda e design}

A FAPESP é uma agência de fomento à pesquisa e não é uma agência de formação de pesquisadores, logo ela concede no máximo 35\% de seu orçamento total em bolsas. O restante, que corresponde a $65 \%$, é destinado aos auxílios, que são projetos de pesquisa que demandam equipamentos para laboratórios, transportes e diárias para fazer viagens de participação em eventos, publicação de livros e a vinda de pesquisadores visitantes de outros países. A premissa para existirem as bolsas da FAPESP é que se não houver pesquisador não há fomento à pesquisa, mas o foco da agência é a pesquisa e não o pesquisador. A CAPES, ao contrário, está voltada a formar pesquisadores (SANTOS, 2016).

O papel da CAPES não é financiar estrutura. Quem financia estrutura é o CNPq. A CAPES só dá a bolsa de qualificação para estudantes pesquisadores. A missão da CAPES é formar pessoas, então a relação que conta é a do programa de pós-graduação com a estrutura de qualificação da pessoa (TRISKA, 2016).

O CNPq por sua vez recebe pedidos de apoio a eventos, bolsas especiais, pós-doutorado, pesquisa, editais de fomento, edital específico de inovação (MERINO, 2016).

A FAPESP não favorece uma área em detrimento de outra. Os projetos escolhidos são os bons projetos. Então, a análise é feita com base em dois fatores principais: qualidade do projeto e currículo do pesquisador. Há dois tipos de destino para os recursos: os auxílios e as bolsas. Auxílios são os custos materiais da pesquisa. Bolsas são ajudas de custo que o pesquisador em formação recebe para fazer a sua formação e envolve Iniciação Científica, bolsas de Mestrado, Doutorado e Pós-doutorado (SANTOS, 2016).

Não há restrição a processos submetidos que vão de encontro à postura ideológica por parte do coordenador de área da CAPES. O que acontece é a priorização de um projeto em detrimento de outro em função do investimento de área. Um exemplo é quando o proponente não tem vínculo com nenhum programa de pós-graduação em design. Nesse caso, ele vai para o final da fila, "o que me parece natural", aponta Triska (2016). 
Em relação às verbas, o CNPq também acredita que é preciso atribuir prioridades. A contemplação com auxílios $\mathrm{e}$, em segundo plano, com bolsas acontece por mérito. $O$ projeto por si só não tem mérito intrínseco. $\bigcirc$ reconhecimento de seu valor deriva de uma série de fatores como 0 projeto, o currículo do pesquisador, entre outros. Esses elementos avaliados em conjunto geram uma classificação. A partir dessa classificação são atribuídas preferências chamadas de P1, P2, P3, onde P1 é superior a P2 e assim por diante (MERINO, 2016).

Assim que os processos são avaliados pelos pareceristas, é preciso classificar os projetos de acordo com a tabela do CNPq. Em seguida, entram em cena as comissões formadas por pelo menos três pessoas que se reúnem para ver e discutir todos os processos e atribuir graus de importância. Essas reuniões acontecem de acordo com os editais e nelas são tratados cerca de cem a duzentos processos dependendo do edital (MERINO, 2016).

As reuniões para definir quais projetos serão contemplados acontecem no prédio do CNPq em Brasília. Merino (2016) comenta sobre algumas que ocorreram em outubro de 2016: cada equipe tem sua sala. É oferecida uma boa condição de trabalho. $O$ governo custeia a ida desses pesquisadores. Essa é uma atividade que exige dedicação, pois toma o dia todo. Esses avaliadores chegam às oito horas da manhã e às vezes saem nove ou dez horas da noite. Essa dinâmica dura uma semana (MERINO, 2016).

O grande desafio nessas comissões é respeitar os editais, pois se qualquer tipo de preconceito influenciar um julgamento, seja com uma área, autor, abordagem ou com a própria proposta do edital, um processo pode ser prejudicado. Para o sistema todas as áreas são iguais. "Não é porque eu sou formado em design gráfico que não vou contemplar projetos em moda" (MERINO, 2016).

Como os projetos de pedidos de bolsa que se enquadram como bons superam os $35 \%$, dos quais a FAPESP dispõe para essa categoria, configurase uma dinâmica de competição por bolsas de estudo da FAPESP, enquanto na modalidade auxílios não há essa disputa. Santos $(2016)$ relata que a distribuição de auxílios nunca se pautou pela competição, pois em todas as áreas os bons pedidos recebem auxílio, ou seja, quem tem parecer favorável ganha, quem tem negativo não ganha, então não há competição por auxílios.

A sigla FAPESP significa Fundação de Amparo à Pesquisa do Estado de São Paulo, então, para receber um auxílio o pesquisador doutor precisa estar vinculado a uma instituição paulista.

A área de Arquitetura e Urbanismo, por tradição, não se encaixa completamente em nenhuma outra área de acordo com Santos (2016). É uma área que recebe projetos dentro da FAPESP com muitas variações. Há pedidos de arquitetura que se aproximam mais da área de Engenharia e se distanciam de Ciências Humanas. Há pesquisas sobre materiais em Arquitetura ou Design, então não dá para encaixar nem em Ciências Humanas nem em Engenharia. Assim, a área adquiriu um caráter fronteiriço.

Para a CAPES, o Design de Moda no contexto de Design é uma habilitação tanto quanto produto e não há qualquer restrição no trato, no conceito de design de moda como uma habilitação, uma especialidade do design (TRISKA, 2016). De qualquer forma, o que se percebe é o que o fomento destinado a projetos no campo do Design de Moda é muito menor se comparado a outras linhas de formação do Design, à Arquitetura ou a Engenharia.

Design de moda e seu ato projetual são vistos exclusivamente como uma competência do Design. E o que aproxima a Moda do Design é a Metodologia de Projeto. É a conduta projetual que caracteriza uma ação do Design de Moda, quando há uma relação entre objetivo, resultado e processo com uma conduta de investigação (TRISKA, 2016).

Talvez essa visão reforce o menor reconhecimento do Design de Moda no tocante a projetos contemplados com bolsas, uma vez que outras áreas do Design como Produto e Gráfico, tidas como mais tradicionais, portanto detentoras de maior capital simbólico, tendem a ditar as regras para áreas mais novas como a moda.

A produção científica dessas áreas mais antigas do design tende a ser reconhecida por seus pares de forma mais evidente, mantendo o interesse da área. Isso quer dizer que, se quem analisa, avalia projetos e fornece o fomento são pesquisadores do campo do design de produto, por exemplo, o olhar sempre será do método projetual, mesmo que tal atitude possa ser negligente em relação a especificidades do projeto em moda desfavorescendo essa última área.

O ponto de vista de Triska é reforçado por Merino, que também defende que o que aproxima um projeto de Design de Moda do Desenho Industrial é um aspecto mais conservador em observância aos métodos, prática projetual e sistemática do Design. No caso de uma manifestação mais artística e momentânea, esse tipo de projeto acaba por não se encaixar na área do Desenho Industrial, dadas suas diferenças em relação ao campo (MERINO, 2016).

É interessante refletir sobre o descrédito dado pela CAPES e CNPq ao estudo de produtos de moda sob o viés do estilismo, e mesmo a pouca atenção aos estudos voltados ao projeto em moda.

A quantidade de processos analisados pelo CNPq dá indícios da diferença entre as áreas. Merino propõe uma comparação entre as áreas de Engenharia e Desenho Industrial. Há editais que recebem trezentos projetos de Engenharia e somente dez de Desenho Industrial. Isso mostra a resistência do campo do Design em atender aos formatos exigidos dentro dos padrões de projetos, nas normas das agências. Até pela própria história, as áreas de Exatas possuem maior tradição na confecção de bons projetos (MERINO, 2016).

De qualquer forma, considerando-se que o Design de Moda se insere no campo do Design, até que ponto ele realmente está inserido como campo produtor de pesquisa, a ser contemplado com bolsas? Qual é o limite em adequar-se às exigências do campo do Design e não desconfigurar o Design de Moda como área científica? 
De acordo com Merino (2016), a moda surgiu nesse processo de estilo, de estilismo em que o profissional afirmava:

Ah, mas o ato projetual, a gente não segue uma metodologia, então a gente faz meio que insight. Tem uma metodologia que faz parte de nossa vida e do habitus que eu aprendi fazendo, aprendi com uma costureira, um modelista que e sensacional (MERINO, 2016.

Mas no final tem processo, tem metodologia mesmo que ela seja diferente. Não é da forma que o engenheiro faz, nem é a metodologia do desenho industrial, mais formalizada, mas o Design de Moda também precisa de metodologia (MERINO, 2016).

Merino reconhece que a moda tem sua própria metodologia. Cabe então às agências de fomento estimularem as pesquisas rumo a descobertas de tais processos e não restringir o número de bolsas do campo de Design de Moda.

O que se distancia do design e da metodologia projetual não pertence ao stricto sensu (TRISKA, 2016).

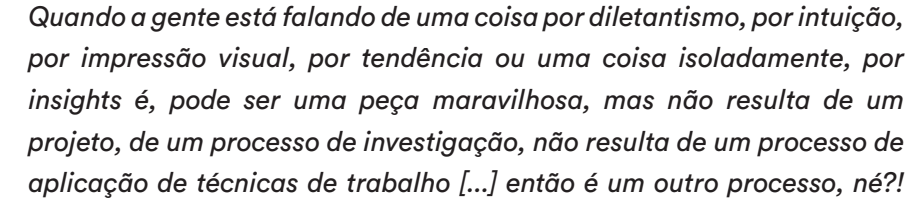

Ao ler atentamente esse depoimento fica claro que se é um "outro processo", é porque há processo fora da lógica do campo do Design de Produtos e do rigor da metodologia projetual. Em última instância, estilismo seria o nome da produção de artigos de moda que não se restringe unicamente à metodologia projetual do Design de Produtos. E como tal, esta não seria contemplada como área de pesquisa.

Para ter reconhecimento como pesquisa científica, o pesquisador tem de comprovar sua premissa por meio de aspectos objetivos, tais como $\circ$ caimento de determinada trama de tecido, sobre determinadas condições de corte e determinado tipo físico (TRISKA, 2016).

Há indícios de uma forma de projetar no Design de Moda, na fala de Triska. Dito de outra forma, independentemente de ser produção seriada ou uma única peça, o produto de moda deriva de uma investigação e de um processo de aplicação de técnicas de trabalho, e não se pode simplesmente dizer o contrário sem comprovação, até porque insights também são processos oriundos da incubação pós brainstorming ou Técnica 635, típicas do Design de Produtos. $O$ fato de as metodologias voltadas ao Design de Moda não estarem amadurecidas e publicadas por meio de pesquisas e livros não as torna inexistentes. E sobretudo, isso requer tempo e apoio das agências de fomento à pesquisa.
Há dois tipos de designers segundo Triska (2016): aqules formados em faculdades, e aqueles que "a vida transformou". Além desses dois tipos, estão:

\section{[.... os que não são nada, mas que usam o nome Design como sendo um escudo das suas incompetências. E nós queremos que o design seja uma condição de profissão qualificada. Então, essa é a razão de nós termos tanta preocupação em caracterizar o vínculo do design de moda com o} processo e o projeto (TRISKA, 2016).

A pergunta "falta reflexão intelectual sobre projeto em moda?" foi feita os três entrevistados: Santos, Triska e Merino. Santos (2016) é enfático ao afirmar que chegam poucos projetos sobre o tema moda à FAPESP.

Triska (2016), por sua vez, aponta que falta à área de moda uma percepção maior de momento e uma discussão sem paixão. Em sua opinião, é necessária uma avaliação da trajetória do campo da moda, para identificar pontualmente qual é o tipo de inserção que está sendo feita e desvincular isso de uma simples sustentação de mercado. Se é para falar de pesquisas que recebem fomento da CAPES fala-se em investigação científica stricto sensu, o que demanda mais reflexão.

Por fim, para Merino, chegam bons projetos ao CNPa sobre Design Design de Moda, mas falta reflexão aos campos. Principalmente porque a proliferação de todas as terminologias novas, aparentes métodos e ferramentas voltados principalmente ao design estratégico evidenciam a necessidade de retorno aos autores clássicos de Design que já falaram sobre isso. As pessoas acabaram perdendo um pouco o rumo (MERINO, 2016).

É fundamental que o campo da moda comprove por meio de uma trajetória consistente suas contribuições para o ensino e pesquisa em stricto sensu e isso levará à maturidade de área. Dentro da CAPES a área de Design nasceu dentro da Arquitetura e Urbanismo, desvinculada de engenharia, design que foi "pendurado" lá (TRISKA, 2016).

A fala de Triska dá a entender que a área de Moda precisa se provar como área produtora de conhecimento no campo da pesquisa de stricto sensu, por meio de contribuições efetivas e numerosas, antes de solicitar uma área para si, pois o campo do Design, que é tradicionalmente mais reconhecido nesse sentido, ainda está alocado em Arquitetura e Urbanismo.

m problema para o campo da moda tem sido a ausência de uma tradição crítica diante das pesquisas, mas também em relação à distribuição de bolsas de estudo por parte dos programas (McRobbie, 1998, p. 53).

Torna-se mais evidente que, pelo fato de o Design desfrutar de uma posição mais confortável por ser uma área mais antiga e tradicional que 0 campo da Moda, atualmente ainda é ele quem dita as regras no campo da pesquisa. E nesse caso, assim como o Design se resignou com sua posição à sombra da Arquitetura no campo acadêmico, a sugestão parece ser que a Moda aceite o mesmo em relação ao Design. 
Até 1998, a relativa ausência de teoria na educação em design de moda enfraquecia a posição da moda na Academia (McRobbie, 1998, p. 53). Hoje, apesar de o número de publicações ter aumentado, ainda não se observam grandes avanços em termos de concessão de aporte de pesquisa que beneficiem o campo da moda.

Reitera-se a necessidade de investimento e apoio das agências de pesquisa ao campo da Moda, ao invés de oferecer como única opção que esta se adapte às teorias do campo do Design de Produtos ou Design Gráfico, o que há tempos não vem se mostrando prolífico, tendo em vista que nem a qualidade nem o número de pesquisas de moda têm avançado significativamente.

\section{Os autores de projeto, 4.3 as especificidades do design de moda e o grupo moda como campo do saber}

Quando questionado se conhecia os autores de projeto estudados po esta tese no primeiro Capítulo (entre eles Munari, Löbach, Bomfim, Treptow, Jones, Renfrew e Renfrew, e Seivewright), o coordenador adjunto da FAPESP, Luiz Henrique Lopes dos Santos (2016) declarou que não fala sobre mérito ou conteúdo científico quando está representando a FAPESP. Esse papel cabe exclusivamente ao assessor ad hoc. Ele expõe seu desconforto diante do risco de má interpretação, o que poderia transmitir uma imagem equivocada de um suposto desconhecimento ao falar do trabalho de certos autores, ou demonstrar preconceito diante de certas obras.

Por sua vez, embora Triska (2016), coordenador da área de Design da CAPES, afirme que o que leva a recorrer a um grupo de autores seja o caminh do projeto, ele assume desconhecer autores de projeto em moda, tais como Treptow, Jones, Renfrew e Renfrew e Seivewright. Triska (2016) declara ainda não ser capaz de opinar quando o assunto são autores de projeto em moda.

O segmento de produto e visual de design, em termos de autores, conta com Munari, Bomfim e Löbach como "rota de fuga de qualquer projeto", pois são os livros que proporcionam certa condição de trabalho e para onde

Em relação ao grupo Moda enquanto campo do saber, Santos (2016) manteve o mesmo posicionamento quando questionado sobre os autores de projeto, ou seja, de que não fala sobre mérito ou conteúdo científico quando está representando a FAPESP.

O grupo Moda como campo do saber pode ser visto como um problema, considerando-se sua repercussão na Pós-graduação. No Sistema Naciona de Pós-graduação, a área Moda, por exemplo, não possui grandes trajetórias nem uma tradição (TRISKA, 2016). Triska acredita que o foco da preocupação deve ser outro:
Eu acho que antes de a gente se preocupar em ter dominio de área, nós temos que demonstrar competência de inserçacao social, competencia de inserção no mercado. Porque náo adín a su subir hum banquinho e gritar que eu quero uma area de moda. Eu quero dizer o que que isso comunidade que vai concorrer $a$ esses cursos (TRISKA, 2016).

Em algumas áreas irá existir mais produtividade; em outras como a moda, menos. Um dos fatores para adquirir reconhecimento é a qualidade e quantidade da produção científica. A grande questão é a moda se adequar às normas, se pautar por regras de convivio em relação às demais áreas, pois é preciso respeitar essas regras que são impostas a todos os campos. Só depois disso é possível tentar modificá-las. A moda precisa fazer um movimento para mostrar seu valor como campo, para depois adquiri condições de propor mudanças (MERINO, 2016). Merino ainda afirma que:

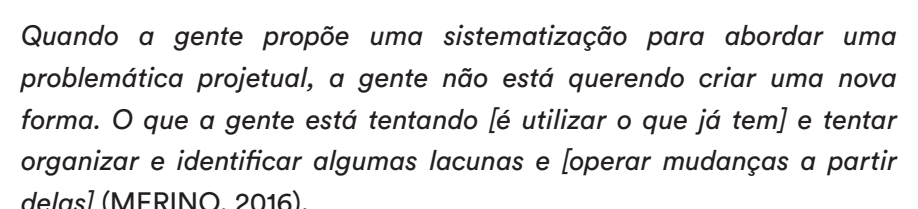
forma. O que a gente está tentando [é utilizar o que já tem] e tentar organizar e identificar algumas lacunas e loperar mudanças a partir

Entre os entrevistados, quem mais se aprofundou em destacar as diferenças entre Estilismo e Projeto em Moda foi Eugenio Merino (2016). Para ele, antes de 1998, a produção de objetos na área de moda se pautava pelo Estilismo, e esta era uma ação muitas vezes desprovida de um processo, ou caracterizava-se por ser um ato criativo, mais intuitivo.

O Estilismo ficou mais atrelado ao marco criativo, a algo menos projetual, enquanto o Design de Moda atribuiria à prática do Estilismo um caráter mais projetual, o que envolve processos sistemáticos e evolutivos de grau de complexidade maior (MERINO, 2016).

Na opinião de Merino, seria um avanço trabalhar em uma missão global, na qual os profissionais envolvidos com os campos de projetação do design e do de design de moda prestassem mais atenção a todos os aspectos que tangem à configuração de um produto, de forma conjunta. Destacam-se aqui os aspectos simbólico, estético e funcional. É preciso ponderar qual deles tem maior importância em cada momento de uso (MERINO, 2016).

A questão da personalidade do autor também interfere na projetação do produto de moda, mas as questões ergonômicas vinculadas ao conforto e à segurança devem ser priorizadas. Além disso, o bem-estar também se expressa por meio do conforto psicológico do usuário (MERINO, 2016).

Conforme já explorado no Capítulo 1, as funções prática, simbólica e estética devem ser contempladas em qualquer tipo de vestuário. A função ergonômica é imprescindível, mas é preciso atentar antes ao conforto psicológico, que está relacionado à adequação do usuário àquilo que ele usa (VICENTINI, 2016). 
A fala de Merino privilegia a questão funcional, em detrimento da visão de Vicentini, que valoriza primeiro a função psicológica. De qualquer forma, ambos os pesquisadores consideram que todas as funções, prática, simbólica e funcional, devem ser consideradas na configuração de um produto de moda.

O campo do Design defende um guia de orientação baseado em três blocos de referência, no que tange ao desenvolvimento de produto: o ser humano; o produto ou sistema ou serviço; e o contexto no qual eles estão inseridos (MERINO, 2016).

O contexto deve levar em conta o sentido dos objetos oferecidos a determinada comunidade, e se eles levam a uma melhoria efetiva da qualidade de vida dessas pessoas. Esse contexto depende do diálogo que se estabelece entre a cultura e o cotidiano dos usuários, de forma a proporcionar um envolvimento mais profundo e mais duradouro com os objetos projetados, para que estes se tornem expressões legítimas do público ao qual se destinam.

Para embasar o desenvolvimento de um produto nos três blocos de referência, deve-se analisar minuciosamente quem é esse ser humano e quais são suas necessidades, aprofundar-se na análise do produto ou serviço a ser oferecido, estudando casos já existentes, para gerar novas alternativas e o contexto. Esses três fatores precisam ser analisados segundo levantamentos e análises simbólicas e funcionais, para que o designer comece a gerar o seu processo projetual em cima dessas informações. A partir de uma pesquisa análise aprofundadas tem-se um guia, um norte (MERINO, 2016).

A reclamação de que o campo da Moda foi cooptado pelo Design é rebatida por Triska (2016), que afirma que "o campo da moda nem foi cooptado". O coordenador segue justificando que a chance de o campo da moda pertencer ao sistema de formalização de pesquisa é pela porta do design, porque assim é em todos os outros lugares, e volta a citar a tradição de que há mais de vinte anos a área de Arquitetura e Urbanismo responde por Design e o Design não demonstra incômodo com isso.

Uma analogia interessante seria a de que o campo da Moda está para o do Design como o do Design está para o das Engenharias dentro do CNPq (MERINO, 2016), ou seja, há uma hierarquização.

Apesar de parecer, entre outras razões, que o Design encampou a Moda visando endurecer o seu núcleo duro como polo de produção científica, a grande questão parece ser evitar ao máximo a forma intuitiva de produzir objetos de vestuário, substituindo-a pela noção de projeto do Design de Produtos. Merino (2016) também não acredita que o Design de Moda tenha sido absorvido pelo Design, mas vê, nessa iniciativa do Design, uma tentativa de fortalecer uma área do conhecimento como um todo, ou seja, a área projetual, em torno da qual, segundo ele, Design e Design de Moda orbitam.

Cada entrevistado expõe o ponto de vista que the parece mais coerente a respeito do seu campo. No caso dos diretores de área das agências de fomento entende-se que cada um pauta sua fala pela ideologia do design Mesmo que as perguntas feitas durante as entrevistas tenham levado à certa setorização, vale lembrar que muitos são os pontos convergentes e as misturas entre ambos os campos no tocante à projeto ao longo desta tese.

Como o design goza de maior visibilidade e, assim, "está um pouquinho melhor" que a moda, o Design de Moda poderia absorver as coisas positivas que o Design tem a oferecer. Além disso, o Design de Moda deveria enxergar os erros que o campo do Design cometeu, para não os repetir. Nesse processo, o Design de Moda tenderia a amadurecer enquanto ganharia tempo e experiência para, em um determinado momento, ganhar sua independência como campo autônomo (MERINO, 2016).

A tentativa de encaixar a Moda dentro da área do Design, com um formato pré-definido para a projetação, é um dos fatores que mais incomodam os profissionais de moda; entretanto, o campo do Design também precisou se encaixar em "algumas caixinhas para o convívio social", para que pudesse fazer parte do sistema. Quando uma área começa a mostrar seu desempenho, habilidades, competências, contribuições sociais e econômicas, daí possibilidade de abertura de seu campo se torna mais fácil (MERINO, 2016).

A possibilidade de um dia a moda ter um campo científico reconhecido está entre as possibilidades apontadas por Merino.

Áreas separadas, pequenas, tendem a se tornar muito frágeis e vulneráveis. É preciso existir um diálogo mais consistente para mostrar o valor da área de Moda, e a forma de construir esse diálogo com outros campos se dá por meio da produção acadêmica, dentro de determinadas diretrizes. Se o Design de Moda auxilia na melhoria da qualidade de vida das pessoas, isso deve ser comprovado por meio de uma produção formalizada de conhecimento, na forma de teses, dissertações e artigos, para que a área consiga obter o reconhecimento $\theta 0$ apoio políticas públicas (MERINO, 2016).

Um dos critérios de referência de qualidade de uma área é a quantidade de artigos científicos que ela publica em veículos relevantes. O Qualis CAPES é "um conjunto de procedimentos para a estratificação da qualidade da produção intelectual realizada a partir dos programas de pós-graduação brasileiros" que mede, por meio da Coleta de Dados, que se trata de um relatório que os cursos e programas de pós-graduação apresentam anualmente, o qual gera, por meio de avaliações trienais, uma análise do níve de qualidade das publicações, criando, por sua vez, uma lista classificatória dos periódicos que os cursos utilizam para a divulgação de sua produção científica (MOURA e LAGO in MATTOS, 2015, pag. 64).

Os periódicos que atendem às áreas de design e de moda estão distribuídos entre: design, design e arquitetura, moda, moda e design e áreas relacionadas como engenharia e comunicação. As revistas científicas voltadas ao campo da moda são lara: revista de moda, cultura e arte, Moda Palavra e Revista Dobras, sendo que esta última se dedica à inter-relação entre moda e design (MOURA e LAGO in MATTOS, 2015, pag. 64).

Sobre o estranhamento causado nos professores e pesquisadores de moda, desde 1998, quando o Design de Moda passa a responder por grande parte do campo da Moda, Triska (2016) entende isso como uma "briga por 
vaidade", onde alguém perdeu seu "feudo", mas, em sua opinião, caso as áreas sejam mantidas separadas, elas tenderiam a se descaracterizar.

Para Triska (2016), o design dá certa condição de competência à moda, por meio da noção de projeto. Daí, recorre-se à tradição do design para reforçar uma ação específica da moda, o que, como resultado, só pode ter um caminho virtuoso.

É interessante notar que as avaliações sobre o encampamento da moda por parte do design sempre são feitas do ponto de vista do design e não da moda, uma vez que quem está à frente da coordenação dessas agências de fomento, no que diz respeito ao campo da moda, são pesquisadores oriundos do campo do design. Sendo assim, estes exercem seu poder por meio de seu discurso. Desse modo, são deixadas de lado, ou tratadas como "vaidade", necessidades específicas do Design de Moda, as quais não são preenchidas pelo Design.

\subsection{Considerações finais sobre}

Há dois pontos sobre os quais a visão de Triska e Merino convergem. Um deles é que não há demérito algum em o campo do Design estar subordinado ao campo da Arquitetura e Urbanismo, ou de Engenharias ou Inovação. $O$ outro é que se as áreas pequenas se mantiverem isoladas, elas se tornariam frágeis e tenderiam a se descaracterizar.

Quanto ao fato de o Design e o Design de Moda estarem alocados no campo de Arquitetura e Urbanismo e Triska (2016) afirmar que "enfim, funciona assim há 20 anos", não existindo um porquê, percebe-se o desconhecimento sobre uma razão clara para o campo de Design e o próprio campo da Moda estarem atrelados à Arquitetura e Urbanismo por parte dos próprios diretores de área das principais agências de fomento do país. Embora não caiba nesta pesquisa, talvez seja tema de interesse de outro estudo se aprofundar nas relações entre as áreas, pois a divisão de recursos pode sofrer influência dos interesses de cada área e de seus representantes.

Quando Triska (2016) fala que Design de Moda é visto como uma habilitação do Design tanto quanto produto, vale lembrar que hoje o MEC defende as "linhas de formação" (conforme tratado no Capítulo 2) em detrimento do termo "habilitação", que caiu. Isso mostra que termos como "linhas de formação" são novos e levam tempo até serem absorvidos e substituírem expressões ainda em uso como "habilitação". Nesse caso, quem sugeriu a mudança ao MEC foi o próprio grupo de designers de produto, embora o novo termo ainda não figure em documentos oficiais das faculdades e agências de fomento, evidenciando certa flexibilidade e fragilidade na fiscalização feita pelo MEC.
A "não restrição" de análise dos projetos de Design de Moda submetidos à CAPES se dá na condição de que estes estejam inseridos no campo do Design, como uma linha de formação, ou seja, devem se encaixar na noção de projeto fomentadas pelo design de produto. Logo, percebe-se que na verdade há restrição. Triska (2016) relata que "o que a gente faz distinção é com fashion que é uma condição que não tem [...]". Apesar de não concluir a frase, o diretor de área da CAPES dá a entender que o problema reside na tentativa de associar o desenvolvimento do produto de moda ao estilismo, dentro da lógica do campo design.

Ao afirmar que o campo do Design de Moda se afasta do Design quando não privilegia a aplicação da metodologia de projeto, Triska (2016) incorre em um protecionismo do campo do Design, anulando as diferenças e especificidades que o campo da moda possa demandar no ato de construir seus produtos. Assim, a criação de produtos de moda tem como única opção - para ter seus projetos científicos aprovados pelas agências de fomento com visão análoga à da CAPES - se submeter aos parâmetros projetuais do campo do Design.

Os autores de projeto em moda são desconhecidos por Triska, conforme declarado por ele mesmo nas entrevistas. Chama a atenção que um importante coordenador da área do Design não tenha intimidade com a bibliografia da área de Projeto em Moda, já que ele também responde pela área do Design de Moda. É interessante considerar qual é o alcance do campo do Design, ao responder a processos do Design de Moda.

A vinculação com o mercado não é uma justificativa suficiente para reclamar para si a constituição de um campo autônomo de Moda ou Design de Moda (TRISKA, 2016).

Deborah Christo (2006) opõe-se a esta afirmação, em artigo publicado no $2^{\circ}$ Colóquio de Moda. Para a autora, o Design atribui menor valor ao conteúdo simbólico que a Moda justamente por privilegiar questões de mercado, que não seriam uma questão central para o estilista de criações conceituais ou "criador". O estilismo estaria limitado ao campo da arte, enquanto o projeto seria influenciado pelos campos da arte e do "mercado" (CHRISTO, 2006).

Se por um lado, Triska (2016) afirma que, para formar um campo, é insuficiente $\circ$ argumento de que o campo da moda está vinculado ao mercado, por outro lado, Christo (2006) aponta para uma maior vinculação com o mercado por parte do campo do Design.

Se $o$ argumento de que a vinculação com o mercado parece irrelevante no mundo da pesquisa, ele deve valer tanto para o Design como para o Design ou da Moda. É inútil querer aumentar o capital cultural do Design desvinculando-o do mercado e colocando a Moda nessa condição a fim de rebaixá-la academicamente, pois essa é uma afirmação falsa. Tanto o Design quanto a Moda possuem ligações diretas com o mercado.

A relação entre tendência de moda, diletantismo e intuição de que fala Triska é uma forma de distanciar o produto de moda do campo do design, quando ele não se pauta pela noção de projeto. Mesmo que configure um processo, o Estilismo é combatido pelo campo do Design, pois segundo 
especialistas da área, ele prescindiria de metodologia projetual, e essa seria a principal justificativa encontrada para o Design de Moda e a Moda não se tornarem uma área de pesquisa independente.

Sabe-se que gênero, classe e etnia tiveram seu papel no processo de subordinação da moda como um campo. Historicamente, a moda tem sido percebida como um campo de atividade feminina, mas a força de trabalho feminina na educação de moda é vista com preconceito e discriminação (McROBBIE, 1998, p. 53). Isso coloca a moda em um espaço institucional baixo em termos de hierarquia (McRobbie, 1998, p. 54).

O acesso ao espaço e aos recursos para pesquisa é, portanto, reconhecido como uma questão de política de sexos. Também pelo fato de a moda ainda ser vista como um entretenimento frívolo (McRobbie, 1998, p. 54), principalmente em sua ligação com o consumo, que evocaria o desperdício e o racional vinculados ao feminino, como aponta Guimarães.

Uma visão oposta à de Triska defende que a pesquisa de tendências realizada pelo Estilismo ou pelo Design de Moda é válida, desde que ela seja elencada como uma etapa dentro dos processos de projeto e considere outras etapas, como definir problemas, diretrizes, conceitos para então trabalhar tendências (MERINO, 2016).

Partindo da noção de problema do projeto em design, uma demanda recorrente ao Design de Moda seria criar produtos para atender necessidades simbólicas. Se for esse o caso, falta difundir que valores são esses, dentro de uma linguagem que seja inteligível para outras áreas (MERINO, 2016).

É o caso então de se investir no campo de pesquisa em moda, para que sejam formuladas metodologias dentro de uma linguagem própria, que tenha contato com o design, mas que não se restrinja por suas metodologias projetuais.

Mesmo defendendo que perante o sistema todas as áreas são iguais, Merino (2016) reconhece que historicamente há um favorecimento das áreas de Ciências Exatas. que sempre têm recebido mais apoio. Ele justifica tal fato pela influência da área, que possui políticas governamentais próprias dado seu impacto econômico.

Por outro lado, ele aponta que o cenário vem mudando bastante, pois apesar das Ciências Sociais Aplicadas sempre receberem menos verba, as áreas das Artes, da Comunicação, da Sociologia, da Antropologia e das Letras vêm ganhando um espaço muito interessante, o que acaba gerando uma divisão mais igualitária dos recursos (MERINO, 2016).

Pode ser que a restrição em conceder mais recursos às Ciências Sociais Aplicadas tenha relação com a postura de parte dos pesquisadores dessas areas. Merino utiliza sua experiência docente para comentar que as escolhas de temas de pesquisa na Pós-graduação muitas vezes parecem limitar-se a comentários como "ah, eu não vou fazer isso aqui" porque envolve cálculos, "isso é coisa para o pessoal das Exatas, o pessoal do dinheiro, da estatística, dos números, então não" (MERINO, 2016).

Apesar dessas falas aparecerem sob a forma de "brincadeira", elas revelam um ethos ${ }^{39}$ do campo do Design, que produz menos pesquisas de mas de pesquisa nas grandes áreas, e esta talvez seja uma das razões que dificulte o reconhecimento do Design e da Moda enquanto áreas do saber, pois as agências de fomento se pautam por classificações.

É interessante observar como Ricardo Triska, que é diretor de área da CAPES e Eugênio Merino, que é diretor de área do CNPq, transitam por ambas as agências. E, em menor proporção, Luiz Lopes dos Santos também se refere à CAPES e ao CNPq em sua entrevista.

A resistência de certo grupo vinculado ao campo da Moda passa pelo incômodo de ver seu objeto de estudo, a pesquisa, criação e desenvolvimento de produto, sujeitado a uma única vertente possível de pesquisa, quando sob a tutela da área de Design. Além de outras áreas como História, Sociologia e Antropologia, às quais a Moda se reporta em termos de pesquisa quando necessário, desde a mudança ocorrida em 1998, ela deve se reportar ao Design para falar de produto.

As conexões imediatas da moda com o feminino, vinculado exclusivamente ao serviço doméstico e subalterno, à costureira do bairro e à loja de imigrantes devem ser desfeitas para que o campo atinja status acadêmico que ele procura (McRobbie, 1998, p. 53) e isso deve parar de depender somente da chancela dos campos do design e da arte.

Outro aspecto a ser combatido a segundo Bourdieu (apud McRobbie, 1998, p. 55), é "jogar o jogo da moda" que mantém a crença na ideologia da criação, em detrimento de uma visão sociológica do mundo.

A pesquisa no campo da moda ganha fôlego a partir de meados dos anos 2000, mas antes disso ela já existia, mesmo que alocada em outras áreas, como as Engenharias e a Comunicação (BONADIO, 2010, p. 19). O que inquieta é a situação de desenvolver pesquisas sobre desenvolvimento de produto de Moda somente sob o viés do campo do Design, se houver intenção de reconhecimento por parte das agências de fomento. Essa situação se configura a partir de 1998, pois em um período anterior a Moda acadêmico, uma vez que seus cursos de nível superior já funcionavam há cerca de dez anos nas principais faculdades do país. 
BONADIO, Maria Cláudia. A produção acadêmica sobre moda na pós-graduação stricto sensu no Brasil. lara - Revista de moda, cultura e arte, São Paulo, v. 3, n. 3, p. 50-146, 2010. [Dossiê]. Disponível em: <http://www. iararevista.sp.senac.br/arquivos/noticias/ arquivos $/ 141 /$ anexos $/$ pdf003.pdf $>$. Acesso em 10 set. 2014.

CHRISTO, Deborah Chagas. Designer de moda ou estilista? Pequena reflexão sobre a relação entre noções e valores do campo da arte, do design e da moda. In: COLÓQUIO DE MODA, 2., 2006, Salvador. Anais... Salvador: UNIFACS, 2006

\section{ETOS. In: DICIONÁRIO Priberam da Língua} Portuguesa. 2008-2013. Disponível em: <https:// www.priberam.pt/dlpo/etos>. Acesso em: 20 abr. 2017

MATTOS, Maria de Fátima da Silva Costa de Mattos (org). Pesquisa e formação em moda. São Paulo: Estação das Letras e Cores, 2015, p. 248.

RELATÓRIO de atividades 2015. São Paulo: FAPESP, [2016]. Disponível em: <http://www. fapesp.br/publicacoes/relat2015_sintese.pdf>. Acesso em: 14 abr. 2017.

TABELA de Áreas do Conhecimento. [2017]. Disponível em: <http://www. CNPq.br/documents/10157//86158/ TabeladeAreasdoConhecimento.pdf $>$. Acesso em: 14 abr. 2017.

TRISKA, Ricardo. Atribuição de Pareceres. [Mensagem pessoal]. Mensagem recebida por: <lanerigatto@gmail.com>, em: 20/4/2017.
MERINO, Eugenio Andrés Díaz. Entrevista realizada com Eugenio Andrés Díaz Merino, em 6 de outubro de 2016, na cidade de São Paulo, com 1 hora e 3 minutos de duração.

SANTOS, Luiz Henrique Lopes dos. Entrevista realizada com Luiz Henrique Lopes dos Santos, 23 de novembro de 2016, na cidade d São Paulo, com 22 minutos de duração.

TRISKA, Ricardo. Entrevista realizada com Ricardo Triska, em 29 de novembro de 2016 , na cidade de São Paulo, com 32 minutos de duração.

VICENTINI, Cláudia Regina Garcia. Entrevista realizada com Cláudia Regina Garcia Vicentini, em 31 de março de 2016, na cidade de São Paulo, com 1 hora e 2 minutos de duração.
216 


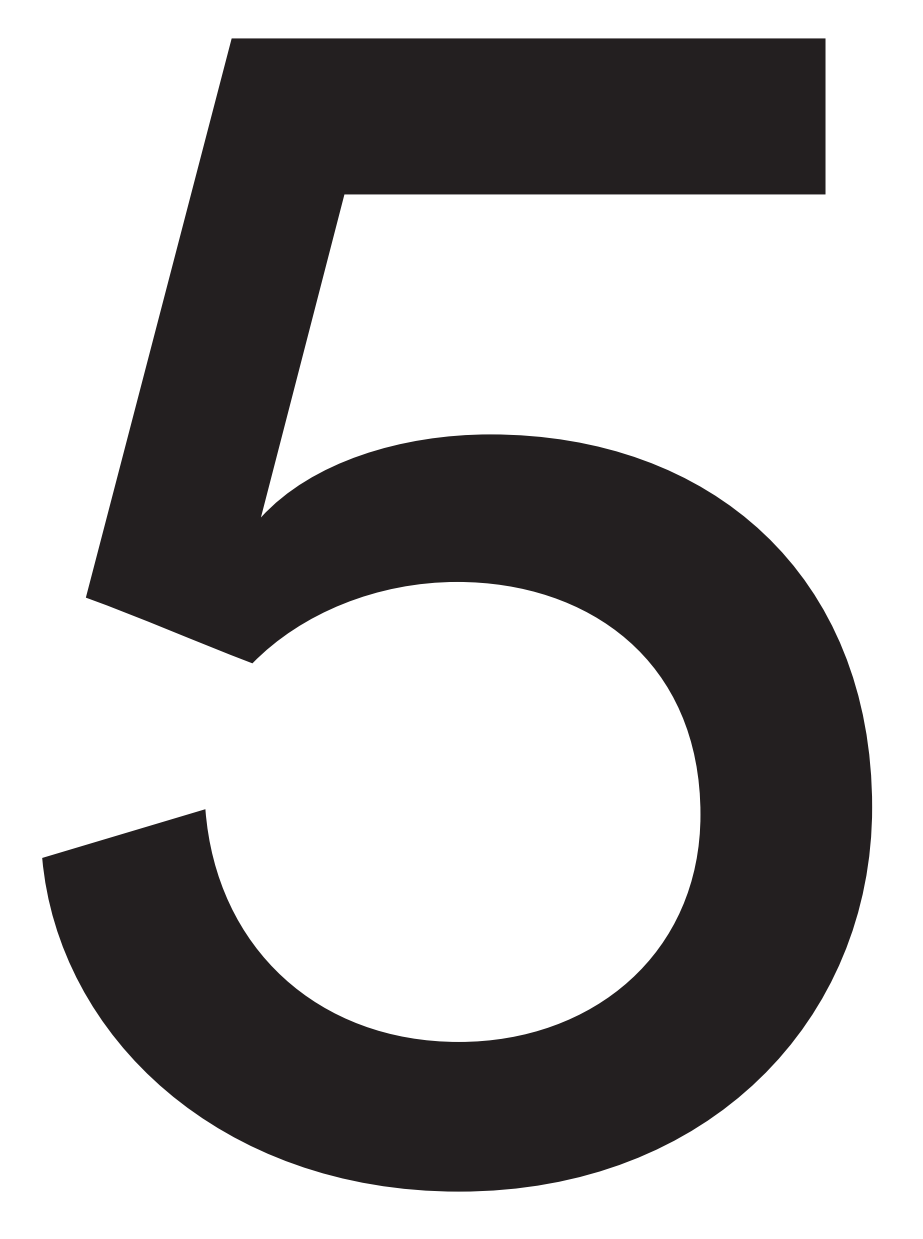

As

nogöos de

estulismo $\theta$

projeto em

moda no

Polfiecnico

Di Milano

na lália 
Neste capítulo são discutidos elementos e fases que permeiam as noções de estilismo e projeto em moda encontrados no contato com professores de algumas disciplinas de Projeto em nível de graduação do Politecnico di Milano. Apesar do foco dessa pesquisa ser a noção de projeto apurada em escolas brasileiras, a justificativa para a pesquisa na Itália são os pontos de convergência que unem o ensino de moda desses dois países. 
É de conhecimento público que vários pioneiros pesquisaram ou estudaram em cursos italianos, com vistas a proporcionar a transferência de conhecimento desse centro para as escolas brasileiras, desde a sua fundação até os dias atuais.

Entrevistas com Kathia Castilho e Vera Lígia Pieruccini Gibert evidenciaram que os primeiros cursos de moda inaugurados no Brasil se espelharam em cursos europeus como os italianos, franceses e ingleses, pois esses gozavam de boa reputação internacional. Assim, nasceu o interesse em tomar como modelo esses cursos.

A partir das investigações realizadas por estas pesquisadoras na Europa, especialmente em cursos italianos, uma série de adaptações foi feita para a abertura dos cursos de Moda no Brasil. Kathia Castilho que se graduou em moda na Itália relata que essa experiência serviu de apoio às atividades desenvolvidas no período da abertura do curso de moda da UAM em São Paulo.

Além disso, textos e entrevistas de importantes pesquisadoras brasileiras que embasam esse estudo foram desenvolvidos a partir de suas pesquisas no Politecnico di Milano. É o caso de Dorotéia Baduy Pires e Patrícia de Mello Souza. Pires foi responsável por importantes convênios e outras realizações com o Politecnico di Milano, que apontaram caminhos para o projeto em moda no Brasil, enquanto Souza se especializou como pós-doutora pela instituição italiana com foco em projeto em moda.

Por essas razões, entende-se que o ensino de projeto em moda italiano se configura como uma espécie de patrimônio para o ensino de moda brasileiro. Como essa tese se debruça sobre a noção de projeto em moda, o ensino na Itália, especialmente no Politecnico di Milano, se mostrou mais interessante por estar mais próximo ao design, se comparado às escolas francesas e inglesas.

As escolas francesas cultivam ainda hoje a cultura de ateliê ou de estilismo industrial com foco no autor (McRobbie, 1998, p. 77). Também não existem centros de pesquisa em nível de doutorado em moda na França, onde predominam as Écoles de moda, que não oferecem cursos de nível superior, portanto não seria possível desenvolver essa pesquisa nesse país. A Inglaterra se destaca por formar o conceptual fashion professional (McRobbie, 1998, p. 47), noção que será vista no capítulo 6 e que se aproxima mais do estilismo.

Por outro lado, esta pesquisa se apoiou basicamente em livros de projeto em moda de publicação inglesa. Isso acontece como consequência de investimentos de recursos em pesquisas científicas que faz com que a Inglaterra tenha produzido até hoje a maior parte dos livros acadêmicos voltados ao projeto em moda. Como resultado também passa a ter aceito mais registros escritos seus como discursos oficiais que ao longo do tempo foram institucionalizando uma noção de projeto em moda no mundo acadêmico. Essa aderência inglesa em termos de registros escritos levou esta pesquisa a utilizar mais livros de projeto desse país.

Além das disciplinas de Projeto frequentadas, foram realizadas entrevistas de caráter exploratório com professores dessa instituição.
O início do curso de Design de Moda do Politecnico di Milano é em 2003. E da sequência de disciplinas de Maglieria é 2008. A malharia retilínea é um setor bastante tradicional e reconhecido na Itália e na aula de Maglieria a importância maior é dada à construção da matéria-prima. Existem outros cursos de Moda na Itália, como o de Veneza que é mais recente e o de Roma. A posição geográfica de Milão favorece as trocas entre o Politecnico di Milano e as empresas de acordo com o professor Giovanni Conti (2017).

Entre as disciplinas frequentadas e seus professores estão Laboratorio di Sintesi Finale, disciplina dedicada à Maglieria ministrada por Giovanni Conti e Metaprogetto, por Paola Bertola. A disciplina de Conti ocorreu no primeiro semestre do ano de 2017, entre março e junho, contando com nove encontros com frequência quinzenal, às segundas-feiras, em período integral. Nessas aulas cada aluno, majoritariamente mulheres, desenvolvia individualmente sua coleção final, ou seja, seu TCC, Trabalho de Conclusão de Curso. Invariavelmente se tratava de uma coleção de malharia retilínea, especialidade da disciplina.

A disciplina Metaprogetto, de Paola Bertolaque aconteceu no segundo semestre de 2017, entre setembro e dezembro, voltava-se à criação de uma coleção em grupo com várias linhas de produtos de vestuário de moda a partir de um briefing fornecido por Bertola. Foram ao todo quatorze encontros semanais, às quintas-feiras, em período integral. $\mathrm{O}$ briefing especificava os tecidos e malhas a serem utilizados, então nesse caso, ao contrário de Laboratorio di Sintesi Finale, os alunos não desenvolviam suas bases de tecido.

A disciplina de Laboratorio di Sintesi Finale acontece no terceiro ano do curso de Design de Moda, ou seja, no último ano da Laurea Triennale ${ }^{40}$, enquanto Metaprogetto acontece sempre no segundo ano de curso.

Mais adiante, outras diferenças entre essas disciplinas serão abordadas, a fim de esclarecer para o leitor qual é o posicionamento de cada uma delas diante das noções de estilismo e projeto em moda.

Além de frequentar as disciplinas, foram coletados os depoimentos de Giovanni Conti e de outra importante designer que atuou como professora do Politecnico di Milano: Nanni Strada. O contato com Nanni Strada foi feito por intermédio de Paola Bertola, com quem Strada entrou em contato. Houve uma coincidência de interesses acerca da noção de projeto, em assuntos que envolvem o Brasil e suas heranças da Itália, considerado de grande valor para este capítulo.

O processo de projeto desenvolvido por Strada tem sido objeto de estudo no Brasil. Nanni Strada e Doroteia Baduy Pires se conheceram em meados dos anos 2000 durante uma banca de concurso de professores de moda na UBA em Buenos Aires, na Argentina. Pires já conhecia e pesquisava o trabalho de Nanni Strada. Inicia-se assim a relação entre as duas designers. que culminou na pesquisa de doutorado de Pires sobre o método de ensino de Nanni Strada, mas que infelizmente restou inacabada dado seu falecimento precoce.
40 A Laurea Triennale se assemelha ao curso de

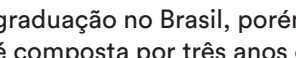
tem caráter mais técnico. Para completar a formação
os alunos italianos os alunos italianos
costumam continuar seus estudos ingressando na Laurea Magistrale que é composta por mais dois ao mestrado profissional no Brasil. 
Por esses motivos, o depoimento de Strada foi incorporado à tese. Por indisponibilidade de tempo, Paola Bertola não pode conceder entrevista para esta tese. Sua contribuição para os depoimentos então, foi propiciar o contato com Strada.

\subsection{A disciplina Laboratorio Di Sintesi \\ 5.1 Finale ministrada por Giovanni Conti}

A observação em sala da disciplina Laboratorio di Sintesi Finale permite observar que o trabalho se dá na forma de orientação individual, onde os alunos passam por Conti, além de outros professores que auxiliam, a fim de mostrar o estágio do desenvolvimento do trabalho de pesquisa, criação e desenvolvimento de uma coleção. Nessa orientação, cada aluno mostra - que foi feito, ouvem críticas, caminhos são discutidos e mais tarefas são dadas para o bom andamento da coleção.

Sobre as etapas que constituem o projeto em moda, Giovanni Conti solicita aos alunos que, antes de tudo, pesquisem um tema ligado ao briefing de projeto. Nessa disciplina, o briefing de projeto e 0 tema dado ou o tema que os alunos escolhem.

A pesquisa engloba imagens, leitura de artigos, estímulos visuais e táteis. "Então, quais são os elementos têxteis, materiais que ajudam que aquela ideia de pesquisa, que aquele briefing de projeto dado possa ser realizado?" (CONTI, 2017). Ao final, cada aluno deve tecer as malhas retilíneas para desenvolver sua coleção, utilizando as máquinas da faculdade.

$\mathrm{Na}$ primeira etapa de projeto, os alunos devem fazer uma pesquisa de imagens que traduza a relação proposta pelo tema e o representem. Além das imagens, os alunos devem buscar quais são os materiais que possam transmitir aquele conceito.

A ideia é criar um paralelismo entre a pesquisa de imagem inspiracional que se concretiza visualmente com a criação do mood (moodboard ou painel de inspiração), o material e a parte mais técnica. Essa segunda pode estar no concept, isto é, painel de conceito onde o figuram imagens do mood/ inspiração mais aquelas que têm a ver com o projeto.

Se a palavra-chave é maciez, no moodboard haverá imagens que remetam à maciez. Já no concept aparecerá um material, tecido, fio ou qualquer coisa que seja macio ou que transmita o efeito de maciez.

Conceito diz respeito a aprofundamento de técnicas, materiais e processos inovadores, onde tais técnicas permitam inovar um produto de moda que não seja descartado na estação seguinte, pois o produto de moda gerado nessas condiç̃̃es é dotado de um valor duradouro. Design é quando se usa indústria para fazer um produto sofisticado técnica ou processualmente (STRADA, 2018).

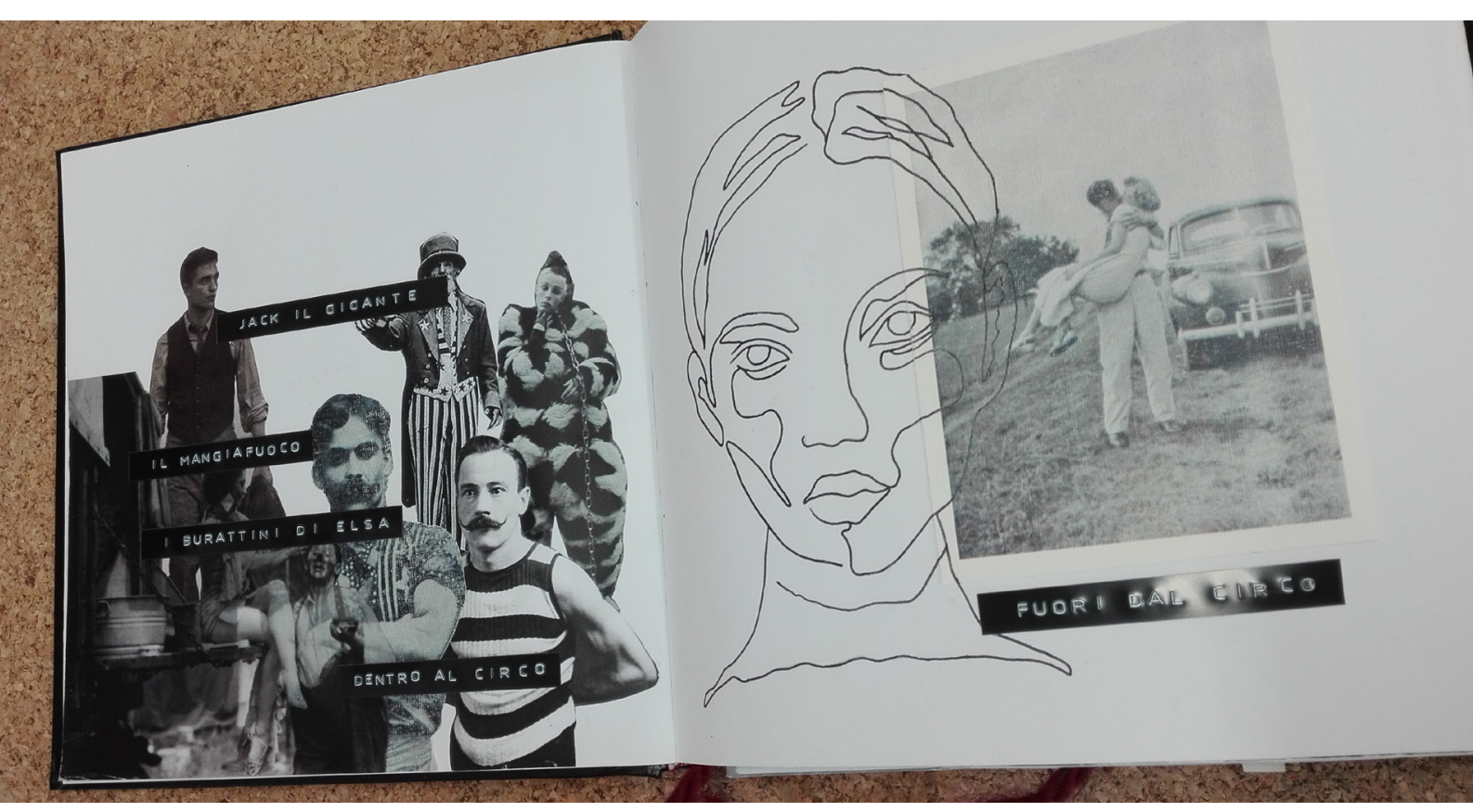

Figura 9-Exemplo de de inspiraçăo (2017)

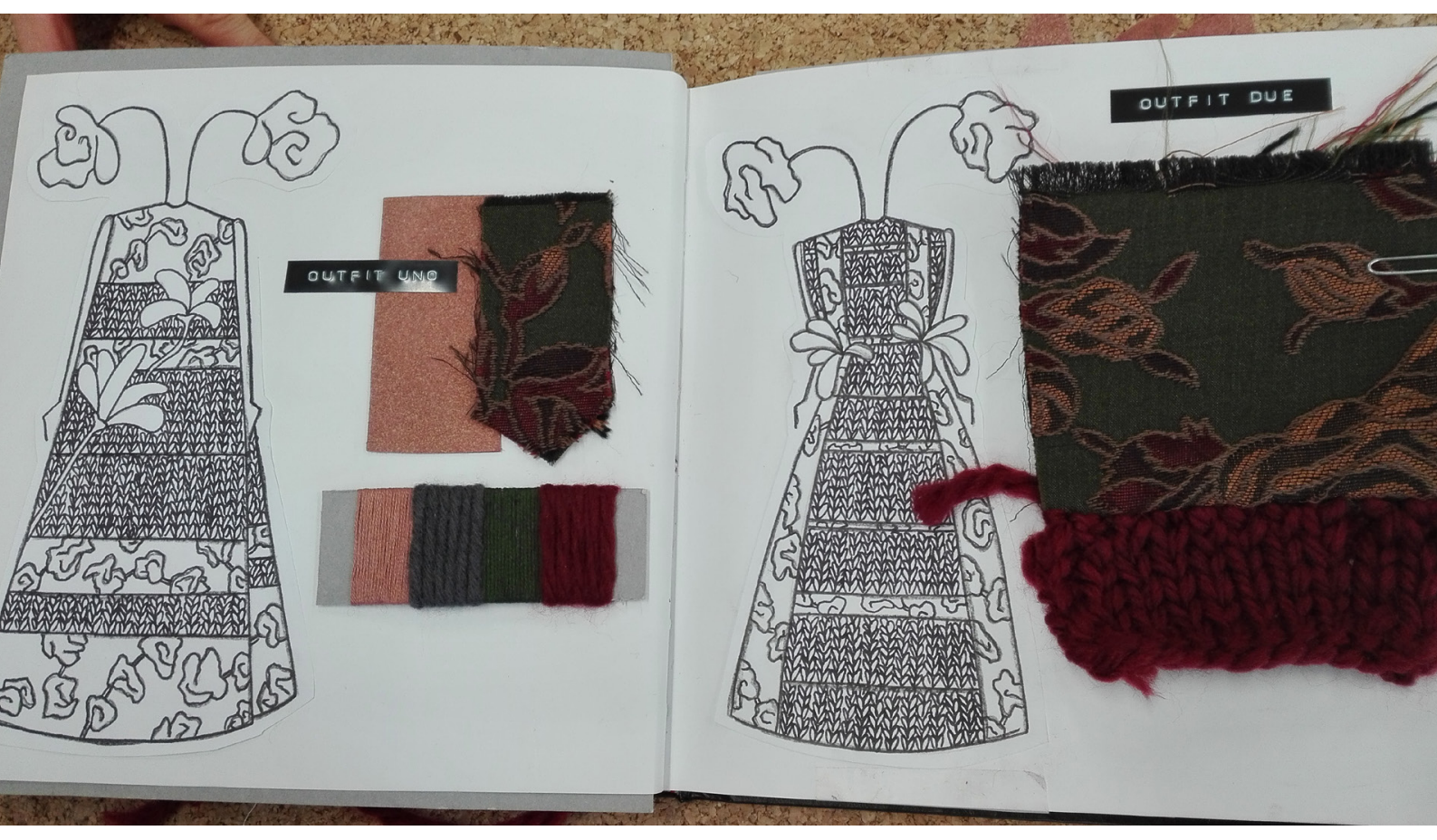

Figura 10 - Exemplo de moodboard ou painel (2017)
Fonte: A autora (2017)
224 
A distinção entre conceito para Strada e Conti é visivel, mas é preciso salientar que Conti se refere ao concept como um painel e, nesse caso, deve-se considerar até onde o conceito está efetivamente investido nele. De qualquer forma, o conceito ou um análogos ou complementares. Novamente aparecem lacunas sobre a falta
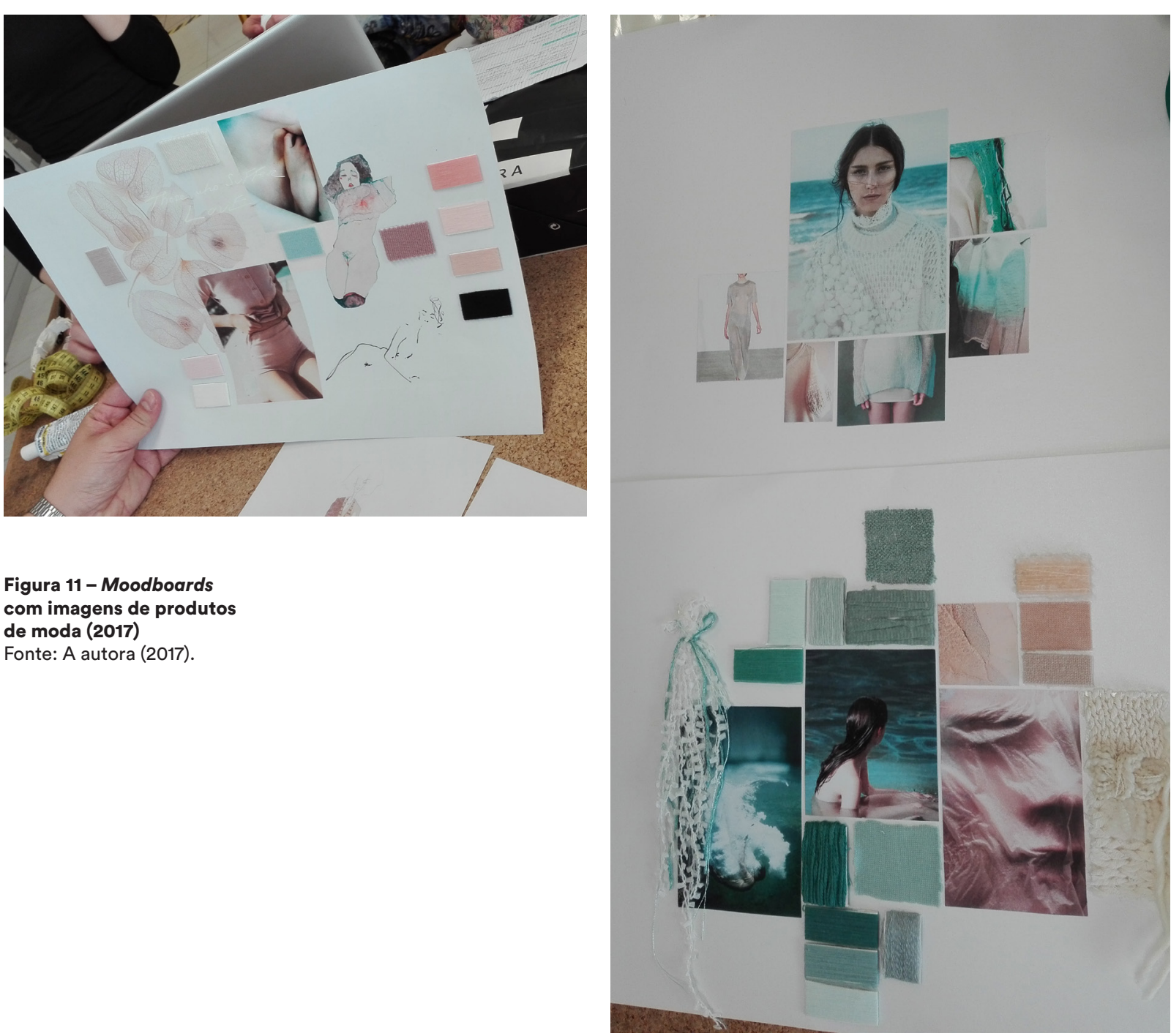

\section{Figura 11 - Moodboards} de moda (2017)
Parte natural na construção do moodboard é a definição e a concatenação da cartela de cores. Ela deve traduzir as imagens do moodboard, assim como ele traduz o tema. A cartela de cores pode ser feita no próprio moodboard ou à parte com amostras físicas, em geral, fios ou linhas. Nessa disciplina, ela contém entre cinco e dez cores ou mais.

Em alguns momentos, percebem-se orientações com um ethos próprio do estilismo. Em uma delas, fala-se sobre cores de forma bastante poética, recorrendo a palavras como "inspiração", sem se basear nos princípios do design para alertar a aluna sobre os efeitos possíveis.

Definindo um direcionamento com a pesquisa de imagens, materiais e cores é iniciada a prototipagem. Ela começa com pequenos estudos de teste de pontos, de elaboração, de forma, composição e materiais e será a base para construir a peça piloto, ou seja, a materialização da pesquisa em produto.

Para esse estudo, cada aluno deve tecer uma amostra de malha de $15 \mathrm{~cm}$ $X 15 \mathrm{~cm}$ ou $20 \mathrm{~cm} X 20 \mathrm{~cm}$ que serve de teste para sentir o peso, o caimento da malha, ver o ponto, como é a tessitura, se ela é justa, se é trabalhada a um cabo ou mais cabos, isto é, a mais fios ou menos fios. Equivale à maquete têxtil, vista no Capítulo 2.

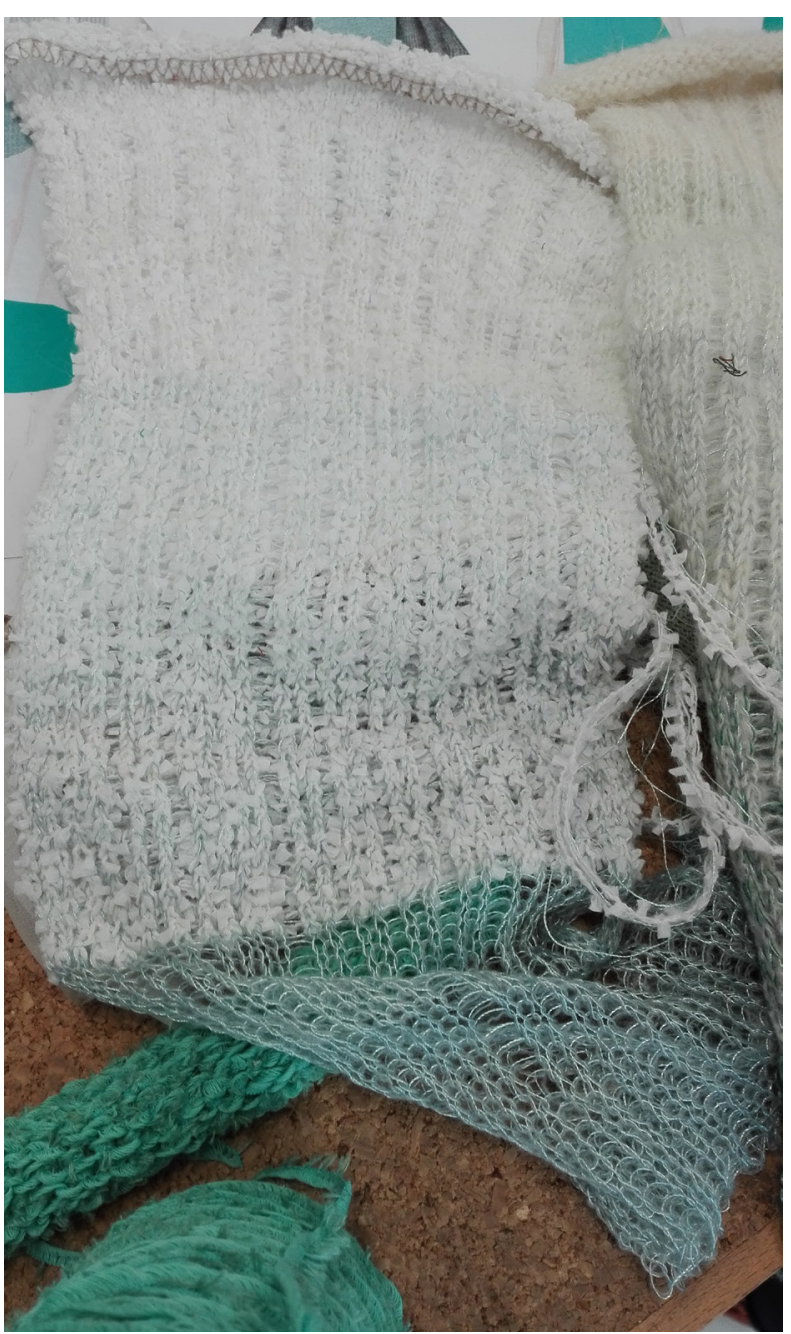

Figura 12-Amostra de Fonte: A autora (2017). de consenso a respeito de algumas etapas projetuais.

Esses painéis podem aparecer juntos em formato de caderno, à exemplo do que é feito na FASM, como mostrado na sessão 2.6 do Capítulo 2.

Embora Conti prefira não trabalhar referências imagéticas de produtos de moda nos moods, ainda há alunas que apresentam referências de moda em seus painéis. Isso dá indícios do mito, no sentido de que nem sempre o estilista ou designer está disposto a seguir regras, mas prefere quebrá-las como afirma Jones (2005, p. 7)

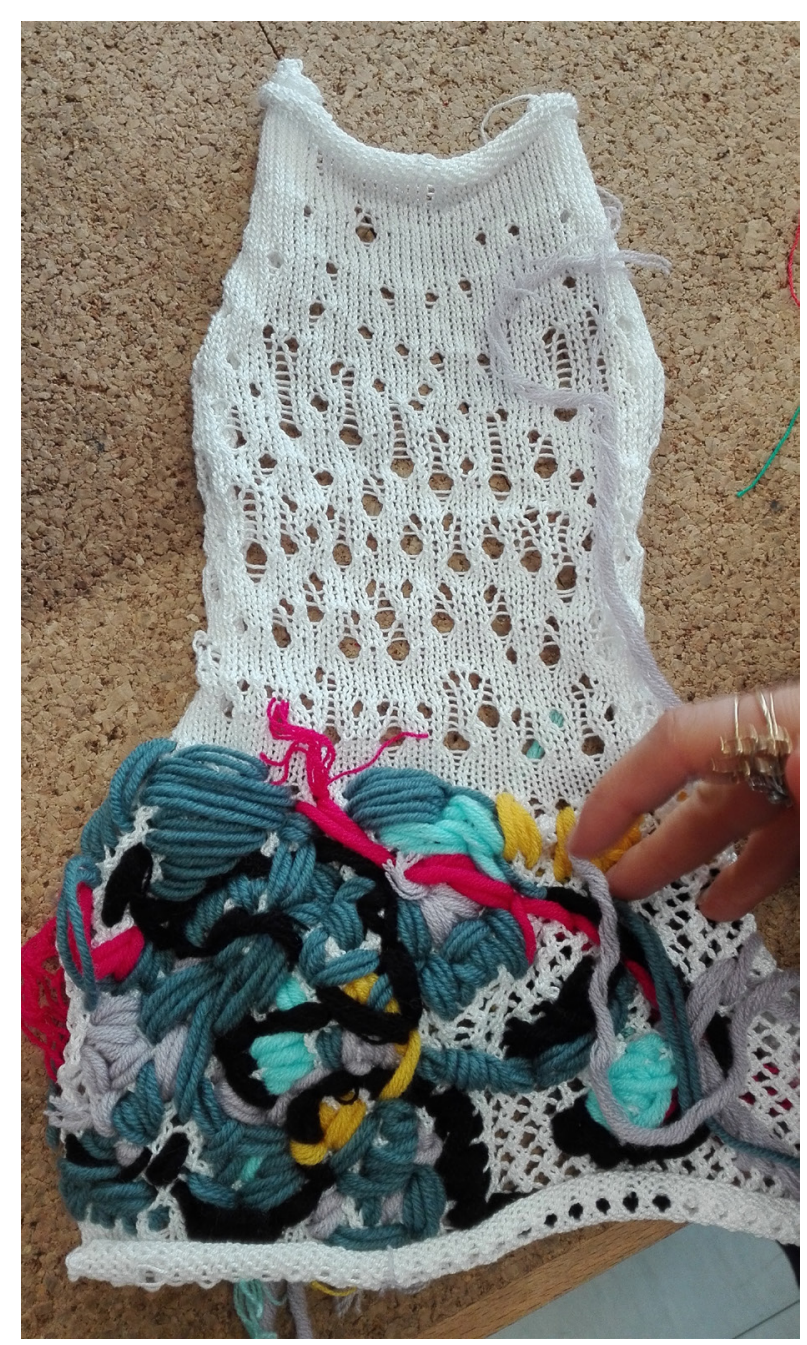

226 


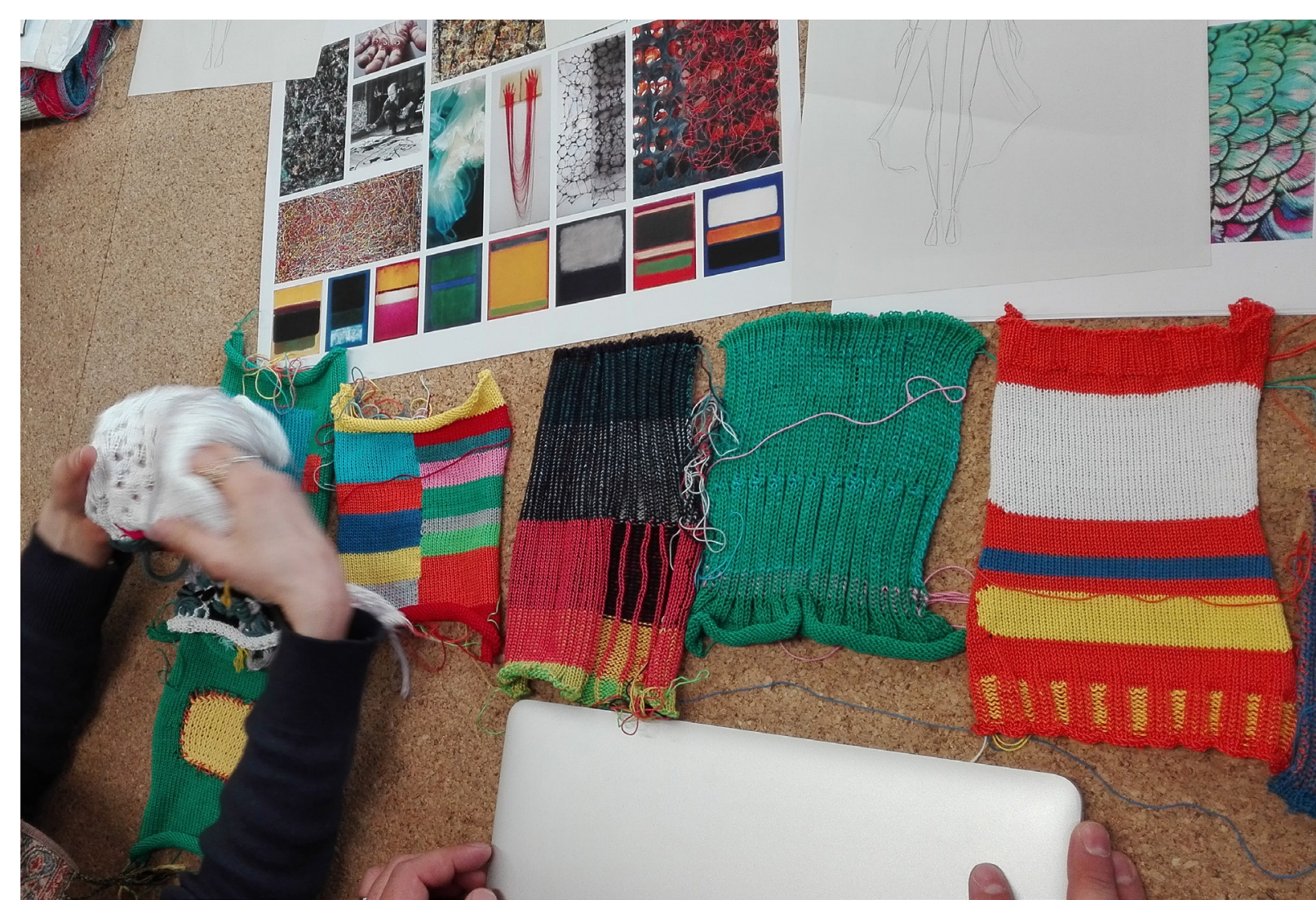
de prototipagem (2017) Fonte: A autora (2017).

\section{Outitit - sinônimo
para look (ver seção 3 .} do capitulo 3)
Embora o professor responsável pela disciplina seja Giovanni Conti, ele divide a aula com a professora Manuela Rubertelli, além de outras auxiliares. O papel de Rubertelli é fazer a interface com a empresa de fios, para pedidos. El solicita à empresa Cotton Store fios que são cedidos gratuitamente aos a di Milano com base nas necessidades de seus projetos. Ao longo do semestre, fios escolhidos há algum tempo podem não estar mais disponíveis, então o aluno precisa repensar seu projeto em função das matérias-primas disponíveis. Os croquis podem ser feitos ao mesmo tempo em que testam as amostras, mas tendem a sofrer mudanças caso não haja fio disponível para a malha definida.

Enquanto se faz a pesquisa e os painéis, também se desenha. Durante todas essas atividades, o desenho visa transformar aquela pesquisa, aqueles materiais e o conceito de projeto em uma coleção de produtos de moda.

Giovanni Conti propõe que seus alunos desenvolvam uma capsule collection com oito a doze outfits ${ }^{40}$, dentre os quais roupas exteriores (mais pesadas como casaco, colete), saias, acessórios etc.

Esses desenhos devem conter indicações sobre acabamentos, materiais utilizados e, no caso específico de malharia retilínea, se há mistura de malhas e outros tecidos, pois isso implica em questões técnicas. Há trabalhos, por exemplo, que misturam tecidos planos como o jeans e malharia retilínea por meio da técnica de agugliatura. Há alunos que diferenciam seus produtos recorrendo à intarsia e também ao tricô manual.
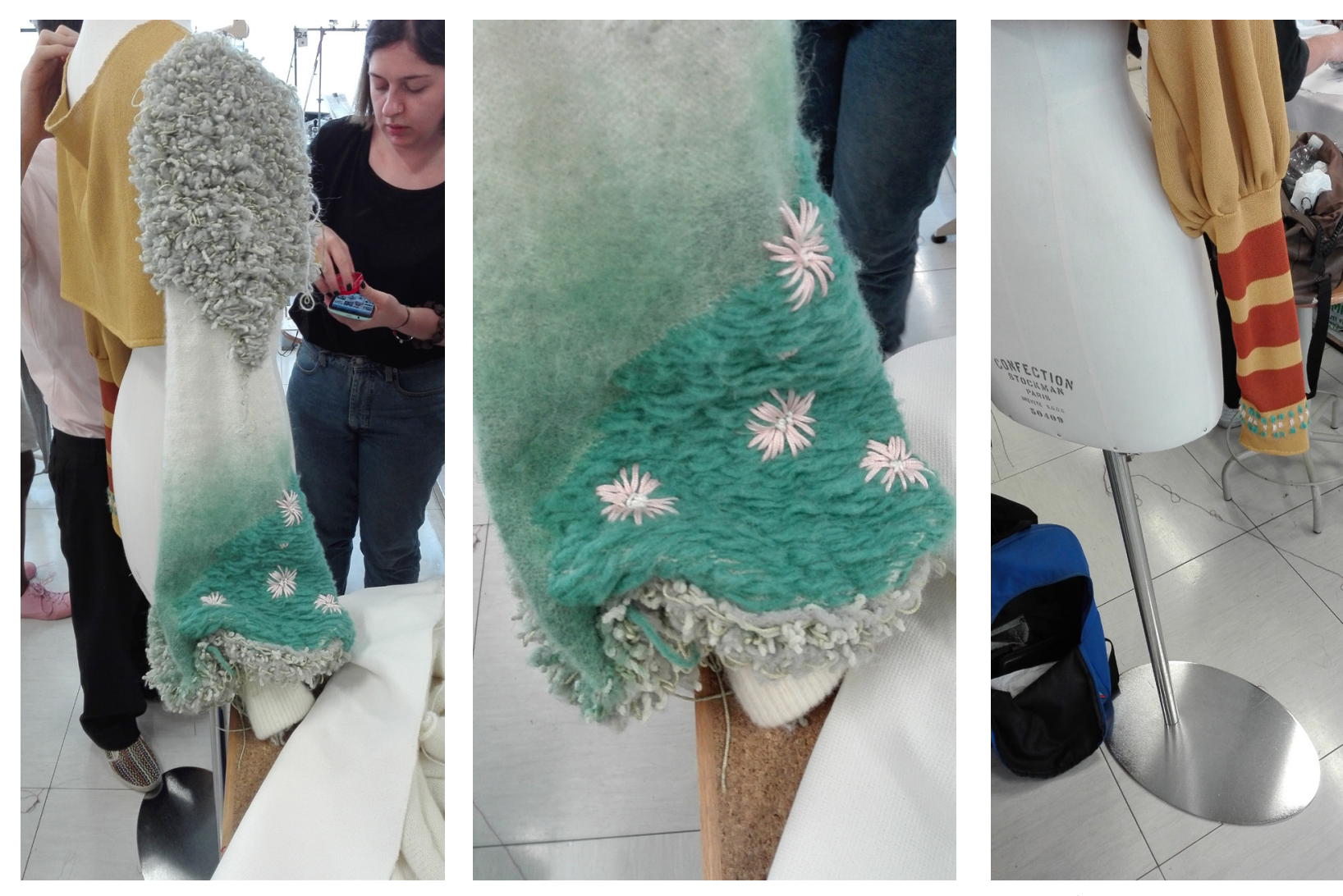
Figura 14 -Trabalhos
manuais no tricô (2017)
Fonte: A autora (2017).

\section{8}

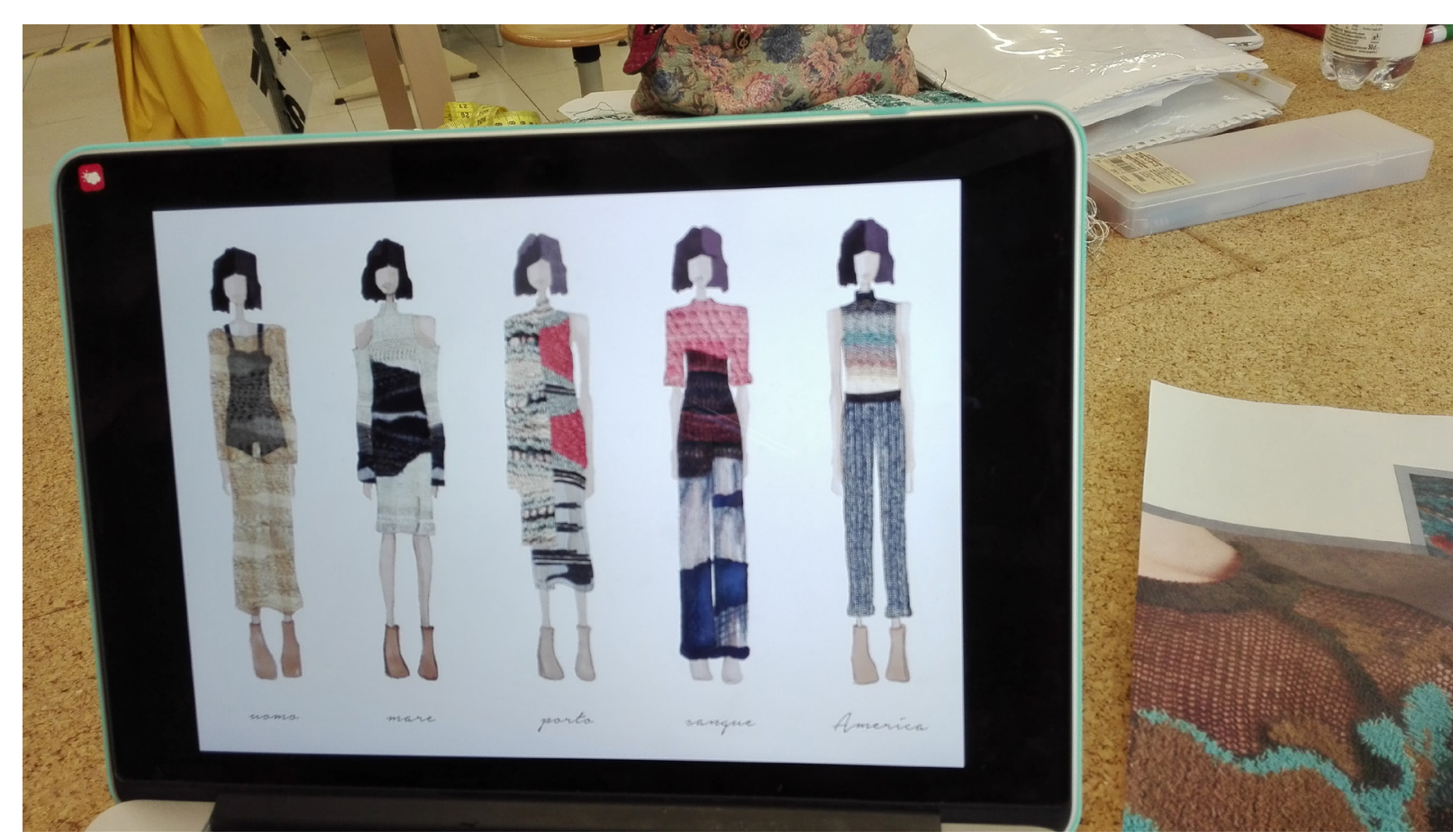

Figura 15 - Croquis
coloridos em

colloridos em

Fonte: A autora (2017) 


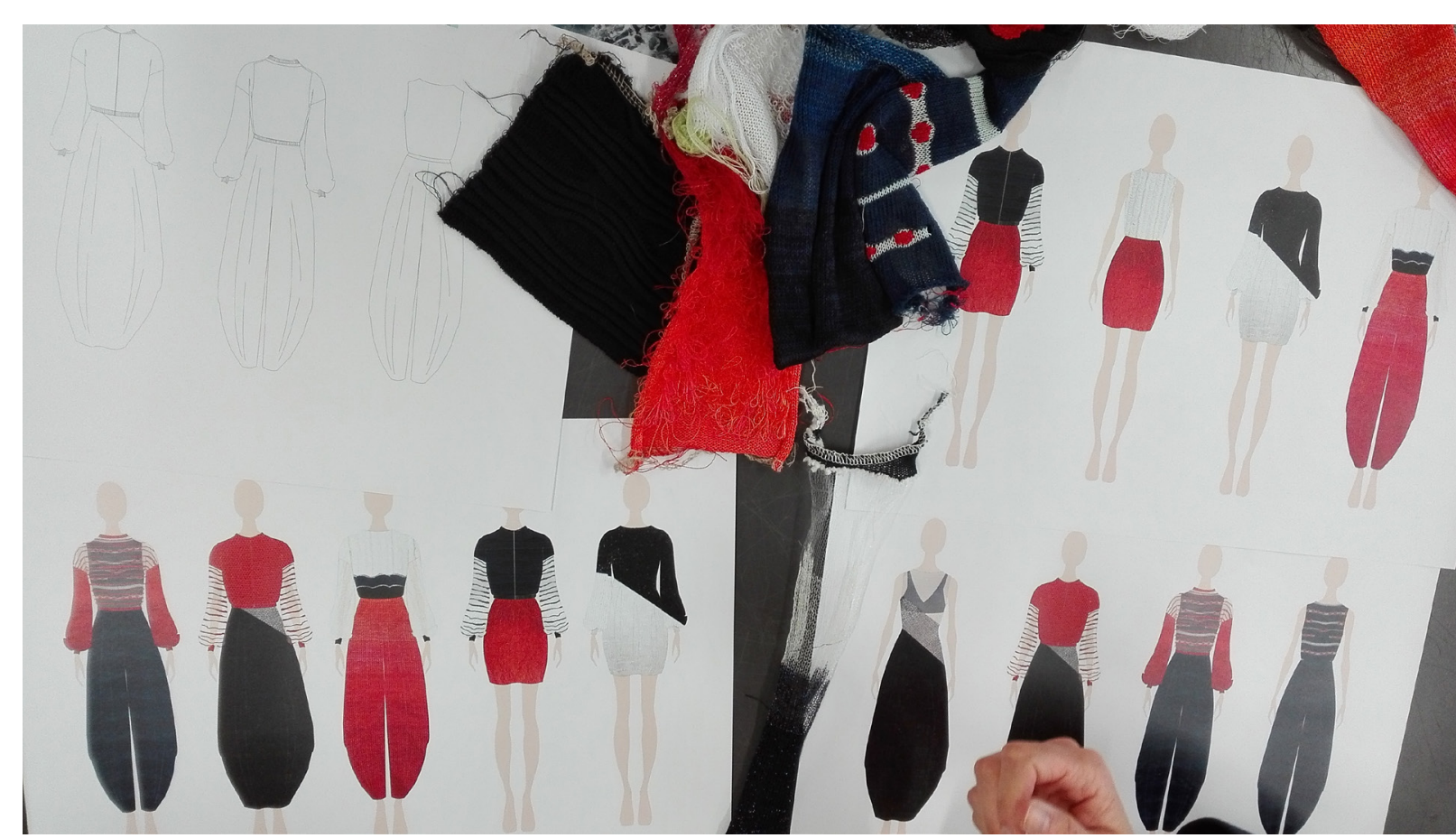

\section{Figura 16 - Croquis
coloridos em lllustrat}

com amostras de malha

Fonte: A autora (2017)

Figura 17 - Croquis

lustrator com

(2017)
Fonte: A autora (2017)
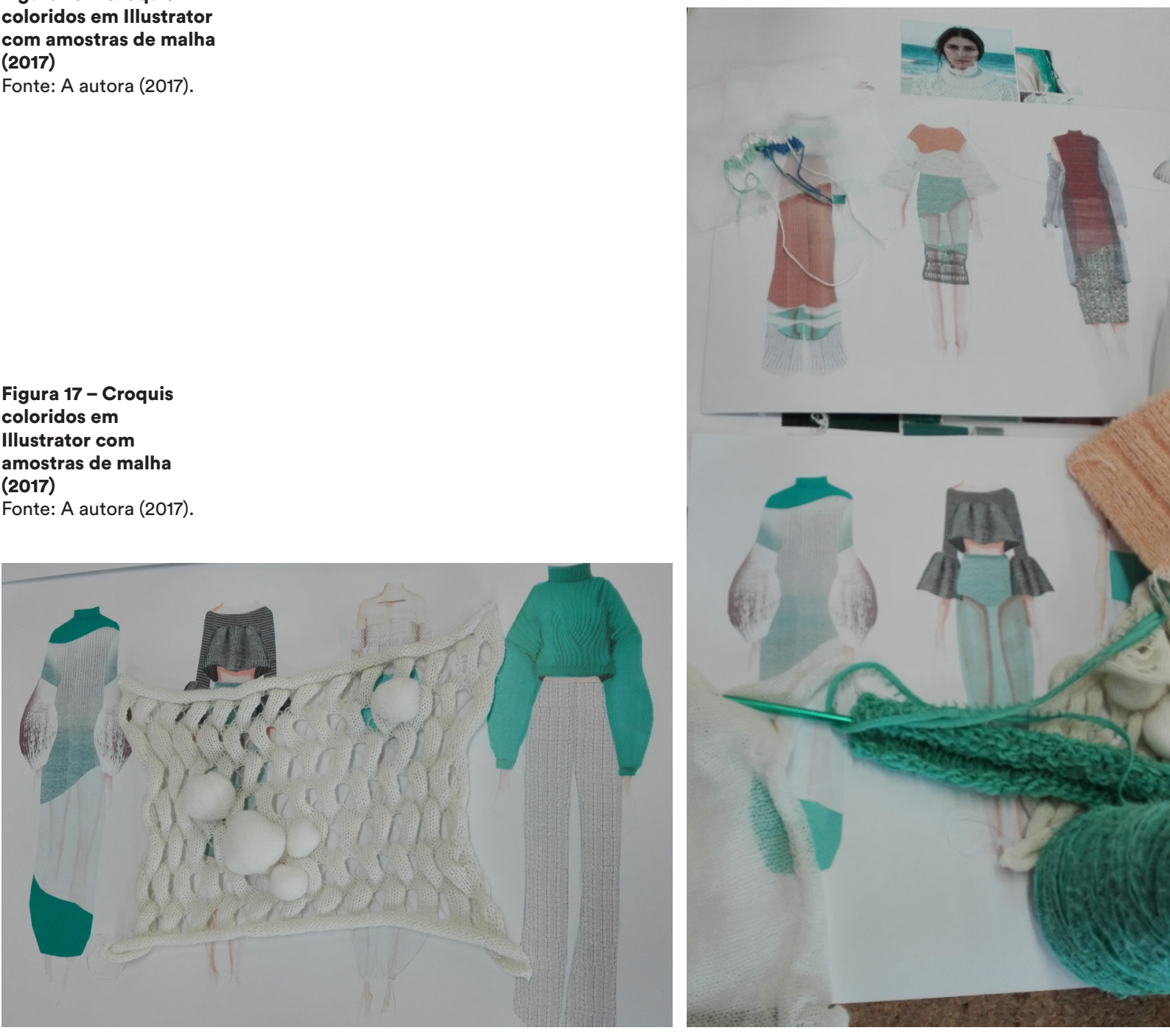

Durante o desenvolvimento do trabalho, os alunos apresentam desenhos coloridoscomsuasideias, acompanhadosdasamostras demalhas. Dessaforma oalunocomeçaamostrarseuprocesso, colocandoostestesdedesenvolvimento de malhas e possibilidades de uso de maquinário sobre os desenhos. É importante que os alunos apresentem desenhos coloridos e fichas técnicas com as medidas das partes que compõem uma peça.

No momento do desenho de uma peça de roupa, deve-se levar em conta o peso da malha, entre outros detalhes. É necessário conhecer quais são os pesos e toques adequados a uma peça de roupa e não a outra. Um casaco exige uma malha mais pesada que uma regata, camisa ou saia. Podem haver materiais sobrepostos e, nesse caso é preciso ter cuidado com o efeito grip, que ao invés de fazer deslizar, faz com que ela "grude". Assim, a escolha em usar materiais diversos, fios diversos, pesos diversos se pauta pela necessidade.

O binômio forma e função pode ser visto no design de moda por meio dessa atividade de escolha do fio apropriado para o efeito que se deseja no produto final, pois o fio e o ponto da malha determinam seu peso e seu caimento, que direcionam o desenvolvimento das peças.

A despeito das orientações estarem voltadas às noções de necessidade e de forma e função, é interessante perceber que, em nenhum momento do semestre, o conceito de problema foi abordado. Embora Conti reforce a importância de mostrar o processo desde o início do projeto por meio do moodboard para desenvolver as demais etapas, a noção de problema passa ao largo. Os comentários se concentram mais na estética a partir das imagens, prática ensejada pelo estilismo.

O material é tema recorrente das discussões de orientação entre alunos e professores. Fala-se de composição do material e da adequação de determinada malha a um produto, se estendendo até sua função estética e aos aspectos prático-simbólicos, nas palavras de Löbach (2007, p. 49, 70). Por vezes, a discussão avança para uma associação de um material a um julgamento meramente estético como "bonito ou feio", o que é bastante subjetivo e, novamente tende ao estilismo e esvazia a prática da moda como design.

No design de moda, onde comumente as funções estética e simbólica prevalecem sobre a função prática, o que se percebe é que, quando 0 repertório e o vocabulário de design de produto não atendem mais às necessidades exclusivamente estetizantes da moda, ele é imediatamente abandonado.

A crítica aqui não é à necessidade do produto de moda, que geralmente tende a se voltar à parte estética, mas até que ponto essa prática realmente alcançou o design de moda ou ainda reproduz o estilismo, no sentido da criação que remete à aura e não ao estilismo industrial. Ou ainda, até que ponto os métodos de projeto em design atendem ao desenvolvimento de produtos de moda.

Esse escapismo do campo do design para o "mundo da moda" também é apontado por Angela McRobbie (1998, p. 51), a qual, a 
partir de suas práticas nas escolas de moda inglesas, mostra que para legitimar a criatividade individual, os alunos fazem uso do vocabulário das artes e seus movimentos como o avant-garde, a pós-modernidade e a desconstrução, para se explicarem para o mundo de fora da moda e, assim, se distanciarem do vocabulário profissional da educação em moda, visto de forma pejorativa, como uma linguagem ligada à tradição da costureira de bairro (dressmaking).

Percebe-se uma resistência em agregar habilidades e técnicas das quais depende o vocabulário do profissional de moda, com receio de diminuir seu capital simbólico.

A experimentação de material e forma em vários desenvolvimentos dos alunos de Conti é preponderante. Essa forma de fazer desperta o olhar sobre quais seriam os limites da prática do estilismo no Politecnico di Milano, que se declara uma escola de design de moda, pois percebese uma constar cunho individual, de designer de autor que se reporta, portanto, mais ao campo da arte, em detrimento do trabalho que tem como premissa a solução de um problema ou aperfeiçoamento de um produto, e que não necessariamente prescinde da experimentação ou foca tanto no resultado final estético.

Será que esses designs produzidos em Laboratorio di Sintese Finale são passíveis de uma produção industrial? E de uma pequena produção seriada? Quem representa essa mão de obra? Seriam os próprios designers ou estilistas, em uma pequena produção seriada, pois em muitos casos provavelmente só eles conhecem alguns processos específicos e não valeria a pena ensinar uma equipe de uma oficina, para uma pequena produção. Isso leva a repensar o papel do designer de moda, que nessa escala atuaria cada vez mais como estilista ou artesão.

O trabalho de design, que na década de 1990 passa a ser entendido como um possível lugar para satisfação do eu, ideologicamente se torna uma fonte de recompensa com ênfase na criatividade, não importando quão irregulares sejam os ganhos e quantas horas a fio o designer tenha que se dedicar; e para emergirem como criadores, esses indivíduos devem trabalhar independentemente, o que não necessariamente os torna apropriados para um trabalho em uma empresa, e no final, a figura do designer mulher/homem de negócios, muitas vezes acaba sobrevivendo de pequenos pedidos como a "costureira de bairro" (McRobbie, 1998, p. 50, 83,87).

As colocações de McRobbie levam a crer que o designer empreendedor independente muitas vezes também atua como produtor, ou seja, como mão de obra que fabrica sua própria coleção, sozinho ou com a ajuda de uma equipe reduzida em um pequeno ateliê, onde só ele domina o processo e isso, sem sombra de dúvida, reduz a sua produtividade e seus ganhos e, ao final, ele acaba vivendo uma realidade que não o distancia tanto assim da "costureira de bairro".

Voltando à sequência do processo ensejado na disciplina de Conti, definidos fios, pontos, amostras e croquis, é realizada a ficha técnica. Ela é parte do processo de industrialização, ou seja, da preparação para a possível serialização daquela coleção no futuro. Na sequência inicia-se a peça piloto. No caso da aula de Conti, os alunos fazem a ficha técnica somente daquilo que eles produzem.

Pelo que se percebe, mesmo que exista uma ordem - pesquisa de imagens, materiais, moodboard, concept, protótipos, desenhos e peças piloto - algumas dessas etapas ocorrem concomitantemente, podem ser invertidas ou ainda, o fato de avançar para a etapa seguinte não impede de retornar à anterior para revê-la. Ao final, esse é o trabalho do designer a fim de ajustar e cumprir o briefing. No caso da malharia retilínea, por exemplo, os testes são contínuos, ou seja, trata-se de um work in progress ${ }^{41}$ para atingir o toque e o peso da malha adequados.

Ao observar cada aluno tem-se uma ideia mais geral do desenvolvimento do projeto ao longo do semestre. Em um dia normal de orientação, uma aluna, chamaremos de $A$, apresentou somente croquis pintados, enquanto a aluna $B$, trouxe um painel aberto, ou seja, sem referências de moda $e$ sem amostras apropriadas àquilo que estava desenvolvendo. A aluna $C$ já trazia consigo peças iniciais desenvolvidas, um macacão e um vestido. Um outro trabalho, podemos chamar de D, exibia alfaiataria e bordados. O trabalho E consistia na apresentação de moodboard e cartela de cores. O F mostrava croquis pintados em Illustrator e painel fechado, ou seja, com referências de moda. O desenvolvimento $G$ mostrava também painel fechado, amostras de malha e desenhos técnicos.

A despeito das variações sobre o que era apresentado em cada orientação, e que naturalmente ocorrem em função do tipo de projeto a que cada aluno se dedica, percebe-se que os itens mais apresentados nas orientações, desde o início das aulas, são painéis e amostras e, em seguida, croquis. De maneira geral, isso mostra que, na prática os alunos, começam a se dedicar aos desenhos técnicos e ao desenvolvimento das peças propriamente ditos nas últimas etapas do projeto. Pode parecer óbvio, mas em outros casos acontece o inverso.

Há casos em que o aluno pode experimentar antes uma amostra de malha maior no manequim e depois definir o croqui. De qualquer forma, ele já passou pelas etapas do painel e escolha de amostras de malha.

À essa altura das orientações, a necessidade de unidade entre os produtos que compõem a coleção passa a ser reforçada no momento em que as primeiras peças pilotos começam a ser apresentadas. As coleções devem prezar por um equilíbrio avaliado a partir do Plano de Coleção e que interfere diretamente no Mix de Produtos, ou seja, deve haver harmonia entre a quantidade de calças, tops e inteiros propostos (CONTI, 2017).

Para avaliar o aproveitamento de seus alunos, Conti busca entender como transformam uma inspiração, um rascunho, um desenho em um desenho técnico e uma ficha técnica. Para Conti (2017), interessa entender essa passagem "da parte artística à parte técnica".

"É um pouco mais subjetivo e individual, porém deve ser um trabalho objetivo. Se você desenhou uma coisa, um esboço eu quero entender como aquele esboço se torna tecnicamente [um produto] ou como você faz aquilo se tornar um elemento técnico" (CONTI, 2017). O caminho
41 Work in progress ou work in process é
uma expressãa usada para designar um processo em aberto ou parcialmente
finalizado, mas que carrega essa potência de poder ser revisto
implementado. 
percorrido deve ser claro e deve ser comunicado por meio das imagens trabalhadas. É preciso mostrar um caminho de projeto.

Além de cortar, costurar e finalizar as peças, no final da disciplina Laboratorio di Sintesi Finale a orientação se volta ao book di tesi. No linguajar de design de moda, ele se refere à parte impressa do trabalho, incluindo o photoshooting (sessão de foto). $O$ formato do book pode ser mais livre, desde que contenha os itens que revelem o processo de projeto da disciplina por meio de etapas, demonstrando sua racionalização. A sugestão é que sejam dispostos croqui, foto do look e ficha técnica de forma a ver a foto e o desenho técnico lado a lado, e o croqui em uma página anterior.

As possibilidades de organizar o book di tesi são inúmeras, mas ele deve expor o metaprojeto (processo) e habilidades digitais, como Kaledo e Rhinoceros. Aqui é resgatado e reforçado o que foi ensinado na disciplina Metaprogetto, ministrada por Bertola no segundo ano do curso, e que servirá de base para a vida profissional desse designer de moda.

Ao analisar os desenhos técnicos e o conteúdo dos metaprojetos dos alunos, torna-se visível sua base de computação gráfica. Apesar de faltarem algumas especificações, como linhas de chamadas e marcações de cotas, as informações técnicas das peças deixam claro que se tratam de formandos que dominam o processo de projetação em moda.

Percebe-se um investimento maior na oferta de disciplinas específicas voltadas ao ensino de ferramentas digitais como Illustrator, Kaledo e Rhinoceros do que no Brasil, além dos alunos também serem mais
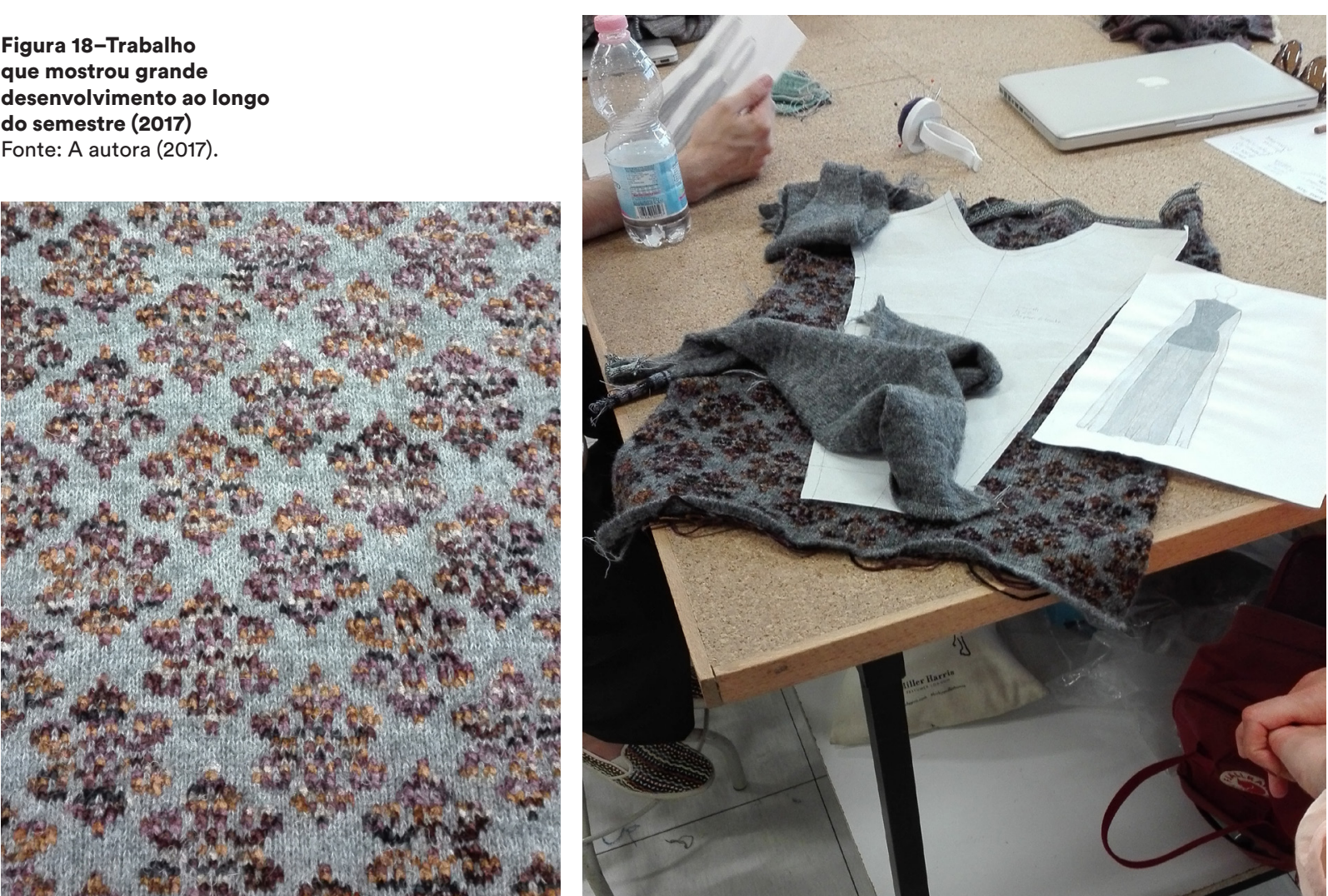

autônomos e pró-ativos. $\bigcirc$ ambiente e o processo levam alunos com trabalhos mais fracos no início do semestre a se desenvolverem.

Uma das últimas etapas de projeto é fabricar dois e três outfits. Esse trabalho serve como a tesi (o trabalho final de graduação) e portfolio. O Politecnico não organiza um desfile, mas estimula seus alunos a participarem de exposições, como a feira internacional Pittifilati em Florença e concursos como o da Loro Piana.

\subsection{A disciplina Metaprogetto}

A disciplina de Metaprogetto tem como responsável Paola Bertola, que tem o auxílio de Federica Vacca, Chiara Colombi e Anna Molteni. É dada bastante importância ao caráter reflexivo do fazer design, sobre como pensar processos de design e não reproduzir fórmulas projetuais. Esta é considerada a disciplina de projeto por excelência do curso de Design de Moda do Politecnico di Milano.

Antes de iniciar o trabalho prático de desenvolvimento de coleção, a primeira aula é dedicada a traçar um panorama teórico sobre a noção de projeto no campo do design e da indústria de moda na Itália, que pautará as demais aulas. Bertola destaca a tradição em inovar produtos, mas sobretudo, os processos que envolvem a criação de moda e vestuário de moda.

Optou-se por separar o material pesquisado nas aulas de Conti e Bertola, porque possuem propostas e objetivos distintos. Enquanto, no primeiro caso, o aluno está no fim do curso e já está pronto para desenvolver sua primeira coleção por inteiro, na aula de Metaprogetto o aluno ainda se encontra no segundo ano do curso e, portanto, está aprendendo os processos envolvidos na prática do projeto, com foco em outras questões.

O trabalho nessa disciplina parte de um briefing fornecido pela professora e volta-se mais ao campo do design e ao seu aspecto científico-reflexivo como prática teórica e comercial no desenvolvimento de uma coleção.

\subsubsection{Aspectos históricos e político-}

Entre os pontos abordados sobre projeto, estão o papel do designer na era da standardização do Arts \& Crafts e o design como método científico. Sobre este último, Bertola fala do papel da Inglaterra e da Alemanha e de 
como a Bauhaus promoveu a grande tradição científica no que diz respeito às pesquisas em design; o avanço da industrialização e a atitude objetiva.

Foi o olhar científico para o design que possibilitou sua organização em processos e seu crescimento como uma prática produzida por reflexão. Não há uma disciplina específica sobre a história do estilismo ou do design de moda. O que existe no Politecnico di Milano é a disciplina Storia e scenari della moda voltada aos períodos históricos da moda e seu contexto, lecionada no segundo ano da Laurea Triennale.

A abordagem da indústria italiana considera $o$ artesanato e a tradição industrial baseadas em uma atitude social, ou seja, é o processo da consciência individual que determina a real ou possivel atividade do indivíduo no mundo social e, para alguns autores, é ainda a tendência de agir de maneira coerente com referência a certo objeto. Além desses aspectos, a cultura politécnica que abrange diferentes campos das artes e ou ciências estaria no centro da cultura industrial desse país.

O discurso do Politecnico abrange engenharia, artes e humanidades onde - aluno é levado a desenvolver o seu componente criativo para a indústria, colocar seu talento, à certa altura, à serviço da produção em série a partir da organização de processos.

As habilidades necessárias para o designer do Politecnico di Milano desenvolver são relativas à organização dos processos, ao conhecimento e domínio de ferramentas e às metodologias necessárias para desenvolver projetos, além do merchandising program.

Por último, Bertola contempla o Italian System. O Sistema Italiano possui uma abordagem entre a costura francesa e o prêt-à-porter americano. Até 1950 a referência estilística era a França e a industrial eram os EUA. A partir desse período a Itália foi marcada por UMA grande tradição industrial. Com o Plano Marshall do segundo pós-guerra havia um comprometimento de modernização da Itália.

Em 1960 surge um distrito industrial em Milão. O magazine de luxo "Rinascente" vendia, pela primeira vez, produtos dotados de um aspecto de modernização, provenientes sobretudo dos Estados Unidos, adotando o modelo americano. Nesse período, a "Rinascente" promove uma série de atividades culturais que a transformariam em uma espécie de janela para mundo, entre elas a criação do Compasso d'Oro em 1954. Os produtos de diferentes mestres italianos que passam a ser comercializados ali, como os de Casina, Artemi, Armani, Ferré, Kriziaetc, representando uma visualidade que transita entre arte, arquitetura e design nesse momento.

Todos esses trabalhos presenciaram a nova cultura do design na Itália, onde era importante manter vivo um componente criativo do design. modelo de gerência de uma empresa baseado nas funções profissionais de CEO e Diretor criativo foi replicado nessa época e mantido ate hoje. A ide é ter um profissional para reger e outro para criar. Nisso consiste o sistema de moda italiano ainda hoje.

\subsection{2 $\begin{aligned} & \text { As aulas de } \\ & \text { Metaprogetto }\end{aligned}$}

As aulas de Metaprogetto também partem do briefing, mas neste caso, especificado pelas professoras. Os alunos devem desenvolver uma coleção para a marca RED Valentino.

Entre os itens do trabalho estão o Cenário de Design que consiste no estudo de caso, pesquisa iconográfica, perfil do consumidor e todas a entregas em torno dessas pesquisas, envolvendo painéis, desenhos etc; 0 Design de Produto, que conta com pesquisa de mercado, conceito, códigos de estilo, fabricação, peças chave, moodboards finais de estilo de vida; e o Plano de Negócios ou Merchandising Plan, onde são destacadas as peças chaves e é realizada a edição da coleção, definição das ocasiões de uso, desenvolvimento de coleção, grid ou mix de produtos, cores e variantes, preço no varejo, lookbook para vendas, press release da coleção que, segundo o programa, é um texto técnico de quinhentas palavras.

É apresentada a marca Valentino e suas tipologias de produtos, onde mais diversidade deve ser oferecida. Debruça-se então sobre a Valentino e RED Valentino como caso de estudo, concorrentes diretos, indiretos e seus públicos. Esse é o primeiro item de Cenário de Design.

A partir daí, Bertola levanta a questão "qual o elemento que permanece como o DNA da marca?" e cita as peças com camadas, a assimetria, as flores, as pregas, os plissados, o pois, a sobreposição, mas sempre mantendo a silhueta Valentino.

O briefing determina que sejam criadas três linhas de produtos com as iniciais RED de Valentino: romantic, eccentric, design.

$O$ tema do trabalho contido no briefing a ser desenvolvido era blondes $X$ brunettes, a partir de referências do cinema das décadas de 1930 a 1980 do século XX. Nesse contexto, era selecionada pelo grupo uma personalidade feminina loira ou morena. A configuração dos grupos ficou da seguinte maneira: anos 1930 morena, anos 1940 loira, anos 1940 morena, anos 1950 loira, anos 1950 morna, anos 1960 loira, anos 1960 morena, anos 1970 loira, anos 1970 morena, anos 1980 loira, anos 1980 morena.

Dentro da década, eles podem escolher a personalidade entre as indicadas pelas professoras. A década auxilia na pesquisa de silhuetas, cores, detalhes e decoração. Ao longo das primeiras aulas foram dados exemplos a partir do tema sobre qual caminho seguir, para que ele se torne produto.

O segundo item do Cenário de Design é ensinado por Anna Molteni, que orienta uma pesquisa iconográfica. A esse respeito ela pede aos alunos que procurem imagens menos óbvias, evitem imagens clássicas de atrizes como divas de cinema, que não procurem em blogs, achem algo interessante realmente original. Defende que a pesquisa em livros nas bibliotecas pode ajudar a encontrar algo realmente novo. Apesar de fazer sentido, ela não embasa nem aprofunda o comentário, dispensando maiores orientações a respeito da pesquisa de imagens, no sentido de seu conteúdo. 
A segunda aula é sobre pesquisa de tendências, com Chiara Colombi. Ela cita os elementos do design, como cores, formas, além do contexto cultural, seguidos por marcas de estilo e também o Guia de Processo Industrial que aborda o que é economicamente seguro.

No mais é uma aula sobre trickle effect. De um lado, existem as pessoas e o tempo que determina a duração de uma tendência, o subir e descer em um gráfico para prever mudanças de longa duração, pois existem mudanças emocionais e psicológicas ao longo do tempo. Para Colombi, dessas pessoas é fundamental compreender quem está interessado nesse conteúdo.

É importante para um designer reconhecer o estilo entre as pessoas. A previsão de tendências muitas vezes se baseia em pequenas mudanças. Trata-se de um sentido de continuidade entre o que já foi feito e o criar, provocando o nível de ruptura ideal que indica uma novidade para o seu público. É sobre olhar o passado e o futuro ao mesmo tempo. Há uma separação entre quem cria tendências e quem as segue. Para Colombi (2017), depende em qual ponto da cadeia você está.

Colombi fala então do modelo das categorias de adoção já tratado na forma de produtos por Pires (2000 apud Treptow, 2013) e Vera Lígia Gibert (1993, p. 202), na seção 2.6 do capítulo 2 desta tese. Ele é representado pelos inovadores, early adopters, early majority, late majority, leggards.

Salientam que é importante a observação de coohunters, formadores de opinião no campo da arte, design, moda e ídolos e a análise de cultura jovem. Nesse momento Colombi indica Ted Polhemus para falar de cultura urbana. Feiras de tecido e fios, bureaux de estilo e revistas especializadas também são indicados como boas fontes de pesquisa.

Por último, no tocante à tendências fala-se do zeitgeist ou spirit of the times que permitem promover algo original e novo. Em outras palavras, a seleção coletiva ilustra de onde deriva a formação do gosto, a partir de um grupo de pessoas respondendo coletivamente ao zeitgeist ou spirit of the time, afirma Colombi (2017) citando Blumer (1969).

Os códigos de estilo, o desenvolvimento inspiracional, a seleção de tecidos, e a definição de cartelas de cores (color stories) são direcionados pela análise do produto, o gosto dos consumidores, que está vinculado à pesquisa de tendências, e aos indicadores culturais que regem as análises competitivas junto aos parceiros e concorrentes.

Após duas aulas expositivas, começa a orientação com Paola Bertola e Federica Vacca. Iniciam a confecção dos moodboards partir de imagens de inspiração do tema, ou seja, imagens relacionadas a cada personalidade feminina do cinema, morena ou loira, escolhida por cada grupo. Em seguida, são feitos pares com imagens relacionadas à época. São pedidas trinta imagens para cada ícone feminino da década, e cem imagens do período histórico e assinalado. Cada orientação dura cerca de trinta a quarenta e cinco minutos.
Alguns questionamentos são propostos por Bertola de forma a estimula os alunos a pensarem da forma como se pensa um problema no design. “Qual é o ambiente?", perguntava apontando para fotos. Durante a seleção de imagens, ela não tira nenhuma da mesa, mas vira para baixo as que merecem ser deixadas de lado. Ela pede que o trabalho tome uma direção e diz que ela começa pelas escolhas. Sugere procurar fotos da atriz em questão com diferentes tipos de vestimenta e detalhes.

A prática de ensino de Bertola mostra que é possível pensar o problema no design de moda como no design, mas, por mais que pareça contraditório, não há uma noção de problema no campo da moda, assim como existe no design.

Durante os atendimentos aos grupos, Bertola chama a atenção sobre como olhar para as fotos. Destaca acabamentos a partir do vestuário que aparecem nas fotos, e aconselha a olharem os detalhes nas fotos, para não os repetir em sua coleção. Nesse momento da pesquisa, ao recorrer a fotos com produtos de moda trata-se de uma pesquisa fechada.

Ao longo do semestre, exige que os alunos trabalhem com autonomia, como em um estúdio ou empresa, o que fica claro no aviso escrito na lousa: "o tempo em sala não é para esperar pela nossa revisão, mas para trabalhar em equipe."

A orientação dada ao grupo atendido por Federica Vacca é que organizem as imagens por contiguidade de cores, estampas e formas. Ela vai explicando e fazendo um pouco do trabalho para sugerir para o aluno como deve ser feito e, assim, vai ensinando a enxergar conexões possíveis entre as imagens para o tema dado. Propõe sempre uma familiaridade entre as figuras. Em um dado momento, ela pede que procurem fotos de mulheres atuais que traduzam essa mulher de época.

É preciso montar histórias diferentes e, para isso, há painéis distintos. Ao rever o programa de aula, além do conteúdo em sala, tem-se mais clareza a respeito de dados objetivos que compõem o trabalho. Inicialmente são 9 moodboards, sendo 3 moodboards de estudo de caso, 3 moodboards de pesquisa iconográfica +3 cartelas de cores (no mesmo painel) e 3 moodboards de estilo de vida. Então no item Cenário de Design são desenvolvidos 9 moodboards em 3 partes: estudo de caso, pesquisa de imagens e de estilo de vida.

No item Design de Produto, na definição do conceito, são desenvolvidos entre 13 e 19 moodboards, sendo 1 moodboard conceitual ou moodboard de códigos estilísticos, 3 moodboards de tecidos e aviamentos, módulos e motivos gráficos para estampas, bordados etc no quesito fabricação e, por último, no item de design dos outfits, quando ocorre o desenvolvimento da coleção propriamente dita, são desenvolvidos entre 9 e 15 moodboards para cada linha, sendo de 3 a 5 moodboards com outfits chave para cada linha. Os moodboards do item design de outfits devem ressaltar os detalhes mais representativos para a identidade da coleção nas 3 linhas: romance, eccentric, design. 
O Plano de Negócios ou Merchandising Plan é uma fase que conta com mais de 22 moodboards. O primeiro diz respeito à definição de ocasião de uso, e seria, na linguagem estudada até agora nas escolas brasileiras, uma mistura entre Mix de Produtos e Plano de Coleção. Outro moodboard está relacionado ao desenvolvimento da grade (GRID), e seria a contagem do Mix de Produtos por tamanho, cores, modelos (básicos, fashion, intermediário) para oferecer à coleção um mix equilibrado. Ele é apresentado em tabelas de Excel. A seguir, vem outro moodboard de fabricação com as cores das 3 linhas colocadas juntas, dando unidade à coleção e suas entradas na estação. Há também o moodboard de nível de preço no varejo da fase homônima, considerando o posicionamento da marca por preço de categoria de produto e, por último, o moodboard do lookbook de venda, que se assemelha ao plano de coleção, reunindo os croquis coloridos, e que conta com 21 looks, que irão originar 21 moodboards.

Ao final, todo o processo é apresentado por meio de painéis, que somam entre 40 e 50 ao final do trabalho.

A partir do segundo mês, a aula se concentra em orientações aos grupos. A classe da qual essa pesquisa se ocupou contava com 11 grupos, de cerca de 6 alunos cada. Cada professora, Bertola e Vacca, se revezavam na orientação dos grupos. Em várias aulas também contribuía Anna Molteni. Eram vistos com frequência os moodboards, dada sua importância, pois serviam de guia e forma de apresentação do trabalho à medida que este era desenvolvido.

Bertola fala da importância de vincular um moodboard a outro, formando um grande storytelling. O moodboard é um objeto que nos transporta àquela época que serviu de tema. $\mathrm{O}$ moodboard do perfil do consumidor (lifestyle), ainda do Cenário de Design, é composto por foto de moda, paisagem, arte, interiores (que seria um painel semi-aberto). Como um painel de estilo de vida, sua revisão é fundamental para o desenvolvimento do produto de moda, já que, segundo as professoras, a roupa seria uma primeira linguagem, pois vem colada ao corpo, além de possuir grande velocidade de mudança.

Entres os atendimentos que se dedicavam aos moodboards, alguns revisavam o moodboard de estilo de vida e a cartela de cores. Durante a orientação notou-se que, de maneira geral, as cartelas de cores contavam com sete cores e era sempre feita com linha de costura. Até esse momento, nas orientações não é explicado passo-a-passo ou de forma objetiva como aproximar, como escolher imagens que vão ou não no painel. Depois das imagens, a orientação segue rumo à cartela de cores.

Algumas práticas de aula observadas na Itália persistem no Brasil. Isso talvez explique algumas atitudes de professores de projeto em ambos os países, como não revelar "segredos" de aula, principalmente entre professores e pesquisadores. Questionei na Itália uma professora por três vezes se existia e qual era um número sugerido ou ideal para uma cartela de cores. Permaneci sem saber.
Isso explica como o meio se fecha, como se torna propício à endogenia e, sobretudo, perpetua uma prática onde cada professor "faz como quer", já que muito do que é praticado em aula e no mercado não está nos livros, e não é revelado ou trocado entre especialistas do campo ou ainda, e mais grave, o que está em livros pode ser tomado como conteúdo pelo professor.

Acontece a primeira avaliação em sala. Ela é individual, mesmo o trabalho sendo em grupo. São entregues fichas para cada aluno, para auto-avaliação. Nesse dia encontrei cartelas de cores com cinco, oito e até nove cores. de Análise de Caso em grafico cartesiano com Cenário de Design (2017) fonte: A autora (2017).
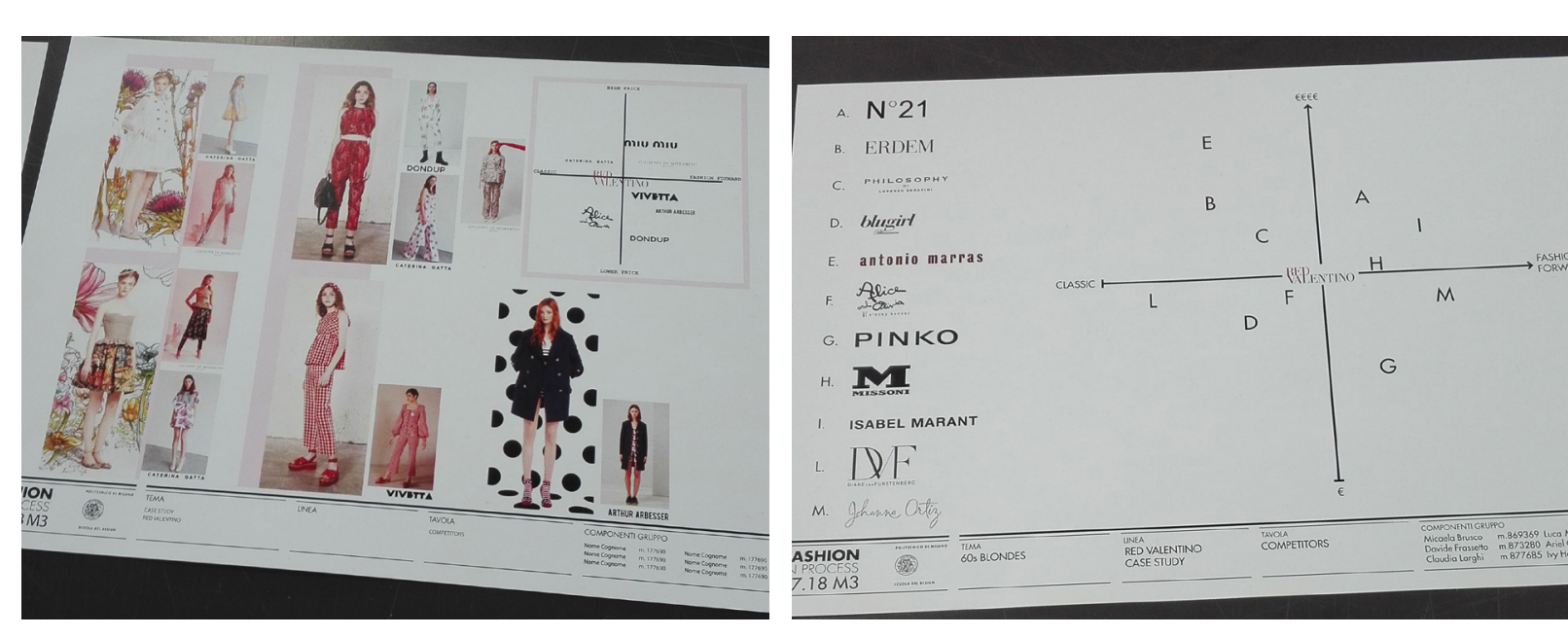

Acima (figura 19) estão os painéis fechados, com referências exclusivamente de design de moda para ilustrar os volumes, cores, modelagens e acabamentos mais recorrentes que observaram na marca dada no briefing, a RED Valentino. Em seguida, são apresentados mais três painéis do tema, divididos entre as três linhas (romance, eccentric, design), com referências de moda e de outros campos. Entre as imagens, são contemplados tema, década, releitura contemporânea do período histórico em questão e as cartelas de cores, sempre feitas com linhas de costura.

Existe um número ideal de cores para uma coleção, que varia de uma marca para outra. Nesse caso, as professoras sugerem que a coleção pode ter até vinte cores, mas fica difícil trabalhar, porque na venda, pode haver 0 "canibalismo" da própria marca, caso esta ofereça um mesmo produto em cores muito próximas. Outra questão é que as estampas devem contemplar as cores da cartela definida para tecidos lisos, alertam as professoras.

Embora não tenha sido dito, uma vasta cartela de cores atrapalha ou até inviabiliza a compra e a entrega dos tecidos, pois as tecelagens não costumam lançar pedidos baixos e, quando o fazem, a produção fica parada, enquanto não chegam todas as cores.

Assim como no Brasil, a maioria das empresas de estamparia na Europa também têm problemas com o desenvolvimento voltado à pequenas quantidades. Na Itália, a amostra é cobrada, para evitar que o desenvolvimento seja feito na Itália e a produção na China. Caso a produção seja feita na Italia, o valor do desenvolvimento é descontado da produção. 
Emum momento mais avançado do semestre, Paola Bertola realiza uma aula teórica para explicar como organizar as imagens coletadas por categorias. Deve-se marcar a diferença de sua natureza, separando-as por volumes, cores e tema. Teria sido útil essa explicação em um momento anterior. Na mesma aula aborda o Plano de Negócios por meio do Merchandising Research Dossier que, em certa medida, equivale ao "Inventário Interno" de Francisca Dantas Mendes, tratado na sessão 2.2 do Capítulo 2. A diferença é que no Politecnido di Milano ele baseia-se mais em imagens.

Os códigos estilísticos ou Stylistics codes devem ser interpretados pelos alunos segundo uma referência histórica. Bertola utiliza como exemplo o exercício de "sombra chinesa" na construção de silhuetas, e cita superficialmente princípios do design. No concept ou concept moodboard devem constar imagens que mostrem os detalhes originais, além do Stylistics codes.

No item Key items/Outfits Design, o processo criativo é organizado passo a passo abrindo e fechando a pesquisa e as opções dela oriundas, além de elencar os tecidos. Uma ideia é desenhada várias vezes, do desenho volta-se à pesquisa, recorre-se novamente à merchandising research e assim por diante para obter um único look. É uma edição cuidadosa de cada look da coleção e se assemelha aos exercícios "pesquisa colada sobre figuras" e "fotomontagem dos registros de moulage" propostos por Seivewright (2009, p. 119), discutidos no Capítulo 2 desta tese. Em último caso, trata-se da geração de alternativas.

O desenho tem um papel bastante específico nesta disciplina, sendo considerado design ao aplicar novas questões àquilo que foi criado, a partir de uma "abordagem cognitiva típica do projeto", nas palavras de Bertola. Novamente, a prática faz alusão à geração de alternativas, mesmo que isso não seja verbalizado a todo momento. Na sequência, ela busca mostrar seu ponto de vista ao exibir a ligação entre os produtos e a aplicação de detalhes, a partir da imagem de um Mix de Produto e Croquis.

Não existe uma receita para fazer design em equipe, mas conhecer os processos inerentes ao design e atribuir tarefas com datas estabelecidas para a entrega de cada uma é a melhor forma de contemplar o processo de design (BERTOLA, 2017).

A ideia de prazos e organização que envolve o briefing, para Bertola, vai ao encontro daquelas apresentadas por Renfrew e Renfrew (2010, p. 140), para as quais o briefing faz parte da "organização" do processo de projetar, conforme discutido Capítulo 1. Também concorda com isso Aline Monçores (2015), a qual, como exposto na sessão 2.5 do Capítulo 2, afirma que o briefing está diretamente ligado ao estabelecimento de prazos para as tarefas, com vistas a cumprir as etapas de um projeto.

Para atingir as variáveis de um produto (geração de alternativas) é importante conhecer bem os detalhes da coleção, os stylistic codes e key itens, para explorar os "princípios do design" (repetição, ritmo, gradação, radiação, contraste, harmonia, equilibrio e proporção), pois estes se tornam mais relevantes ao se compreender que projeto é "fazer o design da sua solução", conforme explica Bertola.
Esses stylistic codes e key itens também são responsáveis por formar famílias dentro das linhas de produtos de uma coleção. No caso das estampas, por exemplo, deve-se prestar atenção para desenvolver sempre os mesmos módulos ou motivos gráficos em toda a coleção, pois eles são um stylistic code que transmite a ideia de coleção e, sobretudo, de famílias de produtos dentro de uma coleção, unindo visualmente seus produtos por contiguidade. Essas famílias de produtos dentro de uma coleção são importantes no design de moda, pois ajudam a configurar um padrão visual para um grande número de desenvolvimentos para cada linha e coleção.

Como já alertado anteriormente nas seções 2.1 e 2.6.1 do Capítulo 2, os stylistic codes e key itens guardam relação com os elementos isomorfos, homeomorfos e catamorfos de Bruno Munari (2008, p. 134). Mas Munari os denomina de elementos no design visual o que Bertola chama de stylistic codes no design de moda.

Em Metaprogetto, além dos tecidos serem determinados pelo briefing, eles são entregues pelas professoras sob a forma de amostras. Essa atitude impede os alunos de colocarem em prática a pesquisa de materiais a ser feita no mercado, mesmo que as docentes alertem que "materiais selecionados na prática do design podem ser tingidos, bordados ou sofrer outros beneficiamentos" (VACCA, 2017).

Claro que os estudantes podem beneficiar os tecidos definidos no briefing, mas saltam as etapas de coletarem seus próprios tecidos, testarem sua capacidade de aliar livremente a escolha de matéria-prima a uma criação e, principalmente, de entrarem em contato com o mercado de tecelagens e importadoras.

À certa altura Federica Vacca começa a dar explicações sobre os kits de tecidos que serão então distribuídos aos grupos. Ao escolher um tecido para uma coleção, deve-se observar sua estrutura (se é um Jersey, uma popeline ou um cetim), sua composição (algodão, poliamida, seda, lã), seu peso (leve, médio, pesado), seu toque (se é suave, peludo, fino), o lado (avesso, direito ou dupla face) e a elasticidade (se tem ou não elastano). Pondera o que é preciso analisar em um tecido, mas não ensina o que deve ser considerado na compra de tecidos e malhas em escala industrial, de tecelagens e importadoras.

Faltam questões como largura, preço, rendimento no caso das malhas, pedido mínimo em metros ou quilos, prazos de entrega. Essa parte industrial que caracteriza o design por excelência é negligenciada pela disciplina de Metaprogetto. Cabe aos alunos se concentrarem "no tecido perfeito para o tipo perfeito de roupa", ou seja, à adequação da matéria-prima à uma criação.

Os kits distribuídos aos grupos de alunos consistem em três conjuntos de tecidos, de acordo com as linhas das coleções a serem desenvolvidas: romantic, eccentric, design.

Para a Linha Romantic foram fornecidas as seguintes bases: piquet, musseline de algodão, organza leve estampada, poliéster vichy, tule, jeans, gabardine, cetim duchese dupla face (rosa de um lado e verde do outro) etc. A linha Eccentric foi contemplada com os seguintes tecidos: crepe de viscose, crepe georgette stretch, cetim de seda, renda, voile plissado, tule, 
tafetá, cady (tecido de alfaiataria misto PA ou PES; CV; CO; WO; PUE), Iã fria com lurex, cetim duchesse com lurex e jacquard. Por último, foram dados os seguintes tecidos para a Linha Design: malha de algodão, tricoline tiedye, tricoline estampada, tricoline texturizada (possivelmente maquinetada), oxford estampado com flocado, algodão leve, algodão pesado, jeans peso leve, tactel (poliamida), neoprene (dublada com malha mesh) e tule.

Alguns tecidos são de baixa qualidade, como o oxford. Isso permite afirmar que tecidos de qualidade inferior não são utilizados somente no Brasil. Deduzi quais eram determinados tecidos de algumas amostras apresentadas à classe, graças à minha experiência como estilista, o que proporcionou grande conhecimento em tecidos, porque não era possível enxergar de longe qual era o tecido apresentado à sala, e também não me foi dado um kit para análise.

Da metade para o final do semestre são apresentadas diretrizes para os desenhos técnicos, por Anna Molteni. Ela cita o livro Fashionpedia como referência e sugere fazer o croqui na mesma proporção do técnico e vice-versa, colocando ambos lado a lado com a marcação das alturas, ou seja, a marcação de cotas. Os croquis devem ser detalhados em preto e branco. Nesse momento Molteni apresenta uma apresentação power point com quatro croquis lado a lado como se fosse um Plano de Coleção, mas em preto e branco, com linhas de chamada indicando o tipo de acabamento e o tecido.

Um aluno questiona Paola Bertola, se pode fazer um novo desenho a partir de outros. Tal exercício equivaleria à geração de alternativas no design de produtos e, o que se vê é que, aparentemente, o conceito não foi ensinado ou vinculado conscientemente à prática de projeto nessa disciplina, mesmo se tratando de Metaprogetto.

A última aula teórica do semestre chama-se Meta Design: Designing the Design Process, e descreve quem são os principais agentes em uma empresa em termos de gerência. Eles são três: o diretor de arte que planeja a comunicação, o gerenciamento de mídia e a produção da comunicação; 0 diretor criativo que é o designer sênior ou júnior que se ocupa na pesquisa e deteç̧ão de tendências e materiais, desenvolvimento do produto, cuidados com a produção e a logística; e o gerente de varejo, que organiza o planejamento das lojas, compras e entregas e gerência da loja. Grande parte dos gestores ou grandes gerentes têm formação em economics na Itália. $O$ mesmo ocorre no Brasil, onde os cargos de CEO de grandes empresas de design de moda são ocupados por egressos de cursos como Administração, Engenharia ou Comunicação e não de Moda.

A disciplina de Metaprogetto abrange um amplo espectro do design de moda, chegando ao ponto de descrever postos profissionais, sempre de chefia, para os quais pretensamente esses estudantes estariam sendo preparados. Porém, já se sabe que a oferta de formados hoje é muito superior à demanda, então muitos sequer irão trabalhar no campo da moda.

Muitos estudantes de Londres, por exemplo, precisam migrar para outros países como Itália e França para tentar trabalhar no campo de moda, porque a indústria inglesa não os absorve, uma vez que a tônica de sua formação é em artes e o interesse da indústria inglesa é em design de moda comercial; outro problema é que em vários países da Europa, a oferta de profissionais graduados é muito maior que a demanda (VOLONTÉ, 2008, p. 160-161, 176). A Itália, por sua vez, é um mercado que recebe mais formandos do que realmente é capaz de absorver (STRADA, 2017), a exemplo da França. Brasil sofre do mesmo problema, porque forma muitos designers, tendo em vista o alto número de faculdades de moda no país.

Talvez fosse mais interessante mostrar outras alternativas profissionais além de designer, e pela mesma razão: faltam postos de trabalho enquanto sobra mão de obra especializada. Mas não são os postos de chefia, relacionados aos negócios e que tradicionalmente já são ocupados por egressos, em sua maioria do sexo masculino, das áreas de administração, engenharia, comunicação ou economia, que irão resolver a questão. Atualmente, no Brasil, o trabalho de modelista tem sido ocupado por formados em moda, indicando caminhos para uma nova inserção desse profissional, e, portanto, vale a pena discutir o alcance do ensino em moda e também a questão de gênero, discutida no capítulo a seguir.

Depois que a coleção está toda no papel, é hora de transformá-la em produto. É a fase do desenvolvimento de produto que diz respeito à comunicação e às gerências das relações entre buyers, os pedidos e a produção.

Esse é o papel do gerente de produto, que precisa conhecer bem o ritmo e os métodos de projeto e o ciclo de todos os pontos-chave dos processos: desenvolvimento de produto, comunicação e varejo.

Uma coleção é um sistema complexo de produtos, nunca inteiramente novos, criados por meio de um processo com pesquisa e retorno de mercado (marketing feedback) e diretrizes de estilo estabelecidas pelo DNA da marca. A "arquitetura da coleção" atua no processo de encontrar a solução apropriada e, para isso, depende de entender o produto. $O$ enfoque, na disciplina Metaprogetto, é criar para atender às necessidades que surgem da pesquisa.

Concorda com essa visão a autora Cláudia Vicentini (2010, p. 97-98), para quem a "arquitetura final do produto" visa atender às necessidades do público em questão, a partir do resultado da combinação de princípios de solução que são representados nos croquis, conforme discutido na sessão 2.4.1 do Capítulo 2.

Apesar de os termos coincidirem até certo ponto em nomenclatura e definições, Vicenti aponta exemplos para testar a efetividade da aplicação de uma solução para um problema por meio de testes objetivos, também no na sessão 2.4.1 do Capítulo 2. É o caso da "análise do conforto e usabilidade", em que se deve fazer um "teste de uso" final pelo menos dos produtos clássicos, aqueles que não saem de linha. Esse teste pode envolver o consumidor, com o intuito de testar caimento, conforto, costuras, resistência etc. Na aula de Bertola, permanece uma lacuna sobre qual seria o problema e se ele corresponderia à noção advinda do campo do design industrial.

As fases do desenvolvimento de produto podem ser resumidas, segundo Bertola (2017), em obter matéria-prima e o protótipo da peça para dar sequência na produção industrial, mantendo a atualização sobre fornecedores e entregas. 


\subsection{A noção de projeto}

O processo de projeto desenvolvido por Nanni Strada tem sido objeto de estudo em outros países além da Itália, como o Brasil, além de exposições de seus trabalhos em importantes instituições de arte como Triennale di Milano e MOCA (Museu of Contemporary Art) de Los Angeles, que levam a pensar o desenvolvimento de produtos dentro da cultura italiana de projeto.

Além de designer, Nanni Strada também atuou como professora no Politecnico di Milano, na Academia di Brera e outras instituições, tendo inaugurado e difundido a noção de projeto para o campo da moda.

Questionada sobre as etapas de seu método de projeto, Nanni Strada argumenta acerca das influências fundamentais sob as quais foi engendrado seu método de projeto. Ela defende uma metáfora do "bosque como projeto" proposta pelo designer alemão Richard Sapper para expor sua visão de projeto: "iniciar um projeto é como entrar em uma floresta escura. Você pode chegar a certo ponto e entender que não achou nada e deve voltar atrás. Isso é projeto."

Parte de uma geração que, além de atuar na academia atuou com excelência no campo do design, a exemplo de Ettore Sottsass e Achille e Pier Giacomo Castiglioni, Nanni Strada formulou seu pensamento em design em termos científico e intelectual, além de colocá-lo em prática por meio de produtos que marcaram a história do design mundial.

Dos entrevistados italianos, o posicionamento político-pedagógico de Nanni Strada é o que mais preza pelos princípios do design e da noção de projeto de produto. Tudo leva a crer que essa troca entre a prática do design industrial e o desenvolvimento do ensino e da pesquisa tendem a colaborar com o campo no sentido da melhoria de vida do usuário do produto.

A manutenção desse pensamento, que preza pela troca entre escola e indústria, manteve a qualidade do Politecnico di Milano, que conta com professores que são profissionais reconhecidos pela indústria mundial, além de professores e pesquisadores de dedicação exclusiva de grande nível. Contar com esses dois tipos de profissionais dentro de uma escola incrementa a prática do projeto, "porque o projeto nasce da cultura, se chama cultura de projeto" (STRADA, 2017).

A primeira motivação para o projeto é a pulsão conceitual, que precede o desenho e a definição de soluções de projeto. "A minha pulsão conceitual se concentra no interesse sobre o corpo e na destruição" (STRADA, 2017) ou recusa à alfaiataria, aversão aos aspectos mundanos da moda, à crença de que criar roupas para os corpos das pessoas dependesse de oferecer um mesmo padrão de vestuário para biótipos muito diferentes que acabasse por acentuar seus defeitos até alcançar um nível de qualidade padronizado, aplicável ao vestido produzido industrialmente (STRADA, 2013, p. 28).

Esse estímulo de que fala Strada em seu caso se exprimia na negação de "um produto de alta moda que era ideal se vestido por uma mulher ideal e, péssimo, conceitualmente se adaptado a um físico considerado não ideal no qual eram destacados todos os defeitos."
Ao invés de vivenciar a melhoria de sua qualidade de vida por meio dos produtos de moda, muitas vezes o usuário vivencia um sofrimento, quando é constrangido por perceber que seu corpo não se parece com aquele corpo "ideal". Esse conceito de corpo "ideal" se tornou real a tal ponto que impôs a condição de anorexia ao corpo considerado ideal, para ser vestido e que é, sobretudo, um modelo negativo.

O primeiro objetivo de Nannni Strada é remover completamente a roupa da configuração desse corpo idealizado, ditado pela indústria da moda. Durante seu percurso, ela encontrou a solução encarando a roupa como um objeto, como um espaço a habitar. A roupa e o corpo devem estabelecer um relacionamento, e ele não pode ser punitivo.

Cada designer tem seu próprio processo, mas existem pontos cruciais. Fazer design implica em conhecer as limitações e o desempenho do vestuário. É preciso conhecer ergonomia, pois mesmo que pareça demasiadamente teórico, é um processo que pode ser apreendido instintivamente. Os valores da prática do design de moda, para Strada, estão centrados em observar como uma roupa veste um corpo e em viver bem, com especial atenção ao corpo.

$O$ processo de design demanda o estudo do corpo e isso se faz cientificamente, com o sistema de medidas e tamanhos. $O$ método para fazer uma moda que veste muito bem é também estudar as combinações físicas e, nisso, os americanos são melhores que os italianos, atesta Strada (2017).

Para uma boa relação entre corpo e vestuário, a forma deve ser livre. Essa liberdade tem como uma de suas fontes a geometria. Para que o corpo seja parte dessa geometria, ele deve transcender a forma, destacando o aspecto material do vestuário, que diz respeito ao tecido, malha ou qualquer outro material do qual a roupa se apropriará para envolver o corpo. $O$ design de moda oferece a possibilidade de criar a matéria e inventar novas formas, por meio da matéria.

Apropriando-se de máquinas de malharia circular para tecer meias, Nanni Strada criou as primeiras peças sem costura em 1973, os vestidos de "O manto e a pele", trabalho que Ihe rendeu o Compasso d'Oro em 1979. Esse projeto ensina como uma tecnologia pode ser apropriada de forma diferente da qual fora originalmente designada, para inovações no campo do design de moda. As máquinas possuem uma potencialidade que pode transformar uma peça piloto em um cenário de possibilidade mecânica.

Em um trabalho de consultoria em design para a fábrica de máquinas de costura Rimoldi, em 1983/84, foi solicitado à designer que propusesse o uso das potencialidades criativas das máquinas, para ver o que era possível fazer. O design é um processo que ajuda a desenhar um cenário para compreender processo e produto.

Para a designer: "a tecnologia é aquilo que te permite usar instrumentos inventados pela indústria para determinados fins, [mas] que se você tem intuição, pode usar não para fazer coisas habituais [mas] inovações" ou melhorias em produtos já existentes (STRADA, 2017). Em resumo, com a intuição, determinada tecnologia pode ser utilizada para outro fim, a serviço da inovação e com vistas ao bem-estar do usuário. 
Há algo estimulante no processo de design para Strada que passa pelo instinto, uma espécie de estímulo que, direcionado pelo repertório pessoal do criador, o leva a intuir uma possibilidade de realizar coisas que ainda não foram feitas.

Em uma fábrica, o interessante ao ver um maquinário funcionando é perceber sua potencialidade. Uma vez entendido o que aquela máquina faz, podem surgir ideias a respeito de seu uso para fazer outra coisa. Strada (2017) define isso como "transpor a metodologia de um âmbito a outro" Ainda segundo a entrevistada, "isso pode te levar ao desastre, mas se dá certo, te leva a grandes descobertas."

No sentido de potencializar esse impulso criador, Strada sempre alimentou sua criatividade pesquisando em fábricas. Além do contato com o maquinário, as trocas com as pessoas e o potencial de um projeto em grande escala, diante de um grande número de pessoas, sempre alimentou suas pesquisas. Ela recorda que sempre teve diálogos com os mecânicos dos teares: "não quero assim, quero de outra forma"; e falou de seu interesse pela dialética do que pode ser feito ou não e, ao fim, seu esforço de design se concentrava também em atingir esse resultado, a partir da colaboração daqueles funcionários.

Uma vez levantadas as tecnologias disponíveis, materiais e o estudo do corpo, é hora de expandir o projeto sentido à criatividade, e com o uso da imaginação começar a desenhar, experimentar materiais nos designs, realizar provas de roupas. Muito esforço é necessário para se chegar a uma roupa que é um objeto a ser habitado, mas quando funciona ao vestir é uma recompensa.

Esse momento mais criativo não prescinde da capacidade conceitual do designer, para compreender o que acontece e quais variáveis envolvem aquele objeto, suas questões funcionais sobre como uma roupa precisa vestir ou que caimento precisa ter para a função que será desempenhada por ela, ou ainda, o que o designer está projetando que as pessoas sintam ao vestir aquela roupa. Em resumo, o vestuário é projetado em sistema.

Como exemplo de sistema, Strada mostra um trabalho realizado em 1971, que consiste em um sistema de peças que se encaixam para cobrir o corpo, à medida em que se deseja fazê-lo. Esse sistema consistia "em roupas que eram colocadas umas sobre as outras e tudo interagia [...] a meia, a calça feita como faixas [que se completavam] era exatamente um sistema [que configurava] um modo de vestir, na verdade...”. Assim, a criação dessa coleção nasceu a partir de um novo conceito, mas também de novas técnicas industriais.

O conceito vem de um percurso projetual e da cultura de projeto. É saber e reconhecer aquilo que foi feito e, em função disso, se posicionar diante do que será criado. Além da consciência, o conceito pode envolver aspectos espontâneos, como o impulso criativo e a aptidão inata que têm caráter instintivo. $O$ conceito guarda relação com a pulsão conceitual, que depende de uma motivação voltada à soluções de projeto.
Os projetos que mais despertaram o interesse de Strada foram aquele dedicados ao sport, como o desenvolvimento de roupas para motociclistas. Nesse caso devem ser considerados aspectos como velocidade e proteção. As roupas devem ser dotadas de próteses, zonas de reforço, para em caso de queda proteger ombros, cotovelos, joelhos.

No segmento sport, além da liberdade do corpo, existe a necessidade de fazer coincidir argumentos sutis, considerando casos já estudados e elementos muito diferentes, somados a materiais e tecidos especiais e formas anatômicas. Ao observar os motociclistas quando descem da moto, por exemplo, e caminham como gorilas porque têm as pernas das calças e os cotovelos praticamente dobrados. Essa é uma de várias questões que precisam ser elencadas para garantir proteção e movimento. Projeto é reunir todas essas variantes que incidem sobre um produto, no ato do design.

Os designers dessa geração rumaram sentido ao desconhecido, um pouco "como Cristovão Colombo" brinca Nanni Strada. Então, quando se acreditava achar uma coisa, se encontrava outra. É o caso do "manto e a pele" onde Strada encontrou uma máquina de meias, mas viu a possibilidade de fazer vestidos. $O$ design também envolve o prazer da aventura, o prazer de inventar. Fazer coisas que, a princípio, parecem impossíveis, mas depois, uma vez que você estabeleceu o princípio ele pode ser reutilizado e servir de modelo décadas depois. Para demonstrar seu raciocínio sobre o estabelecimento de um princípio, compara o caso de o "manto e a pele" da década de $1970 \mathrm{com}$ as atuais máquinas de malharia circular jacquard Shima Seiki. O princípio é o mesmo, é idêntico.

Questionada sobre a ordem das etapas, se a cartela de cores viria antes ou depois de materiais ela elenca outros aspectos dessas duas etapas de projeto. Aparentemente, no projeto de Nanni Strada não se observa a relevância de uma ordem no caso de algumas etapas.

As cores e o aspecto tátil e visual dos materiais estão relacionadas à parte emocional da criatividade que envolve $o$ ato de projetar em moda, para Nanni Strada (2017). Para ela a cor na moda é completamente emocional. Quanto mais sensível à cor mais emoção se tem. E a leitura das cores é um dos aspectos criativos mais gratificantes que podem existir para o ser humano. Em seu trabalho as cores possuem um aspecto simbólico.

No caso dos têxteis, essa habilidade criativa-emocional está ligada à capacidade de reconhecer a qualidade têxtil e tátil do tecido, isto é, seu caimento considerando se ele tem movimento ou é fluído, por exemplo. Uma palha de seda é fluída, portanto jamais fará uma forma, mas sua qualidade tátil é extraordinária.

Entender ao que o material se presta no design de moda é parte do projeto e pode ser encarado como aquela parte do processo que pode ser associada ao binômio forma e função.

A ideia de problema no design de moda estaria vinculada a desenvolver pesquisa e o pensamento para criar formas com maestria, resolvendo a parte interna da roupa, seu caimento, vestibilidade, portabilidade e conforto. Em uma analogia com a arquitetura de Frank Gehry, Strada propõe que a visão artísticodecorativa externa compensaria o lado construtivo ou funcional interno. 
Como uma das últimas partes de seu processo projetual, Strada fala sobre o imaginário. Só ele leva à construção de uma imagem estética. Ele está relacionado ao que reaparece associado à pesquisa e ao que foi absorvido durante o processo de design, e guarda relação com a fase da incubação de Löbach (2007, p. 153), que seria a fase do descanso mental após a pesquisa.

\subsection{Oensino do projeto
por Nanni Strada}

No início dos anos 2000 a Nanni Strada foi chamada para o primeiro laboratório de moda do Politecnico di Milano, que até então não existia. Era o início da sequência de disciplinas de Laboratorio de Moda, que contava com Nanni Strada, Arturo Dell'Acqua que fazia a parte mais integrativa, além de outro professor fazia o laboratório sobre negócio e distribuição. É Nanni Strada quem implanta a visão de design no campo da moda no Politecnico di Milano.

Mais do que mood e tendência, importava uma pesquisa sobre design de moda. Ela era fundamental e estava diretamente ligada à performance do produto a ser desenvolvido, que deveria responder a situações de uso como roupa para montanha, cidade, viagem etc.

O processo de trabalho de Strada, sempre marcado pela pesquisa, dá pistas de como ela desenvolvia o ensino no Politecnico. $O$ "manto e a pele" pode ser tomado como o primeiro metaprojeto, pois fundou uma forma de criar roupas inovadoras. Ele partia da existência de uma tecnologia para a produção de um artigo específico (meias-calças), e a potencialidade criativa desta máquina descoberta por Strada por meio de suas pesquisas permitiu criar outros designs além de meias-calças, inaugurando a cultura de projeto em moda na Itália.

O design, para Strada, implica na tecnologia aplicada e na presença da máquina, daí a cultura de projeto vinculada à indústria. $\mathrm{O}$ "manto e a pele" precisou de ajustes até funcionar plenamente, fala-se de dez a quinze anos até o processo se efetivar. Foi uma inovação enorme que envolveu também marketing e distribuição, de acordo com Strada (2018).

"manto e a pele" envolvia características que mudavam o produto e a forma de fazê-lo, o design. Design de moda é sobre levar adiante uma tecnologia. Não importa se o que está sendo criado é vestuário para a noite, dia, mas o DNA do design de moda é a tecnologia (STRADA, 2018).

Quanto ao ensino. um bom número de alunos em uma sala de aula, desde que não seja excessivo, torna-se estimulante, segundo a designer. Uma classe de sessenta alunos que trabalha em grupo, ou seja, dez grupos de seis alunos, produz muitas ideias novas e interessantes que acabam por contagiar 0 restante da sala. Strada prefere deixar os alunos separados por grupos, porque a diversidade de seus produtos e soluções encontradas aumenta.
O papel do professor é ajudar os alunos a ter uma mente programada conceitualmente. Não é possível formar todos designers pesquisadores, mas o professor deve fazer o melhor para formar o melhor profissional na sua especialização (STRADA, 2018).

O ensino que promove Bertola é mais próximo ao do estilismo industrial, aquele inglês e francês da década de 1960, que visa primeiramente à massificação, em detrimento de processos inovadores. São tantos os níveis de estilismo e design que devem ser considerados, que as atividades devem se pautar pelo valor daquilo que o que é produzido sustenta, na forma como é produzido, e na forma de produto (STRADA, 2018).

Como o ensino do Politecnico di Milano é voltado ao design, graças ao pioneirismo de Nanni Strada, que levou a noção de design ao ensino de moda na instituição, existe um esforço para que os alunos tenham contato com novas tecnologias e possibilidades.

Nem todos os alunos vão fazer design, afirma Strada, referindo-se à falt da noção de problema no campo da moda. Ela ensina design, mas no caso de alunos com mais predisposição à criatividade ela busca extrair um bom trabalho a partir daquele potencial que lhe é oferecido.

É preciso propor um trabalho no qual a imaginação do aluno tenha vazão, isto é, quanto ele é capaz de escrever sobre aquilo que quer dizer, sua capacidade de síntese e criação de um conceito que seja culto, bem explicado e, sobretudo, bem escrito, que use palavras que não sejam banais.

Toma como exemplo palavras como "elegância" e mood que, de tão utilizadas em escolas de moda, tiveram seus sentidos esvaziados. Ela combate esse tipo de uso, pois o aluno deve contar aquilo que está em seu imaginário e onde quer chegar, e depois e fazer a síntese disso. A partir dal, propõe uma coisa dotada de um componente de criatividade.

Em resumo, ela pode ensinar o método, mas para desenvolvê-lo é preciso ter capacidade, o que depende não só de criatividade, mas também do repertório do estudante.

Embora a noção de projeto em moda de Strada tenda à fragmentação e à subjetividade, escapando a uma lógica objetiva como aquela elencada po Conti ou Bertola, observa-se a forte presença de máquinas e a capacidade de produção como elementos experimentais que compõem o processo criativo, aproximando sua metodologia de abordagens do design industria como ocorre nos trabalhos de José Bornancini, no Rio Grande do Sul ou nos de Guto Índio da Costa, no Rio de Janeiro. 
GIBERT, Vera Lígia P. O entorno acadêmico $e$ industrial textil no vestir e mora

brasileiros. 317 p. (Dissertação) - Escola de Comunicação e Artes da Universidade de São Paulo, São Paulo, 1993.

JONES, Sue Jenkin. Fashion design manual estilista: Sue Jenkyn Jones. São Paulo: Cosac Naify, 2005.

LÖBACH, Bernd. Design Industrial - Bases para a configuração dos produtos industriais. São Paulo: Blucher, 2007.

McROBBIE, Angela. British Fashion Design: Rag Trade or Image Industry? Londres: Routledge, 1998.

MUNARI, Bruno. Das coisas nascem coisas. São Paulo: Martins Fontes, 2008.

\section{RENFREW, ELINOR; RENFREW, COLIN.}

Fundamentos de design de moda:

Desenvolvendo uma coleção. Porto Alegre: Bookman, 2010.

SEIVEWRIGHT, Simon. Fundamentos de design de moda: Pesquisa e Design. Porto Alegre: Bookman, 2009.

STRADA, Nanni. Moda-design e cultura delprogetto. Milão: Lupetti, 2013.

TREPTOW, Doris. Inventando moda: planejamento de coleção. 5. ed. São Paulo: Edição da Autora, 2013.

VICENTINI, Cláudia Regina Garcia. Ferramentas e metodologia de projeto indústria têxtil-ça de produtos para a - Faculdade con Universidade Estadual de Campinas, 2010.

VOLONTÉ, Paolo. Vita da Stilista. Milão: Bruno Mondadori, 2008.
CONTI, Giovanni Maria. Entrevista realizada com Giovanni Maria Conti, em 21 de junho de 2017, na cidade de Milão, com 44 minutos de duração.

MONÇORES, Aline. Entrevista realizada com Aline Monçores, em 15 de outubro de 2015, na cidade do Rio de Janeiro, com 1 hora e 47 minutos de duração.

STRADA, Nanni. Entrevista realizada com NanniStrada, em 06 de dezembro de 2017, na cidade de Milá, com 1 hora e 38 minutos de duração.

STRADA, Nanni. Entrevista realizada com Nanni Strada, em 10 de janeiro de 2018, na cidade de Mila por duração.

VICENTINI, Cláudia Regina Garcia. Entrevista ealizada com Cláudia Regina Garcia Vicentini, Paulo, com 1 hora 2 minutos de duração. 


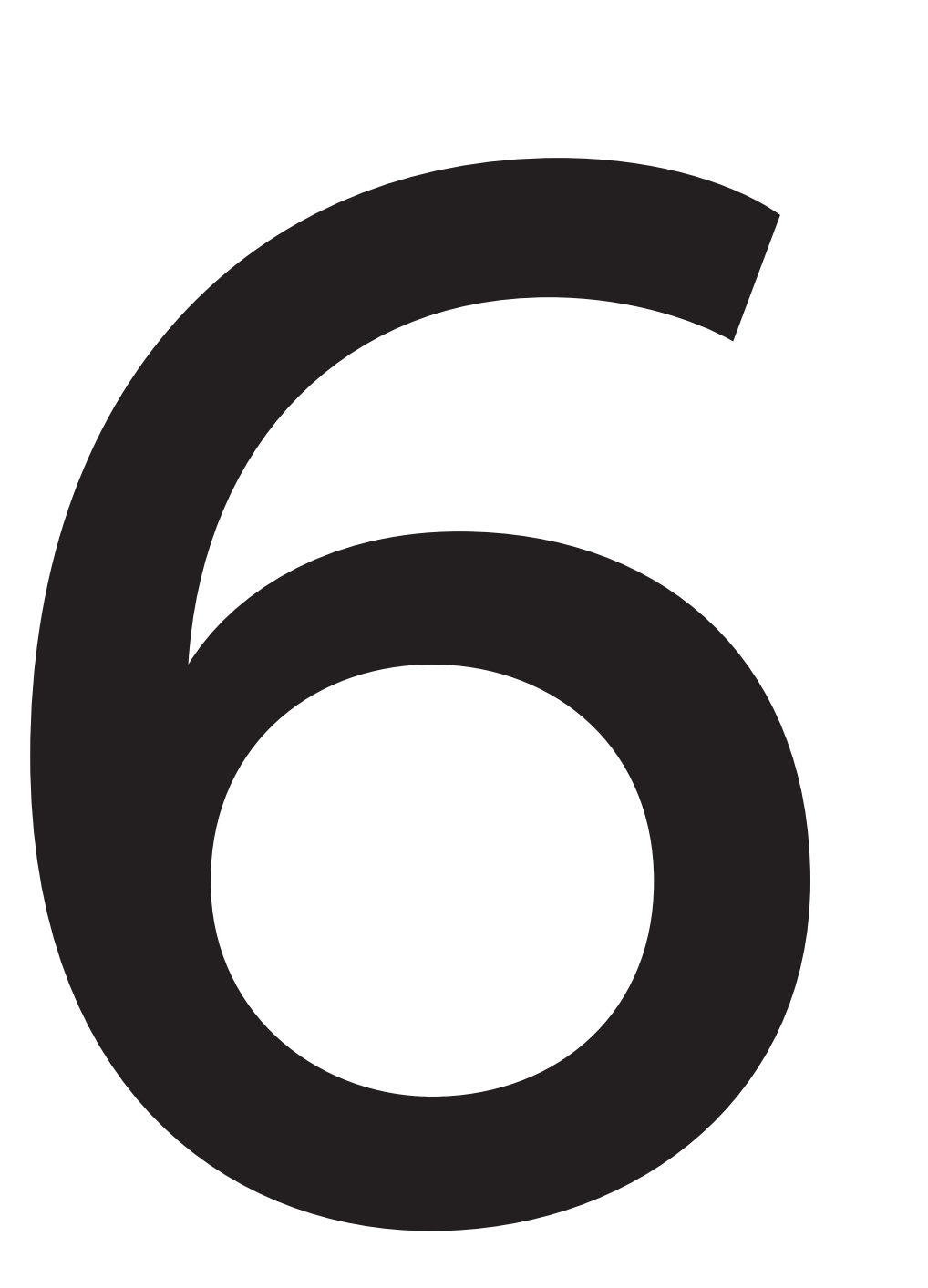

Mito e

aura versus anonimato

e produção industrial nas noçőes de estilismo e projeto em moda 
Tomando por base a revisão de literatura e os depoimentos cedidos à esta pesquisa, este capítulo se dedica à fundamentação da noção de mito, com vistas a sustentar a discussão sobre aura, anonimato e produção industrial, todas elas expressões que permeiam o fazer projetual do designer de moda e do designer. 


\section{1 fundamentação}

A partir do conceito de mito. este Capítulo busca discutir as noções de estilismo e projeto em moda que parecem vigorar no campo do design de moda. Para fundamentar tal discussão, foram utilizadas como apoio teórico as obras "O costureiro e sua grife: contribuição para uma teoria da magia" (2001) de Pierre Bourdieu e Yvette Delsaut; "Moda, luxo e economia" (1988) de José Carlos Durand; "Gesto Inacabado: processo de criação artística" (2013) de Cecilia Almeida Salles; e "Mitologias" (2007) de Roland Barthes. As acepções de Bourdieu e Delsaut, Barthes e Salles coincidem e se complementam. Quando reunidas alargam e tornam mais claro o conceito de mito.

O mito está associado ao capital simbólico, de autoridade, social e cultural que um criador possui, mas que se baseia, sobretudo, no capital de relações que este acumula, que o protege de julgamentos mais severos quanto às suas criações e faz com que se torne mais importante à medida que sua posição ocupada no meio for mais elevada (BOURDIEU; DELSAUT, 2001, p. 26).

As noções de mito de Bourdieu e Delsaut são complementadas pelas de José Carlos Durand (1988), Roland Barthes (2007) e Cecilia Almeida Salles (2013).

O mito é um sistema de comunicação que emite uma mensagem e investe imagens e certos usos sociais à matéria que seria representada pelo produto de moda. Com o tempo o mito se modifica e tende a desaparecer, mas na verdade ele se transforma ou é substituído por outro mito (BARTHES, 2007, p. 199-200).

Essa espécie de transubstanciação de um mito em outra forma de mito é fugidia, vazia, parasitária e empobrecida e se revela em um "saber mítico [que] é confuso [e] constituído por associações frágeis, ilimitadas" (BARTHES, 2007, p. 208-210).

Dessa maneira, o mito opera a violência simbólica tratada por Bourdieu e Delsaut que só se mantém porque, assim como o mito, ela não é apreensível pela realidade. Não se pode combater o que não é apreensível.

$O$ objeto imaginado torna-se um universo real a partir de um sistema construído que gera significado, ou seja, gera uma nova realidade. A obra concretizada é a capacidade de fazer ver ou tornar acessível e experienciável o efeito do mito por meio da materialidade da obra (SALLES, 2013, p. 139).

A materialidade da obra é mediadora do mito que possui caráter imperativo e interpelador e como tal, já estava presente antes de qualquer coisa ou alguém. $O$ produto dotado de mito passa a imagem de que já existia sem a ajuda de ninguém (BARTHES, 2007, p. 216).

O mito é uma fala roubada e restituída. A fala que se restitui não é exatamente a mesma que foi roubada. Quando retorna não ocupa seu lugar exato e esse breve roubo que tem caráter de falsificação consitui o aspecto da fala mítica (BARTHES, 2007, p. 217).
Em linhas gerais, "o mito prefere trabalhar com imagens pobres, incompletas, nas quais o sentido já está diminuído, disponível para uma significação: caricaturas, pastiches, símbolos etc” (BARTHES, 2007, p. 219).

Em meados do século XIX surge a noção de alta-costura, associada ao criador e seu ateliê, e dessa maneira a ideia de autoria na moda desponta. $O$ coutourier cria pensando em um público específico com o qual ele consegue estabelecer uma conversa, pois domina os signos desse grupo. Esse conhecimento, nesse contexto, permitirá que ele crie o que deseja, ou seja, crie para si mesmo, pois encontrou pessoas dispostas a vestir suas criações. Ele é o gênio criativo que logra do benefício de ter clientes dispostos a utilizar suas criações. É também nesse período que nasce a ideia de coleção. Esse profissional passa a assinar cada peça da sua coleção por meio da criação da etiqueta, ato que equivale à assinatura do artista na obra de arte.

O fato de a moda buscar o pertencimento ao mundo da arte é histórica e já se tornou um de seus traços constitutivos. Na Inglaterra da década de 1960, as escolas de design filiaram-se ao campo das artes, por meio de um currículo segmentado em quatro áreas: Têxtil e Moda, Design Gráfico, Design de Produto e Artes. Entretanto, em um movimento ambíguo, a arte julgava ser incompatível com a natureza pragmática do design quando 0 assunto envolvia o aspecto têxtil e de moda, sendo que, ao mesmo tempo, os campos têxtil e de moda dependiam do aval das artes para serem reconhecidas no meio acadêmico (McROBBIE, 1998, p. 33).

O costureiro busca se igualar ao artista operando a transubstanciação simbólica ${ }^{42}$ do objeto por meio de sua assinatura, como ocorre com o artista por meio da obra de arte. Esse criador é dotado de um poder quase mágico que é atribuído a um homem singular, capaz de produzir objetos que se tornam raros pelo simples fato de que ele os produz, ou confere raridade pela imposição da "marca", da "grife", como ato de marcação simbólica (BOURDIEU; DELSAUT, 2001, p. $36-39$ passim).

É a raridade do criador, ou seja, a raridade da posição que ele ocupa em seu campo que se transfere para o produto. Essa raridade justifica-se pela fé na magia da assinatura (BOURDIEU; DELSAUT, 2001, p. 37) que sustenta a crença no mito do criador.

Dessa forma, o valor do objeto está fundado na raridade do produtor "E produzindo a raridade do produtor que o campo de produção simbólico produz a raridade do produto: o poder mágico do criador é [seu] capital de autoridade" (BOURDIEU; DELSAUT, 2001, p. 38).

O poder é investido na figura do criador e não no produto, portanto, relaciona-se com sua prática, o estilismo ou o projeto, interesse primeiro desta tese. É na relação entre o criador, ato criativo, produto e os meio e agentes necessários para que ocorra a transubstanciação simbólica que reside o mito.

É requerido um tipo de disposição por parte do aspirante a ser criador. Segundo Foucault (1977 apud McRobbie) essa abertura que se espera dos ingressantes no curso de moda é na verdade uma encenação de um comportamento ensejado pela ideia de um estúdio aberto voltado às relações
258 
aparentemente não-hierarquizadas, e que constitui na realidade um espaço onde tanto a vida pessoal como profissional dos estudantes é forçada a ser vivida na frente de todos. "A aula de moda ideal deve permitir antes de tudo que essa ou esse aluno esteja aberto à vigilância nesse sentido."

A exposição do "eu" ou de suas emoções chega ao campo dos "namorados", - que ajuda a constituir a ideia de que a moda, como campo de estudo, é um espaço "feminilizado" e de ethos heterossexual (McROBBIE, 1998, p. 41).

Acima de tudo, o setor se mantém amplamente feminino, à exceção da Academia. que é um exemplo vívido como segregador do trabalho do gênero feminino até porque, entre outras razões, na moda, muitos professores são também profissionais dos quais se espera que incorporem e transmitam esta cultura de moda (McROBBIE, 1998, p. 43).

Em uma aula de Projeto no Politecnico di Milano pôde-se observar a influência de uma professora na perpetuação do mito. Ela aparece em expressões vagas como "eu amo essa figura", "essa imagem e super forte", "mais que bonito!", para julgar um trabalho de projeto, sem nenhuma outra explicação inteligível para isso. $O$ valor desse tipo de afirmação baseia-se exclusivamente no gosto pessoal de quem detém mais poder simbólico, nesse caso a professora. Cinco minutos depois os alunos estavam repetindo "eu amo..."

Na mesma aula a professora apontou a importância do domínio do "vocabulário de criação", pois ele permite que o designer cresça em diferentes direções.

O comportamento do couturier é um desdobramento da influência que este tinha em relação ao meio artístico, por intermédio das obras que colecionava e do estreitamento de relação que nutria com artistas. Segundo Maria Eduarda Araújo Guimarães, a alta-costura ensaia uma aproximação da arte, vinculando o estilismo à aura, que por sua vez, remete ao criador de moda como um ser divino, aquele que possui um dom.

Toma-se aura aqui no sentido cunhado por Benjamin (2012, p. 27), de: "um estranho tecido fino de espaço e tempo: aparição única de uma distância, por mais próxima que esteja", onde a unicidade da obra de arte equivale à sua inserção no contexto da tradição que encontra sua expressão no culto (BENJAMIN, 2012, p. 31).

É a relação entre raridade e a aura que sustenta o mito de que criar moda não seria algo que é aprendido, mas seria quase um dom. Essa noção de mito aparece comumente associada ao estilismo. É possível perceber essa intenção de ligação com a arte na fala dos pioneiros associados às faculdades de moda, analisadas por esta tese.

\section{2 dos autores e pioneiros}

Na FASM a noção de mito é mais evidente e contaminou muitos outros cursos. E essa ideia de que a criação é essa coisa "assim meio mágica, intuitiva" (BONADIO, 2015) continua a se proliferar e a perpetuar distorsões. A figura do estilista, por uma tradição do campo, mesmo com níve universitário, está ligada à afetação, a se achar um grande gênio e essa ideia foi engendrada, em termos acadêmicos, pela FASM nas aulas de Carlos Mauro Rosas (BONADIO, 2015).

Há também quem defenda a noção de estilismo segundo a diferenciação entre o trabalho do estilista, este vinculado ao campo da moda, e o do designer de moda, vinculado ao campo do design. É o caso de Francisca Dantas Mendes, que acredita que o estilismo não precisa necessariamente se apresentar como uma atividade ligada ao mito.

O mito também se manifesta no campo do design, por meio do trabalho do "design de autor"43, mas esta não é a principal vertente que marca a identidade profissional neste campo, nem sua atividade. Se a moda em termos acadêmicos é fundada no Brasil baseando sua atividade criativa e de produção no estilismo, o campo acadêmico do design se estrutura baseando-se no ideal funcional-racionalista alicerçado em conceitos como o design anônimo, o design universal e o design industrial.

Em termos acadêmicos, o projeto no campo do design diz respeito majoritariamente ao anonimato e à criação de padrão para produtos seriados, logo, é mais distante da noção de mito que o estilismo. Se o objeto criado pelo projeto em design não é único, mas industrial, fabril, produzido em série, não há porque dotar seu projetista do mesmo valor simbólico compartilhado pelo estilista, ou seja, a maior parte dos designers não precisa construir sua imagem como uma figura dotada de aura sustentada pelo mito, embora nem sempre seja o que se vê.

“A ideologia carismática da 'criação' é um erro bem fundamentado, como a religião", por isso tem a ver com crença e magia (BOURDIEU; DELSAUT, 2001, p. 39).

O princípio da eficácia da operação ritual não deve ser procurado no formalismo mágico, ou seja, no próprio ritual, mas nas condições sociais que produzem a fé no ritual (BOURDIEU; DELSAUT, 2001, p. 44).

O poder reside nas condições que dão poder, para criar a crença coletiva. O irreconhecimento coletivo do arbitrário da criação de valor se consuma pelo uso de palavras (BOURDIEU; DELSAUT, 2001, p. 45) e imagens na crítica de moda, no jornalismo de moda e nos meios de divulgação dos trabalhos de estilismo.

Esse arbitrário da criação de valor pode ser equiparado ao arbitrário cultural a que Gilberto Velho se refere. Segundo o autor, mais importante que a interpretação de dados brutos, é a interpretação das interpretações
43 Trata de objetos sinados, mesmo que não de produtos de design já "design de autor" em lojas 
Dessa forma, um dos objetivos deste capítulo se debruça em compreende a maneira como o grupo social vinculado ao campo do design de moda (projeto e estilismo) representa e classifica suas experiências (VELHO, 1980, p. 18).

Essa tarefa consiste em captar o arbitrário cultural, que seria a concepção cultural dos grupos e classes dominantes imposta a toda a sociedade por meio da dissimulação das forças coercitivas, no caso do design de moda e desta tese, das visões impostas sobre as noções de estilismo e projeto em moda pelos pioneiros dos campos da moda e do design segundo os interesses dos grupos dominantes.

O aparelho de celebração representado por clientes, mídia, relaçõespúblicas, jornalistas etc do estilismo equivaleria aos professores, pesquisadores, estilistas, designers, críticos etc reconhecidos pelo meio acadêmico do campo da moda ao qual são vinculados.

É o poder de mobilizar a energia simbólica que o aparelho possui que produz o capital simbólico que, por sua vez, por meio do irreconhecimento coletivo, gera a crença (BOURDIEU; DELSAUT, 2001, p. 45-46).

Um exemplo da noção de valor incorporada pelo estilista como principal membro da equipe aparece no livro "Fundamentos de design de moda: desenvolvendo uma coleção" (2010) de Elinor Renfrew e Colin Renfrew. Nele os autores defendem que o processo é centralizado na figura do estilista, responsável pela criação.

No final do século XX, três modelos principais de profissional em moda são discutidos por Angela McRobbie, a partir de suas pesquisas nas escolas inglesas. Trata-se do professional fashion, managerial fashion e o conceptual fashion que em tradução livre são o profissional de moda (mais generalista), o gerente de moda ou produto e o estilista conceitual.

professional fashion é direcionado a vagas em grandes empresas, de luxo e, de preferência, empresas de moda europeias. Seu perfil é voltado atuação na criação industrial, como funcionário, consultor ou empreendedor de seu próprio negócio (McRobbie, 1998, p. 44-45).

O managerial fashion atua como profissional de negócios e marketing de forma integrada. Esse perfil profissional é fruto dos primeiros cursos de Fashion Marketing. Por trás do pensamento que sustenta esses cursos, est a ideia de que nem todo profissional de moda terá sucesso como designer. Então esses cursos tentam mesclar criatividade com comércio, mesmo que às vezes haja um desencontro entre as habilidades desenvolvidas durante a graduação e as necessidades da indústria (McRobbie, 1998, p. 45).

A popularização da moda como profissão, por parte da mídia, a exemplo dos programas que ensinam a se vestir, cria uma demanda por formação especializada onde antes não havia, como é o caso das funções de styling, promotor de produtos de moda, vitrinista, gerente de varejo de moda e com foco na empregabilidade que essas instituições oferecem seus cursos (McRobbie, 1998, p. 45-47), o que acaba por atribuir nova imagem a funções já existentes no mercado associando-os à cultura do design de moda.
O terceiro e último modelo em educação em moda é também o mais visto na cultura popular e na mídia de massa. É aquele que se identifica com estilista ou criador. O conceptual fashion tem forte ênfase em experimentação e inovação individual de forma a atuar como um guia para o resto da cadeia têxtil. Contraditoriamente nota-se certa liberdade para experimentar sem responsabilidade com a indústria ou com os negócios, pois somente sob essas circunstâncias a criatividade encontraria sua verdadeira expressão (McRobbie, 1998, p. 47).

Parte da construção social do eu, do designer de moda como um artista criativo é um trabalho orientado e institucionalizado pelo sistema da escola de arte que é representado com excelência pelo profissional que atua nos termos do conceptual fashion (McRobbie, 1998, p. 63).

Tanto as noções de managerial fashion como conceptual fashion coexistem nas práticas ensejadas em universidades.

De acordo com Bertola (2017), professora de Metaprogetto, como a moda conta com o componente criativo, então um bom gerente de produto aquele capaz de interpretar o que o estilista está propondo. Entende-se que o gerente de produto é alguém que deve estar atualizado a respeito da cultura e costumes de sua época, mas essa afirmação também transmite de certa forma a responsabilidade para a compreensão da obra do "autor" estilista, para o gerente de produto.

Essa crença ganha força quando Bertola discute o desenho. Segundo a professora, a ilustração não tem obrigação de comunicar nada tecnicamente. Já para Federica Vacca é importante fazer o croqui na mesma proporção do desenho técnico, colocando ambos, lado a lado, com linhas de chamada e marcações de cota, de forma a permitir o esclarecimento do projeto partir de vários tipos de desenho. Mesmo não se tratando de um desenho técnico, o comprometimento do desenho com a informação e, sobretudo, a complementação entre diversos tipos de representações gráficas parece ser producente como forma de evitar gargalos e, consequentemente manter um ritmo produtivo convincente em termos de sustentabilidade ecológica, social e, principalmente, econômica.

Ao mesmo tempo que acena ao descompromisso no tocante à ilustração de moda, Bertola entende que o desenho técnico, que comunica, entre outras coisas proporç̃es, não deveria se opor ao croqui que muitas vezes aparece longilíneo e portanto, distorce a figura humana, problema recorrente no design de moda.

Também é preciso compreender ao que se refere cada tipo de desenho ensejado na disciplina de Metaprogetto. Se essa divisão é apresentada, isso não ocorre nessa disciplina e também nesse momento nenhuma revisão feita a esse respeito. Vale retomar as noções de desenho de Zaganin (2014a), que considera esboço o rascunho inicial somado ao desenho de detalhes isolados, o desenho de moda a representação do corpo com proporção, o técnico mais rigoroso quanto ao detalhamento do produto, a ilustração de moda que trata do resumo do conceito da coleção e, por último, o desenho promocional que está vinculado ao tema como proposta criativa, completamente desvinculado de aspectos práticos. 
Se for tomada a acepção de Zaganin para ilustração de moda, lembrando que o ensino em moda no Brasil é herdeiro da prática de design de moda italiana, a ilustração de moda que trata de conceito e tem aspecto mais livre jamais torna o gerente de produto o único responsável pela tradução do produto, no processo de design de moda.

Mesmo o curso de moda do Politecnico di Milano tendo iniciado suas atividades em 2003, quinze anos depois dos primeiros cursos superiores de moda brasileiros, sabe-se que já existia uma prática de design de moda italiana sedimentada, baseada na alfaiataria italiana, sua indústria e seus cursos que embora não fossem de nível superior, gozavam de grande tradição no meio da educação em moda. Essa prática italiana de design de moda serviu de apoio para a construção dos cursos de moda no Brasil, pois sabe-se de pioneiros que pesquisaram intensamente os cursos de moda italianos para um direcionamento inicial dos cursos de moda no Brasil.

Procurando manter-se invisível, o mito só faz aumentar as contradições. A luta entre os aspectos práticos e a liberdade criativa se estende a diversos aspectos. Na tentativa de se distanciar do mercado é abraçada a "economia invertida" onde o dinheiro não interessa" (BOURDIEU, 1993 apud McROBBIE, 1998, p. 49), assim negar o capital financeiro seria o caminho mais claro para a consagração cultural. Mas o que se vê frequentemente é que experiência de trabalho e patrocínios oferecidos pela indústria são aceitos mais ou menos sem questionamento (McRobbie, 1998, p. 49).

As contradições presentes no sistema que sustenta o mito são apontadas por diversos autores. Em um primeiro momento, ela contraria a visão acadêmica que prepararia o egresso para a vida profissional, mas percebese que no processo de institucionalização que a academia promove o mito se perpetua.

O design industrial construiu para si a imagem de um ensino mais sério, que estaria atrelada ao anonimato e à funcionalidade como elementos que desempenham um papel social na fabricação e determinação do uso de objetos. Mas como já visto, o design de autor tratado por Ethel Leon também já se mostrou de certa forma uma estratégia para estabelecer a ideia de mito no campo do design de produtos.

A popularização das carreiras de estilista e de designer de moda e a profusão de novas profissões no campo da moda tornará cada vez mais difícil a produção de um novo gênio criativo, bem como a sua manutenção.

Quem trabalha com produto precisa fazer um estudo para fazer aquilo, não vai "baixar uma entidade e dizer para ele faça tal coisa" (BONADIO, 2015). Não depende só da figura do criador. $O$ designer de moda está alinhado ideia de um projeto, com todas essas variáveis que não dependem só dele. Ele tem de acompanhar a tendência, o que a empresa quer, o direcionamento que a empresa vai adotar, então não é possível chamá-lo de estilista na visão de Maria Cláudia Bonadio, pois para a pesquisadora esse termo na moda está associado a estilo. Estilo como em arte, design, música ou literatura, como o conjunto de traços e características individuais que diferenciam a produção estética (TREPTOW, 2013, p. 28).
Bonadio reconhece que o mercado chama coloquialmente os profissionais de criação de produtos em moda de estilista de maneira generalizada, sem fazer diferença entre estilistas e designers de moda. Essa prática é percebida inclusive no registro da carteira de trabalho, mas Bonadio acredita que $\circ$ termo designer de moda seja mais adequado atualmente, pois quem atua no setor de magazine, como a Renner, a C\&A, ou seja, em grande escala é designer de moda.

Por essas questões designer de moda é mais cabível, enquanto o termo estilista é mais restrito. Os ditos "mais criativos" têm mais dificuldade de se adaptar ao mercado. Se houver uma comparação entre profissionais do mesmo nível, o jovem designer é mais bem remunerado que o jovem estilista, dotado da aura do artista, que trabalha na manutenção do mito. Há um abismo entre a faculdade que permite projetar coisas incriveis e o mercado, que é mais limitador (BONADIO, 2015).

Sobre o fato de sequer o mercado reconhecer a diferença entre designer e estilista, surge a dúvida se havia necessidade de o campo do design encampar moda, uma vez que nem ele conseguiu impor a diferença entre estilista e designer de moda, e muitas vezes entre estilismo e projeto no ensino.

A visão de Cyntia Santos Malaguti de Sousa (2015) difere das demais, pois ela tem a impressão de que o estilista está conectado à alta-costura, referindo-se ao lado criativo e, aparentemente desinteressado dos ganhos financeiros, da moda. Se for tomada como referência a moda francesa, é exatamente o contrário, pois o estilista é a figura que ressurge na década de sessenta para cuidar da produção industrial em série.

O estilista no modelo inglês e americano, antes do francês da década de 1960 está vinculado ao sistema industrial para vestir a massa, pois se debruça sobre o estudo do corte com foco na produção industrial (STRADA, 2017).

O fashion designer seria seu equivalente em inglês, também mais ligado ao "mercado". Apesar das confusões em relação à terminologia, as impressões de Sousa e Bonadio coincidem no sentido de ambas acreditarem que $\circ$ estilista no Brasil sustenta o mito de ser mais criativo que o designer de moda.

Antes de a moda passar por intersecções com o design Sanches (2015) afirma que tem

certeza que o estilista fazia esse trabalho de projetar, essa prática com tantas conexóes entre campos cultural, produtivo e mercadologico. Eu campo da prótica profissiona parra do campo acadêmicossaliss do os cursos, o estilismo ficou muito restrito a projetar linguagem visual ou a projetar formas, a configuração do produto [...] parece um pouco desvinculada de todo o contexto mais complexo que envolve quvela configuração como produto mesmo (SANCHES, 2015). 
A impressão que se tem é a de que o estilismo tende a ficar limitado ao desenho ou ao exercício de formas, negligenciando aspectos da configuração industrial, como pesquisa de público, necessidades da comunidade local, viabilidade técnica e financeira. Na visão de Sanches, algumas etapas do projeto podem escapar ao estilismo.

Mesmo que se fale em métodos de projeto, eles não devem ser seguidos rigidamente. Os exemplos de projeto oferecidos por Jones em seu livro não são uma prescrição, e "as pessoas da moda geralmente são rebeldes que sabem que as regras são feitas para serem quebradas" (JONES, 2005, p. 7).

Se por um lado, métodos são feitos para serem repensados e seguidos até onde servem ao projeto, não devendo, portanto, engessá-lo, essa percepção de Jones reforça certo excesso de informalidade e liberdade, mais associado ao estilismo, e que sustenta o mito. $O$ mito é responsável pela liberdad criativa do estilista, que explica o mistério, ou o mito dispensa o mistério no uso das etapas de projeto.

Embora a profissionalização seja uma exigência atualmente no campo da moda, o "aluno-artista" aposta muito mais na "atmosfera etérea" ligada à produção do mito do que na técnica. Antes de pretender a linguagem mais artística em seu trabalho, o aluno deve ser formado tecnicamente, para então subverter as regras (OLIVEIRA, 2014a).

A informalidade, que é um traço marcante no mercado de trabalho de moda, pode ser confundida com "liberdade criativa". Essa liberdade, supostamente, seria um dos princípios que regem a profissão do estilista mas ela também contribui para sustentar a instabilidade no campo do trabalho. O mito de que o criador em moda é um "artista livre" pode ser visto como um dos fatores que colabora para desestabilizar o campo do trabalho, na área de moda.

A maioria das vagas de criação é preenchida por recomendação, e "indústria da moda é famosa por não ter empregos seguros, e [apesar disso] muitos valorizam a diversidade que isso traz" (JONES, 2005, p. 200).

A área mais popular como campo de atuação profissional, sem dúvida, é o estilismo no segmento de moda feminina. No entanto, há tempos a moda feminina tem a reputação de ser o ramo mais instável da indústria de roupas, com a maior rotatividade de mão de obra (JONES, 2005, p. 10), ou seja, nem para o gênio criativo há a garantia de manutenção de emprego. Descortinase um cenário onde muitas vezes o mais importante são as relações pessoais, e não a genialidade conforme a noção de mito aqui abordada.

Para Guimarães a produção (industrial) éo lugar da razão, da regulamentação, do masculino e o consumo é o lugar do irracional, do feminino, do desperdício. Nas palavras de José Carlos Durand (1988, p. 130) há um jogo de interesses po trás do ciclo da moda, de importância econômica e de prestígio. Tomando por base o raciocinio de Guimarães e Duran, há mais de um século os interesses econômicos vinculados à indústria da moda muitas vezes são representados pela esfera do masculino, enquanto o prestígio associado ao uso, mas não necessariamente à aquisição desses bens de consumo, foram relacionados exclusivamente relacionados às características femininas.
Uma forma de separar habilidades e manter divisões sociais e étnicas, é não questionar arbitrários culturais que tornam natural a violência simbólica contra a a força de trabalho concentrada na produção industrial, majoritariamente feminina, as "mãos invisíveis" de que fala McRobbie (1998, p. 39).

Demandas repentinas por modas passageiras geram novas formas de exploração do trabalho dessas "mãos invisíveis". Esse modus operandi da indústria de moda atinge imediatamente grupos sociais mais vulneráveis a recessões econômicas. Da grande escala das cadeias de varejo, passando pelas grandes marcas e pequenos negócios, a exploração do trabalho de penufar gregas, cipriotas ou asiáticas de Londres (McROBBIE, 1998, p. 72).

No Brasil, afeta as comunidades bolivianas, chinesas e, no passado, coreanas, judias e italianas que passaram pelos bairros do Brás e do Bom

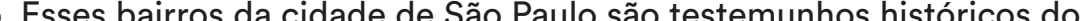
ciclo de exploração da mão de obra de minorias.

A escola de moda dentro da escola de artes, que ocupa um lugar de poder na sociedade, revela posicionamentos políticos que estão profundamente imersos em antagonismos culturais. Análises sociológicas mostram relações de poder que são, e têm sido usadas, para manter e reproduzir um campo onde mulheres, e o fenômeno cultural associado as mulheres, ocupa uma posição subalterna, onde atividades e práticas associadas ao trabalho manual são igualmente relegadas à base da pirâmide social (McROBBIE, 1998, p. 65).

$\mathrm{O}$ status rebaixado atribuído à costureira torna difícil prever qualquer movimentação na escala hierárquica do trabalho de moda, em qualque sentido (McROBBIE, 1998, p. 39).

Segundo Foucault (1977 apud McRobbie), essa abertura que se espera dos ingressantes no curso de moda é na verdade uma encenação de um comportamento que nega as relações hierárquicas, enquanto esse suposto estúdio aberto tende na verdade a forçar cada um a viver sua vida pessoal e profissional $\mathrm{n}$ frente de todos (FOUCAULT, 1977 apud McROBBIE, 1998, p. 40,41).

Esse estúdio aberto, voltado às relações não-hierarquizadas, constitu na realidade um espaço de exposição do "eu", onde tanto a vida pesso como profissional dos estudantes é forçada a ser vivida na frente de todos. "A aula de moda ideal deve permitir antes de tudo que essa ou esse aluno esteja aberto à vigilância nesse sentido." A exposição de emoções chega à esfera das relações amorosas, o que ajuda a constituir a ideia de que a moda (McROBBIE, 1998, p. 41).

Mesmo a moda sendo um campo constituído basicamente por mão de obra feminina, o estrelato, tanto nas instituições acadêmicas quanto na mídia de moda, é profundamente normativo e suspeitamente masculinizado. Parece que os garotos tendem a ser mais estimulados a se sentirem confortáveis no papel de celebridades da moda, e por isso tendem a assumir essas posições com uma frequência muito maior (McROBBIE, 1998, p. 70). Em outras palavras, o aparelho de celebração que sustenta o mito, exerce sua violência simbólica quase invisível, oferecendo maior suporte ao sucesso profissional masculino no campo da moda. 
Nos trabalhos desenvolvidos em grupo no Politecnico di Milano, na disciplina de Metaprogetto, liderada por Paola Bertola, quando algum grupo tem um ou mais componentes masculinos. é sempre um deles quem inicia a falar na apresentação. Ele toma a fala e o protagonismo na apresentação do trabalho em grupo naturalmente para si.

Em um campo no qual a ligação com o mundo fora da academia é a publicidade, o sistema midiático que constrói imagens fortes e altamente sexualizadas, principalmente de mulheres, atrai uma atenção que às vezes é problemática para os profissionais de moda, se for considerado que a moda é um campo dominado por mulheres, mas o poder continua concentrado nas mãos de homens, donos do maiores meios de produção, grandes grupos comerciais e veículos midiáticos (McROBBIE, 1998, p. 42), dos quais a mulheres ainda dependem para se colocarem profissionalmente.

Este problema também colabora para que a estrela do ano nas faculdades de moda inglesas seja quase sempre masculina, pois esse garoto que irá ingressar no mercado, além de preencher os requisitos da criatividade individual, será mais valorizado no meio dos negócios que regem a indústria da moda (McROBBIE, 1998, p. 52).

Essas visões dicotomizadas entre produção e consumo estão alinhadas, e uma não existe sem a outra (GUIMARÃES, 2015). Dessa forma, só o criador genial, dotado de criatividade especial, saciaria o desejo consumista feminino, por meio de produtos de moda. Se esse estilista foi escolhido dentre tantos outros, é porque ele tem um "algo a mais" que, inicialmente soa inexplicável, mas que pode ser desvendado por meio de suas relações pessoais. De qualquer forma, as ideias de um estilista só "valerão se se impuserem ao pessoal da empresa, à sua clientela direta e ao público consumidor" (DURAND, 1988, p. 55).

Sobre o profissional que atua na indústria, Sue Jenkin Jones (2005, p. 7) conta que a maioria dos criadores de moda não é rica e nem famosa mas tem trabalhos gratificantes e com salários medianos. Há por trás dessa fala uma tentativa de desmistificar a aura que ronda o grande criador. Aparentemente, parte dos alunos que ingressam em uma graduação em moda identifica-se quase que imediatamente com o mito do grande criador.

É comum alunos de moda, ainda durante o curso, se fazerem passar por designers ou estilistas já graduados, na tentativa de serem aceitos em feiras de negócios e desfiles. Jones (2005, p. 41) confessa que, em algum momento, cada um deles terá que "fingir que é um profissional para participar" de eventos; e continua afirmando que não há nenhuma garantia de que eles conseguirão entrar nos desfiles. Entretanto, com energia e engenhosidade, e muitas horas nas filas, eles devem conseguir ver alguns.

Percebe-se que o mito também se estende à imagem que o "gênio criador" deve comunicar, mesmo que ela não represente a verdade. Essa imagem do aluno

Isso reflete a dificuldade, a concorrência para entrar em certos eventos, como feiras e desfiles, e como isso aumenta o capital simbolico desse eventos. Há uma transferência, quase que como em uma corrida de bastão, da aura do profissional para o evento, do evento para o estudante etc.
Além de pesquisadora, a autora da presente pesquisa também atua como designer. Nessa função, já passou por situações em grandes empresas nas quais os convites da SPFW eram destinados à amiga ou à cabeleireira da esposa dos donos ou acionistas da empresa, em detrimento dos profissionais que faziam parte da equipe de criação, e necessitavam desse conteúdo de pesquisa. Percebe-se aí grande amadorismo e negligência com a pesquisa.

$\mathrm{Na}$ tentativa de desmistificar o mito, Jones (2005, p. 51) defende que, para o estilista saber criar, ele não depende de intuição, pois seu trabalho depende de muita pesquisa, planejamento, experimentação, inspiração e capacidade de "ler" as tendências culturais.

Se, por um lado, Jones defende a pesquisa como prática séria, por outro alimenta o mito pela forma como enxerga o desenho de moda. Para autora, o desenho deve assinalar e exagerar certos pontos de interesse do corpo, ao invés de fazer um registro fiel, e isso em certa medida inventaria (a musa e, consequentemente,) a figura ideal do criador (JONES, 2005, p. 82). Esse exagero refere-se aos esboços e croquis que alongam a figura humana feminina quando estes são estilizados, prática relativamente comum nas escolas investigadas.

Em outras palavras, se a ênfase é nos ombros, exagera-se na dimensão deles, se é na altura, deforma-se o corpo em nome do caráter longilíneo assim por diante. Dessa maneira, o problema reside no desenho se afastar da realidade, criando um corpo que só existe no desenho. Isso afeta o projeto, na medida em que as proporções de recortes, bolsos, pences etc não são passíveis de serem transferidas da proporção do desenho para a do molde e, por consequência, para a costura. A falta de proporção do desenho de moda pode afetar o desenho técnico e, consequentemente, a modelagem de uma peça.

Essa forma de desenhar que descola o aluno da realidade, se distancia de soluções voltadas ao problema do vestuário para pessoas com um corpo real, como afirma Irina Aragão, que não é esse "corpo da moda", estilizado no desenho do projeto em moda, que em nada colabora para que as dificuldades relacionadas a vestir um corpo real sejam superadas.

Uma vez concebidos os protótipos dessas peças, os desenhos posteriores, ou seja, o desenho de ilustração, a ilustração de moda, o desenho promocional ou arte-final, marcadamente mais livres e artísticos, comuns na divulgação das coleções em revistas de moda, não afetam o processo, pois são desenhados depois do modelo pronto. Logo, o fato desse tipo de desenho não ter compromisso com a realidade não afeta o processo de confecção da peça.

Afirmações como desenhar "é como brincar, se divertir, fazer uma bagunça não precisa ser realista: você pode se expressar no papel e deixar fluir sua originalidade" (TANGUY apud JONES, 2005, p. 83) só têm alguma serventia se relacionadas à ilustração de moda, desenho promocional ou arte-final, e não ao croqui nem ao desenho técnico, que se prestam a fazer parte do processo de pesquisa, criação e desenvolvimento de produto de moda. 
Essa estilização do croqui também está diretamente relacionada à ideia do mito, do gênio criador que se impõe artisticamente, negligenciando aspectos funcionais do projeto no design.

O aspecto dos desenhos pode ser artístico na medida em que sejam compreensíveis e passíveis de serem traduzidos em uma etapa posterior para um desenho técnico, ou seja, cumprindo seu papel de ferramentas projetuais que comunicam para que o processo se desenrole.

Um grupo de significados com o qual os estudantes contam é a influência de artistas conhecidos. Foram encontradas referências à Egon Schiele, por exemplo, em trabalhos de faculdades de moda brasileiras, italianas e inglesas.

"A coleção é inspirada...na vulgaridade erótica de Egon Schiele...". Esse é um trecho de um press release da coleção de um aluno inglês encontrado em McRobbie (1998, p. 61).

Uma aluna do Politecnico di Milano buscava traduzir por meio de materiais como malha retilinea, organza e bordado, sua apropriação da obra de Egon Schiele.
Figura 20 - Seated
Woman with Bent Knee, Egon Schiele,
1917 Fonte: <http://ww bridgemanimages. bridgeman/news/ alessandro-s-picss
Acesso em: 2016.

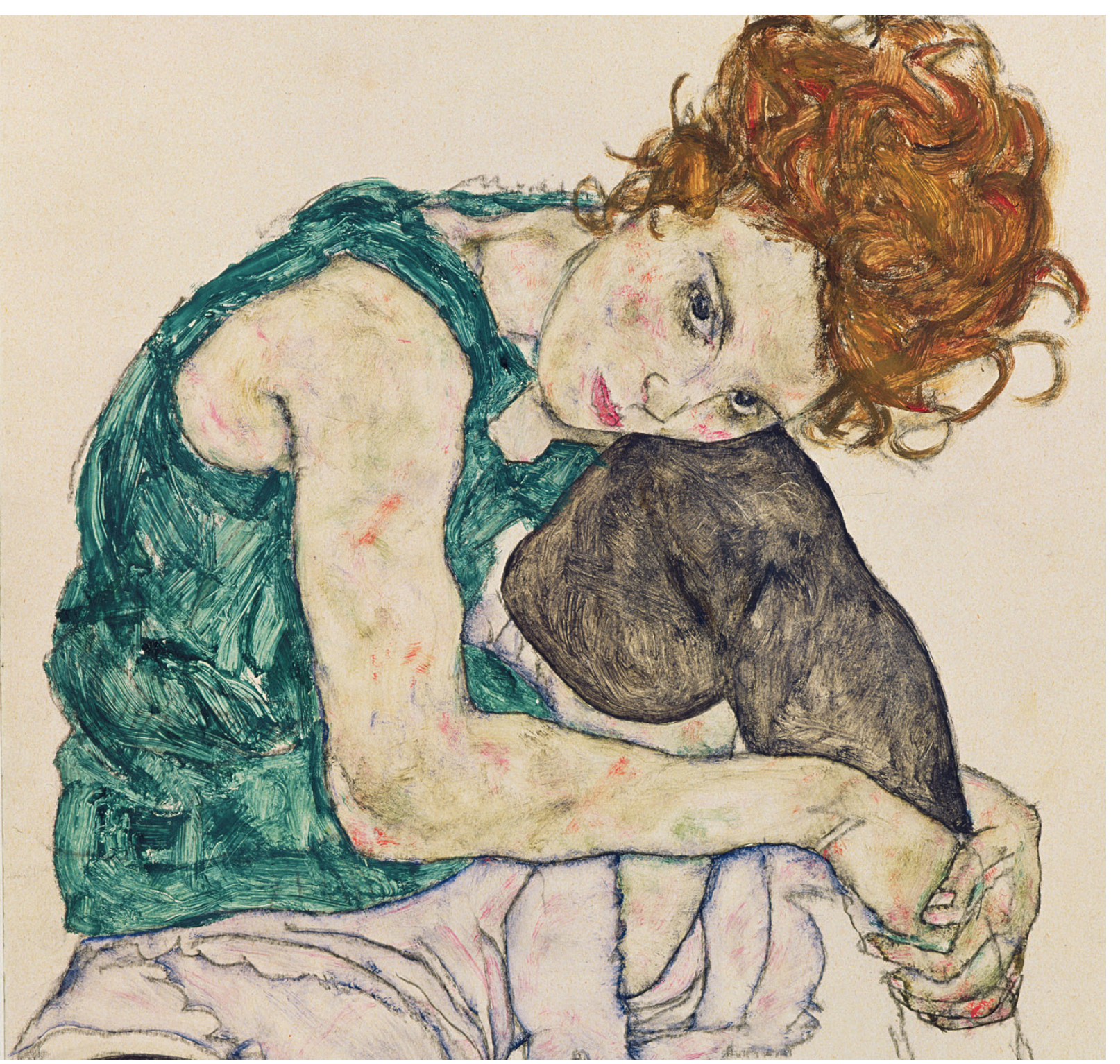

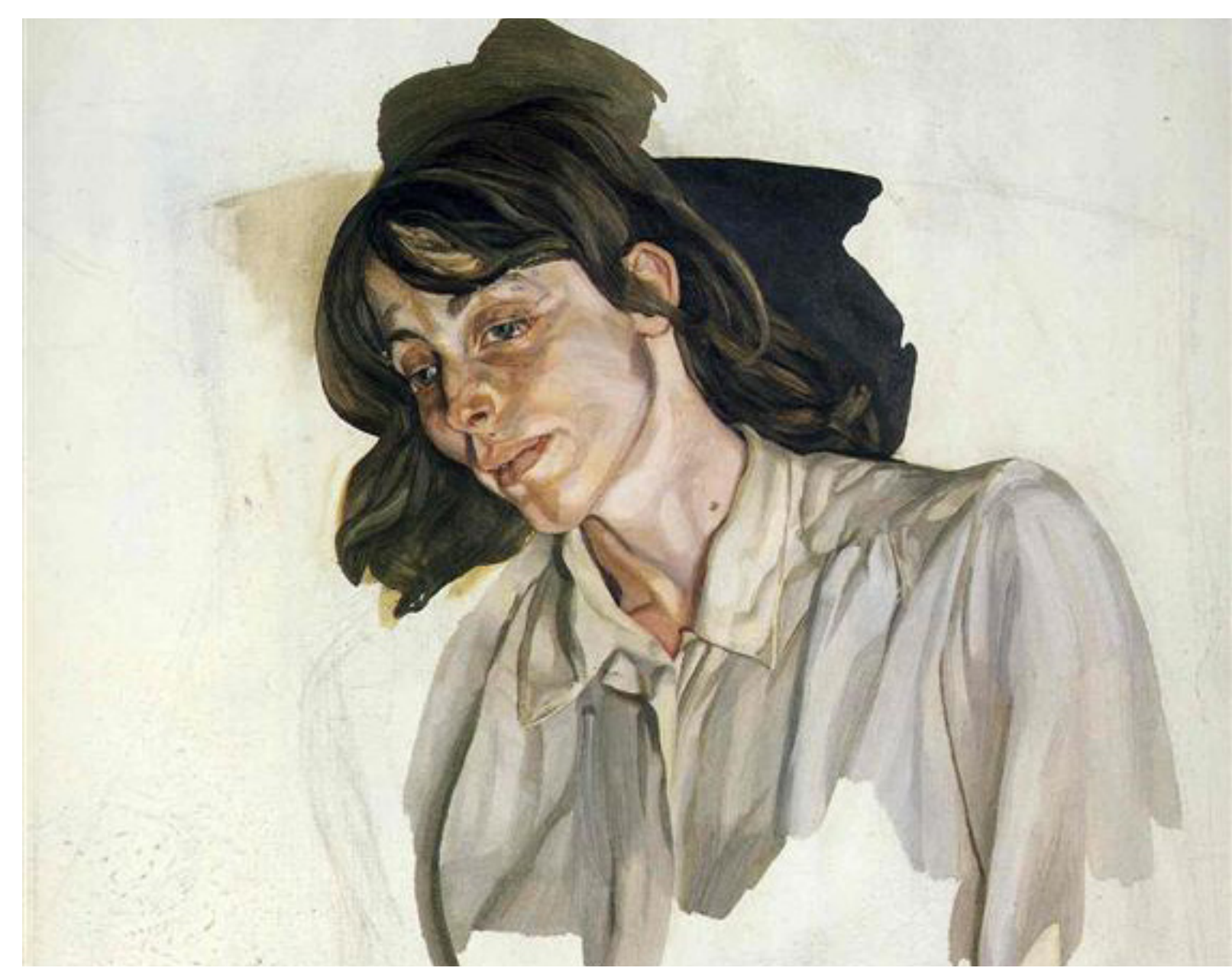

O que se observou em uma faculdade de São Paulo é que são normais desenhos de moda que distorcem a figura humana, que isso "faz parte" e que é comum alunos se inspirarem em desenhos de artistas como Egon Schiele ou Lucien Freud. Percebe-se um tom resignado na fala dos depoentes de quem reconhece o mito, mas como ele não é algo palpável, não é fácil desconstrui-lo.

A repetição e a insistência no uso de Schiele como referência é um de vários casos que mostram a carência da pesquisa nos trabalhos desenvolvidos pelos alunos. Esse fenômeno estético por associação que a moda se tornou, como define McRobbie (p. 63), é flagrante, pois o conhecimento sobre arte permanece superficial, seja na Inglaterra, na Itália ou no Brasil, a fim de ganhar um lastro de legitimação do campo da arte, mesmo que seja forçando uma ligação com ele.

No que se refere ao mito, a "mágica" está em não querer enxergar o que cada grupo está disputando, assim como não se pode perceber o que está sendo disputado, não se pode ter clareza ou pelo menos não se pode reconhecer oficialmente quais são as estratégias dentro de qualquer campo de criação para obter prestígio e mantê-lo, pois a sobrevivência do mito baseia-se em seu irreconhecimento. Se ninguém consegue reconhecer oficialmente essas estratégias, é mito. $O$ mito depende do seu irreconhecimento (DURAND, 1988, p. 53).
Figura 21 - Final Portrait, wikiart.org/en/lucianAcesso em: 2016 . 
Uma das estratégias para conservar o status e a identidade como designers é manterem-se afastados do conhecimento de "costura". Esse comportamento é adotado ainda na escola, já que poucos professores realmente estimulam uma aproximação dos estudantes com a modelagem e a costura. Há uma tendência em manter distância também da computação e da tecnologia (McROBBIE, 1998, p. 58) voltada ao desenvolvimento de produto.

Há uma divisão no trabalho de moda na qual o lado criativo permanece sem contato com a fabricação de roupas. Uma vez que desconhecem aspectos produtivos fundamentais para colocar ordem na produção, esses jovens tornam-se profissionais vulneráveis à exploração pelo empregador (McROBBIE, 1998, p. 58,59).

Embora a contradição resida no fato de que os estilistas ainda buscam - reconhecimento (e, portanto, especializar-se deveria ser como visto necessário), mas, ao mesmo tempo, desprezam os conhecimentos técnicos, essa é a ética do campo que produz o mito. Os alunos a reproduzem ao perpetuar a ideia de mito no campo do design de moda, necessária à manutenção do status da profissão mesmo que ele seja ambíguo.

Nem sempre quem sustenta 0 mito consegue sustentar sua relação almejada com a arte. Jones (2005, p. 83) destaca que as técnicas (e materiais) empregados na ilustração de moda são muito diferentes das empregadas na pintura. Assim, o desenho tradicional confere autoridade à arte e limita o poder simbólico e a capacidade de transubstanciação do desenho no design de moda.

estilismo busca se aproximar do fazer artístico por meio de uma atuação ambígua. Aproxima-se da arte por meio de seus processos, mas não pode ser chamado de arte, de maneira geral. Por outro lado, também não tem o caráter racionalista que marcou o desenho industrial no Brasil.

Se a roupa desempenha tantas funções práticas, o estilismo em vestuário é forçsosamente arte visual aplicada. Seus suportes são o tecido, a linho, (DURAND, 1988, p. 124).

A persistência no reconhecimento do estilismo como arte consiste na diferenciação do prestígio de um gênero cultural que pode se dividir em artes "puras" ou "aplicadas", onde a última é subalterna à primeira (DURAND, 1988, p. 123). A homologia, ao mesmo tempo em que aproxima discursos de entes em posições homólogas, mantém a hierarquia da legitimidade entre os campos. Quando um costureiro tenta transferir seu capital para um campo artístico, o campo de categoria superior se mobiliza imediatamente para fazer lembrar as hierarquias e os críticos de arte ilegitimam o capital artístico no campo da moda (BOURDIEU; DELSAUT, 2001, p. 27).

Por outro lado, entender objetos artísticos e objetos de uso não demandaria divisão entre "arte útil" e "arte livre" (LÖBACH, 2007, p. 35), pois, de acordo com o depoimento de Preciosa (2016), o lugar da moda é tão rico quanto o das artes visuais, mas há muito preconceito contra "o povo da moda".
No livro "Pesquisa e formação em moda", o capítulo produzido por Cyntia de Queiroz e Silvia de Moraes (2015, p. 73) fala sobre o preconceito contra o curso de moda.

O fortalecimento da dimensão teórica, pensamos, contribuiria para a construção de uma imagem mais distanciada do campo das frivolidades, e que, portanto, pudesse afastar as ideias preconcebidas que se faziam acerca do campo [...] as professoras percebiam, ou tinham sobre si, uma noção preconceituosa do curso [que inclusive desacreditava os alunos] na possibilidade intelectual do curso de Moda.

O fato de os próprios entes do curso de moda em algum momento terem demonstrado preconceito contra a própria área na qual lecionavam não é uma contradição tão grande, se for observado que estes reproduziam um pensamento advindo de outros campos que haviam formado o campo da moda.

Entre os britânicos, por exemplo, classe social e etnia são transformados em indícios de sucesso meritocrático. $O$ reconhecimento de seu trabalho e sua pessoa funciona como uma (suposta) evidência da mistura de classes sociais e do multiculturalismo da sociedade britânica contemporânea. É o caso de estudantes que vieram das camadas sociais mais baixas, como John Galliano, descrito pela mídia inglesa como "de origem hispânica" e "filho de um encanador do sul de Londres", ou de Alexander McQueen, "filho de um taxista da parte leste de Londres" (McROBBIE, 1998, p. 79).

É tão flagrante a necessidade de tornar reconhecida a inclusão, que a todo momento a mídia e a tal "sociedade multicultural inglesa" fazem questão de frisar a origem dessas pessoas, ou, o lugar ao qual elas pertencem de forma que nunca pertencerão a outro lugar, ainda que ascendam financeiramente. Esses designers conceituais com origem étnica ou oriundos da base da pirâmide são tratados à semelhança jogadores de futebol brasileiros que imigram para a Europa, com a exceção de que os designers continuam a viver no próprio país onde nasceram. Não obstante, põem fim às suas carreiras tentando provar o poder excessivo compensatório, seja exaltando o racismo, como Galliano ou, por fim, se suicidando como McQueen, pois no fim não foram aceitos, nunca pertenceram a esse extrato mais elevado. Eram bobos da corte.

A preocupação em elevar o capital simbólico dos produtos industriais como "arte útil" geralmente ocorre em associação com os produtos artísticos, "arte livre", que têm reconhecidamente maior capital simbólico. Dessa forma, enaltecer o valor simbólico do objeto artístico acabaria por inferiorizar esse mesmo valor, quando associado ao objeto industrializado, seja no design de moda ou em qualquer outro produto.

O design de moda enquanto prática acadêmica no Brasil, estaria em um meio termo entre arte e design, ou seja, seria arte visual aplicada, e isso incomoda ambos os campos e, inclusive, dificulta a inserção da moda nas áreas do conhecimento acadêmico por parte das agências de fomento. 
O mundo da moda e o da pintura estão ligados de várias formas, principalmente por compartilharem profissionais, a exemplo de pintores que trabalham como artistas gráficos e fotógrafos, formando uma espécie de "fecundo ambiente artístico, pouco apreciado por ambos os universos de que participam" (BOURDIEU; DELSAUT, 2001, p. 54).

Sousa (2015b) conta que nascer vinculado ao campo da arte não é privilégio da moda. Os cursos de design no Brasil também nasceram da arte. $O$ design de moda se comporta de forma semelhante à arte, buscando impor o ponto de vista pessoal do estilista. A opinião pessoal é um dos principais privilégios oferecidos pelo mito ao estilista, pois o processo de transubstanciação simbólica que legitima produtos de moda como arte visual aplicada é baseado no gosto do autor.

A importância dada ao lado pessoal do estilista fica novamente marcada na expressão a seguir: "a inovação surge com a visão e a coragem para mudar as regras sem medo de ser feliz" (JONES, 2005, p. 172). A exaltação do lado pessoal beira o hedonismo do "fazer sem pensar", desde que se garanta a felicidade. Chega a soar ingênuo e inadequado, se comparado a outros livros de projeto em design.

A centralização na figura do estilista é perpetuada pelo comportamento de alguns professores, que vão procurar no projeto de seus alunos o "estilo próprio do aluno" que se forma a partir de seus gostos, personalidade, posição social e experiências. "Isso será o cerne de seu espírito expressivo singular" (JONES, 2005, p. 172). Essa singularidade expressiva em uma faculdade que se pretende ser de design de moda soa elitizada e distante da indústria, em um cenário onde muitas escolas particulares se desdobram para atender aos desejos de seus alunos e futuros criadores, não ensejando um ambiente propício a cultivar a visão do design.

Esse desequilíbrio lembra em algum momento a relação dos Cavalcanti e cavalgados ${ }^{44}$ mencionada pelo pesquisador Alberto Cipiniuk (2014, p. 61), já que onde um cria, muitos executam. A posição social do criador é um dos diferenciadores na luta pelo poder nesse campo profissional.

Uma atuação comum do aparelho de celebração é promover a ideia de "revolução" a partir da "novidade", quando na verdade se está camuflando o mito. Na Itália fala-se com frequência de arte de vanguarda, e por vanguarda entende-se alguma coisa que "nasce de um princípio estético que revoluciona o modo de fazer precedente" (MUNARI, 2011, p. 20). Hoje o modo de pensar e agir, típico das vanguardas, já não serve. A própria palavra, de origem futuristafascista, evoca audácias românticas (MUNARI, 2011, p.21) que, antes de tudo tentam ocultar as lutas pelo poder fomentadas pelo mito.

É possível estabelecer certa relação entre o design de autor (LEON, 2012), e vários trabalhos apresentados na semana de formatura dos cursos de moda. A coleção de cada aluno é apresentada em um desfile na forma de looks, onde cada peça é coordenada para apresentar a visão do estilista (RENFREW; RENFREW, 2010, p. 36), ou seja, o designer autor, aquele que por meio do seu olhar "mostra" o que é bom gosto. Vale lembrar que a noção de autoria é mais cotejada pela moda.
Essa forma de expressão está intimamente ligada à ideia de mito, pois mesmo que seja possível falar sobre a objetística ${ }^{45}$, esse design elitizado não corresponde à realidade do mercado e acaba por aproximar o estilista do lugar do artista, gênio criativo.

A criatividade é um exercício que depende de prática, e quanto mais exercitado mais aprimoradas serão as ideias do designer (TREPTOW, 2013, p. 136). E se de acordo com Charlotte Perriand, citada por Nanni Estrada (2000, p. 58 apud TREPTOW, 2013, p. 41), "o próprio designer [...] se torna responsável por esses novos rumos, através de propostas oriundas da sua sensibilidade estética", não fica clara qual é a diferença essencial entre designer de moda e estilista, uma vez que as autoras supracitadas associam a sensibilidade criativa à figura do designer de moda e não ao estilista.

Odesigner de modateria como habilidade "comunicar os desenvolvimentos [de produtos de moda] através de croquis, modelos, modelagem e pilotagem" (RECH, 2001, p. 49 apud TREPTOW, 2013, p. 41). Além de não ser função do designer de moda nem do estilista fazer modelagem e costurar profissionalmente, não há registro de que nas principais faculdades de moda os alunos sejam orientados a fazer modelagem ou pilotagem dentro de uma empresa, nem que recebam treinamento suficiente para tal função durante a graduação.

Talvez isso deflagre uma crise no mercado de moda que afeta diretamente a constituição do campo social do trabalho de moda, uma vez que, por falta de postos de trabalho, dada a saturação de egressos no campo do design de moda, estes estariam se submetendo a funções que originalmente não eram as suas: modelagem e costura. De maneira geral, a situação na Europa e nos Estados Unidos também não é animadora. De acordo com Paolo Volonté (2008, p. 176), professor do curso de moda do Politecnico di Milano, a oferta de profissionais com nível superior é muito maior que a demanda.

O campo social do trabalho é formado por posições intermediárias que envolvem o trabalho de interpretação das "obras" dos criadores, sua divulgação etc (o que inclui o aparelho de celebração). No campo da moda "a roupa em si é também o resultado de uma enorme massa de trabalho não criativo e de capital" que se revela nas indústrias, lojas, matérias-primas etc. Há uma tendência em manter esses interesses subordinados ao trabalho estético, mas eles não podem se desvencilhar das necessidades da produção industrial. De qualquer forma, esses fatores que configuram e complexificam o campo social do trabalho em moda estimulam a profissionalização do estilista de moda (DURAND, 1988, p. 54).

Mas o mundo dos negócios da moda e da sua indústria persiste, à sombra do desemprego e da baixa remuneração, com jornadas ostensivas de trabalho e diferentes e abundantes formas de exploração, embora aparentemente necessárias à sua sobrevivência. Por trás desse mercado precário há uma atitude de resignação em afirmações recorrentes de que a indústria da moda sempre foi assim (McROBBIE, 1998, p. 70).

Os alunos recém-formados não têm uma imagem ou entendimento da indústria como um todo. Consequentemente, estão ansiosos para ingressar no mercado e para a própria exploração que sofrerão sem, no entanto, 
incorporar a estetização do mercado de trabalho como estratégia do governo até porque a história não é contada por inteiro ao profissional (McROBBIE, 1998, p. 74 e 83).

O seu entusiasmo inicial e a necessidade de liderar levam esses jovens profissionais a tolerar condições que rapidamente eles reconhecem como exploração. Mas, ao invés de questionar porque a indústria é assim, eles tendem a interpretar suas experiências, individualisticamente $e$ retrospectivamente, como parte do folclore da moda, com seus maus empregados famosos, seus designers famosos e celebridades tirânicas, fofocas e práticas inescrupulosas (McROBBIE, 1998, p. 81).

O que se observa no relacionamento entre empresas e designers de moda é uma comunicação que não é clara, com acordos contratuais insuficientes. Alguns relatos tornam mais clara essa situação de exploração, inclusive dos designers. Uma profissional recém-formada descreve as más condições de trabalho em que esteve submetida durante três anos. Ela conta que er deixada em um quarto sujo e com pouca luz. Durante as cinco semanas que antecediam o desfile, ela trabalhava todos os dias, sem direito à folga e sem receber pelas horas extras trabalhadas. Ela conta ainda que, muitas vezes ,nem precisaria estar lá, pois o trabalho já estava terminado, mas queriam a profissional ali só para estar ali, à disposição. Existem ainda relatos de confecções com condições ainda piores (Melanie M. apud McROBBIE, 1998, p. 75).

Em visita a Paris para uma entrevista de emprego, Yvette S. (apud McROBBIE, 1998, p.79) relata que ao chegar lá, não havia mais entrevista. Em outro momento, ela foi contratada como assistente de designer, mas durante quatro semanas ainda não tinha um contrato e depois de seis semanas ainda não havia recebido seu primeiro salário. Ela abandonou o trabalho sem pagamento algum.

Cansada de trabalhar há anos de forma independente, sem ter dinheiro suficiente para se sustentar, uma designer formada há poucos anos relatou a McRobbie (1998, p. 87) que, aos vinte e seis anos de idade, tinha uma dívida de cheque especial de trinta mil dólares, e que fechou seu negócio para ser gerente de loja e saldar sua dívida. $O$ governo inglês oferece um apoio bastante precário para quem está abrindo um negócio, e essa situação não é diferente no Brasil.

Nas últimas décadas houve uma popularização do trabalho criativo por intermédio da mídia de do aumento na oferta de cursos de moda. A parti daí o "mercado criativo" deixou de ser exceção para se tornar a norma, mas seus profissionais continuam sonhando com o estúdio onde o trabalho criativo é cercado por uma aura romântica. Também para evitar a exploração da indústria, os designers vêem como solução abrir uma "marca própria" (McROBBIE, 1998, p. 81, 82)

Para o governo este é o cenário ideal, pois esse profissional trabalha por longas horas e é mal remunerado em nome de sua independência criativa. Não poderia ser mais oportuno para o governo, querer livrar-se da "cultura de dependência". E para o capital, isso significa força de trabalho não remunerada (McROBBIE, 1998, p. 82).
No mercado de moda, prevalecem os trabalhos free lancer ou "falso autônomos"46 que McRobbie (1998, p.88) chama de "economia mista do design de moda".

Essa imagem de "ser como um artista" cria profissionais desejosos de renderem à promessa de "prazer no trabalho" (DONZELOT, 1991 apud McROBBIE, 1998), onde se buscam o sonho da satisfação criativa no trabalho e também a "fantasia de empreendedor" (DU GAY, 1993 apud McROBBIE, 1998), que se encaixam perfeitamente na agenda política arbitrária voltada asse profissional selfmade contaminado pelo ethos do século XIX: "o que feito com prazer pode ser feito com ganhos!” (McROBBIE, 1998, p. 82).

A cultura coorporativa age como um ataque aos aspectos da cultura jovem, transformando cruelmente habilidades pessoais e estilos de vida radicais em meios de subsistência (COHEN, 1997 apud McROBBIE, 1998). Esse jovens se tornaram capitalistas mesquinhos por meio do trabalho criativo que agora tomam como forma de subsistência pessoal, incorporando um "neutralização da contra-cultura" (McROBBIE, 1998, p. 83).

Para Bomfim, a moda é essencialmente um fenômeno econômico e não estético, baseado na mudança constante (HAUG apud BOMFIM, 1998, p. 158), mas ao mesmo tempo "falsa é a interpretação de que toda questão estética no processo de fabricação é uma consequência econômica" (BOMFIM, 1998, p. 158). Seguindo este raciocínio, moda não se trata somente de um fenômeno econômico, e nem todo investimento estético no campo do design da moda objetiva o lucro, embora estas questões mereçam atenção.

No tocante à profissionalização também é importante que o designer de moda ou estilista tenha um conhecimento razoável em modelagem e costura para dominar o processo. Mas acreditar que o profissional tem de ser exímio modelista ou costureiro gera um ruído, uma vez que essa abordagem não é oferecida pela formação em Moda em nenhum curso estudado.

Atividades manuais como modelagem e costura ainda hoje possuem menor capital simbólico do que o trabalho criativo. Logo, o mito do "gênio criativo" não se sustentaria se o criador assumisse o trabalho manual, haveria o risco de descaracterização da profissão.

Na tentativa de desfazer equívocos baseados no mito, Munari (2011, p. 16) sugere uma escola para empregadores, para que, entre eles, pelo menos se possa estabelecer um contato inteligente com os designers, no sentido de haver clareza entre o que se espera do profissional e o que ele aprende, e o que se the deve fornecer durante sua formação.

Há um muro intransponível entre o estudante que aprende tudo sobre comunicação visual e o seu empregador, "que geralmente nem sequer desconfia que este gênero de estudos existe", os dirigentes de indústrias e chefes. Estes, por sua vez, também se comportam como "pessoas importantes, a quem não se pode ensinar nada” (MUNARI, 2011, p. 15). Esse problema, averiguado no campo da comunicação visual, também é deflagrado no campo do design de moda, o qual, embora atualmente conte com empresários que já demonstram mais receptividade com egressos com formação superior em Moda, nem sempre compreendem sua atuação no campo. 
Outro fator importante no reconhecimento da profissão é a legitimação de valores estéticos que contribuem para a formação do gosto na esfera do mito. Esse é um processo normativo, onde a afirmação do valor não depende de procedimentos objetivos. Esse valor só será aceito por determinado grupo de pessoas e jamais alcança a validade universal. Os processos de legitimação estética podem ser representados por pares dialeticamente opostos (BOMFIM, 1998, p. 134), como ocorre entre os campos da arte e da moda.

É entre procedimentos autoritários e consensuais que se dá a dialética. Um exemplo de procedimento de legitimação autoritário é a estética da Idade Média imposta pela nobreza e pela Igreja. Um exemplo de procedimento de legitimação consensual é quando essa estética representa diferentes interesses da sociedade, como o art nouveau, aceito pela burguesia europeia no início do século XX (BOMFIM, 1998, p. 134).

A dialética se dá entre critérios implícitos (imprecisos) e explícitos (precisos). A questão se volta para a clareza ou obscuridade dos processos de legitimação (BOMFIM, 1998, p. 134). A imposição arbitrária e interessada do criador não pode ser assumida abertamente, sob pena de se destruir. Como violência simbólica, ela só se consuma caso se mantenha irreconhecível (BOURDIEU; DELSAUT, 2001, p. 41-42).

47 Na década de 1980, Vera
Lígia Pieruccini Giberté é chamada pela Rhodia para atuar no CIT, a Coordenaçä
Industrial Têxtil , onde atuou de 1983 a 1991 . Os cursos do CIT Rhodia, situada na Avenid Brasil, em São Paulo naquele periodo. O desejo no Brasil uma iniciativa parecida com a da Europa, pela Rhône-Poulenc para brasileiros. As aulas de Vera Lígia Gibert eram de desenho têxtil e desenho
de moda. Nesse momento ela percebe deficiências na formação dos estilistas, pois tinham dificuldade
em se comunicar com os modelistas, incorrendo en inúmeros erros de projeto. Foram seus alunos cerca
de seiscentos estilistas que passaram pela Rhodia. Entende-se que essa para o nascimento do curso de Moda da FASM. Carlos Mauro Rosas era o

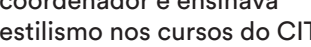
Ele viajava periodicamente para a França e teve contato
com os principais estilistas do periodo. Posteriormente, ele é convidado por Vera Lígia Gibert para atuar
curso da FASM.
O relato de Renata Zaganin de Oliveira, egressa e docente da FASM, mostra que o mito da criação ainda paira sobre as faculdades de moda:

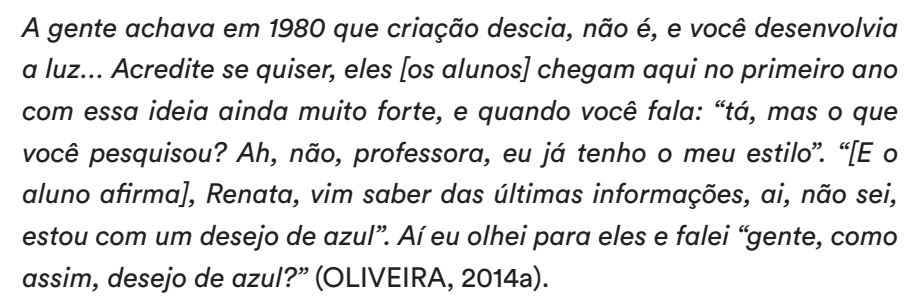

A fala de alguns depoentes mostra algum receio de que os esforços feitos para profissionalizar a área de criação em moda até o momento, tenham sido em vão. Mas é preciso lembrar que essa profissionalização também teve o mito como base.

Há frases de Marie Rucki, diretora do Estúdio Berçot, que preconizou o estudo em estilismo no Brasil, que são bastante imprecisas, tais como: "o estilismo é um estado de espírito, é saber captar a fantasia no ar". Para Oliveira, a moda encontra-se em um campo entre design e arte e reúne características, artísticas e industriais, de ambos os campos ao mesmo visual aplicada.

Até a década de 1980 o estilismo tinha um caráter etéreo, era outro momento da profissão. Na Casa Rhodia ${ }^{47}$, que era uma referência para profissionais da área, a atmosfera era a mesma. No Jornal Hoje, da Rede Globo, havia um quadro de Cristina Franco. Ela era a única jornalista no Brasil tempo, confirmando a constatação de Durand de que o estilismo é a arte que falava sobre moda na televisão e fazia pequenos relatos dos grandes desfiles. $\mathrm{O}$ conteúdo vinha carregado de expressões como: "desejos de...", onde a abordagem era extremamente poética, não tinha nada de substancial ou palpável (OLIVEIRA, 2014a).

O papel de Cristina Franco era simplificar a sofisticação dos desfiles de moda, para colocar o público brasileiro em contato com a moda. Não era um conteúdo voltado aos profissionais, mas como a informação na área de moda era exígua na década de 1980, até eles se interessavam por seu quadro no Jornal Hoje.

Em relação aos estilistas sem formação com quem conviveu na década de 1980, Oliveira conta que eles acreditavam que tinham o "feeling para a coisa", e que o profissional formado em faculdade de moda era um produto pré-moldado, plástico. Havia preconceito de ambos os lados, entre os formados e os autodidatas.

O corpo docente do início do curso de Moda da FASM, da década de 1990, formado majoritariamente por artistas, não estaria mais apto a formar um profissional para atuar no mercado de moda atual, segundo Oliveira. Ela reconhece que a visão de projeto da FASM é artística, embora não exclusivamente.

Se nas décadas de 1970 e 1980 um pretendente a estilista era oriundo dos campos das artes ou da arquitetura, hoje o aluno da faculdade de moda, futuro estilista, nasce como um consumidor afetado, voltado à aquisição de produtos de moda assinados por um estilista, ao invés de criá-los desenvolvê-los. Oliveira afirma, em tom de decepção que, se por um lado, a luta pela formalização acadêmica do campo visou combater a informalidade comum até a década de 1980, por outro lado não consegue compreender quando surgiu esse hiato, que traz para a faculdade de Moda um consumido afetado, que acha que vai fazer moda sem nenhuma técnica.

Nas faculdades ainda perdura a visão de que o "aluno-artista" é o sujeito que não projeta nada, e do qual de repente "brota" uma grande criação. $\bigcirc$ mito permanece ao longo do tempo, mudando somente a forma como se apresenta (OLIVEIRA, 2014a).

O estilista surge no Brasil associado ao mito. Durante a entrevista concedida por João Braga para esta pesquisa, ele relatou que, com 0 surgimento das FENITs em 1958, houve uma resistência a comprar tecidos. A clientela preferia roupas prontas. A FENIT acaba "inventando" as figuras da costureira e do estilista brasileiros. A feira começa a chamar pessoas para desenhar para as fábricas, os estilistas. E Braga reitera que foi uma tentativa de criar uma identidade nacional de moda ligada à indústria. Com isso FENIT se torna uma feira de confecção e não mais da indústria têxtil como havia sido programada. Inicia-se aí a dicotomia entre estilista e designer de moda, pois no linguajar da época o termo que vigorava era estilista, mas na prática seu trabalho era um esforço relacionado a impulsionar a indústria que seria mais voltado ao projeto em design 
O consumidor não vê a diferença entre estilista e designer, chamando ambos de estilista. Para o consumo isso não é efetivamente algo a ser questionado. No campo acadêmico, a entrevistada Maria Eduarda Guimarães acredita que essas forças estão empatadas, que ainda estão se articulando em um nível que não tem um claro vencedor. Mônica Moura (2015) considera desnecessária a discussão sobre a separação das áreas, porque isso, de alguma forma, é contrário o momento atual que estimula o diálogo interdisciplinar, mas é importante ressaltar que a figura consagrada é a do estilista e não a do designer de moda.

Muita gente pode fazer uma roupa, mas ser um estilista é conferir uma identidade ao produto, defende Márcio Ito, que parafraseia Chanel "estilo não é para todo mundo", em uma frase que propaga o mito.

A identidade do produto, que pode ajudar a identificar um criador, também pode ter a mesma função ligada a uma marca, ou seja, dotar um produto de identidade não é exclusividade do estilismo. A construção de identidade do produto ou da marca pode ser operada também pelo designer de moda.

Ito afirma que estilismo é uma coisa que envolve o intelecto, mas se contradiz em seguida ao defender que também é uma coisa que já é "natural da pessoa", ou seja, nata. Para ele, estilismo está ligado a um produto feito com mais recursos e ao projeto mais ligado à larga escala. Ele recorre a alguns exemplos para demonstrar seu ponto de vista. A marca de moda Adriana Barra pratica estilismo, enquanto a marca Farm pratica design de moda.

Essa diferenciação acontece porque as pessoas consideram o estilista como um artista. "O cara que vai trazer o sonho". O que vai fazer o vestido exclusivo para a pessoa, como o estilista Sandro Barros, que fornece esse sonho (ITO, 2014). Adriana Barra possui uma segunda marca chamada A. Farra, com produtos mais acessíveis que produz em série como a Farm, mas em menor escala. A marca Adriana Barra é responsável por sustentar o mito, enquanto $A$. Farra traz retorno financeiro.

As afirmações de Márcio Ito não permitem concluir que a atividade do designer de moda, quando entendida como prática industrial, abra mão do intelecto. $O$ que se percebe na fala de alguns depoentes são diferentes formas de assegurar o poder simbólico do estilismo, para que a atividade se mantenha elitizada por meio da sua aura.

Apesar de tentar aproximar o estilismo da arte, Ito admite que o artista tem mais liberdade quanto ao planejamento e o estilista não. $O$ estilista tem de fazer aquilo acontecer em termos de execução e retorno financeiro. $O$ estilista tem de pensar em prazo, em produção, valor para aquela peça, pois afinal o sonho tem de ser vendido, o que novamente leva a moda ao status de arte visual aplicada.

Até agora foram apresentados pontos onde estilismo e design de moda convergem e divergem, em busca de pensar o campo criticamente. Nesse sentido, Cipiniuk critica que os agentes de legitimação não estão preocupados em pensar a questão criticamente, e que em pouco tempo não devem trazer mudanças relativas à questão do mito.
Além da diferença entre design de moda e estilismo, existe a distinção entre design de moda e de produtos, a primeira herdeira da segunda. $A$ impressão que se tem ao estudar autores do campo do projeto em design de produtos, é que alguns deles forçam a indiferenciação entre ambas as formas de design, constrangendo o objeto de moda a se adequar dentro da teoria do design de produtos, ignorando o simbolismo gerado a partir de certos produtos, do ponto de vista da moda.

Um exemplo dessa coação simbólica é dado por Löbach por meio da descrição de duas jaquetas, "uma simples jaqueta [que] protege o corpo do frio e possui principalmente funções práticas" e outra "jaqueta moderna de couro com bordados e franjas" (LÖBACH, 2007, p. 63).

No primeiro caso, o autor considera a jaqueta funcional e no segundo a "de moda", desconsiderando a produção de subjetividade do usuário em ambo os casos no que diz respeito à função simbólica, reduzindo a função da jaqueta com bordados e franjas a somente atrair "por meio de sua estética, a atenção do público sobre si e sobre o seu usuário" (LÖBACH, 2007, p. 63). A jaqueta simples também se veria compelida a cumprir somente prescrições funcionais, o que não procede no campo da moda.

Posteriormente, Löbach (2007, p. 62) acaba por reconhecer na função estética a relação entre produto e usuário, no nível dos processos sensoriais. Ela é um aspecto psicológico da percepção sensorial durante seu uso. Criála significa configurar produtos de acordo com as condições perceptivas do homem, atendendo à percepção multissensorial do usuário.

A configuração [.... com critérios esteteticos e importante para as relaçôas do homem com os objetos que o rodeiam, pois a relação do homem com o ambiente artificial é tão importante para a saúde psíquica como os contatos com seus semelhantes (LÖBACH, 2007, p. 62).

A função simbólica, ou função estética, nas palavras de Löbach, determinada por todos os aspectos espirituais, psíquicos e sociais do uso (LÖBACH, 2007, p. 64). Vai além da função estética, sendo capaz de gerar associações. Assim, o produto adquire dimensões sacras e místicomeditativas, onde ele passa a representar o status do usuário, a exemplo da gravata de seda (LOBBACH, 2007, p. 64-66).

A reflexão no campo do ensino do design tem relação com o surgimento de novos processos produtivos e segmentos. Em 1998, Bomfim (1998, p. 144) afirma que esta, aliás, já é uma tendência verificável no "design de móveis", "fashion design" etc. Ele aponta o que professores e pesquisadores do campo do design vão confirmar no processo de inserção do campo da moda dentro do campo do design.

Orientando de mestrado e doutorado de Gustavo Amarante Bomfim, Sérgio Sudsilowsky conta que, em 1998, Bomfim tinha acabado de ser um dos relatores da lei de diretrizes de base para o design - dos decênios para design - junto com Rita Couto e João Carlos Cauduro. Aparentemente, 
estes três agentes trabalharam ativamente para que novas diretrizes de regulamentação dos cursos de design no Brasil fossem oficializadas, incluindo a inserção do design de moda no campo do design.

Em vários setores do campo do design, onde ainda há resistência à moda, o fato desta não apresentar a formalização de um problema que justifique sua atividade de projeto, como ocorre no design de produtos, é um dos principais fatores que a desvalorizam em termos simbólicos, diante do design de produtos.

Em um capítulo de seu livro, intitulado "Fazer sem pensar", Munari (2011, p. 32-34 passim) se dedica a uma forma de operar que ele acredita ser a ideal para a criação do projeto. Nele, o teórico orienta os alunos a não pensarem antes de fazer, pois uma ideia pré-concebida cria dificuldades para o operador.

Esse "fazer livre", sem se programar, se assemelha àquele "aguardar inspiração" que Löbach critica, mas ao mesmo tempo pode se confundir com a ideia de incubação, ${ }^{\mathbf{4 8}}$ tratada pelo mesmo autor. Estas práticas se parecem em alguma medida com a visão de estilismo baseada no mito parecem em alguma medida com a visão de estilismo baseada
criador, que é bastante criticada pelo campo do design industrial.

Pensar, neste caso, seria antes deixar de fora a razão e usar a "intuição", dispor as formas ao acaso, reagrupar, dividir, mudar, reagrupar, deslocar, rodar, girar, até que a combinação de formas possa sugerir a maneira de terminar a composição (MUNARI, 2011, p. 34) na comunicação visual.

A palavra "intuição" pode ser comparada à "inspiração" de Jones e Seivewright, já que as maneiras de dispor as formas sustentadas por Munari também não são ordenadas ou seguem quaisquer critérios em seu texto, assim como a "inspiração" do estilista que surge sem aviso. Isso evidencia que no ato projetivo há uma parte puramente subjetiva, pautada pela criatividade que talvez não demande sistematização.

Também baseia-se na intuição parte do ensino em projeto em moda. A maioria dos entrevistados no Brasil e na Itália desconheciam autores de projeto em moda e de produto. Quando conheciam os autores tratados na revisão de literatura desta tese, afirmam que usaram suas obras para trabalhos teóricos, mas não para o ensino em sala de aula. $O$ problema da não adoção de autores é visto na Itália, além do Brasil.

Bruno Munari (2011, p. 58) acredita que a comunicação visual se estende ao comportamento de uma pessoa, seu modo de vestir, à ordem ou desordem de um ambiente, ao modo como alguém usa certo instrumento etc. Isso permite entender que o produto de moda também faz parte do conjunto de elementos da comunicação visual, ou seja, o design de moda não se restringiria somente ao design de produtos, como pretende Bomfim. Também a estamparia ou design de superficie dependem do projeto de comunicação visual, e não de produto.

O produto é concebido pela unidade entre forma e conteúdo a partir dos aspectos "internos" do objeto, ou seja, sua natureza e "externo" que sua estrutura visível. Essa unidade é dada pela configuração dos elementos como cor, superfície, proporções e textura (BOMFIM, 1998, p. 14).
Para Bomfim, a forma como o produto se configura no design de moda seria ditada pelo design de produtos. Na verdade, pode-se observar que essa objetividade funcionalista poucas vezes é pauta no desenvolvimento do produto de moda, como atestam os livros de projeto em moda, assim

Há profissões consagradas com seus próprios princípios éticos, técnicos etc, no design e na moda, e o estilismo e o projeto são atividades regidas e influenciadas por esses princípios.

A noção de mito mais marcante no estilismo ensejado pelo campo da moda, em geral difere do campo do design, que tem sua prática marcada pela noção de projeto, fomentada pelo ideal de racionalização industrial.

Essas diferenças ideológicas no Brasil se constituíram no contexto do surgimento dos cursos. $O$ design de moda se formalizou como campo acadêmico mais recentemente nos anos de 1990. Em 1988, a FASM passa a oferecer o primeiro curso de Moda do país, mais voltado à ideia de formar um criador que soubesse impor seu estilo pessoal pela prática do estilismo do que um projetista industrial. Essa noção se manteve até 1998, quando, a pedido do $\mathrm{MEC}$, os cursos de moda foram encampados pela área do design. Desde então se assiste a lutas simbólicas no que diz respeito à discussão entre estilismo e projeto.

O curso superior de design se estruturou quase trinta anos antes do curso de moda, no início da década de 1960. Historicamente é reconhecido o fato de que a FAUUSP desde 1962 foi a primeira a exibir em sua grade disciplinas do que à época era chamado desenho industrial (CARVALHO, 2015), e a ESDI inaugura o primeiro curso de formação superior específico em Desenho Industrial em 1963, no Rio de Janeiro. O curso de design, naquele momento, foi impulsionado a partir da ideia de industrialização, pois se acreditava no nascimento e no fortalecimento da indústria nacional.

O contexto em que cada curso surgiu justifica a forma como cada um pauta sua noção de produzir bens materiais e simbólicos. Faz sentido para o design privilegiar a noção de projeto calcada no anonimato e na seriação industrial, tendo em vista sua história, como também é aceitável a argumentação do campo da moda de que ele se baseia na noção de estilismo, pois nasceu ligado à ideia de aura e ateliê, como o do couturier Charles Frederick Worth.

Porém, a moda não precisa elevar seu status, uma vez que ela pode perfeitamente estar dentro e fora das escolas de arte, mantendo-se firme como uma prática cultural e como parte da industrial cultural (McROBBIE, 1998, p. 64).

Seja no design de moda ou de produto, os profissionais por vezes associamse ao mito, quando produzem estilismo ou design de autor, e também operam de forma anônima na indústria a moda que é representada maciçamente por inúmeros estilistas ou designers que trabalham anonimamente, com salários medianos (JONES, 2005)

Seja pelo viés do mito ou do anonimato como elogio racional, tanto o campo da moda quanto o do design alternam sua posição entre esse status, mas é importante ter clareza sobre qual visão pauta cada atividade em momentos diversos. É importante reforçar que as diferenças ideológicas 
entre os cursos de moda e de design se refletem nas práticas de estilismo e projeto e, portanto, na produção oriunda de suas pesquisas.

\subsection{A noção de mito nos artigos}

Alguns trechos encontrados nos artigos publicados nos Colóquios de Moda e P\&D ressoam a questão do mito, por isso foram reservados para este tópico. Em um deles Colin Campbell citado por Maria Cláudia Bonadio (2006) argumenta que o estilista pode promover o "prazer imaginativo, a que a imagem do produto se empresta, sendo o consumo verdadeiro, em grande parte, resultado desse hedonismo mentalístico" (CAMPBELL apud BONADIO, 2006).

O que se percebe a partir da fala de Bonadio é que o estilismo, em última instância, seria a ferramenta que promoveria o consumo associado ao prazer, então o estilismo seria até certo ponto uma fonte de prazeres que se realizaria por meio do consumo, na condição de que a imagem do produto possa ser sedutora o suficiente para, fazendo uma adaptação da teoria de Cecília Almeida Salles (2013, p.139), esse produto imaginado se transformar em um universo real por meio de um sistema artificial gerador de significados que sustenta esse mesmo produto como meio material, para tornar essa experiência simbólica acessível.

Traduzido de outra maneira por Deborah Christo e Flávio Sabrá (2016), "a diferenciação que os objetos podem propiciar aos indivíduos movimenta a indústria na busca por formas que possam traduzir esse valor simbólico".

Em função do teor ideológico associado ao design, o hedonismo de que fala Bonadio e a diferenciação de que falam Christo e Sabrá (2016), costumam ser mais comumente vinculados à moda e, por isso, de acordo com Christo (2006), esta preconiza o aspecto simbólico na projetação por meio da prática do estilismo.

O conteúdo simbólico tem sua importância enaltecida na construção do produto de moda a partir da fala de duas autoras de um artigo para o 40 Colóquio de Moda, Amanda Cristófoli e Bruna Mayer (2008), as quais acreditam que algo pessoal, do cotidiano do designer de moda, como vivências e lembranças, podem ser transformados em produtos que pessoas do mundo inteiro possam desejar.

É evidente que, como as próprias autoras defendem, o alicerce intelectual e a sensibilidade do designer também influenciam na criação, mas permanecem dúvidas sobre quais os limites entre a influência da formação cultural do designer e seus gostos pessoais.

No que tange ao binômio projetação e consumo, é possível pensar que a legitimação do uso de referências pessoais de forma tão direta na criação encontre explicação na fala de Deborah Christo e Alberto Cipiniuk (2010), que citam Roland Barthes (2007), o qual, por sua vez, esclarece que talvez por meio dos mitos a sociedade tente resolver as contradições que surgem entre as crenças das pessoas e suas experiências cotidianas de vida (BARTHES, 2007 apud CHRISTO; CIPINIUK, 2010).

A despeito da afirmação de Cristófoli e Mayer, a teoria de base de projeto do campo do Design não parece aprovar a prática do ato projetual a parti de referências do cotidiano e recordações do designer. Essa prática é muito mais comum no campo do estilismo e do design de moda.

Apesar de Christo e Cipiniuk (2010) defenderem que os processos de produção da indústria do vestuário, assim como noções e valores dito como característicos do sistema da moda estão incorporados no conjunto de conhecimentos específicos do design, eles não explicam como.

Não é clara a associação de valores simbólicos que podem resvalar no gosto pessoal do estilista ou designer de moda, no momento da prática projetual com o campo do design de produtos. Na verdade, os valores nos quais o desenvolvimento do produto de moda está imerso parecem muito distantes da realidade do campo do design propriamente dito.

Ao mesmo tempo que tomam os valores do sistema da moda para o campo do design, Christo e Cipiniuk admitem que pelo menos até a década de sessenta, objetos de "estilo", leia-se "de moda", não faziam parte do campo de atuação de um designer.

Os autores reconhecem que em 1960, em função da abertura dos primeiros cursos de design no Brasil, a questão da moda era relegada a segundo plano pelo campo do design, e reforçam que o design só começa a olhar com interesse para a moda nos anos noventa (CHRISTO; CIPINIUK, 2010).

$\mathrm{O}$ que se percebe é que essa atitude do campo do design industrial em rechaçar o design de moda perdurou pelo menos até 1998, quando a moda é encampada pelo design, mas até hoje é vista na postura de alguns entes do campo do design.

Estilista e designer de moda estariam envolvidos em atividades com níveis distintos de responsabilidade e de abrangência, apesar de ambos se dedicarem à atividade de desenvolvimento e planejamento de produto de acordo com Doroteia Baduy Pires (2004).

As vezes parece que alguns pesquisadores do campo do design padecem do mal de, em sua busca por reconhecimento para o campo do design, menosprezarem outras áreas, como o campo da moda. A afirmação acima evidencia isso, pois nela não há embasamento crítico e ela não permite fazer generalizações quanto aos campos de trabalho do estilista e do designer.

A respeito da criatividade desvinculada do desenvolvimento de produto, há uma preocupação patente vista nos artigos publicados, que se evidencia por meio de uma citação de Pomeroy que aparece em dois artigos distintos sobre projeto em moda, um de Eloize Navalon e outro de Danielle Silva Simões e Hans da Nóbrega Waechter. Abaixo o trecho de Pomeroy citado nos dois artigos: 
A essência da criatividade não é uma noção romântica de que a imaginação está no ar e, somente um talento genial pode pegá-la, mas sim, encontram-se na seleção de informaçoes, açбes e definiçбes quV

A crítica à criatividade se dá contra a ideia de gênio criativo, que em geral, ilustra um designer que fica isolado na fase da criação, e é quase excluído da oportunidade de interação com outros membros da cadeia. Nesse contexto, haveria uma nítida separação entre quem projeta e quem executa, e a fragilidade da indústria têxtil e de vestuário reside justamente no fato de que não há uma visão do todo (RUTHSCHILLING; ANICET, 2014).

Como o designer de moda detém uma "posição central" no processo de desenvolvimento de produto, ele tem o poder de influenciar sua equipe e, quanto menor a empresa, maior a influência do designer em todas as fases do desenvolvimento do produto (RUTHSCHILLING; ANICET, 2014).

Assim como outras, a afirmação acima se baseia na noção de mito, mas nesse caso ela não pode ser negada. Um estilista tem mais domínio quanto menor seu universo de atuação mesmo que soe contraditório que essa influência ocorra em um ambiente onde esse designer se mantenha até certo ponto isolado. $\bigcirc$ mito e suas contradições aparentemente não precisam se explicar.

\section{4 nomenclatura dos cursos
de moda em São Paulo}

Outro aspecto que influencia a sustentação do mito na atuação profissional do estilista ou designer é o título de bacharel que ele recebe. A diversidade de nomes para cursos de "Moda" existentes em São Paulo evidencia a luta simbólica entre os campos da moda e do design, que se desdobra sobre a noção de projeto em moda.

A partir de 1998, os cursos que se chamavam Moda, entre outras variações, deveriam então passarem a se chamar Design de Moda, sob a premissa de que a noção de projeto garantiria uma atuação mais ampla e profissionalizada ao novo profissional que surgia, o designer de moda, caso estivesse respaldada pelo campo do design.

Não houve tempo e nem era o objetivo desta tese se dedicar a uma análise profunda da grade curricular voltada às disciplinas de estilismo e projeto, mas o que se percebe com certa facilidade é que mesmo as nomenclaturas dos bacharelados voltados ao campo da moda ainda guardam muitas diferenças entre si, o que gera dúvidas sobre os conteúdos dos cursos e disciplinas de estilismo e projeto oferecidas, com as quais esta pesquisa teve contato.
O marco da luta simbólica entre os campos da moda e do design se inicia formalmente com a Resolução CNE/CES n. 5, de 8 de março de 2004, que levou os cursos de Moda a se tornarem Design de Moda. Como a faculdade de Moda no Brasil, entidade profissionalizante por excelência, surge como campo autônomo inicialmente desvinculado do Design, nota-se o estranhamento dos pioneiros do campo da moda quando ela passa a ser chamada de Design de Moda. Os diplomas abaixo oferecem algumas pistas para uma investigação mais cuidadosa que pode ajudar a dirimir dúvidas.

Sabe-se que nem todas as instituições acataram as inúmeras normativas do MEC lançadas desde 1998, incluindo a de 2004 supracitada, seja no que diz respeito à nomenclatura do curso em si, seja no uso de "habilitações". A seguir, alguns diplomas de cursos de Moda emitidos entre 1998 e 2015 por várias instituições de São Paulo expõem a fragilidade na fiscalização por parte do MEC no que diz respeito à nomenclatura dos cursos superiores voltados ao campo da moda.

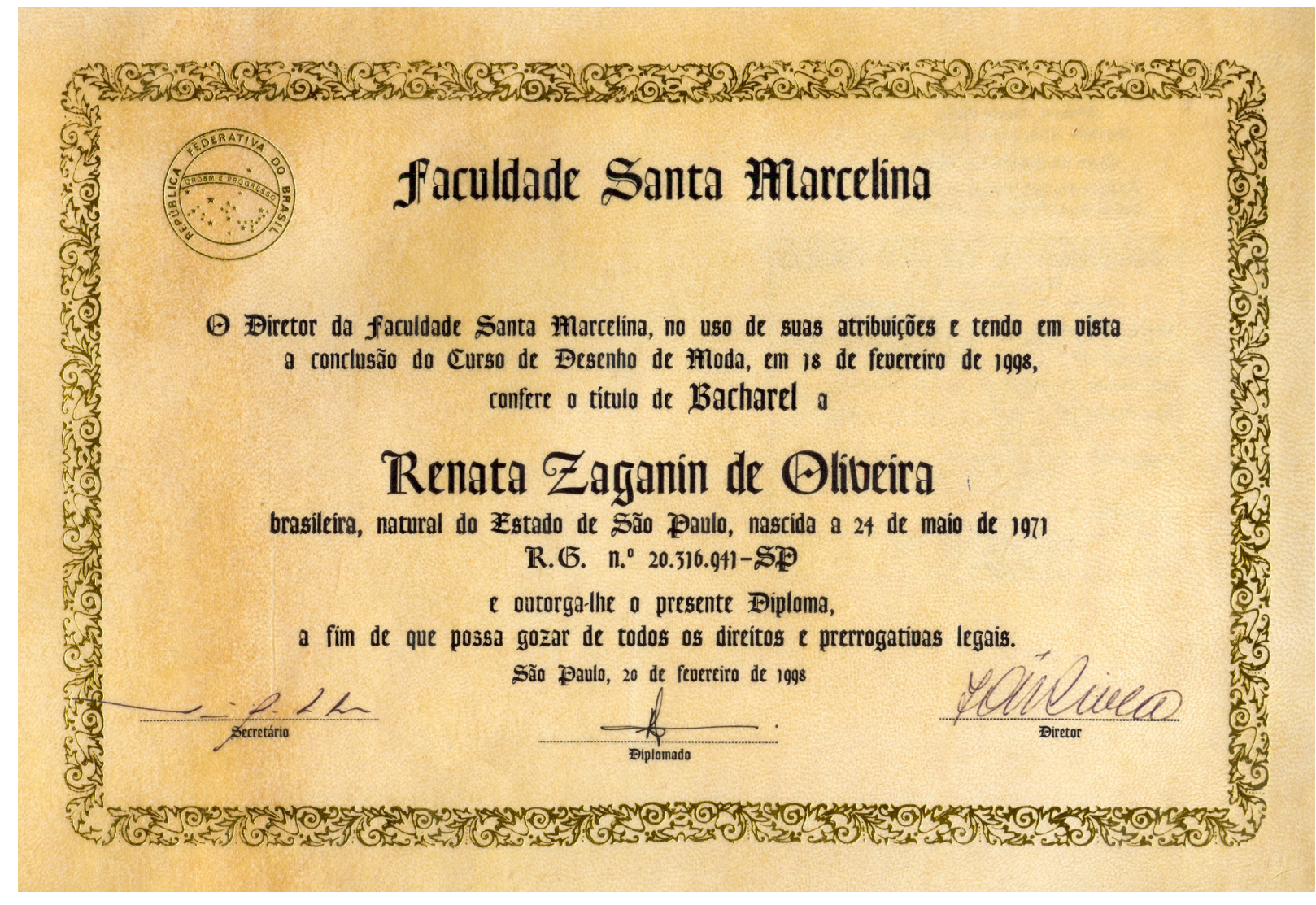

Acima (fig. 22), o diploma da FASM de 1998 refere-se ao seu curso como "Desenho de Moda". Antes desse período na UAM o curso superior se chamava "Moda", mas em 1999 com a mudança para a nova grade, de Design de Moda, os diplomas passam a ser emitidos com o título de bacharel em Design de Moda, como se observa abaixo (fig. 23).
Figura 22 - Diploma de
bacharelado em Desenh Moda da FASM de 19 (2018) 


\section{Figura 24 - Diploma Design de Moda do} SENACSP de 2013

\section{Qniversidade Anhembi ztlorumbi}

(a) Reitor da quniversidade anhembi morumbi,

no uso de suas atribuiç̃óes $\mathfrak{e}$ tendo $\mathrm{em}$ bista a conclusão do

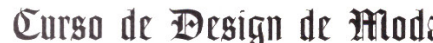

em 26 de março de 2004 , confere o título de

Bacharel em Pesign de mtoda a

\section{Leilane Rigatto Hetartins}

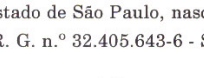

outorgas-lhe of presente fiplombs a fim de que pose gozar de todas os direitos \& precrogatioas legais.

São paulo, 26 de março de 200
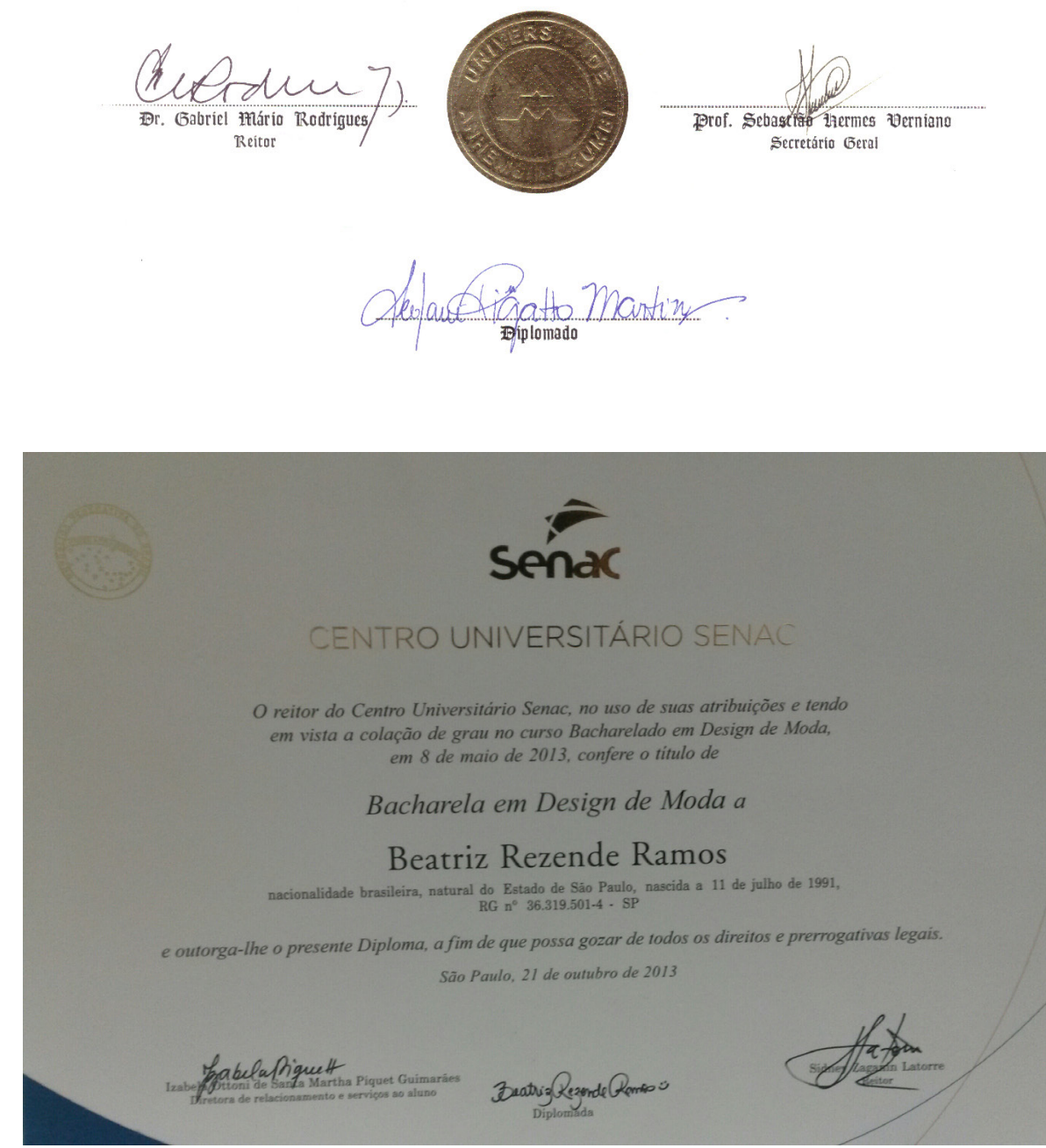

O curso do SENACSP desde seu início em 1998, adota a nomenclatura Design de Moda, embora até hoje mantenha as "habilitações" em "Estilismo" e "Modelagem", contrariando o MEC, que atualmente autoriza o uso do termo "linhas de formação", mas também aparece "ênfases" em substituição a "habilitações". Tanto "habilitações" quanto "linhas de formação" ou "ênfases" são expressões utilizadas para definir a especialização do egresso relativas ao curso de Design de Moda do SENACSP. Esse fato denota certo atraso do SENACSP na adoção de nomes exigidos pelo Ministério da Educação. De qualquer forma, o SENACSP utiliza a indicação das linhas de formação em sua publicidade, mas não na emissão de diplomas.

Dessa forma, ao analisar um diploma não se sabe a linha de formação do egresso, se é "Estilismo" ou "Modelagem".

Mesmo o curso da FMU não tendo sido objeto de investigação desta pesquisa, pelo fato de não ser definido como um curso pioneiro, chamam atenção os diplomas emitidos por esta instituição, que até recentemente emitia aos seus egressos o grau de bacharel em "Moda", passando ao largo das questões de design e evocando o nome de um dos primeiros cursos analisados por este estudo, o curso superior de "Moda" da UAM. Atualmente, conferir tal título contraria as normativas do MEC (fig. 25).

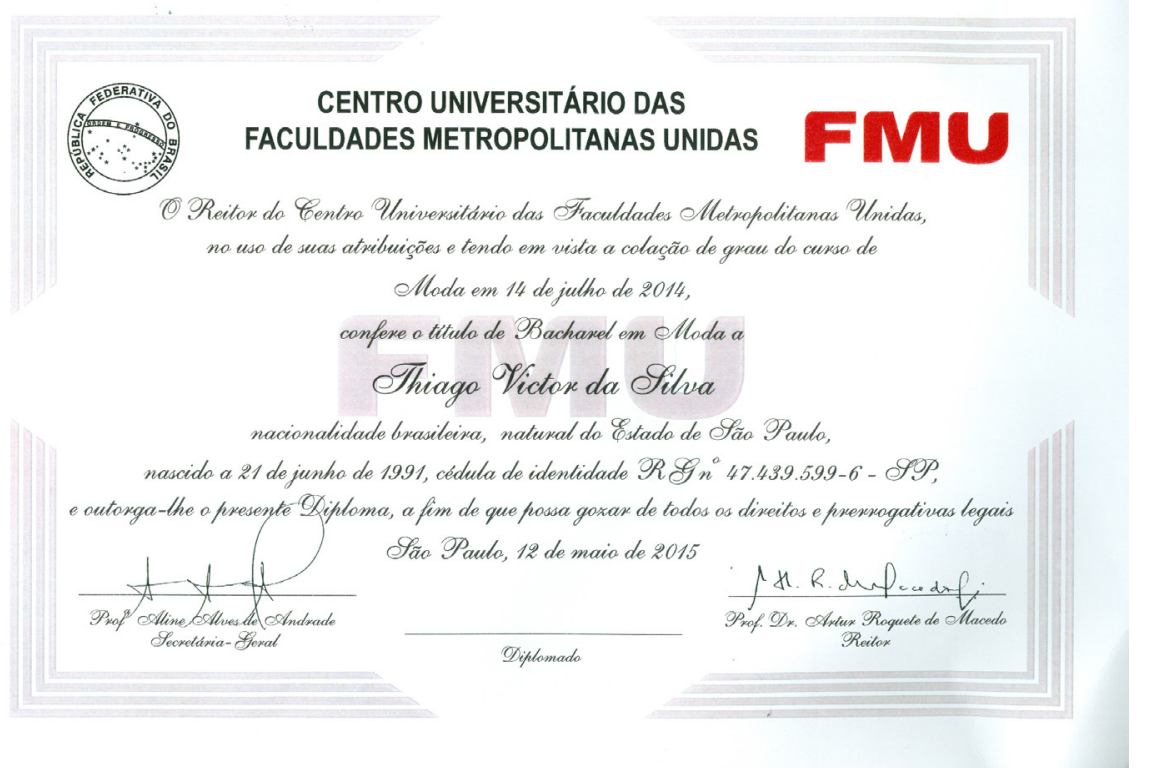

A suposta autonomia que o design passaria a garantir aos cursos de moda que vieram a se tornar design de moda gera dúvidas, pois essa tutela do campo do design sobre o campo da moda gerou uma luta simbólica, ainda que tácita, entre os dois campos, a qual se arrasta até hoje, seja pela titulação que o estilista ou designer de moda recebe, seja pela grade curricular que cada curso enseja. Esta última deve definir as habilidades desenvolvidas pelo egresso ao longo do curso superior, mas o que se percebe é que há casos em que os nomes dos cursos nem sempre equivalem às práticas de projeto ensejadas e divulgadas pela instituição. 
Na Itália, Projeto de Vestuário é o termo que aparece no depoimento de Conti (2017) do Politecnico di Milano ao invés de Design de Moda. Em uma comparação com a Royal College e a Central St. Martins, duas grandes escolas de moda inglesas, ele explica que na Inglaterra se fala em Design de Moda, ou seja, o design engloba produto e vestuário. No Politecnico di Milano produtos como uma cadeira e máquinas em geral referem-se ao design, enquanto vestuário seria algo diferente do design, daí a ideia de Projeto de Vestuário.

Ao mesmo tempo, quando questionado sobre o nome do curso do Politecnico di Milano ser Design de Moda e não Vestuário, Conti (2017) acredita que, embora o curso da escola milanesa tenha grande demanda de alunos, o nome moda tem mais apelo para atrair o público que quer fazer moda e não se restringir ao vestuário. Dessa forma, incorre-se mais uma vez na ação do mito, reafirmando a necessidade de o campo da moda ser reconhecido pelo design para obter vantagens político-educacionais, ao mesmo tempo que não quer abrir mão dos privilégios da criação livre. É patente a diferença de posicionamento da moda como campo de ensino e pesquisa em relação à ideologia que envolve o design e a arte. Em última instância, ela configura uma terceira via.

Apontado como "antiacadêmico" por Doroteia Pires e Renata Molho, o método de Nanni Strada mostra as arestas por onde a moda precisa escapar para exercer a identidade de seu ensino e pesquisa. Superando a ideia de que "antiacadêmico" também incorreria no mito, pois negaria o que é institucionalizado, tem-se a clareza de que a moda escapa e ao mesmo tempo participa dos campos do design e da arte, alimentando não só o mito, mas buscando certa autonomia.

Conforme foi afirmado anteriormente, apesar de esta tese não se ocupar efetivamente da investigação da grade curricular nem dos nomes dos cursos superiores em moda, o assunto resvala nas noções de estilismo e projeto em moda, a despeito do nome pelos quais essas sejam tratadas pelas instituições, e, portanto, elas são relevantes. O pouco contato que se teve com os diversos nomes encontrados em diplomas e disciplinas dos cursos de graduação em moda, somado à certa indolência do MEC em regularizar esses documentos, aponta que a questão está longe de ser esclarecida.

\section{REFERÉNCIAS
DOCAPITULO}

BARTHES, Roland. Mitologias.

Rio de Janeiro: DIFEL, 2007.

BENJAMIN, Walter. A obra de arte na época de sua reprodutibilidade técnica. Porto Alegre: Zouk, 2012.

BOMFIM, G. A. Idéias e Formas na História do Design: Uma Investigação estética. 1. ed. João Pessoa: Editora Universitária da UFPB, 1998. v. 1

BONADIO, Maria Claudia. A Rhodia têxtil e a "criação da moda nacional". In: COLÓQUIO DE MODA, 2., 2006, Salvador. Anais... Salvador: UNIFACS, 2006.

BOURDIEU, Pierre; DELSAUT, Yvette. O costureiro e sua grife: contribuição para um teoria da magia. Trad. Maria da Graça Jacinth Setton. Educação em Revista,

Belo Horizonte, n. 34, p. 7-66, dez. 2001. ISSN 1982-6621. Disponível em: <http://docslide.com br/documents/bourdieu-o-costureiro-e-suagrife.html>.

30 jul. 2016.

CARVALHO, Ana Paula Coelho de. 0 ensino paulistano de design: a formação das escolas pioneiras. São Paulo: Blucher, 2015.

CIPINIUK, Alberto. Design: o livro dos porquês: o campo do Design compreendido como produção social. Rio de Janeiro: Editora da PUC; São Paulo: Editora Reflexão, 2014.

CHRISTO, Deborah Chagas; SABRÁ, Flávio G. Caminada. Moda é design ou design é moda: análise da relação entre design moda metodologia de projeto. In: COLÓQUIO DE MODA, 12., 2016, João Pessoa. Anais... João Pessoa: Campus do Centro

Universitário de João Pessoa (Unipê), 2016.

CHRISTO, Deborah Chagas; CIPINIUK, Alberto. Reflexões sobre epistemologia do design enfocando o design de moda. In: COLÓQUIO DE MODA, 6., 2010, São Paulo. Anais... São Paulo: Universidade Anhembi Morumbi, 2010.

CONSELHO NACIONAL DE EDUCAÇÃO (CNE). Câmara de Educação Superior (CES). Resolução CNE/CES n. 5, de 8 de março de 2004. Aprova as Dirtizes Curniculares Graduação em Design e dá outras providencias. Disponivel em: <http://portal.mec.gov.br/cne/

CRISTOFÓLI, Amanda C.; MAYER, Bruna. A importância da pesquisa como primeira etapa para um projeto de desenvolvimento de design moda. In: COLÓQUIO DE MODA, 4., 2008 Novo Hamburgo. Anais... Novo Hamburgo: Feevale, 2008.

DURAND, José Carlos. Moda, luxo e economia. São Paulo: Babel Cultural, 1988.

JONES, Sue Jenkin. Fashion design - manual do estilista: São Paulo: Cosac Naify, 2005.

LEON, Ethel. Design em exposição: o design no Museu de Arte Moderna no Rio de Janeiro (1968-1978), na Federação das Indústrias de São Paulo (1978-1984) e no Museu da Casa Brasileira (1986-2002). 195 p. (Tese) - Faculdade de Arquitetura e Urbanismo da Universidade de São Paulo, São Paulo, 2012.

LÖBACH, Bernd. Design Industrial - Bases para a configuração dos produtos industriais. São Paulo: Blucher, 2007.

McROBBIE, Angela. British Fashion Design Rag Trade or Image Industry? Londres: Routledge, 1998.

MUNARI, Bruno. Design e comunicação visual: contribuição para uma metodologia didática.
São Paulo: Martins Fontes, 2011.

NAVALON, Eloize. Corpo, cultura e percepções: reflexões para um método de design de moda. 
In: COLÓQUIO DE MODA, 3.,2007, Belo Horizonte. Anais... Belo Horizonte: Faculdade CIMO, 2007.

PIRES, Dorotéia Baduy. O desenvolvimento de produtos de moda: uma atividade

multidisciplinar. In: CONGRESSO BRASILEIRO DE PESQUISA E DESEN OLVIMENTO EM Anis. S̃ Palo: FAAP; AERD/BR, 2004.

\section{RENFREW, Elinor; RENFREW, Colin.}

\section{Fundamentos de design de moda:}

Desenvolvendo uma coleção. Porto Alegre: Bookman, 2010.

RUTHSCHILLING, Evelise A.; ANICET, Anne. Estudo para construção de metodologia de design de moda sustentável. In:

CONGRESSO BRASILEIRO DE PESQUISA

E DESENVOLVIMENTO EM DESIGN, P\&D

DESIGN, 11., 2014, Gramado Anais... Gramado:

UFRGS; UNISINOS; UNIRITTER, 2014.

\section{SALLES, Cecilia Almeida. Gesto inacabado:} processo de criação artística. São Paulo: Intermeios, 2013, p. 186.

SEGNINI, Francisco. Arte, técnica e mercado: o trabalho do arquiteto. Pós n. 27 - Revista do Programa de Pós-graduação em Arquitetura e Urbanismo da FAUUSP, São Paulo, n. 27, p. 122-135, 2010. ISSN 1518-9554.

SEIVEWRIGHT, Simon. Fundamentos de design de moda: Pesquisa e Design. Porto Alegre: Bookman, 2009.

SIMÕES, Danielle S.; WAECHTER, Hans da Nóbrega. Procedimentos metodológicos para criação de coleções para o polo de confecções do Agreste do Pernambuco. In: CONGRESSO BRASILEIRO DE PESQUISA E DESENVOLVIMENTO EM DESIGN, P\&D DESIGN, 9., 2010, São Paulo. Anais... São Paulo: Universidade Anhembi Morumbi, 2010
TREPTOW, Doris. Inventando moda: planejamento de coleção. 5. ed. São Paulo: Edição da Autora, 2013.

VELHO, Gilberto. $O$ desafio da Cidade: novas brasileira. Rio de Janeiro: Campus, 1980.

VOLONTÉ, Paolo. Vita da Stilista. II ruolo sociale del fashion designer. Milano: Pearson Paravia Bruno Mondadori S. p. A., 2008.

FONTES DAS ENTREVISTAS

BONADIO, Maria Cláudia. Entrevista realizada com Maria Cláudia Bonadio, em 17 de novembro de 2015, na cidade de São Paulo, com 1 hora e 21 minutos de duração.

BRAGA, João. Entrevista realizada com João Braga, em 8 de dezembro de 2014, na cidade de São Paulo, com 2 horas 36 minutos de duração.

GUIMARÃES, Maria Eduarda Araújo. Entrevista realizada com Maria Eduarda Araújo Guimarães, em 9 de outubro de 2015, na cidade de São Paulo, com 1 hora e 50 minutos de duração.

ITO, Márcio. Entrevista realizada com Márcio Ito, em 16 de dezembro de 2014, na cidade de São Paulo, com 1 hora e 42 minutos de duração.

MOURA, Mônica. Entrevista realizada com Mônica Moura, em 26 de maio de 2015, na cidade de São Paulo, com 1 hora e 42 minutos de duração.

OLIVEIRA, Renata Zaganin de. Entrevista realizada com Renata Zaganin de Oliveira, em 28 de novembro de 2014a, na cidade de São Paulo, com 2 horas e 9 minutos de duração.
OLIVEIRA, Renata Zaganin de. Entrevista

realizada com Renata Zaganin de Oliveira, em de dezembro de 201 ba, nacidade de Sáo Paulo, com 53 minutos de duração.

SANCHES, Maria Celeste de Fátima. Entrevista realizada com Maria Celeste de Fátima Sanches, em 5 de setembro de 2015, na cidade de Londrina, com 1 hora e 13 minutos de duração.

SOUSA, Cyntia Santos Malaguti de. Entrevista realizada com Cyntia Santos Malaguti de Sousa, em 4 de novembro de 2015a, na cidade de São Paulo, com 51 minutos de duração.

SOUSA, Cyntia Santos Malaguti de. Entrevista realizada com Cyntia Santos Malaguti de Sousa, em 25 de novembro de 2015b, na cidade de São Paulo, com 57 minutos de duração.

SUDSILOWSKY, Sérgio. Entrevista realizada com Sérgio Sudsilowsky, em 20 de outubro de 2015, na cidade do Rio de Janeiro, com 44 minutos de duração. 


\section{Considerações Finais}

Nessa fase, buscou-se promover a interlocução dos resultados obtidos em cada capítulo e foram expostas as últimas reflexões que, considerou-se merecerem maior destaque. Também será evidenciado o caminho feito para que os objetivos propostos fossem atingidos de forma a contribuírem com a comunidade científica.

Um dos objetivos principais desta pesquisa foi apurar as noções de estilismo e projeto em moda, de modo a oferecer um mapeamento homogêneo sobre essas noções praticadas no campo. Entende-se que essa etapa foi cumprida por meio de um dos objetivos secundários, ou seja, ao relatar as etapas que definem essas noções, apresentado o processo descrito na mesma ordem em que tais etapas ocorrem, tendo como embasamento os depoimentos dos professores e pesquisadores de cada uma das instituições investigadas.

Outro objetivo secundário, que consistia em gerar registros escritos e reconhecidos como discursos oficiais sobre a noção de estilismo e projeto em moda, está sendo cumprido com a publicação desta tese.

Os capítulos 2.6, 3, 4, 5 e 6 trataram de promover um diálogo entre professores e pesquisadores das categorias de estilismo e projeto em moda, a partir do cruzamento de visões convergentes e divergentes, contemplando, assim, outro objetivo previsto pela tese.

Os resultados também contribuem para a compreensão de como a noção de estilismo foi influenciada pela noção de projeto ao longo do tempo, principalmente a partir de 1998.

É interessante considerar que, ao longo do desenvolvimento da pesquisa, percebeu-se que o inverso também ocorre: como, em várias situações, os termos e atividades que delineiam essas práticas convergem, é possível perceber a noção de estilismo influenciando a noção de projeto em moda. 
Até os dias atuais, algumas etapas que constituem a noção de projeto tais como "problema" e "solução", só para citar as mais elementares, não são encontradas nem nos livros nem nos depoimentos da maioria dos entrevistados sobre projeto em moda e, quando surgem, elas não se configuram como no design de produto, e acabam por remeter a uma atividade que o estilismo já realizava antes de vir a se tornar projeto em moda.

A pesquisa na Itália demonstrou como o problema é abordado no campo da moda. A resposta para a solução de um problema parte de escolhas que determinam uma direção. Essas escolhas estão relacionadas com questionamentos sobre uso, lugar de uso e acabamentos de peças.

A investigação no Politecnico di Milano levou a perceber que, apesar do design de moda contemplar a solução a partir de um problema, o conceito de problema no campo da moda é consideravelmente diferente de como ele surge no de especificidades da moda são respeitadas de forma velada, pois mesmo que elas aconteçam, elas encontram-se sob a denominação de design.

preciso ter cuidado quando as faculdades de design de moda adaptam metodologias de projeto em design aos seus cursos. As habilidades que são cobradas do designer são muito generalistas se comparadas às do designer de moda.

Ainda hoje, os livros, relatos e a observação em aulas de projeto levam a crer que o emprego predominante de expressões como "o espírito da sua coleção" ou "coleção que traduza o tema", seja no Brasil ou na Itália, tendem, na prática, à perpetuação do ensino do estilismo, que exalta a inspiração com base em um tema, mas que hoje, por força da lei, se chama projeto em moda.

Entre os autores estudados e os pioneiros entrevistados observou-se que muitos enxergam na necessidade de "cobrir um corpo" um problema, quando na verdade se configura mais uma demanda, segundo Monçores, ou uma oportunidade, como apontam Sudsilowsky e Aragão.

Outros, como Mendes, associam a noção de problema a questões ergonômicas para o vestuário de performance. Isso torna o projeto em moda mais próximo ao design, mesmo no caso de Mendes, que defende noção de estilismo.

A postura de Mendes faz perceber que sempre foram necessárias certas premissas do projeto de design no projeto em moda, e que, portanto, noção de estilismo não precisaria ser substituída pela de projeto.

Grumach também se pauta pela noção de problema quando se refere ao projeto de uniformes, assim como Aragão, mas esta última prefere o termo oportunidade, mais adaptado à realidade do design de moda.

Se ainda hoje percebe-se uma falta de vinculação do projeto em moda com certas etapas do projeto em design, no final da década de 1990, quando a noção de estilismo foi legitimada como noção projetual, o trabalho do estilista ainda estava voltado ao desenvolvimento de um coleção, com foco na criatividade e na colaboração individual do autor, partir de referências próprias.
Em outras palavras, partia-se de um tema, muitas vezes relacionados ao próprio universo do criador, o qual buscava referências imagéticas para formular essa proposta por meio de painéis, que reuniam essas referências visuais nas quais a coleção se baseava sem recorrer a qualquer metodologia de projeto, mesmo que a prática já tivesse mudado seu nome para projeto. A transmisso oral sempre prevaceu no ensino do estilismo, sendo o modelo predominante desde a década de 1990. De maneira geral, ness época a preocupação primeira era profissionalizar os discentes do curso de Moda e não se aprofundar na análise da literatura sobre projeto.

O que se observa na maioria dos casos é que a moda, na tentativa de se adequar ao design por meio da noção de projeto em moda, o faz sem aprofundamento na bibliografia de projeto de produto ou sem trocas mais efetivas, que poderiam gerar posicionamentos mais coesos entre professores e pesquisadores dos campos, para servirem de diretrizes que guiassem a atividade em direção ao projeto.

Por outro lado, esse hiato aumenta quando se nota o desconhecimento e o desinteresse dos entes do campo do design em relação à bibliografia sobre estilismo e projeto em moda. Uma vez que o design assumiu o campo da moda formalmente em termos acadêmicos, a expectativa era de troca, mas restam dúvidas sobre $o$ alcance desse intercâmbio entre os campos, pois muitas vezes é percebido que o desenvolvimento de produto de moda, respaldado pelo projeto, realiza as mesmas atividades que já estavam na pauta do estilismo.

Há algum ruído na conversa entre projeto em moda e estilismo. Mesmo os partidários declarados de uma ou de outra vertente, não conseguem explicar, por exemplo, as limitações de determinados conceitos de projeto quando aplicados à moda, ou parecem não querer admitir que, muitas vezes, as especificidades do campo do design de moda que já vinham sendo contempladas pelo estilismo passam a ser ignoradas, quando entram em cena as metodologias ofertadas pelo campo do design.

Faltam explicações sobre como proceder em relação ao design e ao projeto em moda com mais assertividade. Não é intenção deste trabalho defender ou eleger um único método, porém, quando os entrevistados são questionados sobre termos que existem no campo do design e não no da moda e viceversa e, principalmente, em relação à atividade que os define, estes recorrem a expressões como: "é preciso ter bom senso ao utilizar as metodologias", como se tal atitude auxiliasse na compreensão do uso da metodologia.

O que se vê é um jogo de "empurra" entre os campos da moda e do design, onde nem os entes vinculados à moda nem os vinculados ao design conseguem elucidar tais limitações. Permanecem lacunas que reforçam a necessidade de se discutir mais profundamente a questão e entender os limite de cada campo e suas metodologias, e até onde elas podem ser flexibilizadas.

Esse último aspecto é muito importante, pois conforme dito anteriormente, não se trata de uma preferência pela abordagem da moda ou do design, mas de entender o que pode ser útil em um campo quando aplicado a outro, e o que é mais adequado ao tipo de situação projetual encontrada. 
Falar em estilismo também não significa que não haja método. Muitas etapas hoje definidas pelo campo do design já constituíam métodos consagrados pela prática do estilismo até os anos 2000. Como o campo do design formalizou sua escrita científica antes do campo da moda, talvez a moda tenha perdido o timing de formalizar suas questões.

Como último objetivo deste trabalho, espera-se abrir para o debate os temas do estilismo e do projeto em moda para que, por meio da publicação de pesquisas e apresentação de trabalhos em eventos como o Colóquio de Moda e o P\&D, sejam discutidas efetivamente, sob o ponto de vista de interessede ambos os campos dodesignedamod, de o ponto de vista de S as áreas e não mantenham o distanciamento entre 0 fazer do design e do designer de moda, muitas vezes fazendo parecer que estes têm pouco em comum.

Isso requer definir práticas e fronteiras para que elas também possam ser cruzadas, desde que isso fortaleça qualquer prática projetual posterior e que paute novas discussões, pois o propósito da prática e, consequentemente, das metodologias, não é serem estanques. Elas devem engendrar novos olhares $\mathrm{e}$ formas de fazer que só tendem a enriquecer a discussão e fortalecer o campo projetual da moda, também por meio da divulgação de resultados de pesquisa.

Conforme apontado no Capítulo 6 e ao longo da tese, as fronteiras entre o modus operandi do estilismo e do projeto são cruzadas com certa frequência pelos campos da moda e do design. Eles se alternam em diversos momentos na escolha da forma de projetar, podendo, dessa forma, se vincular à aura, que se traduziria por meio do estilismo, ou ao anonimato industrial, ilustrado pela noção de projeto.

Essas visões de que estilismo sustenta o mito do criador e a aura do produto, enquanto a noção de projeto garantiria a neutralidade almejada pelo designer dotado de idoneidade ideológica durante o ato projetual, é uma legitimação construída pela Academia. Isso não é suficiente para dizer que há uma divisão clara entre as áreas e seus modos de projetar. O registro escrito pode delimitar dessa maneira, mas não é o que se percebe no ensino e na prática. Mais importante que as denominações é como se desenrolam as atividades pelas duas áreas e suas intenções.

A moda, no âmbito do ensino e da pesquisa, sai da informalidade para a formalidade por meio da criação de cursos superiores, e no mercado profissional encena a substituição de uma mão de obra autodidata em moda por uma mão de obra especializada, que começa a tomar o mercado em meados da década de 1990.

Críticas a respeito do desempenho dos egressos dos primeiros cursos de Moda da FASM e UAM só foram possíveis a partir de sua atuação. Esses profissionais foram os primeiros a praticar como sistematizar as etapas de pesquisa, criação e desenvolvimento de produtos de moda por meio da atividade do estilismo e, a partir da opinião do mercado que os recebia, 0 curso e a prática do estilismo passaram a ser objetos de reflexão constante para a Academia.

Até hoje é apontada certa reserva dos cursos de Moda em relação ao campo do Design. A cisão entre os campos da Moda e do Design se reforça no início dos anos 2000, após os cursos de Moda se tornarem Design de Moda. Como a faculdade de Moda no Brasil, entidade profissionalizante por excelência, surge como campo autônomo, inicialmente desvinculado do Design, o estranhamento causado nos cursos de graduação em Moda é notado na maior parte das faculdades que vieram a se tornar Design de Moda.

As consequências se traduzem na tentativa de manutenção de atividades relativamente autônomas no tocante à atividade projetual de moda que, por sua vez nem sempre vê suas especificidades respeitadas pelo projeto de design. Essa tentativa de manutenção de uma noção de projeto em moda autônoma, se desdobra por meio de lutas simbólicas entre ambos os campos, como exposto no Capítulo 6.

Se os cursos de moda tivessem nascido vinculados ao campo do design desde seu início e, dessa forma, fosse fomentada então a noção de projeto em moda, seria possível afirmar que a noção de estilismo não existiria? O Capítulo 3 demonstra, ao analisar as ações da Rhodia, que a moda já operava entre o estilismo e o design de moda no período concomitante à formalização acadêmica dos cursos de Desenho Industrial no Brasil, nos anos sessenta.

Embora, aparentemente, na época do surgimento dos cursos de Desenho Industrial, as atividades de estilismo e de projetação em moda já coexistissem, o estilismo parece ser predominante como atividade, embora tal afirmação demande uma averiguação mais profunda. De qualquer forma, é interessante compreender e respeitar as especificidades da moda que foram engendradas pelo estilismo, para então reforçar as questões do design perante o projeto em moda via formalização acadêmica, uma vez que esta é a demanda do MEC.

As falas dos designers Ernesto Hauner, Fernando Lemos, Pietro Bardi, Francesc Petit, Mona Gorovitz e Alceu Penna permitem concluir que são raras as iniciativas que reconhecem o design de moda, em detrimento do estilismo, na década de 1970. De qualquer forma, eles defendiam que desenho de moda era uma atividade de design, e, portanto, do design de moda. Fica a sugestão de que ambas as atividades podem ter se desenvolvido concomitantemente.

Em matéria publicada pelo Jornal do Brasil em 1970, Alceu Penna é reconhecido como designer de moda pelo menos desde 1940. Para Bardi e Gorovitz, em 1970 muitas dificuldades já haviam sido superadas em relação ao reconhecimento da moda como design e, tal fato permitia falar em design de moda. Resta saber se na década de 1940 a atividade se chamava design de moda, e, em caso negativo, quando foi que passou a ser chamada assim, para que esse grupo precursor assim se referisse à mesma, em 1970.

Nesse contexto, interessam as transformações ao longo dessas três décadas, de 1940 a 1970, que as noções que abarcam o desenvolvimento de produtos em moda sofreram, reforçando que as atividades que delineiam tanto o estilismo quanto o projeto por vezes se fundem ainda hoje e, talvez, uma das causas dessa mistura seja um possível surgimento híbrido de ambas as noções, que demandaria uma pesquisa específica e mais profunda. 
Em 1998 havia a promessa de que, ao encampar a área de moda, o campo do design proveria as diretrizes necessárias para regularizar as inadequações que ele apontava na prática de desenvolvimento de produtos de moda segundo o estilismo, o qual, com o tempo, viria a se tornar design de moda.

A proposta de alinhamento à atividade projetual do design implicou na mudança de nome dos cursos de moda, sob a justificativa de conferir uniformidade a eles no que dizia respeito não só aos nomes dos cursos, mas também às suas grades curriculares. Os cursos de bacharelado em Moda e suas variações deveriam assumir o nome Design de Moda, como aconteceu em muitos casos.

Talvez a flexibilidade na fiscalização dos cursos de moda possa ser apontada como uma das justificativas para a diferença que ainda hoje persiste entre os nomes encontrados. Isso leva a pensar até onde vai o alcance da mudança dos cursos de moda desde que foram alojados no campo do design, pois, ainda hoje muitos cursos se reservam o direito de não utilizar o nome Design.

Como essa tese se debruça sobre a noção de projeto principalmente por meio de relatos dos pioneiros, é importante ressaltar que o foco não foi analisar e comparar as grades curriculares dos cursos de Moda e Design de Moda que as faculdades estudadas já tiveram. Isso por si só seria um trabalho de grande dimensão e já constituiria outra tese. De qualquer forma permanecem dúvidas sobre a variação de práticas que as nomenclaturas dos cursos e disciplinas de estilismo e projeto sugerem.

Trata-se de um posicionamento ético que deve ser tomado diante do aluno que está se formando em um curso de moda, para que esse passe a ter clareza de vocabulário, instrumentos e posicionamentos em uma indústria tão ambígua quanto a da moda. Esse é um problema recorrente dos cursos de moda estudados no Brasil e que pode ser entendido como influência das escolas europeias, como a italiana, a inglesa e a francesa, que serviram de modelo para as faculdades de moda brasileiras.

O que esses nomes podem revelar? Que práticas de projeto se desenvolviam nesses cursos além das pesquisadas por esta tese? $\mathrm{O}$ que esses diplomas podem revelar sobre os cursos de moda em diferentes momentos e sobre possíveis posicionamentos político-pedagógicos que resvalam na prática projetual?

A despeito das expectativas geradas em 1998, quando o campo de moda passa a ser tutelado pelo design em nível acadêmico o que se vê é que o consenso sobre uma noção de projeto em moda não aconteceu, mesmo quase duas décadas depois. Portanto, é possível afirmar que a hipótese proposta de que não há consenso sobre o conceito de projeto em moda no Brasil no âmbito acadêmico que se inaugura em 1988, se confirma. 


\section{REFERÉNCIAS GERAIS}

ALBERTI, Verena. Manual de historia oral. Rio de Janeiro: Editora FGV, 2013, p. 386.

ANDRADE, Raquel R.; PEREIRA, Livia M.; LANDIM, Paula da Cruz. Processo de seleção de materiais e o desenvolvimento projetual do vestuário. In: COLÓQUIO DE MODA, 10 2014, Caxias do Sul. Anais... Caxias do Sul: Universidade de Caxias do Sul, 2014.

BARTHES, Roland. Mitologias. Rio de Janeiro: DIFEL, 2007.

BENDER, Ana. Design de moda: intersecçõe no processo de projeto. In: COLÓQUIO DE MODA, 6., 2010, São Paulo. Anais... São Paulo: Universidade Anhembi Morumbi, 2010.

BENJAMIN, Walter. A obra de arte na época de sua reprodutibilidade técnica. Porto Alegre: Zouk, 2012.

BOMFIM, G. A. Ideias e Formas na História do Design: Uma Investigação estética 1 d. Jo Pesso: Editora Univeritária da UFPB,

BONADIO, Maria Claudia. A Rhodia têxtil e a "criação da moda nacional". In: COLÓQUIO DE MODA, 2., 2006, Salvador. Anais... Salvador: UNIFACS, 2006.

A produção acadêmica sobre moda na pós-graduação stricto sensu no Brasil. lara Revista de moda, cultura e arte, São Paulo, v. 3, n. 3, p. 50-146, 2010. [Dossiê]. ISSN $1983-$ 7836. Disponível em: <http://www.iararevista. sp.senac.br/arquivos/noticias/arquivos/141/ anexos/pdf003.pdf>. Acesso em: 10 set. 2014.

Moda e publicidade no Brasil nos anos 1960. São Paulo: NVersos, 2014.
BOURDIEU, Pierre. 0 poder simbólico. Rio de Janeiro: Bertrand Brasil S.A., 1989.

BOURDIEU, Pierre; DELSAUT, Yvette.

$O$ costureiro e sua grife: contribuição para uma teoria da magia. Trad. Maria da Graça Jacintho Setton. In: Educação em Revista, Belo . (1) documents/bourdieu-o-costureiro-e-sua-grife. html>. Acesso em: 30 jul. 2016.

BRAGA, Marcos da Costa. Projeto cabide. In: CONGRESSO BRASILEIRO DE PESQUISA DESENVOLVIMENTO EM DESIGN, P\&D DESIGN, 1.,1994, São Paulo. Anais... São Paulo: UNIP/AEnD BR, 1994.

BROEGA, Ana C.; MAZZOTTI, Karla.

Metodologias facilitadoras da criatividade em design de moda: uma experiência acadêmica. In: COLÓQUIO DE MODA, 11.,2015, Curitiba. Anais... Curitiba: Universidade Positivo, 2015.

CAMARGO, Cariane W.; MEDEIROS, Lígia. Disciplinas de projeto: o desafio de ensinar a desenvolver produtos de moda. In: COLÓQUIO DE MODA, 8., 2012, Rio de Janeiro. Anais... Rio de Janeiro: SENAI/CETIQT, 2012

CARVALHO, Ana Paula Coelho de. 0 ensino paulistano de design: a formação das escolas pioneiras. São Paulo: Blucher, 2014.

CHRISTO, Deborah Chagas. Designer de moda ou estilista? Pequena reflexão sobre a relação entre noções e valores do campo da arte, do design da moda. In: COLÓQUIO DE MODA, 2., 2006 , Salvador. Anais... Salvador: UNIFACS, 2006.

HRISTO, Deborah Chagas. Designer de moda: construtor de significados. In: CONGRESSO BRASILEIRO DE PESQUISA DESENVOLVIMENTO EM DESIGN, P\&D DESIGN, 8., 2008, São Paulo. Anais... São Paulo: Centro Universitário Senac (campus Santo Amaro), 2008
Estrutura e funcionamento do campo de produção de objetos do vestuár no Brasil. 146 f. (Tese de Doutorado) Departamento de Artes e Design da Pontifícia Universidade Católica do Rio de Janeiro, Rio de Janeiro, 2013.

CHRISTO, Deborah Chagas; CIPINIUK, Alberto. Reflexões sobre epistemologia do design enfocando o design de moda In: COLÓQUIO DE MODA, 6, 2010, São Paulo Anais... São D. Univid 2010.

CHRISTO, Deborah Chagas; SABRÁ, Flávio G. Caminada. Moda é design ou design é moda: análise da relação entre design, moda metodologia de projeto. In: COLÓQUIO DE MODA, 12., 2016, João Pessoa. Anais... João Pessoa: Campus do Centro Universitário de João Pessoa (Unipê), 2016.

CIPINIUK, Alberto. Design: o livro dos porquês: o campo do Design compreendido como produção social. Rio de Janeiro: Editora da PUC; São Paulo: Editora Reflexão, 2014.

CRISTOFÓLI, Amanda C.; MAYER, Bruna. A importância da pesquisa como primeira etap para um projeto de desenvolvimento de design moda. In: COLÓQUIO DE MODA, 4., 2008, Novo Hamburgo. Anais... Novo Hamburgo: Feevale, 2008.

DURAND, José Carlos. Moda, luxo conomia. São Paulo: Babel Cultural, 1988.

ETOS. In: DICIONÁRIO Priberam da Língua Portuguesa. 2008-2013. Disponível em: <https:// www.priberam.pt/dlpo/etos>. Acesso em: $20 \mathrm{~d}$ abr. 2017

GIBERT, Vera Lígia P. O entorno acadêmico e industrial têxtil no vestir e morar brasileiros. 317 p. (Dissertação) - Escola de Comunicacão o Artes da Universidade de São Paulo, São Paulo, 1993.
HORN, Bibiana S.; MEYER, Guilherme C. O uso de metodologia de projeto no desenvolvimento de coleção de moda. In: COLOQUIO DE MODA, 8., 2012, Rio de Janeiro. Anais... Rio de Janeiro: SENAI/CETIQT, 2012.

JONES, Sue Jenkin. Fashion design - manual stilista: Sue Jenkyn Jones. São Paulo: Cosac Naify, 2005

LEON, Ethel. Design em exposição: o design no Museu de Arte Moderna no Rio de Janeiro (1968-1978), na Federação das Indústrias de São Paulo (1978-1984) e no Museu da Casa Brasileira (1986-2002). 195 p. (Tese de Doutorado) Faculdade de Arquitetura e Urbanismo da Universidade de São Paulo, São Paulo, 2012.

McROBBIE, Angela. British Fashion Design: Rag Trade or Image Industry? Londres: Routledge, 1998.

LIPOVETSKY, Gilles. O império do efêmero: a moda e seu destino nas sociedades modernas. São Paulo: Companhia das Letras, 1989.

ÖBACH, Bernd. Design Industrial - Bases para a configuração dos produtos industriais. São Paulo: Blucher, 2007.

MACIEL, Dulce M. H. Métodos e criatividade. A influência do uso de métodos no processo de criação. In: COLÓQUIO DE MODA, 7.,2011, Maringá. Anais... Maringá: Universidade ESUMAR, 2011.

MARTINS, Suzana B. O paradoxo sustentáve na moda: diretrizes para sustentabilidade en produtos de moda e vestuário. In: CARLI, Ana Mary Sehbe de; MANFREDINI, Mercedes Lusa. Moda em sintonia. Caxias do Sul: Educs, 2010. p. 80-89.

MATTOS, Maria de F. (orgs.). Pesquisa e formação em moda. São Paulo: Estação das Letras e Cores, 2015. 
MENDES, Francisca Dantas. Cadeia Têxtil e as estratégias de manufatura na indústria do vestuário de moda. 209 p. (Dissertação de Mestrado) - Programa de Pós-graduação em Engenharia de Produção da Universidade Paulista, São Paulo, 2006.

MERLO, Márcia; NAVALON, Eloize. Processos projetuais para a criação em design de moda: pesquisas teóricas e referenciais. In: CONGRESSO BRASILEIRO DE PESQUISA EDESENVOLVIMENTO EM DESIGN, P\&D DESIGN,, 2010 S̃ O Paulo: Universidade Anhembi Morumbi, 2010

MONTEMEZZO, Maria Celeste de Fátima Sanches. Diretrizes metodológicas para projeto de produtos de moda no âmbito acadêmico. 97 f. (Dissertação de Mestrado) - Universidade Estadual Paulista, Faculdade de Arquitetura, Artes e Comunicação, 2003. Disponível em: <http://hdl.handle. net/11449/97020>.

MORAIS, Michael Medeiros. Reflexões metodológicas sobre o design de moda. In: CONGRESSO BRASILEIRO DE PESQUISA EOSENVIVIMENTO EM DESIGN,PAD DESIGN, 7., 2006, Curitiba. Anais... Curitiba: UnicenP, 2006.

MOREIRA, Bruna R.; CAMARGO, Cariane W.; SOARES, Luciana B.; GIONGO, Marina A. A relevância da multidimensionalidade das disciplinas de projeto na graduação em moda. In: COLÓQUIO DE MODA, 10., 2014, Caxias do Sul. Anais... Caxias do Sul: Universidade de Caxias do Sul, 2014

MOURA, Mônica. A moda entre a arte e o design. In: PIRES, D.B. Design de moda: olhares diversos. Barueri, SP: Estação das Letras e Cores, 2008. p. 37-73.

MUNARI, Bruno. Das coisas nascem coisas. São Paulo: Martins Fontes, 2008.
MUNARI, Bruno. Design e comunicação visual: contribuição para uma metodologia didática. São Paulo: Martins Fontes, 2011.

NAVALON, Eloize. Corpo, cultura e percepções: reflexões para um método de design de moda. In: COLÓQUIO DE MODA, 3.,2007, Belo Horizonte. Anais... Belo Horizonte: Faculdade CIMO, 2007.

PICOLI, Julia. Metodologia projetual no ensino do desenvolvimento de coleções. In: COLÓQUIO DE MODA, 7.,2011, Maringá. Anais... Maringá: Universidade CESUMAR, 2011.

PIRES, Dorotéia Baduy. O desenvolvimento de produtos de moda: uma atividade multidisciplinar. In: CONGRESSO BRASILEIRO DE PESQUISA E DESENVOLVIMENTO EM DESIGN, P\&D DESIGN, 6.,2004, São Paulo. Anais... São Paulo: FAAP; AEnD/BR, 2004.

POUPART, Jean. A pesquisa qualitativa: enfoques epistemológicos e metodológicos. Petrópolis, RJ: Vozes, 2008.

PRECIOSA, Rosane S.; HAGEDORN, Adriane. Notas sobre o design de moda e suas práticas experimentais In: CONGRESSO BRASILEIRO DE PESQUISA EDESENVOLVIMENTO EM DE PESQUSAE DESENVOLVIMENTOEM Anais... Curitiba: UnicenP, 2006.

PUBLICAÇÕES. <http://www.fapesp.br/ publicacoes/relat2015_sintese.pdf $>$. Acesso em: 14 abr. 2017.

RANKING UNIVERSITÁRIO FOLHA 2017. São Paulo: RUF, [2017]. Disponível em: <https:// ruf.folha.uol.com.br/2017/ranking-de-cursos/ moda/>. Acesso em: 15 jun. 2018.

RENFREW, ELINOR; RENFREW, COLIN. Fundamentos de design de moda: Desenvolvendo uma coleção. Porto Alegre: Bookman, 2010.
RUTHSCHILLING, Evelise A.; ANICET, Anne. Estudo para construção de metodologia de design de moda sustentável. In CONGRESSO BRASILEIRO DE PESQUISA E DESENVOLVIMENTO EM DESIGN, P\&D DESIGN, 11., 2014, Gramado. Anais... Gramado: UFRGS; UNISINOS; UNIRITTER, 2014.

SALLES, Cecilia Almeida. Gesto inacabado: processo de criação artística. São Paulo: Intermeios, 2013.

SEGNINI, Francisco. Arte, técnica e mercado: o trabalho do arquiteto. Pós n. 27 - Revista do Programa de Pós-graduação em Arquitetura e Urbanismo da FAUUSP, São Paulo, n. 27, p. 122-135, 2010. ISSN 1518-9554.

SEIVEWRIGHT, Simon. Fundamentos de design de moda: Pesquisa e Design. Porto Alegre: Bookman, 2009.

SIMÕES, Danielle S.; WAECHTER, Hans da Nóbrega. Procedimentos metodológicos para criação de coleções para o polo de confecções do Agreste do Pernambuco. In: CONGRESSO BRASILEIRO DE PESQUISA E DESENVOLVIMENTO EM DESIGN, P\&D DESIGN, 9., 2010, São Paulo. Anais... Säo Paulo: Universidade Anhembi Morumbi, 2010.

SOUSA, Cyntia Santos Malaguti de; HARDAGH Cláudia Coelho. Problematizando o design de moda - o papel da disciplina metodologi de projeto. In: CONGRESSO BRASILEIRO DE PESQUISA E DESENVOLVIMENTO EM DESIGN, P\&D DESIGN, 8., 2008, São Paulo. Anais... São Paulo: Centro Universitário Senac (campus Santo Amaro), 2008.

SOUSA, Cyntia Santos Malaguti de; NEIRA, Luz Garcia; BASTIAN, Winnie. Regulação do ensino do design de moda - para quem? In CONGRESSO BRASILEIRO DE PESQUISA EDESENVOLVIMENTO EM DESIGN, P\&D E DESENVOLVIMENTO EM DESIGN, P\&D Paulo: Universidade Anhembi Morumbi, 2010.
TABELA de Áreas do Conhecimento. Disponível em: <http://www.CNP br/documents/10157/186158/

TabeladeAreasdoConhecimento.pdf $>$. Acesso em: 14 abr. 2017.

TÉCNICA MÉTODO 635. Disponível em: <http://www.innovaforum.com/tecnica/ meto635_e.htm>.Acesso em: 29 mar. 2017.

TREPTOW, Doris. Inventando moda: planejamento de coleção. 5. ed. São Paulo: Edição da Autora, 2013.

\section{TRISKA, Ricardo. Atribuição de Pareceres.}

[Mensagem pessoal]. Mensagem recebida por: <lanerigatto@gmail.com>, em: 20/4/2017.

TRONCOSO, Samira M.; TEIXEIRA, Fábio G. Estado da arte: desenvolvimento de produtos para a moda. In: CONGRESSO BRASILEIRO DE PESQUISA E DESENVOLVIMENTO EM DESIGN, P\&D DESIGN, 10., 2012, São Luís do Maranhão. Anais... São Luís do Maranhão: Universidade Federal do Maranhão, 2012.

VASCONCELOS, Camila B.; BORGIANI, Danielle S. S. Ensino de pesquisa e criação em moda: uma abordagem aplicada. In: COLÓQUIO DE MODA, 12., 2016, João Pessoa. Anais... João Pessoa: Campus do Centro Universitário de João Pessoa (Unipê), 2016.

VELHO, Gilberto. $O$ desafio da Cidade: novas perspectivas da antropologia brasileira. Rio de Janeiro: Campus, 1980.

VICENTINI, Cláudia Regina Garcia. Ferramentas e metodologia de projeto aplicados na criação de produtos para a indústria têxtil-confecção. 157 p. (Tese de Doutorado) - Faculdade de Engenharia Mecânica da Universidade Estadual de Campinas, 2010.

VOLONTÉ, Paolo. Vita da Stilista. II ruolo sociale del fashion designer. Milano: Pearson Paravia Bruno Mondadori S. p. A., 2008. 
WOLFF, Fabiane; KUNZLER, Lizandra; PRATI, Marina; NASCIMENTO, Júlia. Metodologia de projeto em design de moda: perspectivas teóricas e práticas. In CONGRESSO BRASILEIRO DE PESQUISA E DESENVOLVIMENTO EM DESIGN, P\&D DESIGN, 10., 2012, São Luís do Maranhão. Anais... São Luís do Maranhão: Universidade

Federal do Maranhão, 2012.

\section{FONTES DAS ENTREVISTAS}

ARAGÃO, Irina. Entrevista realizada com Irin Aragão, em 21 de outubro de 2015, na cidade do Rio de Janeiro, com 1 hora e 15 minutos de duração.

BERNARDES, Circe. Entrevista realizada com Circe Bernardes, em 22 de janeiro de 2015, na cidade de São Paulo, com 2 horas e 42 minutos de duração.

BONADIO, Maria Cláudia. Entrevista realizada com Maria Cláudia Bonadio, em 17 de novembro de 2015, na cidade de São Paulo, com 1 hora e 21 minutos de duração.

BRAGA, João. Entrevista realizada com João Braga, em 8 de dezembro de 2014, na cidade de São Paulo, com 2 horas e 36 minutos de duração.

CANTON, Andrea. Entrevista realizada com Andrea Canton, em 12 de outubro de 2016, na cidade de São Paulo, com 1 hora e 33 minutos de duração.

CAMARENA, Elaine Soares. Entrevista realizada com Elaine Soares Camarena, em de dezembro de 2014, na cidade de São Paulo, com 52 minutos de duração.

CASTILHO, Kathia. Entrevista realizada com Kathia Castilho, em 15 de dezembro de 2015, n cidade de São Paulo, com 1 hora e 33 minutos de duração

CHRISTO, Deborah. Entrevista realizada com Deborah Christo, em 21 de outubro de 2015 , na cidade do Rio de Janeiro, com 1 hora e 46 minutos de duração.
CIPINIUK, Alberto. Entrevista realizada com Alberto Cipiniuk, em 19 de outubro de 2015, na cidade do Rio de Janeiro, com 1 hora e 43 minutos de duração.

GIBERT, Vera Lígia P. Entrevista realizada com Vera Lígia Pieruccini Gibert, em 25 de Deve 2014, na cidade de São Paulo, com 2 horas e 27 minutos de duração.

GRUMACH, Evelyn. Entrevista realizada com Evelyn Grumach, em 14 de outubro de 2015, na cidade do Rio de Janeiro, com 1 hora e 35 minutos de duração.

GUIMARÃES, Maria Eduarda Araújo. Entrevista realizada com Maria Eduarda Araújo Guimarães, em 9 de outubro de 2015, na cidade de São Paulo, com 1 hora e 50 minutos de duração.

HIGA, Eunice. Entrevista realizada com Eunice Higa, em 5 de julho de 2016, na cidade de São Paulo, com 1 hora e 34 minutos de duração.

TO, Márcio. Entrevista realizada com Márcio to, em 16 de dezembro de 2014, na cidade de São Paulo, com 1 hora e 42 minutos de duração.

KHOURY, Feres. Entrevista realizada com Feres Khoury, em 9 de dezembro de 2015, na cidade São Paulo, com 27 minutos de duração.

MENDES, Francisca Dantas. Entrevista realizada com Francisca Dantas Mendes, em 29 de junho de 2016, na cidade de São Paulo, com 1 hora e 47 minutos de duração.

MERINO, Eugenio Andrés Díaz. Entrevista realizada com Eugenio Andrés Díaz Merino, em 06 de outubro de 2016, na cidade de São Paulo, com 1 hora e 03 minutos de duração.

MESQUITA, Cristiane. Entrevista realizada com Cristiane Mesquita, em 23 de novembro de 2015, na cidade de São Paulo, com 58 minutos de duração.
MINA, Simone. Entrevista realizada com Simone Mina, em 19 de dezembro de 2014, na cidade de São Paulo, com 2 horas e 9 minutos de duração.

MONÇORES, Aline. Entrevista realizada com Aline Monçores, em 15 de outubro de 2015, na cidade do Rio de Janeiro, com 1 hora e 47 minutos de duração.

MOURA, Mônica. Entrevista realizada com Mônica Moura, em 26 de maio de 2015, na cidade de São Paulo, com 1 hora e 42 minutos de duração.

NACHTIGALL, Troy. Entrevista realizada com Troy Nachtigall, em 7 de março de 2016, na cidade de Eindhoven (Holanda), com 50 minutos de duração.

OLIVEIRA, Izabel Maria de. Entrevista realizada com Izabel Maria de Oliveira, em 25 de outubro de 2016, na cidade do Rio de Janeiro, minutos de duração.

OLIVEIRA, Renata Zaganin de. Entrevista realizada com Renata Zaganin de Oliveira, em 28 de novembro de 2014a, na cidade de São Paulo, com 2 horas e 9 minutos de duração.

OLIVEIRA, Renata Zaganin de. Entrevista realizada com Renata Zaganin de Oliveira, em de dezembro de 2014b, na cidade de São Paulo, com 53 minutos de duração.

PRECIOSA, Rosane. Entrevista realizada com Rosane Preciosa, em 10 de março de 2017, nas cidades de São Paulo e Juiz de Fora (via Skype), com 1 hora e 31 minutos de duração.

QUEIROZ, Mario. Entrevista realizada com Mario Queiroz, em 15 de julho de 2016, na cidade de São Paulo, por email.

ROCHA, Mariana M. L. Entrevista realizada com Mariana Machado Lousada Rocha, em 9 de dezembro de 2014, na cidade de São Paulo, com 1 hora e 50 minutos de duração.

SALATA, Robinson. Entrevista realizada com Robinson Salata, em 30 de setembro de 2015, na cidade de São Paulo, com 1 hora e 6 minutos de duração.
SANCHES, Maria Celeste de Fátima. Entrevista realizada com Maria Celeste de Fátima Sanches, m 7 de setembro de 2015 , na cidade de Lond com 1 hora e 13 minutos de duração.

SANTOS, Luiz Henrique Lopes dos. Entrevista realizada com Luiz Henrique Lopes dos Santos, em 23 de novembro de 2016, na cidade de São Paulo, com 22 minutos de duração.

SOUSA, Cyntia S. Malaguti de. Entrevist realizada com Cyntia Santos Malaguti Sousa, em 4 de novembro de 2015a, na cidade de São Paulo, com 51 minutos de duração.

SOUSA, Cyntia S. Malaguti de. Entrevista realizada com Cyntia Santos Malaguti de Sousa, em 25 de novembro de 2015b, na cidade de São Paulo, com 57 minutos de duração.

SOUZA, Patrícia de Mello. Entrevista realizada com Patrícia de Mello Souza, em 8 de setembro de 2015, na cidade de Londrina, com 29 minutos de duração.

STEPHAN, Auresnede Pires. Entrevist realizada com Auresnede Pires Stephan, em 19 de novembro de 2014, na cidade de São Paulo, com 2 horas e 32 minutos de duração.

SUDSILOWSKY, Sérgio. Entrevista realizada com Sérgio Sudsilowsky, em 20 de outubro de 2015, na cidade do Rio de Janeiro, com 44 minutos de duração.

ARALLI, Cibele H. Entrevista realizada com Cibele Haddad Taralli, em 2 de dezembro de 2015, na cidade de São Paulo, com 55 minutos de duração.

TRISKA, Ricardo. Entrevista realizada com Ricardo Triska, em 29 de novembro de 2016, na cidade de São Paulo, com 32 minutos de duração.

VICENTINI, Cláudia Regina Garcia. Entrevista realizada com Cláudia Regina Garcia Vicentini, em 31 de março de 2016, na cidade de São Paulo, com $1 \mathrm{~h}$. 
Anexos 


\section{Anexo A}

$C D$ com as entrevistas 


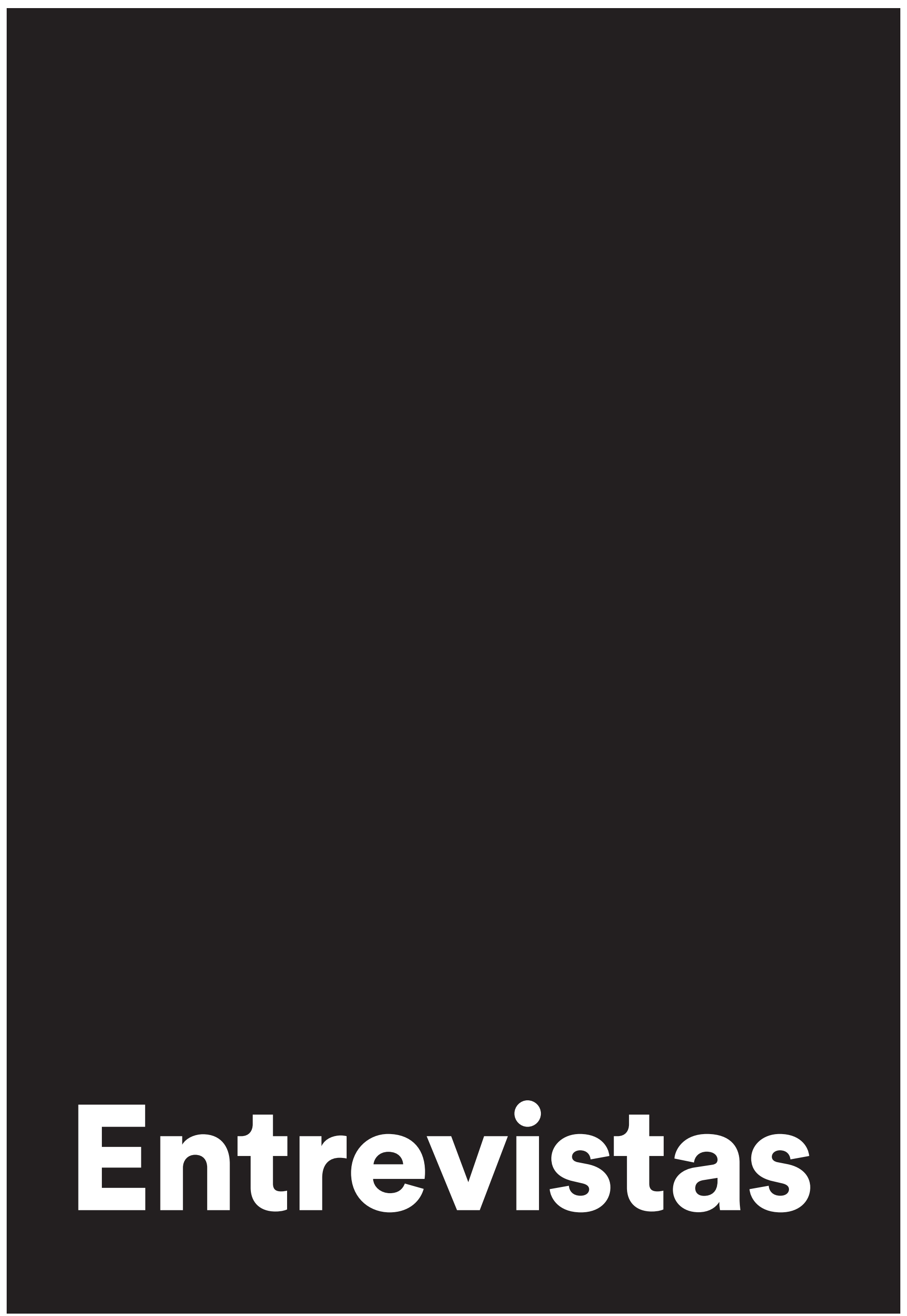


STEPHAN, Auresnede Pires. Entrevista realizada com Auresnede Pires Stephan, em 19 de novembro de 2014, na cidade de São Paulo, com 2 horas e 32 minutos de duração.

Leilane: Então hoje é dia 19 de novembro, e a gente vai começar a entrevista sobre o projeto moda, (não consegui entender).

Eddy, eu queria que você falasse um pouco, por favor, sobre o conceito de projeto em moda. A gente que... você é formado em design, e há várias vertentes sobre o surgimento da moda, e eu queria que você me dissesse 0 que caracteriza inicialmente o projeto em design.

Eddy: Projeto em design, do curso de design. O hábito de projetar é um desafio, na verdade. São desafios para resolver problemas. São vários niveis e vários universos, necessidades, eu acho que quando você fala em design tem que colocar como centro de atenção o homem. Você projeta para o homem, o homem nas mais diversificadas condições que você pode pensar: no trabalho, no lazer, enfim, todos os ambientes são passíveis de termos um projeto, e tendo como centro o homem. E o projetar é um processo, é um processo contínuo. Quando você pensou que terminou o projeto, está começando já um novo projeto. E quando você resolve um problema sabe que vão surgir outros problemas. E aquele que você muitas vezes, é... É o campo da incerteza. Não existem certezas. Existem caminhos, alternativas. Muitas vezes o mesmo problema pode ser observado, pode ser avaliado sob várias óticas. Então o projeto, digamos, é um terreno movediço. Pensar em um projeto em uma região como São Paulo é uma coisa, se pensar em Paris são outras, então o projeto envolve a questão de cultura. Que cultura é essa, que tecnologia, que meio ambiente é esse, que geografia é essa? Claro que eu tenho que avaliar, digamos, em vários níveis, não é? Os projetos locais, os projetos regionais, os projetos, digamos, de um determinado país e os projetos globalizados, então em um projeto é preciso entender essa amplitude que ele tem, ou as restrições. Então falar sobre projeto é um grande desafio, mas eu consideraria um processo onde o centro de atenção é o homem. E apesar dessa multiplicidade hoje, tecnologias, design social, no fundo é sempre uma coisa, é uma essência, é o design em si. É colocar o design no centro de um projeto, digamos, dentro de um significado, então vai envolver o homem, vai envolver as tecnologias existentes, o envolvimento econômico, interesses, digamos, em relação a isso. Então pra mim, digamos, o projeto é esse todo, e essa a capacidade de ter uma visão ampla e restrita das coisas, e questionar tudo isso. $O$ designer é um eterno questionador, o projeto tem um caráter de inquietude, as pessoas inquietas $e$ as pessoas curiosas, e acho que isso na verdade é o designer. A inquietude é entender o homem e entender esses artefatos ou serviços desses sistemas que o cercam. Então esse projeto tem, digamos, uma amplitude muito grande, projetar essa amálgama, não é, entre homem, ambiente, contextos, Faculdade Santa Marcelina 
equipes, não é, porque ninguém mais hoje trabalha sozinho. São trabalhos interdisciplinares, eu não posso fazer um projeto, toda a complexidade dele, sem ter ao meu lado, digamos, ao segmento digital, à engenharia, ao antropólogo, essa ideia do gênio, do "deusigner", podemos eliminar. Ele tem a sua capacidade, tem a sua percepção, a sua sensibilidade, mas entre outras coisas a capacidade de desenvolver a proposta em conjunto. Os vários projetos, grande parte deles, sempre numa equipe. Eu faço parte de uma equipe. Quem sabe, muitas vezes, pela experiência vivida, pode até certo ponto estabelecer alguns parâmetros, mas efetivamente é um conjunto de esforços. A não ser que seja um projeto muito especial, muito particular, são casos especiais. Noventa por cento, é... Um designer só existe se ele estiver ligado a um - eu digo designer, pensando em indústria, no processo - tem que ter um parceria com uma pessoa que é empresária, que é empreendedora. Então nesse momento você pode fazer um belíssimo projeto, mas se não tiver alguém com tanta ideia, porque essa pessoa, digamos, acredita naquilo, quem é você? Você não é nada. Na hora que você for comercializar isso. Tem que entender que alguém vai comercializar, porque sozinho, não sei se ele, digamos, entre aspas, tem o seu ateliê e tal, mas ele vai precisar de um fornecedor da matéria-prima pra fazer alguma coisa. Existe sim uma capacidade, mas é um trabalho, efetivamente, sempre, duplo, em trio, em contextos, não é?

Leilane: Você acha então que liderar é dar autonomia pra quem está trabalhando com você, pra desenvolver cada função?

Eddy: Claro, ou seja, você estabelecer, digamos, os limites e as cercanias de cada um deles, e nisso você estabelece esse agrupamento de pessoas.

Leilane: Gerenciamento de conflitos...

Eddy: Então, isso que podemos considerar como sendo a gestão de pessoas.

Leilane: A parte mais difícil (risos)

Eddy: Comprar um computador, comprar os programas e alugar uma sala, claro, é um investimento, mas, contratar gente, e saber que gente é essa, as potencialidades de cada um, a seriedade de cada um, e outra coisa também, a humildade de cada um, de entender quais são os seus limites, quem é quem nessa estrutura toda? Não digo todos, mas grande parte dos designers, muitas vezes, eles se sentem, assim, um pouco donos de certas verdades, então um pouquinho de cuidado com isso. Então o problema do design é gente. Um que tenha habilidade em desenhar, em fazer modelos, tal, mas antes de tudo isso tem que entender o que eu quero, ou seja, existe um lado que é a materialização. Não é uma imagem, a imagem está lá, mas antes disso tem um certo, ou seja, a gramática, digamos assim, como é que eu construo o meu pensamento, depois que eu materializo as coisas, aí eu desenho bem como um suporte o desenhar, eu digo é um suporte do dissenhar (acho que é isso, Leilane), dissenhar é uma prospecção muito maior, de reflexões e de eternas dúvidas, quem tem certeza já está morto, porque a dúvida permanece o tempo todo, quando estiver pronto, sendo industrializado em micro, pequena, média ou grande escala, continuam as dúvidas.
Leilane: É isso que fomenta o trabalho em grupo, se você tivesse certeza faria sozinho.

Eddy: Exatamente.

Leilane: Você compra o computador, aluga a sala e faz. Deixa eu te perguntar uma coisa: você dá aula na Santa Marcelina, que é um curso de moda. Antes de tudo eu gostaria de te perguntar se você já trabalhou como professor, com design, com moda anteriormente, em outros projetos, e assim: eu entendo até agora historicamente que a origem da moda, do design de moda, isso também é uma discussão a se ter, é como um curso superior, como instrução de projeto no nível acadêmico, ela surge da arte ou do design? Eu queria saber se pra você a moda surgiu da arte, do design ou de alguma terceira essência?

Eddy: Eu creio que a vertente maior, digamos, essa pergunta, é no sentido de Brasil?

Leilane: Brasil. Claro que a gente não pode esquecer que somos influenciados pelos italianos, franceses, japoneses..

Eddy: Digamos que tem vários níveis, pensando no livro do João Prata, entre outros livros, da história da moda, você vai encontrar, digamos, de um lado, pessoas habilidosas, o Brasil dos croquis, esses estilistas que mostravam através do desenho como seria o desenhar uma roupa. Do outro lado você tem os atrações, os alfaiates, aquelas pessoas que trabalhavam nas oficinas, então essas pessoas também têm uma importância muito grande. Eu diria assim: são essas duas vertentes: um lado essas pessoas que têm habilidade no desenho e de outro lado as pessoas que trabalharam como mestres nas oficinas, nas costureiras, modelistas... Então elas vêm desse aspecto do artístico (foi o que entendi, Leilane). E o design, de uma forma ampla, o design, de uma maneira ou de outra, está embutido nisso. Porque se eu for fazer a roupa pra alguém, existe esse alguém. Existe um dimensionamento, de um lado antropométrico. Não tinha, não sei, na década de 20 , 30, essa tecnologia (ou terminologia), mas no fundo, até certo ponto, estava embutido, seriam os designers intuitivos, pessoas que não tiveram formação acadêmica, mas que no dia a dia resolviam, autodidatas, e muitas vezes, adivinhos (acho que foi isso) dessas oficinas, desses ambientes de trabalho do dia a dia. Eu vejo assim.

Leilane: Agora assim: existe uma história que o design surge a pedido das indústrias, o design de moda, como curso superior, ele vai surgir como curso superior a partir de uma demanda feita da indústria, pela indústria, para os cursos de design, que já existiam desde 1963, desde o surgimento do curso de design. $O$ que vai acontecer na década de 70, a partir dos cursos livres, depois na década de 80 , que demanda de maneira aprofundada, um projeto em moda. Principalmente quem faz esse pedido é a Rhodia, e a gente sabe que a Rhodia tem uma ligação muito grande com as principais faculdades de São Paulo, especialmente com a Santa, e eu queria entender uma coisa, se isso pra você é esquizofrênico, porque o que eu entendi é que se fala muito do Dener, do Marquito, e o Dener tem esse lado artista, que desenha, 
não é? E você tem aí o ato projetivo, e aí de repente você está colocando a prática associada ao design, mas precisa saber também que o design tem esse processo criativo e artístico. Eu queria entender de você se isso não é um conflito, porque, por exemplo, você é formado na Faap, em desenho industrial, das primeiras turmas.

Eddy: Primeira turma.

Leilane: $\mathrm{E}$ num momento em que o racionalismo era uma vertente bastante forte, bastante crítica, reflexiva... E, não, eu não tenho problema com o racionalismo, risos, eu acho OK.

Eddy: Sabe que isso é muito interessante. Eu fazia desenho industrial na Faap de manhã, e à noite eu fazia ESPM, e grande parte dos professores que ministravam aula na Faap (ruídos atrapalharam o entendimento da fala dele) E aí diziam: que história é essa? Você vem aqui de manhã brincando, não é? Quer dizer então que você de manhã vem aqui fazer o desenho industrial, e à noite vai se prostituir então, vai para as bocas, fazer o quê lá? Aí, eu nunca me esqueço, eu inventei na ESPM (ruídos), só existia a ESPM, não tinha mais nada, e era um curso de dois anos, não é, que tentava atender os profissionais. E eu era um peixe fora d'água. Eu era um estudante, e eles aceitavam, na classe toda, eram uns senhores, e pessoas que atuavam no meio publicitário. Eu nunca me esqueço, eu ingressei, tal, e tive a primeira aula. Na primeira aula não me lembro quem deu a palestra, tudo era venda, tudo era negócio, e tinha um senhor do meu lado, ele virou pra mim e falou: "Eu vou embora porque este não é o meu ambiente". Eu não vim aqui pra aprender a enganar as pessoas. $E$ eu nunca mais o vi. Porque eram estratégias, os planejamentos, e tem as mídias, então vocês vão ter essa visão exatamente pra poder alavancar as vendas, não é, a publicidade, e eu tenho que aprender isso.

Leilane: $E$ como você ficava em relação ao seu curso de design de moda (sic)? Você não ouviu que queria ser artista também na ESPM?

Eddy: Na verdade eu fazia o meu curso de cinema, eu fazia os três, então pra mim eu queria, assim, quem sabe, pode ser um aspecto ingênuo e bobinho de um lado, mas do outro estou aprendendo coisas. Trabalhei cinco anos na revista Supermercado Moderno, uma revista especializada no setor. Eu fiz de tudo lá, conheço de cabo a rabo, mas um dia eu falei assim: meu Deus, não é isso. Foi bom? Claro que foi bom, mas uma dia eu parei e disse... não, agora eu sou a gerência, a (não entendi), uma americana, uma expertise no assunto, o pai dela foi um dos precursores dos supermercados nos Estados Unidos. Ela fez Harvard, nossa, aprendi muito, mas um dia eu falei: precisamos resolver um assunto muito importante, gostaríamos de tê-lo n nossa equipe e contratá-lo, porque eu era freelancer, eu nunca fiquei preso. E nós precisamos pensar agora... meu Deus do céu, eu falei: continuamos amigos, posso fazer uns trabalhos de casa.

Leilane: Com toda a bagagem que você tinha, não é?

Eddy: Eu tinha toda a experiência, mas foi muito bom, porque eu administrava aula, eu atendia meus clientes, e era mais um cliente, eu ia lá, tinha um espaço reservado pra trabalhar lá, mas eu fazia coisas em casa, ela queria que o espaço fosse ocupado por alguém que ficasse lá full time. Como foi caso do jornalista, que era o editor, escrevia e tudo mais, ele está vivo ainda, mas ele vivia lá 48 horas por dia, ou seja, eu falei: eu, hein. E depois começou a surgir a oportunidade da Belas Artes, de Guarulhos, eu tinha alguns atendimentos, não tinha dúvida, eu não sou muito amigo deles, mas eu acho que o que eu tinha que aprender eu já tinha aprendido. O que aprendi foi $o$ seguinte: a máquina registradora tem que tilintar. A essência da revista era, digamos, a rotatividade. Tinha que ganhar dois centavos em cada rolo (acho que foi isso), somando vai dar uns milhões, a conversa sempre era essa. No primeiro ano, ah, que legal, no segundo ano, hum... que bacana, no terceiro ano, ah, é bom, o mecanismo é esse. Quarto ano... é interessante. Quinto ano... você sabe muito bem como funcionam as revistas, não é? Carnava em novembro, o dia das mães é em fevereiro, aquele processo, o meu calendário continua o mesmo, eu tenho sempre que pensar com antecedência, tudo no desespero, tem que fechar a revista... Valeu? Valeu muito. Mas ao mesmo tempo foi um tempo que passou, uma experiência, vou pro Belas Artes ser coordenador... Se eu fosse montar uma espécie de estrutura da minha vida, os ciclos que eu tive, como estudante, em 1969 até 1978, eram prêmios e mais prêmios, e depois eu inverti, hoje eu coordeno os prêmios e concursos, que também é outro lado da história, digamos, do jovem, depois teve um período que fiz um tipo de consultoria mais técnica de alguns setores, então eu tenho várias nuances nesse processo todo. Teve um júri que eu participei em 1972, o primeiro que comecei, na revista Transportes Modernos, e pelo qual eu fiz parte até com (ele cita nomes que não entendi.. Marquino?), Roberto Araújo, todos falecidos.

\section{Leilane: Você era jovem também, não é?}

Eddy: Ah, sim, eu era um menininho perto deles, mas é interessante que cada momento de vida foi muito especial. Mas voltando ao diferencial, da questão do ensino, eu diria que, não sei se as empresas estavam procurando designers, porque eu tinha um pouco de dúvida sobre isso...

Leilane: Por causa de moda, especificamente?

Eddy: É, eu acho que ninguém nunca entendeu muito isso. Mas, quem sabe, eu vou colocar agora pra você, isso vai interessante. O Carlos Mauro Fonseca Rosa foi meu colega na Faap.

Leilane: Ah, é? De sala?

Eddy: É, eu estudava de manhã, estudava à noite e a gente se encontrava...

Leilane: Porque ele foi coordenador na Rhodia, não é?

Eddy: Foi, e ele trabalhava como um dos responsáveis pela coordenação de tendências da Rhodia. Como é que ele chega na Rhodia? Ele chega através de um convite que foi feito pelo Nelson Alvim e Fábio Alvim, que faziam vitrines para a Rhodia. E, com isso, naturalmente, eles eram pessoas, e o falecido Fábio Alvim e o Nelson Alvim também eram amigos nossos da Faap. Eles estudavam na mesma classe. E nesse período o Carlos Mauro 
desenhava muito bem, tanto que ele ganhou a bolsa pra fazer a faculdade, pois não tinha condições, então ele ganhou uma bolsa de estudos através do prêmio Álvares Penteados (não entendi tudo), que hoje é o salão de artes plásticas, que faz parte do "pibinho", do orçamento da Álvares Penteado, todo ano tem que ter esse evento anual, é consignado ao testamento dele, de incentivo às artes, do qual eu ganhei prêmio também, como estudante, $e$ me ajudou muito para terminar a faculdade.

Leilane: Mas não era só de artes plásticas? Participavam outros alunos, porque era misto...

Eddy: No ano que eu estudava eles aceitavam, depois que passou a ser voltado para artes plásticas. Era artes plásticas, depois entrou o curso de desenho industrial...

Leilane: Você pôde experimentar bastante, não é?

Eddy: Ah...

Leilane: Você teve uma vontade, não é?

Eddy: Ah, graças a Deus... E aí, o que acontece? O Fábio Alvim e o Nelson Alvim, eles tinha, digamos, trabalho, porque eles faziam objetos e tudo mais, e isso ia pra muitas vitrines. De outro lado, você tinha o quê, tinha o Donato Ferrari, o Nicolas (?) trabalhava pra Rhodia, porque a Rhodia investia muito nisso, investia nos artistas, tanto é que a Fenit era um mundo à parte. Se você for verificar, a Rhodia comandava um pavilhão, funcionava aqui no Parque do Ibiraquera, foi pra lá e depois morreu devido a essas mudanças todas. Ela se perdeu no tempo e no espaço. Então você tinha Donato, esses artistas, o Fábio, Nelson e outras pessoas trabalhando junto com a Rhodia, e nisso, e nesse período o Carlos Mauro trabalhava como secretário da faculdade de economia da USP, que era na Rua Doutor Villa Nova, pra sobreviver, trabalhava lá o dia inteiro como secretário junto ao Roberto Pinto de Souza, que era tesoureiro da Faap. Ele trabalhava lá e estudava à noite. E com a bolsa que conquistou através do trabalho dele no curso livre, porque existiam uns cursos livres na Faap, que são os cursos de desdobramento dos cursos...

Leilane: Foi na década de 1990, mais ou menos?

Eddy: Não, isso é 1970...

Leilane: Mas os cursos livres foram extintos?

Eddy: Noventa, pra depois ter essa reformulação, porque hoje tem vários cursos. Passou por uma fase de reestruturação, as mudanças da Faap. Então o que acontece? Com essa e com outras, tem uma oportunidade lá na Rhodia, aí o Carlos falou: "acho que vou fazer". Ele tinha uma insegurança muito grande, aparentava uma segurança, publicamente, muito grande, essas coisas de "sou diretor-presidente", mas atrás...

Mas aí tinha uma colega nossa, a Silva, ela falava assim: "Não, Carlos, você tem talento, tem condições, faz moda". E o Carlos Mauro nunca fez moda, ele nunca desenhou roupa, ele tinha conhecimento de francês, moda francesa, e aí ele estabelece essas conexões junto à Mari Ruqui (é isso?), que ela vinha pra cá, dar uns cursos... Então com essas e outras ele se formou em comunicação visual, mas mesmo comunicação visual ele nunca fez. Ele era um secretário da faculdade de economia da USP, e gostava de desenhar, coisa e tal, era uma pessoa que tinha cultura. E ali dentro da Rhodia ele nunca desenhou coleção nenhuma.

Leilane: Mas depois ele vai pra Santa (é isso?), não é? 26:00

Eddy: Ele vai. Aí o que acontece, ele está nesse processo, ou seja, o Carlos Mauro passa a ser uma referência, uma referência na Rhodia. E quando você trabalha em uma empresa, eu trabalho em tal empresa, então você queira ou não dá um status. E ele tinha essa sensibilidades, suas neuroses, mas uma pessoa que agilizava isso. Então ele ficava o dia inteiro na casa da Avenida Brasil atendendo as pessoas, as empresas, mas "olha, contratamos um designer". Nada disso. Ele estava ali dentro trabalhando naquilo que seria, digamos, trazendo essas novidades, ou ele vai aprender, com viagem pra França, em cursos. Não aprendeu isso na Faap.

Leilane: E com a Marie Rucki, não é? 27:01

Eddy: Sim, com a Marie. Então ele está lá, então nesse período eu estou no Santa Marcelina...

Leilane: Quando você entrou na Santa Marcelina, Eddy?

Eddy: 1975.

Leilane: Então você dava aula no curso de desenho e plástica, não é?

Eddy: Exatamente, eu fui pra lá no ano de 1974, estava na secretaria da Faap, quando o menino que era o secretário falou assim: "tem um bilhetinho aqui, eu mostrei pra vários professores e ninguém se interessou, o professor $X$, tal, ele não pode ministrar aula à tarde, é de serigrafia, o que você acha?" E eu disse: "Ah, dá o nome aí". Aí lá fui eu, no mês de janeiro.

Leilane: Vocé já sabia serigrafia?

Eddy: Eu não aprendi na faculdade porque eu não tinha aula disso, eu aprendi com o Mario Ishikawa, que foi aluno da Faap e era professor, então eu fui no ateliê dele pra aprender. Mas como eu trabalhava com o Mauricio Pereira Lima (acho que é isso 28:17), tem obras dele (não entendi 28:24), ele dizia: Eddy, aqui vai ser tal cor, então eu ficava pintando pra ele, ele só assinava embaixo, natural. A gente fazia isso, então uma profissão em vários níveis, com essas o com outras, o que acontece? Eu vou pro Santa Marcelina em 1974, em 1975 eu já, agora vai fazer 40 anos que estou lá, não é. Então eu chego lá na porta, não era esse prédio que tem hoje, era uma casa, atrás daquele construção que hoje é o colégio.

Leilane: Na Cardoso ali, não é?

Eddy: Na Cardoso. Esse prédio também não existia. Então eu cheguei naquela porta principal do prédio mais antigo, da Itapicuru, eu nunca me esqueço. Eu bati na porta e na hora e aí a irmãzinha abriu: "Quem é o senhor?". E eu disse: "Eu soube através de um secretário..." "Ah, pois espere 
um pouquinho só, vou procurar a irmã Maria da Glória"

Leilane: E nessa época eram elas que administravam, não é?

Eddy: Tudo. Estavam no mesmo terreno onde funcionava o colégio, a faculdade de música e a de artes. E ali onde hoje é o espaço recreativo tinha uma casinha pequenininha, uma condição de uma oficina, daquelas assim... não tinha nada praticamente. Aí ela pergunta: “O senhor é católico?" E eu: "Ah sim", e ela: "Ah, que bom, o senhor é casado?", "Sim, sou casado", e ela disse: "Ah, estamos precisando de alguém pra poder colaborar, porque é muito importante pra nós...", e aí eu fui conhecendo o pessoal, e entra as pessoas eu conheci a Vera Ligia, porque a Vera Ligia se formou no Santa Marcelina, e quando a conhecia, nossa, foi amor à primeira vista, e ela já conhecia a minha esposa, foi aluna dela, então já tinha, digamos...

Leilane: Uma empatia..

Eddy: Ah, e a Vera é muito especial pela firmeza que ela tem... você não conhece, não é?

Leilane: Só falei com ela ao telefone.

Eddy: Você vai adorar, que simpatia, que educação, que fineza. E aí tinha a Lina Valle (acho que é isso 31:19), a gente acabou se enturmando, porque eu era bem novinho, na verdade, e eles eram pessoas que estavam lá já há um bom tempo. E no decorrer desse processo eu entrei em 1975 e em 1980 um bom tempo. E no decorrer desse processo eu entrei em 1975 e em 1980
eu assumi os cursos livres, comecei a coordenar os cursos que livres que envolviam música, artes plásticas e, de repente, um pouco do design. E muitos alunos que faziam o curso de educação artística, de desenho e plástica, que tinham uma disciplina com a Vera Ligia... a minha esposa foi estudar lá porque a Vera Ligia desenvolvia partes em têxtil.

Leilane: Ela dava aula de desenho de moda...

Eddy: É, e isso acontecia dentro do curso de educação artística, de desenho e plástica. Bom, com essas e com outras, eu via muitas pessoas interessadas em querer fazer desenho têxtil. Eram alunos da Faap, de lá, de cá, tudo mais... "Ah, Vera... vamos abrir um curso de desenho têxtil?" E o curso encheu de gente. A procura era muito grande. Então diria assim, ali estava, e o desenho têxtil, naquele período, régua, lápis, caneta e ecoline (32:44).

Leilane: Era calcular tudo com régua...

Eddy: Exatamente. E os cursos que a gente implantou ali começaram a ter uma procura muito grande, sabe. Naquele período não existiam nas faculdades, ilustração, sketch, não existia isso.

Leilane: Nem nas de publicidade?

Eddy: Mas aí é mais um marcador, também, teria, eu diria, uma ligação. Era mais pra marcar layout, coisa e tal. Ali não, era pra desenhar produto. Então eu me sinto muito feliz porque esses cursos tiveram uma procura tăo grande...

Leilane: Isso foi em 1975?
Eddy: Não, isso já é década de 1980.

Leilane: $\mathrm{E}$ isso foi até que época?

Eddy: Até acho que 1985, que foi até quando eu fiquei à frente disso. E o curso de aquarela da (não entendi. Ioli? 33:50), que daí nasceu o núcleo de aquarelistas, que a loli é responsável.

Leilane: Eu acho que é 1987, que surgiu o Cebraphan, que depois vai dar origem ao curso da Anhembi Morumbi. Eu só queria pontuar uma coisa, desculpa te interromper. Eu queria também entender da sua fala, por exemplo, você foi coordenador da Belas Artes, que futuramente vai..

Eddy: Belas Artes eu entrei em 1985.

Leilane: Isso, depois vai contar com a Patricia Fonseca, que vai ser coordenadora do curso de moda, você esteve na Santa Marcelina, você esteve na Faap que hoje tem o curso de moda, e aí tem umas questões ao longo disso que, assim, pra cursos como a Faap e Anhembi Morumbi é muito mais fácil assumir historicamente essa postura do design ligado à moda, da moda ligado ao design ou até a moda como design de moda, como o fruto evidente do design. Mas a Santa, como você falou, ah, de vez em quando eu até dava aula, eventualmente dava aula de alguma coisa de design, mas tradicionalmente ela não tem o curso de design. Então ela se apoia nesse discurso de artes e eu li a tese (35:00) da Ligia, mas muitas vezes eu percebo uma fala de design, de forma e função, de preceitos previstos pelo Bruno Munari pra comunicação visual, pelo Löbach (35:06) pra produto, e eu queria entender um pouco a sua relação, se não aconteceu uma esquizofrenia, porque você é de design e está lá no meio da moda, uma moda que veio da arte, então o seu ambiente mais próximo era esse, e até que ponto isso não causava estranhamento..

Eddy: 35:27 Carlos Mauro, digamos, é ou não é, reuniões que, assim, ia conversar com a Vera Ligia..

Leilane: Você sabe que até hoje a moda não é um campo do saber, autônomo, pra Capes, Fapesp...

Eddy: Mas eu preciso contar pra você como que, digamos, o curso de moda foi implantado..

Leilane: E, desculpa, depois eu queria entender de você, assim, se você tiver que dar uma posição, se você puder, se é moda-design ou moda-arte. Te comprometendo, risos.

Eddy: Eu, nesse período, ou seja, entrei na Santa Marcelina em 1975, administrava aula de oficina... Existia um curso chamado assim: bacharelado em desenho, era esse o nome.

Leilane: Não era o desenho plástico?

Eddy: Não, não.

Leilane: Era outro curso? 
Eddy: É. E por que será que não tem alunos nesse curso?

Leilane: $\mathrm{E}$ o de desenho plástico tinha bastante procura?

Eddy: Não, uns 15, oito, 12 alunos. Nós tínhamos todos os cursos de desenho, porque cada noite o aluno tinha aula de desenho, de projeto mecânico, aula de desenho têxtil, aula de embalagem, tudo desenho. E história, desenho geométrico.

\section{Leilane: Projeção ortogonal...}

Eddy: Tudo isso.

Leilane: Perspectiva...

Eddy: $\mathrm{E}$ à noite tinha aula de desenho de história em quadrinhos, o cara gostava de história em quadrinhos, e deitava e rolava... Então esse curso ficava nesse limbo (37:18), vai ou não vai, e eu ministrava uma aula dentro desse curso que era de embalagem, mas esse curso não caminhava, e tro desse curso que era de embalagem, mas esse curso não caminhava, e
aí foram surgindo problemas (não entendi 37:14) desenho arquitetônico. Aí a menina, excelente, sabia que eu desenhava muito bem, estava fazendo um estágio num escritório de arquitetura. Terminou o curso, pela capacidade dela, o desempenho dela, então resolveram contratar. Aí chegou lá, na hora de contratar, perguntaram: você é técnico em edificação? Não. Você é arquiteta? Não. Você é engenheira civil? Não. O que você é? Esse curso não tem validade. Não tem categoria pra isso. Então você vai ser contratada como desenhista técnica arquitetônica, esse nível superior não vai existir. Então era um curso que remava em uma situação muito difícil, então a irmã disse: ah, mas esse curso tem tudo. E de fato tinha tudo, era um espectro muito grande, e de uma maneira ou de outra nesse eu curso incomodava um pouquinho com o design, eu falava um pouco de design.

Leilane: Embalagem, não é?

Eddy: É, alguma coisa que digamos, mesclava um pouco isso. Era muito difícil também mas ia caminhando. Bom, com essas e com outras, nesse período eu estava ministrando aula na Faap, no Santa Marcelina, já estava começando na Belas Artes como professor e já estava há nove anos em Guarulhos, na UnG. E o que aconteceu? Nada mais, nada menos, ocorreu um fato que me despertou, alguma coisa eu sentia, e o próprio João Braga já colocou isso como livro também, como documento, fica pra você também como uma referência. A menina estava se formando em comunicação visual, que hoje é essa terminologia da época, 1985, 1986, aqui na Belas Artes. Quero fazer um desfile. Quero roupa, quero roupa. Ai, meu Deus do céu.

Leilane: Quem era, você lembra o nome, Eddy?

Eddy: Ah, não... E por que você vai fazer isso, não entende nada de modelar... "Ah, mas a minha mãe modela", aí quis porque quis e desaparece da faculdade. No sentido metafórico. Fez na casa dela, e tudo mais. "Aí eu preciso de luz pra fazer o desfile..."

Leilane: Não tinha uma oficina pra produzir projeto, produto de vestuário..
Eddy: Imagina... e aquilo foi uma cafonice total, analisando... mas pra ela ( visual está comunicando visualmente, a minha tia era modeladora, a minha mãe, fez umas roupas lá e quis fazer um desfile.

Leilane: Tinha estampa?

Eddy: Não...

Leilane: Estampa não pode comunicação visual?

Eddy: Calma, vamos chegar lá. Engraçado, ela veio fazer comunicação visual e tem interesse por isso. Fiquei matutando.

Leilane: Isso foi em 1986, certo?

Eddy: Sim. Em Guarulhos eu acompanhava o trabalho de graduação. Aí apareceu a Selma, você vai poder entrevistar. Muito boazinha, simpática, e ela: "ah, mas no meu trabalho final eu quero fazer design de estamparia, desenho de estamparia". E agora, o que eu faço com essa menina, porque ela nunca fez nada disso..

Leilane: Risos, começou a aparecer gente que queria fazer produto de design têxtil, design de moda...

Eddy: E aí, claro que, naquele momento, como eu já tinha um relacionamento muito bom com várias pessoas, então ela foi, tinha amizade com a gerente da TVB (41:53), vai lá, fala com ela. Foi lá, eles gostaram do trabalho dela de graduação e ela foi contratada pela TVB.

Leilane: Qual o nome dela?

Eddy: Selma, mas depois eu vejo pra você, tem um desdobramento nessa história toda, ela está atuando neste setor. Então, engraçado, aqui em Guarulhos também apareceu uma menina que faz comunicação visual e que está interessada no desenho têxtil. Bom, aí vem a outra. Aí vem a Faap. E que o pessoal não queria de jeito nenhum, não estavam aceitando. A menina queria desenvolver uma linha de uniformes.

Leilane: Pra ficar dentro da ética racionalista, não é?

Eddy: E eu assisti a apresentação dela, e isso não é moda, não existe, tal, mas era um trabalho centrado nisso, era um trabalho centrado em alguma coisa que tinha confecção. $E$ ela fez um trabalho interessante, me lembro que (não entendi 43:00).

\section{Leilane: Foi aprovada?}

Eddy: Foi aprovada, o trabalho era interessante, utilizou uma série de mecanismos baseados no conceito de design. E vi que essas pessoas estavam interessadas em design, mas estavam interessadas no design de moda. E nesse momento a Vera Ligia ministrava uma disciplina no curso de desenho, de têxtil, e ministrava esse curso livre, que tinha uma procura muito grande. Naquela entrada do Santa Marcelina, lá vou eu, né, risos, falei para a Vera para a Irmã Ângela Rizero (43:49), que é uma figura muito importante, hoje 
ela está atuando só no colégio, não pode passar de 75 anos, ela chegou até 80 anos dirigindo a escola. Aí disse: Irmã Ângela Rizero, está acontecendo isso nessas faculdades, por que não abre aqui um curso de moda? Porque naquele momento eu sei que a filosofia francesa, era um curso que existia, estavam querendo implantar em São Paulo, e todo esse know-how acabou indo pro Senac. Eu não lembro do nome, e esse curso acabou não deslanchando. Era na Frei Caneca...

Leilane: Era um curso livre, ainda não era graduação?

Eddy: É, e a Faap já fazia alguns cursos livres também, foi a sequência, até chegar o sequencial e agora depois o bacharelado. Então ali perto de onde é a cantina eu encontrei as duas... por que não abrem um curso de desenho? E a Vera: "ah, não sei, será que vai, não vai, não sei, acho interessante". E eu disse: "ah, acho que tem condições sim". (45:13, um ruído). Ah, vamos pensar nisso sim, e aí foi a nossa corrida contra o tempo, ou seja: onde vai buscar currículo, XYZ, e aí o que acontece? Nada mais, nada menos a Vera fala: "nossa, mas e o Carlos Mauro?", que já era nosso conhecido e meu colega, não é, podia conversar com ele em relação à Rhodia, já que ele está colaborando no curso livre de desenho têxtil, então quem sabe ele é a pessoa que a gente pode conversar sobre isso. E aí começa a se estruturar o processo todo.

Leilane: Mas deixa eu só entender: os cabeças do curso foram a Irmã Ângela Rizero deu abertura pra você, a Vera Ligia junto com o Carlos Mauro?

Eddy: Não, o Carlos Mauro vem depois...

Leilane: Mas foi você, a Vera Ligia que...

Eddy: Sim, nós três que até sonhamos...

Leilane: Que legal.

Eddy: E eu não entendia nada de moda, o que eu entendia assim é que existia uma possível demanda, no final do curso que as pessoas desviavam pra esse segmento. E eu vi também que pessoas que fizeram psicologia também queriam atuar em moda.

Leilane: A Cristiane Mesquita, da Anhembi Morumbi, que me deu aula, é graduada, mestre e doutora em psicologia na PUC.

Eddy: Começa de uma forma, digamos, meio destrambelhada...

Leilane: Mas qualquer área, o design também, você não tinha designers formados... eram como artistas, não é?

Eddy: Claro, se for contar a minha história (47:10), foram quatro anos sensacionais, que eu entrei num lugar que não sabia onde tinha entrado.

Leilane: Uma profusão, nao é...

Eddy: Ah, muito complexo. E no segundo ano, 1968, ai foram quatro meses de greve, sem aula...

Leilane: Foi o ano que nunca acabou.
Eddy: $O$ ano que mais aprendi. As comissões paritárias, um professor e um aluno, um professor e um aluno nas reuniões, risos, então quando você começa a ver a fraqueza dos professores é evidente, não é. "Precisa arrumar gente pra administrar aula", uma história muito empolgante pra quem viveu como eu vivi, de 1967 a 1970. Então o que foi que aconteceu? O curso então precisa se estruturar, então a gente foi buscar informações e arranjar gente pra dar aula no curso de moda. Mas nesse momento aconteceu um dado muito interessante: estava acontecendo a mudança da estrutura curricular do desenho industrial. E ele saía do desenho industrial e comunicação visual pra ser programação visual e desenho industrial.

Leilane: O PPDV, em 88, não é? (48:34)

Eddy: O que aconteceu? Estava sendo aprovado. Vera, vamos pegar isso aqui de desenho industrial, era história do desenho industrial. Isso era moda. Tecnologia, materiais, mecânica, tecnologia têxtil. Então a gente foi fazendo um acoxambramento de pegar aquela estrutura e ver o que servia. Materiais têxteis, e no fundo, certo, as coisas, plástica, desenho, antigamente era a base, mas não se sabia muito bem o que ia conter tudo aquilo, mas depois haverão, normalmente, transformações. Então aquele curso de bacharelado em desenho passa a ser o curso de desenho de moda, que eu muito afoitamente coloquei design de moda, risos.

Leilane: Que era o que gerava estranhamento na Faap.

Eddy: Claro...

Leilane: $\mathrm{E}$ o curso de desenho, você sabe me dizer exatamente quando nasceu? O de desenho. Porque o de plástica surgiu em 1929.

Eddy: É. O desenho, você diz..

Leilane: O que virou depois desenho de moda.

Eddy: Ah, formaram poucas turmas. Então num sentido amplo da palavra, esse curso de desenho de moda nasce de uma estrutura, não só do desenho industrial. Foi um jeito que a gente teve... Nós precisaríamos de uma autorização do MEC, então na verdade tinha um tipo de transformação daquele desenho pra alguma coisa que se direcionasse pro segmento.

Leilane: Mas vocês se pautaram pela reforma curricular do design?

Eddy: Ele é usado como referência.

Leilane: Mas existia um contexto lá, que é uma aura, um mito de estar ligado à arte. É o que o Santa vende, não é?

Eddy: Isso permanece, não é? Aí eu falei: vamos colocar design de moda..

Leilane: Mas, assim, não sei se você concorda comigo, sou professora também na Anhembi. Há essa incoerência, porque a gente percebe muito de design num curso que não se assume, e às vezes fica a minha dúvida, se eles não assumem ou não falam disso por de repente não ter um curso de design, não ter esse conhecimento profundo. No contexto da FASM. 
Eddy: $E$ esse nome design não seria aceito quando o pessoal (não entendi 51:37) na terminologia acadêmica (acho que é isso).

Leilane: Demorou, começou uns dez anos depois.

Eddy: Isso. Então, professor, não tem jeito, eu afoitamente imprimi $\circ$ material, nossa, vai dar confusão, então foi eliminado esse folheto, não é? (51:53)

Leilane: Mas ainda chamava desenho industrial?

Eddy: Nas faculdades era design de produto (52:00 acho que é isso, você falou em cima dele). E com essas e com outras o que ficou consignado esse universo, desenho de moda, que foi o Monteiro, uma empresa terceirizada na implantação do curso. Acho que em Marília tem, se você for fazer um levantamento, o nome dele é Monteiro. Qualquer entrevista que aparece nos jornais especializados sobre educação, coisa e tal, a empresa dele $\mathrm{faz}$ assessoria e consultoria para implantação e reformulação de cursos. E ele foi um dos responsáveis pra poder fazer toda esse intermédio (52:38), pra ser um intermediário junto ao MEC. A parte burocrática, e ele trabalhou muito também na Belas Artes. Então é uma figura que é parte integrante desse processo, desses processos burocráticos, ele entende desses mecanismos, de causas e também de alguns problemas.

Leilane: Mas ele sabe mais ou menos o caminho das pedras.

Eddy: Exatamente. E com isso então o curso é implantado, e nós assim, o que é que vai acontecer? E lá vou eu...

Leilane: Isso em 1978 (acho que é isso 53:22)?

Eddy: Em 1977, por aí. E lá vou eu na frente do São Paulo, não é? Nesse momento eu diria assim: logo em seguida, devido ao fato de ter assumido, comecei a administrar aula na Belas Artes, o curso começou em 1984, em junho. Quando chegou em dezembro só tinha dois alunos.

\section{Leilane: Na Belas Artes?}

Eddy: É.

Leilane: $\mathrm{E}$ aí?

Eddy: Ele começou lá na Pinacoteca. Em 1985 eu vim pra cá porque uma pessoa me indicou pra dar aula, e eu comecei a administrar aula. E depois logo em seguida eu passei a ser chefe de departamento, depois passei a se coordenador. Então... dando aula em Guarulhos, na Faap, no Mackenzie, eu não tinha condições de ficar coordenando lá. Mas durante os seis primeiros meses eu colaborei no projeto (54:12). Acho que, digamos, eu tinh que dividir algumas coisas, e aí nós já tínhamos implantado a disciplina de comunicação visual que até hoje eu ministro lá

Leilane: Isso que eu queria te perguntar. Tem uma disciplina que eu ia te perguntar, ela mostra aqui um primeiro currículo, e aí eu já atribuí a você.

Eddy: Exatamente.
Leilane: Metodologia visual e desenvolvimento do projeto do produto.

Eddy: Isso. Mas essa de metodologia visual que eu sempre, digamos, trabalhei.

\section{Leilane: Cadeira}

Eddy: É, até hoje, mas vai mudando um pouco a terminologia, mas no fundo permanece. Bom, o que vai acontecer com tudo isso? Eu continuei no Santa Marcelina ministrando aula, mas estou na verdade envolvido com meus projetos particulares, muitas exposições, foi um período em que fiz muitas exposições, seja no Center Norte, seja no Pavilhão do Anhembi...

Leilane: Se quiser dar uma olhada tem metodologia aqui, e mais adiante tem, na página, só falar que a gente está consultando o trabalho da Vera Ligia, pra depois eu lembrar o que a gente fez aqui, preciso lembrar, risos. Desenvolvimento de projeto de produto.

Eddy: Tanto é que (55:43) forma de comunicação visual.

Leilane: Isso, é revestimento cerâmico, cartões, notas fiscais...

Eddy: Aqui é metodologia visual, é mais da plástica, eu mexia mais com essa parte da comunicação visual, detalhe visual... que até hoje a gente faz isso lá.

Leilane: Desenvolvimento de produto, sacola, embalagem, joias..

Eddy: Isso, até hoje a gente faz isso porque considera que uma pessoa que vai se formar na moda tem que ter esse conhecimento. E sou muito feliz porque encontro vários ex-alunos meus dizem, nossa, como foi importante.

Leilane: Você dá aula de sapatos lá pra eles, joias?

Eddy: Não, essa parte de acessórios e sapatos é o Guto. São projetos separados. Então com isso eu continuei no Santa Marcelina, mas não mais ocupando o cargo de coordenação, porque, cá entre nós, um parênteses: tinha as reuniões. E nessas reuniões tinha o Carlos Mauro, você não tem ideia, que Deus o tenha. Você já ouvir falar, né? Essa questão de discutir o design, a moda, aquilo era de começar à uma da tarde e ir até nove da noite, empatado o processo. E eu tinha outros compromissos...

Leilane: 57:10 Não entendi a sua pergunta. Que moda era arte..

Eddy: 57:12 (Difícil de entender) A Vera deu isso, ficou tudo pra ela. E eu fiquei, era tranquilo...

Leilane: E de tranquilo você não tinha nada, tinha seu escritório, na Belas Artes, na UnG, na Faap e no Mackenzie.

Eddy: É, das seis à meia-noite. É uma dinâmica, mas eu sempre fui assim, não é. Eu digo que sou passarinho, estou sempre voando.

Leilane: É bom.

Eddy: Ah, sim. Você não tem rotina. Uma coisa que eu sempre tinha uma dúvida é: ser personal de uma empresa. Que legal, não é, bacana? Todo 
dia naquela mesma sala, aquelas mesmas pessoas, é tudo uma novidade, depois de um mês, mais ou menos novidade, no segundo mês, a mesma história de tudo. Eu gosto de ministrar aula por causa disso. Cada semestre é gente nova.

Leilane: É, e quando você tem uma turma chata, diz: é só um semestre.

Eddy: É, está acabando... mas é sensacional, é muito bom. Tem umas três ou quatro... (58:28)

Leilane: Ainda bem que é fim do ano. Ano que vem vai ser mais legal, não é?

Eddy: Isso, eu sempre tenho essa esperança, e tem turmas muito bacanas, então eu me sinto mais descontraído com isso, turmas novas, outras pessoas, e outras pessoas que eu tenho um carinho muito grande, mas não está todo dia com a pessoa.

Leilane: E você também atua e já atuou como designer efetivamente...

Eddy: Ah, sim, e hoje eu diria assim que a minha identidade tem essa capacidade de promover, através de concursos, eventos, mostras.

Leilane: E pelo seu próprio doutorado, não é?

Eddy: Exato, que agora é resgatar o IAD.

Leilane: Eu lembro.

Eddy: Esse é um sonho que eu tenho, e eu tenho uma série de ideias que estão pipocando, porque tem o IAD que é a instituição, mas tem outro IAD, são os pais dos alunos do IAD. É outra história que tem que ser contada. Os pais, como é que o aluno se formava e atuava... aí é..

Leilane: Não tinha nem um maluco lá que queria fazer têxtil, vestuário...

Eddy: Tinha de tudo, e era uma escola, aliás, foi uma escola que teve um lado político, de um lado, mas ao mesmo tempo meio paradoxal de outro, porque quem ministrava essa escola eram pessoas que tinham uma condição econômica bastante boa...

Leilane: Deixa eu te perguntar uma coisa: você faz parte do júri, da direção, do Museu da Casa Brasileira (01:00:13), você já passou por tudo lá, não é?

Eddy: No museu eu comecei a participar do júri em 1986.

Leilane: Ah, quando surgiu.

Eddy: Surgiu em 1983.

Leilane: Deixa eu te perguntar uma coisa: você lembra de uma gestão do João Marino? Anterior. Porque existia uma iniciativa da Rhodia de pedir pra que acontecessem exposições de produtos da Rhodia lá dentro, e também existia um pedido do prêmio da Dahruj Têxtil. E ele negou! Ah, foi com você?

Eddy: A Dahruj fui eu. É, foi comigo.

Leilane: Se você souber um pouco disso pra falar..
Eddy: A Dahruj você pode conversar com a Vanilda. A Vanilda era gerente da Joy Eventos, que até por sinal encontrei na semana passada. E eu a conheci justamente no prêmio Dahruj, que era um trabalho feito no segmento têxtil. Era uma tentativa de alavancar os jovens, criadores e tudo mais. esse foi um trabalho que eu fiz junto com ela, e foi daí que eu fiz amizade com ela, e que eu passei dez anos trabalhando para a Alcoa, o prêmio da Alcoa. E no caso do museu, por diversas vezes fui membro do júri, uma vez eu fui presidente do júri, e nessa trajetória toda, principalmente, teve o tempo da Adélia, que tinha o contato da Adélia Borges...

Leilane: Até 2009.

Eddy: E depois entraram esses dois, que são sensacionais, que é a Mirian Lerner e o Pieter Thomas Tjabbes [?] (01:02:07). E tem uma outra figura que é a Renata Melão, ela é da ação social, coordena, trabalha com o museu. E há três anos atrás, então houve um convite pra participar do conselho, então eu pertenço ao conselho administrativo do museu. Então é muito gostoso, eu diria assim que é um outro momento muito especial, porque é um grupo de pessoas que trabalham.

Leilane: Você também, né, Eddy?

Eddy: Ah, sim, mas eles trabalham.

Leilane: Você também!

Eddy: Mas os dois, impressionante, o museu é a vida deles, ou seja, abre o fôlder deles e vê a programação mensal, é um número de coisas que tem ali. (01:03:08)

Leilane: Agora essa coisa do terceiro setor..

Eddy: Mas produzem, fazem as parcerias, e eles têm um cuidado muito grande em relação à entidade do museu, e vem mudanças boas por aí, até 0 01:03:20 falava pra mim, professor, é muito fácil ser conselheiro aqui, tudo é feito na sinceridade, na seriedade, com uma transparência muito grande. (muitos ruídos) Depois daquela reunião longa de três horas (ruídos) eles têm tudo preparado por uma equipe muito boa. Tem uma Carol lá, Caroline, que é a responsável pelo prêmio, uma figura maravilhosa também, são pessoas que trabalham em movimento e que a gente tem um carinho muito grande, a gente se dá muito bem, o nosso relacionamento é muito envolvente.

Leilane: Deixa eu te perguntar uma coisa: em relação à disciplina e a atuação no mercado, misturar um pouco as duas coisas. A gente se refere à questão de pesquisa, de processos e de desenvolvimento de produto como projeto.

Eddy: Sim.

Leilane: E na Santa eles dão o nome de estilo. E se você falar em moda, quero entender qual á preferência de nomenclatura, o que faz sentido pra você, projeto ou estilo?

Eddy: Pra mim, desta minha formação, projeto é design. Por quê? Eu en- 
tendo que à medida que esse alguém vai designar alguma coisa em microescala, em pequena escala ou grande escala, ela está projetando. Então, claro, existe sim no âmbito da moda algo que, como o próprio nome diz, algo que tem um tempo relativamente menor. Eu tenho que lançar uma coleção de seis em seis meses. Há um tempo. Mas no fundo eu tenho tecnologia, eu tenho um processo de produção, eu tenho mão de obra, eu tenho custo, investimento, eu tenho administração, eu tenho gestão em tudo isso. Então ela vem com o nome de estilo, quem sabe a vaidade nesse conceito, digamos, de 1800, mas na verdade, sim, tem uma característica de estilo, mas na essência administrar tudo isso é negócio, é investimento, é produção, é mão de obra, é tecnologia, então pra mim eu considero design de moda.

Leilane: E você consegue propagar essa visão dentro da Santa ou há uma limitação para as coisas serem entendidas como mais ligadas ao instituto tradicional, das Belas Artes?

Eddy: Aí é interessante... eu não tenho nenhum poder, eu tenho a disciplina, gosto dela, me parece que uma parte dos alunos se entusiasmam mas eu não entro muito nessa polêmica, porque eu diria assim: eu estav naquele período com uma série de compromissos, na coordenação, e essa conversa vai virar, virar, virar e não vai caminhar, mas no meu ponto de vista, em se entendendo... vou colocar o caso de uma menina que eu encontrei em Ribeirão Preto semana passada. Ai, professor, como foi importante a sua aula, porque agora eu trabalho com calçados, e quando eu dei a parte da identidade visual eu falei: pode esquecer, hein. Aplicação, bordados, tinha a indústria, como é que vai ser, vai ser impresso, não vai ser... Aquilo tudo que o senhor falou eu sinto no dia a dia no meu projeto. Então ela, o que estava fazendo, projetando, não é? $\mathrm{E}$ agora mesmo tem uma menina que fez um trabalho em caráter mais artesanal, mas ela foi buscar no conceito do estampar, não é, no conceito de carimbo. Claro, o trabalho dela tem um caráter, digamos, restrito, mas ela tem todo o encaminhamento, o raciocínio de design. Eu diria assim: dá pra você produzir na tipografia? Não. É único, não é? Mas tem design que não acaba mais lá, então eu vejo agora, quem sabe existe, na moda, essa questão do espaço-tempo. Você lança e move e aí nasce $\mathrm{o}$ outro. Mas eu acredito que na essência, as máquinas industriais que estão funcionando lá, as estampas, estamparias, tudo tem um processo de reprodução. E se tem reprodução está embutido a ele uma ideia de design, em micro, pequena ou alta escala.

Leilane: Você acha que de repente esse uso da nomenclatura estilo, ou dessa essa ligação com a arte, seria pra fomentar, pra dar um status maio para o curso, para a área da arte ter mais capital simbólico?

Eddy: Possivelmente, possivelmente. Porque na verdade é isso que você ouve no mercado.

Leilane: Tem um trabalho da Ethel Leon agora, quando ela fala de artificação, ela fala que, assim como a moda, me chamou a atenção porque eu uso muito isso no doutorado, assim como a moda, o design possui estatuto inferior ao das artes. E ela que é por isso que o design vai tentar se aproximar da ideia de designer-autor, o deusigner, o starchitect, do "deusign", que é o que você está falando, também pelo número de formandos que aumenta muito desde a década de 1990, e vai criar esse mercado de designer-autores, que vai fomentar um objeto muito mais "escultórico" do que fomentando o design como ergonomia, projeto social e vida pública.

Eddy: De fato, algumas coisas, digamos, têm produção maior e outros são peças assinadas (01:09:53), em 2014.

Leilane: Mas também tem um problema, estávamos discutindo isso outro dia com o Marcos Braga (01:09:58) na aula, e ele falou: ué, se a gente for reduzir tudo que é produção seriada, pequena, de um prêmio como o Prêmio Design Museu da Casa Brasileira, o mais importante que tem no Brasil, você vai reduzir a $1 / 4$ da produção industrial, serão sempre os mesmos diretores de criação. Então eu também entendo pela forma de pensar, de refletir filosoficamente, quando se produz um design contemporâneo, a Ana G., Alessandro Mendini, ela não me compromete, mas se a gente for nos radicais, Juicy Salif do Philip Stark eu queria saber o que você acha um pouco disso, porque eu vejo muitas vezes designer comparando isso como um elgoio-moda, falando isso numa ideia de moda porque moda é passageiro, vai mudar logo mesmo, e a ideia é o público ávido pelo consumo, queria saber se você acha isso válido.

Eddy: É um momento em que nós estamos no olho do furacão.

Leilane: Mas desde a década de 1990, não é?

Eddy: É, agora isso, posso não entender, caso esteja enganado, só poderá, a gente só poderá fazer uma real avaliação daqui uns 50 , cem anos.

Leilane: 01:11:14 Fala incompreensível. Falo sobre o Michel Maffesoli.

Eddy: Eu diria assim que, agora, quem sabe, tem que começar a estudar o Renascimento.

\section{Leilane: Entendi.}

Eddy: Então nós estamos num período clássico, onde as coisas estão acontecendo, e nós temos muitas vezes visões, percepções, de Bauhaus..

\section{Leilane: Sei...}

Eddy: Eu nunca me esqueço de um texto que li e achei muito interessante que falava do comunismo, e socialismo, comunismo, Rússia, e assim sucessivamente, Marx... e o que foi gerado de livros em relação a isso... e essa pessoa diz assim: quem sabe, daqui duzentos anos, dirão assim, de 1917 até 1980 existia um país, vai ser um verbete embaixo, que tem outras coisas acontecendo. E a pessoa diz assim: nossa, é mesmo, em 1917 aconteceu essa guerra, essa revolução? Porque da Segunda Guerra Mundial pra essa criançada toda? Se ele for de origem judaica, alguma coisa, quem sabe, mas os outros? Outro dia eu falava de Brasília, não é, eu falei: olha, eu tinha 7 anos de idade quando foi inaugurado o Ibirapuera. Nossa, ele é múmia, será? (01:12:48) Então, digamos, quem sabe... o Niemeyer, será, espera um pouco, o que ele gastou de concreto... E a publicidade, a máquina 01:13:08, a Bloch, não é, as revistas, é o futuro do Brasil, não é? Seria o futuro. Quando eu era 
pequeno, um período maravilhoso também, em 1961 eu estava começando o ginásio. Era tudo Brasília. Sabe aquela capela, do Palácio da Alvorada, nossa, você não tem ideia, eu fiz em papelão, em cartão, em artes manuais, não é, era Brasília, aquilo seria o futuro, a esperança, não teria mais sinaleiros, tinha as alças de acesso. Aí cinco anos atrás, quando eu passei, porque já fui várias vezes, nossa, apareceu um sinaleiro lá, no que eu pensava da alça de acesso. Aí você olha a Esplanada, tem uma força, um vigor muito grande, mas como isso está velho, como isso já passou, ou seja, quem sabe, eu não sei como a arquitetura andou, mas é uma coisa que... se eu vou, digamos, no lbiraquera, eu vou no 01:14:25, eu vou pra Brasília, é tudo a mesma coisa, porque tem uma marca dele. Uma marca importante, mas no fundo, no fundo, é um espaço, um concreto. Era prospectivo porque era moderno, e hoje passível de questionamentos. Passou a validade também, mas, ou seja, há uma dinâmica. Então eu diria hoje, nós vivemos principalmente pelos sistemas que você tem, eu até discuti isso, qual a razão das faculdades, pra onde elas vão, o que elas vão fazer como (1:15:07 ?), então eu sinto certas coisas. Por exemplo: hoje, a Mauá (ruído), da minha ex-aluna, que é a coordenadora, Claudia Paiva (acho que é isso), que foi minha aluna no $\mathrm{Ma}-$ ckenzie, fofíssima, maravilhosa como ela só, estão com aproximação com comunicação visual (01:15:29). Tudo bem que tem o curso de engenharia, então o design dela, eu falava com um dos meninos do salão do automóvel, ele falava com uma segurança, com uma certeza, isso no projeto que ele fez, equipamento, sinalização, o que é colocado sobre o veículo, então estão fazendo um conjunto com a General Motors, é, está claro: é a engenharia, é a tecnologia, é o processo. Não quer dizer que não exista, que não possa mais existir comunidade criativa (1:16:09), coisa e tal, mas é a tecnologia (ruídos). Aí você vai numa outra instituição, aí você encontra umas coisas que leva mais para o lado experimental, os professores têm um grau de flexibilidade [não entendi], chega na PUC do Rio é outra coisa. A ESDI (1:16:34) vive outro momento complexo, depois de 50 anos, o que vai fazer com tudo isso, faz ou não faz, e muitos que saem de lá com a formação (1:16:46), no dia a dia profissional vai pra outros segmentos, e questiona essa postura.

Leilane: A própria formação, nao é?

Eddy: Claro, então tivemos hoje, nesse olho do furacão, vários caminhos, tendências, e olha que quer dizer, eu acompanho, é obrigação, não é, não no Brasil, mas no mundo. Você vai procurar os designers da Holanda, eu fiquei maravilhado com aquilo, achei extremamente interessante, e depois vem, de repente, não sei, uma exposição do Japão. Outra situação. De um lado tem aquela carga cultural deles, e outro tecnologia pura. Então eu diria assim, não sei se é certo ou errado, mas eu estabeleceria lá em cima um guarda-chuva design, e depois os vários caminhos, as várias maneiras de interpretar os desígnios.

Leilane: E aí envolveria, no caso, você concorda mais ou menos com a visão do MEC, de 2002, que viria nesse guarda-chuva tudo que pertenceria ao design: design de interiores, embalagem, vestuário... Deixa eu te perguntar uma coisa, você acredita que a moda, porque assim, o que faz com que a moda não seja um campo autônomo, um dos principais problemas é que não tem exame, no Enade, próprio.
Eddy: Mas vai ter.

Leilane: Então, durante alguns anos a gente prestou do tecnológico, o tecnológico foi extinto, a gente voltou a prestar do design, e cursos de moda prestando o design a sabe sabe que não tem dado bons resultados. Inclusive, eu não sei se isso é pressão das faculdades, mas a maioria surgiu, eu te perguntei essa coisa da Santa porque a Santa é bem específica.

Eddy: Isso, claro.

Leilane: A quase totalidade de faculdades do eixo Rio-São Paulo, onde se concentram as maiores e as mais bem avaliadas, elas tributam seu surgimento ao design e não à arte. E como elas fazem isso acabam se encaixando, dando brecha para o MEC encaixá-las no exame de design. Mas eu sei porque me formei em moda pela Anhembi Morumbi, eu não tive aula de resistência dos materiais, eu não tive aula de história do design, então eu também não teria condições de fazer uma prova dessas. Então só que eu entendo que, agora, cursos tradicionais que vêm do design justamente porque a faculdade tem um curso de design dentro. Na Anhembi Morumbi, no Senac, que são cursos fortes, tiraram a nomenclatura de design no nome, com exceção de Senac e Belas Artes. $\mathrm{Na}$ Belas Artes continua se chamando design de moda, agora IED, Santa Marcelina, Anhembi Morumbi, Faap, todas tiraram o nome design, eu não sei se isso também não está claro, porque o meu doutorado não é sobre ensino, é sobre projeto, mas se não é pra comentar uma ideia de, da moda como campo atual no mundo do saber, uma área específica. Tem até um grupo de estudo da professora Francisca Dantas Mendes, você deve conhecer, que é da EACH USP, se chama Moda como Campo do Saber. Ela luta pela instituição da moda como campo autônomo.

Eddy: Mas eu diria a você, eu torço, vale a pena, é um processo constante. Mas, de outro lado...

Leilane: Desculpa, só te interromper, não negando a história, eu particularmente acho que a coisa é muito mais ligada ao design.

Eddy: Claro, mas eu vejo assim: esse processo, chamamos de processo.

\section{Leilane: Sim, claro.}

Eddy: Um processo constante de reflexão e questionamento. Acho estranho ter pessoas que não optam por um caminho, por outro... eu vejo isso como uma qualidade muito grande, são pontos de vista, são referências, são encaminhamentos, são dados que você tem, eu diria que vai ser impossível dizer assim: "Vai ser isso, este é o modelo que devemos seguir".

Leilane: Nem vem ao caso..

Eddy: Acho interessante, os cursos livres, pode ser que esteja errado, por esse pulsar.

Leilane: Você não acha que, quando reconhece o campo, não precisa ser único nem direcionado, quando você reconhece uma área como o campo autônomo, também não está dando campo simbólico para ela trabalhar, ganhar mais força? 
Eddy: Claro, claro.

Leilane: Como uma área, é..

Eddy: A pessoa, digamos, da área de biologia.

Leilane: Que não precisa, sabe, ficar voltando à arte, design, para conseguir mais fomento, mais verba para pesquisa, risos.

Eddy: Agora tem que discutir com muito cuidado o objeto. Então quando se fala em design, tem muitas dúvidas, e ele não tem grau de autonomia. Nós estamos ligados, digamos, aos... agora mesmo eu fui numa feira, então, olhando aqui lá, conversando, praticamente $90 \%$ eram multinacionais, não é? O que acontece? Nada mais, nada menos, você vai desenhar o quê? Ou seja, você, num momento em que tiver, digamos, um avanço da tecnologia, tudo vai mudar. Tem uma outra forma de você entender, não vai mais dessa maneira..

Leilane: Já mudou, não é? Design de interfaces..

Eddy: Eu nem sei se isso vai existir. Então, digamos, o design, desenhar. eu nunca me esqueço, numa ocasião, eu tinha um amigo que trabalhava na Philips. E eles tinham um departamento, isso é da década de 1970 para 1980 Eles tinham um departamento de desenho industrial e estilo de produtos, no qual esse colega trabalhou. A caixa preta estava lá. Agora tem que fazer os frisos, o acabamento em madeira, então os desenhistas, projetistas industriais, estilistas, e tudo mais procuravam um componente, era uma caixa, que era um paralelepípedo que você colocava lá, para o quê? Entre aspas, criar, digamos, o desenho, o facelift, de uma (01:23:51). Mudou a tecnologia, mudou tudo. A caixa de madeira está boa, tudo está bom, é outra coisa. Então o design, ele vive, entre outras coisas, pelo avanço, ele vai dentro desse universo...

Leilane: Cronológico, não é? Risos. Não vou falar em evolução que é delicado...

Eddy: Ou seja: existe um outro mundo nas empresas. E as escolas estão ensinando um design que já não existe mais.

Leilane: Ignoram uma realidade econômica, tecnológica, administrativa...

Eddy: Ou seja, o que acontece, o indivíduo se forma em industrial e de repente ele vai pra indústria automobilística. Chegou lá, dois anos pra reciclar esse menino, pra ele poder entender o que aquela empresa pensa. Porque ele vai na oficina, serra madeirinha..

Leilane: É isso que eu ia te perguntar: se o cara não fizer isso, for direto pro computador também compromete o pensamento..

Eddy: Aí a escola, pior ainda, ainda não tem o departamento comercial.

Leilane: A gente tem aula de marketing, assim, um ano, dois semestres..

Eddy: É interessante, por isso eu gosto de trabalhar com a Tok\&Stok (está se referindo ao concurso). Você vê que eles têm um trabalho interessante, mas são todos ingênuos: professor, orientador e aluno. Eles fazem projeto, mas esquecem que, na Tok\&Stok, passa pelo departamento comercial. Deu pra entender?

Leilane: Sim. Quanto vai custar a produção...

Eddy: Então, esse componente aqui, hum... vai precisar de dois centavos. (01:25:53). Mas aí vai dar 200 mil. Então eles fazem... o que é bom, aluno solto, criando mais, mas depois tem esse internexo.

Leilane: Isso é um conflito muito grande, ser criativo dentro de uma série de demandas financeiras, tecnológicas, aí que é difícil criar, não é?

Eddy: Então você vê, aquela meninada sensacional, jovens ainda, 25, 24 30 anos, eles chegam lá às nove e saem muitas vezes seis, nove da noite, quinta e sexta, você não tem ideia do que é trabalhar lá, não que seja mal, tem muitas pessoas que trabalham há muitos anos lá também, tem que discutir com a equipe toda pra estabelecer o argumento e ver como aquilo funciona. Interessante fazer isso, mas não dá pra entrar na Tok\&Stok (1:26:53). Precisamos dele. Aí vem o pessoal do técnico, da contabilidade, e o indivíduo sai de lá às dez da noite pra discutir, porque toda semana são lançados 50 produtos diferenciados. E a escola diz assim: ah, então, olha esse projeto, vou registrar lá no Inpi, vou registar, não tem problema nenhum... Já pensou, por semana, registrar 50..

Leilane: Qual a variedade disso, durante quanto tempo, se pensar num celular, quanto tempo isso dura...

Eddy: Já estão copiando e tem outro, e não está dando bem com a cor, digamos, grafite, mas há uma tendência, vamos fazer uma experiência, tecnologia, vamos lançar em branco, lançou, não deu certo, tira, uma equipe enorme o tempo todo na frente dos computadores, é uma outra dinâmica, e que exige a criatividade, e muito, mas é uma outra criatividade, não, digamos, de acreditar..

Leilane: Sim, não só ideológica.

Eddy: $O$ buraco é mais embaixo.

Leilane: Talvez hoje não tenha tanto espaço pra ideologia, a gente percebe isso até na moda, estava aqui na frente te esperando, e vi muitos aluno daqui e da Belas Artes, você vê um com um estilo hippie e outro com um estilo rock'n'roll, mas isso, ainda na minha adolescência, na década de 1990 a gente ainda tinha que rasgar os nossos jeans, a gente ainda tinha que se virar, não se comprava isso pronto. Coturno já foi mais fácil, já se encontrava, você não tinha que pegar o coturno da Polícia Militar, eu pegava por charme, mas, se você, na sua adolescência, quisesse um coturno, tinha que pegar da Polícia Militar, não tinha coturno pra roqueiro, pra skinhead, não fazendo apologia, mas hoje é tudo mais socializável (01:28:52). Está todo mundo muito igual, é uma coisa de fala, você tem que ser diferente (01:29:00).

Eddy: Então tudo nisso tem que ser dimensionado, tem que ser pensado, é um outro mundo...

Leilane: $\mathrm{E}$ é interessante porque a moda que fomente individualidade de 
uma maneira mais agressiva, da gente cortar, é nossa primeira casa, porque na nossa casa a gente vai lá e tem um aparelho de som, um sofá da Forma, são poucas pessoas que vão lá e conhecem isso, eu não preciso conhecer necessariamente marca pra dizer da identidade da pessoa.

Eddy: Deixa eu colocar um dado pra você, não sei se é melhor ou pior, preferencial, da maneira como eu até certo ponto percorro este circuito. Vou ao Museu da Casa Brasileira e tem a exposição da Lina Bo Bardi. Nossa, eu vi tudo isso, eu vi tudo que estava na exposição. Aí eu saio de lá e vou até o Centro Cultural da Caixa Econômica Federal. Olha, o Elias Andreato, nossa, reverenciando Vinicius de Moraes. Aí desce, 1:30:22, as gravuras, acho que no ano passado, aí você passa na 1:30:32, o artesanato do pessoal. Se você sobe pra Paulista, vai numa feira, digamos, de arte e tecnologia, que eles fazem todos os anos.

Leilane: A File.

Eddy: Então esse é o mundo que nós vivemos.

\section{Leilane: Heterogêneo}

Eddy: Ah, então eu prefiro viver assim, eu gosto. Não posso julgar, nesse momento, o que está certo ou errado, são caminhos.

Leilane: Não dá pra dizer que é democrático, a gente ainda tem muita desigualdade, mas, assim, e não acessível, ele é plural, você dá acesso, dá escolha. São as alteridades.

Eddy: Eu gosto muito do 1:31:21. E eu gosto muito de um texto em que ele fala sobre a questão do tempo. $O$ tempo de plantar, o tempo de colher, 0 tempo da espera. Esse tempo é singular.

Leilane: É o processo.

Eddy: $O$ processo. Depois... eu lembro disso quando era criança. $O$ tempo que virou uma linha reta. Circulava, não é? Depois o tempo, no futuro, que você tem a linha, isso começa, quem sabe, no Renascimento e na Revolução Industrial. Mas a partir da Segunda Guerra Mundial isso é muito evidente. Não vamos ter mais guerra, o mundo vai ser uma grande paz, como está hoje, e aí vem meu pai: olha, no futuro você tem que fazer engenharia elétrica; você dominando a eletricidade está dominando tudo. Eu tenho ainda algumas revistas, Mecânica Popular e Mecânica llustrada. As cidades, no futuro, serão domos geodésicos, você vai controlar a temperatura e ninguém mais vai andar. Vai ser tudo deslizante. Não vai precisar mais comer, vai ser uma pílula na hora do almoço.

Leilane: O Orson Welles, em Admirável mundo novo...

Eddy: Isso, tudo tem esse outro universo. E em 1985 tem colônias de humanos lá em Vênus. A equipe espacial vai levar isso. E chegamos no século $X X I$. Agora é um cone, o que era linha agora é um cone.

Leilane: Então cada coisa é uma nota de rodapé, como você falou.

Eddy: Então, digamos, as crianças, esse jovens, nossa, vai fazer um texto, não consegue escrever um texto. Mas não vai conseguir mesmo. Porque nós vivemos nesse ponto fragmentado.

Leilane: $E$ hoje as formações são cada vez mais superficiais.

Eddy: É outro mundo, é outra realidade.

Leilane: Eu já não fiz geometria como você fez. Eu nunca fiz maquete. Eu não tinha esse 1:33:46 tridimensional, foi pela faculdade de moda, mas foi sempre no papel, com compasso e tudo mais. Deixa te perguntar uma coisa: a gente falou um pouco de projeto como pesquisa, processo, eu queria que voce falasse o que conhece sobre projeto em moda, antes só queria te perguntar se você conhece esses autores, 1:34:13 (nomes de autores, não entendi, desculpe). Porque Löbach, Gustavo Amarante e Bruno Lonari, risos, é evidente.

Eddy: Na parte de cima não tanto, eu não estou muito ligado a isso.

Leilane: Desses o que the pode parecer estranho é a Sue Jenkin Jones. Eu queria que, dentro desse projeto, ver se consegue me falar sobre projeto em moda porque vi que você me falou, você tem algum 1:34:39, o prêmio Dahruj, você tem alguma afinidade com projeto de moda.

Eddy: E mesmo o Prêmio Rhodia.

Leilane: O Prêmio Rhodia, você tem afinidades.

Eddy: No caso do Prêmio Rhodia, o que acontecia com o Prêmio Rhodia?

Leilane: Eu queria que você falasse do processo de criação, o que você percebe, como se dão as etapas, inspiração, o que norteia o projeto em moda, como se sente em relação ao design, além da questão do tempo.

Eddy: Eu acho que aí a imagem, esse projeto volta muito ao lado experimental das artes visuais.

Leilane: Ah, é? Por quê?

Eddy: Por exemplo, vou falar como referência das três edições do... o Carlos Mauro, que já estava na Rhodia, me convidou. Sabia como estavam as minhas aulas na faculdade, mas você não tem ideia, entrei numa fria, mas valeu a pena, porque a Rhodia lançava fibras das mais diversas. E com isso eles precisavam utilizar um mecanismo dos estudantes como criadores. Então a gente precisava pesar uma quantidade $X$ de material parar entregar para cada instrutor. E eu e os professores lotávamos os carros para levar nas faculdades. Chegava nas salas, nós temos um treino da Rhodia, vai ter um catálogo, e o meu escritório naquela ocasião fazia o catálogo, fazia tudo, mas tinha essa responsabilidade de ir nas faculdades.

Leilane: Isso em que ano, Eddy?

\section{Eddy: Isso aí é 1982}

Leilane: Você já dava aula em quais faculdades? Porque não tinha o curso de moda, não é?

Eddy: Não tinha, era o curso de design 
Leilane: Era isso que ia te falar.

Eddy: Faap, na Santa Marcelina era o curso de desenho, Guarulhos, a própria FMU, em que cheguei a dar aula um período, do tempo que era Faam, Faculdades Alcântara Machado, Mackenzie também... Então eu levava o material. O que acontecia? Nada mais, nada menos, explicar o inexplicável. Por quê? Daquele conjunto de estudantes só duas conseguiram captar a ideia e fazer um trabalho. Trabalho plástico visual. Então assim, tem que usar harmonia, composição e organização e montar, dar vida, à essa matéria-prima. A matéria-prima está aqui. Um saco de dois, três quilo que você comprimia. Ah, pode desfiar? Pode desfiar, pode colocar textura, pode fazer tudo. Você tem a liberdade, mas aí as pessoas: liberdade pra onde? Os mais racionais. E aí, Eddy, quantos vão ter? Ah, a faculdade tem, 70 alunos. Aí no dia de recolher os trabalhos, ah, eu peguei e não consegui fazer nada, as pessoas não faziam nada. Aí daqueles 70 alunos dez conseguiam fazer, daqueles dez tinham estavam muito ruins, ficavam uns cinco, mas no final das contas a exposição que acontecia na Casa Rhodia foi uma beleza.

Leilane: Sim, na Avenida Brasil.

Eddy: Isso. Aí um dos diretores da Rhodia: nossa, como esses alunos são criativos, e tinha coisas criativas também. E eu posso agregar um outro material? Metal?

Leilane: Então já que os cursos de design, na época, eles eram muito racionais para a lógica da moda?

Eddy: Ah, fazer uma experimentação num material era uma coisa um pouco distante.

Leilane: Então isso é um caráter experimental mais ligado às artes, $n$ moda, que é mais presente na moda do que no design.

Eddy: Ah, você não tinha um produto final que ia ser reproduzido. É uma peça, um objeto, usando a fibra industrial através da química da Rhodia, você fazia objetos e experimentações. Eu não sei, deve estar guardado em uma das caixas, eu tenho os catálogos, agora onde está preciso verificar, porque eu tenho seis boxes que eu pago todo mês pra poder manter tudo la dentro, coleção da revista Quatro Rodas, revista Veja... Nesse momento está nas caixas. Eu preciso ir até lá e resolver o mais rápido possível, porque um acervo que fica tudo lá quardadinho. Mas eu preciso me organizar em relação a isso, porque meu tempo é muito exíguo, até já falei com o Marcos sobre isso, preciso bolar um jeito, se pudesse, digamos, ter uma instituição que pudesse ter esse material. Mas foi feito um fôlder, um material gráfico, que mostrava as especulações dos estudantes usando a fibra, sempre um trabalho de caráter experimental usando essa matéria-prima sintética, mas criando objetos experimentais.

Leilane: Mas ao mesmo tempo que você fala que é um caráter experimental que eu acho que se volta mais para a arte, também você fala a palavra objeto várias vezes. Dá pra encarar a moda também como design de produto em certo aspecto?
Eddy: Eu acho que sim.

Leilane: A moda é meio esquizofrênica? Será que ela também se atribui à arte $e$ ao design?

\section{Eddy: Eu sou muito descontraído nisso.}

Leilane: Desculpa só te interromper. Quando você falou que ia para a Faap ter aula de design, que era algo digno e sério, que ia se prostituir no curso de marketing e publicidade à noite, é um pouco o que eu sinto da moda em relação ao design, a moda prostitui todo mundo porque precisa gerar informação rapidamente, pra mastigar e cuspir.

Eddy: O tempo é outro. Eu fico numa grande dúvida, pode ser que esteja enganado, dessas denominações ou espaços, eu acho que é um todo absoluto, uma coisa liga à outra, soma...

Leilane: É mais importante deixar aberto do que a preocupação em fechar e definir. Mas aí, então 1:41:40, é que eu li o Bordieu. E aí existem delimitações inclusive jurídicas para definir uma área de atuação, senão a gente estava arrancando dente e operando coração. Isso é muito complicado.

Eddy: Sim. Muito complicado mesmo.

Leilane: $\mathrm{E}$ aí principalmente no nosso caso, que a gente não vai abrir a cabeça de ninguém, mas é a questão do capital simbólico, muitas vezes de transformar a arte em arte pra conseguir estar em um museu, pra conseguir lançar seus profissionais, ou conseguir fomento pra pesquisa.

Eddy: O Aldemir Martins, ele, um artista plástico, desenha, e tudo mais, ele fez a reprodução de um dos pratos plásticos da Gauguin [?] 1:42:26. Como você colocando no plástico, seu produto para ser reproduzido...

Leilane: Parecia Romero Britto, ele já é um designer gráfico.

Eddy: Essa questão do próprio Romero Britto também. Ele está produzindo, está vendendo, tem que consume?

Leilane: Essa questão de gosto é uma outra coisa. Por favor, eu não estou comparando o Aldemir Martins com o Romero Britto, risos.

Eddy: Claro... como será que, daqui duzentos anos, vão fazer a leitura do Romero Britto?

Leilane: Mas esse ambiente da arte parece que é sagrado, não pode se vender, não pode virar produto, que é um problema para a maioria dos artistas, mas ao mesmo tempo traz a aura... eu acredito que a moda tenha um movimento muito ambíguo. Essa questão da arte como capital simbólico e a área autônoma também se distancia. Você concorda com isso?

Eddy: Concordo e assino embaixo, ela imbrica por caminhos, não é? Ela se utiliza de ferramentas, de momentos, de situações..

Leilane: Você acha que isso é mais complexo do que tentar definir. 
Eddy: Depende da formação da pessoa, depende do tipo de empresa, porque há um questionamento em relação aos irmãos Campana. Quando eu vi a primeira exposição deles, a primeira exposição mesmo, no MAM, eu fui lá, olhei tudo aquilo e falei: nossa, o que é isso?

Leilane: Isso foi na década de 1990 ainda, não é?

Eddy: Oitenta pra noventa. Eu olhei tudo aquilo, eu falei, tudo bem, aí vinha a minha linguagem racionalista: isso não é design, estar num museu, uma peça enferrujada, soldada, o que é isso? Mas, veja o seguinte, a Melissa produziu várias sandálias dos..

Leilane: Eu dei aula para a filha do dono da Melissa.

Eddy: Como?

Leilane: A menina que é proprietária da Melissa faz Faap.

Eddy: É o conceito do produto que depois passa para o...

Leilane: Eddy, você está falando da cadeira de design, da mesa de design que virou as sandálias de design, eu falei isso segunda-feira da sandália para - Marcos Braga, pior ainda, agora você vai arrancar os cabelos. Tem uma cópia da Macy's feita em 2011 por uma marca chamada Material Girl, supostamente desenhada pela filha da Madonna, que na época tinha uns 10, 11 anos, e que copia, assim, o acabamento é bem mais grosso, vai machucar o pé, a cava da lateral externa do cab edal é bem mais alta, vai machucar o pé, o material é bem mais frágil, está todo desbeiçando, dentro, no pé na curvatura e na frente é pior, tem um plástico grande, assim, e vai afinando. Gritante. Então eles conseguiram piorar a cópia? Acho que tamanho o valor da mudança pra nós.

Eddy: $O$ que é efetivamente, digamos, novidade?

Leilane: É pós-produção, não é?

Eddy: $\mathrm{O}$ que é original hoje? Existe um imaginário muito grande por aí, a falsificação passa a ser um original muita vezes.

Leilane: Sim, Victor Hugo, que faz bolsa, Louis Vuitton, e não é fina, é aquela coisa com defeito.

Eddy: Não, não, não, não, não, outro dia 1:46:42 Será que existe design mesmo? Esse foi um dos pontos criados, digamos...

Leilane: Culturalmente, pra criar um mercado.

Eddy: Será que existe esse design mesmo? Quem é tudo isso? Quem escreve sobre isso, como vive isso, quem vive isso? Que história toda é essa, essa história tem que ser melhor contada...

Leilane: Até que ponto... O Richard Senett fala no artista, divisões de arte...

Eddy: Então eu diria assim, eu acho que é por isso, tudo isso que ele vive que... Na hora que você tiver uma resposta vai perder a graça.
Leilane: Eddy, consegue ler isso aqui, quer que leia pra você?

Eddy: 1:47:36 No plano plástico, ..., aplicada à estética. No que diz respeito à moda, ..., que provocam uma criação e revolução.

Leilane: Mas esse tipo de frase é muito poética. $O$ estilo é essencialmente o estado de espírito, é saber captar a fantasia do ar. Eu queria saber o que você acha desse tipo de afirmação.

Eddy: Essas coisas nos levam, digamos, ao romantismo, ou seja, isso é como as pessoas... "Ah, minha filha está fazendo moda, gosta de desenhar, tem um talento, desde criança é assim..." Há sempre essas coisas...

Leilane: Você não acha que há um perigo de fundir esse tipo de pensamento? Esse tipo de frase sem explicação aí...

Eddy: Você pode questionar isso, mas essa é a realidade do dia a dia. Tudo é mais bonito, é diferente dos outros, isso é o lado, digamos assim, a forma pela qual as pessoas também encaram que 1:48:52.

Leilane: Então, por isso eu falo, quando eu quero entender um pouco, a minha hipótese é a seguinte: é que não há um consenso sobre a ideia de projeto em moda, que é o meu foco. Mas é que tem alguns autores clássicos todo mundo consente que consente que existe um produto em visual. $\mathrm{Na}$ moda as pessoas conhecem essas pessoas, mas isso é muito difuso, cada um usa um, esse discurso não se fecha. Então, assim, não estou em busca de parâmetros definitivos, eu concordo com você que tem que estar aberto, mas tem determinações jurídicas, que implicam o capital simbólico, do mito da profissão, e também tem que levar em alguma direção, porque senão perde essa seriedade que você está falando.

Eddy: Hoje, eu diria assim, num certo aspecto que é um imbróglio, que ninguém sabe o que é.

Leilane: Interessa saber o que é?

Eddy: Não interessa muito porque, digamos, a menina do Santa Marcelina se forma e aí no trabalho de graduação, trabalhos excelentes, da Faap, faz um trabalho que tem um desfile, maravilhoso, coisas incriveis. Aí depois, terminada a apresentação, entregue a avaliação, ela tirou dez com louvor, os pais choraram, as avós mais do que nunca, mas...

Leilane: A madrinha de batismo..

Eddy: Aí vai chegar, vai ter uma férias também para descansar, muito pesado o final de semestre, aí chega em fevereiro: agora, pra onde eu vou? $\mathrm{E}$ tem a oportunidade de trabalhar no Bom Retiro, no Brás...

Leilane: É muito parecido com o pensamento do Seu Regy, que você falou um pouco, só que em escala diminuta. São quatrocentas empresas. Eu trabalhei lá.

Eddy: Então é isso, tem que produzir, tem que vender...

Leilane: $\mathrm{E}$ no ambiente é outra coisa. Um universo paralelo. 
Eddy: Então no Santa tem o desfile, que bom...

Leilane: Você conhece as confecções no Brás e no Bom Retiro, Eddy?

Eddy: Eu passo porque lá porque gosto muito de caminhar, eu ouço pelas alunas, as pessoas falam cada coisa, vão tendo consciência do processo, e algumas são alunas de alunas, aí monta alguma produção de bordado, por aí. Precisaria, eu não sei se isso é pertinente ao seu trabalho ou não, uma coisa que eu sonhava em fazer mas não tenho tempo: aonde estão os formados? Se formou? Há dez anos? Aonde você está agora?

Leilane: É um trabalho feito pelo Francisco Segnini, professor da FAU, que fez arquitetura.

Eddy: Tem que fazer um grande levantamento para entender aonde estão. Mas essas alunas, querendo ou não, são vasos comunicantes... 1:52:34 muito ruído

Leilane: Está acontecendo com a moda o que aconteceu com o design na década de 1990.

Eddy: $O$ que acontece? Nada mais, nada menos, quando o curso foi implantado no Santa Marcelina, claro que a primeira ou segunda turma, eu fui na Folha de S. Paulo. Aí levei um folheto, disse que vai abrir o curso, a moça olhou: "Ah, sim, vai ter o curso, ah, que bacana..." E quando vai escrever de moda na Folha de S. Paulo? Não existia isso.

\section{Leilane: Achou que tinha um preconceito grande.}

Eddy: Tudo bem, e eu bobinho, aí saiu no jornal: "agora pra costurar precisa ter diploma universitário". Falava das inscrições, mas um lado irônico...

Leilane: Que piada... Em um tom jocoso.

Eddy: Exatamente. Então era um...

Leilane: Você tem esse anúncio?

Eddy: Ai, meu Deus do céu. Agora hoje, o que acontece? São páginas e páginas do jornal...

Leilane: Sim, eles têm Lilian Pacce, Alcino Leite Netto...

Eddy: Bom, também há de convir comigo, que jornalista era ela, que visão ela tinha, ela pegou e colocou isso, assim. Quando você implanta alguma coisa causa um estranhamento, quem sabe nem eu saberia explicar..

Leilane: Será que também tem a questão de vestuário, a Vera Ligia falou, não está ligado também ao ambiente doméstico, mais ligado ao ambiente feminino, isso tem até um machismo, parece que design é mais aceito, e a moda acaba sendo, como você comentou e eu também comentei, uma espécie de "espera-marido", pelo menos no início.

Eddy: Voltando agora, no começo, a primeira e a segunda turma, mas aí apareceu o Herchcovitch, e isso deu uma visibilidade enorme pro Santa Marcelina, muito grande. Então eu diria que na terceira, quarta, quinta tur- ma, as pessoas estavam ávidas, os empresários, do curso do Santa Marcelina, porque ali estaria, digamos, o futuro da empresa deles. E com essas e com outras a contratação se faz de imediato, fazia o estágio, estava lá. Porque, digamos, tinha o Santa Marcelina e logo depois a Anhembi Morumbi, mas que era, digamos, a parte de negócios e tal.

Leilane: Então, você sabe que me formei lá, em 2003, e o curso era design de moda e tinha um negócio de moda separado. Na época que cursei não era isso, a menina dos olhos ainda era o design de moda, tanto que existia uma briga com a Santa, porque quem chamava o André Hidalgo, quem chamava o Tufi Duek, que ia numa banca ou outra, que eles marcavam no mesmo dia pro cara ter que escolher. Ainda peguei uma parte que era criação, mas eu entendo que depois voltou bastante pro negócio.

Eddy: A procura era, digamos...

Leilane: Lá era exclusivamente, não é?

Eddy: Hoje, não quero dizer que não temos alunas que estão sendo tratadas 1:55:58.

Leilane: Não tem uma velocidade de absorver Herchcovitch, Dudu Bertholini...

Eddy: Hoje são mais de duzentos cursos de moda no Brasil.

Leilane: Eram 88 há alguns anos. Até porque o Herchcovitch não terminou, depois voltou, terminou...

Eddy: Então o mercado não vai absorver essa gente toda, é impossível. Eu acredito que vai ter vida, mas nos próximos anos haver um estreitamento de tudo isso, vai se reduzir e vão ficar as melhores, vai acontecer alguma coisa, porque não tem lugar pra toda essa gente, é impossível. Então vai encontrar na sala de aula aquelas pessoas...

Leilane: Uma deterioração do campo de trabalho, não é?

Eddy: Claro. Era como o curso de educação artística. Quando ocorreu a mudança da estrutura de ensino no primeiro e segundo grau, os professores precisavam fazer o curso de educação artística. Ministrava aula no sábado, domingo, segunda... Na Faculdade Paulista de Artes chegavam três a quatro ônibus lotados, tinha que dar aula no sábado e domingo. E onde estão as pessoas de educação artística? Acabou. Desapareceram.

Leilane: A Faap é uma das poucas que tem licenciatura e bacharelado.

Eddy: É, mas o pessoal dificilmente faz. Quer ver um dado, outra situação, extrapolando o recurso, tem o Ricardo Bloch, já ouviu falar do Ricardo Bloch?

Leilane: Não... Ah, o Ricardo Bloch.

Eddy: Bloch, um dos maiores expertises em automóveis do Brasil. E a FE tem um dos melhores cursos do setor. Este ano, tem que ter 20 candidatos, não teve candidatos suficientes 1:58:13 acho que foi isso que ele disse, 0 áudio diminuiu 
Leilane: Por que isso, não tem aluno?

Eddy: Não tem procura. Deu para entender?

Leilane: Porque não tem mercado.

Eddy: Então certas áreas crescem, ou elas se mantém ou não mantém. Em Guarulhos, quando eu ministrava aula lá, quando implantamos o curso de 1978, na época me chamaram para, digamos, agilizar o processo todo, tinha design de produto, projeto de produto e comunicação visual. Eu ministrava aula para uma classe que tinha 80 alunos, de projeto de produto, duas classes. Esse ano passado fui dar uma palestra, tinha duas turminhas de projeto de produto, cada uma com 12,16 alunos. E depois o que aconteceu? Nesse próximo ano vai ficar só o design gráfico.

Leilane: Pulverizou, não é, cada faculdade está se segmentando, ficando responsável por uma parcela.

Eddy: Então você, digamos, eu me lembro, na Faap, me formei em 1970, aí em 1972 oficialmente eu comecei a dar aula na Faap. A Faap, em 1972, o cursos de desenho industrial, era uma sonoridade bonita, tinha baiano, tinh pernambucano, tinha gente do interior de São Paulo, era impressionante, a Faap era o curso que centralizava. E o tempo passou, as pessoas que moram na região de Bauru nunca mais virão para São Paulo, porque tem a Unesp. Quem mora em São Bernardo do Campo vai para a Mauá. Quem mora perto do 02:00:16 vai para Lorena. Quem mora em Campinas vai para a PUC. Então com isso a Faap reduziu o número. $O$ próximo semestre eu não vou dar aula porque não tem aluno.

Leilane: $O$ curso de artes também está diminuindo, não é?

Eddy: O que vai dar tudo isso? Não sei. Mas é uma realidade.

Leilane: Mas é que a Faap tem um aspecto cruel, porque eles elitizaram muito, aumentaram demais as mensalidades, porque a Santa não passa po esse problema, a Santa tem as turmas dela, não é?

Eddy: Ali é uma outra situação, outro assunto, complexo, como consegue administrar no top, não é, o network, as famílias tradicionais, e depois desce a Avenida Pacaembu e vai dar na Uninove.

Leilane: Quase outro extremo. 02:01:20 um pessoal com muito mais bo vontade, é que não tem aquela base cultural, o que já é ruim é de um alun de elite hoje, a gente percebe, mas o cara tem muito mais boa vontade, só que ele só despertou para isso porque pelo financiamento ele pode ter a oportunidade tardiamente, não é?

Eddy: Então você vai lá e dá duas palestras na Uninove.

Leilane: Era a Heloísa que era a coordenadora, faz um tempão, não é?

Eddy: Agora é um professor que era de Guarulhos. E com essas e com outras você vai dar palestra na Uninove, olha a carinha deles, assim, puxa vida, tem gente bacana também...
Leilane: Tem.

Eddy: Dentre aqueles 30, tem dois ou três com um potencial muito grande. Leilane: Tem muito o que a gente chama de formiga, não é?

Eddy: Então eles ficam olhando, assim, o aluno que trabalhou o dia inteiro na empresa, não é, é um funcionário, e à noite ele tem que ouvir uma coisa que não consegue entender.

Leilane: Não consegue projetar, é meio aquela coisa do homem que virou suco. É triste, porque tem muitas pessoas que fazem faculdade e pagam 1.500 reais. Isso é muito triste.

Eddy: Uma violencia até.

Leilane: Sem dúvida. A gente já conversou sobre projeto, até onde vai a arte e o design, e você acha que isso não tem que se fechar mas, por outro lado, pra que pede que se feche, um conflito, também concordo que não tem que se fechar, mas é possível compreender, pra tornar mais clara essa abordagem, até onde vai a arte, até onde vai o design, ou até onde a moda vai nos dois...

Eddy: A moda vai nos dois e precisa utilizar esses dois segmentos. Separar isso seria uma atitude de uma inflexibilidade muito grande.

Leilane: Seria uma atitude dialética.

Eddy: Sim.

Leilane: Mas você acha que há interesse nessa discussão?

Eddy: Quem sabe um possível interesse num segmento mais intelectual, cultural.

Leilane: No âmbito acadêmico.

Eddy: Sim. Lá fora, a não ser, digamos, um empresário que tem uma visão mais... mas a grande maioria, a produção...

Leilane: Tanto que tem os fast-fashion, não é? O que você acha da questão da autonomia cultural e da identidade nacional dentro do projeto de moda? Porque a gente, hoje mesmo era muito pra tendência, principalmente pra 2000, 2000 e pouquinho se olhava mais para tendência, mas hoje você vê, até a Macy's, que é um magazine americano de luxo copiando uma sandália da Melissa. Quer dizer, não é só a gente que copia.

Eddy: A sandália Havaianas, o que é a sandália Havaianas?

Leilane: Uma sandália, com todo respeito, uma sandália de pedreiro, da minha infância. Uma sandália de solado azul, preto, amarelo.

Eddy: A concepção dela é um guetá. Então, como eu digo...

Leilane: Não tem nada novo, não é? Novo, novo..

Eddy: $\mathrm{E}$ tem algumas coisas que foram uma grande novidade, mas, depois, eu tenho muitas dúvidas hoje. Eu diria assim: no momento em que houver mudanças.. 
Leilane: Quebra de paradigma, nao é?

Eddy: Nas matérias-primas, nos processos, aí o desenho avança, senão, praticamente, digamos... Então a cara que parece mais uma. Olha que novo! $\mathrm{O}$ que é novo de fato? Na ideologia das famosas cadeiras de plástico. Põe uma ao lado da outra, tem um detalhe, tem uma curvatura $X$, mas quem sabe tem quatro pernas.

Leilane: Paradigma que eu falei, tem quatro pernas, tem assento e tem encosto.

Eddy: Porque na verdade nada mais é do que a reprodução negativa do homem. Tem que mostrar as costas e o bumbum. Depois eu coloco um componente, pode ser, num nível industrial, tentar baixar o custo dela, que vai render um pouco mais, vai ter um diferencial, mas na essência é sentar.

Leilane: $O$ que é mais novo na moda é a postura, a lingerie sem costura, que já é antigo, que é da década de 1990, que é antigo, e a de spray, que não virou nada comercial.

Eddy: Aí seria interessante fazer um discurso dessa cronologia, e onde vão ocorrer esses desdobramentos e transformações.Você vai ver.

Leilane: De regra, de projeto...

Eddy: Aí eu acho que é fundamental, eu não sei, é difícil, mas pra mim eu não tenho dúvida.

Leilane: Acho que são visíveis, não é?

Eddy: Ah, são. Tem um livro que foi lançado agora, até comprei, é um livro sobre as 50 máquinas que mudaram o mundo. Conhece esse livro? Tem na Livraria Cultura. Vale a pena. Aí você vai ver, aparece lá o tear, a máquina de escrever, o telefone... são 50 produtos que mudaram.

Leilane: Aí eu vou falar do design, do design de moda como um parâmetro de comportamento também. A vida se modificando em torno da tecnologia e o comportamento de design seguindo o comportamento, gerando comportamento também, quando você tem um iPhone, você também modifica.

Eddy: Aí é um recorte muito interessante. $O$ aparecimento da Vespa, da lambreta e o comportamento da menina que, digamos, tem que esconder roupa e usar calça comprida.

Leilane: Sim.

Eddy: Aí são coisas interessantes para observar, também não ficou um coisa isolada, está contextualizada, e alguma coisa, digamos, levou a isso. Ou pensar nas aeromoças, da Air France, que mostrava todo um, aí tem a contextualização que o homem chegou à Lua, e a PanAmerican fez muito isso também.

Leilane: Sim, sim, eles têm um apelo futurista absurdo

Eddy: Muito. E as mulheres são sensuais, e as roupas..
Leilane: Faz muito sentido, porque na década de 1960 foi a época do anticoncepcional...

Eddy: Então eu acredito que um estudo interessante é sempre contextualizar o momento histórico. Acho que aí contextualizou essa história, a tecnologia existente, por que vai à Lua? Porque tem a Braun [?] 02:08:50. Ele vai pra Lua, mas na verdade tem um lado bélico, o presidente falou que 0 mundo só acabaria por causa das guerras. Eu estudei história, diziam, então, na paz... não. Como a Guerra do Cem Anos. Só guerra.

Leilane: Desde a Idade Média, ou é peste ou guerra.

\section{Eddy: Não é verdade?}

Leilane: Aí desenvolve uma vacina ou uma arma e aí a coisa anda.

Eddy: Então, digamos, ah, a paz, não vai existir a paz porque o homem criou a própria guerra, é a luta constante do espaço, por mais teorias que existam mas, tem alguma coisa que rumina. A exposição do Da Vinci que está aqui no Sesc tem as máquinas de guerra.

Leilane: Eu vi uma exposição dele quando estive na Galeria Ambrosiana, em Milão, aí do lado da Santa Ceia tinha os projetos feitos em Rhino, como funcionava, o elevador, até canhão, é mais ou menos isso.

Eddy: E ele, um gênio, fazia máquinas. Por quê?

Leilane: Muita coisa para forte, guerra.

Eddy: Então não há muito que fugir. $O$ design, não, o design também é o desenho das coisas, não dá pra fugir. E tem o jato, o Boeing, tudo mais, é tudo para guerra.

Leilane: A meia-calça, não é?

Eddy: Risos, tem que começar a entender que, digamos...

Leilane: A lingerie de lycra surge na década de 1930, não foi nem só por causa da guerra, mas pára de ser produzida para a guerra, a mulher volta a usar lingerie de tecido plano e depois volta.

Eddy: Eu creio que esse recorte, esse estudo, que dá pra entender essas interfaces, econômicas, políticas, design, indústria, e outro lado que trabaIha com um conceito mais romântico, que também existe.

Leilane: Eddy, eu vou tentar reduzir agora, que são dez para as duas, não é? Bom, metodologia visual, você disse que sua disciplina era mais voltada para o design de projeto, desenvolvimento do projeto do produto. É uma disciplina pra tratar de projeto, você também já falou...

Eddy: É sempre a parte gráfica. O que eu faço? Especulações com tipografia, eu faço especulações com a questão de suplementar imagem, depois, no segundo semestre, é o terceiro ano, essa disciplina estava no segundo ano quando foi implantada e depois passou para o terceiro ano.

Leilane: Era do segundo? 
Eddy: Exatamente. Aí nós consideramos numa ocasião que essa disciplina no segundo ano pedia informações que os alunos não tinham, então colocamos no terceiro ano e vai muito bem.

Leilane: Que são as exposições que eu vi lá na Santa.

Eddy: Isso, então o terceiro ano acho que é o momento ideal para isso.

Leilane: Dentro dos cursos de particular (? 02:12:48) a gente percebe que em geral tem uma disciplina, um grupo de disciplinas que regem as outras. Em geral, os cursos de moda, de design, acontecem em torno do projeto, das materias criativas. Você acha que isso acontece na Santa, o que você percebe?

Eddy: Tem algumas que são um pouco mais de ponta, coleções, tudo mais. .

Leilane: Design de coleção, estilo...

Eddy: Isso, tem uma força maior. Mas eu sinto também um equilíbrio. Mas a força maior está aí, centrado nesse segmento. Mas, por exemplo, com a subdivisão hoje editorial, joalheria, acessórios e têxtil, tudo mais, hoje, digamos, as pessoas entendem que é um universo.

Leilane: Que projeta uma ação em grupo.

\section{Eddy: Exatamente.}

Leilane: A Ethel Leon também fala, ela dá um exemplo da luminária SS do Giorgio, o Giorgio, do Falanghi, que ela foi feita pela Lumni e faz em metal, depois vem a Artemide e faz em plástico, uma coisa assim, não sei se é ao contrário, mas mostra que o design é uma coisa feita em grupo, não é definitivo, $\mathrm{o}$ ato projetual.

Eddy: Claro, sempre será assim. Alguém vai produzir, vai ter um engenheiro de produção...

Leilane: Um responsável, um chefe de produção pelo menos...

Eddy: Claro, e vai ter algum 02:14:23, concorda comigo? A não ser que você faça a sua produção independente, na sua oficinazinha e tudo mais...

Leilane: Mas mesmo assim, precisa ter o retorno.

Eddy: Agora precisa ter alguém no comercial, você não tem condições nem tempo de administrar tudo isso.

Leilane: Seus alunos de moda, você acha que eles estão, em relação ao seu projeto no mercado, eles estão mais ligados à essa realidade? Acha que eles estão muito descolados, saem muito autores, não tem aquela facilidade de falar com o cara da estamparia que de repente tem um nível de instrução menor e não entende que vai ter que brigar por preço, de se criar uma peça que crie gargalo.

Eddy: Pontualmente, por exemplo, quando, o que eu sei, mas está se formando essa turma este ano. Tem uma aluna chamada Mayara. A Mayara está na Swarovski. Aquilo é um doce de pessoa, de uma seriedade, não é? Essa..
Leilane: Eu conheço só de vista, porque na verdade dou aula na pós, eu sei quem é.

Eddy: Ela foi duas vezes para o Japão, e ela mora em Santo André. Aquilo pra mim, digamos, claro, tem que depender dos valores (acho que é isso 02:15:54, o resto não entendi)...

Leilane: É um estímulo a mais.

Eddy: Nossa senhora, e é uma pessoa assim que tem uma troca bonita, entende, por e-mails, conversa, professor, impressionante, um professor que colaborou comigo, não é? Então aquela troca positiva profissional. E ela, digamos.

Leilane: Madura, que reconhece.

Eddy: Agora tem a Giovanna, essa é outra, sete e meia está lá. Ela é bonita, o trabalho dela é bonito, e ela trabalha também, atua profissionalmente. Então você conversa com ela e é um outro nível. Agora a maioria, $80 \%$..

Leilane: Muito descolado da realidade. Isso parece que é uma constante, não é?

Eddy: É uma constante. Pelo menos no caso do Santa Marcelina.

Leilane: É, mas acho que não é só lá, viu...

Eddy: Porque ainda vive o romantismo do glamour do curso de moda.

Leilane: Eu acho que numa faculdade de um nível mais baixo, necessariamente, como uma FMU, eu dei aula na FMU há nove anos. Percebi que os alunos tinham mais força de vontade.

Eddy: Pra poder conquistar o espaço dele.

Leilane: Porque sabia que tinha que tinha uma defasagem cultural. Eddy, só pra fechar: o processo de criação a gente falou, existe uma preocupação em criar uma identidade nacional, um estilo nacional, ou ainda de mais tendência vinda da França?

Eddy: $O$ que eu posso falar é o seguinte: essa magia francesa, que começa na Rhodia, isto ainda é um embargo que permanece com força. Essa força desses grandes centros, a moda feminina francesa e a moda masculina italiana, essas duas referências, são internacionais. Elas espelham ou demonstram a sua estrutura. Então essa história do Brasil é um negócio complicadíssimo, muito complicado. Eu, por exemplo, faço parte do comitê da Renner, você sabia?

Leilane: Não, não sabia.

Eddy: Do prêmio da Renner.

Leilane: Ah, que legal.

Eddy: Então eles estão entusiasmados em fazer todo ano a premiação da estampa com temáticas brasileiras. Então muito bacana, fui lá, teve exposição aqui no Shopping Bourbon, foi feito o catálogo, muito bem feito por sinal, e já 
estamos preparando a terceira edição para o ano que vem. Quem coordena esse trabalho é a Renata Rubi, do design de superfície, é ela que comanda isso. E as temáticas sempre serão ligadas ao Brasil, como foi, digamos, o sonho da Arte Nativa Aplicada, em usar artes nativas brasileiras. Mas a arte nativa aplicada, vai ser lançado um livro, estão completando um livro, quem está organizando é o Marcelo 02:19:31, como documento histórico. Nunca deu lucro.

Leilane: 02:19:41 Fala da Leilane, A companhia de tapetes ocidentais, mais ou menos o mesmo pensamento.

Eddy: Exatamente. Tudo isso fica na estrutura de uma elite intelectualizada que compra, digamos, da empresa $X$ ou autora $X$.

Leilane: Compra exclusiva.

Eddy: Exatamente. Quer dizer que, entre os dias de hoje, dos sistemas de comunicação, precisamos quem sabe, de buscar essa marca brasileira, nós não temos uma marca, já percebeu? O México tem, nós não temos. Eu trabalho lá com a Joyce, do prêmio lberj, ai, o Brasil, mas no fim das contas, sim, ganhamos prêmio na Alemanha, na Itália, mas eu sou entusiasmado por isso, só que também tenho pé no chão. Mas quanto está revertendo em dinheiro para o Brasil e a nossa produção? Não é nada. É reconhecido sim, mas tem que pensar em exportar tudo isso. $O$ prêmio, a condecoração, é tudo maravilhoso. Ah, digamos, os produtos do Sérgio Rodrigues estão sendo vendidos em Nova York, mas quantos milhares saem daqui? O móvel brasileiro sai cem, duzentas unidades, isso é um design de exclusividade.

Leilane: Produção seriada.

Eddy: É, mas pensando em fazer um projeto em plástico no Brasil. Tem que pensar muito nisso. A Itália faz um projeto em plástico lá, ou nem faz mais lá, faz na China ou na Coreia, e aí você esparrama por todo o mundo, aí dá pra você investir. E depois vem com uma chancela que é italiano, não é?

Leilane: Claro, ainda valorizam

Eddy: Nós, que móvel temos produzido em plástico? Um ou outro em uma escala muito pequena. Então nós temos uma premiação, somos reconhecidos criativamente, mas, sim, respeito, mas o quanto é que...

Leilane: Qual a adesão disso que gera retorno?

Eddy: É mais fácil dar uma olhadinha em alguma coisa, muda isso aqui, esse molde eu faço na Itália, produz na China e vende.

Leilane: A obra do Alessandro Mendini 02:22:19, que você acha no 1,99, de cores que não existem.

Eddy: Claro, então é um pouco delicado esse processo todo.

Leilane: Acho que é isso, Eddy. Tem mais alguma coisa que você queria pontuar, que deva servir de referência, até coloquei aqui: para o designer de moda ou desenhista de moda, estilista ou criador a despeito do nome que ele tem, há alguma referência para ele se pautar no momento do ato projetivo, ainda na pesquisa, na formação?
Eddy: Eu não acredito que nós precisaríamos.

Leilane: Considerando essa questão que você falou que é muito interessante, de colar qualquer análise que seja feita com o contexto histórico, como preparar, de repente?

Eddy: $O$ que nos precisamos é de um triunvirato nessa história toda. Um é encontrar designers efetivamente criativos, é muito difícil. Uma tonelada está se formando, mas efetivamente, mas criatividade, se pensando em projeto, não é? Em indústria e processo. Muito difícil. Se você encontrar alguém, me avisa porque esse vale a pena. Alguns eu, sabem que têm essa visão e são até anônimos, muitas vezes, as pessoas que têm um trabalho muito importante.

Leilane: É, porque a gente vê isso, um projeto de ônibus para a 02:23:49, é dificílimo achar o nome da equipe de design, a equipe Betanin(foi o que entendi 02:23:55), da vassoura, a equipe Betanin é diferente da cadeira Ovo, da cadeira da Ovo, você sabe quem é.

Eddy: Então o que acontece? Tem pessoas trabalhando e com seriedade, e que tem grande produção. Você nem sabe. E depois do outro lado, isso um detalhe que precisaria ser estudado com muito cuidado esse processo todo. Aí precisamos entender que precisamos, de um lado esse design, da sua equipe, precisamos de técnicos, e pessoas com alta capacidade para resolver problemas técnicos, ou seja, esse homem, essa menina, não sei, que tem, digamos, um conhecimento profundo nisso. Aí precisamos somar com um empresário que não seja industrial, sabia disso? Eu conversava um dia com o Passos Jordão, que é o 02:25:00, ele falou assim: "Eddy, o Brasil tem industrial, mas não tem, digamos, empreendedor".

Leilane: Ah, entendi.

Eddy: Industrial, ele fala assim: "ah, vamos fazer essa cadeira aqui, alugar aquele galpão todo não é, ah, ganhando dinheiro e tudo mais, vixe, está perdendo dinheiro, fecha tudo, acabou". O empreendedor não tem mercado. Ele tem uma visão, ele acredita em design e acredita em mercados, ele acredita que pode pode ser, então, um empreendedor.

Leilane: E o design como solução, não só como estética.

Eddy: $\mathrm{E}$ depois de tudo isso, essa é uma base importante. Aí depois vem uma figura muito importante e fundamental, não pode se intrometer, porque la tem outra função nessa estrutura toda, mas é de fundamental importância: a política governamental. Porque se não tiver essa não vai adiantar nada. Esse é criativo, mas perai, e agora, e as linhas de crédito, como eu trabalho complicado: a ignorância dos empresários. São ignorantes, porque não têm formação, não êm cultura. E outro lado, o dos designers, que têm umas elocubrações que não tem nada a ver também, bobagem. E de outro lado um emaranhado, como erasília 02,26,49, você vê aqueles corredores, ah, mas é, andar de cima, da indústria, ministério tal, mas a pessoa não está, ah, mas como é que era mesmo? Fiquei três anos lá. Ah, você é premiado, tem design, tudo bonito... 
Leilane: Design como adjetivo.

Eddy: Então se esse triunvirato, a preparação de gente, somado à liderança de um bom designer, a tecnologia somada ao empresário efetivamente empreendedor e que respeita e conhece isso. Ai vai trabalhando, vai fazendo, vai sofrendo, patina, patinando um pouquinho, depois volta, o buraco é mais embaixo. E do outro lado sério dos designers, dos estudantes de design, estou sempre rindo com eles, eu falo assim: vocês gostam de política? Não, não gosto de política. Ah, então desculpa, mas... o design é política em todos os sentidos. Mas é claro que eles estão pensando na política partidária, mas não é isso, é a política em um sentido maior da palavra. A política que define e determina caminhos e que dá o respaldo institucional, e dá abertura para que isso aconteça, somado a empresários bem intencionados, que também vão investir em tudo isso.

Leilane: É porque é reconhecido juridicamente, como eu comentei, mas quais as ações para que isso cresça e floresça? Não é bem logicamente só como processo social, mas como questionamento filosófico. Na década de 1990 mesmo a gente vê um acesso muito grande de vários setores ao design, isso já é um avanço.

Eddy: E é muito interessante, acho que o próprio Marcos tinha levantado isso. É interessante, quais as proporções, no governo militar, foi o que mais se investiu no desenho industrial no Brasil. É incrível. Uma coisa é você olhar..

\section{Leilane: Para exportar, não era isso?}

Eddy: Ene coisas foram feitas, não estou defendendo. Então será que é paradoxo, será que as pessoas entendiam isso, como elas interpretavam tudo isso, então isso tem que ser estudado hoje.

Leilane: $\mathrm{E}$ é uma atividade também que se alastrou muito mais, claro que o nível vai ficando cada vez mais heterogêneo. Mas era uma atividade de elites, não é?

Eddy: Hoje é um outro universo, e com isso causa essas dúvidas, onde começa, onde termina, como é que soma, como é que se multiplica tudo isso?

Leilane: Os espaços diferentes.

Eddy: Sim, sim. Além dessas outras coisas, tem um dado que não pode ser esquecido: as faculdades de design que nasceram da arquitetura, faculdades de design que nasceram do departamento de Letras, sabia disso?

\section{Leilane: Letras?}

\section{Eddy: Letras.}

\section{Leilane: Que cursos?}

Eddy: $O$ curso de desenho industrial do Paraná, da Universidade Federal do Paraná, em 1973.

Leilane: $\mathrm{E}$ é bem reconhecida.
Eddy: Sim, mas aonde ela nasceu, não é?

Leilane: Achei que você ia me falar até que era de artes.

Eddy: De artes foi grande parte delas. $O$ Rio de Janeiro, por exemplo, precisa ser estudado urgentemente o curso de desenho industrial da Federal do Rio. $O$ desenho industrial nasceu na ESDI ou tem todo um passado, no tempo da Belas Artes, na ocasião tinha uma pessoa que não me lembro onde foi, mas teve uma discussão e falou assim: essa história está mal contada, tem outras histórias atrás de tudo isso, não é? E o próprio Marcos Braga se formou na Federal.

Leilane: É, mas é aquela coisa também, tem essas discussões, essas lutas pelo poder, tal, a Anhembi também fala: ah, a gente criou moda primeiro, a Santa fala, não, foi a gente que criou. A Anhembi tinha o Cebrafan antes, acho que em 1987, a Santa no MEC reconhecida em 1988, é, mas é, foi antes, e aí?

Eddy: São essas as histórias, eu diria: são importantes, mas também são um pouco relativas. É importante $\mathrm{o}$ aspecto, digamos, o outro...

Leilane: Não é definitivo, muitas vezes não é determinante.

Eddy: É... acho que são dados que devem ser estudados, mas por outro lado tem outros problemas para serem resolvidos. Está bom, linda?

Leilane: Está bom, Eddy. 
BERNARDES, Circe. Entrevista realizada com Circe Bernardes, em 22 de janeiro de 2015, na cidade de São Paulo, com 2 horas e 42 minutos de duração.

Formada na FAU (1972-1978) e em artes plásticas na FAAP (1970-1974). Entende projeto e estilismo como a mesma coisa, como sinônimos. Fez muita estamparia têxtil, tudo de forma autodidata. Ela fazia estampa para a Arte Nativa Aplicada chamada pela Maria Henriqueta Gomes que era a dona e fundadora da empresa.

Ela é altamente especializada em desenho. Quando a chamaram na Arte Nativa falaram que sabiam da qualidade do desenho dela e que ela era amiga do Fernando Milan.

Falaram para ela que iriam abrir uma loja só de desenho indígena. As referências vinham de cartões postais. Isso aconteceu quando a Circe cursava a FAU. Muita pesquisa era feita a partir de cartão postal e assim surgiam lenços. A chefa dela ia para Paris e trazia cangas e faziam cangas, lenços e almofadas. A Anna Maria Henriqueta Marsiaj (nome d solteira), proprietária da Arte $\mathrm{Na}$ tiva Aplicada, foi casada com Severo Fagundo Gomes notório político e empresário proprietário da fábrica dos cobertores Parahyba. Ele foi ministro da Agricultura no governo Castelo Branco, ministro da Indústria e do Comércio no governo Geisel e senador de 1983 a 1991 por São Paulo. Ele e sua espos faleceram em um acidente de helicóptero que também vitimou Ulysses Guimarães e sua esposa, Mora Guimarães. Na Arte nativa aplicada sempre contavam com algum dono ou empregado de oficina para ensinar o básico sobre silk. Não usavam cilindro. A Arte Nativa fazia panôs, mas não fazia corrida.

Abril de 1976 seguiam as tendências de cor que vinham de Paris. Muitas cores eram reduzidas por questão de custos. Viajavam a Maria Henriqueta Gomes e a Matilde Penteado Milan. Maria Henriqueta era casada com o ministro Severo Gomes e era conhecida do Carlos Mauro Rosas da Fonseca. Maria Henriqueta, Matilde Milan e Carlos Mauro formavam a tríade de ponta da estética, que traziam a moda para cá. Maria Henriqueta foi quem trouxe o primeiro smoking do YSL.

Depois foi solicitado à Circe criar desenhos para estamparia corrida. Isso uma pessoa da oficina que ensinou o ofício da estamparia, do silk para ela. Lembra-se de usar tons terrosos com azul petróleo e cinzas. Circe fazia as cores da estampa para serem impressas no tecido. $O$ primeiro desenho era feito a guache, nanquim tudo em pincel, para depois solucionar a questão no tecido que leva em conta o encaixe, o rapport, o registro. Inicialmente o desenho da estampa não considerava nada pertinente à estamparia. Conta que fazia manualmente linhas de 1 metro com pincel e guache.

Ela desenhava com o pé no chão como o índio como uma forma de inspiração para chegar a desenhos indígenas para a Arte Nativa. Havia um ritua para desenhar estampas para a marca. Ela chegava a levar um mês para desenhar um almofada inteira, desenhava quadrado por quadrado e não só o rapport. Nesse caso o desenho era reproduzido inteiro. Antes de ser instruída sobre rapport ela chegou a desenhar $1,5 \mathrm{~m} \times 1,5 \mathrm{~m}$ à mão antes de descobrir o conceito e como aplicar rapport.

Ela conheceu Carlos Mauro na casa da Maria Henriqueta Gomes. Circe era amiga das filhas de Maria Henriqueta. Circe era bandeirante junto com as filhas de Maria Henriqueta.

Quando ela estava na FAU Carlos Mauro solicitou à Circe que trouxesse para ele um currículo na Rhodia para viajar para a França. Eles se conheciam desde quando Circe tinha 12 ou 13 anos.

Carlos Mauro conta que lembra dela subindo e descendo as escadarias da FAAP quando ele cursava graduação em artes plásticas. Lembra que ela fazia teatro com o Naum, falavam dos baús de figurinos do Naum. Nessa época havia uma comunicação entre o Teatro Municipal e a FAAP.

Nessa época Circe fazia vários cursos de desenho e pintura na FAAP. Ela conta que não sabia fazer currículo e como não tinha perfil corporativo Carlos Mauro achou melhor ela não entrar em uma empresa fechada, cheia de regras como a Rhodia. Nessa época ela já tinha entrado na FAU, aí ela teria que largar a FAU e ela não queria.

Ela tinha bolsa na FAAP de mérito. No começo da FAU ela ainda fazia FAAP a noite então não poderia ingressar em um emprego integral na Rhodia. Ela lembra de estar na Arte Nativa em 1976 e sempre encontrava Carlos Mauro em eventos.

Ela queria fazer as cartelas de cores para a Rhodia e se oferece para isso, antes do CIT. Ela abriu uma empresa, como autônoma para prestar consultoria à Rhodia e então Rosas chamou Circe como artista plástica para fazer cartela de cores para a Rhodia. Com a empresa que ela tinha ela entrou no $\mathrm{CIT}$ e pagava o CIT representada por sua própria empresa para poder fazer o curso.

$\mathrm{Na}$ FAAP ela era monitora do Donato Ferrara. Era aluna a noite e monitora a tarde.

Naum Alves de Souza foi professor de teatro da FAAP. Ela fazia teatro na hora do almoço.

O Flávio Motta trabalhava direto com o Bardi e o Chateaubriand no MASP e participou ativamente da composição do acervo do museu. Ele era o diretor dos cursos da FAAP. Era o curso de desenho para professor, de objetos plásticos [27'] Cursaram esse curso Carmela Gross, Cândida (esposa do Nelson Leirner), Marcelo Nitsche, Fábio...

Para ela eram todos gente grande nessa época. Ela devia ter uns 15 anos. Ela sempre conviveu nesse ambiente desde sua infância.

Ela conta que fez muita performance estimulada pelas aulas de teatro do Naum. Conta inclusive que o Serginho viu. Ela falou dessa performance, chamada "O diploma do amor".

A turma dela a noite era o Marco Zanine...e iam para a casa do Donato 
Ferrara. Diz que eles iam fazer a "nova arte contemporânea". Os trabalhos aconteciam por meio de sorteios com números e entrava somente quem era contemplado no sorteio em detrimento da qualidade do trabalho que não era analisado. Contava somente a causalidade. Ganhavam o lote (um pedaço de espaço) para criar o seu trabalho.

Volta a falar do Diploma do Amor inspirada no Diploma da Mãe criticando os chavões e a comercialização de datas. Falou que ruiu a performance que - Flávio Império foi lá para filmar por causa da presença da miss Brasil no centro que causou alvoroço. $O$ Gregório, o Serginho compareceram.

Ela conta que conseguiu a autorização para a performance no viaduto do chá porque sua mãe era prima do prefeito Figueiredo Ferrari e levou biscoitinhos lá de Cajurú que ele adorava e colou. Ela queria também proteção policial. Ele riu e colaborou com a performance dela.

Em 1990 ela recebe outro telefonema de Carlos Mauro, mas desconhecia o curso de moda da FASM.

Em 1977-78 ela se inscreve na Bienal para pintar outro outdoor. Enquanto isso o Carlos Mauro ia acompanhando sua carreira.

$\mathrm{Na}$ Rhodia quando ela fazia as cartelas Carlos Mauro se aproximou mais dela e nessa época ele chama Marie Rucki para ensinar o processo de estilismo aqui no Brasil. A partir daí ela se aproxima mais do universo do projeto em moda ou estilismo.

\section{O Carlos Mauro também foi vê-la no teatro.}

Carlos Mauro liga para ela em 1990 e fala que a Vera Lígia irá procurá-la orienta a fazer curso de estamparia com Vera Lígia. Ela assume a disciplin "Oficina Experimental" no curso de moda da FASM. Lá se fazia de tudo, chapéu, sapato etc e como isso se equilibra, qual material deveria ser usado. Ela também ensinava cartela de cores na disciplina dela.

Quando frequentava a FAAP ela tomava chá com a D. Annie Penteado na casa rosada. Era uma casa com cômodos com pé direito alto, salas amplas com a filarmônica tocando ao fundo.

O Flávio Motta foi quem criou esse curso de formação de professores na FAAP. Tinha curso de cerâmica, escultura com o Cacipore Torres etc.

Depois disso o Flávio Motta vai para a FAU dar aula no departamento de História.

uando a Circe entra na FASM ela tinha que desenvolver tudo: ementa, metodologia, plano de aula etc. Ela lembra de ensinar qual era a sequência de uma cartela de cores. Ela discorre sobre a relação das cores umas sobre as outras ou umas próximas às outras. Os tons influenciam uns nos outros. Criam-se cores também que servirão de referência para o fabricante tingir e desenvolver tecidos e aviamentos. A ideia era isolar a cor sem referência do lado para pensá-l livre, sem intenções na criação e no desenvolvimento de produto.

Ela fala que os alunos traziam "a cor que tinham vontade" e assim também funcionava quando ela trabalhava na Rhodia. Surgiam as "cores que tinham vontade" a partir das reuniões e sempre calhava de as cores da Circe serem rosas. Conta dos varais na Casa Rhodia na Avenida Brasil. Tudo para ela foi tirado de experiências pessoais para dar aula. Ela contou de sua experiência fazendo cenários para o Palace e conta que trabalhou com o Flávio Império.

$\mathrm{Na}$ FASM a Circe solucionava problemas de estamparia, joalheria. Onde havia problema a chamavam para resolver. Ela deu a disciplina até o Carlos Mauro precisar de uma assistente.

Ela conta do problema causado pela Sandra Harabagi ao tentar invadir o conteúdo de estilismo de Carlos Mauro. Ela era professora de Laboratório de Criação, matéria introdutória ao estilismo, mas não era estilismo. E sua postura gerava muitos problemas.

Ela queria dar estilismo então ela deturpava o conteúdo ou dava de uma maneira avançada comprometendo o ensino inicial da disciplina. Ela invadia o espaço do Carlos Mauro. Ela dava o shopping no primeiro ano de acordo com sua leitura que não era a maneira dele. Faltava diálogo e chocavam as confusões.

Circe deu a disciplina dela uns 6 anos e aí virou assistente de Carlos Mauro.

Ela conta que chegou a ser convidada para dar aula na FAU, mas na época não pode aceitar.

Ela conta que encarou bem virar assistente. Acha que o professor é um instrumento da universidade e não é dono da disciplina. Ela conta que sua geração era de ponta que quebrava paradigmas.

Ela conta que viu shows da Rita Lee, dos Mutantes no Mackenzie. Seu comportamento de ponta despertava o interesse de Carlos Mauro.

Ela fez curso com a Christine Yufon que dava curso de elegância. Foi modelo também. Conta como copiava as roupas de Courrèges em costureiras finas.

Conta que desfilou para alunos na FASM. Ela era muito prestigiada.

Lá pelo quarto ano de FASM ela foi viajar, passear na Europa. Todos apoiaram sua viagem. E aí colocaram no lugar a Paula Motta, filha do Flávio Motta. Era amiga da Circe, conviviam juntas há muito tempo. Fizeram o colegial no Mackenzie e a FAU juntas e ficaram muito amigas. Ela indicou a Paula Motta que ficou lá, pois se adaptou muito bem. Vera Lígia defende a presença de Paula Motta na faculdade dada sua boa performance como professora da disciplina de "Oficina Experimental". Mas há um dark side nessa história.

Somado a isso a situação de Carlos Mauro se complica com muitas turmas e Vera Lígia e o próprio Carlos Mauro sugere que Circe seja sua assistente. Carlos Mauro precisava de alguém que falasse a sua língua para ajudá-lo em sala.

Circe fala dos vários cursos que fez com Marie Rucki. E fala que o Carlos Mauro quem a trouxe para o Brasil.

O Carlos Mauro era puro mistério...e soltava um "bárbaro". O que é bárbaro? 
Circe conta que isso era complicado.

Ela conta que estava como estilista na loja de Renata Milan e aí ela foi fazer o curso com ela quando Renata Milan se filia ao CIT.

Circe conta que sentava com Rosas para fazer o programa do curso. Ele partia do princípio que a Circe já sabia como ele ensinava estilismo. A fala dele era "quando você não fala claro, você tem que pensar" porque tudo era um jogo. Para ele Moda é jogo e depende de você montar esse quebra-cabeça, esse xadrez, você é que monta.

Ele não dava os elementos e falava para os alunos saírem e fazerem o shoping que podia ser em qualquer lugar, até no armário da casa. Mas rua, fora e ver tudo o que você acha interessante.

es programaram o curso por ano. No segundo ano que seria o primeiro de estilismo haveria o primeiro contato com o estilismo.

A documentação e o shopping para Circe eram nomes distintos para um mesmo fim, eram coisas parecidas, análogas, quase a "mesma coisa". Era mudança de palavra para a mesma coisa.

Ela lembra que no segundo ano a preocupação era como seriam trazidas mais informações. Os professores queriam mostrar que havia segmentos diferentes na moda, streetwear, alta moda, clássica, noite etc. Como entrar em contato com isso?

No segundo ano a referência era sua vida, estava em você, na sua in fância. Primeiro você "catava" tudo o que você gostava. No terceiro ano os alunos "caiam" na rua.

Você trazia elementos, mas ia formar mesmo lá no terceiro ano. Isso que diferenciava.

Primeiro os alunos buscavam referências em suas vidas, na sua infância.

No shopping a sala era dividida em 3 grupos e cada grupo ia buscar suas referências e decidiam para onde iam: o CEASA, a "rua das putas" (rua augusta), terminal tietê de ônibus, gafieira, salão de baile etc. Daí surgiam 3 tendências diferentes. Nenhum grupo sabia para onde o outro iria.

Depois todo mundo trazia a pesquisa para a sala e eram definidos os elementos mais fortes e havia discussão sobre os elementos trazidos. Dessa discussão saia tudo, cartela de cor, forma, shape etc.

Fala como o método da Mari Rucki era parecido com a Première Vision. Falou sobre a possibilidade de Rucki influenciar outros teóricos e vice-versa.

Até que ponto a Ambience da Rucki era painel ou espaço físico.

A moda casa também saia da ambience discutida em sala, poderia sair de uma das 3 tendências.

Não se falava em tema na aula de Carlos Mauro (preciosismo). Os alunos ficavam perdidos por falta de direcionamento objetivo. A própria Circe se dizia perdida para orientar os alunos.

Circe ficava muito depois do horário da aula tentando ajudar os alunos a decifrar o que o Carlos Mauro queria.

A Circe pediu a demissão porque repetiu um aluno e o pai queria acabar com ela. $O$ bedel precisou defender a Circe e as irmãs apoiaram o pai a aluna. $O$ pai estava furioso. As irmãs diziam que ela não podia reprovar o aluno. E a Circe replicava: eu até gosto da aluna, mas ela teve mau desempenho. E as irmãs respondiam: minha filha, aqui nós não gostamos dos alunos, são todos iguais. Ela conta que chorava, chorava e chorava. Ela foi para casa e no dia seguinte voltou à FASM e pediu demissão. $E$ as irmã disseram: tudo bem, tudo bem, nós também já estamos aceler..., então nós vamos fazer um acordo. Não, você vai embora e vai receber...(era a irma Angela quem estava por trás disso).

O bedel que a defendeu bateu em um aluno a mando de João Monteiro. Foi um escândalo na época. Foi uns 10 anos depois que a Circe saiu.

A Circe conta que também teve que entender o processo do Carlos Mauro. As alunas pediam ajuda para fazer cartela de cores etc, mas isso era mais claro com a Sylvie Leblanc e com a Chiara Gadaleta. Parece que se fazia muito pouco de objetivo na aula de Rosas.

Depois Sylvie Leblanc e Chiara Gadaleta foram demitidas por João Monteiro, administrador que demitiu 13 pessoas.

A Circe fez pós em aquarela na FASM. Ela conta que teve problemas com indumentária com as irmãs como usar chinelo, regata. Ela conta que as irmãs chamavam a sua atenção.

Para o aluno o que era mais forte era $\circ$ aluno entender o que ele tinha que fazer. Porque eles não conseguiam entender o que tinham que fazer. Todos os alunos passaram por isso. O clima de arrivismo dependia da turma da qualidade da turma. Diz que Rosas dificultava quando a turma era pior.

As dúvidas dos alunos eram sobre referências, "como eu posso usar isso para transformar em uma cartela de cores?" Cada uma trazia seus elementos, ferramenta do avô, a barbie. Circe conta que ele respeitava muito as referências do aluno, nunca espinafrava. Podia ser as canetas que você brincou a vida inteira. $O$ que contavam eram as referências que te levaram fazer um trabalho de moda.

Circe conta que às vezes ele ficava bravo e ele falava assim: isso não tem nada a ver com moda. O que você está fazendo aqui? Você deveria faze curso de culinária chinesa. Rosas acabava com as pessoas e muitas desistiram do curso. Em geral quem saia era gente fraca, aluno com potencial não sofria isso. Mas Circe conta que viu muito isso.

Ela conta que no primeiro trabalho já via o potencial dos alunos e conta que muitos cresciam, evoluiam, mudavam de um trabalho fraco para um trabalho que se fortalecia. O temperamento e o meio de campo da Circe fez com que muitos alunos continuassem o curso. 
A irmã Ângela dizia: Ah! Era você que estava lá na frente? Você é uma das nossas, não pode estar vestida com esse vestidinho, de regata...vamos ver se você agora vem sempre de manguinha, que é legal. Ela conta que isso acontecia na frente de outros professores.

Circe conta que na aula de Rosas já ouviu uma bronca: você é minha assistente ou está me assistindo? Apesar de fazer sempre os cursos de Rucki entre outros. $O$ primeiro ano de trabalho ao lado de Rosas foi muito mais difícil para Circe porque para ela entender o que ele queria levou certo tempo.

Ele queria que ela falasse, participasse, mas ela deixava ele falar, comandar. Ela interferia, mas tinha dia que não se sabia como ele iria estar. De qualquer forma, ela conta que Rosas sempre respeitava suas falas em sala. Rosas era uma pessoa muito difícil de lidar.

Circe diz que não sabe se era o processo que ele queria, mas parece que para ele fazia parte do aprendizado o aluno ir descobrindo o jogo. Fazia parte do jogo descobrir sozinho o que tinha que fazer. $O$ professor não podia falar para o aluno o que ele tinha que fazer. Soa vago.

\section{OS 3 TEMAS}

Cada coleção se referia a uma tendência.

No segundo ano você fazia sua coleção sobre a sua referência pessoal e de infância.

No shopping, no terceiro ano você tinha que fazer 3 tendências por isso dividia a turma e tudo era mostrado ao grupo.

Tudo era corrigido e havia muita exigência então os alunos tinham que voltar várias vezes aos lugares do shopping e ficavam apreensivos se Rosas iria gostar ou não da pesquisa realizada.

Você escolhia qual das 3 tendências você tinha mais afinidade para desenvolver sua coleção. Era uma tendência para cada coleção.

As referências não eram cruzadas, nem ligadas. Geralmente, no terceiro ano as alunas acabavam trabalhando com o que elas foram atrás e tinham pesquisado.

No quarto ano a pesquisa era individual, no TG.

Tinham que ser feitas 3 tendências, isso sobrecarregava. Circe saiu da FASM no início de 2000.

Ela repetiu a aluna do terceiro ano junto com a Sylvie Fleury, mas a responsabilidade recaiu sobre a Circe. Ela lembra da demissão de Sylvie. Lembra que ela estava no jardim regando as flores quando recebeu (acho que em casa) um telegrama de demissão.

\section{Com a saída de Rosas:}

A Circe deu aula com a Elaine Milane no segundo ano, em 1997. 0 Carlos Mauro gostava muito dela.
Ela ficou com a Sylvie Leblanc no terceiro ano.

E no quarto ano ela dava aula com a Chiara Gadaleta.

O temperamento da Sylvie e da Chiara era completamente diferente e a ideia era integrar os conteúdos das aulas das duas. Sylvie como era francesa tinha temperamento forte.

Aí com a saída do Carlos Mauro não há mais centralização da disciplina na mão de um só professor de estilismo. E a invasão da Sandra se intensifica.

Com a saída de Carlos Mauro Sandra avança mais ainda no terreno do estilismo, mas não há problemas aparentemente. Não é dada muita atenção ao fato e, nesse momento isso é secundário.

A Circe descobriu no meio do ano que a professora era ela, mas aí entra Sylvie e então a Circe volta a ser assistente. Ela reclama nunca terem dado a ela uma oportunidade legítima de ser professora, mas somente assistente.

Conta que recebeu uma lista para assinar e aí seu nome constava como assistente e não como professora. Ela acha que não tinha o mesmo capita social e cultural. Atribuía a isso o fato de a Sylvie ser francesa, ter estudado e dado aula na França e a Circe não. Também fala no final da entrevista da importância do networking que ela chama de uma postura pessoal.

O nome da FASM estava acima de tudo. Chiara havia sido assistente de Marie Rucki.

Depois das críticas às suas roupas ela foi de chemisier de crepe e colocou um guarda pó com um bordado "Tia Circe" e sapatinho de salto baixo de normalista em reação às reclamações das irmãs às suas roupas. Conta que $\circ$ Feres riu, mas não percebeu o que era, mas que havia uma mudança.

Circe conta que agiu assim em relação à roupa durante uma semana.

As irmãs reclamavam que ela subia a escada de 2 em 2 degraus e assim poderia aparecer sua calcinha. Na hora de fazer as missas ela era solicitada para fazer cenário, mas depois a criticavam por sua roupa e comportamento, aparentemente sem razão.

Apesar de tudo ela se dava bem com a Irmã Ângela Rizero que era a irmã mais influente lá. Hoje a equivalente é a irmã Valéria.

Ela reclama que as alunas não podiam desfilar roupas transparentes porque aparecia o seio e a genitália. E que isso era um contrassenso para FASM que se pretendia vanguarda, conceito.

Conta do caso que uma aluna jogou uma caixa de lápis na cabeça do Carlos Mauro durante uma discussão.

Circe conta que ela se sentiu ofendida e que Rosas realmente era muito ofensivo com os alunos. A aluna ficou muito nervosa e Rosas era muito nervoso e fumava demais.

Apesar das diferenças ela era amiga de Rosas e conta que dedicou seu trabalho de formação (TG) a ele. 
A inspiração do shopping, por exemplo, se você foi a um salão de baile, não dizia respeito nesse momento da pesquisa ao público alvo, mas a estética e elementos de inspiração que direcionariam a coleção.

Ela fala que os alunos deveriam direcionar seus produtos entre básico, intermediário e fashion para seu público.

Em sala de aula:

Depois do shopping a pergunta era: qual é o elemento mais forte, você tirava sempre qual é o elemento mais forte que ia dar a "cara" do "negócio", então que nome que ia ter isso aqui. Então a gente dava um nome para essa tendência. Que nome que tem isso aqui? Lanche da tarde, entrevista das seis, suco...cheiro de fruta...você que sabe...cada um dava, cada um fazia.

Então cada um dava, cada um fazia. Então a classe tinha 3 tendências todas escolhidas no ambience. Qual era o elemento mais forte? Então esse fica, não, esse tira, esse não tem nada a ver, isso não tem a ver com essa história, não sei o que...então como você chegava a nisso, ficava isso.

Então agora, a partir daí cada um vai fazer o seu trabalho. E cada um fazia sua cartela de cores, matéria, tecidos (você fazia os tecidos = maquetes têxteis), tecidos oferecidos pelo mercado, shapes (formas do seu objeto = forma - nada a ver com boa forma, era estudo de forma), silhueta, desenhava sua coleção e confeccionava um look (fora da aula ou na aula de modelagem), pois não havia tempo para fazer em sala.

Eles ensinavam o que era um look, composição etc. A ideia de look era mais enfatizada no terceiro ano. Mas no segundo ano os alunos já faziam a peça, no terceiro o look e no quarto a coleção.

A aluna filha de usineiros de Piracicaba trouxe um casaco de pele e tirou a etiqueta $e$ ainda assim o Rosas gostava dela pela sua influência e isso contava muito na FASM nesse período.

Ela conta que no primeiro semestre era o protótipo, mas no final do ano tinha que fazer a roupa super bem acabada. Essa informação não bate com o depoimento da maioria das entrevistadas como alunas.

Ela lembra do desfile da Fabia Berseck, da Gisele Nasser, Wilson Raniere, Sara Kawazaki (da Clos to teve um problema com os judeus ?!), Simone Mina.

Ela fala que o círculo de influência em torno de Herchcovitch era forte po ser judeu. As relações pessoais contavam muito. A Circe e a Sylvie deram dinheiro para a coleção de Wilson Ranieri e ajudaram muito não só a ele, mas a outros bons alunos.

Conta que o curso de moda tb tinha um perfil de "espera marido", muito parecido com a escola normal.

A Circe via o estilismo em tudo na hora em que ia ser feito o TG, na joalheria, na fotografia, no vestuário. As diretrizes do estilismo eram aproveitadas em todas as áreas.
CAMARENA, Elaine Soares. Entrevista realizada com Elaine Soares Camarena, em 5 de dezembro de 2014 na cidade de São Paulo, com 52 minutos de duração.

Teve aula de Estilismo com o Carlos Mauro Fonseca Rosas. Era o único professor de estilismo. A Sandra Harabagi deu desenho, foi a resposta quando perguntei sobre outros professores envolvidos em disciplinas relacionadas à processo criativo.

"Criação, criação mesmo só o Carlos Mauro e o Donato Chiarella. O Donato Chiarella (era da FAAP) dava aula de metodologia visual que hoje a Paula Motta dá. Ensina a questão da composição, cores complementares e opostas, comunicação visual, técnicas de composição, linhas imaginárias que ligavam uma imagem à outra, como se fazia para compor, como se fazia para conseguir uma cor, como você fazia a combinação entre elas, a questão do exercício.

Exercício de fazer vestidos iguais em papel e faziam listrados sobre eles para mostrar como as listras influenciavam o vestuário. Era só o vestido de papel (produto), não era o croqui.

Não teve aula da Vera Lígia, nem teve aula de Estamparia, Design Têxtil. (Ver histórico da Elá). Também não teve aula com o Eddy, nem com a Miti. Ela também não teve Computação Gráfica. Ela teve aula de História com a Maria José Jorenti.

Desenvolvimento de Projeto de Produto ela não lembra nem do nome da disciplina. Era a disciplina do Eddy.

A Evandra começou como Professorado em Desenho e acabou como Moda. A da Elá foi Desenho de Moda desde o início do curso. Mas chama a atenção ela não ter tido algumas disciplinas. A turma dela foi a que consolidou o Bacharelado em Desenho com habilitação em Moda.

A Elá participou do CIT uma época e fez curso com a Marie Rucki depois.

Como os conceitos de estilismo / projeto em moda eram ensinados em sala?

O Carlos Mauro era muito amigo da Marie Rucki quando ele começou.

A ideia era você encontrar tema em qualquer coisa, de preferência que não fosse moda. Ela citou o livro que escreveu sobre ele e que será lançado em 2015. Ele levava os alunos ao Largo da Batata para fazer o que ele chamava de Shopping. Ele falava a gente aceitava (autoritarismo).

Shopping

Você pode tirar inspiração de qualquer coisa, de qualquer elemento, do que você quiser na verdade. E que de preferência, nesse momento, não seja nada relacionado a moda. Não é Oscar Freire. Não vai a uma rua que tenha vestuário. Porque se você for olhar isso você tende a copiar. A ideia 
a princípio era se descolar da moda. A Elá foi à loja de panelas e comprou o pinguim de geladeira. E a partir dele nasceu a inspiração para criar toda a coleção.

O shopping permitia desenvolver uma maneira de criar coleção de moda que não fosse literal e que fosse conquistada ali só a inspiração e que isso desse a ideia do que fazer.

Depois do Shopping fazia a o painel de inspiração que ele chamava de Ambiência. Hoje a Elá entende que ela acaba se tornando o seu escritório, 0 seu lugar. $O$ ambiente te inspira e não a cartolina branca, o painel. Trata-se de um processo de imersão. Na época faziam colagens.

[Penélope dá show sem cobrar ingressos].

Fazia 12 looks por coleção, 3 looks por ano confeccionados (36 looks) com 3 temas (as tendência que a Mari apontou) e aí modelava tudo e desfilava. Ela teve aulas de estilismo em 1989, 1990 e 1991.Ele pedia 3 temas em uma coleção só. Os 3 temas da Elá eram: índio (touro sentado), boneca (poupée), e egérie (um ídolo de infância, mentor). Isso tudo foi no terceiro ano, um ano antes de ela se formar. $O$ egérie dela foi sobre o Freddy Mercurie.

As ambiências eram feitas por meio de colagens coloridas A3, por meio da junção de 2 folhas de A4, mas só a Elá imprimiu na Cópias Brasil, nem tinha Alpha Graphics ainda. Fez a colagem no pc, o Amiga. Esse rendeu o videoclipe. Foi o TF dela.

No shopping você encontrava algo que te chamava atenção, um "tema" Buscavam-se a partir daí imagens para criar a Ambiência e depois disso Cartela de Cores pintada com Ecoline à mão fazendo o 8 à mão, mas fazia vazado e cortava depois. $\mathrm{O}$ oito era para pintar as fibras de um lado e de outro do papel e pintar retângulos grandes para depois recortar do tamanho que você queria. Pelo que eu entendi era feito o oito grande e dele se recortavam os retângulos. Sempre as cores deveriam estar dispostas em fundo branco, todas do mesmo tamanho, à mesma distância e distribuídas da seguinte maneira: a cor dominante, depois a duas cores próximas à essa dominante que fazem com que ela seja mais importante ainda, então essas são as intermediárias e por último as tônicas. Então tinha que ser essa a composição e tomar cuidado para que uma cor não brigasse com a outra.

Cor dominante é a que apareceria em maior quantidade na coleção, intermediárias eram para compor com a dominante e complementar a coleção as tônicas poderiam aparecer em certos momentos na coleção, em pequenos detalhes.

Depois da cartela de cores vêm os grafismos. Eram os estudos dos elementos para estampa. Mas ela não teve design têxtil, então não estudou nesse momento rapport. Os grafismos também deveriam ser provenientes da Ambiência. Depois disso vinham as Maquetes de Tecido. Era exigido que fossem feitos 12 grafismos em geral.

As maquetes de tecido demonstravam a visão do estilista sem conhecimento técnico. Ela conta de uma conversa que teve com um engenheiro têxtil que achou incrível. O foco era a visão como estilista que estava sendo desenvolvida ali, sem conhecimento técnico, sem saber se funcionava ou não para depois passar para o engenheiro têxtil avaliar se era tecnicamente viável.

Para a Elá estilista nada tem a ver com designer porque nem sempre o que o estilista está pensando vai ser passível de ser produzido. Ela fala que quando vê alguém criando não vê a pessoa pensando onde vai o botão, o zíper, se entra ou se sai, qual é o forro.

A FASM privilegiava esse fazer absolutamente livre. A Elá fala que eles só faziam isso.

A Elá falava já sei o que eu quero, mas como é que eu vou fazer? O DonatoChiarella comentou com ela uma vez: você não tem que ficar pensando como é que vai ser feito. Você tem que criar. Mas seu eu criar e não souber fazer isso não vai existir.

O fato de a maior parte do corpo docente ser composta de artistas influenciou nesse processo de não normatização.

Em seguida vinham os desenhos, depois das Maquetes. E em seguida iam trabalhar a forma, modelagem.

Faziam croquis, mas sem quantidade cabeças, "bem livre". Critica a rigidez da regra das cabeças para a ilustração de moda e a falta de regras para o desenho técnico. Para ela as regras nesse segundo é que importam. $O$ croqui é um esboço rápido da sua ideia e só funciona se o próprio estilista for para o manequim. Ilustração é o croqui promocional, pós coleção feita.

Ela trabalhou na Rhummel. Fez curso de malharia circular e contou de vários cursos de modelagem e calçados que fez. Realmente o fazer projetual fica prejudicado durante a formação em detrimento da "criação do autor livre" em decorrência não de má fé, mas até por falta de tempo. Alunos saem das escolas sem conhecer as etapas de estilismo ligado à mercado. Isso prejudica a visão que se constrói sobre a área.

Ela comenta que o currículo dela está repleto de cursos livres que nem sempre tem certificado. Mas ela está sempre estudando.

Na FASM quem dava Moulage era o Tino Adamo, professor italiano. A modelagem era feita na aula do Tino porque não dava tempo na aula do Carlos Mauro.

Depois do croqui básico, faziam a forma intuitivamente na aula do Tino e sem ficha técnica. Hoje ainda não tem.

Ela não usa marcação de cotas (que marca as medidas no desenho) porque faz proporção e acha que só pode ser feito isso depois da piloto. Medidas só iriam na ficha de produção e não na de pilotagem. Ainda há muitas divergências na área sobre isso. Ela faz uma pré ficha, de criação porque ela fazia muito China então não acompanhava a confecção da piloto. Concordou que a ficha técnica deveria ser feita em conjunto entre o estilista o modelista. 
O modelista tem o estatus do "instrutor técnico de oficina" do design na área de moda. Quem realiza o tridimensional é reconhecido por possuir menor seu capital simbólico.

As pilotos eram feitas longe da Elá como estilista, pois o chefe não pagaria viagem ao exterior para acompanhar a pilotagem, por isso ele desenvolve métodos de desenho por proporção para minimizar erros. Foi em 1993 que isso aconteceu e desde então ela vem aprimorando este conhecimento projetual por meio do desenho. Ela fez o primeiro desenho de moda feito em coreldraw2no Brasil.

A Elá chegou a frequentar o Cebrafan.

Voltando ao estilismo com o Carlos Mauro eles faziam o desenho ilustrativo, fazia a roupa, resolvia a trilha sonora, escolhia os modelos e desfilava 1 look de 3 executados e 12 desenhados.

O desfile também compunha a nota. Ela só teve contato com os autores de moda de projeto em moda no Mestrado, depois da graduação. Na graduação não conhecia, até porque eles nem existiam na primeira turma da Moda. Usavam livros de arte, Gombrich, Argan etc como referência para estilismo.

Na UAM apesar da justificativa de o curso ter surgido do design nunca conheci bibliografia de design na graduação. Não havia contato entre os cursos de moda e design no campus Morumbi, após 2002 e isso era mais forte enquanto o curso de moda da UAM funcionou na Rua Quatá, até 2001, ondecada curso funcionava em um prédio, então a possibilidade de troca era mais remota.

Na FASM as aulas eram mais práticas e não se praticava a escrita.

Conseguiria conceituar projeto em moda na época da graduação até certo ponto, sem conhecer nomes, mas tinha clareza do processo. A Elá era a melhor aluna do Carlos Mauro.

Livro "Book de Moda" do Senac sobre o Carlos Mauro.
BRAGA, João. Entrevista realizada com João Braga, em 8 de dezembro de 2014, na cidade de São Paulo, com 2 horas e 36 minutos de duração.

Leilane: Bom, hoje é dia 8 de dezembro de 2014 e vamos fazer a entrevista com o professor João Braga, para o meu doutorado, o Projeto em Moda.

João: Projeto como, não entendi?

Leilane: O nome do meu doutorado é Projeto em Moda, porque em hipótese não existia um conceito sobre um projeto em moda, depois das minhas andanças em diversas faculdades dando aula de projeto. As discussões são muito difusas, muito abertas, a gente até já tem uma bibliografia, vou começar te perguntando isso.

João: Não sei nem se existe um projeto no MEC com relação a isso.

Leilane: Existe. A Vera Ligia que registrou.

João: Porque é aquela história: moda é encaixada na área de design.

Leilane: Até 2002, pelo MEC. Isso mesmo, certinho, tudo que tiver contato com o design, interiores, móveis. Aí a gente tem 2005 tem a Doris Treptow que é do Rio Grande do Sul, a Sue Jenkins Jones, e aí uso também o texto de projeto, Simon Seivewright, Colin Renfrew. Queria saber se você conhece esses autores, e de repente vai falar, "por que você está me entrevistando, sou estética de moda, de projeto, de luxo?", você não é de projeto efetivamente, não orienta coleção e tal. Já orientou como professor mas nunca deu a disciplina, então você é estilista, sua marca de camisa, já orientou aluno e um professor de história muito graduado, já vi muita coisa com olhos críticos e isso me interessa nessas disputas simbólicas. A primeira coisa é se você conhece esses autores.

João: Não, esses dois não, esse Simon é aquele que tem filosofia em moda? Não, esse é o Lars Svendsen.

Leilane: Esse é o cara de Liverpool, faleceu superjovem ano passado. João: E essa é daquele livro da Cosac\&Naify?

Leilane: A Sue, é, é esse mesmo. Esse é clássico, são os clássicos. E aí tem uns autores de design, que eu sei você também fez artes plásticas, então nas suas andanças deve ter cruzado com esses livros. Tem um autor de produto que é clássico, tem dois na verdade, que é o Bernd Lobak, que é alemão, o Gustavo Amarante Bonfim, que é brasileiro, e o Bruno Monari, comunicação visual, queria saber se você conhece esses autores também.

João: Do Bruno Munari alguma coisa, ele está em algum livro?

Leilane: Das coisas nascem coisas e Comunicação visual.

João: Ah, não, até pensei que fosse um outro que tem um capítulo sobre moda, inclusive, num livro, acho de design, enfim, Bruno Munari sim, Das 
coisas nascem coisas... Esses daqui, às vezes me fogem os nomes, é tanta gente, é aquele livro um da capinha vermelha, um livro interessantíssimo, eu não lembro.

Leilane: Qual deles?

João: Não, alguns desses.

Leilane: Ah, esse do Simon 03:33 eu acho que é pai e filho, se nao me engano. Uma capa preta e verde.

João: Possivelmente eu tenho. Alguns deles é o de moda masculina?

Leilane: Não, esses são de coleção, da Simon é pesquisa para moda e principalmente para vestuário. 04:08 Projeto em moda para vestuário e administração de empresas e a Sue é aquele que é inicial. Na verdade estamos aqui hoje na Faap mas vou te entrevistar principalmente também pelo momento atual da sua carreira e fazer um foco na Santa, que estou falando como instituição primeiro, mas meu foco é nos agentes. Bom, quais faculdades você já lecionou, João?

João: Olha, faculdade, faculdade mesmo comecei na Unip. Enfim, dei aula na Unip até 1993, 1994. Como faculdade eu já dava aula em cursos livres e técnicos do Senac. Mas como faculdade a primeira foi a Unip.

Leilane: Cebraphan você nao participou?

João: Cebraphan eu dava palestras, não como professor. Aí depois como faculdade eu fui para o Senac, que ajudei até a montar o curso para o Brasil. Éramos quatro pessoas para adaptar à realidade brasileira. 05:17. Era o Daievos, a Elza Bastos, e um moço que nunca mais vi, chamado Eduardo, nao lembro o sobrenome. 05:28 Os três tinham feito moda em Paris e eu não, mas eu já trabalhava no Senac, então enfim. Depois eu já dava aula de moda em cursos livres aqui na Faap, desde 1990, que se chamava Faap Moda, ali na Rua Ceará, depois eles saíram e veio aqui pro prédio, e ficou só pós-graduação, eu dava aula e depois me chamaram para montar o curso de graduação. Então eu já dei aula, resumindo: Unip, Senac, depois Faap, UAM, Santa Marcelina e também no IED, mas no meu tempo de IED ainda não er curso superior, e dou aula também pela Federal de Juiz de Fora, em Minas, mas no curso de pós-graduação.

Leilane: Qual curso?

João: Em moda. Como professor convidado. Inclusive até cursei desenho e plástica lá na Federal de Juiz de Fora, e depois eu fiz educação artística. Dois cursos, então duas licenciaturas. E eles têm um prêmio chamado Medalha Presidente Juscelino Kubitscheck, que cada faculdade indica um ex-aluno, é um prêmio somente para ex-alunos das faculdades, foi instituído em 2008, se não me engano. $\mathrm{E}$ a faculdade de artes me indicou. Então eu fui o único da faculdade de artes que recebeu pelos serviços prestados à nação pelos meus livros. Curiosamente, o primeiro reitor, o professor Moacir, recebeu, e Itamar Franco também recebeu, porque Itamar era prefeito de Juiz de Fora quando a Universidade Federal de Juiz de Fora foi criada.
Então estávamos todos lá e fui agraciado. E nisso me chamaram para ser o padrinho dos cursos. E dei várias sugestões, esse da pós. Dou cursos livres e pós também na Santa e na Faap.

Leilane: Em qual faculdade você ficou mais tempo?

João: Olha, creio que tenha sido a Faap. Porque primeiro foi a Unip, depois o Senac quando mudou para Santo Amaro eu deixei porque ficou muito longe para mim, então acho que foi a Faap. Quando foi lá para Santo Amaro, eu moro aqui no Centro, muito distante.

Leilane: É, porque tive dois campus, tive aula com na vila olímpiae depois na Vicente Rao. Então metade do meu curso foi na Vila Olímpia e metade no Morumbi. 08:50

João: Sim, mas estou falando do Senac, aí eu ficava somente na Lapa, então montei um curso fora de graduação, de História da Moda, formamo duas turmas depois eles não fizeram mais.

Leilane: É, tem um histórico, né, aconteceu isso com mestrado também. Você está desde que ano na Santa?

João: Na Santa desde 2000. Eles sempre me chamaram, mas eu não podia, porque trabalhava o dia todo. Eu trabalhei 12 anos em uma companhia de tecidos, na

Leilane: Ah, você trabalhou lá? Fazendo design têxtil?

João: Estamparia, exatamente. Coordenava o ateliê. Eu saí do Ragueb em 1998.

Leilane: Conhece o Aieto Manetti?

João: 10:05.

Leilane: É, não sei se é parente também, é um cara que trabalha desde 10:11, pelo menos na década de 1970

João: Enfim, mas aí lembro que eles não quiseram continuar exatamente por causa dos importados. O São Lourenço, quando começaram os importados, começou muito tecido 10:31

Leilane: Isso no final da década de 1990?

João: Meados, assim quando foram abertas as exportações, seguraram, seguraram, seguraram, aí o concorrente começou a ter o mesmo produto com um preço bem inferior. Ele não quis continuar porque não admitia comprar sem nota.

Leilane: Sabe quem eram os concorrentes?

João: Eram Niazi Chohfi, não, Casa Fátima vende confeccionado, camisetas..

eilane: Mas vende tecido também?

João: $\mathrm{Na}$ época não vendia não. TBS, Duica 11:14, e tinha outro tambem, 
tecido nao sei quê Mansur, enfim, moda atacado também.

Leilane: Mas será que foi isso que também fechou a Braspérola?

João: Não poderia te afirmar. Inclusive o Marcos 11:45, porque quando nos anos 1980, eu entrei lá em 1985, eles praticamente me tiraram da faculdade. Em 1984 um amigo meu chamado Miron, fizemos faculdade juntos, veio fazer o curso 12:00.

\section{Leilane: No CIT?}

João: No CIT. Aí ele veio fazer o curso e a Lelia Gomes, que trabalhava como coordenadora de moda o convidou para montar um ateliê de estamparia porque a estamparia estava super na moda. Mas eles queriam alguém para não se preocupar, queriam moldar no nível deles. Então chamaram o Miron, ele não aceitou e me indicou, que eu gostava, já pintava camiseta, trabalho de faculdade, fazia tudo voltado para moda, nisso fiz a entrevista e eles me aprovaram. Vim para São Paulo em 1985. Fiz o curso da ClTem 1985 e ali na Casa Rhodia, na Avenida Brasil, com o Carlos Mauro.

Leilane: Isso, tinha que fazer porque a Gueda??? era uma das empresas, ○ Jun Nakao consegue um estágio na Rhodia para fazer, não é? Tinha que conseguir. Quem é Anita, João?

João: A Anita Campos Luiz. Ela é brasileira, mas ela tinha até um sotaque francês, que tinha que falar fluentemente, o Carlos Mauro infelizmente morreu, mas Anita Luis..

Leilane: Faz uns dois anos, não é?

João: Ele morreu acho que em julho de 2011, porque ele lançou o livro da Moda no Brasil em 8 de junho de 2011, o Carlos Mauro acho que foi a última aparição pública dele, depois logo veio a notícia da morte dele. E ele gravou, foi um dos expoentes do nosso vídeo. $O$ vídeo não pôde ser comercializado, enfim, me cobra. Então, da Anita, eu soube uma vez que alguém encontrou com ela, talvez a Vera Ligia tenha notícia da Anita. A Vera Ligia leciona estamparia na Casa Rhodia.

Leilane: Sim, e ela que levou o Carlos Mauro para a Santa.

João: Foi, exatamente.

Leilane: Esse DVD, falamos dele em outra ocasião, desculpa voltar nele, mas era sobre criação e pesquisa ou só sobre criação do Carlos Mauro, porque a gente falou dele em outra situação. Vários depoimentos, foi um que passou na TV Cultura?

João: Foi, então foi o nosso projeto de moda no Brasil, das influências às autorreferências. Só que tudo aquilo que temos de licença de imagem, autorização, e no DVD ficou dificílimo, tem 20 modelos, uma modelo maquiada, quem é quem ali? Aí o advogado de direitos autorais nos aconseIhou: produza, mas não venda, dê de brinde, então quem foi na noite de autógrafo do livro ganhou o DVD de brinde. Foram dois casos curiosos de livrarias, que a caixa do livro era igual à caixa do DVD. E uma das livraria foi uma caixa vendida, mas não tinha preço, só que quem comprou nessas duas livrarias acabou ganhando o DVD, risos. Mas não vendemos, ainda tenho alguns exemplares e se quiser te dou um. E aí, Leilane, o que acontece? Fiz esse curso, sempre gostei de sala de aula, agora na Santa eu não dou aula para o pessoal da moda, na Santa na graduação eu dou aula de História da Arte. Na pós-graduação que dou aula de Cultura e História da Moda.

Leilane: Quando você estava na Santa, entrou pelas mãos da Raquel Valene?

João: Raquel e Vera Ligia. Porque as duas já tinham me chamado para dar aula na graduação, mas eu trabalhava no Ragueb e não tinha condição. 16:37. Aí o que aconteceu? Foi montado o curso de pós-graduação de Moda e Criação, isso coloca uns 15 anos atrás, que hoje a Renata Zaganin coordena. E aí quem dava uma disciplina chamada Estudo das Correntes Comportamentais de Moda seria a Vera Ligia, mas ela teve um problema de saúde e precisou se afastar para fazer o tratamento. Aí as duas me chamaram, conversaram comigo e pediram para dar essa disciplina. Então fui como convidado, porque não era da graduação. Então eu dei essa disciplina e dei sempre, ela mudou de nome, só que no final a Raquel Valente em duas ou três turmas ela não quis que eu desse essa disciplina como professor, mas os alunos estão solicitando que eu dê porque eles gostaram. E eu já dei e a Renata gostaria que eu desse junto com as próximas turmas.

Leilane: Isso é que é moral, hein, João, risos.

João: Talvez eu possa dizer que estive em todas as turmas. E aí eu saí do Ragueb, porque aquela história toda, o Ragueb não queria mais e resolveu fechar porque não queria conviver com irregularidades, porque estavam deixando de vender porque os mesmos produtos e tecidos eram encontrados mais baratos, aí foi devagarzinho fechando e diminuindo..

Leilane: Ah, eu lembro de ver isso ainda na adolescência, entrei na faculdade e não vi mas Ragueb Chohfi.

João: Hoje eles continuam, mas não como têxtil, estão no mercado imobiliário. E quando eu saí do Ragueb fui convidado para dar aula na Santa em uma disciplina chamada Cidadania e Moda, que depois foi transformada em Cultura de Moda, e que depois a Raquel também quis acabar com essa disciplina.

Leilane: Em que ano isso?

João: Ah, isso deve ter sido 2000, quando entrei, era Cidadania e Moda. $\mathrm{E}$ aí dei anual, e a partir do ano que vem será semestral. $\mathrm{E}$ aí nesse processo todo, uma professora, Maria José, que dava aula de História da Arte, saiu de lá e como eu fiz artes tínhamos que fazer registro no MEC para ser professor e sou registrado para dar aula de História da Arte pelo MEC também. Aí comecei a dar aula de História da Arte na Santa e estou lá até hoje e de História de Moda sempre foi a Miti Shitara. Na graduação eu dou História da Arte e na pós Cultura e História da Moda. 
Leilane: Mas nos cursos de moda?

João: Nos cursos de moda, a gente direciona o olhar com essa possibilidade de interface, e aqui na Faap dou aula para os cursos de moda e Histori da Moda; para o curso de design dou Estética e para o curso de produção cultural dou aula de uma disciplina que se chama Moda, mas seria cultura de moda, tem a ver com o universo da moda, o que por sinal, até há um tempo, não sei hoje, mas é o único curso de produção cultural que tem uma disciplina de Moda.

Leilane: Parece que é voltar no tempo, porque a moda na Santa Marcelina surge a partir de uma disciplina, do curso de desenho.

João: Em 1964, a irmã Eugenie Villien esteve em Paris e viu a faculdade de artes, viu que aquilo era interessante e introduziu como uma disciplina do curso de artes, então foram visionárias. Quem introduziu curso de moda no Brasil foi Irmã Valéria, na Santa Marcelina, Eddy e Vera Ligia.

Leilane: A Irmã Valéria está lá ainda?

João: Não, se aposentou, ah, falei Irmã Valéria? Não, é Irmã Ângela, desculpa! Porque o Eddy se não me engano dava aula na Universidade de Guarulhos nessa época.

Leilane: Eu já o entrevistei, ele dava aula na UnG, na Belas Artes, no Mackenzie, na Faap...

João: E muita coisa voltada para estamparia, e aí conversou com Vera, Irmã Ângela e montaram o curso. Então eles têm esse mérito, mas foi na mesma época que 22:07 estavam moldando a Anhembi Morumbi. Mas aí uma começa antes e a outra tem aprovação primeiro, então ficam sempre disputando quem é quem. Apesar que um pessoal de Belo Horizonte da UFMG que dizem que foram os primeiros, mas não era superior, eram cursos técnicos, tecnológicos.

Leilane: Eles têm o discurso mas quando você pede provas eles não têm. Até aí então a Anhembi Morumbi foi a primeira, e o Senac tinha cursos antes.

João: Não, a Santa, em 1964, como curso superior. Esse ano faz 27 anos de curso superior de moda. Lembro que vim para São Paulo em 1985, já formado, e tinha o curso de moda, que legal, enfim.

Leilane: Você ficou sabendo antes de surgir?

João: Não, quando surgiu, aí eventualmente me chamaram pra dar palestras lá na UAM, a Wandy Cavalheiro e Laís, que eu conhecia principalmente de mercado.

Leilane: Quem é Laís?

João: Laís Thompson, elas tinham montado lá na Anhembi e aí depois a Laís foi montar junto com a Cleusa a Unip.

Leilane: Em 1991.
João: É, que foi a primeira faculdade que de fato eu dei aula. Então fica esse quem é quem.

Leilane: Acho que a primeira Santa, esse negocio de ser a primeira oficialmente não é... não entendi 24:07

João: Engraçado que a primeira escola pública de moda foi a Federal do Ceará, com a Andreza.

\section{Leilane: Ah, é?}

João: Das públicas.

\section{Leilane: Eu achava que era a de Minas.}

João: Não, a Federal do Ceará, então quem fazia qualquer curso no exteror e vinha com seu diploma tinha que ter o reconhecimento por uma instituição pública que reconheça como curso superior. Conclusão: a do Ceara que tinha que reconhecer e curiosamente a Federal do Ceará se baseava nas scolas de moda de São Paulo, Santa e Anhembi.

Leilane: Teve uma reunião, não sei se foi em 1998 ou 1999, os coordenadores lá da Federal do Ceará que decidem se vão seguir os modelos de Anhembi e Santa.

João: Aí depois começaram a aparecer, teve a Estadual de Londrina, da Doroteia, que lamentavelmente faleceu, eu fui banca na aprovação, eu, Katia Castilho, Cris Mesquita, fomos convidados para fazermos as bancas de todos os concorrentes, fomos até Londrina...

Leilane: Estou usando texto dela no meu doutorado.

João: E curiosamente a última vez que vi a Doroteia foi em novembro de 2011, que eu fui lançar o meu livro em Teresina, a convite da Gisela Falcão, ela tinha ido dar um outro curso, uma outra história e daí à noite a gente se encontrou num restaurante. Foi ótimo, me trataram superbem, aí depois soube que a doença estava em um estágio mais avançando e depois soube que ela morreu recentemente. Mas a Doroteia é uma querida, nos encontrávamos em Paris e íamos tomar sopa de cebola, ela fazia viagens a Milão no Projeto Milano, enfim, Doroteia de fato é uma querida. Enfim, Doroteia foi dar palestra par ela em Curitiba numa escola e depois pela própria PUC de Curitiba, teve um curso de moda em que ela também estava envolvida. Enfim, mas foi isso, aí vi a Doroteia pela última vez lá em Teresina. Isso foi novembro de 2011. Então hoje tem na UEL, tem na Federal de Goiás, Udesc... Udesc acho que foi ate antes da UEL.

\section{Leilane: Mara Rubia, não é?}

João: Sim, ela foi minha aluna on-line num curso do Senac. Ela já tinha tudo.

Leilane: Nossa, o Eddy me falou que tem 155, 158 cursos de graduação.

João: É. Muita gente. O Brasil é o país que mais tem cursos superiores no mundo. A Esmod tem mais de 70 anos. 
Leilane: 73.

João: É, tem mais de 70 anos, estabilizados, você falou aí. Só que a Esmod continua funcionando, está lá. Nem França, nem Itália, nem Inglaterra tem tantos cursos de moda como o Brasil. Mas, ah, a questão da dimensão geográfica. Agora nós temos praticamente a mesma idade e a mesma dimensão geográfica dos Estados Unidos, e nem Estados Unidos tem tanto curso de moda como aqui no Brasil.

Leilane: Você tem indício do porquê disso?

João: Olha, moda ficou na moda.

Leilane: Isso tende a diminuir então?

João: Não, não sei, porque acho que hoje a dimensão já é outra, está ganhando até uma área específica do saber.

Leilane: Você sabe alguma coisa disso?

João: Não.

Leilane: Porque a Faap tem aquele estudo da Vera Ligia, quem assumiu foi a Tita, até estive com a Tita semana passada. 28,17

João: E quem fez um belo trabalho em relação a isso foi a Astrid, e o Wagner Leilane: A Renata falou que pode me dar esse trabalho.

João: Sistematizaram tudo, redigiram... Enfim, e a Astrid que ainda está lá, o Wagner saiu da Santa. E hoje está em Goiânia, Maringá, as públicas, particular então tem muito mais. Os cursos de moda viraram quase que prêt-à-porter, risos.

Leilane: Perdão do trocadilho, risos.

João: Perdão do trocadilho, não estou desqualificando, mas é uma realidade mais ou menos assim: se você faz medicina, se for pro interior do Acre, de Rondônia, vai ter trabalho até dizer chega, não precisa nem ir para lá, pode ser interior de São Paulo. Se faz moda, precisa de um centro urbano. Se o pessoal do Rio e de Belo Horizonte já reclama que é todo mundo focado em São Paulo na moda atual do Brasil, imagine.

Leilane: Você pode até ficar lá, mas vai fazer boné jeans ou modinha classe B. João, você lembra quem dava aula de estilo na Santa em 2000?

João: Sandra 29:57.

Leilane: Porque a Sandra dava laboratorio, o que me falaram até 1999 queria saber se está a par disso, o Carlos Mauro.

João: Carlos Mauro dava, é verdade.

Leilane: Aí ele foi desligado, e durante um ano fica a Chiara Gadaleta, tem até o nome dela no 30:19 de algumas alunas que orientou, a Mari.

João: Eu não estava, mas acho que a Sandra também dava uma disciplina de estilo.
Leilane: Será que foi no momento que o Carlos Mauro saiu?

João: Acho que ela dava, não tenho certeza,

Leilane: As alunas com quem falei até 2000 falaram que o estilismo era só centralizado na figura do Carlos Mauro. Quando perguntei se haviam outras disciplinas de processo criativo elas falaram da Sandra.

João: Curiosamente quando Raquel e Vera Ligia me chamaram queriam que desse estilo e eu nao aceitei.

Leilane: Isso que ia te perguntar agora, você conhece projeto de moda, tem um nome projeto em moda que usávamos na Anhembi, você conhece as etapas?

João: Um pouco. Eu era voltado muito para esse estilismo têxtil...

Leilane: A ideia de projeto que falo é calçado, joalheria, eu queria entender as etapas que você conhece e que te são caras quando você pensa projeto. Você se formou em artes e tem uma prática de mercado, que foi referência para você depois.

João: Com relação a moda, foi muito mais um autodidatismo baseado numa realidade comercial. Não tinha uma sistemática.

Leilane: Tinha cópia?

João: Tinha, tinha.

Leilane: De quê, de peça, de foto?

João: De tudo, porque se você chegasse para o confeccionista, 'eu quero comprar' - na epoca era assim - 'dez mil, 20 mil metro, mas eu quero esse desenho', e faziam, o objetivo era, eu criava, criava,

Leilane: Até onde você entende o que é criação e até onde você falava: ai, caramba, estou me estressando 32:37.

João: Quando eu estava no Ragueb, entrei lá em 1985, estava começando a chegar no Brasil, recém-trazida pelo Arena Imperial os cadernos de tendência. Promostyl, Dominic 33:00, era uma época em que isso já estava na Europa desde os anos 1970 e nisso o Brasil estava começando a receber essa ideia de trabalhar com tendências. Então essas tendências que vinham prontas e que todo mundo comprava...

Leilane: Então essa ideia de tendência não vinha da Rhodia? Talvez de uma tendência brasileira, mas ela veio..

João: Ela nos ensinou a fazer isso. 33:35, ela foi pioneira nisso, e esses temas vinham, normalmente era uma moda esportiva, uma jovem...

\section{Leilane: A Vera Ligia descreve exatamente isso}

João: Vanguarda, a gente poderia chamar de vanguarda, arrojadinho, não é? Cada um com seu papel de cores, e eu tinha que mostrar para o... não vou nem falar de uma macrotendência, era microtendência, dava para durar uma estação. Não era macrotendência como os japoneses, era tema mes- 
mo, sabe?! Brigitte Bardot...ah...vira Anos 1950. A gente inventava um outro nome nesse sentido para dialogar com essas tendências internacionais, onde isso tudo era falado.

Leilane: Você sabe quando surgiu aPremière Vision?

João: Surge, por causa da crise do petróleo, em 1973. Por qual razão em especial? A indústria têxtil europeia depende do sintético. A crise do petróleo, e aí, a gente não vai ter mais a matéria-prima para fazer essas coisas todas, aí os industriais têxteis franceses se reúnem e criam na cidade de Lyon, a Primière Vision. Acho que foi 1973. Eram só franceses, a coisa foi crescendo e passou para os europeus, hoje tem no mundo inteiro, e mais do que isso, hoje ainda tem o quê? Tem a 35:56 ruídos. Nova York, Tóquio e tem São Paulo também.

Leilane: Tem, isso já faz uns anos, 2012.

João: É, por aí. Não. Antes. Foi 2009, 2010. Porque a Fenit durou exatamente 50 anos, em 2008, começou em 1958, seguraram para fazer 50 anos certinho, e logo depois veio a primeira Primière Vision, essa filial, sucursal. aí a primeira foi criada e ficou super dimensionada, que já tinha os temas, paleta de cores, aquilo tudo. Quando foi em 1982, veja só, voltando um pouquinho antes: as regras da alta-costura saíram durante a Segunda Guerra Mundial, quando o 37:01, que era o presidente da (não entendi). Terminada a guerra, veio a moda francesa. Nos anos 1950, 37:13, era o Jacques (não entendi), que tinha loja no Rio de Janeiro. Aí logo depois da guerra os norte-americanos inventaram o READY TO WEAR, apesar de já existir na Europa desde o século $19 \mathrm{com}$ a Revolução Industrial. Só que eram chamadas roupas de confecção, você vê, a loja de departamento francesa mais antiga é de 1822! La Belle Jardinière. Não existe mais. E com o processo de Revoluço Industrial, começaram a produzir roupas em série. Se você pega o Émile Zola, O paraíso das damas, esse livro é genial, como que as grandes galerias e magazines estão destruindo aquele comércio familiar, pequenininho, o armarinho, depois veio o Le Bon Marché, La Samaritaine, a última foi a Galeries Lafayette, que como Galeries Lafayette é só de 1912, antes era não sei o quê Lafayette que era de 1900, mas não como Galeries Lafayette, que foi só em 1912, hoje talvez a mais famosa. O Le Bon Marché é o mais antigo que está de pé. 0 38:56 fechou, porque a 39:03 foi comprada por um grupo de árabes, e o francês ainda é xenófobo, e está deixando de comprar na 39:14,

Leilane: Não tem aura, não é, é diferente da indústria da confecção que você falou no século 19, eles têm uma capacidade de atribuir a aura...

João: Pois é, esse negócio da aura, a moda roubou das artes. É o seguinte, a aura é aquela teoria de que o artista é o abençoado, o divino e tem uma revelação e faz a arte. Que tem a peça única, essa teoria foi roubada pela moda por essa onda de luxo, vamos roubar a aura, e até a aura foi banalizada. Isso do artista abençoado, intocável, como eram em outros tempos. artista não é isso hoje, mas isso aí era uma coisa das artes, que o Rodeschi? fala muito disso também. Então nessa história toda já existiam as roupas de confecção, no século 19 na Europa. Mais Inglaterra, Itália não muito, tem uma loja italiana de 1971, não é tão velha. É Giovanni Battisti Giorgini, que tinha artesanato, objetos manuais, e voltando de Nova York para a Itália encontra com uma jornalista e resolvem entrar nesse ramo de moda. A segunda semana bombava e se você pega Sorreli Fontana, Schober 41:14, era Dior puro, baseado totalmente na moda francesa.

Leilane: E na década de 1990 é diferente isso.

João: Depois a coisa muda, mas muda pelo design. A Itália é forte no design de objetos e cria esse paralelo. Mas voltando a essa questão, o Jacques 41:39, o que ele faz? Em meados dos anos 1950 ele criou o prêt-à-porter création e não funcionou, porque era muito voltado para produção e aind era caro. Aí em 1955 ele cria o prêt-à-porter demi.Os anos 1950 são bonitos, sofisticados, o último suspiro de sofisticação, as 42:14 foram os penúltimos, depois os anos 1950, depois a moda jovem e isso foi debandar. E aí o que aconteceu? Ele criou as feiras em Paris. Pra ter uma experiência do prêt-à-porter nos Estados Unidos, a tal da ? wear, logo depois da guerra, já está bombando. Tanto que o Jean Claude Yves, que é um produtor têxtil de Lyon, montou uma missão de espionagem industrial nos Estados Unidos, o que es tavam fazendo, ganhando dinheiro com moda, embora fosse uma tradição francesa. Ou seja, qual o segredo, as roupas em série já sabiam fazer, logística e marketing para despertar desejo de consumo. Isso foi por volta de 1954, 1955. Aí o Alcântara Machado, já baseado nessas feiras que tinham em Paris, 43:20 para vender tecido. Só que as primeiras Fenits eram manuais, você mostrava o tecido, as pessoas olhavam, ah, bonito, mas era muito mais fácil convencer a pessoa com uma roupa pronta. Aí o que a Fenit vai fazer? Inventar a costureira brasileira. Aí inventaram o estilista e vão começar a chamar as pessoas que precisavam desenhar para as fábricas.

Leilane: Foi uma tentativa de criar uma identidade nacional?

João: Foi. Exatamente.

Leilane: Porque eu vejo coisas do Marquito e do Dener, me parecem tão Balenciaga, tudo tão francês..

João: Não, eles vêm depois, mas a gente nem precisa ir para os ano 1970, pega os anos 1980, ainda temos gente bebendo da fonte francesal Você pega pessoas daqui com toda a ideia do minimalismo japonês, vamos contar por partes, senão não chegamos lá, é só a minha análise de raciocínio. $O$ que aconteceu? A Fenit passa a ser uma feira de confecção e não da industria têxtil como foi inicialmente programada. Aí os industriais têxteis de Lyon criam a 45:05. Caio de Alcântara Machado, e quando chega 1982 ele cria a Fenatec, pra ter a feira de tecidos do Brasil, a Fenit de indústria confeccionada e a Fenatec de tecidos. E aí foi quando o Ragueb e o 45:22 que resolveram investir, já era uma potência, quando quis montar o ateliê em 1985, para participar da Fenit, aquela coisa toda.

Leilane: $\mathrm{E}$ como você desenvolvia o seu processo criativo?

João: Tinha as tendências, a gente fazia as tendências internacionais, 0 croqui, aí foi criado na Fenatec o Cim, não sei se você já ouviu falar dis- 
so, o Centro de Informação de Moda. Sabe quem era a coordenadora do Cim? Uma jornalista chamada Ana Maria Braga. Eu tenho fotos de Ana Maria Braga que nos anos 1980 ela está mais velha do que está hoje. Aí tinha a tendência lá do Cim e cada um trabalhava com um estilista, por exemplo, 46:24 com Lino Villaventura, Luiz de Freitas com Nova América (acho que é isso), aí, nos anos 1980, o que é moda no Brasil? A coordenadora de moda ficou mais importante que o estilista. $O$ dinheiro do tecido estava na 46:46 transporte (?).

\section{Leilane: $\mathrm{O}$ Carlos Mauro?}

João: Não, o Carlos Mauro era fibra, não era tecido. Era a Leila... esqueci o sobrenome dela, da Multifabril, era Ana da Bangu, junto com a Leila tinha o Edmundo da Nova América, enfim.

Leilane: $O$ tecido passou a se sobrepor em termos de estilo, você fazia vestuário com o que tinha de matéria, você pegou essa fase?

João: Porque dava muito mais grana. Peguei, eu comecei exatamente nisso. Eu tinha formação em desenho, por um estágio em Minas, na Industria Cataguases, aprendi a fazer um acetato, então eu era esse estilista têxtil. Eu na realidade já tinha me formado em dois cursos e estava fazendo um bacharelado que eu não sabia se ia fazer 48:10. Nem os professores me entendiam.

Leilane: Mas você estava com insegurança de arte não dar dinheiro?

João: Mais ou menos, vou ser sincero com você. Eu não gosto do meu desenho, é fraco. Primeiro: eu sou 100\% tendencioso ao abstrato, não ao figurativo, acho que quando nasci aquela coisa de abstrato dos anos 1960, risos, e não figurativo. Apesar de que isso vem lá de 1910, esse abstrato mais rico, enfim, e eu talvez por isso desenvolvia meus trabalhos, eram aprovados na escola, mas enfim, eu não curto. Essa coisa do desenho técnico eu tinha uma afinidade. 49:30 gente falando e ruídos, é uma reguinha, você coloca uma ponta seca aqui, tem a caneta aqui, e você vai desenhando, enfim. Na prova, o professor sentou na minha frente e ficou a prova inteira na minha frente.

Leilane: Você consegue fazer?

João: Consigo. Aí ele pediu a minha pasta de trabalho para ficar de exemplo na faculdade. Eu desenhava a letra.

Leilane: Você fez caligrafia no colégio?

João: Não. Então o três tinha que ser desenhado desta maneira, por exemplo, porque tinha regra pra desenhar o número, não, perdão, o três não podia ser desenhado assim, porque podia ser confundido com cinco. $O$ três tinha que ser desenhado redondinho assim, embaixo tinha que ser maio que o de cima, eu só riscava a altura, um traço bem fininho pra poder medir e uma letra não ficar maior que a outra. Conclusão: aí ficou de exemplo lá a coisa toda. No curso de desenho plástico eu tinha tanto as disciplinas de desenho artístico como as técnicas, e depois você optava. E eu optei por fazer desenho mecânico e desenho topográfico. Aqueles cortes de morro, desenho topográfico, você vê panelas...
Leilane: E pra peça mecânica você vai fazer peça de avião...

João: $\mathrm{E}$ aí o que rola? Fora desenho geométrico, fora geometria 52:07, três tinham o curso de artes para desenvolver um raciocinio especial, então eu era craque nisso, eu gostava.

Leilane: E era um porto seguro, não é?

João: De certa forma sim. Mas eu gostava das artes, porque as pessoas começavam a comprar as minhas camisetas e ninguém acreditava que eu pintava à mão.

Leilane: Tem alguma?

João: Tenho algumas delas guardadas. E eu inventei, antes de vir a coisa gay, as cores do arco-íris, eu fiz desenho e plástica, pintava com aquelas cores todas, o hit era ter uma camisa pintada pelo João. Isso na faculdade, era 1982, 1981, por aí, fiz dois cursos, eu fiz o vestibular no final de 1978 para arquitetura no Rio e não passei.

\section{Leilane: Na Federal?}

João: Não, 53:20, ia para as particulares, dependendo da quantidade de pontos. Aí para artes eu passei, só que eu tranquei por seis meses e fiz arquitetura de novo no Rio e não passei de novo. Hoje eu dou graças a Deus porque não teria me dado bem. Aí eu fiz artes, ou seja, eu tenho essa afinidade, e era, de certa forma, até na condição de jovem precisando de emprego, eu via que o desenho técnico tinha muito mais possibilidade de emprego pós-faculdade.

Leilane: $\mathrm{E}$ aí você estava na Cataguases...

João: Não, aí eu vim para São Paulo.

Leilane: Fez estágio?

João: Aí eu vim e fiz 54:09, depois fui para a Cataguases fazer estágio em estampado. Junto com o Ragueb, eles têm fiação, tecelagem, estamparia, eles têm tudo.

Leilane: Aí você foi primeiro pela Ragueb, e contratado pela Ragueb você faz o estágio na Cataguases?

João: É, eu cheguei vai fazer 30 anos, cheguei no dia 25 de fevereiro de 1985. Esperei amanhecer na rodoviária Tietê e vim com o Ragueb com as malas, sacolas...

Leilane: Isso já contratado?

João: Já, eu tinha vindo em janeiro.

Leilane: Qual foi o primeiro lugar que você morou?

João: Eu morei na rua Varnhagem, atrás da Ladeira Porto Geral, porque aquele prédio todo é do Ragueb, é da família e eles me deram o apartamento para morar. Morei ali 12 anos, até 1994. O que aconteceu? Aí eles começaram a alugar os residenciais para comércio. Teve uma época em que fiquei 
morando sozinho, num edifício de oito andares, cada andar com oito apartamentos, eram 64 apartamentos, morei sozinho durante mais dois anos. $\mathrm{E}$ eles não davam chave da portaria, tinha um senhor, seu Denizário, eu tinha que chegar "seu Denizário", se eles estivessem fazendo revisão no prédio eu ficava na 25, esquina com a Ladeira Porto Geral, e às vezes para entrar eram 15 minutos. Não tinha nada, aquela 25 era péssima.

Leilane: E depois você mudou para onde?

João: Aí me mudei para a Marquês de Itu, mas mantido pela Ragueb. Aí quando a Ragueb acabou de fato eu saí e eles continuaram pagando até terminar o contrato, são honestíssimos.

Leilane: Quantos anos você ficou na Ragueb?

João: Doze anos. Aí eles pagaram esse aluguel três anos, e quanto terminou o contrato eu segui.

Leilane: Claro. E como era seu processo de trabalho, pintava a tela à mão?

João: Não tinha nada de tela, era tudo no papel canson, na cartolina, e eram definidos os temas, vai ser isso, vai ser aquilo, uma cartela de cores $\mathrm{e}$ aí precisava fazer os desenhos. Isso é floral, e fazia em guache. Se você me pede para fazer esse tom com as cores primárias 57:13, eu chego no tom. É incrível. Desde a faculdade. Eu pego guache, pode ser o Gato Preto, nacional, ou um importado.

Leilane: Era o TGA?

João: Na época no tinha o TGA, era o Tales. Eu comprava na Papelaria Rosário ou na Leonardo da Vinci, ambas na Líbero Badaró. Aí eu comprava tudo, fazia o desenho.

Leilane: Você fazia para todas as temáticas, ou um para cada temática?

João: Não, para cada. Porque tinha o clássico, tinha o esporte, enfim. A tinha seis, oito cores em cada, baseada em quê? $\mathrm{Na}$ cartela de cores. Eu não viajava, só fui viajar em 1986. Aí era flor, e a gente vai fazer flor miúda, vai fazer flor graúda, seja o que for, porque tem a questão do raport 58:52, porque eu lembro que tinha na Cataguases um acetato com todas as medidas.

Leilane: Você tem essas coisas ainda?

João: Alguma coisa eu tenho. As minhas camisas que comecei a fazer eu devo ter mais de 250... Ai o que acontece? O raport no Brasil, nao sei se essas medidas continuam, porque era uma unidade internacional, a unidade era 64.4. Então você trabalhava com 32.2, 16.1, 8,05, então eu tinha isso no acetato, comprava papel vegetal, fazia a medida certinha, desenhava no vegetal, porque se era uma flor graúda, você usava 64.4, se é para infantil não precisa desenhar desse tamanho. Para repetir a florzinha, tinha desenhos imensos e desenhos pequenininhos. Então eu fazia sempre assim, fazia estampa aqui, bonitinha, e aqui a quantidade de cores. Tipo, tem cinco cores, e aqui um pedacinho das variantes. Então se aqui tem cinco cores, aqui predomina o azul, aqui predomina o verde, aqui o amarelo, as variantes, aí esses desenhos eram aprovados e o Ragueb ia produzir o tecido. A Ragueb nao tinha fábrica, não tinha tecelagem.

Leilane: Só comprava?

João: Só comprava.

Leilane: E quem estampava?

João: Todo mundo, Bangu, Nova América...

Leilane: A Vicunha, eu trabalhava lá em 2000, conseguia fazer 5 mil metros. Hoje você consegue no papel para ver 30 metros.

João: Pois é. Aí quando estava saindo do Ragueb eu chegava até a comprar a incipiência ???? da computação para a moda, não para modelagem.

Leilane: Qual era o sistema? Era Macintosh?

João: Não, PC. Eu comecei, iniciei um curso no Senac mas não me adaptava. Leilane: Em que ano isso?

João: Ah, isso foi... saí de lá em final de 1995-1996, eles compravam e não deram mais corda porque resolveram fechar. E me seguraram por mais um ano...

\section{Leilane: Então nem era Photoshop ainda.}

João: Não, apesar deles não terem comprado nem... impressora sim, eram serrilhados, não tinha pixel nem nada. $E$ foi assim que a coisa foi, meu processo era esse. Aí eu fazia os painéis, dava palestras, ambiência, a panóplia, e eu tinha aprendido com quem? Marie 01,02,34. Ela tinha uma sensibilidade imensa, ela que ensinou a fazer pesquisa de cores, tendência.

Leilane: E você tinha segurança? Como você pesquisava tendência? Fio, painel, vou tirar cor daqui...

João: Feeling. Lógico que a Ragueb também deixava participar de tudo, mas eu ia para os lugares, ah, hoje quero ir no shopping, não tinha essa agilidade de hoje.

Leilane: Claro, eu não peguei isso, internet. Não tinha Google, era Barsa, risos.

João: Barsa, Planeta, e aí o que acontece, eu fazia essas coisas todas, o Ragueb assinava revista, então estava sempre tomado.

Leilane: Que revista vocês assinavam?

João: A gente assinava, tem os cadernos de tendência, ele assinava o Faces, Duomo, Colezione, Baby... 01,04,13

Leilane: Você tinha todos os segmentos?

João: Eu tinha essas informações todas, o Ragueb dava.

Leilane: $\mathrm{E}$ isso era uma empresa muito grande, porque as assinaturas eram caras. Lembro que trabalhei em confecção em 2001 e era caro. 
João: Mas mesmo assim a gente comprava com a HB, por telefone, mas - Ragueb também assinava via marítima, porque a via aérea era mais cara, e chegava depois. Mas todo mundo, sem concessão, tratava o Ragueb na palma da mão, porque a quantidade de tecidos era tão grande que muitas vezes quando essas informações chegavam eu já tinha ido conversar com 01,05,17, Leila, já estava sabendo de tudo, participava do Cedit, da cartela de cores deles, ela me contatava e muitas vezes me dava contribuição.

Leilane: E esse networking servia justamente para fazer o que hoje a internet traz, para confirmar.

João: E o pessoal do Rio dizia que não tinha isso, todo mundo escondia informação, como São Paulo era maravilhoso, e todo mundo falava vou fazer isso e aquilo e no Rio ficava todo mundo fechadinho.

Leilane: $E$ vocês se ajudavam mais. E você acha que isso contribuiu para constituir uma Fashion Week aqui...

\section{João: Depois tinha a Margarete Medeiros.}

Leilane: Mas qual era seu cargo com o Ragueb?

João: Estilista. Mas eu acabava fazendo as coisas da coordenação também, trabalhavam juntos. Aí montei um ateliê, e eles perceberam que eu gostava de falar, então fazia palestras, rodava o Brasil, dava palestra primeiramente para os vendedores e depois para os clientes. A Ragueb tinha 13 filiais.

Leilane: Batiam isso no tecido e te mostravam como ficava?

João: Sim, tinham as amostras. Tinha o comprador, éramos uma equipe. Leilane: Era mais fibra natural ou sintética?

João: O que fosse mais comercial no momento. Eles não produziam nada, então comprava de todo mundo, e os vendedores do Ragueb brigavam, entre aspas, por um centavo, só que um centavo em um milhão de metros, risos, era muito dinheiro, eles discutiam por um centavo no preço do metro do tecido. Conclusão: então fui aprendendo isso tudo, o Ragueb me tratou muito bem, eles me 01,08,54, fui na missa de sétimo dia do Seu Lourenço, que morreu faz dois anos.

Leilane: Você tem um relacionamento com a família?

João: Não que eu tenha um relacionamento, mas eles têm um respeito imenso, se eu ligo eles me atendem, é incrível. Uma vez dei uma palestra no Shopping Iguatemi, o Seu Raul foi com a esposa dele assistir. Eles têm muita importância na moda do Brasil.

Leilane: São uma das onze principais tecelagens. Engraçado que, pelo que você está falando não é tecelagem...

João: Não era tecelagem, era Companhia Têxtil Ragueb Chohfi.

Leilane: A Vera Ligia escreve com muita clareza e destreza: as onze principais empresas têxteis. Ela é muito clara. Era o meu entendimento de tecelagem, não o dela, não dá para ficar falando sobre tudo.
João: Mas a Vera foi muito preciosa nessa informação. Conclusão, Leilane, eu fazia isso tudo.

Leilane: Você aprendeu na prática.

João: É, eu falei, quando fui lá eu agradeci e tudo, fiz uma carta e agradeci na carta que eles investiram e acreditaram no meu trabalho, a confiabilidade e tudo, falei assim: eu frequentei escola de artes e não de moda, escola tradicional, mas tive a melhor escola de moda do Brasil e se chama 25 de Março. Da melhor escola eu tive a melhor sala de aula, que é o Ragueb Chohfi. E da melhor sala de aula tive os melhores professores, que foram meus patrões e a equipe de contadores e coordenadores de moda que contratamos. Eles eram muito afinados.

Leilane: No seu setor quem era chefe? Você era chefe de estilo ou o coordenador que...

João: Não, o estilo ficava vinculado a compras. Seu Pedro, Lelia Ragueb $01,10,13$, que era coordenadora, e eu cuidava do ateliê.

Leilane: Você respondia a...

João: A Lelia e Seu Pedro.

\section{Leilane: Era só você, tinha mais alguém criando?}

João: No ateliê chegamos a ter, trabalhei com mais três pessoas. Na verdade eu que montei. Inclusive montei uma biblioteca imensa, quando saí de lá depois me ligaram: João, vamos nos desfazer da biblioteca. Quer para você? Eles me ofereceram. Eu disse: olha, atualmente estou em escolas e montei uma biblioteca para tecidos, em especial para estamparia e se vocês permitirem vou oferecer ao Senac, então a biblioteca do Ragueb foi inteirinha para a biblioteca do Senac na Lapa. Eles compram muito, mas a parte têxtil era tudo do Ragueb, e o Senac fez uma carta agradecendo a doação. Eu acho que vai ser muito mais útil, estou me enveredando pela história, talvez não faça mais estamparia, e pode ser útil, o Senac tinha montado um curso de estamparia. Ah, está na hora, a gente vai se desfazer, eles se desfizeram, o Senac mandou um carro, pegou a biblioteca toda e levou. Não era uma biblioteca absurda, mas era legal.

Leilane: Você sabe que tenho um desenho pronto feito à mão pela Edi, na Vicunha, quando não era computador? Porque entrei lá na época de transição do computador e estavam jogando fora. Aí perguntei se podia guardar.

João: Eu tenho algumas coisas também. Aí fazíamos cartelinha... aí, Leilane, quando eu viajava, nas primeiras vezes o Seu Raul...

Leilane: Já falava francês?

João: Já, já tinha ido para a Europa, fiz Aliança Francesa, e quando fui para lá, nas primeiras viagens eu ia no Grupo 01,12,24, começou levando 150, 170 profissionais de moda.

Leilane: Te chamavam? 
João: Eu não peguei essa época, pegue um grupo de 40, 50, mas mesmo assim. Eram três semanas, para Paris, depois Milão, depois Londres e depois voltava para Paris. Mas as primeiras vezes eles me davam $10 \mathrm{mil}$ dólares. Eram 21 dias, três semanas, então tinha 100 dólares por dia para me alimentar e transporte, não precisava apresentar nota, então eu tinha 2.100 dólares, e o restante era para fazer as compras, comprava tudo que fosse importante Em Paris eu enlouquecia. Levava a minha máquina, era rolo, quando vi o Arco do Triunfo, fiz tanta fotografia, acho que três filmes, risos.

Leilane: Eu estava procurando como atravessava a rua ali no Arco do Triunfo. Eu pensava: mas vão todos morrer atropelados, não é possível.

João: Risos. Mas aí, Leilane, a minha sistemática quem desenvolveu fui eu. Porque aprendi com a técnica da Industrial Cataguases, fiz amizades excelentes lá.

Leilane: A Marie 01,14,07

João: A Marie foi estilismo, as sacadas, olha aquilo ali, o que está forte, ela me ensinou esse olhar, eu falo abertamente o que ela falou, abre a sua cabeça, coloca tudo lá dentro, fecha e não deixa sair.

Leilane: É, eu fiz curso com ela em 2007.

João: A primeira vez que ela veio aqui em 1978. Primeiro para jornalistas de moda

Leilane: É, então, era só fechado.

João: Depois era a Leda da Santista. Gente, na Santista era tratado como se fosse rei. A Sueli, que estava aqui, e depois teve o Marcio, que lamentavelmente morreu também, mas a Sueli, lembro dela entrando como assistente da Leda na Santista.

Leilane: A Sueli me deu 80 metros de jeans no meu TCC.

João: A Sueli e o Guilherme, que é irmão da Gisele Araújo. Os dois trabaIhavam com a Leda.

Leilane: João, em relação à teorização, porque depois você migrou para a faculdade de moda. E você teve uma teorização muito mais voltada para estética, história da arte, quero te perguntar se você teve algum contato com a teorização de estilismo.

João: De estilismo não, o que passei com estilismo foi todo um processo que desenvolvi na Industrial Cataguases. Aprendi lá, mas desenvolvi à minha maneira, a técnica era quase a mesma. Agora uma metodologia para pesquisa teórica não posso dizer..

Leilane: Não, não quero criar metodologia, só quero analisar as possibilidades.

João: Com quem aprendi? Com a professora Serafina Borges Amaral. Ela foi a minha grande mestra de história da moda daqui de São Paulo. O meu primeiro livro dedico a ela. As aulas dela eram tão maravilhosas que eu fiz um mês de curso e fiz uma pós-graduação com ela.

Leilane: Onde era?

João: Conheci a professora Serafina por intermédio da Tânia Mara, fez Marie Rucki comigo. Eramos eu, Tania Maria, Dani e Jun Nakao, eu o conheci fazendo Marie Rucki.

Leilane: É, foi na epoca que ele consegue o estagio na Rhodia.

João: Eu cheguei em fevereiro e a gente se conheceu, eu tenho fotos do casamento dele.

Leilane: A gente estava na casa dele esses dias, risos.

João: Eu sou padrinho de casamento dele com a Eunice. Aí um dia a Tania Mara me convida para assistir uma aula da professora Serafina, era assistente dela, na Esmod, a primeira vez que trouxeram a Esmod, nem era Senac, que funcionava ali na Rua Frei Caneca, próximo à Paulista. Eu assisti a aula da professora e fiquei assim, ela dava aula no Senac, eu ia, seguia, ela deu o curso pelo Museu Odebretch, na Vila Romana, eu ia todo sábado.

Leilane: Eu trabalhei na Vila Romana.

João: Trabalhou? A gente tem vários pontos em comum aí, não é? Aí montamos um grupo de estudos, éramos 14 pessoas e ficamos três anos todo sábado vindo para cá. Estudava moda até meio-dia, fazia um lanche e era uma maravilha, inclusive a filha dela também, a Ana Carlota, e nisso fiquei completamente envolvido, sempre gostei de história, qualquer viés da história. Aí veio uma coisa muito curiosa comigo, que isso é o dedo de Deus, sem dúvida, aí eu fui chamado para a Esmod, ah, eu fiz uma pós com a professora Serafina, a última turma de pós em história da moda, inventário da moda, na Fundação Escola de Sociologia e Política de São Paulo. Era no Centro, na Rua do Ouvidor, mas a sede da Fundação sempre foi na Rua General Jardim. Mas o curso era na Rua do Ouvidor, essa rua dava na Praça da Bandeira. O curso acabou mas comecei a acompanhar a professora. Ela dava um curso aqui na Faap, ela me chamou e eu me enveredei, conheci a Dona Matilde e Seu Jaime, ela já estava velhinha, ela me chamava de príncipe. Aí eu: professora, com razão, príncipe, o primeiro na linha de sucessão ou como uma forma carinhosa? E ela: os dois. Aí teve a Esmod, a adaptação, a primeira turma. Aí as donas da Esmod em Paris vieram aqui para ver a instalação, aí a Esmod já tinha ficado aquele tempo, aquele contrato, não deu certo, o Senac trouxe a Esmod, vinculado a José Gayegos, que tinha feito Esmod. Eu já estava enveredando pelo Senac. Aí a 01,20,40 estava lá, elas foram visitar as aulas e eu estava dando aula de história da moda numa turma de modelagem. Ela olha para mim e fala assim: quer fazer um curso de história da moda em Paris? Eu: quero. Ela falou assim: te dou uma bolsa, então vai em agosto deste ano para Paris, isso foi em 1996. Era fevereiro e eu falei assim: olha, desculpa, mas eu tenho um compromisso, em agosto tem aula no Brasil e eu trabalho numa empresa, só consigo tirar férias em julho. E ela: então julho. Ela montou um curso e colocou todos os outros professo- 
res da Esmod de Paris para fazer o curso de história da Moda com o Xavier Chaumette, que tem livros publicados. Ela deu a bolsa mas a minha avó bancou. Foi quando tirei minhas férias do Ragueb em julho daquele ano. E eu cada vez mais me enveredava por isso, sem menosprezar nada, até poderia ser pretensão da minha parte, eu de repente cuspindo no prato que comeu, mas eu aprendi muito mais com a professora Serafina do que com a Esmod. Eu ali fiz um curso automaticamente de história da moda, tive contato com a Esmod e tive a oportunidade de ficar uma temporada em Paris vivenciando a cultura local.

Leilane: Que é o que conta. Nem sempre é o diploma, de onde ele vem é o lugar que mais ensina, não é?

João: Nem sei se eu tenho esse diploma... eu tenho uma carta. Conclusão: então quando fiz desenho geométrico já sabia muita coisa, aprendi com a professora Serafina Borges Amaral.

Leilane: Estilo ou estilismo, chamo carinhosamente a disciplina de estilismo ou a prática de estilo. Estilo pode ser sinônimo de projeto, pensando num projeto em moda, pro design, mas para nós.

João: Eu acho que atualmente sim. Porque as palavras vão mudando de conceito ao longo do tempo. É como eu explico para os alunos: esse estilo eu acho que é uma criação, o projeto é uma sistematização desse processo criativo. Inclusive quando o design chega no Brasil nos anos 1960, chegou pela Esdi, Escola Superior de Desenho Industrial, você sabe qual seria o nome sugerido pelo Houaiss?

Leilane: Estou lendo sobre isso.

João: Sabe como chamaria isso no Brasil, o Houaiss do dicionário que sugeriu, mas ele foi vencido. Chamaria-se projética.

Leilane: Que é o nome da revista da UEL.

João: Que deveria ser o nome, o design não é um projeto.

Leilane: Mas, por exemplo, eu tinha disciplina de projeto e fiz faculdade no berço de design, que é a Anhembi Morumbi, e eu tinha aula de criação, eu lembro, a gente faz projeto, não faz só criação.

João: Você pode ser criativo em qualquer área. Você vai sistematizar a sua criação para produzir, é em série, você está produzindo um projeto.

Leilane: Você está defendendo a faculdade.

João: Não, porque o projeto envolve produção em série, que é o conceito do design.

Leilane: Você já contou isso para um professor de projeto, de estilo, de criação?

João: Já devo ter falado. Eu naturalmente sou voto vencido.

Leilane: Não, fantástico isso, nunca vi ninguém falar isso.
João: Como eu explico? De onde vem a palavra estilo? Vem de stilus, do latim. $O$ que era o stilus? Era um graveto de metal com os quais os romanos escreviam em plaquinhas enceradas. Então elas iam arranhando e tirando aquela cera e imprimindo a letra deles ali. Então veja, etimologicamente é isso. Então desse stilus vem estilete, estigma, vem daí, o raciocínio é o mesmo, estigma não é uma marca, estigmatizada, uma pessoa marcada por algo que fez? Enfim, então esse é o significado etimológico, estilete, como é caneta em francês? Stylo. Que é o objeto assim, só que hoje tem a tintinha que sai lá. Esse é o significado etimológico? E o conceitual? É o prolongamento do seu braço, o prolongamento da sua mão, você transforma ideia em produto. A primeira área que usou isso foi a literatura, tem o estilo shakesperiano, machadiano.

Leilane: $\mathrm{E}$ invariavelmente vem da arte.

João: Literatura não deixa de ser uma arte. Então vem daí e migra para as outras áreas. Tem os estilos arquitetônicos na arquitetura, os estilos artísticos das artes plásticas, e migra para o design e migra para a moda. A palavra estilo. Conceitualmente é isso. Então você teve a ideia e eu vou terminar de fazer um turbante para os pés e um sapato para a cabeça. No momento que você estigmatiza, isso vira um projeto que você está projetando para produzir em série.

Leilane: Seria então viabilizar técnica e financeiramente.

João: Não deixa de ser financeiramente, mas além de técnica e financeiramente para atender uma demanda e uma necessidade de uma época. Então o design só passa a existir na Revolução Industrial, em meados do século 19. Então seria isso que rege esse conceito, esse negócio. Só que, antes dessa tal Revolução Industrial, quem era o estilista?

\section{Leilane: Ah, eu faltei nessa aula, ha ha ha ha ha.}

João: Estilista era aquele que cuidava de cabelo e maquiagem na corte de Luís XIV, recebia o nome de estilista. E há um que se chamava Monsieu Champagne, ele devia borbulhar na fonte de Luís XIV, e ele era estilista. Só que ele era tão sofisticado, tão sofisticado, que ele inventa a palavra coiffeur, que coiffe em francês é coifa. Coifa é qualquer coisa que você coloca na cabeça, então ele inventa a palavra coiffeur, para esse estilista sofisticado, e coiffeuse para mulher. A palavra estilista caiu em desuso. Totalmente, mas originariamente era quem cuidava de cabelo e maquiagem. A palavra estilista foi reabilitada nos anos 1960, por causa de moda jovem e esse consumo exacerbado do jovem para atender essa produção em série. Então quando a gente fala 01,28,40 não era estilista, era costureiro. Se hoje você fala 01,28,48 é extrema sofisticação na França, 01,28,52, que morreu nos anos 1940, não existia essa palavra na moda.

Leilane: Mas nem Balenciaga, Dior...

João: Alguns, não, alguns podem ser costureiros e estilistas. Porque o costureiro está lá na alta-costura, produção customizada, assinada, peça única, aquelas regras todas. E o estilista vai trabalhar com a produção em 
série, associado ao design, para atender a demanda da moda jovem. Então a palavra veio à tona novamente e assim ficou. $E$ brasileiro não entende isso. Costureiro no Brasil virou sinônimo de afetação, e costureira virou sinônimo daquela senhorinha que comprou uma máquina nas Casas Bahia e está bombando na rua dela. Só que se você fala je suis couturier, je suis couturière, você sabe que é sofisticação na França, e styliste, ele cria para a indústria, não para ateliê, para produzir em série, uma peça comercial, fácil de produzir. Aí se você pega esse negócio aqui, esse negócio: estilista, português. E igual o styliste em francês. Ao pé da letra em inglês é stylist. Então aqui é diferente. Esse stylist, que anteriormente era o produtor da moda, que caiu a palavra e agora virou assistente de stylist, que em francês é o quê? É o réalisateur, ou então o producteur. E aí esse estilista é o quê? É o fashion designer em inglês. E em inglês não tem diferença de fashion designer se é o estilista ou o costureiro. Então isso daqui é a palavra..

Leilane: Mas aqui também não tem, é tudo estilista, não é?

João: É. E você ouve, ah, eu sou estilista de alta-costura no Brasil. Meu querido, você não é nada. Então isso aqui é uma coisa, mas conceitualmente isso é uma coisa e conceitualmente isso é outra.

Leilane: Produção de imagem, de vestuário, em vários níveis, não é?

João: É. Então esse negócio do projeto e esse negócio do estilo, uma ideia, o que é uma coisa pessoal, para você ver, tem coisa mais pessoal do que a sua letra? Tem coisa mais pessoal que a sua assinatura? Então quando você fala estilo passa a ideia de subjetividade. Quando se fala moda, passa a ideia de coletividade. Moda é uma coisa que já foi aceita. A gente fala desfile de moda, deveria ser desfile de estilo. Porque é a visão de mundo daquele criador ali. Se aquilo ali vai ser aceito e usado, vai ser moda.

Leilane: Mas ainda não é. É estilo.

João: Não é. Na teoria. Se falar: vou fazer um desfile de estilo, ninguém vai saber, desfile de quê, o que é isso? Então a palavra moda é muito mais impactante e chega com facilidade.

Leilane: Para você, moda tende mais ao design ou à arte?

João: Depende. Acho que moda dialoga com o design, dialoga com arte e dialoga com artesanato. Ainda tem uma outra coisa, porque aí, isso eu também trabalho muito com os alunos, você tem aqui essa célula mor. Esta célula aqui, digamos, seja a arte. Esta célula aqui seria do artesanato. E esta célula aqui seria do design. Design pode dialogar com artesanato, pode dialogar com a arte, e os três podem ter também uma faixa comum. Então o que caracteriza? Primeiro lugar, o que caracteriza um artesanato? Artesanato não tem o compromisso de inovação, ao contrário, preservação, tradição. Então você tem sua mãe, que aprendeu com sua avó, que aprendeu com sua bisavó, enfim, então o artesanato não tem compromisso de mudança, por isso torna-se igual, mas a obrigatoriedade do artesanato é isso, que é isso tudo associado ao sentido de cultura. Cultura vem de cultus, do latim, do verto colere, que era das culturas, cultura da terra mesmo, plantio. Ou seja, você prepara a terra, planta para colher mais adiante, então esse é o sentido de cultura, você recebe uma geração anterior, mantém a sua e tem a obrigação de passar para a próxima geração para que aquilo não se perca.

Leilane: A transmissão.

João: A transmissão. A arte tem as suas características próprias. Mudança com regularidade, subjetividade, intenção do artista, muitas vezes o aspecto de divinização, dependendo do fundamento, do teórico, não tem a produção em série. O design tem compromisso de mudança, tem compromisso de atender uma demanda, tem que ter uma funcionalidade, tem que ter uma realidade. Então a moda dialoga com a arte, no meu ponto de vista, pela ideia da alta-costura: peça única, bordado feito à mão, ela dialoga com o artesanato na manutenção de uma tradição. Tudo bem, aqui eu tenho uma mão bem treinada e pode bordar muito bem. Mas se eu não tenho uma cabeça pensante para transformar, não cria nada, esse aqui tecnicamente mantém. Então a moda, pegando até o caso do bordado, você bolou o bordado, desenho mais lindo do mundo, eu quero inventar um ponto, treinei essa pessoa aqui, então vai manter, está dialogando, mantendo a tradição. E o design na moda dialogaria com o quê? O prêt-à-porter, a produção em série.

Leilane: Colocar o estilismo industrial.

João: Produção em série, então essa meia, essa calca, essa saia vende 5 mil, 20 mil. Então eu acho que a moda pode estar de mãos dadas, de braços dados, abraçada, pode estar com caminho até diferente, hoje em dia ela dialoga muito mais com o design. Produção em série, o prêt-à-porter está aí, com o fast fashion. Então ela dialoga muito mais com o design.

Leilane: Banaliza, pelo menos até o prêt-à-porter.

João: Então não há uma resposta absoluta. Se você pega o traje eclesiástico de 01,36,50. Que de repente está lá em Istambul, num museu. E é moda? É. Nem conceito de moda tinha.

Leilane: E também não era naquele contexto, é hoje.

João: Talvez naquele contexto fosse. Porque talvez fosse o conceito de arte associado à revelação divina, a igreja...

Leilane: A simbologia. Na Santa tem uma tentativa de aproximar estilismo da aura benjaminiana da arte. Você acha que é mais na prática ou no conceito?

João: Tem, inclusive na minha disciplina de história da arte tem nos estudos iniciais, os conceitos em sala que aula, que era um objetivo da Raque Valente, fazer esse diálogo. E lapidar, despertar para que o aluno possa observar isso, dando exemplos típicos, talvez o mais banal, não desmerecendo, sejam os vestidos Mondrian de Saint Laurent, mas se pega o Gaultier dos anos 1980, então tem uma série de possibilidades, e mais do que isso, eu faço um diálogo da moda com a arquitetura, faço um diálogo com joalheria, enfim, com outras áreas, outras especialidades.

Leilane: João, você é uma pessoa muito pura de coração, não é? Agora vou ser um pouco mais maliciosa, como você vê essa coisa da arte, não sei você 
conhece o conceito de designer-autor, que é o designer-estrela, tinha muito isso no Museu da Casa Brasileira, aí discutiu o que era design, ah, design é produção em série, uma cadeira, e que aí tem um papel social, em detrimento de Sérgio Rodrigues. 01,39,14 Ela fala que isso na tese dela que defendeu na FAU USP, que isso é 01,39,19 de capital simbólico. A moda tem até um movimento, pelo menos na minha percepção, queria ver o que você acha disso, que ela se aproxima da arte e do design quando precisa ganhar capital simbólico e se afasta quando precisa ser entendida como campo autônomo. A moda tem esse jogo duplo. Queria que você analisasse, antes da moda como campo autônomo, essa questão do estilista-autor, porque na tese da Vera Ligia, até conversei com ela sobre isso, do autor agregando, do estilista agregando 01,39,49. E aí eu coloquei de uma maneira crítica e falou: ah, quando você foi pra outro lugar, foi pra ganhar mais, agregou sotas a uma marca? Mas eu também tenho um olhar bastante crítico para isso, porque a ação tem essa ideia de querer formar o autor, o cara que se destaca e está na Fashion Week, mas não tem mercado para absorver somente os autores.

João: Em primeiro lugar, até o uso dessa palavra 'autor'. Hoje em dia você nem fala mais fulano é escritor, fulano é autor. Hoje a palavra autor está muito mais para a área literária, esse seria na moda é o que vem sendo chamado atualmente de créateur, que em francês é criador. No sentido até de se apropriar da realidade divina, criador é Deus, mas tem se usado esse nome. Ou seja, aquela teoria da arte, da aura, aquela coisa toda. $O$ que acontece? Isso vai depender da época, essa aura, se o 01,41,03 soube criar essa aura em cima desse universo, que na verdade 01,41,09 já criava para Josephine, a 01,41,12 já criava para Maria Antonieta, então o que rola? Na moda tem, você sabe que moda sempre precisou dessa realidade de um fulano que precisa estar na crista da onda. Não significa que ele seja o melhor, o mais criativo, mas acaba tendo, cada época, o seu ícone, cada época tem a sua referência, como já foi Chanel, como foi Dior, Galliano, inúmeros deles. Então tem modismos dentro da moda, no meu ponto de vista.

Leilane: Poderia ser também a metamoda, no sentido de passageiro.

João: Sim, poderia ser. Nos anos 1970, com o surgimento do conceito de kitsch, era muito mais a marca que aparecia. A logomania era o resultado visual. Alguns até com o nome do fulano, Pierre Cardin, Yves Saint Laurent, mas falando até de uma realidade nossa. Era assim: Company, Mister Wonderful, Cantão... Aqui em São Paulo, até um pouquinho antes, Soft Machine, tem uma publicidade da Staroup, tem uma publicidade muito interessante, que é uma mulher nua, não aparece o olho dela, aparece um pouco do rosto, ela tampando os seios e aqui no braço dela uma etiqueta da Staroup, não precisava de roupa, mas da marca. Quando a Gloria Kalil trouxe a Fiorucci para o Brasil, Energia, mas o que é? É company. Eu quero company. 01,43,30. Eu quero uma roupa do Mister Wonder. A moda ficou mais popularizada, fo ganhando aí uma acessibilidade...

Leilane: Isso veio junto com a ideia de moda jovem?

João: Não, a moda jovem vem um pouco antes, que no fundo a moda jovem foi o resultado dos babyboomers, as crianças nos anos 1950 e os joven nos anos 1960. E para atender esses jovens, não um estilista, a grife vai surgir já nos anos 1970, no Brasil especificamente vai ser 1977, 1978, quem sabe até 1979. Um pouco mais atrasado. Dijon... Aí na realidade do Brasil tem essas escolas de moda, começam a aparecer uns nomes, vem a época das coordenadoras de moda, Teresa Cristina Jorge, da Mesbla, Lilian 01,44,4 do Mappin, Geni, daquela que fazia as linhazinhas, Icasa, que depois foi para a Dahruj, aí lá fora começa a aparecer uma marca Biz, para pegar o jovem, e quando esse público crescer, quero continuar usando Gaultier, continuar usando Lacroix. A moda foi se popularizando, a moda passou a ser "importada" da rua, o universal dessa pirâmide, streetwear, as tribos urbanas, começaram a fazer muito mais sucesso, e os estilistas e costureiros 01,46,04 ruídos. O streetwear veio nos anos 1980 e super nos anos 1990 e popularizou demais na moda. $E$ a moda, que vive de paradoxos, e um deles é você quer usar moda para estar na moda e quer ser diferente, quando você vê está igual a todo mundo, e a moda vai encontrando essas dinâmicas de se sobrepor. E nisso cada vez mais veio a ideia de subjetividade na moda, até nos perfumes. $O$ perfume do Lacroix chamado C'est la vie não deu certo, vie é vida, é um consignado muito grande. Foi quando o Calvin Klein inteligentemente bombou com os perfumes, era uma época de corpo a corpo, aquele casal nu, no balanço, depois veio uma coisa mais família e ele lança o Eternity. Aí veio a onda de subjetividade, aquela época que as modelos faziam maquiagem de cicatriz, então você pode ter uma irmã gêmea, mas você tem uma cicatriz sua, ninguém vai ter uma cicatriz igual. $O$ acidente foi com você, não com ela. Aí o Calvin Klein vem e lança o One, um, depois foi o Be, be yourself. O que começa a acontecer na moda? A grife está lá, a marca está lá, a gente precisa de uma alma. Não basta ser só, vou ter dar um exemplo. Cori, não basta ser Cori, tem que ser Cori por Alexandre Herchcovitch. Precisa ter um nome para agregar valor e para que o cliente e a mídia reconheçam o valor agregado. Então isso passou a ser uma realidade. Aí no caso o Alexandre vai assinar pra Caderno Melhoramentos, Tok\&Stok, Zêlo, enfim.

Leilane: Eu começo a me questionar com produto quando vejo isso, edredom da Zêlo não tem projeto nenhum.

João: A gente está falando do prestígio do nome.

Leilane: É, prestígio.

João: Sei lá se a estampa foi ele que desenhou, enfim, mas, ou seja, houve necessidade, a moda estava tão street, tão foto, que precisou usar algo mais para sofisticar. Hoje em dia às vezes nem precisa de nome, quase que uma 01,49,20, a Riachuelo com a Donatella. Quem começa com isso foi a H\&M. Que chamava alguém da Chanel para fazer uma coleção da H\&M. Então isso deu certo e depois não deu mais. Então isso foi uma maneira, e obviamente com uma assessoria de imprensa, a moda ganhou prestígio, a moda foi portando como objeto museológico importante no cenário da produção cultural, querendo status de museu. A indumentária já está no museu, agora a moda passa a fazer parte do museu também. 
Leilane: Porque ela quer usar desse artifício. Foi parecido com o que aconteceu com o design, o Marcos fala isso no Museu da Casa Brasileira, o design entra no museu para durar, ele busca isso. Um delay, risos.

João: Mas se a moda é cíclica, o final está muito próximo, risos. 01,50,42

Leilane: Ela corre atrás do próprio rabo. Dentro da Santa, você percebe que tem uma disciplina que seja mais importante que seja considerada principal e norteia as outras disciplinas? Você não vê isso.

João: Não, não sei se com essas mudanças atuais que virão em função dessa nova coordenação, em função dessa nova equipe, não sei como que está. Mas o conjunto de disciplinas eu acho que está na hora de atualização01,51,37 (a voz dele fica longe). Mas já teve a teoria da arte, teoria de história da moda, eles não conseguiram juntar.

Leilane: Você entende a moda como uma área autônoma, ou ainda é um campo que depende da arte? Da arte na Santa, do design na Anhembi Morumbi e no Senac...

João: Acho que a moda há de ser autônoma e tem lutado para ser uma área do Ministério da Educação. Acho que não há nem um diálogo interministerial, para o Ministério da Cultura a moda é uma área autônoma, para - Ministério da Educação não, para o da Exportação, sei lá, é um produto para vender e fazer dinheiro, não há diálogo interministerial para a moda ser uma coisa, está dentro de diversos campos, diversos ministérios e cada um enxerga de uma maneira ou com o benefício que eu quero para mim.

Leilane: Nossa, essa não tinha ouvido ainda. Porque o que falam é que $\circ$ que falta, entre outras coisas, é que falta um exame de Enade.

João: É porque, você vê, como campo científico, não é só criação. Sao sistemáticas, você tem maneiras de interpretar

Leilane: Eu entendo a moda como campo autônomo, ela tem especificidades tantas que não dá para deixar no design.

João: Isso a ponto de já se questionar isso.

Leilane: Porque na Fapesp, para as agências de fomento tem que entrar em áreas sociais aplicadas e ficar caçando projeto de moda por não existi uma área de moda. E tem projetos de moda da Anhembi Morumbi, da PUC, com bolsas. Porque são bons, senão não teriam bolsas.

João: Então, acho que isso é processo, começou? A gente faz parte desse processo? Sim. Não sei se a gente vai ver benefício, construção de memória, construção de história, de cultura material. E essa investigação.

Leilane: Os preceitos básicos de forma e função no design, o racionalista, você conhece? Forma segue a função. Na moda você acha que a moda segue o quê? Tenho uma sugestão, mas vou, risos.

João: Eu acho que a moda não segue uma função específica, quer dizer, até segue se fosse analisar um pouquinho mais aprofundado filosoficamente, né?! Ela segue especialmente a função de estética. Ela segue um cam nho da satisfação, do prazer estético, é que no fundo moda tem uma chance muito grande, plagiando Tolstoi, "a beleza salvará o mundo".

Leilane: Ilusão, não é?

João: Não, não é ilusão, só que moda envolve beleza? Envolve, mesmo que muitas vezes valorizando um antiestético, que também é um estético, uma expressão.

Leilane: Sim, uma expressão da moda, antimoda. Você que me ensinou isso.

João: Enfim, uma expressão da moda, eu quero chegar no Lancôm 01,55,44. Qual o significado etimológico da palavra 'beleza'? Teo significa Deus, beleza é o caminho, é o que te aproxima da vida. Isso é uma tipologia, não sou estou que estou inventando, e elegância é revestir-se na aura divina.E quando você está de uma maneira tal que você tem a capacidade de algo a mais. E para 0 grego, qual é o maior sinônimo de beleza? Aí fugindo desse pensamento, que é proporção mais equilíbrio mais harmonia. Então, o que acontece? A palavra beleza perdeu totalmente o próprio sentido, até mesmo nas artes. Não sei no seu sentido etimológico, independente do pastiche, nada contra, mas aquele monte de poeira ali vira instalação. Até que ponto tem um conceito mas até que ponto aquilo tem a capacidade de embelezar? Então a palavra beleza mudou completamente o seu sentido. É lógico que se não houvesse essas mudanças não haveria estilo, essa gramática dos estilos, não haveria uma série de coisas. Mas reflete uma sociedade, e se essa sociedade hoje está em crise, os processo artísticos são reflexos dessas questões sociais.

Leilane: Você conseguiria definir: moda segue o quê?

João: Moda tem uma forma porque hoje é mais amplo, hoje é arredondado, hoje é isso, hoje é aquilo. A função é cobrir o corpo, agora o cobrir o corpo não necessariamente preciso cobrir com amarelo, roxo, verde, xadrez, listrado, então tem a função estética da sensibilidade que é a capacidade de criar um l'air du temps. Moda muitas vezes não dialoga com o zeitgeist mas tem a capacidade de criar um novo zeitgeist.

Leilane: Então poderia dizer que forma segue a estética na moda?

João: Na moda eu poderia falar isso, que a moda segue um percurso que vai te levar à sensibilização.

Leilane: Menos de lógica e mais de design industrial e pensar na indústrias de massa. Posso falar que a moda segue apelo de venda?

João: Moda segue o quê, não ouvi?

Leilane: Forma na moda pode seguir o apelo de venda?

João: Total! Moda é business também! A gente não pode esquecer moda não é uma coisa só. Ela dialoga com várias artes, está com artes, está com business, tecnologia, industrialização. Se hoje a gente tem esse tecido que tem hidratante, que dança balalaica, então o que rola? Tem uma função, até 
tem. O conforto que você quer, mas tem a questão do poder estético. Moda tem essa capacidade de levantar, inclusive a estética em geral. Aristoteles já cantava isso, de funcionalidade da beleza, ele na Grécia antiga já cantava essa bola. Se você ver a forma mais recentemente depois do século 20, mas ele já falava isso, o que vai falar da forma e da função ele já dizia, a função da beleza, que tem a capacidade de sensibilizar. E o que tem nesse processo todo? Hoje temos o antiestético como forma de estética, a moda tem a sua realidade. Ela tem a função? Tem. Porque aí vamos cair num outro fundamento. Quais são as razoes pelas quais a gente cobre o corpo? Sao três. Porque era protecao. Sob o ponto de vista criacionista, o ponto de vista teológico, é o pudor. Você pega o livro do Gênesis, capítulo 3: "Abriram os olhos e viram que estavam nus e sentiram vergonha, e desceram para si aventais com folhas de figueira". Ou seja, uma forma de desobedecer a Deus, proibido perceber a nudez e fizeram, esconderam as partes pudendas. Sob o ponto de vista teológico, a roupa nasce com caráter de indignidade. Pela desobediência ao Pai. Não faça isso, fizeram, o pecado original, não que eu vá que usar a roupa, mas vou perceber a minha vergonha. A muIher vai pagar com a dor do parto, pecado original, o homem vai pagar com o suor do rosto, trabalhar, enfim. Porém, a bondade divina é tamanha que Deus dá ao homem e sua mulher, na continuidade do livro do Gênesis, peles de animais. Ou seja, primeiro foi a folha vegetal, e isso foi a folha de figueira, a história da arte que inventa a folha de parreira, então veio um material melhor, que foi a pele de animal, então Deus em sua infinita bondade dá a Adão e sua esposa peles de animais para cobrir o corpo. Do ponto de vista teológico é isso. Essa é a antropologia teológica. A antropologia científica descarta o pudor. $O$ homem cobriu o corpo ou por adorno ou por proteção. E acredita-se mais que tenha sido o primeiro corpo por adorno, que sempre o homem em inerente condição humana queria se diferenciar dos demais. E depois a história da ciência, a ciência tem a comprovação, tem um sítio arqueológico ali na esquina, você não encontra a roupa, encontra o adorno. O osso, a pedra, uma pepita de metal, a roupa, por ser a pele ou por ser a folha, virou pó. E depois o caráter de proteção. Aí há um acordo entre teologia e ciência. $O$ primeiro material foi a folha vegetal. $O$ segundo foi a pele animal. $O$ registro de pinturas parietais e rupestres que tem um ser humano vestindo alguma coisinha que poderia ser chamado de roupa são folhas vegetais mais antigas e não a pele animal. Olha o compromisso da França com a moda, com a roupa, risos, carma francês. Agora cientificamente por que 0 homem passou a usar pele?

Leilane: Por proteção, para chefiar?

João: Independentemente da proteção, o homem começou a imigrar para lugares mais frios e precisou de material que o protegesse para conviver com o inverno, essa coisa toda. Então vamos cair em um ciclo que não vai ter fim, é um processo que você vai analisando e uma coisa puxa a outra e mais outra, e precisa focar e direcionar.

Leilane: Aquelas idas e vindas da moda que eu falei que se aproximam para ganhar capital simbólico ou como campo autônomo. Você concorda?
João: É evidente. Uma das primeiras no Brasil a fazer isso foi a H. Stern os Irmãos Campana uma vez fizeram uma coleção de joias, depois Carlinhos Brown, Constanza Pascolato. Fulano da esquina pode ter uma ideia bem mais interessante, mas fulano da esquina não é ninguém. Então a moda se faz disso. Por que a C\&A não faz uma coleção de uma aluna de uma escola? Porque os nomes bacanas vão dar muito mais prestígio. Tem essa aura inatingível.

Leilane: Do seu ponto de vista que está, de tudo que estuda, com o que observa em volta do mercado, falta reflexão intelectual sobre projeto? Você, que aprendeu sozinho, na unha, risos.

João: Com a professora Serafina e lendo muito, lendo muito.

Leilane: Mas projeto você aprendeu sozinho, não é?

João: Perdão, Leilane, eu falei, minto...

Leilane: Falta reflexão intelectual no projeto em moda?

João: Acho que falta um pouco. Principalmente no fast-fashion.

Leilane: A gente tem alguns poucos na comunicação, a Cris Mesquita, tem uma turma bacana. Só que assim, em projeto...

João: Acho que falta, porque as pessoas ficam muito mais envolvidas com a criação, e o prestígio, o status, essa aura que a criação dá em função do prestígio do artista, falando da realidade, não tem uma moda sem um estilista e um modelista. $O$ prestígio vai para quem? O estilista. $O$ modelista que está muito mais envolvido com projeto, com o protótipo, ele não sobe numa passarela. Então tod mundo, a vaidaide humana quer o reconhecimento

Leilane: É isso que eu falo que tem em projeto. Com o estilista ele não pode criar gargalo, seja um couturier, o créateus ou um estilista de Bom Retiro, de Brás, de magazine. $O$ problema é você dar uma ficha técnica, um desenho para o coitado do modelista e ele tem que se adaptar ao seu jeito, e vocêaté fez uma faculdade mas não sabe projetar.

João: Agora quem dá o prestígio?

\section{Leilane: É o design.}

João: É o fulano que você fez a fama e está dormindo na cama. Agora eu não desmereço porque umas pessoas são mais sensíveis, não conseguem se adaptar a uma metodologia. Dener assinava contratos para fazer prêt-à-porter e não conseguia, ele não conseguia se adaptar com produção em série, com sistematização, com produzir e entregar em época, e isso e aquilo, não conseguia, por mais que ele assinasse contrato.

Leilane: Diz que ele e o Clodovil brigavam muito, que eles ressaltavam os defeitos um do outro em brigas para tentar vedar, não mostrar uma falta de estudo mesmo.

João: Olha, me desculpa, isso é, eu vejo, segundo o próprio Clodovil, que a gente entrevistou para esse vídeo que te prometi, foram quase duas hora de entrevista, foi super reduzido e editado, temos 120 horas de gravação 
para produzir um documentário de uma hora e quarenta. Então o Clodovil falava, nós éramos amigos, a gente falava e simulava essas brigas para um dar prestígio ao outro. Nós nos reuníamos à noite e ríamos das nossas brigas, porque dava visibilidade um para o outro, inclusive o Dener sendo meu opositor só me dava prestígio. E a 02,09,22 que botava panos quentes, era a guerra das tesouras.

Leilane: Os dois eram do interior..

João: Sim, simplicidade, Dener era do Pará e o Clodovil do interior de São Paulo, você pega nomes bacanas na moda que se fazem de inatingíveis, grosseiros ou qualquer outra coisa que o valha, muitas vezes

Leilane: Uma atitude defensiva, cria a aura...

João: É, porque eu não vou pra 02,09,59, eu posso fazer maravilhosamente bem mas não vou conseguir colocar um negócio teórico. Você sabe que isso já aconteceu comigo?

Leilane: Dentro dos grandes hoje, João, aqueles sem graduação nenhuma, e são, não desmerecendo, são homens, é uma outra questão, é que sou mulher e sou muito sensível.

João: Sim, sim, mas eu já fiz um artigo sobre isso. Mas às vezes soltam umas coisas perdidas, não é? São sensíveis, têm uma capacidade criativa, mas falta uma palavrinha que se chama humildade. Uma vez uma joalheira me chamou, um ex-aluno, criou a coleção, a gente vai vender isso, gente que sabe vender. Junta pra gente o que eu falo com quem e cria um tema.

Leilane: Ah, tudo bem, mas se não tinha apresentado um briefing. 02,11,30

João: Agora junta lé com cré e cria cinco temas para a gente justificar o que fez.

Leilane: Esse tipo de coisa é um absurdo. É um antiprojeto e acontece. Joalheria para você é design ou moda?

João: Design e moda.

Leilane: Pô, João! Hahaha

João: Leilane, você é só seu pai?

Leilane: Não, não dá, hahaha. Para você a moda é bem híbrida, não é?

João: Totalmente. Qual é a raça pura hoje? Não existe. O conceito do Gilberto Freyre, do que ele chamou de mensagem para as massas, não. Sempre foi assim.

Leilane: Se intensificou e se admitiu.

João: E ele que plantou sociologicamente essa moda.

Leilane: Agora quando você fala com um designer de joias que veio que veio do design de produto começa a citar história, aulas de joalheria...

João: Ah, mas agora é isso, agora é o ouro branco, agora é a turmalina paraíba, agora o diamante amarelo, isso é moda.

Leilane: Moda como efeito passageiro.

João: Sim, dura até um pouquinho mais, mas tem uma durabilidade maior. Porém, como design, como objeto, que eu vou ter que ter o diâmetro do dedo, quantos gramas, mas por que vou fazer agora em ouro rosé e não com ouro amarelo? Isso é moda, meu Deus do céu. Então não tem como ser uma coisa genuinamente pura. Não dá. Medicina hoje. Consegue viver sem tecnologia?

Leilane: Não, claro que não. É que eu não queria deixar essa coisa da joia, então fiz matelado porque fiz matelado $02,13,57$, queria deixar na conta do fenômeno passageiro.

João: Mas é, pode durar um pouquinho mais, mas é.

Leilane: Não suplantando e deixando de lado, mas caminhando ao lado do design como projeto.

João: Eu fiz uma pesquisa, fiz um artigo, a única década do século 20 com mais mulheres fazendo sucesso na moda foram os anos 1930 . Todas as outras são homens, sem exceção, para vestir as mulheres.

Leilane: E o homem é superantigo, não é? 02,14,40

João: Risos. Aí entra muito do trabalho até do Duran 02,14,48, que lembro que quando lançou o livro assisti uma palestra dele, isso foi nos anos 1980, ele falou assim: 'Todos os estilistas franceses, à exceção de um, todos, mesmo casados, são homossexuais'. O único que não é homossexual é o Daniel 02,15,11. Ele era casado, prefeito de uma cidade no sul da França, ou seja, ai entra aquela teoria da psicologia. $\mathrm{O}$ homem faz uma roupa para mulher para quê? Para se identificar nela, ou para vesti-la ou para despi-la, para possui-la. Muito mais na identificação do que na posse. Não dá para desvincular moda de psicologia, moda de arte, moda de design, não, é um bololô só.

Leilane: Quando você fala do fast-fashion, essa reflexão absurda, incrivel o que você está fazendo aqui, histórico, sociológico, não dá tempo.

João: E econômica.

Leilane: O projeto já é prejudicado nessa lógica, imagina uma produção desse nível.

João: As pessoas querem respostas verdadeiras e imediatas. Não é as sim, por que um processo cultural, que é coisa do homem, seria? Tudo bem, lei da relatividade é lei da relatividade, lei da gravidade é lei da gravidade, na China ou em qualquer lugar. Se há uma diferença entre ciência e tecnologia, é muito diferente. Aí essa questão do Lancome. 02,16,43. Não entendi. Baroque, minimalismo, ou seja, é o novo 02,17,03 com a mesm coisa, ou seja, tem uma nova roupagem, uma nova maquiagem. E aí entrevistaram uma maquiadora, ela disse: usei 16 maquiagens diferentes no rosto das modelos para que elas parecessem que não estivessem usando maquiagem. Ela usou 16 produtos para que elas parecessem não estar 
maquiadas. Tudo bem, sabemos que tem flash, tem luz, tem luz colorida, mas para parecer que fosse natural usou 16. Isso é base qual? Risos, tudo isso para criar um uniforme.

Leilane: Para vender um produto de moda.

João: Também.

Leilane: Duas perguntas em relação ao Brasil. Falta estilo nacional, se é possível falar em estilo nacional, design de moda nacional?

João: $\mathbf{A i}$, meu Deus, agora a coisa apertou sem me abraçar. Depois daquele livro lá da questão da moda no Brasil, o subtítulo eu quero que seja: "das influências às autorreferências". Eu vejo uma coisa muito diferente en tre moda no Brasil e moda brasileira, inclusive vai haver um moda-documento em maio, a Marcia Merlo me colocou para fazer a palestra de abertura, na Santa. E o tema eu sugeri e ela adorou, vai ser exatamente esse: moda no Brasil ou moda brasileira? Moda no Brasil, Leilane, é tudo aquilo que você usou, falando só de moda. As mulheres da belle époque compravam roupa de Paris, estão usando moda no Brasil? Estão! E moda brasileira? Aquela questão de amor de mãe, amor materno, risos, amor de pai, amor paterno, moda no Brasil, moda brasileira, na teoria seria o radical, mas não é. Por que razão? No meu ponto moda brasileira só surgiu com Collor de Mello, porque Collor de Mello teve aí, impeachmado, aquela coisa toda, foi ele que abriu o país para as importações, e os famosos tecidos, os famosos tigres asiáticos da época, quebraram as indústrias têxteis até dizer chega, depois vieram confeccionados, agora vem as supermarcas, marcas de produtos sem ser roupa. O que, no princípio dos anos 1990, com o Collor de Mello, o que o profissional, nem vou falar estilista, o que o profissional de moda no Brasil precisou fazer? Olhar para o próprio umbigo para ter um diferencial, convencer a imprensa, o cliente internacional que começou a vir aqui, os compradores, enfim, então aí acho que começa a surgir moda brasileira. Pós Collor de Mello, porque aí você passou a olhar para o próprio umbigo, para criar uma identidade.

Leilane: Você está falando das escolas mineiras, todo aquele grupo paulista?

João: Sim e não. Não, porque grupo paulista, grupo cearense, grupo mineiro bebia na fonte dos anos 1980, dos japoneses, de Paris..

Leilane: Havia uma arte nativa carioca?

João: Uma arte nativa aplicada?

Leilane: Isso.

João: Já era outra coisa, mas estava muito mais design gráfico, joguinho americano, era o tecido, não sou dono de uma verdade mas tenho direito a ter um ponto de vista. Quem foi o primeiro a cantar essa bola? Muito antes, e verdade seja dita: Zuzu Angel. Quando ela pegava as rendas brasileiras, do Nordeste, uma série de outras coisas, renda paraíba, Paraíba do Sul, tem uma fábrica de renda linda, e aí, independente disso, ganhava essa identida- de do interior, Zuzu na época, como mostra no nosso vídeo, era considerada cafona porque se inspirava no Brasil. $O$ chique, plagiando as palavras de Elke, era copiar a moda de Paris, Elke era modelo de Zuzu. Ou seja, Zuzu cantou essa bola antes de ter acontecido o que aconteceu com o filho dela. Então continuo na opinião de que o melhor crítico que existe é o tempo, que hoje reconhece isso em Zuzu. E na moda masculina Luis de Freitas 02,22,31, ambos no Rio de Janeiro. Ele revolucionou a moda masculina, e aí você pega os bacanas dos anos 1980, minimalismo, os japoneses, depois nos anos 1990 o desconstrutivismo, e aí na indústria, Luis de Freitas tinha confecção, Zuzu foi muito mais ateliê do que confecção, apesar de ter a loja, um dos primeiros a cantar essa bola foi o Tufi Duek, que ele se inspirava no Niemeyer, na Amazônia, ele fez um pioneirismo na indústria, no prêt-à-porter. E agora é bacana você se inspirar no Brasil. Apesar de toda a globalização, estamos em busca de um design nacional.

Leilane: Nós temos gente que tem um trabalho incrível, o Ronaldo Fraga, o Lino...

João: Aí o que a imprensa me pergunta? Quais são? Eu falo que tenho quatro nomes: Vera Arruda, sempre gostei dela. Olha, eu tenho três ou quatro nomes, em ordem alfabética, para não privilegiar nenhum. Alexandre.

Leilane: Você acha que é identidade nacional?

João: Não, ele tem identidade internacional. Mas ele ajudou a colocar, ele trouxe a ideia do desconstrutivismo, que era uma ideia forte, para o Brasil e ajudou a colocar o Brasil no cenário internacional. No meu ponto de vista, ele tem uma moda urbana, jovem e ajudou a colocar o Brasil na contemporaneidade lá fora. Outro que acho que tem uma identidade bem brasileira é o André 02,24,29.

Leilane: Trabalhei para ele.

João: Outro, por ordem alfabética, Lino Villaventura, que se rendeu ao atacado faz seis meses, perdeu a identidade. E outro o Ronaldo Fraga, que tem essa identidade de interior do Brasil, uma realidade do Brasil feita à mão, uma mineirice sem ser pejorativo.

Leilane: André e Lino muitas vezes foram considerados cafonas. Ronaldo é cult.

João: Pois é. Por alguns. Por eles terem identidade própria muitas vezes incomoda. E a crítica é no mesmo caso de Zuzu, que tem identidade. Uma roupa do Lino precisa de etiqueta? Uma arquitetura de Niemeyer precisa ter uma plaquinha? Uma música do João Gilberto, precisa saber que é dele? Isso é autenticidade, isso é genuinidade. Se agrada a imprensa e tem uma mudança constante, com artefato jornalístico, se agrada ao consumidor, é outra história. Ele é autêntico e não está nem aí, ele faz o que tem que $02,25,46$, sem desmerecer nada. Eu faço das minhas camisas o que eu quero, se não gostar, está bom, tem onde achar. Eu não dependo disso e satisfaço a minha experiência criativa. 02,26,14

Leilane: Vera Arruda você considera? 
João: Nossa, demais, tanto que Vera Arruda morreu logo depois da minha mãe e eu fiz um artigo contando a história do luto e dediquei à minha mãe e à Vera Arruda. Agora tem outras marcas. Tem a Ethos, elas querem seguir tendência, não, querem fazer o trabalho delas. A 02,26,56, de Brasília, Walter Rodrigues, da valorização das rendeiras, e antes de vender produto vende lifestyle. Então tem identidades de brasilidade? Talvez o mais bacana ainda com design seja a sandália Havaianas, já tem mais de 50 anos. Então acho que não há respostas absolutas, análises, leitura, e sempre tem esse pioneirismo de alguém, os franceses vão fazer o curso de grafite, onde vão buscar a origem disso? Nas pinturas do $02,27,48$. Pintura na parede, então eles têm um olhar e muito das escolas dos $02,27,54$ que nos ensinam a historiografar maravilhosamente bem, nesse sentido de ver os antecedentes. Não estou arremedando a roda.

Leilane: $\mathrm{E}$ como fica então nosso estilo nacional em relação às tendências?

João: Hoje buscando cada vez mais, cada escola contribui muito, esse processo de abertura das importações, inevitavelmente os processos de comunicação, hoje está acontecendo uma coisa no Japão, já está aqui, em tempo real. Conclusão: então cada vez mais a gente precisa do trabalho autoral, para ter uma identidade precisamos de valorização das nossas raízes, sem ser traje típico. Eu estava aqui no Shopping Higienópolis com a turma, aí dão o brinde da L'Occitane. Eu já tinha pegado um e falei 'toma pra vocế. Aí peguei um tíquete e a menina falou para ir na loja de baixo. Aí eles fizeram vários produtos com a técnica da L'Occitane mas com jenipapo, cupuaçu.

\section{Leilane: É uma delícia, supercheiroso.}

João: Depende se é gostoso ou se não é. Aí eles têm sabonete de banho de sal, banho de ouro, e é sabonete, e gente, as marcas internacionais pegaram as nossas coisas. As nossas matérias, o cupuaçu, jenipapo, a pitanga, 0 que quer que seja, fizeram as coisas, pegaram as nossas culturas e superstições e venderam sabonete do primeiro banho do ano, coisa que não tem na Inglaterra. E fizeram. Tudo bem que o Boticário já fez uma coisa ou outra em relação a isso, Natura, mas são marcas internacionais que vêm e roubam a nossa brasilidade para ganhar dinheiro. Comércio é comércio, apesar de Boticário e outros que querem fazer coisas bacanas, com uma essência de um perfumista não sei de onde, os outros vêm e fazem com a nossa realidade. Aí as coisas da L'Occitane tudo com desenhos de repentistas, xilogravura, e a gente continua nessa postura colonizada de valorizar o que vem de fora. Então a gente busca para solucionar os problemas? Não. E não vai solucionar $100 \%$, porque é tudo banalizado, a gente recebe festa de todos os cantos, a gente influencia.

Leilane: Talvez se tivesse desenvolvido mais.

João: Aí entra a questão comercial, questão de política pública, de iniciativa privada e comercial.

Leilane: Você que aprendeu a projetar praticamente sozinho. Existe um modo de projetar diferente do que você tenha visto, estudado fora do Brasil?
João: Eu acho que tem modos de projetar no Brasil. Porque uma cearense é uma brasileira, uma gaúcha é uma brasileira, uma mineira é uma brasileira, então a gente sempre vai ter um padrão de beleza que o Brasil nasceu híbrido, então existem códigos no meu ponto de vista que são códigos de brasilidade, como nos meus próximos livros. Os conceitos no meu ponto de vista que regem o Brasil, a brasilidade na moda. Vou lançar em 2015. Ou seja, eu acho que não tem uma maneira de projetar, existem tantas identidades, tanto que no Brasil tem a magra, a gorda, a alta, a baixa, a cadeiruda e a mais retilínea do Sul, com tendencia mais europei, e a gente não consegue ter retilnea do sul, com tendencia mais europeia, a gente nac consegue ter ia muito mais associado para ter uma unificação do 36 , do 38 , e mais do que isso, os modismos, agora o skinny. As calças skinny são tão apertadas que eu uso 40 e não consigo, se a calça é skinny tenho que comprar 42. Não entra. Então que padronização é esta? Não tem. Então existe uma maneira de projetar no Brasil? Existem inúmeras tentativas, e existe um dançar conforme a música.

Leilane: E isso compromete a ideia de projeto, muito, seja de modelagem, de estilo.

João: Apesar de que o mundo está misturado.

Leilane: Mas também não pode virar qualquer coisa.

João: Mas uma inglesa é muito mais magra, não tem as ancas, francesa é mais mignon.

Leilane: Mas também se vai para a França, Inglaterra, estive agora na Inglaterra, é cheio de indiano. Mesmo na França não tem, 55\% da população de Paris não é francesa. Só $45 \%$ é francesa.

João: Como se diz em São Paulo, o mais populoso do Nordeste é São Paulo.

Leilane: Fernando Henrique Cardoso falou isso, que a cidade mais populosa do Nordeste...

João: É São Paulo. Então é isso, você encontrar uma resposta absoluta..

Leilane: Não, nem estou procurando isso.

João: 02,35,22 tentou criar um padrão, a Fit, a ABest também, estão há um ano sem fazer o caderno, cadê o caderno de tendências?

Leilane: $\mathrm{E}$ os coreanos saíram em uma reportagem, sobre os coreanos que estão pagando 02,35,49 de designer autor. Os filhos, netos de coreanos agora estão querendo virar autor, estão querendo fazer virar marca. João, acho que é isso.

João: Leilane, não sei se te ajudei, se valeu...

Leilane: Você deu um ponto de vista que outras pessoas não deram. 


\section{ITO, Márcio. Entrevista realizada com Márcio Ito, em 16 de dezembro de 2014, na cidade de São}

\section{Paulo, com 1 hora e 42 minutos de duração.}

A disciplina dele na FASM é Planejamento e desenvolvimento de coleções

Foi orientado pela Simone Mina no TCC sob o tema gonias. Trabalhou com o Walter Rodrigues e isso influenciou seu interesse pelo vestuário étnico. Ele comprava peças étnicas há um tempo. Cores, formas e ajustes saíram da sua pesquisa (quimonos $X$ vestes africanas) uma se cobre a outra realça, uma é pequena, a outra é maior. Usou elástico para ajuste. Ele foi para o fórum, desfilou e teve uma das melhores notas na FASM.

Ele teve aula de estilismo com a Simone Mina, principalmente no quarto ano. Investigação do corpo, questão da forma. Ele teve aula de moulag com ela no primeiro ano e no último ano ele orientou a turma do Márcio.

No segundo ano ele teve aula com a Mariana Rocha e depois, no terceiro ano, com a Sílvia Sato (fórum e diretora da Lucy in thesky também). Fala que a Sílvia Sato ensinou a ver a roupa dentro de uma coleção.

Tem até hoje os trabalhos que fez na disciplina dela. Ela que falou de produto, o que era produto. Ele trabalhou na Chocolate e diz que aí aprendeu na marra o que era uma coleção.

\section{MÉTODO DA MARIANA ROCHA}

Mais fácil de lembrar, é um clássico, está nos livros o que ela usa. Ele conta que saia de um ponto de partida, fazia um brainstorming de ideias, pesquisava todos os elementos que envolvem aquelas ideias e aí desenvolver através de imagens ou através de particularidades como uma coia sensitiva, olfativa, sensorial, no sentido de toque e daí começava fazer a coleção.

Ele critica dizendo que o resultado era muito solto. Não havia um limite, isso é uma camiseta, isso é uma calça. O look virava uma massa, um amontoado de informações. Isso fazia com que os alunos tivessem uma liberdade que pudessem pensar que a calça é um objeto de vestir, ou seja, não precisa ser exatamente por baixo, pode ser um outro desenvolvimento de fazer aquilo ser focado no corpo.

MÉTODO SÍLVIA SATO

Ela trazia muitas ideias, muita informação de mercado. Ela fazia com que os alunos olhassem também as outras marcas. Fizeram muita pesquisa de marca como Balenciaga, quem era balenciaga? $O$ que fazia balenciaga? Qual era a linha de produtos?

Era emocionante porque ele trazia peças dela de acervo. Ela trazia bols Prada, por exemplo. Foi a primeira vez que ele tocou numa bolsa da Prada.

Ela tinha um ícone do guarda roupa e aquilo tinha elementos que eram en- contrados no mercado, mas com uma lapidação certa, com uma cor diferente, colocada num acessório que é convencional, mas com outras costuras, outros acabamentos, virava uma coisa única. Então a Silvia Sato mostrava que era possível fazer o novo através de uma mesmice que se encontra no mercado.

O modo de fazer uma coleção mesmo ele não se recorda, era muito vago. Era muito solto, mais prático mesmo.

SIMONE MINA

Ele tem fotos do TCC dele, de projeto etc. Com a Simone Mina o TCC começou envolvendo todos os itens da coleção até etiqueta e ele foi mergulhando cada vez mais nesses itens. Então vou fazer estampa, pensava no meu limite de fazer uma estampa e no que eu gostaria de fazer uma estampa. Na época não tinha como fazer uma estampa nem digital, nem quadro, por causa de grana.

Na época ele trabalhava para a Adriana Barra e ela estampa muito em Americana. O Márcio viajou muito para lá a trabalho e lá descobriu que havia quadros que poderiam ser reutilizados sem a autorização prévia dos donos.

Ele não usou as telas para regravar em seu TCC. Usava desenhos prontos, alguns caducados (há mais de 10 anos) e descontruía tudo estampando um sobre o outro, por exemplo. Às vezes ele até conseguiu desenho que não havia sido usado.

Conseguiu assim um resultado com quadro de até 8 cores, com cores clássicas, usando os melhores tecidos, como organza de seda, sarja de seda, musseline e outro tecido que ele não lembrou na hora e o resultado do toque ficou perfeito, preservando o caimento do tecido.

Era da Sakuda Sedas (a tecelagem), os tecidos da Helena são maravilhosos. A Helena é muito chique.

\section{SÍLVIA SATO X SIMON SEIVEWRIGHT}

Na página 139 ele fala de um exercício, a geração de alternativas. Há alguma similaridade com o que a Silvia propunha?

Márcio = Sim, tem. É uma coisa usada até hoje. A Sílvia era uma pessoa de mercado, foi da fórum, deu aula, parou de dar aula, sumiu, mas ela tinha uma agilidade, era uma pessoa consumista em moda, de formação de moda. Então era gostoso ter aula com ela porque ela sabia o que acontecia. Então ela também olhava o desenho e se você fazer (fizer) e disso virar um casaco, disso virar uma jaqueta, disso virar uma calça, funciona, você cria uma unidade, você pode repetir esse detalhe e disso virar uma outra peça que você misturando com outras você cria um novo look. Ele fala que aprendeu muito mais com ela por meio das orientações.

O Márcio conta que cuspia desenhos e fazia 50 desenhos para tirar 5 ter alguma coisa diferente. Ele fazia parte de um grupo de desenho. Então ele conta que pegava uma ideia e ficava pensando naquela mesma ideia às vezes saiam 50 desenhos. Então laço...laço, laço, laço.....até dizer chega $e$ daí selecionava 5, 6. A camisa de laço, aí agora vamos fazer de zíper, calça 
de zíper, jaqueta de zíper, vestido de zíper, só no zíper, pensando só em zíper e pensando numa outra base. Daí juntava a calça de zíper com a camisa de laço e criava um look. Então esse look não pode ficar sozinho e pensava na continuidade. Aí pensava no vestido de zíper e com a sobreposição de uma blusinha que vai aparecer só a manga com lação. Então a gente criava esses grupos (de looks). Então tinha produto e tinha coleção, conceito, toda...[fica fugidio, é difícil explicarem processos com clareza].

PESQUISA COLADA SOBRE FIGURAS SIMON SEIVEWRIGHT P. 119

Alguém usou isso como ferramenta com você? Você usa, reconhece isso?

$M=$ essa linha de pensamento que a Mariana usava. Pensava na forma, na sombra e recortava o papel e com a sombra tinha a ideia de uma silhueta sem partir de uma forma figurativa, mas depois em algum momento da aula vinha a parte figurativa também. Quebrava esse desenho ou quebrava aquela imagem e fazia recortes.

Teve aula de Metodologia visual com a Paula Mota. E rolou uma brincadeira de desmontar uma imagem e fazer outra e isso ajudou o Márcio par fazer estamparia no terceiro ano. Tem muito a ver com o raciocínio de estamparia que ele desenvolveu no terceiro ano. Ele elaborou esse pensamento na minha frente. E continuou: porque eu desconstruía a própria estampa, porque é uma coisa que está chapada e eu criei movimento modificando o tecido usando sobreposições de transparências no TCC. Montou o desenho da flor, pétalas, flores etc e encaixou e o deslocamento do movimento criou uma nova estampa. Ele conta que foi muito corrido fazer o TCC. Teve as estampas no final de setembro e no final de outubro já era a apresentação.

\section{ELINOR E COLLIN RENFREW}

Conhece e adota o livro. Falou que o livro é muito bom, que gosta muito dele. Mas esgotou e não dá para a FASM comprar agora. Parece que ele cedeu o livro dele para deixar na biblioteca da FASM.

Ele falou daquele livro "MODA: DO CONCEITO AO CONSUMIDOR" ele não lembrava. É um livro preto. Esse livro fala de PLANEJAMENTO o método americano.

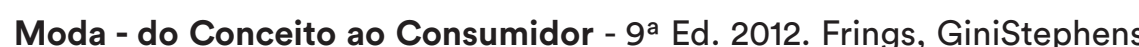
- Bookman

Ele usa o livro para falar sobre mercado e também para a divisão da coleção. É um livro mais de planejamento, de negócios e mais generalista sobre a cadeia têxtil sob uma visão do marketing. Esse livro ajudou os alunos verem as parte que compõem uma coleção, pois ele disse que alguns antes viam a coleção como massa. Divisão em tops, bottons e onepieces. Número proporcional de peças de cada categoria. Separa em itens uma visão geral: roupa de academia, porque às vezes em uma coleção grande você tem um pouco de cada (academia, alfaiataria...). e esse livro facilita visualizar as divisões de um mesmo produto.

Ele usa como base o livro dos Renfrew mas vai precisar trocar porque es- gotou. O que ele mais usa o é o Fashion Design (Sue Jenkin Jones) é o único que não gonga esse livro. Ele acha que é um livro bom, o primeiro que surgiu no mercado. Nop não é. O primeiro é da DorisTreptow.

A disciplina dele PLANEJAMENTO E DESENVOLVIMENTO DE COLEÇÕES

Antes era dada no terceiro ano e depois passou para o segundo. Agora a Walquiria Caversan dá Estilo (Estilismo) no terceiro só que vai mudar na nova grade. $O$ Márcio volta para o terceiro.

Dá uma ideia de planejamento, ideia, forma, mas é do grupo de disciplinas de Estilo. Ele fala que é possível fazer uma coleção sem Estilo, uniformes, por exemplo. Fazer sem estilo, roupa para companhia área por exemplo. Mas confessa que não foi brilhante o resultado.

Quando um estilista coloca a mão num uniforme ele muda e coloca a essência da nação (falamos do Courrèges, Pierre Cardin, YSL).

\section{LIVROS DE DESIGN}

Conhece o Bruno Munari, mas o BerndLöbach não.E o Gustavo Amarante Bomfim também não conhece.

\section{MODA É DESIGN OU ARTE}

É bem ampla, comportamento. Conhece o "Moda como campo do saber". Ele pensa moda como um campo global, não só no Brasil.

Tem Desenhista de moda ou fashion designer, assim como na França e na Itália. Não há um termo restrito à moda (estilista de produtos de design).

Dentro do design de moda posso fazer um sapato, uma joia, uma cenografia, um VM, por exemplo. Moda é uma área do design, mas como comportamento ela entra como saber e de maneira muito mais ampla. A moda é a área que tem mais abertura em relação à outras áreas.

É preciso conhecer as vontades do consumidor, conversando, entendendo para saber o que eles querem. Minissaia com babado de godet. Sempre existiu, mas explodiu de vender no Brasil. Os grandes estilistas compram o desejo, a marca, quando começou a falar da bolsa da Céline, Chloé que só vira no Brasil. Trabalham com desejo, sonho.

\section{DESIGN NACIONAL}

MODA PRAIA. Lenny, Água de coco, Adriana Degreas, Vix (da filha da Lenny). Amir Slama é reconhecido, mas deixou de ser depois da Rosa Chá, quando ele sai. E aí a Lenny cresceu.

TRICOT = Cecília Prado, Lucas Nascimento (que é uma referência. Who?) $70 \%$ da produção deles é exportada de $M G$ para o mundo. A produção é verticalizada, máquinas de jacquard que funcionam quase 24 horas.

Adriana Barra faz digital lá em Americana.

Reconhece que o Lino Villaventura representou, mas não mais. Ronaldo também foi, vendia bem para o Japão. 
A referência para o Márcio quando ele entrou na FASM era o jeans. A zoomp era uma referência, a Gisele Bundchen. Para o Márcio dá para falar em jeans com identidade nacional, mas ele tem que estar marcado dentro do território mundial. E temos identidades regionais.

A Vix colocou um bumbumzinho, com uma lycra melhor, uma estampa dela e criou um design próprio. Falou da calça da Gang.

Uma referência para o Márcio na faculdade foi o Feres.

PRÁTICA

Não tinha muito texto, era mais prática em projeto. Na aula da Marian Rocha eles criaram uma marca. Conta que não sabia o que era currículo lattes. Foi apresentado no dia da entrevista.

$\mathrm{Na}$ faculdade ele aprendeu processo criativo, mas como desenvolver uma coleção de fato não, só no mercado.

Fazia harmonia de cores dentro de um quadrado para maquiagem ou azulejo no fundo branco e preto com a Raquel Valente. A moldura branca em cima de um fundo bege. Tinha a parte da forma com papel ou tecido que é a moulage. la direto para o manequim e depois desenhava ou desenhava e ía para o manequim. Interessante é fazer a moulage virar outras peças olhando a primeira moulage. É o que a Clos Orozoco fazia. Alexander Wang usa o mesmo material, mesma forma para fazer uma blusa, um colete e uma jaqueta. Partir do manequim ou do desenho tanto faz, os 2 são válidos. Os processos podem ser adaptados e terem sua ordem invertida.

ESTILISMO

Estilo não é para todo mundo. Chanel. Fazer roupa muita gente pode fazer, mas ser um estilista é colocar uma identidade ali. Tem muitos estilistas que não são autorais, mas atendem o mercado. Estilismo é uma coisa que envolve o intelecto. Ee é uma coisa que já é natura da pessoa (MITO). Comparou farm e adriana barra e surgiram quase competindo, mas é quase como se a Adriana Barra fosse estilo e a Farm mais projeto.

\section{ESTILISMO X AURA}

É uma questão mais conceitual que prática na verdade. Ele acha que isso acontece porque as pessoas colocam o estilista como um artista. $O$ cara que vai trazer o sonho. $O$ que vai fazer o vestido exclusivo para a pessoa, como o Sandro Barros. Dele vem o sonho.

É muito louco pensar que estilista é artista, mas na real não é.O que o Valentino faz no Prêt-à-porter é um haute couture no Prêt-à-porter.

Eles não são artistas, porque eles trabalham muito. Hahahahaha. Produziram uma coleção em 1, 5 mês. Penso que o artista tem um pouco de liberdade quanto ao planejamento e $\circ$ estilista não. 0 estilista tem que fazer aquilo acontecer. $O$ estilista tem que pensar que tem prazo, tem produção, valor para aquela peça, limitado, vender o sonho.

\section{MOVIMENTO COMPLEXO DA MODA X ARTE}

Contraditório, ambíguo, estranho, bizarro. Amir Slama fez estampa com os Romero Britto e vendeu muito bem. Hoje é difícil pensar que o Slama chamasse o Britto para fazer algo.Chamaria o Vik Muniz, rs. Foi uma atitude estratégica, para ganhar ponto. Essa comunicação com a arte na moda é para vender mais. YSL que usava Picasso, Braque. Falei da Valérie de Givry.

Aquilo não é bacana mais, já passou. Então a moda se distancia, porque moda, não é arte. Como o bordado no PAP que era cafona, antigo, mas vende.

As disciplinas que norteiam o curso de moda da FASM são de estilo: laboratório de criatividade no primeiro ano, planejamento no segundo e estilo no terceiro e quarto anos.

Laboratório de Criatividade $=$ Walkiria Caversan

Como estilista ele aprendeu a ver o que vende. Performance por produto. Fez 50 vestidos e vendeu só 15, então vamos entender porque os 15 foram sucesso e vamos fazer 20, o corte, modelagem, tecido certo e faz. Perguntavam para o vendedor o que fazia aquilo dar certo. Porque aumenta o peito, porque dá para usar soutien, tira barriga.Então na próxima coleção tem que fazer um vestido com a mesma cara com um design diferente.

\section{Falei sobre a MFM eeeeccccaaaa.}

Peças de continuidade, inovação = relembrar isso da Vera Lígia

Só a experiência traz essa fluência, para o Márcio não é só analisar relatórios.

Falei da Docci e os vestidos que só encurtavam, de $85 \mathrm{~cm}$ para $82 \mathrm{~cm}$. Falamos de identidades cambiantes, a indiepiriguete, a gótica periguete, a mulher que é executiva, mas a noite quer ousar (a tigresa). Ser piriguete um estado também não uma única condição. Tem a ver com o Instagram.

\section{REFLEXÃO INTELECTUAL SOBRE PROJETO EM MODA}

Falou que na disciplina dele há mais detalhes práticos e o teórico nem sempre é contemplado, mas também não falta reflexão. É que ele consegue refletir a partir da prática.

Falou que o público alvo é um ponto chave para fazer uma coleção. Ele afirma que os alunos que leem conseguiram fazer um trabalho que atendeu o que era o projeto com uma informação a mais e tinham mais clareza. Tinha quantidade de peças, tinha organização do bidimensional, a seleção de matérias, tinha matérias leves, pesadas, tinha cores equilibradas. Parecia que pegou a receita e soube aplicar da maneira certa.

Falou de um texto sobre público alvo que é fundamental. Tá! A mulher é sempre alta, magra, classe A. Quem é o corpo que eu vou vestir na cia. aérea? Quem é esse público? Essa mulher é alta, é baixa? É magra, é gordinha? Não. O critério é competência. E como você vai fazer um uniforme para um grupo de pessoas com corpos diferentes. E se for internacional? Como é 0 corpo de uma americana e de uma brasileira? Ele está falando de questões que são a ideia de problema do design, de Löbach. 
Ele afirma que o aluno de moda tem pouco hábito de leitura. Mesmo quando folheia uma revista, folheia, não lê. Um New York Times vai falar com detalhes por meio da Suzy Menkes. Não interessa só que uma pessoa vai sair de uma marca, mas sim porquê?

\section{Há um modo de projetar brasileiro?}

Somos rápidos na resposta de resolver o problema proposto. Temos problema com matéria prima. A pilotagem tem, mas a produção não chega e aí é correr atrás de algo parecido. Num mercado americano isso é inadmissível.

Nós sabemos encontrar novas possibilidades. $\mathrm{O}$ mesmo produto requisitado que custa 200 reais dá para fazer com uma matéria parecida mais barata e cobrar os mesmos 200 reais.

Não se esperava isso, mas funcionou. $O$ processo também é feito de acasos. De um jeito que o brasileiro consegue lidar melhor.

Tem também o jeito de pegar o que não está vendendo e propor uma espécie de redesign com aquilo. A gente faz acontecer e se rebola. $O$ problema é quando é usada uma peça, uma solução durante 6 coleç̃os seguidas a mesma peça, como a Martha Medeiros.

É pensar em soluções sazonalmente. A inovação tem que ser constante, a nova leitura, o novo olhar. É isso que faz a gente continuar.
ROCHA, Mariana M. L. Entrevista realizada

com Mariana Machado Lousada Rocha, em 9 de

dezembro de 2014, na cidade de São Paulo, com 1

hora e 50 minutos de duração.

Cursou moda de 1993 até 1995, parou por causa da gravidez de risco e voltou de 1996 para fazer estamparia, estilo, fotografia, as disciplinas mais práticas.

Foi da turma da Simone Mina, Walquiria Caversan, Karla Girotto, Priscila Daroult, Gisele Nasser.

Foi professora de Estilismo na FASM por 11 anos, de 2001 a 2012. Substitui ○ Carlos Mauro. Ela teve aula na graduação com o Carlos Mauro, a Sylvie Leblanc e a Chiara Gadaleta.

O único professor de estilismo era o Carlos Mauro até 1997. Ele saiu em 1997. Ela teve aula com ele no segundo ano e até metade do terceiro, lembrando que o curso era anual até 2014. Ela entrou mais velha na faculdade, já sabia o que queria, tinha muito interesse. Ela é filha da Ruth Rocha e o pai tinha uma fábrica de acessórios onde fazia projetos próprios desde pequena.

Fizeram muita coisa no ateliê do pai, que era um artesão de bolsas, para Daniel Esther?,Company, Glória Coelho, Sears (produção maiores). Tinha mais de 100 funcionários e fabricava. $O$ pai dela tinha marca própria Eduardo Rocha e foi badalado na década de 70, vendia na Rua Augusta, na Loja do Aparício, da Rastro Perfumes. Ele descobriu o Eduardo Rocha, saia em revistas, a ConstanzaPascolato adorava. Desde pequena ela frequentava esse ambiente de fábrica.

Ela cantava e estudava música, teve banda e o pai insistia que a filha cuidasse da fábrica, que era um bem que a família tinha. Ela preferiu cantar profissionalmente. Passou um ano na Europa, depois de trabalhar com o pai. Lá ela descobriu a moda no início da década de 80, os japoneses, Myiake. Já se identificava com o punk. Ela teve contato com a DepecheMode, Jean Paul Gaultier, AzedineAlaïa, ChantalThomass que era o movimento dos jeunescréateurs. Ela foi lá para procurar uma professora de canto, mas voltou achando que ía trabalhar com moda. Quando voltou, a antiga banda dela "Garotas do Centro" estava bombando no meio alternativo, na cena do rock da década de 80. Elas faziam muitos shows. Ela manteve a carreira de cantora com as "Garotas do Centro" e como voltou apaixonada por moda o pai permitiu que ela trabalhasse em horários mais flexíveis na fábrica de acessórios. Foi nessa época que atendeu a Glória Coelho.

Fazia representação para fazer contatos comerciais com especialização em design de moda, o PL, privatelabel. Trabalhou quando tinha 20 anos na Daniel Esther, com representação no Brasil, na Avenida Faria Lima.

Comentários sobre sotaque carioquês e botuquês. Ela não queria fazer faculdade, era rebelde e queria seguir um caminho "menos formal" 
Nessa época chegou a entrar em contato com o Carlos Mauro por meio do CIT da Rhodia. Eduardo Rocha quem indicou para a Mari esse curso. Ela também falou com ele pessoalmente na época. Fez cursos com a Serafina no $\mathrm{MCB}$, fez vários cursos de moda. Nesse período, no início da década de 80 não havia faculdade de moda. Fez ESMODE na primeira versão, na Rua Frei Caneca.

Não fez o curso do CIT pois não estava ligada à empresa filiada à Rhodia. Carlos Mauro indicou a ela cursos e a aconselhou a fazer todos os cursos livres que encontrasse. A banda dela ocupava muito tempo também. Assim, ela tinha que dividir seu tempo e não se dedicava o tempo todo à moda.

Foi assistente da Isabela Graco, na Daniel Esther. Ela participava de escolha de tecidos, venda para representantes, passava roupas, organizava araras. Como assistente da Isabela Graco, dona da representação, trabalhou em 1983-1984.

Foram 3 anos de muitos shows com as "Garotas do Centro". Ela tem 52 anos, nasceu em 1962. Nessa época não se dedicava exclusivamente à moda.

Entrou na graduação em moda, em 1995 com 30 anos.

Além do Carlos Mauro ela teve aula com Sylvie Leblanc (parece que estudou no Berçot). Ela foi da Cia. de Moda (conferir na tese da Vera Lígia), do Walter Rodrigues e do Conrado Segretto, Marjorie Geller, Maira ????stein

A Sylvie Leblanc ficou 2 anos na FASM lecionando estilo. A segunda vez que a Mari fez o terceiro ano foi com ela. E o quarto ano ela fez com a Chiara Gadaleta.

Segundo a Mari, a metodologia da FASM é toda dos Bureaux de Estilo, não vem de escola. $O$ Carlos Mauro tira essa metodologia da Mari Ruckique dava os cursos do CIT e em quem ele bebia muito e isso fica como uma marca da FASM. A ideia de projeto na FASM segue a metodologia dos Bureaux franceses por mais que a Vera Lígia tenha montado uma grade para o curso de moda sobre a grade curricular dos cursos de artes. Ela vem da prática do mercado e da construção que visa construir a coleção com foco em vestuário, embora tivesse moda casa. Já tinha joalheria nessa época, mas não acessório.

Consegue descrever os processos do projeto criativo de moda dos 3 professores?

\section{Carlos Mauro, Sylvie Leblanc e Chiara Gadaleta.}

O principal era o Carlos Mauro. Era impressionante porque ele tirava algo das pessoas que eles não sabiam que tinham, mas o método para isso era completamente empírico, psicológico e não tinha nada racional, pouca coisa racional.

A geração que teve aula com ele quando se tornou professor passou por um problema: como é que era mesmo? Se referindo a puxar na memória as etapas processuais do projeto em moda, porque tinha um caderno de anotações, mas não tinha explicação nenhuma, nem descrição de quaisquer etapas. No flipchart eram os alunos que escreviam seus brainstormings de desejos em um processo coletivo. $O$ que estavam ansiando. Tudo partia disso, não tinha método. O clima na sala era de guerra, era só emoção, emotivo, experimental, vinha das entranhas e se transformava em experiência concretizada ali.

A primeira aula de estilismo: contar 3 histórias do seu passado que tivesse alguma relação com têxtil por meio de objetos como imagens, tecidos, objetos. Era um shopping interno, a DOCUMENTAÇÃO. Era uma primeira experiência afetiva. Ele dava pistas, ele não dava nome a nada, nem documentação que é como a Mari se refere era um nome dado por ele. Eram pistas rápidas. $O$ resultado era proveitoso e as experiências incríveis apesar da falta de linearidade no processo.

Lane - Ele não dava nomes a nada porque não queria contaminar o processo criativo de cada aluno?

Mari - Ele não dava diretrizes para fomentar um clima de tensão para propiciar a coisa da criação.

Alguns anos depois a Mari fez o curso da MarieRucki e ela foi cicerone dela no Brasil no seu último ano de faculdade. E o curso da Marie Ruckinão era tão misteriosa, ela dava pistas assim....mas ○ Carlos Mauro era puro mistério, você tinha que descobrir, porque as coisas não eram dadas. Ele dava pistas e o aluno tinha que ir atrás, mas não sabia o que que era.

L-E como eram essas pistas? Você não ficava insegura em busca de alguma noção metodológica?

M-Não é que você ficava insegura, você ficava completamente louca, ficava surtando. As pessoas ficavam doidas, choravam, tinham ataques.

Mas ela reconhece que às vezes era exagerado. Tanto que ele reconhecia que gerava um clima de competitividade na sala porque ele queria criar líderes. Jogava um aluno contra o outro, criava inimizades entre eles. Ele jogava muito com as pessoas para criar um clima de tensão, pois acreditava que aquele clima de tensão ia gerar uma coisa criativa. Então, não tinha metodologia.

A Maria ainda tem os cadernos dele e pediu para cobrar

Falar de projeto nesse contexto parece uma piada, segundo a Mari.A Mari teve aula de Design Têxtil com a Vera Lígia. Ver cadernos do Carlos Mauro e da Vera Lígia.

Ela vê uma racionalização do projeto, uma objetivação que no "método" da FASM não tem.

O Carlos Mauro não deixava outros professores interferirem na área de estilismo. A Sandra Harabagi deu aula de Laboratório de Criação no primeiro ano e de Desenho de Observação no segundo, mas o Carlos Mauro detestava que ela facilitasse o processo porque aí, de alguma maneira estereotipava uma série de coisas. 
Maquete têxtil, por exemplo, a Sandra ajudava muito a entender uma série de coisas, mas formatava segundo Carlos Mauro. No caso da maquete quando chegava no segundo ano e se falava em maquete têxtil o aluno $j$ recorria imediatamente ao formato dado pela Sandra e não que isso tolhesse a criatividade, mas pelo fato de ela introduzir algumas questões e aí todo mundo fazia igual, como já tinha feito antes. Entender o que é esse "fazer igual" da Mari. Saia tudo igual mesmo ou utilizavam o mesmo método?

Porque cartela de cores tem sempre $3 \mathrm{~cm} \times 3 \mathrm{~cm}$ ? E a subversão? Por isso não pode mostrar, cada um deve encontrar o seu formato. Nada tinha formato para o Carlos Mauro por isso ele era o mais radical representante nessa "metodologia".

Com o Carlos Mauro faziam 2 coleções por semestre a partir de 3 tendências que gerava mais uma para moda casa, a tendência casa. Essas tendências não estavam alinhadas ao mercado, mas às histórias pessoais.

No segundo ano as tendências vinham das histórias pessoais, bem íntimo. Faziam um círculo imenso de mesas, "roda de conversação". O segundo ano exigia muita exposição por parte dos alunos, era muito tenso e forte.

Surgiam grupos de 3 tendências, de ideias próximas. E essas tendências iam sendo costuradas, juntadas, unidas.lam juntando por similaridade, por contiguidade as tendências. Os objetos iam ficando no armário. Só ficavam os objetos selecionados de acordo com o que aparecia muito.

Uma cor poderia ser tirada de uma imagem (não de moda) e como era uma cor específica aquilo era fotografado, reproduzido para que todos pudessem levar para casa. A imagem era uma foto da sua família, por exemplo, a blusa da Siclana, a joia do Beltrano, a bolsa do Fulano etc. Assim recorria-se à uma memória afetiva para criar sua tendência.

No segundo ano ía só até o desenho no primeiro semestre, no segundo já tinham as toiles. Faziam ambiência, cartela de cores, texturas e desenhos.

Houve uma época em que a fábrica do pai da Mari produziu roupas. Os planos econômicos das décadas de 80 e 90 atrapalharam muito a fábrica do pai e virou um ateliê pequeno e depois fechou. No fim da vida Eduardo Rocha virou ilustrador dos livros da esposa Ruth Rocha.

A mãe, a brincadeira com o Jersey estampado da confecção do pai, a criança foram as tendências da Mari no segundo ano.

\section{No segundo ano}

Shopping (terceiro ano) ou Documentação (segundo ano) (história pessoal) (tecido, cor, imagem de coisa, objetos) - nada de moda.

Temas coletivos para a sala. Aír repete a partir da Cartela de Cores.

Toiles só no segundo semestre.

\section{No terceiro ano}

Qual é o seu desejo? Era a primeira coisa que surgia na aula como pro- posta de trabalho. Escreviam os desejos, anotavam no flipchart/lousa e depois sobravam poucos. Segundo a Mari, aí tinha esse "painel", selecionavam as coisas e iam para o Shopping.

Faziam o Shopping (buscavam materialidades que concretizassem os aspectos daqueles desejos, bem subjetivo)

Formavam as mesas para trabalho em grupo. Definiam 3 desejos: dominante, intermediário e tônico.Não confundir com peças de continuidade (básicas), evolução (fashion)e novidade (vanguarda) (Gibert, 1993: 202) e (PIRES (2000) apud TREPTOW, 2013: 96). E aí na sala iam sendo depuradas as 3 tendências que iam se mexendo à medida que se produzia uma cartela de cores, depois podia mudar para a cartela de matérias. A cada aula os objetos mudavam de lugar, iam e voltavam. Essas mesas já eram uma Ambiência prévia.

\section{Cartela de Cores}

Cartela de Matérias(texturas, tecidos e outros materiais, avimentos)

Ambiência (para a Renata e para a maioria das entrevistadas aparece depois do Shopping, para a Mari aparece aqui, nas últimas aulas. A dinâmica de sala para a Mari já era uma espécie de ambiência), mas na sua lembrança a ambiência física era feita no final do processo de pesquisa.

\section{Maquetes Têxteis}

\section{Estudos de forma}

Coleções ( 3 coleções com 6 desenhos (look ou peça?) = 18 desenhos $)$ Desenhos / Pilotos

\section{Desfiles}

Desenho ( 6 desenhos de cada tendência+ moda casa) e no segundo semestre terminava com o desfile. Confeccionava 6 protótipos (3 looks). Não tinha aula de modelagem nesse ano.

As alunas faziam na aula a "moulage" dos looks sem orientação específica era um exercício de decalcar imagens e construir formas. Buscavam-se formas, privilegiando o processo mais que o resultado final. Então as roupas não tinham cava, fechamento, abertura. Isso distancia o aluno de saber o que uma roupa com bom caimento tem. Imagina calça então?

Ela critica posteriormente [57:55] que, embora o Carlos Mauro valorizasse a forma, ele não sabia trabalhar a forma. A coisa ficava muito ate a parte têxtil. Os alunos tinham que fazer o exercício da forma muito sozinhos. Uma saída era replicar as formas dos objetos reunidos. Tem que ter cuidado para não ficar caricato. Ela comenta que as pessoas ficavam presas demais às formas dos objetos de maneira a interpretar literalmente na roupa buscando que parecia com uma saia ou manga. Não saiam do lugar comum.

Ele era cruel e não tinha meias palavras nos comentários sobre os trabahos. Para criar essas mesas de tendências a partir do Shopping havia uma uta, brigas, grupos rivais e inimizades. Um trabalho de uma colega ele fa- 
lou: "O que você está pensando? Que negócio é esse? Isso aqui é bolo de aniversário? Isso aqui é moda! Você está totalmente equivocada!" Mas ao mesmo tempo não dava um direcionamento claro sobre o que era moda. Chamava de cafona, burra. E o pior é que é os alunos não sabiam o que fazer quando isso acontecia. Tinha gente que largava o curso. Os alunos descobriam as coisas sozinhos.

Um dia ele soltou algo sobre a Trends Union da Lee Edelkourt. As alunas foram atrás da ViewColour e perceberam que era aquilo que ele queria, mas sem comprometimento por parte do professor se era aquilo mesmo. Isso também incorria no risco dos alunos copiarem a View.

Fazer um super trabalho de estilo era uma espécie de passe social dentro da faculdade, dentro do ranking.

Exercícios para a forma podem funcionar, mas o aluno tende a repetir a faculdade inteira sem ser inventivo. Mas quais métodos mais o professor apresenta e como ajuda o aluno a desenvolver para que ele saia do lugar comum? Lembrando também que existe a relação número de alunos $\mathrm{X}$ hora aula. Definir formas de trabalho sejam métodos específicos ou processos relativamente livres não é colocar o aluno em uma caixa. Isso é uma questão que reforça a "liberdade do artista criador" que dispensa o método porque tem a inspiração. Falta especialização, formação e conhecimento ao corpo docente.

\section{Como professor}

Ficou no estilismo até 2011 e saiu porque foi muito exaustivo e agora ela dá Linguagem de Moda.

Sílvia Sato - foi professora na FASM. Dava a Estilismo no terceiro ano e aí o quarto ano já era a Simone e a Walquiria dava primeiro ano, Laboratório de Criação. Enquanto isso a Mari dava o segundo ano de estilismo.

Com a saída da Sílvia Sato entra a Cristina Grenier e depois o Márcio Ito, sempre no terceiro ano.

Quando a Mari vai para o primeiro ano os professores trocam os anos das disciplinas de Estilismo. Na verdade, o terceiro ano é Planejamento de Coleção.

No primeiro semestre no segundo ano não tinha protótipo, só no segundo ano. No segundo semestre já tinha protótipo e já tinha desfile de final de ano. Tinham 6 peças no desfile.

Dominante $=3$

Intermediário $=2$

Tônica $=1$

O desfile tinha trilha sonora e acontecia dentro da sala mesmo.

O Icarius foi chamado no segundo ano para desfilar junto com o quarto ano. Isso variou um pouco, mas percebo que foi excessão. Houve uma época em que o Paulo Borges fazia os desfiles do TG da FASM. A Rhodia patrocinava, pagava modelos, era mais profissional. A Mari parece que já pegou assim [1:06:40], mas durante a faculdade os alunos que faziam tudo.

Houve outra época em que os alunos do terceiro ano aproveitavam a estrutura do desfile do quarto ano e desfilavam no dia seguinte. Eram menos looks, 3 ou 4. Hoje no TG são de 6 a 8 looks.

A Raquel proibiu a Mari a certa altura de fazer desfiles com as turmas do segundo ano, pois ela fazia. Dizia que desgastava a imagem do desfile diminuía o interesse do aluno para o desfile de quarto ano.

A Chiara Gadaleta era orientadora geral do quarto ano.

\section{Sylvie Leblanc}

Com a Sylvie a metodologia já mudou completamente. Com ela a coisa era mais domesticada, tinha menos impacto. Era muito mais desenho de roupa. Não tinha o shopping, a documentação, era mais simples, menor, era mais imagem, mais bidimensional, sem objetos. As referências eram mais imagens. Ela se refere dizendo que era mais normal, não tinham etapas coletivas de pesquisa.

A Mari fazia as coisas da Sylvie no formato das coisas do Carlos Mauro, parece ser um porto seguro. Nesse momento os alunos escolhiam o tema não depuravam em grupo. Eram referências mais distantes (que ela se refere como fechadas e externas). Em seguida, desenvolviam o tema com imagen e faziam o painel, sei lá uma ambiência. Usavam mais dossiês, usava muito esse termo com a Sylvie Leblanc. Depois cartela de cores, matérias podia ser em um caderno, diferente do cahier d'annotations. Faziam coleção e produziam só 2 modelos em desfiles coletivos. A Mari ajudou a Sylvie a organizar esse desfile.

\section{Chiara Gadaleta}

Foi um inferno! Rs. (em off). Não tinha metodologia, nem generosidade, nem parcimônia. Impera o gosto pessoal dela na orientação. A orientação dela esvaziou. Só iam lá se fosse muito necessário. A Mari percebe que ela sofria para dar aula. Ficou de 1 a 3 anos no máximo. Ela não tem formação reconhecida aqui. Em off, não foi boa professora, não era interessante, não tinha metodologia nenhuma. Sua maior colaboração foi propor uma instalação ao invés de desfile no primeiro semestre do quarto ano, do TG.

Um entrave era que não existiam professores formados em moda com muita experiência. Só ex alunos. A Mari reconhece o processo de endogenia praticado pela Raquel que leva muitos ex alunos para lecionarem na FASM. Não sobrava opção para a escola quando precisavam substituir professores. O Carlos Mauro dava estilo para os 3 anos. Isso é impossível, são 4 turmas. Eram 2 ou 3 turmas. As turmas têm em torno de 40 alunos, no máximo 50.

Desconhece quase todos os autores de projeto em moda, só conhece Sue Jenkin Jones e os Renfrew.

A Mari acha que a moda tem que ser reconhecida como Campo do 
Saber. Comenta que os processos de criação e produção, matérias e acabamentos da tou o regionalismo (jeans, lingerie, moda em áreas específicas do Brasil) e disse que entender tudo como design não corresponde a realidade da moda, essa determinação de a moda ser entendida como design arrisca uma massificação da moda.

Mari não se importa com o caráter simbólico. Moda pode até carregar o nome design desde que não tenha disciplinas ou deva satisfação à área do design.

O Enade de Design. A FASM migra de Desenho de Moda para Moda, não assume o nome Design no seu curso.

Mari fala sobre o Lúdico (Ver o teatral e o Lúdico na moda)

O lúdico é inerente ao lado teatral da moda e isso auxilia a moda em sua fuga de normatizações. A moda ser transdisciplinar por vocação também é outro entrave que reforça a falta de comprometimento. A moda tem um componente de rebeldia. Para se reinventar a moda precisa transgredir. Ver LIPO. O design não acompanha essa velocidade de mudança da moda.

Ela defende que moda não é arte, mas é avessa às questões técnicas. A moda acaba por "ficar em cima do muro".

Versatilidade $=0$ bom estilista faz moda vanguarda e moda comercia segundo a Mari.

Jeito mais brasileiro de se vestir, mais hippie, mais solto, mais à vontade, mais roupa de malha. Está cada vez mais calor

Não acredita que exista um design brasileiro. Acha que muita coisa é caricata e universal, mas não brasileira.

Josi é professora de costura, Elisa e Ângela são professoras de modelagem.

A Mari não aprendeu nomes de acabamentos na faculdade. Mas defende também que não dá tempo para o professor de estilo passar isso. Hoje, segundo ela, quem passa é a disciplina de modelagem.

Não dá tempo de discutir acabamentos (costura, modelagem, estamparia, bordado, laser etc). $O$ conteúdo de acabamento se perde, pois por causa do capital simbólico da modelagem ser menor o aluno não valoriza o conteúdo que está sendo dado. $O$ aluno ainda é ensinado a valorizar mais as disciplinas de estilo. E não é o professor de modelagem quem vai discutir acabamento em nível de criação, transgressão. Aí os acabamentos que são parte fundamental da diferenciação da roupa ficam no vácuo, sem área específica.
OLIVEIRA, Renata Zaganin de. Entrevista realizada com Renata Zaganin de Oliveira, em 28 de novembro de 2014a, na cidade de São Paulo, com 2 horas e 9 minutos de duração.

Leilane: Hoje é dia 28 de novembro de 2014 e vamos começar a terceira entrevista do projeto em moda, minha tese de doutorado, com a professora Renata Zaganin, coordenadora da pós-graduação e professora da Faculdade Santa Marcelina. De moda. É isso?

Renata: Sim.

Leilane: Então vamos lá. Quem orientou o seu TG foi o Carlos Mauro, não é? Renata: Foi.

Leilane: Eu queria que falasse um pouquinho do seu TCC, o que foi, como foi a questão de projeto nele, as etapas, principalmente os processos, o que te marcou mais, como é o seu processo de criação e, como estou falando de pesquisa, eu já puxei aqui que você é pesquisadora do Itaú Cultural, do Boticário. Queria que falasse depois, ou junto, como achar melhor, sobre a sua atividade de pesquisa. Fiquei curiosa, risos.

Renata: Bom, meu processo como PG em estilo com o Carlos Mauro, o tema da coleção foi "Vícios da Alma", então eu abordava desde fragmentação, loucura, a questão da violência, do sexo, todos os vícios que contaminavam a alma. Isso no final de 1990, 1997. A profusão de imagens que a gente passava a ver na televisão, e tudo mais, e o Carlos Mauro tinha essa característica de fazer uma primeira aula onde você trazia tudo que interessava na criação, te interessava visualmente, e a gente abordava aqueles objetos, livros, via aquelas histórias e a gente começava a criação, cada um levando para o seu lado, sua essência. A minha base de criação sempre foi: "eu precisava começar pela pesquisa", sempre foi fundamental para mim, se não tivesse fundamentação teórica e muita pesquisa antes não rolava, e às vezes fica falho, tem gente que começa mais, "ah eu criei uma forma disso, como é que eu puxar uma história?". Pra mim não, isso sempre foi importante. Em 1997 fui ver Bispo do Rosário, tinha uma questão com pesquisa do Luis González Palma, que é um fotógrafo guatemalteco, ele falava exatamente da tristeza e da dor dentro do amor, ele fotografava isso, usava momentos de amor e dor. Então tudo que me trazia essa questão em vários aspectos, quanto a amor, na paixão, aos vícios, todos esses tipos de vícios eu acabei condensando nesse trabalho chamado "Vícios da Alma". E daí partia desenho, que para mim sempre foi fundamental, sempre trabalhei com desenho, e dessa experimentação com desenho é que surgia a pesquisa de tecidos, se era isso que você estava perguntando..

Leilane: É. E, desculpa, como é esse caminho? Quando você fala desenho não é só o croqui. Do desenho para a matéria, como é esse caminho?

Renata: Então, aí passava por essa catalogação que até depois veio fun- 
damentar o meu trabalho de mestrado, porque era meio que categorizar essa questão da criação via desenho. Eu sempre achava que esboçar fora do corpo, pegar primeiro fragmentos de forma, ela me dava mais possibilidades de criação quanto à volumetria. Então eu sempre começava pelo croqui, por essa anotação gráfica, que eu extraía dessas minhas referências, então eu primeiro tirava os croquis, depois eu ia para a base do corpo, que eu acho daí sim de desenho de moda, quando a gente trabalha com o desenho e tudo mais, ecomecava a trabar a parte interna. Primeiro eu trabalhava, eu acho, não é, para mim a experiência de criação, eu trabalhava com a volumetria, depois eu trabalhava a parte interna das roupas, depois eu ia para a escolha dos materiais, e em cima das volumetrias que eu havia escolhido, daí era pesquisa de campo, de adequar os tecidos que achava interessante, então eu fazia um caminho meio ao contrário. Não escolhia primeiro as matérias para depois desenhar.

Leilane: Então do desenho para depois o estudo de volumetria, as silhuetas..

Renata: Não, o estudo de volumetria, eu ia para a definição de formas, e aí recortes, detalhes de costura para depois ir à pesquisa de matérias.

Leilane: Mas antes você estava no desenho?

Renata: No desenho.

Leilane: Fazia estudo de forma...

Renata: Por croqui rápido. Vários fragmentos soltos. Ideias que vinham d referência. Eu começava assim, porque daí o tal do look conceito, às vezes de um look conceito que eu conseguia montar com tudo isso já saíam três desenhos de moda fechados, entendeu?

Leilane: Simon Seivewright fala disso.

Renata: Então isso para mim era muito mais importante e eu achava que dava mais qualidade. Eu via isso também em sala de aula. O dia que você dava um corpo para o aluno desenhar em cima, ele engessava. Quando você falava para ele: "desenhe fora ideias, rápido, não fica pensando muito, puxa esses detahes novos", ai ele conseguia criar coisas diferentes fora do corpinho, para depois, num segundo momento, montar isso dentro do corpo.

Leilane: Fazer edição.

Renata: Exatamente.

Leilane: Vai repetindo os elementos. Então você saía do desenho de partes, como se fosse um quebra-cabeça.

Renata: Isso.

Leilane: São como aquelas bonequinhas que a gente ia montando, só que lá era a roupa inteira. Sabe aquela que a gente..

Renata: Eu acho que esse primeiro momento vai te dar a força da coleção, você vai ter os looks mais diferenciados. Depois, preencher isso com looks que sejam mais ou menos da mesma família, e que tenham força mais de look, depois colocar os acentos de cores, 06:47, acho que fica mais fácil para você nivelar isso. E eu sempre achei, mesmo com essa experiência em sala de aula, eu via pelos alunos. Se você falasse para eles: "pegue uma base e um corpinho e crie uma roupa em cima", eles iam fazer os básicos, aqueles mais... o decote, o tomara-que-caia, eles vão sempre naquelas referências infantilizadas. Se você fala para o cara: "pira, pensa numa manga, mas essa manga pode ser o recorte que for, pega a referência e tenta pensar a referência, pira nisso". Ele se sentia depois mais leve para colocar, na manga, piração diferenciada naquele corpo. Agora se você diz: "desenha uma manga". Ele vai buscar nas referências infantilizadas que ele tem. É que nem quando a gente manda um adulto desenhar rosto e ele nunca desenhou, vai puxar as referências infantilizadas dele. Porque é onde ele tem segurança. E desenho é uma coisa que dá muita insegurança, botar no papel. Então quando o cara está desenhando em cima do corpo, ele não fica pensando em "estou criando", ele fica pensando em "eu preciso representar uma manga, não sei como faço isso". Então para tirar esse estigma e você ter essa opressão, o cara que fica do teu lado, como fala, o... cada um tem o seu bedel, não é, um pouco o seu bedel que fica te limitando, um sensor. Exatamente. Então para você sair disso sempre achei melhor criar croqui, isso para mim é croqui.

Leilane: E depois você ia dar conta de achar uma matéria que pudesse cair ou balançar...

Renata: Isso. Isso eu fazia, já com os alunos era ao contrário. A gente parte desse esboço rápido, a gente monta alguns esboços na sequência, procura a cartela de matéria e fecha o look, que é a sequência do mercado.

Leilane: A gente vê tecido até antes.

Renata: Exatamente. Geralmente a gente vê tecido antes, tem que aproveitar..

Leilane: Prazo de entrega, preço...

Renata: Exatamente, mas eu criava, até por um esquema de faculdade, que depois tem que adequar o tecido que você pode comprar..

Leilane: E o que você acha no varejo...

Renata: É, exatamente.

Leilane: A gente pode falar então que o seu processo começa ou se dá principalmente pelo desenho?

Renata: Sim.

Leilane: Você acha que isso é uma característica da Santa Marcelina?

Renata: Não cem por cento. Por exemplo, quando eu tenho, sei lá, trinta por cento dos meus alunos falam: "Renata, não gosto de desenho, não sei desenha e como eu posso fazer para criar sem ser via desenho?". Então tem alunos, dependendo da especificidade de cada um, às vezes mando o aluno para o busto, ele faz via moulage primeiro, aí depois que ele fecha cada look a gente vai representando graficamente isso, porque a moulage é você desenhar sem lápis. 
Leilane: Tem uma pessoa que saiba forma então?

Renata: Eu acho que continua sendo um desenho, não é..?

Leilane: Eu acho engraçado porque gosto de desenhar. Só que eu gostava de moulage, eu gostava de fazer forma...

Renata: Então, aí eles me falam: "mas tem algum problema, porque a sua matéria é desenho de moda, eu não vou fazer desenho?" Não, eu sempre falo que está fazendo desenho, só que, ao invés de usar lápis está usando direto o tecido no manequim. Então é uma forma de você desenhar em cima do corpo, e a representação gráfica que vem depois disso, dependendo do tempo, a gente até fotografa e contorna o desenho para esse cara.

\section{Leilane: Faz a silhueta.}

Renata: Para mostrar para esse cara que, tirar aquela coisa que, para ser um grande estilista precisa ser um grande desenhista. $O$ desenho, para mim..

\section{Leilane: O ilustrador, não é?}

Renata: Então, ilustração para mim já é uma outra coisa.

\section{Leilane: É, também.}

Renata: llustração para mim é a parte conceitual do desenho.

\section{Leilane: É tipo um desenho maneirista, realista.}

Renata: Sim, sim. Mas eu tenho alunos que também indico para colagem, como a que você viu agora lá embaixo, a das folhas? Então a gente pode trabalhar das três maneiras. O importante, a questão forte da Santa Marcelina com o desenho não é obrigar o cara a sair daqui um desenhista. É porque quando a gente estuda volumetria corporal, a gente passa a enxergar um modelo de uma forma totalmente diferente. O cara, o que eu percebo fora daqui, é que o cara que nunca estudou corpo ou volumetria corporal, o cara cola detalhes em cima do corpo. Ele não faz roupa, pensa o giro da peça. Ele pensa assim: vou colar alguma coisa na frente, e em algumas faculdades nem costas, as pessoas pedem. Então eu fico pensando: como é pessoa pode ter alguma noção? É como se alguém pedisse um liquidificador e só desenhassem a frente dele e entregassem para a produção. Não existe isso, é um braço de desenho de produto. Então estamos fazendo um produto, e se você não pensa o giro da peça na sua cabeça, aqui você já está pensando. Então você não é um designer de moda. Você está fazendo um "frankensteinzinho" pra sua frente. Esse corpo, quando gira, na minha pesquisa de mercado, eu estava pesquisando a questão dos retratos, que antigamente as mulheres eram realmente retratadas pela frente. Então a questão das roupas também acompanhava isso. Tinha muito mais detalhes na frente, as pessoas não se preocupavam nem com a lateral e nem com as costas, e hoje a gente não vive um momento desses, a gente vive um momento onde o importante é o giro dessa peça.

Leilane: Sempre foi, mas está se pensando nisso.
Renata: É, eu fiz muitos cursos, desde que comecei e vi que ninguém se preocupava com isso. E hoje, em algumas outras instituições, eu vejo o trabalho de estilo, mas cadê as costas? Ah, não, professora, só está de frente. Então essa questão que estava te falando do desenho na Santa Marcelina, o mais importante para a gente, de desenho, de forçar a questão do traço, é para o aluno pesquisar corpo antes de fazer roupa para esse corpo. Ele chega em estilo muito mais maduro para criar formas que tenham uma continuidade, que geram equilíbrio de formas e cores, do que o cara que só pensa frente e que não conhece corpo. Então para mim tanto faz se ela vai reconhecer, num trabalho, esse giro da peça, aqui no desenho, se ela vai reconhecer primeiro no busto ou numa colagem? Ela está trabalhando com essa história dos três giros. Toda peça que eles fazem aqui têm que pensar a frente, as costas e 0 perfil, esse giro inteiro, para depois fazer um desenho, o tal do desenho, como a gente fala, promocional, que é o que todo mundo acha que são os croquis de moda, a gente brinca, não é, na realidade aquilo é só um promocional, a gente nao usa aquilo para pensar produto. $O$ produto precisa estar nas cabeças corretas, o aluno se acostumar com isso, e mesmo a pesquisa de cores. Praticamente desenhista é um escultor. Então você está esculpindo um corpo, eu tenho uma aula que dou, eu mostro uma aluna minha que era modelo de passarela, tinha a minha altura, um metro e oitenta e 45 quilos. E ela vestida com a roupa de uma aluna daqui, quando essa menina vem aqui, elas olham $e$ dizem: nossa, uma menina baixinha e gordinha. Ah, e seu eu falar para vocês que essa menina tem um metro e oitenta e pesa 45 quilos? Ninguém acredita. E é aí que eu falo: a gente tem o poder de criar uma imagem ou de destruir uma imagem através do tipo de corte, de frequência, de cor, é uma escultura.

Leilane: Deixa eu te perguntar outra coisa: você sair do manequim, do plano desses três giros tendo como suporte - o suporte manequim, o suporte papel, o suporte peça, isso modifica a maneira de criar.

Renata: Modifica, exatamente. Acho que o ideal mesmo seria que todo aluno partisse dos três pontos. A gente não tem tempo hábil dentro da nossa carga horária para fazer o aluno experimentar, e até porque o aluno tem medo também. Se ele acha uma zona de conforto e uma receitinha ele fica naquilo até o final porque sabe que está certo. Mas, por exemplo, o cara que vai no corpo vai fazer diretamente algo mais conceitual do que o cara que parte do papel, e o cara que vai também fazer uma colagem. É lógico que é muito mais fácil sair com uma abordagem mais conceitual. O legal seria, esse cara que parte da colagem ou do busto, em algum momento parar o processo dele e ter que pensar uma parte da roupa mais técnica.

Leilane: Ou colocar essa colagem lá no manequim e fazer isso existir.

Renata: Isso eles fazem. Mas se ele se acostuma com aquele método, é lógico que a roupa dele vai sair bem mais conceitual que o cara que faz 0 "desenhinho" no corpinho. Então, por exemplo, se o cara que fez o "desenhinho" no corpinho tivesse que pensar uma manga no busto, ele sentiria as duas coisas e depois juntaria.

Leilane: Ele sai da zona de conforto, no início é uma violência, mas eu acho um exercício super válido. 
Renata: Super válido, porque o cara que se encontra na moulage sempre vai ter formas mais elaboradas, mas se você olhar os recortes vai acabar meio que abolindo isso da linguagem. E você não pensa, ah, eu quero fora toda aquela parte mais conceitual, eu quero, de repente, daqui pra baixo, começar e ter um recorte que vai... então ele usaria as duas coisas, a modelagem plana e a modelagem da moulage, tridimensional, para fazer meio a meio. E às vezes eles, é um em cada nicho e ninguém atravessas essas fronteiras.

Leilane: Não enxerga que os suportes se complementam.

Renata: Sim, e que tem que saber as duas coisas.

Leilane: Essa coisa que você também falou da lateral, eu comecei a prestar muita atenção nisso, a partir de 2002 com o jeanswear. A gente era obrigado a desenhar a lateral. Não sei se isso pra você também aparece.

Renata: Até o ano retrasado eu começava o quarto ano com eles pedindo o line-ups de jeans. Porque era meio um exercício de arrogância e de humildade. $O$ cara que chega no quarto ano acha que é um supercriador. Quando você fala jeans, eu acho que de todas as categorias que a gente tem dentro de moda, o jeans é o que mais te obriga quanto a questões técnicas. E aí 0 cara chegava e eu falava: "gente, vocês tem que fazer um line-up de oito jaquetas jeans até o final da aula". Aí eles olhavam e falavam: "jeans, fácil, OK". E quando eles começavam aí era um exercício de humildade, de chegar uma hora e reconhecer: "não sei mais o que colocar".

Leilane: 19:29 Maquinária, pala contra a chuva, a costura, os tracejados, traço reto... você pode até fazer o desenho, mas às vezes na produção não funciona.

Renata: Exatamente. E eu falava pra eles: "isso não é questão de dizer que vocês têm que trabalhar com o jeans, você pode ser um cara que pode trabalhar com noiva, tanto faz. Mas isso é pra vocês verem o quanto tem que ter de conhecimento pra usar e o jeans te mostra isso".

Leilane: E reforça o raciocínio, você está criando projetistas, e não desenhistas.

Renata: Exatamente, novamente a questão do desenho de produto. Não é um desenho artístico, a gente pode até partir do desenho artístico, de uma ideia que me veio na cabeça, faço um esboço rápido, mas aquilo tem que se transformar em produto.

Leilane: E de ser viável tecnicamente, economicamente...

Renata: Exatamente, exatamente, e sem desmerecer, e sem tirar o caráter, ai, é uma peça mais de conceito, mais arte.

Leilane: Você pode ensejar arte, pode trazer tudo isso, mas, enfim, isso tem que ser fixo, ter um tecido, ter um corte... Como você define estilo, porque na verdade na verdade o nome da disciplina, com a Vera Ligia, é estilismo, não é estilo, mas entendendo o estilismo como estilo, como você define a disciplina, a prática de mercado, pode falar das duas coisas.
Renata: Você está falando quanto à questão de desenvolvimento de produto ou estilo?

Leilane: É o que a gente chama de processo-projeto-produto. A pesquisa, desenho, criação, desenvolvimento de produto até o feedback.

Renata: Eu não sei se vou responder a sua pergunta, mas uma coisa que foi, até quando comecei a montar a área de pós, a gente começou a falar: "ah, mas estilo é, o estilismo é um termo tão antigo, da década de 1980, vamos colocar outra coisa, planejamento...” Então eu acho que...

Leilane: $\mathrm{O}$ nome projeto nunca surgiu para voces?

Renata: Nao.

Leilane: Engraçado isso, porque é muito natural no design, não é [afirmativo] projeto... Você acha que estilo vem da ideia de estilo, da arte?

Renata: Acho que vem mesmo da década de 1980. Acho que é uma coisa, assim, que vai contar marketing, vai chamar a atenção do aluno se voce colocar uma matéria "Projeto", nossa, projeto, se você colocar "Estilismo", nossa, é ali que eu vou, eu vou aprender a ser estilista, eu acho que tem isso. Mas eu acho que quanto à questão de estilismo e desenvolvimento de produto ou planejamento de coleções, acho que, não sei se é isso que você estava me perguntando, mas acho que aí tem uma mistura que, até na pós isso acontecia, eles contratavam professoras diferentes e trocavam as matérias todas as horas, então elas davam as mesmas coisas em matérias diferentes. E tem uma diferença, o estilismo acho que esbarra muito mais na parte artística, do criador, do diferencial, que é aquela coisa do formador de opinião, onde você quer que o cara, você quer moldar um cara que tenha uma estrutura de criação diferenciada, e do desenvolvimento de produto que é você dar um, como é que fala, instrumentar o cara para ele trabalhar dentro de uma empresa de moda, desse giro empresarial de moda. São duas coisas totalmente diferentes, e eu acho que aqui a gente sempre esbarrou muito mais no estilismo. Aqui sempre foi muito mais estilismo do que desenvolvimento de produto ou desenvolvimento de coleções. Agora a gente tem uma matéria dessa no segundo ano, que daí foca mais no mercado, 0 chão de fábrica e tudo mais. Que é mais ou menos o que acontece com você na pós-graduação, você está dando Desenvolvimento de coleção e o Mário está dando o estilismo. Então a gente quis dar essa diferenciação. Era isso que você estava perguntando?

Leilane: Mais ou menos. Eu queria te perguntar se estilismo pode ser sinônimo de projeto.

Renata: Pode. Pode. Eu acho que estilismo é sinônimo de projeto. Aliás, acho que tudo é sinônimo de projeto. A gente fala que, aqui na Santa, a gente até uma vez gravou um depoimento sobre a ideia de projeto. Quando - aluno entra aqui no primeiro ano, a primeira coisa que os professores de primeiro ano começam a trabalhar é a ideia de projeto. Porque o cara chega meio que num limbo e num processo criativo que é extremamente empírico. Ele não sabe se tem um começo, meio e fim. Então a função do primeiro ano 
é meio que introduzir esse aluno à ideia de projeto, insistir que a questão textual, a pesquisa, a leitura é algo imprescindível, porque eles acham que não, eles acham que criação ainda é aquela coisa antiga que a gente achava em 80 , em 80 a gente achava que criação descia, não é, e você desenvolvia a luz... Acredite se quiser, eles chegam aqui no primeiro ano com essa ideia ainda muito forte, e quando você fala: "tá, mas o que você pesquisou?". "Ah, não, professora, eu já tenho o meu estilo". "Não, não é estilo, é projeto, a gente está avaliando o projeto." E quando você coloca a palavra muito abstrato, não palpável e você não tem como 'formatizar' uma nota.

Leilane: Tem um marketing, não é, pra chamar alguma coisa de estilismo, qualquer faculdade faz isso, mas ao mesmo tempo tem um papel ético, formal, o cara sabendo que ele vai trabalhar com projeto. Mesmo que ele trabalhe numa marca de Fashion Week, existe uma coleção de dia, uma coleção que tem que virar pra sustentar a marca.

Renata: Sim. Mesmo a questão conceitual que a gente coloca na passarela é uma parte do grande projeto da empresa, que você quer divulga Então essa é a questão, fazer o aluno pesquisar antes, parar, formalizar essa pesquisa para depois começar a criar. E também te dar, eu acho que quando você fala de projeto te dá uma segurança, que o cara sabe que você vai ser avaliado, aliás, que você vai avaliar segundo critérios muito específicos.

Leilane: Etapas que têm que ser cumpridas.

Renata: É, e que vão ser notas, por mais que seja um processo irracional, e essa coisa fantasiosa, ele vai saber que você tem um criterio muito raciona para avaliar o projeto dele, principalmente em desenho. Eles perguntam feio, eles acham que é tudo muito impalpável.

Leilane: $\mathrm{E}$ não são só as cabeças também.

Renata: Sim, então quando você fala que é um projeto, eu sempre falo isso, não dou nota por feio ou bonito, dou nota pelo projeto.

Leilane: Voce já estimula essa ideia de projeto.

Renata: Totalmente. É uma coisa que a gente faz já há uns dez anos, que o cara pode até ter um desenho feio no final, mas se as etapas do que foi passado, ele conseguiu desenvolver em determinado tempo, cumprindo as etapas de uma forma bacana, e aquele processo me dá um profissional.

\section{Leilane: Sim}

Renata: Então isso é mais importante para a gente, do que o desenho bonito no final. $\mathrm{O}$ cara ainda tem anos para desenvolver um desenho legal. Mas esse raciocínio de projeto, a gente formando esse cara com raciocínio de projeto, ele trabalha... vou fazer Kichute. O Kichute, não é, demonstra a idade...

Leilane: É old school, risos.
Renata: É, old school, a gente tem um aluno que está na Penalty desenvolvendo tênis, ele se formou aqui em Moda.

Leilane: Que legal. Isso é bom.

Renata: Então a gente tem alunos aqui que, nossa, então eles falam disso como uma característica formativa do Santa Marcelina, que é o aluno que vai atrás, ninguém precisa ensinar para ele. Sabe como pesquisar, sabe se virar, se mexer e achar as coisas.

Leilane: Isso é uma coisa muito do design, você sabe, tem uma pessoa que está na Topper que é da Unesp de Bauru. Design, não é de moda, mas o cara que se você ensina a pesquisar ele vai atrás. Então a ideia de projeto, meiro momento, como ideia de projeto.

Renata: Sim, sim. Exatamente.

Leilane: Rê, pergunta chata, risos. Moda tende mais ao design ou à arte?

Renata: Então, eu vou puxar a sardinha para o meu lado. Eu comecei no mercado pelo desenho, dando aula de desenho e tudo mais..

Leilane: Você deu aula na Sigbol, isso que ia ter perguntar. Em 1990 você começou a dar aula lá.

Renata: É. Em 1987.

Leilane: Você nem fazia faculdade.

Renata: Não, não existia faculdade, era uma coisa assim, eu comecei em 987 a fazer freelas porque eu desenhava. Então perto da minha casa tinha um lugar chamado TIC Assessoria de Moda.

Leilane: Você sempre desenhou?

\section{Renata: Sempre.}

Leilane: Você fazia curso de desenho?

Renata: Não, porque minha avó era costureira, então eu desenhava e desenhava roupa e fazia competição em uns caderninhos, desenhava cinco bonecas diferentes e dava nota para o cabelo, para o rosto..

Leilane: Onde você conseguiu essa proporção?

Renata: Então, aí o primeiro curso que fiz na vida foi acho que em 1986 na Recrearte, que era da Regina, que até lançou um livro, um glossário de moda, mas a Regina também era da arte. Então quando fui fazer aula com ela, ela ensinava uma coisa muito solta e que não dava base de nada, então ela arriscava, era um desenho muito solto. Não seria nem moda ainda, porque era meio desenho artístico, porque ela falava: "Ah, primeiro a gente vai ter que focar nas formas", então ela ensinava o cânone das cabeças, mas isso eu já tinha visto em livro. Então era uma coisa assim, falar que não acrescentou nada, mas foi uma experiência que eu tinha aprendido muito mais, eu comprava aqueles livros da Ediouro, e tinha um lá que era dese- 
nho de moda. Por isso eu brinco até hoje de desenho de moda, porque...

Leilane: Você ainda tem?

Renata: Tenho, mas não ensinava nada, porque tinha os desenhos, e mostrava o cânone.

Leilane: Mas o cânone, o primeiro contato que você teve com isso...

Renata: Foi com esses livros. E não contava história nem nada, só tinha umas demonstrações de aguadas e aí... Lembro que uma época meu pai foi na Michelangelo, na Líbero Badaró, e comprou um monte de coisas para mim e eu comecei a brincar com as coisas. Isso foi em 1986 e depois em 1987 eu ganhei um curso na Sigbol. Era forte antes. E aí o curso que era de um ano fiz em três meses. Acabei, tirei dez, a primeira vez que um aluno tira dez no Sigbol, fui fazer um diploma, era diploma mesmo, e no dia que fui buscar o meu diploma a professora veio e falou: "Renata, a gente quer que você dê aula aqui". E eu: "Como assim?"

Leilane: Você tinha quanto anos?

Renata: Dezoito, 17 para 18. E eu dar aula, como assim, era super tímida. E aí comecei a dar aula lá, só que aí precisa ser formada, mas posso falar que a melhor faculdade de moda que fiz foi lá. Por mais que a gente hoje tenha como referência o Sigbol como uma coisa pejorativa, na época era uma coisa muito formativa e muito boa.

Leilane: O nível de ensino caiu muito, não é?

Renata: Exatamente.

Leilane: Era o que a gente tinha. Eu fiz Senai. Então a gente fazia as coisas serem boas porque queríamos muito, porque não tinha graduação.

Renata: $\mathrm{E}$ em dois anos, quando fui professora lá...

Leilane: Em qual unidade você dava aula?

Renata: Na Vila Mariana. Era a única.

Leilane: Ah, eu fui chamada para dar aula lá, risos.

Renata: Então, era a única que existia.

Leilane: Ah, nao sabia. Lá era a sede.

Renata: Era a sede. E tinha a Lourdes Tacon, que era uma superestilista, a diretora de ensino e diretora técnica de lá. E ela havia feito cursos em todos os lugares fora e tinha um material muito legal. E aí chegou uma hora que ela disse: "a gente precisa refazer todo o material técnico, redesenhar tudo pra fazer a apostila de engenharia de moldes, e você vai desenhar tudo isso e vai estudar pra reescrever toda a história da Sigbol". E eu falei: “como assim?" Ela me contratou pra ficar com ela e fundar o departamento técnico. E aí eu redesenhei tudo, e sem saber modelagem tinha que planificar os moldes, então pra mim não foi que eu aprendi a fazer modelagem, pra mim foi uma coisa paralela, e aí eu fui entendendo por osmose, e foi muito legal. E foi daí que veio a primeira coisa com o desenho, tinha uns alunos que faziam comigo em casa, aula particular de desenho, e, ao mesmo tempo, por causa dessa assessoria de moda que era perto da minha casa na Avenida Pompeia, comecei a fazer pra elas, então elas me contratavam das oito da manhã até uma...

Leilane: Você ia pro Sigbol depois...

Renata: E eu não sabia o que ia fazer, elas montavam as coleções de grandes empresas, elas que faziam o desenvolvimento, e aí chegava lá elas me falavam assim: "hoje 36 jaquetas jeans diferentes até meio-dia", e aí eu ficava lá trabalhando, terminava a minha hora, a dona da TIC vinha, assinava os meus desenhos, e eu pegava o dinheiro e ia embora, risos. Então foi por aí que entrei, sabe...

Leilane: Você não ficava chateada por isso?

Renata: Não, porque para mim, nossa, não tinha mercado na época, para você entrar no mercado, isso era 1987, 1988, nossa, ninguém sabe que eu sou estilista.

Leilane: Eu me formei em 2003, as pessoas perguntavam: o que você faz? Faço moda. Todo mundo: faz o quê?

Renata: Ainda. No terceiro colegial, em 1989, os professores perguntavam o que eu ia fazer e eu dizia: quero ser estilista. Eles olhavam e falavam: nossa, coitada. Não tem nem faculdade.

Leilane: Como você veio a saber da Santa?

Renata: Porque eu tinha uma vizinha que fazia artes plásticas aqui. E aí ela me falava: "Renata, mas agora tem moda lá."

Leilane: Sabe o que eu tenho ouvido? Tenho uma amiga da ECA que se formou aqui em artes plásticas e fez doutorado lá, e ela me chamou um dia e disse: "você dá aula na Santa?", eu achava que o curso de moda era anterior ao de artes de tão tradicional, é de 1929...

Renata: Então, essa Célia, minha vizinha, a família dela inteira trabalhava com o Mauricio de Sousa. A Célia falou pra mim: "Renata, eu sei que você desenha, na faculdade que faço tem uma matéria de desenho."

Leilane: Que era da Vera Ligia.

Renata: Era da Vera Ligia, exatamente.

Leilane: Era o curso de moda em uma disciplina.

Renata: Isso, era um mix.

Leilane: Seus olhos brilharam, risos.

Renata: Nossa, aí passou um tempo, ela falou para mim: "Renata, agora tem faculdade de moda", que era em 1987, e eu achava que ela estava viajando, ela está achando mas não é. Aí depois eu vi que era, nossa, e eu já trabalhava... 
Leilane: Você chegou a vir aqui e se informar..?

Renata: Não, não cheguei a vir aqui me informar logo na hora, eu fiquei um tempo incrédula, risos, e depois acho que lá pra 1990 que fui ter certeza que era faculdade. E depois que eu já estava na Sigbol fiquei sabendo que era e fiquei louca porque queria fazer. E daí passei no vestibular em 1990.

Leilane: $\mathrm{O}$ que seus pais falaram quando você disse que ia fazer graduação em moda?

Renata: Ninguém nunca falou: "não, o que é isso?" Eles achavam incrível. $\mathrm{Na}$ minha casa era super bem aceito. Na escola foi meio estranho, mas aí eu falo que teve a minha tutora, que foi minha professora de educação artísti$\mathrm{ca}$, desde a quinta série. Ela me trazia material de moda, tinha uma tia na biblioteca que sabia do meu interesse, e tudo que chegava falando de moda ou de técnica de desenho... ela me deu uma coleção de desenho. Então eu falo que eles foram os meus tutores de resiliência, e mesmo nesse meio adverso eles foram me incentivando, e até na minha dissertação de mestrado eu agradeço a Maria Terezinha, e aí agora, depois que comecei a dar aula no Santa...

Leilane: Ela foi sua professora de educação artística?

Renata: Comecei a dar aula aqui, e uma das minhas alunas fazia aula com ela em Tatuí, ela já estava em Tatuí dando aula de artes lá. E aí a gente se reencontrou, eu fiz uma carta para ela e fotografei a página da monografia mostrando a dissertação, aliás, agradecendo, ela disse que eu quase a matei, ela quase morreu do coração. Foi linda a passagem, porque se não fosse eles eu não faria moda, ela quer fazer moda, é louca. E eles que me incentivaram.

Leilane: A Vera Ligia que falou do seu perfil, aliás, a Vera Ligia te mandou um beijo e falou: "ótima aluna, excelente, dedicada..."

Renata: Então, e ela me ajudou muito também porque a aluna dedicada aqui dentro, chegou uma hora que eles precisavam indicar alguém, e a Rhodia fazia muitos eventos, a Polyenka nesse momento nem tanto, várias grandes têxteis, no começo de $1990 . .$.

Leilane: Braspérola, TMC...

Renata: Tinham umas mais tradicionais, elas começavam a chamar, a Dupont, Vicunha, eles chamavam para eventos para fazer eventos para desenhar na frente do cliente nas Fenits da vida e, fora isso, tudo que precisava de desenho, chama a Renata Zaganin, porque ninguém desenhava na faculdade. Porque, assim, os professores de desenho aqui eram fracos, não era uma coisa tão forte assim, o desenho de moda.

Leilane: Era novo, né?! Então, pra conseguir, porque pra gente ter acesso ao desenho, porque ensinavam a gente a ler, escrever..

Renata: É, exatamente, exatamente. E então, foi por isso que meu nome começou, porque, ah, chama a Renata Zaganin, ela participou muito disso, era coordenadora na época...
Leilane: Ela é super humilde, ela não falou isso, não ia falar, só falou super, superbem de você. Supergenerosa.

Renata: Ela é.

Leilane: Rê, deixa continuar, há uma tentativa de aproximar aqui na Santa a ideia de estilismo na aura, aura no sentido do Benjamin. Há uma ideia de aproximar estilismo da ideia da aura de arte, mais em conceito do que numa realidade prática, efetivamente?

Renata: Sim.

Leilane: É mais um marketing que você falou...

Renata: Não.

Leilane: $O$ que você acha?

Renata: Isso é consciente. Mas por quê? Porque a gente acredita aqui que o cara, se um cara, num trabalho dele falar: "ah, vou fazer uma sandalinha", o cara que faz uma sandalinha e que fica naquele comum, naquele meio comum, OK, ele sabe fazer uma sandalinha, agora, o cara, para, sabe, praticamente se desdobrar numa criação, que é extremamente conceitual, que é extremamente poética, que tem uma reflexão e uma pesquisa muito mais aprofundada e que isso transforma num produto que a pessoa fala e olha, nossa, então para fazer um trabalho legal no Santa Marcelina tem que se virar, fazer uma coisa extremamente diferente, mas isso não é usável. A gente acha que o cara, para dar uma solução técnica para aquilo, tem que estudar tanto e abrange tantas esferas do conhecimento que aí sim você está formando um grande estilista. $O$ cara que faz a rasteirinha dele, OK, ele sabe fazer um produto, mas é um designer mais limitado. Agora o cara que faz algo que quase esbarra no intocável, para ele solucionar isso, graficamente, tecnicamente, volumetricamente, ergonomicamente, aí sim ele se forma em várias esferas. Entendeu, então?!

Leilane: A ideia então não seria só criação solta, e sim o que a gente chama de criação direcionada (controlada), não é? Para depois ir à criação direcionada (controlada) e dar vazão àquilo.

Renata: E, porque formar o cara para ação de fábrica é muito fácil. Agora formar um cara para ser criador, isso abrange aspectos até culturalmente, que é muito mais difícil.

Leilane: De uma formação anterior.

Renata: Exatamente. Então, isso que todo mundo fala, "ah, Santa Marcelina é muito criação, umas coisas loucas”, então eles acham que, assim, é muita piração, eu ouço isso sempre, ate do aluno que está entre o segundo e o terceiro ano. "Ah, mas para ir para fora tem que fazer aquelas coisas diferentes". Não, tem que ter um raciocínio diferenciado e que também, tem a questão da técnica pura, o cara também tem que conhecer a técnica, 0 como fazer, mas é um sistema muito mais complexo do que resolver uma rasteirinha. Então para a gente é muito mais importante formar um criador do que o cara que simplesmente faz aquela criação que a gente sabe que 
não é criação, é uma reprodução.

Leilane: Pré-fabricada.

Renata: É.

Leilane: Eu passei por isso na Anhembi, a gente tinha que experimentar muito e às vezes, mas, e aí, quando vou fazer isso? Não, faz nem que seja um moulage errado pra depois resolver isso.

Renata: Exatamente. E quando você tem esse atrito, e tem a insegurança e a coisa do lugar incerto, é daí que saem as melhores coisas.

Leilane: A gente tem paradigmas em design, por exemplo, de uma cadeira, com os quatro pés, assento, encosto, talvez os paradigmas da moda, não têm menor importância, tem tanta importância quanto a criação, mas talvez deveriam ser considerados em um segundo momento como um plano de criação mais autoral. Eles vão ser considerados de qualquer maneira, mas talvez teriam que ser pensados em um segundo momento para não tolher a criação.

Renata: A gente tem várias matérias que, por exemplo, se a gente fosse falar isso na matéria de desenho de moda, a gente começa de um jeito diferente.

\section{Leilane: Pelo contexto.}

Renata: Em desenho de moda a gente começa dando teoria pura para eles e falando: o corpo tem que ter oito cabeças e meia, quando na verdade tem sete e meia, então aprendam primeiro a construir um corpo, engessem o seu desenho e aí no segundo ano eles desengessam o desenho, entendeu?

Leilane: Desenho é uma coisa muito específica.

Renata: Mas eu tenho, por exemplo, professores de desenho artístico que pensam ao contrário. Eles acham que, realmente, é um processo mais rico começar pela desconstrução, pelo caos, pelas incertezas do desenho artístico e depois aos pouquinhos você entregar uma regra para eles. Isso seria o rico, seria a forma ideal de você ensinar alguém a desenhar. Mas como em moda a gente tem muito a questão da roupa que já começa no primeiro ano, a gente não tem esse tempo hábil. E eles já têm coleção no primeiro ano, então eles precisam de um corpo, representação gráfica, pro objeto. Tenta depois dar conta de desengessar com qualidade. Entendeu?

Leilane: Entendi. Para tentar não perder tanto do que seria o ideal.

Renata: Exatamente

Leilane: Etapa a gente já falou, eu queria saber a sua opinião a respeito de estilo nacional, você acha que é possivel falar de um design de moda nacional, e como a gente fica em relação às tendências, das cópias hoje?

Renata: Não, eu acho que a gente não tem nenhum estilo nacional, acho que ainda é uma questão super... acho que até alguns discursos de alguns designers...

Leilane: O Lino Villaventura, talvez, a Vera Arruda...
Renata: É, mas eu acho que não se cria movimento quando se tem uma pessoa...

Leilane: Sim, sim, eles existem, mas são pontuais.

Renata: É, são pontuais, exatamente, você não tem uma linha de grandes designers, não é? Você tem algumas pessoas que acabam surgindo.

Leilane: Acho que é assim também no design de produto, os Irmãos Campana, aqui e ali, ainda não tem um...

Renata: É, e talvez porque a gente não tenha uma cultura que incentive isso. Ainda acho que as faculdades de moda são extremamente, os cursos são muito mal articulados, então as matérias às vezes vêm fora da sequência, a gente tem várias questões que ainda...

Leilane: Você tem algum exemplo de disciplina que acha absurda?

Renata: Ah, mesmo a matéria de criação. Por exemplo, você mandar um cara desenvolver uma coleção sem ele ter um aprofundamento mais real e fora da arte da moda, você acha que, "ah, mas é criação pura, é do ser, é da pessoa". Eu acho que isso não existe.

Leilane: Acaba fazendo referência histórica, o que é pior, não é, na ignorância.

Renata: Exatamente, pode até ser isso. Nossa, o que eu tenho de aluno que acha que descobriu a roda é incrivel.

Leilane: Tal década, tal século. É frustrante para eles também, né?

Renata: Eu acho que ajuda na humildade do processo, porque a gente tem aluno que chega no terceiro ano e acha que já sabe tudo. $E$ aí eu olho pra eles aqui nos 40 anos, nessa experiência de mercado e falo "nossa, o cara está com 18 anos achando que já sabe de tudo e não sabe nem 1/10 do que vai ter que saber", e acho que isso acaba deixando o cara mais acomodado. $O$ aluno não corre tanto atrás, eu acho que a gente corria muito mais atrás, na minha época, quando não tinha moda, imagina, a gente tinha moda de Polyenka, e até bem antes disso, bem antes disso, por exemplo, 1987, 1988, que comecei a fazer cursos, a gente não tinha nada para pesquisar, a gente ia na Mário de Andrade e na parte de arte você tinha que garimpar as questões de roupa, vestuário e moda. Então não existia nada, e...

Leilane: Você fala da Mário de Andrade ali, no Bom Retiro, nao é?

Renata: Não, a Biblioteca Mário de Andrade, na Consolação. E se eu te falar que alguns conteúdos, eu montei pra Sigbol em 1989, são melhores do que alguns trabalhos que eu vejo hoje, com todos os tipos de recursos que eles têm hoje. Às vezes eu vejo até, eu até brinco hoje com o Sigbol..

Leilane: Sigbolinha, não é?

Renata: E qualquer um dá aula lá hoje, eles pegam qualquer pessoa que desenha um pouquinho e enfiam lá pra dar aula. E eu vejo, porque antes era tão criterioso, era tanto estudo... 
Leilane: Você ia em biblioteca, deve ter passados poucas e boas, não é? Não tinha esse material, só tinha na França..

Renata: Não tinha, ela me trazia uma parte, eu pesquisava outra, e a gente montava o material pra realmente ler, se a gente comparar hoje, e eu brincava, "ah, Sigbol, Sigbol", e hoje eu digo: "nossa, a minha formação foi lá e foi meio autodidata", porque para montar coisas para os outros eu tive que estudar para mostrar para os outros uma coisa que hoje, com todos os recursos que a gente tem, não cresce. A história do mercado de moda é muito parecida com isso, acho que a gente não tem um parque industrial decente até hoje, em vez de crescer a gente regrediu nesse setor violentamente, a gente não tem uma formação de moda adequeada, ainda não é adequada, a gente não tem incentivo para moda como uma área tanto comercialmente falando como uma área do saber mesmo, a gente não

Leilane: Você fala também em termos de governo.

Renata: Em termos de governo, fiscal, não temos incentivo.

Leilane: Queria que você falasse das suas experiências como estilista. Você falou de confecção, também já passei por poucas e boas, mas em termos de projetar, de fazer uma pesquisa, quais eram os principais problemas, você olhava para a estrutura e falava "ai, meu Deus".

Renata: Noventa por cento das empresas de moda no país por onde passei, pelo menos da minha experiência, noventa por cento não tem nada do seu processo normatizado. Nada. Comecei a trabalhar primeiro fazendo freelas, não tinha muito esse contato porque entregava meu trabalho a uma pessoa que repassava. Quando entrei mesmo nas empresas, entrei tanto como dese nhista de estampa, desenhista de coleção, porque eles não tinham quem desenhasse, então eu pegava uma coleção inteira e planificava, então eu atuei de várias maneiras, e até estilista efetivada dentro da empresa.

Leilane: Você falava com a modelista, com a costureira, com o cara da estamparia.

Renata: Sim. Nada é normatizado no Brasil. Até hoje é assim. Isso quando acontecia lá na década de 1980 eu achava "ah, porque é novo". Não, mas até hoje, as minhas últimas experiências dentro de empresas de 2000 para cá, continua tudo igual, e até os relatos que ouço das minhas alunas, elas falam dos absurdos, até na pós, dou uma aula chamada Expressões Gráficas, que a gente fala de vários métodos gráficos que a gente usa dentro da confecção. Então a parte de estampas, assinaturas, etiquetas, os sites, a parte de ferragem, tudo, a gente faz um mix de tudo que assina a coleção. $E$ aí eu conto uns 'causos' para elas e elas ficam bobas. $E$ a minha gerente de produto em uma das empresas pedia, e era mulher do dono, era uma figura simbólica, que é o que mais tem hoje em dia. Acho difícil ter uma gerente de produto como você, uma gerente de produto que sabe fazer.

Leilane: Na verdade eu nunca fui gerente de produto, fui estilista e coordenadora de estilo. Eu acabava me virando porque não tinha...
Renata: Geralmente a gerente de produto que é quem deveria saber de tudo isso...

Leilane: Eu fazia tudo, criação, compra...

Renata: Então, mas hoje em dia a gerente de produto é uma figura emblemática, lá no topo, só dá chicotada e você se vira. E já passei de tudo, de falar "ah, precisamos aproveitar esse tecido hoje, bate uma estampa em dez minutos", e de ter que fazer uma estampa em dez minutos, aquela coisa mais horrível que você já fez na sua vida, e de passar dois dias e ver a estampa na Vera Fischer, na novela das oito! E de repente te falarem "nossa, Renata, sua estampa bombou, está sendo supervendida”. Não teve projeto nenhum e de repente, e também saía de arte final acontecia demais. Estudar 20 layouts, está chegando no vigésimo, quando já está lá, não aguento mais, e faz qualquer coisa pra ser o número 20 , e aí chega na mesa da gerente de produto e ela olha tudo e fala: "!!!".

Leilane: É o 20.

Renata: É o 20. Tudo que teve projeto, raciocínio, esquema cromático, que você usou tudo que aprendeu formalmente... Então, quer dizer, porque você também é avaliado por aquela pessoa que só fala com aquele feeling

Leilane: Não tem aquela formação, não é?

Renata: Não tem. E aconteceu depois quando fui para a parte têxtil, agora a última empresa por onde passei, eu era estilista, trabalhava como enge nheira têxtil, não sei se já te contei isso.

Leilane: Não.

Renata: E eu criava, quer dizer, fazia prospecção de quatro anos antes, então eu criava, junto com a engenheira têxtil que tipo de fio ia ter binagem, se ia ter retorção, já pensando no tecido que ia dar essa binagem, o acabamento desse fio para dar um tecido tal, para daí ver que forma ia fazer com aquilo, e eu vendia esse pacote todo para os caras lá na frente, para os estilistas de terceiro setor. Então eu lá de primeiro estava pensando no fio ainda, a gente trabalhava junto. E lembro muito bem que eu tinha um showroom incrivel na Rua General Flores, e era uma empresa muito bacana, era uma multinacional coreana que estava se instalando no Brasil e eles montaram o showroom.

Leilane: Qual é o nome?

Renata: A Sintecfil. Era um monstro, e eu tinha tudo, tinha Italtex, eu tinha Nelly Rodi, tinha Promostyl, eu tinha, tudo que falei, "olha, quero uma estrutura dessa", eu tinha um showroom com trezentas peças trocadas a cada dois meses.

Leilane: Isso foi quando?

Renata: Foi em 2004

Leilane: Já tinha dado WGSN, né?!. 
Renata: Já, fui eu, a C\&A e a Hering foram as três primeiras assinaturas de WGSN no país. Então eu tinha na minha máquina, e eu olhava aquilo e tinh a Renata Coraza, que era contratada para passar as informações ao vivo.

Leilane: Fazer o tête-a-tête.

Renata: Porque eu recebia estilistas do Brasil inteiro no meu showroom para contar a eles o que era tendência. E eu tinha a engenheira têxtil...

Leilane: Porque lá tinha uma coordenadora de estilo também?

Renata: É, é que lá eles chamavam estilista.

Leilane: Era um cargo fake, sabe, não tinha mais para onde subir. Estilista, coordenava os estilistas.

Renata: É, e eu tinha uma equipe, assim, tinha vários técnicos têxteis, essa engenheira têxtil, então eu trazia uma informação que para eles era extremamente pirada...

Leilane: Sim, a gente era completamente descolado da realidade.

Renata: Eu era a louca lá, porque se vestir de uma tal forma, todos aqueles engenheiros têxteis engravatados, risos.

Leilane: Eu parei de raspar cabelo, outras coisas, porque não conseguia fechar pedido de tecido. Estava conversando hoje isso com uma amiga, supercareta.

Renata: E eu saí de uma XXXXX, onde a gente ia trabalhar de calça manchada,

Leilane: Se fosse de tanga ninguém ía falar nada, né?

Renata: Não! No calor os meninos tiravam a calça no showroom e ficavam de cueca. A gente trabalhava no showroom, porque eram só três estilistas, os meninos trabalhavam de cueca.

Leilane: Ar-condicionado, não é...

Renata: Tinha, mas, sabe, coisas que se você conta por aí, e caí num nicho de engenheiros têxteis, e eu era um ET lá. E eu tinha que passar essas informações das texturas, do que eu queria para os engenheiros, até fui dar uma palestra na FEl sobre o trabalho da engenharia têxtil com estilismo e os preconceitos, porque existiam, porque engenheiro têxtil abomina estilista. Acha que é uma figura ilustrativa.

Leilane: Aquelas coisas, seu sonho é o meu pesadelo.

Renata: Então dava briga, e nunca imaginei isso... mas do que estávamo falando?

Leilane: Estávamos falando de design de moda nacional.

Renata: Ah, ia te falar das primeiras experiências que tive em setembro, no meu showroom, eu recebi, as estilistas, nesse momento, tinham 60, 65 anos, ganhavam 30 mil reais.
Leilane: Trabalhei com a Jogê.

Renata: A gente fornecia para a Jogê também. Era um cliente nosso. E, assim, 65, 63 anos, ganhavam de 25 mil a 35 mil reais por mês, e qual era essa figura de estilista, isso em 2003, 2001 a 2005. Olha isso. Elas sentavam no showroom e falavam assim: "ai, Renata, vim saber das últimas informações, ai, não sei, estou com um desejo de azul". Aí eu olhei para elas e falei "gente, como assim, desejo de azul?". Então era uma outra geração de criadores, e que agora acho que foi extinta, porque...

Leilane: Desculpa te interromper, aquele tipo de frase da Marie Rucki, mas ela falava "isso é coisa da época", aquele tipo de frase que acho superperigosa, aqueles casos, "o estilismo é um estado de espírito, saber captar a fantasia no ar”, soltas, não é...

Renata: Mas era um outro momento. Até a década de 1980 o estilismo foi muito isso. Lembro quando a Casa Rodia se instalou aqui, a atmosfera era essa mesmo. Você via as super publicações que a gente tinha em moda, até mesmo aquele programa que passava no Jornal Hoje, um quadro de uma superjornalista, era a única no Brasil que falava, tinha meio que um esquema de flash no Jornal Hoje, que falava de moda. Outro dia falaram dessa muIher, de como ela foi pioneira. Então ela fazia pequenos relatos dos grandes desfiles que a gente tinha, e o texto era totalmente esse: "desejos de ...", era extremamente poético, não tinha nada de substancial, paupável, era isso. Não sei se você conheceu o Video Fashion News.

Leilane: Não.

Renata: Era um sistema de vídeos, de VHS, que vinham com todos os desfiles, você comprava e era milionário.

Leilane: Imagino, na época não tinha internet.

Renata: Então, e a narrativa dos desfiles, era exatamente isso. A gente vive isso até o começo de 1990.

Leilane: Como se estivesse vendendo a imagem, que a gente ensina os alunos a venderem, como na alta-costura, para a imprensa, só que não colava, estava vendendo para profissional, precisava de uma informação um pouco mais palpável.

Renata: Exatamente, era exatamente isso.

Leilane: Legal você falar isso do exterior, de identidade nacional, você acha que tem um modo de projetar o Brasil que é diferente do exterior? Se baseando principalmente na bibliografia que a gente usa muito, nossa bibliografia basicamente é do exterior.

Renata: Não sei se você percebeu isso no seu mestrado e agora no seu doutorado, se você pegar os grandes autores de fora e ler livros na integra nos idiomas, vai ver que $90 \%$ das nossas publicações chuparam literalmente esse autores.

Leilane: Com outro nome, não é? 
Renata: Sim, os livros de história da moda que a gente tem no Brasil..

\section{Leilane: Elizabeth Wilson, não é?}

Renata: Sim, para mim é um dos melhores livros, tudo, se pega e lê esses livros na íntegra vê que a gente também não tem uma bibliografia nacional, que muito do que a gente tem, principalmente do começo de 2000 depois foi melhorando mais, mas era isso, não tinha um acesso irrestrito às bibliografias, não chegavam aqui, já era mais caro, e as pessoas acabaram fazendo isso.

Leilane: Mas você acha que tem um jeito de projetar que é diferente.

Renata: Tem, totalmente, acho que a gente ainda tem um resquício meio tupiniquim, a gente tem esse ranço de ainda criar com essas, ai, tive uma inspiração, acho que o brasileiro ainda se enxerga, quando o cara chega aqui e fala, ai, vou ser estilista, ele acha que tem um pouco dessa atmosfera etérea, e aí o brasileiro aposta muito mais nisso do que na técnica, ele acha que é o que eu falo muito dessa questão das alunas-artistas. Não tenho nada contra uma linguagem mais artística, mas acho que o cara, depois de ser formado tecnicamente, pode ser o que quiser, pode subverter o que ele quiser, mas acho que para a gente subverter alguma coisa precisamos ter técnica antes.

Leilane: Concordo com você. Eu queria pirar. Eu brigo muito com meus alunos...

Renata: Eles querem desenhar rápido..

Leilane: Eles querem fazer a peça icônica. É a palavra do momento de uns tempos para cá. A minha bolsa icônica, preguiça.

Renata: Ai, jura? Não conhecia. Preguiça! E os alunos querem desenhar rápido, e ter um traço forte, emblemático...

Leilane: Como se fosse fácil. Faz a coisa parecer fácil.

Renata: E sem aprender base. Às vezes estou dando uma aula técnica e eles não têm paciência para aula técnica, eles querem ir para o estilo.

Leilane: Muito do profissional estilista-criador se sobrepõe ao cara que estuda.

Renata: Até hoje, isso que não acredito.

Leilane: E simbolicamente depõe ao contrário, não é?

Renata: Depõe muito ao contrário

Leilane: Que aí o estilista é aquele que não estuda, "o que você faz, fica lendo revista?"

Renata: Eu nunca ouvi isso, porque já trabalhava.

Leilane: Eu já ouvi isso. “Você só desenha?", sim, desenho, para virar produto. Fazia relatório de venda.
Renata: Eu acho que, essa questão ainda de ser uma área não muito normatizada,

Leilane: Já é formalizada, mas..

Renata: Não, normatizada no sentido de cada um meio que faz do seu jeito, tudo bem..

Leilane: Não tem os marcos processuais reconhecidos.

Renata: Exatamente, acho que isso também depõe contra, e eu percebo que, pelo menos dentro das empresas em que trabalhei, o próprio departamento de estilo, criação, não quer ser normatizado porque acha que isso é meio careta. Então eles gostam dessa coisa, ai, eu quero fazer, e eu acho que não, pelo contrário, isso que está atravancando o processo, entendeu?

Continua valendo menos em face de tradição, de normatização do que a arte, a arquitetura, o design...

Exatamente.

Leilane: $E$ é um prato cheio para o design, não é? Não sei se você conhece o trabalho da Deborah Chagas Christo.

Renata: Não.

Leilane: Ela é da PUC-Rio, de moda, e foi orientada pelo Cipiniuk. E ela fala - de uma maneira bem grosseira - mas, em suma, o artigo dela saiu na Dobras, que foi premiado, ganhou o Prêmio Gilda de Mello e Souza, gosto muito da visão da Kathia Castilho porque ela é hibrida, ela é interdisciplinar, quem vem da arte, quem vem do design, desde que tenha inteligência. Só quem vem da arte, quem vem do design, desde que tenha inteligência. Só construções etéreas e materiais sazonais, passageiros, e que, risos, vestuário é mesmo design de produto. $O$ que você acha disso?

Renata: Eu acho que é design de produto.

Leilane: Sério?

Renata: Sério.

Leilane: Eu fiquei puta da vida. Pô, eu fiz faculdade de moda, estou brigando há 20 anos por isso, ninguém quis. $O$ cara formou um curso, aí parece eles falam: lembra que vocês surgiram da gente? Como se falasse uma coisa assim.

Renata: Ah, mas você está falando como área de saber.

Leilane: Também. Uma parte seria privilégio, seria pertencente à área do design, não da moda. Enquanto pensamento projetual.

Renata: Não, não, eu não falei nesse sentido. Eu estava falando em outro sentido, estava falando, eu quis dizer que acho que é produto, tudo que a gente faz é em função do produto, mas seja esse produto caretinha, careta no sentido de liquidificador, ou um produto mais requintado que seja de conceito. Foi nesse sentido que falei, não era do saber. 
Leilane: Para você é moda.

\section{Renata: Moda.}

Leilane: Risos.

Renata: É, eu entendi outra coisa.

Leilane: Eu também não fui clara. Há uma disciplina ou um grupo de disciplinas no curso que norteia o curso, que seja considerada mais importante, que direcione?

\section{Renata: Tem. Estilo e desenho.}

Acho que isso corrobora com a ideia de estilo, desenho é uma coisa bem forte aqui.

\section{Renata: Sim, mas por essa vertente.}

Leilane: É, mas não só, você falou dos $30 \%$... qual o papel do desenho no estilismo, se o desenho era mais marcante..

Renata: Ah, sim, mas volto a enfatizar aquilo que falei: a questão do desenho não só como fisicamente o traçado, mas desenho como pesquisa do corpo.

Leilane: Forma de expressão.

Renata: E pesquisa corporal, volumetria, por isso o desenho norteia e dá o embasamento necessário para estilismo discutir roupa, não só estilismo discutir roupa, mas joalheria discutir joia, é nesse sentido que eles são importante, ele entra principalmente porque o mais importante para a gente é projeto. Nessa gravação que eu te falei de anos atrás, a gente enfatizou: Santa Marcelina, o mais importante, antes de tudo, é ensinar o aluno a projetar. A ter um raciocínio.

Leilane: É muito engraçado você falar, porque eu vim de uma faculdade que tinha o curso de design, e o curso da Anhembi chamava design de moda, era separado, tinha negócios e design, e entrei em design desde $\circ$ primeiro ano, e projetar, lá é muito forte, muitas das falas da Vera Ligia, bate muito com livros de design como o Löbach, que fala que você tem que tirar o fator quadradíssimo, muito racional, mas bate muito, porque eles têm etapas já muito estabelecidas, eles vieram antes da gente, querendo ou não, assim como a arte veio muito antes do design, mas é engraçado como esse discurso coincide com o design, embora a coisa tenha surgido inegavelmente da arte.

Renata: Acho que a única diferença nossa, a gente bebe do design. Com certeza.

eilane: Mas não tem um curso de design, surgiu do curso de design.

Renata: Mas não tem como fazer um produto sem as etapas do design Mas acho que a grande pérola do Santa Marcelina foi meio viver nesse ambiente arte, música, a gente dá aula ouvindo... Acho que isso, ao mesmo tempo, meio que fazia parte desse DNA, não podia perder isso.
Leilane: A arte estaria mais na pesquisa, estaria em tudo, mas na pesquisa, mesmo na hora de passar para o aspecto técnico, na experimentação, na forma, no processo, a forma como você faz.

Renata: E os professores ficarem em cima falando que estão avaliando o processo, então a gente o tempo todo tem que ser babá, principalmente no quarto ano, tem cinco professores avaliando o seu projeto.

Leilane: Babá de TCC.

Renata: E, mas mesmo dos outros, porque os trabalhos interdisciplinares, às vezes, então tem o professor de desenho que norteia a parte desenho, tem o professor de têxtil que norteia a parte têxtil, e você é avaliado pelo processo. $O$ teu produto final pode até ser uma coisa péssima, mas você é avaliado pelo projeto. Então desde o primeiro ano a gente fala isso pra terem muita consciência disso. Mas não é qualquer projeto. É o projeto que carrega o DNA, a arte também junto, não pode ser só um projeto experimental.

Leilane: E quando eu falo projeto, a gente da moda, a gente tem esse preconceito com o design por ser muito racionalista, formalista, quadradinho, mas não tem como fugir das etapas. Na minha visão, quando a gente aceita essas etapas do design, ao mesmo tempo se aceita e tem que admitir que a moda já é um campo autônomo.

Renata: Mas eu vejo pelos projetos que a gente tem aqui dentro.

Leilane: Joalheria eu acho que é o mais polêmico de todos, não é? Se é produto ou se é moda. Para mim é moda, mas para eles é produto. Até a década de 1980 todo mundo torcia o nariz para moda, quando a coisa se constituiu, se formalizou, agora vem gente falar que é design. Peraí, risos, tudo bem que era do design, mas ninguém tinha lutado por isso antes. Era inferior a fazer computador ou eletrodoméstico, existia um preconceito com a área de moda dentro do design.

Renata: Sempre existiu, desde que me conheço por gente de dentro desse mercado, sempre existiu, mas que é uma área autônoma, Le, vejo at pelo sistema de aulas que foi sendo modificado, a gente percebe, a gente bebe de tudo um pouco.

Leilane: Até adaptar e virar moda, não é?

Renata: Até virar um processo autônomo, que na verdade ele não faz só uma coisa ou outra, a gente já tem algumas normatizações no processo. Tem coisas que a gente faz aqui no Santa Marcelina que depois de implantar e ver rodando a gente vê as pessoas escrevendo em livros, normatizando uma coisa que a gente já fazia antes, "nossa, eles copiaram da gente". Não, ê porque aqui sempre tudo foi muito fechado. Então praticamente essas crias da casa que já fizeram moda com o Carlos Mauro...

Leilane: Acho que muito da coisa do design vem do Eddy, não ê?

Renata: Sim, matérias.

Leilane: O Carlos Mauro. 
Renata: O Carlos Mauro que fazia vivência na Rodia.

Leilane: E ele trabalhava com moda, mas era formado em design.

Renata: Ah, sim, mas muita gente, muitos professores daqui, a Santa Marcelina, quando eu fui aluna, era 50\% Faap, artes plásticas, e 50\% USP, FAU.

Leilane: $O$ pessoal de design industrial da Faap.

Renata: É, exatamente, então isso foi a base do Santa Marcelina. Agora as crias da casa já vêm com um perfil diferente, porque tiveram essa formação e mais mercado.

Leilane: Não é só um saber acadêmico.

Renata: E a gente bate muito nessa tecla. Os alunos que saem daqui e são empregados não vão para o chão de fábrica. Vão para o topo da pirâmide como criadores. É isso que a gente fala, a questão..

Leilane: Se você faz uma faculdade top vai para..

Renata: E nem é questão de ser faculdade top, mas é uma faculdade mais expressiva. Você não quer só aprender a fazer a sandalinha.

Leilane: Quer aprender a pensar formas de fazer...

Renata: Exatamente, você quer meio que suplantar e sair desse meio comum. E eu falo para os meus alunos quando chegam no quarto ano. Bom, se vocês chegaram até aqui e vieram procurar moda porque acham que aí dentro de vocês tem uma coisa que os diferencia muito, do resto de toda a população, que vocês têm um olhar específico e um gosto específico, aí elas ficam assim na cadeira. Aí depois elas falam: "ai, professora, mas tem que ser já tudo isso no quarto ano?". Eu falo: "vocês não vieram fazer uma faculdade de criação?". E aí eu brinco com elas com a história do fundo do mar, eu falo pra vocês, gente, quero fazer uma estampa de fundo do mar. Que cores vão ter nessa cartela? Aí elas começam: azul. Que formas? Ah, peixe, concha. Aí eu falo: tá, isso seria o engenheiro mecatrônico fazendo a estampa, né?

Leilane: Inclusive o tema, não é?

Renata: $O$ tema já é recorrente e extremamente estereotipado.

Leilane: É até legal pegar uma coisa estereotipada. Egito, circo, fundo do mar.

Renata: Aí eu falo: vocês pensaram que, se eu tenho que contratar vocês para fazer estilo dentro da minha empresa, eu vou querer um fundo do mar que seja totalmente diferenciado desse fundo do mar que vocês estão me falando. Isso aí que vocês me falaram eu peço para o engenheiro mecatrônico, ah, tem um cara lá mal utilizado na minha empresa, é o engenheiro mecatrônico, você manda ele fazer uma estampa de fundo do mar e ele vai fazer literalmente isso. Se estou pedindo para vocês formados em moda, eu quero exatamente uma mensagem subliminar.

Leilane: Tem a coleção da Sofia Kokosalaki do fundo do mar.
Renata: Exatamente, exatamente.

Leilane: Não precisa ser entregue assim, de bandeja. A gente já falou, para você moda age como campo autônomo, a ideia de estilismo como uma atividade produtora de sentidos mais profundos para você é afetada pela obsolência perceptiva? Obsolescência perceptiva não é obsolência programada, não é que isso "quebrou, eu jogo fora", é aquela que eu falo: essa minha blusa está muito boa, está perfeita, não tem nenhum fio puxado, mas amanhã, mesmo que não seja moda, já não faz tanto sentido, eu deixo de usar. Na percepção geral ela não faz mais parte desse tempus, ela não traduz mais... não que eu tenha que seguir tendências, mas ela começa a soar anacrônica pelo tempo ela obsolescência perceptiva, você acha que essa obsolência perceptiva, principalmente quando eu falo do fast-fashion, não é, afeta a atividade de
projeto como uma produtora de sentido mais profundo.

Renata: Acho que banaliza, muito raso, ninguém se preocupa muito mais.

Leilane: Não dá para fazer projeto do dia para a noite.

Renata: A gente vive isso, na verdade a gente brinca que faz pastelaria.

Leilane: É, eu não queria falar, mas você falou, hahaha.

Renata: No fundo, no fundo, a gente vive mesmo uma pastelaria e vejo que muitos alunos se decepcionam quando se formam por isso.

Leilane: $\mathrm{E}$ onde fica a parte da reflexão, de fazer algum projeto?

Renata: Acho que hoje a gente já tem uma resposta que tem muita gente se voltando para um tipo de design diferenciado, slow fashion, clássico, dá um requinte à marca, uma identidade à marca e quebrar um pouco essa história. Eu brinco, na pós em acessórios a gente até falava do diferencial na criação, e hoje em dia a marca que não tiver um diferencial forte não sobrevive. Se é pra fazer o commodity, você não vai competir com a C\&A, não vai competir com uma grande, então tem que fazer uma coisa... Por isso acho o papel da criação tão importante, mas uma criação coerente com $\circ$ projeto. A criação que tenha técnica, eu acho que só sobrevive hoje no mercado quem tem um diferencial muito forte e com essas características de, até mudando o cronograma, acho que hoje em dia a gente não valoriza mais o fast-fashion, veio rápido, acelerou tudo e a gente já não gosta mais disso, dessa ideia de ficar descartando roupa. Isso tudo achatou qualidade.

Leilane: Uma questão social nisso tudo, que a gente sabe do tipo de mão de obra que é usado para isso. Desvalorização do trabalho manual de quem faz.

Renata: Sim, e eu acho que a questão está mesmo aí, nesses nomes, outsiders, que despontam e começam a fazer o seu tipo de cronograma, 0 seu processo. Acho que é a nossa escape hoje, fugir do que causou o fast-fashion. Achatou tudo, fez perder o sentido, e até a moda para se reinventar, senão acaba a moda, para quê estudar moda?

Leilane: Achatar é a palavra.

Renata: É. Não tem mais o que criar ou ensinar, para quê ensinar? 
Leilane: Eu chego em aula e para eles e falo assim: gente, alguém aqui é dono da Dupont? Não. Alguém aqui inventou a roupa de spray? Não. Supondo que vocês tenham essa grana. Saindo da faculdade vocês tem know-how, vocês conseguem chamar as pessoas pra conseguir desenvolver o negócio mais bacana tecnologicamente, vocês têm uma ideia? Não. Tem a grana? Não. Agora vamos pensar no fast-fashion. Tudo super-rápido, por que alguém vai querer pagar mais caro num produto, que, em geral, em função da escala, não é supertecnológico, mas é diferenciado, a que ponto tem que chegar essa diferenciaça para atingir o sujeito? Qué oqueo Deyan que chegar essa difercichar Sudjic fala. Voce tem que ser único, mas desde que seja dentro da produção em série, e você tem que se diferenciar, mas preservando o instinto gregário, essa é uma preocupação. E aí dentro de um contexto econômico, onde commodity se faz na China, llhas Maurício, Índia, sei lá o quê, e aí eles falam: é, então... realmente é algo a se estudar, a questão cultural, de design, de arte, de moda. É impossível, não é?

Renata: Eu respondi sua pergunta?

Leilane: Respondeu, a gente começou ainda da disciplina, qual norteava, a gente foi andando. Se a obsolescência perceptiva afeta a questão de desenvolvimento de produto do estilismo como uma atividade produtora de sentidos mais profundos, você já falou que tem um movimento, inclusive comentado pelas universidades, tem que ser, que é um produto de reflexão. Você conhece os preceitos básicos de forma e função do design racionalista. A forma segue a função. Chato. Dentro do contexto que a gente viveu, não só de fast-fashion, dos grandes magazines, porque todo fast-fashion é um magazine, mas nem todo magazine é fast-fashion.

\section{Renata: Sim, sim}

Leilane: A Marisa ainda até hoje é muito lingerie, Besni é calçado... Você acha que a forma na moda não segue a função, mas segue o apelo de venda, pensando numa moda industrial? Pensando na moda industrial, na maior parcela do mercado, e mesmo pensando numas coisas bacanas que a gente vê por aí, mesmo a Gisele Nasser, Adriana Barra, essa turma tem que ganhar dinheiro, por mais que goste de fazer uma roupa, ela tem uma linha que é menos...

Renata: Formula de novo a questão.

Leilane: A forma segue a função no design. Na moda, a forma seguiria o apelo de venda?

Renata: Sim. De várias maneiras, vou te dar até um exemplo do tempo da Sintecfil. Eu fazia prospecção de quatro anos antes, e eu tinha informação do mundo inteiro, dos melhores materiais, as revistas de conceitos, tudo que você possa imaginar de fonte de pesquisa, a gente fechava uma coleção, era tudo muito redondinho e, de repente, aparecia, ah, a prospeção para esse ano é de sintéticos, de repente aparecia naturais, e aí eu falava "meu Deus", e daí eu rodava o Bom Retiro, me informava. Então, de onde vem esse natural? Esse natural veio da batinha da Edwiges da novela das oito... então uma pesquisa de quatro anos era suplantada por uma novela, por uma per- sonagem forte de uma novela, isso foi um caso. Um outro caso: ai, Renata, você me falou de geométricos, blá-blá-blá, e agora de onde vieram essas formas orgânicas e manchadas da Daslu? Você não me avisou que tinha isso na coleção. Eu não me preparei e não bati nada de manchado. Eu tinha uma aluna que trabalhava na Daslu na época, liguei pra ela: de onde veio isso? Renata, mas isso aí foi uma peça encalhada que a gente tinha, e pra desovar a gente montou uma miniproduçãozinha num fundo de quintal e a gente manchou. Eisso suplantou a minha pesquisa de quatro anos. Então no Brasil

Leilane: Isso é um jeito de projetar bem brasileiro que a gente tinha falado antes.

Renata: Não, realmente tem, que á a coisa da aceitação, eu não te respondi isso?!

Leilane: $\mathrm{E}$ aí tem a adversidade, que é essa coisa meio mambembe.

Renata: Mambembe, exatamente, totalmente mambembe. Sempre falo isso. $\mathrm{E}$ isso aconteceu comigo em todos os setores em que trabalhei dentro de moda e isso ficou muito claro. Por mais que você queira implantar um cronograma, uma forma de fazer as coisas correta e que dê menos gasto, você não consegue, porque aqui a gente tem a novela da Globo, o Carnaval...

Leilane: Não tem cultura de moda.

Renata: Não tem cultura de moda, então a Daslu é "uau", imagina, uma Daslu ser uma formadora de opinião a ponto de mudar toda uma prospecção de pesquisa séria, de anos, para isso. Entendeu, a gente vive isso aqui dentro, qualquer coisa acaba quebrando tuas pernas e, de repente, mesmo que você queira ser autoral, ah, não, mas o que está acontecendo lá fora, ainda influencia pra caramba.

Leilane: Legal você ter falado isso. Eu queria falar um pouco com você sobre a ideia de capital simbólico, do Bordieu, e que a moda tem movimentos de idas e vindas em relação à arte e ao design, ela se aproxima do design e da arte quando precisa se valorizar para ganhar capital simbólico, se associar ao capital cultural... Olá, Marcos! Do Bordieu, a ideia do capital simbólico, que ele fala inclusive de áreas garantidas juridicamente, porque senão a gente... hoje vou ser advogada, não vou ser estilista, isso não existe em profissões tradicionais, como direito, engenharia, e mesmo odontologia aqui, que é posterior à medicina o reconhecimento. A gente vê arquitetos falando com designers, designers com arquitetos, esse pampeiro, né?! Então a gente percebe que a moda se aproxima do design e da arte para ganhar capital simbólico, capital cultural de pessoas, e ao mesmo tempo a moda se, numa tentativa de constituir um papel autônomo nega o tempo todo também. A moda é muito sem vergonha. Ao mesmo tempo que ela precisa se afirmar como campo autônomo ela diz não sou design, não sou arte. Queria saber o que você acha dessa afirmação.

Renata: Eu acho que é verdadeira.

Leilane: Se confere, se procede, risos. 
Renata: Se confere, procede... e acho que a gente se acostumou com esse papel em moda. A gente se acostumou a usar desses artifícios para se legitimizar e a questão do negar é uma forma de falar, ok, já aprendemos tudo que nós queríamos, então agora somos gente grande.

Leilane: Talvez nem tenha uma mudança, mas no movimento de falar: puxa, olha só, obrigado, a gente não vai negar que veio da arte e do design, talvez uma cultura um pouco parecida com o pós-moderno, o contemporâneo, a arquitetura, mas que a gente fala assim: olha, então a gente olhando bem, a gente quer moda para saber que é um campo, realmente, com características muito específicas, próprias e já não faz mais sentido a gente tributar ou devotar nada ao design ou arte hoje.

Renata: Não sei se isso te exemplifica, mas, por exemplo, mesmo nos nossos debates entre desenho de moda e desenho artístico, que, no caso os professores de desenho artístico acham que desenho de moda é uma aberração, que é horrível porque achata, a linha tem que ser única, não pode ser uma linha interrompida, rabiscadas, que agregam valor, nessa nossa briga, às vezes quando estamos em reunião e temos que falar: mas para a aula de modelagem a gente começa a colocar as questões técnicas de moda, o pessoal de arte: ah, existe isso?

Leilane: Não é você que manja para caramba? Sacanagem..

Renata: Mas é uma briga que acontece, então se você pegasse hoje a estrutura do Santa Marcelina que existia na minha época, a faculdade não se sustentaria. $O$ professor de arte hoje não conseguiria formar um estilista para hoje, nossas linguagens, necessidades e demandas de hoje.

Leilane: Para o mercado de hoje, já substituiu o estilista autodidata.

Renata: Exatamente, eles me formaram, eu já era estilista aqui. E eu lembrava disso e falava...

Leilane: Mas você ainda trabalhou com a turma (das confecções, escritórios etc) quando ainda não tinha faculdade. Eu já estagiava, mas via aquela rixa de estilista não gostar de mim, você percebia porque é o cara que está se especializando.

Renata: $\mathrm{O}$ cara que entrei no lugar na Sintecfil era um estilista da década de 1980. Ele queria me matar.

Leilane: Principalmente quando não tinha uma formação, não é?

Renata: E eles acabavam achando que eles tinham o feeling para a coisa, e que o cara que vinha depois com faculdade era um produto pré-moldado. Plástico. Então vinha dos dois lados o preconceito, não era só de um lado. E é o que acontece aqui, então hoje um cara de artes não forma mais um estilista, então não dá para esse cara falar: "ah, mas bebe", pode até beber ainda.

Leilane: É o que eu falo, não estamos negando a história.

Renata: Também acho, nunca vai deixar os processos são muito parecidos, mas tem uma essência aí no meio e tem umas características que você não consegue mais, se hoje a gente pudesse falar que um designer de produto ou um estilista ou um artista plástico pudessem gerar uma coleção de moda do começo ao fim, ok, mas ele não consegue.

Leilane: É, porque a gente vê arquiteto, designer, fora os modelos fazendo coleção, mas não vemos estilistas projetando prédios, com exceção do Pierre Cardin.

Renata: Ah, mas o Pierre era arquiteto.

Leilane: É, ele retomou agora.

Renata: Os grandes nomes da moda de 1970, 1980 e até o comecinho de 1990 vieram da arquitetura. Agora não é mais assim, agora tem esse ser híbrido que nasceu dentro da moda, e por isso acho que ele é mais raso às vezes. Sabe como eu acho que nasce hoje o estilista, pelo que pergunto para o meu aluno no primeiro dia de aula? Ele é um consumidor primeiro, de moda. Antigamente era um arquiteto migrando, hoje não, ele nasceu como consumidor afetado.

Leilane: É legal você falar isso de consumidor afetado, se você pensar o arquiteto ou o designer, eles já têm mais tradição na área, então já tinha uma preocupação com legitimar o curso que passava pela ideia de refletir. Porque na moda se confunde muito com o oba-oba, que é o consumo ávido.

Renata: $O$ cara que vem aqui é consumidor ávido, incessante, transloucado por moda. Por isso eu não sei que hiato foi esse que, eu achava que isso só acontecia na década de 1980, do cara afetado com desejos de azuis, e agora, de repente, a gente passou um tempão tentando legitimar isso aí e vem um consumidor afetado achando que vai fazer moda sem nenhuma técnica. $E$ você entende que a gente voltou para a estaca zero de repente, é muito difícil você colocar na cabeça do aluno que estudar cada vez mais, que pesquisar cada vez mais, ele não acha que moda é isso, e muita gente desistiu no meio do caminho: "nossa, eu achava que era uma coisa tão fácil”.

Leilane: Tem muita evasão?

Renata: Eu acho que não. A Suli esse ano achou que esse ano teve uma evasão muito forte, mas tem a ver com a crise, acho que são outras coisas. Mas aqui dentro falamos muito para o nosso aluno que fica quem tem vontade mesmo, é diferente da Faap, por exemplo. A gente aqui ainda tem autonomia de pegar um aluno que não faz nada e não tem interesse, de chegar para ele e meio que forçar o cara a ir embora, ele se sente mal perto dos outros, porque a gente fala desde o primeiro dia do primeiro ano que aqui fica quem vai trabalhar. Eu tenho nota em todas as minhas aulas para turmas de 50 alunos. Então o cara sabe que está entrando aqui e vai ter que ralar muito, não sabe muito bem porque está fazendo laboratório, não emenda lé com cré.

Leilane: É difícil também para a nossa parte como professora. 01:38:05 Renata: Eles não ligam porque estão fazendo aquela matéria, é só traba- 
Iho, trabalho, trabalho e eles vão fazendo. Eles viram noite direto. Para eles é normal aqui, porque a gente meio que criou uma regra no Santa Marcelina, o cara faz ou faz. E quem não quer trabalhar atravessa a Pacaembu.

Leilane: Isso é fogo, não é, triste isso.

Renata: É, mas assim, até quando?

Leilane: Porque o curso de artes mantém o mesmo coordenador e está minguando, não é? Mas o TCC tem 3, 4 alunos.

Renata: Não, não, não. O curso de arte? Aqui também!

Leilane: Sério?

Renata: Sério. Ninguém mais quer ser artista.

Leilane: Quer consumir e, para consumir, precisa ganhar dinheiro.

Renata: Exatamente. Aqui também está minguando. Música também. Quem rege o Santa Marcelina ainda é moda.

Leilane: Ninguém quer ser artista, ninguém quer ser músico.

Renata: Mas ninguém quer ser nada que dê muito trabalho.

Leilane: Ou que a chance de estrelato seja muito remota...

Renata: Mas tem grandes salários dentro de moda, tem muito salário bom dentro de moda, mas para poucos.

Leilane: E é um mercado muito restrito, se você for comparar marketing, o cara não tem vida às vezes, magazine, essas coisas. Deixa te perguntar, acho até que você já respondeu: acha que falta reflexão intelectual sobre o projeto em moda e de maneira geral dentro do curso de moda?

Renata: Sim, nunca li ou ouvi alguém questionando o projeto. E a utilidade do projeto como raciocínio mesmo. Algumas pessoas acham que você pensar projeto antes enquadra a criação.

Leilane: Mas é uma confusão de projetar com produzir

Renata: Não, não, não, pelo contrário. Eles acham que meio que afeta e às vezes aniquila o aspecto artístico da coisa.

Leilane: Sim, mas projetar no sentido que é produzir, não só produção industrial. Que precisa ser produzido algo, então você já tolhe liberdade.

Renata: E eles acham que de alguma forma o artista é aquele cara que não projeta nada, e que de repente brota uma grande criação.

Leilane: Você acha que ainda vigora isso?

Renata: Muito, muito, muito, por mais que eu queira falar que não, porque me choca muito isso.

Leilane: Isso vem com os alunos quando eles vêm para as faculdade de moda de maneira geral ou porque nós também das faculdades fomentamos outras ideias? 01:41:30
Renata: Não. Aqui chegam para mim no primeiro ano, sempre faço uma pergunta para eles: por que vieram fazer moda? Aí ouço as respostas: ah, eu adoro ir ao shopping comprar roupa e por isso vim fazer moda. E agora les falam assim: não, eu já sou um estilista formado. Formado onde? No umbigo dele. E eu só vim aqui lapidar o meu talento.

Leilane: Isso no primeiro ano?

Renata: No primeiro dia de aula. Sabe a tal da geração... qual é a última? Leilane: É a Z. A da internet.

Renata: A que só olha para o seu próprio umbigo? É isso agora. É outra característica, não é mais o cara de 1980 que não tinha conhecimento e viava artista. Agora é o cara que só olha para o próprio umbigo e ele vem em moda achando que é um ser extremamente único.

Leilane: Legal você falar isso. É a primeira vez que me surge isso.

Renata: E para domesticar esse cara?

Leilane: $E$ domesticar não no sentido que ele tem que fazer daquele jeito, domesticar no sentido que precisa ser mais humilde e trocar.

Renata: Sim, vai colocar isso na cabeça do cara, então passa por outros tipos de inteligência. A inteligência emocional do cara está bichada, já vem da casa dele desse jeito.

Leilane: É diff́cil, desgastante, não é?

Renata: É outro desafio, mas isso consome pelo menos $50 \%$ das turmas. Então enfrentar isso, então a gente teve a geração $X$ e agora demorou dez anos falando para os alunos de moda que eles tinham que ser humildes pensar em tingir menos o cabelo de azul e pôr piercing na bochecha para fazer estilo. Eles tinham que ralar para fazer estilo. $E$ aí a gente conseguiu dar uma domesticada nesses alunos, e de repente chega uma nova geração que agora...

Leilane: Nem experimentam, não é? Vai no fast-fashion ou na Chanel. Pior que o cara do cabelo azul e do piercing estava experimentando pelo menos uma coisa para ele.

Renata: Desses personagens teve um dia um super, "ai, hoje estou muito, muito, muito nervoso porque preciso ir até o JK e conseguir um Chanel".

Leilane: Você se pronunciou?

Renata: Não, eu nem... não dá, é uma coisa muito...

Leilane: Espetaculista, não é?

Renata: É, e não tem como entrar nesse mundo deles, está criado já ali. Ou você joga uma bomba e estoura tudo ou o que você vai fazer para colonizar aquele lugarzinho ali? Demanda um tempo absurdo.

Leilane: Eu te perguntei se falta reflexão intelectual sobre o projeto em moda porque eu percebi na Santa, a Vera Ligia até falou isso e queria saber 
sua opinião. A grade, o curso vai ficando cada vez mais prático, tem disciplinas de filosofia e vai ficando mais prático. Então isso é uma preposição, porque a gente fomenta, porque cobram da gente também como professor ser pesquisador, a reflexão intelectual, mas ao mesmo tempo os cursos onde a gente trabalha vão ficando cada vez mais práticos.

Renata: Mas eu acho que isso foi um pouco da confusão de 1990, 2000, da questão dos cursos profissionalizantes. A gente via às vezes que o cara que se formava no Senai era mais apto a trabalhar com moda do que um cara que fazia quatro anos.

Leilane: Na hora que ele vai trabalhar é outro, não é? Outro setor. Planejamento, compra...

Renata: Não, mesmo em estilo...

Leilane: Era bom aquele curso, era bem legal.

Renata: Era. Ainda tem. É muito bom. Mas... nossa, perdi o fio da meada.

Leilane: Estávamos falando que o curso vai ficando cada vez mais prático.

Renata: A gente vai virar semestral agora. Na hora de rever a grade...

Leilane: Por que vai virar semestral?

Renata: Tinha uma questão até financeira da faculdade e quanto a trancamento, para os alunos era mais interessante, a gente não queria, até...

Leilane: Você tinha alunos que ficavam o ano inteiro.

Renata: $\mathrm{O}$ ano inteiro, você trabalha com o aluno não só a questão, por exemplo, no meu caso, que é desenho, mas a questão de projeto, então ele começa a entender, ah, olha, não é só desenho, tem um tempo maior para trabalhar com ele, e o semestral é muito descartável, dá uma amostra grátis do que poderia ser um curso legal. É mais ou menos isso. A questão do semestral, quando começamos a cortar e ver o que tinha que sair, primeiro veio aquela questão do DNA Santa Marcelina, estilo, desenvolvimento de produto e desenho. E aí o que sobrava, o que poderíamos cortar? E na hora de cortar, meio que por unanimidade da equipe que estava fazendo acabou sobrando corte para História da Arte e da Moda e Têxtil!

Leilane: Diminui um pouco a carga horária.

Renata: Pouco, muito pouco.

Leilane: Para entrar também aquela coisa da LDB.

Renata: Isso.

Leilane: Existe uma empresa administrando?

Renata: Não.

Leilane: É uma tendência de todas, aumentar o lucro e diminuir um pouco a aula, o próprio MEC permitiu isso.

Renata: E porque a nossa aula ia até 12:40. E aí o cara que queria estagiar não achava estágio porque se você estagiar à tarde tem que entrar meio dia $\mathrm{e}$. . isso estava sendo um grande problema também. E nossos concorrentes terminam às 11. Então agora ficou mais balanceado.

Leilane: Vocês têm dia que vão terminar à uma, mais ou menos, e dia que terminam às 11 , é isso?

Renata: Não, acho que vai ser às 11.

Leilane: $\mathrm{E}$ à noite também. Aquela coisa que são quatro horas. Eu tinha pensado nisso.

Renata: $E$ tem uma questão que se você abrir à noite, a carga tem que ser idêntica à de dia.

Leilane: Ou faz o que a ESPM fez. Os dois primeiros anos são obrigatoriamente de manhã e os dois últimos obrigatoriamente à noite para trabalhar E aí você pode fazer diferente.

Renata: $\mathrm{E}$ isso gerou uma briga, da questão das matérias que caíram, não só dos professores da cadeira, mas eu fui uma que falei: poxa, a Santa Marcelina já tem, todo mundo no mercado sabe que a nossa carga de matérias praticas é muito maior que as teóricas, e eu acho que pelo contrário, pelo menos têxtil para mim, quando fui trabalhar na Sintecfil é que eu vi a carência que tem de profissionais

Leilane: A gente aprende muito a tecnologia têxtil, mas já a aplicação de material e de confecção.

Renata: Então, e cortar isso? Eu aumentaria isso. Foi uma grande discussão, mas por outro lado não poderíamos perder a cara da Santa que era de manter o prático. Mas o que te falo, Le, é que no quarto ano fica muito evidente que a qualidade final do projeto tem totalmente a ver com o tipo de pesquisa que foi feito antes. Então a questão das teóricas são fundamentais pesquisa que foi feito antes. Então a questão das teóricas são fundamentais
para esse projetista, para esse cara que tem que aprender a projetar usando qualidades que foram agregadas durante os quatro anos. Então fizemos uma ginástica incrível para termos, no final do quarto ano, um TCC e um projeto escrito muito bom. Eles passaram por cinco revisões, de uma doutora uma mestre mais todos os orientadores, fora os orientac ilustração, a gente também orientava, mas esse conteúdo deles foi visto e revisto mil vezes porque nunca foi uma característica daqui, porque o projeto era o mais importante, desfile era o mais importante.

Leilane: $\mathrm{E}$ agora o trabalho escrito está sendo.

Renata: A gente equiparou e com uma nota agora na finalização do projeto, porque antes a nota da parte escrita não entrava, então eles falavam: ah, para quê escrever se a nota não... Então agora entra também exatamente para começar a exigir uma reflexão, porque é importante, a gente sente a diferença. $O$ aluno que não pesquisou direito tem um projeto final mediano.

Leilane: $E$ você medindo isso para mapeamento tem até como dar o feedback para eles, se foram bem. 
Renata: Sim.

Leilane: E, para fechar, você falou no começo antes de estar gravando de cinco tipos de desenho. Pode me explicar de novo esses cinco tipos de desenho, risos, me dar essa aula, risos?

Renata: Quando pedimos para o aluno, por exemplo, um exemplo aplicado, no quarto ano vai começar a desenvolver a coleção dele. E tudo isso depois vai ter que estar registrado na metodologia, no capítulo de metodologia. Então eu já começo falando a eles no início do quarto ano que esses cinco desenhos na verdade são um caminho de projeto. Então quilo que estávamos comentando de esboçar uma ideia, um raciocínio, primeiro começa a ter uma pesquisa que falamos, o cara deve estar muito embasado na pesquisa dele e tem que ser o maior conhecedor de tudo que está pesquisando, e esse painel imagético e semântico não é só um painel morto, então por isso pedimos o caderno para o aluno, porque tem que ir agregando e cruzando informações com novos artistas, seguindo uma vertente, um eixo de pesquisa, e é desse caderno que surgem os primeiros desenhos, que são anotações gráficas, são realmente croquis. Isso chamamos de croqui aqui.

Leilane: De onde vem a ideia inicial.

Renata: Exatamente. Então são esboços rápidos de ideias que surgem dessas percepções do caderno. Pode ser uma manga, pode ser uma ideia de beleza para cabeça, pode ser um sapato, são os primeiros esboços. É daí que você vai começando a pensar, como se fosse um aquecimento do que vem pela frente, sem a preocupação de já ser um projeto final, um produto final. Então isso para nós é croqui, as anotações gráficas. Anotações gráficas rápidas. Isso é croqui. Desenho de moda é quando ele já pega todas essas informações mais todo o conhecimento técnico que ele tem e começa a criar num corpo com proporção. Porque esse corpo com proporção vai dar informações técnicas para ele, se o equilíbrio das cores está bacana, as formas não tão exageradas em relação à altura, quantas vezes eu vejo as pessoas criando num corpo de dois metros e dez, e aí quando coloca em um metro e oitenta, que é o da passarela, já achata absurdamente. Então isso para nós é desenho de moda. É a hora que o cara cria em cima desse corpo totalmente equilibrado. Na sequência temos o desenho técnico.

Leilane: A proporção seria mais ou menos isso?

Renata: Isso, desenho de moda.

Leilane: Página 147 (Seive). Estou gravando e depois vou saber o que é. E esse tipo de sketch seria o croqui?

Renata: Isso, uma anotação gráfica rápida de alguma ideia, detalhes, com cor ou não...

Leilane: Sem compromisso técnico.

Renata: É. Do desenho de moda a gente pula...

Leilane: Isso no caderno?
Renata: No caderno, a ideia do caderno sempre foi superimportante por isso, a gente chega no fim do quarto ano e tem aluno que não tem caderno. $E$ você vê as ideias vagas. $O$ caderno então é um diário de bordo.

Leilane: É cobrado?

Renata: É cobrado. E tem aluno que passa o caderno a limpo. Depois, se você quiser material disso tudo, tenho vários exemplos, posso até te passar, tenho um exemplo de caderno de uma aluna incrível, mostro em aula, o que é desenho de moda, se precisar disso me pede que te passo.

Leilane: Você falou do croqui..

Renata: Croqui, desenho de moda, na sequência o que ficou aprovado no corpo, que o volume, porque às vezes você passa um volume do seu sketc para um corpo de verdade e fica horrível, às vezes não funciona, por isso precisamos disso, porque passando pelo crivo do desenho de moda a gente já pode planificar e colocar no desenho técnico.

Leilane: Que é o que a Colin (e Elinor) Renfrew fala.

Renata: Exatamente. Verificar, tudo bem, ok. Aqui a gente obriga o aluno a verificar depois frente, costas e perfil num desenho de moda, para ver se dá certo, para depois planificar. Planificou com todos os detalhes e tudo mais, estamos tirando um pouco da questão da ficha de desenho técnico industrial, não queremos um desenho técnico industrial, queremos um desenho técnico de cada um deles. Pode ser um desenho técnico onde tenha que funcionar como formativo, até para ele se acostumar que o desenho deve estar lá.

Leilane: Tem que ser proporcional.

Renata: Todo o rigor do desenho técnico deve estar ali, os fios, tem que usar uma caneta mais grossa por fora, uma caneta intermediaria nas costuras e uma caneta mais fina ainda nos detalhamentos. Disso, chega uma hora de dentro de todo esse processo que está na hora de divulgar o que você fez. Aí vem o promocional, porque você não vai mandar esse desenho caretinha, com oito cabeças e meia, para uma revista. Isso não chama atenção. Aí chega a hora que todo mundo gosta que, ah eu posso alongar perna, falo que posso colocar chifre, rabo, não tem problema, isso é o promocional. Geralmente o line-up, o teu traço rabiscado, não precisa informar muito bem o teu modelo. Você já dá uma ideia do que vai ser. $\mathrm{E}$ por último a ilustração de moda. llustração de moda é ilustração de conceito, então você pode ilustrar numa página que a ilustração de moda, a gente conversa sobre isso na aula, bebeu muito da fotografia de moda. Então a ilustração de moda é um resumo, uma narrativa de tudo que pode ter numa coleção. Então você pode ter uma folha de uma revista para contar toda a narrativa de uma coleção de uma forma mais lúdica, menos racional e é esse tipo de ilustração..

Leilane: Desenhos artísticos. A ideia da coleção.

Renata: Desenhos artísticos, é onde a gente mais se aproxima de arte. É 
uma narrativa. Você conta toda a história, então no fundo eu posso ter cores que são as cores da minha cartela.

Leilane: É o que vai estar nos fóruns.

Renata: Isso, a estética da minha mulher já pode remeter para a década de 1970, posso ter colagem, posso bordar a folha, então a gente praticamente cola no artístico, justamente para ilustrar toda a sua coleção, a finalização, então esses são os cinco tipos de desenho. Então aqui o aluno usa na monografia final dele, acho legal você até vir no fórum para ver, porque isso não está somente na monografia, mas no bidimensional, então você enxerga esses cinco desenhos que é o que é uma coleção de verdade, pesquisada profundamente e feita com atenção que deveria ter. E é nesse momento que a gente fala que as alunas-artistas meio que fogem. Não querem desenhar, não querem projetar nada, querem ir direto para o corpo, não passam por nem um desenho, vão direto para um, sei lá, lycra, joga ur look inteiro, sabe, porque aquilo para elas é o processo criativo real.

Leilane: Pode até ser inicialmente, mas depois tem que normatizar isso.

Renata: Ou ao contrário, fazer toda aquela reflexão normatizada e depois chegar numa conclusão que tenha embasamento do porquê ela ter feito daquele jeito.

Leilane: Alguns direcionamentos para ela conseguir repetir e medir.

Renata: É isso que eu acho, um trabalho para ser feito como se deve, com toda a prospecção que se deve é superlongo. $O$ trabalho do artistas, essas coisas acho que meio que queimam o filme também da academia em moda. É você às vezes abrir, ah, mas é um outro jeito de você pensar moda, mas não para um trabalho de conclusão. É como se eu quisesse escrever uma dissertação de mestrado usando um tipo de português que eu vou inventar.

Leilane: Não existe.

Renata: Então, mas é isso que eu quero, não quero que exista.

Leilane: E o mais difícil é ser criativo dentro de certas normas, o tanto de processos...

Renata: É a geração que menos tem limite, Le. Eles não têm limite para nada. Então tudo que você fala, normas da ABNT. Convence hoje um aluno a usar as normas da ABNT, "mas por quê, quem falou isso, e se eu quiser subverter?".

Leilane: "Ah, mas eu não vou fazer mestrado...", risos.

Renata: Entendeu, tem esses discursos. Então acho que estamos muito no começo. E estou no mercado desde 1987, praticamente, sempre acho que estamos retrocedendo, e não numa visão pessimista, mas crítica e muito clara para mim, eu pelo menos nessa vivência não enxergo a gente... a normatização que esperava dentro das empresas, ate hoje vejo minhas tudo igual. Você chama um cara para pilotar qualquer coisa pra você só pra depois usar aquilo e depois cotar com os outros dois. Sabe coisas bobas, aí você diz, mas isso devia ter uma questão ética, como pilar, todo tipo de negociação, não existe isso.

Leilane: Falta de profissionalismo, você manda para a estamparia, aí sei lá, cai uma bituca de cigarro, como assim?

Renata: Não sei se te falei que tenho uma prima do meu ex que faz FGV e está estudando agora as leis de moda?

\section{Leilane: Não.}

Renata: Tudo, tudo, e formaram um núcleo de pesquisas só para isso, ela até me entrevistou para fazer alguns cases e falamos muito disso, "mas não é normatizado?", não, nada.

Leilane: Só quem trabalha na área, você precisou, esbarrou...

Renata: Exatamente. Não sei se te contei que ainda na XXXXX fizemos um - abafa - não cita o nome, era a coleção Terra, primeira vez que trouxemos a Alek Wek, era coleção terra, fomos procurar uma estampa que tinha, era uma artista plástica e um engenheiro químico, era na Vila Madalena.

Leilane: Acho que sei, uma que só trabalha com produto natural.

Renata: Não sei, faz muito tempo isso, não sei se trabalhava com produto natural, mas o mais legal é que conseguimos captar terra da Chapada com areia de rio com barro, todos os tipos de terra que existem no Brasil e fizemos a coleção Terra. E a gente batia num silk nas roupas, então você comprava uma roupa que tinha terra do Brasil inteiro misturada com uma resina. Estourou de vender, a gente tinha regata..

Leilane: Mas não era terra, terra, com uma resina, era corante com uma resina?

Renata: Nao, era terra, terra.

Leilane: Como vocês descolaram essa terra? Compraram?

Renata: Veio de todo lugar, veio de tudo, de todos os lugares. E esse apelo...

Leilane: Conceito, não é?

Renata: É, nossa, uau, é terra, Chapada, foi incrível. E a gente, poxa, então vamos bater isso na peça inteira, nas regatas, nas calças, e vendeu, vendeu, vendeu. De repente começam a voltar as peças. As pessoas saíam com as peças para dançar e desmaiavam porque o corpo não respirava.

Leilane: Ah, porque a resina era muito pesada.

Renata: Então o que foi assim, em três meses, uau, de repente tudo fo devolvido, tudo.

Leilane: Você acha que isso é problema de projeto?

Renata: É problema de projeto, e eu via naquele momento. 
Leilane: Eu tinha uma camiseta da Gloria Coelho em 2001 que você estava usando e ela estourava, você não aguentava, ficava um pouco e tinha que tira

Renata: $\mathrm{Na}$ época ninguém tinha feito isso com essa estamparia, foi um super auê, e aí de repente paramos e tudo era... por exemplo, todas as estampas que fazíamos, não sabíamos o que ia acontecer e como ia ser lavado. Então o que a gerente de produto indicava? Coloque "não lavar" que para a legislação que está tudo bem.

Leilane: Lavava a seco...

Renata: Não, não podia lavar a seco. A gente não sabia e depois vimos que não podia

Leilane: Desidratava.

Renata: É, e não sei se você chegou a ver, o silk screen projetava uma formas para frente. Chifre, saía como se fosse plástico mesmo, 3D mesmo, o cara da estamparia não sabia falar para nós, nós não sabíamos, e a gerente de produto: "coloca "não lavar".

Leilane: Com aquela tagzinha, essa peça é delicada.

Renata: Isso para mim foi o maior choque de falta de projeto.

Leilane: $\mathrm{O}$ contrário de tudo que aprendemos na faculdade.

Renata: Tudo, tudo ao contrário. Como você não pode falar para o cara como cuidar da peça dele? Como você coloca isso no mercado? E fala is para qualquer designer de produto.

Leilane: Na década de 1990 aconteceu muito isso com a Imaginarium, com aquele abridor de vinho bailarina, que foi parar no 1,99, só que é mais comum ainda na moda, porque talvez a mão de obra seja muito barata, uma mão de obra majoritariamente feminina, que é desvalorizada, apesar de ser um trabalho manual e extremamente desvalorizado,

Renata: Não, e do tempo, isso quando ainda tínhamos três meses para rodar a coleção. Agora nem temos mais isso.

Leilane: Você tem uma semana para fazer isso.

Renata: Então. E lá ainda tinha um pouquinho de tempo. Então já vi tanto absurdo, mas tanto absurdo, e continuam até hoje.

Leilane: É geral.

Renata: E por isso acho muito legal a tua pesquisa.

Leilane: Às vezes o mercado está na contramão, não é?

Renata: Sim.

Leilane: Isso mostra que talvez a faculdade precisa de atualização, talvez o mercado tambem, de uma troca, os dois, parecem que eles competem, um está querendo roubar a formação do outro. Elembro que o José Mindlin falava isso na década de 1970.
Renata: Eu nunca pensei assim.

Leilane: Que o mercado tinha que ter uma troca mais prolífica com a universidade e vice-versa, não com medo de voce ir lá fazer espionagem industrial, esse negócio dos processos, lembra daquele negócio de levar a Focus para a Faap, e depois partir para uma coisa de tecnologia, eles estavam superabertos. Mas não rolou. É bem difícil, bem difícil mesmo. Rê, acho que isso, deixar dar um stop aqui.

Renata: Bom, depois se faltar alguma coisa.

Leilane: Eu te procuro. 
OLIVEIRA, Renata Zaganin de. Entrevista realizada com Renata Zaganin de Oliveira, em 4 de dezembro de 2014b, na cidade de São Paulo, com 53 minutos de duração

Como era quando fez faculdade. Só o Carlos Mauro deu aula para ela. E a Sandra Harabagi dava Laboratório de Criação, ligada a processo criativo.

A Chiara Gadaletta ficou 1 ano e meio só, mas não tem sequer formação no Brasil. Em 1997 o Carlos Mauro foi desligado. E a Chiara Gadaletta entrou em 1998. Ela trabalhava na lódice e teve conflitos que os modelos começaram a aparecer na lódice (em off, não usar). Foi um momento de menor profissionalismo da FASM.

A Sirce Bernardes ajudou o Carlos Mauro. Ela era formada em artes, era amiga da Vera Lígia.

O Carlos Mauro foi a referência de estilismo na FASM porque era da Rhodia e trouxe o método ESMODE para a Santa. Onde ele bebia. Era muito respeitado.

Com o Laboratório era mais "artístico" de criação livre. Criavam-se sapatos, acessórios em papel e outros materiais. Disciplina experimental de início de curso.

O Carlos Mauro não tinha mestrado. A Renata afirma que ele era o equilíbrio entre o acadêmico e o mercado, mas como se ele nem tinha mestrado? Mas era muito respeitado. Era muito culto, viajava muito, conhecia muito bem Paris e trazia as tendências de lá para cá, para a Rhodia e por consequência para a FASM.

Era impopular com muitos alunos porque perguntava se o aluno "não queria fazer economia ao invés de moda". Faleceu em 2012 de complicações do coração, perto dos 60 anos. A irmã do Carlos Mauro doou o acervo para a FASM.

Ele e a Vera Lígia são centrais na história da Santa. A Elá é a única que trabalha com moda das primeiras turmas. E a Evandra também, mas ela faleceu. Ela era mais velha e fazia tudo muito bem.

Da turma da Re, só ela e mais 4 trabalham na área. Tinha que fazer estágio, mas pagava-se para fazer estágio. Não contratavam estagiário. Dificuldade em assinar o estágio. A Re estagiou em uma revista de graça, mas não pagou.

\section{Aulas do Carlos Mauro - Conceitos de Projeto ensinados em aula}

Ele não gostava de cultivar o individualismo. Ele fazia uma "roda de conversação", uma grande mesa quadrada e propunha que todos fizessem shopping que consistia em trazer objetos de viagem, do cotidiano, tecidos. Tudo era disposto sobre a mesa central e aí se extraia o que se repetia, o que se destacava, o que era diferente. Esse material era filtrado e a partir daí - Carlos Mauro perguntava se isso poderia ser uma tendência geral. Ele buscava gerar um discurso.

Não eram permitidas tendências de moda, porque ele estava formando "formadores de opinião, primeira fila de desfile".

Do shopping cada um começava a criar a sua pesquisa individual depois de ter uma tendência raiz, macro que vinha do shopping. Criava-se assim um clima de competição entre os alunos onde eles buscavam esconder seus trabalhos. E ai o Carlos Mauro começava a fazer atendimentos individuais. O Fabiano Grassi era o assistente dele, cobrava os alunos.

Um aluno era eleito para ser uma nota geral para a sala toda. $O$ professor e o assistente eram provocantes. A primeira nota era do Carlos Mauro, a segunda do Fabiano e a terceira do aluno e o Carlos Mauro respeitava a nota proveniente da média. Ele fazia isso porque se assumia excessivamente crítico. Muitos alunos ficavam de exame. Ele não usava meias palavras para se referir aos trabalhos ruins.

A Renata dava essa nota, já era professora, e afirma que costumava bater com a de Carlos Mauro. A média da Santa é sete. A nota era dada para cada aluno, não era uma nota geral para a sala toda. (Ver Painel Semântico p. 3).

Em seguida escolhiam a cartela de cor, matérias, construção de maquetes. Dois anos de aula só com o Carlos Mauro, mas não teorizava. Era "vire-se". Ele era uma espécie de mentor, mas sem orientar objetivamente, levantava a sobrancelha, ele não verbalizava, era enigmático, ele se baseava muito mais no seu gosto pessoal. Às vezes soltava um "bárbaro" e todo mundo ficava pensando...porque está bárbaro.

O estigma de que não deveriam ser criadas "receitas de bolo" impedia que se sistematizasse qualquer informação, que se desse qualquer informação mais objetiva. Não era ensinado Mix de Produtos, Plano de Coleção. Confusão clara entre objetividade e artistagem.

Não existia teorização, o curso era essencialmente prático. Isso afastava o ensino de normatizações positivas que não se pretendem imposições.

Os autores de projeto em moda são poucos conhecidos. Não são tão conhecidas as referências em moda. Isso é mais intenso na moda, uma espécie de anti academicismo macularia a "aura" artístic

a do criador de moda.

A Renata ía à Biblioteca Mário de Andrade buscar livros de desenho e moda, pois não tinha em São Paulo.

Segundo a Renata, foi essa primeira geração formada em moda que voltou à escola para dar aula e quebrou a cara no mercado para aprender. Da a preocupação do empírico organizado por métodos, teorias de forma reflexiva sobre o fazer e não uma imposição de etapas. Ela se questionou porque que nunca ninguém ensinou isso antes no curso de moda e percebeu isso na trajetória de vários colegas. Acredita que a evasão da área se deva a esse afrouxamento em projetar. 
Há inúmeras maneiras de criar e desenvolver produtos. Em função do tamanho da empresa, porte, prestígio. Em função desses aspectos consegue-se mais ou menos no desenvolvimento do seu fornecedor.

Para a Renata não dá para criar uma "receita de bolo" para a parte de criação, de projeto, porque há mecanismos diferentes para serem aplicados em empresas micro, pequenas, médias e gigantes.

No exterior a forma como se usa ou não tendência (falou do concurso na Itália) = [27:24]. Na FASM em um convênio com uma marca italiana eles fazem um projeto e o ganhador pode fazer um estágio lá. A forma como eles trabalham é tudo diferente do desenvolvimento de produto que se tem no Brasil. São muitas realidades. Então é difícil tornar essas nuances apreensiveis para o aluno em sala de aula.

Depois da maquete já ia direto para o manequim e colocava uma "roupinha".A ESMODE era bem cheia de regras, embora o Carlos Mauro fosse avesso às regras, mas seguia muito a ESMODE.

Trabalhando a tendência individual, depois do shopping faziam o Paine Semântico e dele eram extraídas as cores, matérias, maquetes. A partir do Painel semântico o trabalho já era individual do aluno. No começo era "um tiro no escuro". Você formava 2, 3 alunos e desmotivava 20.

Faziam coleções de 8 looks. Só na forma de desenho de moda (que naquela época era dado pela Cris Burguer que desenhava para a manequim) que era mais livre,

Atribui o fato de não saberem exatamente sistematizar como se fazia uma roupa ao fato de os professores serem provenientes de cursos de artes plásticas, arquitetura. Era raro os professores falarem a linguagem de moda.

O Carlos Mauro entendia tendência, mas não vestuário. Eram aceitas peças sem cava, quase uma toile (Renfrew). Ele falava que era protótipo, não ía direto para a pilotagem como é hoje. Podia ser em papel, morin, quase ninguém usava tecido e isso para que um ou outro aluno não se destacasse em função de mais recursos financeiros, pois o tecido é mais caro.

A proposta não era roupa para consumo. Houve uma aluna que entregou uma coleção da Dolce\&Gabbana sem etiqueta como se fosse dela e fo achincalhada.

Havia falhas na formação, mas era geral. Havia exigência grande em relação à bagagem cultural que desperta um olhar diferente.

O intuitivo, de fazer direto no manequim também se dava em função do professor não ser especializado em modelagem, costura. Costuravam no Senai. Havia um foco maior na forma, no que era considerado artístico.

A Renata desenhava desde pequena, a mãe fazia lingerie e tinha maquinário, então se saia melhor.

Divisão entre vanguarda, conceito e o comercial. Como veste? Como fecha? Como abre? Mas como processo criativo é válido.
Mas ela reconhece que falta um braço técnico para domínio da produção desde a pilotagem até a produção em série afeta o curso e deveria apoiar 0 lado criativo.

Falei da maldição de ser ótima estilista, mas que não pode entender de técnica, leia-se de modelagem e costura, senão fica tachada de técnica, "caretinha" e não de criativa. Você deixa de ser quem cria para ser quem resolve. Mas o que é resolver?

Crítica a tender só ao lado criativo. Afirma tomando o desenho como exemplo que processos concretizam o desenvolvimento técnico e intelectual do profissional.

Ensinar o desenvolvimento de produto com vistas à criação. Fazer o aluno perceber o que dá errado e como. Para valorizarem a pesquisa, o entendimento de processos.

A ideia de inspiração ainda aparece, senão prevalece.

A normatização do campo do saber ainda não temos. Parece aula de desenho livre. "Tudo é muito fazer por fazer. Ah! Desenhem. "Desenho [não] é um espírito que baixa na pessoa e que a pessoa vai traçando." Isso perpetua 0 mito. Faz parecer que quem domina é porque foi "tocado" pela "aura" e não porque aprendeu por meio de pesquisa, técnica e prática exaustiva.

Há inclusive ainda hoje professores estilistas que acham que ser estilista é um dom divino e que o estilista já nasce com bom gosto.

$\mathrm{O}$ autodidatismo ainda acontece. Ver o número de fashionweekers formados fora da área e não formados. Se esconder por trás da estrela, ver biografia do Dener e brigas com Clodovil e as pessoas acham que para ser estilist isso vem no pacote. As pessoas têm que ser arrogantes, tem que ter xilique.

Existe o modo certo de fazer a partir de uma orientação que funciona com a maior parte dos profissionais e processos.

Quem realmente se dedica e se aprofunda na pesquisa sabe que não existe nada como um "ente divino", o "vamos fazer" livre e descompromissado. $O$ design exige compromisso. Tem que ter a técnica, o estudo, o parar para fazer.

No design a técnica não é pejorativa. A prática, a repetição, execução aprimora o ato criativo, de pesquisa, enfim de projeto.

Alguns professores serem os mesmos da UAM. Raquel Valente era do Cebrafan e depois foi para a FASM.

Os processos devem obedecer a algum tipo de ordem (mais ou menos uma ordem) que não é definitiva, mas que existe um raciocínio.

Senão não adianta fazer Painel Semântico depois de fazer cartela de cores. Isso é fraude. Aí ele não faz mais sentido. É mais do que válida a discussão acerca do projeto em moda contra a fraude. Criação, inspiração divina, aleatória, artistagem é fraude. 
Coleção com lepra. $O$ aluno faz o desenho, sente dificuldade na modelagem e na costura (mesmo que não faça e mande fazer) e aí muda o desenho. Isso é fraude, não é projeto em moda. E a ideia de talento nato só agrava este tipo de problema.

Comparação com o design a partir do liquidificador. Cabe um desenho mais ou menos?

A gente é um braço, uma vertente do desenho de produto.

Cabe descobrir o seu processo e ate alterar ordens no projeto em moda, mas de uma forma ou de outra ele tem que existir.

Hoje os professores tem melhor formação específica, mas menos repertório que os professores da primeira geração.

Radicalismo. Com processos na área da criação vira um curso profissionalizante. Há um comodismo entre as áreas de moda, design e entre área de criação e técnica, onde a primeira se entende alheia ao processo holístico do projeto em moda. Isso corrobora com a "aura" prejudicial fazer projetual em moda.

\section{Renata Zaganin 1 - como professora 28/11/2014}

Sobre $\circ \mathrm{TG}=\mathrm{O}$ Carlos Mauro tinha essa característica de fazer uma primeira aula onde você trazia tudo que interessava na criação, te interessava visualmente, e a gente abordava aqueles objetos, livros, via aquelas histórias e a gente começava a criação, cada um levando para o seu lado, sua escencia.

Eu sempre achava que esboçar fora do corpo, pegar primeiro fragmentos de forma, ela me dava mais possibilidades de criação quanto à volumetria. Então eu sempre começava pelo croqui, por essa anotação gráfica, que eu extraía dessas minhas referências. Para mim a experiência de criação, eu trabalhava com a volumetria, depois eu trabalhava a parte interna das roupas, depois eu ia para a escolha dos materiais, e em cima das volumetrias que eu havia escolhido, daí era pesquisa de campo, de adequar os tecidos que achava interessante, então eu fazia um caminho meio ao contrário. Não escolhia primeiro as matérias para depois desenhar.

Antes fazia o desenho e depois o estudo de forma por croqui rápido. Vários fragmentos soltos. Ideias que vinham da referência. Eu começava assim, porque daí o tal do look conceito, às vezes de um look conceito que eu conseguia montar com tudo isso já saíam três desenhos de moda fechados, entendeu?

Um método válido para criar e desenhar para ela é montar as peças por edição. Desenhar mangas, punhos, volumes, golas soltas e depois montar o look a partir de formas que, inicialmente, podem até ser abstratas, quase como um quebra cabeças.

Eu acho que esse primeiro momento vai te dar a força da coleção, você vai ter os looks mais diferenciados. Depois, preencher isso com looks que sejam mais ou menos da mesma família, e que tenham força mais de look, depois colocar os acentos de cores, 06:47, acho que fica mais fácil para voce nivelar isso.
Faz esboços de croquis, cartela de matérias e aí fecha o look. Desenha, testa o desenho no manequim e depois confirma se é isso mesmo mediante a matéria que será usada e aí coloca cor. É quase ao contrário do processo criativo da Simone Mina.

Então tem alunos, dependendo da especificidade de cada um, às vezes mando o aluno para o busto, ele faz via moulage primeiro, aí depois que ele fecha cada look a gente vai representando graficamente isso, porque a moulage é você desenhar sem lápis. $O$ estudo de forma é entendido como desenho aqui. A Renata dá vazão ao processo do aluno pela moulage como alternativa ao desenho. E uma forma de você desenhar em cima do corpo, e a representação gráfica que vem depois disso, dependendo do tempo, a gente até fotografa e contorna o desenho para esse cara.

O mais importante em relação ao traço é que o aluno pesquisar corpo antes de fazer roupa para esse corpo. $O$ objeto principal da moda em termos de projeto é o corpo. Corpo como suporte do ato de projetar.Ele chega em estilo muito mais maduro para criar formas que tenham uma continuidade, que geram equilíbrio de formas e cores.

O aluno pode fazer o croqui, ir para o manequim ou a colagem do ponto de vista de projeto da Renata, mas ele tem que fazer os 3 giros: frente, costas e lateral. Isso é fundamental. A cor também é importante como dado de equilíbrio. Ela ajuda a criar uma escultura, projetar, desenhar é esculpir. $O$ ideal é aluno passar pelos três processos.

O cara que se encontra na moulage sempre vai ter formas mais elaboradas, tende a ser mais conceitual, mas acaba abolindo os recortes da linguagem dele, tende a fazer sem costura o que for possível. A modelagem plana ajudaria nos recortes. Mas os alunos se intimidam ao cruzar as fronteiras de cada forma de produzir criação.O cara que vai no corpo vai fazer diretamente algo mais conceitual do que o cara que parte do papel, e o cara que vai também fazer uma colagem. Por quê? Pensar nisso. Porque já trabalh diretamente sobre o suporte corpo.

Faço um esboço rápido, mas aquilo tem que se transformar em produto.

Acho que é uma coisa, assim, que vai contar em termos de marketing, vai chamar a atenção do aluno se você colocar uma matéria "Projeto", nossa, projeto, se você colocar "Estilismo", nossa, é ali que eu vou, eu vou aprender a ser estilista, eu acho que tem isso.Aura.

Mesmo a questão conceitual que a gente coloca na passarela é uma parte do grande projeto da empresa, que você quer divulgar. Então essa é a questão, fazer 0 aluno pesquisar antes, parar, formalizar essa pesquisa para depois começar a criar.É uma coisa que a gente faz já há uns dez anos, que o cara pode até ter um desenho feio no final, mas se as etapas do que foi passado, ele conseguiu desenvolver em determinado tempo, cumprindo as etapas de uma forma bacana, aquele processo me dá um profissional. 
Há uma ideia de aproximar estilismo da ideia da aura de arte, mais em conceito do que numa realidade prática, efetivamente? Renata: Sim.

Agora o cara que faz algo que quase esbarra no intocável, para ele solucionar isso, graficamente, tecnicamente, volumetricamente, ergonomicamente, aí sim ele se forma em várias esferas.

De maneira geral, as empresas não têm seus processos normatizados.

\section{O Anti projeto}

E já passei de tudo, de falar "ah, precisamos aproveitar esse tecido hoje, bate uma estampa em dez minutos", e de ter que fazer uma estampa em dez minutos, aquela coisa mais horrível que você já fez na sua vida, e de passar dois dias e ver a estampa na Vera Fischer, na novela das oito! E de repente te falarem "nossa, Renata, sua estampa bombou, está sendo supervendida". Não teve projeto nenhum e de repente, e também saía de arte final acontecia demais. Estudar 20 layouts, está chegando no vigésimo, quando já está lá, não aguento mais, e faz qualquer coisa pra ser o número 20 , e aí chega na mesa da gerente de produto e ela olha tudo e fala: é o 20 “!!!”.

Tudo que teve projeto, raciocínio, esquema cromático, que você usou tudo que aprendeu formalmente... Então, quer dizer, porque você também é avaliado por aquela pessoa que só fala com aquele feeling, sem formação na área de moda muitas vezes.

Jeito de projetar brasileiro

Acho que a gente ainda tem um resquício meio tupiniquim, a gente tem esse ranço de ainda criar com essas, ai, tive uma inspiração, acho que o brasileiro ainda se enxerga, quando o cara chega aqui e fala, ai, vou ser estilista, ele acha que tem um pouco dessa atmosfera etérea, e aí o brasileiro apost muito mais nisso do que na técnica, ele acha que é o que eu falo muito dessa questão das alunas-artistas. Não tenho nada contra uma linguagem mais artística, mas acho que o cara, depois de ser formado tecnicamente, pode ser o que quiser, pode subverter o que ele quiser, mas acho que para a gente subverter alguma coisa precisamos ter técnica antes.

Falta normatização na área de projeto em moda

Não, normatizada no sentido de cada um meio que faz do seu jeito, tudo bem... [L] Não tem os marcos processuais reconhecidos.

E eu percebo que, pelo menos dentro das empresas em que trabalhei, 0 próprio departamento de estilo, criação, não quer ser normatizado porque acha que isso é meio careta. Então eles gostam dessa coisa, ai, eu quero fazer, e eu acho que não, pelo contrário, isso que está atravancando o processo, entendeu?

Ela entende desenho não só como traçado, mas desenho como pesquisa do corpo, projeto (draw e design, dibujo e diseño, desenho e design).

$\mathrm{Na}$ FASM o mais importante, antes de tudo, é ensinar o aluno a projetar. A ter um raciocínio.
Não é qualquer projeto. É o projeto que carrega o DNA, a arte também junto, não pode ser só um projeto experimental.

O criador de moda não é literal, escreve mensagens com sutileza, nas entrelinhas, de forma subliminar, daí o interesse em desvendar o seu trabalho.

\section{Normatização e Cronogramas}

E isso aconteceu comigo em todos os setores em que trabalhei dentro de moda e isso ficou muito claro. Por mais que você queira implantar un cronograma, uma forma de fazer as coisas corretamente e que dê menos gasto, você não consegue, porque aqui a gente tem a novela da Globo, o Carnaval...

Se você pegasse hoje a estrutura do Santa Marcelina que existia na minha época, a faculdade não se sustentaria. $O$ professor de arte hoje não conseguiria formar um estilista para hoje, nossas linguagens, necessidades e demandas de hoje.

\section{5 tipos de desenhos}

1)Croqui, as anotações gráficas baseadas na pesquisa.

2)Desenho de moda é num corpo com proporção (de $1,80 \mathrm{~m}$ para a passarela) passando a limpo o croqui (página 147 do Seivewright).

3)Desenho Técnico(com rigor, mas sem ficha técnica, desenho deles, mas com caneta grossa, fina etc)

4)Desenho Promocional (estilizado)

5)Ilustração de Moda(resumo da narrativa da coleção).

O caso da XXXXX é bem interessante, mas não pode citar o nome. 
MINA, Simone. Entrevista realizada com Simone
Mina, em 19 de dezembro de 2014, na cidade de São Paulo, com 2 horas e 9 minutos de duração.

$\mathrm{TG}=$ trabalho de graduação.

Ela se formou em 1999 e a orientação era feita na disciplina de estilismo pela Sirce Bernardes e pela Chiara Gadaleta. Ela estava no lugar do Carlos Mauro no quarto ano.

O segundo ano ela teve aula com o Carlos Mauro e a Sylvie Leblanc no terceiro. A Sirce foi muito importante na formação dela.

Ela percebe que faltava pensar o trabalho de moda de um jeito mais sistêmico que pudesse dar uma contribuição no sentido da reflexão para o projeto de moda quando ela se formou. Nesse sentido ela começa a dar aula imediatamente depois de formada em 2000 e começam a serem implantadas várias mudanças, entre elas: de fazer dentro da metodologia, de como se relacionar com o projeto.

Ela fala que a Sylvie foi a que constituiu realmente um trabalho, embora tivesse a questão do idioma.

A aula do Carlos Mauro no segundo ano não chega até o fim do ano. A Sirce era assistente dele. Ele sai em 1997, no final do ano. Em 1998 trocam o professores, mas na turma da Simone quem assume com a saída do Carlos Mauro é a Sirce que manobrou bem a situação.

A Chiara sai da faculdade em 2000 e a Sirce no final de 1999. Em 2000 Simone é chamada para ser assistente na aula de Moulage da Euzita. A Simone já tinha feito Senai, sua formação é marcada pela modelagem e moulage.

Assim em 2000 a Simone passa a assumir o TG quando a Chiara viaja po alguns meses. Assim, de forma não efetivamente assumida a Simone passa a suprir a orientação do TG junto com a Euzita, coisa que já faziam em relação à construção da roupa.

A essa altura a FASM chama o Walter Rodrigues para ter alguém grande ao lado dos alunos. $O$ importante para a Raquel Valente era ele trabalhar em conjunto com a Simone Mina e a Euzita. O Walter ficou cerca de 2 meses no máximo e ele mais fala do seu trabalho, seu processo o que não supri 0 aluno que está trabalhando por meio do seu próprio processo. A turma não tem aderência a esse tipo de trabalho nesse momento. $O$ foco a essa altura, no quarto ano, era no trabalho do aluno.

Houve uma troca muito grande entre a turma de 2000 e a Simone Mina, pois a turma se sentiu "abandonada". No ano em que a Simone se formou, em 1999, ela perde sua mãe e se forma para ela, aconselhada pela Sirce. Simone assume o trabalho de orientação no meio para o final do caminho, mas foi um trabalho muito proficuo. Foi bastante gente para o Forum da FASM, cerca de 17 alunos, entre eles Wilson Ranieri e Sara Kawazaki.
A Sylvie, a Sirce e o Carlos Mauro foram pilares para a ideia de estilismo (a) portante na formação da Simone. Também foi marcante a contribuição do Feres Lourenço da FAU com seu grande conhecimento.

O Feres dava um ano de forma em Metodologia Visual I, tudo isso considerando o plano tridimensional. E a cor era trabalhada também pelo Feres em Metodologia Visual II. E para ela era impressionante, o olhar começa a mudar.

"Sem crise, dê sua contribuição legítima para a moda. A moda precisa. Transforma o mal estar em produção." Feres.

Também elogiou a Chris Burger como uma professora de desenho incrível, que ajudou na sua formação.

Ela teve 2 anos de estilismo e um ano de planejamento de coleção, no meio, no terceiro ano de formação.

\section{Carlos Mauro}

Resgate do seu passado e do passado da moda no segundo ano. Ele fazia um retorno. A referência histórica não pautava o estilo do seu trabalho, mas - Carlos Mauro centrava na importância da história, da sua própria história, o que é a sua marca, de origem inclusive. $O$ aluno deveria encontrar 3 pontos importantes no seu passado que fossem relevantes para contribuir com a moda. $O$ ideal era trazer isso para a sala e montar seu ambiente por meio de fotos e objetos e deveriam contar para a turma que momentos foram esses por meio do ambiente montado. Isso viraria a matriz temática, ou tendências para a coleção, para o seu projeto em três estações. $O$ termo projeto não era muito usado, era mais utilizado o termo coleção. A pergunta era: qual e a sua ambience? Ela poderia ser bi ou tridimensional e não tinh conhecer mais os colegas.

Ela não tem a memória da competição entre a turma. Ele não vê o desfile, porque ele não chega até o fim com aquela turma, ele é demitido antes.

O professor de estilo precisa de um tempo antes de falar sobre o tema da pesquisa do aluno ele precisa contrariar sua posição hierárquica de quem "tem que falar alguma coisa".

Com o Carlos Mauro a turma da Simone Mina fez uma instalação. A certa altura ele pede para passar na sala com a coordenadora, a Vera Lígia e os 2 em silêncio. Em seguida ele sai e não faz nenhum comentário e diz que "só comenta dentro de sua sala", porque a instalação havia sido em outra sala.

De volta à sala dele, a 208, e em silêncio pensando se pronuncia em seguida: "eu vou precisar de mais tempo para falar do trabalho de vocês, mas - que eu posso falar de imediato é a minha intuição e a minha intuição é que vocês vão ser as verdadeiras turbinas da moda brasileira."

Na semana seguinte ele complementa a avaliação. $O$ professor também precisa pensar para avaliar. 
Parece que ele sai no terceiro bimestre.

A ideia é que essa ambience construída a partir do resgate histórico desse condições de textura, cores para a criação da coleção. Ele sempre falava em Ambience e nunca em Painel, isso tinha a ver com a revista View e as referências não precisarem estar chapadas no caderno. A cor, por exemplo, poderia estar representada em um pedaço de madeira.

A ambiência contemplava esboços, cores, estampas, texturas, as quais ele nomeava de maquetes.

Textura e maquetes se aproximavam e rapport era outra coisa, estava dentro do conceito de estampa. No terceiro ano o foco era estamparia na aula da Vera Lígia. A Simone falou de tirar a linha com guache.

Ela não garante se ele estabelecia essa ordem e se hoje ainda a ordem é essa. Ela vai fazendo uma convergência.

Ela não se recorda de ter feito coleção estrita, mas havia os esboços, as "vontades de forma".

Do croqui as pessoas iam estudar volumes no manequim. No caso da $\mathrm{Si}-$ mone ela primeiro experimentava no manequim e fazia o desenho em seguida, por isso ela aprendeu a fazer rápido, a fazer projeto rápido.

\section{A moulage é como o desenho no espaço.}

\section{Sylvie Leblanc: 42'}

Ela era mais centrada no "projeto". Ela coloca entre aspas porque havia alguma sistematização mais objetiva, mas o nome projeto não surgia.

O desenho era mais formal, diretivo. Ela dizia o que precisava em termos de coleção. Quantos looks precisaria, quantos teriam que ser saias etc. Ela era mais objetiva nas solicitações.

No caso do Carlos Mauro a objetividade se centrava no resgate histórico, nos processos iniciais, que depois teria como consequência uma demanda de trabalhos objetivados a criar uma coleção, mas o trabalho feito pela Sylvie era mais objetivo e não demandava menos pesquisa. Ela já pedia aquilo que ela iria precisar no final do processo, cartela etc. Era uma lógica diferente.

O que era shopping para o CM era a Coleta, Pesquisa de Mercado. Ela pedia a coleta, o GARIMPO em lugares para o reconhecimento de matérias e afirmação de moda jovem que vinha das ruas. Não era o caso de ir ao showroom. Busca proposital ou falta de acesso ao showroom?

Desenvolviam cor, matéria, padronagens a partir do garimpo e em seguida desenvolviam a coleção.

conhecimento do $\mathrm{CM}$ era resgatado aqui. A partir da sua pesquisa pessoal (ambience) você retirava as cores, as texturas e então ia para a rua fechava essa pesquisa em 15, 10 matérias que você encontrava. Em seguida vem o vazio, não encontrando tais texturas e aí era a hora de fabricar as texturas e tudo o mais que não havia sido encontrado.
Pesquisar é abrir e fechar. Isso com textura, cor, estampa (fecha, abre e fecha novamente). E aí ia para a coleção.

Faziam em torno de 10 a 15 looks por semestre (estimado).

A Simone ia sempre para o manequim antes. "O sulfite e o morin são materiais correlatos." A Sylvie queria ver a coleção em desenho, mas a Simone já tinha o processo da moulage agilizado.

As peças eram confeccionadas e apresentavam o look. Tinha ajuda da aula de modelagem e costura? Havia esse tempo? As peças eram bem acabadas????

No quarto ano com a Euzita sim, por isso ela entrava no quarto ano. Mas no terceiro era meio ir atrás, porque no horário da aula de modelagem havia um conteúdo programático a ser ministrado. No terceiro ano podia ser no morin mesmo. $O$ importante era a equivalência de matéria para 0 peso e público. A Simone usava muito o organdi. Então o morin cabia porque 0 caimento é próximo. Quando desenhava malha, buscava uma malha.

\section{A questão do universo simbólico: 37'}

A pirâmide de valor simbólico que envolve a arte, a arquitetura, o design e a moda.

O "antes" da peça que vai entrar na engrenagem de reprodução não deve ser desprezado. Esse processo anterior, artístico ou projetual, se as-

Falei que projeto era tudo isso. No design ele visa muito a produção em série, na moda mesmo. A ideia é também averiguar a posição da moda em relação a esse aspecto da ideia de projeto.

O design, o design thinking leva muito em conta a necessidade do cliente (usuário). E a curva que se faz na FASM é: qual é a urgência do estilista (estudante) em termos de criação?

Sabendo dessa urgência, dessa necessidade que te toma você vai saber fazer..

O Carlos Mauro fazia muito bem essa figura. Porque a partir dessa influência de quem você é e do seu âmbito é que você consegue pensar na necessidade desse outro e pode colaborar com a inserção de um produto voltado para o outro, que faça a diferença. Questionável essa coisa de "sabendo quais seus anseios você consegue projetar para o outro." Há um domínio repertorial outro aí que extrapola o universo do criador.

Ss manuais de produtos de design são voltados muito para fora prerrogativa muito ? e esquece dessa responsabilidade, contingência (nas minhas palavras) do criador.

Livros europeus que influenciam a moda são manuais de design e são patentes nesse sentido. Já pressupõem que moda é design e são taxativos nisso, não deixam outra opção (Débora Christo fala isso em "Olhares diversos" de 2008). 
Acerca da teorização?

O CM usava muito "As espirais da Moda" da Françoise Vincent-Ricard. Era o que tinha na época. Os primeiros livros de projeto em moda são de 2003.

Nem usava livros sobre processo de criação. Ela foi conhecer Fayga Ostrower na Pós, mas a Donis A. Dondis ela conhecera ainda na graduação com o Feres.

Laboratório de Criação com a Sandra Harabagi e de Estilismo com o CM e Sylvie; ela não se recorda de qualquer bibliografia utilizada ou indicada.

Foi o Ivan Bismara que introduziu Cecília Salles, "Gesto inacabado" na FASM. A partir daí ela se interessou pela crítica genética, crítica de processos para derrubar a crença no inatismo criativo.

Citou também o Rollo May "A coragem de criar", psicanalista americano. Ele fala dos "nós" na criação.

\section{Conhece a bibliografia de moda e design?}

Os de moda todos e o do Bruno Munari também. Desconhece o Bernd Löbach.

\section{Campo autônomo? Moda ou Design?}

Moda é um campo multidisciplinar. Ela entende como campo autônomo, mas dialoga com design, arte, cultura.

Ela teve aula com a Kazuyo no Senai.

O que o mercado precisa? Será que a gente sabe o que ele precisa? Não é reduzir ao arroz e feijão só para dar continuidade ao processo?

Fala da demanda de quem ainda não domina o processo, $\circ$ aluno da FASM, de quem faz o contraponto. $O$ mercado é assim e não precisa de mais gente repetindo o mesmo.

Ela não forma para o mercado. (60')

Mas tudo isso é contratado? Há essa demanda?

O diploma lá sai "Bacharelado em Moda" há cerca de dois anos. Tirar o nome Design e fazer um exame de tecnológico no curso de moda suscita o questionamento se o curso precisa ser de graduação ou só um tecnológico bastaria.

Hoje ela afirma que há teorização e que passa conceitos. Hoje a aula de estilismo era bastante diferente. Ela tem que passar conceitos e autores e a boa formação é um reflexo do que foi passado, toda a parte de metodologia.

A diferença não implica em ser melhor ou pior, mas o processo de endogenia leva também a questionamentos de gente que se forma mais (mestrado e doutorado) e que começa a disponibilizar conceitos e autores até então não cobrados. cesso criativo de artistas na aula do Feres e também fragmentos de entrevistas na aula do $\mathrm{CM}$ sobre o processo criativo da Chanel, por exemplo. $\mathrm{Na}$ época não havia bibliografia sobre projeto em moda no Brasil.

Se a moda se aproxima de alguma coisa é de artes visuais e plásticas, pois na FASM a moda nasceu nesse ambiente, mas também comenta a contribuição interdisciplinar do design e da arte nas mãos do Feres, Guto, Eddy, Vera Lígia.

Percebe-se uma contaminação do design na fala de alunos e professores quando se referem a termos. Isso não é problema. Talvez pela própria formação do corpo docente.

A moda é essencialmente inter ou transdisciplinar.

Como define estilismo?

Estilismo é uma ênfase no traço que você dá desde [?], no traço do criador. Citou o filme sobre o Niemeyer, "O Risco". Ele fala do desenho como risco e como o ato de arriscar-se. A ideia desse documentário se relaciona muito com a relação que a Simone faz com o desenho e a modelagem. Você não faz um desenho, você se arrisca. A responsabilidade que uma proposição impõe também ao outro é um risco. E a pessoa que topa esse risco ela se transforma em estilista.

Isso pode ser sinônimo de projeto em certo sentido, mas para além dos manuais que se fazem para tornar o processo rápido. Moda, arquitetura não dá para ser assim: faça assim que vai funcionar, não é receita de bolo. Não é "Você passa por ali e chega lá."

Quando o projeto sai dessa esfera é estilismo e interessa, aí eu posso te dizer: é projeto.

\section{Estilista-autor e a "aura" + capital simbólico?}

A moda é. (arte, design, arquitetura e cultura) é transdisciplinar. Isso precisa parar senão continua a ideia de que a moda precisa ser a "outra" para se legitimar. A gente precisa parar de ser "patinho feio" perante as outras áreas da visualidade. A gente pode falar que moda é autônoma.

\section{FASM ser mais voltada para a arte}

Viria do vínculo com o desenvolvimento da expressão do aluno ensejada lá. E que veio de um curso de artes de lá. O vínculo vem dessa expressividade que se busca. De um fazer processual mais artístico, um fazer protagonista daquilo que se faz. A ideia de protagonismo é muito importante.

Não significa que só vai praticar o estilismo de autoria. Mas isso vai permitir que esse aluno vá se desenvolver no âmbito da criação autoral e industrial.

Movimento ambíguo da moda

Uma parcela busca essa legitimidade em contato com a arte. 
Agora da perspectiva da Simone, intra, porque ela está na formação: se arte for pensada em termos de reprodução, o movimento que o Andy Wahrol fez e o que o Ron Mueck, que está na Pinacoteca e a exigência de engenharia e de tecnologia que tem ali. Ele é um agente de tantos colaboradores que ele tem ( $r s)$.

A arte se faz indústria assim também.

A arte contemporânea difere da arte renascentista ou moderna que se pretende copiada pela moda. E a arte, aí ela cita o Beuys e ele dizia que "ensinar era a principal obra de arte dele." Isso muda alguma coisa na gente.

Assim ela vê moda como esse território vivo, novo que tem uma tradição de 30 anos no Brasil, mas de 173 anos na França, em contato com o seu tempo que o Agamben vai falar que é contemporâneo.

O aluno sabe menos de uma coisa e mais de outra (tecnologia) hoje.

Essa área propõe muita relação em termos de mobilidade. Há uma elasticidade entre as áreas. Pensando o corpo eu posso me expressar por meio da arte, posso usar o corpo como suporte. Não há preocupação com a reprodução aqui, nem em termos de moda nesse contexto.

O estudante de moda também pode ter contato com esse processo estreito do "um" que não está pensado em reprodução.

Isso é projeto ou estilismo. Criação mais voltada à quebra de paradigmas, à forma de pensar. (Mendini, Starck).

Isso vai estar na parede? Mais em contato com a arte? O próprio contexto define se é moda ou arte.

Depende até se vai estar alinhado à perspectiva da indústria.

A moda é um campo como a arte também é. $O$ design é menos porque ele nem tem objeto de autoria.

Ela vai falar do cinema e de processos das áreas artísticas que se assemelham à moda. $O$ cinema cult, francês, de autor, a experiência fílmica, até meio blasé.

A moda tem essa mesma dicotomia do filme de arte e do filme comercial, blockbuster.

É cineasta o que faz Truffaut ou o que faz Hobitt?

A moda para ela se encontra exatamente nesse dicotomia, nessa fronteira.

Se é bom ou ruim de acordo com a crítica vai variar, mas é moda. A problemática é a mesma.

\section{Disciplina Norteadora}

O conjunto de disciplinas de criação costuma ser o pilar para os trabalhos interdisciplinares e TG.
O TG faz ser integrado de verdade porque há uma coleção para ser feita e que representa seu trabalho de graduação, final.

Tem desenho, estilismo e tem modelagem. Essa tríade é o que norteia o curso.

Criação, estilismo e modelagem. Em criação estariam laboratório de criação, estilismo I e II, planejamento e desenvolvimento de coleção, desenho de acessórios, estamparia.

A metodologia foi incluída no processo do TG. Foco nos trabalhos escritos, pensar sobre o seu processo criativo orientado pela Sílvia.

Perspectivismo da orientação dado por ela e 2 professores de metodologia, a Sílvia e mais uma que foi contratada agora, além do Márcio Ito, a modelagem com a Ângela.

Ela costuma falar para os alunos que o mais interessante, o mais inteligente é eles buscarem co-orientações dentro do seu âmbito, onde você coloca o seu trabalho em perspectiva.

Em geral os grupos de disciplina de criação correspondem aos pilares de cada ano.

Comunicação visual do produto com o Eddy + Planejamento de Coleção + Modelagem + Desenho + Estamparia = são ou deveriam ser os pilares do terceiro ano.

$O$ ideal primeiro seria estabelecer as diretrizes curriculares para moda para depois se falar em um exame para ENADE. A tendência é que isso demore.

O fato de moda ainda ser recente no país como formação e que nós passamos por ela a gente está agora junto com a area que a gente escolheu dando condições de ela ser entendida como campo autônomo, próprio, de ela ser reconhecida pelo MEC, de daqui há pouco ela ter mais pesquisa. Isso é bonito, incrível estar ao vivo fazendo isso, estamos fazendo história

Fast fashion = "Essa moda sem cara, essa moda sem nada" como sintoma da sociedade em Lipovetsky. Não é só criticar, mas compreendê-la.

Obsolescência das pessoas é em parte a da moda e está nas empresas e agride em algumas instâncias.

Filosofia $=$ descarte como suicídio ou morte e como efemeridade da moda.

\section{Forma e função}

Na moda forma segue o apelo de venda?

Mas qual moda?

Marcas de esporte de performance a forma seguiria a função.

Sim para uma esfera da moda e a Simone Mina olha para outra, rs. 
Covardia se proteger só na moda de criação. Isso também é se alienar. 0 papel é dado, o professor só faz isso porque foi consentido que ele fizesse isso.

A reflexão intelectual está começando no Brasil no campo da moda. Citou a Dorotéia Baduy e o livro de 2008 no âmbito do projeto em moda.

Os manuais clássicos de projeto não contemplam a nossa realidade brasileira nem as questões de reflexão que falávamos anteriormente e a Dorotéia Baduy tocava nisso.

Falamos sobre resgatar o trabalho dela sobre a Nanni Strada, seria um trabalho de doutorado isso.

Falamos sobre a Rosane Preciosa, a Cris Mesquita e a Kathia Castilho.

Temos um design de moda nacional?

A identidade é uma ideia de unidade, mas também uma ideia de apartheid. Seria bom ter uma moda brasileira, ter uma caixinha que eu pudesse falar: moda brasileira.

A escola francesa: passar pela ideia de identidade quando for se desvincular dela.

Está se fomentando uma produção daqui que se possa levar ao âmbito do país ou dos diversos "Brasis". Apesar disso ser importante ainda não acontece.

Talvez o biquíni, a moda praia configurem algo de moda brasileira.

O Ronaldo [Fraga] é um construtor de imagens e narrativas. Ele se assemelha muito a um artista contemporâneo que constrói narrativas. É interessante o resgate e a maneira como ele funciona e o protagonismo do seu lugar. Ele está no âmbito pessoal e territorial.

John Galliano no desfile dos trens, qual é a diferença entre ele e Lino Villaventura? É uma opinião pessoal. Ela gosta de Lino, mas não vê como moda brasileira. Nesse caso até é mais o Ronaldo.

Vera Arruda e Marta Medeiros não quer desqualificar.

\section{Existe um modo de projetar brasileiro?}

Texto "A estética da ginga" diz respeito ao nosso modo de projetar no Brasil.

Discussão do Popper sobre a tecnologia e o Paulo Freyre, sobre tecnologia no ensino. De onde vem a questão da cultura? Um fala do EUA e outro do Brasil. Qual é a realidade sobre a qual se fala?!

Não existe uma fórmula universal. Sempre tem que traduzir. Isso serve para os manuais.

Justamente CM trabalhava a beleza. Qual é o ponto de vista, o mal estar da civilização (e do aluno) para eu querer determinado objeto do meu lado e a partir dessas referências como isso vai ser devolvido em forma de produto.
Você rapidamente vê, se relaciona e acha um modo de falar aquilo que é importante para o seu público-alvo.

Pesquisar muito, pois moda tem muito de antropologia, sociologia e os cahiers têm papel importante nisso. Como eu estou vendo essa realidade $e$ como eu transformo?

O mestiço se reconhecendo como tal se descola da realidade de colonizado e pode se reconhecer como criador de moda. Estamos engatinhando na nossa identidade, mas esse é o processo natural.

Em 2003 começam a surgir as principais bibliografias sobre projeto em moda que se pretendem antes de tudo manuais e que por isso mesmo muitas vezes exibem sua fragilidade diante do processo criativo que nem sempre é passível de ser desvendado, mas nem por isso impraticável. 


\section{GIBERT, Vera Lígia P. Entrevista realizada com \\ Vera Lígia Pieruccini Gibert, em 25 de novembro de 2014, na cidade de São Paulo, com 2 horas e 27 minutos de duração.}

[Leilane Rigatto] Bom, hoje é dia 25 de novembro...(2014)

[V] Dia de Santa Catarina de Alexandria, né?

[L] Não, sei, é?

[V] Padroeira dos estilistas.

[Voz Feminina] Ah, não acredito! É mesmo?

[L] É. É. Agora que eu olhei. E a gente vai começar a segunda entrevista do Projeto em Moda, que é o meu doutorado, aqui é Leilane Rigatto Martins, e a gente vai entrevistar hoje a Professora Vera Lígia Pieruccini Gilbert.

[V] Isso. Voilá.

[L] Está certo? Olha! Então, eu vou gravar também no celular, só para se der algum xabu.

[V] É. Deixa só eu te contar. Quando a gente estava montando o curso e aí que eu fui conversar com Benjamin Steinbruch da Vicunha. [0:00:37]

[L] Da Vicunha.

[V] Da Vicunha. E aí marquei, né? Ele nos recebeu e tudo o mais, [0:00:44] eu vou gravar. Pois não, e não sei o que e tal. E bom, liguei. Era gravador de gravador. Eu não sei o que é que aconteceu, fiquei com ele duas horas, não gravou uma linha. Nada. [risos] Nada, nada.

[L] [0:01:05]

[V] Pois é. Olha bem, porque às vezes pode acontecer. Lógico, pode até ler as duas... [0:01:10]

[L] E aí, bom, eu li o seu... a sua dissertação de mestrado [0:01:19] mas aí a gente pode discutir um pouco juntas alguns aspectos também. Então, a gente tem alguns marcos, né? Definições diferentes de vestuário e estilismo. Antes eu vou te perguntar se você conhece uma bibliografia básica. Eu trouxe alguns livros mais recentes de projeto, eu não sei se você conhece?

[V] Conheço.

[L] E Simon Seivewright[0:01:39]. Esse é um, inclusive, que a Simone Mina [0:01:44] está usando atualmente lá, como eu conversei com ela e "Desenvolvendo uma coleção" da Elinor e Colin Renfrew.[0:01:48].

[V] De que período, você sabe?

[L] Isso é de 2009 e 2010 [0:01:53].
[V] É bem recente.

[L] São bem recentes.

[V] Não, naquele tempo também não existia isso.

[L] É. Eu queria te colocar... te perguntar se você conhece a Sue Jenkin Jones, já é do início do século [?] e a Doris Treptow que eu acho que anterior a isso.[0:02:01]

[V] Essa sim, isso sim.

[L] Isso e a Sue Jenkin Jones [0:02:08], que eu acho que é anterior a isso.

[V] Anterior, assisti.

[L] Que até você fala do Painel Semântico e é aí onde a gente encontra relatos do Painel Semântico voltado para a moda, é nela (na Doris Treptow).

[V] Sim.

[L] São as principais. E aí eu estou perguntando também estou dando destaque, não é o meu foco principal, o meu foco principal é desvendar a questão do Projeto em Moda, as diferentes visões, né?

[V] Certo.

[L] Então, eu sou formada na Anhembi. Tem sempre [0:0229] ah, você é formada não sei onde. Isso não me importa. Eu quero boas visões sobre projeto [0:02:33]

[V] Não, eu acho que a moda precisa é de visões, né?

[L] O lance da moda é que ela é constituída com as pessoas de vários lugares.

\section{[V] Lógico.}

[L] E assim, me interessam as visões dos pioneiros. Quem eu chamo de pioneiros? São pessoas que formaram o campo ou e trabalham ainda no campo e entender essas pessoas. Eu tenho, por exemplo, o professor Eddy que é um professor dedicado ao design, das artes e da moda. Tem professores que se dedicam exclusivamente à moda, graduação, pós-graduação esses níveis também vão variar. Tem professores que são mais, vamos dizer, que lutaram pelo surgimento do stricto sensu na moda. Tem o do Senac, que não continua por razões políticas. Então, assim, é uma série de coisas.

[V] Econômico e político [risos]

[L] Econômico e políticas, né? É um acordo com o governo...

[V] Governo, é. Eles tinham que fazer. Do lado político, realmente, tiveram que atender a questão que eles são...

[L] Curso técnico.

[V] Técnico.

[L] E bolsa, né? Hoje tem muita bolsa. 
[V] Muita bolsa.

[L] É uma pena...

[V] Eles fizeram uma escola monumental, maravilhosa, aquele espaço.

[L] O CAS, né?

[L] Então são os principais que eu estou elencando, o Santa Marcelina por ser a primeira das pioneiras, a primeira. A Anhembi e o Senac eu não sei se é segunda ou terceira, estão ali juntas. E eu estou falando principalmente juntos em São Paulo, que era anos 90.

[V] E a Unip, né? Que era antes do Senac.

[L] É antes, anos 90.

[V] Só que...

[L] Anhembi é 90, e a Unip é ano 91. Tem uma série que são de moda, mas... [V] E o NIDEM continua?

[L] O NIDEM, eu acho que ainda existe. O NIDEM, eu acho que ainda existe. Pelo menos eu peguei publicação, relativamente recente.

\section{[V] Recente.}

[L] Eu não sei dizer se hoje ainda está atuando, mas eu acho que sim. É que a Suzana Avelar está na... lá... tá todo mundo.

[V] É. Aquela menina do Rio...

[L] [0:04:22] enfim, é. E aí tem... eu estou estudando, eu acho que o Rio e São Paulo. Por que? Muito antes... o que me interessa é a discussão em nível acadêmico, intelectual da ideia de Projeto em Moda. Um conceito sobre isso. Claro que a gente pode falar da prática no mercado, isso é muito bem visto. Mas entender também a questão histórica de que a moda foi ensejada pela indústria em relação ao design. Você me diga qual é o comportamento da Santa Marcelina? A Santa não tinha o curso de design. Bateram lá. Opa, vamos abrir um curso de design de moda ou de moda [0:04:52] o design? Mas aconteceu porque você tinha um contato muito fresco com a Rhodia...

[V] [0:04:56]

[L] Foi quem mais solicitou isso. Então...

[V] Eu trabalhei na Rhodia, gente.

[L] Sim, é o período que você me falou que esteve lá.

[V] Eu também... quer dizer, eu fui atrás da Rhodia em 73, pensa bem, porque a... aquele momento rápido... eu estudei no Santa Marcelina e entrei na Desenho de Moda. Me formei em 70.

[L] Isso ainda em Desenho e Plástica, né?

[V] Desenho e Plástica. Em 1971, eu já estava formada, eu fui convidada para ser uma auxiliar da professora de Desenho de Moda. Isso. Em 1972, a mesma coisa. Em 1973 ela faleceu, que era a Eugenie Jeanne Villien. O que é que aconteceu?

[L] Mas era só o espaço que tinha desde a década de 60.

[V] Desde a década de 60

[L] Você sabe o ano em que isso começou a ser introduzido?

[V] Em 1964, parece.

[L] 1964?

[V] O que eu vejo, assim, é que você fica com... bom, quem ficou com a disciplina fui Eu. Ela faleceu, a gente era muito ligada, ela, no hospital antes de falecer, me mandava aula a aula o que ela queria que fizesse. Eu fui uma repetidora, praticamente, daquelas coisas.

[L] Uma herdeira natural.

[V] Natural. Até o ponto de eu pesquisar, querer e me interessar para saber se aquilo que eu estava fazendo era aquilo que a indústria precisava. E aí eu descobri o Carlos Mauro. E antes de descobrir o...

[L] Isso foi dentro do... desculpa te interromper...

[V] 1973.

[L] Foi dentro do curso de Desenho e Plástica, [0:06:37] foi dentro daquele curso dentro de..

[V] [Professorado em] Desenho.

[L] O curso que era de desenho amplo que a gente falou.

[V] Isso é aquilo que pegou no curso de desenho amplo.

[L] Joia.

[V] Porque eu dei aula nos dois, né? Teve Desenho de Moda para os dois no sétimo semestre. Depois ficou no Desenho, tá? Eu fiz Desenho, tinha desenho arquitetônico, desenho mecânico, desenho topográfico, desenho design, desenho.

[L] Projeções...tudo

[V] Você tem que [0:07:04] muito, né? Porque está na base do desenho. Desenho de observação, tinha. Mas tinha técnico, um monte desses desenhos até chegar em desenho publicitário, desenho de moda que eram os finalizantes. E aí eu... bom, fiquei com a disciplina e tive de me cercar de novos conhecimentos, de ver se o que eu estava fazendo estava de acordo e tudo mais. Fazendo um parêntese, meu marido é quem fez... trabalhou na Rhodia...

[L] Hum. Você conheceu ele na Rhodia?

[V] Não, a história nunca... a história é mais engraçada, ainda. A minh mãe era professora de português no Liceu Pasteur e ele foi aluno da minha 
mãe no colegial. A gente só veio a namorar quando ele já estava... terminou... tinha terminado a engenharia. Estão fazendo 45 anos [risos] esse ano.

\section{[L] Que lindo!}

[V] Então, e aí nós conhecíamos... o Pierre fez... construiu lá... era engenheiro civil dentro da Rhodia, do departamento de engenharia. E ele construiu o CDT, é Centro de Desenvolvimento Têxtil. O prédio, ele fez o prédio. Quando ele fez...

[L] Ah, o projeto do prédio é dele.

[V] Isso. Quando ele fez esse prédio e tal, ele fez para a uma atender uma área da engenharia têxtil. Esse era o seu Louis Besse que era um engenheiro têxtil.

[L]Pierre, Pierre?

[V] Pierre Georges Gibert, meu marido.

[L] E o Louis, quem era?

[V] É Louis Besse. Era o engenheiro-chefe, era o diretor, né? Tinha um alto cargo da engenharia têxtil, na época.

\section{[L] Tá.}

[V] Tá? Dentro da Rhodia. E o Louis Besse eu conhecia. Então, primeiro eu quis conhecer a parte têxtil. Então, foi lá que eu vi, pela primeira vez, polímeros, que eu vi uma tesoura, que eu vi a matéria-prima do têxtil que está virando fibra, estiramentos, tararatarara. Ele conversou e tudo o mais e tal e ele falou, bom, Vera o que você veio buscar aqui, tudo bem que você tenha interesse nessa área, mas eu acho que não é... não é comigo, eu mostrei o que você podia ver aqui e o importante seria você começar... conhecer uma determinada pessoa. Daí o Mauro do CIT da Rhodia[0:09:28] e aí que ele me indicou o Carlos Mauro. Aí eu marquei uma hora...

[L] [0:09:33]

[V]

[L] Com o Carlos Mauro.

[V] Daí eu fui com o Carlos Mauro e naquele então existia na escola um curso de pós-graduação lato sensu em História da Arte e eu estava fazendo. Naquele dia, fizeram a maior gozação porque eu cortado o cabelo e eu com esse negócio de fitas e tal, então diziam que eu era a menina FASM na Rhodia. Um monte de brincadeira fizeram, até... até caricaturas, sabe? Porque mudou. $O$ seu cabelo seria o que?

[L] Clássico.

[V] Naquela época [0:10:12] e aí eu cortei aqui. Todos disseram que era porque eu ia à Rhodia, eu queria parecer..

[L] De vanguarda.
[V] [0:10:19], vanguarda. Foi uma gozação. Bom, aí fui, ele me recebeu, ssim, magnificamente, sempre e de lá para cá, a gente nunca tinha mais [0:10:29]. Até que quando começou o curso, aí 73 para 87, você imagina...

[L] 14 anos.

[V] 14 anos. Aí, a gente... eu já estava trabalhando na Rhodia. Eu comecei a trabalhar na Rhodia em oitenta e..

[L] Como é que você foi absorvida pela Rhodia?

[V] A Rhodia que me convidou para dar os cursos para os estilistas de desenho têxtil, de desenho de moda. Era o croqui de moda. Porque o pessoal queria fazer o croqui de uma roupa e aí o bolso, por exemplo, que tinha que estar num determinado lugar, não estava. E [0:11:05] estranhava demais e os estilistas reclamavam muito porque a modelista não sabia pôr o bolso. Não era, era deficiência dos estilistas que não sabiam... [ela deu aula de estamparia e desenho de moda para cerca de 600 estilistas que passaram pela Rhodia].

[L] Avaliar o caimento da lapela...

[V] Exatamente. Então, a gente resolveu ter lá... e eu acredito que estava ali..

[L] Foi uma luta, né? Da graduação para...

[risos]

[V] Pois é. A ponto de ter conseguido até eu levar... creditado e tudo, mas a gente teve lá o... o esqueleto para mostrar uma linha do mamilo, por exemplo, o que é que... o que é que fica atrás, por exemplo, aonde vai o omoplata. Então, as pessoas não têm ideia. Como é o calcâneo, esse pé pisava ou não pisava, então para ver direito como era, sabe? Então, foi isso. Foi todo... eu trabalhei lá de 81 a $91 \ldots$ de 83 a 91.

[L] Bacana!

[V] De 83, não foi 81. Em 81 eles queriam... o Carlos Mauro teria ido me procurar na FASM querendo que eu fosse dar esse curso...

[L] Isso foi em 81?

[V] Em 81. Mas aí até montar e realmente..

[L] Eu só quero entender uma coisa, o Louis Besse te indicou o Carlos Mauro, aí você entrou em contato com ele...

[V] Isso em 73.

[L] Tá. Aí vocês mantiveram um relacionamento de troca profissional...

[V] Isso, porque nessa época eu desenhava estamparia, eu já dava aula de desenho de moda...

\section{[L] [0:12:31]}

[V] Mas era a disciplina de desenho de moda da faculdade, inclusive a Renata que fala, eu dava um curso... eu dava uma faculdade [0:12:40] 


\section{[L] É verdade. [risos]}

[V] Porque... porque eu dava [risos] a noção de todas as modas, eu dava uma noção da estamparia, justificava, obviamente não dava para fazer todas as estamparias.

[L] Eram quatro horas?

[V] Eram quatro horas de uma vez.

[L] Ah, legal.

[V] E... e aí dava também... além dessa parte histórica, o desenho, o croqui, né? $\mathrm{O}$ croqui de moda. A parte de...

[L] O bom é que era um curso de desenho, pelo menos mobilidade pelo menos já tinham.

\section{[V] O pessoal já tinha, já adquiria.}

[L] Da anatomia, do...

[V] É, então. A parte de anatomia desenvolveram também ali porque... a anatomia, anatomia é importante ser vista, mas o desenho de moda sempre é uma estilização, né? E aí é o estilo mesmo de cada um, era que a gente queria. Como uma escola de arte, você quer desenvolver a individualidade, a personalidade e as três ali, a gente buscando... e conflitava, por exemplo, com o estilo do Estudio Berçot. Enfim, a gente recebia... tinha material vestido de seda, materiais que era aquela coisa nu, todo mundo fazia um a mais um a menos era problemático. É, era [0:13:55]

$[\mathrm{L}]$

[V] Autônomos. Aí eu tive contato com Mari Rucki veio várias vezes..

[L] Eu já fiz coleção com ela, aqui.

[V] Você fez? Então, as várias vezes que ela veio, a gente esteve junto e tudo o mais e eu não era nunca convidada para fazer o curso.

[L] Quem trouxe ela para cá... só para eu achar uma pessoa...

[V] O Carlos Mauro, trouxe.

[L] Carlos Mauro. Então, pera aí, em 81 você estava quietinha, em 83 fazendo... em 81, fazendo as suas atividades na FASM e aí ele volta, te procura...

[V] Daí ele me procura...

[L] Para solicitar o curso, você fica aí um ano e meio, dois anos trabalhando para disponibilizar esse curso.

\section{[V] Curso técnico}

[L] Tá. E a Mari Rucki já vinha desde a década de setenta...

[V] Ela veio em setenta e cinco... como é? Em setenta e seis, sei lá... setenta e nove foi a primeira vez que a Rucki veio.
[L] Tá. Está bem perto da...

[V] É.

[L] De uma década antes de começar o curso.

[V] E lembrar que o estilismo na França estava sendo também... na década de 60 e 70 é que estava... estava sendo procurado como estilismo. Porque antes entra [0:14:58] essa visão de coordenação da moda, só produtos, várias pessoas e tudo o mais. E uma coordenação das... as pessoas começam a fazer o que, né? Vendo a matéria-prima, depois a coloração... coisas que eu quero dizer que isso tudo é... caiu na cabeça das pessoas para estruturar é recente, se você for pensar bem, tem muito... historicamente nos Estados Unidos tem.

[L] Hum. Bom, e daí você estava falando que nunca te chamavam para o curso da Mari Rucki [risos]

[V] É. Porque o Carlos... porque o Carlos Mauro queria me preservar. Ele achava que era incrível sem eu ter tido contado, assim, com a Rucki, como é que era possível eu ter engendrado todas essas informações. Primeiro, porque eu acho que eu era muito... assim, eu gostava da área...

[L] Sim.

[V] Essa proximidade com... com o pessoal da Rhodia, de uma certa forma me curtia também, O Bete [?] [0:16:04], tudo ali para você pensar, a casa dele, eu conhecia, essa coisa e tal. Eu grávida, os meus filhos, ele era uma pessoa porque tem horas que força muito, ele fiz questão, eu com a barriga desse tamanho, eu ia ter filho em janeiro e ele... sabe? Assim, ele era um desse tamanho, eu ia ter filho em janeiro e ele... sabe? Assim, ele era um
gentleman, um homem alto, [0:16:25] fez questão de dançar comigo. Sabe? Uma pessoa que foi muito querida... ele foi sempre muito querido, então, essas coisas foram, sabe? Foram dando certo, vão te levando, você tem o interesse e a coisa casa, vai dando certo, você vê e tal é interessante, o Carlos Mauro é um mundo, né? De coisas assim. Porque o Carlos Mauro por causa da Rhodia, ele ia anualmente para lá, para a França, e ele conheceu todo o mundo que estava na crista da onda e os costureiros todos, então ele viu nascer dali da... da coisa do estilista. E foi por isso que ele trouxe Mari Rucki.

\section{[L] É ele quem traz para a Rhodia.}

[V] Trouxe para a Rhodia. Trouxe [0:17:07], ele trouxe um monte de gente.

[L] Que legal! Deixa eu ver os pontos aqui, só para eu não me perder. Eu queria de pergun... essa é difícil [risos] essa é longa. A gente vai entrar em várias coisas, mas eu queria entender, para você, primeira coisa se eu... eu entendo o que é que a gente chama de projeto [0:17:28], vocês chama de estilo [0:17:30]. A gente, por um período, também chamou de estilo...

[V] Mas a gente também usa a ideia de projeto.

[L] Eu queria saber se para vocês são sinônimos, projeto e estilo. Pode ser um sinônimo ou não? 
[V] As vezes até pode. E hoje, eu acho que tem muito a ver. Agora, o que eu acho é que o que não pode ser sinônimo é designer e estilista. Isso não dá.

[L] Não, porque designer é produto e... moda é outra coisa.

[V] Mas moda é produto, para a gente. E eles, os designers..

[L] Que legal! [risos]

[V] Eles, os designers, acham que tudo... tudo pode, entendeu? Mas não é a mesma coisa.

[L] Você conhece o trabalho da Débora Christo? Ela fez o doutorado... Débora Chagas Christo. Ela fez o doutorado lá na PUC. Ela é professora da PUC.

[V] Lá tem curso de moda, inclusive, né?

[L] Na PUC Rio de Janeiro.

[V] Rio de Janeiro.

[L] É. E ela foi orientada pelo Cipiniuk. Lá tem uma visão muito diferente, é por causa da proximidade com a ESDI, né?

[V] Foi. Lá no Rio de Janeiro, é.

[L] É produto, não tem moda. Então, a grosso modo, talvez...

[V] O que ela acha que é moda?

[L] Eu vou ser maldosa com ela, mas ela fala que moda é um sistema mais amplo, até aí, ok...

[V] Hã, hã.

[L] Comunicação, difusão de tendências de ideias, algo mais. Até aí, tudo bem. Mas aí, ela vai falar que vestuário é design produto e não é moda. Ah, isso, não pode fazer, fiquei uma arara quando eu li isso...

[risos]

[L] Eu vou falar isso com ela quando eu encontrá-la.

[V] [0:18:57] para mim, até concordo que seja tudo isso...

[L] Também. Mas também é visual.

[V] E até acho que moda... não, eu acho que... até acho que algumas áreas de design, da moda, podem ser tidas como tudo isso.

[L] Fazem interface com o design. [0:19:15]

[V] Fazem interface muito mais rápido do que o design, perfeito. Porque ela... ela tem uma... uma linguagem dupla no sentido de forma, métodos de produção...

[L] Processos [0:19:27]

[V] Processos, são muito mais... [0:19:29] Porém, eu acho que a... filosoficamente, uma coisa não é a outra. Para mim, eu...
[L] Eu acho até que... eu concordo com você, eu acho que moda é... pode ser design, mas moda não é design.

[V] É. Ela pode ser, mas eu acho que estamparia...

[L] Até porque design não é moda.

[V] Estamparia, design têxtil, eu acho que é design.

[L] Tá.

[V] Tá? É uma criação, ela pode estar de acordo com... com a... o fato de que existe uma especificação de uma... de uma coisa de característica do criador, ela pode atender tendências ou não, certo?

[L] Sim.

[V] Ela pode ser totalmente..

[L] Mas ela vai...

[V] Atender um quadro...

[L] Uma forma...

[V] Um pedido, uma forma, uma série de coisas.

[L] Policromias e tudo o mais.

[V] Tudo. É. Está certo? E é inerente ao processo têxtil, ao processo industrial. Então, nessa medida, eu acho. Agora, a sazonalidade, eu acho que o produto necessariamente de design, ele não tem essa preocupação dessa sazonalidade como tem a moda. E hoje, mais do que a sazonalidade, o término. Quer dizer, o liquidificador saiu, vai durar muito mais do que um ano, certo?

[L] [0:20:52] da perspectiva, né?

[V] Não é? Você tem a necessidade da variação e da [0:20:57] do produto numa rapidez, assim. $O$ produto de design não necessariamente precisa perder essa condição.

[L] Deixa eu perguntar uma coisa em cima disso. Ela fala, então, que o movimento, a filosofia, que no início da filosofia seria a moda e o... as técnicas, os processos seriam mais... seriam o design. Que o resultado seria o design nesse sentido aqui. Vamos considerar assim, que na fala dela está aberto, mas [0:21:24] a nossa vida.

[V] Tá.

[L] Será que a gente não está concordando com ela? Quer dizer, você não está concordando com ela quando você coloca isso? Porque a minha posição é a seguinte, tem um estudo da Tita lá na EACH que chama "A moda como campo do saber." É ela está falando sobre a autonomia no campo da moda. A gente não tem a mesma liberdade, está para sair, mas não tem...

[V] Não é dela. 


\section{[L] É, não é dela, hein!}

\section{[V] [0:21:44]}

[L] É. Hoje é um grupo de estudo dela, lá na EACH.

[V] Então, era... sabe quem é [0:21:50]

[L] Tem vários integrantes, não é só ela, tá? Eu é que estou falando dela, tá?

[V] Eu preciso te contar... não, isso nasceu comigo e o Sérgio Garrido, só para você ter uma ideia.

[L] Ah, tá.

[risos]

\section{[L] O Sérgio Garrido, eu tive aula com ele.}

[V] Então, nós dois é que fizemos um documento [0:22:04] quando o MEC pediu para estabelecer as diretrizes curriculares... isso, sei lá que ano que foi. Eu não sou capaz de lembrar.

[L] Eu acho que em 88, só vai entrar em vigor em 2002. Demora para caramba! Porque tudo o que entra dentro do guarda-chuva do design, [0:22:22]

[V] E a gente fez toda uma pro... um projeto, fizemos super bem, não se o que. Só que a gente tem exatamente essa visão que é muito mais ligada à área do estilismo do que do design.

[L] [0:22:41]

[V] Ignora a forma. E é isso o que a gente defendeu e esse documento [0:22:46] assim. Ajudou bastante a gente a escrever, [0:22:50]

[L] Várias faculdades que tiveram, né? (Na verdade estiveram envolvidas nesse grupo de estudo).

[V] Sim, foi.

[L] Teve um congresso de coordenadores, eu acho que em noventa e pouquinho.

[V] Isso, também foi levado isso também.

[L] Em 98, eu acho, teve o congresso dos coordenadores. Foi no norte do país, né?

[V] Foi, foi. Foi levado. E aí, a gente defende, tem uma diferença, que não dá para encaixar mesmo porque os teóricos da moda não são os teóricos do design. Seria desconhecer um campo do saber que tem uma estrutura... a partir de Roland Barthes, de Umberto Eco é botar... esquecer disso tudo e vai pegar outros... eu acho que eles têm que ser destroçados, mas eles não podem ser fluídos.

[L] Podem ser complementares...

[V] Complementares.
[L] Mas não sobrepostos.

[V] Não sobrepostos.

[L] O design e a moda. Eu também... eu... bom, sou suspeita, eu sou graduada moda, mas você, de certa forma, também é graduada em moda porque você também teve a disciplina de Desenho de Moda, né?

\section{[V] Exatamente.}

[L] A discipli... no curso da [0:23:54] E aí é o que acontece... aconteceu com isso, assim, que muitas das disciplinas como resistência dos materiais, mesmo a forma do design, elas não dão conta das questões... tem a questão de como vamos fazer até as técnicas...

[V] Isso.

[L] Que rebatem o ponto técnico da moda. E, sabe? Eu fico pensando, se a gente... se não seria mais interessante a gente pensar... uma das hipóteses também menor, secundária é a seguinte, de que moda é design de produto e moda é design visual que a gente chama hoje de programação visual.

[V] Sei. Programação visual.

[L] Que vem da estamparia, da revista, da fotografia. É o design de produto [0:24:34] e materialidade, joalheria, vestuário. Também é bem... meio polêmico. Mesmo porque, você entra no site da Fapesp, da Capes, não tem o campo moda, tem que ficar caçando nas artes, nas ciências sociais aplicadas, na ECA, na FAU...

[V] Por isso é... por isso... por isso que é grande [0:24:48] porque até então, até a gente entrar com esse documento, quem esteve em Brasilia para as entrevistas fui eu, junto... [0:24:59] foi a contramedida, eles entenderam, tanto que não teve mais o Enade, graças a Deus..

[L] Suspendeu o Enade...

[V] Suspenderam porque até estruturar... eu dizia, gente, tudo bem...

[L] Em que ano entrou o Enade, Vera Lígia, você sabe?

[V] Pois é, em que ano entrou o Enade?

[L] $O$ Enade para a moda?

[V] Ah, eu acho que foi em dois mil e poucos, né?

[L] Eu não sei o que era o Enade, eu me formei em 2003. Eu não cheguei a pegar o Enade. [0:25:25]

[V] Então, talvez seja dois mil e... talvez seja por aí.

[L] 2004.

[V] É, pode ser. Porque a gente faz avaliação desde dois... fazia, antes, [0:25:35] desde $\mathrm{o}$ ano 2000. [0:25:37]

[L] O Ena... ah, aquela avaliação que a gente [0:25:41] 
[V] Isso. Não, e a gente fazia um... fazia lá para... para saber tudo como funcionava, a parte física e tal. Cada disciplina e tudo o mais. Isso era feito anualmente.

[L] Anualmente.

[V] E tudo. A avaliação, sim. Agora, deixa eu te falar uma coisa, essa história, eu... eu continuo copiando nela, eu acho, o principal, existem várias pessoas, vários teóricos altamente qualificados que escreveram sobre a moda, sobre um aspecto que não tem nada a ver com o design. Então, não dá para... para associar... mudar tudo... agora tudo virou design. Não é assim. É um campo do saber específico, a gente acredita nisso, que em determinadas... determinados desenvolvimentos ele pode ser visto como design. A questão do eventual, por exemplo, você vai projetar um sapato, um tênis, hoje, você quer... você quer uma coisa mais projeto de design do que o tênis?

[L] Depende de maquinário [0:26:53]

[V] Maquinário, solado, um monte de coisas completamente... aquelas borrachas infláveis...

\section{[L] Que são injetáveis.}

[V] Aquelas injetáveis e tudo o mais. Quer dizer, ele tem um cunho altamente de projeto, como ele é injetado depois, também no computador, como ele chega lá, é uma visão muito mais, assim, que permite. Não tem a questão de você estar analisando tanto o sonho, o desejo, o imponderável, o clima.

\section{[L] Não sei.}

[V] Entra... entra de uma outra... [0:27:29] me falou o seguinte, entra de uma outra... [0:27:29] você me falou o seguinte, o obje... tinha um aspecto amplo, assim...

[L] [0:27:33]

[V] É, isso, exato. É.

[L] E tem uma fala... deixa eu ir pegando aqui, senão eu não vou na ordem [0:27:45] [risos]

[V] É, fica muito dispersa a conversa.

[risos]

[V] Tem uma fala aqui de vestuário... [0:27:50] vestuário e estilismo.

[V] Bom, é a coisa é [0:27:53] entre... é, o vestuário é desenvolvido pelo estilismo, mas o vestuário não é o grosso, né?

[L] Ah, isso que eu acho está aqui, ó, nisso que está escrito aqui. Você está falando do [0:28:05] aí você fala que ela forma designers para os diversos ramos de mercado a saber, vestuário para homens, mulheres e crianças...

[V] Crianças.
[L] llustração, estilismo, jornalismo de moda... e você vai citando. Aí eu coloquei assim, umas setinhas [0:28:20] qual a diferença aqui da questão do vestuário e estilismo?

[V] Eu acho que aí [0:28:26].

[L] Não era tão relevante.

[V] Cá entre nós, não era tão relevante.

[L] Eu fui chata. [risos]

[V] Eu acho que isso daí é mais do documento deles, né? Eu extraí do [0:28:34]

[L] Certo. Está respeitando as diretrizes deles.

[V] Respeitando aquelas diretrizes.

[L] Mas para você, estilismo então seria esse ato processual, mas livre, faz...

[V] Isso.

[L] De projetar as histórias e tal.

[V] Hã, hã.

[L] Então, você consegue definir estilo? É o projeto na definição do estilo? Você consegue lidar com estilo?

[V] OK. Estilo... gente, eu penso tanta coisa diferente]

[L] Você vai andando também, vamos [0:29:09]

[risos]

[V] Então, mas olha, o estilo... você tem estilos que não é a mesma coisa. [L] Vamos lá. Vamos ponderar as diferenças.

[V] As diferenças. Estilismo é uma área do fazer ou dos [0:29:52] que está aspectos muito mais aspectos de... o que eu quis dizer é assim, eu estou tentado do lado de cá, o momento, o eu dos indivíduos, aquilo... o desejo de uma coletividade porque a gente está fazendo a roupa para eles, não é uma roupa lúdica, tá certo? Não é um sapato... ele vai [0:30:25] Então, eu sei que vai um drama do usuário, né? Então... mas, está dentro de conceito de época, mas não necessariamente de... até de momento, muito mais do que de época, se eu falo do estilo... num estilo, melhor dizendo. 0 estilo... o estilo indiano, o estilo japonês, o estilo do... Renascimento, o estilo greco-romano, o estilo futurista, entendeu? Isso é estilo. Estilismo tem a ver com a... você fornece estilo e você aplica o estilo... por isso é que tem o [0:31:15] que é a aula de história da arte, o [0:31:18] que é a aula de design ligado ao sentimento do estilo. Tá? Então, o estilo...

[L] Até aí, tudo bem, eu achei essa definição também, o estilo passa pelos marcadores que marcam a época.

[V] A época. 
[L] Acabam se tornando clássicos...

\section{[V] Isso.}

[L] E é uma forma de expressão de um tempo...

[V] Do tempo.

[L] Que... que tem a ver com essa tradição também da gestalt que a gente falou.

[V] Exatamente. Por isso é que todos... os alunos, os professores falando aula de estilo, tudo bem. De novo, uma coisa, todo o mundo fala assim, mas não é correto isso.

[L] É porque a disciplina chama estilo, né? Legal você falar isso.

[V] É errado.

[L] Eu ia falar isso agora.

[V] É exatamente errado.

[L] Deveria ser estilismo.

[V] Estilismo.

[L] Etimologicamente falando.

[V] É, o correto seria estilismo. [0:32:01]

[L] Fica carinhoso, né? Chamar de estilo. Uma coisa até mais próxima.

[V] Né? Fica mais íntima.

[L] Mais afetiva.

[V] É. [0:32:11] do documento, a primeira reunião na França que um grupo de estilistas, quando eles fizeram a Associação dos Estilistas, então eles definem isso. Eu vou localizar isso, eu vou ver se eu acho isso para você.

[L] A Associação Industrial. Faz sentido?

[V] É.

[L] Ah, se você achar, não sei, eu posso pegar posteriormente, se for o caso. Se não te atrapalhar.

[V] Porque então, você veja, toda a vez quando eu dou o curso, a intenção não é que os alunos saíssem desenhistas de alta-costura. Eles até poderiam, porque aí é objeto único, né? Vai fazer um vestido de noiva, vai fazer para aquela noiva, aquele vestido, não é? Porém, o aprendizado é tão global numa faculdade de moda que te leva a poder fazer também... eu já vi várias pessoas, né? Que fazem.

\section{[L] É a questão do atelier, né?}

[V] Do atelier. A Emannuelle Junqueira tem atelier, faz... ela tem um lado... [L] Noiva.
[V] Noiva ou não, né? Você tem outra... tem uma linha também dela de vestidos, né? Que ela fez. A Gisele

[L] Nasser.

[V] Nasser, é a mesma coisa. Então, há pessoas que têm essa facilidade, tem esse interesse sobretudo e tal e têm essa condição de fazer isso. Agora, a estrutura do curso foi muito mais voltada para atender a indústria da moda aqui. Desde a confecção, o processo industrial. Então, é por isso que os designers daí...

[L] Se apropriaram.

[V] Se apropriaram. E isso foi uma... uma coisa que eu acho que como a gente estava praticamente nascendo e eles já eram estruturados e houve em Brasília..

[L] [0:34:09]

[V] Então e houve em Brasília, na década de... foi naquela época, um pouquinho antes de eu ficar doente que foi em 2000, eu acho que foi em 98, por aí, já reuniu em Brasília os designers e a aí eles já estavam dando uns toquinhos que a moda faria parte do conhecimento e do perfil do campo do design.

[L] Tanto que em 2002, o MEC determina...

[V] MEC. [0:34:39] e aquela coisa toda deles [0:34:48] eu não quis liquidar, tratar, sabe? Eu recebia...

[L] Estava na coordenação.

[V] Foi muito depois [0:34:56] [risos] Mas eu acho que [0:34:59] é assim mesmo. Mas para... para outras... outras situações aí foi tudo bem e tudo o mais. Eu tive que [0:35:06] para ter uma... uma voz no MEC contra.

[L] Você lembra quem eram as pessoas do design que estavam lá? Gente dos cursos aqui de São Paulo.

[V] Ah, tinha um monte de gente. Eu tinha... tinha os donos da [0:35:22] Eu não tinha carta pedindo verbas tipo cartas, né? Ofício, tipo assim com os relatórios das pessoas.

[L] Estavam envolvidas as pessoas da Capes, da Fapesp [0:35:37]

[V]

[L] Porque é engraçado, tem uns argumentos que são inegáveis, né? A pesquisa mesmo em projetos tecno [0:35:46], ela vai começar primeiro nos cursos de design, comunicação e aí vão se expandir para história, antropologia, sociologia, segundo a Ana Cláudia... a Maria Cláudia Bonadio que era do Senac que é da Federal de Juiz de Fora, eu tinha que contatá-la [0:36:00]

[V] Ah, ela está em Juiz de Fora, eu achei que ela tinha ido para o Rio.

[L] Não, ela foi, ficou anos no Senac, depois foi para Juiz de Fora. A metade foi para lá, [0:36:08] 


\section{[V] Ah, sim? Olha só.}

[risos]

\section{[L] A Maria Lúcia Bueno.}

[V] Está lá também?

[L] A Madu está lá, a Maria... Maria Eduarda Magalhães.

[V] Olha só.

[L] [0:36:17] A Preciosa também decidiu ir para lá também.

[V] Não diga!

[L] A Preciosa está lá, faz alguns... dois ou três anos.

[V] Olha, que maravilha! Ela deu um pouquinho de aula no Santa Marcelina, também.

[L] Deu, deu aula na pós. Ela, a Cris. Vira e mexe a Rê chama elas, não sei se elas vão voltar. A Kátia está com a editora.

[V] A Kátia [0:36:36]

[L]

[V] Você conheceu a Dorotéia?

[L] A Dorotéia Baduy?

[V] Isso.

[L] Ela faleceu agora, né? Mês passado. Eu gostaria de ter entrevistado ela porque eu estou também tentando falar com pessoas de design, como a Patrícia Fonseca, coordenou a Belas Artes, mas está se aproximando mais de moda. Como a Mônica Moura, uma visão bem distinta da gente, mas é interessante ouvir.

[V] Vai ter que ouvir.

[L] Mas ela... eu a conheci, ela teve inclusive [0:37:06] de orientadora, a gente fez algum contato, mas não foi muito próximo. Eu tenho mais contato com a Maria Celeste Sanches, era bem amiga dela.

[V] Maria Celeste Sanches, eu acho que foi minha aluna.

[L] Mas... Maria Celeste Sanches se formou na Federal do Paraná

[V] Porque o pessoal de Londrina...

[L] [0:37:18] federal de... é, eu acho que ela foi para a federal ou ela... eu acho que ela foi para a federal, ou ela... não, a federal do Paraná.

[V] A federal do Paraná. O pessoal de Londrina, quando foi estruturar o curso de moda deles lá, fizeram dentro de design. Mesmo [0:37:34]

[L] Sim, e a Dorotéia dava aula lá.

[V] Dentro do design. É. Do campo lá o design era dentro de artes, era uma [0:37:42] meio estranha [0:37:46] E aí eu fui para dar o primeiro... para dar curso para eles... para elas... para eles lá, né? Para... eu participei do primeiro lato sensu.

[L] Que legal! Ah é, o primeiro lato sensu é de 97, lá, não é?

[V] É.

[L] Teve no Rio Grande do Sul.

[V] Também. Não, e teve também em Santa Catarina. Foi um fiasco. Eles copiaram pedaços desse tamanho das minhas teses [0:38:14] Mas não fizeram de bom gosto. Não creditaram. [0:38:18] o chato foi que me convidaram para dar aula. Ah, tenha a paciência, é meio chato, né? [risos] Eu fui indo...

[L] Aquele texto [0:38:31] da Doroteia Baduy que ela fala sobre as primeiras faculdades...

[V] Fala. Ela faz tudo isso, mas me localiza.

[L] Eu usei no meu projeto de doutorado, porque eu reescrevi, né? Eu entrei esse ano, mas daí eu passei o ano todo reescrevendo, mexendo, agora eu já parti para as entrevistas.

[V] Ah, que bom!

[L] Então, eu uso o trabalho dela. Eu acho o trabalho dela bem importante para...

[V] Eu gosto muito, também. Ela é muito séria.

[L] E ela dá uma visão de design.

[V] Ela tem uma visão de... uma visão de design, mas ela não é tão rígida quanto outras pessoas.

[L] É. Não, ela tem uma visão de design, mas ao mesmo tempo que ela tem uma visão de design porque essa é a formação dela, é natural ela respeita a dos designers famosos. Ela não tenta forçar o objeto moda para impor a teoria de design.

[V] Não, não tenta. Não tenta, né?

[L] A gente percebe muito isso. Aí eu queria te perguntar..

[V] Agora, ela foi uma pessoa muito próxima do Paulo... me esqueci o nome, aquele lá da... do INEP que foi a pessoa que eu acho que deu uma visão para o INEP muito de design também. Tá?

[L] Ah, tá. Para o INEP avaliar os cursos...

[V] É, tudo. Porque ela é que trabalhou muito, ela trabalhou como assessora e era a visão dela, era o jeito que ela percebia.

[L] Sim. Claro. É pós a trajetória que...

[V] Não é? A oportunidade foi dada a ela e ela fez o que ela...

[L] O olhar... o olhar dela. É interessante isso porque... 
[V] E ela sabe que eu pensava diferente porque a gente conversou depois sobre isso também e tudo. A gente... ela foi... é, foi muito querida para mim, também.

[L] Ela escrevia muito bem, né?

[V] Escrevia.

[L] Ela articulava muito bem.

[V] Ela era muito... escrevia muito... os emails, facebook. Porque o meu computador deu uma pifada de tanto que eu recebo facebook, você acredita? Vem o aviso, eu não sei tirar. Então, vem aquele monte e estragou tudo. Está tudo assim... eu preciso arranjar alguém que venha me dar uma ajeitada porque eu não consigo destravar sozinha.

[L] Ai, eu também não uso o facebook. Eu sou ermitona. Eu estou na contramão.

[V] Você sabe quando você dá uma parada é interessante porque você tem... acaba responsável pelas pessoas, por exemplo, a Dorotéia era ativa, escrevia muito e também era gostoso.

[L] Tem isso também. Ai, que legal! Nossa! Eu levei um choque quando ela faleceu, eu fiquei sabendo [0:40:42]

[V] Foi uma pena. Bom, voltando aí um pouco.

[L] Bom, eu queria te perguntar, você foi professora de desenho da CIT, Coordenação Industrial Têxtil.

[V] Fui. Na Casa Rhodia.

[L] Então, eu queria que você me falasse um pouco mais sobre essa CIT, que epoca que você explica, mas como não... para mim eu não... eu não tenho acesso a isso.

[V] Tá. De 83 a 91. Porque era dentro da Casa Rhodia, na Avenida Brasil, funcionavam os cursos. Você deve ter feito lá Mari Rucki, talvez? Ou não, você já fez em hotel?

[L] Eu fiz na Escola São Paulo.

[V] Ah, você fez bem mais recente, então.

[L] Em 2007

[V] Ah, você fez bem mais recente. Certo. Então, a gente... foi o Carlos Mauro que me convidou e era... era um conglomerado de empresas que constituíam o CIT. Então, Paramount era uma delas, a...

[L] Braspérola.

[V] Braspérola. Foi um grupo grande, mas no fim era uma gestão muito Rhodia, mesmo. Eles tinham obviamente um comitê que se encontrava, fazia as diretrizes, mas ficava muito na mão do Carlos Mauro e ele depois, como eu trabalhava lá, quando a gente estruturou o curso ele não participou da estruturação, mas foi o primeiro professor de estilismo que a gente fez...

[L] Deixa eu entender uma coisa então, então essa iniciativa é [0:42:07] que o Carlos Mauro te convida a pedido da Rhodia para dar [0:42:11]

[V] Do CIT.

[L] Isso é o CIT.

[V] É.

[L] Perfeito. Então, você falou, você teve que montar tudo sozinha, deu as aulas, montou os primeiros cursos, mas aí você percebia uma atitude muito centralizadora por parte da Rhodia, na figura do Carlos Mauro? É isso?

[V] Não. Não, não. Não, porque não chegou a atrapalhar, nem um pouco.

[L] Quando você complementou, ah, mas isso é muito Rhodia. Você acredita nisso?

[V] Não, não. Em relação às outras empresas.

[L] Como assim?

[V] A Paramount Lã Sul, a... essas outras..

\section{[L] A Braspérola.}

[V] A Braspérola e tal. Ele era o coordenador dentro do CIT. Ele era funcionário da Rhodia, mas ele era coordenador [0:42:46]

[L] Competente.

[V] Isso. Então, e ele como coordenador do CIT, tinha a Rhodia... ele, era uma figura forte e ele tinha essa... esse domínio, essa coisa toda. Então, eu percebo que ele fez o Rhodia... o CIT funcionava muito mais numa gestão Rhodia do que numa gestão Braspérola, uma gestão... entendeu? É nesse sentido.

[L] Ah, você acha que tinha um certo formato, [0:43:12] no sentido de dar um atendimento bem homogêneo para todas as empresas? De repente não via as necessidades da...

[V] Não, não. Eu acho que não. Dava para todos, mas era o co... era o comitê gestor que no duro mesmo, a Rhodia era bem... tinha o grosso da... da parte de gestão até, o forte da gestão era a Rhodia.

[L] Então era quem pesava, né?

[V] Pesava, é.

[L] Quem estava aí e acabava ficando...

[V] É. Os outros, obviamente apoiavam, estavam usando e tudo. Mas uma... uma coisa... por isso que quando eu digo, trabalhei na Rhodia, eu fui contratada pelo CIT, para a Rhodia, né? Para a Rhodia, pelo CIT, quer dizer. Então era uma... uma situação assim, quer dizer, a Rhodia é quem me procurou, mas para trabalhar no organismo CIT. 
[L] Então, de repente, você sente alguma especificidade, desenho do lado das empresas, elas ficavam um pouco de lado [0:4:07]

[V] Não, ao contrário. Não, tanto... tanto que eram clientes, eram clientes que eram... compravam matéria-prima da Rhodia, né? E não só porque tinha... tinha gente da... todas as tinturarias, [0:44:22]

[L] Qual era o interesse da Rhodia em ter uma pessoa, como você, que é expoente, que é referência, já era na época, dando aula para essas empresas?

[V] O que eles queriam era formar em paralelo que eles estavam estruturando na Europa, que eles eram a Rhône-Poulenc lá na... né? Fazer aqui no Brasil.

[L] Ah, tá.

[V] E foi graças a isso que houve um fato extraordinário porque senão gente ainda estaria...

[L] Mais atrasados.

[V] Engatinhando. Tanto, quer dizer, a nossa parte... a parte criativa, a parte de trabalhos... de conceitos da moda brasileira é legal. O que se está discutindo hoje é a parte financeira e econômica, política, a entrada dos produtos estrangeiros, especialmente da Ásia, as dificuldades todas advindas disso. A gente não tem um custo tão baixo, não conseguir exportar devido ao nosso custo que é alto.

[L] A matéria-prima, né? Digamos...

[V] Então, e não tem tudo para brigar... é. Não tem...

[L] Você comenta aqui, ó, sobre o noticiário da moda que teve um papel na indústria e na Abril, né? Que é gerado pela Abril uma espécie de um comitê, né? Especializado em tendências com pessoas altamente... falta informação, também tivemos uma produção nacional, adaptação de tendência ao estilo brasileiro, enfim. E aí isso tudo voltava para as revistas, né? E a isso teve reflexo na indústria. Eu queria ter uma ideia, se você conseguir me passar de como isso foi importante. Por exemplo, em relação a iniciativas como o CIT da Rhodia.

[V] Então, a gente se encontrava, tinham trocas.

\section{[L] Se cooperavam.}

[V] Existiam trocas, a Rhodia montou, eu não sei se você chegou a pegar, ela fez uma Moda Fio que era uma exposição que eles faziam todos os livros...

[L] É, eu estudei, mas não cheguei a ver.

[V] Desenvolvimentos, né? Dos clientes deles, né? Porque, na realidade, não era a Rhodia que desenvolvia todos os fios, né? Eles faziam a... primeira, né? E os tecidos então eram feitos para as modelagens as mais variadas, coisas superdiferentes para produtos muito diferentes. Às vezes chegava lá era para fazer... era um nylon para tênis. É que a Rhodia no começo, nes época, fazia não só poliéster ou microfibra como [0:47:06] né? Ela produzia várias... várias fibras de nylon..

[L] É sempre sintético, né?

\section{[V] Sintéticos.}

[L] E esse noticiário da moda, então, tinha a conversa entre essas pessoas?

[V] Tinha. E todos eram... no fundo, eram as mesmas que iam para lá e para cá [risos]

[L] Legal!

[V] Então, o lvan trabalhou no noticiário também.

[L] Ah, é?

[V] É.

[L] Eu não falei com ele, vou até falar, eu não falei com ele ainda.

[V] Ele era o fotógrafo e ele desenhava [?][0:47:36] e depois passou a ter.. então, isso se você quiser... se você tiver interesse uma hora, então separar, que eu tenho algumas dessas coisas.

[L] Ah, eu tenho sim. Sempre ajuda para a gente entender, né? [0:47:53]

[V] Então, quando eu tiver tempo... é, você vê como é que era essa...

[L] Aí também tem uma fala sua que me chama a atenção... porque assim, eu trabalhei como estilista, né? Então, falar desse negócio na entrevista, a gente não está falando muito das etapas de projeto que eu falei tanto que queria falar, né? Mas é que... eu quero retomar, mas de uma certa. eu acho que de certa forma ela é... é claro para a gente que existe uma pesquisa, tendência...

\section{[V] Tendência.}

[L] Adaptação. Hoje a gente vê cópias no exterior... até de gente copiando a gente no exterior mesmo.

[V] É, e tem gente que nem vê, né? Que faz questão de não olhar fora. Por exemplo...

[L] Também, uma Vera Arruda, né? Que nem é ela, hoje é o marido dela, né? A Martha Medeiros. A gente tem muita coisa natural.

[V] É, são mais, assim, naturais e... e livres da mistura, também tem assim, alguma vez...

[L] E [?] o Ronaldo.

[V] É. Até eu acho que culturalmente, para quem entende desse jeito, sim, mas que perde uma ciência muito direta na... na criação verde simplesmente..

[L] Na criação de arte, assim.

[V] É. Ele é muito leonino, né? Assim, teatro, ele gosta... via muita coisa, né? 
[L] Sim.

[V] Mas ele não era um indivíduo de ficar pesquisando [0:48:57]

[L]

[V] É. isso.

[L] Tem... é, aí tem uma... uma fala aqui que me chama a atenção, depois eu quero ver... saber das suas etapas também, que você comenta... diz ter umas... as diferenças entre arte e moda?

[V] E moda.

[L] Como uma questão de criação pura, muito ligada à arte...

[V] Arte.

[L] E criação controlada, a da moda, né? Que estaria entre a estética e o comercial.

[V] Por que controlada? Porque você depende de processos industriais. Não só depende de processos industriais, como você depende de uma coisa que é o tempo, né?

[L] Da moda.

[V] Da moda.

[L] Aí entra de novo, quando eu falo processos industriais, não seria design? Será então... [0:49:43] eu vou pensar, me deu essa sensação, eu queria que você me confirmasse, eu entendi que até aqui eu vou com [0:49:47] né? Mas assim, ter esse tempo, eu já estou falando da [0:49:51] da moda, que era a cada seis meses, virou quatro, depois com Le lis blanc e os magazines do Brasil dá para a gente rodar a cada dois meses, mensal [0:50:00]

[V] Ah, a disputa Zara. Aí é a Zara.

[[L]] Zara, década de 80 é, virou uma coisa doentia que é semanal, que é o que o [0:50:07]fast fashion prega.

[V] Semanal, você tem na... na China, hoje, você tem um navio no mar produzindo para já entregar. Nem em São Paulo, essas lojas estão vindo. Precisa ir lá ver.

[L] É, essa do navio eu não sabia. Então, será que esses tempus da moda, somadas às especificidades de uma peça, será que não constituiriam então o campo da moda? Ele ser chamado o campo da moda, o campo projetual da moda?

[V] Eu acho que sim.

[L] Colaria no design, mas eu vejo que é muito complicado a gente falar que... ah, então moda é só essa coisa imaterial, a minha tese até foi.. eu vou falar... [0:50:43] de Projeto em Moda, o Material e o Imaterial no Campo da Moda.

[V] Sei.
[L] [0:50:47] dentro da moda. Eu acabei não deixando você falar ainda, mas assim, porque é fácil às vezes você falar do que é material e imaterial, jogar o material para o design e o imaterial para a moda, mas não é só essa história...

[V] Não é, de jeito nenhum. E é complicado.

[L] Entendeu? Precisa falar mais no tempo e isso é uma coisa mais ampla, mas esse tempo que vai passar ao lado, assim, do Bourdieu...

[V] Bourdieu. Hã, hã.

[L] Na moda, né? E as premissas de trabalho, inclusive as defesas jurídicas do campo que dizem que você é artista, eu sou estilista, fulano é estilista e beltrano é [0:51:21] parece engraçado quando a gente fala que tal pessoa é estilista. Ainda mais se eu falar que eu sou artista porque eu vou estar querendo comprar, caçar o simbólico.

[V] O simbólico. Ainda bem que a gente tem a moda, né?

[L] Então, justamente esses são os impactos que nós estamos falando da [0:51:37] essa aproximação foi muito interessante e já quando foi naturalmente que ela é interessada em vários [0:51:44]

[V] É uma escola de arte, né? Ela só trocou de nome, né?

[L] É uma escola de arte, ela só trocou de nome em 1929, né? Isso também acontecia isso, e enfim, falar um pouco dessa porque... como [0:51:54] mas como a gente... uma da questão simbólica, a outra... quando a gente fala do tempo, ele também controla esse tipo de processo, é óbvio, e são muito manufaturados principalmente para quem nem vê...

[V] [0:52:04] aí é que tem essa ligação do simbólico... será que eu não escrevi? Não sei. Você leu uma hora ali...

[L] Ah, sei. Fazer opções conscientes e coerentes tomadas nos quadros nãnãnã... e mais, que são funções não sendo as da criação pura serão, isso sim, as da criação controlada.

[V] Controlada.

[L] E fica [0:52:26]

[V] E descontrolada. A palavra controlada que eu acho que é porque não basta você querer fazer. Uma coisa... na área do vestuário, por exemplo, se você não tiver em mente que você vai ter que seguir um processo que é um processo que depende de máquinas, que depende de sistemas, que depende do produto final e de um tempo para ele ficar divulgado e depois exposto e vendido. Então, tem toda uma coisa que não é a criação pela criação.

[L] Como ela é gratuita na arte.

[V] Como é na arte. Na arte é muito mais aberto e até, acho, era...

[L] É, se a gente pegar um Christo ou até uma Jeanne Claude que faleceu.

[V] Era, porque hoje em dia em dia também não é, tem a arte conceitual hoje... 


\section{[L] É muito programada.}

[V] É muito programada e muito processual.

[L] Industrializada, em alguns aspectos.

[V] Então tem isso.

[L] E inclusive quando você comentou, ah, o tênis eu faço injetado, eu vou desenvolver um maquinário que vai custar tempo para eu conseguir...

[V] Reproduzir.

[L] Reproduzir no mínimo cinco milhões para eu pagar esse contrato pelo uso.

\section{[V] Exatamente.}

[L] Isso é quase inviável, pensando em moda, por causa desse tempus da moda.

\section{[V] Da moda.}

[L] Da sazonalidade, não é? Que talvez também estaria dentro do...

[V] E o mais incrível é que a palmilha é feita em um lugar, o tecido é feito em outro e ele é montado num outro lugar.

[L] Fica louco, né? Não tem mais nacionalidade.

[V] Aonde a palmilha é mais em conta, o lugar aonde ele se desenvolve que não tem essa possibilidade de produção numa quantidade e qualidade que atenda, né? As tendências...

[L] A demanda, é.

[V] De demanda e depois aonde montam. É impressionante, eu acho, assim. Mas é isso o que a gente está vivendo. Porque a globalização trouxe essa facilidade, né?

[L] A quebra das fronteiras nas grandes nacionalidades, né?

[V] A nossa dificuldade é que o Brasil é Brasil, né? Então, a gente é...

[L] Mas aí entra... eu concordo com você em termos de... isso também a gente falou de eu... essa questão de não tem isso política, que se estimule, muito pelo contrário, né? A gente ainda dá uma passo trás e dois para frente.

[V] É impressionante, é impressionante, é impressionante. Eu, apesar de... aqui entre nós, porque se...

[L] [0:54:49]

[V] A Martha Suplicy. Eu não sou nem um pouco favorável, não acho ela uma maravilha, não sei o que. Mas ela foi uma pessoa que teve politicamente um papel, assim, importante quando ela foi secretária da cultura com relação à moda. Duas aberturas que a moda teve foi... foram na gestão dela. Enquanto prefeita, para São Paulo, a São Paulo Fashion Week e depois, agora no ministério da cultura, fazendo com que a moda participasse de deter- minados projetos e podendo receber orçamento da [0:55:26]

[L] Lei Rouanet.

[V] Lei Rouanet e tudo mais, como a moda como cultura. Que é uma coisa..

[L] É um avanço.

[V] Um avanço, é um avanço.

[L] Porque a gente tenta a construção [0:55:38] saber isso também não vai [V] Não vai, né? É impressionante.

[L] Eu acho que é um dos setores que mais empregam. Você sabe que a gente também...

[V] Continua sendo. O pior é isso, né? Continua sendo.

[L] Dependendo [0:55:47]

[V] E depende muito do têxtil...

[L] Do têxtil.

[V] Empresas do têxtil, da indústria. Da figura humana lá.

[L] O que ela fez como prefeita, hein? Ela continua como ministra da cultura ainda agora. (Tinha largado em 11/11/2014.)

[V] Primeiro ela estava à frente.

[L] Sim.

[V] Ela era uma pessoa frequente e ela, num certo momento, usou marcas nacionais, coisa hoje ela pode usar Chanel da vida e tudo o que ela pode pagar as bolsas Vuitton e etc. e tal, né? Mas ela teve até um certo apelo, quer dizer, mostrando que a gente tinha condições. E ela fora também do Brasil, ela conseguiu projetar alguma coisa.

[L] Será que isso... aí, simbolicamente, nós vamos de novo para a questão simbólica. Não tem a ver também com um fazer doméstico ligado ao ambiente feminino, sempre desvalorizado.

[L] É uma questão machista. Vai falar que hoje não existe machismo hoje? Por favor.

[V] É uma questão machista, machista. Pode ser, mas se você pensar bem, tanto que existem capitães da indústria, a maior do pe... das pessoas que militam, né? $\mathrm{Na}$ indústria têxtil são homens. $\mathrm{Na}$ indústria têxtil.

\section{[L] Certo. [0:56:56]}

[V] Empregam... mas se você for pensar também, a maioria continua [0:57:00] Tem muita mulher no setor.

[L] Não, e os que brilham, né? Você pega numa Fashion Week... não é um setor que majoritariamente, constituído majoritariamente por mão de obra feminina, seja no setor chão de fábrica ou no setor projetual, no pensamen- 
to, no planejamento o número que a gente vê de nomes no jornal, assim você fala de uma Faschion Week, isso no mundo também, é sempre maior masculino.

[V] Né? Na maioria é masculino, né? Eu até fico assim... contente de ver que depois de... nas escolas, e não só a Santa Marcelina, das escolas em geral, você vê muita mulher trabalhando.

[L] Tem a sua própria marca, né?

[V] Ou trabalhando...

[L] Como coordenadora de produtos...

[V] Pois é. Você vê a... aquela menina que foi nossa aluna, outro dia eu ainda estava lendo umas coisas a respeito do que ela tinha feito. Ai! O Tufi Duek era dono da...

[L] A Karen.

[V] A Karen. A Karen Fuke.

[L] A Karen Fuke Tivemos uma entrevista com ela.

[V] Chegou lá?

[L] Cheguei [risos]

[V] Então, é uma que se fez... eu acho que tem uma trajetória incrivel, sabe? Então...

[L] Ela se dedica...

[V] E ela se dedica demais. Então, para você ver, é uma pessoa que de estagiária, ela foi se dedicando, botando os seus... se dedicou à marca, né? E ela está bem, né? Ela é diretora. Ela leva para a frente, né?

\section{[L] Ela assume, né?}

[V] Não é uma empresa... e ela..

[L] [0:58:30] ela assume mesmo [0:58:32] A Fórum eu acho também, né?

[V] Eu acho que a Fórum, não.

[L] A Fórum não tem mais, é... é...

[V] Eu não sei qual é... outra equipe, acho.

[L] É, ainda tem o grupo AMC [0:58:40]

[V] Então, porque não, a Carina é Duek, tudo bem, Duek é a marca dela mais a assistente... que é assim, uma tem o nome do pai, a social é dela, né? Agora, nesse caso não, é uma pessoa que não é da família e que tem a direção da marca, da empresa, tudo.

[L] Que rege a coisa, né? Está à frente.

[V] É. Isso é... não era tão comum, o que era comum, no tempo em que eu comecei a dar as aulas na Rhodia, era assim, a mulher do diretor, do dono da empresa que tinha bom gosto, entre aspas, por saberem isso, e resolvia fazer a roupa de jeito, do outro, do outro, do outro. E o que é que queria dizer isso, né? Era a desarticulação total, né? Porque não tinha... se você quisesse ir lá na... para poder dar uma olhada no que é que tinha, qual que é o conjunto dessas... dessas peças, não tin... não teria a mínima situação...

[L] Não tem coordenação, né?

[V] Não tem coordenação nenhuma. Não tem...

[L] Mix de produto, valor de coleção

[V] Não era coleção. Completamente sem plano de coleção.

[L] É, isso...

[V] [0:59:44] A gente fala que a moda não é roupa, né? A roupa ou a arte de você saber fazer uma coleção, a estrutura de uma coleção, você aprende, então, tem menos [0:59:59] que é mais do que a questão do estilo. Nossa! Aqui tem tanta coisa para dizer que é muita coisa [risos]

[L] É muita coisa. Eu li, você vê que eu tenho um monte de dúvidas, né? Realmente é amplo. Hã... ah, eu queria te perguntar, como é que foi o encontro... criação controlada, isso não se coaduna com a ideia de projeto de design? A gente já falou um pouco sobre isso, né?

[V] A gente já falou um pouco, né? Até onde vai o conceito de arte dentro da realidade da moda? É possível mensurar, compreender?

[V] Eu acho que é o seguinte, a arte influenciou a moda e, hoje em dia, existe... é de mão dupla.

[L] Embora neguem [risos]

[V] Está certo?

[L] Tá.

[V] Existe uma... eu diria, quase complementaridade em alguns momentos. Então, eu acho que é assim, é difícil você separar aquilo que é visual e a... a moda é essencialmente visual, dos conceitos e dos elementos constitutivos da arte: forma, função... a função, forma, ponto e linha, plano, cor...

[L] Arnheim.

[V] Toda aquela... tudo aquilo já envolve efeito de...

[L] Os efeitos...

[V] Composição. Você tem que levar tudo isso em consideração. Você está usando os mesmos elementos, só que você está constituindo uma coisa, um resultado completamente diferente.

[L] Tá. E em relação à... à criação controlada, você acha que pode... tem relação com a arte?

[V] Tem relação com a arte. Pois é, mais o projeto do que design, né? 
[L] Mas eu consigo relacionar o design também com a ideia de projeto...

[V] Pode, pode. Especialmente se você... eu... é como eu te digo, assim, a questão do calçado, a questão da estampa...

\section{[L] Para você são mais...}

[V] Para mim é tão... muito.

[L] Design.

[V] Design. A joalheria... você vai falar, e a joalheria, eles não ou... não dizem muito que a joalheria... design de joias, design de joia?

\section{[L] Isso.}

[V] Então, eu acho que tem uma coisa o seguinte, tinha o estilismo em joalheria que é o que a gente faz... fazia na faculdade.

[L] Isso, com gesso, com a Beth Salles.

[V] faz, trabalha prata, trabalha [1:02:33]né? Quer dizer, você tem a parte técnica, você tem... mais antes... tem que conhecer a parte técnica, você tem uma elaboração que vai muito além da parte técnica. E essa elaboração, o que é que ela é?

[L] Ela é mais afeita ao campo da moda...

[V] Da moda...

[L] Do que do design.

[V] Do que do design, lógico.

[L] Eu fico satisfeita, só pode ser isso, né?

[risos]

[L] Já tem gente lá fazendo mestrado falando sobre joia na FAU, daí fica essa discussão.

[V] Já tem essa discussão?

[L] Eu percebo que eles... se deram um tempo.

[V] A Eliana Gola está fazendo doutorado?

[L] Eu acho que é mestranda nessa turma.

[V] Eu acho que mes... mestrado ela fez, eu não sei se ela já fez doutorado.

[L] O nome... eu já falei para você, agora eu não sei te dizer. Não, eu te devo isso. Se eu lembrar, eu falo.

[V] É, pois é, de repente... tem tanta gente, né? Que...

[L] É, realmente, até a próxima eu lembro, mas nesse momento...

[V] Agora você me trouxe essas duas obras para ver se eu conhecia...

[L] Ah... [1:03:31]
[V] Estão em português?

[L] Estão. É que hoje são bibliografias básicas. A Doris Treptow, a Sue Jenkin Jones e você sabe que o Simon Seivewright infelizmente até faleceu o ano passado, muito jovem.

[V] E é fácil da gente achá-los?

[L] Estão esgotados.

[V] Ah.

[L] Eu posso tentar procurar...

[V] De quem era?

[L] Não era de ninguém, são só autores recentes, mais jovens...

[V] Não, eu sei, mas de que... de que...

[L] Editora, a Bookman.

\section{[V] Puxa!}

[L] Esse eu acho que a gente ainda acha com mais facilidade, se não achar novo, acha no Estante Virtual, você vai achar novo no Estante Virtual. Esse eu comprei o último na Martins Fontes, mas eu liguei lá e falaram tem um no estoque (sobre o livro dos Renfrew).

[V] Design de moda volume 4.

[L] É uma coleção.

[V] Ah, tem outros?

[L] É. Se você olhar aqui na orelha, você tem toda a coleção. Tem de moda, tem outros com design também.

[V] Hum, hum. Isso é legal! Bacana a coleção.

[L] É, ele é legal. Se você quiser ficar com ele, depois eu pego. Não sei se você já leu. É bem bacana.

\section{[V] E esse aqui?}

[L] Esse é bem bacana. Bom, aí existe uma preocupação com uma criação nacional, né? De interlo..

[V] Isso. Então, é importante você ver aí quando eu falo...

[L] Você fala em buscar identidade própria e sobretudo autonomia cultural. Eu anotei aqui todas as falas em que você faz menção a uma cultura, ó. Se você pudesse só comentar, aí você... ter elementos sempre o estilo da vida brasileira...

[V] Isso.

[L] Na página 168. Aí, 179...

[V] Não adianta você fazer Armani, cópia de Armani e vender na Itália. 
Não vão querer comprar.

[L] Já tem, né?

[V] Já tem, né? Com uma excelente qualidade.

[L] É verdade.

[V] Então, se vo... quem quer, inclusive, exportar e tudo tem que ter uma característica que não... obviamente não tem nada a ver com o folclorismo, nada com sair vestida de baiana, não é isso que eu estou falando, mas quer dizer, eu ser o sentido, pensar o... a forma de se relacionar do brasileiro porque tem que retratar esse lado para você conseguir que o outro se interesse pelo seu produto.

[L] Ser inédito.

[V] É. Tem que ser inédito sob o ponto de vista de uma criação autoral e que reflita também o Brasil. O que é que as pessoas esperam? Quer dizer, o que buscam? É que o Brasil... eles acham que é tudo muito promíscuo porque é tropical e a gente faz roupa[1:06:01], né?

[L] São Paulo, né? A ética aqui é puritana, do trabalho.

[V] É, sobre isso.

[L] É o que as pessoas imaginam.

[V] E você tem uma possibilidade de ter uma outra visão...ou por que é que os nossos estampados, eles fazem o maior sucesso fora?

[L] Arte Nativa Aplicada, né?

[V] Imagina, né? A Maria Henriqueta, a gente...

[L] [1:06:25] pioneira, né? Depois teve muita gente que copiou essa loja e essa ideia. O que ela também difundiu, né?

[V] Difundiu. E ela ainda pesquisa os livros de [1:06:35] né? Nossa! Que pessoa querida, viu!

[L] É. E porque a gente é cidade também, né? Esquecem disso às vezes. A gente é um ente urbano, né?

[V] Não, e aqui... a gente tem que lembrar que São Paulo não só é uma metrópole como é uma, sei lá que cidade maior do mundo, que é um caldeirão de misturas..

[L] É, você falou, diferenças regionais...

[V] Regionais e étnicas, né? E...

[L] Dentro de um ambiente a gente já tem inúmeras, né?

\section{[V] Inúmeras.}

[L] Aí eu peguei mais algumas, deixa só eu ver se tem alguma que fala do folclore aqui também. Que a Mari Rucki fala nesse sentido, né? Então você fala da Mari Rucki, na verdade aqui até elogiando, fala que ela comenta, né?
O Brasil está ligado à ideia de muita vegetação e muita luz. O brasileiro deve respeitar a sua própria possibilidade, tradição e cultura para oferecer uma contribuição adicional à moda universal. Quando a gente fala de muita luz, sol, vegetação não estaria caindo um pouco no folclore a fala dela? O que é que você acha, hein? Eu nisso... eu sou um pouco crítica [1:07:36]

[V] Não, eu acho que não. Eu acho que não.

[L] Mas como você... você deve ter tirado de uma fala maior, eu queria entender a...

[V] Aí, eu acho que eu estava lá. Não sei, deve ter a referência aí.

[L] Tem, tem. Deixa eu ver. Essas palavras foram pronunciadas pela Mari Rucki quando de sua estadia em São Paulo para ministrar curso pela CIT.

[V] Está vendo? A gente dava aula, ela numa sala e eu na outra. A gente estava até ao mesmo tempo, como colegas...

[L] Enfim, eu acho que a questão do nacional aí... tem mais uma menção aqui. Características brasileiras aparece também. Como a minha preocupação não é tão prática, [1:08:19]

[V] É. O design é visceral, eu acho que isso tem que ser feito.

[L] À luz de tendências internacionais adaptadas aos locais. A gente ainda importa muita tendência, embora hoje já seja até difícil de se falar de onde vem.

[V] De onde vem, né?

[L] E com que rapidez.

\section{[V] De onde vem.}

[L] Mas a gente ainda importa..

[V] Não é o caso de fazer vestido com palhas ou coisa... com palha de coco.

[L] Vestido de coco.

\section{[V] Não é, né?}

[L] Não, mas... você acha que a gente... você é favorável a importar tendências, assim, ao invés de trabalhar conceitualmente, mas adaptá-la? Você acha que ainda está acontecendo? Você vê no mercado mais alguma piora, melhora? Como é que está?

[V] Sim. Não, eu acho que... parece assim, ainda tem muita coisa que... vaquinha...o boi vai, a vaca vai atrás. Eu ainda acho que tem.

[L] Magazine não é?

[V] Magazine.

[L] O mercado popular.

[V] Exatamente. [1:09:12] Mesmo quando está falando dos shoppings e das grandes redes. Exatamente. [1:09:19] sabe, assim? É diferente. Você 
tem... tem várias possibilidades, vários... o gosto da população ainda é... eu acho.

[L] [1:09:31] Hum, bom.

[V] Agora, o que nós estamos vendo no [1:09:38] jovem, assim, a moda está... eu acho que... quer dizer, o importante é que ela seja democrática. Ela tem que atingir a todos, né?

[L] Democra... eu vou complicar a sua vida, democrática ou acessível?

[V] Poderia ter sido [1:09:55]

[L]

[V] É.

[L]

[V] Você falou?

[L] Eu falei democrática, o pessoal me perguntou isso. Eu pensei...

[V] É, democrática no sentido de que é uma proposta fazer com que todos tenham acesso...

[L] Tá.

$[V]$ À roupa ...

\section{[L] Roupas pessoais}

[V] Minimamente e que essa roupa tenha uma boa qualidade. Você não precisa fazer produtos simples para pessoas pobres. Você pode e deve fazer legal, o melhor possível..

[L] Isso melhorou muito, você não acha?

[V] Eu acho. Isso melhorou.

[L] Qualidade virou um pressuposto básico.

[V] Se a gente fizer até um paralelo, eu estava olhando outro dia, comigo, chegou um encarte da Casas Bahia. Essa era uma coisa assim tão impossível, você olhar um sofá na Casas Bahia não dava, né? Hoje em dia deu até... deu uma melhorada, eu acho que eles também perceberam que podem trabalhar uma coisa... sabe? Melhor acabada, uma... com uma parte ergonômica melhor resolvida.

[L] Mais bonita [1:10:58]

[V] Era uma coisa muito esquisita, assim, a proporção do encosto com o assento não tinha nada a ver.

[L] Conforto também. Com beleza.

[V] Com bele... é, sabe?

[L] $O$ jacquard.
[V] Eu acho que deu... deu uma melhorada. Então, é isso que eu falo, porque ser o democrático, eu acho que o democrático... democrático, dar um bom, aquilo que é interessante. Não é... né?

[L] Colocar qualquer coisa.

[V] Pôr qualquer coisa só porque é [1:11:23]

[L] É, eu acho que isso até depende, já tenha vindo antes na moda, né? Aquela substituição rápida, a gente tem essa possibilidade.

[V] Tem essa possibilidade.

[L] Eu lembro que na minha faculdade a possibilidade era pressuposto básico você ao [1:11:34] você tem regatinhas... tinha quatro reais, [1:11:37] ela pode ficar aqui, mas ficava a barriga aparecendo.

[V] Entendo, é.

[L] Não é roupa para todo o mundo, para o alto, para quem tem mais peito, mas ela, em geral, está com uma [1:11:48] reguladinha, um [1:11:49] bem feitinho.

[V] Qual que você falou?

[L] Dorinho. A Dorinho é Masculina, até uma...

[V] Eu não conheço Dorinho.

[L] A Dorinho é uma de masculino social, bem popular.

[V] É?

[L] Bem popular mesmo. Ah, mas tem a Caedú que tem feminino.

[V] Ah, legal, eu vou reparar.

[L] Não, tem, depois se você quiser eu te passo, eu faço uma aula sobre isso na Santa.

[V] Olha que legal?

[L] De segmentação. Elas ficam chocadas com o que vem.

[V] Ah é, é?

[L] Bem-vindo ao mundo onde a maioria das pessoas compra roupa. Magazines. Se elitizaram.

[V] Se bem, você viu uma Riachuelo querendo usar essas...

[L] Chamava a Cris Barros.

[V] É.

[L] A Cris Barros.

[V] A Cris Barros, é. E agora tem Versace, você acha?!

[L] É. 


\section{[V] Você acha?}

[L] É, mas é... eu acho que é... é ... realmente em busca de aumentar o capital simbólico da marca.

\section{[V] Da... da marca.}

[L] É, vai por aí. [1:12:47] da própria marca.

[V] Claro.

[L] Esse valor se aproxima algo com mais valor para...

[V] Realmente, para poder dar um up.

[L] Aquele valor, é um tanto melhor.

\section{[V] Está certo.}

[L] Dentro da Santa, que é o seu conhecimento maior, você percebia que existia uma disciplina que norteava os demais ou não? Que tinha peso igual.

[V] Não, tinha um equilíbrio.

[L] Tá. Eu imaginava.

[V] Agora, sempre lá, isso teria que ver isso daí com as outras discussões, por causa do histórico da arte e mais o desenho têxtil, portanto. Ele inclusive ficou uma segunda forma, assim, de transmissão oral, dos desenhos que levaram ao projeto.

[L] Ah, entendi, mas aí como um desencadeador, como a maior forma de expressão do projeto.

[V] Isso, do projeto.

[L] Ah, então considerar a moda uma área autônoma, você também concorda com isso?

\section{[V] Sim.}

[L] Você acha que deve ser considerada ou a gente ainda tem um problema por não ter prova (de Enade, nem diretrizes curriculares). Parece que vão gerar provas para a moda, agora. Está uma tragédia.

[V] Eu acho que sim. Agora que... está mais do que na hora isso, quer dizer...

[L] A gente acabou fazendo [1:13:50] tecnológico uns anos, né? Fomos muito bem. Aí atingiram no tecnológico. E não precisava para curso de dois anos.

[V] Não acredito.

[L] Era uma...

[V] Fizeram uma confa generalizada na prova. A primeira... uma das provas que eu até estive acompanhando, em 2009 foi a última que eu estive mais perto, assim, o horror da prova porque não tinha uma citação que fosse ligada à moda. $\mathrm{O}$ evento... a diferenciação que estava lá era de uma cadeira, porque é desejável que o aluno até saiba. $\mathrm{O}$ aluno de moda, eu acho que estruturalmente, é bacana. Mas, quer dizer, sabe?

[L] Tá, precisa ter uma [1:14:29] de design.

[V] Reconhecer [1:14:31], tudo bem, deve ser legal você saber. Mas não é.. né o seu fort...

[L] Paradigmas da cadeira são os quatro pés e o encosto e o assento. [risos] [1:14:43]

[V] Não e se essa... primeiro[1:14:48] da cadeira.

[L] Em geral não [1:14:53]

[V] É, não, não é tão impossível, mas é assim, é uma Mackintosh ou é uma, sei lá? Sabe? Quando eu estruturei o curso, tinha a história do design também e aí era superlegal. Na época, você... acha aí [1:15:11] você vai ver que tem...

[L] Essa é uma grade aqui mesmo, olha.

[V] Então, era uma proposta de grade. História da Arte e do Design.

[L] Deixa eu dar uma olhada?

[V] Então...

[L] Deixa eu achar aqui. Ah, tinha arquitetura, [1;15:29] teoria... história da arte, história da moda, folclore, estudos dos problemas brasileiros, [1:15:35] tecnologia, metodologia visual, laboratório...

[V] Então eu acho que não está porque era História da Arte e do Design. Era uma disciplina que...

[L] É, só tem história da arte.

[V] No primeiro ano era história da arte...

[L] É, é que o currículo do primeiro ano.

[V] É. E depois... e no segundo... [1:15:48] e no segundo ano era história do design.

[L] Tá. É.

[V] E aí o que... era muito importan... muito interessante isso, eu acho. Depois isso foi mudando com o tempo porque acharam que estava englobando demais a... sabe? Tem uma hora que você tem que fazer uma... tem que suprimir alguma coisa.

[L] A FAAP ela está dando aula de design, você sabe, né? É uma aula, como você falou, uma disciplina, continua uma disciplina, [1:16:12] e da história, resistência do material [1:16:15] tudo junto e os caras falando as maiores bobagens [1:16:18].

[V] Eles se acham. Você vê a resistência dos materiais que é um negócio super profundo... né? 
[L] Não tem nada a ver. São técnicos. Plástico, metal, alumínio.

[V] Tudo. Os materiais mais... variadíssimos, né? Super variados [1:16:30]

[L] A gente não dá conta de dar essa... essa questão dos materiais fora da coluna têxtil. [1:16:36]

[V] Não, e... pois é, porque fica... e ainda se souber bem, tela faz o cetim... [L] Já é [1:16:53]

[V] Já... [1:16:54] né? Já é um começo.

\section{[L] [1:16:56]}

[V] E tudo... é um mundo, [1:17:00], né? Agora, por exemplo, tinha um tecido que chamava Cloquê numa certa época. Depois ele veio o mesmo, obviamente, mudou de [1:17:10] aí já tinha outro nome. Tinha outro nome... tinha outro nome... tinha outro nome, então...

[L] É o que, o cloquê? Eu não conheço.

[V] O cloquê é um tecido... ele tem um... ele é um cloquê, é uma... uma... [1:17:21] uma coisa assim.

[L]

[V] Então, esse era o cloquê. Então, a pessoa... por isso é que se pelo menos souber...

[interrupção]

[V] Pelo menos souber os quatro... as quatro possibilidades, as variantes, né?

[L] Básicos.

[V] Básicas, minimamente não vai errar, né?

[L] [1:17:46]

[V] É, o que é que é malha, né? O que é que... tem que conhecer, né?

[L] [1:17:53]

[risos]

[V] Não é? Bem a malha, malha mesmo.

[interrupção]

[L] Aí... hã... bom, categorias de produto e segmentos do mercado. Não... ah é, eu queria te perguntar, eu acho que não é [1:18:13] mas só para confirmar, para você elas parecem mais... hã... específicas na moda do que no design?

[V] Repete, desculpe.

[L] Nas categorias de produto e segmentos de mercado no... são mais específicas na moda ou no design?

[V] Eu acho que sim, são mais específicas.
[L] Deixa eu ver aqui só o texto [1:18:33] está meio óbvia.

[V] Não é... não é aquela hora que eu dou uma listagem monumental de tudo o que tem na moda e no design? Na moda?

[L] Pode ser. Aqui os gráficos, pesquisa de tendência... e deixa eu ver se eu acho aqui essa coisa. No que for categorias de produtos e segmentos de mercado. [1:18:55] Agora eu não vou lembrar o que é. Deixa eu aproveitar para fazer uma outra coisa aqui, você fala em colorido e estilo, em 93, né? Você usava muita cor. O que é que você define como "colorido-estilo"?

[V] Porque é o seguinte, é o colorido do desejo estruturado a partir de uma... de uma sensibilidade. Então, você vai falar assim, eu vou usar azul. Mas o que é que pode ser esses azuis?

[L] Azul claro...

[V] Azul do mar ou o azul... [1:19:26] Prússia, cobalto, os azuis das tintas. Eles são os azuis da sua sensibilidade, você vai determinar às vezes o nome. Então, eu lembro bem na Rhodia uma vez fizeram uma cartela de cor e na hora de estruturar a cartela de cor chega uma pessoa com aquele azul, o tratamento para ter ideia do azul por causa disso, que é o papel que enrola o algodão.

[L] Tá!

[V] E é um azul bastante específico. E uma outra pessoa trouxe um pedaço de concreto do chão. Ela trouxe do chão mesmo, assim. Então, eram aquele... aquelas cores. Essas... se você pegasse um pedaço de concreto e transformasse numa cor.

[L] Usa o carbono, você vai definir qual era...

[V] Qual é o tom do carbono, qual... se ele é o mais arroxeado ou de fundo mais pesado e se ele [1:20:21]

[L] Tá.

[V] É isso.

[L] Ou se é mais vermelho. É, a gente...

[V] Porque falar ver... vermelho é outra coisa. Você fala vermelho. Na sua cabeça, vermelho é verme... é aquele ver...

[L] [1:20:32]

[V] É. E é esse... é esse vermelho dessa cor é uma cor que a sua sensibilidade é que vai dar porque você vai pensar nele articulado com alguma outra cor. Então, não é a cor pela cor, é a cor...

[L] É isso na comunicação de cor, né? Eu lembro que na UAM a gente dava o jogo do brincar... eu tirava [1;20:55] que era brincar de foco na cartela de cor para... ah, agora só com frutas, então só com... e tinha que ir achando uma coisa que [1:21:04]

[V] Achando semelhanças, né? 
[L] A gente achava que... e tinha também nessa mesmo [1:21:08] esses... os sentidos [1:21:11] que escapava.

[V] O emocional e tudo. Hã, hã.

\section{[L] Passava dias, assim.}

[V] Até descobrir o que isso podia ser, né?

[L] Engraçado como tem cores que viram, né? Que nem o nude que... pegou...

[V] Pois é, pegou, né? Pegou como nome e pegou como...

[L] Como conceito.

[V] Como conceito. E o que é que é branco colorido? Na moda tem preto colorido.

[L] Branco colorido.

[V] Branco e preto colorido. No têxtil.

[risos]

[V] Off whites e off whites, né? Você vê bem como é que você... esses são os grandes mistérios...

\section{[L] [1:21:47]}

[V] As cores do estilo, não é branco branco, não é branco óptico que se... né? [L] Sim. [1:21:54]

[V] Você tem essas possibilidades. Então, na luz negra tem aquele branco, assim, né? Então é o branco que ele é ligado a um dado sentido.

[L] Será que essa sensibilidade, ela não acontece porque a roupa, ao contrário do sofá, a gente senta no sofá muitas horas, mas a roupa, ela está sempre sendo colada no nosso corpo, ela é um primeiro habitáculo...

\section{[V] Lógico.}

[L] Antes dos objetos de design da casa e a gente comporta ele onde a gente quer que [?]. Será que não é por isso que a gente tem essa necessidade de estabelecer uma relação quase afetiva?

\section{[V] Com a cor?}

[L] Com a cor, com a matéria..

[V] Com a matéria. Com a matéria também, eu acho.

[L] De apelar ao lúdico quando a gente fala de moda.

[V] Eu acho. É, de moda.

[L] $E$ ao mesmo tempo será que isso não desmerece a moda em função de uma racionalidade advinda do design e da forma [1:22:41]
[V] Não porque se você pensar que a arquitetura a gente está falando de uma coisa tão... de um saber bem... bem e tal...

[L] Delimitado. É.

[V] Delimitado. E se você for feito... pegar o estudo da cor deles é o mesmo que o nosso, é dentro da mesma coisa da sensibilidade..

[L] [1:2:59]

[V] Da maté... é a mesma coisa.

[L] Tá. É, mesmo na arquitetura tem um caráter racionalista, né? No... se a gente pegar o aspecto do período moderno por exemplo, e a gente percebe que isso contaminou, né? Desde a Bauhaus até a Escola de Ulm da década de 60 , esses preceitos de forma seguem a função, não é?

[V] Hã, hã.

[L] Isso parece que é muito contrário à moda, né? Ele faz sentir isso...

[V] Não, não... exatamente não segue. Porque se fosse o caso não teríamos usado em outros períodos os sapatos das chinesas, não teríamos usado o espartilho, não teríamos usado saltos 18 , não teríamos usado... nada disso é ergonômico, nada disso...

[interrup̧̧ão]

[V] Então vamos retomar.

[L] Deixa eu... é, deixa eu tentar acelerar também para não te cansar muito. Bom, estilista autor como designer autor... tem uma hora em que você comenta que o estilista, ele pode agregar valor à marca. Ele pode interessar para a marca como forma de valorizar a marca. Você não estaria comparando ele ao autor, ao artista ai?

[interrupção]

[L] Isso não passa só por uma questão da qualidade do trabalho, né? Mas se ele conseguir..

[V] Isso é o trabalho e é o nome que ele já adquiriu

[L] Justamente, o nome, né?

[V] O nome. É uma valorização de marca, ele funciona como uma..

[L] Você não acha que isto é nocivo em termos de projeto? Assim, no campo do espaço social, do espaço público?

[V] Não, eu acho que não, porque senão as pessoas não teriam também como ter uma promoção. Porque isso pode representar uma promoção para o próprio estilista, quer dizer que se ele vai para uma outra marca, ele vai levando [1:25:50] Ele vai ser reconhecido pelo seu próprio trabalho.

[L] [1:25:55] 
[V] Eu... é, eu acho que é uma possibilidade interessante ser uma... você é uma estilista, você não foi de uma marca para outra e certamente você não... não foi bem vista quando foi recebida numa marca?

[L] Sim. Trabalhei bem.

[V] Então, eu acho que para a pessoa, isso reverte como um ponto positivo, quer dizer, ela se vê de uma maneira, assim, sabe o que está contribuindo, ela não é um mero prestador de serviço pelo serviço.

[L] Tá. É porque a gente percebe que em design, acontece um pouco isso... tem autores que são um pouco contra essa ideia do designer autor, embora no Museu da Casa Brasileira, a maioria dos[1:26:38] nada, entendeu?

[V] É.

[L] Mas, espaço do aspecto público, social do design de [1:26:45] do design como projeto industrial e não fomenta o starsystem...

[V] [1:26:50] Mas é uma reconquista da década, então, eu acho porque eles vão falar [1:27:01] ainda, né? Porque...

[L] É, porque essa lógica do designer autor, ela faz sentido a partir da década de 90 , né? Cores aparecem, o rádio não parece mais rádio parece bonequinho...

\section{[V] É. [1:27:14]}

[L] Mas tem ainda quem critica. Eu não sei se é de um longo tempo de formação também.

[V] Também. Talvez.

[L] Porque a gente vê isso em faculdades como a ESDI essas coisas são muito terríveis, lá.

\section{[V]}

[L] Mas eu acho que nos dias de hoje..

\section{[V] Falar Bauhaus não dá, né?}

[L] Até porque a Bauhaus naquele contexto tinha um aspecto crítico.

[V] Sim. Tinha um assédio continuo porque todo o mundo estava [1:27:42]

[L] Eu acho que o problema maior [1:27:44] porque veio a universalização, o pessoal já estava sentindo um processo de guerra.

[V] Isso. Também. Está certo.

[L] [1:27:50] e tinha uma questão política, né? Atrás disso, né?

\section{[V] E militar.}

[L] Bom, tem também... ah, e aí surgiu um problema. A disciplina deveria se chamar estilismo. E aí eu tenho estilo... eu só coloquei aqui estilo como estilo "clássico" e estilo como projeto. A gente já falou nisso.

\section{[V] Já falou. É.}

[L] Tendência com papel dominante. Diante de tanta heterogeneidade cultural de públicos e comportamentos qual é o papel das tendências em relação ao projeto. [1:28:19] já falou. Percebe-se muita cópia inclusive... eu estou mais passando [1:28:25] eu até já falei...

[V] Vai, vai. Porque aqui é... mas é igual o que você estava checando.

[L] Percebe-se muita cópia inclusive entre marcas do exterior mesmo, não é?

[V] Olha, só para te dar um exemplo, o primeiro São Paulo Fashion Week, ainda não era o São Paulo Fashion Week, era o...

[L] Morumbi Fashion.

[V] O Morumbi Fashion. O que deu de Prada e de Gucci. [1:28:43]

\section{[L] Desfilando.}

[V] Desfilando.

[L] Homenagens, como diz o João Braga.

[risos]

[V] Foi impressionante. De você achar num... de uma ou... de uma marca na outra a mesma estampa. A única coisa que mudou foi o tamanho, entendeu? Quer dizer, foram beber na mesma fonte, não tiveram nem a criatividade de recriar.

[L] Você acha que a projeção de um desfile então fez o pessoal se movimentar.

[V] Nossa! Eu tenho certeza que fez isso.

[L] Para não passar vexame.

[V] Pois é. E uma das coisas que me prega na faculdade é a não cópia. Isso aí... o trabalho copiado é básico. É impossível a gente aceitar alguma coisa nesses termos.

[L] Eu tinha um professor que achava referência a um trabalho que eu não tinha pensado [1:29:37] mandava fazer de novo. E era recebido como uma espécie de agressão você se afastar justamente para conseguir se diferenciar, dissociar.

[V] É. Exatamente. Então, você pode imaginar [1:29:50] Prada e uma série de marcas. Tudo bem, você vai buscar na fonte, mas você não pega uma estampa do próprio e refaz a mesma estampa.

[L] E que não era só venda, né? Ele surge... o evento dele... essa situação, talvez inicial, se perdeu [1:30:06]

[V] E a minha preocupação foi de fazer bonito. Era bonita a estampa. Ótimo. Bonita. Mas a mesma? Aqui e lá ser feito. Cada um fez como... Depois eu acho que essa questão da sensibilidade, da variação, da... se começou a falar em autoria. É depois de... é por isso que o Paulo teve uma... o Paulo 
Borges teve uma importância monumental para isso. Porque essa concepção de... de conjunto, desse caldo fervilhante ali, todo o mundo queria fazer (abstrato?)[1:30:40]

[L] Daí veio a semana de moda.

[V] Daí veio... é... de moda.

[L] E tinha um aspecto até mais vanguardista no final da década de 90 até 2000, 2005.

$\mathrm{V}=$ Eu acho que sim.

$\mathrm{L}=$ Depois volta a ficar mais comercial, mais.

$V=$ Tem a ver com o momento político né, depois de 2009 piorou, teve uma crise violenta...[1:31:09] e agora no Brasil vamos ver o que vai acontecer neste próximo ano. Temos muitas restrições.

$L=$ Espero que a gente não enfrente um novo 2009, né?

$V=$ Talvez pior, porque o de lá...aquele era externo. Aqui o clima interno é muito ruim, né?! Eu vejo assim, muita preocupação porque pessoas para fazer bem feito hoje em dia a gente tem. Porque a turma que está hoje trabalhando... a mai...[oria] grande parte dessa discussão são as saídas das escolas, né? Com 157 escolas no Brasil eu te diria que a grande maioria não tem nem a projeção, nem a qualidade, nem os meios porque estão em locais que não vivem a moda, que têm dificuldade de ver os elementos. Agora, eu acredito que mesmo assim tenha sido de colaboração para o [pouco, povo] Mas assim, nos grandes centros, São Paulo, Minas, Rio de Janeiro, lógico que para o produto, a parte de [01:32:20]de malharia muita coisa, Cianorte no Paraná, [L] o jeans, [V] isso, muito bem desenvolvido ou então os jeans lă no Piauí, né?! Piauí faz muita coisa, faz para a Guess, Gap, Diesel..

L= Que é mais barata a mão de obra, né?! Bom então, eu ía até te perguntar se essa questão dos comportamentos e tudo mais, da heterogeneidade de públicos de comportamentos não sei se isso afetava a questão da identidade nacional...você já respondeu a uma pergunta muito parecida. Essa obsolescência que não é a obsolescência programada, mas que é perceptiva a minha blusa não acabou, mas não está mais na moda, por mais que eu não queira, quando isso incomoda você substitui. Você acha que isso afeta a ideia de estilismo, do fazer estilismo, projetar como uma atividade produtora de sentidos mais profunda ou atividade mais sensível, ela acaba sendo afetada por esse excesso de substituição? Acaba levando à cópia, senão à cópia do de fora, à cópia do seu próprio trabalho. $O$ que vendeu. Eu pego relatório e mudo de cor.

$V=$ Talvez sim. Mas pelo que eu vi, eu não acompanhei de perto esse ano eu não estive fora eu não tive oportunidade de sair, mas o que eu vivia sempre demais [1:33:49] e tal, a moda volta ao bem feito, ao quase clássico. Você reparou como muita coisa mais durável, no sentido de você provavelmente vai usar não uma estação, você vai usar várias estações a mesma peça.

$L=$ Uma reposta ao fast fashion.
$V=$ Ao fast fashion, eu acho que sim.

L= Já está saindo, na Europa já tem [uma tendência nesse sentido].

$V=$ Não Europa já está tendo isso. Eu achei França, Itália isso ficou muio evidente. Agora eu sempre acho isso. França, Paris....delícia que é Paris, funciona como a vitrine do mundo, né? A francesa mesmo não tem essa preocupação de estar mudando, de estar tararátarará..

\section{$L=$ Ela tem que estar bem vestida}

$V=$ Estar bem vestida ponto. $O$ manteaux dura 12 anos lá, não é um por estação. Uma roupa assim, principalmente roupa de inverno..

$\mathrm{L}=\mathrm{Sim}$ eles conservam

$\mathrm{V}=$ Conservam e ninguém faz uma coisa tão, que mude tanto a forma, que seja tão inconveniente no uso, no corpo, né?! Justa demais, agarrada ou ombro muito exagerado nada [disso]. Porque é exatamente para ter uma durabilidade um pouco maior. Eu acho que isso está voltando, tá. Está acontecendo e é interessante que depois do japonismo na década de 80 teve uma coisa assim mais uma volta ao clássico.

\section{$\mathrm{L}=$ Minimalismo, é!}

$V=E$ agora a gente está tendo, eu acho, um revival dessa situação de ...Eu gosto dos... tem básico você pode olhar como, pegou né?

$\mathrm{L}=$ Veio $o$ colour bloc meio sorrateiro.

$\mathrm{V}=\mathrm{E}$ hoje em dia as pessoas têm muita coisa básica, uma saia.

$\mathrm{L}=$ Coisas boas

$\mathrm{V}=$ Bem boas.

L= Uma camisa bem boa. Lembra da nutrisport? Eu tenho saia de brechó da nutrisport. Perfeita.

V= Perfeita. Calça da...[Beta?].

L=É uma Dudalina hoje. Você pega uma camisa da Dudalina é muito bem feita.

V= A Sônia sempre foi muito caprichosa. Ela foi minha aluna. Rs.

$\mathrm{L}=\mathrm{Ai}$ que legal!

$\mathrm{V}=$ Olha, você pode consultar a grande maioria desse pessoal mais velho, foi minha aluna na Rhodia. Mais velho no sentido de que já está há mais tempo no mercado, não quer dizer de idade, mas gente que está...

$\mathrm{L}=$ Até que ponto $\mathrm{a}$ ideia de público alvo deve nortear a visão de estilismo?

$V=S e$ for industrial sem dúvida nenhuma tem que nortear senão você faz belos produtos e que não vão vender. Voce não atinge a sua necessidade. 
$\mathrm{L}=$ Que é uma premissa ali dentro de um ambiente industrial. Queria te perguntar também o que são "coleções-estilo"? Deixa só eu ver de onde eu tirei isso.

$\mathrm{V}=$ Coleções estilo são as autorais

L= Tá.

V= Tá?

$V=$ Porque se, por exemplo, se você faz uma coleção para criança por mais que você possa ter estilo você está fazendo a roupa que é confortável, que tem uma boa malha, que tem tarará. Agora, que criança? Qualquer criança. Agora quando eu falo em uma coleção estilo eu estou pensando normalmente no adulto, em uma roupa assim, bem acabada, autoral, diferenciada ou que leva uma mensagem que você está procurando.

$\mathrm{L}=$ que busca formar opinião...

$V=$ Que busca formar opinião.

$\mathrm{L}=$ Isso. Legal, só para esclarecer, porque a gente estuda muito isso na faculdade também ou como vanguarda ou como conceito. É um nome.

\section{$V=E$, é um nome.}

$L=N a$ verdade é um nome que eu que não conhecia. Aí agora mais voltado para projeto [?] [1:38:05] mesmo, aqui tem um plano de coleção.

$V=$ Deixa eu acender a luz, vai ficar melhor.

L= Eu vou dar uma corridinha, eu estou tomando um tempão seu, né?!

$\mathrm{V}=\mathrm{O}$ meu problema único é esse, eu não posso ficar sem ir para a minha mãe.

$L=$ Você fala aqui ó...Plano ou estratégia de coleção. Você elenca alguns elementos que devem ser considerados quando vai se fazer uma coleção. Público alvo, análise do resultado da coleção anterior, as vendas, quantidade de modelos por família, preços, margem de lucros, materiais, estilo, tendências, tribos, movimentos culturais, datas de entrega, de reposição em loja e atividades de apoio, merchandising, publicidade. Tem alguma coisa que você julga mais importante aqui?

$V=$ Acho que é um conjunto de coisas que tem que ser feito. Se você falha em um você quebra a cadeia. É uma sequência ali que deve ser atendida.

$\mathrm{L}=$ Quando a gente é...porque na faculdade também ela te encaminha para a disciplina de estilo, para projeto.

V= Você chegou a ser aluna do....ai...

$\mathrm{L}=$ Mario Queiroz?

V= Mário Queiroz!

L= Fui. Ele foi orientador da faculdade inteira. Ele está na Santa também, na Pós hoje.
V= Ah! Ele está na Pós lá. Ai que bom!

$L=A i ́$, ele é muito legal! $E$ assim quando a gente...

$\mathrm{V}=\mathrm{E}$ como é que vocês estão de aluno na pós em moda lá? Está bom?

L= Estava muito bem assim. Eu dei aula lá o ano inteiro tendo turma, uma turma por bimestre. Esse ano agora, no final do ano não formou turma. Mas também porque o povo se enrolou com diploma...a Renata falou: sexta-feira eu tinha 12 alunos, era uma turma menor mas ía abrir. Mas aí, ai eu preciso do diploma, eu preciso disso, aí eles declararam que não, porque ía sair fora do período, do prazo e então...mas está indo bem. Agora não formou, mas no geral tem formado. Bom, ãh...

$\mathrm{V}=$ Nossa que cheiro...

L= É (rs), legal! Moda dentro do estilismo...ah! Tem uma fala sua na página 211.

V=Ela está fazendo uma lasanha, não estou entendendo o que..

L= Ela está refogando carne, não é?!

$V=$ Mas já estava feito isso.

$\mathrm{L}=$ Olha, o estilismo é uma concepção geral e a moda é um movimento no interior do estilismo. Você considera a possibilidade contrária de moda ser um sistema maior e o estilismo estar dentro da moda? Moda como um sistema mais amplo, não moda mudando, sazonal só, não o movimento passageiro.

V= Tá! Considero, pode ser.

$\mathrm{L}=\mathrm{A}$ confecção, a joalheria, o estilismo, não só...tá. Eu só queria entender isso.

$V=$ É que nessa época em que foi escrito, em 93, quando se falava moda, você estava enxergando que aquela revistinha de moda xexelenta que não era...sabe assim, uma coisa bem assim...

L= Eu fiz em 2003 o pessoal falava você faz o que? Moda???? Eu ainda sou dessa época que as pessoas falavam: Moda????

$V=$ Por isso não cabia, era uma coisa assim, era restringir o campo, 0 interesse da área praticar[?] [1:41:16] a moda. A moda era uma coisa muito [doida?] [1:41:17]. Agora se você imaginar o fashion como campo do saber, o estilismo como uma parte disso, eu acho que pode ser entendido inversamente [?].

$\mathrm{L}=$ Porque moda sempre era modinha...

V= É modinha e não e não só modinha, era uma coisa [1:41:32] assim, trazia uma informação assim de...

$\mathrm{L}=$ Algo superficial...

$\mathrm{V}=$ Isso, sabe?! 
$\mathrm{L}=$ Você fala da FASM, né e você pesquisou muito curso no exterior. $\mathrm{A}$ gente vê vários cursos, franceses, ingleses, italianos, japoneses e americanos. É, tem algum desses cursos que você acha que serviu mais como espeIho para o seu trabalho na Santa e depois de projeto ou estilismo mesmo?

$V=E u$ acho que foi meu trabalho com o do Eddy mesmo. $O$ quê que ele achou?

$L=$ Ele falou que vocês conversavam assim: mas nossa como é que a gente vai chamar isso? ĺa lá e pesquisava o nome, no Brasil é assim, em São Paulo é assim e ía lapidando. Ele falou isso, legal.

$V=$ Foi muito da gente. A gente foi...ele tinha uma visão das escolas de design e eu tinha uma visão mais assim porque eu já tinha comprado, ido atrás dos livros, ido atrás das escolas e tudo mais, dessa coisa, estava interessada em saber como é que faziam? O que acontecia? Onde eu podia eu fui.

\section{$\mathrm{L}=$ Como era na realidade?}

$\mathrm{V}=$ Como era na realidade. E aqui no Brasil, o quê que tinha de moda? Eram umas escolinhas assim bem...

$\mathrm{L}=$ Sigbol...

$V=$ Não, Sigbol era o ótimo. Tinham umas coisas piores, menores, piores

$\mathrm{L}=[$ Não]tem demanda, né? Porque a manequim, a manequim é a revista mais vendida até hoje.

$V=$ Mas naquela época tinha Gil Brandão.

$\mathrm{L}=$ Siiiiim.

V= Que era arquiteto e médico. Então ele era um cara que conhecia modelagem para caramba. E tinha um porquê também.

\section{[1:43:12] pulado porque só balbucio.}

L= O IED, você pega o caso da Itália, a gente tem o IED no Brasil. Moda, lá vem do design, [se eu entendo isso como ato projetivo][1:43:23]?, embora você tenha um problema no site. Você acha só como moda. Isso é uma questão que está acontecendo estão tirando o nome design dos cursos.

$V=$ Estão tirando?

$\mathrm{L}=$ Estão, à revelia.

$\mathrm{V}=\mathrm{Na}$ Itália?

L= No Brasil, à revelia. FAAP tirou, o curso da Santa mesmo hoje é moda, né? $\mathrm{V}=\mathrm{O}$ nosso é moda, depois dessa conversa que eu tive lá.

L= A UAM virou moda. Os únicos que não viraram foi Belas Artes e Senac. $\mathrm{V}=\mathrm{A}$ Belas Artes porque tem design. Então talvez para eles seja interessante.

L= A grande maioria está saindo fora. $V=E$, é? $L=$ Tá, tá. Porque desde
2010 tinha que ter uma revisão, se eu não me engano, se eu não me engano, não sei se é 2010 ou, essa revisão do MEC e eu estava conversando com o Marcos Braga que é esse professor da FAU. Ele participa desses eventos educativos, né, do Sinaes e tudo mais. Ele falou: está completamente abandonado. Então não sei se sobra espaço para o [1:44:25 deixar?] como moda.

V= Eu saí de lá, né? Porque eu me aposentei. Eu saí de lá em 2012.

$\mathrm{L}=$ Ah lá, está vendo?

$\mathrm{V}=\mathrm{Me}$ aposentei depois de 42 anos.

$L=$ Mas você está bem ainda.

V= Então 42 anos de trabalho. Mas o meu problema não era o trabalho em si. Por mim eu teria continuado. Mas é que eu tenho a minha mãe que tem Alzheimer. Você não sabe o que é ver sua mãe se acabando e a você não pode fazer nada. Eu entrava de manhã e chegava 21h da noite. Que horas que eu ía lá? Entendeu? Não dava. Essa hora ela já estava indo dormir. Não dava. $\mathrm{E}$ a coisa vai né, piorando né, então chegou num ponto que assim, eu vou todos os dias lá e agora tem uma cuidadora, então facilitou. Porque antes eu tinha que estar lá mesmo não tinha outra opção. Quem vai dar comida? Quem vai dar remédio?

\section{$\mathrm{L}=\mathrm{E}$ perto para você?}

\section{V= Não. É na esquina da Oscar Freire com a Bela Cintra.}

L=É trânsito, né?! Deixa eu dar uma corrida para você poder ir lá. Ah! Isso eu queria confirmar com você. Roupa, função e bom uso. página 236. $\mathrm{Ha}$ menções a esse texto. Forma não segue a função, né? Como seria no design. Como forma, como elemento, design, desenho industrial, forma e função, deixa eu ver. Será que na moda forma não segue o apelo de venda na maioria dos casos? Ela não segue função. Tem um lado, não vou dizer romântico, mas uma minoria que segue esse lado sensível, da tradução do espírito do tempo e do momento, mas se a gente pegar...

\section{$\mathrm{V}=$ Zeitgeist}

L= É o, zeitgeist, Gestalt, sprit du temps, ou l'air du temps, mas será que de maneira mercadológica, né falando, industrial, que é a maior parte, que é o que representa em números, eu digo, a indústria da moda. A forma não segue $\circ$ apelo de venda? Forma segue o quê para você? Porque a última coisa que dá para falar na vida é que forma segue a função em termos de moda. Você não usaria ombros largos, você não usaria sapato de salto, você já falou isso.

V= Essas coisas. Eu acho que não, não é. E apelo de venda.

$\mathrm{L}=$ Pensando em indústria

V= Bom, vamos lá

$\mathrm{L}=\mathrm{E}$. Você tem alguma sugestão?

$V=$ Eu acho que a forma é uma coisa que, ela realiza o desejo do estilista. 
Ele às vezes pode estar, querer pirar e vai pirar e vai fazer tudo esférico. E há pessoas que usarão esférico. Certo?! Naquele momento querem uma coisa muito diferente, frequentam ambientes em que isso cai bem e tá?! Mas para poucos. Por isso que o estilismo, aí é que está. Ele pode ter uma visão de produtos que são mais comercializáveis dentro de atendimento a públicos diversos ou ele pode ser setorizado. Por isso é que você quando faz o seu Mix de Produtos [1:47:35] você tem que conhecer muito bem para quem você está fazendo.

$\mathrm{L}=\mathrm{Se}$ usa um determinado tipo de peça.

$V=$ Tem gente que, você vai pegar uma faixa etária de senhoras, não adianta querer pirar tanto, né.

L= Nem regata, né?!

$V=$ Nem regata. Só vai usar [1:47:55]

$L=$ Não é nem que não dá. As senhoras hoje são cada vez mais jovens.

$V=$ Estão muito tratadas.

$\mathrm{L}=$ Mas tem um choque, tem uma questão cultural. As cobranças para si mesmo do que é aceito.

$V=$ Né?! E dos outros também. Agora, o Brasil tem uma coisa que não tem muita cobrança, né?! Você vê corpos assim, cintura fina, bumbum grande, quadril largo etc e tal. Muito ou pouco busto, porque hoje em dia todo mundo tem, né?! Rs. Nada contra, mas as roupas com elastano grudadas e todo mundo com feição de periguete. Quer dizer, também é uma coisa que..

L= Desnecessária.

V= Desnecessária, né?

$\mathrm{L}=$ Lembra daquele livro da Lycra? De 2006?

$V=$ Acho que eu sei.

L=Foi até processada a moça que fez.

$V=E$ É. Por causa do nome? Que era elastano e usou lycra, né?

L= Ela vai tirar fotos de lugares muito humildes, comunidades e ela associa a ideia de roupa justa a uma classe social menos abastada. Na época não tinha essa moda de periguete que hoje vai de $\mathrm{A}$ à $\mathrm{Z}$.

V= Vai de $A$ à Z. Não agora veste todo mundo.

$L=E$ ainda predominante nas classes sociais menos abastadas, mas hoje ainda é um pouco mais difuso. E ela foi processada porque ela associava à lycra...

$\mathrm{V}=$ Você quer tomar alguma coisa? Um refrigerante, um suco...

$L=$ Não, fica a vontade. Toma você.

$\mathrm{V}=$ Não, eu estou preocupada com você.
$\mathrm{L}=$ Eu estou super bem.

V= Você veio aqui não tomou nada, não comeu nada, não servi nada.

L= Eu acabei de almoçar antes de vir aqui. Relaxa. Obrigada pela hospitalidade. A arte e a alimentação do universo simbólico da moda. É, isso acho que eu já comentei, mas você cita muito um autor que eu estou usando muito que é o Durand.

V= Ah! O José Carlos Duran.

$\mathrm{L}=\mathrm{Na}$ questão do mito da profissão. Há certo desdém pela moda, mesmo com tanto profissionalismo hoje, a gente pegava propaganda de 1997, propaganda premiada do Morumbi Fashion, que falava "a moda é muito mais que fofocas", não sei se você lembra disso.

\section{$\mathrm{V}=$ Eu lembro.}

L=Eu usei esse cartaz esses dias para um trabalho e era uma moça, só uma silhueta dizendo "a moda é muito mais que fofocas", falando que era indústria. Mas ao mesmo tempo em que a gente se aproxima dessa idealização de moda como algo de expressão do sensível, você está associando ela à futilidade.

$\mathrm{V}=\mathrm{E}$ complicado, né? Para a gente que está dentro do ambiente...

$\mathrm{L}=\mathrm{E}$ é um processo extremamente extenuante trabalhar com projeto.

V= Só para te dar uma ideia. Moda surgiu numa faculdade religiosa.

$L=$ No Brasil, sim.

$V=$ Tá. Agora você pode imaginar os esforços que eu fiz pra vender a ideia de que seria legal o curso de moda, o curso superior.

$\mathrm{L}=$ Quando você falava de curso de moda o que você ouvia? Você ouvia falar que era a indústria que pedia? O que você ouvia?

$\mathrm{V}=\mathrm{Ah}$ ! Depois que eu trabalhei na Rhodia com certeza. Depois que me deu, mais que certeza.

L= Por que que a Santa Marcelina que nem é efetivamente ligada a indústria, podia nem ligar para isso..

V= Então, porque, a gente estava lá. Eu e o Eddy, dois loucos, por uma motivação pessoal nossa e a diretora que era a Irmã Eugenie Villien [?] [1:51:03] que comprou totalmente a nossa ideia. Ela curtia também o que a gente fazia, os resultados. E eu, aí que está, os levei à Fenit. Levava, pegava as irmãs, a superiora, a diretora...e vamos à Fenit. Para elas verem o lado do negócio, né?! Para verem as empresas fechando vendas monumentais, para conhecer os empresários, para elas verem que não era aquele "oba oba" só. Levei à Modafio várias vezes. A Abravest tinha eventos, palestras. Carregava sempre comigo alguma irmã dessas que eram assim de [?] [1:51:43]. Você conhece hoje a diretora? Não sei nem se pessoalmente você conhece.

$L=$ Não. Acho que eu não conheço. 
V= Era de outro lugar, não cheguei à levar, mas a Irmã Zenaide.

\section{$L=E$. Eu conheço de nome.}

$V=$ Irmã Zenaide você deve saber quem é. Várias delas foram comigo. $\mathrm{E}$ era importante mostrar.

L= Eu estou achando que a Irmã Zenaide eu conheci. É uma que é uma fofa?

V= É muito simpática.

$\mathrm{L}=\mathrm{Ah}$ ! Ela que me deu uma medalhinha...

V= Ah! É a própria.

$\mathrm{L}=$ Ela falou que morou um ano em Botucatu quando eu falei com ela. Minha mãe estudou lá. Ah legal!

V= É ela mesma. Então eu tive que mostrar a indústria, que era sustentáculo da economia, que empregava muita gente. Aí pegar dados do IBGE e mostrar, pegar uma série de coisas e sair fazendo, mostrar. E ainda assim, quando houve o primeiro desfile dos alunos, assim naquela época eram muito ousados, mais do que hoje. Porque hoje já não tem mais graça entendeu?

$\mathrm{V}=\mathrm{O}$ desfile da primeira turma de graduação foi em 1991. 1992 foi a turma do Alexandre (Herchcovitch), que fez todo mundo sabe. $O$ desfile dele era um aborto, né?! Então você pode imaginar numa instituição católica. Não e ele foi excelente aluno na disciplina que era filosofia teológica e ele foi preparado por rabinato.

L= Ele é judeu, né?! Ele estudou no Peretz, né?!

$V=$ Isso. E eles faziam exatamente, ele o padre que dava a disciplina faziam pontes maravilhosas porque ele contava o lado da experiência judaica e o padre fazia o contraponto católico, então casou perfeito. Não teve problema nenhum, quer dizer, ele nunca ficou de DP passava bem, ficava livre logo, também né. Então, quer dizer, estas questões todas... eu estou te contando por causa do desfile. Então houve um primeiro desfile das meninas, porque vieram coisas...a transparência, né, total, né. Ou sem nada por baixo, aparecendo o seio e tal, aquela coisa assim, né. E aí...

$\mathrm{L}=$ Mas é porque era uma linguagem inerente à década de 90 , na moda, chocar. Tem o Alexander McQueen.

$\mathrm{V}=\mathrm{E}$ os jovens? Estão aí para isso também. Para transgredir, quer dizer. Então você tem que contar para as irmãs, fazer, mostrar: olha irmã eles estão tendo um comportamento que pode não ser o desejado, mas é o esperado. Para mim não choca que eles queiram fazer assim, porque eles querem mostrar que a cabeça deles está mandando nesse momento. Eles estão...então foi assim, aos poucos. E aí fizeram uma reunião e foram convidadas todas as superioras de todos os colégios e eram 20 e tantas irmãs lá para validar o curso. Para ver se continua ou não continua? Eu não estava nem sabendo disso, tanto que depois eu fiquei sabendo. E aí elas conversaram com esse padre que era o Padre [Ivan?] [1:24:48] na época que falou: Não, imagina isso é maravilhoso. $E$ aí, uma das irmãs que era a médica, que era a diretora do hospital foi quem deu o maior apoio também no momento. A médica era a que mais, sabe assim, tinha mais afinidade com o corpo e tal. "Não imagina, maravilha, tem que fazer mesmo, tem que levar para frente."

$\mathrm{L}=\mathrm{E}$ elas assistiam aos desfiles?

$V=$ Então elas foram nesses primeiros com tudo, para ver se...

$\mathrm{L}=\mathrm{Ah}$ ! Elas iam. Essa junta.

$V=$ Essa junta ía para ver se valia. Vamos continuar com esse curso ou não? Porque as meninas aparecem peladas, porque isso, porque aquilo, não sei o que tal, né. Eu sei que era um tal de gastar meia depois porque era a Patrícia Ramalho que fazia os primeiros desfiles, então eu pedia para ela: "Olha lá, dá um jeito. Põe pelo menos bota lá uma meia, cola por baixo, dá um jeito". Ai, ai, rs. Mas foi assim quer dizer então. Por que? Porque eu tive que mostrar que a moda não é a futilidade no dia a dia que você está vendo lá no desfilinho, né?! Que existia naquela época, antes disso, existiam os desfiles do Mappin, que certamente elas viram, sabe assim? Bom e só para eu te contar uma muito engraçada. Aí um dia eu estou com umas irmãs idosas até que era superior, mas era um amor, uma cabeça, viveu até os 97 anos com todos os dentes na boca perfeitos, maravilhosa. $E$ ai eu fui com ela a uma Fenit e nossos alunos estavam desfilando em um desfile especial das escolas e nossos alunos tinham uma coisa importante lá. E fomos lá para assistir. Não é que me senta um grupo de drag queens, assim né, aquela coisa, falando, senta do lado da irmã que era superiora geral. Eu pensei: acabou curso de moda. O que eu vim fazer? Vim trazer para poder que elas conhecessem vissem os alunos e estimular, mas depois dessa. Você não acredita, esse que ficou do lado, super interessado assim no desfile e tudo comentava com a irmã e disse: irmã, vocês estão de parabéns. Elas que me contaram depois. Você estão de parabéns, porque além do hospital maravilhoso que vocês tem, tem o hospital lá em Itaquera da faculdade de Medicina, vocês estão fazendo essa área como ninguém.

$L=I$ sso era desfile de aluno que acontecia depois?

$V=$ Dentro da Fenit, né. Era um desfile especial feito lá. Tenho a impressão que nesse momento, não éramos só nós, tínhamos nós e os de vocês também talvez. Anhembi Morumbi, é.

$\mathrm{L}=\mathrm{A}$ Anhembi participava de bastante coisa.

V $=$ Participava

$\mathrm{L}=$ Tinha uma disputa até, eu lembro que no meu ano a gente chamou.

$V=$ Vocês eram muito mais "marquetólogos" que nós. A gente não tinha dinheiro nenhum, para nada.

$\mathrm{L}=$ Mas a Santa tinha uma imagem incrivel.

$V=E$ É Imagem, mas sempre gratuita. Porque nunca a gente tinha dinheiro.

$L=A h$, não. 
$V=O$ que saiu na imprensa foi porque eles nos procuraram ou a gente tinha um contato e.

$\mathrm{L}=$ Mas a Anhembi era muito legal, tinha muita gente boa.

$\mathrm{V}=\mathrm{A}$ Anhembi tinha $\circ$ Gabriel, diretor da Anhembi, diretor, reitor da Anhembi, né. Ele era um cara de mkt, ele tinha mais visão, né. Ele queria que eu fosse coordenar a Anhembi. Me convidaram eu fiz reunião com ele e falei não dá, olha.

$\mathrm{L}=$ Isso quando abriu? Ele chamou? E ० Airton? Era a Vani?

$V=$ Antes de abrir. Entrou uma pessoa, não. $O$ Airton entrou depois, bem depois. Era um cara, era um outro, ele era até advogado e veio conversar comigo na Santa Marcelina, olha a minha situação. E me propôs e tudo e eu falei: eu até aceito fazer uma reunião lá, mas aí eu não, daí eu cheguei e expliquei para o Gabriel. Não dá para ficar o pé cada um em uma canoa, fazendo a mesma coisa. Não posso, né? Não tem jeito.

\section{$\mathrm{L}=\mathrm{E}$ delicado.}

V= Eu já era da Santa Marcelina há muito tempo e não tinha, não dava né. E...ele foi muito, com jeitinho e tal.

\section{$\mathrm{L}=$ Lisonjeiro, né?}

$\mathrm{V}=$ É. Para mim foi muito gostoso saber que outra escola tinha interesse.

$L=$ Uma escola que depois virou referência, né.

$V=$ Nossa, depois eu fiquei muito amiga da Vandi. Você acredita que achavam que a gente era competidora.

$L=N a ̃ o$, isso era meio lenda. Eu lembro no meu TCC só o que falavam, que chamaram o André Hidalgo, aí tinham chamado o Tufi Duek, aí a Santa tinha chamado antes e ficavam essas coisas assim: ah, ele preferiu ir na Anhembi, ele preferiu ir na Santa. E eu acho que era só uma coisa de chamou antes, né.

$V=$ Não tinha nada, né.

$L=$ Até, e tanto que meu "padrinho" de TCC foi um cara que era contemporâneo meu que é o Dudu Bertolini, ele ía desfilar e ele é da Santa. Eu tinha amizade com muita gente da Santa. Ele ía desfilar para mim. Ele é um barato. Ele não pôde no dia porque ele dava consultoria para a Arezzo, ía viaja e ele falou: não sei se é um dia antes ou depois. Ele falou: mas deixa no dia tal que é mais provável, foram 2 dias, só que ele não conseguiu e então eu falei. Ah! Tudo bem Dudu, relaxa. Eu até ía até a casa dele na Piauí que ele morava perto, vivia lá. Aí ele não, não, não. Ele ligou para a L'Equipe chamou um menino que ele tinha contato e me deu assim. Uma delicadeza, eu nem contava. O menino apareceu acho que foi o meu melhor modelo. Rs. O mais profissional. Eu falei caramba.

$V=$ Olha, que legal, né! Ele tinha trabalhado na Vogue. Ele tinha feito a parte de produção. Ele é bem relacionado.
$\mathrm{L}=$ Eu tinha muito contato também de quando eu trabalhei na Santa Constância, no André Lima.

$V=$ Ele e a Rita, né?

L=É. A Rita Comparato. Eu cheguei a ir para uma final de Semana de Moda em 2002. Aí depois sabe quando você fala, ai isso não dá dinheiro, acabei indo trabalhar em indústria. Engraçado isso, né?! E muito legal. Eu cheguei a vender na Ellus 2nd Floor, cheguei a vender a minha marca no Japão. Eu tinha contato com essa turma mais do underground.

$\mathrm{V}=\mathrm{A}$ 2nd Floor eram bem legal mesmo.

$L=$ Mas até virar isso é... demanda, né. Bom,

Balbuciei e pensei em voz alta.

$\mathrm{L}=\mathrm{Eu}$ te pergunto se a moda não está mais ligada ao design do que à arte. Acho que a gente também já falou sobre isso.

$V=$ Também

Pensei em voz alta de novo.

L= Eu percebi olhando a grade que ao longo do desenvolvimento do curso em 4 anos ele vai ficando cada vez mais prático. Tem muitas disciplinas filosóficas, e tudo mais, como o meu também, mas mais no começo do curso, mas no final, depois a Anhembi retomou isso e ate por isso colocou o stricto sensu.

$\mathrm{V}=\mathrm{Sei}$

$\mathrm{L}=$ Mas eu percebo que a coisa fica mais prática. É isso mesmo?

$V=$ Eu acho que sim

$\mathrm{L}=\mathrm{E}$ marcante para a maioria dos cursos, né?

\section{$\mathrm{V}=\dot{E}$ marcante}

$\mathrm{L}=$ Queria saber, na sua opinião, se falta ainda bastante reflexão intelectual sobre projeto em moda? Acho que seu trabalho é um dos pioneiros. Acho que tem na década de 50 a Gilda Mello e Souza.

$\mathrm{V}=\mathrm{Da}$ Gilda eu tenho a tese ainda, eu tenho antes do livro.

$L=A i$ que legal. Mas hoje você já acha que está...

$V=A h$, acho hoje já tem bastante, já tem produção brasileira, né?! Perto do que era. Na PUC tem o pessoal da semiótica tem muito.

$L=E$. Antes de surgirem os cursos de moda em stricto sensu. Porque nunca vai poder bater. Porque a produção ainda é maior em outros cursos, porque tem há muito tempo. [Pausa para pensar]. $O$ estilista que faz estilo, que tenta formar opinião como algo mais duradouro, ele estaria tentando imortalizar esses estilos ao invés de fazer moda, passageira? Como que você vê essa possibilidade? Ainda existe espaço?

$V=$ Imortalizar não. 
$\mathrm{L}=$ Como fez um Saint Laurent, com o smoking.

$V=$ Eu acho difícil. Eu acho que hoje o que vai valer, o que vai diferenciar ou vai ser criativo vai ser o desenvolvimento tecnológico. $O$ que a área tecnológica puder fornecer de novo para um estilista criar em cima.

$\mathrm{L}=\mathrm{Em}$ termos de processo também.

$\mathrm{V}=\mathrm{E}$ hoje tem tanta coisa nova saindo. $\mathrm{O}$ livro da, você leu o livro da Suzana Avelar?

$\mathrm{L}=\mathrm{Sim}$.

$V=$ Eu que fiz a orelha

$\mathrm{L}=$ Eu não lembro. Eu não estava tão ligada na época. Eu li faz uns anos.

$\mathrm{V}=$ Ela tem também essa parte toda da tecnologia lá.

$\mathrm{L}=$ Das tecnologias vestíveis.

$\mathrm{V}=\mathrm{E}$ hoje as crianças vão para a praia com roupa contra o sol, contra os raios UVB.

L= Tem alguma coisa de spray, né. Isso ainda não está em escala comercial. São novos paradigmas.

$\mathrm{V}=\mathrm{E}$ depois eles nem pensavam em computador fazendo 3D, né? Rs.

$\mathrm{L}=$ Fazendo $\mathrm{o}$ body scan. Isso é recente mesmo.

$V=$ Nem para escanear. Não existia plotter, não existia nada.

L=É. Eu peguei a implantação disso... eu comecei a trabalhar em 2000. Já no primeiro ano de faculdade eu já comecei a estagiar. Era tudo feito à mão, aí eu via as pessoas implantando, pondo Lectra, Gerber e o mouse.

$V=$ Nossa. Eu me lembro o primeiro computador que a gente teve, o primeiro programa que a gente comprou, foi comprado, depois a gente fez parceria com eles lá, ganhou de graça, da Lectra.

L= É. Eu tive aula de ampliação e redução. É, eu queria só por último que você me falasse sobre o CEBRAFAN. O Centro Brasileiro para Formação Profissional para a Moda. Foi o que deu origem à UAM. Como eu sei que você é uma referência na área. É uma enciclopédia ambulante, desculpe que eu sei que isso vai dar origem à minha faculdade, mas eu queria saber as impressões.

$V=$ Eu participei de algumas palestras, tinham umas coisas interessantes lá. $O$ curso mesmo eu não estive tão próxima. Eu fui convidada para várias palestras que eu achei bem interessantes. Nossa o salão ainda era bem acanhado da UAM, não tinha muita coisa.

$\mathrm{L}=$ Era na Quatá, ainda?

V= Era na Quatá.
L= Eu comecei a faculdade lá. Fiz 2 anos lá e 2 no Morumbi. Quem era o cabeça do Cebrafan? Quem dirigia?

$V=E u$ acho que a própria Vandi. Se bem que ela estava no turismo. Não sei se ela ficava no turismo e fazia um pouco no Cebrafan. A Raquel que coordenou o curso da gente, foi professora lá, mas eu não sei se, ela não tinha, não era coordenação.

$\mathrm{L}=\mathrm{A}$ Raquel Valente chegou a atuar no Cebrafan.

$[\ldots]$

$\mathrm{L}=\mathrm{A}$ gente falou dos autores de moda, de repente os nomes desses mais recentes não sei se vão ser familiares, mas com certeza esse conteúdo que está aqui dentro é uma atualização desses conteúdos. Você já conhece na verdade. Só te perguntar.

$V=$ Eu acho que está sistematizado. Por isso eu gostaria até de conhecer porque deve estar bem...e deve ser interessante a maneira como eles estruturam.

$L=$ Você quer ficar com eles? Depois eu volto aqui também, você me acha aqueles documentos? A eu fazendo [troca?] [ 2:07:22]. Você quer dar uma olhada?

$V=$ Vou ver. Sabe o que é? Eu tenho um quarto da casa, um parede, do tamanho dessa parede aqui (em torno de 10 metros e mostra com a mão apontando) inteirinha que são só livros, dos quais a maior parte de moda. Eu tenho um guarda roupa que daí é outro que ocupa a parede inteira com papelada e coisa de moda. Então tem assim, tecidos, pastas, motivos para es-

$\mathrm{L}=$ Você chegou a trabalhar com empresas fornecendo desenhos?

$\mathrm{V}=\mathrm{Fiz}$.

$\mathrm{L}=$ Você trabalhava para a Rhodia fazendo o seu desenho ou não?

$V=$ Não, não! Para empresas. Existia uma loja que chamava Rakan, na época [?]

$\mathrm{L}=$ Você trabalhou bastante para eles?

V= Sim. É como free lá, né?!Não fui da empresa. Eu desenvolvia...

$\mathrm{L}=$ Você também assoviava e chupava cana.

$V=$ Rs. E dava aula, né?!

$\mathrm{L}=\mathrm{E}$ dava aula ainda. Deixa eu te perguntar só isso. Autores de design, design de produto, esses nomes são conhecidos para você??

$V=$ São...

L= Bernd Löbach? Gustavo Amarante Bomfim? E "Design Visual" Bruno Munari?

$V=$ Sim, lógico. 
$\mathrm{L}=$ À excessão do Bruno Munari o resto são estranhos?

V= Já ouvi, mas não li.

$L=$ Não é uma coisa que tenha aderência.

$\mathrm{V}=$ Para mim não.

$\mathrm{L}=\mathrm{E}$ só para confirmar. Porque eu tive que ler fora [da faculdade].

$V=$ Mas deixa eu te falar porque. É o seguinte, eu passei de coordenadora do curso de moda a assessora da direção e depois eu passei a diretora acadêmica da faculdade. Nessa de ficar como diretora acadêmica da faculdade muitos anos, e aí, é totalmente um trabalho burocrático mais assim distante da moda que...

$L=$ Você não faz a parte gostosa, né?!

$V=$ Pois é, para mim era mais gostoso fazer [2:09:29]. Mas também, por outro lado o que que eu podia almejar tendo um cargo há tantos anos na faculdade. Não teria cargo acima.

$\mathrm{L}=$ Era muito melhor estar lá do que como professora, evidentemente.

$\mathrm{V}=$ No sentido do crescimento profissional foi. Isso foi, foi aquilo também. Não era tanto a minha área, eu tenho [?] todos os relacionamentos com o MEC. Então tinha que ir para Brasília, tinha que receber Comissão, tinha que fazer uma série de coisas. E outra, né? Curso de música, curso de moda, curso de relações internacionais, reunião com todo mundo, projeto pedagógico de todos os cursos, tudo isso a gente, com os coordenadores obviamente, mas é atendimento a todas as necessidades.

$\mathrm{L}=\mathrm{E}$ é interessante. Porque claro, o Bruno Munari eu fui até ingênua de perguntar. Você é artista plástica, né?!

$V=E$ É o Bruno Munari eu li bastante.

$\mathrm{L}=\mathrm{O}$ Arnheim?

$V=$ Sim, todos esses.

L= Maria Cecília Salles. Não, legal. É porque isso eu estou perguntando para todo mundo para quem se identifica com design ou com moda. O Eddy também olhou esse "Pesquisa de moda", olhou para a minha cara: é para ver ou é para comer, sabe?! E aí eu falo disso, né, porque um campo, ele é formado por pessoas que não são do campo. Não existiam pessoas formadas em moda, então a gente chama artistas plásticos, designers...

$V=$ Muitos arquitetos no caso.

$\mathrm{L}=$ Arquitetos. $\mathrm{O}$ Feres que é da FAU.

V= Então, o Feres é da FAU, o João Novelli, é arquiteto, a Paula Motta é arquiteta.

L= Eles também são formados na FAU.

$V=$ Tinha a Sirce Bernardes também da FAU. O Carlos Coelho que não está mais lá, mas que também era arquiteto, também está no Mackenzie. Arquitetura é só eu acho.

$\mathrm{L}=$ Então tem alguns que voltaram para $\mathrm{o}$ seu campo de origem. Outros permanecem, como o Eddy. É engraçado isso. Outros como o próprio João Braga que é historiador (sic) [ele é artista plástico na verdade], mas não tinha historiador de moda, que fosse formado em moda, então vai se formar com pessoas de outros campos.

$V=A$ pós graduação, ai é que está. A gente foi fazendo e foi buscando, né. Para mim você pode imaginar, fui a primeira na USP a querer fazer alguma coisa na área de moda.

$L=$ Eu imagino.

$V=$ Teve um rapaz antes que escreveu alguma coisa.

\section{$\mathrm{L}=$ Você cita $\circ$ trabalho dele aqui.}

$V=E$, que fez. Que ele também fez aquele calhamaço, mas tinha menos contribuição assim para o campo de interesse, esse interesse, mas depois teve que abrir, tem muito mesmo, sabe porque você não conhece as pessoas no campo de moda. Moda, imagine?! E essa foi a minha orientadora que eu achei sensacional, ela era socióloga. Sociologia da arte ela dava. E ela falou: Vera olha, eu não entendo, mas eu gosto e eu vou problematizar. Eu vou ser uma pessoa muito crítica com tudo o que você me apresentar e você por favor, até ela falou, me perdoe porque eu desconheço $\mathrm{o}$ assunto [...?] e com isso eu acabei lendo muita coisa de sociologia que para mim foi uma ajuda muito grande.

L= A própria Gilda Mello e Souza, Seurat (sic) [o correto é Saussure], "Moda ensinada aos seus pais". Ai, engraçado, eu comprei esse livro esses dias chegou em casa. Eu consultava na faculdade só que eu nunca tive.

$\mathrm{V}=$ Sei.

L= Eu achei um na Abbooks para comprar aí eu comprei. E aí chegou e aí eu fui ler eu vi que você cita...ai que legal. Rs. As coisas batem, isso é bom. Isso é bom.

V= A Françoise Vincent Ricard que é interessante também e tem um livro que mostra como fazer as coleções. Você está falando de desenvolvimento de coleção.

$\mathrm{L}=\tilde{\mathrm{A}}$ ?

$V=$ Tem um outro. Deixa eu ver.

L= É, aí meu Deus do céu. Não estou lembrando o nome, mas acho que tem na Bibliografia.

$[\ldots]$

$\mathrm{V}=\mathrm{E}$ não está ruim de ler, né?! Não está chata de ler né? Assim ela é.

L= Não. Está uma delícia. É leve, sua escrita é gostosa. Aliás, essa entre- 
linha maior é melhor do que um monte de coisa apinhada. Porque ler coisa com entrelinha simples, não dá, né?

$V=$ Eu não gosto, muito justo para mim...

$L=$ Obras de referência [eu estava folhando enquanto falava da tese dela com ela].

$V=A h$, então, para você ter uma ideia eu fui a primeira pessoa, porque o original você deve ter visto tem umas folhas de corpo.

$\mathrm{L}=$ Tem 2, eu só posso tirar o segundo. $O$ número dois, o primeiro fica lá.

$\mathrm{V}=\mathrm{E}$ não mais eu, você sabe que..

$\mathrm{L}=\mathrm{Na}$ parte de trás tem até uma resenha...

$V=$ Resenha, porque era coisas mais...

$\mathrm{L}=$ De base né?!

$V=$ Então o que eu te falei, eu comecei a pesquisar na Sorbonne.

$L=A i$ que legal...

V=A primeira pesquisa de bibliografia do mestrado eu comecei lá.

$\mathrm{L}=$ Você foi orientada por alguém lá? Você fez sanduíche?

$V=$ Não, não. Eu fui para fazer pesquisa bibliográfica. Queria as obras que a Sorbonne poderia ter sobre moda.

$\mathrm{L}=\mathrm{E}$ era a mão nessa época, né?! Ou já tinha computador?

$V=$ Na mão! Não, os fichários enormes assim que você abre.

$\mathrm{L}=$ Como os franceses são geralmente meio tecnofóbicos.

$\mathrm{V}=\mathrm{Rs}$. Nossa, foi maravilhoso. Foi incrível, tinha muita coisa.

$L=$ Mas tudo dentro da Paris V, né?!

$V=$ Isso.

[Busca por Françoise Vincent Ricard na Bibliografia na Tese da Vera Lígia]

$L=$ Sabe $\circ$ que eu queria te perguntar? O Carlos Mauro, ele era formado na FAAP, né? Em Design.

$V=$ Ele era formado na FAAP em Comunicação Visual.

$L=$ Vocês faziam discussões...eu comentei, perguntei isso para o Eddy. Como eram essas discussões de ai, moda é design, moda é arte. Como que se davam essas discussões?

$V=$ Nós fizemos com todos os colegas esse...nunca se chegava a um consenso.

$\mathrm{L}=$ Principalmente porque ele também deu aula de estilismo no $\mathrm{CIT}$, né?

$V=$ Deu. Ele que costurava.
$\mathrm{L}=\mathrm{A}$ disciplina dele era a que norteava, costurava a disciplina dele [estilismo] na Santa com a de desenho, né.?! E como era essa mediação não rolava você falar, mas eu digo que é arte, estamos em dentro da Santa [falas juntas incompreensíveis] e ele era do design da FAAP.

$V=$ Nunca teve muitos problemas assim. A discussão é...a gente combinava muito, foi muito bom, foi muito profícuo. Até ele ficar doente, e eu acho, ele teve um problema que ele foi um filho que a mãe esperava que fosse filha. E ela era muito...assim....seca com ele. Então ele queria beijar, ele era pequenininho. Mal ele chegava do lado assim ela punha fora, sabe? Depois ele ficou.... mãe ficou doente e tal e ele foi cuidar da mãe. Ele fez aquela troca. Eu acho que na cabeça dele, naquele momento, deu uma embaralhada nos sentimentos, sabe. E ele ficou muito nervoso. Até um dia que não deu mais. Os alunos reclamavam e ele dava nota baixa e era uma choradeira, aí pai que vinha, chegou num ponto que a direção houve por bem afastá-lo. E a gente não perdeu o contato. Ele chegou a vir a jantar aqui em casa. A gente saiu junto. Na primeira vez, foi até meio esquisito, depois que ele foi mandado embora, aí nós recebemos e ficou um clima meio assim. Mas fui eu que mandei por ordem da direção, né, mas enfim. Quando teve uma peça no Senac nós dois sentamos juntos. Todo mundo olhava, o pessoal da Santa Marcelina, né? Mas ué? O que é que aconteceu? Ué, estamos juntos. Ninguém acredita. E eu com a Vandi dormimos na mesma cama uma vez. [Rs]. Fomos para um congresso, chegamos, era no Guarujá. Lá no Casa Grande, fizeram uma festa e tal, mas na hora de embora era tão tarde, ela falou quer saber: estou com a chave do meu apartamento, quer dormir aqui? Tá ta bom eu topo! Ao invés da gente subir então, eu liguei para SP, para o meu marido disse: olha acho que eu vou ficar aqui, não sei o que lá. A gente entrou na casa dela, a empregada tinha lavado todos os lençóis, estava tudo pendurado. Não tinha nenhum lençol seco só tinha um para forrar a cama. Ela falou: o jeito é a gente dormir no mesmo.

$\mathrm{L}=$ De presidiário, $\mathrm{rs}$

$V=S i m$, as duas lá. A gente contava isso, ninguém acredita porque achavam que a gente, né, era assim oponente e não, não era.

$\mathrm{L}=$ Que bobagem.

$V=$ Tanto que no aniversário dela ela sempre faz uma reunião, esse ano eu não pude ir. A minha mãe precisou, não estava boa aquele dia e eu fiquei com a minha mãe. Mas ai que graça, viu. Pera lá, segura para mim, eu vou pegar os meus óculos.

[Buscando os óculos e achando e comentando "As espirais da moda", ela tem em francês e português].

L= Deixa eu te perguntar uma coisa: formada em artes como que você se especializou em design de superfície, design têxtil? Onde você foi aprender a fazer rapport?

$\mathrm{V}=$ Eu aprendi na faculdade.

$\mathrm{L}=$ Vocês aprendem lá nas artes? 
V= Depois com a mulher do Eddy, a Sueli. A Sueli foi minha aluna, depois ela foi para a indústria têxtil, se especializou, aprendeu muito mais, daí ela voltou para trabalhar comigo. Nós demos o curso juntas e aí eu aprendi outras coisas.

$L=$ Mas você aprendia essas estruturas assim, de rapport de têxtil na faculdade de artes?

$V=$ Ué, dentro da disciplina de desenho de moda.

$\mathrm{L}=\mathrm{Ah}$, é verdade, é verdade, claro. Que legal, você pegou pelo rabo, né?! Porque é um negócio dentro...

$V=$ De uma disciplina. Eu antes, quando era bem mocinha assim, tinha sido modelo fotográfico.

\section{$\mathrm{L}=$ Você é bonita mesmo}

[Falando sobre a beleza dela e da minha mamãe e depois do livro para me indicar. Ela folheava enquanto procurava o livro na bibliografia].

$V=$ Isso tudo fica prometido. Essas coisas ficam prometidas para você.

$L=$ Não, fica tranquila.

$V=$ Tem uma prima minha que fez pós, ela fez jornalismo na PUC e ela fez pós, ela quis fazer pós em jornalismo de moda. E aí ela me pediu um monte de coisa e eu emprestei para ela e acho que ela já usou.

L= Sua bibliografia é excelente. Tem muito livro que eu não conhecia. Conhecia o autor, mas não sabia que tinha outro livro. É legal, né, porque esse momento pré internet, né, forçava a gente a pesquisa. Tinha a Barsa, lembra da Barsa?

\section{$V=E$ mais isso mesmo.}

$\mathrm{L}=\mathrm{O}$ Gillo Dorfles mesmo. Esse livro "A psicologia das roupas".

$\mathrm{V}=\mathrm{O}$ do Flügel. Ai que bom que você gosta.

L= Esse livro não tem mais para vender. 1966 foi a última edição. Eu usei muito para um trabalho na faculdade.

$\mathrm{V}=\mathrm{E}$ ele foi de 30 e tantos. Ele é psicanalista e ele tem a tese de pós doc dele.

$L=$ No segundo colegial eu entrei em psicologia como treineiro na Unesp. Aí eu descobri que queria fazer moda. Eu já tinha afinidade. Quem me orientou muito no TCC foi a Rosane Preciosa que tem mestrado e doutorado em psicologia. Então eu amava, fazia muitos trabalhos sensíveis, sinestésicos.

[Conversa sobre livros de 1960 ou 1965 que ela queria me indicar. Falamos sobre os fichamentos que constam no fim da tese dele. Falei sobre o Manual da Verena Alberti].

$\mathrm{L}=$ História oral.

$\mathrm{V}=\mathrm{E}$ tem que ser registrado, né?! Porque as pessoas vão embora, né?
$\mathrm{L}=\mathrm{Sim}$. $\mathrm{A}$ ideia é você pegar de 50 anos para cá. É o ideal né.

$V=\mathrm{Oh}$, eu olhando assim eu não estou achando. Eu garanto para você que peço para ela...

$\mathrm{L}=$ Ted Polhemus, "Street Style".

$V=$ Bruno de Roselle também é muito interessante.

[Marcações na tese dela, falei sobre a Lúcia Santaella, o Serginho, ela perguntou quem era meu orientador].

$\mathrm{V}=\mathrm{A}$ hora que eu achar. Eu vou te contar. Ele é listradinho, é paisagem a capa é branca e preta, ele é interessante porque ele dá...[mais detalhes].

L= Artista plástica, estilista, é bem visual, né. Lembra o formato, a cor, o peso. [mais detalhes que está recoberto por celofane ainda]. Eu comprei esse livro, eu trouxe da França, eu comprei, foi muito engraçado. A gente estava em Paris com as crianças [falou dos filhos falarem francês e ficarem independentes na França].

$V=E$ era perto do Pompidou. [mais detalhes] e fui à Biblioteca do Georges Pompidou e fui selecionando um monte de coisas, uma pilha...

[Falou que enviou por correio os livros porque eram muitos e ficava pesado e contou que confundiu a conversão na época do franco e acho que stava mais barato e selecionou muitos livros, uma pilha e depois teve que escolher o que realmente ia despachar].

$V=$ Acho que eu vi um zero a menos. E escolhia, eu quero esse etc.

$\mathrm{L}=$ Vera eu queria te agradecer. Vou pausar por aqui. 
MESQUITA, Cristiane. Entrevista realizada com Cristiane Mesquita, em 23 de novembro de 2015, na cidade de São Paulo, com 58 minutos de duração.

Graduada em psicologia. Professora da UAM desde 1996-1997. Moda a princípio não tem a ver com a formação dela. Ela começa a trabalhar no varejo, embora não tivesse interesse profissional no início. Trabalhou na Fiorucci de Belo Horizonte. Vira subgerente e vai ficando por dinheiro. Ela trabalhava meio período. E tinha consultório e atuava em um hospital. Em algum momento ela descobriu que o provador era uma grande pesquisa de campo. O provador era um lugar muito especial para pensar essas interações entre roupas e pessoas. Não era algo que ela procurava, mas percebeu que as coisas mais absurdas ligadas à psicanálise, à psicologia apareciam. $E$ isso despertou o interesse dela em moda. A moda entrou na vida dela por uma história de provador. Isso chamava a atenção dela de alguma forma. Um ano depois ela vira gerente e por uma questão financeira fica no varejo e para um pouco com a psicologia.

Então ela resolveu fazer um curso técnico de estilismo que durava 6 meses em BH com uma professora que veio da ESMODE de Paris e foi um curso em uma escola independente. $O$ curso foi ministrado por Fanny Whitman que abriu uma pequena escola em BH. Ela trabalhava com calçados e vem da ESMODE. A Cris cresce, vira gerente e passa a cuidar de 3 lojas. Abre mão da psicologia naquele momento e com vontade de voltar em algum dia, de alguma maneira.

Além de ser gerente na Fiorucci, ela começou a trabalhar como estilista na Gabarito, uma tecelagem, malharia. Essa tecelagem tinha marcas e a Cris trabalhava com uma das marcas da Gabarito. Ela desenvolvia estampa, tecido e basicamente uma linha de malharia. E seguia trabalhando como supervisora na Fiorucci, onde tinha horário mais flexível, então dava para ter 2 trabalhos.

Além disso ela trabalhava como produtora de moda para publicidade, figurinista para teatro, para cinema, para filme publicitário. Porque na verdade era isso: era um mercado que não tinha muita gente naquele momento. E aí eu fui indo e fazia de tudo. Tinha muito contato com gente do cinema, fotógrafos.

UAM

O primeiro interesse teórico pela moda veio quando ela ganhou de um marido na época o livro "O império do efêmero" do Lipovetsky. E quando ela leu o livro ela conta que entendeu que podia pensar sobre isso tal como ela via lá no provador. Ela podia fazer conexões entre a roupa das pessoas, o jeito que as pessoas desejavam as roupas, ou seja, a moda em outras palavras e o comportamento, a sociedade, o contexto, a subjetividade.

Ela vem para São Paulo e começa a fazer mestrado. É quando ela coloca isso em pauta. Depois da Gabarito ela trabalhou com a Graça Otoni, de quem foi assistente de estilo por uns 3 anos. E ainda fazia free la para a Fio- 
rucci, mas passa a ficar mais na Graça. Ela fala que sai do varejo e vai para os bastidores. Além da coleção, na Graça ela fazia catálogo, styling, fazia de tudo. As coisas sempre foram assim nessa área. Em algum momento meio que as coisas se especializaram um pouco, mas em geral é assim, todo mundo faz tudo.

Projeto e Estilismo quase como sinônimos, mas envolvidos em uma luta simbólica por poder.

Falei da minha formação em design de moda $X$ minha carteira de trabalho assinada como estilista. E o que me interessa não são termos, mas a prática. Pergunto se ela se lembra se me deu a disciplina Moda contemporânea. Ela diz que pode ser.

Provavelmente eu te dei ou Estudos da Moda em 2000, ou talvez Moda Contemporânea. Mas eu acho que ela me deu disciplina em 2001 e 2002. Mais avançada deve ser Moda Contemporânea.

Ela elogia a grade do meu curso vendo meu histórico. É cheio, todo recheado de disciplinas, olha que beleza! Ela conta que já deu Produção, mas tive com a Cris Frange e a Rose Andrade.

Ela é do conselho científico da D.A.M.T.E. e do Colóquio de Moda e dá aula de Metodologia da Pesquisa no doutorado. Pesquisa e Criação de Moda na FASM e no IBModa e Pós do Senac de Styling. Ela conta que a carreira dela era muito mais Senac do que essas 2. Na FASM e no IBModa ela era professora convidada O trabalho dela no Senac é muito mais relevante na Pós. Ela foi coordenadora, professora lá durante uns 9 anos e ainda é consultora do Senac e faz projetos para eles "vez por outra".

\section{PARECERISTA AD HOC DA FAPESP}

Designa moda dentro dos campos como Design. Ela conta que em geral recebe demandas de pareceres dentro do campo do design. Ela conta que não sabe o que a pessoa escolhe, a pessoa que aplica, que submete. Mas ela está lá como parecerista desse escopo Design, Design e Ciências Humanas, Moda. Mas ela diz que não sabe como a "caixinha" da FAPESP é qual. Eu não sei, eu acho que você teria que perguntar diretamente para eles.

Por exemplo, você vai submeter um projeto. Que eu saiba eles fazem dentro, igual CNPq, na gradinha do CNPq. Se é ciências sociais aplicadas é design. E aí dentro já existe a gradinha que você abre, no sistema tem Design de Moda. "Eu imagino que a pessoa faça isso."

Ela conta que quando ela submete lá, nem sempre submete como Mod porque ela pesquisa outras coisas. Às vezes ela vai para a área de filosofia..

$\mathrm{L}=$ Você vai muito para o pós-estruturalismo, né?!

$\mathrm{C}=$ Sim.

L= Nossa aula era muito baseada no pós-estruturalismo, na transmissão oral né?
Às vezes ela vai pela Filosofia e agora, por exemplo, ela está lá com um projeto aprovado do Design, não é Design de Moda, é do Design. Aparece para ela dar parecer em projeto de moda e de design também.

$\mathrm{C}=\mathrm{Eu}$ acho complicado, Leilane. Porque parecer é sigiloso. Eu acho muito complicado essa questão. Eu aliás, prefiro que isso não apareça. Porque assim, a gente como parecerista ad hoc, eu não posso te falar nada dos pareceres que eu faço...então nesse sentido eu acho uma questão complicada para você fazer.

Eu falo que me interessa como a área está atrelada à FAPESP. Ela responde que isso sim, mas não mais que isso.

$\mathrm{C}=$ Pode usar que eu sou atrelada ao...mas se me chega processo de design, se me chega... não, não. Sim que eu estou atrelada à área do design, design de moda, filosofia...

$\mathrm{L}=$ Arte também?

$C=$ Então, isso que eu não quero entrar. Eu não sei, pode ser que no meu histórico da FAPESP eles me mandem um projeto de arte...mas num...

$L=$ Deixa eu entender uma coisa. Nem pra você é claro como a FAPESP te designa?

$C=$ Não

$\mathrm{L}=$ Isso é uma percepção sua pelo tipo de produção acadêmica que chega na sua mão.

$\mathrm{C}=$ Sim. Porque eu tenho cadastro na FAPESP, como eu tenho no CNPq, como eu tenho na CAPES. É a partir daí eu imagino que eles designam um parecerista.

$L=$ Você entende minha curiosidade?

$\mathrm{C}=$ Então, mas eu acho complicado, ainda mais bolsista.

$L=$ Meu interesse é entender um pouco melhor como as agências encaixam a área e entendem a área, sabe?

$C$ = Mas é na grade de lattes. Que eu saiba você não vai ver nenhuma novidade. (Estímulo à pesquisa)

AUTORES DE DESIGN

LÖBACH, BOMFIM, MUNARI, BURDEK.

São familiares para ela, mas sinceramente não são a especialidade dela. AUTORES DE MODA

SEIVEWRIGHT, RENFREW, JONES E TREPTOW

SEIVE E RENFREW - nunca ouviu falar

JONES E TREPTOW - conhece, mas...

Rollo May - nunca trabalhou com ele 
Cecília Salles - sim, já trabalhou.

Ela trabalha com processo de criação.

Autores de moda dela - dentro do design como um todo a abordagem preferida dela é a do Flusser, tá, do filósofo. Autores de moda, teorias de moda, Lipovetsky.

$\mathrm{L}=$ Isso pensando em projeto?

$C=$ Não, eu não tenho propriamente essa especialização, viu Leilane. Desde sempre eu acho um pouco estranho até você me querer porque eu realmente não tenho nada a ver...eu vou para o design eu trabalho a ideia de projeto [e porque então eu não quereria o depoimento dela?] às vezes, por exemplo, teoricamente em pesquisas. Então assim, o que é um projeto? 0 projeto dá conta da contemporaneidade? Dá conta do processo do designer hoje? Por exemplo, questões sobre isso podem tornar-se uma pesquisa ou podem atravessar a pesquisa.

Mas ela ressalta que orienta pesquisas que não têm nada a ver com projeto. Isso não está em questão, então não passa por aí. 19'40"

Terminando os autores: Flusser, Rafael Cardoso (especialmente com o design para um mundo complexo), tá duas bases; Moda: Lipovetsky e outros autores transversalizando a situação. Ela não usa muitas vezes um autor de moda. Ela vai usar autores da filosofia: Deleuze e Guatari, Foucault e sim a Cecília Salles porque em algum momento ela pesquisa processo de criação. Ela tem um trabalho dentro da crítica genética que me interessa. Não que ela seja minha base. Agora Rollo May é um autor da psicologia, mas nada a ver comigo.

Minha formação contemplada pelos filósofos pós-estruturalistas. Ela confirma.

Ela se adianta: eu acho esse termo estilista algo muito estranho 20'37"

Aí já lanço ESTILISTA OU DESIGNER DE MODA?

Ela prefere designer de moda. Agora ela não entende design como uma visão racionalista, careta. Ela entende design como um profissional absolutamente atrelado à cultura, completamente pensante, reflexivo sobre o mundo que ele existe. "Então se eu entendo design assim, para mim está ótimo."

Ela não gosta de ESTILISTA porque acha que não diz nada. O que é criar um estilo? O que que é isso? Isso existe hoje? "A meu ver, não. Existiu até a segunda guerra mundial. Acabou."

O segundo capítulo da tese de doutorado dela, chamado "O império do estilo". Ela faz uma trajetória pela etimologia da palavra estilo. Ela constrói um pouco essa ideia afirmando que isso não existe mais. Não existe criar um estilo na arte, nem na moda. Não existe com o purismo que existia. E o que hoje pensar nesses campos arte, literatura para pensar o que é um estilo. Ela não vê a arte contemporânea clamando por isso, nem a moda. Sinto muito. Eu acho que essa palavra não cabe mais. Eu acho.
Agora design de moda da conta do que se teria como profissional que cria roupas?

Para ela dá se não limitar o termo. Limitar o design às escolas muito caretas, que ENCARAM O DESIGN COMO SOLUÇÃO DE PROBLEMA. Essa é a ressalva dela. Mas ela não acha que o termo estilista dê conta.

Falo que ela foi estilista em um momento de abertura do design racionalista já

Sobre a abertura do design do racionalismo ela não vê como algo linear. Não é que essa abertura veio e aí tudo mudou. Acho que muda num lugar, não muda no outro, tem lugar que não mudou até hoje. Tem lugar que jamais mudará. Tem pessoas agindo, coordenadores, escolas, que jamais mudarão de design. Jamais entenderão, design de objetos, design de móveis [?], vários campos do design que funcionam no sistema da moda, na lógica da moda, não é só a roupa.

A moda torna-se um modo de funcionamento de todas as instâncias do contemporâneo. A moda rege até sorvetes, gastronomia.

Então eu não vejo com a entrada de um fator estético ou fator simbólico que vai determinar que o design é mais complexo.

Fala de algumas aberturas no design, de Krippendorff do design centrado no usuário, design social. Parece que alguns campos do design estão um pouco mais alheios ao efêmero, mas a maioria não está.

O design vai levar em consideração modos de vida, gostos, estilos em alta ou em baixa.

Como ela entende projeto?

Quando ela me deu aula, há mais de 15 anos o tempo de desenvolvimento desse projeto era outro. Hoje os currículos têm um projeto por semestre então é preciso ter mais foco em uma certa metodologia por etapas. $\mathrm{O}$ currículo da UAM que ela trabalha mais tem um projeto por semestre. Só no último ano que o aluno tem um ano para desenvolver o projeto.

Tem que ter etapas para cumprir prazos. Em 2000 ela afirma que isso nem passava pela cabeça naquele momento. Ela nem cuidava disso para dizer a verdade. Agora ela orienta esses projetos. Então de fato, é necessário que existam ali, caminhos. E há pouco tempo para deixar o aluno divagar, focar mais em determinada parte do processo.

\section{ETAPAS PROJETUAIS}

Tem o briefing que um projeto, uma temática, um público-alvo já que o olhar de um público-usuário que é definido por semestre. Os projetos muitas vezes já têm essas temáticas gerais e o aluno tem que criar um recorte. $O$ grupo de aluno. Daí eles vão investigar que usuário que é esse, eles vão para campo. E eles vão pesquisar revisão de literatura desse mega-tema.

O projeto desse semestre, 2015/2 é moda e inclusão social. Ela falou que era mais fácil explicar a partir dele. Então esses grupos vão investigar o que 
é deficiente, qual deficiência eles vão trabalhar, que faixa etária, vão observar em campo, tem essa coisa inicial. Eles vão produzir também teoricamente sobre essas pessoas, sobre esse usuário, sobre o tema.

Na sequência eles vão começar a criar. A partir daí referências visuais para se criar painéis de referência, painel semântico, cartela de cores, os elementos projetuais, os elementos formais projetuais com isso em mente, quer dizer, tem algumas referências mais centrais que seria o que antigamente a gente chamava de conceito da coleção. E pode chamar assim: qual é o conceito que vai pemear? Mas isso não vem de uma tendência, isso não vem de uma vontade, isso não vem de uma paixão. Isso vem de alguma coisa que eles detectam, como uma característica subjetiva desse usuário e desse tema: inclusão social e o usuário é então um deficiente.

O que esse grupo de designers estão olhando, vendo que pode emergi como conceito?

Então eles vão fazendo processos mais soltos nesse momento de criação mesmo, brainstorming, para que o conceito emerja. A partir dessa emergência do conceito eles vão criar painel semântico, derivado desse conceito para que surja estudo de formas, cartela de cores, técnicas etc.

E aí as experimentações vão acontecendo, os testes etc, modelagem ergonomia incluída, ainda mais no caso desse público que é um elemento formal muito importante e aí vai desenrolando.

MODA TENDE À ARTE OU É DESIGN?

Para ela moda sempre foi design. Ela não acha que moda é arte. Moda não e arte. Ela trabalha com DIVERSOS CRIADORES DE MODA, que aliás ela acha uma palavra e um termo muito bom para alguns, e é um termo que data lá dos anos 60, do PAP. Ela acha que até hoje esse profissional existe, ele atua, no caso alguns só são criadores de moda.

O cara que está lá no Bom Retiro e importa da China é designer. Ele não é um criador de moda. Pode estar exercendo o seu projeto, mas ele é um designer de moda.

Existem criadores. Ela pesquisa criadores, esses Ihe interessam. Eles muitas vezes esbarram nas fronteiras da arte, da literatura etc.

Ela não vê a roupa que se torna arte. $O$ artista é alguém que em algum momento se denomina artista e diz "eu sou artista". Então esse exercício não vem da... nem se a pessoa se formou em arte na FAAP, ele vem, é igual à psicanálise, também é assim. Você estuda, mas o que que te reconhece como psicanalista? A comunidade.

Sobre ARTE

Outra característica do artista. Ele a princípio não está fazendo nada que tenha utilidade. A preocupação não é essa. Ele trabalha com uma problemática que ressoa nele como criador, reverbera nele e a materialização disso torna-se arte.
Eu faço isso de vez em quando e você também. Porque eu não sou artista? Porque eu não me chamo artista. Não significa que eu não faça arte de vez em quando. Que a arte para mim problematiza o contemporâneo necessariamente, não é que o artista expresse o mundo que está...não, ele problematiza.

Há designers de moda, criadores de moda que fazem isso. Ronaldo Fraga, Herchcovitch, Marcelo Sommer, Karlla Girotto, Jun Nakao e fora Hussein Chalayan, Margiela, Yohji Yamamoto, Rei Kawakubo só para dar uns exemplos. Essas pessoas são artistas? NÃO!

Para a Cris são criadores de moda que como problematizam o contemporâneo muitas vezes esbarram na arte.

Essa questão de pegar a aura, o único, isso não tem vez no campo da moda, se referindo à moda não ser arte.

Busca da aura pela aproximação, na busca por capital simbólico.

Eu acho esse termo (estilista) super ultrapassado. Ela fala da coisa do costureiro ser valorizado. Eu falo que a costureira é desvalorizada e ela responde que não acha. Ela me pergunta retoricamente, você sabe como eu me chamo atualmente? Costureira!

Porque em termos de legitimação [é menos valorizado] eu falo. Ela é, mas isso é divagação :0

Não é que eu sou costureira, mas eu costuro filosofia, costuro um monte de coisa.

Entender porque que a costureira do bairro em termos de legitimação vale menos que o costureiro pode me dar alguma base boa no meu trabalho, ela afirma!

Porque estilismo para mim, se foi ó. Não é por causa da moda. Banco do brasil estilo, o gerente de banco é estilista, estilista da sua conta bancária. $O$ termo se banalizou, virou qualquer coisa.

DISCIPLINAS DE PROJETO NORTEIAM O CURSO NA UAM?

Sim. Tem o Projeto Interdisciplinar desde o primeiro semestre.

Há disciplinas de PESQUISA, CRIAÇÃO E ESTILO e disciplinas de DESENVOLVIMENTO DE COLEÇÃO que são separadas, fora quando tem a disciplina de Projeto ainda separada ou Estilo.

Ela afirma que NÃO É MAIS na UAM. Ela tem uma disciplina em determinado semestre que ela vai congregar, por exemplo, esses meus alunos desse semestre...

$\mathrm{L}=\mathrm{E}$ projeto isso, Cris?

$\mathrm{C}=\mathrm{E}$ ! Eu oriento projeto. Aí as disciplinas têm ergonomia, acho que esse semestre eles fazem Criação de Imagem \& Styling e mais alguma outra. Aí o que que acontece? Na disciplina de Projeto tem conhecimento da ergonomia, tem conhecimento...tá...é isso. 


\section{MODA COMO CAMPO DO SABER AGÊNCIAS DE FOMENTO}

Ela diz que não é desse grupo. Ela conhece e acha uma luta insana para uma coisa que vai só...eu não sei como estão essas lutas, mas esses engavetamentos que são feitos pelas instituições e pelas agências CNPq e CAPES é insano!

O próprio Design já caminhou tanto e é uma área ali, coitada! Preterida, nem é um campo autônomo. Vai começar tudo de novo, entendeu? Eu ná vou, sinto muito. Eu to velhinha, tenho 50 anos, entendeu?!

Eu não vou entrar nessa luta. Eu sei, eu posso estar pensando pequeno. Isso é para as gerações futuras, mas não dá pra prever. Olha o mercado como já mudou. Olha o que é o designer hoje saindo para o mercado. No que ele precisa pensar? Ele precisa pensar em projetos com inovação e sustentabilidade, com modos novos de comércio. É outra onda.

Eu vou pensar numa coisa e o mundo muda muito. Daqui há 20 anos, sei lá o que será um designer de moda. Será que ele vai se preocupar com materiais e não mais com moda? A ideia de tendência, que já caiu há muito tempo, talvez caia mais ainda.

Então eu acho insano. Eu acho que não está politicamente...olha! Olha o Colóquio custou, o Colóquio tem 11 anos. Qual o problema de se ligar ao Design? O CIMODE tem isso (a ligação com o design) como base. Congresso de Moda e Design. Está articulado.

Eu acho muito mais saudável se você está bem inserido em um campo, você lutar micropoliticamente para você criar fugas ali para o seu campo do que inventar um outro e entrar nessa luta.

Eu a lembro que não inventaram. O campo existia autônomo antes de ser encampado pelo design.

Ela fala que isso é uma estrutura de ensino do Brasil e do mundo.

Ela defende que lógico que a moda é multidisciplinar por natureza, o design também. A não ser as caretas que não enxergam ele assim. Mas a meu ver ele é sempre multidisciplinar.

Talvez se ambas as áreas envolvidas (design e moda) fizessem sua parte mostrando mais a transversalidade entre elas, talvez a coisa acontecesse melhor.

FAST FASHION/OBSOLESCÊNCIA PERCEPTIVA AFETA A NOÇÃO DE PROJETO?

Totalmente!

É difícil. Eu entendo como pesquisadora que você em uma pesquisa vai ter que criar formas de olhar isso de um jeito com mais DISTANCIAMENTO. Mas o que que acontece?

O estilista que trabalhava na época em que eu trabalhava (anos 90?). Em muitos momentos o que ele fazia? Ele copiava roupas da Europa e ele era chamado estilista. Oi? Que nome é esse para alguém que está copiando roupa da Europa? Idem para o design.

No fast fashion ele vai desenvolver a roupa que a Kate Moss "inventou". Ele é designer? É. Ele está fazendo papel dele, mas não está criando, mas está executando etapas. Ele está sendo designer, sem dúvida. Mas talvez não esteja sendo designer na plenitude do termo, como o criador de moda, como alguém que possa levar além outras questões para além do marketing, como alguém que possa pensar em soluções muito legais, inovadoras, não nesse sentido babaca do inovador, mas de fazer uma solução interessante para alguma coisa, de juntar coisa que ninguém nunca pensou, de experimentar. Não, ele não vai ter tempo. Ninguém vai pagar ele por isso porque lógica é outra. E aí eu acho que é tudo meio que no mesmo saco, sabe?!

E esse é o ponto que talvez junte tudo no mesmo saco. A lógica neoliberal é essa. Ela suga tudo e ela acelera tudo. Então seja designer, estilista, qualquer coisa, [ela faz gesto de bater os dedos de uma mão nos da outra], minha filha ó...se vira aí que a celebridade fez a coleção e você tem que executar, está bom?! Bem crítica.

FORMA X FUNÇÃO

São aplicáveis. A roupa tem uma função e tem sempre uma forma. Obviamente no caso da moda, os atributos simbólicos vão superar a função, absolutamente, completamente. E daí eu não chamaria de atributos estéticos, mas simbólicos. O simbólico tem a ver com essa ideia de marca, de valor agregado.

A função simbólica nomeia melhor a coisa do valor simbólico da marca, por exemplo.

Pq comprar uma sandália de salto tão alto e fininho se você anda de ônibus?

Você vai comprar porque é a marca da sandália que a moça da novela das $20 \mathrm{~h}$ usa e ela te deu essa identificação etc.

Esses atributos simbólicos superam funcionalidade.

FALTA REFLEXÃO ACADÊMICA SOBRE PROJETO?

Eu acho que essas coisas sempre faltam, por isso a gente trabalha nisso.

Tem gente que acha que não serve para nada a pesquisa dela que transversaliza Moda e Filosofia

Ela fala que é sempre psicóloga, mesmo quando atua como designer. são os estudos de filosofia dela que fazem ela fazer um figurino, criar uma roupa, vender uma roupa etc. É o modo como ela vê o mundo.

Talvez essa ideia de campo do saber aí, seja pensar que ensinando Moda, A Moda, isso a tornaria um campo de pensamento. Mas para ela a Moda está sempre transversal. Para a Cris ela deve estar aliada a outro campo.

ESTILO NACIONAL E MODO DE PROJETAR NO BRASIL

Ver Revista da Cultura - 
Tem uma entrevista da Cris com a jornalista que viu o documentário "Mas isto é moda?" que tem uma parte que chama Moda no Brasil ou o Brasil na Moda.

Ela pergunta porque a Cris fez esse bloco no documentário e se ela faria esse bloco hoje?

Naquele momento surgiam novos criadores no Brasil, era a época do Phytoervas e do Morumbi Fashion. Ela achava importante falar de cultura para pensar como esses criadores estavam colocando suas singularidades em questão. Porque a cultura da cópia predominava ainda e esses caras é que começavam a se mostrar na imprensa como criadores singulares. Depois de Zuzu Angel foram muito poucos os nomes que fizeram alguma coisa singular na história dos anos 60/70.

Então nesse momento em que a mídia estava dando uma visibilidade para os eventos a Cris achou importante falar com essas pessoas sobre isso.

Mas ela faz uma ressalva de que não entende moda brasileira dessa forma (como no documentário) há muito tempo. Nem naquele momento, era só um jeito de dizer isso.

Porque o Brasil é um absurdo de mistura cultural. Então não há nada a meu ver ? que identifique uma cultura brasileira. Só tem clichê...bunda, carnaval, copa etc. Isso é clichê do Brasil. Para eu falar de cultura brasileira eu vou ter que falar do mundo aqui dentro do Brasil.

Um ótimo exemplo que eu gosto de dar aula disso é a coleção do Ronaldo Fraga que chama Disneilândia, que é sobre a América Latina. Com um nome que é irônico sobre o imperialismo americano. Para a Cris aquilo é moda brasileira, super brasileira.

Ele tem uma pesquisa cultural sobre isso.

MODO DE PROJETAR BRASILEIRO

Ela não sabe dizer se tem uma singularidade.

O DOCUMENTÁRIO “MAS ISSO É MODA?” ESTÁ NO YOU TUBE. SÃO 6 BLOCOS OU ESTÁ INTEGRAL.
MENDES, Francisca Dantas. Entrevista realizada

com Francisca Dantas Mendes, em 29 de junho

de 2016, na cidade de São Paulo, com 1 hora e 47

minutos de duração.

O estilismo tem a aura imagética, mas está ligado a uma coisa concreta que é o produto final.

ESTILISMO X DESIGN

Ela busca estabelecer um paralelo entre design e moda para poder conceituar. Quando o termo design começa a ser utilizado ele vem carregado de um conceito imagético só que ele tinha esse foco para a indústria.

Esse design brasileiro estava dissociado de uma coisa de artista plástico. Era um artesão, mas pensando na indústria. Como isso iria funcionar no processo de industrialização e de copiar aquele produto, seriar, replicar esse produto.

Então esse era o conceito de design. Quando a moda começa a chamar os estilistas de designers aí houve uma coisa muito gozada, lá desde o PAP, os designers ingleses, os tailors em Portugal, Espanha e Itália.

Eles eram pessoas que criavam produtos, desenvolviam, então eles eram artesãos que faziam do começo ao fim e com possibilidade de replicar porque existia uma modelagem pronto. Não existia o conceito de projeto. Ninguém falava "vou fazer um projeto". Era impírico, "eu vou fazer isso, depois vou fazer isso, depois vou fazer isso e depois vou fazer aquilo." Que a gente hoje coloca isso metodologicamente e define como um projeto.

Mas não era assim, ninguém pensava, nem Worth "vou fazer um projeto". O que acontecia era um grande envolvimento com aquela ansiedade humana de vestir algo diferente e os estilistas conheciam as suas clientes $\mathrm{e}$ quando estavam fazendo suas coisas, naturalmente percebiam e lembravam das suas clientes, tanto que Worth começa a fazer as primeiras coleções já pensando "a princesa normalmente vem aqui no inverno X". A criação era livre até certo ponto. $O$ gosto da cliente direcionava um pouco a criação.

Worth fazia o que ele gostava, era autoral, mas ele tinha quem vestir sua autoria. A Tita acha que é completamente autoral, mas acha que alguma cliente se identificava e consumia. $\mathrm{O}$ estilista continuava autoral, mas alguém iria consumir aquilo porque esse alguém era uma cliente que se identificava com a autoria.

E a Tita acha que isso acontece no "estilo" mesmo. E o estilista se sente satisfeito e continua "viajando nessa maionese" ou fazendo suas criações, suas pesquisas, suas grandes "viagens" para aquele público, para aquela mulher que ele sabia que gostava daquilo.

Dando um salto a Tita acha que é o que temos hoje. Há um número imenso de marcas e há críticas de que não são autorais. Ela pondera que não 
são autorais em partes. Porque hoje já tem um mercado estabelecido para determinado estilo, mas por um período esse estilista "criou o que ele queria para aquela mulher que queria o que ele queria", então ele foi fiel. Por isso começaram as marcas na década de 1960. O PAP vem com essa cara de industrialização, só que antes dele nós tivemos as boutiques e as boutiques já vinham dando um passo PAP. A boutique já montava uma coleção e já apresentava para a gente. Mas o cliente já sabia em qual boutique ele iria comprar porque ela tinha a "pegada" do que o cliente gostava, isso na rua augusta, no Mundo Mix.

O termo design entra no Brasil por uma questão de moda. Ele veio "design" (ela fala sussurando) com aquela aura da mudança de um nome que isso "é muito na moda" (acho que no sentido de em voga pelo que eu entendi).

Cropped $=$ mini blusa, mas a moda traz essa necessidade de mudança. É um nome porque a peça continua a mesma, projeto e processo não tem grandes mudanças além do nome. O "label" que vem e diz "Ah! É novo!", ou seja, estilista é velho, designer é novo.

Ela acha que um grande equívoco as pessoas que adotaram design de moda e acharam que a moda no Brasil é design de moda não são pessoas da indústria. E muitas delas não conhecem nem um departamento de desenvolvimento de produto e processo produtivo. Não tem nem como vincular a moda e esse processo de criação e desenvolvimento de produto e depois mercado.

$O$ design tem esse olhar de desenvolver para o mercado. E a Tita conta que ela sempre olhou e pesquisa e acha que as coisas devem ser feitas pensando no desenvolvimento de produto, no paradigma produtivo e olhando para o mercado. Só que para a Tita não é possível deixar de olhar para a moda. Porque se você fizer isso, dissociado desse anseio de inovação, de ditar o novo e de quantidade você não atende ao mercado. Por isso não dá para se sustentar só no design.

Aí usam a palavra design para viajar, ver, olhar e que para a Tita isso é estilo.

Um dos problemas de trazer design para dentro da moda (cito a geladeira da Cyntia Malaguti que leva 6 meses para ser projetada enquanto no ciclo da moda eu projeto mais de uma coleção a cada 6 meses). Na verdade o design quis encampar a moda.

Para a Tita a moda tem design porque ela precisa do design para fazer um processo produtivo, mas sem chamar de arte.

Antes de 1998 tudo já estava estabelecido dessa forma pelo Estilismo praticado pela moda, o problema é quando a palavra design quer substituir a palavra estilo e ela vem carregada de um conceito industrial. E aí que se esbarra nas diferenças como o fato de o design de produtos levar 6 meses para fazer uma geladeira.

Para a Tita o "problema" da moda seria um só: aquela mulher ou aquela pessoa ou aquele público alvo. $O$ importante é a marca ter um olhar e defini quem é a consumidora dela e isso era ensinado desde o início nas escolas de moda.
O principal foco das escolas de moda é mostrar que o aluno tinha que pensar em alguém que iria consumir aquele produto, principalmente na UAM.

Falo da experimentação do meu TCC e a Tita coloca que no caso do meu curso o que acontecia é que a palavra design estava sendo colocada como estilo. A Tita concorda comigo que era um período de transição o ano 2000 de renovação em cima da mudança de um termo.

A Tita fala que eu me formei "designer-estilista" e não "designer industrial" e completo dizendo que isso não deixou nenhum gap para eu trabalhar Ela atribui o fato de eu conseguir trabalhar na indústria por estar dentro da UAM, uma escola que tinha uma "pegada" de negócios. E os cursos da UAM vêm com base em um curso de negócios.

A UAM sempre teve esse olhar, o tripé "tecnologia, gestão e criação". A Tita se formou em gestão. Ela lembra que eu não estava dentro da escola d estilo, de desenho de moda que era a FASM, que veio das artes.

Na UAM a Tita teve aulas de Estilismo com a Laís Pearson, Carlos Simões e a Raquel Valente. Esses dois últimos que davam mais estilo. A Laís Pearson participava mais da coordenação.

Pelo background da Tita ela discutia muito lá na UAM e lá tinha muita gente de mercado da Alpargatas e de outras empresas importantes. Era um momento em que o conhecimento era produzido em conjunto, entre aluno $e$ professor. Ambos eram responsáveis pela construção do conhecimento no campo da moda. O CEBRAFAN foi criado pelo Gabriel da UAM para preparar professores para dar aula no curso de Moda.

\section{ETAPAS DE ESTILISMO NA FANTASTITA E NA UAM}

Fantástita era a marca da Tita de figurinos. Ela começou a confecção dela pouco antes de 1980 e oficializou em 1980. Ficava em uma travessa da avenida Pompeia. Ela tinha 3 motoristas. Todas as atividades que ela desenvolvia lá já tratavam de projeto.

Começou como Fantástita e depois a Chiquitita rigor infanto-juvenil. A preocupação da Tita era atender um público, então tinha que atender uma necessidade.

Em um momento posterior, quando ela começa a dar aula na UAM ela leva toda a experiência de confecção que ela tinha para dentro do curso de Moda.

BRIEFING

Ela conta que conversava com a dona de Academia sobre o tema e o que seria feito. Aí definido o tema começavam a estipular detalhes que iriam nos figurinos por faixa etária. Em uma turma vai colocar florzinha, na outra bichinho, na outra passarinho etc e isso ia crescendo.

Os segmentos para os quais a Tita criava figurino eram clássico, jazz, sapateado, contemporâneo e ballet de repertório. Nessa variedade ela tinha todas as faixas etárias e um único tema. 
Depois de definido o tema a cliente (dona da academia) começava a descrever o que ela queria para o baby ou tinha que ver se a professora do baby já tinha desenhado alguma coisa.

PESQUISA

A pesquisa começava no olhar da necessidade. $O$ que as academias de ballet necessitavam? Ela alerta que era muito próximo do processo de dequema de alta-costura.

Existe um "tema" para um festival para colocar todas as alunas no palco, por exemplo, "o guarani", "o quebra-nozes", "Gisele", "chapeuzinho vermeIho". E cada turma era contemplada com o mesmo tema que variava anualmente para cada escola.

Quando ela se refere à pesquisa de tendência, não é só da moda. É a pesquisa de tendência do mercado, do inventário interno da marca, do social (como é que está vivendo aquele seu público).

Na pesquisa do campo social uma marca começa a caminhar para uma estética mais vintage e seus clientes para uma "pegada" mais gótica. O estilista tem que prestar atenção nisso. Aí é possivel atender ao desejo da sua cliente.

Dentro da pesquisa de tendência o estilista já faz um tema, um esboço, uma ideia e aí parte para o painel.

A pesquisa permite ter "a grande sacada" que é fazer determinado produto para atender ao desejo da cliente.

Para a Tita o tema pode até não ter relação com a pesquisa inicialmente, como se saísse da cartola, mas ele precisa fazer sentido dentro desse contexto. O "tema" escolhido precisa se encaixar com o produto da pesquisa de tendências. $O$ tema precisa ser confirmado pela pesquisa.

REGISTRO DA PESQUISA

Depois da pesquisa de tendência e do direcionamento do tema é feito o painel. Em 1'06" a Tita diz que o painel está junto, no momento em que está sendo feita a pesquisa de tendência.

O painel vai sendo confeccionado à medida que o estilista vai fazendo pesquisa de tendencias. Ele é finalizado com os registros dessa pesqui Então quando a pesquisa é finalizada o painel também finaliza. Pelo que eu entendi finaliza para o uso do estilista.

A Tita chama de "painel de pesquisa de tendência". E depois ela fala que ele ainda é finalizando gerando a ambiência ou ambience. Pelo que eu entendi a finalização aqui diz respeito a um momento de apresentação e conta também com peças. Pelo que entendi é mais para apresentar para público e loja.

A pesquisa e o painel passam mais pelas mãos do departamento de estilo
O departamento de desenvolvimento de produto vem com a informação do inventário interno. $O$ que o histórico mostra em termos de resultados concretos da empresa no mercado?

Fechou a gestão da coleção, aí vamos começar a criar.

\section{"CRIAÇÃO DO PRODUTO"}

Para a Tita grafismos, painel, cores, formas e silhuetas estão dentro da "criação do produto".

$\mathrm{Na}$ UAM o primeiro ponto era a pesquisa de tendência de moda (e a Tita acha que ela continua até hoje). É preciso saber o que está acontecendo lá fora e, dentro dessa pesquisa de tendência, é importante contemplar as questões de marketing, mercado (que aí entra a estratégia de Potter). Sabe? A empresa ter o conhecimento de qual é o seu foco no mercado, seu paradigma produtivo e o INVENTÁRIO INTERNO.

O INVENTÁRIO INTERNO é para saber quantas peças vendeu nas últimas coleções. Ele vai além do Relatório de Vendas, pois além dos números você tem dados de modelagem, matéria, cor, padronagem e beneficiamento. São as variações de diferenciação que entram na estratégia de Potter, para você aumentar o número de produtos no mercado.

Essa etapa serve para Pesquisa e Mix de Produto.

Ela fala para eu consultar a dissertação do Décio que parece que descreve tudo em etapas. 1'09"

Depois da gestão o estilista recebe a informação de que ele tem que desenvolver 35 bottoms, por exemplo, dividido em básico, fashion, vanguarda dentro da coleção de tecidos escolhidas, dentro da cartela de cores definida. Então quando o estilista está criando, naturalmente é ele quem sugere o produto, o tecido, a cor e o tamanho dentro do tema.

O estilista já está criando no momento da gestão. Ele não fica parado. Gestão e criação ocorrem mais ou menos ao mesmo tempo. Mas com a gestão de coleção realizada os estilistas e outros departamentos têm que ver se o que criaram batem ou não bate. É um trabalho em equipe. Aí começa um esforço de "elimina, tira", "isso pegou, isso não pegou, isso aqui é legal, isso aqui não é legal". E o momento de apostas novas, pensar se não tem dejavus. Aí fecha. Se tem mais bottom fashion do que a gestão orientou corta e assim por diante, a coleção é negociada, senão nunca fecha a coleção com 150 peças. Só exceções aumentam a coleção por conta de modismos.

MIX DE PRODUTOS

Ela insiste no INVENTÁRIO INTERNO porque ele permite olhar os números. Por ele é possível perceber que sua consumidora gosta de determinada coleção, pela estética ou pela cor, shape, mas invariavelmente ela gosta e compra sempre "decote V". É olhar além. Perceber que todas as peças que têm decote $\mathrm{V}$ foram bem vendidas, todas que tem um mesmo tecido também foram bem vendidas. 
A Tita concorda que posso utilizar o termo "elementos do design" para me referir aos elementos que sustentam as vendas no inventário interno. E este inventário está ligado ao histórico da empresa. Alguns elementos-chaves são eleitos pelo público, mas de acordo com o histórico da empresa. No inventário interno é o histórico da empresa que está em foco.

\section{GESTÃO DE COLEÇÃO}

Na gestão de coleção é onde se planeja a coleção. Quantas peças vão ter? Quantos básicos, quantos fashion, quantos vanguarda? Qual a porcentagem? A Tita ministra esse conteúdo na disciplina de "Projeto de Coleção" dentro do Mestrado.

Aí é feito o Plano de Coleção, mas a Tita prefere chamar de Gestão da Coleção mesmo. É onde será feito o Mapa da Coleção, onde se tem todas as porcentagens, número de peças no básico, no fashion e no vanguarda, número de peças em porcentagem na cartela de cor, porcentagem por tipo de tecido, porcentagem por tipo de tecido com estampa corrida, porcentagem no tipo de estampa localizada, porcentagem no tipo de bordados. Essa gestão acontece em cima de uma quantidade definida de número de peças para a coleção.

Então se a coleção contará com 150 peças quantas serão de top, bottom e one piece? Quantas serão de peças básico, fashion e vanguarda? Quantas em tecido plano? Quantas em malha? Quantas de cada cor? Isso serve para a coleção toda.

A Gestão de coleção é planejada antes de entrar no processo de criação. Trata-se de estabelecer limites.

Feita a gestão da coleção são chamados os estilitas.

Ela fala que não se deve chamar de Design, mas sim de Estilismo porque é aí que surgem os gaps de que não se viu nem se verá a questão efetiva de um "problema", nem de "solução" efetiva sob a ótica do design, nem parâmetros mandatórios etc.

Em seguida que "você vai mexer com o processo de criação de cada um, que você já está encaixotando essas pessoas."

Há estilistas que já estão envolvidos no processo de desenvolvimento de coleção, mas só aqueles muito lógicos que não vão ficar defendendo o "sexo dos anjos".

Então a gestão de coleção é feita pelo departamento de desenvolvimento de produto que trabalha em conjunto com o departamento de estilo, mas não o tempo todo. E segundo a Tita junto com o mercado, com o marketing, com compras e com os pensadores da empresa porque esse é um momento de sucesso da empresa. É um grupo.

ESTUDOS DE FORMAS/SILHUETAS

A Tita não fazia propriamente um estudo de silhuetas, mas modelagens em miniatura, uma espécie de transferência de pences pelo que ela descreve.
Até porque a silhueta do ballet é bastante específica e, por vezes, deforma mais o corpo que uma roupa. E tem também referências históricas que podem ou não serem interpretadas. Mas não é possível no caso da Fantástita pensar em corpo pêra etc para o ballet clássico. Para o ballet contemporâneo as demandas já são outras também.

CORES

Havia um acordo entre a Tita e a cliente a respeito de cores. Havia cores que a cliente queria e o que o mercado disponibilizava. Tudo isso dentro do olhar do tema e do que a cliente estava querendo que fosse executado para cada classe.

Na UAM a Tita ensinava e ensina até hoje que é na Gestão da Coleção que será definida a cartela de cores em cima do que se conhece de tecido no mercado, inclusive do que dá para tingir.

\section{MATÉRIAS}

No momento da segunda entrevista, quando a Tita apresentava as fichas técnicas elas falavam em tecidos. Isso antes do desenvolvimento de modelagem. Aí que a Tita fazia uma cartela de materiais.

Imediatamente após a definição do tema você precisa ver se tem materiais para fazer o produto. É uma pesquisa de tendências também, mas de materiais. E aí na reunião de todas as informações o que se tem é um grande brainstorm. Aí o estilista chama representante, vai para o mercado, ou traz da première vision. Aí fecha a cartela de materiais.

Depois dessa conversa a Tita ia para a 25 de março onde pesquisava preço de tecidos e se achava alguma coisa diferente. $O$ preço do tecido er relevante para ver se cabia no custo.

A Tita pesquisava matéria 2 vezes. Uma vez antes de apresentar as fichas técnicas, outra vez, depois dos técnicos apresentados para verificar custo se achava mais alguma coisa em termos de matéria.

Na UAM depois do tema, painel e pesquisa de tecidos começa a gestão da coleção. Então a pesquisa de tecidos ocorre antes da gestão da coleção.

A Tita conta, a partir de vivências que ela teve no mercado, que trabalhou com equipes de 10-15 estilistas que chegavam a reunir 200 amostras de tecidos com materiais parecidos. A Tita coordenava para que se fechasse a coleção com 70 tipos de tecidos.

A Tita deu consultoria de qualidade no desenvolvimento de produto da Lucy in the Sky (confecção média, mas não publicar nomes). E gerava um estoque imenso, comprava um rolo de cada tecido.

Ela não autoriza colocar o nome de nenhuma marca para qual ela tenh prestado consultoria.

Essa negociação de materiais acontecia antes de desenvolver a coleção. DESENHO 
Em escolas muito organizadas o briefing já era passado para a Tita com todos os desenhos. Alguém era pago para fazer os desenhos. Nesse caso, era que nem escola de samba, chegava lá e já estava tudo pronto. Aí ela transformava tudo aquilo em "ficha técnica".

Quando a academia não oferecia um croqui a Tita fazia um desenho técnico direto.

Quando ela precisava por algum motivo apresentar o croqui, ela chamava um artista plástico. Mas nesse caso ela era contratada para fazer toda coleção.

O artista fazia o croqui à lápis e a Tita mexia em todas as proporções para depois ele arte-finalizar.

No processo da Tita ela primeiro fazia o desenho técnico e depois, quando havia necessidade, ela recorria a um artista. A referência da Tita sempre era o desenho técnico porque ela precisava disso para a modelagem.

$\mathrm{Na}$ segunda entrevista os técnicos eram corrigidos de acordo com o que a cliente desejava. Aumentava volume, diminui comprimento de manga etc. Daí ela fazia a segunda pesquisa de tecido para fazer o custo do produto.

$\mathrm{Na}$ UAM e nas consultorias da Tita ela conta que eram desenhados os croquis e depois de escolhido e negociado em equipe o que vai e o que fica eram desenvolvidas as fichas técnicas de criação, onde consta a descrição do volume da peça (silhueta), sugestão de tecido, cores e tamanho. Na ficha também devem constar medidas importantes como profundidade da prega, do decote, largura do cós etc, beneficiamento. Ai quando é o caso, cria-se a ficha técnica de estampa localizada, estampa corrida, de tingimento, de bordado etc.

E o momento de fazer todo o detalhamento em cima de uma criação. $O$ estilista pode desenvolver um botão, um caseado novo, um tipo de costura nova, faz avesso à mostra. Isso tudo vai na ficha técnica de criação onde o criador está descrevendo tudo.

\section{MODELAGEM}

Então havia turmas de "baby classy", "primeiro prime" ou "prime"[?], o primeiro ano, segundo ano, sexto ano, advanced etc. Ela trabalhava muito com a Royal Academy, academias que tinham a Royal Academy. E ia até chegar o ballet moderno, o jazz, o contemporâneo, todo mundo ia para o palco. Havia aí então um problema ergonômico do baby que são crianças de 3-4 anos, até as meninas que fazem parte do grupo.

Modelagem era custo fixo na confecção da Tita.

No processo da Tita a cliente aprovava as fichas técnicas com modelo, custo e material e a próxima etapa era a modelagem.

Depois as peças eram cortadas e provadas. Na prova eram eliminados defeitos. E fazia uma segunda prova.

Eram 15 escolas às vezes (até 20 ) e a roupa era personalizada na medida da aluna. As provas ocorriam em outubro.

$\mathrm{Na}$ UAM e em consultorias a ficha técnica de criação é a ficha de criação de um modelo que vai ser interpretado por um modelista para fazer a modelagem.

Depois da ficha a próxima etapa é a modelagem. Aí a modelagem vai ser interpretada pelo material. Aqui devem ser consideradas tabela de medidas em cima de inventário, confirmação de forma e silhueta do cliente, conferir a modelagem base da confecção e a graduação.

CONFECÇÃO

Ela começava a trabalhar em abril-maio para entregar em outubro-novembro. Ela produzia cerca de 5000 peças/ano.

A Tita usava ficha de criação e de custo. A necessidade da ficha de custo ocorre porque a Tita vendia um produto antes de produzir.

Depois da segunda peça, confirmando que estava tudo certo, aí a próxima etapa era finalizar a peça. Aí era para colocar manga, fazer bordado, colocar rendinha, colocar saia porque tudo era provado em partes. $O$ acabamento, bordados eram os trabalhos mais intensos. Finalizadas as fantasias elas eram colocadas em cabides com saquinho plástico e ficava estocado até o final de novembro.

Na UAM como professora é ela quem introduz fichas técnicas. A piloteira vai interpretar a ficha técnica de criação, mas antes tem a modelagem.

Com a modelagem a peça é pilotada e, em seguida, provada. Depois disso, vem as correções na peça, na modelagem, e, novamente é confeccionada outra peça piloto.

Este é um processo de criação que é pertinente ao estilista, pois é ele quem vai definir se haverá correção na peça ou não. Tudo nesse momento de avaliação está na mão de quem criou a peça. Se vai ajustar e quanto vai ajustar quem define é o estilista e não o modelista.

O modelista é o executor para a Tita.

Ela explica porque não gosta do termo pilotagem. Porque parece que vai só para a piloteira e, ela na verdade é a costureira. A ficha técnica é de criação porque ela detém esse processo e a piloteira tende à criação, ela é influenciada pela criação, porque ela pede pesponto, cor específica de linha, ponto de $3 \mathrm{~mm}$ e mais uma série de descrições.

Depois da prova, o projeto em moda cessa por hora. O que vem adiante é produção.

APRESENTAÇÃO

Já na fase dos desenhos técnicos a Tita fazia todas as fichas técnicas mostrava para as donas de academia de dança. Ela fazia em meia folha sulfite. Essa era a segunda entrevista. Na primeira era apresentado o briefing.

Aprovadas as fichas técnicas de criação e custos com o valor de cada 
peça e materiais definidos a Tita multiplicava esse valor pelo número de alunos por sala.

Todas as provas eram feitas nas academias, então tudo era levado para lá.

No final, depois de tudo provado e aprovado tinham ainda os acessórios, peças de cabeça etc.

\section{ESTILISTA OU DESIGNER DE MODA?}

Estilista.

Ela lembra do Colóquio de Moda em 2011, depois de ter enviado o primeiro documento do "Moda como campo do saber" em 2010 para o MEC.

SOBRE MODA COMO CAMPO DO SABER

Ela mantém estilismo por conta dessa dinâmica que não cabe na área de design. E muita gente que usa a palavra design utiliza como tradução para estilista e pessoas que conhecem o que é um design e usam como sinônimo de desenho industrial.

Só que fazer design como desenho industrial dentro de um departamento de desenvolvimento de produto em moda não cabe dentro do que a Cyntia Malaguti falou de levar 6 meses para desenvolver uma geladeira.

Outra coisa, você faz uma geladeira em algumas cores. Você não faz uma geladeira em muitas cores, estampas e tamanhos (ênfase em tamanhos) para públicos diferentes. $O$ design não contempla as questões do estilismo.

Então design não compete. Não atende ao estilismo. No design também não existe a dinâmica de colar lantejoula por lantejoula em uma peça.

No processo industrial, na engenharia também não cabe o que o estilismo prega, mas se eu não colocar um lacinho à mão em peça por peça não vende. Esse é o imperativo do estilismo, está dentro da sua gestão da coleção. Está dentro do processo de criação que tem que ser preservado.

Eu me formei estilista dentro de um curso de design.

E ela alertou para a discussão atual se EXISTE DESIGN DE MODA?

Como vai "designar" Moda? Não existe design de moda, é design de produto.

Falo para ela que o BOMFIM dizia que moda era design de produto e do seu trabalho junto ao MEC para moda virar design. Comento das leis de 2004 e 2010.

Na diretriz curricular de design...

Uma especialista do INEP esteve na EACHUSP no final de 2015, época em que estava sendo discutido se Moda iria ou não fazer o ENADE.

Ela explica que as faculdades que optaram por não fazer o ENADE não estão boicotando a prova. É porque não compete.

E outra coisa, essa especialista do INEP que esteve na EACH esclarece que não é solicitado ao curso de Moda que participe do ENADE. E ela coloca que dentro da matriz curricular do design de vestuário [alerto que não é só design de vestuário, é de modas também]. A Tita insiste que no contexto é vestuário.

O que essa especialista afirmou foi que quando se cria uma diretriz, depois a escola tem que seguir essa diretriz. E nesse sentido, os conteúdos que as escolas têm que dar têm que ser compatíveis com aquela diretriz. E aí começa a se discutir junto ao grupo de design o que vai ser cobrado das escolas. E nunca, as pessoas envolvidas no design olharam para as escolas de moda e $\circ$ que precisa que elas atendam. Nunca foram estabelecidos parâmetros para os cursos de moda pelo design.

Tanto que o grande problema do ENADE é que ele não abarca, não acolhe os conteúdos ministrados dentro das escolas de moda.

Porque muitos conteúdos que são ministrados dentro de escolas de moda não competem à área de design.

As escolas que começaram a encaixar para atender à exigências das diretrizes curriculares de design começaram a ter falta de espaço para dar o conteúdo necessário para formar o profissional que vai para o mercado de moda.

A Tita não lembra o nome dessa especialista, mas ela disse que não e obrigatório que cursos de moda realizem o ENADE.

Por isso há o grupo Moda como campo do saber que continua ativo. Vai ter reunião do grupo Moda como campo do saber. Vai ter no ENE Moda (Encontro nacional das escolas de moda), pode ser que role logo, esse ano. Ele é junto com a ABEMODA (Associação brasileira de ensino em moda).

Nesse encontro são discutidos os conteúdos, grades curriculares, os livros.

Em 1998 aquele encontro foi a primeira intenção de uma diretriz curricular em moda, mas foi em SP pelo que a Tita falou.

O MEC abre uma consulta pública para as escolas definirem suas diretrizes curriculares. E aí a FASM e a UAM se encontram. A Wandy Cavalheiro chama alguns alunos formandos de moda e parece que também tinha formando de moda da FASM, mas só pessoas que estivessem no mercado para que pudessem entender.

Existe esse documento que ensaiou uma diretriz curricular de moda, mas ela não vingou por lentidão. Nessas o design foi muito mais rápido aí o MEC não sabe o que fazer com o grupo de Moda e aí jogou embaixo do Design.

Bate com a história que a Mônica Moura me contou que foi enviada (e dançou). 
Como $\circ$ design se organizou e em suas diretrizes colocou que havia design de vestuário e moda dentro de seu campo o MEC coloca moda sob o guarda-chuva do design porque moda foi lenta [deu margem para que 0 design englobasse a moda].

A Tita fala que o design já estava muito mais organizado burocraticamente para atender a uma solicitação daquela. O pessoal de moda era todo novo, todo mundo vinha do mercado e não havia uma organização, academicismo.

FAPESP

Ela não sabe e tem que sair para reunião.
CASTILHO, Kathia. Entrevista realizada com Kathia Castilho, em 15 de dezembro de 2015, na cidade de São Paulo, com 1 hora e 33 minutos de duração.

Eu falo que ela, Cris e Preciosa sempre deram disciplinas análogas à criação de onde surgia um projeto. Então também eram disciplinas de Projeto.

Nunca deu disciplina sobre etapas de criação. "Nunca dei disciplina assim, Le". Eu semprei dei disciplinas mais de teor acadêmico.

História da moda, Moda e cultura, Moda e comunicação na pós. Ela afirma que onde "se insere mais com as questões de projeto" é com projetos que ela foi desenvolvendo dentro da UAM. Que é uma pós-graduação digital, o projeto de mestrado, a linha de pesquisa em moda, projeto de site. Mas sempre mais informação, construção.

Ela declara "Eu especificamente nunca trabalhei com disciplinas de construção de objeto ou de coleção, não"

Insisto que existia trabalhos conceituais feitos na disciplina dela e ela foge...fala da Sandra Harabagi..

Insisto que quem sempre deu disciplina associada à produto ou criação, foi sempre ela, a Cris, a Rosane ou Mário Queiroz.

Ela nega: diz "eu não!"

Lembro do look do sleepping bag feito para a aula dela que foi para expo. Era a coisa do corpo modificando a roupa.

Ela se lembra desse trabalho mesmo. Aí eu comento, então era um produto. Mesmo que não fosse uma aula formalizada de projeto. Era um curso com 6 horas/dia. Tinha produto até em História da Moda. Ela conta que quando deu história da moda também dava produto.

Ela conta que quando a Rita Andrade entra ela já quase não estava mais na graduação.

Ela fala de 2 trabalhos recorrentes: recriar os drapeados do período antigo e releituras do contemporâneo. Esse segundo dizia respeito a "Como é que a partir de algum período histórico a gente criava alguma coisa na contemporaneidade."

Insisto que não foi nessa disciplina, mas foi em algo como "Estudos do Corpo" ou "Moda contemporânea". Comento que realmente era uma disciplina de caráter teórico, mas gerava um produto. Ela balbucia "engraçado, né?!"

Foram as pessoas que muitas vezes me ajudaram a gerar os produtos mais interessantes que eu tive na faculdade. E mesmo no TCC quem me orientou foi a Preciosa. Ela tinha um interesse muito maior, tinha mais afinidade.

CONHECE OS AUTORES DE DESIGN?

Afirma que todos (Löbach, Bomfim, Munari) são bastante familiares. 


\section{E OS DE PROJETO EM MODA?}

Seivewright, Renfrew, Treptow e Jones - está abaixo.

Eu falo que eu não tive uma formação de projeto em moda porque esses livros nem existiam.

Ela conhece a Doris, conhece seu trabalho, deu aula (parece que com ela) e conhece o livro. A Jones ela já viu referências, mas não teve contato com fonte direta dela.

Cecília Salles de criação ela super conhece. Estudou com ela na PUC.

Falo que peguei uma fase de transição de quando saiu de moda para virar design e talvez por isso também não tive conteúdo de design. Eu comento que havia uma série de conflitos. E ela continua: "Tem, né?!" e ri. Ainda é muito discutível.

Eu tive filosofia com a Cris e a Preciosa, mas não projeto e o Mário também não contemplava. Era uma aula super prática.

Ela fala que é construir um pensamento de área. Não existia. No exterior também, você vê pelos nomes e datas. Tem uma relação muito americana e inglesa. Todo o pensamento humanístico europeu de onde é a formação dela e das profas. Da UAM não vem do projeto, vem muito mais da filosofia.

E cita Cecília que trabalha mais com processo criativo.

Falo que nos cursos de Design e Arquitetura tem Projeto que engloba tudo. Na moda tem disciplina de Pesquisa \& Criação, Desenvolvimento de Produto, quando não tem a disciplina de Estilo/Projeto ainda separada.

Ela foi avaliadora de cursos do MEC. Ela fala que encontra nomes de disciplinas, mas na ementa o conteúdo que é colocado é outro. Tem disciplinas preparatórias. Comenta que é muito complexo olhar isso. Às vezes não chama nem assim, nem assado, mas no conteúdo programático está lá em exercícios, coisas que constroem ainda como antigamente coisas como Estilo. Hoje tem uma super diferença para definir qual a diferença entre estilo, designer? Quem trabalha com o quê?

\section{AGÊNCIAS DE FOMENTO}

Até para salvar um pouco esses cursos como formação e como área. A ABEPEM trabalha muito com "como se constitui a área?", "Como é que a área se coloca?", "Porque que hoje mais de $90 \%$ dos cursos de moda estão em design?"...lembro que tem Lei.

Porque tem os que não querem ser design? Porque foi normativo, ela afirma.

\section{MODA COMO CAMPO DO SABER}

Até 1998 eram cursos de moda e moda foi um curso que não foi regulamentado. Mas tem os que nascem e querem ser Moda ainda hoje. E brigam até hoje. $O$ grupo Moda como campo do saber. Esse documento já foi revisado 2 vezes. Ela ofereceu de me mandar.
Eles acreditam que moda não se encontra dentro da área de design e queco saber. E aí está mais preocupado com a questão de preparar um estilista que é alguém que pense moda como conceito e não como produto.

Hoje é complexo. Há acepções aceita pela academia e não pelo mercado.

Falo da minha carteira de trabalho versus meu diploma e do protagonismo da criação no meu curso. Falo de como se apresentar profissionalmente e quando.

Ela foca além do valor, no que a empresa espera que seja feito pelo profissional. Para ela um estilista dará um respaldo mais criativo no sentido de pensar soluções únicas, enquanto o designer está mais relacionado com essa questão de projeto industrial e de mercado. Pelo menos todas as teorias têm apontado (mas não o mercado).

Reafirmo que foram acepções que foram compradas e ensejadas pelo meio acadêmico.

Falo que estou olhando diplomas.

Peço se ela consegue falar das etapas da parte que se voltava a produto na aula dela. Agora ela "nem lembro desse trabalho, de ter sido alguma coisa...quando você fala que você é da segunda turma de design..." ela se pergunta se deu aula para mim. Diz que para essa nova fase da UAM ela nem dava aula lá, dava no Mestrado.

Ela fica em dúvida sobre trabalhos que tinham esse teor prático. Falo de cada professora.

Arte ou Design? Há desejo de aproximar-se da aura artística, o ato criativo dentro do contexto da disciplina de estilismo?

Ela acha que escolas que usam estilismo buscam aproximar-se da aura artística.

Mas comento que da FASM por exemplo, que é a epítome desse caso, a maioria não vai para a Fashion Week. A maioria vai para o mercado, onde estão os designers.

Ela concorda que varia, acha que são especificidades de cada aluno ou diferenciada.

Design vai construir muito mais uma relação de [derivação/utilização/ inaudível] produto, de mercado, de industrialização do projeto, menos [inaudível/único]. Você [não] faz uma coleção de design de moda pensando numa peça ou em 10 peças. O design é mais amplo. Não como a noção de alta-costura que a gente tinha antes. Ela bebe muito na Deborah Christo. Para ela, o estilo dá essa concepção de reclamar o mercado 18'40". Ela acha que o Estilo tem essa abertura para pensar outras categorias de produto que não só os vestíveis como colour \& trim da indústria automobilística. 
Estilismo seria mais abrangente em termos de mercado nesse sentido, segundo ela porque olha mais as concepções artísticas, olha o mercado como uma possibilidade de linguagem, desejo, consumo mais de um ponto de vista sensível do que realidade de consumo e tendência. E aí esses cursos de moda/estilismo também abrangeriam a visão do curso que engloba Visual Merchandising, Comunicação que segundo ela "Não deixa de ser moda". Ter o carro da moda, também é moda.

Ela afirma que fazemos essa relação de moda com vestuário muito fácil.

Ela cita a Feira de Design de Milão onde moda é importante, mas ela está aplicada na lambreta, no toldo, na comida. Então é moda e a origem da tendência dos têxteis está tudo dentro da indústria têxtil de confecção e moda, mas tem essa aplicabilidade maior que o design traz. E ela acha que estilo pense mais nessa chave, mais artística, mais conceitual.

Para ela, design atinge mais campos industrializáveis. O estilo pensa mais conceitualmente diferentes abrangências de campo. $O$ estilo não está voltado para o industrializável ou de sequência de produto.

Engraçado que isso parece ser diferente de tudo o que ela fazia (e as outras profas da UAM) na época em que me dava aula. Na prática o curso voltava-se muito mais para estilo até 2003.

Ela fala da importância de uma construção ser replicada no mercado e não ser só conceitual. Fala do concurso de modelagem do Colóquio.

Para ela a ideia de solução de problemas é muito mais do design/projeto do que do estilo.

Estilo para ela pensa mais conceito, conceito no sentido artístico. E design está mais ligado à larga escala, resoluções de problemas e não construções de leituras artística do seu tempo vivido, vai.

Ela conta que chega da Itália e existiam 3 cursos: FASM, UAM E UNIP.

Fala do curso da FASM que era um curso de desenho com habilitação em moda. Na UAM existia o CEBRAFAM do qual ela não participou, mas tinha vários cursos e ali eles já trabalhavam muito com moda e mercado de moda. Então a diferença é que todos os professores eram originários da Alpargatas. A Raquel Valente foi um tempão professora lá. Era muita gente de mercado que se organizava para pensar curso de moda.

No caso da UAM tinha uma aproximação muito grande com a Alpargatas. Esse olhar para o mercado foi muito característico da UAM. As 3 escolas começavam a pensar o ensino de moda na mesma época. Ela deu aula para a Tita, a Romy. Ela formou a primeira turma. Era comum encontrar em reunião a Laís Pearson que era uma grande pesquisadora. A Laís, a Wandy Cavalheiro e a Vera Lígia que eram amicíssimas e criavam pontes de diálogos e combinavam "ah, você vai fazer mais assim, então vou fazer mais assado." Então foi uma coisa muito combinada. Ela foi convidada a dar aula no RJ e se dava aula em SP não podia dar aula lá. Tinha essa coisa. E ela conta que definiam, você quer uma coisa mais estilo vai para a FASM, você quer uma coisa mais negócios, UAM, onde vai trabalhar com coleções para grandes magazines. Quer ser autoral e ir para a SPFW vai para a FASM. Ela conta que faziam isso em sala de aula. Vai para a FASM, falava. Havia uma troca de alunos.

A UNIP era imensa e não entrava muito nesse diálogo e ficou sendo uma faculdade mais baixa renda.

Ela conta que como estudou na Itália chegou no Brasil e chocou porque aqui havia grande necessidade de se trabalhar com definições. $O$ que é moda, $O$ que não é? A alta-costura vai morrer? O que é moda autoral o que não é?

Como ela morou 9 anos na Itália ela era chamada para esse grupo de reuniões. Naquela época na Itália nem se pensava em design de moda. Parece que lá não havia controvérsia e a Wandy Cavalheiro parece que falava "não pode ser."

E hoje para a Kathia, design está muito mais atrelado às definições de mercado, de fast fashion, de design de produto, o design italiano que é super valorizado e tanto o método criativo.

Ela fala que no POLIMI design vem de engenharia e vai para a moda. Às vezes arquitetura nem aparece no meio. Aqui no Brasil, essa visão que vem da engenharia, depois do design e daí para a moda é uma visão que se quer matar. Porque no Brasil a engenharia é muito exatas. Na Itália há uma engenharia "humanicista", onde há faculdades na Itália em que engenharia é uma área das ciências humanas.

\section{EACH USP}

E essa era a proposta da USP. Transformar a POLI em uma engenharia de humanas.

O Moacyr Martucci Junior, primeiro coordenador do curso de moda da EACH USP, era engenheiro e a ideia é que esse curso tivesse esse olhar mais voltado para engenharia têxtil e moda, dentro da área de humanidades. Eles estavam nesse momento de pensar engenharia como humanas e não como um curso de exatas.

Ela acha válido enquanto pensamento contemporâneo.

Projeto ou estilismo norteando os cursos?

Ela acha que hoje tem uma visão alterada pela convivência com outras associações, com o Hidalgo que faz desfile. Por causa das associações ela acabou convivendo com quem pega esses projetos um pouco na mão.

Ela dá uma mudada de assunto. Ela falou que a primeira coisa que "a impacta" é essa coisa de criar conceito, criar conceito, criar conceito. A gente precisava falar: chega de cópia, pensa alguma coisa que vem da sua cabeça, do seu coração, da sua casa, da sua família, da sua cultura (tem a ver com Rosas FASM). E até resgatar a cultura brasileira, porque se tinha a ideia errada de que o que vinha da Bahia não era bom, que o que era legal era estudar Galliano. O resgate da cultura brasileira como valor e que isso podia ser colocado como diferencial no processo criativo, acho que isso era muito 
importante. Falou-se muito tempo de conceito. Em um colóquio em Recife, um dos primeiros, ela teve contato com o pessoal de Toritama e do Sebrae. Foram convidados alguns professores. Estavam Walter Rodrigues, Evelise Anicett para conversar e conhecer a região. Pelo que eu entendi a Kathia tb estava. Ela se lembra que eles começaram a mostrar números impressionantes da região e que a Anelise afirmou que não existia isso no Sul.

A preocupação deles era agora criar desfile e todo mundo questionou. Para quê desfile? Com o que já se vendia, com essa projeção de mercado e nem esse tipo de produto é para ser colocado na passarela. E daí surgiram várias questões. $O$ que é para ser colocado nas passarelas?

Ela conta que eles escolhiam expoentes do mercado criativo do Recife e mandavam para o RJ e SP fazer faculdade. E diz que formados, esses estilistas voltavam com essa coisa de "conceito" e "passarela". Ela conta que foi o primeiro impacto que ela teve como professora e pensou: "Meu, o que que a gente está formando? E cadê toda essa questão própria de mercado? De públicos diferenciados?"

Ali eu aprendi que essa região vende muito mais para a África do que para a Europa, não tem essa relação com a Europa. Existem outros mundos.

No dia seguinte, 16/12/2015, ela assumiria como Conselheira Nacional de Políticas Culturais pela área de Moda, a nível Federal.

Ela fez uma crítica que não conhece várias semanas de moda e criadores espalhados pelo país. Que tudo está muito centrado no Sudeste.

Ela fala da Casa de Criadores. Ela conta que Hidalgo fala que é desanimador. Que tudo que já chega na nossa mão você já se sabe de uma universidade, se é da outra. E ela pergunta: das faculdades de São Paulo? Hidalgo responde: Não! Pode vir de qualquer lugar do mundo. Porque existem umas etapas de construção de projeto que faz o Book (portfólio) desse cara no final do curso. Aí precisa colocar a peça para levar para o mercado internacional, o cara não sabe fazer etiqueta, o cara não sabe fazer preço, não sabe nada, segundo eles (associações que recebem candidato para desfilar, ou para exportar produto, ou para uma feira de design). Tem várias ações e os alunos não sabem nada do prático, nada o que fazer com esse conceito.

Então você fala: como é que o seu processo criativo. Você aprendeu "aqueeeelas" etapas, não é que você se solta...então primeiro, qual é o meu tema, depois qual é ...

Ela critica bem essas coisas das etapas!!!

Não tem vivência nessas questões. Ela conta que foi outro momento que ela falou: "Nossa senhora!". Ela acha muito instrumentalizado, mais do que mecânico. Ela acha que esses projetos com etapas não flexibilizam e que talvez esse não seja o objetivo do projeto. Então pensar em também como isto está sendo aplicado/ensinado em sala de aula.

\section{UNESP BAURU}

Ela fala principalmente que percebe que UNESP/FAAC DESIGN BAURU eles trabalham muito METODOLOGIA DE DESIGN. Ela fala da Cleusa da UEL, a Téti que era da UEL.

Então você vê, existe tanta preocupação que talvez a crítica genética vã falar: QUAL E O PROCESSO CRIATIVO?" Como é que você institui o seu processo criativo? Então como nos cursos de moda ninguém tem ainda um processo criativo que vai mostrar pela crítica genética que você tem um "eu preciso ouvir música antes", "tomar suco de laranja", sei lá...primeiro isso, primeiro aquilo, então a gente vai categorizando, fica muito categórico.

Claro você pode puxar da segunda etapa para a quarta, para a quinta, depois voltar para a terceira, mas só a leitura. Essas etapas não são fixas, claro que não. E dependem se é autoral ou comercial também. No autoral possível fazer uma coleção subvertendo todas ou quase todas as etapas ou simplesmente, abandoná-las.

Mas é uma necessidade nossa de entender o processo, de sistematizar Para o aluno, muitas vezes isso é complexo e engessa, você lê aquelas tabelas, você pode ir para lá ou pode ir para cá na hora em que você tem que criar uma coleção. Você olha aquilo e fala: "hummmm". A minha geração escapou dos métodos rígidos. Eu me salvei disso, porque embora rolassem as etapas, era tudo muito fluido, não tinha um manualzinho. Hoje eu estou estudando os livros. É um estudo formal que tem que ser feito de alguma maneira. Mas não desejo apontar o ideal ou o melhor, nem que tem que ter etapa.

Mas ela fala: que tem etapa tem, né?

Ela reconhece que tem etapas. Mas eu desejo com a minha tese proporcionar o debate, como esses métodos se aplicam, que tipos de resultados, em determinados locais, em determinados segmentos. Abrir o debate.

Para ela eu estou dando uma visão panorâmica de tudo o que foi construído, pelo que eu entendi e fala que leu meu artigo da Dobras.

\section{GRUPO MODA COMO CAMPO DO SABER}

Ela acha muito importante. É um grupo que se deu conta de que moda é um campo enquanto pesquisadores e a partir disso (ela fala fazendo alusão a ter feito parte desse grupo). Ela esteve envolvida no nascimento desse grupo. Quando teve o Colóquio de Moda em São Paulo. Ela fez parte desse grupo. Hoje não faz mais, mas auxilia de algum modo na construção do documento. A Vera, o Paulo Wollinger (Coordenador Geral de Regulação da Educação Profissional e Tecnológica da Secretaria de Educação MEC) estavam no colóquio. E ele era um contato da Doroteia. E ela já vinha discutindo a questão há muito tempo com ele e com a Patrícia (Mello Souza).

O Paulo Wollinger já auxiliava há algum tempo na construção do documento, desde o terceiro colóquio e esse era o quinto colóquio que ele participava dessas discussões sobre Moda como campo do saber. E aí ele falou, 
vocês precisam se organizar para fazer com que esse documento chegue (ao MEC?) e a Vera Lígia oferece ir para a FASM. E ela oferece as salas da FASM para essas reuniões acontecerem.

Começaram a acontecer essas reuniões e esse documento foi sendo formatado. Teve uma comissão para a escrita do documento. $O$ documento ficou pronto, foi apresentado. Em Brasília ainda não foi encaminhado e entãong recebeu ainda efetivamente.

A Vera Lígia estava na direção da FASM. Em Maringá a Vera Lígia foi para apresentar o documento, colher assinaturas e falar da proposta e tal.

A Kathia acha a iniciativa muito importante porque permite um diálogo entre os professores de moda, renova as possibilidades dos professores de moda também se conectarem com o que acreditam ser, ou que seja eficiente enquanto curso de moda. Mas ela hoje pessoalmente não acredita mais nessa possibilidade.

Design não é um campo de conhecimento autônomo.

\section{AGÊNCIAS DE FOMENTO}

E no último colóquio (2014) ela conta que tiveram a presença de dois avaliadores de área: CAPES e CNPq. O Triska e o Kindler.

Ele disse que na moda a turma não sabe fazer projeto (acadêmico), tem pouca publicação, não tem apoio para eventos, não tem unidade como uma área. E aí, como é que se constrói uma área de conhecimento?

Na medida em que você tem publicações, você tem revista científica, você tem boas avaliações de evento, você tem avaliação de publicação, você tem grupos de pesquisa, você tem projetos temáticos, você tem blá, blá, blá...

Aí ele mostrou dentro dos índices de projetos a serem submetidos. Moda não tinha nem projeto sendo submetido, não tem grupos de pesquisa autônomo que tenha resultado para a nação, ou para qualquer coisa que seja...

Então estamos tão, tão, tão atrasados que é bacana a gente pensar em transversalidade de área.

Falou do Fausto Viana que defendeu outro mestrado. Ele atua hoje na pós-graduação da ECA e na graduação da Moda na EACH. E ele percebeu que moda tem muito mais possibilidade de crescimento enquanto área, do que figurino só isolado. Ele é uma pessoa que trabalha muito com FAPESP, CNPq.

Quando ele pedia fomento em moda era negado a ele porque ele não tinha formação na área de moda. Essa foi uma das razões de ele fazer um mestrado na moda.

O "Moda como campo do saber" discutiam essa possibilidade de projetos de envolvimento de docentes, de instituições...então isso não inviabiliza na percepção dela a relevância de um projeto desse como área, que é importante principalmente para ir se posicionando e construindo esse fazer. Mas hoje ela não acredita na possbilidade de isso (da moda como área autônoma) acontecer...falar "ah, isso vai acontecer. Estamos trabalhando para isso!"

Ela diz que apoia assim: Ai gente, que legal. Sabe? Precisa de alguma coisa? Informação eu acho que a gente deve.

Há um grupo de pessoas que encamparam o projeto de fazer o documento para o Moda como campo do saber.

Hoje, ela entende moda como design?

Moda hoje no Brasil se constrói como campo do design, por lei, pelo número de instituições. AGÊNCIAS DE FOMENTO.

Percebe-se ao comparar Moda com Design, que é um pouco o que você está fazendo (referindo-se à minha tese) que Moda não é nem uma coisa nem outra, nem Moda, nem Design.

Se você tomar por base um curso de Design e pensar em uma habilitação em Moda que é o que seria recorrente (esperado, na verdade!), por isso tantos problemas de ENADE e tal. Você vê que não dá mesmo para um aluno de curso de Moda fazer ENADE. É uma discussão.

Substituir disciplina só cria buraco na educação. Em Moda, muitas coisas precisariam ser revistas com muito cuidado. Ela fala que olha para o curso de moda não como professora, mas como mãe. AGÊNCIAS DE FOMENTO

Tem muito curso que não tem nem uma filosofia coesa entre o corpo docente, o coordenador, não sabe exatamente quem está entendendo como design...eu acho que são muitos no Brasil. Na grande maioria ocorre isso. Então é difícil. MITO

\section{O que é esse design na moda?}

Ela não participa nem das reuniões do Moda como campo do saber.

OBSOLESCÊNCIA PERCEPTIVA E PROJETO COMO ATIVIDADE MAIS RASA

Acho que não afeta o projeto como atividade produtora de sentidos, mas a atividade é modificada por fenômenos como o fast fashion.

Ela cita o Enrico Cieta que fala da "Revolução do fast fashion". Ele é um economista e tem vindo muito para o Brasil. Ele diz que o fast fashion está na forma de criação e não na de produção. Não é mais um estilista, ou um designer, mas um grupo coletivo que cada um divide em grupo colaborativamente e desenvolvem resoluções e criam projetos mais rapidamente, mais consistentes para o mercado contemporâneo.

E ela continua afirmando que isso afeta sim, porque trabalhar em grupo, ela pelo menos acha o máximo. Principalmente quando a complexidade do contemporâneo exige soluções amplas, diferenciadas e tal. E eu acho que pensar isso coletivamente com possibilidades de inserção no mercado é um fator que muda a forma de projetar. E muda...mas acho que a gente está vendo isso muito atrelado a um discurso do sustentável, mas acho que tudo isso está na criação. E eu acho que o design é a grande solução. Não sei se 
é o Design de Moda, esse Design.

Ela acha que design no Brasil está virando uma coisa meio careta. A origem do design era meio careta. Parece que falar "sou designer" não vem carregado de uma coisa "moderna/arrojada" como vem fora do Brasil.

A crítica que ela faz é que ninguém olha o lado bom do fast fashion, como uma atividade produtora de sentido enquanto criação e projeto coletivo de uma equipe que otimiza o ato projetual. Há um discurso muito forte pautado pelo que é politicamente correto que só condena o que não é sustentável nos 3 tripés: econômico, social e ambiental, este último sendo a vedete.

O designer não vai trazer uma solução econômica, mas vai trazer uma solução de produto, de projeto. Então o que é o fast fashion nessa visão? Onde está o bacana do fast fashion? Está na criação. Está no criativo e não na colocação de mercado.

A rapidez já existe. Então o que vai acelerar? Criar mais roupa? Não. É o designer ou o grupo de designers que vão trabalhar diferentemente em cadeia, em colaboração para pensar...[produto].

Ela não fala de discurso redentor, não fala de produto incrível ou insubstituível. Se eu falar de tempo. $O$ tempo, se eu estiver na rua, pesquisando e encontrar soluções que eu te mande para você desenvolver amanhã e isso estiver pronto, é um tempo acelerado também. Tudo hoje é tempo acelerado para começar.

Os conglomerados também estão usando agências de trabalho. Isso constrói possibilidades de criação ou de invenção de produtos diferenciados. Se todos estão dentro de uma mesma empresa, se cada um é responsável por um ritmo ou trazer inputs de coisas diferenciadas, o tempo de producão da ide a fazendo mil coisas. E vai ser muito mais arejado porque está contando com esse diálogo de grupo coletivo.

A Farm por exemplo faz isso. Mas não sei se a FARM é um exemplo de fast fashion. Eu posso falar que a FARM é uma empresa de fast fashion?

Eu coloco que não tem como criar tantas coisas diferenciadas e tão úteis, 80 peças por semana, entende?

Ela rebate: porque a gente está falando em tão úteis? Ou tão diferenciadas?

Eu falo: em termos de sustentabilidade ou você substitui ou adquire algo útil ou bem diferenciado.

Ela fala, mas isso não é a questão do modelo fast fashion ou do que é o fast fashion. É isso que eu entendo. $O$ fast fashion não como produção de mercado, mas é interessante pensar na lógica do designer que cria para esse modelo fast fashion.

Eu falo que não vejo tanta possibilidade de ser tão criativo, mesmo em uma equipe grande, motivada, que não vai se acomodar em determinado tempo depois de criar tantos produtos. Eu acho que afeta sim. Já vi cópia no
André Lima também.

E ela coloca: mas isso também não faz parte do processo?

A noção que a moda se cria na $\mathrm{HC}$, depois vai para o PAP está muito ligada à ideia de estilismo. O design está muito distante disso. $O$ design de certa forma nega a história da moda?

Há uma percepção maior do estilista de moda ou do designer de moda para a sociedade?

Do estilista porque está mais no vocabulário comum. Você fala: você trabalha com moda? Ah, você é estilista. E a palavra estilista, na fala, ainda tem uma aura. Ah, eu sou estilista. É a mesma coisa sua carteira profissional.

E para ela, não para a sociedade? O que é mais interessante? Estilista ou designer de moda?

Para ela hoje é uma questão de valores. É uma questão complexa.

Ela não acha que a Deborah Christo cria uma oposição de mercado. Eu explico que é o trecho em que ela coloca que "design de moda" vai surgir como oposição de campo, porque já existe um campo constituído anteriormente, o da moda.

Ela reitera que não existe alguém falar que trabalha desenhando moda e alguém perguntar: ai, você é designer de moda? A pessoa vai logo achar que é estilista.

SPFWers são todos estilistas. Não há nada que seja nomeado como designer de moda, a não ser academicamente. $\mathrm{E}$ a academia fica buscando definições. Essa a noção de designer de moda, ele faz isso, isso e aquilo. E esse profissional é um pouco os 2: designer de moda e estilista.

\section{Qual é o mais valorizado? Qual é a terminologia?}

A Kathia acha que design ainda não entrou na nossa linguagem e reconhecimento, o que é um designer de moda. Então as pessoas confundem, dizendo do estilista, mas está se referenciando também o designer de moda.

Mas mesmo quem é designer de moda, fazendo roupa para a C\&A ele vai falar que é um estilista.

Realmente é só a Academia que fala disso.

Tem curso que se autodenomina design de moda e não tem a mínima noção do que está fazendo, que não tem nada relacionado a design.

Falou da Mônica Moura que criou junto com o Mário Queiroz e a Heloise Navalon o curso de Design de Moda. Isso depois de estudar muito os cursos de Design e de Artes 1'33"03

Então curso de Design de Moda da UAM é um curso que foi crescendo misturando certas coisas e aí todo mundo parou para pensar um curso de Design. $O$ curso da UAM é modelo para o país.

O Bomfim era super parceiro da Mônica, o pessoal da PUC RJ. E foram os 
mesmos que sentaram junto com a Mônica para pensar o Mestrado em Moda. A graduação em Design de Moda da UAM foi pensada nesse sentido de transversalidade com o design e a Pós muito alinhada à PUC RJ.

Denise Portinari, Cipiniuk, Bomfim têm uma abordagem do Design muito menos engenherística, ligada à psicologia, à filosofia. É muito diferent dos cursos de Design do Sul que estão imersos na questão da engenharia do método. São outras metodologias, então isso também é super claro, de onde vem o projeto, de onde é pensado...que tipo de diferenças cada programa constrói.

Peguei a coordenação do Airton, Sérgio Garrido, mas a Rita Andrade eu já tinha saído. A Kathia comentou adaptações de grade. Eu não lembro.

E ela critica o Airton ser psicólogo. E eu comento que na FAAP o Ivan Bismara é jornalista. E ela coloca: isso é uma premissa minha. O curso ganha a cara do coordenador. Mas nem tinha gente formada em moda ainda para ser coordenador.

FORMA E FUNÇÃO

Ela acha que são aplicáveis à moda, claro. Ela fala que hoje pensar só forma e função, mesmo no design é muito primeiro estágio né, primeiro momento.

A forma vai detonar uma série de possibilidades de inclusão, de leitura do produto. E a função também. Agora, todos os desdobramentos se a função pode ser negada, pode ser alterada, pode ser acoplada...todos esses desvios de percurso contemporâneo aparecem a partir daí. Mas ela entende que é importante forma e função. Tem vários outros elementos que podem se acoplar na contemporaneidade.

Não é por ser moda que prescinde ter função?

Não. A primeira delas é vestir. Cobrir o corpo é uma função. $O$ design se flexibiliza quando abarca a moda no sentido de forma e função. Hoje o de sign pode ser atualizado. $O$ Rafael Cardoso faz isso brilhantemente.

DIPLOMAS BACHAREL EM MODA X DESIGN DE MODA

Design de ? não é uma forma do design exercer poder sobre a moda? Não é uma visão reducionista ser só Design depois de 2010.

\section{AGÊNCIAS DE FOMENTO}

Ela acha que as áreas que o design abarca não cabem mais no design em si. São muitas especificidades de base, mas as habilitações envolvem a área de formação, inclusive laboratório, espacialidades completamente diferentes uma da outra. O MEC não permite mais habilitações.

Tá eu sou designer e faço carro e o outro faz vestuário/moda. Como eu diferencio? O uso das habilitaçôes não è mais permitido pelo MEC, mas ele não fiscaliza. $O$ curso não permite saber que tipo de design se está fazendo. É a crítica da Cyntia Malagutti de que o MEC no Brasil está andando na contramão dos cursos na Europa. Lá especializa, aqui generaliza, mas não dá conta.

O documento do MEC não é assinado, não tem com quem falar.

\section{PARECERISTA AD HOC FAPESP}

Ela faz pareceres para a FAPESP na área de comunicação, mas vão projetos de moda para ela. Mas ela recebe muito mais projetos de comunicação por causa do título de mestre e doutora em comunicação na PUC.

Ela conta a mesma coisa que a MC. Que recebeu subsídio da FAPESP e fica no banco de dados da FAPESP para ser parecerista, como "devedora", vai ou "parceira". Aí eles vão olhar o teu lattes ou a sua área de formação, os projetos que você vai desenvolvendo e eles fazem esse tipo de relação.

É frisado no Colóquio para quem vai pedir fomento para ir ao Congresso que seja em nome da Moda. Senão o projeto vai parar em qualquer lugar.

Cópia do Brás e Bom Retiro é para chorar. Isso é muito triste. E tem aluno que faz de conta que está fazendo a cópia e dá um jeito de fazer diferente. E tem que fazer moda de um jeito diferente no Brasil, porque esse tipo de moda calcado na cópia pode ser resistente, mas pelo que a gente entende esse tipo de moda está com os dias contados, não vai criar nenhum tipo de diferenciação, de mercado, não cria economia, aí vem os produtos chineses a 20 reais e muitas confecções estão fechando também.

Ela acredita que são 27 anos (tempo que existe curso de moda no Brasil) de tentativa de educar diferente da cópia na moda.

Mas também tem um mercado muito resistente, de empresas familiares, que ganham dinheiro assim.

Ela acha que hoje a gente tem marcas, estilistas, designers que também já pensam e conseguem se manter de um modo muito reconhecido como marcas que têm trabalhos diferenciados e que também nos enchem de pequenos orgulhos.

Falei da minha marca autoral que eu vendi na XXXXX 2nd floor e na Dual. FALTA REFLEXÃO INTELECTUAL SOBRE PROJETO NO CAMPO DA MODA?

Falta muito. Se eu pensar o que que falta? Falar de indústria têxtil brasileira. Falta muita coisa. Ela puxa a sardinha para o lado dela e solta: é um lado bom para a Editora, um lado bom para quem está se formando. Ela acha que não está saturado. A saturação pode ocorrer da mesmice.

Mas tem tanta coisa para construir na área ainda. Moda é uma coisa que desperta muito.

Enquanto projeto falta. Ela consegue elencar 4 ou 5 bons estudos que pensaram projeto, mas é pouco. Não há acompanhamento, isso funciona como dentro de uma empresa?

A Téti vai acompanhar um grupo de alunos para o doutorado dela, mas 
não dentro da indústria. A Kathia vai ser banca da Téti na Defesa. Já foi na Quali.

Falta olhar o mercado brasileiro para a Academia. Dar um apoio para a industrialização, para as empresas, as marcas, os designers que pensam em se colocar no mercado.

Porque a ideia do conceito, da subjetividade é o que eu mais curto. Mas aí, como é que isso de algum modo ajuda o país? Ou alavanca alguma coisa no país?

Dá para ver que ela está muito entre uma posição de quem é da criação e de quem acaba de assumir um cargo em nível federal.

Ela fala que o Colóquio vai ser em João Pessoa e lá tem uma indústria enorme de algodão, a EMBRAPA. Então vão falar de algodão. Eles tocam nos regionalismos. Fala do algodão colorido, pirateado. Ao invés de produzir o algodão colorido eles tingem e falam que é colorido. Vão surgindo questões.

ESTILO NACIONAL E UM MODO DE PROJETAR NO BRASIL

Ela acha um absurdo falar que não existe moda brasileira, mesmo quando se refere à história da moda. Ela concorda com a MADU do Senac. Chegav aqui dava um jeitinho de amarrar diferente, mudava o estilo. A Madu fala que essa "produção de moda" já configura uma moda brasileira.

Amálio Pinheiro fala de miscigenação. Ele vai falar que o Brasil é um país barroco, que a América Latina é.

Fala sobre a roupa do gaúcho, da baiana. Quando a gente entende o nosso referencial cultural como possibilidade de criação estética, você não faz moda brasileira, mas você parte de um referencial cultural de onde você aprende a ler o mundo.

Por último, sobre a FAPESP ela fala que sempre tem uma pessoa que puxa a orelha, tem sempre alguém, mas ela tem que olhar no email. Até agosto quem era o coordenador da área de comunicação era o Norval Baitello Jr.
QUEIROZ, Mario. Entrevista realizada com Mario

Queiroz, em 15 de julho de 2016, na cidade de São

\section{Paulo, por email.}

Biografia (Currículo Lattes)

2010 - 2013 Doutorado PUC SP - Comunicação

2006-2008 Mestrado PUC SP - Comunicação

1999-2000 Especialização Negócios da Moda UAM

1982-1986 Graduação em Comunicação Social UFF

\section{Disciplinas Ministradas de interesse para essa pesquisa}

IED, SENAC, SENAI

Pesquisa, Criação e desenvolvimento de coleções

UAM

Pesquisa e Criação de Moda

Projeto Experimental dos Formandos em Estilismo

FAAP

Estilismo

Perguntas

1)Por favor, descreva as etapas de projeto em moda ou estilismo (o que adotar) como docente e como estilista Mário Queiróz. (Pode responder 2 vezes se preferir).

Abaixo segue uma lista de etapas. É só uma sugestão. Se ajudá-lo, coloque na ordem em que realiza o seu processo e descreva cada etapa, ou ignore as etapas que não utilizar ou ainda acrescente alguma etapa que julgar necessária no momento em que leciona e como estilista. É importante que descreva como realiza cada etapa e qual a linha de raciocínio que te conduz de uma etapa à outra (a ordem em que elas ocorrem).

Pesquisa ou Coleta de Dados - Primeiro temos a pesquisa de público, depois a pesquisa de macrotendências e ao chegarmos ao tema, a pesquisa do mesmo

Registro da Pesquisa (Painel/Cahier ou outro meio de registro)- pastas, moral, arquivos no computador

/ Cartela de Cores

/ Cartela de Matérias

Estudo de formas e volumes 
/ Desenvolvimentos (estampas, aviamentos, etiquetas, bordados, lavagens etc) / Desenhos - 1. Croquis

Desenhos - 2. Técnicos

/ Modelagem e Moulage /

Geração de Alternativas - ???

/ Confecção do Look /

Apresentação (Desfiles - Fashion Show e/ou Desenho Técnico)

2)Soube que você participou de um momento fundamental do curso de Moda da UAM, a organização do curso Design de Moda no final da década de 1990 e, posteriormente, se tornou coordenador do curso. Qual era a abordagem de projeto naquele contexto que diferenciava o curso da UAM? E como foi a passagem do ensino do estilismo para o ensino de projeto em moda?

Minhas primeiras experiências em sala de aula aconteceram no curso de Negocios de dado a orientar os TCCs dos alunos. Em seguida surgiu a possibilidade da criação do curso de Design de Moda que conduzi, implantei e coordenei. Naquele momento a direção de Design possibilitou a transdiciplinaridade, a conversa entre as diferentes áreas do Design (moda, gráfico, produto, digital). Foram excelentes experiências que mostraram a necessidade do estudante de Moda pensar o todo.

3)Conceitue Desenvolvimento de Produto. Abaixo envio algumas dúvidas específicas a esse respeito.

Na minha opinião o Desenvolvimento de Produto começa após a etapa e Pesquisa e Criação da Coleção. Há uma participação dos profissionais do desenvolvimento na concepção do produto já que as adequações resultado final.

Para você Desenvolvimento de Produto se refere à modelagem e costura? Ou ao ato projetivo como um todo (da pesquisa à peça piloto costurada)? Inclui a produção em série? Ou desenvolvimento de produto só se inicia a partir do momento em que tem contato com a pesquisa de materiais ou outra etapa? Por favor, conceitue.

4) O que cursos de Moda como a FASM chamam de Estilismo, cursos de Design de Moda, como a UAM, chamam de Projeto em Moda. Essa últim prática tem sua origem no design e busca nele sua equivalência, embor por vezes seja dificil transpor alguns conceitos da área do design de produto para o design de moda, como por exemplo os conceitos de "problema", "parâmetros projetuais", "mandatórios restritivos", "mandatórios desejáveis"

Abaixo segue um resumo dos processos das áreas de produto e moda para pensar na questão.
Design de Produto $=$ Processo - projeto - produto

Design de Moda ou Estilismo = Pesquisa - criação - desenvolvimento de produto

Gostaria que você comentasse as divergências e convergências entre estilismo/design de moda e, em seguida, entre design de moda/design de produto com foco na forma de projetar. Por favor, lembre que em cursos de Moda temos disciplinas distintas para Pesquisa, para Criação e para Estilismo ou Projeto em Moda, ao passo que em cursos de Design, a disciplina de Projeto contempla todas essas etapas.

Pelo que venho acompanhado são poucas as diferenças entre cursos que usam o termo Estilismo e os que usam Design de Moda além da compreenão por parte dos últimos que a Moda está relacionada as outras expressões que em função de determinado público passam a analisa-lo a fim de desenvolver projetos que possam atender suas necessidades e vontades.

5)Mario, você sabe que em 1998 a Moda é encampada pelo Design. Nese sentido eu cursei Design de Moda na UAM em um período de transição (2000-2003), pois o curso já se chamava Design de Moda, mas contava com docentes que tendiam mais ao Estilismo que ao Design de Moda pelo fato de, anteriormente, a moda ser um campo autônomo. Se lembra como era nsinar Projeto em Moda naquele contexto?

A UAM possibilitou a conversa entre diferentes profissionais de design que na verdade se complementam. Cada professor tem sua história e sua características, mas devemos considerar que pelo baixo valor da hora/aula os professores pouco tempo para se reciclarem, então são poucos os que por um grande esforço pessoal - conseguem se atualizar, o que pode explicar que encontramos entre o corpo docente, profissionais que ficam muito fechados em sua disciplina e ainda aqueles que não se atualizam mesmo no seu setor.

6)Você atualmente se entende estilista ou designer de moda?

Pela minha história e até por entender a necessidade da conversa com outros setores me posiciono como designer e consultor de moda. 


\section{PRECIOSA, Rosane. Entrevista realizada com \\ Rosane Preciosa, em 10 de março de 2017, nas cidades de São Paulo e Juiz de Fora (via Skype),} com 1 hora e 31 minutos de duração.

Entre uma conversa e outra a entrevista mesmo começou em 11 minutos. Atualmente ela leciona "Diálogos entre arte e moda" e da "História da Moda I" quando "jogam" para ela, mas não é a praia dela. As disciplinas do Lattes não estão atualizadas. Ela lembra de outra disciplina que se chama "Práticas inovadoras da moda".

Falo do artigo dela do P\&D de 2006 com o da Adriana Hagedorn. Ela disse que botou o nome da aluna no artigo.

A roupa, o sujeito e a cidade está tudo integrado, como as vanguardas modernas com Baudellaire. Você é visto e você vê. A roupa pode ser um lugar de pequenos deslocamentos onde você não precisa usar isso ou aquilo como a moda dita.

A ideia é que o camarada transforme a roupa em uma experiência de algo que lhe interessa. A coisa de passar mensagem com a roupa é muito chato. Emais umvés onde a roupáu um disparad eu estou sentido que pode ser isso ou pode ser aquilo. É muito mais incorporar, um pouco como o Flávio de Carvalho fez. É sobre a roupa que abre um espaço sensível, a sensibilidade e a inteligência que na verdade pode [descobrir ?]. Ela fala dos modificadores que o Balla progeta e as pessoas usam pouco isso.

Interessa uma roupa que dialogue com as cidades de hoje, inóspitas e com grandes dimensões. Ela fala de gente que projeta para refugiados como a Lucy Orta. Essa gente que experimenta pensar a roupa para morador de rua, não tem a ver com o compromisso social, mas como é que é se deslocar na cidade, o que nos interessa, o que pode ser mais simples. Isso é no primeiro ciclo.

Quando ela vai para o segundo ciclo aí tem o TCC e ela cita um trabalho de "roupas de noite" sobre roupas de casamento das moças, e das mulheres e ela busca brechas porque ela não pode ser autoritária de dizer não faz isso, mas ela diz que entra numa conversa de dizer: é o seguinte, vamos ver se a gente não experimenta...porque se a gente experimentar fazer alguma coisa que não é aquilo que a gente já conhece, a gente de alguma maneira vai ganhar experiência. Ela tenta ir para "outros lugares" que forneça outro repertório visual e que desperte a vontade, como fotos de japoneses, ir a brechós também, dar trechos poéticos, mas esse ela acha que não funcionou tão bem.

Ela unia a coisa do brechó com a coisa dos trechos de poesia. É mais esse caminho menos conhecido para o projeto e para esse aluno. Ela leva filmes, referências como Inés Bardot.
Ela fala que desconhece bibliografia de moda de projeto. Não há registros de como as pessoas das classes subalternas se vestem, e hoje a moda poderia fazer mais isso. Qual é o conjunto de interesse delas, qual é o universo sensível e estético delas.

Ela encara a coisa mais como uma prosa do que como uma pesquisa alentada. Interessa a ela mais os rumores do tempo. É um outro modo de ver e julgar menos. Sempre a juízo e isso interessa pouco. Interessa menos a roupa do tapete vermelho.

O relevante dentro da Universidade é como é que você acessa (vou usar uma palavra ruim) os talentos que você tem para poder inventar a sua vida.

Ela cita a marca da Ruthschilling chamada Contextura.

O curso de Moda da UFJF é dentro do Instituto de Artes. Ela acha que o curso está se direcionando muito para produto. Ela gostaria que fosse um curso mais livre, mas os alunos têm necessidade de se instrumentalizar logo para ingressar no mercado.

O projetual é abalado por várias coisas e também não é só estilismo. Será que os nomes das coisas são importantes ou será que é importante como as coisas se realizam? Os nomes existem por causa do nicho, do CNPq etc.

O embaralhamento de territórios é muito mais interessante (cita a amizade de Poiret com Klimt e Émille Flöge).

Divisórias móveis (casa Rietveld).

O cara usa nomes para ser entendido. Inventar outros nomes é correr o risco de não ser entendido. Mas também fica desorganizado se cada um quiser inventar um nome, né?!

Se a moda não for abastecida de outros discursos ela está ferrada. Não tem mais lógica nenhuma...

O Mário Queiróz era super quadrado, porque com ele tinha que estabe lecer público.

Tendência de certa forma é dizer como e o que tem que fazer, diferente de se alimentar de cinema, artes visuais e poesia, além de outras referências além-moda. Tem a ver com o comentário do Troy Nachtigall sobre tendências. E o trottoir atrasado da moda.

Tem alunos-criadores que têm uma leitura muito boa do que está acontecendo à sua volta. O lugar da moda é tão rico quanto o das artes visuais. Tem muito preconceito com "o povo da moda".

Ela fala mais de uso do que de projeto e cita as melindrosas negras do filme do Noel Rosa. Ela fala bem da Andrea Saltzman e do livro dela e elogia muito. Para ela as visões de projeto diferente têm origem no olhar distinto para a vida.

As coisas não se definem pela funcionalidade só.

Cita a Agostina Comas / Beth Moyses / Gilda Chatanie 
Ela diz que na orientação de TCC da UFJF fica tentando convencer as pessoas de que talvez valha a pena se arriscar em coisas mais desconhecidas.

Lembrei que ela me orientava "escondido" e que hoje o nome dela está no meu Lattes.

Associo ela mais à parte da pesquisa no projeto

Lembro que as aulas de criação que eu tive com ela, com a Kathia e com a Cris nunca se referiam a tema. Era direcionamento.

O trabalho mais compartilhado com projeto da Preciosa apareceu mais na UAM. Ela curtiu trabalhar com a Suzy porque ela trabalhou com a Karla Giroto, que segundo ela, tem um viés mais "anarcomoda".

Ela diz que fórmulas, modelos de projeto não funcionam bem com ela. Ela lembra de uma coisa já vai metendo no meio, já vai descosturando.

Aí eu falo que eu não sei se o projeto tem que ter todas as etapas que citam e quando tem se elas precisam seguir determinada ordem,

Ela diz que é interessante eu falar isso. Isso que eu penso ela diz que nem chega a pensar desse jeito porque eu não penso, não tenho estudado projeto. O legal é suspeitar isso, olha não precisa ser desse jeito, a ordem pode ser outra, etapas podem ser eliminadas talvez. TALVEZ SIRVA PARA A CONCLUSÃO.

Não pode ser que todo mundo se adapte àquilo ali, eu digo.

Ela responde: mas o que se quer é instituir universais, né?! A melhor coisa para correr com esses sistemas é suspeitar desses sistemas.

Ela comenta que a Cecilia Almeida Salles dá pistas pelos relatos e dá pistas de como é que cada um opera. Ouvir o modo que cada um opera e de repente mesclar esses modos com o de outros pode levar a descobrir outros modos.

Ela sugere que um estudo interessante seria perscrutar os processos dos estilistas e a forma como cada um faz, cria, desenvolve uma coleção.

\section{SENACSP Serviço Nacional de Aprendizagem Comercial de São Paulo}




\section{CANTON, Andrea. Entrevista realizada com Andrea Canton, em 12 de outubro de 2016, na cidade de} São Paulo, com 1 hora e 33 minutos de duração.

Entrevistei a Andrea Canton na Benjamin Abraão

Ela se guia pelos TCCs do Senac e pelo seu trabalho para a área têxtil. Ela também pode tocar nos Projetos Gerais.

Tinha a disciplina de TCC mesmo, Projeto de Dossiê quando era na Lapa ainda, quando ainda havia o projeto integrado pela SMODE. Havia uma adaptação da SMOD de Paris para o Brasil e trabalham o Projeto diluído nas disciplinas. Por exemplo, no jeans. Esse projeto é bem antigo e as versões de projeto eram revistas. No projeto jeanswear o aluno deveria estudar $o$ universo de um criador mais conceitual e fazer uma tradução a partir dos elementos principais de criação desse criador pesquisado, o que se repetia mais em termos de material, volume, silhueta de forma a se perceber qual era a fonte de referência trabalhada ali.

Cada disciplina trabalhava uma questão. Criação de Estamparia trabaIhava a matéria, estampa, a interferência têxtil, como iria traduzir estampa, criar tecidos tridimensionais, eram várias as possibilidades.

Criação de Coleção levantava os elementos de estilo e assim o projeto era diluído entre várias disciplinas, mas cada disciplina com seu foco. An tigamente na época da Lapa tudo era muito diluído em termos de etapas. Planejamento de Coleção talvez fosse a disciplina que cuidasse um pouco mais disso, como uma coisa mais concentrada. Era a Higa que lecionava essa disciplina e a Canton também já deu. Mas ela conta que as coisas foram se modificando. Havia um projeto de lingerie, moda praia.

O processo mais comum era cartela de cor, elementos até a criação. $\mathrm{H}$ via muitas mudanças e cada professor fazia de forma muito diferente.

Havia uma discussão sobre projeto entre os professores no sentido de entender como cada um iria se responsabilizar por projeto e por qual parte.

Então aparecia cartela de cores, referências da tradução imagética ou só de silhuetas. As referências variavam muito com o objetivo do projeto, como um briefing. Se era um segmento jeanswear etc. Era assim na era Lapa.

No TCC era onde o aluno trabalhava o que tinha aprendido ou não nos 4 anos de curso e eram projetos mais individualizados.

estímulo podia ser visual, um clipe da Bjork, por exemplo, obras e mistura dessas referências. $O$ que era solicitado ao aluno era que ele entendesse qual era esse universo e qual era a intenção do aluno dentro disso.

Tinha o briefing, o tema para amarrar a relação estética, como organizava no painel essas informações. Sempre havia um painel. $O$ nome variava entre painel temático, painel semântico e caderno de criação quando eram "só referências".
Em laboratório de criação 3...

Sobre os painéis usava tudo junto. Havia referências objetivas e subjetivas nos dois tipos de painel temático e semântico. No fundo era a mesma coisa, quando foram para Jurubatuba começaram a chamar de Painel Semântico.

Ela falou para eu entrevistar a Jung que foi coordenadora com a Ana Laura que também foi e que iniciaram o curso.

Não existe congelar ensino. A moda é uma estrutura dinâmica. É importante buscar o que está acontecendo. Interessante pensar sobre isso, pois metodologia é mais fixa justamente para pautar, mas a intenção não é engessar.

Quando o foco era desenvolver no aluno o aspecto criativo, mais autoral, fazendo com que ele percebesse suas próprias referências e não precisasse ter um segmento. Havia um público, mas era construído. Nesse cenário, o caderno de criação é importante para fazer leitura em diversas expressões dentro da moda (silhueta), não tem muito uma etapa. Tem aluno que começa pelo protótipo, pela moulage, em miniatura. Ela percebia o volume sem ser roupa ainda e aí transformar isso em roupa. Ele configura um projeto menos linear do que esse projeto pautado por etapas.

Então (eu tentando puxar): tem cartela de cores, estudo de silhuetas, materiais, desenho (rabisco, rascunho, esboço), desenho técnico, modelagem e prototipagem.

Ela diferencia protótipo de piloto. O protótipo para ela seria um estudo da forma para virar roupa, não é ainda uma pilogem. $O$ protótipo para ela antecede a tela, seria algo que não está finalizado (é bem o oposto do design de produtos onde o protótipo é o produto bem acabado).

Ela admite que na moda a gente não costuma sistematizar.

AUTORES

Ela usava um pouco do Munari e reconhece que sentia falta de se pautar por autores.

Ela entende que projeto em moda é uma noção mais ampla, mas embora ela utilize etapas de projeto, o ritmo da aula dela parecia ser mais voltado ao estilismo.

Ela elogia o livro do Simon Seivewright.

Havia disciplinas de Laboratório de Criação e Estilismo.

Ela tem bastante dificuldade em relatar as etapas. Para ela existe uma ordem mínima, uma sistematização das etapas de projeto. Ela julga importante a partir da vivência dela ter contato com o material primeiro, antes de desenhar.

desenho pode ser limitador se você projeta antes de conhecer o material. Primeiro falamos de escolher um segmento, isso é um projeto específico, mas para ela o tema vem antes.

Quando se escolhia do segmento antes de tudo, no SENACSP trata-se de 
um projeto específico. Mas a gente pode dividir como $\circ$ próprio projeto: público, segmento, tema, cartela de cores. Ufa, até que enfim algumas etapas. Essa era uma das formas de se trabalhar, mas poderia mudar.

As referências culturais eram a primeira provocação e depois a organização dessas referências. Pode ser em painel, pode ser em caderno. Pode ser um agrupamento de imagens. As referências são um início, um recorte.

Assim como na SMOD a cartela de cores sempre vinha antes. Qual era a expressão das referências em cor?

Para ela o mais interessante é unir material + cor.

Silhueta ela trabalhava mais para coisas conceituais e menos quando $o$ trabalho era de estamparia.

Às vezes as mudanças são em detalhes na roupa, se tomarmos como exemplo o uniforme.

É preciso uma sutileza para observar os pequenos detalhes das roupas. Ela aprendeu isso no curso da Marie Rucki.

Da silhueta vai para desenho. Eles trabalhavam com "sombra chinesa" quando você só percebe o volume escuro, do teatro, só a sombra, é só a siThueta. Esses exercícios, embora ela tenha julgado muito primários, ela diz que eram importantes porque tinha aluno que não conseguia perceber a silhueta.

É tirar todos os detalhamentos da peça para enxergar só a silhueta d peça. Depois de desenho, vai para os técnicos e modelagem.

O desenho pode ter duas linguagens: aquilo que vai para a ilustração $e$ quilo que vai para a prototipagem. $\mathrm{E} \circ$ aluno podia escolher qual acessar mais, ilustração ou técnico de acordo com a forma como ele direcionava o trabalho dele, se mais voltado a um catálogo ou a um editorial, por exemplo.

Chamavam de croqui o primeiro desenho.

Ela fala de um intervalo no desenho que são os detalhamentos. Podia aparecer no desenho técnico onde o diferencial era uma costura para desenvolver mais além da silhueta.

Sobre os desenhos, quando o aluno tinha o croqui mais voltado à produção, menos artístico, ele fazia o desenho técnico de qualquer forma? (eu pergunto).

Ela fala que era sempre uma briga o desenho técnico para ela que era mais da "parte criativa", mas ela sempre achou o desenho técnico importante porque ninguém é obrigado a ler uma interpretação. E ela acha que o desenho técnico não tem o reconhecimento de sua importância devido.

Depois da modelagem vai para a prototipagem

Falei que tudo o que ela me descreveu até agora é estilismo e não projeto, porque as de projeto são muito diferentes.

Se voltando às etapas, pensando no profissional que vai se formar. Se você pensa nos processos e projeto de moda eu posso ir para alguns campos da moda: criação, desenvolvimento, produto final, consigo contextualizar, vou fazer a pesquisa, o desenvolvimento, a criação, os protótipos, os desenhos, nananã e o produto final. $O$ estilista faz uso desse conhecimento de projeto de moda. O estilista é um trabalho de moda mais específico.

Ela defende que a moda tem suas especificidades.

\section{RESUMO DO DEPOIMENTO DE ANDREA CANTON}

Entre as disciplinas que se dedicavam ao projeto estavam "Projeto de Dossiê", Criação de Coleção, Planejamento de Coleção, Laboratório de Criação e Estilismo. Criação de Coleção levantava os elementos de estilo, Planejamento de Coleção trabalhava as etapas de projeto de forma mais concentrada. Cada professor fazia de forma muito diferente e havia uma discussão sobre projeto entre os professores no sentido de entender como cada um iria se responsabilizar por projeto e por qual parte (CANTON, 2016).

Os alunos iniciavam o projeto a partir de um briefing direcionado a deerminado segmento/público ou adotavam como referência um criador conceitual. No segundo caso, o trabalho era traduzir os elementos principais de criação desse estilista pesquisado e o que se repetia mais em termos de material, volume, silhueta de forma de modo que a referência trabalhada ficasse clara (CANTON, 2016).

No que diz respeito às etapas o trabalho começava pela pesquisa de público ou criador de referência, em seguida havia as pesquisas de tema para amarrar a relação estética, cartela de cores, referências da tradução imagética e de silhuetas por meio de painel. Sempre havia um painel que variava de nome entre painel temático e painel semântico, mas havia também o caderno de criação para registrar as referências. Painel temático e semântico acabavam sendo a mesma coisa. Mais recentemente o nome painel semântico passou a ser utilizado com mais frequência. Nele havia referências objetivas e subjetivas (CANTON, 2016).

Depois do painel havia a pesquisa de material para só então o aluno se dedicar ao desenho da coleção que podia aparecer na forma de rascunho, esboço ou croqui. Com os croquis prontos o aluno desenvolvia os desenhos técnicos, a modelagem e a prototipagem (CANTON, 2016).

Quando o foco era desenvolver no aluno o aspecto criativo, mais autoral, fazendo com que ele percebesse suas próprias referências o processo dispensava a escolha de um segmento. Havia um público, mas ele era construdo pelo próprio aluno. Nesse cenário o fazer era menos linear que a noção de projeto de moda pautada por etapas (CANTON, 2016). 


\section{SOUSA, Cyntia S. Malaguti de. Entrevista realizada com Cyntia Santos Malaguti de Sousa, em 4 de} novembro de 2015a, na cidade de São Paulo, com 51 minutos de duração.

Ela cita bonitinho as etapas de design na moda na aula de graduação que ela deu. Está no roteiro.

Ela entra no Senac para uma consultoria para o curso de moda que estava entrando no guarda-chuva do design. A coordenadora do curso de moda do Senac na época era a Lucila Mara Sbrana Sciotti.

É ela quem convida a Cyntia para essa consultoria e nesse processo convida a Cyntia para atuar como professora no curso de design de moda e é contratada em 2003

Ela confirma a afirmação do Robinson Salata que Design Industrial, digita e gráfico estão sob o mesmo guarda-chuva para o Senac, mas que Design de moda não entrou pelo menos por enquanto.

Quando ela entrou lá se começou a falar desse projeto do Mestrado. E ela não era exclusiva do Senac. Na época ela havia assumido um trabalho bastante grande junto ao MINISTÉRIO DO DESENVOLVIMENTO e a CÂMARA DE PROJETO BRASIL-ALEMANHA. É um projeto que ela tinha em muita consideração porque era um projeto que ela montou e elaborou, então não tinha como se dedicar ao Senac integralmente. Esse trabalho dela era para levar o design brasileiro para competir em prêmios internacionais e surgiu aí o convênio que se chama DESIGN EXCELLENCE BRASIL, dentro do trabaIho de fortalecimento da marca Brasil. Foi ela quem elaborou esse projeto. Tudo isso + o Senac aconteceu em 2003. Ela fez parte do grupo que trabaIhou o PROGRAMA BRASILEIRO DO DESIGN. A FIESP tinha um acento no programa e era a Cyntia quem representava em várias reuniões. Então ela diz que acabou tendo bastante contato...

TEXTO QUE ELA ESCREVEU PARA O $10^{\circ}$ P\&D QUE FOI NA UAM, COM A LUZ GARCIA NEIRA

Defendiam nesse artigo uma diretriz do MEC que defendia que o bacharelado deveria ser um curso generalista em design e aí os tecnólogos que sim, que poderiam ser de moda, de produto, de joias, enfim..

Ela tem ouvido falar da discussão ser grande nos Colóquios de Moda e do grupo que questiona a entrada do curso de moda no design. (moda como campo do saber).

Ela conta que introduziu no curso de Design de Moda do Senac as disciplinas de ergonomia que não tinha, o ecodesign, história e teoria do design, metodologia de projeto. Houve uma discussão porque o curso concebia que onde havia a criação era nas disciplinas de laboratório de criação e era um outra condução. Sempre houve a dificuldade de dialogar e trabalhar a ideia do projeto com a equipe do curso ou com a maneira de pensar a moda. E por outro lado, nesse início havia uma carência enorme de bibliografia. Ela diz que entende a dificuldade porque ela tem a visão do design e também não entendia a dinâmica da moda, mas ela diz que não é possível mudar um curso, a "casca" do curso, você mudar a sua ementa, mudar o seu projeto político-pedagógico, e claro que isso é fundamental, mas ele se consolida na articulação dessas disciplinas, desses professores. Então houve uma época algumas palestras e workshops que ela preparou para trabalhar com os professores essa visão de design, sugestão de bibliografias, mas não houve uma...houve um interesse e tal, mas no fundo é...que toda a mudança um pouco as pessoas ficam inseguras, então é um pouco da condução do processo, de uma acomodação, mas precisa ter uma fase onde você vai trabalhando a construção de uma forma conjunta de forma que as pessoas se sintam participantes dessa construção.

Então ela acha que houve uma construção muito bacana no início, mas a continuidade foi difícil.

DESCONFIANÇA COM A GENERALIDADE DO DESIGN POR PARTE DA MODA

AULAS DE PESQUISA E CRIAÇÃO OU DESENVOLVIMENTO DE PRODUTO NA MODA E PROJETO NO DESIGN

Ela percebia essa separação no Senac também. A própria maneira como eles inseriram a metodologia de projeto na grade da graduação era fruto dessa percepção. Então Metodologia de Projeto era uma terceira disciplina de 2 horas introduzida na grade. E ela diz que sinalizava: gente ela é uma disciplina âncora e tal, ela é eixo. E ela assume a disciplina e deram a ela projeto de "cama, mesa e banho" porque aí ela não interferia.

Ela entende que tem muitas particularidades na moda. Entre elas é que tem uma pressão de criação, uma velocidade que é diferente do design de produto, você cria sempre uma coleção, você não cria uma peça única, é muito difícil você criar uma peça única na moda. No design você fica um semestre desenvolvendo uma geladeira, não tem como você ficar um semestre desenvolvendo uma calça.

Se você vir as temáticas de projeto, de criação é assim...marca concorrente, extensão de marca, à maneira de..eram as frases. Então era uma maneira completamente diferente de pensar a criação no design. À maneira de...é para você desdobrar em função de um...(?), marca concorrente é voce criar uma marca para concorrer com a outra, quer dizer, tinha uma cois muito pragmática de (inaudível) o mercado, mas absolutamente diferente a maneira, a visão de projeto no design, né?!

$\mathrm{L}=$ À maneira de...seria ao estilo de?

\section{$\mathrm{C}=\mathrm{E}$ (titubeando quase)}

Era à maneira de...trabalhar o projeto no semestre, completamente diferente da maneira de trabalhar o projeto no design que era por palavras-chave, por verbo, você pensava no contexto, numa necessidade humana, 
numa demanda, portar, experimentar.

\section{FUNÇÃO ESTÉTICA NA MODA}

Existe certo preconceito do design em relação à moda e um dos fundamentos, ou uma das nossas abordagens desse preconceito é essa fase funcionalista do design que é considerada ultrapassada na sociedade atual onde dentro dessa visão reducionista onde a visão estética estaria aí excluída.

Existe uma crítica veemente à ULM em relação a isso. Ela que foi modelo para a ESDI, implantado inicialmente por Max Bill, depois por Maldonado. Vários autores colocam hoje que é uma visão reducionista do conceito de função daquela época. Porque se você olhar os diagramas da Escola de Ulm você vai ver que eles dizem que o produto preenche várias funções. Então o termo função tem outra conotação, não é essa funcionalista. Então existe a função ecológica, a estética, prática, a simbólica. Então se você olhar programa original de ULM você tem umas 9 funções ali.

Então esse racionalismo, talvez, foi a maneira de conduzir o processo, a maneira de tratar o método, mas não de excluir outras variáveis que numa visão reducionista e crítica e rasa fizeram.

A visão que ela tem do período ULM é que a abordagem era funcionalista, mas que abordava várias funções. A abordagem era funcionalista, mas não no sentido de eliminar funções que seriam consideradas menores. E ela fala que foi essa visão que veio para ESDI, mas reconhece que há uma crítica a uma estética gratuita, ao decorativismo, ao styling e que existe uma fun-

Tem aí a questão da Gestalt, da forma, da pregnância, da redundância que mostram q sidere a estética.

SOBRE O MESTRADO DO SENAC

Ela foi chamada sim a compor esse corpo original do mestrado em moda, mas seu contato com a moda foi em 2002 e ela sente que não quer capitanear esse processo, pois nunca tinha dado aula em moda e achou que 0 mestrado iria ficar com cara de design. Ela não sentiu que tinha experiência para montar um mestrado em moda. Ela ajudou no início, mas não assumiu até por falta de tempo.

Ela recorre ao Ernesto Boccara que tinha uma entrada bastante grande no design pela arte (ele é professor de artes da UNICAMP). Ele por sua vez convidou a Maria Lúcia Bueno (da história da arte da UNICAMP). E foram eles 3 que começaram o processo de montar esse mestrado focado na arte, na cultura, na abordagem do corpo mais centrado na cultura. A montagem o mestrado foi centralizado na Maria Lúcia Bueno.

No design gráfico tb rolou o mestrado. $\mathrm{O}$ mestrado de design ficava na Scipião e o de moda na Faustolo. Na época a instituição questionava porque se fazer 2 mestrados e não um só. E haviam divergências de visões, das pes- soas e também o medo aí desse campo (moda) de prevalecer um mestrado em design e não se ter um mestrado em moda.

A Cyntia era a única do campo do design no mestrado de moda do Senac. Ela diz que chamaram pessoas do mercado, mas naturalmente pela experiência do Bocara e da Maria Lúcia ser mais na Arte, na Cultura e na História então o curso já tinha um pouco essa tendência. $E$ talvez também por medo de se perder espaço para um curso mais voltado para a moda e não se ter essa cara de moda, então do ponto de vista mais estratégico se achou mais adequado seguir esse caminho que daria uma perspectiva de autonomia do design.

O mestrado em Arte, Cultura e Moda do Senac era um mestrado acadê mico e ficou com esse olhar mais voltado para arte, história, sociologia, an tropologia e o mestrado em design ficou com a questão do projeto. Ela nem deu aula no mestrado em moda, porque a Cyntia vai pelo viés da ecologia, do projeto e eram áreas que não estavam tendo relevância.

Toda a formação do mestrado em moda era feita para manter autonomia em relação ao design.

\section{METODOLOGIA X MÉTODO}

Jargão da área do design. Metodologia no sentido de experimentação não de estudar os métodos, mas é mais um jargão. Hoje a maioria das faculdades dá a disciplina de Projeto. No design gráfico ela observou que quando dá o projeto chega no ENADE os alunos de gráfico não tiveram vários autores de design clássicos, de produto, porque por uma tradição a bibliografia dos cursos de design é mais voltada ao design de produto. Bruno Munari era o único que conheciam. Não conheciam Baxter, Löbach (de produto). Ela questiona seria o caso de ter esse contato?

E qual seria o papel do professor de projeto em apresentar efetivamente para o aluno o método embasado em algum autor e em que medida ele consegue discutir com esse aluno esse autor. Ela fala que no Senac os alunos têm 3 anos de projeto e que se fosse trabalhado um autor por semestre, $O$ aluno sairia da faculdade com pelo menos 6 autores trabalhados. A aula vira um eterno "método do professor" que não fala em autores. Até usa a metodologia de alguns, mas não identifica ou usa um "método próprio" e vira a "chave do baú", a "receita" e aluno vira um tarefeiro que ele repete aquilo e não questiona, não critica. Tem seu mérito porque intuitivamente o aluno aprende muitas coisas, mas se ficar só no intuitivo o aluno não sistematiza essa informação.

A aluno vai trabalhar no mercado de forma intuitiva. Ele não reflete sobre aquilo que fez.

Ela fala que eu tive processos de criação, mas não metodologia. E é fato

Era um processo que se equiparava ao dos artistas. Recebia o tratamento de algo autoral, do artista. Ela diz que cabe uma crítica ao processo racionalista do design, mas que também essa ênfase só no processo criativo que foi o que eu tive na UAM também é complicado. 


\section{TERMINOLOGIA}

Segundo ela tinha que haver um trânsito para entender o que era peça piloto, o que era protótipo. Ela usava a nomenclatura da moda e do design para fazer a transposição de conceitos. Ela usava o painel semântico, o painel de ambiência também. Ela sempre procurava usar as duas nomenclaturas.

Nem sempre, não sei se corretamente, mas procurando uns paralelos nessa linguagem. Ela trabalhou com ergonomia um projeto para dança. Houve críticas do pessoal da moda, no sentido de não, não faça isso. E também não trabalha[va] junto, então havia realmente uma barreira bastante grande. Nessa época a disciplina se chamava Estilismo [?] BUSCAR UM DIPLOMA DO SENAC DO INÍCIO DO CURSO 1998-2000 E DE 2005.

É preciso um processo de experimentação com os professores. É o que eu estava falando no início da nossa conversa. Você construir essa nova visão em conjunto. Não é uma questão de substituir pessoas ou substituir uma coisa pela outra. Não dá para você transpor o projeto do design para a moda com a visão de design. Tem particularidades a moda e o design também pensa diferente. Se acha com uma função social, pretende fazer certas coisas, mas de uma forma utópica, dentro de uma realidade mercadológica que você está sujeito a certas diretrizes que não adianta você negar né?! Você está dentro de uma efemeridade, de um ciclo de vida [curto] e muitas vezes, mesmo que ele não queira, o design acaba também virando moda. $\mathrm{E}$ a moda contaminar o design também é um tabu.

Isso também depende de o quanto as pessoas estão dispostas a constituir uma ideia nova, um projeto novo de design. $O$ contato com as faculdades do exterior também aponta que é design (ela citou Bunka, St. Martins etc).

Por a moda ser um fenômeno social tem que entender que ela é diferente, e uma forma de pensar diferente. É preciso pensar dentro dessa dinamica e a gente vive dentro dessa dinâmica e o design querer dizer que está fora dela é uma ilusão também. É uma utopia de certa forma. Não é a moda como uma ditadura. As pessoas se comportam pela semelhança e pela diferenciação, faz parte da dinâmica social. Pensar a moda do ponto de vista sociológico é um ganho também para o design. Da mesma forma que o curso de design daqui [da FAU] não tem antropologia, sociologia. A disciplina que tem no curso de design é "Aspectos sociais do design".
SOUSA, Cyntia S. Malaguti de. Entrevista realizada

com Cyntia Santos Malaguti de Sousa, em 25 de

\section{novembro de 2015b, na cidade de São Paulo, com}

57 minutos de duração.

FAPESP

Fez alguns pareceres, mas recentemente nesse ano (2015) não recebeu mais nenhum para fazer e o último que fez foi no ano passado. Mas não fez nenhum parecer para projeto em moda. Não sabe como designam os projetos, nem quem designou.

Pelo tipo de projeto que ela recebeu para analisar não tinha um enfoque voltado à sustentabilidade, nem à moda. Tinha um cunho voltado ao empreendedorismo. Procurou saber, mas não conseguiu.

Ela não sabe dizer quem pode me ajudar dentro da FAPESP para compreender melhor como a agência de fomento localiza a área de moda dentro das áreas do saber.

Ela conta que houve uma reunião do grupo e no dia ela fazia mudança, então não pode comparecer. $O$ parecerista faz um parecer e depois tem uma reunião onde esse parecer é compartilhado. É uma reunião onde se discutem vários projetos. $E$ foi na primeira semana de agosto, só que não foi nesse ano. Nessa reunião eram vários pareceristas que receberam projetos como a Cyntia. Era projeto de outra natureza, não era projeto de mestrado, nem de doutorado. É uma reunião grande, com várias pessoas.

Ela se credenciou como orientadora por causa de uma candidata, aluna do mestrado do Senac. E a partir dai é enviado seu perfil, seu lattes e isso faz tempo, ela conta que foi em 2008. Eu acredito que haja uma reciprocidade porque alguém analisou o projeto da orientanda dela e hoje ela analisa o de outras pessoas. Ela concorda dizendo talvez. Mas nunca teve bolsa da FAPESP.

Sou designer de moda no diploma e estilista no mercado.

AUTORES

Bruno Munari, Löbach, ok, claro que ela conhece

Sue Jenkin Jones ela também conhece.

Simon Seivewright e Collin e Elinor Renfrew ela não tem, não viu ainda.

Treptow ela não tem também. Acho que não conhece.

Bomfim não falou nada, mas deve conhecer.

ESTILISTA X DESIGNER DE MODA

Não tem fundamentação para falar, segundo a própria, mas vê mais estilista aqui e no exterior fashion designer. 


\section{QUAL AGREGA MAIS VALOR?}

Não saberia te dizer. Lá fora, em Londres, Paris eu vejo muito fashion design. E vejo também muito essa coisa da alta costura. A impressão que ela tem é que tem essa coisa do estilista conectado à alta costura. E o fashion designer essa coisa um pouco mais "mercado", mas pode ser que seja só uma sensação. Não saberia te dizer.

Ela fala do ready to wear na Inglaterra associado ao fashion designer e que lá não vê a denominação estilista.

MODA COMO UMA ÁREA AUTÔNOMA, CONHECE "MODA COMO CAMPO DO SABER"?

Hum...hun. Comento que moda surgiu relativamente autônoma, ligada à arte. Ela fala do design no RJ que veio ligado às Belas Artes, na Faculdade Belas Artes em São Paulo também. Ela conta que nascer da arte não é privilégio da moda. Os cursos de design no Brasil também nasceram da arte.

Para ela isso é uma característica, uma peculiaridade aqui no Brasil. $O$ IAC teve uma ligação com o MASP...o RJ também teve isso no MAM. Em pouquíssimos lugares é diferente. Só na FAU que design estava ligado à arquitetura quando Milly Teperman pede para separar há 10 anos. Na FUMA o design tb era ligado à arte.

Tomas Maldonado e Max Bill eram artistas neo concretos que fundaram a ESDI. E o Kandinsky e o Paul Klee que foram professores da Bauhaus? Para ela o que aconteceu com a moda no Brasil no âmbito acadêmico quando de seu nascimento não é diferente.

Van de Velde dirigiu uma escola de artes. Escola de Glasgow, Macintosh.

Questionamento grande da arte do descolamento da realidade como futurismo é o berço do design.

DESIGN EXERCE UMA FORMA DE PODER SOBRE A MODA? É REDUCIONISTA DIANTE DAS ESPECIFICIDADES DA MODA?

Família de produtos do design = portfólio de design .

A relação da moda com o corpo é bastante diferente. A matéria prima é bastante diferente. Porém a moda como campo é maior do que seus acessórios e seu vestuário.

Para ela do ponto de vista da produção defender como campo o vestuário como moda é tomar a parte pelo todo.

O estilismo também é uma parte da moda. É uma das maneiras como a moda se materializa é no vestuário, seus acessórios, maquiagem, no corte de cabelo. A moda é muito maior. Você querer reivindicar só moda é um pouco você querer dar conta de um campo que é maior do que o que você está propondo, o projeto.

NAS AGÊNCIAS DE FOMENTO!!
MEC e o bacharelado integral generalista de design está na contra mão do que está acontecendo no exterior. Lá fora você tem esse guarda chuva do design, você tem vários cursos independentes. Aqui foi feito o contrário. Apesar de ter o design de moda, design de joia, design disso e design daquilo você voltou para trás [sic].

Isso criou essa situação constrangedora de você se ver embaixo do guarda-chuva do qual o design não dá conta. Da mesma maneira que $\circ$ web design tem particularidades muito diferentes do design de produto. Eu vejo uma situação muito semelhante à da moda. Um sujeito ficar fazendo moda quando quer cursar web design. Ela vê que existe uma diretriz que não se sabe quem definiu isso, mas que está na contramão do que está historicamente no resto.

Essa diretriz de tudo é Design (2010) fez com que os cursos específicos ficassem menosprezados. Porque virou um curso de tecnólogo [para ser independente].

Essa decisão foi criada e foi equivocada, foi ela que criou problema. Talvez tenha sido luta de poder, ela admite, mas não vê isso como uma decisão do campo, vê como uma decisão de um determinado grupo, que conseguiu legitimar isso. Mas essa legitimação criou um conflito que é pertinente, no sentido de que é uma camisa de força.

É mais como se recortou isso do que estar dentro do campo o problema.

Deveria haver uma diretriz para permitir "Design de..." e não até o "Design de sobrancelha...", mas ela questiona: aí é 8 ou 80 . Houve uma radicalização onde se partiu para um só (se optou por deixar só design).

Como formada em uma profissão que até hoje não foi regulamentada ela acha que o mercado que baliza essas questões e cita minha carteira de trabalho.

Para ela é uma relação dialética, de mão dupla. O conhecimento vem da Academia, mas tb troca, recebe do mercado. Citou a GROUNDED THEORY. A Academia produz conhecimento, mas ela também olha o que está acontecendo na cidade, na vida afora. A Academia tem métodos para sistematizar uma informação que às vezes lá ela está sendo produzida gerada, mas não está sistematizada numa forma de poder transmitir esse conhecimento, entender como ele se situa em relação ao que veio antes e como base para o que possa vir depois. Ela acha que o papel da Academia é também esse. Entender o conhecimento e traduzir aquela informação em conhecimento e transmitir esse conhecimento.

As disciplinaS de criação dentro do Senac passa pelo "à maneira de", "marca concorrente" o que para a Cyntia não é você copiar, mas é você partir daquela referência diretamente, né?! Não é uma cópia, mas é uma inspiração direta no vizinho.

BINÔMIO FORMA X FUNÇÃO

Cultura do corpo, da saúde, do envelhecimento, moda inclusiva fez a 
moda se repensar um pouco. Não é um dobrar-se à moda. Mas é que existem questões humanas que foram trazidas para a moda de um lado. E essa questão do desempenho, do bem estar e o avanço da cultura do esporte, da saúde trouxe esse referencial para a moda de outra maneira. Então ess forma funcional, ergonômica, do conforto, do bem-estar.

$\mathrm{Na}$ opinião dela isso tem feito a moda trabalhar um pouco melhor a questão da forma e função e não só a questão do simbólica.

Há outro lado da industrialização da moda. Do lado operacional da moda. Falou dos moldes reaproveitáveis, a saia que usa para fazer vestido etc ela fala que é uma escala um pouco mais profissional. Ela diz que é inescapável, que o design veio para atender a essa demanda e por outro lado a necessidade das pessoas.

\section{REFLEXÃO INTELECTUA}

O problema dos cursos de design é o excessivo caráter racionalista que às vezes o aluno se tolhe para viajar. Então você fala quero 10 desenhos e aluno de design é meio limitado às vezes. Ele tem dificuldade em cima de um processo muito racional.

E na moda os alunos não estão tão conectados com essas diretrizes mai racionais de briefing e não sei o que. Eles saem criando, saem criando, saem criando um monte...então tem às vezes essa liberdade expressiva que ela acha que falta ao design em alguns momentos.

Por outro lado, o aluno de moda tem muita dificuldade da ideia de problematizar. Ele não consegue muitas vezes entender qual é o problema, quais são os problemas situados em um contexto, ele muitas vezes não consegue situar aquela criação dele em cima de um contexto de uso, de uma situação. $E$ às vezes ele cai na criação espelho, está criando o que ele gosta, o que ele acha bacana. Então aí ele vai criar para um espelho. Ele tem dificuldade de sair de si e olhar o outro, o objeto de sua criação e entender o que esse outro está querendo. E isso nos vários planos, não é só atender uma necessidade objetiva, social, direta, mas se colocar na pele de um outro.

40'06" AS ETAPAS PROJETO EM MODA - SENAC (Deu aula de cama, mesa e banho e depois foi para a criação de vestuário e acessório na disciplina Metodologia de Projeto)

Criava um cenário de bem-estar, um contexto, uma situação de uso. Era uniforme, uma situação de viagem ou eles tinham que criar um personagem, uma pessoa, um perfil de pessoa e sempre a ideia de um contexto no cotidiano dessa pessoa ou uma situação onde ela precisaria desenvolver uma coleção de roupa. A primeira coisa era pesquisar essa pessoa, pesquisa esse público, entender quem era, entender esse contexto...quando era uma empresa de uniforme localizar uma empresa para entender como é que er essa situação não caso fosse um restaurante, ou uma clínica de bem estar.

Pesquisa de público e uso (do produto/contexto) - qual era a necessidade, qual era a identidade desse lugar, quais eram as características, era essa dupla, a pessoa e o lugar.
Concorrentes - FOFA - buscava criar um diálogo com as outras disciplinas de criação (TRICOTOMIA) e olhava possíveis concorrentes, analisava pontes fortes, pontos fracos, olhava também empresas fabricantes de uniformes, o que elas produziam, o que não produziam. Olhava também materiais, aviamentos, faziam também uma pesquisa temática em cima da identidade daquele lugar. Cita como exemplo um restaurante indiano. Então a pessoa ia entender um pouco o que era a India, que link que esse lugar tinha com a Índia, filme, novela que também de certa maneira abordou aquela temática. Pesquisava também o segmento. Quais diretrizes para produzir para spas, restaurantes. $O$ que aquele segmento colocava como exigência. Aí era feito um trabalho com eles de extrair disso quais eram os requisitos de projeto, do ponto de vista das necessidades do público, da identidade do restaurante, do ponto de vista do segmento em si, quais eram as possibilidades das fabricantes de uniformes. Então o aluno identificava essa exigências, essas diretrizes e a partir daí ele conceituava e definia então tá...a pesquisa temática era a última. Ele ía definir dentro desse tema um recorte para o seu projeto. la também investigar outras coleções, outros autores que produziram alguma coisa com relação àquele tema aí a Cyntia volta ao cinema, tv...fica andando em círculos.

la retirar referências de tecidos, aviamentos, volumes, silhuetas que tinham a ver com isso e aí partir para a parte de criação;

Desenvolver formas. Ela lembra de trabalhar com os alunos o que iria demarcar aquilo como coleção, que tipo de estrutura de roupa que ia marcar. Aí o aluno construía um MIX DE MODA, MIX DE PRODUTOS para definir esse guarda-roupa dessa pessoa que ele iria vestir. Pergunto se primeiro desenhavam, para em seguida fazer o MIX DE PRODUTOS. Ela confirma que sim.

Em seguida vinham as fichas técnicas, dentro do possível, especificação dos tecidos, dos aviamentos, mais ou menos assim. Eram essas as etapas.

Pedia sempre aos alunos para irem a campo e citava o Roberto Strunk ? (TBC - tirar o bumbum da cadeira). $O$ aluno tinha que testar, olhar o funcionário trabalhando, então ele não queria de jeito nenhum aquele perfil fake que o cara inventa aquele painel.

\section{PAINÉIS}

\section{PAINEL SEMÂNTICO}

Em cada etapa da pesquisa eles faziam painéis e tinham um relatoriozinho, imagens, síntese e palavras-chave de cada etapa. Pedia aos alunos para levantar qual era a logo, as cores, como era o ambiente, quais eram os objetos que tinham, toalha da mesa, os materiais e ela conta que saiam umas coisas muito interessantes.

Os alunos tinham metade do semestre para a pesquisa e conceituação e a outra metade para fazer, para a criação.

Havia um painel da pesquisa (só da fase de requisitos, briefing e conceituação), outro dos requisitos filtrados, com formas, tecidos. 
É na conceituação que eles definiam a paleta cromática e desse painel extraia, saia [acho que cores, volumes, etc].

Existia um painel de pesquisa, do briefing mais elementar.

Outro onde a forma já se voltava mais à silhueta (ela fala: é mais inspiracional), com tecidos e já voltado mais para produto em um segundo momento.

Ela usou pouco o Baxter, elogia mais para gestão. $\bigcirc$ painel ela tirou da prática dela. Ela começou a dar aula na Belas Artes onde começou a dar aula com a Andreia Almeida que a influenciou muito na abordagem de projeto, do painel semântico. Então na Belas Artes usava bastante. Cita um autor Pinatti [?].

SE USA PAINEL NA PRÁTICA DO DESIGN?

No design gráfico usa bastante. Para trabalhar identidade de marca.

Ela falou que em relação ao painel também usava bastante para silhueta com a Andreia Canton, mas aí no Senac.

PAINEL ABERTO / PAINEL FECHADO

Giorgio Giorgi usa, Helena Rugai Bastos, Denise Dantas (com quem já deu aula) também usa. Mas tem gente que fraciona mais.

PAINEL ABERTO [FALOU ERRADO, DEVE SER O FECHADO!]

Expressões que você quer traduzir na sua coleção, como por exemplo "leve". Você tem referências de imagem do campo da moda mesmo, então o que seria uma roupa leve? Como está sendo traduzida essa qualidade abstrata? Isso é para a equipe inteira ter o mesmo direcionamento.

E você tem isso numa imagem mais abstrata também que é um PAINEL REFERENCIAL ABERTO onde voce traz essa "leveza" fora do seu campo, fora da moda, da luminária, mas o que significaria leveza quando você usa.. para descolar o aluno um pouco do figurativismo.
HIGA, Eunice. Entrevista realizada com Eunice

Higa, em 5 de julho de 2016, na cidade de São

Paulo, com 1 hora e 34 minutos de duração.

De 39’a 53’ tem ruídos, pois estávamos lá fora na Galeria Metrópole. A entrevista foi realizada na Tapera Taperá.

curso do SENAC SP chama Design de Moda - Estilismo. Esse nome é muito doido porque como é que é estilismo se é design? Ou é ambos?

Ela separa o que é uma criação industrial de conceitual ou de uma estruura que já está estabelecida, montada, mas que não necessariamente seja super industrial.

Ela acha fundamental pensar que está falando de um profissional que se upõe que já esteja inserido no meio e já tenha percebido as necessidades do que é fundamental como a pesquisa.

BRIEFING

Podia ser uma marca durante o curso. Nesse caso o aluno tinha que fazer uma apresentação da marca, análise da marca, público, segmento, tipos de produto, materiais, cores, aviamentos.

A proposta era que o aluno entendesse como era o trabalho em uma confecção. Uma delas era escolher uma marca, analisar uma marca e propor uma coleção de moda. Esse tipo de briefing era mais para Projeto Integrador.

Conta que a Cyntia Malaguti apresentava os conceitos de design na disciplina dela como geração de alternativas, anteprojeto, mock up, protótipo etc até porque ainda hoje o curso está sob o guarda-chuva do design, então o "aluno tem que saber". Mas na aplicação mesmo da construção da coleção eles utilizam os conceitos do design, mas não tão afim.

briefing poderia ser sair da forma também como uma proposta de desencadear o processo.

\section{PESQUISA}

A pesquisa para ela é um processo contínuo de se atualizar, saber o que está acontecendo nas mais diversas áreas, tecnologia etc.

Também é importante estar "antenado" (ela comenta que essa palavra é bem antiga), estar inserido na sociedade, vendo o que está acontecendo culturalmente, porque isso tudo faz parte. É preciso saber e participar, observação participativa. Isso se torna um alimento para poder pensar realmente na criação.

Quando você começa a desenvolver uma coleção de moda é preciso saber qual é o público, o segmento, a estação, se é para uma marca é preciso identificar o estilo, o conceito da marca, as necessidades da marca, entender como foram as coleções passadas, o que já foi feito, o que deu certo, o que não deu certo. 
Então isso é a vida de um profissional dentro de uma confeç̧ão.

Sobre a formação de um profissional nas escolas de moda hoje, isso varia de acordo com o perfil da escola.

Os alunos chegam à faculdade com uma visão ainda muito fantasiosa, de que moda é aquilo que eles vêem nas revistas, na televisão, na internet, no blogs, nos sites e eles não sabem realmente qual é a realidade para se chegar nesse resultado de imagem que eles estão acostumados a ver.

$\mathrm{Na}$ faculdade é muito importante haver uma conscientização do aluno sobre o que ele está fazendo. E ver se o que ele quer realmente é isso. Que vá proporcionar a ele esse aprofundamento e essa transformação desse ol har do que é moda.

Ainda existe certa banalização sobre estudar moda, de que moda não precisa estudar, não precisa pesquisar, que precisa aprender a costurar. Lógico que tem que aprender a costurar, mas não é só costurar, senão toda costureira era estilista.

Moda não se formou ainda como área do conhecimento. Ela está passando por um momento difícil. Está sendo revisto se ela vai para a área do design, se vai ser mantida autônoma.

No último documento enviado ao MEC as coisas não estavam muito definidas, mas existe uma tendência para ela ficar no design.

O curso de design de moda é uma coisa. O curso de estilismo ou de criação em moda está em como pensar a criação, como desenvolver isso como processo.

O dia-a-dia mesmo da criação em moda exige uma postura diferente. $A$ criação em moda abarca a criação do design, mas vai além. Vai além do que se vê na faculdade de design industrial.

Ela se orienta pela criação e desenvolvimento de produto dentro de uma instituição de ensino. Primeiro é sensibilizar o aluno para que ele saiba a real necessidade de se pesquisar, depois conhecimento dos produtos de moda, história de moda, o que já foi feito, como foi feito. É super importante ter conhecimento de história da moda, tanto aluno quanto profissional. Isso diz respeito a formação básica que no Brasil observa-se que o aluno chega muito cru à faculdade.

É papel do professor mostrar a importância disso. Porque é a partir daí que o aluno e o profissional vai conseguir desenvolver o processo de criação.

Também é importante desenvolver o olhar para a arte, pensar na forma.

Durante o curso varia por onde o aluno começa. Na aula da Eunice era comum explorar a forma. Nas últimas disciplinas que ela lecionou lá, ela trabalhou a parte de criação, mas ainda não de moda, fazendo uma sensibilização dos alunos com relação à formas e volumes. Cada disciplina de projeto o SENAC tem um foco especifico. A Eunice trabalhava muito a questão das formas e volumes no início.
Mais adiante existiam os Projetos Integradores que incluíam várias disciplinas. Nele existiam BRIEFINGS que se baseavam em marcas e os alunos tinham que pesquisar qual era o público, o perfil da marca, o tipo de produto, a necessidade. A Eunice dava orientação da criação. Ela trabalhava $n$ adequação do público.

Ela chama "tema" de "referências" também.

No TCC o aluno define o que ele quer pesquisar. Ele define os assunto que irão ajudar a trazer um olhar que possa trabalhar esteticamente isso em uma criação. Então o aluno escolhe por onde ele vai começar na realidade.

REGISTRO DE PESQUISA

É preciso também desenvolver uma habilidade de comunicação do processo de criação. Ela está falando do desenho como manifestação dessa criação.

Existe o caderno de criação onde o aluno registrava...

E existiam também os painéis onde o aluno mostrava as ambiências. No painel iam todos os elementos, em um painel só ou apresentado em vários painéis.

$\mathrm{O}$ aluno podia escolher quantos painéis. Normalmente ele tinha que mostrar os conceitos. Era difícil apresentar tudo em um painel só, principalmente porque costumavam apresentar em Power point e tinham também os textos sobre a coleção, mas eles eram entregues à parte.

Ela chamava os painéis de Painéis de apresentação do projeto.

ELEMENTOS DO DESIGN

Pensar na forma, em elementos muito importantes como forma, volume, linha, cor. Na criação de moda sempre tem que pensar na "forma, volume, silhueta".

Ela colocava 5 pontos/itens que quando você está dentro da criação de uma roupa você tem pensar em FORMAS, VOLUMES SILHUETAS [correspondem a 1 item], CORES, MATÉRIAS, ACABAMENTOS E DETALHAMENTOS DAS PEÇAS.

Materiais é o estudo de tecidos e aviamentos.

Detalhamentos é da roupa, bolsos, tipos de bolsos, golas, que tipo de golas. Acabamentos seriam os tipos de costuras, como aquilo vai ser comunicado. Isso é o momento da criação. Depois vêm outras etapas, a etapa da modelagem, vem a pilotagem, seria a prototipagem da peça.

Nesses 5 pontos que a Eunice cita existem subdivisões como ESTAMPARIA que está atrelada aos materiais.

ESTUDOS DE FORMAS / SILHUETAS

A aula de projeto era basicamente orientação. Nela eram construídas toiles / telas de algodão em um primeiro momento e depois a peça no tecido escolhido, no cenário ideal. 
Às vezes os alunos faziam direto no tecido escolhido por falta de tempo. CARTELA DE CORES

É um elemento importante ou não? Então como o aluno se relaciona com cor? Até onde a cor é importante ou não? Como ele interpreta a co na vida dele.

Número de cores na cartela? O perfil do público direcionava essa informação.

O aluno tinha que mostrar como a marca trabalha as cores? Tônicas, básicas etc.

No projeto final, no TCC ela pede...

\section{MATERIAIS}

A questão dos materiais é muito ampla e não resume a tecidos e aviamentos. Ela demanda pesquisa e estudo desses insumos para eleger os materiais possíveis para se trabalhar o vestuário, o produto de moda. Devem-se levar em conta novos produtos e tecnologias disponíveis.

O sucesso relativo aos materiais depende de inúmeros testes e desenvolvimentos que estão ligados à capacidade criativa do profissional. $\mathrm{O}$ conhecimento de matérias norteia as possibilidades acerca do processo de criação.

Para Higa há dois tipos de aviamentos. Os básicos que são os realmente necessários para que a roupa exista como, por exemplo, linha, zíper, elástico, botão. Existem outros aviamentos que não são funcionais, estão mais no âmbito da ornamentação como o strass, fita de cetim, apliques etc.

BENEFICIAMENTOS

\section{ESTAMPARIA}

\section{Faz parte de materiais.}

Que materiais são esses? Há uma série de questões para se pensar aqui. Que tipos de tecidos são esses?

Aí começa a recorrer a tecnologia têxtil a todos os conhecimentos dessa área que determina a existência desse material que vai ser transformado em uma roupa. E por todos os aspectos físicos que envolvem esse material como tipos de tecidos, fibras, estamparia de que tipo, bordado, lavagem, que tipo de intervenção.

\section{COMO COMEÇA A CRIAÇÃO?}

O profissional deve estar preparado para assumir qualquer tipo de produto em quaisquer segmentos e gêneros, mas não é bem assim. Ele também deve ter a possibilidade profissional de escolher qual é a área de interesse de atuação. $\mathrm{E} o$ aluno tambem tem que começar a observar isso.

Quais são os tipos de produto que ele se interessa? Que gênero? Que segmento?
O trabalho do professor de estilismo não é fácil. Tem que ter sensibilidade para uma série de coisas que talvez o aluno ainda não perceba.

A questão maior no ensino superior de moda é a experimentação. Colocar a mão na massa é difícil para o aluno em termos de apresentar um produto de qualidade.

Os alunos projetam uma cliente sem pesquisar, que ela é linda, culta, inteligente, sofisticada, magra e alta, chavão e sem pesquisa.

E começa a haver um contato com produto, uma descoberta, uma sensibilização para o aluno entrar em contato com o seu universo pessoal. Então tentar trazer por meio da consciência, de o aluno se perceber dentro desse universo criador. $O$ que toca? $O$ que move?

A partir daí a gente começa a trabalhar esses 5 pontos.

Higa afirma que existe um processo. E ele tem que abarcar todos esses pontos.

É importante que em uma escola o aluno passe por várias experimentaÇões e que ele possa se perceber nisso. E possa perceber se se identifica mais com cor, com materiais, formas e volumes. A escola deve propor essas vivências.

Todo esse conhecimento é o programa do curso superior de Moda do SENAC SP.

E descubra por onde começa o seu processo.

ACABAMENTOS/DETALHAMENTOS

O aluno pode começar seu processo pela cor, pelos materiais ou pelos acabamentos ou detalhamentos.

DESENHO

Existia o desenho de ilustração, com o corpo inteiro, atitude e comportamento (mais jovem, mais discreta), acessorios, tipo de poses, traduzir nessa ilustração esse público estilizado. $O$ desenho poderia ser feito à mão e no computador. Sempre existiu uma variação em termos de quantidade, mas não poderiam ser poucos desenhos. Era preciso um número consistente que pudesse mostrar realmente o trabalho do aluno. Durante o curso pediam de 20 a 30 produtos.

No TCC o aluno tem que apresentar pelo menos 50 produtos depois de uma série de desenhos. Têm que ser escolhidos 50 , mas para se escolher 50 tem que passar por vários. Tem que desenhar muito mais.

E depois vinham os desenhos técnicos, planificados. E existe hoje uma variação da representação dos desenhos planificados. A possibilidade de ser 3/4, em movimento, usando 3D Max, por exemplo.

O técnico era para poder conversar com o profissional que iria traduzir isso para uma roupa. Era para poder conversar com o modelista. Pensar sobre o desenho planificado. Se ele é suficiente? Traz todas as informações? 
Esse diálogo? Essa linguagem? Ela funciona ou não? Como está funcionando? Atende ou está deficitário? Precisa melhorar?

TCC

No TCC os alunos devem desenvolver um projeto autoral. Aqui ele põe em prática tudo o que vivenciou na faculdade e escolhe se vai começar pela cor, ou pela forma, ou pelos materiais, ou pelos detalhes, ou pelo produto, gênero, segmento etc.

Essa decisão inicial de projeto do TCC seria um BRIEFING que desenvolve a partir daí uma questão de projeto.

No TCC eles tinham que ter um trabalho com imagem e também produzir um editorial.

Tanto estilismo quanto modelagem têm que confeccionar peças. No estilismo os alunos têm que confeccionar 5 looks.

São 5 linhas de TCC no SENAC SP: criação, figurino, imagem de moda, pesquisa e marketing.

Criação para games faz parte de figurino.

No estilismo o aluno do Senac cria e confecciona suas criações. E na modelagem eles precisam mostrar domínio técnico de modelagem. Partem da interpretação de algum trabalho já realizado. É muito mais focado na técnica da modelagem.

No TCC de estilismo o aluno pode contratar um modelista e costureiro ao passo que na modelagem $o$ aluno precisa modelar e costurar.

Ela afirma que ambos são difíceis porque cada um tem as suas exigências. Quem desfila é estilo. Modelagem vai para exposição. Mas depois vira tudo exposição, modelagem e estilismo.

No estilo eles avaliam adequação dos materiais.

\section{MODELAGEM}

Depois dos desenhos vinha a construção desse produto. Depois das fichas técnica especificamente.

No começo do curso de estilismo o aluno confeccionava suas próprias peças no ateliê do SENAC SP, mas em um trabalho mais avançado, do quarto ano, por exemplo, o aluno precisava entrar em contato com profissionais que pudessem atender à qualidade exigida.

CONFECÇÃO

A ideia da prova de roupa é muito importante porque é o entendimento da qualidade da confecção da roupa e é o momento de mostrar para o aluno a relação dessa linguagem do desenho da ilustração, do desenho técnico e da roupa confeccionada. É preciso que aluno seja bom em tudo para que o projeto se efetive. Depende de uma comunhão entre 2 profissionais, estilista e modelista, onde este último irá interpretar o que o criador quis.
O modelista pode fazer a roupa, mas ela pode ficar sem "alma" se não souber interpretar. Por isso existe o curso de Design de Moda - Modelagem no SENAC SP para desenvolver um egresso com capacidade de pesquisar e de entender essa comunhão.

Vai além do método de modelagem. $O$ modelista precisa entender como construir a forma, ou metodologias para isso, para se chegar ao resultado real do que o criador tenha projetado. Nesse sentido o modelista é um criador também. Embora o desnível simbólico entre estilista e modelista seja imenso.

\section{APRESENTAÇÃO}

Existia um formato final de apresentação nas disciplinas de Estilismo que Higa compara ao caderno como o registro acadêmico, mas se trata de Apresentação do registro nesse caso.

Quem desfila é estilo. Modelagem vai para exposição. Mas depois vira tudo exposição, modelagem e estilismo.No estilo eles avaliam adequação dos materiais.

Tanto que era apresentado junto com as peças confeccionadas.

$\mathrm{Na}$ apresentação constavam materiais, consumo, ficha técnica. $\mathrm{O}$ formato de apresentação desse material variava.

O look confeccionado no tecido escolhido é apresentado em sala em uma apresentação final e no TCC são 5 looks para a banca + um trabalho de imagem de moda que é o lookbook e o editorial.

Antes do TCC é look + caderno + painéis em PC ou colagem e podiam variar um pouco.

DESIGNER DE MODA OU ESTILISTA?

Para ela o termo designer de moda valoriza mais o profissional hoje. Baseando-se na intuição ela percebe que hoje o status do designer de moda é maior que o do estilismo.

Valoriza enquanto criação de produto voltado à indústria, não como produto artístico.

Na condução da ideia de projeto cada disciplina no SENAC SP tem uma continuação, um ponto específico no qual vai trabalhar na construção desse projeto inteiro.

No caso da Eunice o que ela desenvolve mais seria um foco no processo de criação a partir da pesquisa, do levantamento dos dados, da marca escoIhida e definir uma nova coleção, como ela vai ser, estação, a quantidade de itens que vai compor essa coleção, o mix de produto.

Aí começava o trabalho mesmo de definir materiais (veja que é primeiro, pois privilegia a forma), cartela de cor, aviamentos.

Primeiro faz os croquis, o plano de coleção e depois o MIX DE PRODU TOS? Sim. 
Aí conforme a marca o aluno o aluno tem que pesquisar assuntos que poderiam nortear a criação desses produtos.

Como o aluno iria trazer o olhar do novo para a coleção? A partir daí havia orientação de como criar intervenção nos tecidos, nas formas, nos volumes, nas silhuetas, sempre ajustando ao olhar da marca. Que tipos de acabamento e interferência que a marca costuma trabalhar?

Antes revistas como a VIEW tinham uma abordagem de materiais muito mais artística. Hoje a ênfase está muito mais em saber quais são as informações, quais foram as influências, a idéias que geraram um tecido, por exemplo, e o resultado.

Ela lembra de desenvolver painéis muito inspiradores na década de 1990 com imagens, que transmitiam sensações, estímulos, um olhar muito mais artístico.

VISÃO ESTILISMO OU PROJETO? PROJETO NORTEIA O CURSO DO SENAC?

Estilismo norteia sim o curso do Senac SP.

No começo do curso era mais tecnicista, hoje é mais conceitual. O que levou a isso foram as mudanças de programa de curso. No começo herdaram um método mais rígido da ESMODE. O aluno é mais versátil hoje.

Hoje tem um olhar voltado para entender que roupa tem forma, tem volume, tem silhueta o que permite entrar nos aspectos mais conceituais. $O$ processo se tornou mais livre, mais pautado pela arte. $O$ processo é mais lento, mas o resultado é melhor. Será que tem a ver com a visão do coordenador atual, Lázaro Eli que é graduado em Artes Plásticas?

Em moda é preciso pensar mais no processo que no resultado e hoje há uma grande preocupação com os resultados. E a frustração é importante nesse processo de CRIAÇÃO, pois quando algo não dá certo o aluno vai se perguntar $\circ$ que não funcionou e $\circ$ que ele poderia ter feito para funcionar. $E$ isso é um crescimento de olhar.

\section{Sem experimentação não há criação, há reprodução.}

Coordenadores que a Eunice teve como chefe lá:

Lucilla Sbranna

Vera Pavão

Marisa Durant

Jung Eun Ro

Lázaro Eli - atual

E modelagem é a Vivian - atual.

Ela pegou 3 ou 4 mudanças de projeto pedagógico no SENAC SP.

O nome da disciplina é Projeto, mas a prática é de Estilismo.
BONADIO, Maria Cláudia. Entrevista realizada com Maria Cláudia Bonadio, em 17 de novembro de 2015, na cidade de São Paulo, com 1 hora e 21 minutos de duração.

No Starbucks, puta barulho de fundo.O Pós doc dela ela fez no Museu Paulista. Pós doc tem que estar numa instituição, não tem que estar ligado um programa de pós-graduação.

Deu aula no Senac de 2004 a 2013, durante 9 anos.

UAM tem disciplinas de pesquisa e criação e produto separadas. Ela nunca trabalhou como estilista.

O contato dela com moda foi um interesse temático. Ela tinha uma bolsa no PAGU na Unicamp na graduação e tinha que levantar a autobiografia de uma baronesa do café. E essa baronesa tinha um livro que chamava "A Moda" e que era de 1920. Ela ficou decepcionada com o livro, pois era um panfleto que mais bradava contra a moda e falava que a moda da década de 20 era um perigo, que os homens não deviam deixar as esposas e as filhas usarem aquelas roupas, que as mulheres estavam se aproximando das francesas, no caso as prostitutas. E a MC ficou encucada de porque o livro de uma mulher letrada, tão estudada era um manifesto contra as modas. O que estava incomodando tanto para a baronesa escrever um livro dizendo "não use". Ela faz um projeto de pesquisa na graduação que é a Monografia de conclusão de curso dela com bolsa do CNPq. Foi esse caminho que a levou de forma meio automática a trabalhar com essa questão da moda.

No mestrado ela foi do NIDEM da UNIP. O Alexandre Bergamo que organizava. Hoje é professor da Universidade Federal de Santa Catarina. Por meio de entrevistas como as com Ciro del Nero ela se encantou e foi estudar a Rhodia no doutorado. Ela acha que é um momento por exemplo [se referindo ao meu artigo para a Dobras e à minha Tese] que a respeito de projeto é tudo muito intuitivo. Não tem formação acadêmica. Quem é o grande estilista da Rhodia? É o Alceu Pena. Ele não tem formação acadêmica nenhuma em moda. Tem uma vivência muito grande nessa área e já tem uma preocupação muito grande com tendências. Poucos meses que acontece alguma coisa lá fora a Rhodia está mostrando na revista aqui no Brasil. Isso é claro na edição de 1966 da revista Joia e foi feito em Londres com as modelos e uma banda que lembra os Beatles. Então eles levam tudo o que era tendência naquele momento e levam para a capa de revista. Então eles pegam depois vestido opart que foi outra tendência forte (que está na expo da Rhodia do MASP). O doutorado dela foi nesse sentido de ela se interessar pelo tema e ver que não tinha muita "coisa" sobre "coisas" muito importantes para a história da moda no Brasil.

Em 2003 ela estava no Doutorado e a Ana Paula Simione, prof do IEB na USP, estava no grupo que estava montando esse mestrado em moda no Senac. A Ana Paula conhecia a MC via Alexandre Bergamo e a chamaram para 
dar uma palestra. Ela deu uma palestra lá na Lapa ainda. Depois ela participou de um evento maior que a Maria Lúcia Bueno estava organizando, um seminário sobre "Moda, cultura e arte" voltado aos alunos da graduação do Senac.

TEM UM TEXTO DO MESTRADO DO ALEXANDRE BERGAMO, É UM CAPÍTULO DO MESTRADO DELE QUE ELE FALA SOBRE ESTILISMO E PODE ME INTERESSAR. CHAMA A EXPERIÊNCIA DO STATUS E VIROU LIVRO TAMBÉM.ELE É DA SOCIOLOGIA. - 8 páginas (eu tenho).

Ela deu palestras no Senac na fase em que o mestrado estava sendo elaborado e a Maria Lúcia Bueno chama a MC e diz que tem interesse em contratá-la. Ela tinha que dar aulas na graduação, pois precisava para estar no Senac, mas o interesse nela era para o Mestrado.Ela tinha 'carta convite' que ela era remunerada pelas horas aulas que ela dava. A mesma modalidade que a Cyntia foi contratada. Ela abre mão da bolsa da FAPESP quando suas horas/aula aumentam. Ela teve no Mestrado do senac como rientanda a habriela Pena que alguem as crientanda a Gabriela Pena que auem assuniu antes e ela pega mais $n o$ final quando já tinha o doutorado concluído. Ela acelerou o doutorado dela para isso.

Ela não tinha experiência docente antes do Senac.

\section{É PARECERISTA AD HOC DA FAPESP}

A única coisa que ela sabe é que ela é parecerista. Ela não está lá dentro distribuindo os projetos. Ela teve muitos financiamentos da FAPESP e mesmo morando em MG ela continua sendo solicitada para dar parecer para vários tipos de coisa. A impressão dela é quando você vai submeter o seu projeto e sua área é moda você escolhe uma área e sub área. Pode ser em projeto e sua área é moda você escolhe uma área e sub área. Pode ser em
comunicação ou história, por exemplo. NAS AGÊNCIAS DE FOMENTO!

Ela acaba recebendo projetos das mais diversas áreas de várias pessoas que estão estudando moda. Na percepção dela na FAPESP ela acha que eles "meio que tem que se virar" quando chega um projeto em moda porque ela não sabe quantas pessoas são pareceristas em moda, mas conhece muita gente hoje que já é. Ela diz que um dos critérios para ser parecerista da FAPESP é já ter tido financiamento (a Cyntia falou o contrário, ela nunca teve bolsa da FAPESP). A MC fala que é uma espécie de uma mão lava a outra. Ontem você teve bolsa, hoje você cede seu tempo fazendo pareceres para a FAPESP.

Ela acha muito bom. Você tem contato com muita pesquisa nova e aprende muito fazendo o que a FAPESP solicita. Ela acha ótimo ter bolsa da FAPESP. No meu caso, por exemplo, ela diz: imagina você fazendo esse monte de entrevista e tendo que escrever. (Se refere ao acúmulo de trabalho se eu ainda trabalhasse).

\section{QUANDO E PORQUE TERMINOU O MESTRADO DO SENAC?}

A última turma que entrou foi em 2008. Tiveram 4 turmas 2005/2, 2006, 2007 e a última em 2008.0 que foi passado para os professores como justificativa do fim do Mestrado foi que o Lula estava pressionando o Sistem $\mathbf{S}$ (Sesi, Sesc, Senac...) a dar alguma contrapartida, pois o Sistema $\mathbf{S}$ tem impostos do comércio e serviços. E boa parte do Senac funciona com esses impostos que são repassados pelo governo. E no caso do Senac os cursos estavam muito caros e estava tendo uma contrapartida muito pequena. Eles recebem o fomento, eles precisavam dar uma contrapartida para a população. E eles foram obrigados a oferecer $70 \%$ de gratuidade no ensino técnico.

E aí agora parece que vão ser extintos os cursos técnicos.

E para ofertar esses cursos técnicos o Senac tinha que cortar alguma coisa. E eles cortaram os 3 mestrados que eles tinham naquele momento. Tinha professor no mestrado com salário muito alto ou que dava aula só no mestrado e tudo isso dava "um up" no mestrado, mas era custoso. Tinha a Eliane Robert Moraesque é da PUC que não dava uma aula na graduação. A justificativa que deram dentro do Senac para os professores foi essa que esses custos pesavam e que o retorno financeiro não era tão grande. Então o Senac resolveu extinguir o Mestrado, parar os processos seletivos, mas quem começou continuou e defendeu.

Ela conta que defender em 2 anos é importante para um programa que está na ativa. Para um programa que não está mais na ativa, o "cara" defender em 3 anos não faz diferença. Porque o curso não vai ter nota mesmo, não vai ter continuidade. Só o aluno que espera mais pelo diploma.

FAPESP

É mais uma impressão sobre como são designados os projetos dentro da FAPESP. Ela não tem uma visão clara de como ocorre a distribuição de projetos dentro da FAPESP. O que ela pode afirmar é que os pareceristas não são de uma área só. Ela mesmo é muito interdisciplinar, é historiadora, recebe projeto de diversas áreas que fazem interface com a moda. Ela recebe projeto de design, de história, de sociologia. Ela acha que o parecerista não pertence a uma área, deve ter um "banco de pareceristas" que eles devem puxar por palavra chave ou coisa desse tipo. Aí eles mandam o projeto e se você aceitar [você avalia]. Ela conta que pode ou não aceitar. Se não é tão da sua área ou se tem conflito.

Ela se recusou a avaliar um trabalho de uma pessoa que tinha ido a um evento e ela viu que a pessoa não tinha feito nada no evento e ela achava que não podia ser imparcial. Então recusou. Se ela tem uma má impressão de uma pessoa ou se é super amiga ela se sente à vontade para recusar o projeto.

Ela falou que só sabe isso e que quem sabe mais seria a PRISCILA FARIASque é lá do comitê.

AUTORES MODA

Familiar para ela é DorisTreptow e a Sue Jenkin Jones. Ela aponta que o que mais aparecia nas falas nas reuniões da graduação do Senac é o livro da Sue Jenkin Jones.

Renfrew e Seivewright ela não conhece.

AUTORES DESIGN 
Bruno Munari ela também conhece, mas nunca usou em disciplina dela. Löbach e Bomfim também não tem contato.

\section{CURSOS COM O NOME SOMENTE "DESIGN"}

\section{NOME QUE CABE MAIS "ESTILISMO" OU “DESIGN DE MODA"?}

\section{SOBRE MEU ARTIGO/TESE (PARA LER COM ATENÇÃO)}

Ela elogiou meu artigo [essa é a contribuição do seu artigo...] no sentido de ser uma coisa pouco pesquisada, principalmente a parte que fala dos cursos no Brasil. É interessante entender de onde vem essa visão artística. Que até vem da FASM, mas que contaminou muitos outros cursos e prolifera essa ideia de que a criação é essa coisa assim meio mágica, intuitiva.

Ela elogia meu artigo por eu entender que tem um cara, que tinha uma experiência, que veio da Rhodia, que virou professor na FASM e como é lá que teve o primeiro curso, ele é uma referência. Então eu acho que isso é muito importante.

\section{E NAS AGÊNCIAS DE FOMENTO?}

SOBRE AS NOMENCLATURAS "ESTILISMO" OU "DESIGN DE MODA"

Ela acha que isso não está nem resolvido mesmo no MEC. Porque na UFJF.

\section{Na UFJF MODA}

O curso é de design de 3,5 anos (com disciplinas de arte, design, de cinema, de moda) e você se forma. E tem um segundo ciclo, que você pode ou não fazer. Esse segundo ciclo tem mais 1,5 ano e a pessoa tem que ter um projeto para entrar, ela tem que se matricular, é uma outra etapa. E um deles é em moda. Tem cinema, tem design, tem artes, licenciatura em artes e moda. Nesse segundo ciclo a pessoa só vai ter contato com disciplinas de moda. Mas para o MEC o segundo ciclo é um curso também. Então a gente é um curso de Moda. As disciplinas são mais de modelagem, de estilismo e aí tem as disciplinas teóricas, mas tem menos. A maior parte das disciplinas são práticas. O curso foi aprovado.

Eles têm História da Moda II, História da Moda Brasileira, mais uma teórica e o resto tudo prático. $O$ egresso sai com uma formação de 5 anos. As notas no MEC do primeiro e segundo ciclo podem diferir. E o segundo ciclo de moda é nota 4.

\section{MODA COMO CAMPO DO SABER}

Beth Morillo????que também é professora do Senac participa desse grupo. Quando ela estava no Senac ela estava convencida de que Moda era Design. Havia reuniões sobre isso. ME INDICOU ENTREVISTAR A LUZ GARCIA NEIRA e ela veste a camisa do design mesmo. O contato da MC com a Luz, a Evelise (EveliseAnicetRuthschilling) fez o olhar da MC se direcionar mesmo para ideia de que moda era design.

A MC conta que direcionou o curso de História dela no Senac para que sempre tivesse essa noção de projeto advinda do design. Contou o exercício
"Bonecas da moda" como de papel. Elaboravam 3 looks com base em um período histórico e os alunos tinham que pegar uma temática dentro desse período e fazer uma pesquisa sobre aquele tema (ex: literatura gótico) e apresentavam 3 looks inspirados na literatura gótica.

Ela achava que os alunos tinham que entender que tinha um porquê das disciplinas de história serem dadas. Pensar na aplicação. Podiam fazer produtos de marcas licenciadas também, fazia moto etc. porque a partir da década de 60 os licenciados passam a ser uma realidade na moda dentro do que era dado na história da moda. No Senac ela achava que tinha que misturar prático e teórico.

O que não é possível na UFJF. Lá elas têm alunos que vem da sociologia, da comunicação. Tem que manter o teórico porque não dá para pedir que 0 aluno costure, use illustrator. No curso público a preocupação de responder ao MEC é menor que no Senac, pois há mais autonomia.

PROCESSO CRIATIVO NO MESTRADO DO SENAC

Tinha uma dissertação de mestrado sobre processo criativo, sobre o Walter Rodrigues de uma aluna que foi da FASM. Parece que ela se chama Ângela Yamashita. Ela tem um apelido. Ela estudou processo criativo no Senac. Ela é professora de modelagem, foi orientanda da Ana Amélia.

Talvez a Agda, o Bocara e a Maria Lúcia tenham orientado alguma coisa sobre processo criativo.

Ela ainda acha que moda está mais para o design (do que para a arte). $O$ que saímos de casa vestindo não é arte, é no máximo artesanato. SPFW não representa uma indústria de moda. Não é o que vai chegar à massa. $O$ que vende mesmo para as grandes marcas são os perfumes, capsule collections para magazines ou peças básicas.

NO SENAC (NA GRADUAÇÃO MESMO) PROJETO NORTEAVA O CURSO?

Ela sentia que os professores de Estilismo tinham grande dificuldade em aceitar a ideia do design/projeto. São otimas pessoas [ela fica um pouco encabulada de falar], então o José Luiz Andrade, a Andrea Canton que eram os professores dessa área de criação, a Eunice Higa, o Gustavo Matavelli (ex-aluno do Senac). MC conta que tem a impressão que para eles causava um estranhamento você ter que sair da sua zona de conforto e buscar o design sempre foi alguma coisa que incomodava. $O$ curso começou como estilismo aí de repente eles tinham que mudar. E aí, como é que você faz para mudar?

É uma resistência. Aí tem a alguns como a CyntiaMalaguti que traz o discurso e a Luz que adere ao discurso, mas são alguns. E os outros, não é po mal, ela já tem uma prática. É aquilo que ela aprendeu, que ela estudou, então de repente ela tem que mudar e fazer uma outra coisa. É complicado. E esses professores estão até hoje no Senac. Isso não foi um impedimento para eles continuarem lá.

É MAIS RECONHECIDO O TERMO DESIGNER DE MODA OU ESTILISTA?

Ela acha que hoje o mais contemporâneo é o design de moda. Falou do 
PAOLO VOLONTÉ que fez uma pesquisa com os alunos, parece que os egressos, do POLIMI para ver se eles se entendiam como designers ou como estilistas. É uma questão lá também, não é só nossa.

Ser designer parece mais interessante no sentido mercadológico.Parece que os alunos do POLIMI preferem ser designers. Que ser estilista é uma coisa de outro momento, do passado.

Ela concorda com isso como historiadora. A figura do estilista que se forma está ligada à afetação, à ideia de se achar um grande gênio ("um pouco o que você fala do Carlos Mauro"). Ela conheceu o Carlos Mauro, entrevistou ele para o doutorado. ME ENVIOU A ENTREVISTA DELE!!!

Hoje com a popularização da carreira, nem todo mundo vai ser gênio criativo. Ela tem a impressão de que quem vai trabalhar com produto, que vai ter que fazer um estudo para fazer aquilo, que não vai "baixar uma entidade" $e$ dizer para ele faça tal coisa. Não depende só da figura do criador. Ele está em contato com uma série de outras coisas, como escritório de tendência etc.

Vejo designer de moda como algo mais adequado. $O$ profissional que vai trabalhar no magazine, na Renner, na C\&A é designer de moda. O Ronaldo Fraga pode até ser estilista, que tem essa possibilidade de fazer uma coisa mais criativa, mas não o profissional do magazine.

O designer de modaestá alinhado à ideia de um projeto com todas essas variáveis e que não dependem só dele. Ele tem que ver a tendência, o que a empresa quer, o direcionamento que a empresa vai adotar, então não é possível chamá-lo de estilista.

Até porque qual é a grande peça criativa que o designer faz? Não é como o cara que faz os grandes desfiles. Esse pode ter um viés mais artístico e incrível e não sei o que. $O$ cara da Hering não.

E dos meus alunos os que estão melhores colocados estão em empresas comerciais, mas não podem criar uma coisa muito louca senão sãoaté demitidos.

Para ela, por isso o designer de moda se aplica mais e o estilista é mais restrito.

No Senac havia uma preocupação muito grande com o mercado. Há prêmios como viagens para a Esmode ou Bornmouth. No Senac, sobretudo no estilismo, ela percebe que a instituição valoriza mais trabalhos voltados ao mercado. $O$ experimental tem mais vazão na Modelagem.

AURA EM TORNO DA CRIAÇÃO

Existe, mas os melhores estão em empresas comerciais, Daslu, Hering, C\&A e viajam todo o ano para o exterior, tiveram êxito.

Os ditos "mais criativos" tem mais dificuldade de se adaptar ao mercado.

As Viktor \& Rolf, Martin Margiela, Hussein Chalayan tem mais capital cultural sim. E quem é o estilista da H\&M, alguém sabe? Mas quando o AlberEbaz assina coleção para magazine o mundo para.
Então são duas esferas: o cara já estabelecido, que ganha dinheiro por meio desse viés artístico e o jovem artista, que sofre mais. Demora para ser reconhecido e conseguir seu espaço.

Ela quer dizer que o jovem designer ganha melhor que o jovem artista.

Ela conta que na ela é pesquisadora e dá 8 horas de aula e sua visão mudou muito de quando dava 20, 30 horas no Senac. O contato dela com os alunos é mais restrito. Ela se dedica mais à pesquisa.

Elizabeth Morillo acha que moda não tem que ser design. A MC diz que não sabe se pode considerar moda um campo autônomo, porque se pensar em indústria, para ela, é design. Mas o mercado contrata como estilista. É uma questão complicada.

E no design moda ocupa um espaço pequeno também. $O$ design também deixa a moda um pouco como outra coisa [à margem]. O IAC produziu 50 peças que foram produzidas para o Mappin. Por outro lado, o PRÊMIO MCB está contemplando trabalhos em moda.

A faculdade permite projetar coisas incríveis. O mercado é mais limitador.

Ela acha que a reflexão sobre projeto em moda especificamente é uma área nova e ainda há o que pesquisar. 
GUIMARÃES, Maria Eduarda Araújo. Entrevista realizada com Maria Eduarda Araújo Guimarães, em 9 de outubro de 2015, na cidade de São Paulo, com

\section{1 hora e 50 minutos de duração.}

Ela é advogada e antropóloga, mestre pela PUC e doutora pela UNICAMP em sociologia.

Ela entrou na folha de são paulo como pesquisadora no acervo depois que a bolsa da CNPq acabou $\mathrm{CEla}$ foi pesquisadora e depois coordenadora na folha. Ficou lá 8 anos de 1997 a 2005. Fez várias publicações pela folha. A carreira acadêmica dela começou no Senac, no mestrado. Ela assumiu a disciplina de Cultura Brasileira, mas para ela nesse momento a atuação dela não tinha nada a ver com moda. A pesquisa dela não tinha nada a ver como moda. A tese dela é Do samba ao rap: a música negra no Brasil que trata da constituição da identidade brasileira por meio da música.

É no Senac que ela monta um projeto de pesquisa em moda chamado $A$ moda e a rua. A experiência anterior do doutorado, a ideia de estilo de vida do Giddens, tudo isso ajudou no seu trabalho. Fala de como a moda é uma forma de visibilidade desses grupos de rua.

O mestrado começou em 2005. O ano de fim é anunciado com turmas ainda acontecendo e defesas marcadas então é difícil pontuar o fim. Há duas datas, uma quando não tem mais processo seletivo e a data das últimas defesas. Precisa escolher qual é a data que eu julgo...(procedente). A fala institucional seria melhor de ser usada.

Acho que foi em 2010 que foi anunciada por vários jornais. Para os próprios professores é difícil entender e como não havia a tradição da pós graduação havia uma dificuldade em lidar com os próprio trâmites que a CAPES e outras instâncias exigem.

As instituições privadas são mais cobradas no caso de ter uma pós graduação. A vocação é menor no Senac que numa pública. $O$ bom é que há iniciação científica até hoje. A pesquisa continua só com os professores mensalistas.

Revista lara tem nota B1 no Qualis Capes e é uma nota bastante alta para uma revista que está fora de um PPG. Hoje a lara publica mais design, a relação da moda com design.

Mas o mestrado passava à largo da noção de projeto. Era mais voltado à arte, antropologia, história, sociologia etc. Tanto que o Senac tinha um mestrado só em Design (aí parece que a questão de projeto estaria mais lá, até para talvez evitar conflito?). E quando foram fechados os 3 mestrados do Senac, em Moda, Design e um profissionalizando em Ambiental mostra que os 3 foram fechados, não só o de moda e mais que isso, é muito representativo que a moda tenha tido um mestrado só para si dentro de uma instituição como o Senac que se volta a tantas áreas.
Falamos em ênfase $\mathrm{x}$ habilitação, mas nada sério (15')

\section{AUTORES DE PROJETO EM MODA E DESIGN}

O corpo docente do mestrado do Senac era basicamente das ciências humanas. Não havia uma reflexão ou pesquisa sobre projetos. Talvez Bocara, Lúcia Leão estivessem mais próximos pelo viés da criação. Se pensava mais o objeto em si do que a produção do objeto. Interessava a interação do objeto no social. Ela diz que eles trabalhavam muito mais o uma abordagem metodológica e o processo histórico do que a produção do objeto em si.

Para ela não existe pensar o produto sem sua interação com o mundo, para além do público e do mercado. Citamos Cipiniuk, Christo e ela fala que gosta muito do Ardjun Appadurai quando ele fala da "Vida social das coisas".

Ela conta que quando começou a dar aula para o design gráfico e industrial que ela se aproximou mais das questões do projeto. Isso aconteceu mais no design do que na moda.

ESTILISMO X AURA

Fala do período pré moda, século XIV e do marco, século XIX que é a alta-costura, associado à alta cultura, quando surge a ideia de autoria. Cria não para o consumidor e cria a ideia de coleção. E ele assina e cria a etiqueta como se assina uma obra e designa para o cliente o que será usado, além da relação que eles tinham com artistas e suas coleções de obra. É pela alta costura que é possível traçar esse discurso de estilismo e aura, como o criador que possui um dom. criar moda não seria algo que é aprendido, mas seria quase um dom.

\section{MODA COMO CAMPO DO CONHECIMENTO}

Não vê uma metodologia específica da moda no campo da pesquisa, por isso não acredita nela como campo autônomo. Ela fala da experiência dela com o mestrado e o que viu como as pesquisas com ênfase em história, ênfase em ciências sociais, arte etc.

E a moda não tem uma metodologia desenvolvida própria que faria dela campo autônomo. Ciência é quando você tem um corpo teórico-metodológico específico. AGÊNCIAS DE FOMENTO!

\section{CABE A MODA SER ENCAMPADA PELO DESIGN?}

Moda é para muitos campos um objeto de reflexão. Moda como desenvolvimento de produto e objeto da cultura. São 2 vertentes. A moda é produzida de fato por um modelo industrial, isso a vincularia ao design para ela ser constituída. Antes de ela ser um objeto da reflexão da arte ou das ciências sociais, mas não há relação entre arte e moda. E nem toda roupa é moda. Mas muita coisa é processo artístico, mas não é moda. O parangolé tem como suporte vestuário, mas ele nunca foi moda.

O vestido Mondrian é arte? Aí vale a discussão porque o Mondrian foi moda antes de ser arte (se for o caso, por estar no museu).

A lógica da moda é menos racional que a lógica industrial do design fo- 
menta, embora ela seja indústria. Talvez o fato de ela se formar academicamente no contemporâneo tenha influência em não ter se contaminado (a moda) com o racionalismo moderno que era anterior.

Muitas vezes o corpo é negligenciado nas discussões. E a moda é performática, só faz sentido se usada pelo outro.

No Senac tem a ênfase no estilismo e na modelagem. São cursos muito diferentes. $O$ vestibular dos 2 inclusive é separado. Sempre teve 2 vestibulares, tem 2 coordenadores separados. Tem uma divisão grande entre o que cria e o que faz a roupa.

Em 2005 estilismo estava em uma hierarquia superior. E nos últimos anos dada as mudanças na grade curricular muita coisa mudou (ai). A incorporação do projeto se efetiva na última mudança do curso. Era uma coisa mais voltada para a imagem. O Senac fica muito tempo em cima do muro diante da campanha encabeçada pela FASM para moda ser um campo autônomo.

ACADEMIA X INDÚSTRIA X CONSUMO = ESTILISTA X DESIGNER DE MODA?

O consumidor não vê essa diferença. Herchcovitch faz roupa, não importa se ele é estilista ou designer de moda. Para o consumo isso não é efetivamente uma questão. Não campo acadêmico ela acredita que essas forças têm um empate. No campo essas forças têm um empate e elas estão se articulando em um nível que ainda não tem vencedor.

Ela é neutra nessa discussão porque é antropóloga. Isso é uma discussão do campo, não é uma discussão dada para o consumidor. E quando sai a regulamentação do design talvez seja muito melhor ser designer porque voce vai estar mais amparado pela lei, em termos salariais, reserva de mercado.

A moda é pública e tem que ser visível na sociedade. É o que é difundido na sociedade. A aproximação com o design é mais efetiva do que com arte. E o Worth? A alta costura não existe mais como antigamente. O sentido de moda é algo que tem que ser usado, algo que vai ser produzido, algo que vai ser usado. $O$ Worth cria dentro de um universo muito distinto do mundo num momento ainda do desenvolvimento da revolução industrial, dos meios de produção. Não sei se é comparável com hoje. É difícil, é outra realidade. $O$ processo de globalização transforma ainda o mundo num outro lugar.

\section{Há cursos que começam de um jeito diferente (FASM, SENAC) e outros} começam direto como design. Parece que nem bem a moda estava vinculada à arte no início. Parece que a moda não se organizou, não se cotizou para organizar e manter seu campo no início.

Em São Paulo houve um processo de adaptação por exigência do MEC. Isso não foi feito com o coração, rs.

Existe uma adaptação em São Paulo. $O$ projeto que se tem ainda hoje em SP é uma disciplina de projeto muito pensada ainda em cima de Laboratório de Criação, por exemplo, não usando a racionalidade. A impressão é que quando você usa um processo racional você tira essa aura do produto.

\section{SOLUÇÃO DE UM PROBLEMA}

Até certo ponto. Vestir é uma questão.

Ela vê que nas novas grades curriculares foi muito mais fácil introduzir a questão do projeto na modelagem. Porque pensar a forma e como vou construí-la está muito mais ligado à construção do problema, como a roupa vai vestir, como vou acertar essa roupa para ela vestir melhor.

A MADU orienta o TCC na modelagem, a parte teórica. $O$ assunto é a solução da roupa representada pela teoria. Falou dos projetos sobre o freak show. Roupa para mulher de 3 cabeças, o bebê xifópago e a mulher sereia. Será que no Senac a modelagem está mais perto de uma criação mais livie que o estilismo?

As alunas da modelagem quase nunca usam o busto tam 36, elas recorrem a outras formas. Hoje há essa visão da vertente da modelagem criativa onde o criativo está na forma. Então a partir dessa proposição é muito mais fácil abordar a ideia de resolver um problema.

Então a vida é um eterno enrolar de mangas, rs. Fala que é um exemplar da mulher baixa.

Na modelagem tem sido mais tranquila a implementação dos projetos.

No estilo a questão está mais voltada para o mercado no Senac, a roupa que não é autoral. O estilista do Senac é o cara que vai sair e abrir sua marca. $O$ modelista sabe que não vai fazer isso. Ele vai resolver problemas relativos ao corpo brasileiro por exemplo. E vai trabalhar em confecções no Bom Retiro por exemplo.

\section{MODA COMO CAMPO AUTÕNOMO}

É uma fraqueza que outras áreas das ciências também têm, a fraqueza dessa discussão. Elas sofrem exatamente por não poder dizer que é uma ciência. Não têm uma metodologia própria de pesquisa.

Não é o objeto que cria uma ciência. É o método e o aporte teórico. Qualquer coisa pode ser estudada por qualquer perspectiva, agora não é o objeto. A roupa pode ser estudada como um edifício. O edifício não é exclusivo da arquitetura. Eu posso tranquilamente estudar um edifício sob a visão das ciências sociais.

Metodologia projetual não é metodologia de pesquisa (quando pergunto se não é estapafúrdio estudar arquitetura sob o guarda chuva das ciências sociais aplicadas). Academia versus prática.

Metodologia projetual é alguma coisa que você vai usar uma sequência de procedimentos que envolvem testes, protótipos, que tem tudo isso e vai chegar no objeto.

Metodologia de pesquisa é a forma de fazer essa reflexão e entender esse objeto no mundo. Uma metodologia de pesquisa é desvendar o mundo. Metodologia de projeto é refletir sobre a construção para você chegar num objeto. A partir daí como eu vou desvendar esse objeto quando ele ganha o mundo necessita de uma metodologia de pesquisa. 
Ela trata vestuário como moda de maneira geral, de uma maneira fluida e associa isso ao design na construção material da roupa. Critica a constituição de público alvo, mulher rica, magra e alta...etc. a moda sofre quando certos grupos a escolhem para a qual ela não foi designada. Romantismo pensar nesse usuário rico é uma falsa premissa. Pensar no Fernandinho Beira-Mar sendo preso com a camiseta da Osklen ou os jovens franceses da periferia de Paris usando Lacoste.

Não há ainda metodologias para alcançar, dar conta das imagens. 1' 02".

A ideia de uma ciência possível é possível quanto mais um objeto é analisado e quanto mais coisas vão sendo agregadas como instrumentais para análise até que você consiga descobrir uma maneira mais adequada...mas isso não é só na moda.

ADM não é ciência também. Como futuro, como premissa todas as áreas que não são ciência podem virar ciência se houver uma convergência de estudos suficientes que vão originar uma forma de analisá-la que até então não existia.

Enquanto não existir a gente só está somando conhecimentos consolidados e adaptando. Hoje para a moda o que se adapta melhor no tocante a projeto é o design.

O que dá vida ao objeto é que alguém teve que criar aquilo e o design de moda é o que cria a roupa. $O$ design hoje é o que é 5,00 entre zero a dez que dá mais conta. Mas lembrar que tudo tem moda, nomes, carros, tecnologia etc.

A moda significa o efêmero. É aquilo que você troca porque há uma nova significação, não pela obsolescência programada. Não é só vestuário.

USAR DESIGN NÃO É REDUCIONISTA?

Tudo é reducionista, animal, vegetal ou mineral. Gênero, mulher ou homem. Tenho mineral nos ossos, calcário (?), não sou só animal, sou mineral também, mas sou classificada como animal porque é o que me representa na minha maior parte. Dividimos em fases para entender as coisas. Mas a coisa não é linear.

Todo processo classificatório acolhe umas coisas e exclui outras.

\section{FORMA E FUNÇÃO}

Ela vê tranquilamente, segundo ela. Mas fora da lógica racionalista. FUNÇÃO SIMBÓLICA, distinção. Ergonomia, conforto, tudo isso está muito longe da moda em vários momentos. Momentos distintos. A moda da mulher de salto alto não é forma e função, mas a moda do activewear é totalmente forma e função (será? Tenista). Mas há um estereótipo da moda, sempre do feminino do red carpet que privilegia certos momentos da vida. É uma parte da moda, mas não é o todo. É um momento específico, tem rituais para isso. E toma-se a parte como um todo. $O$ que existe é um foco no feminino pensado a partir da alta costura.
Para ela todos os objetos têm momentos onde a forma e a função passam por outras questões.

CÓPIA NAS CONFECÇÕES PEQUENAS E MÉDIAS

Os alunos percebem essa cópia e muitas vezes a função do aluno é desmontar a peça e remontá-la com aviamentos, tecidos e às vezes quando dá sorte o aluno pode adaptar a roupa para um corpo brasileiro.

A média é aquela coisa que é ruim para todo mundo. Cita o homem ideal do Weber, o capitalista, é um método só, o ideal.

Apesar de tudo a cópia tem um processo criativo. Tem que pensar que não é o limite, nem conseguem copiar pq o material é diferente, o tecido é diferente. Citou a pesquisa da Louis Vuitton que percebeu que a maioria das cópias de Louis Vuitton eram bolsas que a marca nem sequer chegou a produzir. Eram modelos desenvolvidos com adaptações de modelos da Louis Vuitton, por exemplo com bolsinho fora para guardar passe de ônibus etc.

Nessa cópia há na verdade o desenvolvimento de um novo produto que vai usar mais a imagem da marca do que o produto. Não é uma cópia necessariamente do produto da Louis Vuitton. Citou a camisa pólo com a coroa do Sérgio K e o passarinho da reserva, ou seja, você compra uma camisa com 2 marcas.

Então ás vezes para fazer a cópia você tem que fazer um novo projeto, ou um anti-projeto de voltar, ver qual foram as etapas ao contrário.

De qualquer forma tem algum tipo de reflexão sobre o objeto que você está reconstruindo. Também pensar que a única coisa que legitima o objeto é o projeto é limitador. O projeto também vira um mantra. Ela acredita que $\circ$ projeto também está em constante mudança porque há mudanças tecnológicas, mudança de tempo de concepção do produto...então o projeto não é o único que define a qualidade final, a racionalidade do produto.

\section{Adjetivações de design}

No senso comum ele vira um valor agregado, como gourmet. Mas dentro do campo intelectual começou a existir adjetivações também, porque a dureza do conceito racional não dava mais conta.

Design thinking por exemplo já é um indicativo de uma necessidade de mudança no design que ainda não está consolidada (a mudança), mas para ela poder abranger mais coisas, mais processos, inclusive abranger a moda também que pode talvez ser mais fácil de ser entendida dentro do design.

FALTA REFLEXÃO INTELECTUAL SOBRE PROJETO EM MODA

Ela acha que sim, mas é tudo muito recente. Não enxerga isso como um falha. No Brasil essa reflexão é muito recente. Vemos pequenos ruídos disso. Podemos marcar de 1987 para cá, o Lipovetsky. Há um antes e um depois do Lipovetsky, é um marco, embora nem sempre a história seja marcada linear por casos específicos assim 1'20". 
O fato de a Gilda Mello e Souza ter escrito em 1957 e só ter conseguido publicar em 1987 fala sobre isso, tudo estava muito esparso, eram esforços individuais e que não houve um adensamento grande desse pensamento. $A$ gente ainda está resolvendo questões...legitimando o campo. AGÊNCIAS DE FOMENTO

Ela lembra que quando publicava em congressos de sociologia tinha que explicar porque a moda é um campo legítimo, tinha que justificar. E hoje como revisora da Revista lara percebe que não precisa mais justificar. É relativo falar que moda é recente.

Falta reflexão sobre projeto porque isso sempre foi obrigação de outro campo e não da moda. AGÊNCIAS DE FOMENTO!

O que esse objeto nos diz, ver na Gilda Mello e Souza, garantir primeiro a importância desse objeto para depois entender como esse objeto foi construído.

\section{ESTILO NACIONAL X TENDÊNCIAS}

Ela não gosta dessa ideia de tendência. A questão é muito difícil, tanto que no Senac eles sempre questionaram a disciplina "História da moda brasileira" (que ela leciona, antes era a Maria Cláudia que dava), a Madu herdou da Maria Cláudia as disciplinas de história da moda. Há uma hipercentralidade da moda que foi construída em Paris e moda era o que estava sendo construído lá. Nosso desenvolvimento industrial no Brasil foi atrasado e moda no Brasil só dá para falar a partir da chegada da família real. A moda é dada pela Lei, ou você é livre ou você é escravo.

Dener - ele fala em constituir uma alta costura na década de 60 que um discurso anacrônico, a alta costura já está em decadência. Ele e outros estilistas tornam a moda um assunto da cultura familiar, então não perde seu valor.

Sofremos de ter a pressão de sermos civilizados e de ser tropical (arara, colorido etc). 1'29"

CULTURA 1'30"

O que a gente aceita de moda, quando pegamos isso é porque faz sentido na nossa cultura.

Temos capital corporal, segundo o termo cunhado por Mirian Goldenberg.

Não existe estilo nacional nem na França. A ideia de nacionalidade é um tradição inventada e foi perdendo força com as ações transnacionais da globalização. Não há hegemonia nacional em lugar nenhum. Há uma narrativa que amarra aqui e ali no Brasil a ideia é que somos diferentes. E o que nos une.

Não aceitamos nosso gosto pelo barroco, pelo emotivo, pelo cafona no Brasil.

O homem cordial = de cordes, de coração, não de gentileza, mas passional. Sérgio Buarque de Holanda.
A indústria de moda age como se a moda guiasse o consumidor e é justamente o contrário. Collin Campbell com a revolução industrial. O lemingue que pula do precipício quando o lemingue chefe pula. A moda quer forçar ser assim.

$\mathrm{O}$ consumidor como co-autor.

PRODUÇÃO é o lugar da razão, da regulamentação, do masculino e o CONSUMO é o lugar do irracional, do feminino, do desperdício = visão dicotomizada entre produção e consumo quando elas estão na mesma linha, um não existe sem o outro.

TEM UM MODO DE PROJETAR BRASIL?

No Senac o modo de pensar a moda como projeto está sendo construída. Brasileiro faz com o que tem, não somos um país da tradição então topamos uma inovação rapidinho.

Brasileiro é solícito a fazer diferente. $O$ brasileiro não sacraliza um método. As corporações de ofício no Brasil só existiu nominalmente. Fora do Brasil, na Europa por exemplo, jamais vão fazer diferente. Isso pode ser uma especificidade nossa, uma forma nossa de pensar.

Há uma aproximação grande entre as áreas. $O$ design também está procurando isso.

O projeto deve ser visto como forma de transformação social. Porque ca-

Vai além do usuário. Como é que eu posso transformar o mundo pelo meu projeto?

Projeto como uma forma potencial de transformar a sociedade. AGÊNCIAS DE FOMENTO - RETORNO PARA A SOCIEDADE. 
VICENTINI, Cláudia Regina Garcia. Entrevista realizada com Cláudia Regina Garcia Vicentini, em 31 de março de 2016, na cidade de São Paulo, com 1 hora e 2 minutos de duração.

PARA ETAPAS = usar e CITAR a tese dela e completar com a entrevista. Professora da EACHUSP de Projeto

Formou-se em Engenharia Têxtil na FEl e foi trabalhar em Desenvolvimento de Produto. Trabalhou na Astrotec (meias e elásticos) que não existe mais, Fibra Dupont (comercial) e Nylonrend (fábrica de rendas no Bomra). Depois ela montou a sua própria empresa de desenvolvimento de produto e comercializava o produto. Era bem casado entre a fábrica e produto e fez muito interior de carro então trabalhou muito com a indústria automotiva.

Toda a vida dela profissional, no ambiente empresarial foi na área de Desenvolvimento de Produto.

Trabalhou com calçados e lingerie.

Ela tinha contrato com os donos dos meios de produção que tinham o parque fabril e ela tinha contato com os clientes que tinham demanda para o uso desse parque fabril.

Ela deu aula no Senac na Pós do João Braga e depois da Cris Mesquita.

Foi para a UEL, terminou o Mestrado em Comunicação na PUC e prestou o concurso na USP e entrou. Foi uma das últimas vezes que a USP contratou Mestres, no final de 2005.

Está a 10 anos na EACH e fez Doutorado na UNICAMP focado em Desenvolvimento de Produto que é a especialidade dela.

Hoje ela leciona na EACHUSP "Desenvolvimento de produto de acessórios" que era no segundo ano e agora foi para o quarto ano, "Metodologia de Projeto" no primeiro ano, "Projeto Integrado", "Resolução de Problema" no primeiro ano e optativas como "Moda e linguagem" voltada à semiótica e à

EACHUSP

Escola de Artes, Ciências e Humanidades da Universidade de São Paulo

E na Pós ela leciona "Processos criativos" e metodologia de projeto. Como autores ela foca na semiótica e na crítica genética, Cecília Almeida Sales e Amabile (autora americana?) em criatividade.

Parecerista ad hoc da FAPESP e revisora da IARA. A FAPESP designa moda como interdisciplinar, dependendo do projeto. A Cláudia já percebeu isso.

Não é por ser moda. Eles lêem o projeto. De repente ele se encaixa mais no design, tem um campo que é arquitetura...

Aí eu pergunto "Ciências sociais aplicadas"? E ela responde: “É nesse que mais vai." 
Ciências Socias Aplicadas é o primeiro. Depois eles dividem. Às vezes vai para Arquitetura, vai para o Design ou às vezes vai para Interdisciplinar.

$\mathrm{Na}$ Moda ou "Interdisciplinar" ela me conta que ela é parecerista, mas também a Mônica Moura, a Patrícia Sant’Anna, a Cristiane Mesquita.

Ela conta que já chegou texto da FAPESP até ela que ela não tinha a mínima condição de ler. Simplismente é designado, os pareceristas não sabem o critério para distribuição dos projetos para apreciação.

AUTORES

Ela conhece todos de Projeto e Moda e Design de Moda. Todos são familiares para ela.

MODA = DESIGN OU ARTE?

Para ela nem moda nem arte. Teria que ser uma discussão muito ampla, pois o campo da moda engloba muitas coisas. Ela acaba englobando e influenciando muito as artes. "A moda tinha que ser olhada com mais...é que a moda, ela tem uma herança do artesanato, do trabalho feminino, doméstico que acaba por tirar o prestígio do campo, a importância da moda." OUCH! Reconhece que o machismo sujeita áreas ditas "femininas"

Para a Cláudia a moda não tende nem para o design, nem para a arte, mas acha que Estilismo tende a querer aproximar o fazer projetual da moda ao campo da arte.

Projeto norteia o curso de Têxtil e Moda da EACHUSP?

É importante dar ao aluno várias visões. Que ele tenha a visão projetual tradicional, que ele conheça as metodologias projetuais tradicionais. Ele tem que ter ouvido falar do Baxter em algum momento, do Munari e do Löbach. Esses 3 ele tem que ouvir.

Depois ele tem que conhecer também o que é pensar um produto do ponto de vista conceitual, entender esse universo. Se o aluno da EACH entender essas "línguas" (linguagens) todas ele sai da faculdade com uma visão gera e ele pode definir o que é melhor para ele de acordo com o que ele pensa, qual ele teve contato ele acaba usando para o trabalho dele.

Estilismo estaria mais ligado à crítica genética. E usa Foucault como "pan de fundo" contra as "verdades que pesam".

INTERRUPÇÃO

$\mathrm{Na}$ área de projeto faz isso. O que acontece é que o egresso do curso, pelos nossos dados têm atuado muito com gerentes de produto.

As disciplinas de projeto não norteiam o curso, pois ele tem áreas muito bem definidas, a área têxtil, a área de moda e ele tem uma área de gestão

A parte de têxtil segue uma linha mais tradicional, do encadeamento das disciplinas da engenharia têxtil.
A área de produto não, a área de moda...as disciplinas de projeto elas norteiam, somente esse espaço do produto, porque não há departamento.

Isso é uma característica na EACH da formação dos professores. Porque a formação dos professores da área têxtil são engenheiros têxteis ou químicos.

Talvez com a entrada de egressos para dar aula isso mude com o tempo.

\section{MODA COMO CAMPO DO SABER}

Ela diz que não gosta muito dessa discussão, mas que ela tem que existir por conta dessas exigências de MEC.

Mas ela, particularmente, não acha que moda é design nem qualquer outra coisa. Para ela Moda constitui um campo do saber na prática.

Pela própria complexidade da moda, por todas as raízes que ela traz com ela, ela deveria ser considerada como Campo do saber. O que atrapalha é origem dela.

Quanto alguém pensa em moda, atrela só a vestuário. E moda é muito maior que vestuário, ele é só uma pontinha da história.

Mas ela concorda com a Madu do Senac que moda não é um campo do saber porque não tem metodologia própria de pesquisa. Ela complementa que quando o aluno da $\mathrm{EACH}$ vai fazer disciplinas de metodologia no design ou na engenharia perde porque é preciso fazer adaptações desse pensar para o campo da moda, porque o campo da moda não tem uma metodologia específica (detalhe que design nem é campo do saber, mas é mais tradicional).

O campo da moda é muito característico. Ele tem uma especificidade. Mas ao mesmo tempo a Cláudia não saberia dizer como a Moda se configuraria como campo do saber.

Mas uma vez conversando com o professor Eneus da ECA eles pensaram em descrever [sic] escrever sobre uma ontologia da moda. É um caminh para começar a lançar as bases para, como bem disse a Madu, é uma questão epistemológica. Moda precisa de uma metodologia de pesquisa científica dela, que dê conta dela. A moda é interdisciplinar por natureza.

Então em relação ao aluno, a metodologia de pesquisa que você tem que utilizar para dar conta da moda é do design, da engenharia, de tudo, você pega um pouquinho de cada lado.

Para ela há reconhecimento social maior da figura do estilista para a sociedade como um todo, sem dúvida. A maioria das pessoas, mesmo nas empresas, reconhece ostilista. O designer para ela leu que venho do mercado, posso te falar isso] faz geladeira, cadeira, principalmente cadeira. Esilista faz vestuário, designer faz cadeira para o senso comum (rs).

OBSOLESCÊNCIA PERCEPTIVA

Afeta o projeto sim, mas estamos passando por um período de mudanças

Ela esteve pesquisando na Inglaterra recentemente e percebeu essa mudança. Primeiro que as empresas diminuíram. As empresas têm somen- 
te 10, 15, 20 funcionários, empresa com alto valor agregado, altíssimo. Fazendo o mesmo commodity, calça jeans, que ele transformou a calça jean no companheiro da sua vida.

E em todas as empresas visitadas eles pregam a "felicidade no trabalho" porque é o que eles estão estudando lá em termos de modelo de negócio.

$\mathrm{Na}$ HIUT DENIM eles trabalham 4 dias por semana. Eles trabalham em cima de produção. Eles fabricam cerca de 400 peças mês e cada peça custa cerca de 140 libras, cada calça. Ele tem 12 funcionários, 8 na produção e 5 na administração, entre desenvolvimento de produto e administração junto.

A produção é como se fosse pilotagem. Cada costureira é como se fosse uma piloteira. Cada costureira monta uma calça. A produção é ali. Eles ficam perto de Cardigan, no país de Gales.

Só o cortador é separado, o resto a piloteira monta tudo, monta a calça inteira. Então são várias piloteiras na verdade. Isso mesmo. E existe um código para saber quem montou aquela peça. Você pode conhecer a moça que montou a sua calça, inclusive.

A pessoa lá trabalha 4 dias por semana, no país de Gales e ganha acima do piso salarial da Inglaterra e está tudo muito bom e todo mundo feliz. Eles adoram a empresa e contam a história para todos. A empresa está com 10 anos.

A outra empresa que a Cláudia visitou está com 100 anos. Possui 20 funcionários que moram perto da empresa, trabalham em uma carga horária reduzida, trabalham em cima da produção. Ela afirma que isso existe e ela viu, mas não é representativo, ainda não.

Forma e função - o produto de moda é um produto com valor simbólico. Há autores que acreditam que a função estética está subordinada à função simbólica e subordinada à função prática $=$ Há autores que estudam a função prática como dominante sobre as funções estética e simbólica, por ex. Löbach (a primeira e a segunda afirmação não são a mesma coisa?). $27^{\prime} 55^{\prime \prime}$

Quando ela fala de moda ela fala de vestuário, uniforme etc inclui tudo (função prática, simbólica e estética). A função ergonômica no uniforme ela entra, mas em primeiro lugar existe uma coisa que chama conforto psicológico e ele passa por uma adequação àquilo que você usa. Esse bem-estar dessa adequação vai muito além do conforto físico, por isso que o binômio "forma e função" não estará em primeiro lugar.

O entendimento desse tipo de suscetibilidade tem que ser claro para quem faz o produto, o aluno dela no caso.

O aluno precisa entender isso. O valor principal do produto de moda é simbólico e é o conforto psicológico que faz com que a pessoa use um produto, um tecido que muitas vezes nem é adequado ao clima, que esquenta demais.

Ela fala um pensamento pessoal e tem dúvidas sobre usar o relato abaixo:

Ela acha que as pessoas têm necessidade de sempre que tentar explicar ${ }^{\circ}$ que elas fazem. É preciso um rótulo, um nome, uma designação, "eu sou" $X$,
Y. Aí que entra o design, aí que entra a engenharia, a arquitetura. Você precisa da profissão e tem todas as [simulações?] de método que corroboram esse discurso que é mais arraigado então há desejos.

Que nem tem aquelas pessoas que falam que a moda tem aquela raiz pouco nobre, vamos dizer assim da moda, aquela raiz que não é no Vitrúvio, é a raiz na dona de casa que compra a máquina de costura.

Eu cito a Zuzu Angel, o coutourier homem e a costureira do bairro mulher e a própria pessoa não aceita isso, então precisa definir de alguma maneira.

O que ela viu na Inglaterra é que a moda é um negócio, então essa discussão que fazemos aqui não existe. A moda é negócio e tem que gerar capita simbólico. O empresário sabe que está [falando] lidando com o simbólico. Ele faz esse jogo muito bem. Nós perdemos tempo tentando dividir tanto, é ingênuo.

Design é muito mais ampla na acepção inglesa. Não tem a ver com projeto só. Para eles isso nem existe.

Se a gente entender que a moda é um negócio e que ela tem um valor simbólico muito grande e ela precisa fazer girar uma parte da economia, pronto.

É preciso ter essa fluência de ora ser design, ora arte etc. A moda não quer ter esse comprometimento justamente para poder ter essa liquidez $d$ que o Bauman fala. Porque inclusive ela se alimenta disso, né?!

Na Hiut denim quando se pergunta se o que eles fazem é design de moda, eles não estão preocupados com isso, não estão "nem aí", não querem saber disso.

Para eles o estudante de moda, eles não fazem essas distinções como a gente faz no Brasil.O Brasil teve que criar essa figura do estilista.

Ela acha que como curso o nome Moda é mais adequado. "O que você estuda? Eu estudo Moda." É isso.

Ela é a única professora de moda que aborda Löbach e bem en passant na graduação. Na pós ela discute muito a questão do processo e do ambiente que fomenta a criação. Por isso que ela acha que a questão do que é moda e o que não é, não fomenta a criação, para pensar e começar a trabalhar algo diferente. Na pós é só processo.

A CÓPIA

A carteira dela costumava ser assinada como gerente de produção, gerente de desenvolvimento, gerente de produto, eram essas coisas.

Ela não acha nada de cópia. Ela tende a pensar mais focada no tipo de negócio. Ela acha que tem lugar para tudo. Se tem lugar para o cara que vai consumir essa copia..

Ele vai lá e vê um Lacroix e não vai dar para usar aqui (acho que se referia mais ao clima). Então eles vão lá e vão "tropicalizar" ela falou que eu vou atualizar meus termos (demos risada). 

inovação. É a "inovação incremental" que é quando você pega um produto que já existe e você muda alguma coisa, passa a ser uma inovação, não é mais cópia. Tem a ver com REDESIGN?

Tem a ver com a ideia de estética relacional do Bourriaud.

REFLEXÃO SOBRE PROJETO E MODA

Ela acha que falta, sobre moda, em geral. Falta profundidade, nos colóquios isso é percebido.

Ela pergunta há quanto tempo se pensa moda academicamente?

Porque o Senac fechou o mestrado, a UAM é design. Só a EACH é moda, moda mesmo tem 4, 5 anos, 6 anos. A EACH está solicitando a abertura de um Doutorado em Moda.

Uma coisa são as exigências formais, outra coisa é fundamentar a área com uma pesquisa consistente. Ela acha que estamos encaminhando isso.

Para ela é lógico que pode ser falar em uma forma "Brasil de se projetar". Para ela o brasileiro tem um jeito peculiar de tropicalizar as coisas. Até 0 nome da cópia ele já tropicalizou. Quem falou isso foi o dono da MOB, Marcelo Dib (mas não é para usar na tese essa info).

Ela fala que quando ela estuda criatividade são vários níveis de criatividade que existem e ela elogia o brasileiro que é muito criativo. Ela acredita que existe um "jeito nosso" de pensar, de fazer as coisas.

SOBRE A TESE DELA

Ela agradece rindo que eu li e brinca "você foi a primeira pessoa que leu." BAXTER (2005)

Ele foi um primeiro teórico que tentou sistematizar as ferramentas projetuais. Ela acha que a grande contribuição dele são as ferramentas para projeto em geral, pois ele é usado para tudo, não só para moda. Ferramentas a que ela se refere são brainstorming, quadros de sintese visual que são as ambiências para a moda. Ela continua "você sabe que até nisso a gente não tem rigor de nomenclatura, isso e problema." Ela acha que isso atrapah ha, pois cada hora chama de uma coisa, ajuda a justificar meu primeiro capítulo.

\section{Sobre ferramentas}

O que é método 6.3.5? O que é método DELPHI? O que cinéctica?

Matriz morfológica ela falou que usa até hoje.

Os métodos 3 citados anteriormente são como o brainstorming só que.. são métodos de você dar ideias, métodos de geração de idéias.

Eu pergunto e os "catálogos construtivos"? Analogia e inversão?

Ela responde também (seriam métodos de geração de idéias).

Para ela "forma e função" é um embotamento do processo criativo. $\mathrm{Na}$ engenharia eles abstraem a função no exercício de analogia e inversão.

A função é limitadora, deve-se ir além dela, desconstruir senão não se chega a uma coisa criativa, ou melhor, um produto que realmente tenha um significado, tenha um valor para aquele público.

Agora o quadro morfológico é legal, ele é bem legal, eu continuo usando, ela diz. A matriz morfológica é o que ela mais usa.

\section{O que é DIAGRAMA DE MUDGE?}

Você faz uma análise da importância daquele item para o seu cliente. $E$ o DIAGRAMA DE MUDGE vai dar nota e você vai somar. Na verdade o DIAGRAMA DE MUDGE faz a importância relativa de atributos do produto.

SOBRE O CARÁTER FUNCIONAL DA TESE DELA

Ela não aplica tudo em aula, acha que nem dá.

A matriz morfológica que organiza o pensamento ela usa muito. As outras ferramentas ela mostra que existem e diz que dá para quantificar algumas coisas e se a pessoa quiser aprofundar tudo bem, mas.

Na página 97 da tese dela é o que ela chama de ferramenta de "geração de ideias".

Tá, mas o que é o quadro ou matriz morfológico?

\section{Ela responde: é esse.}

Então o quadro são as alternativas e o cruzamento delas que implica em escolha corresponde à "geração de idéias". = geração de idéias do Löbach.

51 '31"

Ela me ensina como usar o quadro. No parâmetro é preciso abstrair o máximo possível.

Em termos práticos esse Quadro Morfológico que possibilita a "geração de alternativas" é usado para desenvolvimento de produtos. Equivale a geração de alternativas do Löbach.

Esse exercício é para garantir coerência da coleção, unidade visual.

Fala que minha tese é um trabalho insano, ler teses e fazer entrevistas.

Na página 99ela vai citar o Dedini

ETAPAS PROJETO - PESQUISA

O que seria a melhor solução para o projeto em moda, tomando por base o projeto preliminar (p. 99) de Dedini. $O$ projeto preliminar é um conjunto de soluções desenvolvidas na fase anterior que vem do estudo de viabilidade.

Ela pergunta: se é bom para a moda? 
Hoje para a moda ela acha que a melhor solução em termos de projeto é um conjunto de diretrizes.

A empresa e a figura responsável pelo desenvolvimento de produto, estilista ou designer, [enfim]...essa "criatura" tem que ter um conjunto de diretrizes para desenvolver produtos para a empresa que vai se basear no público alvo e no que é o valor simbólico desse público-alvo.

Um projeto preliminar seria então um conhecimento que é da empresa, não é da pessoa sobre o negócio, porque isso é conhecer negócio.

Ela acha que isso é solução de projeto em moda em moda, porque 0 resto, quando você conhece o público-alvo fica muito mais fácil a criação porque a partir daí você sabe o que pesquisar, você sabe como usar suas referências pessoais. Ela diz isso se voltando a produtos comerciais. Ela sempre faz essa distinção.

\section{DESENVOLVIMENTO - DESENHO?}

O uso das referências pessoais do criador do produto serve para caracterizar um produto que tem um apelo único, ligado à produção de subjetividade.

A base de tudo é conhecer o público-alvo.

Ela defende que tem que ter a "análise do conforto e usabilidade". Tem que fazer teste de uso final. A moda não tem isso, mas ela defende que tem que ter, pelo menos de produtos clássicos, que são produzidos sempre.

Esse tipo de produto, pelo menos, tem que ter "teste de uso".

Por isso ela acha que moda é um negócio complexo, não para estudar ela "pelo cabide dos outros". Tem que estudar ela por ela mesma.

E como faria esse teste de uso?

Seria feito via consumidor.

58 '29"= fala de erros de produto do Shoulder.

Fala que o profissional tem que fazer valer sua autoridade. Ela pergunt "quem foi a criatura que desenvolveu isso? Porque se for meu aluno eu vou pegar a tapa."

Buscar na tese da Cláudia o desenho, páginas 79/80 (Fase 1- estudo de viabilidade) e 98 (arquitetura final do produto).

\section{PONTO IMPORTANTE PARA A MINHATES}

\section{MODELAGEM}

O Brasil não tem uma proximidade com o seu confeccionista. $O$ país não tem entidades que façam uma aproximação real entre confeccionista e consumidor. O SEBRAE ainda tenta fazer alguma coisa nesse sentido, mas é muito [incipiente]. $O$ Brasil precisava investir mais nisso. $O$ brasileiro, de modo geral, não é também um consumidor exigente.

\section{EMAIL 13/07/2016}

Cláudia, bom dia!

Percebi que faltam algumas informações na entrevista que fiz. Se importa em responder por email?

Se tiver esta disponibilidade the envio abaixo as fases que gostaria que bordasse brevemente. Preciso que me diga como realiza cada uma e como vai de uma para outra.

Registro da Pesquisa

Caderno? Painel? Caderno e painel

\section{Estudo de Formas / Silhuetas}

\section{Cartela de Cores}

Cartela de Matérias

\section{Beneficiamentos}

Estampas, bordados, lavagens, tecidos e aviamentos exclusivos e outros beneficiamentos se for o caso.

Isso tudo.

Desenhos

Croqui e técnicos (são esses nomes que você usa?) croquis e técnicos

\section{Geração de Alternativas}

\section{Modelagem/Moulage}

Confecção do Look

\section{Apresentação}

Forma de apresentação do trabalho final. O que consta nele?

Portfólio com todo o registro da pesquisa, desenhos tecnicos croquis, coleção, tudo. 
TARALLI, Cibele H. Entrevista realizada com Cibele Haddad Taralli, em 2 de dezembro de 2015, na cidade de São Paulo, com 55 minutos de duração.

Ela não tem nenhuma experiência nem nas disciplinas, nem nas orientações de aluno com o tema moda. Também não tem experiência projetual no mercado de moda.

O professor que orientava moda era o Minoro Naruto que já se aposentou. Ela falou de uma ex-aluna da FAU que tem uma loja na Vila Madalena que se chama Antes de Paris. Ela foi orientada pelo Minoro Naruto.

AUTORES DESIGN - SIM PARA TODOS

Reiterou que Bruno Munari usa para Metodologia para iniciar o pensar em design, além da Comunicação Visual, é o "Das coisas nascem coisas". Ela diz que usa para instrumentar esses primeiros passos, na área de interface entre produto e espaço que é onde a Cibele está: um pé na arquitetura, um pé no espaço e um pé no produto.

Ela elogia no Munari que a metodologia dele não é rígida como a do Löbach e que ele é muito comunicativo.

AUTORES DESIGN MODA

Ela concorda/nota que são muito recentes se comparados à bibliografia de design PP e PV. Ela não conhece e me pergunta se falam de PROJETO ou de METODOLOGIA PROJETUAL.

Ela acha o nome "Pesquisa em design" amplo.

FAUUSP

\section{Faculdade de} Arquitetura e Urbanismo da Universidade de São Paulo

Ela me fala como a regulamentação da profissão de design é muito recente. Há quantos anos o Brasil tenta votar para aprovar?

Ela imagina que essas demandas profissionais da moda vão levar muito tempo, que não é assim que se faz, rapidamente.

O Munari é bom para quem vai fazer um projeto mais experimental. É uma metodologia onde se cabe uma experimentação. Não é um método.

O Munari respalda essas atuações e como na FAU USP não é comum o trabalho com moda, normalmente se vai por esse caminho.

ESTILISMO X DESIGN DE MODA

DESIGNER DE MODA X ESTILISTA

Ela se diz uma profissional de RG baixo [?], ou seja, a formação dela é toda focada na corrente moderna. Quando falam para ela sobre estilismo, ela fala que vem essa associação como Styling que, segundo ela, não é verdadeira, mas é um nome que parece que está impregnado na palavra, no texto. Então eu acho mais adequado, DESIGNER DE MODA.

No Design de moda ela vê uma possibilidade de atuação mais estrutural, 
mais ligado a mudanças de procedimentos, acompanhamentos de mudança de tecnologias para produção, a inovação.

Também tem uma parte de estar mais ligada à parte produtiva, da produção, das tecnologias, [das máquinas], dos materiais, dos processos, porque decorre muito desse exercício aqui [e aponta para a ponte construída com varetas sobre a mesa]. Esse é um exercício de produto para a arquitetura e é dado também no design. E é só uma vareta e ele tem que se auto sustentar em um vão. Só as extremidades são apoiadas e ela tem que sustentar sem cair no meio.

Ela afirma que tem uma metodologia de experimentar. Estruturar com vareta. Esse exercício é dado há 20 anos. Você vê o que é experimentação? [Ela pergunta]. Ninguém pede para construir uma ponte calculando. Não! Você vai fazer dentro dos recursos que você tem.

Para ela nesse aspecto o termo designer de moda tem mais sentido. Não é só superficial.

CONSEGUE ENXERGAR A APLICAÇÃO DE MÉTODOS/METODOLOGIAS DO DESIGN NA MODA?

Ela responde que sim e explica que por isso escolheu na minha comparação acima a palavra design. Porque o design para ela faz mais sentido. Mesmo que você vá trabalhar com uma moda mais experimental, mais inovadora.

Ela não vê nenhum antagonismo no uso da palavra mesmo que você tenha essa visão mais artística.

O QUE AFERE MAIS VALOR?

Pelo consumo a pessoa vai entender que essa roupa foi feita pelo estilista.

\section{ELA SUGERE POSICIONAR OS AUTORES DE PROJETO EM MODA}

De onde eles vêm? Do ponto de vista de que área do conhecimento? Porque a gente tem também escolas de design que estão dentro de escolas de arte. Isso muda um pouco.

Fazer uma discussão sobre os termos. Incluir uma subseção com essas definições, com os entendimentos dos termos. Arte como área, arte como algo artístico e de onde vem essa definição [a que literatura ela se refere]. O conhecimento foi se especializando e amarra demais as áreas. Se por um lado protege a área, por outro amarra.

Ela foi parecerista da FAPESP da área de moda, mas não é mais.

Há 2 anos na FAPESP quem analisava projetos de design [isso inclui moda] eram só arquitetos. Ela diz que há 2 anos os designers entraram e aí se separou realmente. Tem poucos projetos que caem hoje em arquitetura.

que ela diz bate porque há 2 anos a Cynthia Malaguti não tem mais projetos entregues a ela pela FAPESP.

\section{MODA COMO CAMPO DO SABER}

Ela diz vamos pegar o design $\mathrm{O}$ design tem vários campos, design de inter- face, games, embalagem. Você tem subáreas dentro do design, tem o pessoa do design centrado no usuário [até mesmo eu acho uma bobagem], diferente da ergonomia e ambos convivem debaixo do mesmo guarda-chuva que é design. E eu não entendo por que essa briga de poder que você está falando.

Falo que a moda surge e se mantém por 10 anos autônoma. Ela me responde que o design vai ficar amparado por um conselho regional que é de design. Não importa se ele é de produto, se ele é gráfico.

Mas quando ela parte em defesa do design, ao insinuar que para a moda é melhor ser amparada por um conselho regional que é o de design, não importando se ele é de produto, gráfico ou de moda, ela já está se posicionando em favor do design ao reconhecer que o campo está mais respaldado que o da moda por ser legitimado há mais tempo.

Ela atribui o fato de eu não ter sido apresentada a bibliografia de design por eu nâo ter tido professores formados em design. Isso é ótimo quando for falar da UAM!

Contei que a certa altura da minha pesquisa eu não lembrava qual era 0 meu título como bacharel. Que era em "design de moda".

Falo dos diferentes nomes de cursos de moda.

Ela observa [se referindo à dificuldade de achar o decreto sobre design de 2010] se não há regulamentação isso dá chance para que cada um faça sua interpretação e sua leitura. O MEC acaba fazendo vista grossa.

Estamos sob uma diretriz de design. "Modas" " "Vestuário" são coisas distintas e os 2 podem ser operados pelo design.

Ela conta que a FAU já teve professores que riscavam o nome moda e colocavam vestuário [João Bezerra de Menezes]. Tem uma posição de produto extremamente clara dentro da vertente bauhausiana, do modernismo que é vestuário e outra área mais aplicada a tecidos é o têxtil e o design de superfície. Para eles não há moda, mas vestuário e têxtil. Uma visão mais racionalista.

Ela diz que tem que discutir a autonomia dos campos do saber. Até onde vai um campo e onde começa outro campo. Ela fala de áreas como a psicologia, a antropologia, a sociologia e que sem elas é difícil conceituar a arquitetura, o design e a moda. Essas 3 últimas não são ciências que têm uma autonomia para auto gerar conhecimento. Voce acaba precisando das outras ciências para poder justificar, para poder aproveitar uma abordagem, uma visão.

Ela diz que vê muito isso na história da arquitetura que pega a geografia a sociologia e essa bibliografia vem para construir os argumentos, suporta os argumentos.

A Cibele diz que também não vê o design como uma área autônoma. Ela é dentro de um campo de divisão de saberes que o racionalismo trouxe. Separou várias engenharias, vários designs e assim vão se fazendo essas especificidades porque a nossa sociedade demanda essa especialização. O mercado está estruturado assim. As economias estão estruturadas assim. 
Comento que só o termo design não dá conta [fui alertada pela Cynthia Malaguti].

O MEC denomina o campo DESIGN.

O CNPq denomina o campo DESENHO INDUSTRIAL.

Para você ver como as coisas no Brasil não são muito [coerentes].

Ela diz não ter uma certeza, mas pelo que ela já viu de história do conhecimento e epistemologia talvez esteja mais próximo dessa vertente das divisões modernas, como a das medicinas, a das engenharias, dessas especialidades todas.

A arquitetura foi ao contrário. Ela foi perdendo. Ela sai da engenharia para formar um grande campo e perde ao longo do tempo o design. Os paisagistas querem pleitear uma área, restauradores também estão querendo sair da arquitetura. E para arquitetura vai sobrar o quê? Projeto da edificação daqui alguns anos.

Aí a gente se pergunta para onde vai esse desenvolvimento?

Depende para onde vai essa corrente de desenvolvimento humano, econômico, das demandas, do contexto

Ela fala da indústria de azulejos que foi projetada pelo Cauduro até os uniformes. Fábrica de azulejos Santana. Nessa concepção era o vestuário. Aquela vestimenta que proporcionava para o trabalhador bem-estar, favorecer o seu desempenho dentro de um maquinário, dentro que ele precisava fazer etc.

Fala da moda desde a década de 60 com nascimento e morte muito rápidos. Eu falo da moda contaminando o design e a arquitetura e ela fala do design também contaminando a moda pela dependência de tecnologia das máquinas geradas pelo design. E isso é antigo.

Citou a sacola premiada no Idea Design da aluna do design da FAU e contou que hoje ela dirige a confeç̧ão da mãe no circuito Brás-Bom Retiro.

Falou das coleções assinadas para grandes magazines.

Falamos da coleção da Adriana Barra e de estamparia digital. Ela falou que a tecnologia propicia isso, mas tem que ter projeto. Tem que ter gente pensando e usando os códigos de máquina, conhecer os processos senão não sai nada.

Que nem o exercício da barrinha aqui [citando o exercício da ponte que estava sobre a mesa]. Ele tem que entender muito a propriedade dessa barrinha para fazer isso.

FALTA REFLEXÃO EM PROJETO?

Falta reflexão científica em projeto. Eu estou falando isso em arquitetura em design, mesmo com mestrado e doutorado. Pouca gente trabalhando nessa área, pouca substância. Ela concorda que não precisa de mais métodos. A metodologia é um meio para você chegar lá, é um caminho seguro, mas não é só. Só com metodologia não se faz um projeto. Ela em si só é um dos aspectos.

Ela imagina que para moda também aconteça alguma coisa nesse sentido.
KHOURY, Feres. Entrevista realizada com Feres

Khoury, em 9 de dezembro de 2015, na cidade de São Paulo, com 27 minutos de duração.

\section{CONTATO COM MODA}

Foi por acaso. Entrou em contato com a Vera Lígia por meio de workshop que ele deu no Sesc de desenho e coisas similares segundo ele. E a aí a Vera Lígia perguntou se interessava a ela dar aula de Desenho na FASM. Mas ele entrou na FASM para dar Metodologia Visual I e II. Não entrou para dar desenho. Das metodologias uma era de cor e outra era de experimentos visuais. Eram aulas de cor o ano todo, trabalho exaustivo de cor. Faziam cartelas, era um trabalho de situações cromáticas o tempo todo, era mesmo para a consciência da cor como linguagem, como aplicação. Mas ele admite que cientificamente não é um professor especializado em cor.

E de metodologia eram trabalhos programáticos, de projeto mesmo, tridimensionais. Ele conta que fazia um gancho da formação dele de arquiteto. Ele dava Desenho III e agora quem dá é o João Novelli. E ele ficou com Desenho II, desenho de observação que era anual e agora é semestral.

Ele defende que é importante que os alunos tenham o mínimo de desenho. Como os alunos podem traduzir em cor, em gráfico e ter consciência da representação.

Ele reclama que os alunos não têm interesse, não tem repertório, não tem vida no que está fazendo, é tudo obrigatório, só para ganhar dinheiro.

AUTORES

Ele falou que eu entrei numa área que ele não trabalha. Conhece o Munari porque é clássico. Cecília Salles ele conhece e alguns pós-estruturalistas. Mas no geral não porque ele não trabalha a questão do projeto/design então ele acaba nem vendo produto.

AUTORES PROJETO EM MODA

Menos ainda. Essas questões não chegam a ele.

Ele conta que não conhece Löbach, nem Burdek. A visão dele de design foi com outros autores. Foi com Maldonado, Max Bill.

PROJETO EM MODA - consegue falar?

Para ele é o trabalho da pessoa dentro de princípios, de ideias que ela desenvolve e cria as relações de conhecimento que precisa o projeto. Né?! Cor, têxtil, ele tem que fazer esse intercâmbio dessas várias áreas porque moda está ligada com indústria, não está só com gosto. Está com gosto no plano da cultura, mas em geral ele tem que estar entendendo tudo para fazer um projeto.

SOBRE A FASM SER MAIS AUTORAL 
Ele acha que a escola tem que ter sua personalidade. A FASM é autoral, mas os alunos não necessariamente ficam autorais.

Ele afirma que boa parte dos alunos da FASM vão para a indústria. Ele acha legal a noção de estilismo. Ele acha que essa é a diferença.

\section{ESTILISMO X DESIGN}

Ele acha que a visão pública é sempre muito jornalística, muito deformada. Ele afirma que sempre tem problemas, mas bons alunos sempre surgem no meio de uma turma de 30, 40 alunos que querem ser autorais e vão atrás.

\section{QUESTIONO QUE O MERCADO NEM ABSORVE TANTOS AUTORAIS}

Ele acha que a terminologia associada a ideia de que designer é o prático e estilista o autoral é tudo estereotipo de frase. Ele acha que quando vai discutir academicamente você tem que discutir os conceitos com mais clareza. E na FAU aparece [inaudivel]. Ele acha que quanto aos conceitos há uma deformação cultural.

Moda não é arte no sentido do projeto artístico. O projeto artístico é uma questão e o projeto de moda é um projeto que aborda uma outra questão do lado que seria artistificado, vamos dizer assim, porque mexe com qualidades visuais, mexe com forma. Não é pejorativo. A moda é artística, mas não é um projeto de arte. $O$ projeto de arte tem outra intenção.

ESTILISMO E AURA

Não acredita que queira se aproximar da arte, do objeto único. É porque o estilismo é contaminado por muitos caras de muita competência, então o estilismo virou assim como eu falar uma estética, ficou como uma tendência de ser alguma coisa.

Não quis responder sobre Styling, disse que não sabia responder.

\section{ESTILISMO NORTEIA O CURSO?}

Começou dizendo que só no final, depois reconheceu que a disciplina de estilismo norteia o curso. Disse que já começam cartelas, pequenos projetos no primeiro ano então é norteadora sim a ideia de estilismo. Ele critica que os alunos não fazem do desenho parte da formação deles. Ele acha que isso os alunos não fazem. São 3, 4 alunos que fazem esse gancho. Afirma que o

Se queixa que os alunos entram muito precários, mesmo com prova de habilidades. Ele diz que nem tem bem uma prova de habilidades [se referindo que elas não avaliam].

Ele falou de alunos que não sabem distinguir volume de linha, linha de tom, tom de cor até agora com um ano de curso de cor.

\section{MODA AUTÔNOMA}

Nunca pensou sobre isso. Ele acha que é moda, mas pode chamar de design de moda. Ele acha que aí as pessoas se perdem muito. Ele concorda que aluno de moda pode ser VM, jornalista (e citou a Maria Prata), tem quem mexe com sapato, o outro resolveu ser cenógrafo, tem um menino que é um cenógrafo genial. Então como que você vai fazer?

A escola me lembra mais um pouco um formato mais tradicional da FAU em que a arte e arquitetura se juntam. Então em alguns momentos a escola [FASM] tem um pouco esse aspecto. Que ele critica que com o contexto econômico a administração atual tende a entender, mas altera algumas coisas.

Ele conta que têm defendido a causa de ter uma escola com uma boa ormação inclusive autoral de alunos que têm uma competência cultural. Ideologicamente a gente se comporta assim.

Ele acha que a formação somente não dá condições de formar o profissional. Ele diz: nenhuma escola, pelo amor de Deus! É impossível dizer isso. Quando você sai da faculdade você não consegue ser arquiteto ainda. Você precisa ter algumas vivências, é igual aqui ó. Eles sabem, entendem, mas quando eles entram no mundo profissional é diferente, tem que lidar com pessoas, tem que tomar decisões, tem aspectos psicológicos, aspectos culturais.

\section{Então a escola é uma etapa.}

Ele defende que se você ensina moda pode ensinar história da arte [no sentido de que os alunos devem ter acesso a repertórios distintos]. Qual é o problema?

Se você ensina moda porque não pode ter uma aula de introdução musical?

Essa visão compartimentada da especialização é muito limitadora. Criar elementos interdisciplinares é muito bacana.

Ele reclama que os alunos não ouvem. Você fala uma coisa eles fazem outra. Eles não ouvem.

OBSOLESCÊNCIA PERCETIVA AFETANDO A NOÇÃO DE PROJETO

Afeta porque a moda é muito autoritária. Roupas boas não se dispensa. $O$ europeu demora a dispensar roupa. A ideia de você trocar de roupa a toda hora é uma coisa ligada a cultura industrial, a cultura jovem, é uma loucura.

Ele acha que não afeta [agora] o estilismo. $O$ estilismo adora isso porque ele tem que produzir. E a novidade é a ideia o tempo todo dentro do estilismo.

\section{CÓPIA}

Tem a 300 séculos. E fala da China onde a cópia é um conceito relativo. Lá quem copia é quem aprende, aqui quem cópia é pejorativo. Na pintura aprendizado é assim, pela cópia.

A cópia de grandes marcas na opinião dele é um equívoco. Você está vestido com uma calça e uma camisa, o problema é a simbolização disso.

FORMA E FUNÇÃO

Ele acha que aparece sempre. No desenho você usa uma técnica não porque você aprendeu. Você escolhe uma técnica porque ela vai expressar 
aquele seu projeto daquela questão. Aqueles resultados plásticos são em função desse projeto. A forma e a função elas entram nessa categoria.

Ele fala na FASM usam o termo Design de Moda. Ele falou que usa todos os termos, que não é equivocado. Não é equivocado porque design é um projeto que tem intenções que têm âmbitos industriais antes do comércio e tem âmbitos de reflexão. Então eu posso fazer desde uma roupa única, bonita, conceitual, maravilhosa onde eu tenho todo o processo projetual embutido. Design é isso. Ele origina uma ideia que você produz, você pensa uma ideia, você materializa essa ideia, você constrói essa ideia, cria um sistema, uma metodologia para ela "tchau e benção".

\section{DESIGN MEC 2010}

É complicado cara, porque você não sabe quem está lá. É uma coisa horrível. A burocracia desses grandes departamentos é uma coisa complicada.

Citou uma bolsa negada para ir a Israel para um congresso que sua muIher teve. Era um projeto artístico sobre memória e quem avaliou foi um engenheiro que julgou irrelevante. Aí o Feres fala: é isso, meu!

CÓPIA AGAIN

O ruim é que a pessoa não é inventiva, ela é muito comprometida com o capital. Ela não se compromete com uma produção interna. Não incentiva jovens inovadores. Ele fala que todo mundo quer estar igual na globalização, criticando como a globalização pode massificar.

REFLEXÃO SOBRE PROJETO EM MODA

É novo aqui para nós. Acho que tem pouca literatura. Tem pouca gente. DESIGN NACIONAL

Tem características bem bacanas, mas a moda é uma relação tão internacionalizada que você não pode dizer ela é só brasileira. Citou o Ronaldo Fraga. Ele lembra o Brasil o tempo todo. O Hercovitch não é tão Brasil, é mais globalizada a imagem dele.

MODO DE PROJETAR NO BRASIL

Tem modos de projetar que são aplicados, modos convencionais como desenho técnico.
SANCHES, Maria Celeste de Fátima. Entrevista

realizada com Maria Celeste de Fátima Sanches, em

7 de setembro de 2015, na cidade de Londrina, com

1 hora e 13 minutos de duração.

Ela era professora de projeto do UEL.

AUTORES DE PROJETO EM MODA - CONHECE TODOS

SEIVEWRIGHT - SIM

RENFREW - SIM

TREPTOW - SIM

AUTORES DESIGN

BRUNO MUNARI - SIM

BERND LÖBACH - SIM

BERNARD BURDEK - SIM

GUSTAVO AMARANTE BOMFIM - SIM

Pesquisa exploratória desses autores para ver o que ela já conhecia e pensava sobre projeto de produto.

DESIGNER DE MODA X ESTILISTA?

DESIGNER DE MODA porque a maneira como o estilismo vem sendo tratada nos cursos de moda com os quais a Téti teve contato nos tempos de MEC e no próprio curso da UEL que era de ESTILISMO EM MODA e depois se tornou DESIGN. Surge em 1997 e em 2004 a UEL muda o curso para Design de Moda. O corpo docente desde o início era formado por designers na UEL - Cleuza Bittencourt.

Projetar sempre foi o foco do curso da UEL.

Para ela estilismo não pode ser sinônimo de projeto. Para ela o estilismo se coloca de uma forma mais reduzida do que projeto. Ela reconhece: "Embora eu saiba que no início o estilista mesmo com uma forma intuitiva, sua prática, sua construção de repertório ele faça o que hoje nós tentamos que o designer de moda..

Antes de a moda passar por essas intersecções com o design eu tenho certeza que o estilista fazia este trabalho de projetar, essa prática com tantas conexões entre campos cultural, produtivo e mercadológico. Eu entendo que o estilista fazia essa prática.

Mas quando nós passamos do campo da prática profissional para a do campo acadêmico e analisamos os cursos, o estilismo ficou muito restrito a projetar linguagem visual ou a projetar formas, a configuração do produto de uma maneira parece um pouco desvinculada de todo o 
contexto mais complexo que envolve aquela configuração como produto mesmo.

A configuração do produto não parte daquela história vamos criar uma coleção com tema tal. Que durante muito tempo a criação de moda dentro dos cursos foi assim. E aí se criou uma visão um pouco reduzida do que seria a atividade desse profissional que concebe o projeto. Algo assim...eu tenho uma inspiração e começo a desenhar algo que expressa uma série de códigos visuais como se isso não tivesse uma ligação com um contexto, com restrições tecnológicas e produtivas. Ou ainda não [como se não] fosse necessário estudar aquele contexto para estudar aquelas restrições, ou seja, delimitar o alcance daquilo que vai ser projetado, que vai ser criado. Por isso que quando clatura mais coerente com a atividade que esse profissional vai desenvolver.

FUNÇÃO SOCIAL NO DESIGN E NÃO NA MODA

Não gosta de definições. A definição de certos termos depende muito do contexto que você está analisando. Eu gosto de destacar que o papel do designer é projetar interfaces entre um contexto sócio cultural e o indivíduo. Nisso já existe implícito um papel social, seja de representação do papel social, ou seja, de melhorar o cotidiano ou até de um papel de inserção social. Enfim, de fazer esta ponte entre o contexto sócio-cultural que envolve as questões econômicas, a cultura do homem e o objeto.

NA UEL tratam muito da sintaxe visual. A coordenação de cores, formas, texturas vai interatuar. Vai dar numa configuração que age de forma integrada que vai se transformar depois na função simbólica do produto.

Ela chama de configuração a sintaxe formal do produto que inclui a matéria, o volume, a cor, a textura. Tudo isso se integra numa composição que é visual, tátil e que é perceptível. Que entra em contato com o corpo, é sensória, e essa relação com meu corpo constrói significados. É o que era conceituado como o conceito de linguagem. Conceito é a essência funcional e de estilo integradas. Não pode haver essa ideia de que conceito é só a linguagem visual. Ex: vou fazer uma coleção estilo romântico. Isso não dá.

Esse conceito é o conceito que todas as peças da coleção vão dividir. Existem uma série de variáveis que confluíram e se integraram para que ele conseguisse chegar naquela síntese que é o que eu chamo de conceito gerador. Porque é uma essência compartilhada por muitos produtos, que ela chama de conjunto integrado de produtos, ou famílias.

Não foi especificamente estilista, mas já trabalhou com consultoria em empresa que queria organizar seu departamento de criação. Ela trabalhou muito como designer gráfica para moda, embalagens, estamparia. Ela percebe que as empresas trabalhavam de forma muito intuitiva e era aí que ela entrava para organizar, dar unidade à coleção, como começar a coleção 18'35".

Concordamos que não gostamos do termo 'TEMA'. Ela usa conceito e referência ou referência. TEM ARTIGO!!!
Existe um universo do usuário e um universo de empresa normalmente nos projetos de produto de moda e o que vincula esses dois é justamente o posicionamento da marca.

MÉTODOS DE PROJETO APLICADOS À MODA (bibliografia não reconhecida entre os cursos)

Para ela nem é possível separar os autores de projeto de design do design de moda. Hoje as pesquisas dela se estendem até o Metadesign, com autores como Dijon de Moraes, Caio Vassão, que falam de metadesign e metaprojeto. Usa muito o Baxter que é do design para a moda.

Ela se interessou pela METODOLOGIA DE PROJETO quando não existiam pessoas da área de moda que escreviam sobre isso. Tanto que a dissertação dela é citada até hoje (na época MONTEMEZZO) muitas vezes porque ela deve ter sido uma das primeiras a falar de um projeto de moda sob ess lógica completamente advinda do design. Ela defendeu em 2003.

Ela diz que não tinha referências de moda/projeto. Ela foi nas fontes que ela conhecia, as dos designers. [e eram as que existiam] e que eram do repertório dela. Ela foi buscar métodos, metodologias para tentar sistematizar quele processo de desenvolvimento de produto da moda, nos autores de design, transpondo isso para a moda.

Ela conta que a Doroteia começou a pesquisar moda antes dela [ela era um pouquinho mais velha que a Téti], mas ela também era designer. E ela também vem com essa visão de projeto para a moda, do design. Na UEL Moda foi um curso de Design, voltado para a Moda e nunca um curso de Moda.

MODA É PP OU CV?

Ela nunca se preocupou em definir isso no objeto do vestuário e acessório, nos objetos vestiveis.

Para ela Moda é como a embalagem. Está no meio. Assim como a embalagem, protege mas a superfície tem informação.

Moda pode ser PP e CV? Ela responde...hum...não sei. As duas definições hoje começam a se coadunar. Mas se considerar que moda possa ter a essências dos 2 no substrato, talvez sim.

NO MERCADO O QUE AGREGA MAIS VALOR? O TRABALHO DO ESTILIS TA OU DO DESIGNER DE MODA? QUAL TEM MAIS RECONHECIMENTO?

É preciso considerar o campo para o qual se projeta. Para ela o designer de moda como ela definiu no começo da entrevista agrega mais. Por conta da visão mais abrangente e mais sistêmica. Porque ela acha que o estilista ficou com uma formação mais reduzida.

1988 MODA SURGE AUTÔNOMA E É ENCAMPADA PELO DESIGN EM 1998

Ela acha que alguns pesquisadores se ofendem com a ideia...como se fosse assim...o design absorvendo a moda. Moda é design.

Quando você fala que vai formar um bacharel em moda você pensa em 
moda como fenômeno cultural e aí você tem vários recortes de abordagem. Eu posso olhar sob a ótica do design, o projeto de artefatos, então eu estou falando de criação, então eu estou falando de produtos, interfaces, então isso é enxergar a moda sob a ótica do design. Termos como design de moda, webdesign sempre parecem faltar algo. Claro que parece esquisito você falar em Design de Moda porque parece que o design está cooptando a moda. Ela entende dentro dessa lógica projetar os artefatos que se inserem no fenômeno moda. Estamos formando os profissionais que cuidam do projeto dessas interfaces.

E COMO DAR CONTA DO QUE JÁ ERA FEITO ANTES E CHAMAVA MODA?

Ela pegou quando era estilismo, mas nunca entendeu design de moda como pegar a moda como fenômeno social e colocar ela lá dentro [do design]. Ela nunca viu dessa forma.

A grande polêmica foi causada quando o MEC determinou que moda seria design. $O$ que soa estranho para a Téti quando se fala que $o$ sujeito bacharel em moda é que esse profissional foi preparado para atuar em todas as frentes da moda.

Como é que um curso vai formar um jornalista de moda, um historiador de moda, um designer de moda? Ela questiona que não dá tempo de formar em 4 anos um profissional tão versátil.

Eu questiono dizendo que não temos várias disciplinas que o design tem como resistência dos materiais, legislação, por exemplo. São dadas sim todas as matérias.

Para ela design de moda é criar um projetista de artefatos de moda. $\mathrm{Na}$ UEL tem alunos que vão ser gerentes de produto, modelistas, além de designers de moda. A preocupação dela de um curso que seja Moda e tudo o que envolve a moda é que se pulverize o desenvolvimento das competências e habilidades necessárias nessa tentativa de abarcar tudo. E isso pode criar no egresso o profissional jornalista de moda, por exemplo, mas ele não teve todo o peso de desenvolvimento de habilidades e competências da comunicação social. É isso que ela questiona na configuração de um curso acadêmico, de um curso de formação em moda. Fica muito ampla.

Como designer privilegiou a noção de projeto quando entra na área de moda para estudar o objeto pelo viés do design. A contribuição dela foi essa: entender o campo da moda, sob a visão do projeto que era a área da criação do produto.

Cada área traz novas visões e a cada momento você vai ter interrelações com esses campos.

MODA CAMPO AUTÔNOMO X REDUCIONISMO DO DESIGN

Acha que tem que discutir muita coisa de legislação ainda.

TRICOTOMIA DISCIPLINAS PROJETO EM MODA X PROJETO EM DESIGN
Nomes diferentes a cada ano de faculdade na UEL, mas todas voltadas nitidamente à gestão de projeto. Para que $\mathrm{o}$ aluno forme esse pensamento sistêmico para gerenciar seus...de todo o processo. Ela tem muito orgulho desse projeto como autora e porque acredita no que fizeram na UEL. A ideia da UEL era integrar tudo para que o aluno não precisasse juntar sozinho todas aquelas caixinhas. Ela é favor de um curso que promova a aprendizagem de projeto. Não era ensinar. Eles tinham que entender o que era projeto $e$ tinham que realmente exercitar essa prática sistêmica e realmente refletir. E ela acha que o projeto pedagógico tem que proporcionar essa condição e os professores têm que estar integrados para isso.

CONFECÇÕES QUE NÃO DESENVOLVEM A NOÇÃO DE PROJETO

Indústrias familiares e pequenas que tem esse perfil. É comum. A Téti participou da APL (arranjo produtivo local) a pedido da UEL. É assim, as indústrias se unem para tentar melhorar a região, fortalecer a região naquele setor. O APL está até meio adormecido, eles pararam as atividades.

Ela notava entre 600 e tantas indústrias que eram empresas pequenas, familiares e mesmo que crescessem continuavam a criar e desenvolver produtos de forma intuitiva. Muitas não se dedicam a criar, mas somente a reproduzir tendências já estabelecidas pelo mercado. E esse é um modelo de gestão bastante comum na opinião dela.

É comum que o aluno que se forma entre na empresa e quando chega lá não encontre um meio propício a inserção do pensamento de design.

Ela acha importante nas suas pesquisas construir um pensamento autônomo, a reflexão sobre o próprio processo criativo e que o aluno consiga se apropriar das próprias decisões dos métodos que o design proporciona.

Ela não é adepta de nenhum método hegemônico. Primeiro faz isso, depois isso e patati patata.

Quando ela fala de metodologia, tem muito cuidado. Ela separa as etapas na sua dissertação por questões didáticas numa sequência lógica. Ela organizou o processo, o que pouca gente tinha feito, mas faz questão de colocar que metodologia na sua visão é flexível porque ela tem que ser adaptável às situações específicas de projeto que são muito [inaudivel].

Ela defende o pensamento autônomo que possa gerenciar de forma flexivel porque o egresso muitas vezes entre em uma confecção onde é o único com uma formação e visão mais ampla de projeto. Ele é o único a pensar daquela forma. Ele vai ter que entender onde buscar as variáveis, como gerenciar, como conseguir a contribuição daquelas pessoas que se envolvem no seu desenvolvimento de produto. A forma de fazer isso é ter uma gestão de processo criativo de uma forma flexível e sistêmica.

Estagiários entram em contato com empresas e implementam o fazer projetual dentro de uma empresa e fazem relatórios com resultados e notam que $\mathrm{o}$ aluno tem uma visão mais abrangente. Não vão dar uma mesa para $\circ$ aluno sentar e desenhar. Os alunos têm agora interesse em entender todo 
o processo que acontece dentro da empresa para depois pensar como se desenvolve o produto dentro da empresa.

BINÔMIO MODA X FUNÇÃO

RAFAEL CARDOSO “DESIGN PARA UM MUNDO COMPLEXO” É UM CAPÍTULO.

Não é possível falar isoladamente em forma e função. Existe também uma função estético-simbólica que muitas vezes sobrepõe a função prática.

REFLEXÃO INTELECTUAL SOBRE PROJETO

Falta, tem certeza disso. Nós duas fazemos doutorado sobre projeto em moda.
SALATA, Robinson. Entrevista realizada com

Robinson Salata, em 30 de setembro de 2015,

na cidade de São Paulo, com 1 hora e 6 minutos

de duração.

Desenhista industrial pelo Mackenzie. Design é uma coisa muito nova. Naquele momento era desenho industrial. Começou a fazer o mestrado na Poli em 1980 e em 1982 ele percebeu que estava se distanciando do que acreditava como atividade de projeto. $O$ curso ficou muito "engenherístico" e não era o que ele queria. Entrou na FAU na disciplina da Marlene Picarell como aluno especial e depois fez outra com o Lúcio Grinover. Ele abandona e perde o que fez de créditos na Poli e prestou mestrado na FAU. E enquanto fazia o mestrado foi convidado para dar aula na FAU. Ele entrou como celetista na FAU. O mestrado durava 4 anos nessa época.

Ele leciona bastante disciplinas voltadas à projeto.

Não conhece projeto em moda, não domina a área. Ele nunca deu aula para moda. Ele até já desenvolveu produto de moda, que ele disse que eu chamaria de moda, mas ele chama de produto de tecidos ergonômicos e com propriedades mais adequadas para chefs de cozinha que ficam horas em pé e em ambientes muito quentes. Ele quer desenvolver uma doma que seja vestida com mais facilidade e que ele tenha um dispositivo corporal que mantenha a coluna ereta, mas relaxada ao mesmo tempo. Os chefs tem movimento muito complicados. Ele disse que é um completo ignorante na área de moda.

O contato dele é sempre com a indústria como desenhista industrial ou como projetista. Ele sempre atuou como designer, nunca parou por opção dele. Ele acha que é obrigação como professor estar no mercado para estar atualizado. Ele mantém o contato com a indústria e procura proporcionar o contato dos seus alunos com a indústria. Ele busca sempre levar os alunos para visitar a indústria. Ele fala que isso é importante para a formação do designer.

No mundo da moda ele acha que não pode me ajudar muito, ou quase nada.

No Senac o contato entre o curso do design com moda se dá somente pela troca de professores entre cursos. Não há trabalhos integrados entre os cursos. Entre esses professores estão a Madu, a Cyntia Malaguti e só. Não há professores com formação em moda que atuem no curso de design do Senac

Há grupos consolidados lá. $\mathrm{O}$ do design industrial, design digital e design gráfico e hoje cada um tem seu coordenador, mas o MEC só entende que exista um único Design. E o curso de moda é separado, o curso é chamado de Design de Moda. Embora o MEC preferisse que moda estivesse dentro do Design existem resistências internas. $O$ curso de Design de Moda é design, mas nasce independente.

AUTORES

DESIGN - todos ele conhece evidentemente. Ele afirma que são todos os 
teóricos e os que trabalham com a questão do método.

\section{AUTORES MODA}

Seivewright - não conhece

Renfrew - folhou, mas só viu.

Treptow - não conhece

Jones - também não conhece.

A literatura é recente e essa questão em moda é mundial, não é só aqui no Brasil.

O design no Brasil tem sido avacalhado enquanto descrição e enquanto termo mesmo. Você dá um nome com o design, de forma completamente equivocada, como o design de sobrancelha.

Design no exterior é claríssimo que é projeto.

TERMO ESTILISMO = DESIGNER DE MODA X ESTILISTA

É CLARA A DIFERENÇA PARA ELE? Ele responde que não.

Estilismo aparece como secundário no Senac na percepção dele. Ele fala da divisão entre os cursos de estilismo e moda (na verdade é modelagem). Ele percebe que estilismo está mais ligado à parte técnica. Estilismo trabaIha a parte do projeto e modelagem é a parte mais próxima do tecnólogo porque você vai aprender algumas técnicas de corte, de costura, de montagem. O estilismo é mais importante para embasar que a modelagem. (ELE TROCA AGORA!O + OU - de 14' a 21'

Não sabe dizer se valorizam mais professores de estilismo. No curso de design que ele coordena ele não privilegia os professores de projeto como entes com maior valor. Ele fala que tem muito projeto e disciplinas que dão suporte como materiais, por exemplo.

ESTILISMO PODE SER SINÔNIMO DE PROJETO?

Ele não entende como sinônimo. Projeto no design vem mais não vem da arquitetura. A palavra projeto significa você lançar alguma coisa, alguma ideia para a frente (vem do latim, do grego). Você lançar alguma coisa que não existe lá para frente para que ele se transforme em algo completo, que exista.

Exemplo: a gambiarra é a inexistência do projeto. É uma coisa que você resolve ali com os recursos que você tem, mas você não está projetando. Você não está organizando nenhuma sistematização acerca do que está sendo feito, nem produção industrial. $O$ projeto hoje tem força no design (parece que sim) porque existe uma indústria. A indústria não existiria sem projeto. Se fizer um a um aí é artesanato, não design, não projeto.

Na opinião dele quando se faz a peça única, não se está fazendo, design, não design industrial. Quando você tem uma produção de calças jeans com gente cortando, costurando e gerenciando você não faz sem projeto. Hoje você não faz se (não) for industrial.
Há pessoas que defendem até teses de doutorado sobre a gambiarra, acreditando que ela seja uma manifestação projetual. Para ele a gambiarra é a inexistência de projeto. Até porque se eu tivesse um projeto eu não estaria fazendo daquele jeito, na gambiarra. Isso muitas vezes é pautado na coisa que você não consegue repetir, não tem um processo. Você não consegue atuar, do ponto de vista metodológico, sem seguir nenhum dos processos em nenhum momento do projeto que você já tenha estudado. Os autores que eu citei são autores que estudaram a questão do projeto. Se você observar de perto, todos eles indicam alguma coisa que é necessária quando você vai projetar. Você identifica um problema, começa a fazer uma análise, começa a gerar algum (inaudível) e depois você vai para a produção.

NÃO HÁ A IDEIA DE SOLUÇÃO PARA A MODA

Para ele na moda, enquanto método de projeto, se vai ser desenhada a peça única ele acha que não tem que seguir "nada disso daí" as teorias sobre método de projeto. Na peça única você vai estar trabalhando muito mais próximo da sua experiência, no trato com os materiais, no manuseio, nos processos e é claro que há um repertório acumulado ao longo do tempo de quem faz isso.

Ele assiste a desfiles e reconhece que tem peças únicas fantásticas e que serão pelo menos parcialmente reproduzidas, alguma coisa que será assimilada. No PAP há um olhar um pouco diferente de quem vai vestir a Gisele Bündchen. Acho que ele quis se referir à produção industrial.

Ele é vizinho de um dos donos da Cavalera (não o Turco Loco). Falou o nome da esposa dele, a Estela, mas não lembrou o nome do cara.

Quem trabalha nesse outro mundo (da peça única ou da produção industrial?) tem que conhecer matéria prima, saber aplicar, conhecer processos, conhecer máquinas. O que ele mais se encanta é com as máquinas (bate com a fala da Cibele - que as máquinas para confecção são design industrial, do qual a moda tb depende). O Robinson foi ver máquinas de costura e pegou catálogos, diz que gosta de se informar sobre o que está sendo lançado.

RECONHECIMENTO MAIOR DO ESTILISTA DE MODA OU DO DESIGNER DE MODA?

Ele ainda não parou para perceber, pois não está dentro desse campo. Ele sempre percebeu como muito confusa a separação que é feita no mundo da moda do designer de moda e do estilista. Para ele existe o profissional de moda que poderia ser chamado como designer de moda, mesmo trabaIhando nesse mundo fashion que não é o mundo do design industrial ele acredita que se trata de um designer industrial porque ele está produzindo e desenhando a peça única, mas ela é calcada no pensamento, que se ele não souber como fazer aquilo lá ele não desenha aquilo lá, ele não faz nada. $O$ projeto não é físico.

Existem hoje vários métodos de projeto. Um deles que o Robinson preconiza é antes de desenhar concluir as coisas. Para ele, ele acredita em projeto, segundo sua experiência de viver que o profissional só consegue colocar para fora, 
projetar alguma coisa a partir do momento que introjetou, adquiriu conhecimento, criou repertório, aprendeu um monte de coisas, estudou, "fez o diabo". Se não acontecer isso não tem o que sair da nossa cabeça. E projetar para ele não é sentar numa mesa e desenhar ou sentar na frente do computador, isso não é projeto. Projeto é muito mais do que isso. Projeto é você ter consciência de que aquilo que você está desenhando no computador ou desenhando no papel ou construindo no manequim pode ser feito de verdade.

Como eu trabalho com design de produto. Antes de eu fazer essa garrafinha aí (e aponta para a minha garrafa d'água) que eu vou produzir isso daqui, eu vou fazer isso em papel em cima da minha mesa, até porque na hora em que eu estiver fazendo isso em papel que é uma superfície semelhante a uma folha de alumínio isso em leva a algumas coisas, fazendo a transposição para uma roupa. Se eu pegar um tecido metalizado, mas ainda não tenho certeza se é um plástico ou um tecido metalizado. Eu vou pegar alguma coisa muito próxima seja na textura, no toque, seja no movimento..

Se você quer testar o caimento, alguma dobra esquisita você testa e faz um modelo de estudo. Quando você chegar à roupa pronta, você está produzindo, projetando a gente projeta com estrutura, com a mão, com os olhos, com o corpo inteiro, com todos os sentidos. Então na minha opinião eu chamaria esse profissional de designer de moda.

O designer de moda se separa daquele que é o estilista, o modelista (hum...não sei se comparam com modelista).

\section{MAS EM DESIGN TEM TANTAS DIFERENÇAS DA MODA}

Ele lançaria um curso generalista que depois permitisse às pessoas se especializarem. Porque pois mais que a gente tenha um "titulão", tem o guarda-chuva e vêm os penduricalhos. É o que acontece no mundo inteiro, em todas as escolas.

Ele falou: você foi fazer moda porque prefere moda à gráfico, à industrial. Ele diz que teve uma formação generalista e diz que quando se aprende tudo, não se aprende nada. Ele acha que o curso de design geral com um primeiro no com disciplinas iguais para todas as especializações do design daria mais

VISÕES SOBRE HONESTIDADE NO DESIGN E NA MODA

Design função social, honesto e moda é honesto quem é especializado.

A questão da função social na moda é secundária. Hoje se fala em vestuário/moda para deficientes. Para ele é um purismo bobo e ingênuo de reserv de mercado. E hoje cada vez mais caminhamos para soluções que envolven muitas pessoas. Não existe profissional de design que resolva tudo sozinho (Bourdieu X Christo) e você tem que conhecer todo o conjunto com quem você tem que trabalhar senão você não faz.

Nome comercial mesmo de tecidos não aprendemos na faculdade. A academia especializa e a gente cai nessa coisa, mas na vida real essa segmentação muitas vezes não ocorre, não tem que ocorrer. As pessoas ficam repetindo modelos muitas vezes, sem saber porque está fazendo daquele jeito e quais as consequências disso.

Então essa discussão é longa se design veio da arquitetura, quem veio primeiro, o ovo ou a galinha.

MODA SURGE AUTÔNOMA

Questão a ser checada junto ao MEC essa dos diplomas (FAAP, FMU, SENAC). O MEC passa no Senac no fim de 2015. Issao Minami é avaliador de moda do MEC.

Ele entende moda como design, não como campo autônomo. Ele entende como design desde que as pessoas entendam também que está se falando de projeto, de um curso que vai ensinar a projetar. Que vai apresentar autores de uma maneira mais ampla. (E o pagodinho da FAU comendo no fundo).

\section{Vê o diploma de "Moda" do Thiago e fala: nossa senhora!}

Para ele $\circ$ termo design de moda qualifica mais e sai dessa postura tão elitista. Para ele colocar o design de moda não é reducionista, está ampliando.

FALTA METODOLOGIA DE PROJETO EM BRÁS E BOM RETIRO (Itiro lida e Gui Bonsiepe $=$ PRÁTICA X BACHARELISMO)

No momento em que você colocar o nome design de moda, para ser chamada uma empresa que promove ou que pratica o design de moda ela tem que ter profissionais trabalhando com projeto. Esses caras vão lá e copiam. Isso acontece em pequenas indústrias moveleiras que vai lá e copia tudo, traz da Europa o catálogo e copia.

O que o coreano está fazendo não é design. $O$ que o coreano está fazendo...(interrompi).

\section{FORMA X FUNÇÃO SE DESDOBRAM SOBRE A MODA?}

Corselet, salto alto são produções em série. Para ele na moda, na maioria dos casos, forma e função passa longe. Mas existem já segmentos onde está sendo pensada a forma, a função numa questão de ergonomia, de saúde em roupas, sapatos. Por exemplo sapatos para pessoas que têm diabetes. $\mathrm{Na}$ Alemanha tem projetos de sapatos para que as pessoas não sintam tanta dor na coluna e que corrigem o andar e outras dificuldades.

\section{REFLEXÃO INTELECTUA}

Acredita que o problema não seja de reflexão teórica. Acredita que exisam pessoas pensando, mas existe uma defesa ferrenha para essa separação (interrompi)...entendendo o design disso, design daquilo... e todos eles no fundo se voltam para projeto.

No Senac vão fazer um vestibular só. Ainda são vestibulares separados. Estão fazendo a convergência de disciplinas para uma proposta que o Robinson tem que é fazer um curso generalista e que depois as pessoas vão se especializando. (MEIO PUC). Moda estaria fora disso. Vamos torcer para mais frente a moda também entrar. Entraria design industrial, digital e gráfico. 
MOURA, Mônica. Entrevista realizada com Mônica Moura, em 26 de maio de 2015, na cidade de São Paulo, com 1 hora e 42 minutos de duração.

Ela deu aula no curso de moda da UAM desde 1991. O curso teve alguns nomes: superior em moda, negócios da moda. Deu História da Arte (ela é formada em artes). Na época, profissionalmente, ela atuava com moda infantil, média produção e depois ela montou uma pequena confeç̧ão infantil. Era quase um ateliê com mais uma linha quase comercial, mas com uma produção pequena. Por isso que ela foi contratada para dar aula na Moda na UAM. Ela entrou na UAM pela experiência com moda.

Ela trabalhou na Belinha em São Mateus. Hoje não existe mais. Eram grupos de confecções e foi gerado por uma confecção que começou na déc. De 1970 e que foi fazendo sucesso e que foi criando outras confecções, outras, várias marcas. Era uma espécie e holding hoje. Diversificação do infantil.

Lá dentro ela era uma designer e como tal cuidava do desenvolvimento de coleção, aplicações de bordado, serigrafia, acompanhava esse processo e ía para as oficinas, seleção de tecidos e acompanhava a produção interna. Na época tinha modelista e cortador interno. Era uma confeç̧ão com cerca de 15 funcionários semi-verticalizada e trabalhava com cerca de 100 costureiras internas, mas não era facção. Ela ía muito a essas costureiras. Ela trabalhava com sistema de facção de oficinas de bordado. Ela era uma profissional com nota PJ ou registrada em alguns momentos. Ela era quase uma coordenadora de estilo, ía além de designer.

Em quantas empresas ela trabalhou como designer de moda?

FAACUNESP BAURU Faculdade de Arquitetura, Artes e comunicação da Universidade Estadual Paulista "Júlio de Mesquita Filho"
Trabalhou como designer em 3 empresas. Duas empresas de moda. Era uma marca, a Belinha, que era confecção de média produção de 5000 a 7000 peças mês de atacado. E depois veio a pedacinho do céu que era esse ateliê menor. Já não vendia mais para alto atacado. A pedacinho do céu sai da Belinha. Uma pessoa que sai da Belinha monta com a Mônica Moura a Pedacinho do céu e parece que a Belinha continuou por um tempo.

PLANO COLLOR

Venderam muito bem, tudo o que fizeram, porque fizeram uma linha de fantasias para o carnaval e o confisco foi após o carnaval. Então não tinha mais mercadoria, nem tecido e todos os recursos financeiros que elas depositaram ficou preso no confisco do Collor. Então elas não tiveram como continuar. Elas chegaram a tirar peça da vitrine para vender, pois vendia muito bem. Trabalhou como moda por cerca de 7 a 10 anos.

Antes ela trabalhou com mobiliário. $E$ antes ainda ela fez curso técnico de decoração de interiores (KK Carlos de Campos) e com 16 anos foi estagiar numa loja de decoração da Rua Augusta. A loja entra em reforma e ela vai para a fábrica o que propiciou contato com tapeceiros, ela desenhava mobiliário, acompanhava produção dos modelos já existentes, falava com 
marceneiro, serralheiro. E aí a fábrica ía mudar de local e era impossível de ela continuar.

Daí ela foi trabalhar numa loja de móveis para refeitórios e restaurantes. $\mathrm{E}$ foi muito bacana e em todas essas empresas ela trabalhou como designer e milita: moda é design, só quem esteve na indústria sabe disso.

AUTORES

Seivewright não conhece, não se lembra. Renfrew sim, acho que sim e Sue Jenkin Jones e Treptow conhece.

\section{PERCEPÇÃO SOBRE PROJETO EM MODA}

Minha percepção vem do design, até porque na época em que eu me formei era raro ter contato com esse tipo de bibliografia, até porque nem existia.

\section{AUTORES DESIGN}

Munari, Löbach, Bomfim ok, conhece e Burdek, Ana Maria de Morais, Itiro lida foram base para ela também.

A formação dela vem do design de interiores e depois ela fez faculdade de artes na Belas Artes. E sem dúvida essa junção foi bem feita para ela. Para ela essas duas áreas dialogam tremendamente.

Em artes você também tem projeto, você também tem desenvolvimento projetual. Ela também usou muito a noção de projeto quando trabalhou com gráfico.

E em confeç̧ão ela usava todo esse processo projetual que ela já tinha aprendido. A fase de levantamento de informações, seleção dessas informações que vão gerar aí o produto, todo o trabalho com tecnologia, ou seja, 0 que que você vai aplicar, de que maneira, quais são os processos técnicos tecnológicos disponíveis. Ela também acompanhava a compra do material. Acompanhava a compra dos tecidos, indo inclusive diretamente na fábrica desenvolvia tecidos, mas recebia esses vendedores (fornecedores) também e ía direto para a 25 de março para ver aviamentos, tipos de linha e, segundo ela, tudo isso dentro do processo projetual. Além de desenvolver mesmo o que seria a peça, a peça piloto, acompanhar, ver quais eram os problemas (AGORA SIM, FAZ TODO SENTIDO SOLUÇÃO DE PROBLEMAS NA ETAPA DO FITTING) e aí ela está fazendo uma ponte com a bibliografia de projeto em design.

Quando tinha que aplicar uma imagem em uma peça. Infantil é um desafio porque a área e pequena. Questão de conforto, áreas pequenas para trabalhar, limitação de aviamentos, e os elementos (uma golinha pequenininha torta aparece muito mais que uma gola de adulto). Então, ela reforça, que aplicava mesmo todas essas fases do processo projetual. E lidar com modelista requer conhecer o próprio segmento, a estrutura de uma roupa, conhecer a base de uma modelagem, saber discutir com esse modelista, acertava a modelagem. Então o processo todo de projeto eu aplicava como...se er mobiliário. Só que você trabalha (em confecção) com outra dimensão, outro público, escala...é outra relação, mas sem dúvida o processo projetual era acompanhado.

CONHECE O TERMO ESTILISMO? PODE SER SINÔNIMO DE PROJETO?

Isso é uma complicação que ficou muito arraigada aqui no Brasil. Por um lado estilismo traz uma visão muito ruim porque aí você remete ao fato do Estilo que sobrepõe a questão projetual porque você entra em questões que são puramente questão visual e necessariamente não tem relação com a função e acho que isso vem muito da questão do Loewy, projetando aquela coisa streamlining e essa coisa ficou muito arraigada.

Para que aquele tamanho de carro? Era só uma questão estética.

Por outro lado, aqui no Brasil a gente tem um peso da questão funcionalista. Porque o design começa a ganhar corpo e se estruturar aqui no pais justamente no governo JK com plano de metas de 1955 e existia ali uma promessa de o país teria uma questão industrial fortíssima. Que não ocorreu. Mas acho que essa ideia ficou muito arraigada no design. Por isso no Brasil design se separa da arte e do artesanato para se colocar como uma área industrial e que na verdade todas as questões políticas, econômicas e tal não deram conta dessa demanda. Então ficou um preconceito muito grande (do que como que?).

Bonsiepe e outros autores que ainda distancia artesanato, a moda, a joaTheria como se não fosse design. E na verdade é uma visão equivocada. Olha que doido a gente teve que ter estrangeiros no país como a Lina Bo Bardi para ir lá e falar que o artesanato era uma coisa importante. $O$ Bonsiepe isola moda do design a tratando como algo somente efêmero. E separa todas essas coisas e para a Mônica essas coisas todas se dinamizam. Por exemplo a Europa não faz essa divisão, os holandeses jamais, trabalham arte, artesanato e design de forma muito relacionada.

\section{Agora tem o "industrianato" = indústria + artesanato.}

Tem que lembrar que o projeto e metodologia projetual não é única. Se pegou isso como se fosse uma receita. E há várias metodologias contemporâneas, como as circulares, a não intencional, metodologias que pensam projeto de maneira mais aberta. Há várias formas de se produzir um produto seja que segmento for esse produto. As vezes falta essa flexibilidade.

MID = design não intencional. A criação de cenários e você já tem metodologias mais flexíveis mesmo para acompanhar a contemporaneidade, não tem jeito.

\section{PROJETO ESTARIA ACIMA}

A palavra estilismo/estilista foi muito denegrida, então cabe mais falar designer do que estilista. Mesmo quando se fala em moda. Em moda pego muito estilismo por conta da origem da moda exclusiva, peça única, da criação que vem, ateliês. Isso acabou ficando muito ligado à ideia de estilismo. E na verdade mesmo quando a peça for única a gente sabe que está envolvida uma questão projetual naquela peça. 
E ela acha que o design contemporâneo também desbanca isso quando também produz peça única.

EM 1988

$\mathrm{Na}$ época em que os cursos foram criados era uma nomenclatura vigente no mercado a palavra estilismo. Na UAM o que existia era Coordenação de Moda, Estilismo e Gerente de Produto. Pensando que o gerente iria cuidar mais da gestão, o estilista mais da criação e o coordenador de moda ía cuidar da comunicação (VM e Mídias = isso é importante esclarecer).

Aquele era o momento do mercado e ele reproduzia essa primeira noção. Então como se chamou o criador de moda que não era, que tinha que se desligar do costureiro?

Por um lado ela reconhece que o isolamento em estilismo é a afirmação do campo, por outro como não existia diálogo com outra área não se falava em design. Ou era porque não havia diálogo com o design? $O$ design não era aberto para isso e, portanto se não era aberto, não tinha diálogo estabelecido. $E$ aí começou a se ver a moda como um campo independente, como a indústria automobilística. Ela compara a moda com a indústria automobilística que apesar de dialogar com inúmeras áreas se mostrou como uma indústria "super estabelecida". Então nesse primeiro momento as primeiras faculdades acompanhavam muito a questão de mercado. A UAM acompanha muito a questão de mercado. De fazer reuniões, conselhos com pessoas de mercado.

\section{UAM - Daqui para baixo é tudo UAM}

Essa situação ficou, tanto é que na UAM moda demorou a virar DESIGN DE MODA como um curso mesmo. Demorou muito para se estabelecer porque o design era entendido dentro da moda como um pedaço da moda (e para a moda não é isso?) e também tinha uma resistência de vários profissionais em relação a isso.

EU PERGUNTO: DA MODA OU DO DESIGN? RS

Da moda mesmo, do corpo de moda (tom de mágoa). Esse grupo da moda estava entendendo como uma separação do curso de moda. As pessoas não entendiam como soma, mas entendiam como subtração. Como se tirasse da moda o design, o estilismo e o design (36’55") e portanto ía acabar e ía morrer moda.

E a Mônica Moura na época dizia: não vai morrer porque a gente está trabalhando de uma forma incorreta. A gente está dando um pedacinho de criação para um profissional que vai trabalhar muito com criação, com projeto e a gente só está dando um pedacinho para ele.

\section{JAM}

E ela achava que como a UAM nunca teve um grande criador entre os seus alunos diferentemente da FASM por exemplo que teve sempre nomes que despontaram. Mas porque eu acho que a UAM não tinha um grande criador? Porque pouco se trabalhava o processo de design e criação do curso. (E A FASM TRABALHA PROJETO? Não eles até hoje defendem a ideia de estilismo nas disciplinas chamadas estilo). Um curso que é estruturado para você tanto formar um coordenador, um gerente ou um estilista não é possível dar condições para esse estilista ou designer de ter tudo o que ele precisa ter para a criação. Porque consequentemente gestão e coordenação são próximos. Agora como você vai ter um profissional que entenda tudo e saiba de tudo? Então se estudava pouco criação, pouco projeto!

E DEPOIS QUE O CURSO SE TORNOU DESIGN/PROJETO? PQ NÃO DESPONTOU NENHUM GRANDE NOME LÁ? ALÉM DO CIRNANSKI QUE LARGOU O CURSO NO MEIO.

Por isso muitos professores do corpo docente não tinham repertório de design.

Em 2003 quando eu entrei eram 2 graduações: DESIGN DE MODA E NEGÓCIOS DA MODA.

A menina dos olhos na época era o curso de criação. Não vejo desnível com a FASM nessa época.

A FASM vem de uma tradição de um curso de Artes. São histórias diferentes. A FASM vem de um curso de Artes, vamos chamar assim de uma criação mais pura, mais conceitual, vamos chamar assim, que sem dúvida, isso ajudou muito a FASM.

Porque que a FASM formou criadores que despontaram no país?

Eu tenho quase certeza absoluta (hahaha) que é por essa junção com artes que eles foram extremamente perspicazes nisso. Eles não saíram da arte para criar um curso de moda (?) e daí eles deram uma super estrutura para formar criadores.

$\mathrm{Na}$ UAM o curso veio de negócios. Praticamente a grande visão é mercado e negócios. Que era o foco da UAM mesmo, atender a novos nichos de mercado. Quando o design começa a despontar e com a implementação lá da área de design aí é justamente que trava. Ou a gente vai nessa coisa ou vai ficar para trás, né! Ela diz.

Aí também a necessidade de desvincular o design, criar, deixar o design de moda como uma coisa mais eficiente. E daí o que aconteceu? Claro que as pessoas que foram trabalhar no design de moda já tinham uma visão mais voltada à projeto. Mesmo que não usasse determinados autores do que exatamente quando se trabalhava com a questão do estilismo. Então acho que nesse sentido foi um ganho para a UAM, ter a área de design de moda e não abandonar o "negócios da moda". Porque a linha de pensamento se manteve. Quem vai trabalhar com negócios tem um outro perfil do que quem vai trabalhar com criação.

O curso de design de moda da UAM perde em termos de criação para um curso como o da FASM?

Não. Hoje acho que não mais. Porque aí trabalha mesmo esse profissio- 
nal de criação. Tem que dar uma base conceitual de criação muito ampla para a pessoa ter condições de atuar em qualquer indústria super sistemática. Você desenvolve na pessoa a capacidade de criação no sentido mais amplo. E as pessoas conceituais são essenciais. Vai explorar as referências, a pesquisa, o desenvolvimento projetual.

Ela acha que não forma um profissional para um determinado nicho. Você forma para atuação. Essa pessoa vai atuar numa indústria, alta produção, hiper sistemática como também ela pode atuar como um grande criador. Você abre o leque na verdade.

Quando vai para a área de design e separa já é um outro momento. Antes disso é que estava misturado e não se dava tanta importância para a criação porque tinha muitas coisas. $O$ curso da UAM era integral quando começou. $\mathrm{Na}$ primeira mudança ele se tornou matutino e vespertino. Era um curso de 6 horas/dia (o meu curso).

Parece que quando o curso começou eram coisa de 6000 horas. Era uma coisa de louco. Depois diminuiu até para que os alunos pudessem ir para o mercado.

\section{AQUI PÁRAUAM!}

\section{DESIGN DE MODA = FORMA DE PODER?}

Não acha que seja uma imposição do campo do design sobre a moda. E volta a origem dela, trabalhando em uma confeç̧ão na periferia ela viu e viveu o quanto de design tem uma confeç̧ão, de uma indústria de moda. Isso sempre existiu, só não era assumido. E se falava da importância da criação em moda, mas não se assumia que havia um papel de um designer atuando.

Eu não acho que é uma imposição do campo. Não é uma imposição no Brasil. Na Europa ninguém está preocupado em discutir se design é ou não moda. Já é, isso é claro.

Pelo contrário, aquelas pessoas que estavam sendo chamadas de estilistas hoje não querem mais ser chamadas de estilistas. Querem ser chamados de designers. É um cenário europeu que também está dizendo coisas.

Mas ela entende que a moda tal qual o design é um campo sim. A moda tem vários segmentos dentro dela, como o design tem. Gestáo, produto, superfície etc. tem vários caminhos. NÃO É TODA MODA QUE É DESIGN E NEM TODO DESIGN QUE É MODA. MAS VOCÊ TEM UM GRANDE SEGMENTO QUE É O DESIGN DE MODA. Como tem o mkt de moda.

A intenção não é fechar, muito pelo contrário. Ela acha uma loucura essa discussão e essa tentativa de separação de áreas porque vai contra o momento que nós vivemos. Quando você pensa que a questão do diálogo e do interdisciplinar é tão mais forte e as pessoas estão querendo separar coisas.

ESSE MOVIMENTO NÃO É NATURAL PARA A MODA NA BUSCA DE RECONHECIMENTO, COMO CAMPO SOCIOLÓGICO MESMO?
É...eu acho que na verdade é uma visão equivocada de muitas pessoas, uma visão de ignorância no sentido de não conhecer. $O$ desconhecimento a respeito de algumas coisas leva a essa visão separatista. Na verdade é uma perda de tempo ficar se discutindo isso.

É vantagem para o design haver design de moda (eu falo isso).

Na verdade se for pensar, moda já está constituída como campo. Independente se está no $\mathrm{CNPq}$, no $\mathrm{MEC}$, são reguladores. Em termos de mercado já está constituída. É a segunda maior indústria do mercado.

Ela percebe um movimento muito mais da academia do que na realidade de mercado. Aconteceu que a moda não se constituiu como área de conhecimento acadêmico, ou seja, e nesse sentido o design fez um caminho.

Historicamente no design houve um movimento em prol da pesquisa. Coisa que a gente não viu na moda. Mestrado em 1994, P\&D também é em 1994 que se estabelece. Foi feito um caminho que foi feito via conversa com esses órgãos reguladores (CAPES, CNPq, MEC etc) para essa área ser constituída. Se a gente pensar o design ainda não é independente.

Pq na CAPES o design está junto com a arquitetura. $O$ grande grupo CIÊNCIAS SOCIAIS APLICADAS e dentro dele tem arquitetura. Abraça uma coisa muito grande e dentro da área específica é arquitetura e design. Para o CNPq o design está junto com as engenharias. Então não é uma área completamente autonoma ainda e talvez, nem seja o caso de ser.

Se é interdisciplinar porque separar o design de arquitetura? Tem 17 programas de pós graduação em design. Isso é muito pouco ainda para separar. Parece que arquitetura são 35 . Precisa separar mesmo. As trocas não fortalecem as áreas?

Ela diz: eu acho que tem um ciúme aí da moda nesse caminho, mas por outro lado, muito já se fez pela moda. Eu acho que a moda no Brasil sai de um universo fútil e se constitui, tem um congresso enorme que mobiliza 1000 pessoas por ano, o CIMODE. Tudo isso só vem a colaborar com a área, as associações (ABEPEM) e começa a se estabelecer dessa maneira. Por isso eu acho que a gente fica numa discussão retrógrada com essa separação.

MODA RECONHECE O DESIGN E VICE E VERSA. É contra moda ser reconhecida como campo autônomo?

Não esquecer o diálogo da moda com o design. A indústria italiana percebe que para o design aparecer mais (em termos de mkt mesmo) ele optou por se associar à moda. Então começaram a aparecer os criadores de moda associados aos criadores em design, principalmente na indústria do mobiliário. Teve na Itália uma estratégia de mercado que aproximou essas áreas. Até hoje tem isso. As melissas, o Lino Villaventura desenvolveu uma coleção de mobiliário junto com o Sérgio e Jack Fahrer (irmãos Fahrer). E antes,Willys de Castro etc e aí a gente vê que arte, design e moda são super próximos.

DESIGNER AUTOR (ETHEL LEON) = ESTILISTA? 
Hoje é tudo hiper misturado. Todo o designer ou estilista seria um autor porque basicamente ele está trabalhando a questão da criação. Se o designer tinha uma vocação mais funcionalista, por sua vez o estilista tinha uma liberdade maior. Ambos trabalhavam uma questão de autoria.

Designer autor viria muito do designer dar conta do projeto todo. Ele atua na criação e vem muito da área de design gráfico...o texto e arte era dele

Certo desprezo por quem cria como se criar fosse pecar na lógica do design funcionalista (EU).

O designer não podia ser muito autor porque ele estava limitado pelas questões funcionais. $O$ que ocorreu foi uma dinâmica da sociedade e do próprio mercado que desmontou isso. Citou o Philip Stark.

Ela questiona: e no sistema de prototipagem 3D quem é o autor?

$O$ trabalho é coletivo no design, pensar nas pessoas envolvidas na confecção.

Mas projeto é uma disciplina só no design. Na moda há projeto/estilismo, pesquisa e criação; desenvolvimento de produto. Ela acha que leva um tempo para as pessoas assimilarem.

Eu discordei dizendo que a FAAP já deixava a disciplina Estilo de lado para dar lugar à Projeto e ainda assim havia a mesma divisão supracitada.

Ela acha que a própria dinâmica de mercado vai alterando essas coisas. Só que não alterou nada até agora. $O$ designer autor é valorizado hoje também e ela acha isso legal. Mas não é tosco ser estilista???? Privilegiar a função simbólica? Não é por esse viés que o design/projeto critica a noção de estilismo?

NÃO HÁ INOVAÇÃO NA MODA (TEXTO DELA) E OBSOLESCÊNCIA PERCEPTIVA.

Ela afirma que tanto no design quanto na moda, nem sempre vai ocorre inovação. A inovação está também em graus, em niveis, às vezes é pouquinho, é difícil algo que mude a forma de fazer algo como sentar. A poltrona "Cadê" da Ovo é uma que muda o paradigma, a forma de sentar. Demanda afastamento, você tem que investigar aquele objeto e tomar segurança que não vai cair para aí sentar. '1'9"

Inovação é uma palavra desgastada como interação, interdisciplinaridade. Nem sempre a inovação vai estar presente, mas são terminologias extremamente usadas e solicitadas tanto pelo design quanto pela moda. Mas na moda parece que ela chama mais atenção. A moda tem um reconhecimento mais rápido que o design.

Hoje a mudança não é tão real. Há muita reciclagem de coisas que já foram. Elas são retomadas. Até que ponto essa inovação está presente. Então porque se fala tanto em inovação? Porque é muito difícil de se conseguir inovação no mundo que a gente vive hoje.

CÓPIA EM PEQUENAS E MÉDIAS CONFECÇÕES
Ela acha isso um problema, são empresas de produção não de criação. Mas é uma realidade ainda e existem empresas de mobiliário pequenas que também fazem isso. E dentre as 400 empresas de Brás e Bom Retiro poucas realmente fazem projeto. E o sistema econômico impõe isso de maneira cada vez mais agressiva.

É o retrô que foi ontem, não sei quando vamos superar isso.

FORMA E FUNÇÃO

Cabe à moda também. Tirando a produção mais conceitual de moda, há uma relação de função e forma muito bem estabelecida em muitos produtos de moda.

Discutimos a linha red da levi's.

O usamos cotidianamente tem muito próxima essa relação de forma e função. Ela falou de Bauru como prestou atenção na roupa, tecidos, us mais vestido, rasteira (que não passe a temperatura do chão para o pé).

\section{NOMES COMERCIAIS DE TECIDOS}

Falta mais conhecimento técnico de materiais mesmo. $E$ a questão de ergonomia no Brasil que é difícil de ser trabalhada pela questão de biótipo muito variados. O Senai Cetiqt está fazendo no RJ um bom levantamento. E nem sempre o mundo acadêmico acompanha as inovações. Ela acha inclusive que muitas aulas nem deveriam mais ser na faculdade, mas sim nas fábricas.

O Senai Cetiqt está se dedicando a entender quais são todos os biótipos do brasileiro.

O corpo também vai mudando. Que corpo é esse corpo contemporâneo? E um outro corpo que vai se constituir. Hoje uma mulher de 50, 60 anos não é a mulher de 50, 60 anos de décadas atrás. Então você tem outras relações com esses corpos que são constituídas. E acho que isso é negligenciado de certa forma, que não é muito estudado, aprofundado.

Que corpo é esse? Como esses corpos querem ser vistos? E tem também questão dos gêneros que estão caindo por terra. Que história é essa de transgênero e que relação de flexibilidade é essa que os jovens têm em relação ao gênero. Hoje eu posso ser homem, amanhã posso ser mulher. Maior liberdade na produção de subjetividade que deve ser muito bom para quem é adolescente agora, por outro lado pode ser um complicador. É o reflexo dos tempos também. Se o corpo é meu eu posso fazer dele o que eu quiser e independe de que arrea eu fico. se momento faz sentido por essa questão ampla, líquida (Bauman).

PÁGINA 71 DO ARTIGO DA MÔNICA - IGNORAR AS ESPECIFICIDADES DO DESIGN

Ela ainda acha que são 2 campos (arte e moda?0) e entre eles há o design de moda que é a intersecção entre essas duas áreas.

Ela fala que os textos também são escritos muito no calor da hora. 


\section{ESTILISTA OU DESIGNER DE MODA - O QUE AGREGA MAIS VALOR?}

Depende do que e depende de momento. Ela acredita que há alguns anos atrás, assinar como estilista tinha mais valor, hoje não mais. Os estilistas e 0 mercado ignoraram a nomenclatura design de moda. E soa estranho que sou designer de moda, mas sempre tenha sido registrada e chamada de estilista.

Eu acho que assinar como designer de um tempo para cá pode ter mais valor. Houve também uma proliferação da nomenclatura design até de forma equivocada.

Para ela o design agrega mais. Varia também conforme o valor que a sociedade passa a dar a determinada nomenclatura.

Falei da reclamação da moda ser autônoma. Ela acha que teve um movimento de ambas as partes de reconhecimento (e de fato houve). As pessoas levam muito em conta essa sobreposição pelo que aconteceu em relação à nomenclatura dos cursos. Parece que vem de cima para baixo (e faz cara de que não).

\section{NAS AGÊNCIAS DE FOMENTO!}

$\mathrm{Na}$ época ela conta que a Doroteia Baduy estava lá e ela conta que na ocasião todas as pessoas receberam questionários de consulta. Pois é, as pessoas foram consultadas e as consultas vem, vão muitas vezes não responde e depois reclamam que não participaram do processo, que não sabiam do processo.

Acho muito ruim quando diminui a carga horária dos cursos, porque esses cursos viram tecnólogos e acho que se perde muito aí.

ENADE TECNOLÓGICO

Os alunos foram bem no exame tecnológico e aí vai ser tudo curso tecnológico? E bombam no exame de design.

Os cursos têm de ser repensados. O perfil do egresso e como esses cursos são estruturados. A academia não segue rapidamente o que está sendo pensado no mercado. É muito difícil se aplicar uma visão interdisciplinar Estamos aquém do movimento do mercado e da sociedade. Porque você acha que crescem tantos cursos livres atualmente? Porque tem aí uma defasagem. Não é que a universidade tenha que dar conta de tudo mas...

FUNCIONALIDADE NA PÚBLICAS X MENOS AULAS NAS PARTICULARES

É mais difícil você contemplar mais conteúdos quando a carga horária dos cursos está sendo reduzida. E nas públicas isso não acontece.

FIES = será que devia? Uma vez que as particulares lucram? E as particulares só vingaram por uma deficiência do governo que não disponibiliza vaga para todo mundo.

REFLEXÃO INTELECTUAL SOBRE PROJETO EM MODA?

Sim, falta. Não só em relação ao projeto. Falta base teórica, conceitual em geral. É um choque para os alunos que não estão acostumados, mas pode ser despertado no estudante esse interesse. Via prática você pode chegar à teoria. (Isso é muito Itiro lida).

A faculdade precisa fornecer uma formação mais consistente para as pessoas poderem lidar com as mudanças que vêm porque vêm outras por aí. Porque para que mercado você forma? Não é para o mercado de hoje. Porque quando ao aluno entra na faculdade, durante os 4 anos que $o$ aluno esta na faculdade o mercado já mudou. Então como eu tenho que formar essa pessoa? E aí a base teórica é super importante. Saber selecionar, senão vai virar um monte de gente que vai copiar um monte de coisa sempre. 
SOUZA, Patrícia de Mello. Entrevista realizada com

Patrícia de Mello Souza, em 8 de setembro de 2015,

na cidade de Londrina, com 29 minutos de duração.

AUTORES MODA

SIMON SEIVEWRIGHT - conhece de nome, mas nunca abriu

RENFREW - já ouviu falar

TREPTOW - conhece

SUE JENKIN JONES - não pergunte

AUTORES PRODUTO

LÖBACH - SIM

GUSTAVO AMARANTE BOMFIM - SIM

BURDEK - SIM

AUTOR CV

BRUNO MUNARI - SIM

O Bruno Munari ela diz que já entrou numa parte, mas os outros ela conhece, já trabalhou com eles, mas não são leituras que ela faça o tempo todo para coisas que ela precisa para o trabalho dela. Mas reconhece o papel de cada um deles.

\section{ESTILISTA OU DESIGNER DE MODA?}

Estilista ela diz que já não cabe mais hoje porque ela está atrelada ao MEC desde 2006 e acredita que isso a tenha influenciado uma vez que o MEC não aceita mais o termo estilista. Em 2006 o MEC decidiu que nenhum curso de moda pode ser mais autorizado se a moda não estiver dentro do design. A moda não é vista pelo MEC separada do design, então quando você pensa em moda, ela pensa sempre que é design de moda porque o estilista é autoral, tem um compromisso com ele mesmo, usa a inspiração, coisa que a gente (designer) não usa, a gente usa mais a referência. $O$ estilista faz um produto inspirado em algo e no que ele pensa daquilo, ele não pensa no consumidor, não pensa no público. Ele não tem compromisso com moda.

Nos bacharelados ser Design seria cobrado como lei, segundo a Patrícia. 2006 foi em relação aos tecnólogos.

CURSOS SUPERIORES TECNOLÓGICOS

A Patrícia participou da avaliação de cursos superiores TECNOLÓGICOS e encontrou de 120 a 130 denominações para o curso superior TECNOLÓGI$\mathrm{CO}$, como "Estilismo, criação e produto", um absurdo segundo ela. Tecnólogo em "Produção em..."

Catálogo nacional dos cursos superiores de tecnologia no site do MEC é onde encontro todas a denominações segundo ela. Tem competências, perfil profissional etc. De 120 viraram 10 ou 12 parece na área de vestuário. Para isso foi envolvido um grupo grande de 2000 a 2006 e entre eles se envolveram tb os sindicatos.

ESTILISMO

Estilista para ela está relacionado a algo autoral e que não tem muito compromisso com o consumidor. E o designer independente de se ele vai projetar mesa, cadeira, moda ou vestuário...Para ela moda é produto então não tem jeito de pensar em moda sem ser design.

Moda é PP e CV para ela. Moda para ela se trata de um produto do vestuário que tem que ser vendido depois; essa comunicação (visual) vai entrar no projeto.

MODA COMO CAMPO AUTÔNOMO? DESIGN NÃO É REDUCIONISTA EM RELAÇÃO ÀS ESPECIFICIDADES DA MODA?

O campo...segundo a Doroteia, não sei de onde veio essa informação, mas eu sei porque ela me deu uns dados que eu precisei uma vez. Em 1998 a Comunidade do Design acatou a moda, aceitou a moda. Para a moda, a moda foi cooptada pelo Design. Visões divergentes.

Sou designer e estilista? Ela diz: não, não..você é designer! Isso tem a ver com a formatação do curso e um momento de transição. Formatação do curso é a coisa mais séria para ela.

Moda é design? Ela falou que até sai quando rolam essas discussões hoje. Para ela é tão óbvio que moda é design porque é produto. $O$ produto de vestuário, de moda, vamos falar assim né?! Tem várias especificidades, mas é um produto como qualquer outro produto. Ela não consegue ver diferente. (PRECISO VER OS HISTÓRICOS E A TRICOTOMIA DAS DISCIPLINAS DE PROJETO, PESQUISA E DES. PRODUTO).

Ela era avaliadora só dos tecnológicos, não de bacharelado, mas não sabe onde viu, mas não vai existir mais nada de "Design de...", os bacharelados são só Design, ponto. Acabou habilitação. Ela falou em ênfase, mas hoje fala-se até que não tem mais ênfase. Mas ela parou de acompanhar a questão por causa do pós doc. Mas ela insistiu que ouviu falar que pode ênfase, mas não sabe como opera, se vai ou não no diploma, mas faz tempo que já não acompanha e até pensaram como é que vamos fazer isso na UEL?

Teria um núcleo. Um ou 2 anos de disciplina básica de design. Mas a conversa na UEL parou por falta de tempo. E na UEL ainda são Design de Moda, não são Design. Mas para ser só Design o curso precisava organizar isso $e$ oferecer um vestibular dizendo que a ênfase seria essa. No diploma ela não sabe como seria, porque pararam de discutir.

Em um curso de 4 anos como o da UEL para ela caberia ter 2 anos de disciplinas que fossem basicas para todos como metodologia de projeto porque

Mas ela diz que não sabe dizer como seriam os outros 2 anos se aí entraria 
só em moda, se for gráfico, só gráfico.

PEQUENAS E MÉDIAS EMPRESAS E A AUSÊNCIA DE PROJETO

Consultorias dela foram só na modelagem e faz bastante tempo e antes ela tinha a própria empresa.

FALTA REFLEXÃO INTELECTUAL SOBRE PROJETO?

Veja só, eu venho da arquitetura então projeto permeia a minha vida. Eu queria fazer moda e não havia curso de moda no Brasil então eu fui consciente. Eu vou aprender moda. Fiz o vestibular em 1979 e eu não tinha entendimento do que era desenho industrial. Pensava pelo projeto, se eu vou projetar um edifício, eu vou projetar uma roupa. E ela diz que resolveu assim também porque tinha mais próxima a ela pessoas formadas em arquitetura.

Ela ainda hoje escreve muito sobre arquitetura e moda, sobre construção de produto. Para ela só muda o tamanho, só muda a dimensão. As coisas são complexas da mesma forma, são importantes da mesma forma.

O diálogo com a arquitetura é difícil, mas com a moda é bom porque há uma visão pejorativa de moda dentro da arquitetura (João Bezerra).

Para ela a coisa é questão de estrutura, só muda o material da arquitetura para a moda. E não que a moda se inspire (rs) na arquitetura.

FORMA E FUNÇÃO NA MODA

Vê sem dúvida. Falou da sua disciplina, Laboratório da Forma. Para ela você tem um desenho e vai interpretar e vai fazer. Para ela a modelagem tridimensional é uma forma de intepretação.

DISCIPLINA DE CRIAÇÃO SEPARADA DE DESENVOLVIMENTO DE COLEÇÃO

Para ela não existe separado. Não tem como pensar uma criação sem pensar em modelagem.

$\mathrm{L}=\mathrm{E}$ como é na sua disciplina? Vem um desenho pronto?

$P=$ Não. Muitas vezes ela propõe uma coisa.

A aula dela é uma forma de expressar. Modelagem é uma forma de expressão.

Ela escreve sobre a dicotomia criação $X$ modelagem. Apesar de haver a diferenciação ela fala que não tem nada a ver.

\section{Escolas do Rio de Janeiro}


CIPINIUK, Alberto. Entrevista realizada com

Alberto Cipiniuk, em 19 de outubro de 2015, na cidade do Rio de Janeiro, com 1 hora e 43 minutos

\section{de duração.}

Noção de campo do Bordieu é empregada aqui. O problema maior no campo do design, assim como no campo da arte é a mediocridade. As pessoas são muito pouco qualificadas para ter os "palcos" que têm. Falam sem fundamentação teórica. E esse problema é grave não pelas origens históricas da mediocridade do campo do design, mas hoje os agentes de legitimação não estão preocupados em pensar a questão criticamente. Na pós-graduação os profissionais reproduzem o que há de pior.

Arte e design são áreas irmãs e por isso não se define com clareza os limites entre uma e outra. O departamento na PUC RJ é de Artes e Design e lá nem tem artes há mais de 20 anos, mas ficar em uma posição ambígua é de interesse político entre os pares integrantes desse departamento especifico.

Diferença entre carismáticos e funcionalistas para discutir/mostrar qual é essa fronteira? (seria um metáfora que serviria para estilistas e designers?)

"Abordagens sem pé nem cabeça..." p. 13

\section{EM OFF}

Até recentemente os colegas do Cipiniuk tentaram demití-lo da PUC RJ. Houve um movimento organizado dentro da PUC RJ que decidiu pela demissão do Cipiniuk. Não conseguiram porque ele está lá há 30 anos e fundou a pós-graduação.

Segundo ele, os "pretendentes" chegaram a "dominantes" e instituíram uma normativa que estabeleceu uma mediocridade geral e há alguns anos, segundo ele, ele vem sendo marginalizado, censurada dentro da PUC RJ (a coisa do complexo de Abrãao).

Olha, toma cuidado

Mesmo assim ele se sente gratificado por pensar na frente crítica, em direção ao esclarecimento. Prêmio MCB ele reclama que não foi nem mencionado com seu livro, "Design: o livro dos porquês" (2014). Critica que o Prêmio MCB virou um prêmio para legitimar só a patota, a igrejinha. $O$ grupo institucionalizado de lá não vai "largar a rapadura".

E os grupos críticos vão ficar à margem mesmo, ele fala que essa postura da "patota" é o passado.

Você é chato, é cricri, está metendo o dedo na ferida quando toca em assuntos de disputa que passam por uma análise lúcida como a do campo social do trabalho de Bordieu.

Sobre discutir os 4 livros sobre o projeto nas reuniões da FAAP, os professores não tinham competência.
Conta que começou orientar moda por uma necessidade de seus alunos de mestrado que ingressaram como professores no curso do Senai Cetiqt e aí começaram a desenvolver teses em moda. Mas o Cipiniuk nunca trabaIhou diretamente com a questão moda, nem nunca se preocupou propriamente com isso.

Quando eu oriento moda eu trabalho com projeto, é o design geral, é o processo de racionalização, planejamento industrial. $\mathrm{E}$ a forma de trabaIho como o designer trabalho. Essa é a preocupação dele, mas não particularmente no campo da moda.

A fronteira entre o trabalho entre o designer de moda e o estilista não se define "que diabo é isto". É o trabalho da Déborah Christo.

Os nomes dos autores dos livros de projeto em moda lhe são familiares, mas não é uma leitura sistemática, segundo o próprio Cipiniuk.

Ele queria criar uma linha de pesquisa em Moda dentro da Pós de Design da PUC RJ. Ele enviou uma ementa onde citava a "mais valia" porque ele é marxista e foi negada a abertura da linha de pesquisa porque a questão da "mais valia" travou o projeto.

É importante usar autores para esclarecer coisas, mesmo que não estejam alinhados ideologicamente à nós (Bourdieu X Marx). A questão da economia e industrial é completamente apartada do campo do design de moda.

Quem é o trabalhador desse métier? No RJ é na favela. Ele falou das costureiras de Rio das Pedras. Chega até elas um "croquizinho", mas quem faz o produto é a costureira a partir daquele desenho que "não tem nada a ver", porque o cara que desenhou não sabe modelagem. Acha que a partir de um desenho vai sair o produto? Ele critica a precária formação técnica no campo da moda, no nível de graduação, falta estudo segundo ele.

O design de moda, de maneira geral, é alguma coisa aplicada à indústria. À formação de quadros profissionais para trabalhar na indústria. Se é isso, vamos dar uma formação técnica. Mas aí, os designers aqui (PUC RJ), sequer sabem desenhar legal.

Os conjuntos se interseccionam em interesses e, em muitos casos, nem leram uma bibliografia.

"Tem uma parte que é meio mágica na criação..." Cipiniuk criticando os medíocres.

Apesar de serem chamados pejorativamente de "manuais" por alguns, os livros de projeto em moda significam além do seu próprio material; são uma contribuição ao campo da moda. Esses manuais não são críticos e eu (Leilane) nem acredito que há uma fórmula para projeto, mas contribuem em um momento onde a bibliografia em projeto em moda ainda é incipiente em termos de reflexão crítica. Falta crítica sim neles, mas é alguma coisa.

É um processo de depuração esse período onde não há muita definição.

Ele abriu uma revista com ISSN 2359-3261 e tudo e chama-se "Taman- 
duá". Ele gostaria que essa revista funcionasse à margem do que o campo do design legitimou como coisa boa. Acha que é difícil ser bem qualificada pelos Qualis CAPES.

Acha que essa fase conturbada, transitória é um processo natural de depuração da própria formação do campo.

Fala do pessoal de engenharia, de comunicação estudando design porque "eles querem as bolsas da CAPES". AGÊNCIAS DE FOMENTO!

Fala que não conhece, não tem familiaridade com os autores de projeto em moda.

Ele não vê a discussão semântica, acha isso de designer de moda ou estilista é uma bobagem. Tem que analisar que prática é essa? 44'02"

Nomear é só uma palavra. Ver texto do Arjun Appadurai que fala de processos de ressignificação onde esses termos são cambiantes.

Agora dentro do campo do design não há uma preocupação de rigor científico, ou seja, qualquer coisa serve, hoje é design thinking, amanhã é outra coisa.

O termo design de moda parece razoável para ele porque tem que definir uma área.

\section{Produção Comercialização (Recepção)}

Legitimação

Na década de 90 o Bordieu era execrado na Europa.

\section{MITO - COLOCAR MAIS ADIANTE (NÃO ESTÁ NA QUALI!)}

Quem é que diz? Quem produz a crença? Porque é bom comprar? Porquê determinado objeto é um bom design? Pq esse sapato está na moda e aquele não?

Quem determina isso são escolas de design, revistas, técnicos, premiações.

Produção, no caso, é design. E comercialização é só consumo. É preciso rigor na relação do que o Bordieu fala.

Ele fala dos agentes que têm uma localização, não classe social, mas um lugar social. E ele fala desses lugares, onde, muitas vezes o produtor também consome. E essa localização no campo que cria essa dificuldade.

Para ser rigoroso, científico tem que respeitar essa estrutura que o Bourdieu propõe.

O consumo é produzido..., segundo Marx, o produtor produz além do produto o desejo de compra, o fetiche. Já para o Bourdieu são instâncias separadas. $O$ consumidor só sai desse lugar e passa a ter alguma importância se ele em algum momento ocupa o lugar de agente legitimador ou produtor.
É parecido como quando ele vai chamar de designer de moda ou estilista. É uma dinâmica. O lugar é movediço, ele pode mudar de lugar, é fragmentado.

É preciso definir o que é essencial e o que é contingente.

A discussão fica reducionista, muito mais que epidérmica. A discussão e burra daí não se discute absolutamente nada.

\section{Moda como campo do saber}

Bourdieu fala de luta pela dominação. Fala de pretendentes e dominantes. E o Cipiniuk chama de "Cavalcantis" e "cavalgados". A discussão é ond está o poder.

Analisar as 5 faculdades e ver o que elas têm em comum, talvez seja 0 caminho.

O departamento de biônica é uma palhaçada. É um grande teatro, é uma farsa. Não tem nada. Não é sério.

"O Brasil não é um país sério." Roissy Charles de Gaulle (anedota contada por Cipiniuk). Essa talvez seja a frase que melhor descreva a academia no Brasil que é um "esquemão" social entre os oligarcas. Segundo o Cipiniuk na Europa não é assim. $O$ orientador dele levou a outro grupo de pesquisa, - Cresa, que não existe mais. Ele entrou naquele grupo.

"Eu tenho muitos problemas.”...quando eu perguntei sobre poder ser crítico em suas opiniões.

Ele acha (lhe parece) mais adequado o termo design de moda, mas rebate que é só um nome. Para ele o estilista estaria mais próximo do "carismático" que ele descreve em seu livro, do que seria dotado de uma natureza especial.

Sobre o Design/Designer de Moda

O designer de moda não é funcionalista, ele não está preocupado com isso, eu acho que é venda de produtos, mercadorias, muito para consumo. Hoje é largo, hoje é amarelo, hoje é rasgado, amanhã não é...

A questão do novo é uma discussão que ele está propondo. Citou o Forty "Objetos do desejo". Cipiniuk conhece ele desde 1987 e ficou encantado com a honestidade do autor, porque o novo para ele está dividido entre o que é novidade e o que é ressignificado. Diferença dos canivetes (capítulo diferenciação em design, p. 89).

E me pergunta a diferença entre uma lâmina de barbear masculino e um aparelho de gilette feminino. Nenhuma, só cor e dimensão. Dizer que cort mais ou é mais macio é balela e é preciso coragem para dizer (denunciar) isso. (lâmpada de Shelby).

\section{O novo permanece, segundo o Cipiniuk.}

A polêmica dentro do campo é natural (moda como campo do saber). Há 10 anos era impossível uma candidatura de doutorado como a minha dentro da FAU, segundo o Cipiniuk. 


\section{Os próprios pares são o MEC 1'43"49 seg}

O que eu chamo de específico é uma construção, segundo o Cipi é o que o Bourdieu chama de arbitrário cultural. Para ele a noção (legitimação, fundamento teórico) precede a prática, ao contrário do Itiro lida. Para ele é um diálogo.

O design também estaria exercendo poder sobre a moda ao encampá-lo. Ele é um dos únicos que admitem isso.

As indústrias estão nas favelas (e baixada = periferia).

Segundo ele, o artesão trabalha com as mesmas etapas do processo produtivo. Mas não é o projeto erudito, processo racional, é um tipo de manufatura doméstica na oficina em uma favela ou afim. Elas sabem mostrar o que tem design, mas não sabem enunciar o que é o design. Elas têm noção que o designer, desenha e antecipa o produto.

O produto e a embalagem tem que considerar o consumidor, quem está lá na ponta. $\mathrm{E}$ as costureiras têm noção do processo direitinho. Elas fazem quase tudo, mas embalagem não, por exemplo.

Elas têm noção ou reproduzem a noção de projeto, mas não sabem com clareza que elas estão operando.

\section{FORMA X FUNÇÃO}

Ele acha que deveria ter na moda

"O sapo não pula por boniteza, mas pula por precisão." Guimarães Rosa.

Critica o descaso da moda com a forma e função que é ignorada em detrimento da produção estética, epidérmica que está voltada para um produto "diferenciado". Não é produto novo, só diferenciado/ressignifido (Forty/ Appadurai)

Desconfia das roupas de alta performance, dizendo que estamos muito longe do que precisa ser na prática, como usuário. Critica "tecidos inteligentes" dos quais o cheiro não sai mesmo depois de se "lavar de todo o jeito". Inteligente para quê? Para ganhar dinheiro?

REFLEXÃO SOBRE PROJETO EM MODA NO BRASIL

Falta sim, segundo ele, em toda a academia no Brasil que é a expressão de uma Oligarquia.

\section{MONÇORES, Aline. Entrevista realizada com Aline \\ Monçores, em 15 de outubro de 2015, na cidade do \\ Rio de Janeiro, com 1 hora e 47 minutos de duração.}

Dissidência da Tita, Romy e Lucas Rosa do campo do design para que a moda se coloque como campo autônomo. A Aline é contra apesar de ser graduada em Moda e não em Design de Moda.

Ela é partidária que o curso de Moda seja abordado pelo viés do Design seja Design de Moda. A implantação do curso como Design de Moda fo feita pela Déborah Christo no Senai. Quando a Aline vai para a UVA ela não teve dúvidas de que deveria ser Design e muito embora o curso de moda da UVA já estivesse dentro do departamento de Design ele teve que sofrer alterações para se adaptar e se tornar um curso de Design de Moda.

Parece a UAM se pensarmos que estava dentro do Design, mas era Moda ainda se for analisado friamente. A bibliografia de Design não era contemplada no caso da UAM, o curso da UVA teve que sofrer alterações para se tornar Design de Moda. É um transição/crise que já dura mais de 15 anos (1988-2015 = 17 anos).

Falou sobre o artigo "Arte e Moda" para o evento da UDESC da Sandra Rech. A Aline concorda com a Deborah Christo. Ela é coordenadora da Déborah na UVA e foi chefiada pela Déborah no Senai e são colegas na PUC RJ.

Elas têm uma "panelinha", segundo ela. Elas têm um sistema de reunião. A Aline é muito objetiva e direta nas reuniões e quando é chamada na UVA fala abertamente que do jeito que está o curso não vai muito longe. Isso quando é chamada pela UVA e é convidada para assumir a coordenação do curso de Moda da UVA que estava em um momento crítico.

A UVA tinha uma nota bem baixa no ENADE em 2011 quando a Aline entrou lá e assumiu a coordenação. $O$ curso estava em "estado de saneamento". A visita do MEC e a nota tinham sido em 2009. A visita seria em 2011, mas o MEC

A UVA só tem graduação em Design de Moda desde 1995. Tem tecnólogo de 2007 para cá em Design Gráfico = games e interiores (parece que são de 2007). O curso de Moda lá surge antes do de Design que é só tecnológico. Mensalidade da UVA é de RS1800,00. Senai é uns R\$1100,00 e a PUC RJ em torno de $R \$ 2800,00$, mas é integral.

De agosto de 2011 até a visita do MEC em dezembro de 2012 a Aline organizou o curso e o campus que também tinha sido considerado insatisfatório segundo o MEC após a visita, após a reprovação no ENADE em 2009. Na UVA há coordenadores de campus:

Barra - Beto Abreu

Tijuca - Ana Paula 
Nesse processo a Aline lidou em reuniões com ex professores dela, então havia um vínculo de memória. Mas havia um medo de a coordenação já ter mudado 3 vezes.

Alunos com medo de fazer mais disciplinas para adaptar para o MEC.

Houve cortes em 2011. Ela tinha um corpo docente e discente mais frágil. Ela conta que a demissão do Pedro Sayd (figurinista) foi a mais difícil e aconteceu porque ele não tinha mestrado que estava sendo cobrado pelo MEC junto com os esforços feitos pela Aline, que, segundo ela, era uma operação de guerrilha.

Em 2012 no ENADE seguinte atingiu nota 3,00 geral. Foram 67 alunos. Teve nota máxima no PPC, máxima no plano de curso. Os alunos tiraram 3,00 no ENADE e a instituição 4,00 na maioria dos requisitos.

22/11/2015 é o próximo ENADE.

Hoje ela é da diretoria da MKT da ABEPEM com a Ana Paula Miranda. (A entrevista está muito barulhenta!)

\section{Reunião da UVA}

Geral - planejamento, metas, objetivos $=2$ horas e break. E depois mais 2 horas eixo por eixo.

São 7 eixos:

\section{PROJETO / DESIGN / FORMAS / DESENHO / TEXXTL / PESQUISA /} GESTÃO

A disciplina de Projeto já tem um peso maior no curso de Design de Moda, mas a Aline pretende que o eixo de disciplinas de Projeto norteie o curso. A disciplina é em sala separada ou em dia separada o que mostra sua importância e espaço ocupado.

\section{AUTORES}

Simon Seivewright - não conhece, depois conhece. Diz que conhece Renfrew e Doris Treptow. Sue Jenkin Jones conhece o livro, mas não a obra.

Löbach, Bomfim e Munari ela conhece, mas Burdek não.

O curso de Design de Moda da UVA contempla os principais autores de Design de Moda e de Design?

Alguns deles estão em Bibliografia. Ela usa também outros autores de moda na sua bibliografia. O Seivewright com certeza não está.

Ela questiona muito a bibliografia de moda. Acha muito incipiente em sua reflexão. $O$ da Sue Jenkin Jones ela acha uma "bobagem", não traz uma reflexão de projeto. Trazem uma fórmula pronta, pré definida, rasa para níve de graduação. Para ela não fazem pensar em projeto. Se comparar o Bomfim com Jones fica ruim.

Questiono que os livros de projeto em moda saem de livros de projeto de design.
Ela tem a ideia de modelo francês para a moda no Brasil (um pouco defasada). Hoje falo de Academia que admite livros bons advindos não só da França. Ainda assim ela acha que ficou um resquício, um lastro na produção dos estilistas da década de 60 a 80 no Brasil.

E ainda complementa com uma preocupação que basta ter dinheiro, certo "bom gosto" e ego inflado para ser estilista e essa visão ela combate, mas fala que é muito incensada e presente ainda no RJ.

Estilismo $=$ Projeto?

Ela começa falando que foi formada em ESTILISMO. Ela fez um curso estruturado por professores vindos do curso de Belas Artes. Conta de um professor que analisava trabalhos.

51"MUITO BARULHO

Conta em aula de graduação do curso dela: COMO VOCÊ PESQUISA TENDÊNCIA DE MODA? (que é a área de pesquisa da Aline).

O professora falava que se aparecer uma vez é ACASO; se aparecer duas vezes é COINCIDÊNCIA; se aparecer três vezes é TENDÊNCIA.

Ela pensava: não pode ser isso. À época ela já trabalhava.

De certa forma ela rechaça a origem artística de sua formação. Isso é interessante porque é diferente do que acontece na FASM, uma defesa de cunho político.

Ela pegou o mercado substituindo a mão de obra autodidata pela mão de obra graduada em moda, aí voltou a estudar e foi fazer faculdade de moda. Ela já era estilista da Mercato antes do curso.

Outras falas sobre Projeto na sua graduação na UVA (julgamento com emissão de valor):

Ai que lindo! Isso é lindo! Tá vendo gente?! É assim que tem que fazer!!!

Ela pensava que não era possível e que aquilo era muito distante da sua realidade de fábrica.

Criar algo que venda, seja fácil de produzir. Projetar/estilstar não é "criar aleatoriamente".

56" INAUDÍVEL

Relação que vem da arte para a moda no projetar.

Ela acredita que hoje a UVA tem uma formação muito melhor que na sua época graças à noção de Design. Ela consegue olhar para trás e ver essa diferença.

Estilismo como objeto criador, seguindo a linha de raciocínio crítica da Déborah Christo. "As pessoas não vivem de abraço", rs.

Até a Beatriz Milhazes não vive de abraço. Até ela faz projeto. 
Se o método avaliativo ocorre com base no "ISSO É LINDO!" ou "ISSO É HORRÍVEL" sem um método de apoio, não há como chamar de projeto. Não há critérios.

Se não há apoio ao desenvolvimento do traço, da habilidade criativa...59", do dado...INAUDÍVEL.

DESIGN exerce uma forma de poder sobre a MODA

Ela acha que sim, mas não é um problema se coligar a uma classe com mais poder para usufruir do poder dela.

\section{1' MUITO BARULHO}

Ela acha válido tirar proveito do prestígio e maior profissionalização já alcançados pelo Design.

Conta que a Kathia a convidou para publicar pela Letras \& Cores.

SOCIALMENTE MAIOR RECONHECIMENTO DO ESTILISTA OU DO DESIGNER DE MODA?

Para ela a maioria sequer consegue diferenciar. E depende da pessoa que vai afirmar. (BOA)

$\mathrm{Na}$ Academia hoje há uma grande divisão de quem chama o profissional de estilista ou designer de moda.

\section{1'05" MÉTODOS DE PROJETO DE MODA - ETAPAS}

No Senai/Cetiqt ela tinha uma atuação muito mais empírica, buscando adaptar o que lia, menos baseada em livros e no que ela lia, mas depois cita Bruno Munari. Seu primeiro contato com bibliografia específica foi no Senai. Buscava implementar a leitura. Criava etapas, função, prazos, vamos avaliar o projeto, qual é a questão do projeto, se o projeto tem problema, se tem etapas a serem resolvidas, segundo ela, uma coisa meio "Bruno Munari para iniciantes".

Ela pensava em um problema para solucionar, mas chamava de DEMANDAS. Ela não chama de problemas e eu questiono que na moda nunca há problemas. Ela pede ao aluno para redigir quais são as possíveis demandas.

\section{ETAPAS}

Aluno redige as possíveis demandas

Alunos íam a campo e escolhiam trabalhar para um marca já existente (duloren etc);

Identificar detalhadamente a linha de produto. E a partir daí o que seria uma demanda para a Duloren? Porque calcinha e soutien a Duloren já faz. Identificar novas possibilidades de trabalho. Qual é o maquinário da Duloren?

E aí começa a identificar as etapas (?)
Deu o exemplo dos bonecos na aula de projeto para sustentabilidade 1"17" e ajudar com desenvolvimento da psicomotricidade em creches ou crianças com necessidades especiais e ajude a produzir objetos com essa pegada, pois são muito caros.

Produtos bonitinhos $=$ parece querer diminuir a criação como um ato em si. 1'19"

Atribui à reflexão e à abordagem ligada ao design a diminuição do penamento do aluno voltada somente para o estético (como se isso também fosse um problema ou devesse ser combatido). Lembrar que muitos apoiam a estética como função.

\section{Falta projeto na indústria $X$ cópia}

Falta projeto na indústria por uma cultura empresarial. 0 empresário não dá valor à noção de projeto, com certeza.

$\mathrm{Na}$ cultura empresarial no Brasil o subordinado é inferior, mesmo sendo um "estilista". $O$ empresário sempre vai te colocar num lugar de inferioridade, mesmo que ele não tenha o conhecimento do estilista, porque "ele é o dono". Além disso há o completo desconhecimento do que é a função do estilista. Isso é muito ruim para a campo do design de moda.

Falou da Reserva como uma marca que comercializa bem, mas que não pode ser considerada uma referência de design. Ela tem vários alunos que trabalham lá. Para ela parece que eles são muito receptivos e abertos à execução de trabalho com uma linha projeto, com uma meta, uma ênfase, objetivos traçados, com uma sistematização de trabalho e a Aline apoia essa visão.

\section{FORMA \& FUNÇÃO}

Vai da formação do professor para ela. O professor deve colocar a evidência de uma funcionalidade naquele uso, naquele objeto com coerência e de uma forma que seja coerente àquela função $e$, consequentemente, uma estética que seja agradável na forma e execute a função. $O$ professor deve habilitar o aluno a tudo isso.

Ela acha que a função preponderantemente estética não vai perdurar.1’32"

Deve-se olhar não só para objetos com valor simbólico, mas para objetos que passam sentido dentro de algum contexto. (= fala muito parecida com a da Simone Mina)

Ela não acredita na produção efêmera de longo prazo. Ela acha que tende cair.

Ela não acredita no profissional que visa só a função estética.

Ela acha que falta reflexão intelectual no projeto em moda. Apoia publicar em congressos de design etc e não só no Colóquio de Moda. Devemos publicar na Estudos em Design. 
Citou a Elizabete Peterman sobre tendência e a supremacia das visões do design sobre a execução do projeto e ignora as ciências sociais e os estudos de tendências como determinantes do cenário. Ela é formada em Moda, é de algum país escandinavo essa Elizabete Peterman

Começou a falar sobre Projeto, mas aí desviou para a Irina Aragão.

Ela diz que para a Irina Aragão é moda é produto, é produto completo, design de produto, desenho industrial total. A Aline leu "Fato social total" de Marcel Mauss e aí ela falou para a Irina, é um desenho industrial total = gesamtkunstwerk. Moda tem gráfico, forma, função, corpo, ergonomia e tem uma série de coisas que ligam diretamente sujeito e objeto, sujeito e função, sujeito e simbolismo, semiótico para aquele objeto de vestuário.

O objeto de vestuário então portaria todas essas funções dessas múltiplas expressões.

\section{CHRISTO, Deborah. Entrevista realizada com \\ Deborah Christo, em 21 de outubro de 2015, \\ na cidade do Rio de Janeiro, com 1 hora e 46}

minutos de duração.

O curso de design da PUC RJ e da UFRJ seguem o modelo do curso de design da ESDI. Ela foi orientanda de mestrado e doutorado do Alberto Cipiniuk.

Em 2004 a PUC RJ lança a habilitação em moda na graduação.

Pergunto se as etapas de projeto em moda são claras para ela e peço a ela que as descreva.

Senai Cetiqt, UVA e PUC RJ a partir da experiência dela com projeto na graduação.

O olhar dela e o que ela vê acontecendo ali.

De acordo com o olhar dela ele percebe um conflito com algumas questões estruturadas na metodologia de projeto de design. Ela entende a metodologia de projeto em design estruturada por um viés ideológico e isso significa que essa ideia de projeto foi construída para dar legitimação ao campo do design quando ele foi construído dentro da tradição modernista. MITO!

Percebe uma ambiguidade porque as primeiras estruturas da ESDI estão dentro de um Museu, o MAM. Há uma estrutura política por trás desse projeto de desenvolvimento voltado à indústria, mas o $\mathrm{RJ}$ nem era indústria. Ela conta que o Aloísio Magalhães também tinha contato com a Carmem Portinho e o Reidy. Lembrar que a Carmem Portinho era uma engenheira, então foco na matemática, na racionalidade, o berço é esse (26'26"). Olha como coisa era estranha: o curso surge lá, no meio de um museu, mas é indústria, mas também não havia indústria, mas também era design e tinha um olhar pesado de exatas que dava seu caráter racionalista...o profissional era para a indústria, mas ía para o campo gráfico, porque não tinha indústria no RJ. $E$ o gráfico era menor que o produto na epoca, como a relação design X moda.

A dificuldade dela com a metodologia de projeto do design reside no fato de algo que tem um viés ideológico estar sistematizando a prática do campo $e$ isso confunde oque é pratica eo que é politico.

Para ela desenvolvimento de coleção é igualzinho projeto. No produto, grosso modo, há a detecção de um problema, o processo de pesquisa, variações entre autores ep e profissionais). Pode desenhar primel Iher materiais depois, mas em suma, as etapas são essas. A pesquisa proporciona uma imersão de entender aquele problema.

Em moda a Pesquisa está em uma disciplina separada. Para ela no RJ os cursos de design de moda são norteados pelas disciplinas de projeto. $\mathrm{Na}$ PUC RJ enquanto as disciplinas têm, em geral, 3 a 4 créditos, a disciplina de projeto tem 10 créditos. 
Na PUC RJ ela é a professora de projeto em moda e outro professor é de projeto de produto. Os dois coabitam a mesma sala na mesma aula/horário. No terceiro período é onde aparece a questão da moda. $\mathrm{O}$ aluno tem que fazer produto ou moda.

Isso ajuda a criar um respeito pela área já na época de formação.

27'26" a confusão da ESDI não era tão racional e clara assim, mas estava lá e até hoje a Deborah tem problemas com essa visão. Fala dos fundadores, dos preceitos, mas não concorda integralmente com eles e como eles são abordados/aplicados. E hoje ainda é Löbach, Munari, Burdek, inclusive para moda.

Quando começou dar aula no curso de moda ela recorreu ao LIVRO de 1995 DO GERSON ABRANTES “MANUAL DA GERÊNCIA DE CONFECÇÃO: a indústria de confecção contemporânea" DO SENAI. [Esse livro é mais voltado à produção na confecção e não a projeto. Isso talvez explique o interesse de a Deborah, uma designer, pesquisar nele, já que o curso de design da ESDI nunca deu base em moda.]. Lá tem um fluxuograma do desenvolvimento de coleção.

Em moda não há a noção de PROBLEMA. Para ela essa é a maior dificuldade ao falar sobre projeto para alunos. Mas de acordo com a Deborah questão da detecção de um problema no campo do design é "não fácil" 30 "

A base de construção do design nega que ele seja consumo, tem dificuldade de trabalhar com esse dado.

Por exemplo, a cadeira bertoia, será que ela é para o usuário efetivamente? Será que o usuário demandou isso???

Será que essas formas escolhidas vêm de um problema ou de uma demanda?

O que se entende por design, grosso modo, é ssinado, tem um "não sei o quê". O cortador de batata do camelô, o escorredor de arroz não é design, porque "essa capacidade de observar eu consigo botar na forma e isso faz essa forma ser super única, né?!"

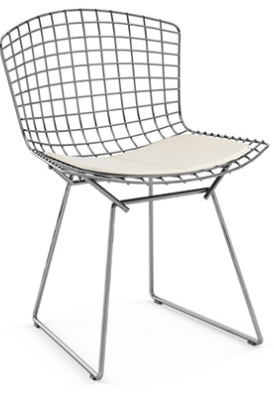

Mas segundo ela, se olharmos especificamente, não é o projeto que fa essa diferença. Essa diferença tem a ver com uma escolha estética.

Não existe a noção de problema em moda. E os professores da PUC RJ tentam apresentar e essa é a coisa mais difícil. 30

Eu digo que a cadeira bertoia é design e o cortador de batatas do camelo não é porque dentro da faculdade de design ela aprendeu a ler (foi dado ferramental) que essas formas consagradas são "mais bacanas" que o que não é um objeto reconhecido como pertencente ao campo do design.

O cachepô do 1,99 do chinês. 0 que me faz entender o que é ou não design não tem a ver com o processo de planejar e projetar, mas tem a ver com a construção do gosto.

\section{ETAPAS DE PROCESSO DE PROJETAR EM MODA}

\section{Detecção do problema}

Tudo pode ser um problema. Se uma empresa diz que o problema é colocar uma coleção na rua, o problema de projeto pode ser colocar uma coleção na rua. A ideia de problema circula pela identificação de algo que não foi atendido ainda. Uma oportunidade de projeto, uma demanda que não foi atendida.

Hoje essa demanda é muito mais complexa. Numa sociedade "da matemáica" do período da ESDI é mais fácil calcular e perceber o que não está sendo atendido. Hoje é muito mais subjetivo e mais complicado que há 50 anos.

O Gustavo Amarante Bomfim vai discutir que a função de um objeto não é só uma função prática. A função de um objeto é estético-simbólica.

Mas numa formação modelo ESDI essa questão não era contemplada. Essa discussão vem à tona no final da década de 90 e aí surge a questão de encampar a moda para dentro do design. O Bomfim participou de reuniões com a Doroteia Pires.

Próxima etapa: Pesquisa, Coleta de Dados

Não é qual é a tendência só, mas é comportamento, lifestyle. Para ela a pesquisa de moda hoje se transformou em comportamento. Mas ainda confirma que os alunos olham as passarelas. Para ela pesquisa também e conhecer fornecedores, insumos e o que é viável técnica e economicamente. Sobre o tema, quais são suas referências gráficas, visuais, sendo bastante amplo.

Pesquisa também é entender e saber contar o Mix de Produtos. 58'10"

No Senai Cetiqt a solução que se deu, de acordo com a Deborah, para a disciplina "Pesquisa de tendências" se tornou uma disciplina específica para discutir a construção de tendências.

É arbitrária essa visão de separar a disciplina de pesquisa em moda se pensarmos sob o viés do design.

O aluno de moda tem dificuldade de entender o que é um problema para o design.

Porque "produção de objetos do vestuário sob a noção de moda" e não "moda".

Ela acha que nem é o melhor termo que ela encontrou, porque é imenso, mas ela quer ser rigorosa no entendimento destas palavras. Vestuário é a margem da moda. Mas o foco era olhar para o objeto da "moda".

Segundo Rafael Cardoso, o surgimento do termo design é do século XV, quando as tarefas são divididas para dar conta da demanda que o comércio começa a exigir. $O$ foco é um pouco diferente na moda que fala da busca pela distinção por parte da burguesia.

A mentalidade, a formação de moda, no sentido de projeto é muito dis- 
tante da visão do design ainda hoje.

Próxima etapa: Desenho

Próxima etapa: Prototipagem

E por fim fazer....(eu falei em cima, para variar)

\section{Autores}

O livro do Simon Seivewright ela não consultou e não trabalha com ele, mas os outros autores de moda (Jones, Treptow e Renfrew) ela conhece e utiliza em sala.

A Deborah não vê em nenhum desses livros a metodologia de projeto que é utilizada em design aparecer nesses livros.

Os considera mais voltados a uma prática profissional.

Para ela a metodologia de projeto é uma tentativa de organizar a prática e para ela os autores de projeto em moda eles estão organizando o passo a passo da prática.

Novos nomes que surgiram no design são difíceis de entender no design e mais ainda e traduzir para o campo da moda. Alguns exemplos, seriam os termos "parâmetros projetuais", "mandatórios restritivos", "mandatórios desejáveis".

Não pode te prender na forma, mas tem que te induzir ao que aquele usuário quer. $O$ projeto é estar no olhar do outro, de quem vai usar. (Ela não falou que estilismo faz o contrário em nenhum momento como está na tese dela).

Design thinking $=0$ usuário é o consumidor na verdade, mas o design o trata como um usuário longe das questões do consumo. E a Deborah concorda comigo que tanto a moda como o design pecam nessa questão ao penderem mais para um lado, o do usuário ou o do consumidor.

Questiona qual é o limite da cópia porque tudo é referência.

DESIGNER DE MODA OU ESTILISTA? PROJETO OU ESTILISMO?

Para ela tudo é projeto. Para ela hoje é design de moda por uma questão de valor. É o design emprestando valor à moda em determinados campos. Mesmo no campo da criação o design se alastra.MITO

Estilismo vem de estilo, do campo da arte, de identificar a característica de um determinado artista.

No design de produto, gráfico ela acha que tem estilo. Acha que dá para unir os dois.

Para ela tudo é projeto porque a essência do trabalho do estilista está lá pautada por etapas. Mas não vê a noção de projeto do design em certos cursos de estilismo porque o ideológico vinculado à noção de projeto está preso ao campo do design.

Ela acredita que dentro do design se trabalha com estilo o tempo todo.
A prática do projeto é contemplada pela maioria das faculdades de moda/ estilismo, mas não projeto enquanto valor como visto nas faculdades de design.

Ela entende projeto também como planejar. 1'02".

A própria análise do processo criativo, que pode se alterar e se repetir posteriormente na prática do próprio aluno dentro da faculdade, está inserida na prática de projeto.

Mesmo na criação pura haverá um objeto real e aí o projeto é necessário como atividade humana. Planejar e projetar está lá, não é só do campo do design. Ele não define o campo do design.

Para ela o que definiria o design seria a "forma". $O$ que eu pego de referência da sociedade e transformo nessa representação. Mas não é o que legitimado.

Quais os valores que definem o que está dentro do campo do design ou não? Isso é definido pelo campo.

Rádio de cera do Papanek = escorredor de arroz, mas é legitimado, então é importante como o rádio da Braun do Dieter Rams.

O letrista lá do morro do RJ. Quer estudar design? Não, não, eu to ganhando meu dinheiro aqui.

Design e a noção de projeto é o que foi reconhecido pelo campo. Design é mais um objeto da prática social e está explicitando as relações que existem, de poder.

Estilismo não é design para o campo do design. Moda antes surge desvinculada do campo do design.

$S P=$ INDUSTRIALIZADA=MAS PREVALECE A VISÃO DE ESTILISMO;

RJ $=$ MENOS INDUSTRIALIZADA = MAS PREVALECEU A VISÃO DE DESIGN.

MAIS CAPITAL $=S P=$ MAIOR CAPACIDADE DE INVESTIR EM PRODUTOS CULTURAIS

\section{MEC = surge como orientação moda virar design.}

Pode haver curso superior de moda. Quando cadastra um curso no MEC tem que pedir o novo cadastramento do curso. "Eu não discuto que o curso tem que mudar de nome, eu discuto que ele tem que se adequar ao currículo do design."

Habilitação não existe mais, desde 2010 é só designer ou desenhista industrial como na PUC RJ, mas sob o formato de design. As habilitações ou ênfases acontecem dentro do curso, mas não estão no nome, nem no diploma.

A partir de 2004 não pode mais cadastrar curso que não for design. O que ntes possuía outro nome que não design mantém, mas todos têm que se adequar ao currículo do design.

REDUCIONISMO 
Ela acha que o design está emprestando legitimidade à moda e não sendo coercitiva em relação à moda. Não foi espontâneo assim. Houve uma pressão e acompanhamento do campo do design (Moura, Pires etc) para que, academicamente, moda se tornasse design aos olhos do MEC.

Hoje, dentro da PUC RJ, existe a disciplina de tendência, afinal juntou com a moda. Antes essa possibilidade sequer existia, mas quem dá a disciplina é o Marcos Maia, um professor formado em design de produto e não de moda, mesmo a disciplina originalmente tendo vindo do campo da moda.

Ele dá tendência para o pessoal de produto e a Aline (deve ser a Monçores) dá para o pessoal de moda

O governo (MEC) vê a indústria têxtil e de confecção como possibilidade de abertura de negócios maior se engendrada pelo campo do design que é mais tradicional.

Ela fala em design e moda como áreas com poderes diferentes (1'25"), mas o entendimento é de que o design tem mais poder, tanto que encampa a área da moda autorizado pelo MEC.

1'29" Amplio o olhar e ganho mais poder em 1998 se eu unir as áreas de moda e design. É que o que rola não é uma união, mas um encantamento, né?! Na época havia o programa brasileiro de design. Havia um contexto para o crescimento e reconhecimento do campo do design.

'33"

Não preciso legitimar o campo da moda porque ele está lá, ele já existe. Ok! Mas porque ele não é autônomo então?! Porque ele está dentro do design? Sim, está por questões políticas, mas isso tira a força, o poder do campo da moda.

140 "

Sobre cópia é difícil algo que surgiu sem referência nenhuma. O segredo está em quanto você se distanciou disso.

Para ela projeto se define por etapas para chegar a um determinado fim, por isso ela não é tão crítica em relação à cópia. Para ela o problem reside que, na cópia, são criados produtos sem um pensamento em cima.

Falta reflexão crítica sobre projeto em moda

Falta como um todo.

Baxter $=$ ferramentas $=$ painel semântico $=$ mas dá outro nome.

Critica a literatura de projeto em moda dizendo que diz "faz isso, depois faz aquilo", mas sem nenhuma discussão, diz o que fazer, mas ninguém para para pensar. Faz sentido. Mas talvez isso ocorra porque também para a moda a discussão não caiba, não interesse.

Qualquer coisa é ponto de partida para um projeto (“tema”...).
GRUMACH, Evelyn. Entrevista realizada com Evelyn Grumach, em 14 de outubro de 2015, na cidade do Rio de Janeiro, com 1 hora e 35 minutos de duração.

Profissional de projeto, toda questão projetual a interessa. Dada sua formação (ESDI), enfrentou muitos campos novos para poder agir dentro do mercado, algumas metodologias próprias nasceram com essa prática e outras foram desenvolvidas no período em que começa a dar aula passa a ter metodologias mais precisas para ser possível passar o conhecimento.

Escritório na década de $80=A 3$ (16 anos, 3 sócias $=$ Ela, Luísa Escorel e Heloísa Faria). Possibilidade de trabalhar em um mercado de pequenos negócios que passaram a necessitar de identidade visual (marca gráfica, estratégia, design thinking...é um grupo de coisas que resolve = o designer era o gestor daquilo). $O$ designer projetista era o designer estrategista naquela época, hoje pode ser um só (estilismo/projeto).

Grupo com Sérgio Liussi e discussão sobre preço equiparado. O que diferenciaria na escolha do cliente seria o design. Tabela de mínimo e máximo de preços a cobrar. Com o tempo, percebeu-se que isso não funcionava.

No campo da moda ela trabalhou muito para lojas, mas sempre na área da identidade visual. Desde a parte efêmera, descartável até arquitetura. Ela sempre esteve casada com o arquiteto no projeto. Isso em confeitaria, restaurantes etc. Parceria em um momento próspero. Ela entrava no am biente de cor junto com o arquiteto, letreiros e lugar (shopping, lojas de rua).

Trabalha com a Aviator desde 1988 ou 1989. Ela era house da casa e Evelyn ficou com a parte que não se descarta (embalagens, letreiros) e para a campanha eles têm uma equipe interna.

Apesar de sempre se dedicar à área da identidade visual ele já trabalhou com uniforme, mas não com roupa da moda. Ela que definia em algumas empresas como as funcionárias iriam se vestir (ver o portfólio da EGG que tem exemplo de uniforme).

Light ela fez o uniforme inteiro. E esse tecido é uma sarja, mas é um tecido especial, tem uma linha que não pode ser sintética para evitar combustão. Trabalhou com o Senac Moda Informação.

Década de 90 a marca era divertida. Ela trabalhou no PVDI, com Aluísio Magalhães. Ela se define como uma designer do modernismo com soluções sintéticas. Na década de 90 ela pode ser o contrário do modernismo, ilustrativa, divertida, explorar novas possibilidades, a computação gráfica.

Com o prêmio da marca gráfica da ECO 92 ela comprou seu primeiro computador.

Quando ela discutiu sobre moda, mas não lembra do evento, não era nada ligado à São Paulo, era só o mercado carioca e a maneira como ele estava trabalhando o design. Sérgio Liussi era da Cantão (vale entrevistar). 
Vendendo moda ou torta o que muda é o paradigma da comunicação.

O Cantão e a Corpo e Moda estava dentro da moda. Ela diz que não estava dentro da moda. Ela estava na interface entre ela por meio do gráfico.

A moda ganhou presença desde os anos 2000. E a PUC tem importante participação no mercado carioca.

Design gráfico, industrial, mídia e moda. Os 2 primeiros anos são generalistas na formação do designer.

Ela não tem contato com os alunos de moda na PUC. O que ela leciona é - TCC e alguns trabalhos vem ligados à moda. Acha curiosa a confluência entre design e moda. Porque que alguns TCCs vêm da moda e outros do design e ambos fazem coleção?

No TCC mistura tudo. Muita coisa é estamparia, mas vão para a questão do corte. Ela não orienta a peça, não entende de corte, mas é capaz de coordenar um pensamento sobre como fazer a coleção.

\section{METODOLOGIA PROJETUAL}

Para ela é claro abordar metodologia (de design) para trabalhar um problema na moda. Não acha as etapas de projeto claras. Ela aborda metodologicamente de forma a construir analogias entre a metodologia de design para a moda.

Ela relata que o aluno chega com um tema (indígena, concha, ditadura etc). A partir do tema, passam um semestre estudando o tema, ela não participa disso. Ela recebe o tema já elaborado com uma pseudo proposta de algo que se concretiza no campo do design com isso e aí não acontece. É o que interessa a ela, a confluência. Tira o aluno do pensamento muito objetivo da pesquisa em si, o aluno sabe tudo sobre o assunto a partir da metodologia. E daí definem o que vão fazer com $o$ assunto.

Como aquela informação toda vai virar conteúdo para alguma outra coisa. Esse processo ainda é muito mal articulado para a média dos alunos.

Ela diz: você tem um conteúdo que é o tema pesquisado e tem um conteúdo do design que você tem que conhecer para poder fazer essa trama. Conhecer essa ponta do design na moda para poder virar um objeto do campo do design como agente transformador. Então o conhecimento de projeto em design é fundamental para transferir o conteúdo da pesquisa para produto.

Laboratório de Biônica

Não existe bibliografia de projeto nessa área segundo Grumach. Então ela usa a mesma metodologia de projeto do design e observando a natureza ela vai transformar isso em comunicação ou em produto. Aprende sobre natureza, simetria, estética e beleza, recursos de linguagem...tudo isso ela leva para a transferência. A observação do mar virando projeto, produto, por exemplo.

Em biônica muitos alunos vão procura-la para desenvolver projetos na área de moda, pois partem da natureza. $O$ grande trabalho da Evelyn é tra- balhar no campo abstrato. Ela diz que os alunos não entendem movimento. E preciso entender (com a mesma metodologia) que você pode trabalhar um conceito visual ou gráfico ou estrutural a partir de alguma coisa.

Hoje esses são os interesses dela, bem diferentes da década de 80 . AUTORES DE DESIGN

Não conhece Löbach, produto.

Conhece Bomfim, Burdek para produto.

Conhece Munari para visual.

\section{AUTORES DE PROJETO EM MODA}

Seivewright não conhece, Renfrew não conhece, Sue Jenkin Jones e Doris Treptow também não conhece.

\section{Ela me pergunta o que é metodologia de projeto em moda?}

Explico que a ideia de solução de problema, muitas vezes inexiste $n$ moda e que não temos um consenso que fui formada por psicólogas que abordam a criação pelo olhar do Rollo May, Cecília Salles.

\section{O que é design de moda, ela me pergunta?}

Vou para a questão "designer de moda" ou "estilista"?

Ela acredita que é mais nobre ser estilista que ser designer de moda porque assumidamente está trabalhando com a questão do estilo.

Para ela dentro do campo da moda estilista é quem faz a roupa, mas não designer de moda. Trabalhar no campo do design de moda para ela inclui design gráfico que ela fez por exemplo. Ela foi uma designer de moda para ela. Ela foi uma designer gráfica dentro do campo da moda.

Para ela o sujeito ser designer de moda não quer dizer que ele seja estilista. 37'50"

As ferramentas de estratégia não interessa a todos, um pode ser estraegista no campo da moda, como um cara de negócios da moda, mas não ser estilista.

Para ela, estilista é quem desenha a peça e cria com ela uma linguagem própria. Isso constrói uma marca própria sua que faz com que você seja um estilista dentro do campo da moda. Não é só pegar a camiseta básica e mudar a cor. Ela sugere mudanças formais mais arrojadas.

Dentro da moda há o design de moda e no design de moda, para ela, o sujeito não precisa ser só estilista. Pode ser estrategista, designer gráfico voltado para a moda etc.

Branding dentro do design é mais recente e é negócio. Ela diz que o profissional pode ser um designer de moda, no campo da estratégia, e vai fazer um design de serviço para atender uma determinada ação deste campo, uma demanda desta fábrica de roupa. 
Ela defende uma visão muito fronteiriça. Aí fala que o estilista é designer que desenha roupa, o designer de moda não quer dizer nada para ela, não diz que é o profissional que desenha roupa.

\section{Como é que eu chamo alguém que desenha a roupa?}

Deveria ter um nome para a atividade de desenhar? Brincou, falou para eu ficar com a dúvida e trabalhar com ela. $43^{\prime}$

A Academia lida com a produção industrial e com a comercialização também. Ela acha que deveria abordar assim.

Curso de Moda seria muito amplo para ela. O nome do curso poderia ser Design de Moda para ela. Ela acha uma maluquice essa separação, essa especialização toda. Mas acha que o curso tem que instrumentalizar para muita coisa dentro da área de moda, não para expografia, por exemplo, mas para desfile, vitrine sim.

Criticando o excesso de especialização ela lança: daqui há pouco vai ter curso de graduação de Design de Superfície? Isso é absurdo.

Critica também, por outro lado, o inchaço de disciplinas dentro dos cursos de design. Ela diz que se passa por tudo muito rápido (essa crítica também é do João Leite).

54 '42"

Fala das inconstâncias de nome do curso e do profissional em design no campo. Para me consolar sobre a moda (bacharel em que?).

Ela conta que primeiro era bacharel em design, depois em design, programação visual e design de produto. Agora você é design, comunicação visual e ...cada vez você está fazendo um campo que se chamava design virar várias coisas.

\section{A moda é tão ampla e tão grande e leva tantas coisas em torno de si...}

Para ela o campo do vestuário é muito maior que a moda. Para ela vestir é maior que a moda. $O$ vestir traz em si questões que nem sempre eu vou resolver com a questão da moda.

Moda é tb estilo, aquilo que está ali naquele momento (comparar com estilista).

Roupa Mao na China como padrão de vestuário opera o pensar do vesti que não diz respeito a moda (sazonal).

Hoje a moda está querendo traduzir tudo e nem sempre consegue porque a moda já vem carregada de significados, conceitos.

Para ela eu posso ser um estilista para o uniforme da Light e eu não estou fazendo moda (em um sentido sazonal).

Quando você se apresenta como um designer de moda sempre estou vendo ele como "estilo" com todo o lado pejorativo que isso possa ter.

O que você faz quando faz moda????
Projeto uniformes industriais ou modinha. Moda inclui estilismo e design

\section{Qual é o pensamento que está nesse produto?}

Se você simplifica ele para a questão da metodologia, você não forma. Há algo que pode ser feito para a sustentação do soutien, mas o mau gosto discutível. O gosto pode ser outra discussão, mas posso reconhecer que há design até na roupa projetada para periguete.

Há o pensamento de projeto em design na moda, mas as diferenças são visíveis, mas talvez a ênfase da PUC ajude a resolver essa questão. Só que é muita disciplina para pouco tempo de experimentação. As disciplinas de projeto na PUC contam com vários professores colaboradores. 1'5"

\section{PROJETO}

$\mathrm{Na}$ PUC quando chega no projeto (isso no gráfico) eles não tiveram tempo de experimentar e disciplinas de antropologia e sociologia são dadas de maneira muito fragmentada.

Acha que mesmo que seja campo autônomo a moda deve trazer para si o que foi transferido da arte e do design.

ESD

Design como algo social, o bem do design. A abordagem de negócios de ser estrategista é recente.

$\mathrm{Na}$ PUC RJ os alunos saem com visão de negócios, mas a visão de projeto não é tão boa na proporção.

\section{Entrevistar Ana Luísa Morales.}

Grupo de reunião anual de uma turma da ESDI, formados em 1973. Mais da metade é atuante em design (primeira geração da ESDI)

Valéria London, Roberto Strunk, Túlio Mariante, Washington Lessa, Evelyn Grumach, Carlos Orcade, Waldyr Carvalho (cineasta), Beto Felício (fotógrafo)..

A ideia de projeto pode ser desenvolvida, mas ela é uma etapa do trabaIho todo (falou de alunos terem marca ou um trabalho mais artístico).

Fala da cópia como um cardápio a escolher. Pesquisa de cópia, similar e diz gostei, vou fazer como isso e não como análise de similares que sería entender o processo do criador.

De certa maneira uma cópia de uma coisa bem feita é melhor que uma cópia mal feita. Então, pelo menos, que olhem bons exemplos.

Para ela o binômio forma e função sempre se desdobra, mesmo sobre a moda.

Colete do fotógrafo é cheio de bolsos por uma função de carregar rolos e acessórios então isso constrói também o estilo. 
Mesmo o soutien que aumenta o peito, o salto que empina a bunda responde a uma função.

Para ela função sempre tem o que se pode discutir é sua natureza.

Onde está o profissional dentro do projeto?

Você é capaz de fazer algo desligado dos seus valores? Da sua identidade? Como roupa para periguete, por exemplo.

Falou da Lougerie.

Curso da PUC pretende ser meio a meio (teoria e prática).
ARAGÃO, Irina. Entrevista realizada com Irina

Aragão, em 21 de outubro de 2015, na cidade do Rio

de Janeiro, com 1 hora e 15 minutos de duração.

Entrevista concedida na Kopenhagen do Largo do Machado.

A fala dela é que os cursos de design "agora" tem habilitação em moda, MAS CONTINUAM SENDO CURSOS DE DESIGN. E insiste no termo habilitação. Cada um fala uma coisa.

Ela fala que ainda não falaram nada sobre usar "habilitação" na PUC RJ, que ainda pode usar. Então fala para o aluno: você não está fazendo faculdade de Moda. Você está fazendo faculdade de desenho industrial que tem habilitação em moda.

A noção de projeto se dá bem no básico no Projeto I e ll a partir de uma metodologia desenvolvida pela Ana Branco.

A Irina assume a partir de Projeto III e ela foca no que se faz no mercado. Isso já acontece há 8 anos dentro da PUC RJ. Só nos conteúdos avançados que os alunos acessam outras habilitações como moda, mídia digital, gráfi$c o$, produto etc. Os trabalhos são sempre em grupo, pois tem 40 alunos por aula, não dá tempo. Além disso são alunos com interesse em moda, produto, gráfico todos misturados e isso inviabiliza a orientação individual. São 10 créditos, 6 de aula com a Irina e outro professor e mais 4 horas de outros conteúdos como Ergonomia, Comunicação Visual, mas dentro de projeto. Agora as 6 horas são voltadas completamente ao ato de projetar.

Projeto I e Il é mais geral, não é focado em uma área. (Falou em uma Renata de Projeto I e II).

A Irina está na PUC RJ há 13 anos. Há 8 anos há uma nova grade curricular para o design.

Projeto I e II utiliza o termo "iscas". Ela se incomoda com o uso do termo "iscas" que significa ir para a pesquisa de mercado, academias de ginástica, escolas, creches e serve para buscar oportunidades de projeto. Essa pessoa que vai para o mercado é chamada de "INTERCESSORA". Ela não simpatiza com esses termos.

Depois dessas disciplinas os alunos vão para Projeto III com a Irina. Ela diz que os alunos sentem uma diferença muito grande em termos de metodologia (É! Parece que cada um fazer do seu jeito é geral em termos de noções de Projeto dadas dentro das faculdades SP-RJ). Para ela, na aula dela, o interessante é o desenvolvimento, os mock ups, os modelos volumétricos, então ela acha bom até outras disciplinas focando em outras visões teóricas de projeto (a coisa das 4 horas) e ela ter as 6 horas exclusivas para desenvolvimento de projeto. Trabalham com tema no Projeto I e Il e essa ideia de briefing para ela é até boa porque eles já chegam no Projeto III para fazer projeto direto, porque já tem uma noção de como seguir um briefing e aí o tempo todo é dedicado a projetar. 
No Projeto III eles ainda não são maduros para chegar em um protótipo, mas é um exercício e dependendo se um grupo é muito interessante (e interessado) vai para frente.

Falou da semana de design da PUC RJ. São só projetos indicados pelos professores, os melhores projetos. Em geral são projetos de conclusão (TCC) e projetos avançados. É raro projeto básico entrar porque a maturidade é pouca, não conseguem sair do modelos [mock up $\rightarrow$ modelo $\rightarrow$ protótipo]. Ela acha que unir as diversas habilitações deu melhor noção de projeto aos alunos de moda, pois depois disso, eles conseguiram começar a chegar nos protótipos que, segundo ela, antes não chegavam.

As alunas de moda levaram o modelo para o sapateiro e teve caso em joalheria também na semana de design que mostraram trabalhos de moda mais maduros. Ela considera a dinâmica de trabalho envolvida na semana de design muito boa, porque os alunos se esforçam. Ela afirma que é difícil um aluno de produto que consiga terminar alguma coisa em produto para a pouca experiência que tem com qualidade.

Antes davam aos alunos um tema com subdivisões de briefing.

Nesse semestre 2015/1, apresentaram 3 temas e as demais orientações do trabalho, depois de explicadas, são enviadas por email.

Autores que ela utiliza: BAXTER, VOLPINI [Javer Wilson Volpini] (para a parte de materiais???), usou Bruno Munari mais no começo. Mas o Baxter hoje é o mais objetivo, dá exercícios como brainstorming. Fala que os alunos não lêem, mas indicam e passam pela transmissão oral. Em aulas teóricas [slides], mostram aos alunos que todos aqueles termos como intercessor, isca não fazem parte do "nosso" universo.

No universo do design de mercado fala-se em USUÁRIO, PÚBLICO-ALVO (eita, mas moda fala disso!). Prezam linguajar e conteúdos de design.

\section{ETAPAS}

BRIEFING 2015/1 é dado a partir de tipos de produtos que os alunos são orientados a desenvolver

2 PRODUTOS PARA PP E 2 PRODUTOS PARA MODA

PROJETO DE PRODUTO: objetos e sistemas de higiene pessoal; objetos e sistemas para limpeza não doméstica [empresas, limpeza pública]. Tinha também um auto falante, mas ninguém quis pegar.

MODA: uniforme para comissário de bordo aéreo; uniforme para quem pratica limpeza profissional.

12 projetos por sala criados por 42 alunos (grupos em 3 ou 4 ).

Desde o começo discute com os alunos o que eles entendem por etapas de projeto. É interessante como isso é discutido no design e na moda não.

Os alunos acham que começa pela pesquisa. Ela diz que antes da pesquisa tem outra etapa de verdade, a proposta. Alguém que te chama, te convida e vai te dizer uma questão, um problema para um oportunidade de projeto.

Alguns clientes entendem o que é um briefing, outros não. Então a aula dela começa explicando o que é um briefing, que ele sofre ajustes, que estes são importantes, quais as responsabilidades de quem contrata, começa dando exemplos, onde maus entendimentos podem afetar o briefing, e os conteúdos do briefing.

Há um briefing genérico, mas que de acordo com a especificidade do projeto, você tem que abrir um briefing novo. Não é engessado, não é receita de bolo.

\section{LEVANTAMENTO DE DADOS}

É apresentado depois do briefing. O que compõe o levantamento de dados? Fala da ambientação (painel), posição do produto no mercado, segmentação demográfica (tudo, tudo, tudo...não disse mais muitos itens, por isso é importante ler o BAXTER!) São vários itens e diz que os alunos ficam com paura. Parece lógico quando está no slide, mas não é de executar.

FASE DE EMBASAMENTO

Pesquisa, levantamento de dados, similares, análise de similares, análise de correlatos. [ANÁLISE DO PROBLEMA (LÖBACH, 2001: 143).

\section{PROCESSO CRIATIVO}

Tem que ter um CONCEITO, que é o resultado da pesquisa. Então o briefing tem que estar te dando alguma informação que já te direciona para alguns caminhos para resolver a oportunidade de projeto.

A partir daí o aluno já pode começar a criar coisas, considerando os elementos do [X? = não deu para ouvir... Essa é a $1^{a}$ FASE. Seria a geração de ideias $=$ geração de alternativas (LÖBACH, 2001: 150-153).

\section{$2^{\text {a }}$ FASE}

Começam a ser analisados os fatos limitadores do projeto. Aí eles começam a cortar o que já estava sendo criado sem muitos critérios, apenas considerando [uma ideia inicial de projeto? = não deu para ouvir]. É aquela coisa do diamante, abrir para fechar, abre e fecha. $O$ Baxter trabalha assim como o diamante, como um funil ele abre a pesquisa e depois fecha segundo critérios limitantes.

A $2^{a}$ FASE seria $\circ$ ajuste das ideias, AVALIAÇÃO DAS ALTERNATIVAS (LÖBACH, 2001: 154).

\section{Depois disso viria a}

\section{FINALIZAÇÃO}

Que inclui o desenvolvimento de fichas técnicas, desenho técnico.

Vai fazer mock up, modelo, protótipo ou quem não tem vai trabalhar em escala. 
Ela define protótipo como a peça acabada, quase que o início de uma produção, já é a final. Tudo feito idêntico ao primeiro da série, dimensão, detalhes, material, mas ainda pode sofrer ajustes. $O$ que sair disso é o protótipo que será o que a produção irá seguir.

Antes disso eu tenho o mock up, eu rabisquei, esbocei, mas não tenho volume ainda. Estou escolhendo o material e vou construir um primeiro a partir do desenho, mas tem a ideia de ser rápido para colocar a ideia em prática.

Mock up = tela em papel, morin é depois. Ela chama de mock up mesmo, não de tela. Depois vai ajustando e vai para o tecido.

Ela conta que tem rendimento maior alunos que já tem alguma intimidade com o produto que está desenvolvendo. A prática da docência permite perceber que o aluno que tem contato com o design por meio das próprias relações profissionais tem um desenvolvimento melhor em sala.

\section{AUTORES}

Conhece autores de projeto em moda?

Renfrew e Seivewright ela desconhece. Jones e Treptow ela conhece. Ela contou que uma galera da UFRJ queria fazer o curso de 1 ano de Estilismo do Senai e que era concorrido que tinha uma aura em cima disso. $O$ sujeito se formava estilista.

Ela me diz: sabe o que me incomoda na moda mesmo? A linguagem.

Os processos podem ser semelhantes, mas as palavras que a moda usa são vazias, inspiradas em editorias de moda [portanto mudam sempre] e cita como exemplos observações a respeito do público alvo, da persona (mãe de alguém ou alguém da mídia, pior ainda)...todo mundo é elegante, minimalista, clássico, sofisticado, arrojado e não sabem muitas vezes nem sabem o que estão falando.

Ela pergunta ao aluno: o que você quis dizer? Porque todos dizem a mesma coisa. E afirma que são todos alunos de moda [puta! Isso queima o filme].

Outra confusão constante: linha e coleção. Diz que os alunos se enrolam quando vão discutir verbalmente o trabalho com os professores.

\section{Ela define Coleção é o número de peças e Linha são as subdivisões que} uma coleção pode querer ter.

Coleção capsula que é marketing e ela considera esses jargões são uma baboseira (que nem icônico), fresh, mas o que é um público fresh?

Eu pergunto a ela se acredita que parte do problema se deva às mídias de moda e ela concorda. Acha um saco isso. Critica que parece que as pessoas normais vestem só isso e isso não condiz com a realidade.

Ela fala que nunca aceita um projeto que preze a estética pela estética. Tem sempre que estar pautado por uma situação de uniforme, pijama, não tão engessado pela estetização que a moda propõe.
Os alunos reclamam e ela rebate que moda não é só o glamour de passarela, ainda mais em uma cidade como o RJ com 7 milhões de habitantes. Ela fala para os alunos que se trata da verdade do dia a dia, de seres humanos e não da fashion week.

A ideia é apresentar problemas interessantes de modelagem que estão aí para resolver, como maiôs para senhoras para exercício como hidroginástica, natação. As alunas foram pesquisar nas academias de maneira muito séria, fotografaram, desenharam, costuras, modelagens, cavas, tecidos. Ela fala apaixonada sobre o trabalho.

O bonito tinha que ser um resultado final, mas eles tinham que ter prioridades anteriores a isso.

Questiona saltos insalubres.

Ela não acredita na parte teatral, lúdica da moda. Reclama que aí você tem dores e deformidades. Ela tem uma visão pautada pelo design de forma clara. E cita Lipovestky que "você tem produtos para todas as camadas e com bolso e gosto que cada camada forma para si." Não se trata de alta moda para todo mundo.

Vestir para ela já é uma demanda. Bem o mal pelado você não vai sair por aqui. A gente precisa vestir.

O primeiro problema que o designer de moda pode resolver é vestuário para pessoas e com questões reais. Há problemas sérios até hoje negligenciados.

Ela acha que o briefing tem que prevalecer (é lógico) porque calçado confortável não dá para ter salto de $15 \mathrm{~cm}$, falando de um trabalho de alunos da PUC RJ.

Também fala sobre os desenhos que são lombrigas. Para ela incomoda muito essa coisa que não é real. Essa coisa que é só para meia dúzia e que tem [necessariamente] um glamour em torno que não representa a massa, mas é somente uma forma de distinção, de hierarquização [pois é, é moda e incomoda ela ter sua lógica própria].

Resultado da pesquisa de body scanner - a pesquisadora passou o link para ela. Aí falei dos manequins da Draft.

Falou dos trabalhos para os comissários de Projeto III. As alunas fizeram uma ótima pesquisa mas há problema no desenho. $O$ desenho não ajuda. Fazem croqui de uma modelo alta e magra e uma saia justíssima e ela fala para as alunas: minha filha, como é que a aeromoça, uma agente de segurança vai correr com essa saia? Na ponta do pé? Horrível...o desenho não ajuda.

A maioria optou por macacão com saídas completamente diferentes (mas uniformizou os trabalhos dos alunos, pois todos fizeram macacão). São 18 itens para a comissária da TAM em um uniforme. Como é que você faz essas combinações com menos peças e isso tem uma série de consequências. $O$ macacão trouxe a possibilidade de brincar e compor. Mas estão todas desenhando sobre o manequim bacalhau, segundo ela...esguio. 
Estilista baiano da faculdade do Recôncavo citou etapas de projeto de um jeito sensacional. $O$ cara era estilista formado, mas citou a partir das etapas do design. E não era um estilista glamour...era um nome normal, segundo ela. hihihihi

Estilismo mais a ver com a metodologia. $O$ estilismo se aproximou mais da ideia de projeto.

Ela diz que o próprio design pega pouquíssima coisa da moda para compor a sua metodologia. O termo "persona" e "moodboard" foram engendrados pelo design. E ela diz que em design "a gente não faz isso". Até usava moodboard, mas por outras razões.

Em design é sempre usuário ou público-alvo e este último está diretamene ligado ao mercado. Ela pede para fotografar pessoas comuns (o monstrinho que eu faço).

Nomenclaturas, pessoas, mistérios no saber fazer aparecem ao longo do tempo [como justificativa de especialização, talvez reserva de mercado] Ela concorda com o movimento complexo da moda se aproximar da arte do design conforme sua necessidade de constituição de capital simbólico.

Formação ou pertencimento é estar no campo? Você ter uma [boa] formação significa construir...o fato de você ter escolhido aquilo significa você ter construído dentro de estímulos, dentro de bagagens, dentro de conteúdos, que não eram conteúdos para todos. Bourdieu novamente, formação de gosto.

Lane $=$ Não tem um preconceito também com essa questão da função social do design?

Irina $=$ Não, ele falou não para mim. $E$ eu adorei que ele falou não para mim [ela se refere ao engenheiro que orientou seu TCC na UFRJ quando ela pedia para fazer joias]. Ela diz que argumentou e levou materiais durante 2 semanas, pois queria fazer joias, Ricardo Wagner [acho] era formado em engenharia, o contexto era década de 1980. Ela conta que ele foi super honesto: sabe porque eu não quero que você faça isso? Porque eu simplesment não posso te orientar. É um assunto que eu desconheço completamente.

Irina $=$ quando ele falou isso, eu fiz um eletrodoméstico. Eu achei ele honeso. $O$ que acontece hoje, aqui, agora é que quem não conhece o campo, começa a menosprezar o campo, e diz que vê muitas vezes professor dizer que não vai orientar determinado TCC porque o "grau de complexidade é baixo"

Ela sempre foi de produto desde o início da faculdade. Podia fazer cadeira, trator...ela ri. Como é que você foi para a joia Irina?

Ela orientou várias já, inclusive a que a substitui na Amsterdã Sauer.

Ela conta que se interessou por joias na faculdade ainda. Ela não se acha uma contradição [eu praticamente sentencio] porque foi estudar joia dentro de um contexto racionalista de design. Ela diz: eu, não [é de uma elegância e firmeza]. E complementa, dizendo que acha totalmente pertinente porque as demandas que a sociedade faz....citando Marx diz: que a mercadoria, para ser mercadoria pode vir de uma necessidade do estômago, como de uma necessidade da alma.

O dito supérfluo é o que mais vigora na sociedade capitalista e o que fala mais com a alma. $O$ adorno vai falar de algo que aquele que não pode fazer expressa usando algo do designer que expressa.

O valor vai sendo atribuído pela sociedade, o ouro não sabe que era ouro. Ouro $=$ divindade solar e Prata $=$ divindade lunar. $\mathrm{A}$ liga de cobre era mais valorizada, mas era mais difícil de trabalhar e oxidava.

Se o aluno não sabe o que que é briefing ele não faz ideia de onde design pode se inserir linteressante tomar o conhecimento de um termo como conheci ento de un conceito a importancia dada ao nome/conceito]. Faasil da função do designer. Diz que pensam mais na função estética. 
OLIVEIRA, Izabel Maria de. Entrevista realizada

com Izabel Maria de Oliveira, em 25 de outubro de

2016, na cidade do Rio de Janeiro, com 55 minutos de duração.

Em 2007 a habilitação em moda foi criada pela PUCRJ porque havia um interesse dos alunos que estavam chegando e que já vinham dos cursos de Design Visual e de Design de Produto, além de um mercado detectado para esse egresso no RJ.

Ela fala muito sobre o formato do curso que tem 4 especializações. É muito bom se eu focar nesse curso que se pauta pela prática de projeto.

Ela fala de um componente de metodologia, conceituação e ferramentas que se aplica a qualquer tipo de projeto.

Em Projeto 5 os alunos precisam chegar a um estudo mais aprofundado do detalhamento e distribuição, estudando o material, desenho técnico e sistemas de produção específicos.

Tem alunos que procuram a PUCRJ, mas querem fazer só moda e voltada ao vestuário.

Para ela é difícil descrever as etapas porque até o sexto período a prática do curso é toda transversalizada e complexa. Só se especializam após o sexto semestre e além disso ela nào é especializada em moda.

Lá na frente quando entram em contato com o Projeto de Moda propriamente dito, existem duas visões fomentadas pela PUCRJ. Uma que prioriza o modelo de projeto de coleção. Isso dá uma identidade maior ao produto de moda, como sistema de produção, cadeia têxtil e delimita mais a metodologia com um processo e ferramentas mais claros já legitimados pelo campo. E tem uma outra linha que argumenta que os tempos são outros e não se trabalha só assim. Esse sistema é válido, mas existem outras vertentes que estão surgindo, estão aparecendo e pode levar a uma ideia de ruptura da ideia do sistema de coleção.

Esse outro argumento é que o sistema de coleção limita o processo criativo mesmo até trazer outras questões como os novos ma 列 tão surgindo aí que mudam o campo da moda.

Esse conflito se reflete na metodologia do final do curso. Um modelo tem uma metodologia mais marcada com um passo a passo, com briefing, número de peças, temática etc.

Em contrapartida, na outra disciplina que é a do Projeto Final, o aluno vai desenvolver sua própria metodologia. Ele não tem uma metodologia pré-determinada. Ele vai construir o seu processo a partir de questões que ele traga para o campo da moda, desde uma temática, segmentação, materiais, questões que surjam para o vestuário.
Isso tem a ver com o último currículo da PUCRJ que entrou em vigor em 2007. Sempre discutirarm o que era moda, o que era o design de moda. Ela afirma que regularizada como design a moda é uma área recente, muito nova. E que é muito normal, ainda mais em um momento com muitas mudanças. Surgem assuntos novos em termos de abordagem de design. E a moda está "se discutindo" em meio a essas mudanças.

O aprendizado da metodologia de que há um escopo amplo e que diz respeito a qualquer projeto de design considera também obviamente que existem as suas especificidades. Quais são as especificidades?

É o caminho da discussão. Quais são as especificidades no raciocínio do design? Como eu penso um produto de moda? Como eu estruturo meu pensamento para fazer o produto, mas o que tem uma particularidade. Inclusive essas particularidades vão mudando com o tempo, mas é majoritariamente tecido, né?!

Ela fala que a Ana Luiza defende a coleção sistema porque entende a relação do consumidor com aquele produto e quando a Adriana diz que não tem que se engessar nesse formato, tem que abrir a cabeça para um trabalho mais conceitual, ISSO É ESTILISMO!, dessa investigação mais voltada à experimentação do produto de moda ela também está pensando em uma outra relação das pessoas com o consumo.

Para ela a fase mais importante é a da problematização quando se definem as metodologias, as ferramentas, articulação de dados etc. É uma fase muito rica que exige muito do aluno.

A síntese vem da análise e a análise e métodos de análise são muito complexos. O que eu vou analisar e para que? Para quem? Com qual objetivo? Esse início da problematização e da análise para Izabel é a base para poder começar a desenvolver a fase de estudos e alternativas para aquilo que é mais conhecido de design.

Ela fala de um tal de Bernard Shawn do MIT que foca mais no processo do que na metodologia, isso é bem interessante. Fala das dificuldades, onde dá nó e até da insegurança do aluno e como orientá-lo em momentos difíceis do projeto.

Cita também "Designly ways of ?" de Nigel Cross. Ele trabalha com a hipótese que surge na fase da problematização.

\section{RESUMO DEPOIMENTO IZABEL MARIA DE OLIVEIRA}

Há duas visões acerca de projeto em moda na PUCRJ. Uma que prioriza o modelo de projeto de coleção voltado ao sistema de produção e à cadeia têxtil delimitando mais a metodologia com um processo e ferramentas mais claros já legitimados pelo campo. Outra argumenta que trabalhar somente pautado pela metodologia não atende satisfatoriamente a questão de projetar moda nos dias atuais. Essa vertente pode conduzir à ruptura da ideia do sistema de coleção (OLIVEIRA, 2016). 
Esse último argumento se baseia na ideia de que o sistema de coleção voltado somente à metodologia limita o processo criativo, a pesquisa de materiais, a experimentação de linguagens que não são tão tradicionais, além de outros aspectos que estão surgindo (OLIVEIRA, 2016).

Em contato mais próximo com a primeira visão de projeto, o aluno desenvolve seu trabalho passo a passo, com briefing, número de peças, temática etc. Em outro momento, pautado pela segunda visão, na disciplina de Projeto Final, por exemplo, o aluno é estimulado a desenvolver sua própria metodologia. Ele não tem uma metodologia pré-determinada. Ele vai construir o seu processo a partir de questões que ele traga para o campo da moda, desce uma temática, segmentacão, materiais e outras questões que surjam para o vestuário (OLIVEIRA, 2016).

Essa metodologia mais independente tem caráter mais amplo e considera que existem especificidades no campo do design de moda que levam em conta como pensar um produto de moda. Essas especificidades vão mudando com o tempo (OLIVEIRA, 2016).

Até certo ponto, Izabel Maria de Oliveira define o que o estilismo já fazia quando a moda era compreendida como campo autônomo. Seria de certa forma um retorno ao estilismo. A sugestão de metodologias pautadas por etapas mais rígidas veio do campo do design. Então porque continuamos a ser design se há interesse em um resgate da prática que já era realizada antes de o campo da moda ser encampado pelo design?

OLIVEIRA, Izabel Maria de. Entrevista realizada com Izabel Maria de Oliveira, em 25 de outubro de 2016, na cidade do Rio de Janeiro, com 55 minutos de duração.
SUDSILOWSKY, Sérgio. Entrevista realizada

com Sérgio Sudsilowsky, em 20 de outubro de 2015 ,

na cidade do Rio de Janeiro, com 44 minutos

de duração.

Ele é desenhista industrial formado na UNEB e nunca tinha pensado em trabalhar com moda. Ele se habilitou em PV e PP, modelo da ESDI. Se encantou por estamparia e padronagem por meio de uma cadeira de azulejaria que ele teve na faculdade.

Foi orientado pelo Gustavo Amarante Bomfim no Mestrado. Estudou espaço e arquitetura moderna. Sem bolsa ele prestou o concurso do Senai Cetiqt orientado pelo Gustavo Bomfim. Ele precisava trabalhar e passou para trabalhar no curso (em formação) de design moda do Senai Cetiqt.

O Gustavo Bomfim tinha acabado de ser um dos relatores da lei de diretrizes de base para o design (dos decênios para design) junto com a Rita Couto e o Cauduro (da FAU USP). Aparentemente foram eles 3 que fizeram as diretrizes de regulamentação dos cursos de design no Brasil.

Então no Senai em 2001 o curso técnico virou curso de Bacharelado, mas era para ser tecnológico. Isso porque o curso era mais robusto, poderia se bacharelado. Para isso precisavam de mestres de doutores, por isso ele entra lá no Senai Cetiqt.

\section{Professores de projeto}

A disciplina se chama projeto no curso de moda. $O$ curso de design de moda do Senai Cetiqt foi o primeiro no país a ser autorizado com o nome Design de Moda. Foi o primeiro autorizado a emitir diploma com a nomenclatura Design de moda.

Ele foi para lá também para ajudar a organizar o curso para que ele tivess a porcentagem de design, de moda em sua carga horária. Inclusive a cadeira de projeto foi reorganizada. Desde sua gênese ele foi um curso de Design de moda e não de Moda ou Estilismo.

Influenciado pelo Bomfim a ideia era que moda era um produto, daí a influência do design de produto. Flávio Sabrá também era estilista, formado em Estilismo pelo curso técnico do Senai e foi uma das figuras importantes na transformação do curso técnico em um curso de graduação em Design de Moda. Outra figura importante foi Mônica Queiroz, formada em arquitetura pela UFRJ, mas atuava como estilista.

A Deborah Christo entra para substituir o Sérgio quando ele vai para São Paulo atuar na UAM.

A maioria dos professores era artista, mas havia alguns arquitetos e designers também, mas quase todos havia passado pelo curso técnico de estilismo do Senai. Processo de endogenia "ninguém melhor do que quem eu formei, para multiplicar esse conhecimento" 8’26” 
Ainda havia um discurso forte de estilismo dada a quantidade de professores artistas que lá atuava no curso de estilismo. Havia também confusão entre projeto e desenvolvimento de coleção.

$O$ projeto era o eixo central. Assumiram nomenclaturas mais ligadas ao design como projeto e indústria, projeto e varejo. Ele recebe uma proposta em 2004 para ir para São Paulo (UAM - design gráfico. Ele vai para a reformulação do currículo da graduação em design gráfico acho que do Senac junto com a Priscila Farias. Deu aula no Senac de lá também 12'15”). A Deborah Christo assume o lugar dele na coordenação do curso de design de moda do Senai Ceniqt

Ele critica muito a arquitetura moderna no mestrado dele e na FAU USP não colou. O Bomfim o convida para voltar e fazer o doutorado na PUC RJ que havia acabado de começar e ele volta, mas o Bomfim falece no final de 2005 e ele acaba sendo orientado pela Denise Portinari com quem ten vergências de pensamento e abandona o doutorado na PUC RJ.

O Senac queria ter profissionais das principais unidades deles para fortalecer o Mestrado em Design em São Paulo.

No curso de design de moda do Senai Cetiqt do RJ houve uma doutrinação do conceito de projeto a partir da ideia de design de produto. Foi sendo construindo um conceito de projeto e fazendo um paralelo o tempo todo entre as nomenclaturas em moda e as nomenclaturas em design.

\section{ETAPAS DE PROJETO EM MODA - INTRODUÇÃO!!!}

Problematização - divisão dos problemas em partes menores... era usado o Bruno Munari, pois apesar de antigo era a forma mais fácil de "aluno de moda" entender e fazer as comparações para o desenvolvimento de uma coleção, principalmente solução, teste de possibilidades, prototipagem e a documentação da coleção, a documentação dos produto desenvolvidos.

Usavam o termo "peça piloto". Usavam a nomenclatura de moda porque os professores entendiam que os egressos iriam atuar em um mercado de confecção, então abordavam as duas nomenclaturas em paralelo.

A questão do problema não é contemplada na moda. Como faziam? Mudaram isso em 2009. Mudaram para "problema" ou "oportunidade de projeto" ao invés de "detecção de problema". Essa adaptação mostra que a moda realmente demanda a partir de suas especificidades.

Eles faziam muito a transposição do repertório da moda para o de design, porque os alunos tinham um bom repertório em moda já.

AUTORES

Ele conhece todos os autores de design, que inclusive eram referência do curso de design de moda do design.

Deborah Christo usavam muito.

LIVROS DE PROJETO EM MODA
Treptow - era parte da bibliografia básica.

Sue Jenkin Jones - conhece, mas no Senai não era abordado.

Simon Seivewright e Renfrews conhece e usava todos dessa coleção na sua bibliografia no Senais, mas titubeou quando falei o nome do Seivewright que parece sempre ser o menos conhecido.

Ele conseguia usar esses livros, mesmo que fosse pela transmissão oral, a partir de 2009 quando ele volta para o RJ e de novo ele faz outro concurso para a cadeira de Projeto Final e reformulam de novo o curso. Eram 13 professores de projeto e de TCC. E a reformulação veio de cima para baixo, do regimento do TCC para baixo e foi descendo de indústria, logística, varejo, metodologia do projeto, conceitos de design que eram fundamentos do design no primeiro período.

Em 2010 a Deborah sai (fica de 2008-2010) e ele assume novamente a coordenação em 2010.

Ele fazia parte do grupo de coordenadores dos cursos de moda para discutir qual área "era maior", design ou moda. Ele é designer e tinha lá o grupo "Moda como campo do saber". Lá ele precisava defender a visão do Sena que era manter a autonomia do design "pelo menos nos órgãos oficiais" porque havia sido uma luta tão grande que o design tinha [passado] em 1998, 2000, 2004...e ele admite que a moda nasce autônoma.

\section{VEJA O DISCURSO DE LUTA SIMBÓLICA PELO PODER.}

Para ele naquele momento foi politicamente mais importante, mais interessante a moda entrar no design. Para quem?????

Ele que defendeu a posição do design hoje entende o "Moda como campo do saber" não quer propor design ou moda. Era Design e Moda, quem quisesse continuar como design continuaria e quem quisesse se tornar moda se tornaria. Isso soa como um contra senso uma vez que moda nasce como moda, autônoma.

\section{LER RELATÓRIO DA FASM SOBRE A MODA COMO CAMPO DO SABER.}

O Senai questionou sua participação no grupo "Moda como campo do saber". Ele mostrou que não era anti design a posição do grupo da Tita e argumento que ele tinha que estar lá como um curso de design justamente para saber o que estava se passando.

Desde agosto de 2014 ele se afasta da moda e hoje coordena um tecnólogo em gráfico. Ele tem proximidade com moda por causa das disciplinas comuns na UnigranRio, mas não participa de perto. Também participa da comissão de avaliação dos cursos, então teve que se afastar dos cursos de moda.

Ele não acha que todo mundo deve se entender como designer. A moda para ele é maior como um sistema, e serve quando as pessoas não querem trabalhar com projeto/produto, quando querem trabalhar com história, filosofia, história, comunicação da moda.

A ESDI tem uma resistência muito grande a trabalhos em moda. A Gisela 
Monteiro faz doutorado lá, mas com o subterfúgio de ser aluna da graduação e mestrado da ESDI anteriormente e tb de comparar em sua tese a ideia de coleção em moda e coleção em design.

No $\mathrm{RJ}$ as escolas de moda sofrem uma influência muito forte do design e por vezes da ideia de design racionalista.

Ele fala que quem faz projeto é designer. Por isso quem faz produto faz design de moda. De 2004 é só design, nem design de...(mas acho que é de 2010), é difícil achar essa lei.

Ele não acha que o design não exerce poder sobre a moda, nem é reducionista. A assinatura design de moda não é um exercício de poder, mas mais uma possibilidade. Para o Sérgio ele é um designer de formação ampla. Tá mas pq ter um curso de moda só? Isso torna o curso um tiro no pé e retorna a questão de se de repente não deveria haver somente tecnólogos em moda.

Farm e Osklen anuncia como designer de moda, mas no ESTILISTA (diretor criativo) da Osklen é o Oskar Metsavah. O Sérgio não gosta do nome estilista, mas entende o Oskar usar o nome assim no caso da Osklen.

Esses conflitos e confusões em torno dos nomes e que são importantes e mostram que há disputa por poder que atravanca o desenvolvimento da moda. CÓPIA

A cultura da cópia ainda é muito forte. Associar o projeto somente ao novo, à inovação.... partir do momento em que tem um passo a passo, tem que resolver "aquele problema" (oi? Estamos falando de cópia na moda), enfim, transformar aquele negócio lá e criar o "vendível" [vendável sic].

\section{Muitas vezes para justificar um amplo mercado de atuação para seus} futuros alunos os professores tentam legitimar a cópia como uma atividade projetual.

O cara é formado em projeto, mesmo que não seja de autoria dele, ele vai ter que fazer com que a costureira e a modelista entendam e que outras pessoas envolvidas no processo entendam. Então ele entende que a cópia contempla a noção de projeto.

FORMA E FUNÇÃO

Para ele na moda isso é muito mais fluido e complexo. Para ele as funções estética e simbólica são consideradas funções. E essa é a visão dele no Senai Cetiqt inclusive fomentado por linhas de pesquisa da escola. A função tem vários aspectos. No Senai Cetiqt os professores passavam para os alunos a múltiplas possibilidades dentre as funções, principalmente na moda onde pode-se trabalhar múltiplas superficies.

Não bate com o discurso racionalista ainda hoje sustentado pela maioria dos designers e arquitetos que fazem piadinha quando se fala em moda. Há um ruído. A coisa [função estética e simbólica] parece que só é reconhecida por designers que atuam no campo da moda.

Mas é uma visão de função muito diferente da lógica do design de pro- duto que se sustenta no Senai, inclusive politicamente. Ele fala de pessoas, suportes e práticas múltiplas na graduação e pós do Senai Cetiqt em moda que fomentaram a troca com a Kathia Castilho, a Doroteia Baduy, a Mônica Moura sobre o fazer e pensar projeto de uma "forma muito maior" que forma e função.

FALTA REFLEXÃO SOBRE PROJETO EM MODA

Hoje ele acha que já tem referências, pessoas, congressos (Colóquio, $\mathrm{Ci}$ mode), livros da Letras e Cores, a revista Dobras...LIVRO SOBRE PROJETO DA LETRAS\&CORES?

Em geral, os entrevistados confundem reflexão em moda com reflexão sobre projeto em moda.

Ele afirma que hoje tem uma melhoria do aluno que ingressa num mestrado e doutorado. Que hoje é mais fácil as pessoas falarem línguas e que tudo isso sustenta essa melhoria. 
STRADA, Nanni. Entrevista realizada com

NanniStrada, em 06 de dezembro de 2017,

na cidade de Milão, com 1 hora e 38 minutos

de duração.

Hai fato la Professoressa a Contratto di Progetto presso Politecnico di Milano

No início da entrevista ela me falou que a universidade pública na Itália como o Politecnico propicia o desenvolvimento do componente humano no alunado. É um espaço interessante para desenvolver uma competição saudável e a troca por meio do aprendizado entre os alunos que estão ali e que ingressarão em um mercado que recebe mais formandos do que realmente absorve a exemplo da Inglaterra, França e Brasil.

Nanni Strada conta que encontrou Doroteia (Baduy Pires) em meados dos anos 2000 durante um trabalho para o qual haviam sido convidadas para atuar como docentes e banca de concurso de professores de moda na UBA de Buenos Aires, na Argentina. A comissão examinadora deveria avaliar esses professores e proferir um julgamento a pedido da instituição que desejava renovar seu corpo docente. No total a UBA chamou três professores: Doroteia do Brasil, a Nanni da Itália e Alan Neumark da UBA. Umas das candidatas a ser avaliada era Andrea Saltzman que deveria ser aquela que viria a assumir a cátedra de Projeto.

Nanni conta que a rotina de trabalho foi de uma semana onde permaneciam fechados em uma sala sem contato com os demais professores da UBA afim de não serem influenciados. Nesse sentido o processo foi muito rigoroso. E, nesse contexto, naturalmente Doroteia e Nanni se tornaram amigas. Nanni ficou surpresa com o fato de que Doroteia já conhecia o seu trabalho. Doroteia conhecia o trabalho de Nanni e já pesquisava sobre ela antes de conhecê-la de fato. Doroteia estava felicíssima em encontrar Nanni Strada.

Doroteia imediatamente disse que queria fazer uma pesquisa de doutorado sobre o trabalho de Nanni, seu método de trabalho, mas sobretudo, sobre seu método de ensino. Nanni afirma que Doroteia era uma pessoa de grande intuição, além de inteligência e, afirmava que o método de ensino de Strada era "antiacadêmico". E Nanni repete "anti acadêmico" e isso me impressionou. $\mathrm{O}$ mesmo termo foi usado por uma jornalista muito famosa e importante, Renata Molho. Ela foi jornalista do Sole 24 ore. Ela é uma intelectual, uma mulher muito culta. E ela disse que o metodo de . É o maior valor dele.

\section{Politecnico di Milano}

E Doroteia queria realmente sublinhar/destacar esse aspecto como $o$ aspecto mais importante da atividade de docência de Nanni Strada. Essa era a essência do ensino de Nanni aos olhos de Doroteia, "mas tinha uma razão porque ela era tão inteligente que não fazia nada só por fazer, tudo tinha um propósito". A Doroteia queria propor estudar um método de ensino, torná-lo 
mais metodológico para propô-lo como método de ensino. "Entende a importância disso?"

Te confio que os documentos/textos que ela gerou trata do processo com o qual ela havia se comprometido para o seu doutorado. Então o doutorado da Doroteia que tem um valor extraordinário como material e método permaneceu inconcluso, não chegou à conclusão e essa conclusão poderia ser algo preciosíssimo.

Ela chegou a certo ponto em que me deu todo o material, me enviou. Isso chegou na primavera e pelos próximos dois meses não nos falamos e "você sabe, um lavora, acaba não pensando, isto é, sabe como é né, há tanta coisa para fazer [e quando eu vi] tinham se passado dois meses."

"Quando eu escrevi a ela, ela me respondeu e, infelizmente, me deu a notícia terrivel de que estava no hospital e havia sido operada e eu fiquei desesperada, mas esperava que ela se recuperasse até o último momento, mas..."

\section{PAUSA}

Falamos da FAU, dos orientadores aqui e no Politecnico, do meu tutor aqui.

Ela fala sobre haver o perfil certo para dar continuidade e finalizar a pesquisa de doutorado de Doroteia. Ela se refere a alguém que queira ser docente. Comento que é minha intenção e que sou professora há 12 anos.

Ela me ensinou sobre os tipos de professores na Itália. Professor ordinário, professor a contratto di chiara fama. E ela sugeriu se procuro alguém que entenda de projeto que eu a inclua como uma consultora externa para uma nova pesquisa na qualidade de professoressa a contratto di chiara fama e sugeriu que eu fale com Paolo Volonté.

Ela diz que não sabe se, academicamente, tem um termo apropriado para dizer "consultor externo" ou "orientador externo", referindo-se a ser co-orientadora de uma possível pesquisa.

Ela me oferece, seu eu quiser, se for útil, de pedir ao Politecnico se há um modo de escriver, de documentar que ela é professoressa di chiara fama porque talvez isso seja útil em termos oficiais no sentido de dizer que tem algum respaldo, que tem alguém por trás, além do Volonté. Talvez, institu-

Eu comentei sobre possibilidades de tentar outra bolsa etc. É interessante eu mostrar ao Politecnico que a Nanni é importante para a pesquisa [até porque a pesquisa é sobre seu método de ensino de projeto]. Digo que eu faço um estudo sobre ela, entrevista com ela, gostaria de envolvê-la como orientadora, se fosse possível oficializar como um apoio também a colaboração dela de orientação, ela se predispôs a fazer de boa vontade. Da parte dela, pessoalmente, ela está disposta, mas seria interessante oficializar.

Em seguida, começamos falar sobre MÉTODO DE PROJETO. Peço a ela que descreva passo a passo como se desenvolve o seu método de projetar.
Ela se considera sortuda por fazer parte de um meio, de estar entre uma geração que além de acadêmicos eram excelentes profissionais como Ettore Sottsass e Achille e Pier Giacomo Castiglioni. Segundo Nanni, aquela geração extraordinária tinha reunido professores que além de profissionais excepcionais eram também professores teóricos e intelectuais.

Hoje também é assim. A qualidade do Politecnico vem do fato que ao lado de profissionais de valor há profissionais de docência que são de grande nível. E isso ajuda obviamente também o projeto. Porque o projeto nasce da cultura. Se chama cultura de projeto.

Qual é a diferença entre o designer de moda e o estilista em geral?

$O$ designer vem de um mundo complexo. $O$ design italiano foi feito na maior parte dos casos por arquitetos, de formação em arquitetura. Depois, têm os designers que não vêm da universidade, mas vêm de uma predisposição artística e que possuem uma bagagem pessoal interna. Isso é uma premissa. Isso para dizer que quando se encara o projeto, a primeira fase do projeto é a pesquisa. Essa é a primeira fase do projeto. Agora a pesquisa pode ser de diversas formas, seguir vários caminhos. Pode ser uma pesquisa histórica, antropológica, cultural, ligada a um período, pode ser uma pesquisa de inspiração, isso é, ligada à arte, pode ser a pesquisa da tecnologia. Isso é, o que existe em tecnologia? Qual é a fase mais avançada da tecnologia?

Antes de dizer, quero fazer um vestido assim e assim e assado [e faz um gestual de estar desenhando], a sua motivação conceitual vem da sua PULSÃO [e me pede para escrever essa palavra = PULSIONE], PULSÃO CONCEITUAL. "A minha pulsão conceitual se concentra no interesse sobre o corpo e à destruição daquele tipo de moda de alfaiataria que se formava sobre um corpo e, nos casos mais felizes, era o corpo de uma mulher "ideal" e, nos casos mais infelizes, era no corpo de uma pessoa "normal" que no corpo feminino se exprimia com seios, quadris sempre mais curvilíneo, bumbum, a altura, então você tinha um produto de alta moda que era ideal se vestido por uma mulher ideal e, péssimo, conceitualmente adaptado a um físico não ideal no qual eram destacados todos os defeitos.

Porque se você tem uma mulher com silhueta ampulheta e a veste com uma ampulheta de tecido, ela aparentará um grande bumbum, um grande seio e se torna uma caricatura e, sobretudo, se torna um sofrimento porque a mulher vê um modelo e diz "eu não sou assim". E esta observação, esse conceito é tão real e atual que nós vemos o que conduziu ao conceito da mulher ideal fisicamente, do físico ideal para se vestir que é a anorexia. Porque as garotas são todas magras, não têm mais coxa etc e também porque mudou a alimentação, a educação, o "bem-estar" levou a mudanças, mas sobretudo, porque o modelo ideal do estilista é ter uma attaccapanni (cabide), que representa uma attaccapanni infeliz acima de tudo.

Porque você vê uma modelo que caminha assim [faz uma cara de mal humor, infelicidade], terrível, um modelo negativo.

Agora o meu primeiro objetivo é o de remover completamente a roupa da configuração de um corpo ideal e daquela anatomia que deveria imitar 
aquele ideal. E nesse percurso eu encontrei a solução vendo a roupa como relacionamento e esse relacionamento não pode ser punitivo.

Agora se você enxerga a roupa como um objeto de valor, não de status simbólico, no sentido de que tem qualidades. Que qualidades deve ter a roupa? Ela deve ser "vivível", habitável, não deve te torturar, te apertar, isso vale também para acessórios. Não deve te obrigar a caminhar como se estivesse sobre um trampolim, deve respeitar o seu corpo.

Isso envolve o fato de que a forma deve ser livre. Na geometria por exemplo você tem uma liberdade maior porque a roupa envolve seu corpo, t envolve. Mas se queremos andar além da roupa, do étnico, da geometria oriental, de tudo que pode ser a forma, você tem na roupa uma grande possibilidade de criar e inventar que é a matéria e isso deve ser destacado.

Ela fala da vestimenta performativa de 1900

Qual é o processo de design?

O processo de design cada um inventa o seu, mas tem pontos cruciais. Se você quer fazer design e não estilismo, você deve conhecer quais são as performances e que coisa ela te oferece sobre o vestuário. Se chama ergonomia. Tudo isso parece muito teórico. Ela diz que é algo no processo dela que ela faz instintivamente. Porque para ela o mais importante é essa paixão pelo corpo, por viver bem, por observar como te veste alguma coisa.

Por outro lado, a moda pode ser feita por grandes artistas. Ela afirma que os grandes couturiers eram os grandes artistas. Representavam a criação pura, a beleza dos materiais, tecidos mais bonitos, mas não se expunham os problemas da "vivibilidade" da roupa.

O estilista é um caso a parte, é democrático. Ela fala do modelo inglês e americano quando eu comentei sobre a França na década de 1960. Ela fala sobre o sistema industrial para vestir a massa quando se refere ao estilismo. É o estudo do corte com foco na produção industrial.

Voltando ao processo, além da pesquisa é muito importante a questão do corpo. Como se estuda o corpo? O corpo se estuda cientificamente com o sistema de medidas, tamanhos. Ela fala do sistema de jeans sobre medida de varejo. E comenta da calça que está usando e sua modelagem.

O método para fazer uma moda que veste muito bem é também do estudar combinações físicas. Os americanos sabem fazer isso melhor que os italianos.

Enquanto o estilista é puramente visual, puramente estético. Com uma estética que pode ser muito ligada à expressão criativa e à personalidade do criador e muito ligada à tendência.

Fala sobre a tendência como inspiração e que há também outro tipo de inspiração e cita como exemplo a Prada, elogiando Miuccia Prada que é a mulher mais brilhante da moda italiana porque é culta. Se entende isso pela forma que fala, pensa, como se porta.
Nanni Strada fala do kitsch da Prada e relaciona ao kitsch de Damien Hirst que é de uma ironia feroz e bem executado. Aí ela começa a explicar que tem o altíssimo nível de estilismo nesse caso, da Prada e inspirações mais banais e comerciais como a Dolce \& Gabbana. Nesse sentido, Nanni posiciona sua crítica no âmbito de uma crítica cultural e não moral.

O estilismo é aquele que leva à degeneração da moda gender com todas aquelas porcarias que se vê e quem usa aquilo crê que assume uma atitude anticonformista. Na época da contracultura nos anos 1960 fazia sentido questionar a cultura de gênero, hoje todos aqueles garotos que fazem moda são todos iguais. Essa a tendência atual que incorre na degeneração que o estilismo promove.

Dando sequência no projeto a gente chega ao vestuário que é matéria.

TECNOLOGIA [ela sugere de sublinhar esse item também]

A partir dos anos 1960 e talvez antes no período bélico do século 1900 (19001940) foram inventadas fibras extraordinárias como o nylon. Mas nos anos 1960 houve uma grande implementação, um aporto de novas tecnologias têxteis. Surgiram as máquinas para fazer o collant que Nanni usou para os seus designs.

Vale lembrar que a Nanni fez a primeira peça de roupa sem costura. A tecnologia é aquilo que te permite de usar instrumentos inventados pela indústria, inventados para produzirem com fins diversos, que se você tem intuição, pode usar não para fazer coisas habituais, mas para fazer outras coisas, que te permitam fazer outras coisas que não haviam anteriormente ou que modificam aquelas já existentes em uma direção que é inovadora, isto é, te permitem de fazer inovações. Além disso, aquilo te permite inovar é um estímulo, um instinto, um modo que te leva a ver as coisas em uma maneira muito pessoal. É alguma coisa que te faz intuir uma possibilidade de realizar coisas que ainda não foram feitas. E então é uma parte do processo muito interessante.

Observação (Inciso)

Ela conta que sempre nutriu uma paixão por andar em fábrica e quando desenvolvia alguma coisa para determinada marca ou fábrica ela sempre questionava quantos funcionários tinham. Porque para ela, a quantidade de operários em certo sentido significava uma noção de expansão, de tantas pessoas e que sua roupa seria destinada a tantas pessoas. Claro que se tratava de um impulso emotivo completamente antitético em relação a roupa de alfaiataria. Ela queria uma roupa que vestisse muitas pessoas.

Sobre quantidade de pessoas, ela se refere também ao número de alunos em sala. Que não precisa de tantos, mas se tem, por exemplo, uma classe de 60 alunos e trabalha em grupo, fala-se em 10 grupos que produzem isso a estimula ainda mais, pois nascem muitas ideias novas e interessantes. Segundo ela, os alunos fazem tantas coisas e ela os deixa separados porque fazem muitas coisas diversas.

Agora retornando à Fábrica, o que estimula Nanni estrada é olhar um maquinário e perceber sua potencialidade. "Olha, aquela máquina faz aquela 
coisa! Espera eu a uso para fazer uma outra coisa com aquilo que é transpor a metodologia de um âmbito a outro. Isso pode te levar ao desastre, mas se dá certo te leva a grandes descobertas."

Ela comenta sobre um grande designer alemão, que propõe a metáfora do " bosco come il progetto", chamado Richard Sapper. Ele dizia: "iniciar [empreender] um projeto é como entrar em uma floresta escura." Você pode chegar a um certo ponto e entender que não achou e deve voltar atrás. E este é o projeto.

\section{L'ESPLOSIONE DI CREATIVITÁ}

Quando você chegou a isso, isto é, percorreu...tem a tecnologia, tem o tecido, o material, tem um pressuposto de corpo, junte tudo isso, coloque na sua mochila e comece (se liberte) com o desenho, com a imaginação, com as provas [de roupa], pegando materiais e dobre, gire, esmague. Faça tudo aquilo que pode para chegar a obter uma roupa que é um objeto e que quando é vestido pelo corpo te recompensa, funciona. E, naturalmente, isso é na fase criativa, mas o designer tem também uma capacidade conceitual para entender que coisa acontece, como precisa vestir de acordo com aquilo que faz ou daquilo que está por fazer ou que você quer que as pessoas sintam, isto é, a roupa que respira, a roupa que é feita em sistema.

Ela cita seu trabalho de 1971-1972 que é um guarda-roupa [coleção] e me mostra as fotos explicando: "isso aqui era um sistema que consistiam em roupas que eram colocados um sobre o outro e tudo interagia e havia, por exemplo, a meia, a calça feita como faixas [que se completavam,] era exatamente um sistema. Um sistema, um modo de vestir, na verdade...

Ela cita o diretor de arte Flavio ? que dizia que das novas técnicas industriais nasce um modo diverso de vestir.

Então a criação dessa coleção nasceu a partir de um novo conceito, mas também de novas técnicas industriais. Ela comenta sobre um jeans de Ia feito na década de 1970 e do casaco feito sem forro, sem entretela e como essas peças ainda são atuais.

Fala da tecnologia da máquina de collant. Era uma máquina com 2 cilindros um abaixo e um acima. 47:30"

Fala do uso que fez da elastiqueira também.

Como os estudantes do Politecnico tiveram ensino em design e que fo ela quem levou ao Politecnico, vêem (vanno a vedere) a Shima Seiki que faz jacquard. E, por último, ela diz "obviamente, se alguém nasce criativo, coloca todos esses elementos reunidos e faz uma coisa criativa."

Ela reitera que os projetos que mais despertaram o seu interesse foram aqueles dedicados ao sport, porque além da liberdade do corpo, havia a necessidade de fazer coincidir a "casuística" [conjunto de casos relativos a determinado assunto], elementos muito diferentes. Por exemplo, a motocicleta, eu fiz roupas para motociclistas. Então você tem que pensar na velocidade, que você deve estar protegido. Deve haver próteses, zona de reforço, porque se cai, o ombro, o cotovelo, os joelhos. Se você observar os motociclistas quando descem da moto, caminham como gorilas porque têm as pernas das calças e os cotovelos praticamente dobrados.

Ela criou e desenvolveu vestuário para motociclitas citadinos e não competidores. Então é preciso pegar todas essas variantes juntas sobre que incidem sobre o produto e você deve pegar os materiais especiais, os tecidos especiais, achar as formas que foram especiais, anatômicas e eu gostava muito dessas coisas porque depois me colocava em contato com o mundo das máquinas e para mim as máquinas, como as máquinas de tecido também as motos eu gosto muito como objeto, como potencialidade, como coisa. É uma paixão pelo aspecto físico da máquina.

Ela fala da máquina de costura e como sua "fisicidade"mecânica é fascinante e, também, as máquinas eletrônicas hoje. Ela conta que sempre teve diálogos com os mecânicos dos teares, "não quero assim, quero assado" do seu interesse pela dialética do que pode ser feito ou não e ao fim acabava conseguindo fazer o que precisava para o seu projeto.

Ela fala que esse foi o caso do "manto e a pele". Você vê essas máquinas que fazem essas coisas que transformam uma piloto em um cenário de possibilidade mecânica. Também foi consultora da Rimoldi de máquinas de costura. Eles queriam que a Nanni usasse suas máquinas de forma criativa para fazê-los ver o que se podia fazer. $O$ design faz entender essas coisas.

Os designers da geração de Nanni foram um pouco como Cristovão Colombo no sentido de que andaram sentido o desconhecido. E assim, acreditava-se achar uma coisa e encontrava outra. Ela mesmo achou uma máquina de fazer collant e fez vestidos. $O$ design é também o prazer da aventura, o prazer de inventar. Fazer coisas que, a princípio, parecem impossíveis, mas depois, uma vez que você estabeleceu o princípio ele pode ser reutilizado e servir de modelo décadas depois. Como comparação propõe o manto e a pele e a shima seiki hoje. O princípio é o mesmo, é idêntico.

Sobre percurso do design para Nanni as passagens são aquelas.

Questiono etapas como cartela de cores, se para ela vem antes ou depois de materiais.

Segundo Nanni é um outro aspecto. Aquele é um aspecto que pode ter bases científicas. Ela cita o trabalho de liderança no campo das cores de Clino Castelli e a padronização de cores e o trabalho para evitar estoques.

Agora para ela na moda a cor é completamente emocional. E você tem mais emoção quando é muito sensível a cor. E a leitura das cores é um dos aspectos criativos mais gratificantes que podem existir para o ser humano, do seu ponto de vista.

Ela conta que não tinha interesse nos cadernos de tendência e em seu processo nunca gostou das cores primárias. No manto e a pele ela conta que quis fazer algo de simbólico, mas tinha que se adequar à realidade dos títulos de fios que as máquinas comportavam. Então ela escolhia e o que era próximo, possível. De qualquer forma, uma das grandes paixões de Nanni 
era a cor. A parte emocional da criatividade é a cor e reconhecer a qualidade têxtil e tátil do tecido, a qualidade tátil, isto é, saber ver, por exemplo, que este tecido é muito "inerte", que não tem movimento, é caído, flácido e se refere a uma palha de seda. Ela continua dizendo que com isso jamais fará uma forma, mas a qualidade tátil, ela encontrou a mais extraordinária qualidade tátil no Japão. Os japoneses têm o sentido de qualidade tátil para tecidos, papéis, nas superfícies duras, em tudo. Eles vêm com o tato. A qualidade da superfície de seus produtos também é percebida tocando as coisas, além de visualmente.

Na verdade, se você vai a uma loja japonesa, vê que eles tocam as roupas. O que pode até incomodar a quem vê, uma vez que quanto mais um tecido é tocado, mais ele se desgasta, mas os japoneses têm um senso de qualidade extraordinário.

Agora, ao fim de tudo tem o imaginário.

\section{IMAGINÁRIO}

O imaginário de uma pessoa é aquilo que te porta à imagem estética daquilo que você por meio do caminho do design construiu, está construindo. $O$ imaginário pode ser um flash, você vê alguma coisa pela rua e aquilo te faz vir

A Nanni conta de forma muito especial que teve uma infância felicíssim e que nessa época andava em uma escola encantadora que ela gostava tanto e se divertia tanto, onde tinham tantas crianças e todos usavam uniforme. E este uniforme gerava identificação nela com aquela escola que ela tanto gostava.

A Nanni nasceu na Itália e parte para a Argentina aos 6 anos, onde passou sua infância, depois retornar à Itália. Enfim, essa relação com o uniforme fez com que ela gostasse do uniforme porque ele quando é bem vivenciado é uma forma de identidade.

Ela conta que tal uniforme era reconhecido pelos transeuntes com quem ela e sua irmã cruzavam no caminho para a escola. Era uma escola muito boa onde se faziam coisas interessantes, desenhavam etc. Isso colocou dentro da Nanni um senso de valorização pelo fato de serem tantas pessoas associadas a um único âmbito positivo.

Quando ela diz em seu livro "A superação do conceito do binômio forma-função[...]" ele e a ideia de problema em moda são contemplados?

Ela cita a desconstrução de Frank Gehry como exemplo. O que tem dentro do edifício deve ter uma relação com o conceito de função. A visão artístico-decorativa compensaria o lado construtivo ou funcional.

Ela cita a exposição Skin and Bones. Ela cita muito o que fora é muito cenográfico e ao interno deve-se ter cuidado para não criar problemas.

Em última instância, o problema seria criar formas etc com maestria resolvendo a parte interna, o caimento, vestibilidade, portabilidade, conforto talvez.
Eu questiono se tem uma noção de problema de verdade em design de moda.

Ela responde se referindo ao aluno. Ela não acha que todos devam fazer design. Ela procura entender qual é a predisposição do aluno. Ela diz que quando ensina design ensina assim, mas se $o$ aluno tem uma predisposição para a criatividade pura dando de ombros para o design ela investe, extrai daquela parte.

Mas ali na aula eles devem trazer o seu imaginário. Ela encoraja os alunos em seus caminhos, mas é preciso propor um trabalho no qual o pressuposto, a sua imaginação, o tanto quanto ele é capaz de escrever sobre aquilo que quer dizer, que sabe fazer uma síntese e faz um conceito que seja culto, bem explicado e, sobretudo, bem escrito, que use palavras que não são banais. Elegante, por exemplo, é um termo muito genérico que não tem sentido algum, o mood, esta história de mood eu combato de todas as maneiras. $O$ aluno deve me contar aquilo que é o seu imaginário e onde quer chegar e depois me faz a síntese disso. E depois aquilo que me propõe será uma coisa que me fascina, que há seu componente de criatividade.

Em resumo, eu posso te dizer o método, mas para desenvolvê-lo é preciso ter capacidade.

Questiono de onde vem o conceito.

É o percurso projetual e a cultura de projeto. É ter e saber aquilo que foi feito, que se fará e onde você se coloca. É a consciência tem também os instintivos, os que trabalham só por instinto.

Ela cita McQueen como um talento puro e Miyake como único designer de moda que fez algo de realmente grandioso. Pierre Cardin outro grande criador de moda, um grande alfaiate. Mas não eram estilistas, eram pessoas que trabalhavam sobre a forma da roupa de alfaiataria.

O estilismo é outra coisa. Nasce com o prêt-à-porter, se desenvolve com a tendência, hoje segue o marketing. O que ela deseja não é desvalorizar, mas é uma outra coisa. Um estilista pode ser também um grande criador.

Segundo ela, Alaïa, que faleceu há pouco tempo em novembro de 2017 era um designer criativo, um artista, mas também era estilista porque deveriam ganhar.

Chanel fez design, mesmo que involuntariamente. Era uma mulher inteligentíssima que the permitia de entender o momento e o mundo. Tinha visão.

Vionnet usou o viés (sbieco) como ninguém. Dior era um grande alfaiate.

Sobre os autores de design de moda não conhecia nenhum. E de design conhecia Bruno Munari, um grande mestre para ela. 


\section{CONTI, Giovanni Maria. Entrevista realizada com Giovanni Maria Conti, em 21 de junho de 2017, na cidade de Milão, com 44 minutos de duração.}

O início do curso de Design de Moda do Politecnico di Milano é em 2003. do curso de Maglieria é 2008

Existem cursos de Moda em Veneza, mas é recente. Há também em Roma. A posição geográfica de Milão favorece as trocas entre o Politecnico e as empresas.

A aulas eram quinzenais, às segundas-feiras, em período integral. $O$ professor da disciplina é Giovanni Conti e conta com a assistência da professora Manuela Rubertelli, além de outras auxiliares.

Manuela fica principalmente à cargo da interface com a empresa de fios para pedidos. Ela solicita a empresa Cotton Store os fios que são cedidos gratuitamente aos alunos do Politecnico di Milano com base na necessidade dos estudantes. Para isso, eles anotam o nome do fio e seu título. É raro, mas problemas podem acontecer, como o fio de linho que à certa altura do semestre não estava disponivel. Nesse caso, o aluno repensa seu projeto em função das matérias-primas disponíveis.

A observação em sala de aula permite afimar que o trabalho se dá na forma de orientação individual e os alunos vão passando por cada professor em diferentes aulas e pesquisa, criação e desenvolvimento de uma coleça de seu trabalho final de graduação. Nessa orientação mostram o que foi feito, ouvem críticas e caminhos são discutidos e mais tarefas são dadas para o bom andamento da coleção.

O trabalho se inicia a partir do desenvolvimento do conceito e então de amostras para chegar ao produto por meio de orientação.

No início eles começam mostrando painéis de inspiração, os moodboards. Enquanto alguns alunos são orientados, outros desenvolvem amostras nas máquinas de tricot do laboratório de malharia. Há alunas que apresentam referências de moda em seus painéis, ou seja, de acordo com Baxter, se trata de painel fechado.

Às vezes, no entanto, as aulas ocorrem na sala de aula e não no laboratório de malharia.

0 que esses estudantes desenvolvem são capsule collections com 6 a 8 outfits, ou seja, 6 a 8 ( 8 a 12 na entrevista) looks e 2 a 4 confeccionados que eles desenvolvem durante as aulas de orientação no maquinário de malharia disponível no laboratório, basicamente Coppo e o restante, trabalho manual.

Durante o desenvolvimento do trabalho os alunos apresentam desenhos coloridos com suas ideias acompanhados de amostras de malha com 0 peso, o fio etc.
Giovanni Conti reforça que os alunos devem apresentam desenhos coloridos e fichas técnicas com as medidas das partes que compõe uma peça.

ESCOLHER FOTOS (PASTA SANDUBA - PROGETTO ou Parallels) FEITO!!!

Determinadas coleções com foco na cor, Conti pede para que sejam trabalhados efeitos tridimensionais, provavelmente para que as peças não passem um efeito chapado.

Em outro caso, além de reforçar que a aluna deve colorir seus desenhos bem como apresentar fichas técnicas, Conti atenta para o equilíbrio do Plano de Coleção que interfere diretamente no Mix de Produtos, ou seja, pede a aluna que crie também calças e tops, pois até então a coleção contava basicamente com vestidos.

Conti elogia as amostras de uma aluna que traduziam bem as imagens do painel de inspiração. Assim começa a se formar o conceito.

Curiosamente, em 2017 tem uma aluna que trabalha como tema as ilustrações de Egon Schiele. Como observado no capítulo 3.6 e ainda no livro de Angela McRobbie esse tipo de referência do campo das artes é recorrente no design de moda. A obra de Schiele especificamente, além de se mostrar uma referência útil do campo das artes na moda por legitimar o fazer do design da moda aferindo a ele maior capital simbólico, aparece também como referência recorrente para o desenho de moda.

A aluna busca traduzir a partir de sua apropriação da obra de Egon Schiele por meio de materiais como malha retilínea, organza e bordado. MITO

Outros temas recorrentes além das artes visuais como Egon Schiele, James Turrell etc, são o mar e a arquitetura. Apesar da repetição de tema observados na Itália, Inglaterra, França e Brasil os trabalhos são bem feitos e interessantes.

Ao mesmo que tempo que são exigidos os painéis de inspiração é exigido que seja definida a cartela de cores. Ela deve traduzir as imagens do painel, do moodboard.

A medida que o trabalho avança as alunas têm a coleção mais completa, em geral com 8 looks desenhados, acompanhados sempre do moodboard da cartela de cores. A cartela de cores pode ser feita no próprio moodboard ou a parte com amostras físicas.

Dessa forma o aluno começa a mostrar seu processo colocando os testes de desenvolvimento de maquinário/malharia retilínea sobre os desenhos. Al-

Ao observar cada aluno tem-se uma ideia mais geral do desenvolvimento do projeto ao longo do semestre. Uma aluna, chamemos de A, apresentou somente croquis pintados, enquanto a aluna $B$, trouxe um painel aberto, sem referências de moda, amostras apropriadas àquilo que estava desenvolvendo. A aluna $\mathrm{C}$ já trazia consigo peças iniciais desenvolvidas, um macacão um vestido. Um outro trabalho, podemos chamar de D, exibia alfaiataria e bordados. $\mathrm{O}$ trabalho $\mathrm{E}$ consistia na apresentação de moodboard e carte- 
la de cores. O F mostrava croquis pintados em illustrator e painel fechado (com referências de moda). $O$ desenvolvimento $\mathrm{G}$ mostrava também paine fechado, amostras de malha e desenhos técnicos.

A despeito das variações que naturalmente ocorrem em função do tipo de projeto a que cada aluno se dedica, percebe-se que os itens mais apresentados nas orientações desde o início das aulas são painéis e amostras e, em seguida, croquis. De maneira geral, isso mostra que os alunos começam a se dedicar aos desenhos técnicos e ao desenvolvimento das peças propriamente ditos nas últimas etapas do projeto. Pode parecer óbvio, mas em outros casos acontece o inverso.

Conti pede de início painel, amostras e croquis que de certa forma são desenvolvidos concomitantemente. Nessa disciplina de projeto o raciocinio volta-se para a necessidade de buscar antes de tudo referências imagéticas que servirão de base para o desenvolvimento de amostras de malha, pois 0 fio e o ponto da malha determinam seu peso, seu caimento que direciona o desenvolvimento das peças. Os croquis podem ser feitos ao mesmo tempo, mas tendem a sofrer mudanças caso a malha já tenha sido definida.

Em casos mais raros o aluno pode experimentar antes no manequim e depois definir o croqui. De qualquer forma, ele já passou pelas etapas do painel e desenvolvimento e escolha de amostras de malha.

A malharia retilínea é um setor bastante tradicional e reconhecido na ltália. Nessa aula observamos que a importância maior é dada à construção da matéria-prima.

Aparecem também trabalhos que misturam tecidos planos como o jean e malharia retilínea por meio da técnica de agugliatura. Há alunos que recorrem à intarsia e também ao tricot manual.

Conti ressalta a importância da apresentação do trabalho com todos os itens: painel, amostras, desenhos e técnicos. Para ele, o caminho percorrido deve ser claro e deve ser comunicado por meio das imagens trabalhadas. É preciso mostrar um caminho de projeto.

Com o trabalho mais avançado percebe-se orientações mais voltadas ao campo da moda que do design. Uma delas diz respeito a cores de forma bastante poética recorrendo a palavras como "inspiração", sem se basear nos princípios do design para alertar a aluna dos efeitos possíveis. Outro ponto muito importante é perceber que no curso de Design de Moda do Politecnico di Milano o trabalho final se baseia na ideia de configurar uma coleção de peças que dialoguem entre si, característica típica do produto de moda e não do produto de design industrial ou de produto.

A unidade da coleção passa a ser reforçada a todo momento à essa altura em que as primeiras peças pilotos começam a ser apresentadas durante as orientações.

Interessante perceber que durante todo o semestre o conceito de problema em nenhum momento foi abordado. Os comentários se concentram mais na estética, prática ensejada pelo estilismo. Conti reforça sempre importância de mostrar o processo desde o início do projeto sempre com o apoio do moodboard para desenvolver as demais etapas, mas a noção de problema passa ao largo.

Material é tema recorrente das discussões de orientação inclusive entre os professores. Fala-se de composição do material, cores, adequação de determinada malha a um produto e aspectos simbólicos-funcionais (LÖBA$\mathrm{CH}, 2007$, p. 67-71) ou função estética (p. 49 e 70) desde a associação de um material a uma ideia até julgamento como "bonito ou feio" o que é bastante subjetivo e tende novamente ao estilismo.

Duas alunas que trabalham na Loro Piana mostram os desenvolvimentos dos trabalhos feitos lá. São malhas com aspectos novos e muito atraentes. moda trata mais de função estética e simbólica que de função prática.

Há um trabalho com pontos frouxos que remete a um destroyed, mas em tricot.

Percebe-se uma experimentação de material e forma em vários desenvolvimentos dos alunos. Essa forma de fazer desperta o olhar sobre quais os limites da prática fomentada no Politecnico quanto ao estilismo, fazer mais voltado à satisfação pessoal, trabalho individual de autor ou ao design, trabalho que tem como premissa uma a solução de um problema ou apermentação, mas menos declaradamente focado em resultado final estético.

Será que todos esses designs são passíveis de uma produção industrial? $\mathrm{E}$ de uma pequena produção seriada? Quem representa essa mão de obra? Em uma pequena produção seriada seriam os próprios estilistas, pois provavelmente sóeles conhecemo processo e nãovaleria a pena ensinar uma equipe de uma oficina para pequena produção. Isso leva a repensar o papel do designer de moda cada vez mais estilista/artesão nesse contexto e, em certo sentido na economia, levando em consideração a pesquisa de Angela McRobbie (1998). Ao final do processo, há um book que no linguajar de design de moda se refere a parte impressa do trabalho incluindo photoshooting e esse trabalho tem um formato mais livre desde que contenha os itens que revele o processo de projeto da disciplina.

Laura, uma professora assistente, relata que nesse book di tesi os alunos elencam as etapas de trabalho em ordem. Na ordem em que foi feito, orientado em sala e, sobretudo, cronológico.

De qualquer forma esse book di tesi varia e nem sempre é claro como os alunos têm acesso a quais itens devem constar nele.

No book di tesi pode aparecer croqui frente e costas pintado + foto do look e em seguida na outra página desenho técnico, mas pode variar. Laura sugere deixar o croqui numa página e passar a foto para outra página junto com a ficha técnica.

As possibilidades de organizar o book di tesi são inúmeras, mas ele deve expor o metaprojeto (processo) e habilidades digitais como Kaledo e Rhinoceros. 
O metaprojeto é a disciplina da Paola Bertola, visto no segundo ano e que serve de base para todos os trabalhos seguintes durante a faculdade bem como para a vida profissional desse designer de moda. Ele pode também ser uma parte mais teórica, sobre refletir o que é fazer projeto em termos práticos e teóricos.

No final do Laboratorio di Sintesi Finale a orientação se volta ao book di tesi e a cortar, costurar e finalizar as peças.

Ao analisar os desenhos técnicos e o conteúdo dos metaprojetos dos alunos torna-se visível a base de computação gráfica desses alunos. Apesar de faltar algumas especificações com linhas de chamadas e marcações de cotas as informações técnicas das peças deixam claro que se tratam de formandos que dominam o processo de projetação em moda.

Parece que há um investimento maior no ensino de ferramentas digitais (illustrator, kaledo, rhinoceros) do que no Brasil e os alunos também são muito autônomos, não são acomodados, não esperam tudo pronto.

O ambiente e o processo leva alunos com trabalhos mais fracos no início do semestre a se desenvolverem.

Colocar fotos do trabalho de Angelo Albano (tricot cinza, bordeau e mostarda com monograma com efeito de veludo devorê).

EXCERTO

Outro ponto muito importante é perceber que no curso de Design de Moda do Politecnico di Milano o trabalho final se baseia na ideia de configurar uma coleção de peças que dialoguem entre si, característica típica do produto de moda e não do produto de design industrial ou de produto que geralmente foca em um único produto ou linhas menores.

Além de a cortar, costurar e finalizar as peças no final da disciplina Laboratorio di Sintesi Finale a orientação se volta ao book di tesi. No linguajar de design de moda ele se refere à parte impressa do trabalho incluindo photoshooting (sessão de foto). $O$ formato do book pode ser mais livre desde que contenha os itens que revele o processo de projeto da disciplina por meio de etapas. A sugestão é que sejam dispostos croqui, foto do look e ficha técnica de forma a ver a foto e o desenho técnico lado a lado e croqui em uma página anterior.

As possibilidades de organizar o book di tesi são inúmeras, mas ele deve expor o metaprojeto (processo) e habilidades digitais como Kaledo e Rhinoceros. Aqui é resgatado e reforçado o que foi ensinado na disciplina de Bertola no segundo ano do curso e que servirá de base para a vida profissiona desse designer de moda.

Ao analisar os desenhos técnicos e o conteúdo dos metaprojetos dos alunos torna-se visivel a base de computação gráfica desses alunos. Apesar de faltarem algumas especificações com linhas de chamadas e marcações de cotas, as informações técnicas das peças deixam claro que se tratam de formandos que dominam o processo de projetação em moda.
Percebe-se um investimento maior no ensino de ferramentas digitais como Illustrator, Kaledo e Rhinoceros do que no Brasil, além dos alunos serem mais autônomos e pró-ativos. $\mathrm{O}$ ambiente e o processo leva alunos com trabalhos mais fracos no início do semestre a se desenvolverem.

Colocar fotos do trabalho de Angelo Albano (tricot cinza, bordeau e mostarda com monograma com efeito de veludo devorê). 


\section{Notas da Disciplina de Paola Bertola - de setembro de 2017 a janeiro de 2018}

\section{Metaproggeto - Fashion in Process}

STEP 1

A disciplina é comandada por Paola Bertola que tem o auxílio principalmente de Federica Vacca e depois de Chiara Colombi e Anna Molteni.

A primeira aula é teórica e é dada por Paola Bertola. Ela defende a tradição em inovar também os processos que envolvem a criação de moda e vestuário de moda.

Quando se fala de standardização se fala em individualismo, criatividade livre e atitude subjetiva, onde o designer é o que está olhando para mundo. Cita como exemplo o arts \& crafts e os designs de William Morris, produtos qualitativos.

Em seguida, fala do design como método científico que tem seu nascimento e desenvolvimento no Reino Unido e Alemanha. A Bauhaus promove grande tradição científica no que diz respeito às pesquisas em design; 0 avanço da industrialização e a atitude objetiva.

$\mathrm{Na}$ Bauhaus o foco era replicar a qualidade dos produtos, ou seja, a serialização dos produtos de qualidade. $\mathrm{O}$ olhar científico para o design possibilitou a organização em processos. Ela também fala da importância de Mies Van der Rohe no design como um método dedutivo (geral para o particular).

Segue afirmando o design como uma prática produzida por reflexão, re flexiva. A abordagem italiana considera $\mathrm{o}$ artesanato e a tradição industria baseada em uma atitude social (é o processo da consciência individual que determina a real ou possível atividade do indivíduo no mundo social e, para alguns autores é ainda a tendência de agir da maneira coerente com referência a certo objeto - wikipedia) e cultura politécnica (que abrange muitas artes ou ciências)

O discurso do Politecnico abrange engenharia, artes e humanidades, justamente a ideia de abranger muitas artes ou ciências. Nessa escola o aluno é levado a criar o seu componente criativo para a indústria, colocar seu talento, a certa altura, a serviço da produção em série a partir da organização de processos.

As habilidades necessárias para o designer do Politecnico desenvolver são relativas à organização dos processos, ao conhecimento e domínio de ferramentas e as metodologias necessárias para desenvolver projetos, além do merchandising program.

Por último, Bertola contempla o Italian System. O Sistema Italiano possu uma abordagem entre a costura francesa e o prêt-à-porter americano.

Até 1950 a referência estilística era a França e a industrial eram os Estados Unidos. A partir desse período e um pouco antes (Max Mara é fundada em
1951) a Itália foi marcada por grande tradição industrial. Com o Plano Marshall havia um comprometimento de modernização da Itália.

Em 1960 nasce um distrito industrial em Milão. A Rinascente vende pela primeira vez produtos dotados de um aspecto de modernização, provenientes sobretudo dos Estados Unidos, adotando o modelo americano. Nesse período, a Rinascente promove uma série de atividades culturais que a transformarão em uma verdadeira janela para o mundo - wikipedia) e mais ou menos um museu de arte moderna (?). Então quais produtos de diferentes de mestres italianos poderiam estar ali? Casina, artemi, Armani, Ferré, Krizia representam um espaço que transita entre arte, arquitetura e design.

Todos esses trabalhos presenciam a nova cultura do design na Itália onde era importante manter vivo um componente criativo do design. $O$ modelo de condução de uma empresa CEO + Diretor criativo foi replicado nessa época e mantido até hoje. A ideia é ter um para reger e outro para criar. Nisso consiste o sistema de moda italiano.

A partir daí a aula se direciona para o projeto a ser desenvolvido pelos alunos durante o semestre. $O$ briefing é especificado pelas professoras. Os alunos devem desenvolver uma coleção para a marca RED Valentido.

Bertola começa a elencar os itens do trabalho contidos no programa de aulas como Cenário de Design (estudo de caso, Pesquisa Iconográfica, perfil do consumidor e todas as entregas em torno dessas pesquisas de painéis, desenhos etc), Design de Produto (pesquisa de mercado, conceito, código de estilo, fabrico, peças chave, moodboards finais de estilo de vida), Plano de Negócios ou Merchandising Plan (peças chaves e edição da coleção, definição das ocasiões de uso, desenvolvimento de coleção, grid ou mix de produtos, cores e variantes, preço no varejo, lookbook para vendas, press release da coleção que, no programa aparece como um texto técnico de 500 palavras).

Ela fala da Valentino e de mais tipologias de produtos, mais diversidade a er oferecida. Debruça-se então sobre a Valentino e a RED Valentino como caso de estudo.

Ela fala de ideias dos anos 1960, como criar um look para o dia. Fala da Dolce\&Gabbana e sua mulher mediterrânea e sensual, fala da Armani e sua mulher mais masculina, voltada ao mercado de trabalho. Enfim, fala um pouco marcas e seus públicos.

A partir daí, Bertola levanta a questão: qual o elemento que permanece como o DNA da marca? Cita o little coat do Valentino que pode ser usado como cocktail dress.

Citou também a Alessandra Facchinetti que trabalhou para a Gucci, Moncler, Tods e teve também sua marca que durou só duas estações, não é fácil.

Comentou alguns acabamentos como cristais e técnicas de tingimento, além de decoração e flores (estampas, bordados etc). Lembrar que floral o motivo mais reproduzido no mundo. 
A marca Valentino teve como diretora de criação até recentemente Maria Grazia Chiuri e Pierpaolo Piccioli. Ela foi diretora criativa por 8 anos na Valentino com Pierpaolo Piccioli. Também responsável pelo sucesso na redefinição dos códigos da marca Valentino e no fortalecimento dos negócios que atingiu a receita de 1 bilhão de dólares em 2015. Em 2015 ela assume a direção criativa da Christian Dior, feito histórico, uma vez que é a primeira mulher nesse cargo. E então Pierpaolo Piccioli assumiu sozinho a direção criativa da Valentino (https://www.businessoffashion.com/community/people/maria-grazia-chiuri-pier-paolo-piccioli)

Quando Bertola fala do trabalho de Chiuri ela lembra dos materiais e $p a-$ tchs usados pela Valentino e como eles remetem ao DNA da marca assim como as camadas, a assimetria, as flores, as pregas, os plissados, o pois, mas sempre mantendo a silhueta Valentino.

Red Valentino propões algumas possibilidades de linhas para essa disciplina: romance, excêntrica, playfull, poética, onírica, rock e digital. Sempre um pouco irônica porque é jovem, lembrando dos millenials e da presença on line.

Atenta também para as peças de sobreposição. Na Valentino em organza e na RED em tule com elastano que é mais acessível. São diferentes interpretações para a mesma estação por duas marcas distintas.

O mote do trabalho a ser desenvolvido, ainda dentro do briefing são as décadas da moda, dos anos 1930 aos 1980 com suas silhuetas, cores, detaIhes e decoração de cada década. O TEMA de Design das coleções a serem projetadas é BLONDES X BRUNETTES.

Aqui as professoras direcionam bastante o briefing uma vez que além de definirem os tema e o período de inspiração, definem também as atrizes que podem ser usadas como referência para a pesquisa.

Produtos icônicos é uma expressão que aparece muito. Elas mostram em um eixo de coordenadas com o nome da marca e seu posicionamento quanto à preço de produto, apelo de moda ou clássico.

Infelizmente como não tenho acesso à plataforma BEEP, não posso receber os slides da aula para uma análise mais aprofundada. Cheguei a pedir para uma professora, mas ela negou e depois tergiversou.

Na verdade, nessa primeira aula, as professoras fazem uma introdução $e$ explicam os itens do Programa de Aulas que são muitos e nem sempre claros, pois podem se confundir. Ao longo das aulas eles vão se tornando mais claros à medida que os alunos vão trazendo em sala, mas nem sempre é contemplado.

Também pude perceber que existia uma comunicação além aula com os alunos, pois eles entendiam bem o que deveria ser feito, mas eu nem sempre. Não sei se para eles tudo ficava mais claro, pois já haviam tido aulas sobre $o$ assunto nos semestres anteriores ou porque havia outra forma de comunicação além da aula mesmo.
De toda forma o que ouvi dizer é que essa era a grande disciplina por exE também ficou combinado que eu não faria o projeto, mas só acompanharia o que nem sempre foi bem recebido.

Um dos itens do Cenário de Design é a pesquisa iconográfica que passa a ser apresentada por Anna Molteni durante a mesma aula.

Os comentários são os seguintes: procurem achar uma imagem menos óbvia, não a imagem clássica da Marylin Monroe (uma das blondies do tema). Não procurem em blogs, achem algo interessante e realmente original. Por isso é bom ir a bibliotecas para buscar algo realmente novo. Apesar se fazer sentido, ela não embasa nem aprofunda o comentário para alunos de graduação.

A segunda aula é sobre pesquisa de tendências com a Chiara Colombi. Basicamente é a aula do Dario Caldas. Ela cita os elementos do design como cores, formas e contexto cultural (?) seguidos por marcas de estilo e o Guia de Processo Industrial que aborda o que é economicamente seguro.

De um lado existem as pessoas e o tempo que determina a duração de uma tendência, o subir e descer em um grático para prever mudanças de longa duração (trickle effect). Dessas pessoas é fundamental compreender quem está interessado nesse conteúdo. Existem mudanças emocionais e psicológicas ao longo do tempo.

É importante para um designer reconhecer estilo entre as pessoas. A previsão de tendências muitas vezes se baseia em pequenas mudanças. É sobre olha o passado e o futuro ao mesmo tempo. Há uma separação entre quem cria tendências e quem as segue. Depende em qual ponto da cadeia você está.

Influências recorrentes para o design de moda são artistas, designers ídolos. Chiara Colombi recorre a Ted Polhemus para explicar o trickle effect

Como usar o bubble up hoje? Analisar culturas jovens no seu habit natura e o que está surgindo nas imediações (nossa, que novo!). Ela orienta também seguir os coolhunters Scott Schuman aka The Sartorialist.

Colombi apresenta o modelo das categorias de adoção. Ele é representado pelos inovadores, early adopters, early majority, late majority, leggards.

FAD - modinha (mania é a tradução).

Dimensão sócio cultural

O zeitgeist e o spirit of the times te permitem promover algo original e novo. BLUMER (1969) e a seleção coletiva ilustram de onde deriva a formação do gosto a partir de um grupo de pessoas respondendo coletivamente ao zeitgeist ou spirit of the time.

DA PESQUISA DE TENDÊNCIAS AO BRIEFING DE COLEÇÃO

$O$ design de moda se encarrega da análise de produto, os consumidores estão vinculados à pesquisa de tendências, os indicadores culturais regem as análises competitivas junto com os parceiros e concorrentes. Direcio- 
nam-se assim os códigos de estilo, o desenvolvimento inspiracional, a seleção de tecidos, e a definição de cartelas de cores (color stories).

Na segunda parte da aula que é em período integral as explicações tomavam como exemplos artistas do tema e seus papéis interpretados nos filmes e qual o caminho para que isso se torne produto.

Onde encontrar informação de moda impressa: corso como 10, feltrinelli, Hoepli, Libreria dele Moda (Navigli).

A Première Vision e a Milano Unica ocorrem a cada dois anos. A Milano Uni$c a$ é focada no mercado italiano. Outra importante fonte de pesquisa são os bureaux como Pecler Paris que orienta inspirações de design e orientações estilo.

A palavra inspiração e estilo começa a aparecer.

Os bureaux também indicam tecidos com antecedência. Eles custam cerca de 10000 euros e costumam ser usados para quando se tem de 10 a 20 clientes e falta tempo para fazer uma pesquisa para cada um de tecido etc.

NextAtlas - é um site que mistura referências visuais. Ele ajuda a visualizar o surgimento de tendências emergentes misturando dados de diferentes mídias sociais em insights processáveis para trazer informação e inspirar processo criativo (retirado do próprio site https://www.nextatlas.com/).

Após essas duas aulas expositivas começa a orientação com Federica Vaca e Paola Bertola. De início se dá sobre imagens de inspiração do tema, ou seja, cada personalidade feminina escolhida do cinema, morena ou loira. Em seguida, são feitos pares com imagens relacionadas à época. São pedidas 100 imagens do período histórico e 30 imagens para cada ícone feminina da década assinalada. Cada orientação dura cerca de 30 a 45 minutos.

Na orientação de Paola Bertola no início do trabalho alguns questionamentos surgiram por parte da professora de forma a estimular os alunos a pensarem da forma como se pensa um problema no design. Qual é ambiente? Dizia apontando para as fotos das atrizes tema de um trabalho. Durante a seleção de imagens, Bertola não tira nenhuma da mesa, mas vira para baixo as que merecem ser deixadas de lado. Ela pede que o trabalho tome uma dires tos da atriz em questão com diferentes tipos de vestimenta e detalhes.

Daí talvez seja possível considerar que pode-se pensar problema com no design a partir dessa abordagem da Bertola, mas por mais que pareça contraditório, não há uma noção de problema igual a do design no campo da moda.

Ela chama a atenção sobre como olhar para as fotos. Nesse momento olham acabamentos a partir do vestuário nas fotos, o que seria uma pesquisa fechada (para o Baxter?). Ela atenta que os alunos devem olhar os detaIhes nas fotos para não repeti-los em sua coleção.

Exige que os alunos trabalhem com autonomia como em um estúdio. Escreve na lousa um aviso "o tempo em sala não é para esperar pela nossa revisão mas para trabalhar em time."
No grupo orientado por Federica Vacca ela sugere organizar as imagens por contiguidade de cores, estampas e formas. Ela vai trabalhando, ensinando os alunos a enxergarem conexões entre as imagens que estão propondo para o tema dado. Ela faz um pouco do trabalho para sugerir para o aluno como deve ser feito. Propõe sempre uma familiaridade entre as figuras.

Em um dado momento ele pede que procurem fotos de mulheres atuais que traduzam essa mulher de época.

É preciso montar histórias diferentes. Para isso tem diferentes painéis e é meio confuso. São muitos painéis, acho que são sete entre os mais importantes.

Revendo agora o programa de aula, inicialmente são 9 moodboards, 3 moodboards de estudo de caso, 3 moodboards de pesquisa iconográfica 3 cartelas de cores (no mesmo painel) e 3 moodboards de estilo de vida. As cartelas de cores são agregadas ao painel de pesquisa iconográfica, jun to com as imagens. Então no item Cenário de Design são desenvolvidos 9 moodboards em 3 partes: estudo de caso, pesquisa de imagens e de estilo de vida.

No item Design de Produto na definição do conceito são desenvolvidos entre 13 e 19 moodboards sendo 1 moodboard conceitual ou moodboard de códigos estilísticos, 3 moodboards de tecidos e aviamentos, módulos e motivos gráficos para estampas, bordados etc no quesito fabricação e no item de design dos outfits, ou seja, no desenvolvimento da coleção propriamente dita são desenvolvidos entre 9 e 15 moodboards para cada linha sendo de 3 a 5 moodboards com outfits chave. Os moodboards do item design de outfits devem ressaltar os detalhes mais representativos para a identidade da coleção nas 3 linhas: romance, eccentric, poetic/interpretations (romance, excêntrica e poética)- RED - Romantic, Eccentric, Design)

Plano de Negócios ou Merchandising Plan é uma fase que conta com mais de 22 moodboards. $O$ primeiro diz respeito à definição de ocasião de uso e seria na linguagem estudada até agora nas escolas brasileiras uma mistura entre Mix de Produtos e Plano de Coleção. Outro moodboard está relacionado ao desenvolvimento da grade (GRID) e seria a contagem do Mix de Produtos por tamanho, cores, modelos, básicos, fashion, intermediário para oferecer à coleção um mix equilibrado. Ele é apresentado em tabelas de excel. A seguir, vem outro moodboard de fabricação com as cores das 3 linhas colocadas juntas dando unidade à coleção e suas entradas na estação. Tem também o moodboard de nível de preço no varejo da fase homônima considerando o posicionamento da marca por preço de categoria de produto e por último, o moodboard do lookbook de venda que se assemelha ao plano de coleção reunindo os croquis coloridos que conta com 21 looks que originarão 21 moodboards.

Ao final, todo o processo é apresentado por meio de painéis e eles somam entre 40 e 50 ao final do trabalho.

Durante as orientações surgem expressões como "eu amo essa figura" (Federica Vacca) que sustentam a ideia de mito baseando o valor no gosto de quem tem mais poder simbólico, nesse caso o professor, sem nenhuma 
explicação inteligível para isso. Cinco minutos depois os alunos estavam repetindo "eu amo..."

Em outra aula, novamente, Federica Vacca refere-se a uma imagem da seguinte forma: "essa imagem é super forte porque ela diz o que você pode fazer com a sua coleção". Ok, mas é forte em que sentido? E como uma imagem diz o que pode ser feito a respeito de uma coleção?". Novamente sente-se o mito prevalecer em meio a afirmações que para a professora prescindem explicações, mas talvez para os alunos não. Acredito que eu não fui a única que fiquei em dúvida e comecei a me perguntar quantas vezes tive essas dúvidas na faculdade e elas não foram esclarecidas.

Na mesma aula, a mesma professora fala a certa altura "mais que bonito" e depois retifica soltando somente um "match" dando a entender que a imagem era coerente e fazia sentido de estar naquela pesquisa. Às vezes parece que o que vale mais é o gosto do professor. Isso afeta a autonomia do futuro profissional por dois motivos: se o aluno tem outro "gosto" pode pôr em risco sua nota e entra em um mercado graduado sem saber justificar suas escolhas com coerência, sem saber porque cada imagem está em um moodboard como no exemplo.

Nem sempre é muito claro o critério de agrupamento das imagens durante o trabalho de confecção dos diversos painéis que embasam o desenvolvimento da coleção. A amplitude de temas e abordagens por vezes pode dar margem para que o mito aja e esclarecimentos sejam relegados a segundo plano. Fala-se em formas de maneira muito banal, mas não se fala em elementos de design, ou não se explica porque o agrupamento de certas imagens ocorre de determinada maneira.

A partir do segundo mês de aula do semestre letivo a aula se concentra basicamente em orientação em grupo. A classe da qual essa pesquisa se ocupou contava com 11 grupos de cerca de 6 alunos cada. Cada professora, Bertola e Vacca se revezavam na orientação dos grupos. Em várias aulas também contribuía Anna Molteni. Nessa aula, foram vistos os moodboards que têm um espaço bastante importante nessa disciplina como guia e forma de apresentação do trabalho a medida em que ele é desenvolvido.

Os temas dados como opção aos alunos era uma mistura das décadas do século XX e uma personalidade feminina da década, loira ou morena, em geral uma atriz de cinema. A configuração dos temas era: anos 1930 morena, anos 1940 loira, anos 1940 morena, anos 1950 loira, anos 1950 morena, anos 1960 loira, anos 1960 morena, anos 1970 loira, anos 1970 morena, anos 1980 loira, anos 1980 morena.

Os primeiros atendimentos que se dedicavam aos moodboards revisavam a cartela de cores e o moodboard de estilo de vida. Durante a orientação notou-se que, de maneira geral, as cartelas de cores contavam com sete cores e era sempre feita com linha de costura.

Bertola fala da importância de vincular um moodboard a outro formando um grande storytelling. O moodboard é um objeto que nos transporta àquela época que serviu de tema.
O moodboard do perfil do consumidor (lifestyle) tem foto de moda, mas mais de paisagem, arte, interiores (que seria um painel semi-aberto). É um painel de estilo de vida que é fundamental para o desenvolvimento de produto de moda porque a roupa vem colada ao corpo como primeira linguagem antes de outros objetos do design industrial. Além disso, o produto de moda possui uma velocidade de mudança muito maior se comparada ao design de produtos ou à arquitetura, por exemplo, por isso deve-se estar atento às mudanças que envolvem o público-alvo.

Na orientação é explicado passo-a-passo como aproximar, como escolher imagens que vão ou não no painel. Aí a orientação segue rumo a cartela de cores.

Algumas práticas de aula observadas no Brasil persistem na Itália. Isso talvez explique algumas atitudes de professores de projeto em ambos os países, como não revelar "segredos" de aula, principalmente entre professores e pesquisadores. Questionei na Itália uma professora por três vezes se existia e qual era um número sugerido ou ideal para uma cartela de cores. Permaneci sem saber, após obter respostas cortantes.

Isso explica como o meio se fecha, como se torna propício à endogenia e, sobretudo, perpetua uma prática onde cada professor "faz como quer", já que muito do que é praticado em aula e no mercado não está nos livros e não é revelado ou trocado entre especialistas do campo.

Acontece a primeira avaliação em sala. Ela é individual, mesmo o trabalho sendo em grupo. São entregues fichas para cada aluno para auto-avaliação.

Nesse dia encontrei cartelas de cores com cinco, oito e até nove cores.

Os alunos apresentam a pesquisa de público em gráfico cartesiano com eixos "X"e "Y".

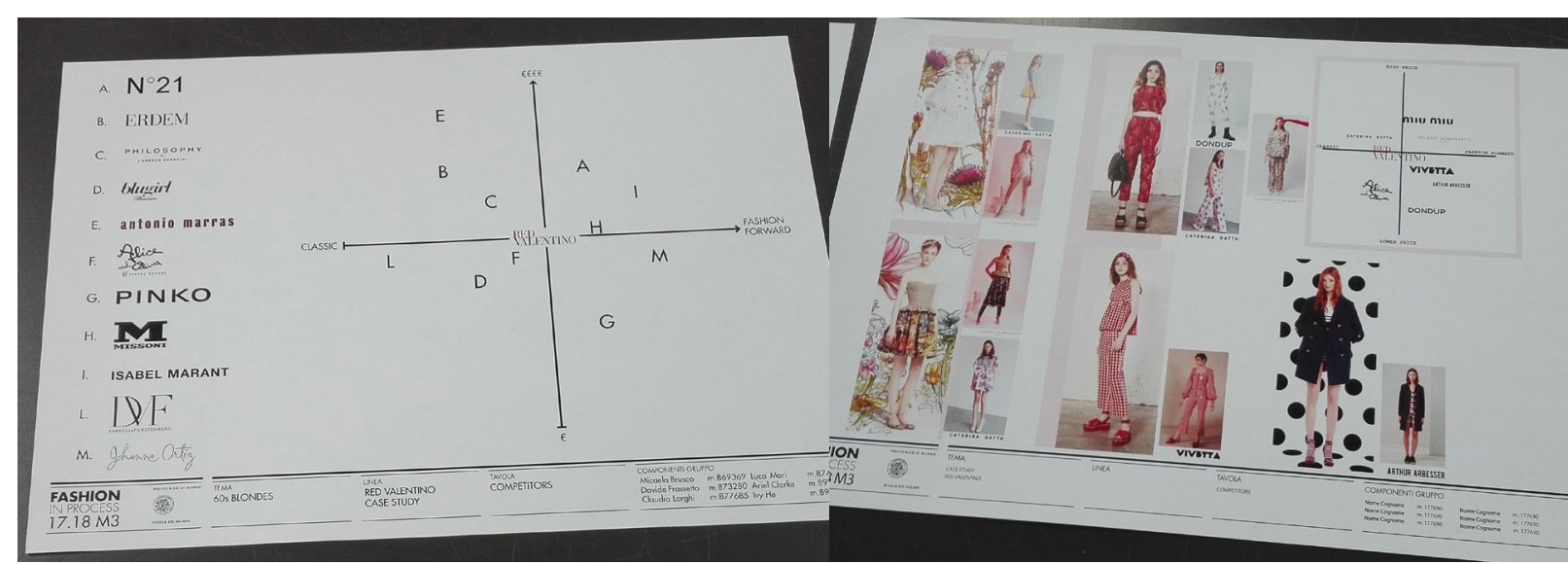

O que se vê a partir daí é mais um painel fechado (o do estuldo de caso/ marca), somente com referências de moda para ilustrar os volumes, cores, modelagens e acabamentos mais recorrentes que observaram na marca dada no briefing, a RED Valentino. Depois, vêm três painéis divididos em três abordagens do tema com referências de moda e de outros campos. 
Entre as imagens estão contemplados tema, década, releitura contemporânea do período histórico em questão e as cartelas de cores, sempre feitas com linhas de costura.

Quando em algum grupo tem um ou mais componentes masculinos é sempre ele quem inicia falando na apresentacão. Ele toma a fala naturalmente para si, o protagonismo (CRUZAR COM ANGELA MCROBBIE).

Anna Molteni insiste na importância de se trabalhar com imagens de qualidade.

Relação entre imagens e cores

Número de cores: pode ter até vinte, mas aí fica difícil trabalhar (desde a produção) até o varejo porque eu "canibalizo" minha própria marca se ofereço um mesmo produto em cores muito próximas e, consequentemente, em cores próximas. As estampas devem pontuar as cores da cartela definida para tecidos lisos.

Fala-se muito em abordagem crítica, mas só no âmbito da construção de imagens e design gráfico.

\section{STEP 2}

Aula teórica com Paola Bertola para entender como organizar as imagens coletadas por categorias para marcar a diferença de sua natureza: volumes, cor e tema. Quanto aos concorrentes ela ressalta que é importante manter a coerência.

2.1)Merchandising Research Dossier (inventário da Tita - UAM) - aqui e mais baseado em imagens.

2.2) Stylistics Code - Silhueta (sombra chinesa) - o aluno deverá criá-la, interpretá-la segundo uma referência historica. Proporção - mais volum em uma parte ou outra. Só que ela também cita "contraste" para falar de proporção, mas aqui é outro elemento do design.

2.3)Original Details - é o que faz uma "designing/combining (?) piece" tudo isso deve estar no concept board (2.2 Stylistic Codes Definition / Concept). Como comunico meu conceito? Também por meio da merchandising research.

2.4)Key items/Outfits Design - o processo criativo é organizar passo a passo abrindo e fechando a pesquisa e as opções dela oriundas. Você desenha várias vezes uma ideia (RENATA ZAGANIN/SEIVEWRIGHT), pesquisa, vai e volta à merchandising research e etc para ter um look.

Se fala pouco no termo desenho nessa disciplina. Aparecem termos no programa de aula como "look [representado] na figura humana por completo". Drawing - é também design e diz respeito sobre aplicar novas questões àquilo que foi criado (cognitive approach typical from design). Ela mostra a imagem de um Mix de Produto e Croquis.

Nos Key Items/Outfits entram os tecidos.
"Não tem uma receita para fazer design em equipe, mas esse é o ponto principal dessa aula."

DESIGN PROCESS $=$ ASSIGN TASKS $=$ DATES $=$ this is the best way

Atribuir tarefas com datas estabelecidas para a entrega de cada uma é a melhor forma de contemplar o processo de design (alguém define isso na minha tese como tarefas $X$ datas como briefing) procurar.

DESIGN YOUR SOLUTION

Variáveis de um produto - glasses/colar - é importante conhecer bem os detalhes da coleção e explorar os "princípios do design" como contraste, ritmo, harmonia, etc, pois aqui eles se tornam mais relevantes (nos key items e Stylistic codes) (aqui anotei para atentar a uma relação possível com os elementos isomorfos, homeomorfos e catamorfos do Bruno Munari - provavelmente falavam de família de produtos)

Obter o look completo para ter o Plano de Coleção que são os boards do key items/outfits design.

2.3 Fabrication (ordem invertida ma vabbè)

Materiais que são selecionados podem ser tingidos, bordados etc (enfim, beneficiados). Usar "graphic motifs in different way". Usar os módulos ou motivos gráficos de forma diferente, mas como? Até porque se mostrarem como já não é mais novo. É preciso mostrar exemplos de criar esse uso diferente.

O vocabulário de criação (elas chamam assim) ter permite crescer em diferentes direções.

À certa altura da aula Federica Vacca assume e começa a dar explicaçõe sobre os kits de tecidos que será distribuído aos grupos.

O kit consiste em 3 subgrupos de tecidos. Ela dá kits a cada grupo para cobrir as três linhas (que só agora se tornaram claras: RED - Romantic, Eccentric, Design).

Ela explica o que deve ser analisado em um tecido, mas não enfatiza na compra industrial por meio das tecelagens. Ao escolher um tecido para uma coleção deve-se observar sua estrutura (se é um Jersey, uma popeline ou um cetim), sua composição (algodão, poliamida, seda, lã), seu peso (leve, médio, pesado), seu toque (se é suave, peludo, fino), o lado (avesso, direito ou dupla face) e a elasticidade (se tem ou não elastano).

Faltam questões como largura, preço, rendimento no caso das malhas, pedido mínimo em metros ou kilos, prazos de entrega. Essa parte industrial que caracteriza o design por excelência é negligenciada nessa aula de projeto.

A ideia aqui é se concentrar no tecido perfeito para o tipo perfeito de roupa.

Amostra distribuídas a sala: Linha Design: malha de algodão, tricoline tie dye, tricoline estampada, cotton texturizado (maquinetado?), Oxford estampado com flocado (não somos só nós que utilizamos tecidos merda), algodão (talvez uma tela peso calça trabalhado, mas não dá para ver porque 
ela mostra de longe e eu não ganhei amostras), algodão pesado, jeans, tactel (poliamida), Neoprene como uma malha mesh dublada, tule. Foram dados os seguintes tecidos na Linha Romantic: piquet, musseline de algodão (deve ser a cambraia brasileira de peso levíssimo), organza leve estampada, polyester vichy, tule, outro tipo de jeans, gabardine, cetim duchese dupla face (rosa de um lado e verde do outro) etc. Por último, na linha Eccentric foram dados os seguintes tecidos: crepe de viscose, crepe georgette stretch, cetim de seda, renda, voile plissado, tule, tafetá, cady (tecido de alfaiataria misto PA ou PES; CV; CO; WO; PUE), la a fria com lurex, cetim duchesse com lurex, jacquard.

Prestar atenção para desenvolver sempre os mesmos módulos/motivos gráficos em toda a coleção = página 12 aqui anotei para atentar a uma relação possível com os elementos isomorfos, homeomorfos e catamorfos do Bruno Munari - provavelmente falavam de família de produtos), pois passa a ideia de coleção e, sobretudo, famílias de produtos dentro de uma coleção. Família traz essa ideia de coleção dentro da coleção e é importante no design de moda dado o grande número de produtos desenvolvidos para cada linha e coleção.

Do meio para o final de outubro são apresentadas diretrizes para os desenhos técnicos por Anna Molteni. Ela cita o livro Fashionpedia como referência. A aula começou atrasadíssima, com th e $20 \mathrm{~min}$ de atraso.

Ela sugere fazer o croqui na mesma proporção do técnico e vice-versa, colocando ambos lado a lado com a marcação das alturas (aí entra a marcação de cotas).

Um aluno questiona se pode fazer um novo desenho a partir de outros. Isso equivaleria à geração de alternativas no design de produtos e, aparentemente, o conceito não foi ensinado ou vinculado a essa disciplina, mesmo se tratando de Metaproggeto.

A última aula de outubro é teórica. Chama-se Meta Design: Designing the Design Process e descreve quem são os principais agentes em uma empresa em termos de gerência. Eles são três: o diretor de arte que planeja a comunicação, o gerenciamento de mídia e a produção da comunicação; o diretor criativo que é o designer chefe e se ocupa de pesquisar/detectar tendências e materiais (sênior \& junior), desenvolver o produto, cuidar da produção $e$ logística; e o gerente de varejo que organiza o planejamento das lojas, compras e entregas e gerência da loja.

Grande parte dos gestores/grandes gerentes têm formação em economics.

Como os produtos se saem no mercado?

De ideias a produtos

Depois que a coleção está toda no papel é hora de transformá-la em produto. É a fase do desenvolvimento de produto. BUYERS > PEDIDOS > PRODU ÇÃO (é o que fala Jones e Seivewright? Conferir e fazer uma comparação).

Gerência de Marca
Conhecer o ritmo e o método de...

Conhecer o ciclo de todos os pontos-chave dos processos - desenvolvimento de produto, comunicação e varejo muito bem.

Arquitetura da coleção (checar se a Tita se refere a alguma tipo de termo como "arquitetura de coleção").

Coleção é um sistema complexo de produtos nunca inteiramente novos criados por meio de um processo com pesquisa e retorno de mercado ( $\mathrm{mk}$ feedback) e diretrizes de estilo estabelecidas pelo DNA da marca.

Essa definição tem a ver com o "inventário interno" da Tita. Bertola fala também sobre o número de produtos e funções que compõem o Mix de Produtos.

Existe uma coisa chamada PRE COLLECTION que apareceu só agora (de continuidade/coleção comercial) e COLLECTION (coleção de design, aparentemente com propostas diferentes).

Desenvolvimento de Produto

De ideias à implementação do produto

Paolo Fanara - gerente de produto para a Red Valentino.

A solução apropriada vem de entender o produto. É preciso criar para tender às necessidades que vêm da sua pesquisa!!

\section{FASES}

Material > protótipo da peça piloto > atualização sobre fornecedores

O desenvolvimento de produto deve estar um ano à frente antes de o produto chegar à loja (no caso de confecção, da parte de confecção).

SKETCHING OUTFITS

Aqui falam sobre desenho. Os croquis devem ser detalhados em P/B - ela mostra 4 croquis como se fosse um Plano de Coleção, mas em P/B com linhas de chamada indicando o tipo de acabamento e o tecido.

As empresas de estamparia na Europa também têm problemas com pequenas quantidades e desenvolvimento. A amostra é cobrada por aqui para evitar o desenvolvimento na Itália e a produção na China. Bertola explica que, então hoje, é pago. Caso a produção seja feita na Itália, o valor do desenvolvimento é descontado da produção.

O bom gerente de produto sabe interpretar o que o estilista está propondo, porque na moda tem o componente criativo. E se o estilista não se express adequadamente? Essa afirmação não recai sobre o mito? Também por dar a entender que o gerente de produto estaria à serviço do estilista. A afirmação é em tom impositivo.Elas não abrem espaço para questionamentos.

Embellishment / Detalhes

llustração - não tem a obrigação de comunicar nada tecnicamente (mai 
gente, e o gerente de produto como é que capta as coisa no ar?) ATA o estécnico colocando ambos lado a lado" que sugere Molteni? Falta uns acertos, fazer uns combinados entre as professoras dessa disciplina. Embora a Bertola dê mais espaço a outras professoras em sua disciplina que Conti, falta alinhar algumas coisas.

Desenho - o desenho técnico comunica proporções, por exemplo. Aí ela segue criticando croquis longilíneos pelo problema de sempre, de distorcer a figura humana. Nós no Brasil já temos uma pista de onde herdamos o problema, mesmo que nossa escola tenha surgido antes como faculdade. Veio de uma prática estabelecida anteriormente.

Vale comparar essa divisão com a de Renata Zaganin? Talvez.

Resumindo

Fases do processo > Briefing de Design > Reunião para Produção > Apresentação da coleção > Lookbook

\section{TU/e Technische Universiteit Eindhoven}




\section{NACHTIGALL, Troy. Entrevista realizada com Troy Nachtigall, em 7 de março de 2016, na cidade de Eindhoven (Holanda), com 50 minutos de duração.}

TUe - 07/03/2016 - Fashion Designer e doutorando da TUe

\section{Parte I - Duração 50 minutos}

NACHTIGALL, Troy. Entrevista realizada com Troy Nachtigall, em 7 de março de 2016, na cidade de Eindhoven (Holanda), com 50 minutos de duração.

O orientador dele de doutorado, chamado Clement Thornquist viajou o mundo inteiro catalogando metodologia de projeto no mundo. $O$ Troy é de Wyoming EUA. Ele foi designer por 12 anos até 2016 e professor em Florença. $\mathrm{Na}$ TUe ele é doutorando em design de interação.

Ele começa o projeto a partir de um grande montante de imagens, mas na Hugo Boss e na Calvin Klein havia uma fórmula, uma teoria sobre como as coisas eram feitas que se modificava a cada três, em cinco ou sete anos a marca foi vendida (não fica claro se 5 ou 7 anos mudava a fórmula antes ou se nesse tempo a marca foi vendida e qual marca?) e eles modificavam essa fórmula de fazer projeto para mantê-la fresca.

Para ele há três fases na moda: trendy moments, ou seja, momentos onde as pessoas tentam fazer a mesma coisa, contralty (?) moments ond as pessoas estão fazendo exatamente $\circ$ oposto à tendência, empty trend moments, quando todo mundo está de fora (outsider), coisas diferentes mas há certa unidade (na coleção deles eu acho). Ele cita a Gucci que cria moda e às vezes é trendy, as vezes é empty trend moments.

A finalidade da moda é o dinheiro, ganhar dinheiro.

Existe $\circ$ designer conceitual e $\circ$ designer technical. $\bigcirc$ primeiro caça tendências e faz muitos moodboards.

Volto para as etapas e ele fala que na Hugo Boss tudo começa com o Brand, que é uma marca Brand Based. Começa com uma pesquisa de tendência e olhando o que as outras marcas estão fazendo. A Calvin Klein é muito diferente. Escolhem tecidos depois na Hugo Boss. E tem um ciclo de coisas acontecendo porque a moda é ciclica e tem que reinventar as tendências que se repetem exaustivamente como o militar ou o boho. Esse é mais o technical designer. Ele fala de marcas, feiras, filmes, livros para os seus alunos. Ele detecta muitas tendências em filmes também e fala de "Pride \& Prejudice", mas fala também porque fez fashion films. E nesse sentido ele precisava viver uns anos na frente, cerca de três ou quatro anos adiantado. Depois dessa pesquisa ele sugere como etapa fazer um moodboard ou v deo para ilustrar e todos e esse livro é um guia para todos os profissionais que trabalham no desenvolvimento de produto se guiarem (bate com a Téti no artigo do Capítulo 3). Depois dessa parte começam os technicals, os desenhos técnicos. Ele fala que pode começar por esboços ou croquis, mas que na Hugo Boss já ía direto para os técnicos e isso tinha a ver com tempo e custo. Uma peça só poderia custar 35 dólares incluindo tudo, tecido, costura, design e poesia, mas tem esses aspectos práticos que tem que ser considerados como 0 custo e que não são nada poéticos.

Ele ensina e defende que o melhor é fazer de uma forma que ninguém nunca fez. É importante não olhar para a marca do lado e fazer do seu jeito, desenvolver o seu processo. Na moda não há fórmula para o sucesso, não como em outras áreas, que seguir um método te leva a um resultado certeiro. Ele cursou FIT e Parsons e prefere a Parsons e que é mais livre e falava para ele fazer o que ele quisesse e não olhar para o lado. Ele fez cursos de ilustração e photoshop na Parsons em 2006.

Diferença entre moodboard e storyboard. Storyboard e mais para desenhar qualquer coisa voltada à passarela, e você precisa fazer o styling de setenta looks e como a história vai ser contada durante o desfile e para a mídia. O moodboard é quase individual e dividido por grupos de assuntos (set), por exemplo, o grupo romântico e pode ser um painel ou livro com as páginas todas diferentes e você divide isso em 3 ou 5 fases dependendo se é uma coleção mais fechada, mais aberta. Os francesas são de certa forma obcecados por cadernos, petit cahier, cahier de création, grand cahier e na opinião de Nachtigall isso e para ocupar os alunos em sala porque eles não têm muito o que fazer nas escolas francesas.

A ideia do moodboard é ser fácil. Não é um processo linear e ele muda a medida que a coleção é desenvolvida ou surgem novidades e isso é exaustivo, mas necessário para manter a coleção nova, fresca (fresh).

Para ele a diferença entre moda ser encarada como arte ou design é que no primeiro caso $o$ estilista define o que o cliente usa, mas não cria para $\circ$ cliente, cria para si, ao contrário do designer. A parte artística se dedica mais a textura e forma. Na abordagem artística se der certo deu, na abordagem do design há um compromisso maior com as vendas.

Stylist pode ser usado para quem trabalha na loja, com vitrine etc ou meio que artista, mas mais quando é um enrolador, em um sentido negativo que não fez nada de bom, só styling. Nesse caso tem um sentido que coincide com o de Cibele Taralli.

Ele é muito fã do modo de projetar italiano mesmo com as ambiguidades. Conta que foi onde mais trabalhou como "designer". Há uma coisa selvagem, prazerosa de discutir em jantares, com sol, à beira da praia, "trepando" com as pessoas certas e isso é moda italiana. Eles nunca trabalham em mais de duas pessoas senão fica confuso. Em três já não funciona.

Fashion Concept é o nome do curso e da disciplina que ensina pesquise criação e desenvolvimento de produto. Eles têm também Research Course, é tudo separado também.

Há nomes engraçados de disciplina para separar tudo e tornar tudo muito específico. 
Para ele Moda é um campo autônomo e há um PhD só em Moda na TUe e é por isso que ele está lá. Para ele Moda é um campo autônomo. E para ser um campo autônomo a moda precisa de um curso de $\mathrm{PhD}$ que é o caso da TUe, por exemplo.

\section{Parte II - Duração 2 minutos}

NACHTIGALL, Troy. Entrevista realizada com Troy Nachtigall, em 7 de março de 2016b, na cidade de Eindhoven (Holanda), com 2 horas e 15 minutos de duração.

Só falo sobre Munari e Bomfim, mas para ele moda é mais sobre Comunicação Visual é uma forma de mediação sobre como vemos uns aos outros.

RESUMO ETAPAS TROY NACHTIGALL

Moodboard é um material que contém todos os resultados de pesquisa e suas atualizações e serve como guia para todos os profissionais que trabaIham no desenvolvimento de produto. Ele pode ser representado sob a forma de painéis ou caderno. É completado e atualizado principalmente pelo designer e é dividido por grupos de assuntos. Ele não constitui um processo linear, pois muda a medida que a coleção é desenvolvida ou surgem novidades. Nachtigall aproveita para diferenciar moodboard de storyboard. Esse último serve volta-se principalmente ao desfile, styling e a forma como a história vai ser contada durante o desfile e para a mídia.

\section{Agências de Fomento}




\section{MERINO, Eugenio Andrés Díaz. Entrevista realizada com Eugenio Andrés Díaz Merino, em 06 de outubro de 2016, na cidade de São Paulo, com 1 hora e 03 minutos de duração.}

Coordenador de área do CNPq e também coordenador dos assuntos relacionados internacionais da CAPES $=$ Grupo Assessor Especial da Diretori de Relações Internacionais (GAl).

L=Dentro de qual área do CNPq a moda está?

$\mathrm{E}=$ Dentro das grandes áreas existe a área de Desenho Industrial. Dentro da área de Desenho Industrial estão alocadas todas as áreas que dizem respeito de alguma forma, mais ou menos direta ou nas ações mais tradicionais de produto e gráfico e as novas, digamos assim, mais contemporâneas que o próprio design está desenvolvendo, que nesse caso, caberia a questão da moda. Então dentro da área de Desenho Industrial está a área de Design de Moda. Entretanto, algumas manifestações de fundo um pouco mais artístico acabam transitando por outras áreas [...] as artes. Algumas áreas por exemplo que se relacionam mais com a parte visual acabam indo mais para a área de artes visuais. Alguma coisa que se trabalhe na moda do ponto de vista comunicacional, eu tenho observado que transita mais pela área de comunicação ou para a área de publicidade e propaganda.

Dependendo do enfoque e da submissão do projeto e solicitação de bolsa no $\mathrm{CNPq}$ os próprios pesquisadores vão direcionar.

O que diz respeito ao Design de Moda que atribui um caráter assim mais próximo do design conservador [...] trazer para o Desenho Industrial, a prática projetual, todos os métodos, sistemáticas etc e acaba não tendo uma manifestação mais artística, momentânea que acaba tendo algumas diferenças em algum momento, ele cabe da na área de Desenho Industrial mesmo.

$\mathrm{L}=\mathrm{E}$ quando você fala dentro das grandes áreas, a área que englobaria o Desenho Industrial para o CNPq seriam as Engenharias.

$\mathrm{E}=$ isso, nós estamos alocados nas Engenharias. Ele está alocado numa área denominada mais de "Tecnológica" atualmente. Porque por ser DI, essa nomenclatura acaba se mantendo historicamente já de muitas décadas em razão dessa associação feita com tecnologia, com processo, com método, com materiais, com coisas um pouquinho mais quantitativas também e gerando um espaço com uma identidade maior das artes, visuais em outras áreas específicas. Acabou sendo alocado nas engenharias por esse motivo [DI, Moda ou ambos?] mais tecnológico e também porque pelas políticas governamentais, o Ministério de Tecnologia também envolvido nisso atribuiu ao design uma característica inovadora, estratégica, geradora de patente, então "aonde" "eles" entenderam que caberia da melhor forma, ela conseguiria lidar melhor, seria nas engenharias.

Entretanto, é uma área pequena. Tanto que estamos juntos com as Engenharias, a Engenharia 3, Engenharia Naval etc. Dentro das Engenharias também há divisões. Isso...tem a Engenharia de Produção, a Naval...porque acaba se misturando um pouquinho mais as divisões feitas pela CAPES e as divisões feitas pelo CNPq. Elas possuem nuances diferentes.

Quando eu falo Engenharias 3 estou me referindo à divisão da CAPES. Em escolas antigas como UFRJ, o design está alocado nas EBA, Escola de Belas Artes. Eu estudei na EBA, na UFRJ. A própria Arquitetura e Urbanismo também estão na EBA na UFRJ. A indumentária, a pintura também. Há um trânsito enriquecedor.

A moda...

No Chile não tinha DI antes. Em Valparaiso, na Universidade de Valparaiso havia uma escola voltada para a Moda, para o Estilismo na década de 1980

Quando Eugenio Merino chegou ao Brasil e conheceu as Escolas de Design achou uma oportunidade muito boa.

Fala dos professores da UFRJ e da ESDI. Naquele tempo, cada professor tinha sua especialidade. Hoje os professores se formam em design e vão buscar conhecimento em outras áreas.

O CNPq tem um sistema muito robusto que tem um banco de consultores, que eu não saberia te dizer o número de pessoas que nós temos. $\mathrm{E}$ o CNPq apresenta um rigor bastante interessante. Os pareceristas são indicados...hoje temos um sistema inteligente. Ele já aloca...O sistema dispara para um membro, dois ou três avaliadores para cada projeto dependendo da demanda também e, a partir disso, o avaliador quando recebe é orientado a verificar o processo. Se esse projeto se enquadra na sua área, se tem experiência nisso, se está alinhado e tal. Então esse é primeiro crivo que se faz. Esse primeiro momento funciona desse forma.

$\mathrm{Se}$, por ventura acontecer algum imprevisto temos uma equipe no CNPa que cuida das áreas de Engenharia que, no nosso caso temos duas pessoas que trabalham direto com nós, que é o Fábio e Vânia que, eles fazem a interface com os membros das áreas especiais. Temos também outros professores a postos que nos ajudam nesse sentido.

Chamam professores quando precisam, desde que não tenha nenhum tipo de problema ético nesse sentido, e então ele vem e faz parte desse grupo para poder fazer a avaliação final. [...o padrão?] nos pareceres que os avaliadores adotam.

$\mathrm{L}=$ Quantos avaliam um projeto?

$E=2$, dois como base, no mínimo.

$\mathrm{L}=\mathrm{Se}$ um avalia muito bem, outro muito mal como é que é?

E= Aí vem um "papel", um "papel" do CA. O CA é a Coordenação de Área constituída pelas pessoas responsáveis por analisar os pareceres. $\mathrm{O} C A / D I$.

Lá na CAPES, por exemplo, é AU, Arquitetura e Urbanismo. E colocamos aí + Design. Então para ganhar aí, digamos essa identidade, o pessoal geralmente coloca AU/DI. Então temos a CA e é designado esse grupo de duas 
ou três pessoas. Nós recebemos os pareceres pelo sistema, na plataforma, cadastrado, bem robusto. Além disso, nós recebemos planilhas e notas de Excel em banco de dados com a produção científica do proponente, com o histórico de petição, todo o processo, o projeto, toda a papelada. Então, antes de vir para nós ele passa por [...] então você faz uma [...] para o CNPq, é revisado no Departamento dependendo da chamada a $P Q$ abre uma chamada para um interno que foi designado para isso, ele abre o processo para ver se estão todas as informações e se o projeto, a proposta, ela atende aos requisitos do edital.

Nós não ganhamos nada para isso. É um trabalho que a gente faz com muito prazer, com muito carinho e que em um determinado momento cada um vai ter que fazer sua parte. Só que se não fizer a revisão detalhadamente, se for para uma pessoa [...]

$L=$ Você está falando dos editais, mas sobre as bolsas que dependendo da nota do $P G$ tem mais bolsas...

$E=$ Isso não é avaliado. $O$ que acontece é que o programa tem a responsabilidade de atribuir a [...], tem seus critérios, porque vai para nossa área ah, pedido de apoio a eventos, bolsas especiais, pós-doutorado, pesquisa, editais de fomento tem edital de [...], edital específico de inovação. Todos os editais eles vêm para nós. E tem um parecer anterior que diz "enquadrado", não "enquadrado".

Antes de ir para um parecerista ad hoc ele passa por uma área técnica Imagina que se na solicitação fala que você precisa ter, inserir sua identidade com foto, o projeto chega com 5 páginas, ele não pode ser avaliado. É óbvio, então isso aí passa. Mas claro que a gente avalia todos os processos porque pode existir algum erro. Então quando a gente vê um "não enquadrado", o técnico já sinaliza "ele não se enquadra no item 3.5...mudou e..

O Eugênio Merino antes de enviar para o grupo que o auxilia como coordenador de área pega todos os projetos, principalmente os "não enquadrados" e revisa. Aí os projetos vão para dois, pelo menos dois avaliadores ad hoc que o sistema distribui e se houver muitos problemas aí vem um parecer que volta para o Eugênio Merino. Aí "nós" (creio que ele e a equipe dele) avaliamos esses pareceres. Se houverem diferenças entre os pareceres a gente precisa rever com muita calma, precisa ser revisto o processo e aí caberia a possibilidade de solicitar mais um parecerista (quando há discrepância), diferente desses dois ou se o membro da área entender que ele tem plena condição de emitir um parecer, ele mesmo emite o parecer. Porque o parecer final é emitido pelo CA (Coordenação de Área). Ah! Teve dois que falaram "excelente projeto", se enquadra, tem todos os méritos, a gente faz uma revisão e atesta isso. Se há discrepância ou alguma coisa diferente, a gente avalia e emite um próximo parecer. Sendo necessário a gente chama um terceiro ou quarto parecerista.

O que funciona com relação às verbas é que você tem que atribuir prioridades. É por mérito. $O$ projeto por si só ele não tem mérito intrínseco ao projeto. É o projeto, é o pesquisador...tem um conjunto (de coisas que são avaliadas) que gera uma classificação. A partir dessa classificação você atribui prioridades, P1, P2, P3 e aí você vai ter...quando vem o recurso...

Quando volta da avaliação é preciso classificar. Aí vem um papel das comissões de pelo menos 3 pessoas para poder se reunir e todos eles, todos eles têm que ver os processos. Aí temos que ver cada um 100 processos, são 200 processos. Essas reuniões acontecem agora de acordo com os editais.

Naquela época haveria uma reunião no prédio do CNPq em Brasília em outubro de 2016, onde cada equipe tem sua sala, sua equipe. Eles oferecem uma condição boa de trabalho. $O$ governo custeia a ida desses pesquisadores. O CNPq deposita o recurso na conta deles, cada um deles compra sua passagem e seu hotel e você vai todo dia. Chega 8 horas da manhã e sai 21h, $22 \mathrm{~h}$ da noite, volta para o hotel e fica uma semana.

As comissões habitualmente nesses órgãos de fomento estão [...]. Eles estavam em Brasília numa reunião da CAPES que começou $8 \mathrm{~h}$ da manhã acabou $18 \mathrm{~h}$ da tarde.

Em relação a esses grupos que se reúnem em Brasília, o grande desafio e você respeitar os editais e, se entrar qualquer tipo de preconceito, qualquer tipo de "prejudicamento" que você tenha com determinado edital, com determinada área...é porque todas as áreas são iguais perante o sistema. Todas as áreas fazem parte. Não é porque eu sou formado em design e gráfico que não vou contemplar moda e outras áreas. As outras áreas têm que ser avaliadas de forma igual.

Historicamente as áreas de exata têm sempre recebido mais apoio (mas as áreas não eram todas iguais?) pelo impacto que ela tem, tem políticas governamentais, o impacto econômico. Como você tira muito dessas verbas, a geração de recursos etc vai acabar diluindo. É só um marco histórico, mas a gente vê que vem mudando bastante.

A área das artes, da comunicação, da sociologia, da antropologia, das letras, elas vêm ganhando um espaço (ISSO ERA PRÉ-TEMER) muito interessante e acaba dividindo um pouquinho porque as ciências sociais aplicadas acabam tendo sempre um pouquinho menos de de de... (verba?)

Entretanto, e isso é opinião pessoal minha, historicamente, nós das ciências sociais aplicadas nós sempre temos tido assim algumas restrições "ah, eu não vou fazer isso aqui", o pessoal das exatas, o pessoal do dinheiro, estatística, números não.

$\mathrm{L}=$ Não é marketing?

$E=$ Exatamente. Como ele transita hoje na engenharia e no design para mim está muito claro. De fato, quando você tem um edital e você tem 300 projetos de engenharia, você tem 10 de Desenho Industrial.

É pouco ainda. Eu não saberia dizer a proporção, mas é significativa. E até talvez, por essa questão histórica. A moda surgiu nesse processo ainda, mais de estilo [...] de estilismo, ah mas 0 ato projetual, a gente não segue uma metodologia, então a gente faz meio que insight. Tem uma metodolo- 
gia que faz parte de nossa vida e do habitus que eu aprendi fazendo, aprendi com uma costureira, um modelista que aqui é sensacional, mas no final, no final tem processo, tem metodologia, só que uma metodologia diferente. Não é da forma que o engenheiro faz, que a metodologia do desenho industrial faz, mais formalizado.

Mas como? A grande questão seria se você tem algumas normas, algumas regras sociais de convívio, posso não concordar e até não concordo com muitas delas, mas eu preciso respeitá-las e, para "mudar elas" eu preciso fazer um movimento para mostrar o meu valor e aí propor. Agora mudanças por mudanças levam tempo. Vou "bater boca" com você. Não concordo porque eu não gosto, porque é feio, porque "sempre zia" [acho que ouvi isso].

Eu preciso mostrar o valor da moda, eu preciso mostrar o valor do desenho industrial, o valor do design gráfico, hoje da animação, todas as tecnologias que vem e falar da importância da embalagem, né?

L= É uma coisa entre produto e gráfico, né?! (sobre a moda).

$E=E$ transita pela própria comunicação, então como eu posso trabalha isso? Eu sou muito partidário disso. Se o Currículo é importante pelas regras, porque imagina uma entidade como do $\mathrm{CNPq}$, enorme, que tenta agrupar todas as áreas do conhecimento, toda a pesquisa científica. Se ela não tiver regras, normas, fica muito difícil.

Então você precisa ter uma produção científica mínima. Você vai ter que ter e tem que publicar. Mas é a forma, lamentavelmente, eu preciso fazer esse esforço agora, mostrar que há condição (de a área de impor) e depois que eu demonstro eu começo a questionar.

A sistematização de áreas de engenharia pela própria tradição e história, não são melhores, mas acabam tendo pela própria formação mais pragmática, mais sitemática, acabam tendo uma sistematização, uma organização mais próxima daquilo que foi convencionado.

$\mathrm{L}=$ Para a gente (moda) é difícil.

E= Eu avalio os trabalhos da FAPESP há muitos anos já e outras agências. A gente emite muitos pareceres e vários da moda. De pesquisas boas, que eu tenho dado pareceres favoráveis, de continuidade. A maioria vem da engenharia, do próprio desenho industrial, mas pelo menos há 2 ou 3 anos eu tenho avaliado da área da moda, moda mesmo, não vestuário.

Há pessoas mais dentro e mais fora da caixinha. A parte mais difícil é atribuir peso, se você diz "esse aqui é um pouco melhor que esse"...então são pontos. Vou ver os pontos 32, 33 [?]. Agora a qualidade dos pontos também dá para ver, mas em princípio não existe [...].

Agora se um tem mais anos de experiência, esse ganha. É um item mais objetivo de avaliar. Outros itens vâo me mostrar a qualidade, o tipo de produção, repercussão social, a inserção social disso, ai eu vou poder ter outros retornos. $O$ retorno social, etc.
A exigência das agências de fomento te transforma em uma pesquisadora melhor. $E$ depois se você aprende tudo isso [...] e você vai criando seu "modo operativo" para desenvolver pesquisa de excelência. A internacionalização que tanto $\circ$ Brasil quer ou as políticas públicas atuais que decidem (decidiam antes do Temer) que desejam que os nossos pesquisadores se relacionem com o mundo, nós precisamos ter pesquisas de nível. Não podemos sair com pesquisas que não tenham um segmento metodológico e é algo muito sério. E ainda não temos isso. Tem algumas áreas que negam isso.

$L=$ Como você enxerga a diferença entre o estilismo que vem da moda $e$ o projeto?

$E=$ Historicamente, $\mathrm{o}$ entendimento que nós tínhamos de tudo isso era que o estilismo era uma ação muitas vezes desprovida de um processo ou é um ato criativo, mais intuitivo e a partir dessa discussão...lá na criação do INEP no ano 2000 discutia-se bastante isso porque dentro da nossa área de avaliação do ensino de graduação a moda, o design de moda estava dentro do nosso grupo.

$\mathrm{L}=$ Como era antes do encampamento da moda, antes de 1998 ?

$E=$ Tinha a comissão de especialistas, dependendo da solicitação para 0 Ministério da Educação, se formavam as comissões, ficavam dentro de uma área próxima e essas pessoas transitavam fazendo as [atualizações ou avaliações ?] do reconhecimento do curso, mas existia essa questão.

Então o estilismo ficou mais atrelado ao marco criativo, a algo menos projetual e o design de moda, segundo as próprias iniciais, atribuiria a essa moda, a esse estilismo, um caráter mais projetual, um caráter que envolvesse processos sistemáticos e evolutivos de grau de complexidade, por exemplo, começa manualmente, termina numa modelagem, mas com vários fatores, os processos envolvidos, os materiais envolvidos [criar por criar?] O que se observava era que o estilismo tinha uma ênfase mais na criação mesmo e esse design, essa moda com essa palavrinha design, teria um viés mais projetual. E envolveria na grade curricular a presença explícita de algumas disciplinas de projeto que contribuiriam, materiais principalmente, processos e práticas laboratoriais que era o que mais conversávamos. Que eram as oficinas, que o cara tinha que ir para a modelagem, tinha que ir para a costura (MAS JÁ ÍAMOS ANTES DE SER DESIGN).

L= Eu ía.

$E=$ Você foi, né? Mas muitos não tinham. Isso ainda acontece no próprio desenho industrial. $O$ aluno acaba dependendo da condição da instituição não tendo oficina. Como que o cara vai fazer isso? Toda a formação ficava "por trás". Atribui-se isso.

Entretanto nos pedidos que vão para o CNPq, se eles se enquadram, se ele tem todos os requisitos que o edital exige, ele é avaliado.

L=Se está fundamentado é avaliado. 
E=Isso, se o projeto está frágil, aí é outra coisa. Ele é avaliado.

L= Então se ele é estilismo ou projeto não é um problema?

$E=$ Não vejo problema. Ele tem que se adequar às regras do edital.

$\mathrm{L}=\mathrm{A}$ moda surge autônoma, em partes vinculada à arte e o design encampa em 1998, falei com a Mônica Moura e os cursos de Moda perderam o time para pedirem para serem autônomos perante o MEC e há uma resistência que busca autonomia ou pelo menos uma discussão sobre poder se manter como [Curso Oficial ?] de moda. Falo dos diplomas da FASM, FMU e FAAP que são Moda. O que você acha dessa situação e desse grupo [Moda como campo do saber] que leva isso adiante. Como é isso para você que tem acesso aos documentos que chegam à esfera federal?

$E=E$ É bem polêmico e controverso porque envolve questões ideológicas, históricas. Institucionalmente não teria como eu te responder em nome do CNPq. O que eu observo nas minhas experiências no CNPq já de alguns anos, onde estou há 10 anos mais ou menos como bolsista produtividade e sou há um bom tempo membro das comissões, coordenador do programa de Pós-graduação, então de alguma forma, tem um vínculo, um conhecimento. Claro que [...] em algumas áreas de atuação, mas a gente acompanha os cursos, até porque faz parte das comissões que avaliam alguns processos de criação em nível de Pós-graduação de curso de moda e tudo. Então isso é controverso.

O CNPq na minha opinião pessoal, como todo mundo para mim tem boas intenções, só que você precisa criar regras, normas para que a gente consiga dialogar (a coisa da Burocrazie da aula do Paolo Volonté 23 e 29 marzo, 2017. E nesse diálogo em algumas áreas vão existir mais produtividade e que eu vejo na moda é exatamente isso. Essa tentativa de "encaixar ela" dentro de algumas caixinhas pré-definidas, eu acredito que o que mais incomoda são muitos profissionais dessa área, mas eu vejo que isso é histórico. Nós tivemos que nos encaixarmos (design) em algumas caixinhas para o convívio social, para que a gente pudesse fazer parte desses processos. E se você como área começa a mostrar esse seu desempenho, as suas habilidades, as suas competências, suas contribuições sociais e econômicas, todas elas, eu acredito que fique mais fácil.

Mas áreas separadas, pequenas, elas se tornam muito frágeis e vulneráveis. Então precisa existir um diálogo maior, mostrar um pouquinho mais o valor de cada uma de nossas áreas e dentro de algumas linhas de diretrizes que eu penso que são políticas públicas.

No país, no continente está se falando que esse tal de design seja de moda, gráfico ou de produto, ele auxilia talvez uma melhoria na qualidade de vida das pessoas? Me mostre isso (fala em nome de uma agência de fomento). Ajuda na produtividade, na viabilização produto? Me mostre isso. E não simplesmente fique dizendo que ajuda, ATA. Mas como? Se sabe que ajuda, mas eu preciso [interrompi]. Aí vem a pesquisa científica que na minha opinião, o resultado de dissertações e teses também têm que caminhar por esse lado, mostrar o valor dessas áreas [constituídas?] e é o traba-
Iho científico que tem o respaldo acadêmico, então ele tem um valor muito grande. E isso vai nos ajudar realmente a valorizar essa área (moda).

Ainda há isso, nos temos em Santa Catarina o curso de Moda na UDESC e só para teres uma ideia, tem a Mara Rubbia, tem a Elizabete [?], tem a outra menina moreninha...elas foram todas minhas alunas nas engenharias, no Mestrado e Doutorado. Porque não tem pós lá. Fizeram nas áreas de produto, materiais que eu atuo lá e foi muito bom. Elas foram muito bem sucedidas, fizeram um bom trabalho e agora elas estão iniciando o processo de [...] cria independência. Um monte de alunos sairam da Moda na UDESC e faziam pós na área de gestão na UFSC, na engenharia, alunos do Paraná e São Paulo.

Na UFSC são mais fortes na parte de materiais, têxteis não é tão forte. Ainda que nós tenhamos um pólo têxtil muito forte (em SC), as parcerias não são tão fortes como empresas de eletrônica, mecânica, agrícola que são investimentos maiores.

E hoje esses professores (como os da UDESC) vão criando a sua identidade. Hoje já tem Mestrado, daqui a pouquinho abrindo o doutorado e a demanda que vinha toda para nós (UFSC) dos alunos da moda, eles vão conseguir se direcionar para sua própria área se eles assim entenderem.

A mistura da moda com design e engenharias é muito saudável para Eugênio Merino.

Fala do Politecnico de L??? acho que é na França.

$\mathrm{L}=$ Falei da resistência da moda.

$E=$ Mas isso não te inibe a explorar novas áreas do conhecimento. Ele fala do ser humani nas engenharias (sistema-produto-serviço).

Você deve ter diálogo, mas eu preciso ter meu núcleo duro.

$\mathrm{L}=\mathrm{A}$ resistência passa por forçar o objeto de moda, mesmo quando é pesquisa-criação e desenvolvimento de forma a sujeitá-la ao design. Além de outras áreas como história, sociologia e antropologia às quais a moda recorre, tem que recorrer ao design para falar de produto e, antes, já fazia isso de forma independente. Passa por aí a resistência.

$\mathrm{E}=\mathrm{Eu}$ acho que $\mathrm{o}$ discurso central é a identidade. "Eu quero ter a minha identidade própria."

O design também cresceu para serviço, não faz mais produto só para fábrica.

Entretanto, é preciso ter um meio termo. Eu concordo com tudo isso que você falou. A moda é algo mais atual, mais nova, não tem esse núcleo duro. Então tem ainda uma caminhada longa ainda pela frente para criar essa densidade e um alinhamento um pouco mais [próprio ou prático?] dos profissionais que é [vetado?].

$\mathrm{L}=\mathrm{O}$ design encampar a moda não é uma coisa também de o design buscar endurecer o seu núcleo? 
$E=$ Eu não vejo dessa forma. Eu não vejo uma absorção [da moda pelo design]. O que eu vejo é uma tentativa de fortalecer uma área do conhecimento como um todo, a área projetual. Eu digo, "o que que eu estou fazendo?” Eu não tenho como prever o resultado final, mas eu não estou fazendo acontecer de uma forma intuitiva.

Eu vejo como fortalecimento. Se eu me juntar, "o design está um pouquinho melhor que eu", tem mais visibilidade, consigo absorver as coisas positivas que ele possa ter (o design). E tentar enxergar os erros que essa área cometeu para eu (moda) não cometer esses erros ou ganhar um pouco mais de tempo em algumas ações e em um determinado momento, ganhar a minha independência na realidade.

Só que na área do design, o design é projeto. Você tem que fazer algo pensado, algo planejado. Isso é que é design. Se eu penso que a moda também é algo que precisa, e isso não significa que ela vá perder suas características criativas, inovadoras, porque está pensando algo ou está planejando, considerando, digamos a classificação econômica do país, estou considerando a logística. Isso não inibe criatividade, não inibe nada. A única coisa que eu estou fazendo, eu estou considerando as variáveis que de fato são importantes para que aquilo que eu estou desenvolvendo se materialize, se torne realidade.

É mais ou menos como estamos (design) hoje na CNPq no ramo das engenharias. $O$ design é pequenininho perto das engenharias.

Vocês da área de moda [...escrever?] sobre os processos de como desenvolver os produtos de moda, eles não [negligenciam...] a necessidade de circular alguns caminhos por esse do desenho industrial [está muito ruim para ouvir]. Definir problemas, definir algumas diretrizes, definir conceitos, definir tendências.

$\mathrm{L}=$ Mas atender a uma necessidade simbólica pode ser entendida como um problema também?

$E=$ Vai depender do enfoque, mas antes de tudo isso o que eu coloco é a consistência desses posicionamentos. Simbólico por simbólico não vale; prático por prático também não, funcional por funcional não. $O$ que eu quero com o projeto além da funcionalidade.

Citei a cadeira bertoia e a ausência de demanda de que Christo fala (Lane).

$E=$ além da ousadia, [ele cita os movimentos modernos], o que é isso? Stjil? Que é essa cadeira que parece que vai cair e não cai? Mas além disso falta disseminar, espalhar esses valores dentro de uma linguagem que seja inteligível para outras áreas.

Fala do design dos Campana e tudo bem com o design contemporâneo, mas também não pode ser "produto por produto". Porque aí você tenta ir na base dele e você não encontra. Você tem uma "obra de arte" feitas por designer de renome internacional só que em determinado momento o cara faz qualquer coisa e é reconhecido. E vira tendência de design
É preciso ter uma base, uma base de sofisticação, antropológica em cima de tudo isso. Que valor é esse? Só econômico? Não.

Eugênio não considera Design social, design de serviços, pois vem da década de 1960, não é novidade. Tudo bem até considerar o Tim Brown, mas ele não renega o pensamento que isso traz na essência.

L= Encontrei 13 nomes só de painéis em projeto em moda.

$E=$ Quando a gente propõe uma sistematização para abordar uma problemática projetual, a gente não está querendo criar uma nova forma. $O$ que a gente está tentando é utilizando o que eu já tenho e tentar organizar e identificar algumas lacunas e nessas lacunas sugerimos.

Ele vê a questão como uma questão de diálogo, trânsito. E quanto mais convicto eu ficar das coisas, piora mais a situação. Ele defende o retorno aos clássicos para tentar evitar que cada um crie uma nova coisa, pois não há necessidade. Porque perde-se décadas e não se cria nada de (efetivamente) novo.

Então eu vou poder melhorar alguns pontos que não estão bem resolvidos em algumas situações específicas, organizar as ideias.

Citou Gustavo Amarante Bomfim; ele trabalhou com a parte projetual e trabalhou com a estética. Merino conta que no início do INEP, Bomfim repassou muitas informações a ele. Ele inseriu Merino no mercado, Dulce Fernandes [?] lá do Paraná, a Solange [who?] e outras pessoas [...]

Ele citou problemas da Escola da Cidade e no IED. O curso de Moda do IED não é graduação, segundo Eugenio Merino. Ele falou de uma onda de alunos procurarem cursos de Design depois de uma novela, há anos atrás.

Ele iniciou seu trabalho em estaleiro, trabalhava com engenharia naval. Conta que ficava medindo em estaleiro para projetar a carenagem para depois subir no escritório e projetar a estética do barco, a ergonomia dele, o banco. Fala em tom crítico em relação a quem pensa que a profissão de designer se limita ao escritório.

$\mathrm{L}=$ Quem tem mais reconhecimento nas 3 esferas? Estilista ou Designer de Moda? E a forma e a função?

$\mathrm{E}=\mathrm{A}$ questão da personalidade da moda, na minha opinião é fundamental. Tanto o aspecto simbólico, estético [...], eu vindo da área da ergonomi que é uma das minhas áreas mais fortes, a qual está muito atrelada à questão do conforto que é uma medida altamente subjetiva e tem também conforto psicológico.

Ele diz que não consegue isolar a questão da ergonomia e cita como exemplo a area da saúde e os uniformes de quem trabalha e as roupas utilizados pelos pacientes na área da saúde. São horríveis porque elas não consideram uma série de fatores.

Ele diz que já realizou 8 a 9 cirurgias e conta que se você vestir aquela "roupinha sem-vergonha", e uma pessoa mais jovem tem vergonha, você 
fica exposto, ela totalmente pouco funcional, não tem movimento (tolhe os movimentos). Essa parte que é funcional que eu vejo com os meus alunos $\mathrm{e}$ alunos da moda, (desconsidera a parte estética que ele mesmo citou) tangem à moda também. Então isso é moda também.

Fala de um estudo biomecânico do salto alto, a funcionalidade, doenças, patologias, mas também os valores estéticos, os valores formais, os valores simbólicos, os valores culturais etc, existe um mundo desses aspectos que eu preciso considerar.

Se a gente conseguisse trabalhar numa missão global na qual a gente pudesse prestar um pouquinho de atenção a todos eles, aferir qual deles acrescentaria maior importância num determinado setor, por exemplo, se eu esto trabalhando em um chão de fábrica [de uma confecção para mulheres] o aspecto estético é importante, não tenho dúvida, mas o que é mais importante? A segurança, que essa roupa quando eu sente não pegue numa máquina, que eu consiga me livrar rápido dela no caso de uma emergência, de um acidente. Mas eu também não posso pensar em uma vestimenta, em um uniforme, no chão de fábrica que os caras se sintam iguais, porque em uma linha de produção feminina (localiza a vontade de diferenciar-se somente no feminino, a ai) onde a vaidade é mais presente que no masculino de forma geral, [vácuo estranho no pensamento] que a menina se sinta mal, jovens ainda ou mais senhoras eu não posso deixar de pensar nesses aspectos.

$\mathrm{L}=$ Cito os uniformes de empresas de limpeza terceirizadas.

$E=$ Todos eles usam um sapato que não conseguem andar, a roupa quando chove molha. Nesses aspectos há uma necessidade. Nós trabalhamo na parte projetual, é parte da nossa sistemática, a gente chama de guia de orientação com 3 blocos que chamamos de referência (são 3 blocos de referência). Que são o ser humano, a pessoa, o produto ou sistema ou serviço e o contexto no qual eles estão inseridos. (TEM MUITO A VER COM A PRODUÇÃO DE CULTURA MATERIAL QUE FAZ SENTIDO DE FORMA MAIS DURADOURA PARA UMA COMUNIDADE DE QUE O MARCOS BRAGA FALA)

Então para fins de se compreender melhor esse fenômeno e todas suas variáveis, se colocar tudo junto fica bagunçado, a gente não consegue se achar. A opção dele é fragmentar um pouquinho esses 3 grupos. Eles destrincham esse ser humano (hahaha), destrincham o produto ou serviço $e$ com base nisso são feitas análises e levantamentos. Entre elas análises simbólicas, funcionais e depois você começa a gerar o seu processo projetual em cima dessas informações. Você tem um guia, um norte.

$\mathrm{L}=$ Pergunto se ele entende como "mais reconhecido" o designer de moda ou estilista de moda.

$E=$ Você diz...

$\mathrm{L}=$ Desde $\mathrm{o}$ senso comum até a Academia.

$E=$ No senso comum eu vejo mais $\circ$ estilista. Ele percebe que $\circ$ termo estilista tem mais reconhecimento. Tecnicamente, até pela formação dele e por reconhecer certo preconceito nele mesmo, ele consegue observar mais alinhamento no design de moda com essa prática projetual. Eu me sinta talvez um pouco mais confortável nesse ponto.

Mas popularmente, ou culturalmente, ou socialmente eu vejo que $\circ$ estilista tem muito mais reconhecimento. É mais acessado nas mídias e outros lugares.

L= Falta reflexão no campo da moda? Sobre projeto, sobre moda?

$E=$ Sim e não essa reflexão não falta só na moda não. Falta no desenho industrial, falta no design muito, muito, muito. Hoje porque principalmente com a proliferação de todas as terminologias novas, aparentes métodos ferramentas, muito estratégicos, hoje pensar no design, e eu trabalho com isso há 20 anos, eu vejo que as pessoas acabaram perdendo um pouquinho o rumo. Só querem estratégia, estratégia, estratégia e eles não conseguem enxergar que não tem sentido você só ficar pensando se você não vê a prática, o acontecimento, o real. Fica-se divagando às vezes e isso é uma [perda?] muito grande. Eu preciso de uma reflexão, eu penso que sim, na moda, mas também no desenho industrial, também no design de moda nessas áreas que vão ganhando espaço como animação, games perdeu um pouquinho da força, mas continua muito forte por essa tendência. 


\section{SANTOS, Luiz Henrique Lopes dos. Entrevista realizada com Luiz Henrique Lopes dos Santos, em 23 de novembro de 2016, na cidade de São Paulo, com 22 minutos de duração.}

$\mathrm{L}=$ Como a FAPESP designa as áreas de moda dentro dos campos do saber e, especificamente se você tem uma clareza sobre a noção de projeto em moda?

$H=$ Veja bem, a FAPESP segue, de um modo geral, a classificação geral do CNPq. De um modo geral, só que não é rígido. Em princípio [desenho industrial?...] estão na área de Coordenação de Arquitetura e urbanismo, certo?! Por que eu digo isso? Porque caso a caso quando o coordenador recebe um processo para indicar um assessor para fazer a análise, o coordenador lê o projeto e, eventualmente, ele pode [zonear?...]. Esse aqui vai ser analisado melhor na área de artes. Então ele passa para um outro coordenador.

A gente não é rígido nessa classificação. Por que? Tudo depende da natureza do projeto. $O$ coordenador de área vê o projeto e analisa qual a natureza do projeto e ele diz isso aqui pode tramitar em arquitetura ou não, isso é melhor que tramite em artes. Então isso é feito dessa maneira, não tem uma coisa rígida de localização.

$\mathrm{L}=$ Quando você comenta que passa de um coordenador e transfere para outro são os coordenadores adjuntos?

$\mathrm{H}=\mathrm{Não}$, coordenador de área. Como é que funciona? Funciona da seguinte maneira: você entra com um pedido. Esse pedido vai para uma coordenação de área que é um conjunto de pessoas e onde tem pessoas de diferentes especialidades. [Eu foco] na especialidade, elas recebem os processos, se elas acham que é ligado à sua especialidade elas indicam um assessor externo para fazer a análise. A FAPESP não avalia, aqui dentro não se avalia nada. Toda avaliação é feita pelo assessor ad hoc externo. $O$ que que faz a coordenação de área? Ela indica a pessoa mais capaz de analisar aquele projeto, depende da área e ela manda e ela recebe o parecer e o que que nós fazemos aqui? O controle de qualidade. Se o parecer bate com o projeto. Às vezes a pessoa fala o projeto é muito ruim porque não tem metodologia e a você vai no projeto tem metodologia. Então o parecer está contraditório e você indica outro assessor. A gente aqui dentro não avalia nada.

$\mathrm{L}=\mathrm{E}$ quem confere a coerência desse parecer com o projeto é a coor...

$\mathrm{H}=$ As mesmas instâncias. É a coordenação de área em primeira instância e aí faz uma reconsideração. A reconsideração é conceder ou negar o que foi pedido. Aí tem o segundo controle de qualidade que nós adjuntos fazemos. Nós controlamos a qualidade das duas instâncias [superiores ou inferiores acho, não sei!]. Aí fazemos uma recomendação. Aí tem uma terceira instância que é o próprio diretor científico que logicamente que não tem tempo de analisar as minúcias de milhares de processos, mas ele "dá uma diagonal" [...] e não tem tempo de analisar, mas ele "dá uma diagonal" e se alguma coisa parece esquisita ele devolve para a gente. Então a gente tem 4 instâncias. A FAPESP tem a clareza de que nenhum processo é [...] objetivo. Não existe, o processo depende de um juízo subjetivo, né?!

Mas a FAPESP investe em multiplicação das instâncias porque aí as subjetividades se neutralizam (rs), não é?! Então nós temos 4 instâncias: assessor externo, coordenação de área, coordenação adjunta e o diretor científico.

$\mathrm{L}=$ No meu caso especificamente, quem responderia por Desenho Industrial seria a Coordenação de Arquitetura [...], a Dra. Doris Kowatowsky.

$\mathrm{H}=$ Em princípio sim. Não é só ela. Havia também o Renato Anelli. O Renato saiu. Ele viajou, enfim.

$\mathrm{L}=$ Ele se desvinculou?

$\mathrm{H}=$ Ele ficou um tempo no exterior e aí ele pediu para sair e a [Doris ainda] não indicou um substituto. Normalmente arquitetura não tem um volume muito grande de pedidos, tem duas pessoas só.

$\mathrm{L}=$ Existe a possibilidade de vincular alguém do campo do Design para substituir o Dr. Renato Anelli?

\section{$\mathrm{H}=$ Existe porque...}

L= Diz que a demanda [de design] está maior que a de arquitetura. Eu fui à palestra da Dra. Doris na FAU há umas duas semanas e ela comentou das demandas. Ela falou que quem demanda mais..

$\mathrm{H}=$ Então, a Doris vai ser ouvida nesse processo. Provavelmente ela vai dizer alguma coisa a respeito disso. Mas quem indica, o Professor Britto conversa com muita gente e tal, aí ele indica a pessoa.

$\mathrm{L}=$ Qual $\circ$ critério para a escolha de um parecerista. Como é designado um parecerista externo para temas tão específicos, porque, por exemplo, quando eu falo moda eu tenho antropologia, eu tenho comunicação, eu tenho sociologia...quando eu falo Projeto em Moda, essa área ela nasce autônoma e permanece de 1988 até 1998 e em 1998, ela é cooptada pelo Design a pedido do MEC. Então você passa a entender Moda como Design de Moda quando eu falo de produto. Então, eu queria saber se existe, se é estabelecido algum tipo de critério e que critério é esse na seleção de um parecerista ou na distribuição dos projetos.

$\mathrm{H}=\mathrm{A}$ distribuição vai, como eu disse, na primeira instância vai pela grade do CNPq. Então moda vai cair em Arquitetura e Urbanismo. Aí a Doris pega e diz, não, isso aqui...

$\mathrm{L}=$ As divisões do CNPq são aquelas lá do Lattes, né?

$\mathrm{H}=\mathrm{Não}$, ○ CNPq tem uma tabela de áreas, com números, 4. não sei $\odot$ que...então a gente segue em princípio aquela área.

Então vai para a Doris. A Doris olha e diz, isso aqui é realmente...são pesquisadores na área de Design, estão na área de Arquitetura que são os [g....] 
Ou ela pode dizer, não! Esse projeto está tão ligado à sociologia que é melhor que vá para a Coordenação de sociologia ou, isso aqui está tão focalizado nos aspectos estéticos que é melhor que a área de artes veja. Então ela tem essa autonomia em dizer, eu não sou a melhor pessoa e então ela tem um conhecimento prévio da área, ela tem o nosso cadastro que é muito rico que dá as especialidades, tem o Lattes para ver quem são os pesquisadores da área. Ela faz uma pesquisa e vê qual é a melhor pessoa, aí ela indica aquela pessoa.

$\mathrm{L}=$ Você comentou do porte. Por exemplo, uma área com menos demanda, a Doris falou que $0,6 \%$ do orçamento da FAPESP vai para essa grande área de Arquitetura, foi o que ela comentou na palestra. Esse é um dado de 2015.

$H=$ Deixa eu corrigir. Veja bem, a FAPESP não tem distribuição de recursos por área.

$\mathrm{L}=$ Isso é designado de acordo com as demandas?

$\mathrm{H}=\mathrm{Na}$ FAPESP não tem área prioritária. A gente brinca, os projetos prioritários são os bons projetos. Você tem dois tipos de ...você tem auxílio e bolsas. Qual é a diferença? Auxílios são os custos materiais da pesquisa. Bolsas são ajudas de custo que o pesquisador em formação recebe para fazer a sua formação (é legal comparar isso com os papéis da CAPES e CNPq). Envolve IC, bolsas de Mestrado, Doutorado e Pós-doutorado. Isso é bolsa.

A FAPESP tem uma distribuição de recursos que deve ser gasto. Não se usa bolsas, por quê? Para evitar uma situação a que o CNPq chegou em um certo momento, alguns anos atrás, em que todo o dinheiro ía para bolsa e aí você formava pessoa e não tinha dinheiro para a pessoa fazer a pesquisa. Era meio...então a FAPESP [visa?] o máximo de $35 \%$ do orçamento para bolsas. O restante é para auxílios, que são projetos de pesquisa, participação em eventos, publicação de livros, visitantes. Tudo o que é auxílio. $65 \%$ vai para auxilio. Porque a FAPESP não é uma agência de formação. Quem é agência de formação é a CAPES. A FAPESP é uma agência de fomento à pesquisa e ela...como não há fomento a pesquisa se não houver o pesquisador, a gente também tem bolsa, mas a bolsa não é o nosso mote.

Existe uma demanda maior que isso (que 35\%). Então a análise de bolsas ela é feita em duas etapas, os assessores ad hoc [...] os bons projetos, é mais do que a gente pode dar. Tem uma análise interna que aí, entram outros fatores, o currículo do pesquisador, do solicitante, uma série de coisas. Então você tem uma competição (para as bolsas). Em auxílio não há competição. A gente não precisa. Até hoje a gente nunca precisou esse tipo de competição no auxílio. Quem tem parecer favorável ganha, quem tem negativo não ganha.

$\mathrm{L}=$ No meu caso eu tenho reserva técnica. Seria a parte de auxílio dentro da bolsa. Quando você se refere a auxílio seriam as bolsas para pesquisadores?

$\mathrm{H}=$ Auxilio é, por exemplo, você tem um projeto de pesquisa, você ganha máquinas, transportes, diárias para fazer viagens..
Esse é o caso do pesquisador doutor e ele tem que estar vinculado a uma instituição. E a FAPESP é paulista, então tem que estar vinculado a uma instituição paulista.

Então nós não temos distribuição por área. Em todas as áreas os bon auxílios, os bons pedidos de auxílio recebem, todos eles.

$\mathrm{L}=\mathrm{Me}$ chamou $\mathrm{a}$ atenção $\mathrm{a}$ área de Arquitetura tem pouca demanda, então tinham dois coordenadores (sic falei pareceristas) e agora está com um..

\section{$\mathrm{H}=\mathrm{O}$ Renato saiu e não foi substituído.}

L= Uma área com muita demanda seria o quê? Biologia, veterinária? Quantos coordenadores de área tem uma área com muita demanda? É para eu ter uma noção de proporção.

$\mathrm{H}=$ Você tem por exemplo, Ciências Humanas tem muita demanda porque são muitas especialidades. Então você tem um coordenador de área de Filosofia, um de Antropologia, um de Sociologia, um de Ciências Políticas, um de História, um de Direito. Aí ele fala das áreas de Literatura e também da de Educação e Psicologia.

Arquitetura, por tradição, como ela não se encaixa, ela é tem projetos demais, tem muito processo, tem muito pedido de arquitetura que está mais próximo da engenharia, nem é Ciências Humanas. Tá certo?! Da área de materiais, então não dá para encaixar arquitetura em Ciências Humanas nem em Engenharia. Então ela ficou, por essa fronteira...

Serginho= Eu me lembro uma vez que eu ía pedir uma bolsa e a gente não sabia como enquadrar.

$\mathrm{H}=$ Mas veja bem, não tem essa preocupação porque frequentemente eles pegam [...] vamos adaptar, está na Engenharia isso aqui é um engenheiro que vai poder analisar melhor.

$\mathrm{L}=$ Você tem conhecimento desses autores de projeto? E mostro a lista.

$\mathrm{H}=$ Veja bem, eu como representante da FAPESP eu não conheço nada. Eu posso até conhecer, mas eu não vou dizer. Eu não falo de mérito científico.

$\mathrm{L}=\mathrm{Na}$ verdade são autores consagrados que eu elegi e eu entendo que o meu parecerista até agora concordou porque ele entende que essas são as pessoas que avançaram mais no campo e eu perguntei isso para falar da questão de considerações na hora da análise do projeto, mas tudo bem, questão de co
vamos adiante.

$\mathrm{H}=\mathrm{Se}$ a gente sentar no bar, aí eu posso dizer. Aqui eu não falo de conteúdo científico.

$\mathrm{L}=$ Que eu não te encontre no bar, rs. Mas você tem alguma intimidade com esses autores de design, evidentemente.

$\mathrm{H}=$ Eu não falo de mérito científico de projeto aqui. Só quem fala é o assessor ad hoc. 
$\mathrm{L}=$ Desculpa a ingenuidade, mas quando você fala "mérito científico", porque eu não estou levando a falar de nenhum pesquisador, mas de autores do exterior.

$\mathrm{H}=$ Eu não falo de conteúdo científico aqui.

$\mathrm{L}=\mathrm{E}$ uma questão política, nem pode?

$\mathrm{H}=\mathrm{Eu}$ falo como a FAPESP funciona, o que pode ser feito, o que não pode ser feito. Enfim, como coordenador adjunto eu não falo de projeto, de conteúdo científico. Você sabe por quê? Eu até explico para você. Não é que você vá fazer isso, mas eu não posso correr o risco de alguém sair daqui e dizer, o coordenador não sabe nada, não conhece nada, tem preconceito, então eu não falo nada. Aqui eu não falo nada. Se vem um colega meu de filosofia no meu assunto, eu não falo nada.

Eu faço análise de projeto na minha área de especialidade. Eu posso achar o projeto um lixo. Se o assessor diz que é bom, não importa a minha opinião pessoal. É delicado, certo? A gente conhece pesquisadores. Então nem na minha área, nem na área da minha especialidade eu dou opinião.

$\mathrm{L}=$ Você conhece um grupo chamado Moda como campo do saber.

$\mathrm{H}=$ Eu não conheço nada da sua área de moda, quer dizer, conheço, mas não vou dizer.

$L=$ Quando colocamos a expressão design de moda, um parecerista me puxou a orelha, para não utilizar o termo moda, é design de moda. Escuta, você não está mais falando de moda, você está falando de design de moda. É muito específico, você está falando de projeto. Então nós entendemos que era Design de Moda. Quando a gente fala em Design de Moda não tem alguma força coercitiva, ou uma forma de poder, de exercer um capital simbólico maior da área do Design em relação à moda?

$\mathrm{H}=\mathrm{Não}$ vou responder, $r$.

$\mathrm{L}=$ Falta reflexão sobre projeto em moda? Sobre moda? $\mathrm{O}$ que chega até você? O que você tem observado? Qual a sua percepção?

$\mathrm{H}=$ Isso eu posso responder que é um fato objetivo. Não é muito, mas chega (acho que ele dizia e submissões de moda.

$\mathrm{L}=$ Desses $0,6 \%$ que vão para arquitetura, você sabe dizer quanto vai para design, quanto vai para projetos de moda?

$\mathrm{H}=\mathrm{A}$ gente nem tem isso, nem tem essa contabilidade. A gente nem tem também porque é muito difícil você classificar um projeto. Alguns projetos são muito fáceis de classificar, outros são, sabe?! Isso aqui é estética da moda, sociologia da moda, história da moda? Então não tem como mapear a coisa nesse nível de detalhe. Eu posso dizer para você quanto vai para Arquitetura e Urbanismo em geral.

A informação do $0,6 \%$ e o que tem de informação tem no relatório anual da FAPESP que está no site.
A gente soltou agora o de 2015 e a gente tem tudo, por bolsa, por auxílio, por temática, por todas as linhas, você tem uma infinidade de tabelas.

$\mathrm{L}=$ Existe alguém que possa discutir, conversar sobre essas questões referentes a conteúdo?

$H=$ Se alguém fizer isso está despedido. A Dra. Doris não pode conceder entrevista porque ele vem aqui 4 horas por semana. Ele é responsável por fazer só análise de mérito. A FAPESP tem um conjunto de normas, de práticas que o coordenador de área não conhece. Só conhece quem tem uma visão de conjunto da instituição que são os adjuntos, que estão aqui 5 períodos por semana.

Então se você for fazer uma entrevista com o coordenador de área, ou ele não vai saber te responder ou vai dar uma resposta errada. Ele não tem ideia de tudo o que não pode e tudo o que não pode, porque a função dele é específica. É dizer qual é o mérito científico desse projeto, ótimo, muito bom, bom, regular. É isso e ele passa para a frente. Aí tem mérito científico, então agora vamos ver se é adequado às normas? As práticas correntes na FAPESP? Aí isso é nós (coordenadores adjuntos) que vamos ver.

Ele diz que trabalha meio período por dia, além da revista da FAPESP e faz tudo à distância, por Skype.

Posso usar o nome dele como representante da FAPESP e falar em nome da FAPESP com essa entrevista. 
TRISKA, Ricardo. Entrevista realizada com Ricardo Triska, em 29 de novembro de 2016, na cidade de São Paulo, com 32 minutos de duração.

Atua muito em ergonomia e linguagem subliminar etc. Graduado em Ciência da Computação pela UFSC em 1984, Mestre em Ciência da Informação em pela UFRJ em 1993, Doutor em Engenharia de Produção pela UFSC em 2000 e professor associado da UFSC desde 2006 e antes professor da UFPR.

Interessante observar como ele que é diretor da CAPES transita pelo CNPq e o mesmo acontece com o Eugênio Merino.

Sobre a fala dele no Colóquio de Moda.

$\mathrm{L}=$ Como a CAPES, ele como representante da CAPES, o que ele pode falar a respeito de como a CAPES designa a área de Moda dentro dos campos do saber e, especificamente, de projeto em moda. Como é essa história de estar atrelada à Arquitetura e Urbanismo, ou se isso vem da Engenharia ou das Ciências Sociais para a CAPES.

$\mathrm{R}=\mathrm{A}$ organização porque que o design está associado à Arquitetura e ao Urbanismo, eu não tenho um documento que me esclareça isso. Quando foi incorporado o Design ao Sistema Nacionas de Pós-Graduação, foi vinculado à Arquitetura e ao Urbanismo. Não tem um documento que me diga o porquê, mas enfim, funciona assim há 20 anos.

$\mathrm{E} \circ \mathrm{CNPq}$ é diferente. $\mathrm{O}$ Design tem um lugar agora no colegiado de inovação. Ele saiu do colegiado de Engenharia, o que para nós (do design) é uma maravilha porque, nós como designers ficávamos disputando as mesmas bolsas das cotas das engenharias, com critérios de ferrolho que então, eu imagino que daqui a uns 2 anos a gente possa começar a respirar com outros ares dentro do design no CNPq.

$\mathrm{Na}$ CAPES nós trabalhamos com duas subáreas, Arquitetura e Urbanismo e Design. O design hoje representa $34,6 \%$ do total de programas de stricto sensu na área de arquitetura, urbanismo e design.

Isso é muito impactante se nós pensarmos que há 10 anos nós tínhamos 3 doutorados de design. Nós tínhamos pouco mais de 8 programas. Hoje nós temos 10 doutorados em design e nós temos 25 em design, considerando o Mestrado profissional. Então a gente tem uma gama importante. $O$ Design de Moda no contexto de Design é uma habilitação tanto quanto produto (detalhe que não existe mais habilitação e sim as tais "linhas de formação" sugeridas pelo design ao MEC e que o MEC repassou, mas ninguém aderiu e ninguém fiscaliza esta parte com rigor!). Não há qualquer restrição no trato, no conceito de design de moda como uma habilitação, uma especialidade do design. O que a gente faz distinção (ou seja, há distinção!) é com fashion que é uma condição que não tem...
L= Você fala em Design de Moda, para você é produto e vestuário.

$R=B o m$, eu estou dizendo assim design de moda é tanto uma especialização quanto é design de produto ou design gráfico etc.

L= $\mathrm{O}$ Gustavo Amarante Bomfim falava que era produto, né?! (sobre o design de moda).

$R=$ Então, mas eu não faço uma limitação ao conceito de produto, eu faço uma classificação como uma competência tal qual produto. Design de moda, design de produto, design gráfico, design de serviços, design de informação...é uma competência do Design. Agora o que faz ficar próximo do design é a Metodologia de Projeto. É a conduta projetual que caracteriza uma ação do design de moda e caracteriza uma ação fashion, por exemplo. Então quando há uma relação entre objetivo, resultado, processo, né?!, com uma conduta de investigação aí a gente está falando de Design de Moda. Quando a gente está falando de uma coisa por diletantismo (de forma amadora, informal), por intuição, por impressão visual, por tendência ou uma coisa isoladamente por insights é, pode ser uma peça maravilhosa, mas não resulta de um projeto (protecionismo da área de design), de um processo de investigação, não resulta de um processo de aplicação de técnicas de trabalho, de investigação (de novo!), então é um outro processo, né?! (mas é um processo?). Não é Design de Moda (fala quase cochichando) dentro do nosso...

$\mathrm{L}=$ Isso seria o quê dentro desse contexto?

$R=$ Não é Design de Moda, não pertence ao stricto sensu

L= Dá para chamar de estilismo?

\section{$R=$ Pode ser.}

$\mathrm{L}=\mathrm{O}$ estilismo não seria contemplando então dentro de uma área de pesquisa.

$\mathrm{R}=\mathrm{Não}$. Se, por exemplo, o estilista trabalhar projeto imaterial por exemplo, para investigar o caimento de determinada trama, sobre determinadas condições de corte e sobre determinado tipo físico. Isso é um projeto de design de moda.

\section{$\mathrm{L}=$ Que tem como comprovar.}

$\mathrm{R}=\mathrm{Sim}$. É porque o procedimento dele é de investigador. E ele vai necessariamente ter que ter conteúdo para responder à pergunta da própria atividade. Então isso é uma coisa que caracteriza o design. $O$ que a gente tem também que lembrar, é que tem designers que são formados em faculdades e tem designers que a vida transformou (como designer de produto em moda) e tem os outros que não são nada, mas que usam o nome Design como sendo um escudo das suas incompetências. E nós queremos que 0 design seja uma condição de profissão qualificada. Então essa é a razão de nós termos tanta preocupação em caracterizar o vínculo do design de moda com o processo e o projeto. 
$\mathrm{L}=$ Mas se um pesquisador submete um processo, um projeto, seja para o que for, um edital ou vinculado aos programas que as bolsas possam ter, que seja de estilismo mas que tenha seus méritos, tenha processo, tudo bem? Mesmo que ele chame isso de estilismo?

$R=$ Não tem problema. Eu tenho uma aluna assim que ela era do design de moda e a gente precisava...ela pontuou para entrar no programa e não tinha um orientador de mestrado e eu tinha uma vaga na UFSC.

L= Tem uma galera que estuda têxtil e inovação lá, né?! É bem forte!

$\mathrm{R}=\mathrm{Na}$ UFSC não. Na UDESC sim.

$\mathrm{L}=$ Mas eu já peguei vários trabalhos de têxtil da UFSC

$\mathrm{R}=$ Mas aí é da Engenharia de Produção, né?! Dentro do Design existe um pessoal que está começando a forçar a barra para fazer Moda, mas a gente não pode porque não é a competência do Programa. Nós não temos uma sala para fazer qualquer experimento de corte, por exemplo. Se eu não tiver uma sala, uma mesa para fazer experimento de corte, não tem como, nem pensar. Então o nosso programa (da UFSC) não pode aceitar esse projeto pela simples condição de que não tem competência de dar espaço para esse trabalho se desenvolver.

Então houve uma conversa mais séria sobre isso. Então no caso dessa minha orientanda, ela vinha do Design de Moda e eu precisava de indumentária para um personagem de desenho animado que era do [X? 9'05']. Porque quando tu faz animação tu tem o personagem pulando de uma pedra aí cai uma capa a 90 graus assim, pum! Aí é aquela coisa que nem criança acredita em movimento.

Aí a gente estava tentando buscar o reconhecimento de uma textura que o desenvolvimento ficasse real.

$\mathrm{L}=$ Que isso se movesse de acordo com $\circ$ peso, velocidade.

$R=I s s o$, tudo, tudo, tudo. Aí eu combinei com ela. Nós vamos fazer assim você vai fazer uma simulação no software e vai ter um bonequinho na mesa.

Então a gente desenvolve games fortemente lá no nosso laboratório, mas nesse caso era um desenho animado para história infantil. Havia um rigor que não poderia concorrer com o conteúdo, então não poderia haver deslize, erro de sequência, essas coisas todas.

A aluna estudou a trama da época e chegamos a uma descoberta que na trama do fio tinha fio de cabelo humano e fio de rabo de cavalo por conta das defesas das flechas (para proteger de flechas) dos índios e tal. E então ela achou um tear da época, como se construía, simulou o tecido, ai tinha o modelo vivo usando o tecido e o modelo animado usando o tecido na hor da apresentação dela.

Então eu orientei um projeto de produto, usando a expertise dessa orientanda em moda (ela era formada pela UNVALE), mas eu não orientei en direto falar sobre Design de Moda, porque só entende Design.

Eu tenho zero experiência em moda. Mas porque que eu me senti competente? Porque o viés foi de projeto e, em se falando de projeto, aí nós estamos em uma praia segura.

L= Então pesquisas voltadas a projeto, mais teóricas, que não dependam de um laboratório, de um investimento, de um aporte, a UFSC, por exemplo, abraça.

$R=$ Dependendo da abordagem, sim. Agora o próprio Mestrado Profissional da UDESC que foi autorizado agora, eu próprio fiz a diligência lá. Fo super bom. Então como tinha já essa condição de preconceito em um contexto de todas as áreas sobre o design, então como no programa havia algumas imprecisões documentais, então em lugar de simplesmente rechaçar a proposta eu optei pela prerrogativa de fazer uma diligência de visita. E aí eu fiz essa diligência de visita, conversei com o pessoal, busquei os documentos que precisava, aí a gente autorizou o...Programa submeteu ao Conselho Técnico Científico de Ensino Superior da CAPES e foi aprovado está funcionando. Está para começar por agora. Isso era novembro de 2016. Abriu com Nota 3,00 que é o mínimo.

A FAU está dividindo, está abrindo design, para separar o design da arquitetura. Eu sou um grande incentivador disso. Estive na FAU agora e fiz diligência de visita também com o Pró-reitor de Pós-graduação da USP para poder garantir as coisas.

Mas enfim, não há qualquer restrição ao conceito de Design de Moda desde que caracterizado como projeto de design. Assim como eu não vou ter para design gráfico.

Falamos de design gráfico.

$\mathrm{L}=\mathrm{A}$ moda surge em 1988 academicamente como um campo autônomo, mas mais vinculado à arte, pelo seu histórico, FASM, UAM, na sequência UNIP e 1998, SENAC, e depois ela se torna Design por uma demanda política, por uma força do além, seja o que for. Como fica isso? Porque existe uma turma formada com esse pensamento como qualquer campo novo, fo formado por profissionais pioneiros, professores e pesquisadores advindos de outros campos. Eu me formei na UAM. Eu fiz de 2000 a 2003. Eu fui a segunda turma que se tornou Design de Moda. E eu tive uma graduação de estilismo, eu não tive uma graduação de moda (sic), seria Design de Moda. Eram professores que vinham recentemente de estilismo e eu não conhec na faculdade um autor de projeto. Fui conhecer todos no Mestrado e no Doutorado. E a UAM é uma referência muito forte em projeto em design.

$\mathrm{R}=\mathrm{A}$ questão particular das escolas, ainda mais em se tratando de graduação eu não vou me reportar. Eu falo da noção conceitual do design de moda no contexto da Pós-graduação em Design no país.

$\mathrm{L}=$ Qual o critério de escolha para um parecerista? No caso de um projeto de pesquisa voltado ao tema projeto em moda. Porque o que eu entendo também é como a CAPES faz caminhar os projetos quando eu tenho proje- 
tos de moda voltados à sociologia, às artes, à antropologia e qual é o critério de escolha do parecerista.

$\mathrm{R}=\mathrm{E}$ justamente esse o problema que nós estamos passando hoje na gestão da área dentro da CAPES. Houve uma intervenção da gestão que recentemente saiu da CAPES nesse processo de atribuição de pareceres. Então eles fizeram uma coisa lá de usar parecerista do CNPq (talvez isso explica o trânsito de que falei no início entre as duas agências) e aí não deu certo porque não respeitava a identidade temática do projeto com a competência do avaliador. Então foi um desastre.

que nós estamos pleiteando agora é devolver ao coordenador da área responsabilidade de atribuição de pareceres. No caso, ele centralizaria, como na FAPESP e atribuiria quem vai avaliar.

$\mathrm{R}=$ Como era antes. Por exemplo, vinha um projeto de moda, eu não vo mandar para quem trabalha com games.

Ele não sabe dizer quem designava no CNPq quando usaram pareceristas do CNPq dessa última gestão.

Antes da última gestão, tinha um sistema que ele recebia uma notificação do projeto, aí eu abria lá um aplicativo onde tinha o elenco de consultores e eu atribuía 4 consultores. Eu escolhia cada um sabendo a identidade temática de cada um e mandava.

Em novembro de 2016 ele estava pleiteando que ele voltasse a escolher o parecerista.

Mas no caso de ele escolher, ele não escolhe parecerista do mesmo estado do proponente. Escolhe do mesmo ramo, mas de outra faculdade, de outro estado. Ele evita ao máximo parecerista do mesmo estado porque os vínculos são muito estreitos.

Vínculo do pesquisador e Identidade temática são os critérios do Ricardo Triska para escolha dos pareceristas.

Com esse critério é mais difícil que os projetos a serem analisados sejam devolvidos à CAPES sem avaliação por falta de aderência do parecerista. Ele pode dizer que não quer dar o parecer porque está com muito trabalho. Caso conheça o avaliado e o Triska por ventura não saiba, o parecerista declara "conflito de interesse".

$\mathrm{L}=$ Sobre os autores de projeto em moda e de design. $\mathrm{O}$ que você acha? $\mathrm{R}=$ De autores de moda eu não sou capaz de opinar [?].

A parte de produto e visual de design, isso aqui é, vamos dizer, a rota de fuga de qualquer projeto. Ele se refere aos livros de Munari, Bomfim Löbach. É onde você vai ter a condição de trabalho de todos os projetos convergem ao uso (a frase está assim mesmo, esquisita), então não tem uma restrição.

Para produto tem mais gente (autor) trabalhando também, né?!
Sim, mas minha tese é sobre projeto em moda. Interessante porque isso me coloca muito em contato com o design de produto principalmente $e$ puxa, os coordenadores de área que rege a parte de moda desconhecem completamente os autores e obras de projeto em moda.

Ele cita como autores de produto o Eugênio Merino, Itiro lida, embora muito vinculado à ergonomia é importantíssimo para produto. O Guilherme Cunha Lima dentro da parte visual, a Lucy Niemeyer. Honestamente eu não fico preso a autor. $O$ que me faz recorrer a um grupo de autores é o caminho do projeto.

Então quando eu estou orientando, a formulação do projeto parte do candidato, do aluno. Aí eu absorvo ou não a corrente que ele está referenciando.

$\mathrm{R}=\mathrm{E}$ se for algo que você não concorda, mas houver coerência no projeto?

O que pauta aceitar um projeto ou não (e aqui ele se dirige mais à orientação) é a postura individual. Ele assume um projeto pela condição de ter competência ou não para orientar um projeto. Se eu concordo ou não...

$\mathrm{L}=\mathrm{Eu}$ te pergunto mais no caso de projetos voltados à CAPES.

$\mathrm{R}=$ Eu não entendi a sua pergunta.

$\mathrm{L}=$ Estou perguntando mais coisas voltadas à CAPES. Se você está avaliando um projeto com o qual você não concorda ideologicamente, político-pedagogicamente com uma visão.

$\mathrm{R}=$ Ideologicamente eu não posso fazer nenhuma restrição. Isso não pauta. O que pode acontecer e já aconteceu é a priorização disso em função investimento de área. Por exemplo, se o proponente não tem vínculo nenhum com nenhum programa de pós-graduação em design, ele vai para o final da fila. $O$ que me parece natural.

Agora se eu concordo ou não, aí realmente, essa prerrogativa eu não faço.

$\mathrm{L}=$ Pareceres de algum projeto que você pode achar péssimo, mas venham muito positivos, você interfere ou não?

$\mathrm{R}=\mathrm{Eu}$ questiono. Porque quem vai no final das contas ser responsabilizado sou eu. Então se o projeto é fraco e o parecer é bom, ai eu vou querer saber qual é a relação do proponente com...

$\mathrm{L}=$ Chama-se um terceiro parecerista?

$\mathrm{R}=\mathrm{Sim}$. Recorro ao quinto se precisar. Em geral, vai para, pelo menos, três pareceristas. Só que em geral, só um responde, esse é que é problema. Nossos colegas não respondem. Acabo tendo resposta de 20 professores dentre todos os professores de design.

Não precisar ser ex-bolsista CAPES para ser parecerista da agência. Para ser parecerista a pessoa tem que pertencer a um quadro docente de un programa ativo. A lista de docentes dos programas.

$\mathrm{L}=$ Moda como campo do saber que defende que a moda nasce autônoma, em 1998, vira design e existe esse movimento que a Dra. Francisca Dan- 
tas Mendes da EACHUSP lidera hoje e eu queria a sua opinião a respeito da Moda querer ser uma área autônoma ou querer, pelo menos, voltar a utilizar o nome "Moda" em alguns cursos se for de interesse de alguns deles.

$\mathrm{R}=\mathrm{O}$ problema é qual é a repercussão disso no contexto de Pós-graduação. No Sistema Nacional de Pós-graduação, a área Moda, por exemplo, não tem grandes trajetórias, não tem tradição.

Para você ter uma ideia, a área de teologia e filosofia era uma área só na CAPES. Depois de quase 20 anos eles conseguiram separar agora para Teologia, Ciência da religião e Filosofia. E são áreas super tradicionais. Em compensação tem a área de alimentos que surgiu agora em função das novas legislações e regulações.

Eu acho que antes de a gente se preocupar em ter domínio de área, nó temos que demonstrar competência de inserção social, competência de inserção no mercado. Porque não adianta eu subir num banquinho e gritar que eu quero uma área de moda. Eu quero dizer o que que isso vai significar para o Sistema Nacional de Pós-graduação e para toda a comunidade que vai concorrer a esses cursos.

$L=E$ que a reclamação é que existia um campo que foi cooptado pelo design.

$R=$ Não é nem que ele foi cooptado. É que a chance de pertencer ao sistema é pela porta do design porque assim é em todos os outros lugares. Então as escolas formais de qualificação estão vinculadas ao conceito de design pelo motivo do começo da nossa conversa.

L= É que isso em 1998 gera um estranhamento para a área (de moda), sabe?

$R=$ Então, mas o problema é que começa a brigar [por] vaidade, aí alguém perdeu seu feudo e aí começa a descaracterizar.

$\mathrm{L}=$ Você acha que é mais uma luta simbólica?

\section{$\mathrm{R}=\mathrm{Eu}$ acho.}

$\mathrm{L}=$ Você não acha que é um reducionismo falar “Design de...” em relação à moda.

$\mathrm{R}=$ Ao contrário, ao contrário, eu acho que se a condição de competência, como a gente começou a conversar, se dá ao projeto, você buscar a tradição do design para reforçar uma ação específica, só pode ter um caminho virtuoso.

$L=E$ se eu falar de moda como um fenômeno social mais amplo, você entende que a moda pode contaminar o design também e a arquitetura?

$R=$ Eu não vejo contaminação. Eu não consigo ver essa interferência (da moda no design). Eu entendo que são 3 atores de um sistema muito grande [...] arquitetura e urbanismo, design e moda.
Mas de novo, como a gente começou a conversa, a história do projeto não tem como desvincular, né?! Porque para fazer qualquer coisa você precisa de um planejamento e o projeto ordena as ações.

$\mathrm{L}=$ Desses $34,6 \%$ desses cursos de pós que estão inseridos na área de Arquitetura e Design.

$\mathrm{R}=$ Porque Design dentro da área Arquitetura, Urbanismo e Design

$\mathrm{L}=$ Você sabe me dizer o que é moda aí?

$R=$ Nós temos um Mestrado em moda que é o mestrado profissional e 0 da UAM que tem uma linha.

$\mathrm{L}=$ Quantos \% da receita da CAPES vai para a área de Arquitetura, Urbanismo e Design em termos de bolsa?

$R=$ Eu não tenho esse número agora. A CAPES não financia estrutura. Quem financia estrutura é o CNPq. A CAPES só dá a bolsa de qualificação. A missão da CAPES é formar pessoas, então é a relação com o programa de pós-graduação e com a estrutura de qualificação da pessoa.

$\mathrm{L}=$ Falta reflexão intelectual sobre projeto em moda?

$\mathrm{R}=$ Falta, falta uma percepção maior de momento. Falta uma discussão sem paixão. Falta uma percepção de momento, uma avaliação de trajetória para identificar pontualmente qual é o tipo de inserção que está sendo feita e desvincular isso de uma simples sustentação de mercado (não bate com o que Christo fala no capítulo 3).

Então se é para falar em CAPES nós estamos falando de investigação científica stricto sensu. Aí precisa refletir mais.

$\mathrm{L}=$ Eu posso te posicionar contra $\circ$ Moda como campo do saber?

$R=$ Não, eu não chego nem a ser contra. Eu não vejo relevância nessa discussão. Eu não sou contra, porque para mim não tem sentido uma discussão dessa. Não agrega nada e causa mais um ruído em um sistema já repleto. A gente precisa muito mais aproximar competência para justificar uma ação coletiva de área, para depois então sim trabalhar. Então eu vou ter a área produto, a área informação e aí vou brigar com Ciência da Informação, Produto eu vou brigar com ergonomia, vou brigar com engenharia.

\section{$\mathrm{L}=\mathrm{O}$ que moda reclama é de ter nascido autônoma, né?!}

$R=A$ condição é essa. Tem que entender como as coisas sempre nascem assim, né?!

A condição é ter uma trajetória consistente em termos de contribuição para ensino e pesquisa em stricto sensu e isso vai dar maturidade de área, como foi o caso que eu te falei de Teologia e coisa. Agora..

Dentro da CAPES a área nasceu Arquitetura e Urbanismo, [desvinculada de engenharia], design que foi "pendurado" lá. Que eu te falei que não tem nenhum documento que me diga isso. 